Andrews University

Digital Commons @ Andrews University

\title{
A Re-Examination of Pentateuchal Hamartiology and Atonement as a Hermeneutical Framework for Interpreting the Laying on of Hands
}

Slavisa Milodar Jankovic

Andrews University, jankovic@andrews.edu

Follow this and additional works at: https://digitalcommons.andrews.edu/dissertations

Part of the Biblical Studies Commons

\section{Recommended Citation}

Jankovic, Slavisa Milodar, "A Re-Examination of Pentateuchal Hamartiology and Atonement as a Hermeneutical Framework for Interpreting the Laying on of Hands" (2020). Dissertations. 1739.

https://digitalcommons.andrews.edu/dissertations/1739

https://dx.doi.org/10.32597/dissertations/1739

This Dissertation is brought to you for free and open access by the Graduate Research at Digital Commons @ Andrews University. It has been accepted for inclusion in Dissertations by an authorized administrator of Digital Commons@ Andrews University. For more information, please contact repository@andrews.edu. 


\section{ABSTRACT}

\section{A RE-EXAMINATION OF PENTATEUCHAL HAMARTIOLOGY AND ATONEMENT AS A HERMENEUTICAL FRAMEWORK FOR INTERPRETING THE LAYING ON OF HANDS}

by

Slaviša Janković

Adviser: Richard M. Davidson 


\section{ABSTRACT OF GRADUATE STUDENT RESEARCH}

Dissertation

Andrews University

Seventh-day Adventist Theological Seminary

\section{Title: A RE-EXAMINATION OF PENTATEUCHAL HAMARTIOLOGY AND ATONEMENT AS A HERMENEUTICAL FRAMEWORK FOR INTERPRETING THE LAYING ON OF HANDS}

Name of researcher: Slaviša Janković

Name and degree of faculty adviser: Richard M. Davidson, $\mathrm{PhD}$

Date completed: October 2020

The ritual gesture of laying on of hands in Scripture has generated significant interest among theologians from rabbinic times until now. Still today, scholars assign various meanings to the ritual. In the second half of the $20^{\text {th }}$ century, the fresh interest that put forward new meanings for this gesture came primarily through the introduction of the new sub-discipline of Ritualistics within Old Testament studies. This relatively new discipline is not founded upon premises found in biblical texts, but rather, upon those found in various secular social, philosophical sciences, and other disciplines such as sociology, philosophy, anthropology, literary criticism, and the study of religion. These disciplines often reject major presuppositions found in biblical texts, and scholarly studies based on these approaches have produced multiple proposals regarding the 
meaning of this gesture. Such proposals generally offer incomplete, limited insights into the biblical meaning conveyed by laying on of hands. I have sought to avoid this interpretative misstep in the context of identifying the meaning of laying on of hands by (1) adopting premises found in the biblical text, especially concerning the nature of human beings and the concepts of sin and atonement, and (2) conducting a reading of the biblical text that applies a terminological/contextual/intertextual approach.

This study is divided into three sections. In the first section, I explore the concept of $\sin$ in the Pentateuch (ch. two) and establish terminology to express the nature of sin (ch. three). I utilize simple legal terminology based upon my reading of Lev 4-6. In the second section, I conduct an in-depth study of the Hebrew רֶֶּ to establish the concept of atonement (ch. four) and critically evaluate the commonly-accepted automatic defilement hypothesis (ch. five). In the third section, I present the ritual theory created by biblical scholars that coincides with the theoretical framework that I identified in the course of this study, which assisted in achieving the main and initial goal of this study, namely, to identify the meaning of laying on of hands in cultic contexts in the Pentateuch. The resulting data of this study enables me to expose limitations and errors included in various scholarly proposals concerning the meaning of the laying on of hands.

The traditional meaning of laying on of hands in cultic contexts has been that of transfer, with various qualities transferred such as sin, guilt, authority, general human sinfulness, and others. Very often the idea of substitution is included in the meaning of the ritual. Through a fresh study of the concepts of sin and atonement, and building upon biblical premises concerning the nature of human beings, I conclude that the meaning of 
transfer emerges from the biblical texts more than any other, and constitutes the foundational meaning of this ritual. 
Andrews University

Seventh-Day Adventist Theological Seminary

\title{
A RE-EXAMINATION OF PENTATEUCHAL HAMARTIOLOGY AND ATONEMENT AS A HERMENEUTICAL FRAMEWORK FOR INTERPRETING THE LAYING ON OF HANDS
}

\author{
A Dissertation \\ Presented in Partial Fulfillment \\ of the Requirements for the Degree \\ Doctor of Philosophy
}

by

Slaviša Janković

October 2020 
(C) Copyright by Slaviša Janković 2020

All Rights Reserved 


\title{
A RE-EXAMINATION OF PENTATEUCHAL HAMARTIOLOGY AND ATONEMENT AS A HERMENEUTICAL FRAMEWORK FOR INTERPRETING THE LAYING ON OF HANDS
}

\author{
A dissertation \\ presented in partial fulfillment \\ of the requirements for the degree \\ Doctor of Philosophy
}

by

Slaviša Janković

\section{APPROVAL BY THE COMMITTEE:}

Faculty Adviser, Richard M. Davidson J. N. Andrews Professor of Old

Testament Interpretation

Jiří Moskala

Professor of Old Testament Exegesis

Ángel Manuel Rodríguez

Retired, Director of Biblical Research Institute

Richard Averbeck

Professor of Old Testament and

Semitic Languages

Trinity Evangelical Divinity School
Director of Ph.D./Th.D. Program

John W. Reeve

Dean, SDA Theological Seminary

Jiří Moskala 


\section{DEDICATION}

To God, the source of all wisdom, knowledge, and goodness, and to my beloved wife Maria,

and to my precious children, Jakov, Ruta Maria, and Aron,

I dedicate this work.

It is my humble token of appreciation

to them for their constant support and love. 


\section{TABLE OF CONTENTS}

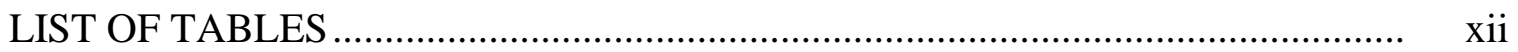

LIST OF ABBREVIATIONS .................................................................. xiv

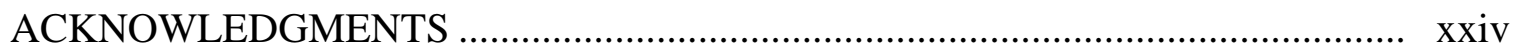

\section{Chapter}

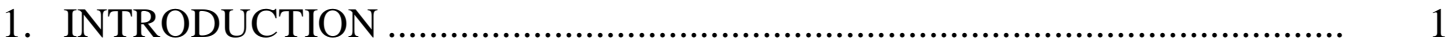

Background of the Problem ........................................................................ 1

Statement of the Problem...................................................................... 12

Statement of Purpose …………………………………….................. 13

Justification of the Research ................................................................ 14

Scope and Delimitations of the Study................................................... 15

Methodology ................................................................................ 18

2. OT HAMARTIOLOGY ................................................................. 20

OT Hamartiology: Obstacles, Weaknesses and Approaches ...................... 21

Obstacles to OT Hamartiology ............................................................... 21

Major Weakness of the OT Hamartiology ................................................. 24

Key Approaches to the OT Hamartiology and Their Weaknesses ............ 26

Terminological Approach .............................................................. 26

Biblical-Theological Approach......................................................... 28

Metaphorical Approach .................................................................. 31

Terminological/Contextual/Intertextual Approach ............................. 34

Remarks on Sin and Impurity: Insights from the Previous Research ........ 36

Impurity in the OT in Modern Studies............................................... 37

David Hoffmann .................................................................... 37

Alfred Büchler .......................................................................... 40

Gedalyahu Alon ……............................................................ 42

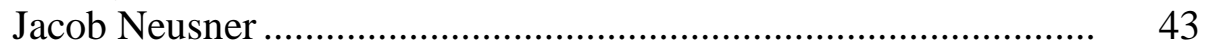

Mary Douglas.......................................................................... 46

Hyam Maccoby ............................................................................ 49

Jacob Milgrom ………............................................................ 51

Tikva Frymer-Kensky ............................................................. 59

David P. Wright ...................................................................... 63

Jonathan Klawans ................................................................... 70 


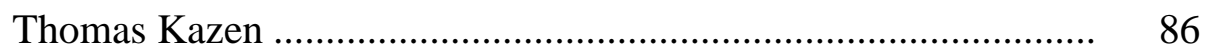

Summary of Scholarly Research on Impurity ………………………. $\quad 89$

Remarks on Sin and Impurity: Insights from the Present Research ......... 95

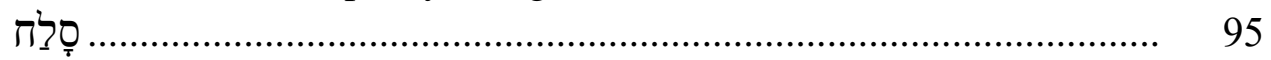

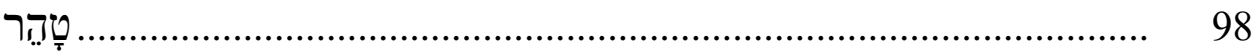

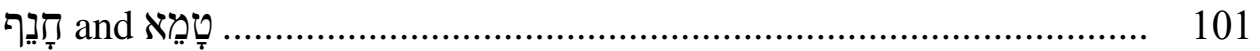

חלֶל חצל

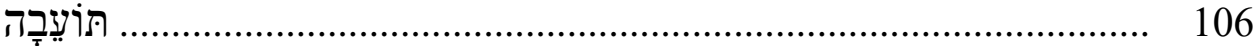

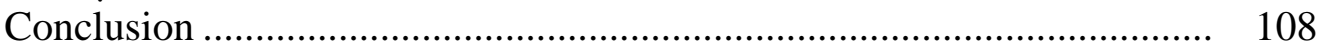

Moral Impurity/Sin in the Pentateuch..................................................... 114

Relevant Terms for Moral Impurity in the OT ………….................. 114

Cut Off (Kārēet) Punishment......................................................... 122

Of What Does Kärēt Consist?................................................. 124

Donald Wold on the Kärēt Punishment................................ 129

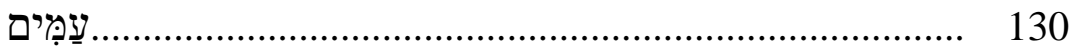

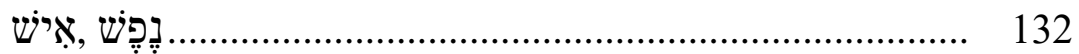

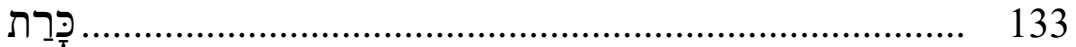

Who Administers the Kārêt Penalty? ........................................... 138

Summary and Conclusions ........................................................ 141

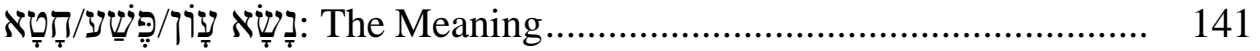

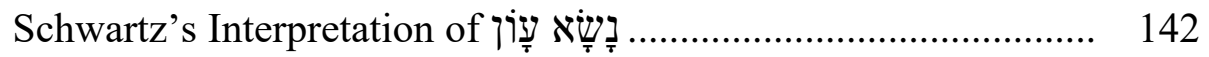

Critique of Schwartz's Interpretation of עָ .................................. 149

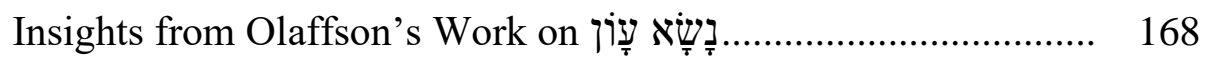

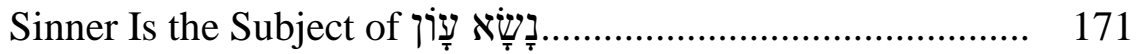

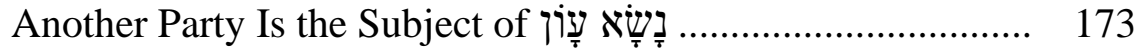

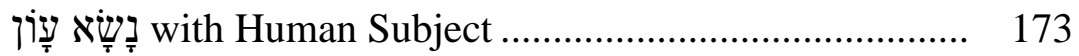

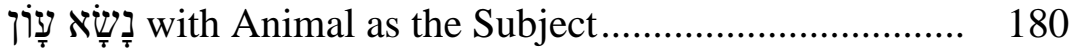

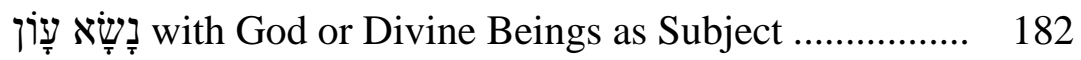

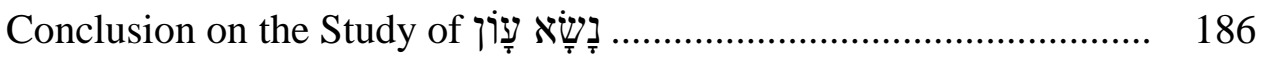

The Root חָּ as a Key Term for Sin in the OT ...................................... 187

The Nature of Tins in Leviticus and the Rest of the Pentateuch .. 192

Intentionality and Expiability Associated to Tָּ Sins ................. 192

Capital Punishment and

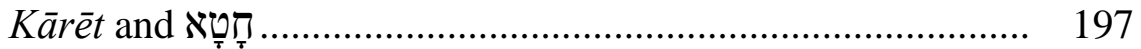

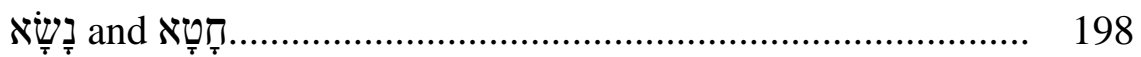

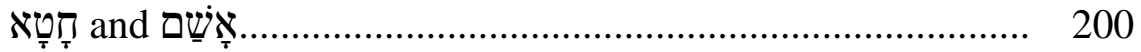

Conclusion on the Study of חָּ ......................................................... 208

The Root

The Nature of עiָ Sins in Leviticus and the Rest of the Pentateuch.... 211

Intentionality and Expiability Associated to עָ Sins ................... 212

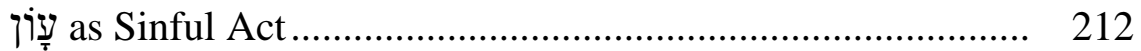




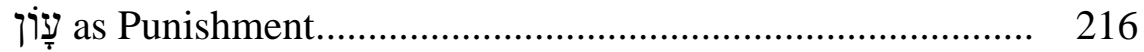

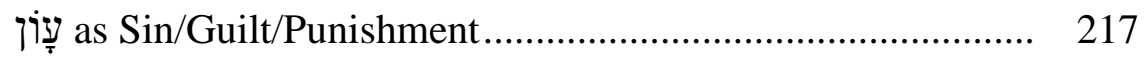

Capital Punishment and עָּ................................................... 219

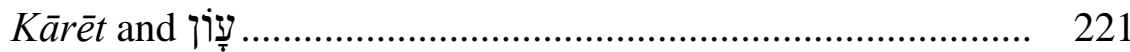

נְשָׁא

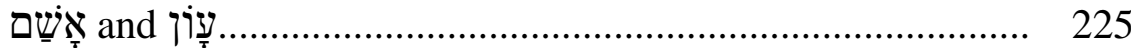

Conclusion on the Study of y̦i........................................................ 226

The Root

The Nature of Sins in Leviticus and the Rest of Pentateuch ....... 232

Capital Punishment and

Kārēt and

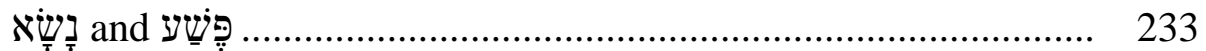

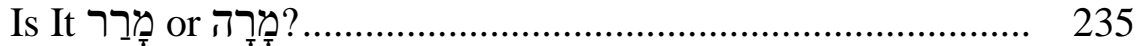

Closer Look at Num 20:10 and Num 20:24; 27:14_.............. 237

אָׁ

Conclusion on the Study of

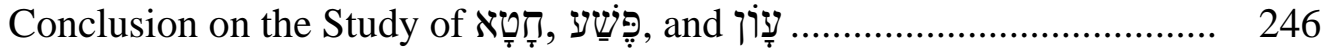

Ontology of Impurity ......................................................................... 248

3. INSIGHTS FROM MODERN LEGAL SYSTEMS AND BIBLICAL LAW ON INTENT AND EXPIABILITY/INEXPIABILITY IN THE PENTATEUCH …………………………................................ 251

Mens Rea and Actus Reus ............................................................. 251

Types of Wrongs .......................................................................... 252

Intent or Mental State/s in the MLS.................................................... 256

Negligence ........................................................................ 258

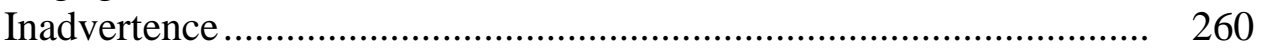

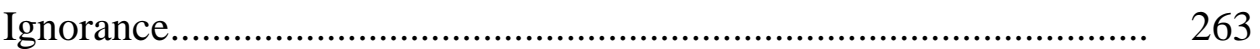

Conclusion ..................................................................... 265

Legal System of Ancient Israel........................................................... 266

Intent or Mental State/s in Biblical Law ................................................ 273

Intent or Mental State/s in Criminal Law ........................................ 274

Intent or Mental State/s in Cultic Law .............................................. 280

Jacob Milgrom on Leviticus 4-5 and Numbers 15 ............................ 281

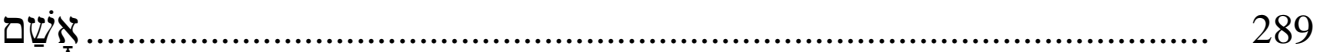

To Be/Become Guilty, To Incur Guilt, To Be/To Become Liable for Guilt......................................................................... 290

Bruce Wells' Suggestion................................................................. 291

"To Realize Guilt" ........................................................................ 298

"To Feel Guilt" ...................................................................... 301

“To Suffer Guilt's Consequences”.................................................... 311

Conclusion on 


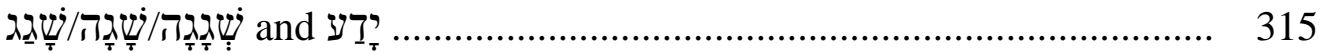

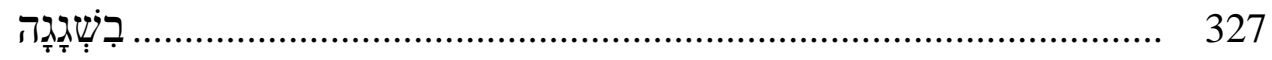

עָשָׁה: Pattern of Uses in the Pentateuch ......................................... 334

עִ עָשָׁה in the Contexts of Verbs that Express the Activity of Sinning

Does पִָׁׁ Refer to the Same Activity as the Preceding Verb?

Conclusion on בִשְׁגָגדה

ידָ

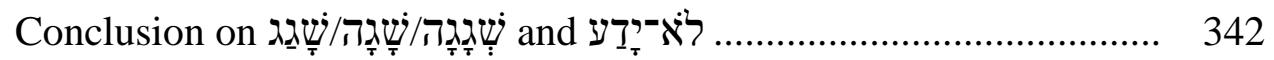

Expiable and Inexpiable Sins in the OT ………….............................. 345

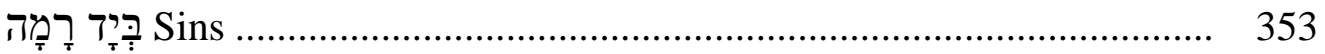

Intentional and Unintentional Sins in the OT ...................................... 354

Interpretation of Leviticus 16:21 ................................................. 358

Gane's Proposal on Function of the Prepositional Phrase לְ....... 361

Gane's Proposal on the Interpretation of Hebrew Terms ............. 363

William H. Shea's Proposal ...................................................... 371

Related Nouns ............................................................... $\quad 372$

Related Prepositions........................................................... 373

Related Conjunction............................................................. $\quad 375$

Related Adjective................................................................. $\quad 375$

4. THE MEANING OF

The Meaning of

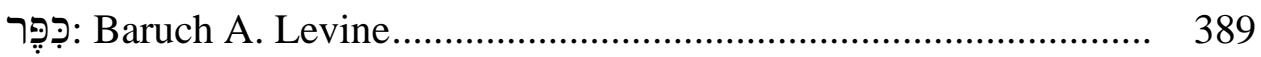

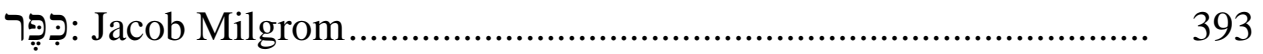

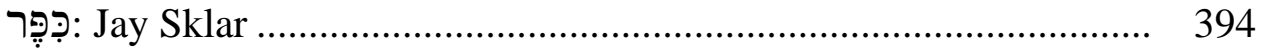

:

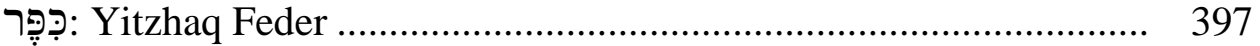

Various States of the Creation …………............................................. 399

Duality of Human Nature.................................................................... 400

Human Sinfulness ............................................................................ 401

Sinfulness as Reflected in Human Experience ........................................ 407

Burnt Offering: A Solution for General Human Sinfulness ................ 408

Neglect of GHS in Scholarly Works on Atonement............................ 411

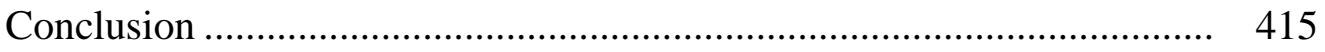

The Meaning of

Analysis of Leviticus 17:11: The Role of Blood and כִּכְ כ....................... 417

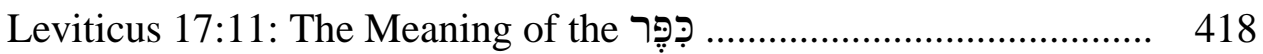

Leviticus 17:11: The Type/s of Sacrifices ......................................... 421

Leviticus 17:11: The Nature of the Preposition $\underset{?}{\mathfrak{T}}$ in

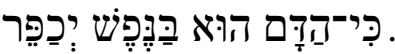




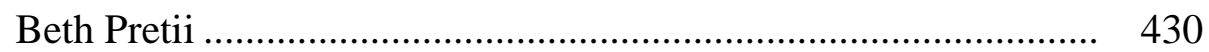

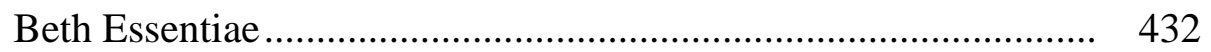

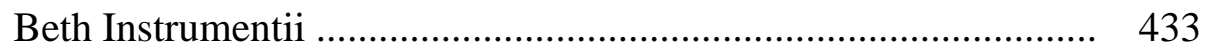

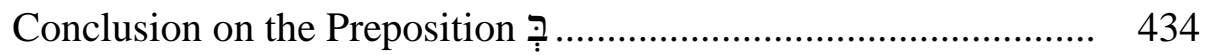

Leviticus 17:11: Probability of the Idea of Substitution...................... 435

Conclusion on Lev 17:11 ............................................................ 436

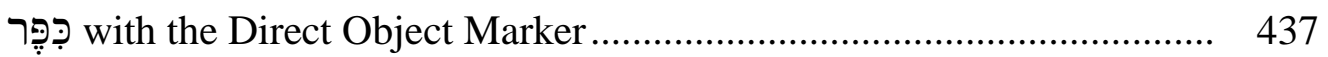

Non-Cultic Contexts .................................................................... 438

Cultic Contexts.............................................................. 440

רֶּ without Object Marker...................................................................... 442

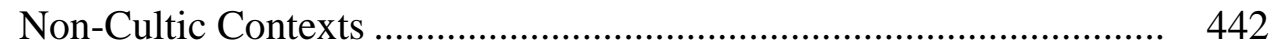

Cultic Contexts..................................................................... 447

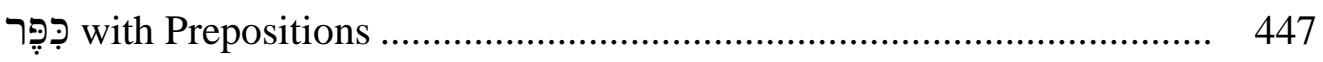

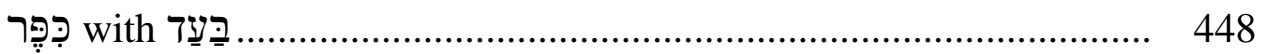

Non-Cultic Contexts ................................................................. 448

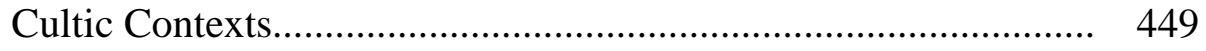

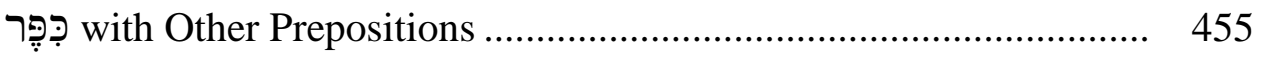

Non-Cultic Contexts .................................................................. 455

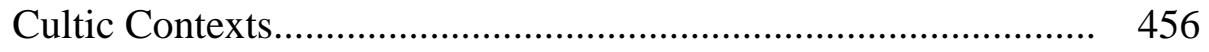

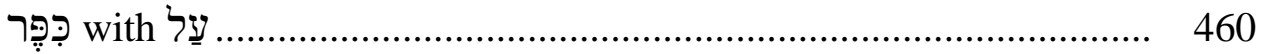

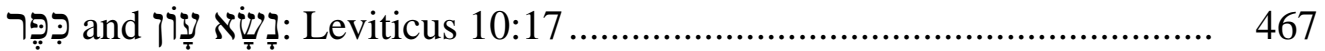

The Meaning of Priests' Eating of Sin Offering Flesh ...................... 467

Does Eating of the Sin Offering Flesh Contribute רכֶ?ֶ??...................... 467

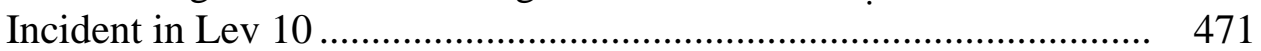

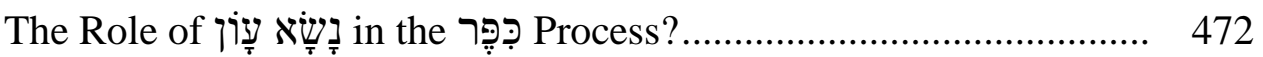

How Is Sin Offering Both Holy and Impure? .................................... 475

Does Sin Offering Refer to the Sin Offering Flesh or the Entire

Sacrifice?.............................................................................. 477

How Does Eating of the Sin Offering Flesh Contribute to the

จִ Process: Simultaneously or Separately/Additionally?............ 482

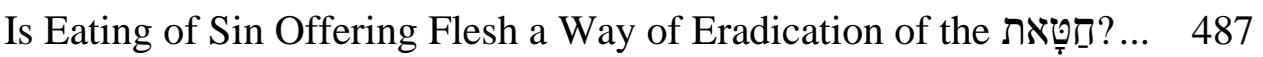

Summary of Leviticus 10:17 ............................................................... 489

רֶּ and Conceptually Related Concepts ................................................. 490

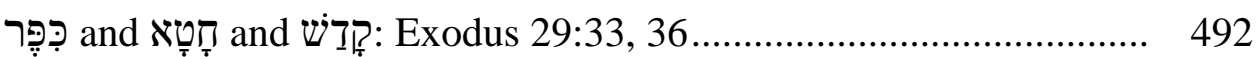

The Consecration of the Priests: Aaron and His Sons .................. 492

The Consecration of the Sacrificial Altar ..................................... 496

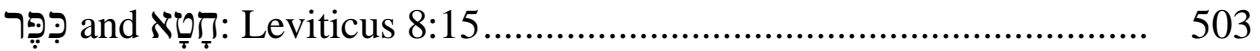

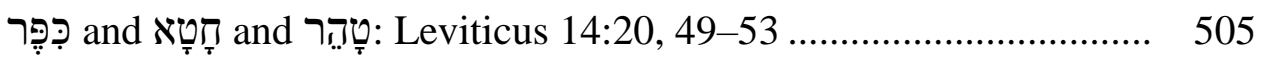

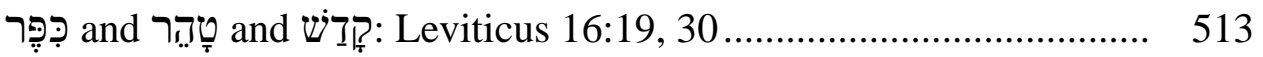

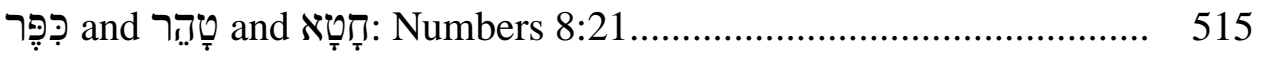

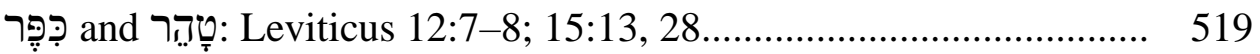

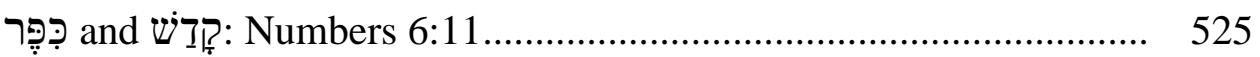




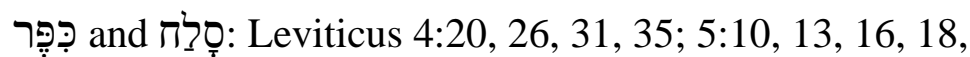
26 [6:7]; 19:22; Numbers 15:25, 26, 28 .............................. 527

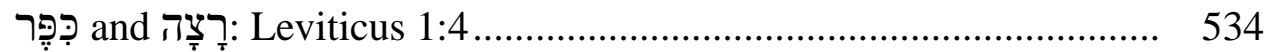

Milgrom's and Gane's Understanding of Atonement and Its Relation

to the Hebrew Preposition מִ ........................................................... 536

Milgrom's Theory of Atonement.................................................... 537

Gane's Theory of Atonement and Understanding of th..................... 540

Milgrom's and Gane's Debate on the Understanding of the

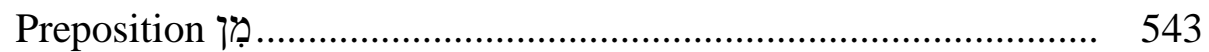

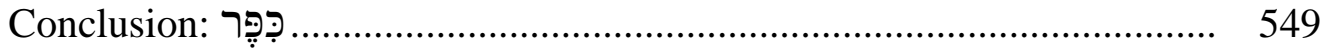

5. AUTOMATIC DEFILEMENT OF THE SANCTUARY …............................ 561

Automatic Defilement: The Hypothesis ……………................................. 561

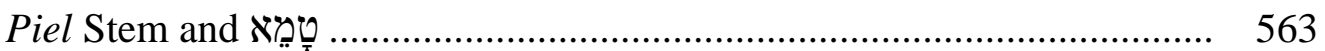

Aspect: Grammatical Considerations on the Use of the Infinitive

Construct and the Perfect ............................................................... 571

Infinitive Construct: A Temporal Use .............................................. 571

Infinitive Construct as Finite Verb …………………….................. 573

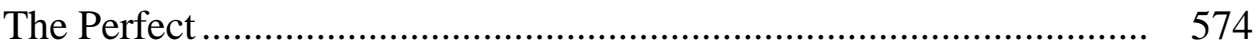

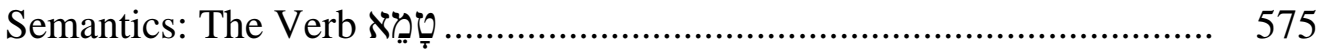

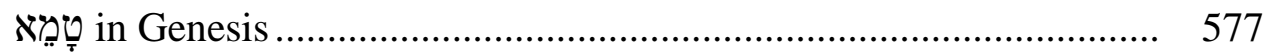

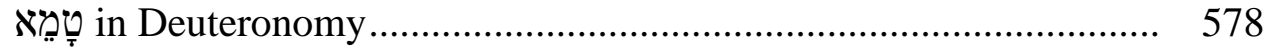

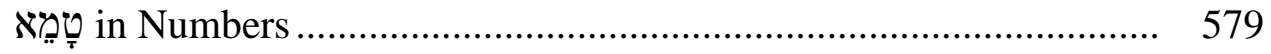

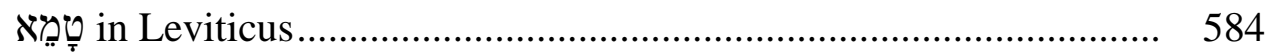

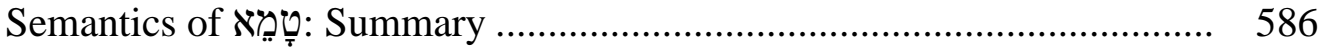

The Concept of Ellipsis....................................................................... 586

The Concept of Delay ........................................................................... 589

Leviticus 15:31.................................................................... 590

Instrumental Sense: "by Defiling My Tabernacle That Is in Their Midst" ................................................................................. 591

Temporal Sense: "When They Defile My Tabernacle That Is in Their Midst" ......................................................................... 592

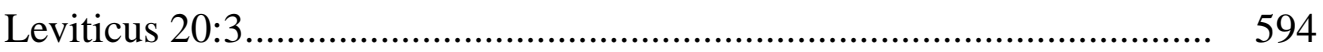

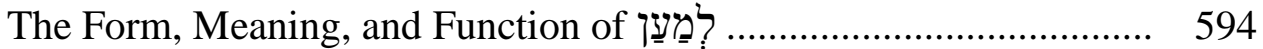

Literary Structure of the Law........................................................ 596

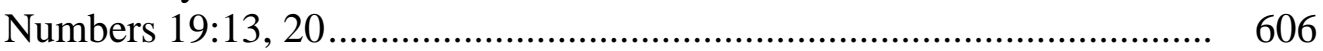

Summary: Automatic Defilement Hypothesis ......................................... 607

Interpretation of Leviticus 15:31 .................................................. 608

Interpretation of Leviticus 20:3 ................................................. 612

Interpretation of Numbers 19:13, 20............................................. 615 
Ritual Theory

Insufficiency of Ritual Texts

Genre Is an Impediment in Ritual Texts .

Textual Redaction Is an Impediment in Ritual Texts

Frank Gorman ...

Roy Gane

Ritual Actions and Substances Do Not Have Inherent Meaning

Ritual Consists of Activity and Attached Meaning

Inadequacy of a Structural Approach in Identifying Ritual Meaning.

The Meaning/Function of a Ritual Is the Goal Assigned to Its

Activity System.

A "Ritual" Is an Activity System with a Special Kind of Goal

The Aid of Systems Theory Concepts in the Interpretation of

Israelite Rituals

The Biblical Text Provides Instructions for Physical Performance

and Interpretations of Activities...

Gaps: The Peculiarity of Ritual Texts.

Laying on of Hands: Texts

Leviticus 1:3-4

Omission or Abbreviation

Leviticus 1:10-11.

Leviticus 1:14; 5:7-10, 14:22, 1

Leviticus 9:8, 12, 15, 16, 18

Leviticus 16:6, 9, 11, 15, 24

Leviticus $23: 8,12,18,19,27,36,37,38$ and Numbers $28-29$....

Leviticus 7:1-7-Reparation Offering

Form of Laying on of Hands: Singular vs Plural vs Dual and

Pressure or No Pressure

Pressure or No Pressure

The Function/Meaning of Laying on of Hand/s .................................... 679

Critique of Theories

Identification/Substitution Theory

Consecration-Separation/Dedication/Presentation Theory

Key Misconceptions in Laying on of Hand/s Debate

Transfer/Substitution.

Evaluation of the Points of Critique of the Transfer/Substitution

Theory.....

The Death of the Victim Cannot be Vicarious..............................

Sacrifice Cannot be Holy and Impure.

Blood Manipulation Versus Slaughter

Substitution Theory Is Untenable

Transfer/Substitution Theory Is Based on Lev 16:21 
Laying on of Hand/s in Relation to Bird, Cereal Offering and the Identity of the Slayer .............................................. 704

Wright's First Argument..................................................... 705

Wright's Second Argument for Ownership Theory and the Role of the Offerer .................................................... 707

Laying on of Hand/s and Confession..................................... 710

Arguments from Current Research .............................................. 714

Insight from Hamartiology ........................................................ 714

Insights from the Concept of Atonement................................ 716

7. SUMMARY AND CONCLUSION ..................................................... 721

The First Part......................................................................... 721

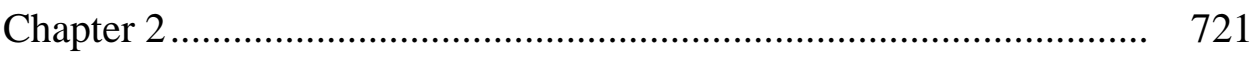

Approaches and Obstacles in the Study of Impurity .................... 721

Impurity in Scholarly Debates ..................................................... 723

Further Insights on Impurity from the Present Study .................. 725

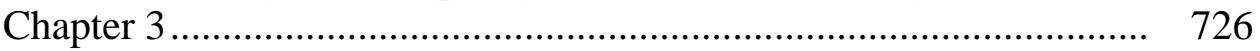

Legal Terminology ......................................................... 726

Intent in Legal and Cultic Texts............................................. 727

Leviticus 4-5: A Fresh Proposal................................................ 729

Fresh Sin Classification .............................................................. 730

The Second Part ................................................................................ 731

Chapter 4 ........................................................................... 732

פִ

Foundational Meaning of

Insights on

Chapter 5 ............................................................................... 738

Automatic Defilement Hypothesis......................................... 738

Leviticus 15:31 ................................................................... 739

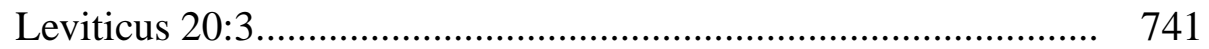

Numbers 19:13, 20......................................................... 743

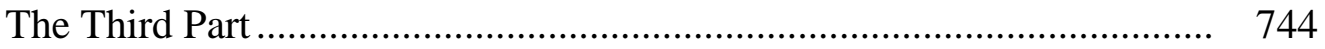

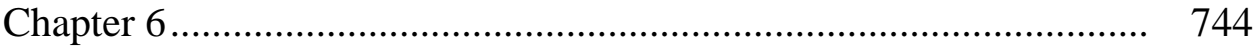

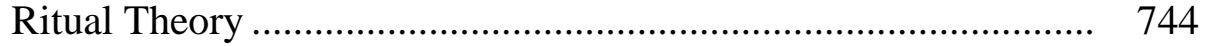

Biblical Data Regarding Laying on of Hands ............................ 746

Critique of Arguments against the Transfer/Substitution Theory ....................................................................... 750

Further Arguments Supporting the Transfer/Substitution

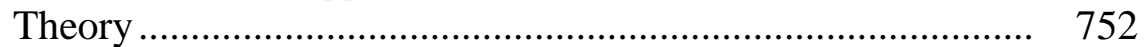

Final Synthesis ......................................................... 753

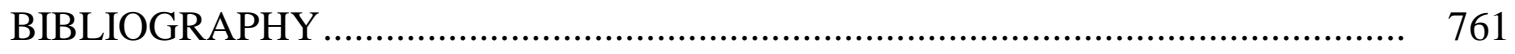




\section{LIST OF TABLES}

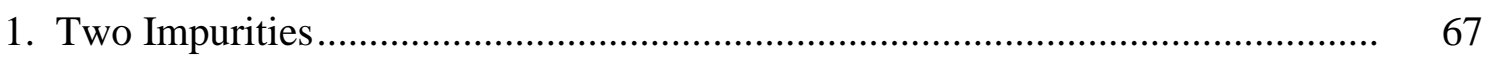

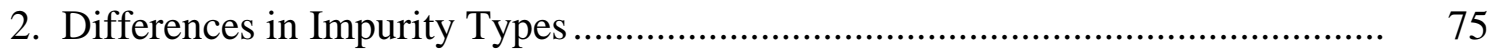

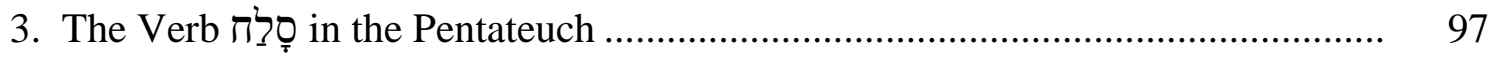

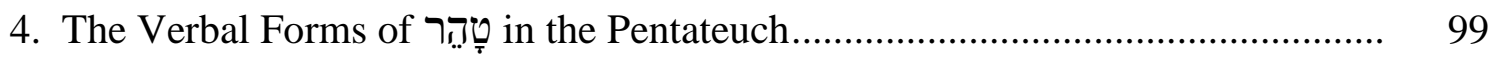

5. The Verb טָָּא in Relation to the Land in the Pentateuch .................................. 102

6. The Verb טָָָא in Relation to Humans and Sanctuary ........................................ 103

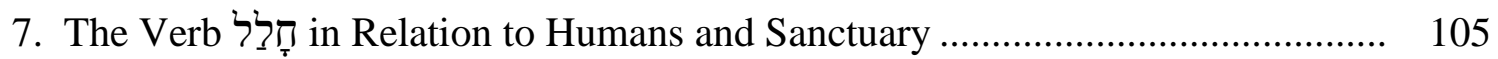

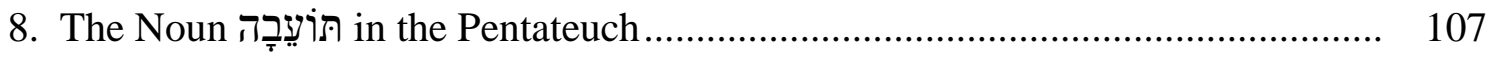

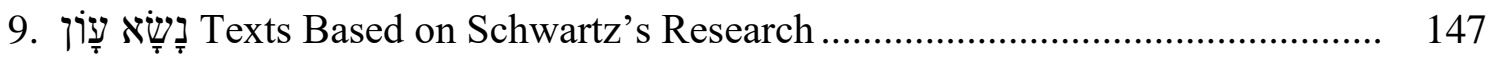

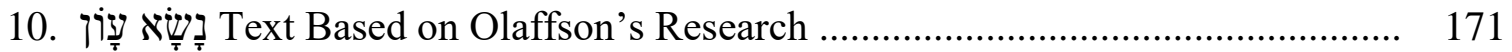

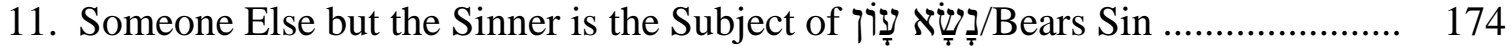

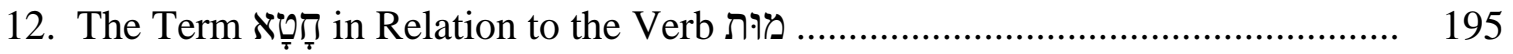

13. The Term

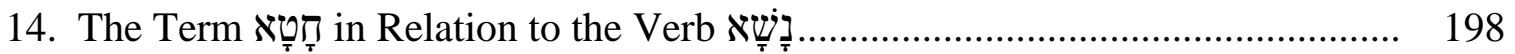

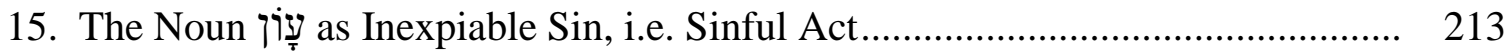

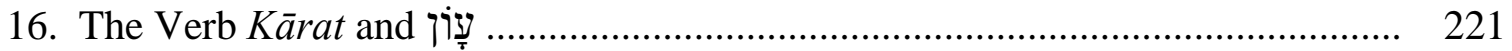

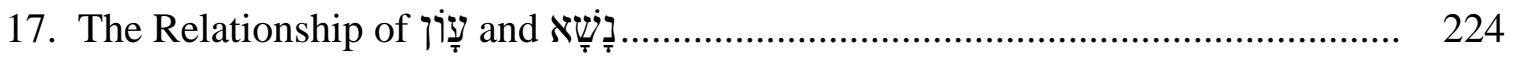

18. The Relationship of 
19. The Assessment of the Sinful Act.................................................................... 265

20. The Verb עָשָ and the Verbs of Sinning .......................................................... 336

21. Sin's Expiability/Inexpiability ……………….............................................. 357

22. The Sinner's Awareness ........................................................................ 357

23. The Preposition

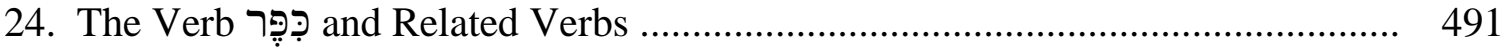

25. Literary Structure of Lev 20:2-5 ............................................................ 598

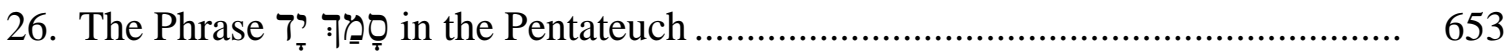

27. LXX and MT Singular Agreement of the Noun "Hand".................................... 672 


\section{LIST OF ABBREVIATIONS}

$A A$

$\mathrm{AB}$

$A B D$

AnBib

AfO

AJSR

AJT

AMJCL

ANEM

AOAT

AOTC

$A S$

AUSS

$B B R$

BCOT

BDB

$B E B$

$B E B T$
American Anthropologist

Anchor Bible

The Anchor Bible Dictionary

Analecta Biblica

Archiv für Orientforschung

Association for Jewish Studies Review

The American Journal of Theology

The American Journal of Comparative Law

Ancient Near East Monographs

Alter Orient und Altes Testament

Apollos Old Testament Commentary

Aramaic Studies

Andrews University Seminary Studies

Bulletin for Biblical Research

Biblical Commentary on the Old Testament

The New Brown, Driver, and Briggs Hebrew and English Lexicon of the Old Testament

Baker Encyclopedia of the Bible

Bauer Encyclopedia of Biblical Theology 


\begin{tabular}{|c|c|}
\hline BHH & $\begin{array}{l}\text { Biblisch-Historisches Handwörterbuch: Landeskunde, Geschichte, } \\
\quad \text { Religion, Kultur, Literatur }\end{array}$ \\
\hline$B i b$ & Biblica \\
\hline BJS & Brown Judaic Studies \\
\hline BKAT & Biblischer Kommentar zum Alten Testament \\
\hline$B L D$ & Black's Law Dictionary \\
\hline $\mathrm{BLH}$ & Biblical Languages: Hebrew \\
\hline$B L T$ & Burton's Legal Thesaurus \\
\hline BMI & The Bible and Its Modern Interpreters \\
\hline $\mathrm{BSC}$ & Bible Student's Commentary \\
\hline BST & The Bible Speaks Today \\
\hline BSTS & Bible Study Textbook Series \\
\hline$B T D B$ & Baker Theological Dictionary of the Bible \\
\hline$B U L R$ & Boston University Law Review \\
\hline CahRB & Cahiers de la Revue Biblique \\
\hline$C A D$ & $\begin{array}{l}\text { The Assyrian Dictionary of the Oriental Institute of the University of } \\
\text { Chicago }\end{array}$ \\
\hline CAT & Commentaire de l'Ancien Testament \\
\hline $\mathrm{CB}$ & The Century Bible \\
\hline $\mathrm{CBC}$ & The Cambridge Bible Commentary \\
\hline$C B Q$ & Catholic Biblical Quarterly \\
\hline CBTEL & Cyclopaedia of Biblical, Theological and Ecclesiastical Literature \\
\hline $\mathrm{CDCH}$ & The Concise Dictionary of Classical Hebrew \\
\hline$C J$ & tive Judaism \\
\hline
\end{tabular}




\begin{tabular}{|c|c|}
\hline$C L P$ & Criminal Law and Philosophy \\
\hline ConBNT & Coniectanea Biblica, New Testament \\
\hline ConBOT & Coniectanea Biblica, Old Testament \\
\hline $\operatorname{COS}$ & The Context of Scripture \\
\hline CPNCOTS & The College Press NIV Commentary Old Testament Series \\
\hline CQS & Companion to the Qumran Scrolls \\
\hline CRS & Commentary Reference Series \\
\hline DAWBIO & $\begin{array}{l}\text { Deutsche Akademie der Wissenschaften zu Berlin Institut für } \\
\text { Orientforschung }\end{array}$ \\
\hline$D B$ & A Dictionary of the Bible \\
\hline$D B D L$ & $\begin{array}{l}\text { A Dictionary of the Bible Dealing with Its Language, Literature, and } \\
\text { Contents Including the Biblical Theology }\end{array}$ \\
\hline DBSup & Dictionnaire de la Bible: Supplément \\
\hline$D C H$ & The Dictionary of Classical Hebrew \\
\hline$D D B$ & Davis Dictionary of the Bible \\
\hline$D J C P$ & Dao: A Journal of Comparative Philosophy \\
\hline$D M L U$ & A Dictionary of Modern Legal Usage \\
\hline DOTHB & Dictionary of the Old Testament: Historical Books \\
\hline$E B C$ & Expositor's Bible Commentary \\
\hline ECC & The Eerdmans Critical Commentary \\
\hline$E D B$ & Eerdmans Dictionary of the Bible \\
\hline ÉHPR & Études d'Histoire et de Philosophie Religieuses \\
\hline EJL & Early Judaism and its Literature \\
\hline$E n c D B$ & Encyclopedic Dictionary of the Bible \\
\hline
\end{tabular}




\begin{tabular}{|c|c|}
\hline EncEth & Encyclopedia of Ethics \\
\hline$E R$ & Encyclopaedia of Religion \\
\hline EncyBib & Encyclopaedia Biblica \\
\hline ERE & Encyclopaedia of Religion and Ethics \\
\hline ERLA & Encyclopedia of Religion and the Law in America \\
\hline$E T$ & Expository Times \\
\hline$E v Q$ & Evangelical Quarterly \\
\hline FAT & Forschungen Zum Alten Testament \\
\hline FB & Forschung zur Bibel \\
\hline$F W N S B D$ & Funk and Wagnalls New Standard Bible Dictionary \\
\hline GD & Gorgias Dissertations \\
\hline GFP & History and Government Faculty Publications \\
\hline HALOT & The Hebrew and Aramaic Lexicon of the Old Testament \\
\hline$H A T$ & Handbuch zum Alten Testament \\
\hline HBM & Hebrew Bible Monographs \\
\hline $\mathrm{HCBC}$ & The Harper Collins Bible Commentary \\
\hline$H C B D$ & Holman Concise Bible Dictionary \\
\hline$H D E$ & The Historical Dictionary of Ethics \\
\hline Hermeneia & Hermeneia: A Critical and Historical Commentary on the Bible \\
\hline HOTC & Holman Old Testament Commentary \\
\hline$H R$ & History of Religions \\
\hline$H S$ & Hebrew Studies \\
\hline HSer & Hornbook Series \\
\hline
\end{tabular}


$H S t$

HSDAT

HSS

HUCA

IBCTP

$I B D$

ICCHSONT

$I D B$

IDBSup

IEE

IJT

ISBE

ITC

IVPBBCOT

IVPBD

JANEBL

$J A O S$

JATS

$J B L$

JBLMS

JCS

JETS

$J H S$
The Hebrew Student

Handbook of Seventh-day Adventist Theology

Harvard Semitic Studies

Hebrew Union College Annual

Interpretation: A Bible Commentary for Teaching and Preaching

The Illustrated Bible Dictionary

The International Critical Commentary on the Holy Scriptures of the Old and New Testaments

Interpreter's Dictionary of the Bible

The Interpreter's Dictionary of the Bible: Supplementary Volume

The International Encyclopedia of Ethics

The Indian Journal of Theology

International Standard Bible Encyclopedia

International Theological Commentary

The IVP Bible Background Commentary: Old Testament

IVP Bible Dictionary

Journal for Ancient Near Eastern and Biblical Law

Journal of the American Oriental Studies

Journal of Adventist Theological Society

Journal of Biblical Literature

Journal of Biblical Literature Monograph Series

Journal of Cuneiform Studies

Journal of the Evangelical Theological Society

Journal of Hebrew Scriptures 
$J J S$

JLSP

JNES

$J N S L$

JPSTC

$J Q R$

JSOTSup

$J S B$

$J S S$

JSFSC

JSTFC

JTS

LANE

LAPO

LHB/OTS

LHML

LXX

MT

MTZ

NAC

$N B D$

NCBC

$N D P R$
Journal of Jewish Studies

Janua Linguarum Series Practica

Journal of Near Eastern Studies

Journal of Northwest Semitic Languages

The JPS Torah Commentary

Jewish Quarterly Review

Journal for Studies of the Old Testament Supplement Series

The Jewish Study Bible

Journal of Semitic Studies

Journal of Spiritual Formation and Soul Care

Jewish Studies in the Twenty-First Century

The Journal of Theological Studies

Languages of the Ancient Near East

Littératures Anciennes du Proche-Orient

Library of Hebrew Bible/Old Testament Studies

The Lewis Henry Morgan Lectures

Septuagint

Masoretic Text

Münchener Theologische Zeitschrift

The New American Commentary

New Bible Dictionary

New Century Bible Commentary

Notre Dame Philosophical Reviews 
NDCE

NIBCOTS

NICOT

$N I D B$

NIDNTT

NIDOTTE

NIVAC

NNIBD

$N W D B$

NZSTR

$O E B L$

OEBT

OECT

OJLS

OTG

OTL

$O t S t$

OTWSA

PA

PHSC

PPPT

PTMS

$R B$
A New Dictionary of Christian Ethics

New International Biblical Commentary: Old Testament Series

The New International Commentary of the Old Testament

The New Interpreter's Dictionary of the Bible

New International Dictionary of New Testament Theology

New International Dictionary of Old Testament Theology \& Exegesis

The NIV Application Commentary

Nelson's New Illustrated Bible Dictionary

The New Westminster Dictionary of the Bible

Neue Zeitschrift für Systematische Theologie und Religionsphilosophie

The Oxford Encyclopedia of the Bible and Law

The Oxford Encyclopedia of the Bible and Theology

Oxford Editions of Cuneiform Texts

Oxford Journal of Legal Studies

Old Testament Guides

The Old Testament Library

Oudtestamentische Studiën

Ou Testamentiese Werkgemeenskap van Suid-Afrika (Afrikaans: Old Testament Society in South Africa)

Philosophia Antiqua

Perspectives on Hebrew Scriptures and Its Contexts

PdR Press Publications in Tagmemics

Pittsburgh Theological Monograph Series

Revue Biblique 


\begin{tabular}{|c|c|}
\hline$R B D$ & The Revell Bible Dictionary \\
\hline RBS & Resources for Biblical Study \\
\hline$R C$ & Religious Compass \\
\hline RIDA & Revue Internationale des Droits de L'antiquité \\
\hline RNBC & Readings: A New Biblical Commentary \\
\hline$R S R$ & Religious Studies Review \\
\hline SANT & Studien zum Alten und Neuen Testament \\
\hline SAOC & Studies in Ancient Oriental Civilization \\
\hline SB & The Schocken Bible \\
\hline SBLDS & Society of Biblical Literature Dissertation Series \\
\hline$S B L S P$ & Society of Biblical Literature Seminar Papers \\
\hline SCR & Studies in Comparative Religion \\
\hline SDABC & The Seventh-Day Adventist Bible Commentary \\
\hline$S D A B D$ & Seventh-day Adventist Bible Dictionary \\
\hline ScrHier & Scripta Hierosolymitana \\
\hline SHR & Studies in the History of Religions \\
\hline SHBC & The Smyth and Helwys Bible Commentary \\
\hline SJHS & The Scientific Journal of Humanistic Studies \\
\hline SJLA & Studies in Judaism in Late Antiquity \\
\hline$S L$ & Sapientia Logos \\
\hline SNTSMS & Society for New Testament Studies Monograph Series \\
\hline SOTBT & Studies in Old Testament Biblical Theology \\
\hline$S R$ & Studies in Religion \\
\hline
\end{tabular}


SSN

TB

$T B D$

TBü

$T D N T$

TDOT

THAT

THeth

ThTo

$T L O T$

TOTC

TSR

TWAT

TWOT

UBCS

VT

VTSupp

WAWS

WBC

WDCE

WEC

WLJ

WMANT
Studia Semitica Neerlandica

Torchbooks

Tyndale Bible Dictionary

Theologische Bücherei

Theological Dictionary of the New Testament

Theological Dictionary of the Old Testament

Theologisches Handwörterbuch zum Alten Testamen

Texte Der Hethiter

Theology Today

Theological Lexicon of the Old Testament

Tyndale Old Testament Commentaries

Toronto Studies in Religion

Theologisches Wörterbuch zum Alten Testament

Theological Wordbook of the Old Testament

Understand the Bible Commentary Series

Vetus Testamentum

Vetus Testamentum Supplements

Writings from the Ancient World Supplements

Word Biblical Commentary

The Westminster Dictionary of Christian Ethics

The Wycliffe Exegetical Commentary

Widener Law Journal

Wissenschaftliche Monographien zum Alten und Neuen Testament 


$\begin{array}{ll}\text { WUNT } & \text { Wissenschaftliche Untersuchungen zum Neuen Testament } \\ \text { ZABR } & \text { Zeitschrift für altorientalische und biblische Rechtsgeschichte } \\ \text { ZAW } & \text { Zeitschrift für die Alttestamentliche Wissenschaft } \\ \text { ZIBBCOT } & \text { Zondervan Illustrated Bible Backgrounds Commentary: Old Testament } \\ \text { ZPEB } & \text { The Zondervan Pictorial Encyclopedia of the Bible } \\ \text { ZThK } & \text { Zeitschrift für Theologie und Kirche }\end{array}$




\section{ACKNOWLEDGMENTS}

First and foremost, I am thankful to God, who has been a faithful Provider, Helper, Protector, Sustainer, and Guide at all times and in all things.

I am immeasurably grateful to God for my dear wife Maria and my children, Jakov, Ruta Maria, and Aron, who have constantly been by my side through this complex process. Thank you for your patience and sacrifice as I often invested the time that belonged to you in order to complete this work.

I would like to thank my dissertation committee in particular: Drs. Davidson, Moskala, and Rodriguez. My dissertation advisor, Dr. Davidson, especially, showed immeasurable trust in me when I was at the beginning of my research, and this trust has continued to encourage me to the end of the journey. His support, guidance, and intentionality to avoid interfering with my independent reasoning created just the right environment for me to do my best. I am grateful that, during the process, he never compromised his well-known high standards of biblical interpretation, which elevated the quality of my work.

Andrews University administration, specifically the Seminary $\mathrm{PhD} / \mathrm{ThD}$ Office and the International Student Office supported me financially during my doctoral journey at Andrews University. Thank you very much.

I would also like to thank the James White Library and its staff. They have been nothing but excellent in providing resources and a pleasant space to research. Your service is much appreciated.

There are many individuals whom God has drawn into my life. Their time, effort, influence, and encouragement are reflected in this dissertation, and I am wholeheartedly thankful to all of them. 


\section{CHAPTER 1}

\section{INTRODUCTION}

\section{Background of the Problem}

The initial goal of the present study was to identify the particular ritual gesture of the laying on of hands. The study of rituals ${ }^{1}$ significantly increased in the second half of the 19 th century and continues to flourish until the present. The growing interest in ritual studies resulted in the introduction in the 1960s of a new sub-discipline within Old Testament (OT) studies called Ritualistics. ${ }^{2}$ The laying on of hands in the OT is one of

${ }^{1}$ This study refrains from assigning any of the numerous definitions suggested by the ritual or biblical scholars studying ritual because they are informed by various scientific disciplines which focus on certain aspects of ritual and because of the diversity of philosophical presuppositions involved in their production. Jan Plavoet listed twenty-four different definitions produced since 1909, starting with van Gennep, through 1991 with David Parkin. Jan Platvoet, "Ritual in Plural and Pluralistic Societies," in Pluralism and Identity: Studies in Ritual Behaviour, eds. Jan Platvoet and Karel van der Toorn, SHR 67 (Leiden: Brill, 1995), 42-45; Gerald A. Klingbeil, Bridging the Gap: Ritual and Ritual Texts in the Bible (Winona Lake, IN: Eisenbrauns, 2007), 14. The biblical text demonstrates that ritual consists of certain dimensions/characteristics which are discussed in ch. 6 of the present study. Klingbeil, Bridging the Gap, 208-24. Biblical ritual and non-ritual texts contain certain premises that can provide grounds to form a conceptual framework and theoretical principles for the study of ritual which is also discussed in ch. 6 of the current work.

${ }^{2}$ Gerald A. Klingbeil, A Comparative Study of the Ritual of Ordination as Found in Leviticus 8 and Emar 369 (Lewiston, NY: Mellen Press, 1998); Klingbeil, Bridging the Gap, 26-69; Patrick D. Miller, "Israelite Religion," in The Hebrew Bible and Its Modern Interpreters, eds. Douglas A. Knight and Gene M. Tucker, BMI 1 (Philadelphia: Fortress Press, 1985), 201-37; J. P. Sørensen, "Ritualistics: A New Discipline in the History of Religion," in The Problem of Ritual: Based on Papers Read at the Symposium on Religious Rites held at Abo, Finland, on the 13th-16th of August 1991, ed. Tore Ahlbäck (Åbo, Finland: The Donner Institute for Research in Religious and Cultural History, 1993), 9-24. 
the most studied ritual gestures. ${ }^{3}$ Interest in this topic was already noted in rabbinic literature, wherein the rabbis argued that this ritual gesture meant the transfer of sin from the offerer onto the sacrificial animal. As a consequence, the animal died, instead of the offerer. This conclusion was reached by taking Lev 16:21 as the model for interpreting the ritual gesture of laying on of hands in the sacrificial context. ${ }^{4}$ The same understanding of the ritual gesture was accepted by the Church Fathers, as well, ${ }^{5}$ and transfer in various contexts was the prevailing interpretation until the end of 19 th and the beginning of the 20th century. ${ }^{6}$ In scholarly parlance, this theory is labeled the transfer/substitution theory.

${ }^{3}$ Roy E. Gane, Cult and Character: Purification Offerings, Day of Atonement, and Theodicy (Winona Lake, IN: Eisenbrauns, 2005), 53-54, 176, 224; B. J. van der Merwe, "The Laying on of Hands in the Old Testament," OTWSA 5 (1962): 38-40; Ángel Manuel Rodríguez, "Substitution in the Hebrew Cultus and in Cultic-Related Texts" (PhD diss., Andrews University, 1979), 201-8; David P. Wright, "The Gesture of Hand Placement in the Hebrew Bible and Hittite Literature," JAOS 106 (1986): 433-46.

${ }^{4}$ The Mishnah Tractate Yoma, 3:8, 6:2 in The Mishnah: A New Translation, trans. Jacob Neusner (New Haven: Yale University Press, 1988); Bernd Janowski, Sühne als Heilsgeschehen: Studien zur Sühnetheologie der Priesterschrift und zur Wurzel KPR im Alten Orient und im Alten Testament, WMANT 55 (Neukirchen-Vluyn: Neukirchener, 2000), 205; Nobuyoshi Kiuchi, The Purification Offering in the Priestly Literature: Its Meaning and Function, JSOTSup 56 (Sheffield: Academic Press, 1987), 113; J. H. Kurtz, Offerings, Sacrifices, and Worship in the Old Testament, trans. James Martin (Peabody, MA: Hendrickson, 1998), 85; Solomon Zeitlin, "The Semikah Controversy Between the School of Shammai and Hillel," JQR 56 (1966): 242-43.

${ }^{5}$ Kiuchi, Purification Offering, 113; Kurtz, Offerings, 85.

${ }^{6}$ Significant studies that affirmed the transfer meaning of laying on of hands in the New Testament were done by Johannes Behm, Die Handauflegung im Urchristentum: Nach Verwendung, Herkunft und Bedeutung in Religionsgeschichtlichem Zusammenhang Untersucht (Leipzig: A. Deichert, 1911); Joseph Coppens, "L'imposition des mains et les rites connexes dans le Nouveau Testament et dans l'église ancienne: Etude de theologie positive" (diss.es ad gradum magistri, Universitas Catholica Lovaniensis, 1925); John Fleter Tipei, The Laying on of Hands in the New Testament: Its Significance, Techniques, and Effects (Lanham, MD: University Press of America, 2009). The understanding that this ritual gesture means transfer, among others, was also established by scholars who studied it in the context of ordination. Johannes Neumann, "Salbung und Handauflegung als Heilszeichen und Rechtsakt," in Wahrheit und Verkündigung: Michael Schmaus zum 70. Geburtstag, eds. Leo Scheffczyk, Werner Dettloff, and Richard Heinzmann (München: Ferdinand Schöningh, 1967), 2:2; Eduard Lohse, Die Ordination im Spätjudentum und im Neuen Testament (Berlin: Evangelische Verlagsanstalt, 1951); W. Everett Ferguson, "Ordination in the Ancient Church: An Examination of the Theological and Constitutional Motifs in the Light of Biblical and Gentile Sources" (PhD diss., Harvard University, 1959); Allen Podet, "Morenu Harabh: Elements in the Development of Rabbinical Ordination in the Codes" (PhD diss., Hebrew Union College-Jewish Institute of Religion, 1964); Keith Edward Krieghoff Mattingly, "The Laying on of Hands on Joshua: An Exegetical Study of Numbers 27:12-23 and Deuteronomy 34:9” (PhD diss., Andrews University, 1997). 
At the beginning of the 21 st century, some scholars still consider it defensible. ${ }^{7}$

The first opposition to this theory appeared, if not prior to, then certainly in the 19th century. Johann K. von Kurtz has listed the main proponents and opponents of this theory between 1859 and $1890 .{ }^{8}$ Significant among the theologians at the beginning of the 19th century who opposed the transfer/substitution theory was Karl Bähr. He held that laying on of hands was "nothing but a formal and solemn declaration, on the one hand, that this gift was his [the offerer's] actual property and, on the other hand, that he was ready to give up this property of his entirely to death — to devote it to death for Jehovah."9

\footnotetext{
${ }^{7}$ Paul Volz, "Die Handauflegung bein Opfer," ZAW 21 (1901): 93-100; William P. Paterson,

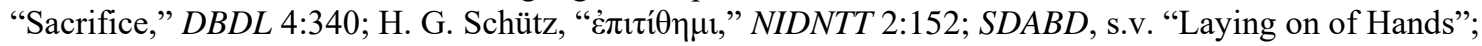
Zeitlin, "The Semikah Controversy," 242; P. R. Akroyd, "די," TDOT 5:423-24; J. C. Lambert and M. H. Shepherd, "Laying on of Hands," DB 572; Nicholaus Adler, "Laying-on of Hands," BEBT 2:495-96; CBTEL s.v. "Imposition of Hands"; TBD, s.v. "Hand"; David W. Baker, "Leviticus," in Leviticus, Numbers, Deuteronomy, ed. Philip W. Comfort, CBC 2 (Carol Stream, IL: Tyndale House, 2008), 22; Michael Fink, "Laying on of Hands," HCBD 413; Allan M. Hartman, "סמך," NIDOTTE 3:270-71; F. Stolz, "סמך," TLOT 2:805; New International Dictionary of the Bible, s.v. "Laying on of Hands"; Alexis Médebielle, "Le symbolisme du sacrifice expiatoire en Israel," Bib 2 (1921): 141-69, 273-302; Mark F. Rooker, Leviticus, NAC 3A (Nashville: Broadman \& Holman, 2000), 87-88; John E. Hartley, Leviticus, WBC 4 (Nashville: Thomas Nelson, 1992), 233; Gordon J. Wenham, The Book of Leviticus, NICOT 3 (Grand Rapids, MI: Eerdmans, 1979), 233; BEB 2, s.v. "Laying on of Hands"; NNIBD s.v. "Laying on of Hands"; Jacob Milgrom, "Sacrifices and Offerings, OT," IDBSup 765. Later on in his work, Milgrom switched from identification/transfer theory to ownership/transfer theory. David Daube, The New Testament and Rabbinic Judaism (New York: Arno Press, 1973), 225; J. R. Porter, Leviticus, CBC (Cambridge: Cambridge University Press, 1976), 19, 38; A. Noordtzij, Leviticus, trans. Raymond Togtman, BSC (Grand Rapids, MI: Zondervan, 1982), 57; Noam Zohar, "Repentance and Purification: The Significance and Semantics of חטשאת in the Pentateuch," JBL 107 (1988): 612-13; Erhard S. Gerstenberger, Leviticus: A Commentary, OTL 3 (Louisville: Westminister John Knox Press, 1996), 26, 30; Derek Tidball, The Message of Leviticus, BST (Downers Grove, IL: InterVarsity Press, 2005), 39-40.
}

${ }^{8} \mathrm{He}$ noted that scholars understood the laying on of hands differently, depending on which sacrifice it was related to. Starting from Kurtz's time, several scholars advocated that transfer occurred with regard to the sacrificial animal when laying on of hands took place on the animal of the burnt offering (Lev 1), peace-offering ( $\operatorname{Lev} 3$ ), sin-offering (Lev 4), and trespass offering (Lev 5). Opposing this interpretation was another group of scholars who held that transfer took place only in regards to the sin and trespass offering, and they attributed a different meaning when the rite was related to the burnt and peace offerings. Kurtz, Offerings, 86-87.

${ }^{9}$ Karl Christian Wilhelm Felix Bähr, Symbolik des Mosaischen Cultus, 2 vols. (Heidelberg: J. C. B. Mohr, 1839), 2:341. 
It seems that in Bähr's opinion, the meaning of the ritual activity consisted of two components: declaration of ownership by the offerer over the sacrifice which is considered as a gift, and giving up of that ownership so that the sacrifice can be devoted to God.

Johann K. von Hoffman, on the other hand, held that the rite meant that "what the person offering the sacrifice inwardly purposed to do, when bringing the animal to the Holy Place, was to render a payment to God; and he had full power to appropriate the life of the animal for the rendering of this payment." ${ }^{10}$ Later, in the second edition of his book, he modified his position and said that "an appointment of the animal for a slaughter, the object of which (as Delitzsch admits) was twofold, viz., to obtain the blood for the altar, and the flesh for the fire-food of Jehovah, whether the intention was to supplicate the mercy of God toward sinner, i.e., to make expiation, or (as in the case of the thank-offering) to present thanksgiving and prayer for the blessing of life." ${ }^{11}$ It seems that Hoffman held that the ritual meant an appropriation or appointment of the animal for slaughter, which would eventually bring expiation for the offerer's sins.

Opposition toward the transfer/substitution theory continued in the 20th century, as well; George F. Moore proposed a very similar conclusion to the one presented by Bähr. Moore summarized his position as follows: "The prevailing conception of sacrifice in the OT is that of the gift or present to God." ${ }^{2}$ As a gift, the sacrifice was a means of

\footnotetext{
${ }^{10}$ Johann C. K. von Hofmann, Der Schriftbeweis: Ein Theologischer Versuch (Nördlingen: C. H. Beck, 1857), 2:153-54.

${ }^{11}$ Kurtz, Offerings, 84.

${ }^{12}$ George. F. Moore, “Sacrifice,” EncyBib 4:4216.
} 
gaining God's favor. He strengthened his argument with the claim that the sacrificial substitution was neither present in biblical times, nor in post-biblical Judaism. ${ }^{13}$

In his paper from 1913, Henry P. Smith recognized that this ritual cross-culturally conveys transfer. This same understanding was effected in Ancient Israel in Lev 16:21 and Deut $21 .{ }^{14}$ However, he proposed a totally unique understanding of this ritual in Lev 8 and regular sacrifices - that laying on of hands transfers the sanctity from the sacrifice to the offerer. ${ }^{15}$ This understanding never received noteworthy attention by other scholars.

Six years after Moore published his article, William P. Paterson argued conversely that sacrificial substitution was indeed present in post-biblical Judaism. ${ }^{16}$

Paterson collected five arguments established by different scholars who wanted to dispute the transfer/substitution theory at the beginning of the 19th century, the time when Paterson wrote his article.

In the judgment of most modern scholars, the theory in question is untenable, and for the following reasons: (a) the death of the victim cannot have been vicarious, since sacrifice was not allowed for sins which merited death ( $\mathrm{Nu}$ 15:30), only for venial transgressions; (b) a cereal offering might also atone (Lv 5:11-13), and in this case there could be no idea of a penal substitution; (c) the victim was slain by the offerer, but on the theory in question should have been put to death by the priest as God's representative; (d) the assumption that the imposition of hands involved a transmission of guilt is inconsistent, not only with other references to this practice, but with the fact that the sacrificial flesh was treated as most holy, and might be eaten

\footnotetext{
${ }^{13}$ Moore, "Sacrifice," 4:4226.

${ }^{14}$ In texts from Greece, Egypt, and India, laying on of hands was practiced to convey transfer. Henry Preserved Smith, “The Laying-on of Hands,” AJT 17 (1913): 48-50, 55.

${ }^{15}$ Smith, "The Laying-on of Hands," 53, 55-57.

16Paterson, "Sacrifice,” DBDL 4:339-41.
} 
by the priest; (e) the central act of the sacrifice was, not the act of slaughtering, but the manipulation of the blood, which was presented to God. ${ }^{17}$

While some scholars rejected the transfer/substitution theory, others favored it and sought to prove its correctness. Thus, between 1921 and 1923, Alexis Medebielle published three articles and eventually a book as an attempt to defend the sacrificial substitution theory. ${ }^{18}$ Summarizing Medebielle's position, Rodríguez identified his four basic principles: "(1) Sacrificial substitution was a well-known practice in the ancient Near Eastern religions; (2) the basic meaning of the sacrifices is found in Lev 17:11; (3) the laying on of hands means transfer and substitution; and (4) the immolation of the victim represents the death of the sinner." 19

However, Medebielle's arguments for the transfer/substitution theory did not change growing negative attitudes towards this theory, and soon after his articles and book appeared in print, Dionys Schötz published his study of expiatory sacrifices in 1930. Schötz concluded that the idea of sacrificial substitution cannot be found in expiatory sacrifices. His argument is that slaughter was not the essential act in the animal sacrifice, but rather, blood manipulation, which he held was an act of consecration, not transfer. ${ }^{20} \mathrm{He}$ found support for his claim in the fact that Gen 22:1-19 and Deut 21:1-9 cannot be used to support the transfer/substitution theory because the sacrifices

\footnotetext{
${ }^{17}$ Paterson, "Sacrifice," DBDL 4:340.

${ }^{18}$ Alexis Médebielle, L'expiation dans l'Ancien et le Nouveau Testament (Rome: Institut Biblique Pontifical, 1923); Alexis Médebielle, "Expiation," DBSup 3:1-262; Médebielle, "Le symbolisme du sacrifice expiatoire en Israel," 141-69, 273-302.

${ }^{19}$ Rodríguez, "Substitution in the Hebrew Cultus," 9.

${ }^{20} \mathrm{P}$. Dionys Schötz, Schuld- und Sündopfer im Alten Testament (Braslau: Muller \& Sieffert, 1930), 111-12.
} 
mentioned in these verses were not expiatory sacrifices. ${ }^{21} \mathrm{He}$ also noted the difficulty of finding grounds for sacrificial substitution in the case of the peace sacrifice which, in his opinion, was probably the most common one. Thus, for Schötz, the sacrifice was essentially a gift to the deity and did not contain the idea of substitutionary atonement. ${ }^{22}$ Schötz agreed that the LXX translation of Lev 17:11 gives the notion of sacrificial substitution, but claimed that it is not present in the MT. ${ }^{23}$

In 1980 Angel M. Rodríguez defended his dissertation entitled, "Substitution in the Hebrew Cultus and in Cultic-Related Texts," which is the most comprehensive defense of the transfer/substitution theory up to the present time. ${ }^{24}$ Resistance towards this theory has continued, however. In 1985, David P. Wright collected five additional objections to this theory, adding to the list provided by Moore:

1. It is informed by the substitution theory of sacrifice which is untenable.

2. The main support of the transfer/substitution theory is the hand placement rite in Lev 16:21. Wright assumes that hand placement in Lev 16:21, performed with two hands, is different from hand placement with one hand, which is the procedure for other offerings. Hence, a difference in form suggests, a priori, a possible different meaning. He also claims that the scapegoat is not a sacrifice; it is merely a rite of elimination and therefore, cannot be used to interpret the gesture of hand placement in sacrifices.

\footnotetext{
${ }^{21}$ Schötz, Schuld- und Sündopfer im Alten Testament, 109.

${ }^{22}$ Schötz, Schuld- und Sündopfer im Alten Testament, 113. See also Rodríguez, "Substitution in the Hebrew Cultus," 10.

${ }^{23}$ Schötz, Schuld- und Sündopfer im Alten Testament, 114. See also Rodríguez, "Substitution in the Hebrew Cultus," 11.

${ }^{24}$ Rodríguez, "Substitution in the Hebrew Cultus," 11.
} 
3. It is difficult to apply the idea of transfer to guilt in the case of the well-being offering since it is not an expiatory offering like the purification and reparation offerings, and, to a certain extent, the burnt offering.

4. If the laying on of hands means transfer of guilt, then it is difficult to understand why it was not practiced on the purification or burnt offering commuted to a bird (Lev 1:14-17; 5:7-11).

5. The view of transfer of sin or penalty by hand placement is usually accompanied by the view that confession of guilt took place at the time of the hand placement There is no evidence, however, that confession took place at that time. The few examples of confession with a sacrifice place the confession before the sacrifice is even brought (Lev 5:5; Num 5:7). ${ }^{25}$

At the beginning of the 21 st century, five distinct theories were maintained as a possible explanation for the meaning of the ritual gesture of laying on of hands: (1) transfer/substitution theory, (2) identification theory, (3) consecration/dedication/presentation theory, (4) appropriation-ownership/designation theory, and (5) manumission theory. The last four theories will be summarized below and compared with the transfer/substitution theory.

The majority of the proponents of the identification theory claim that by placing one hand on the sacrificial animal, the offerer identified him-/herself with the animal, and by offering the animal, was offering him-/herself through it. ${ }^{26}$ However, when the ritual

\footnotetext{
${ }^{25}$ Wright, "The Gesture of Hand Placement," 437-38.

${ }^{26}$ Everett Fox, The Five Books of Moses: Genesis, Exodus, Leviticus, Numbers, Deuteronomy, SB 1 (New York: Schocken Books, 1995), 511; René Péter-Contesse and John Ellington, A Translator's Handbook on Leviticus, UBS Helps for Translators (New York: United Bible Societies, 1990), 14.
} 
gestures included placing both hands as in the scapegoat ritual, then it meant transfer. ${ }^{27}$

M. C. Sansom seemed to accept this theory as his initial understanding of the gesture, but he also allowed for the possible meaning of the victim's being the property of a particular individual and that it is presented in his behalf. Consequently, the ritual gesture signified "attestation (as much to the priest as to God) that the victim comes from this particular individual or group, that it is offered in his or their name, and that the fruit shall be his." 28 In order to encompass all these nuances of meanings, Sansom stated that the gesture signified that the sacrifice has a representative nature. ${ }^{29}$

The advocates of the consecration/dedication/presentation theory claim that the laying on of hands on the sacrificial animal signified the act of separation or setting apart from the larger group for a special purpose. By placing the hands on the animal's head, the offerer was dedicating the sacrifice to God and making it his/her own representative and substitute..$^{30}$

Advocates of the appropriation/ownership/designation theory hold that placing hand/s upon the sacrificial animal was a demonstration of the offerer's ownership over

\footnotetext{
${ }^{27}$ René Péter, “L'imposition des mains dans l'Ancien Testament," VT 27 (1977): 52. Péter holds that identification occurs only when the ritual is performed with one hand. J. A. MacCulloch, "Laying on of Hands," ERE 6:493-94; I. H. Marshal, "Laying on of Hands," NBD (1962), 724; I. H. Marshal, "Laying on of Hands," IBD 2:889; D. W. Wead, "Hands, Laying on of," ISBE 2:611; Henry Barclay Swete, "Laying on of Hands," DBDL 3:85; R. D. Parkins, "סמך," TWOT 2:628; RBD s.v. "Laying on of Hands"; Porter, Leviticus, 19. Even though Martin Noth used a term that would point to the transfer, he essentially thought of identification: "The 'laying' of the hand on the animal brought to the holy place for sacrifice is hard to explain. It may have its origin in special sacrificial rites, as in Lev 16:31, in the sense of the transference of the offerer's own person to the animal thus making the latter his substitute." Martin Noth, Leviticus: A Commentary, OTL (Philadelphia: Westminster Press, 1965), 22.

${ }^{28}$ M. C. Sansom, “Laying on of Hands in the Old Testament,” ET 94 (1983): 325.

${ }^{29}$ Sansom, "Laying on of Hands in the Old Testament," 325.

${ }^{30} D D B$ s.v. "Laying on of Hands"; Frank Thielman, "Laying on of Hands," BTDB 473; NWDB, s.v. "Laying on of Hands."
} 
the animal which he/she offers to God. In addition, the gesture meant that the benefit of that sacrifice belongs to the offerer. ${ }^{31}$ However, some proponents of this theory also see transfer of guilt as a meaning of the ritual gestures in some cases where the gestures occur, mainly in the case of the scapegoat. ${ }^{32}$ Roy Gane proposed a hybrid theory that encompasses the meanings of several theories. ${ }^{33}$ Basically, the ritual gesture expresses ownership of the offerer over the animal. Gane accepts Péter's distinction between the form of the gesture, one-hand and two-hand, but for him both forms "have a common denominator: each signifies a (different) kind of identification that is involved in transfer." 34 Transfer is accomplished through other required actions. Thus, the use of one hand signifies the transfer of the animal from the offerer to God, while the use of two hands, as in the case of scapegoat (with simultaneous confession), transfers moral sins to the goat. ${ }^{35}$ Gane's understanding of the ritual gesture seems to be identical to the position of Bähr. ${ }^{36}$ However, Gane's application of OT offerings to the sacrifice of Jesus Christ in

\footnotetext{
${ }^{31}$ Porter, Leviticus, 20; Wright, "The Gesture of Hand Placement," 437-39; Fox, The Five Books of Moses, 511. Followed by Tipei, The Laying on of Hands in the New Testament, 28-9.

${ }^{32}$ Norman H. Snaith, Leviticus and Numbers, CB 3 (London: Nelson, 1967), 30; Clyde M. Woods and Justin Rogers, Leviticus-Numbers, CPNCOTS (Joplin, MO: College Press, 2006), 42-43; Gane, Cult and Character, 245; Adrianus van den Born and Louis Hartman, "Imposition of Hands," EncDB 1044-45.

33"When hand-leaning is performed, it identifies the offerer/owner of the victim, to whom the benefits of the sacrifice accrue, within the context of transferring the offering material from the offerer to the deity." Gane, Cult and Character, 64.

${ }^{34} \mathrm{Gane}$, Cult and Character, 245.

${ }^{35}$ Gane, Cult and Character, 245.

${ }^{36}$ Page 4 in this study. Also, Rolf P. Knierim, Text and Concept in Leviticus 1:1-9: A Case in Exegetical Method, FAT 2 (Tübingen: J.C.B. Mohr (Paul Siebeck), 1992), 37-40.
} 
the NT reveals that he goes beyond Bähr's position by including the idea of transfer of sin and substitution. ${ }^{37}$

Supporters of the manumission theory propose that the laying on of hand/s on the animal's head meant "renunciation of personal possession" of the offerer. The emphasis in this theory is not on the fact that the animal is owned by the offerer, but rather, the offerer's willingness to give up his property. Most proponents of this theory do not deny the idea of substitution, but also do not hold it as the dominant one. ${ }^{38}$

Contrary to the proponents of other theories who include the idea of transfer/substitution, there are some who totally deny it. Some advocates of consecration/dedication/presentation claim that the ritual gestures "[meant] nothing more than a setting apart of the victim in consecration to its sacred purpose." ${ }^{39}$ For others, the ownership theory is an important component of the consecration/dedication/presentation theory since the presentation of the animal, marked by the laying on of hands, signifies transfer of ownership from the offerer to God. ${ }^{40}$

At least two proponents of the identification theory do not see any transfer in the gesture of laying on of hands. They claim that the gesture signifies only identification. ${ }^{41}$

${ }^{37}$ Roy E. Gane, Leviticus, Numbers, NIVAC 3 (Grand Rapids, MI: Zondervan, 2004), 68-9.

${ }^{38}$ Walther Eichrodt, Theology of the Old Testament, trans. J. A. Baker, 2 vols. (Philadelphia: Westminster Press, 1967), 2:165; E. Kautzsch, "Religion of Israel," DBDL Extra:720; Theodore C. Vriezen, An Outline of Old Testament Theology, 2nd ed., rev. and enl. (Oxford: Blackwell, 1970), 263.

${ }^{39}$ M. H. Shepherd Jr., "Laying on of Hands," IDB 3:521; R. K. Harrison, "Hands, Impositions of (Laying on of)," ZPEB 3:29; Philip J. Budd, Leviticus: Based on the New Revised Standard Version, NCBC (London: M. Pickering, 1996), 47.

${ }^{40}$ Baruch J. Schwartz, “Leviticus," in The New Interpreter's Bible: One-Volume Commentary, eds. Beverly Roberts Gaventa and David L. Petersen (Nashville: Abingdon Press, 2010), 59-60.

${ }^{41}$ W. H. Bellinger, Leviticus and Numbers, NIBCOTS 3 (Peabody, MA: Hendrickson, 2001), 20; Edward E. Nourse, "Laying on of Hands," FWNSBD 510. 
Most proponents of the appropriation/ownership/designation theory do not see any idea of transfer/substitution in this ritual gesture. Some hold that transfer is the correct meaning in the scapegoat ritual, but the scapegoat is not a sacrifice and therefore, the offerer's ownership of the animal remains the only correct meaning of the gestures in sacrificial contexts. ${ }^{42}$

At least one proponent of the manumission theory rejects the idea of transfer/substitution. His arguments are as follows: (1) transfer of sin/guilt would make sacrificial animals unclean and unsuitable to be brought to the altar, and (2) transfer is certain only in the case of the scapegoat which is not a sacrifice. ${ }^{43}$

Even though the initial and final goal of the present study was to identify the meaning/function of laying on of hands, it became clear in the course of the research of this topic and even in this short literature review that the meaning of this ritual gesture greatly depends on the understanding of the two other concepts, that is sin and atonement.

\section{Statement of the Problem}

Although the ritual gesture of laying on of hands has generated significant interest and extensive scholarly research from the beginning of the 19th century until the present, which underscores its importance in OT studies, no unified position has been reached.

\footnotetext{
${ }^{42}$ Wright, "The Gesture of Hand Placement," 437-38; David P. Wright, "Hands, Laying of," $A B D$ 3:47; Jacob Milgrom and David P. Wright, "סמך," TDOT 10:282-84. Wright holds that attributive identification, which assumes ownership, is the meaning when the ritual is performed with one hand. When the ritual is performed with two hands, then its meaning is designation. See also Wright, "The Gesture of Hand Placement," 436-38; Born and Hartman, "Imposition of Hands," 1044-45; Joseph Coppens, "Handauflegung," BHH 2:632; Samuel E. Balentine, Leviticus, IBCTP (Louisville, KY: John Knox Press, 2002), 23; Lloyd R. Bailey, Leviticus-Numbers, SHBC 3 (Macon, GA: Smyth \& Helwys, 2005), 48; Cecilia Wassen, "Laying on of Hands," NIDB 3:615; Frank H. Gorman, Leviticus, HCBC (San Francisco: Harper, 2000), 148.

${ }^{43}$ Merwe, "The Laying on of Hands in the Old Testament," 39-40.
} 
The fact that no biblical texts explicitly state the meaning of this ritual gesture further complicates identifying its meaning. Due to the absence of any explicit statement regarding the meaning of this gesture, a crucial factor that made the identifying its meaning even more difficult is the lack of a proper hermeneutical interpretative framework. The lack of clarity regarding the meaning/function of this ritual and the lack of a proper hermeneutical interpretative framework that includes a comprehensive exegetical analysis of relevant Pentateuchal passages and a broader interpretative framework suggests that further research is needed.

\section{Statement of Purpose}

The purpose of this dissertation is to form a hermeneutical interpretative framework based on the biblical texts, mainly those from the Pentateuch, in order to facilitate clarifying the theological meaning/function of the ritual gesture of laying on of hand/s. This hermeneutical interpretative framework includes an exegetical, contextual, and conceptual analysis of the key Pentateuchal texts in cultic ${ }^{44}$ contexts. The analysis includes passages where this ritual gesture is not found, even though it seems that it should be present. Inasmuch as they are foundational for the present study, and due to their interrelatedness, the concepts of sin and atonement in the OT are thoroughly researched and, as a result, redefined. Research on sin and atonement can provide a hermeneutical interpretative framework that facilitates identifying the meaning/

\footnotetext{
${ }^{44}$ Cultic text or contexts in the present study refer to biblical texts and contexts related to the cult. "Cult describes the entirety of religious actions and must be seen against the backdrop of the world view of a specific group.” Klingbeil, Bridging the Gap, 11. It “... consists of a specific number of rituals comprising subrites and distinct symbols." Klingbeil, Bridging the Gap, 8.
} 
function of this ritual gesture. These two concepts, sin and atonement, form the immediate literary and conceptual context of laying on of hands. From the exegetical, contextual, and conceptual findings, the proposed theories regarding laying on of hand/s is evaluated and a meaning of the ritual gestures is suggested.

\section{Justification of the Research}

Throughout the last two centuries, no unified position has been reached on the meaning of laying on of hands in cultic contexts of the Pentateuch. The reason for this lies partly in the presuppositions accepted by scholars who studied this ritual gesture. Some scholars have been significantly influenced in their interpretations by the NT understanding of atonement. Others have reacted against this methodology and have wanted to propose explanations free of NT influences. In the process of identifying the meaning of this ritual, major scholars have skipped or performed limited study of the concept of sin and at the same time understood the concept of atonement based on the ANE texts and the Bible. ${ }^{45}$ Ultimately, many scholars used phenomenological, textual, cultural-anthropological, socio-cultural, or comparative studies perspectives for understanding this ritual gesture. The conceptual import from the ANE texts is most frequent among biblical scholars who deal with ritual texts. ${ }^{46}$

\footnotetext{
${ }^{45}$ These unsound hermeneutical tendencies are exposed throughout the present dissertation.

${ }^{46}$ I will use as an example two prominent Pentateuchal scholars, David P. Wright and Bruce Wells as they propose meaning to two different ritual texts/concepts in the Pentateuch. Examining laying on of hands, Wright stated: "We now turn our attention to examples of a hand gesture from ancient Anatolia which has a meaning almost identical to that of sacrificial hand placement in the Bible. The Hittite literary corpus contains numerous examples of this gesture. But despite this fact, to my knowledge, very little has been written about it, either by itself or as it might relate to the biblical rite. Because of this lack of treatment and so that we will be able to perceive fully the similarity of the meaning of the Hittite gesture to that in the Bible, we need to enter a somewhat detailed discussion regarding the form and meaning of the Hittite gesture." Wright, "The Gesture of Hand Placement," 439-40. This detailed discussion takes place in
} 
Although the meaning of the laying on of hands in cultic Pentateuchal contexts has been the subject of significant interest and intensive study over the last two centuries, no comprehensive exegetical analysis of the passages or dissertation research dealing directly with this topic has yet been undertaken. The present dissertation attempts to provide a hermeneutical interpretative framework for laying on of hands. It first undertakes exploring the concepts of sin and atonement inasmuch as they are the key elements of the immediate literary and conceptual context within which laying on of hands is found. It also includes exegeting the key passages where this ritual gesture is found in the Pentateuch with the insights acquired through the study of sin and atonement. The ultimate goal is to form a system that rests on the data found in the Pentateuchal texts, but without imposing any system or interpretation based on extrabiblical sources. ANE texts will be sporadically consulted as a secondary tool, never as the primary.

\section{Scope and Delimitations of the Study}

This study will be exegetical, contextual, terminological, and conceptual in its

6.5 pages of an essay without any mention of method how to compare two texts originating from two significantly different historical eras and geographical locations. Wright himself stated that these two sets of texts are not necessarily coming from the same historical era. This study suggests that such a brief study is insufficient to establish the connection and the impact between these two sets of texts. In addition, the ANE texts corpus is unstable in the sense that it continues to grow, while the biblical corpus is completed. Attempting to give meaning to Lev 5:1 Wells suggested: "There are a number of Neo-Babylonian texts, however, that do not derive from law codes but that shed light on the use of this expression. These are records from trials and other legal contexts and prove helpful in understanding the function of the expression in Lev 5:1." Bruce Wells, The Law of Testimony in the Pentateuchal Codes (Wiesbaden: Harrassowitz, 2004), 72. 
scope and does not intend to extend into the areas of systematic theology, ritual studies, ${ }^{47}$ or ethics. The exegetical process will consist of a close reading of the biblical text on the following levels: historical context, grammar, semantics, syntax, historical and cultural background, genre, biblical context, text, structure, and theology. ${ }^{48}$ Texts in which the laying on of hands is found (Exod 29; Lev 1, 3, 4, 8, 16, 24; and Num 8) and where it is not found, but expected (Lev 1:10-11, 5, 6, 12, 14, 15 and 9, 16, 23; Num 6, 15, 28-29) will be exegeted in order to bring out as much data as possible from the texts themselves that will help to determine the biblical meaning/function of this ritual gesture. The exegesis of these texts is not exhaustive, but rather, focuses on the aspects of the analysis that will inform the meaning/function of the ritual gesture. Exegesis is not needed in cases of the multiple tables that are supplied in the present work, especially tables dealing

\footnotetext{
${ }^{47}$ For ritual theories based upon these disciplines see Wesley J. Bergen, Reading Ritual: Leviticus in Postmodern Culture, JSOTSupp 417 (London: T \& T Clark International, 2005), 1-12; David P. Wright, "Ritual Theory, Ritual Texts, and the Priestly-Holiness Writings of the Pentateuch," in Social Theory and the Study of Israelite Religion: Essays in Retrospect and Prospect, ed. Saul M. Olyan, RBS 71 (Atlanta: Society of Biblical Literature, 2012), 195-216; Ithamar Gruenwald, Rituals and Ritual Theory in Ancient Israel (Leiden: Brill, 2003), 1-39; Bryan C. Babcock, Sacred Ritual: A Study of the West Semitic Ritual Calendars in Leviticus 23 and the Akkadian Text Emar 446, BBRS 9 (Winona Lake, IN: Eisenbrauns, 2014), 1-78; Gane, Cult and Character; William K. Gilders, Blood Ritual in the Hebrew Bible: Meaning and Power (Baltimore: Johns Hopkins University Press, 2004); Jonathan Klawans, Purity, Sacrifice, and the Temple: Symbolism and Supersessionism in the Study of Ancient Judaism (Oxford: Oxford University Press, 2006); and Jay Sklar, Sin, Impurity, Sacrifice, Atonement: The Priestly Conceptions, HBM 2 (Sheffield: Sheffield Phoenix Press, 2005). These sources contain references to the previous generation of ritual scholars.

${ }^{48}$ For more details on exegetical analysis, see Walter C. Kaiser, Toward an Exegetical Theology: Biblical Exegesis for Preaching and Teaching (Grand Rapids, MI: Baker Book House, 1981), 24-36; Grant R. Osborne, The Hermeneutical Spiral: A Comprehensive Introduction to Biblical Interpretation (Downers Grove, IL: InterVarsity Press, 2006), 35-344; John H. Hayes and Carl R. Holladay, Biblical Exegesis: A Beginner's Handbook (Louisville: Westminster John Knox Press, 2007), 35-212; Otto Kaiser and Werner Georg Kümmel, Exegetical Method: A Student's Handbook (New York: Seabury Press, 1981), 1-41; Gordon D. Fee and Douglas K. Stuart, How to Read the Bible for All Its Worth (Grand Rapids, MI: Zondervan, 2003), 5-32; John Barton, Reading the Old Testament: Method in Biblical Study (Louisville, KY: John Knox Press, 1996), 20-236; W. Randolph Tate, Biblical Interpretation: An Integrated Approach (Peabody, MA: Hendrickson, 2008), 11-244; Mary H. Schertz and Perry B. Yoder, Seeing the Text: Exegesis for Students of Greek and Hebrew (Nashville: Abingdon Press, 2001), 19-148.
} 
with sin classifications. The reasoning behind these classifications is not stated since the questions pursued in them are very simple and in the majority of cases does not require extensive study.

The gesture of laying on of hands is embedded in the sacrificial offering process when the latter includes offering of an animal. Sin and/or general human sinfulness (GHS) stand in the background of multiple reasons that initiate offering of a sacrifice, such as acceptance, forgiveness, sanctification, and sin removal. The focus of the present research is not the sacrificial process itself, with its multiple reference points for potential research, even though attention is given to various elements in the analysis of certain ritual texts. Rather, it seeks to establish a broader hermeneutical interpretative framework to understand the meaning/function of the laying on of hand/s by studying the concept of sin in the Pentateuch, as one of its major triggers, along with the GHS, and atonement as a key sub-process of a broader process resulting from sacrificial offering. The present study follows mainstream OT atonement scholars who claim that, based on Lev 16:16, it is possible for the sin, both ritual impurity and moral, to be accumulated in the sanctuary. ${ }^{49}$ The two phase atonement is also accepted in this dissertation as a biblically sound concept. ${ }^{50}$

Besides basic theological concepts that connect the books of Exodus and Leviticus, the organic unity of the Pentateuch will play an important role throughout the

\footnotetext{
${ }^{49}$ Gane, Cult and Character, 158, 161, 178, 231, 279, 314, 352, 380; Maccoby, Ritual and Morality, 186; Milgrom, Leviticus 1-16, 260; Johann C. K. von Hofmann, Der Schriftbeweis, 2 nd ed. (Nördlingen: C. H. Beck, 1859), 2/1:257-58; J. H. Kurtz, Sacrificial Worship of the Old Testament (trans. James Martin; 1863; repr., Minneapolis, MA: Klock \& Klock, 1980), 142.

${ }^{50}$ See the scholarly sources for this theory and details about it in the subheading: Gane's Theory of Atonement and Understanding of מִ̣ in the present study.
} 
exegesis of the selected passages in order to determine the meaning of laying on of hand/s. This means that the Pentateuch is considered as an account of a continuous history and a literary whole written by a single author, Moses, in great part. ${ }^{51}$ The final form of the OT text is accepted as primary material for deriving conclusions in the present dissertation. The MT will be accepted as a basic source for the texts cited above and others used in the process.

\section{Methodology}

The introductory chapter includes a survey of the literature relevant to the meaning/function of the laying on of hands and classification of the main theories proposed by biblical scholars. Due to its scope, delimitations, and goal, the present study is divided into 3 major sections. The research in the first section is distributed in the second and third chapters and focuses on the concept of sin in the OT, specifically in the Pentateuch. The second chapter specifically deals with OT hamartiology, establishing a proper method to study sin in the OT and specifically, moral sin in the Pentateuch. The third chapter defines terminology that is used to express the nature of sin and the insights from the Modern Legal System (MLS) and biblical law (BL). Special attention was given to Lev 4-6.

The second section is spread over the fourth and fifth chapters and includes a reexamination of atonement in the Pentateuch. The study of רִִּ and other ways of atonement is studied in chapter four, which includes an in-depth analysis of Lev 17:11 and 10:17. Chapter five analyzes the automatic defilement hypothesis (ADH) that is

\footnotetext{
${ }^{51}$ Charles Elliott, "The Unity of the Pentateuch," HSt 2 (1883): 305, 308.
} 
embedded in the concept of sin and atonement by the majority of biblical scholars of the Ancient Israel cult.

The third section is covered in chapter six which presents the ritual theory adopted in this study ${ }^{52}$ and evaluates arguments biblical scholars have proposed against the transfer/substitution theory as the meaning of laying on of hands. Most of the attention is given to the transfer/substitution and ownership theories since these two are most debated in present scholarly dialogue. The present study proposes the meaning/function of the laying on of hand/s based on the understanding of the concepts of sin and atonement as its interpretative framework and evaluation of the arguments proposed against it.

The seventh chapter will provide a conclusion of the entire study. It presents the findings of the study in a coherent system where the details support the main goal of the study: the meaning/function of the laying on of hands in cultic contexts.

\footnotetext{
${ }^{52}$ This study does not apply any pre-formed ritual theories.
} 


\section{CHAPTER 2}

\section{OT HAMARTIOLOGY}

The first part of the first section covered in this chapter is divided into two major parts. In the first part, I identify certain elements embedded in the study of $\sin$ in the OT, such as obstacles, weaknesses, and various approaches that biblical scholars utilized to define sin. I also review developments of the understanding of this concept in the OT. Finally, having reviewed the major approaches and their weaknesses, I develop my own approach to counter the weaknesses detected in previous approaches, and ultimately, suggest a more solid and comprehensive understanding of sin.

With the knowledge acquired in the first part of this chapter, I undertake a more focused study of the terms terms play a key role in the overall understanding of atonement in the Pentateuch since they are used in crucial passages such as Lev 4 and 16. The study of these terms reflects a rigorous application of the approach developed in the first part of this chapter. The goal is to define the sins that these terms refer to and establish whether they are intentional or unintentional and expiable or inexpiable. ${ }^{1}$

${ }^{1}$ Two basic components in defining sin are sin's expiability and the sinner's intent. In terms of sin's expiability, intentional sin refers to both non-brazen and brazen sin which differ by the fact that the former is expiable and the latter is not expiable through the cult. In terms of the sinner's intent, the term intentional sin refers to the sin that is done with the sinner's full awareness and intent to perform activity and with the knowledge of the fact that that activity conflicts with God's revealed regulations. 


\section{OT Hamartiology: Obstacles, Weaknesses and Approaches}

This chapter deals with certain elements of OT hamartiology such as major obstacles, key approaches, insights from previous and research presented in the present study, and a terminological study of the three most relevant Hebrew terms for sin

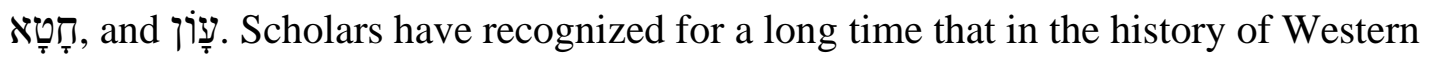
theological research, sin is one of the central, yet most complex concepts ${ }^{2}$ in the OT. ${ }^{3}$

\section{Obstacles to OT Hamartiology}

There is at least one literary (metaphorically) and two linguistically informed reasons for the difficulty related to the study of $\sin$.

First, the concept of sin has been expressed through several sets of different

In terms of sin's expiability, unintentional sin refers to the sin that is expiable if God's regulations to handle it are followed. In terms of the sinner's intent, the term unintentional sin refers to the sin that is done with the sinner's full awareness to perform activity that accidently or unknowingly turned into committing a sin. The intent to act was not to perform sin, but the act accidentally or unknowingly turned to be sin.

The use of terminology intentional/unintentional and expiable/inexpiable, along with their meaning in this study are fully defined and explained in the subheading "Intentional and Unintentional Sins in the Old Testament" on pp. 354-58 of the present study.

${ }^{2}$ In the present study, the term concept refers to units of thought without a firm position on their ontological status, that is, whether they are mental representations, abstract objects, or both. Joseph Ching Po Lam, "The Metaphorical Patterning of the Sin-Concept in Biblical Hebrew" (PhD diss., University of Chicago, 2012), 5. As will become obvious from the data derived from OT texts, the concept of sin is variously portrayed - sometimes as a mental representation, sometimes as an abstract object, and sometimes as both. However, since the core of this study does not examine the ontology of concepts, this will not be explored here. For a more elaborate study on the ontology of concepts, see Eric Margolis and Stephen Laurence, "The Ontology of Concepts-Abstract Objects or Mental Representations?," NOUSS 41 (2007): 561-93.

${ }^{3}$ Gnana Robinson, "A Terminological Study of the Idea of Sin in the Old Testament," IJT 18 (1969): 112; Robin C. Cover, "Sin, Sinners," ABD 6:31-40; Edward J. Young, The Study of Old Testament Theology Today (Westwood, NJ: F. H. Revell, 1959), 18, 20, 44, 70, 74, 82. 
metaphors in the OT. ${ }^{4}$ Some of the most frequent ones used to portray sin against God are rebellion (Ezek 2:3), forsaking and despising God (Isa 1:4), breaking the covenant (Deut 31:16), and so on. ${ }^{5}$ Based on the basic or literal meaning of the root חָָָא, Ryder Smith noted that $\sin$ is metaphorically expressed as missing the target (Judg 20:16), losing the path (Prov 19:2), and bearing the burden (Lev 20:20). ${ }^{6}$ The metaphors which focus on the effect of the sin on the people convey that sin: it defiles the people along with the land (Ezek 14:11; Lev 18:24-27), ensnares and rules over the people (Ps 119:133), causes the people to stumble (Ezek 7:19), separates the people from God (Isa 59:2), and causes the people to rot (Ezek 24:23). ${ }^{7}$

Second, the plethora of Hebrew terms was used to express this concept. ${ }^{8}$ The statistics of the terms employed vary from at least $10,{ }^{9} 28,{ }^{10}$ and $31^{11}$ to over $50 .{ }^{12}$ A high

${ }^{4}$ Jay Sklar, "Sin," OEBT 2:298; Charles Ryder Smith, The Bible Doctrine of Sin and of the Ways of God with Sinners (London: Epworth Press, 1953), 16-22; Phillip P. Jenson, "Sin," DOTHB 901. It has to be recognized that Smith's use of metaphors is usually closely related to the etymology of the Hebrew terms for sin.

${ }^{5}$ Sklar, "Sin,” 2:298-99.

${ }^{6}$ Smith, The Bible Doctrine of Sin and of the Ways of God with Sinners, 19.

${ }^{7}$ Sklar, "Sin,” 2:298-99.

${ }^{8}$ Cover, "Sin, Sinners," ABD 6:31; Robinson, "Terminological Study," 112; Sklar, "Sin," 2:298; Mark J. Boda, A Severe Mercy: Sin and Its Remedy in the Old Testament (Winona Lake, IN: Eisenbrauns,

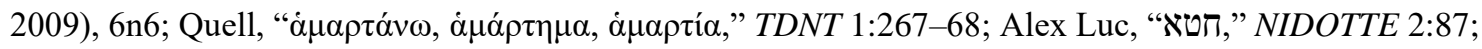
Ronald Youngblood, "A New Look at Three Old Testament Roots for 'Sin,"” in Biblical and Near Eastern Studies: Essays in Honor of William Sanford LaSor, ed. Gary E. Tuttle (Grand Rapids, MI: Eerdmans, 1978), 201; Gerhard von Rad, Old Testament Theology, trans. D. M. G. Stalker (Louisville: Westminster John Knox Press, 2001), 1:263.

${ }^{9}$ Luc, "חטא," NIDOTTE 2:87.

${ }^{10}$ Cover, "Sin, Sinners," ABD 6:31-40.

${ }^{11}$ E. Beaucamp, "Péché," DBSup 7:407-71; Cover, "Sin, Sinners," ABD 6:31-40.

${ }^{12}$ Sklar, "Sin," 2:298; Boda, A Severe Mercy, 6n16; Cover, “Sin, Sinners,” ABD 6:31-40. 
number of terms with a variety of contexts in which they are used and nuances they

emphasize are the primary reason why some purely terminological studies are not rewarding in their treatment of the subject. In addition, some terms are used very infrequently, which reduces the data base upon which one can establish the potential meaning of that particular term.

Third, in observing the irregularity and inconsistency of the LXX's use of Greek terms to translate the Hebrew terminology employed for the concept of sin, Gottfried Quell pointed to another issue related to the concept of sin:

The reasons for these defects in translation are not to be sought only in the methods of the translators, but also in the peculiar difficulty of the Hebrew usage. It is obvious that among the many words to be considered, none was exclusively devoted to religious and theological use and therefore, none constitutes an exact equivalent to the English "sin." All the Heb. words in question had a secular, as well as a religious sense, and, disparate though the relation often is, the very fact of this twofold usage constitutes a warning not to overestimate the purely religious content of the term. On closer inspection, all seem to be more or clearly the results of rational reflection which is religious in content. They are theologoumena rather than original terms of spontaneous experience, and the meaning falls into different groups. ${ }^{13}$

These are some of the difficulties which contributed to the complexity of studying and understanding sin. In Quell's understanding, the terminology in the first place was not strictly related to the specific activities, but rather was to convey the occurrence of a concept. He observed that six Greek terms were used to translate about 26 Hebrew expressions for $\sin ,{ }^{14}$ which further confirms his claim that the terms for sin refer to the

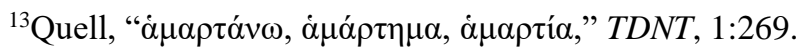

${ }^{14}$ There is no consensus among scholars on the definite number of terms used to refer to the concept of sin in the OT. Thus, this study will use the statistics used in the leading works on the topics. It does not intend to resolve this issue since determining the exact number of terms for sin is not crucial for the resolution of the problem as laid out in the introduction. 
concepts, rather than to the specific activities, the understanding that was also transferred into the Greek-speaking world. ${ }^{15}$

This conceptual understanding of sin was also endorsed by other scholars. Ghana Robinson noted that "the Old Testament writers were not interested in a theoretical or philosophical discussion of sin." ${ }^{\prime 16}$ Rather, as S. J. de Vries has pointed out, they only "strove to reflect in their rich and vivid terminology the profundity and the widespread effects of $\sin$ as they experienced it." 17

\section{Major Weakness of the OT Hamartiology}

To arrive at the conceptual understanding of sin, the above-mentioned scholars analyzed all or most of the OT texts. The method they used to arrive at this conclusion is based on the etymology of certain verbal and nominal terms for sin which, itself, has weaknesses. ${ }^{18}$ This approach of over-relying on the basic meaning of certain terms was correctly criticized by James Barr in his seminal work Semantic of Biblical Language. ${ }^{19}$

The essence of his critique is found in the following quotation:

Nevertheless there is a normative strain in the thought of many people about language, and they feel that in some sense the "original," the "etymological meaning," should be a guide to the usage of words, that the words are used 'properly" when they coincide in sense with the sense of the earliest known form from which their derivation can be traced; and that when a word becomes in some way difficult or

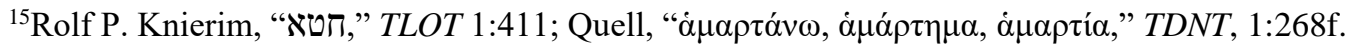

${ }^{16}$ Robinson, "Terminological Study," 112.

${ }^{17}$ Robinson, "Terminological Study,” 112.

${ }^{18}$ Lam, "Metaphorical Patterning,” 64-68.

${ }^{19}$ James Barr, The Semantics of Biblical Language (London: Oxford University Press, 1961).
} 
ambiguous an appeal to the etymology will lead to a "proper meaning" from which at any rate to begin. ${ }^{20}$

Based on the previous quotation, etymology is not a reliable guide in determining the meaning of words in all the contexts they are found in due to the fact that, as Barr continued, "the etymology of a word is not a statement about its meaning but about its history; it is only as a historical statement that it can be responsibly asserted, and it is quite wrong to suppose that the etymology of a word is necessarily a guide either to its 'proper' meaning in a later period or to its actual meaning in that period."21 While etymology is helpful in shedding light on the usages of a given word, context $\mathrm{t}^{22}$ seems to be a substantially more reliable guide than the historical meaning that was once associated with that particular word. Especially relevant for the Hebrew terms is the concept Barr labelled as "root fallacy:"

It seems to be commonly believed that in Hebrew there is a "root meaning" which is effective throughout all the variations given to the root by affixes and formative elements, and that therefore the "root meaning" can confidently be taken to be part of the actual semantic value of any word or form which can be assigned to an identifiable root; and likewise that any word may be taken to give some kind of suggestion of other words formed from the same root. This belief I shall for the sake of brevity call "the root fallacy.",23

\footnotetext{
${ }^{20}$ Barr, The Semantics of Biblical Language, 107.
}

${ }^{21}$ Barr, The Semantics of Biblical Language, 109.

${ }^{22}$ Context has been recognized as one of the crucial and the most important elements in biblical hermeneutics, at least since the 1980s and on, especially in the process of selecting the most appropriate meaning to Hebrew/Greek/Aramaic words. Context consists of multiple levels of which the basic ones are literary, historical, and logical. For a more in-depth analysis on the context in biblical hermeneutics, see Osborne, The Hermeneutical Spiral, 35-56, 97-99; Moisés Silva, Biblical Words and Their Meaning: An Introduction to Lexical Semantics (Grand Rapids, MI: Zondervan, 1983), 138-69; Walter C. Kaiser and Moisés Silva, Introduction to Biblical Hermeneutics: The Search for Meaning, rev. and exp. ed. (Grand Rapids, MI: Zondervan, 2007), 61-65; Lam, "Metaphorical Patterning," 66. Moises Silva went as far as to state that "the context does not merely help us understand meaning - it virtually makes meaning." Silva, Biblical Words and Their Meaning, 139.

\footnotetext{
${ }^{23}$ Barr, Semantics, 100.
} 
The weakness of the root fallacy is that it does not notice the potential semantic shift of given lexical items derived from a common root. In other words, the meaning of various root derivatives and roots themselves expand/change over time. Thus, once more, context is crucial to determining the most appropriate meaning in a given usage.

\section{Key Approaches to the OT Hamartiology and Their Weaknesses}

There are 3 basic types of analyses that scholars used in researching this concept ${ }^{24}$ but nonetheless, it has to be stated here that these types of approaches are not mutually exclusive as the reading of the works that utilize them shows. Even more, a slight or a greater overlap of two or even all three of them can be detected as one reviews the studies on hamartiology mentioned below. Thus, the taxonomy of the approaches rather indicates the emphasis each author placed on their analysis, rather than the totally unique and independent approach.

\section{Terminological Approach}

The first analysis is labelled terminological, in which the emphasis is placed on the meanings of certain, or a majority, or even all of the verbal or nominal derivatives of the Hebrew roots that are associated with sin. Most of the analysis of this type includes

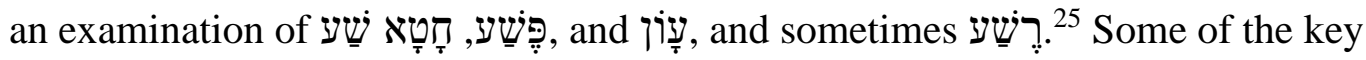
representatives of this approach are R. C. Cover, ${ }^{26}$ R. Y. Youngblood, ${ }^{27}$ S. Lyonnet and

\footnotetext{
${ }^{24}$ Lam, "Metaphorical Patterning," 64-139.

${ }^{25}$ Lam, "Metaphorical Patterning," 64-65.

${ }^{26}$ Cover, "Sin, Sinners," ABD 6:31-40.

${ }^{27}$ Youngblood, “A New Look,” 201-5.
} 
L. Sabourin, ${ }^{28}$ Štefan Porúbcan, ${ }^{29}$ and Rolf Knierim. ${ }^{30}$ The findings of some of these studies are considered later in the study and thus will not be presented here but it has to be noted that scholars of this approach noticed them.

Undeniably, this type of analysis is inescapable since it provides a basic step to gain understanding about a concept. However, the review of the studies in which this approach was utilized reveals some serious weaknesses. First, by dealing with so many terms that are associated with sin in the OT in its entirety, one is forced to be superficial in his/her analysis and insensitive to all the linguistic possibilities and literary particulars in regards to the terms in question due to the comprehensiveness of the scope of his/her study. ${ }^{31}$ Second, the context in which the term is used and all usages of a term have to be taken into consideration in order to gain a complete understanding. ${ }^{32}$ Finally, what lacks in some studies that were limited in scope to limited ability of a researcher to observe linguistic patterns that were utilized in regards to the uses of all the terms. ${ }^{33}$

\footnotetext{
${ }^{28}$ Stanislas Lyonnet and Leopold Sabourin, Sin, Redemption, and Sacrifice: A Biblical and Patristic Study, AB 48 (Rome: Biblical Institute, 1970), 12-16.

${ }^{29}$ Štefan Porùbčan, Sin in the Old Testament (Rome: Herder Roma, 1963), 4-107.

${ }^{30}$ Rolf Knierim, Die Hauptbegriffe für Sünde im Alten Testament (Gütersloh: Gütersloher Verlagshaus, 1965).

${ }^{31}$ Lam, "Metaphorical Patterning," 70-72.

${ }^{32}$ Rolf P. Knierim, "The Problem of an Old Testament Hamartiology: Considerations to the Book of Štefan Porúbcan, Sin in the Old Testament: Soteriological Study, Roma, 1963," VT 16.3 (1966): 384, doi:10.2307/1516567.

${ }^{33}$ Lam, "Metaphorical Patterning," 74.
} 


\section{Biblical-Theological Approach}

The second analysis is identified as biblical-theological and actually refers to the pool of approaches which emphasize broader, over-arching ideas and themes which come out of the historical-literal reading of the biblical texts. This approach assumes a solid philological interpretation which, in part, overlaps with the previous, terminological approach. As already mentioned above, a degree of emphasis and the organization of biblical texts are two points of difference between this and the previous approach.

This approach inclines toward merging the biblical material into an allencompassing view of a topic or a historical development of a concept during the biblical period. Works utilizing this approach do not offer fresh lexicographical or philological aspects of terms under question and the concept is described in relation to other biblical notions. ${ }^{34}$ The interrelatedness or organic relationship between some biblical concepts, in the opinion of the proponent of this approach, is so important that examining them in isolation "would destroy the organic texture of the texts and distort the results." 35

Representative scholars who employed this approach in their research on the concept of sin include Yehezkel Kaufmann, ${ }^{36}$ Walter Eichrodt, ${ }^{37}$ Gerhard von Rad, ${ }^{38}$

\footnotetext{
${ }^{34}$ Lam, "Metaphorical Patterning," 82-84.

${ }^{35}$ Jože Krašovec, Reward, Punishment, and Forgiveness: The Thinking and Beliefs of Ancient Israel in the Light of Greek and Modern Views, VTSupp 78 (Leiden: Brill, 1999), xvii; Boda, A Severe Mercy.

${ }^{36}$ Yehezkel Kaufmann, The Religion of Israel: From its Beginnings to the Babylonian Exile, trans. Moshe Greenberg (Chicago: University of Chicago Press, 1960), 292-95.

${ }^{37}$ Walther Eichrodt, Theologie des Alten Testament, trans. J. A. Baker, 3 vols. (Göttingen: Vandenhoeck \& Ruprecht, 1961), 2/3:264-345.

${ }^{38} \mathrm{Rad}$, Old Testament Theology, 1:154-60, 262-72.
} 
Brevard Childs, ${ }^{39}$ C. Ryder Smith, ${ }^{40}$ Jože Krašovec, ${ }^{41}$ and Mark Boda. ${ }^{42}$ Scholars following this approach usually linked the concept of sin to the topics of forgiveness, retribution/punishment, reward, confession, mercy, atonement, and so on. ${ }^{43}$ The intention in these studies was to integrate various insights about the concept of sin found throughout the entire canon into a general definition of it.

Thus, Eichrodt defined sin as "Verletzung des Gebots," or "die Sünde als Verletzung des Gebots." ${ }^{44}$ Von Rad, limiting material he examined to P and Ezekiel, suggested the conceptual understanding of sin as "any grave breach of this divine law which Israel knew both in the shape of the series of cultic commandments and in the shape of general 'unwritten' laws," 45 which, based on the terminological study which he also included, also includes its penalty. ${ }^{46}$ Kauffmann defined sin as rebelliousness: "The idea of man's rebelliousness, by which Genesis explains the origins of the human condition, is a fundamental idea of biblical literature and of Israelite religion in general. One might call the Bible a chronicle of human rebellion." 47 Press, 1986).

${ }^{39}$ Brevard S. Childs, Old Testament Theology in a Canonical Context (Philadelphia: Fortress

${ }^{40}$ Smith, The Bible Doctrine of Sin and of the Ways of God with Sinners, 15-22.

${ }^{41}$ Krašovec, Reward, Punishment, and Forgiveness.

${ }^{42}$ Boda, A Severe Mercy.

${ }^{43}$ Lam, "Metaphorical Patterning," 82-96.

44"Action contrary to the norm," or "transgression of the commandment." Eichrodt, Theology of the Old Testament, 2:265, 266.

${ }^{45} \mathrm{Rad}$, Old Testament Theology, 1:264.

${ }^{46} \mathrm{Rad}$, Old Testament Theology, 1:266.

${ }^{47}$ Kaufmann, The Religion of Israel, 295. 
The change that Childs contributed to this approach was his introduction of the canonical-theological element in which he claimed "that the object theological reflection is the canonical writing of the Old Testament, that is, the Hebrew scriptures which are the received traditions of Israel." 48 He defined sin as "the offence against the God of the covenant." ${ }^{\prime 49}$ Applying Child's extensions to the biblical-theological approach, Boda came up with the already seen definition of sin as "as a violation of God's command."50 However, Boda's conclusions on his findings on sin of each of the three parts of the OT are descriptive, rather than conceptual ranging from 2 to even 7 pages. His example, as well as those of the previous scholars associated with this approach, present the main weakness of this approach as verbalized by Lam:

Perhaps this is one of the weaknesses of the "canonical-thematic" approach: while it encourages the construction of theology based on exegesis of the individual literary portions of the Hebrew Bible, it encounters a greater obstacle at the level of synthesis, for there is no theoretical basis for synthesis beyond the historical principle of canon itself, which is by definition imposed on the material from the outside. ${ }^{51}$

The final results of this approach are always partially accurate with embedded incompleteness of their assessment of the concept of sin along with descriptiveness, rather than a precise definition of it. In addition to Lam's criticism, Barr noticed that "canonical criticism as it now stands, far from being the genuinely theological approach, lies in an uneasy balance between the historical, the literary and the theological, unable to

\footnotetext{
${ }^{48}$ Childs, Old Testament Theology, 6.

${ }^{49}$ Childs, Old Testament Theology, 87.

${ }^{50}$ Boda, A Severe Mercy, 517.

${ }^{51}$ Lam, "Metaphorical Patterning," 92.
} 
accept any one of them completely and unwilling to cut loose completely from any of them either." 52

\section{Metaphorical Approach}

The third analysis is metaphorical in its scope. Scholars using this approach attempted to explore specific themes relevant to sin, rather than endeavoring to describe sin in its entirety. The review of studies that utilized this approach shows that the concept of sin is mainly related to retribution, suffering, and impurity. ${ }^{53} \mathrm{~A}$ basic review of the association of sin with retribution and suffering is presented below. The relation of sin and impurity is not presented for multiple reasons, some of which follow.

First, impurity is just another term used by some key scholars, to which Lam referred under the subheading "Studies on Sin and Impurity" in his dissertation to denote sin in the OT. A review of some studies that use the term impurity undeniably refer to sin which is a concept rather than a metaphor. Lam himself recognized that. ${ }^{54}$ Second, a scholar's treatment of impurity as a metaphor is essentially minimal. One type of impurity, ritual impurity, is perceived by all scholars as a literal entity, while they are divided on the use of moral impurity. Third, none of the scholars who used the noun metaphor or more often, the adjective metaphorical proposed a valid explanation as to where to draw a line between the majority of literal uses and the few metaphorical uses of

${ }^{52}$ James Barr, Holy Scripture: Canon, Authority, Criticism (Philadelphia: Westminster Press, 1983), 104; Krašovec, Reward, Punishment, and Forgiveness, 10.

${ }^{53}$ Lam, "Metaphorical Patterning," 96.

${ }^{54}$ Lam, "Metaphorical Patterning," 128. 
impurity in the OT. ${ }^{55}$ Also, by rule, the definition of the metaphor is missing in those studies. Lam himself noticed that the studies on sin in the OT were closely related to the etymologies of certain terms for $\sin .{ }^{56}$ Some totally or almost always avoided metaphor in their studies.${ }^{57}$ The concept of metaphor was important for Neusner,${ }^{58}$ but Lam also noticed significant weaknesses of his use of metaphor. ${ }^{59}$ Milgrom and Wright used the terms metaphorical and metaphor, but in an inconsistent way. ${ }^{60}$ Klawans rejected metaphor as an option for expressing sin and proposed that sin/impurity, both ritual and moral, are real. ${ }^{61}$ Lam omitted reference to some significant scholars who tried to utilize metaphor in their studies on sin, but none of them offered what metaphor or metaphorical represented in their studies. ${ }^{62}$ Fourth, all these scholars were interested in delineating the nature of sin that is expressed in the OT texts, which is an attempt in the present study, rather than finding metaphors associated with sin. These are just some, but not all, of the significant reasons why considering impurity as a metaphor for sin seems to be an

\footnotetext{
${ }^{55}$ Lam, "Metaphorical Patterning," 128, 115.

${ }^{56}$ Lam, "Metaphorical Patterning," 65, 75, 89.

${ }^{57}$ Lam, "Metaphorical Patterning," 116-17, 123.

${ }^{58}$ Jacob Neusner, The Idea of Purity in Ancient Judaism (Leiden: Brill, 1973), 11.

${ }^{59}$ Lam, “Metaphorical Patterning," 114

${ }^{60}$ Lam, “Metaphorical Patterning,” 122, 125.

${ }^{61}$ Lam, "Metaphorical Patterning," 127.

${ }^{62}$ See Jonathan Klawans, Impurity and Sin in Ancient Judaism (New York: Oxford University Press, 2000), 32-33. For treatments of Helmer Ringgren, see Helmer Ringgren, "טהר," TDOT 5:291-95; G. André and Helmer Ringgren, "טמא," TDOT 5:331-40; Baruch A. Levine, Leviticus = [Va-yikra]: The Traditional Hebrew Text with the New JPS Translation, JPSTC 3 (Philadelphia: Jewish Publication Society, 1989), 134; Baruch A. Levine, Numbers 1-20, AB 4 (New York: Doubleday, 1993), 207; Baruch J. Schwartz, "Selected Chapters of the Holiness Code: A Literary Study of Leviticus 17-19" (PhD diss.,
} Hebrew University, 1987), xii. 
unjustifiable endeavor. One should, rather, look at it as the term some scholars used to refer to the concept of sin.

Among those scholars who studied sin in relation to retribution is Klaus Koch in his extensive article "Gibt es ein Vergeltungsdogma im Alten Testament?"63 His response to the question is that retribution is misleading when applied to biblical texts. Instead, Koch claimed that there is a link between a deed and its consequence. The latter is a fated result (good or bad) bound up with a deed in nascent form, the way a seed produces a plant. ${ }^{64}$ The change Koch brought to the discussion on the relationship between sin and retribution was a major alternative to the juridical view of divine retribution in the OT. This view generated a lot of criticism, even though it was accepted by many other scholars. ${ }^{65}$

As regards the question of the relationship between sin and suffering, scholars traditionally claimed that it is either literal-causal (sin causes suffering, either by the imposition of God or by some intrinsic effect of sin) or metaphorical (i.e., sin is being portrayed as physical suffering or sickness). Still, the predominant response is the former one and it is based on attempts to synthesize insights from biblical material. ${ }^{66}$ The views

\footnotetext{
${ }^{63}$ Klaus Koch, “Gibt es ein Vergeltungsdogma im Alten Testament?,” ZThK 52 (1955): 1-45.

${ }^{64}$ Koch, "Gibt es ein Vergeltungsdogma im Alten Testament?," 31.

${ }^{65}$ For a fuller discussion and critique of this view, see Lam, "Metaphorical Patterning," 97-100.

${ }^{66}$ Lam, "Metaphorical Patterning," 100-101.
} 
of Klaus Seybold, ${ }^{67}$ Michael Brown, ${ }^{68}$ Frederick Lindström, ${ }^{69}$ Karel van der Toorn, ${ }^{70}$ and Günter Röhser are some of the key studies in this regard. However, due to in-depth analysis devoted to these studies, along with critiques presented in Lam's work, it will not be replicated here. ${ }^{71}$

\section{Terminological/Contextual/Intertextual Approach}

Review of the findings of all these approaches makes it obvious that there is a tendency, or even necessity to portray $\sin$ as a concept. The terminology for sin is immense. Terms are associated with a variety of settings and contexts. All these facts related to sin add so many facets to it that treating it as a concept, as the research on the topic shows, seems to be a necessity and the correct way to approach the term. Thus, the conceptual understanding of sin is accepted in the present study. The present study seeks to explore the concept of $\sin$ in two steps.

The first step will be to derive the data about sin from texts. The focus of this step is to gather elements of the concept of sin from Pentateuchal texts and establish the meaning of the concept. This step consists in presenting and evaluating previous research on the concept and evaluating of the understandings of the key representatives of various

\footnotetext{
${ }^{67}$ K. Seybold and U. B. Mueller, Sickness and Healing, trans. D. W. Stott (Nashville: Abingdon, 1981).

${ }^{68}$ Michael L. Brown, Israel's Divine Healer, SOTBT (Grand Rapids: Zondervan, 1995).

${ }^{69}$ Fredrik Lindström, Suffering and Sin: Interpretations of Illness in the Individual Complaint Psalms, ConBOT 37 (Stockholm: Almqvist \& Wiksell International, 1994).

${ }^{70} \mathrm{~K}$. van der Toorn, Sin and Sanction in Israel and Mesopotamia: A Comparative Study, SSN 22 (Assen: Van Gorcum, 1985).

${ }^{71}$ See Lam, "Metaphorical Patterning," 101-9.
} 
schools of interpretations against the texts of the Pentateuch. This step will finally propose an understanding of the concept of sin based on the findings gained during the process.

The second step is reviewing the terminology used for sin. In order to avoid the fallacy of "defaulting" to the etymology, the present study will establish certain pattern that will consider certain elements of the literary context. This pattern will provide a more complete understanding of sin where context plays a key role in the process of determining the meaning of terms and the concept itself. The higher awareness of the literary and linguistic specifics found in the texts where terms are used is provided by

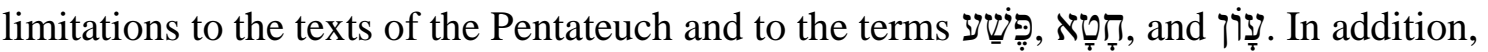
this will prevent this terminological study from the inadequacies noted in the previous

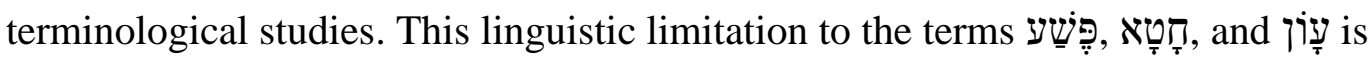
particularly relevant for the present study since its overall goal is linked to the removal of sin from the sanctuary and consequently, from the people on the Day of Atonement. The

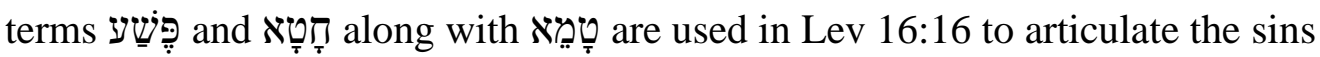
accumulated in the sanctuary while the list is modified in Lev 16:21 where and Notable scholars in the area of atonement and ritual studies in the OT have suggested that these three terms refer to very specific and particular types of sins. ${ }^{72}$ This step will examine whether the uses of these terms in the Pentateuch texts confirm such a claim.

\footnotetext{
${ }^{72}$ Gane, Cult and Character, 285-88; Jacob Milgrom, Leviticus 1-16, AB 3 (New York: Doubleday, 1991), 1034, 1044ff; Jacob Milgrom, Leviticus 23-27, AB 3B (New York: Doubleday, 2001), 3: 2460 .
} 


\section{Remarks on Sin and Impurity: Insights from the Previous Research}

A survey of scholarly attempts to define the concept of impurity in the OT shows

that there are two major schools. One school recognizes that there are two distinct types

of impurity, ${ }^{73}$ while the other school studies impurity as an organic whole. ${ }^{74}$ In regards to

the former proposal, one type is referred to as ritual and the other as moral impurity. Two questions permeated scholarly dialogue on the topic of impurity: (1) Is the division of impurity to ritual and moral plausible or it should be considered as a whole? and (2) What is the relationship between the two types of impurity? The goal of this section is based on the up-to-date scholarly findings and additional research provided in the present study and to suggest proposals on both of these questions.

The existence of one or two types of impurity and the relationship between possibly two types was considerably debated in the last century, ${ }^{75}$ and delineating the

\footnotetext{
${ }^{73}$ D. Hoffmann, Das Buch Leviticus (Berlin: Poppelauer, 1905), 1:301-8; Adolf Büchler, Studies in Sin and Atonement in the Rabbinic Literature of the First Century (London: Oxford University Press, 1928); Mary Douglas, Purity and Danger: An Analysis of Concepts of Pollution and Taboo (New York: Routledge, 2002); Hyam Maccoby, Ritual and Morality: The Ritual Purity System and Its Place in Judaism (New York: Cambridge University Press, 1999); Milgrom, Leviticus 1-16; Jacob Milgrom, Leviticus 1722, AB 3A (New York: Doubleday, 2000); Milgrom, Leviticus 23-27; Tikva Frymer-Kensky, "Pollution, Purification, and Purgation in Biblical Israel," in The Word of the Lord Shall Go Forth: Essays in Honor of David Noel Freedman in Celebration of His Sixtieth Birthday, eds. Carol L. Meyers and Michael Patrick O’Connor (Winona Lake, IN: Eisenbrauns, 1983); David P. Wright, "The Spectrum of Priestly Impurity," in Priesthood and Cult in Ancient Israel, eds. Gary A. Anderson and Saul M. Olyan, JSOTSup 125, eds. Gary A. Anderson and Saul M. Olyan (Sheffield: JSOT Press, 1991); Klawans, Purity, Sacrifice, and the Temple.
}

${ }^{74}$ Neusner, The Idea of Purity in Ancient Judaism; Thomas Kazen, "Dirt and Disgust: Body and Morality in Biblical Purity Laws," in Perspectives on Purity and Purification in the Bible, eds. Baruch J. Schwartz, et al. LHBOTS 474 (New York: T \& T Clark, 2008).

${ }^{75}$ Kazen, "Dirt and Disgust," 43; Maccoby, Ritual and Morality; Neusner, The Idea of Purity in Ancient Judaism; Klawans, Impurity and Sin in Ancient Judaism. The works of Jacob Milgrom, Tikva Frymer-Kensky, and David P. Wright can be added to the works listed in this footnote due to the considerable contribution of each author to the topic. 
types of this concept and their potential interrelatedness is a complex task. ${ }^{76}$ It seems that there are multiple reference points of the research on this concept in the OT which heavily influence the final outcome. ${ }^{77}$ The chronological development of this debate will be presented below, along with the arguments of the key representatives. The topic is still unsettled in scholarly debates regardless of massive attempts by biblical scholars to resolve it. ${ }^{78}$ This disagreement is more related to the question of the relationship of the two natures than to the number of natures.

Impurity in the OT in Modern Studies

\section{David Hoffmann}

The earliest attempt to define the relationship between two natures of impurity in the OT in modern times is that of David Hoffmann. ${ }^{79}$ In his significant commentary on Leviticus he divided impurities into two groups following a division accepted in various traditional Jewish sources. The first type of impurity, the ritual one, stands in opposition to purity, while the second type, the moral one, stands in opposition to holiness. ${ }^{80}$

The bipartite division to ritual and moral impurity was not an innovation developed by Hoffmann himself. Terminologically and conceptually, this division

\footnotetext{
${ }^{76}$ Sklar, Sin, Impurity, Sacrifice, Atonement, 140.

${ }^{77}$ Wright, "The Spectrum of Priestly Impurity," 151-52.

${ }^{78}$ Susan Haber, “They Shall Purify Themselves:” Essays on Purity in Early Judaism, ed. Adele Reinhartz, EJL 24 (Atlanta: Society of Biblical Literature, 2008), 10.

${ }^{79}$ Sklar, Sin, Impurity, Sacrifice, Atonement, 140-41; Kazen, "Dirt and Disgust," 42; Klawans, Impurity and Sin in Ancient Judaism, 5-6.13.

${ }^{80}$ Hoffmann, Das Buch Leviticus, 1:303-4.
} 
originated from Talmudic and medieval rabbinic literature down to Philo and the early rabbinic sages (the Tannaim) wherein this distinction of ritual bodily impurity and impurity resulting from sinful behavior was also debated. ${ }^{81}$

Hoffman categorized the sources of ritual defilement into three groups: (1) impurity contracted from a dead human (Num 19) or dead animal (Lev 11:24-40; 22:5);(2), impurity obtained from natural or unnatural genital discharges (Lev 15), childbirth (Lev 12), and leprosy (Lev 14); and (3) impurity attained via contact through ritual objects that rendered one impure like a scapegoat (Lev 16:26), a burnt sin offering (Lev 16:27-28), and the ashes for the water of cleansing (Num 19:7-10). These sources of impurity are discussed basically in Lev $11-15$ and Num $19 .{ }^{82}$ Ritual defilement, contrary to moral defilement, is symbolic and symbolizes $\sin .{ }^{83}$ Hoffmann noted that ritual impurity can be transferred to other humans and objects, but its effect is temporary and can be altered through a purification ritual. ${ }^{84}$

The second type of impurity originates from sinful behavior including eating forbidden foods, performing idolatrous acts, and various sexual sins. ${ }^{85}$ There is no means of purification for this type of impurity except for the sacrificial ritual on the Day of Atonement (Lev 16). ${ }^{86}$ Based on Lev 18:24-25, Hoffmann concluded that this impurity

\footnotetext{
${ }^{81}$ Klawans, Impurity and Sin in Ancient Judaism, 6.

${ }^{82}$ Hoffmann, Das Buch Leviticus, 1:303.

${ }^{83}$ Hoffmann, Das Buch Leviticus, 1:315, 340; D. Hoffmann, Das Buch Leviticus (Berlin: Poppelauer, 1906), 2:59.

${ }^{84}$ Haber, “They Shall Purify Themselves,” 10-11.

${ }^{85}$ Hoffmann, Das Buch Leviticus, 1:303; Hoffmann, Das Buch Leviticus, 2:22.

${ }^{86}$ Hoffmann, Das Buch Leviticus, 1:315.
} 
defiled the land and caused the exile of its inhabitants. ${ }^{87}$ In addition, based on Leviticus 11:43 and 19:31, this impurity affected the sinner's well-being. ${ }^{88}$ For this reason, Hoffmann also referred to this defilement as defilement pertaining to the soul. ${ }^{89}$ Although emphasizing that this defilement affected the soul of the sinner, he believed that it also defiled their body. ${ }^{90}$ However, the defilement by sin which was the concern of Lev 18 was of a different kind than the ritual defilement which was delineated in Lev 15. The latter one was temporal and could be removed by ablution, while the former one affected both body and soul and could not be removed by ablution. ${ }^{91}$ Commenting on the commandment against necromancy in Lev 19:31, Hoffmann concluded that this defilement, being moral in nature, affected both sinner's body and soul and, as a result, the sinner was rejected by God..$^{92}$ In his understanding, this defilement was concrete rather than symbolic. ${ }^{93}$

Hoffmann's division portrays two basic natures of the concept of impurity/sin. Sklar has correctly noted that this division does not differentiate defilement that originates from intentional and unintentional sins. In addition, symbolic correspondence between the three sources of ritual impurity and three different types of $\sin$ is

${ }^{87}$ Hoffmann, Das Buch Leviticus, 2:22.

${ }^{88}$ Hoffmann, Das Buch Leviticus, 1:303.

${ }^{89}$ Hoffmann does not provide his own conception nor that of Ancient Israel of the term soul in his commentary. The present study will also avoid this since it is not directly relevant to the current research.

${ }^{90}$ Hoffmann, Das Buch Leviticus, 1:340; Hoffmann, Das Buch Leviticus, 2:22.

${ }^{91}$ Hoffmann, Das Buch Leviticus, 2:22.

${ }^{92}$ Hoffmann, Das Buch Leviticus, 2:59.

${ }^{93}$ Hoffmann, Das Buch Leviticus, 1:340; Hoffmann, Das Buch Leviticus, 2:59. 
unconvincing due to the lack of objective criteria to support it. ${ }^{94}$ Susan Haber added more substantial criticism of Hoffmann's work by noting that his division of impurity to ritual and moral was driven by his dualistic view of humans to body and soul. The first was affected by ritual and the latter was affected by moral impurity. However, texts of the OT do not give support for the concept of human dualism. ${ }^{95}$

\section{Alfred Büchler}

Alfred Büchler followed Hoffmann in adopting a bipartite division of impurity, but used different terms for each impurity. However, Klawans noted that Büchler never settled on a fixed terminology regarding these two defilements which, beside other issues related to his work, ${ }^{96}$ seems to confuse the readers. ${ }^{97}$ However, instead of Hoffmann's ritual defilement, Büchler frequently used the term levitical defilement to refer to the defilement that originates in certain natural conditions. ${ }^{98}$ These defilements are outlined in the regulations found in Leviticus 11-15 and Numbers 19. He claimed that this defilement was impermanent contagion. ${ }^{99}$ For acts resulting from sinful behavior, he used multiple terms such as moral, spiritual, and religious, instead of Hoffmann's term moral defilement. ${ }^{100}$ Sklar noted that Büchler established four points of difference between these 86-88.

\footnotetext{
${ }^{94}$ Both these two types of sin produce defilement. See Sklar, Sin, Impurity, Sacrifice, Atonement,
}

${ }^{95}$ Haber, “They Shall Purify Themselves,” 11.

${ }^{96}$ For a critique of Büchler's work see Klawans, Impurity and Sin in Ancient Judaism, 6.

${ }^{97}$ Klawans, Impurity and Sin in Ancient Judaism, 6; Haber, “They Shall Purify Themselves, ” 12.

${ }^{98}$ Büchler, Studies in Sin and Atonement (1928), 214.

${ }^{99}$ Klawans, Impurity and Sin in Ancient Judaism, 5.

${ }^{100}$ Büchler, Studies in Sin and Atonement (1928), 229. 
two defilements. ${ }^{101}$ First, moral defilements are the result of some moral lapse. ${ }^{102}$ Second, moral defilements are cleansed via punishment, while levitical are cleansed by prescribed rituals. ${ }^{103}$ Third, moral defilements are not contagious, while levitical ones can be. ${ }^{104}$ Fourth, the biblical use of defilement language to discuss moral defilements is symbolic or figurative, while that is not the case with levitical defilements. ${ }^{105}$ Sklar's criticism of Hoffmann's work also applies to Büchler's. That is, Büchler does not differentiate between defilement that originates from intentional and unintentional sinful behavior. ${ }^{106}$

Both the works of Hoffmann and Büchler were neglected by subsequent scholars on purity/impurity due to their weaknesses and the style in which they were written. Klawans pointed out that Büchler's work is outdated in terms of methodology and the discovery of Qumran corpus. ${ }^{107}$ Sklar noted that neither of these two authors made a difference between the defilement that arises from unintentional and intentional sins and they did not discuss the difference between minor and major ritual/levitical defilements. ${ }^{108}$

${ }^{101}$ Sklar, Sin, Impurity, Sacrifice, Atonement, 142-43.

${ }^{102}$ Büchler, Studies in Sin and Atonement (1928), 220.

${ }^{103}$ Büchler, Studies in Sin and Atonement (1928), 225.

${ }^{104}$ Büchler, Studies in Sin and Atonement (1928), 235.

${ }^{105}$ Büchler, Studies in Sin and Atonement (1928), 237.

${ }^{106}$ Sklar, Sin, Impurity, Sacrifice, Atonement, 144.

${ }^{107}$ Jonathan Klawans, “The Impurity of Immorality in Ancient Israel," JJS 48 (1997): 1; Klawans, Impurity and Sin in Ancient Judaism, 5-14.

${ }^{108}$ Sklar, Sin, Impurity, Sacrifice, Atonement, 143-44. 


\section{Gedalyahu Alon}

Just two years before Büchler's death, Gedalyahu Alon published his first essay wherein he pioneered the thesis that the major impurity debate among ancient Jews concerned geographical boundaries of the realm of purity. ${ }^{109}$ Alon claimed that in the Second Temple period, two conflicting trends established themselves among Jews. One insisted on restrictions and limiting the laws of purity to the sphere of the Temple and priests, and the other one insisted on enlargement and extending these laws to be applicable to all of Israel. ${ }^{110}$ Based on this model, the Pharisees were maximalists, expanding the realm of purity beyond the temple limits, while the Sadducees were minimalists, restricting the realm of purity to the temple confines only. ${ }^{111}$ Alon's thesis was criticized in details by Sanders ${ }^{112}$ and proven to be problematic in terms of method and the interpretation of the evidence, ${ }^{113}$ nevertheless, along with Jacob Neusner's, Alon's works became the most influential treatments of the topic. ${ }^{114}$ Klawans correctly criticized Alon's proposal on the fact that the defiling force of impurity cannot be

\footnotetext{
${ }^{109}$ Klawans, Impurity and Sin in Ancient Judaism, 6.

${ }^{110}$ Gedalyahu Alon, Jews, Judaism and the Classical World: Studies in Jewish History in the Times of the Second Temple and Talmud (Jerusalem: The Magnes Press, 1977), 232.

${ }^{111}$ Klawans, Impurity and Sin in Ancient Judaism, 7.

${ }^{112}$ E. P. Sanders, Jewish Law from Jesus to the Mishnah: Five Studies (Minneapolis: Fortress Press, 2016), 183-353.

${ }^{113}$ Klawans, Impurity and Sin in Ancient Judaism, 7.

${ }^{114}$ Klawans, Impurity and Sin in Ancient Judaism, 6.
} 
exclusively in spatial/geographic terms only. ${ }^{115}$

\section{Jacob Neusner}

Jacob Neusner is an important scholar who evidently eliminated the distinction between ritual and moral impurity. That is especially obvious in his monumental work The Idea of Purity in Ancient Judaism. ${ }^{116}$ He suggested that "the notion of 'an ethical offense, a sin' evolved from the general class of 'acts that make you unfit for the holy community." "117 Neusner's work covers various corpuses such as (1) Hebrew Bible, (2) Qumran texts, (3) Second Temple Literature, and (4) Rabbinic literature. In regard to the Hebrew Bible, he stated that "the biblical corpus of ideas about purity may be divided into two distinct parts, the interpretation of purity and impurity as a metaphor of morality, on the one hand, and the specific laws about purity and impurity in connection with the Temple cult, on the other." 118

This statement is virtually identical to his conclusion on the purity/impurity in ancient Israel as the following quotation shows: "Two important ideas about purity and impurity come down from ancient Israel: first, purity and impurity are cultic matters; second, they may serve as metaphors for moral and religious behavior, primarily in regard to matters of sex, idolatry, and unethical action." 119

Neusner understood that purity/impurity is a single-nature concept but it can be

\footnotetext{
${ }^{115}$ Klawans, Impurity and Sin in Ancient Judaism, 6.

${ }^{116}$ Neusner, The Idea of Purity in Ancient Judaism, 1-2.

${ }^{117}$ Neusner, The Idea of Purity in Ancient Judaism, 25.

${ }^{118}$ Neusner, The Idea of Purity in Ancient Judaism, 11.

${ }^{119}$ Neusner, The Idea of Purity in Ancient Judaism, 108.
} 
interpreted in two different ways. In his opinion, the texts in the so called Priestly Law Code which are related to the cult ${ }^{120}$ are to be understood literally. On the other hand, texts from the rest of the Hebrew Bible are to be understood metaphorically ${ }^{121}$ and are related to moral behavior. ${ }^{122}$ These behaviors involve idolatry, illicit sexual relationships, which includes marital fidelity, and they all defile the land. ${ }^{123}$

However, Neusner was not able to uphold this distinction to the literal and metaphorical interpretation of the purity/impurity in his own work. Neusner equated his two distinct ways of interpreting purity/impurity laws by equating defilement of the people and the land through the land's connection to the cult in texts such as Lev 18:2425, Lev 20:25-26, and Num 35:34. ${ }^{124}$ In doing that, Neusner related both of his interpretations of impurity to the temple, and this association of impurity and the temple became fundamental to his understanding of impurity. ${ }^{125}$ The following quotation demonstrates that:

The Temple supplied to purity its importance in the religious life. As the Temple signified divine favour, and as the cult supplied the nexus between Israel and God, so purity, associated so closely with both, could readily serve as an image either of divine favor or of man's loyalty to god. From that fact followed the assignment of impurity to all that stood against the Temple, the cult, and God: idolatry above all.

${ }^{120}$ Neusner, The Idea of Purity in Ancient Judaism, 15.

121 "When we compare the references to purity in prophetic, sapiential, and historical literature with those presented in the priestly code of laws, we find a remarkable correspondence... the one represents in the context of concrete cultic ritual what the other describes in the setting of ethics, morality, or theology." Neusner, The Idea of Purity in Ancient Judaism, 24.

\footnotetext{
${ }^{122}$ Neusner, The Idea of Purity in Ancient Judaism, 13-15.

${ }^{123}$ Haber, “They Shall Purify Themselves,” 16.

${ }^{124}$ Lam, "Metaphorical Patterning," 113; Neusner, The Idea of Purity in Ancient Judaism, 20-21.

${ }^{125}$ Haber, “They Shall Purify Themselves,” 16.
} 
Neusner abandoned this dichotomy between literal and metaphorical understanding of purity/impurity as he studied this concept in two corpuses of literature, Qumran texts, and Rabbinic literature. In regards to Qumran texts, he stated: “One cannot distinguish between cultic and moral impurity. In themselves and in their consequences, they are identical." ${ }^{126}$ In regard to Rabbinic literature, Neusner noted that

the variety and character of the rabbis' list of social evils yielding leprosy-gossiping, selfishness, and the rest-are routine and unexceptional. Such commonplace social vices will characterize any sort of society. What is striking is not the catalogue of sins, therefore, but the imputation of leprosy as the result of those sins. This extreme interpretation begins with nothing more than the biblical use of impurity as a metaphor for sin. The metaphor is, however, shattered. Instead of maintaining impurity is like gossip of fornication, or gossip or fornication is like impurity, the rabbis held gossip or fornication produces impurity. ${ }^{127}$

The critique of Neusner's position on impurity/purity written by Mary Douglas is found in the appendix of his The Idea of Purity in the Ancient Judaism. The main thrust of her critique was directed towards Neusner's dichotomy between literal and metaphorical understanding of purity laws concerning the temple. In the Priestly texts, these laws are understood literally, while in the rest of the Bible, they are interpreted metaphorically suggested: "Since it is clear that the temple rules and sex rules and food rules are a single system of analogies, they do not converge on any one point but sustain the whole moral and physical universe simultaneously in their systematic interrelatedness. ${ }^{\prime 28}$

\footnotetext{
${ }^{126}$ Neusner, The Idea of Purity in Ancient Judaism, 54.

${ }^{127}$ Another way is to use metaphor transformed into allegory. Neusner, The Idea of Purity in Ancient Judaism, 117.

${ }^{128}$ Neusner, The Idea of Purity in Ancient Judaism, 140.
} 
Klawans took a further step in critiquing Neusner's work directly, and Douglas's critique indirectly, by stating that neither Neusner's nor Douglas's positions adequately make sense of the biblical impurity system. The question left unanswered is whether the defiling force of sin is merely a metaphor and whether the adulterer is considered to be ritually impure. Neusner would say "yes" to the first question, contrary to Douglas, while Douglas would say "yes" to the second question, contrary to Neusner. ${ }^{129}$

\section{Mary Douglas}

Some consider Mary Douglas as a proponent of one nature of impurity, ${ }^{130}$ but this is a too simplified portrayal of how she understood this concept. Douglas' Purity and Danger, published in 1966, has been recognized to advance the theoretical foundation for all subsequent works on ritual impurity in the OT. Some of her ideas were refuted and shown to be mistaken, ${ }^{131}$ but the basic claims of her work are still widely accepted. For the purpose of the present study, four of them will be summarized here. ${ }^{132}$

First, Douglas proposed that defilement is not a primitive concept. She challenged a conceptual barrier common for anthropologists and scholars of religion that the notions of defilement were totally absent from the categorization known to contemporary man. As a result, many scholars today recognize that all people in all times have concepts of

\footnotetext{
${ }^{129}$ Klawans, Impurity and Sin in Ancient Judaism, 11.

${ }^{130}$ Lam, “Metaphorical Patterning,” 110.

${ }^{131}$ Especially see Milgrom, Leviticus 1-16, 720-21.

${ }^{132}$ Klawans, Impurity and Sin in Ancient Judaism, 8.
} 
dirt and pollution which are structurally similar and can be compared in spite of their significant differences. ${ }^{133}$

Douglas's second suggestion is the claim that the conception of defilement is systematic in its nature in any given culture. Referring to pollution by analogy, she said that "where there is a dirt there is a system." Dirt, in any given system, is "matter out of place." 134 Douglas claimed that defilement is a structure and as such, all its components should be studied in the context of the system rather than as separate entities. ${ }^{135}$ For instance, the menstrual taboo cannot be properly understood by collecting examples from various cultures that shun this substance and then comparing the results. Rather, the systems of defilement should be studied, such as the way defilement is conveyed, the totalities of things that pollute, and so on. Her definition of pollution as "matter out of place" has not convinced all, ${ }^{136}$ but seeing systems of defilement still remains essentially unchallenged until the present. ${ }^{137}$

Third, building on the concept of purity/defilement as systematic was Douglas's next step in claiming that this system is symbolic. She saw a symbolic system at work in the fact that some animals are shunned, some body fluids are to be avoided, and so on. To Douglas, body symbolism was central in understanding the defilement system. Since the body symbolizes society, there is a correspondence between the attitudes toward societal

\footnotetext{
${ }^{133}$ Douglas, Purity and Danger, 35, 50. The entirety of both chapters, "Ritual Uncleanness" and "Secular Defilement" in Purity and Danger, point to this claim.

${ }^{134}$ Douglas, Purity and Danger, 44, 50.

${ }^{135}$ Douglas, Purity and Danger, 35.

${ }^{136}$ Milgrom, Leviticus 1-16, 721.

${ }^{137}$ Klawans, Impurity and Sin in Ancient Judaism, 8.
} 
and bodily boundaries. ${ }^{138}$ As a result, she also set forth a symbolic interpretation of the Israelite dietary laws. Here, symbolism is not found in the correspondence between the body and society, but between diet and the categories of creation. However, her symbolic interpretations of Leviticus 11 in light of Genesis $1^{139}$ are not universally recognized. ${ }^{140}$ Some notable theorists still believe that the ancient Israelite impurity system is $\operatorname{arbitrary.~}^{141}$

Fourth, Douglas also claimed that symbolic systems have social functions; they influence and control human behavior and interaction. They influence all social classes and control undesired social and sexual behavior. ${ }^{142}$ It is ironic, as Douglas noted, that such systems are likely to flourish in the absence of desired effective forms of social control rather than when the society has them. Note Douglas's statement:

When male dominance is accepted as a central principle of social organization and applied without inhibition and with full rights of physical coercion, beliefs in sex pollution are not likely to be highly developed. On the other hand, when the principle of male dominance is applied to the ordering of social life but is contradicted by other principles such as that of female independence, or the inherent right of women as the weaker sex to be more protected from violence than men, then sex pollution is likely to flourish. ${ }^{143}$

Keeping in mind these key claims of what Douglas' system consists of and of

${ }^{138}$ Douglas, Purity and Danger, 141-59.

${ }^{139}$ Douglas, Purity and Danger, 51-71.

${ }^{140}$ Howard Eilberg-Schwartz, The Savage in Judaism: An Anthropology of Israelite Religion and Ancient Judaism (Bloomington, IN: Indiana University Press, 1990), 177-79, 189-90, 218-19; Milgrom, Leviticus 1-16, 704-42.

${ }^{141}$ Jonathan Z. Smith, To Take Place: Toward Theory in Ritual (Chicago: University of Chicago Press, 1987), 108.

${ }^{142}$ Douglas, Purity and Danger, 3-4, 139-40.

${ }^{143}$ Douglas, Purity and Danger, 176. 
remarks she wrote particularly in the chapter "Internal Lines of her Purity and Danger," it can be inferred that her understanding of impurity is complex and cautious. There are statements that lead a person to conclude undoubtedly that Douglas saw defilement and sin as a single category, having one nature like the following one: "Pollution has indeed much to do with morals." 144 On the other hand, there are statements which point to the fact that she saw two natures of this concept, such as the following: "Pollution rule only highlights a small aspect of morally disapproved behavior." 145 Therefore, Klawans seems to be right in stating that Douglas's understanding on this phenomenon was rather more nuanced than that of scholars who made such claims based on her work. ${ }^{146}$

\section{Hyam Maccoby}

Hyam Maccoby believed that there is a basic distinction between ritual and moral in the OT, as well as in rabbinic literature. Ritual impurity originates from various actions and physical conditions, many of which are not sinful. Being ritually impure was never a sin and was limited to Israelites only. He claimed that "ritual purity forms part of the code of holiness, by which the Israelites were set apart as a 'kingdom of priests.' Other parts of this holiness code are the rules about permitted and forbidden foods, the rules about the Sabbath and the festivals, the rules about the performance of sacrifice in the

\footnotetext{
${ }^{144}$ Douglas, Purity and Danger, 160.

${ }^{145}$ The following statements and others in this chapter also point in the direction of two natures: "It is true that pollution rules do not correspond closely to moral rules." Douglas, Purity and Danger, 160. "Pollution rules, by contrast with moral rules, are unequivocal." Douglas, Purity and Danger, 162.

${ }^{146}$ Klawans, Impurity and Sin in Ancient Judaism, 9. For claiming Douglas's understanding of one nature of impurity, see Lam, "Metaphorical Patterning," 110-12.
} 
Temple. All these rules are laid down for Israelites alone."

On the other hand, "the laws of morality, which Israelites share with the rest of humanity, take precedence over them. In every case where there is a conflict between ritual and morality, ritual gives way to morality." 148

Maccoby denied that morality stands behind ritual laws and claimed that they are rather dedicatory in their nature and function. He followed the proposal of previous scholars ${ }^{149}$ in accepting that the cycle of birth and death is the rationale behind ritual laws in the OT. ${ }^{150}$ Observing that ritual impurity results from physical states and conditions related to birth (genital fluxes, childbirth) and death (corpses, scale-disease), he concluded that the ritual purity laws guarded the Temple/tabernacle not just from death, but from the entire cycle of mortality. In Maccoby's view, there is a significant gap between moral and ritual laws. For him, ritual laws are related to the Temple/tabernacle, while moral laws are applicable to both Jews and non-Jews. Even though Maccoby's work encountered dispute and critique on some points, especially the metaphorical use of

\footnotetext{
${ }^{147}$ Maccoby, Ritual and Morality, 193.

${ }^{148}$ Maccoby, Ritual and Morality, 193.
}

${ }^{149}$ Milgrom traced this proposal to Rachel Adler, whose quotation states: "Begetting and birth are the nexus points at which life and death are coupled. ... The nexus points are those in which there appears to be a departure or a transfer of vital force." Rachel Adler, "Tumah and Taharah: Ends and Beginnings," in The Jewish Woman: New Perspectives, ed. Elizabeth Koltun (New York: Schocken, 1976), 65-66. Even before R. Adler, Walter Kornfeld also recognized that the threat to life is a rationale for impurity in Lev 11-15. Walter Kornfeld, "Die Unreinen Tiere im Alten Testament," in Wissenschaft im Dienste des Glaubens: Festschrift für Abt Dr. Hermann Peichl, O.S.B., Präsident der Wiener Katholischen Akademie, dargeboten zum 35. Abtjubiläum, eds. Josef Kisser, et al., Studien der Wiener Katholischen Akademie 4 (Wien: Wiener Katholische Akademie, 1965), 11-17. This same position was subsequently accepted by Paschen and Wenham. For further discussion, see Milgrom, Leviticus 1-16, 767-68.

${ }^{150}$ Wilfried Paschen, Rein und Unrein: Untersuchung zur Biblischen Wortgeschichte, SANT 24 (München: Kèosel-Verlag, 1970), 60-64; Adler, “Tumah and Taharah,” 65-66; Tidball, The Message of Leviticus, 167. 
impurity terminology in Lev 18 and 20 and insistence on the total separation between moral and ritual laws, ${ }^{151}$ his fresh emphasis on mortality as a rationale for the ritual laws, along with the division of moral and ritual impurity, were welcomed among scholars.

\section{Jacob Milgrom}

The understanding of impurity in the works of Jacob Milgrom ${ }^{152}$ is informed by his application of critical approaches of redaction criticism ${ }^{153}$ and source criticism to the OT texts. ${ }^{154}$ He believed that Leviticus comprises two sources—-the so-called P source/tradition, which is mostly found in Lev 1-16, and the $\mathrm{H}$ source, which is found in Lev 17-27. However, P source is also found in H texts and vice versa, but in a rather small number of texts. ${ }^{155}$ In Milgrom's system, impurities in these two sources in Leviticus differ greatly. In P, טָָָָ strictly means ritual impurity, referring to three sources of impurity: (1) corpse, (2) scale disease, and (3) genital discharges. In H, to the contrary, it is used metaphorically in non-ritualistic contexts such as the law against adultery (Lev 18:20) and other sexual violations (Lev 18:24), and Israel's land (Lev 18:25-28). ${ }^{156}$ Klawans noted that three of the four claims of Douglas's ritual theory mentioned above

\footnotetext{
${ }^{151}$ Christine Hayes, "Ritual and Morality: The Ritual Purity System and Its Place in Judaism: A Review Article,” JQR 93 (2002): 287-92; Klawans, Impurity and Sin in Ancient Judaism, 32-36.

${ }^{152}$ The analysis of impurity in Milgrom's works presented in the current research is based on Jonathan Klawans' article "Ritual Purity, Moral Purity, and Sacrifice in Milgrom's Leviticus" which will be cited below.

${ }^{153}$ Milgrom, Leviticus 1-16, 2.

${ }^{154}$ Milgrom, Leviticus 1-16, 2, 61-63.

${ }^{155}$ Milgrom, Leviticus 1-16, 1, 3-25.

${ }^{156}$ Milgrom, Leviticus 1-16, 37.
} 
greatly impacted Milgrom's understanding of ritual impurity. First, avoidance behaviors are not inherently or distinctively primitive. Second, avoidance rules in any culture as a system form a coherent definition of things which are permitted or forbidden, and things that are sacred and defiled. Third, a system as such is symbolic in its nature. As a result of adopting these claims, Milgrom treated ritual impurity as a system wherein rules for certain ritual impurities apply to other impurities similar to them, even though they are not stated in the latter, but only the former texts. ${ }^{157}$

He also endorsed the fact that the entire system of ritual impurities has death as a common denominator, admitting that this rationale was suggested by many other scholars ${ }^{158}$ first by A. Dillmann and V. Ryssel in $1897,{ }^{159}$ and later by Feldman, ${ }^{160}$ and Füglister in $1977 .^{161}$

Klawans traced the first-time occurrence of this suggestion even earlier, namely to the work of Edersheim ${ }^{162}$ in $1874 .{ }^{163}$ This systematic and symbolic understanding of ritual impurity is thoroughly developed in the first volume of Milgrom's Anchor Bible

\footnotetext{
${ }^{157}$ Milgrom, Leviticus 1-16, 45-46. To see how this is an accurate assessment of Milgrom's systematic understanding of ritual, see Jonathan Klawans, "Ritual Purity, Moral Purity, and Sacrifice in Jacob Milgrom's Leviticus," RSR 29.1 (2003): 20. To see Milgrom's symbolic interpretation of ritual, see Klawans, "Ritual Purity," 20-21.

${ }^{158}$ Milgrom, Leviticus 1-16, 1001-2.

${ }^{159}$ A. Dillmann and V. Ryssel, Die Bücher Exodus and Leviticus (Lepizig: Hirzel, 1897), 523.

${ }^{160}$ Emanuel Feldman, Biblical and Post-Biblical Defilement and Mourning: Law as Theology (New York: Yeshiva University Press, 1977), 13-30.

${ }^{161}$ Notker Füglister, "Sühne durch Blut: Zur Bedeutung von Leviticus 17, 11," in Studien zum Pentateuch: Walter Kornfeld zum 60. Geburtstag, ed. Georg Braulik (Wien: Herder, 1977).

${ }^{162}$ Alfred Edersheim, The Temple: Its Ministry and Services as They Were at the Time of Jesus Christ (London: Religious Tract Society, 1908), 348-50.

${ }^{163}$ Milgrom, Leviticus 1-16, 1002.
} 
Commentary, Leviticus $1-16$ which was published in $1990 .{ }^{164}$

Besides ritual impurity, Milgrom endorsed the existence of moral impurity, which works very differently than ritual impurity. Milgrom has done this by studying the defiling force of these two impurities. Agreeing with previous scholars who adopted two natures of impurity, Milgrom noted that contrary to ritual impurity defilement that originates from various sources of defilement and refers to the state, moral impurity originates from sinful actions ${ }^{165}$ and does not defile the sinner in any distinct way. ${ }^{166}$ The defining power of moral impurity is directed towards the sanctuary, not the sinner, and, in Milgrom's view, cleansing of the sanctuary from this impurity is achieved via a sin, or as he renamed it, a purification offering. ${ }^{167}$ Being informed by Milgrom's theory of the

\footnotetext{
${ }^{164}$ Klawans, "Ritual Purity,” 21.

${ }^{165}$ Milgrom, Leviticus 1-16, 256.

${ }^{166}$ Klawans, "Ritual Purity,” 21.
}

${ }^{167}$ The first attempts to establish purification offering translation for the first half of the twentieth century. James Barr and A. R. S. Kennedy, "Sacrifice and Offering," DB 874. However, Milgrom was the most influential proponent of this translation in modern times. He claimed that

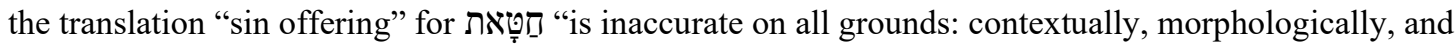
etymologically" Milgrom, Leviticus 1-16, 253. This is an overstatement, and it is more accurate to say that this translation is partially inaccurate. All the arguments he cited to support this claim are informed by the

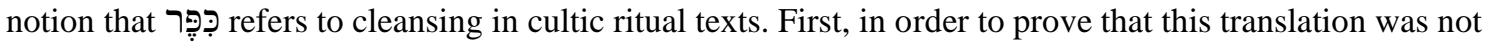
contextually supported, he cited Lev 8; Exod 29:36-37; Lev 12, and Num 6 and concluded that "the hatt $\bar{a}$ 't is prescribed for persons and objects who cannot have sinned." Milgrom, Leviticus 1-16, 253. It is impossible to suppose that the persons involved in the events these texts record would not sin during periods of different lengths after which they were required to offer a sin offering (Lev 12, Num 8) or were offering sin offerings on a daily basis (Lev 8; Exod 29:36-37). For instance, a new mother is prohibited from coming to the sanctuary and subsequently offering any kind of sacrifice forty or eighty days, depending on the child's gender. Failing to include in his atonement theory GHS as a constant disadvantage of human beings before God and the necessity that actual sin could have been committed by the participant of the events described in these texts, caused him not to see that the sacrifice involved in mending those experiences, actually deals with sin or GHS. Consequently, the texts Milgrom selected to support his contextual argument do not support it if GHS and actual sin are considered. Second, Milgrom's morphological argument was anticipated by James Barr already in 1963. Barr and Kennedy, "Sacrifice and

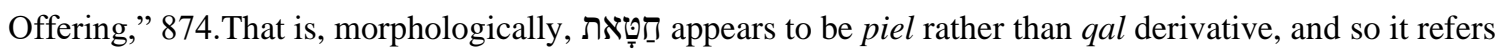
to cleansing or decontaminating. Milgrom added that "water of functions. It is correct that in a limited number of texts, 
sacrifice in Lev 4-5, some scholars concluded that passages like Lev 18:24-31, Lev

20:1-3, and Num 35:33-34, which are associated with moral impurity and use purity terminology, represent a metaphorical use of purity language. However, a number of others, to the contrary, concluded that these texts use purity language literally as the ritual texts do. The land is defiled in some way by the grave sins listed in these texts. ${ }^{168}$ The same line of interpretation was suggested by Hoffmann and Büchler almost a century ago, as shown above, and it was taken up by some modern scholars as well, ${ }^{169}$ whose systems will be presented below.

Thus, the works on moral defilement by other scholars in the $90 \mathrm{~s}^{170}$ were

most cases, חסטָטָאת atones individuals/groups because of their sin or GHS based on ransom as established in

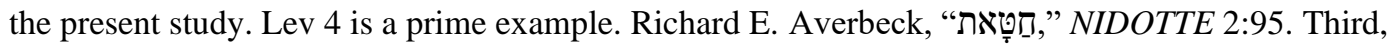
Milgrom's etymological argument is unconvincing since the sources he cited-LXX, Philo (Laws 1. 226), Josephus (Ant. 3.230), and Rabbi Eliezer (m. Zebah. 1:1) —all follow sin offering translation. Milgrom did cite two other rabbinic references (b. Šebu. 8a; Ker. 26a) which are insufficient to prove that הַטָָ is

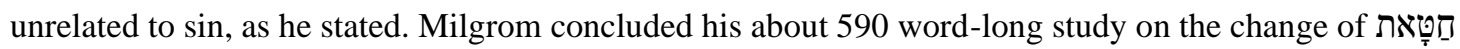
translation from sin offering to purification offering with the following statement: "The advantage of freeing the hatt $a^{\prime} t$ from the theologically foreign notion of sin and restoring to it its pristine meaning of purification is that now it is possible to see this sacrifice in its true ancient Near Eastern setting. Israel was part of a cultic continuum which abounded in purifications both of persons and of buildings, especially sanctuaries. The hatt ${ }^{\prime} t$, I aver, is the key that opens the door to this world (for details see Milgrom 1971a)." Milgrom, Leviticus 1-16, 254. Based on the study of hamartiology and atonement presented in the current study, Milgrom's freeing חַטָטָת from its relations to sin by suggesting its name of purification offering instead of sin offering is not advantageous in discovering its correct meaning/function, but rather a disregard of explicit statements in biblical texts, as well as an overall biblical portrayal of human nature and the complexity of divine-human interaction due to human nature. Removing sin or, in Milgrom's words "cleansing," is a very limited function of הַטָָאת while atonement of human beings because of their sin or GHS is much more frequent. Therefore, sin offering remains better, even though not the best translation, of חָָָּאת. It is certainly significantly more accurate than purification offering.

${ }^{168}$ The three main impurities outlined in these texts are sexual immorality, idolatry, and murder, respectively. Other texts, outside of the Pentateuch, also speak about these three sins: Jer 2:4-7; Ezek 22:14; Ps 106:34-42.

${ }^{169}$ See below works of Frymer-Kensky, "Pollution, Purification"; Wright, "The Spectrum of Priestly Impurity"; Klawans, Impurity and Sin in Ancient Judaism.

${ }^{170}$ Frymer-Kensky, "Pollution, Purification"; Wright, "The Spectrum of Priestly Impurity"; Klawans, Impurity and Sin in Ancient Judaism, 26-31. 
informed by Milgrom's two claims: (1) a systematic look at ritual defilement which paved the way for also considering moral defilement as a set of regulations that operates in a coherent fashion and (2) like ritual impurity, moral impurity is also symbolic and forms a background of his understanding of the sacrifice outlined in Lev 4-5. However, Klawans noted that Milgrom's own work on moral impurity in the second volume of his Anchor Bible Commentary, Leviticus $17-22$, published in $2000,{ }^{171}$ was not systematic. While Milgrom included multiple excursuses or digressions in Leviticus 1-16 to develop his systematic approach to ritual impurity, such an approach on moral impurity is absent from the subsequent volume on Leviticus 17-22. He uses other terms such as metaphorical impurity ${ }^{172}$ and non-ritual impurity ${ }^{173}$ to refer to moral impurity. Klawans claimed that "in these cases [referring to the references from Milgrom's Leviticus 17-22], the adjectives are not the additional ones qualifying a description of moral impurity; rather these adjectives are used instead of the referent 'moral."'174 Milgrom was also inconsistent in using the term "impure" because, in a number of instances, he used it metaphorically, ${ }^{175}$ while in a number of other instances, he used it literally. ${ }^{176}$ The lack of a terminological consistency along with the absence of tables to map out moral impurity, which are noticeable in great numbers in Leviticus $1-16$ in relation to ritual impurity,

\footnotetext{
${ }^{171}$ Milgrom, Leviticus 17-22.

${ }^{172}$ Milgrom, Leviticus 17-22, 1353.

${ }^{173}$ Milgrom, Leviticus 17-22, 1404, 1572.

${ }^{174}$ Klawans, "Ritual Purity," 22.

${ }^{175}$ Milgrom, Leviticus 17-22, 1326-27, 1353, 1438, 1702.

${ }^{176}$ Milgrom, Leviticus 17-22, 1578-79.
} 
shows a deficiency of a developed system of moral impurity in Milgrom's work. ${ }^{177}$

Milgrom's approach to all 3 main sources of moral impurity is different. He claimed that the act of murder defiles the land (Num 35:33-34) as an age-old notion based on texts such as Gen 4:10-12 and Deut 21:1-9. ${ }^{178} \mathrm{He}$ affirmed that the defilement in this case is literal. ${ }^{179}$

However, Milgrom claimed that the sexual prohibitions of Lev 18 and their defiling effect on the land involve a metaphorization of the earlier idea that murder defiles the land in a literal way. This metaphorization takes place at two levels: (1) In Lev 18, טָָמָא is used metaphorically, contrary to its literal use in ritual impurity texts, so-called $\mathrm{P},{ }^{180}$ and (2) Lev 18 developed and applied to sex the earlier ideas applicable to murder only. ${ }^{181}$ The latter level is based on the following quotation: "Thus whereas homicide literally pollutes the area where the blood is spilled, in $\mathrm{H}$, sexual violations metaphorically pollute the entire land."182

Milgrom's treatment of the defiling force of idolatry is the most complex one. His treatment of idolatry is actually limited to Molech worship (Lev 20:1-3), and he claimed that its defiling force is limited to the sanctuary only. ${ }^{183}$ This mode of sanctuary

\footnotetext{
${ }^{177}$ Klawans, "Ritual Purity,” 22.

${ }^{178}$ Milgrom, Leviticus 17-22, 1573, 1579.

${ }^{179}$ Milgrom, Leviticus 17-22, 1438.

${ }^{180}$ Milgrom, Leviticus 17-22, 1326-27.

${ }^{181}$ Klawans, "Ritual Purity,” 22.

${ }^{182}$ Milgrom, Leviticus 17-22, 1579, 1438.

${ }^{183}$ Milgrom, Leviticus 17-22, 1729-38, especially 1730 and 1734 . This is also claimed in his comment on Lev 19:31. Milgrom, Leviticus 17-22, 1702.
} 
defilement is based on Milgrom's proposal postulated in his article "Israel's Sanctuary: The Priestly 'Picture of Dorian Gray"' wherein he proposed that the impurity defiles the sanctuary without any threat to the land. ${ }^{184}$

In order to maintain this claim, Milgrom had to propose two additional claims. First, idolatry is not morally defiling in $\mathrm{H}^{185} \mathrm{He}$ did so by stating that the defiling force of idolatry is evident in $\mathrm{H}$, but it is limited to Molech worship. ${ }^{186}$ In general, idolatry is not defiling ${ }^{187}$ Encountering the fact that the defiling force of idolatry is evident and well established among seventh-century prophets, Milgrom claimed that based on the defiling effect of Molech worship, they adopted the view that all forms of idolatry are defiling. ${ }^{188}$

Second, since Molech worship is mentioned in Lev 18:21, Milgrom had to address this text, since in this text, Molech worship, like other sins enumerated in this chapter, defiles not just the sanctuary, as stated Lev 20:1-3, but based on Lev 18:24-30, also defiles the land. His comments on Lev 18:21 seem to assume that the prohibition against Molech worship essentially does not belong with the sexual sins of Lev 18 at all. It was placed there because child sacrifice destroys human seed and thus interferes with procreation, even though the defiling effects of Molech worship, which defiles the sanctuary only, is different from the defiling force of sexual sins, which defile the land. ${ }^{189}$

\footnotetext{
${ }^{184}$ Jacob Milgrom, “Israel's Sanctuary: The Priestly 'Picture of Dorian Gray,” RB 83 (1976).

${ }^{185}$ Klawans, "Ritual Purity,” 22.

${ }^{186}$ Milgrom, Leviticus 17-22, 1374, 1397.

${ }^{187}$ Milgrom, Leviticus $17-22$.

${ }^{188}$ Milgrom, Leviticus 17-22, 1384-85.

${ }^{189}$ Milgrom, Leviticus 17-22, 1374, 1558-59.
} 
However, Milgrom showed inconsistency regarding this claim when he discussed the Holiness topic in one of his Leviticus 17-22 excursuses where he stated that Molech worship does defile both sanctuary and the land. ${ }^{190}$ Regardless of the inconsistency of his view on the defiling force of Molech worship, Milgrom generally believed that this activity defiles the sanctuary only. Klawans correctly countered Milgrom's position on two grounds. ${ }^{191}$ First, the act of Molech worship itself includes the act of bloodshed associated with murder, which would undeniably defile the land (Num 35:33-34). Milgrom did endorse the defiling force of bloodshed and murder. ${ }^{192}$

Second, it is well established in the prophetic books and writings that idolatry, along with sexual and murderous sins, was morally defiling in Ancient Israel. ${ }^{193}$ For these two reasons, the claim that sexual sins and murder defile the land and that only one form of idolatry, worship to Molech, defiles the sanctuary but not the land, is highly questionable. ${ }^{194}$

Idolatry, presented in the Pentateuch and the rest of the OT, is combined with both sexual sins and murder and, as such, it does morally defile all: the participants of such activity, the sanctuary and the land. It would be possible to imagine idolatry that would not include any sexual sins or murder and, as such, could have been non-defiling

\footnotetext{
${ }^{190}$ Milgrom, Leviticus 17-22, 1397.

${ }^{191}$ Klawans, "Ritual Purity,” 22.

${ }^{192}$ Jacob Milgrom, Numbers = [Ba-midbar]: The Traditional Hebrew Text with the New JPS Translation, JPSTC 4 (Philadelphia: Jewish Publication Society, 1990), 295.

${ }^{193}$ Klawans, Impurity and Sin in Ancient Judaism, 15.

${ }^{194}$ Klawans, "Ritual Purity,” 23.
} 
in its nature, but that is not the sort of idolatry that the Pentateuch and the rest of the OT portray. ${ }^{195}$

Milgrom's distinction between sanctuary defilement and land defilement is also problematic because in some places he maintained this concept, ${ }^{196}$ while in other places, he mitigated it. ${ }^{197}$ The distinction between sanctuary defilement and land defilement seems to be indefensible based on the texts from the Pentateuch and prophetic books listed above. These texts show that Molech worship defiles both the sanctuary and the land, which leads to the conclusion that the separation Milgrom suggested is rather nonexistent in the OT. Klawans suggested that defiling the land would automatically render the sanctuary defiled since it is situated on that land. ${ }^{198}$ Thus, after reviewing Milgrom's view on impurity, it can be said that he saw two natures of impurity, ritual and moral, but his approaches to them were different and, at times, conflicting. ${ }^{199}$

\section{Tikva Frymer-Kensky}

The article by Tikva Frymer-Kensky, "Pollution, Purification, and Purgation in Biblical Israel" in The Word of the Lord Shall Go Forth: Essays in Honor of David Noel Freedman in Celebration of His Sixtieth Birthday, presents one of the most systematic

${ }^{195}$ Klawans, "Ritual Purity," 23.

${ }^{196}$ Milgrom, Leviticus 17-22, 1346, 1353, 1373, 1583.

${ }^{197}$ Milgrom, Leviticus 17-22, 1396, 1578, 1734.

${ }^{198}$ Klawans, "Ritual Purity,” 23.

${ }^{199}$ For a more detailed analysis of conflicting parts of Milgrom's understanding and relationship between ritual and moral impurity, see Haber, "They Shall Purify Themselves," 20-21. 
approaches to impurity in the OT. ${ }^{200}$ She opened up her exposition on the topic by

confronting two forms of impurity and their effects:

Pollution, the lack of purity, could affect individuals, the temple, the collectivity of Israel, and the land of Israel itself. Some forms of pollution could be eradicated by rituals; the performance of these purifications and expiations was a major function of the priesthood. The pollution caused by the performance of certain deeds, however, could not be eradicated by rituals; Israel believed that the person intentionally committing these acts would suffer catastrophic retribution. Wrongful acts could cause the pollution of the nation and of the land of Israel, which could also not be "cured" by ritual. There was therefore an ultimate expectation of catastrophic results for the whole people, the "purging" of the land by destruction and exile. ${ }^{201}$

All essential characteristics of Frymer-Kensky's understanding of impurity are contained in the quotation above. First, impurity can defile individuals, the temple, and the entire land of Israel. Second, similarly to what Büchler and Hoffmann claimed, Frymer-Kensky noted that there are two types of impurities that defile in different ways. Third, the way these impurities were to be handled also differs. Ritual impurity is handled through various rituals, while wrongful acts, which pollute the land, are handled through catastrophic retribution, that is, exile.

Later in her article, she called the first type of impurity "simple impurity," the impure state of the Levitical ${ }^{202}$ or priestly laws. She also mentioned that these impurities are called pollution beliefs, ${ }^{203}$ but also frequently used the term ritual impurity. The other impurity, she termed dangerous beliefs. ${ }^{204}$

\footnotetext{
${ }^{200}$ Klawans, Impurity and Sin in Ancient Judaism, 15.

${ }^{201}$ Frymer-Kensky, "Pollution, Purification,” 399.

${ }^{202}$ Frymer-Kensky, "Pollution, Purification," 399.

${ }^{203}$ Frymer-Kensky, "Pollution, Purification," 404.

${ }^{204}$ Frymer-Kensky, "Pollution, Purification," 404.
} 
Frymer-Kensky found that ritual impurities are comprised of major and minor ones. Concerning major impurities, she found (1) that death-related pollution, originating from the human corpse is the most contagious pollution (Num 19:11, 14, 16), ${ }^{205}$ (2) the disease of leprosy (Lev 13-14), and (3) impurities deriving from the human body, such and childbirth (Lev 12) and menstruation and genital discharges (Lev 15). ${ }^{206}$ As minor impurities, Frymer-Kensky listed (1) contact with impure things, such as carcass of impure animal, (2) contact with something that has become impure through contact with someone under a major impurity, (3) contact with someone who is under major pollution. ${ }^{207}$

The first feature Frymer-Kensky endorsed is that these impurities are contagious. Individuals who contract them can defile others, making them defiled for the duration of one day. They can also defile an entity, which in turn can defile other persons for a day. ${ }^{208}$

Second, the profound observation is that even though these impurities are contagious they are only potentially dangerous. There is no harm to an impure person except that he/she needs to be isolated from other people and holy things. Association between the impure and the holy is fatal for the impure party. In addition, since they are contagious, the contagion can spread, separating the entire community from God. There is no guilt associated with the impure condition of an individual. Even more, some of

\footnotetext{
${ }^{205}$ Frymer-Kensky, "Pollution, Purification," 399-400.

${ }^{206}$ Frymer-Kensky, "Pollution, Purification," 400-401.

${ }^{207}$ Frymer-Kensky, "Pollution, Purification," 401.

${ }^{208}$ Frymer-Kensky, "Pollution, Purification," 401-3.
} 
these impurities originate from God's explicit command, such as the one to procreate. Furthermore, contact with the human corpse is unavoidable during the burial of a family member. ${ }^{209}$

The only potential connection between an instance of an impure state and some kind of harm is the case of leprosy. There are some instances of leprosy being imposed on individuals as punishment for moral impurity. However, it was the impure state that was imposed on the individual as a sort of punishment for moral impurity ${ }^{210}$ and thus, ritual impurity does not originate from any form of moral wrongdoing.

Frymer-Kensky's moral impurity refers to the performance of forbidden activities. These activities bring about divine punishment. ${ }^{211}$ She focused on the kārēt punishment as the main mechanism to prevent intermingling of sacred and profane. Another punishment that is also frequently found in the Pentateuch for moral impurity is that "he shall bear his penalty." Frymer-Kensky saw the separation between sacred and profane as fundamental aspect of Israelite cosmology. God is holy and the people must be holy (Lev $11: 44,45 ; 19: 2 ; 20: 7,26)$ and must not defile the camp, the temple, or the land. Violation of this distinction would disrupt the entire system. ${ }^{212}$ She listed many examples of direct contamination of the sacred by the impure from the Pentateuch to prove this claim. ${ }^{213}$

She generally held that pollution of the sanctuary takes place via direct contact,

\footnotetext{
${ }^{209}$ Frymer-Kensky, "Pollution, Purification," 403.

${ }^{210}$ Frymer-Kensky, "Pollution, Purification," 403-4.

${ }^{211}$ Frymer-Kensky, "Pollution, Purification," 404.

${ }^{212}$ Frymer-Kensky, "Pollution, Purification," 404-5.

${ }^{213}$ Frymer-Kensky, "Pollution, Purification," 405.
} 
that is, an impure person coming to the sanctuary, but she also accepted Milgrom's hypothesis that the sanctuary can be defiled aerially. In regard to defilement of the land and the people, Frymer-Kensky listed a number of moral impurities that defile the land and the people, such as idolatry, Molech worship, necromancy (Lev 20:1-5), improper sexual acts (Lev 18), and murder (Num 35:33-34). All of these, because they assault the very basis of Israel - its relationship with God - pollute both the land and the people. The whole community is encouraged to stand actively against these moral impurities by punishing doers, and thus exterminate evil among them. ${ }^{214}$ The progressing pollution finally brings catastrophic punishment in the form of exile. ${ }^{215}$

Frymer-Kensky's understanding of impurity is conceptually very clear and is heavily based on a careful study of the Pentateuch and general in its scope. For these reasons, it did not receive much critique. However, it is not clear whether Frymer-Kensky understood that ritual impurity has any defiling impact on the land or that only moral impurity can defile the land. The terminological search conducted later in the present study proved that the land was always and only defiled by moral impurity.

\section{David P. Wright}

Wright's work on the topic is a seminal one. He also divides impurity into two major types and uses fresh terminology to label them. Wright labeled the first type, which is referred to as ritual, or cultic, or levitical impurity in the previous research, ${ }^{216}$ with the

\footnotetext{
${ }^{214}$ Frymer-Kensky, "Pollution, Purification," 406-7.

${ }^{215}$ Frymer-Kensky, "Pollution, Purification," 408.

${ }^{216}$ Wright, "The Spectrum of Priestly Impurity," $151 n 3$.
} 
adjective tolerated. This defilement is discussed in Lev $11-16$ and Num $19 .{ }^{217}$ Wright sorted them out into four classes, listing the potential sources of defilement with biblical references for each class: (1) death-related impurities (human and animal carcasses), (2) sexual impurities (menstrual blood, a lochial discharge after birth, an abnormal genital discharge in a male, or an irregular blood flow in a female), (3) disease related impurities (leprosy as diagnosed or suspected in a person, cloth, leather, or house), and (4) cultic

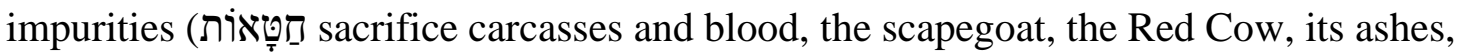
the water of purification of leprosy purification made from ashes, and possibly the birds and blood used in purification of leprosy impurity). ${ }^{218}$ In addition to these which are considered major or fathers of impurities, Wright listed another 6 impurities: (1) a corpsecontaminated person, (2) a person suffering a menstrual, lochial, or abnormal sexual discharge, (3) a person who has had intercourse with one of these sexually impure persons, (4) an object on which any of these sexually impure people (including one who has had intercourse with the severely impure) have sat or lain, (5) a person or object suspected or diagnosed as having șāra 'at, and (6) a person in her/his seven-day period of purification from șāra 'at. All these impurities are contagious. They can defile other objects and persons. ${ }^{219}$

Wright's analysis was led by three criteria when he graded these impurities. First, the means required for cleansing them are different. Sacrifice is not needed for lesser

\footnotetext{
${ }^{217}$ Wright, “The Spectrum of Priestly Impurity,” 152.

${ }^{218}$ Wright, "The Spectrum of Priestly Impurity," 154.

${ }^{219}$ Wright, “The Spectrum of Priestly Impurity,” 155.
} 
grades, while it is for higher grades. Second, the extent of pollutions varies. A higher grade of these impurities defiles the sanctuary, while a lesser grade does not. Third, the communicability of these pollutions is different. Some were communicable to the profane sphere and were prohibited from both the sanctuary and, in some instances, the camp, while some were non-communicable to the profane sphere and thus allowed within the camp, but not the sanctuary. ${ }^{220}$

Wright himself acknowledged that the label tolerated is an oxymoron due to the fact that an impurity is a negative quality and a threat to what is holy. However, these impurities are "tolerated" due to necessity. Many of these impurities are unavoidable natural conditions or particulars of Israelites religion such as menstruation, contraction of diseases, or death. Some of them, such as childbirth and seminal emissions, cannot be prohibited since they are an essential part of Israelite religion. ${ }^{221}$ These impurities are thus allowed, but not encouraged in Wright's opinion. Even more, he claimed that this kind of impurity should be generated as infrequently as possible. ${ }^{222}$ No sinful notion is related to these impurities in Wright's analysis. ${ }^{223}$

Wright labeled the other category, called "moral" or "religious" by previous scholars, ${ }^{224}$ by the adjective prohibited impurities which arise from sinful situations ${ }^{225}$

\footnotetext{
${ }^{220}$ Wright, "The Spectrum of Priestly Impurity," 155-56.

${ }^{221}$ Wright, "The Spectrum of Priestly Impurity," 157-58.

${ }^{222}$ Wright, "The Spectrum of Priestly Impurity," 158.

${ }^{223}$ Wright, "The Spectrum of Priestly Impurity," 150-81.

${ }^{224}$ Klawans, Purity, Sacrifice, and the Temple, 55; Wright, "The Spectrum of Priestly Impurity,"

${ }^{225}$ Wright, “The Spectrum of Priestly Impurity," 158.
} 151. 
and he identified two types of this impurity: (1) intentional and (2) unintentional.

Following Milgrom's ADH of the sanctuary, Wright claimed that unintentional sins defile the sanctuary. Lev 5:2-3 states that one's inadvertent delay to perform purification from tolerated impurity defiles the sanctuary. The parts of the sanctuary that are defiled are the outer altar and the shrine, depending on the sinner's social status. ${ }^{226}$ The same principle of sanctuary defilement is also found in Num 6:9, 10-12 which discusses defilement of the Nazirite, and Lev 4:1-5 and Num 15:22-29 which explain the procedure when one errs unintentionally. ${ }^{227}$

The effects of intentional sins, most likely considered high-handed since the punishment for them was capital, on both the sanctuary and the sinner are more severe. That is, the most holy place is defiled by these sins and the sinner suffers $k \bar{a} r \bar{e} t$, premature death of the sinner, and no personal sacrifice is allowed for these sins. The sanctuary is cleansed from these sins on the Day of Atonement. Some of these sins are (1) intentional delay or refusal of purification, Num 19:13, 20, ${ }^{228}$ (2) sacrifice to Molech, Lev 20:1-5, (3) intentionally defiling holy things, Lev 7:19-21; 12:4; 22:3-7, Num 18:11, 13, (4) sexual sins, Lev 18:6-23, ${ }^{229}$ and (5) other general intentional sins, Num 15:30-31. ${ }^{230}$ Wright produced the following (Table 1) to present these two impurities. ${ }^{231}$

\footnotetext{
${ }^{226}$ Wright, "The Spectrum of Priestly Impurity,” 159.

${ }^{227}$ Wright, "The Spectrum of Priestly Impurity,” 159-60.

${ }^{228}$ Wright, "The Spectrum of Priestly Impurity,” 161.

${ }^{229}$ Wright, "The Spectrum of Priestly Impurity,” 162.

${ }^{230}$ Wright, "The Spectrum of Priestly Impurity," 163.

${ }^{231}$ Wright, “The Spectrum of Priestly Impurity,” 152.
} 
Table 1. Two impurities

\begin{tabular}{|c|c|c|c|}
\hline \multirow{2}{*}{\multicolumn{2}{|c|}{$\begin{array}{c}\text { Tolerated }^{232} \\
\text { (no distinction between } \\
\text { unintentional and intentional) }\end{array}$}} & \multicolumn{2}{|c|}{ Prohibited } \\
\hline & & Unintentional & Intentional \\
\hline No sacrifice & $\begin{array}{c}\text { Individual ad hoc } \\
\text { sacrifice }\end{array}$ & $\begin{array}{c}\text { Individual, sometimes } \\
\text { communal, ad hoc } \\
\text { sacrifice }\end{array}$ & $\begin{array}{l}\text { Day of Atonement } \\
\text { sacrifice }^{233}\end{array}$ \\
\hline $\begin{array}{l}\text { Pollution of } \\
\text { person }\end{array}$ & $\begin{array}{c}\text { Pollution of } \\
\text { sanctuary [outer } \\
\text { altar] and person }\end{array}$ & $\begin{array}{l}\text { Pollution of sanctuary } \\
\text { [outer altar or shrine]; } \\
\text { ritual personal } \\
\text { pollution if deriving } \\
\text { from tolerated } \\
\text { impurity }\end{array}$ & $\begin{array}{c}\text { Pollution of } \\
\text { sanctuary [adytum, } \\
\text { shrine, outer altar], } \\
\text { sometimes land; } \\
\text { 'moral' pollution of } \\
\text { persons'; 'ritual' } \\
\text { personal pollution if } \\
\text { from tolerated } \\
\text { impurity }\end{array}$ \\
\hline $\begin{array}{l}\text { Non- } \\
\text { communicable to } \\
\text { profane; hence, } \\
\text { restriction only } \\
\text { from sanctuary as } \\
\text { sacred }\end{array}$ & $\begin{array}{l}\text { Communicable to } \\
\text { profane; hence, } \\
\text { restriction from } \\
\text { the sanctuary and } \\
\text { other sacred } \\
\text { matters and } \\
\text { restriction from or } \\
\text { within the } \\
\text { [profane] } \\
\text { habitation }\end{array}$ & $\begin{array}{l}\text { Potential removal } \\
\text { from life; restriction } \\
\text { from sanctuary and } \\
\text { sacred, and sometimes } \\
\text { from habitation [if } \\
\text { communicable to } \\
\text { profane] if the sin } \\
\text { derives from a } \\
\text { tolerated impurity }\end{array}$ & $\begin{array}{c}\text { Removal from life; } \\
\text { kārēt or capital } \\
\text { penalty; in some } \\
\text { cases, exile; } \\
\text { restriction from } \\
\text { sanctuary and } \\
\text { sacred, and } \\
\text { sometimes } \\
\text { habitation if sin } \\
\text { derives from a } \\
\text { permitted impurity } \\
\text { (unlike the penalty } \\
\text { takes effect) }\end{array}$ \\
\hline
\end{tabular}

${ }^{232}$ Wright singled out the prohibitions regarding eating impure meats and touching the carcasses of a camel, hyrax, rabbit, or pig as exceptions not belonging to this group. Wright, "The Spectrum of Priestly Impurity," 153.

${ }^{233}$ Wright's position when sins of this category are cleansed is not accepted in this study, but since it is not crucially relevant to this paper, it is not analyzed here. 
Wright affirmed Milgrom's "Dorian Gray" hypothesis that states that unintentional prohibited impurities defile the outer altar and the shrine of the sanctuary and require offering a sacrifice, while intentional prohibited impurities defile the most holy place and the sinner's life is forfeited. The sanctuary is cleansed from these impurities through the sacrifice of the Day of Atonement. ${ }^{234} \mathrm{He}$ also noted that these two impurities are not connected just by the metaphorical use of language originally used for tolerated impurity, which is also used related to prohibited impurity, but also by the object of pollution (the sanctuary) and similar ways of removing the pollution (mainly hața $\underline{t} \underline{t}$ sacrifice). ${ }^{235}$ Based on these three points, Wright deduced that the two types of impurity with their two subdivisions are of the same conceptual family and system so instead of looking at them as two separate types of impurity, he preferred looking at impurity as a single phenomenon, a spectrum of impurity. ${ }^{236} \mathrm{He}$ placed the prohibitions against eating and touching certain animals in Lev 11:4-8, 10-12, 13-20, 41-45; $22: 8$ among the tolerated impurities. ${ }^{237}$

The fundamental difference between the two kinds of impurity is the issue of intention. Emphasizing more numerous points of connectedness led Wright to view the entire spectrum of impurity as a symbolic system with a moral foundation. ${ }^{238}$ Klawans eloquently and correctly countered all of the points that led Wright to his conclusion.

\footnotetext{
${ }^{234}$ Wright, "The Spectrum of Priestly Impurity,”, 163.

${ }^{235}$ Wright, "The Spectrum of Priestly Impurity," 164.

${ }^{236}$ Wright, "The Spectrum of Priestly Impurity," 165, 170-73.

${ }^{237}$ Wright, “The Spectrum of Priestly Impurity," 165.

${ }^{238}$ Klawans, Impurity and Sin in Ancient Judaism, 37.
} 
First, the similarities singled out by Wright are overdrawn. In terms of terminological

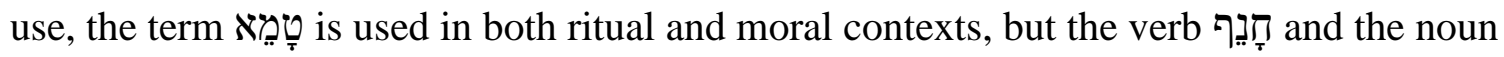
תוֹעָרָה are used exclusively in moral contexts. Second, the loci of defilement are different. That is, certain moral impurities can defile the land, while no ritual impurity does so. In addition, ritual impurities, in Wright's system, defile the sanctuary via contact, while the prohibited ones defile it from a distance. Third, in terms of methods of removal, the sacrifice is the point of similarity between the two impurities. However, ablution does not remove moral impurity. In fact, there is no method for removing of the defilement of land by $\sin .{ }^{239}$ Fourth, restrictions and exclusions also differ. For instance, those involved in moral impurity are not declared ritually impure and are not excluded from the sanctuary. Each of these differences demonstrates that the points of difference are more numerous than the points of similarity when the defiling force of these two impurities are compared. ${ }^{240}$ These obvious differences lead to the conclusion that it is better to emphasize and recognize the distinctive nature of the defiling effects of the two impurities regardless of the minor overlaps between them.

Wright's innovation in comparison to the previous research on impurity is that prohibited, or in traditional language, moral impurity can be unintentional and intentional. Previous research did recognize that there are two basic types of impurityritual and moral. Wright expanded the classification of ritual impurity by stating that among tolerated impurities, there are those that do not require sacrifice, do pollute the

\footnotetext{
${ }^{239}$ One could refer to the law of intentional homicide in Num 35:33-34, but this text talks about moral impurity, not ritual.

${ }^{240}$ Klawans, Impurity and Sin in Ancient Judaism, 37.
} 
person, but are not communicable to the profane, contrasted with those that do require a sacrifice, do pollute both the sanctuary and the person, and are communicable to profane. Frymer-Kensky documented the fact that ritual impurity may be divided into minor and major. Wright elaborated more on moral impurity, observing that among prohibited impurities, there are those that are unintentional and require sacrifice, pollute the sanctuary, and require more severe punishments (potential capital punishment and others), contrasted with the intentional that require communal sacrifice; pollute the person, sanctuary, and land; and require the most severe punishments (capital punishment and others). ${ }^{241}$

\section{Jonathan Klawans}

The most recent and also thorough study on impurity was carried out by Jonathan Klawans in several of his works. ${ }^{242}$ He followed the division into ritual and moral impurity that was well established by previous research. ${ }^{243}$ Ritual impurity results from direct or indirect contact with multiple natural sources/events such as childbirth (Lev 12:1-8), scale disease (Lev 13:1-14:32), genital discharges (Lev 15:1-33), the carcasses of certain impure animals (Lev 11:11-47), and human corpses (Num 19:10-22) or is a consequence of particular purifications (Lev 16:28; Num 19:8). There are three basic characteristics of this impurity. The first characteristic points to the fact that they arise from generally natural and more or less unavoidable sources including birth, death, sex,

${ }^{241}$ Wright, "The Spectrum of Priestly Impurity,” 153.

${ }^{242}$ Klawans, Impurity and Sin in Ancient Judaism; Klawans, Purity, Sacrifice, and the Temple; Klawans, "The Impurity of Immorality in Ancient Israel"; Klawans, "Ritual Purity."

${ }^{243}$ Klawans, Impurity and Sin in Ancient Judaism, 21-31. 
disease, and discharges. ${ }^{244}$ This kind of defilement is transmitted through various direct or indirect contacts with any of a number of natural processes. ${ }^{245}$ The only exception to this characteristic is the impurity that happens when priests perform the purification ritual (Lev 16; Num 19). Klawans also considered this impurity to be natural since he saw the temple, along with the cult and all cultic procedures which involved all natural things like animals, blood, and death, as an essential part of ancient Israel's life. ${ }^{246}$ In addition to this, it may be claimed that the Day of Atonement ritual was an unavoidable event of Israelite religion.

Ritual impurity is both avoidable (not touching impure animals, not having sex with a menstruant) and unavoidable (discharges, disease, death). Even more, some impurities were obligatory (burial), except for priests who were allowed to touch a corpse only in certain circumstances (Lev 21:1-4). However, even priests, including the high priest, were obliged to defile themselves by being involved in reproduction (Gen 1:28; 9:7) or to perform cultic rituals that rendered them impure (Lev 16; Num 19). ${ }^{247}$

A second characteristic of ritual impurity is that contracting a ritual impurity is not sin. Milgrom, Frymer-Kensky, Sanders, and Wright have already noted that it would

\footnotetext{
${ }^{244}$ Klawans, Impurity and Sin in Ancient Judaism, 23. As noted by Frymer-Kensky, Sanders, and Wright, it would be impossible and absurd to consider these processes as prohibited. Frymer-Kensky, "Pollution, Purification," 403; Sanders, Jewish Law from Jesus to the Mishnah, 140-42; Wright, "The Spectrum of Priestly Impurity," 157.

${ }^{245}$ Klawans, Purity, Sacrifice, and the Temple, 53.

${ }^{246}$ Klawans, Impurity and Sin in Ancient Judaism, 23-24.

${ }^{247}$ Klawans, Impurity and Sin in Ancient Judaism, 24.
} 
be impossible to consider natural processes as something to be prohibited. ${ }^{248}$ Conversely, Sanders and Wright claimed that some or all of these defilements were discouraged. ${ }^{249}$ However, there is no indication that permitted sex, physical contact between an Israelite father and the mother of his newborn child, or contact with the dead was discouraged at all. Many of these events were proper and even obligatory. The texts do not have any warning against contact with ritual impurity in general. Priests had to limit their contact with corpse impurity (Lev 21:1-4), but were allowed to contact other impurities (Lev 47). The key concern necessary for priests was to maintain a separation between ritual impurity and purity (Lev 10:10). They were also prohibited from eating sacred food or entering the holy precincts in a ritually impure state (Lev 7:20-21;22). They were technically not prohibited from touching any ritual impurity, but had to be aware of it. Thus, both the priests and the Israelites were to be aware of their impure state so that they did not accidentally contact the sacred in their impure state (Lev 7:20-21; cf. 15:31, etc.). ${ }^{250}$ Regardless of the fact that ritual impurity is not sinful, there are several OT narratives that view one form of ritual impurity as punishment for moral wrongs (Num 12; 2 Kings 5; 2 Chr 26). Again, both Frymer-Kensky and Wright have noted that the legal texts provided no basis to view the one stricken with scale disease as being a

\footnotetext{
${ }^{248}$ Milgrom, Leviticus 1-16, 758-63; Wright, "The Spectrum of Priestly Impurity," 157; FrymerKensky, "Pollution, Purification," 403; Sanders, Jewish Law from Jesus to the Mishnah, 140-42.

${ }^{249}$ Wright, "The Spectrum of Priestly Impurity," 158; Sanders, Jewish Law from Jesus to the Mishnah, 141-42.

${ }^{250}$ Klawans, Impurity and Sin in Ancient Judaism, 24-25.
} 
transgressor. ${ }^{251}$ The leper is ritually impure, but is not guilty. ${ }^{252}$

Nevertheless, ritual impurity can lead to sin in two ways. First, Num 19:13, 20 state that the refusal to purify ritual impurity resulting from contact with a corpse is punishable by kārēt which could further result in defilement of the sanctuary. ${ }^{253}$ The nature of the punishment points to the nature of the impurity. It is not ritual, but moral, that is, disobedience to following divinely prescribed laws of purification. Second, every Israelite was warned not to enter the sanctuary or come into direct contact with holy foods in the state of impurity (Lev 7:20-21; 15:31; 22:30-7). Disobeying these laws could result in defilement of the sanctuary and was sinful since the sinner was subject to $k \bar{a} r \bar{e} t$. Association of these prohibitions to ritual impurity did not mean that being ritually impure was sinful. As long as the prohibitions were observed, the impure Israelite was not morally impure. ${ }^{254}$

The third characteristic of ritual impurities is that they convey impermanent contagion to persons. The Israelites who came in contact with a menstruant or someone afflicted with an irregular flux contracted a defilement which lasted until sunset (Lev $15: 5,21)$. Contact with a more severe impurity such as corpse impurity prolonged the impure status to a week (Num 19). The state of defilement after giving birth lasted, depending on the sex, up to 33 days for a son or 66 days for a daughter (Lev 12). Genital

\footnotetext{
${ }^{251}$ Frymer-Kensky, "Pollution, Purification," 403-4; David P. Wright, The Disposal of Impurity: Elimination Rites in the Bible and in Hittite and Mesopotamian Literature, SBLDS 101 (Atlanta: Scholars Press, 1987), 84-85.

${ }^{252}$ Milgrom, Leviticus 1-16, 822, 857.

${ }^{253}$ Klawans, Impurity and Sin in Ancient Judaism, 25.

${ }^{254}$ Klawans, Impurity and Sin in Ancient Judaism, 25.
} 
flows, scale disease, and house funguses lasted for an unspecified time, but not permanently. ${ }^{255}$ None of the ritual impurities was permanent. Some lasted for a short period of time and some lasted longer, but they were all impermanent.

Klawans's definition of moral impurity is as follows: "Moral impurity results from what are believed to be immoral acts." 256 The sins that belong to this impurity include (1) sexual sins (Lev 18:24-30), idolatry (Lev 19:31; 20:1-3), and bloodshed (Num 35:33-34). They defiled the sinner (Lev 18:24), the land (Lev 18:25) and the sanctuary (Lev 20:3) morally rather than ritually, and the final result was exile (Lev $18: 28){ }^{257}$

Klawans's comparison of these two impurities results in five points of difference between them: ${ }^{258}$

(1) Whereas ritual impurity is generally not sinful, moral impurity is a direct consequence of grave $\sin .^{259}$ (2) Whereas ritual impurity often results in a contagious defilement, there is no contact-contagion associated with moral impurity. One need not bathe subsequent to direct or indirect contact with an idolater, a murderer, or an individual who committed a sexual $\sin ^{260}$ (3) Whereas ritual impurity results in an impermanent defilement, moral impurity leads to a long-lasting, if not permanent, degradation of the sinner and, eventually, of the land of Israel. ${ }^{261}$ (4) Whereas ritual impurity can be ameliorated by rites of purification, that is not the case for moral impurity; ${ }^{262}$ moral purity is achieved by punishment, atonement, or, at best, by

${ }^{255}$ Klawans, Impurity and Sin in Ancient Judaism, 25.

${ }^{256}$ Klawans, Impurity and Sin in Ancient Judaism, 26.

${ }^{257}$ Klawans, Impurity and Sin in Ancient Judaism, 26.

${ }^{258}$ Klawans, Impurity and Sin in Ancient Judaism, 26.

${ }^{259}$ Frymer-Kensky, "Pollution, Purification," 404-5; Wright, "The Spectrum of Priestly Impurity," 162.

\footnotetext{
${ }^{260}$ Frymer-Kensky, "Pollution, Purification," 404.

${ }^{261}$ Frymer-Kensky, "Pollution, Purification," 406-7.

${ }^{262}$ Milgrom, Leviticus 1-16, 37, 1056.
} 
refraining from committing morally impure acts in the first place. (5) In addition to these phenomenological differences, there are also terminological distinctions used in the texts themselves. Although the term impure (טָָָָא) is used in both contexts, the term abominations (תועבה) and pollute (חנף) are used with regard to the sources of moral impurity, but not with regard to the sources of ritual impurity. ${ }^{263}$

Klawans noted these differences in Table 2:

Table 2. Differences in impurity types

\begin{tabular}{|l|l|l|l|}
\hline Impurity type & Source & Effect & Resolution \\
\hline Ritual & $\begin{array}{l}\text { Bodily flows, } \\
\text { corpses, etc. }\end{array}$ & $\begin{array}{l}\text { Temporary, contagious } \\
\text { impurity }\end{array}$ & Bathing, waiting \\
\hline Moral & $\begin{array}{l}\text { Sins: idolatry, } \\
\text { incest, murder }\end{array}$ & $\begin{array}{l}\text { Defilement of sinners, } \\
\text { land and sanctuary }\end{array}$ & $\begin{array}{l}\text { Atonement or punishment, } \\
\text { and ultimately, exile }\end{array}$ \\
\hline
\end{tabular}

Klawans explored the texts that confirm that idolatry, incest, and murder morally defiled the sinner, the land, and the sanctuary. The most explicit text that speaks about moral defilement through sexual sins is Lev 18:24-30. The sexual sins enumerated in this text defiled both the sinner and the land. However, the exact way this defilement took place is unknown. It is crucial here that the impurity contracted through these deeds was conveyed to the land. Ritual impurity was never conveyed to or contracted from the land. ${ }^{264}$ The defilement of the land in this passage does not threaten the ritual status of those who are on it. Rather, the threat to all those living on the earth is exile. ${ }^{265}$

The morally defiling effect of sexual sins is also detailed in Num 5:11-31, the law

\footnotetext{
${ }^{263}$ Paschen, Rein und Unrein, 28-30, 67-68.

${ }^{264}$ Büchler, Studies in Sin and Atonement (1928), 216-17.

${ }^{265}$ Klawans, Impurity and Sin in Ancient Judaism, 27.
} 
of the suspected adulteress. The impurity referred to in this law seems to be moral and not ritual because the ritual ceremony referred to in this chapter could never take place at the sanctuary. ${ }^{266}$ All sexual sins defile ritually, at least for a short time (Lev 15:18), so it would be unnecessary to determine that status. ${ }^{267}$ Rather, the concern is to determine whether the woman has been defiled morally by committing adultery. ${ }^{268}$

The defiling effect of idolatry is articulated in Lev 19:31 where it is stated that necromancy defiles. In addition, the act of sacrificing children to Molech is portrayed as defiling in Lev 20:1-3. Klawans adduced a number of OT texts to support his claim that idolatry defiled the sinner and the land (Ps 106; Deut 18:9-12; 2 King 16:3; Jer 7:9-15; 16:18; Ezek 20:30-31; 22:4; 36:18; 37:23) and the sanctuary (Jer 7:30; 32:34; Ezek 5:11; 8:10; 2 Chr 29:5, 16). However, there is no indication that idolatry defiled ritually. It defiled morally, but contact-contagion was not included. ${ }^{269}$ Klawans's claim is in agreement with the conclusion reached by Büchler ${ }^{270}$ and Wright. ${ }^{271}$

The defiling force of bloodshed is described in Num 35:33-34. Klawans followed Büchler's claim that the verb ḩānēp is a technical term that articulated the defiling force of moral impurity. ${ }^{272}$ This term is also synonymous with the term tâme $\bar{e}$, but only when it

\footnotetext{
${ }^{266}$ Levine, Numbers 1-20, 207.

${ }^{267}$ Milgrom, Numbers, 37.

${ }^{268}$ Klawans, Impurity and Sin in Ancient Judaism, 27.

${ }^{269}$ Klawans, Impurity and Sin in Ancient Judaism, 28.

${ }^{270}$ Büchler, Studies in Sin and Atonement (1928), 212-14.

${ }^{271}$ Wright, The Disposal of Impurity, 283-85.

${ }^{272}$ Büchler, Studies in Sin and Atonement (1928), 218-19.
} 
is used in moral contexts, since hānēp is never used in ritual contexts. ${ }^{273}$ In the same way as moral impurity originating from idolatry is articulated in many OT texts, so is the case with moral impurity resulting from bloodshed (Deut 21:23; 1 Chr 22:8; Ezek 9:7, 9; $22: 1-4 ; 33: 25)$. Thus, the impurity associated with murder, sexual sins, and idolatry is moral in nature and defiles the sinner, the sanctuary, and the land morally, not ritually. To further support this claim, Klawans cited the narratives about Dinah (Gen 34:5ff) and the legislation regarding the suspected adulteress (Num 5:13ff). Since moral impurity does not include ritual defilement of the sinner he or she is not excluded from the sanctuary. The case of the suspected adulteress, as well as of the murderers who sought safety of the sanctuary confirms this (Exo 21:14). Klawans accepted Milgrom's ADH of the sanctuary from afar, which is moral in nature. ${ }^{274}$ Klawans also applied his claim of moral defilement to the land. The land is never ritually defiled, nor is it ever the source of or a means of transmitting ritual defilement. The land thus suffers noncontagious degradation with the exile of its inhabitants as the ultimate punishment. The effect of moral impurity upon the sinner and the land is degradation in status. The sanctuary, by contrast, is cleansed from moral impurity once a year on the Day of Atonement. ${ }^{275}$ Klawans provided the definition of moral impurity as follows: "Moral impurity is best understood as a potent force unleashed by certain sinful human actions. The force unleashed defiles the sinner, the sanctuary, and the land even though the sinner is not ritually impure and does

\footnotetext{
${ }^{273}$ Klawans, Impurity and Sin in Ancient Judaism, 28.

${ }^{274}$ Klawans, Impurity and Sin in Ancient Judaism, 29.

${ }^{275}$ Klawans, Impurity and Sin in Ancient Judaism, 30.
} 
not ritually defile... As a result of this defilement, the sinner and the land experience a degradation in status." 276

Impurity that the morally impure person suffers is moral in its nature and not ritual. ${ }^{277}$ In sum, Klawans's understanding of impurity is twofold. First, he kept a sharp distinction between ritual and moral impurity. Second, a similarity between these two impurities is that they are both real. ${ }^{278}$ Before expanding on these two points, it is useful to notice that Sklar accurately criticized Klawans's table of impurity for not providing more elaborate differences within the realms of these two impurities. That is, Klawans listed only three activities as moral sins which are intentional, grave sins, refusing to acknowledge unintentional sins which also defile the sanctuary and were discussed at length in the Pentateuch (Lev 4:1-5:13) ${ }^{279}$ and also in Num 15:22-29. Reasoning from the assumption that major ritual impurities require sacrifice/s just like unintentional moral impurities, Sklar criticized Klawans for not including this similarity and connection between the two impurities in his table. ${ }^{280}$ However, Sklar's criticism on this point is not substantial since the way impurities are resolved does not seem to affect their ontological nature. Regardless of the similarity in the way they are resolved, ritual impurity remains

\footnotetext{
${ }^{276}$ Klawans, Impurity and Sin in Ancient Judaism, 29. Klawans's ontological understanding of moral impurity resembles Milgrom's. Aerial miasma is understood by Milgrom as a physical substance, but yet aerial that had a magnetic attraction for the realm of sacred. Milgrom, Leviticus 1-16, 257-58. However, Klawans cited Robert Parker's work to refer to the source which provides for such an understanding of moral impurity. R. Parker, Miasma: Pollution and Purification in Early Greek Religion (Oxford: Clarendon, 1983), 104-43, esp. pp. 120-25.

${ }^{277}$ Büchler, Studies in Sin and Atonement (1928), 221-26.

${ }^{278}$ Klawans, Impurity and Sin in Ancient Judaism, 34-35.

${ }^{279}$ Sklar, Sin, Impurity, Sacrifice, Atonement, 148.

${ }^{280}$ Sklar seemed to be driven in his analysis by default meaning of the atonement process expressed through the verb כפר. Sklar, Sin, Impurity, Sacrifice, Atonement, 149.
} 
ritual in its nature and moral impurity also remains moral in its nature.

The first point Klawans put forward regarding the understanding of moral impurity is that scholars usually understand the concept of moral impurity either as metaphorical or figurative. Even Milgrom and Wright, who recognized the defiling effect of moral impurity, also referred to it as metaphorical. ${ }^{281}$ Klawans claimed that the dichotomy between literal and metaphorical is not helpful when one wants to understand the differences between these two impurities. None of the scholars mentioned offered the precise meaning of "metaphorical" or "figurative." This might be due to the fact that these terms are very difficult to define and the phenomena to which they refer are difficult to isolate ${ }^{282}$ and the philosophical debate on this continues. For this reason, Klawans suggested that they should be dropped from the discussion on this topic. In addition, this debate has not yet had a significant effect in biblical and ancient Jewish writings. $^{283}$

When scholars characterized moral impurity as metaphorical or figurative, they used these terms in a traditional way which means that metaphorical language is not to be taken literally. In addition, the terms in question are transferable, meaning the term or phrase with literal meaning in one context can be transferred into another context in which it is not literal. Thus, metaphorical language is secondary and nonliteral, and its

\footnotetext{
${ }^{281}$ For the details about the way the following scholars understood moral impurity as a metaphor, see André and Ringgren, "טמא," TDOT, 5:331-40; Ringgren, "טהר,, TDOT, 5:291-95; Levine, Numbers 1-20, 207; Levine, Leviticus, 134; Schwartz, "Selected Chapters of the Holiness Code," xii; Milgrom, Leviticus 1-16; Wright, "The Spectrum of Priestly Impurity”; Klawans, Impurity and Sin in Ancient Judaism, 174nn72-73.

${ }^{282}$ See Klawans, Impurity and Sin in Ancient Judaism, 175n75.

${ }^{283}$ Eilberg-Schwartz, The Savage in Judaism, 115-40.
} 
usage is informed by the literal meaning of the particular language. ${ }^{284}$

Klawans responded to both of these claims. First, applied to the purity language of the OT, this implies that the metaphorical use of the purity language does not mean that the defilement is happening at all. For instance, this is the case with Lev 18:24-25 that speaks of the land defilement for which many commentators think that it is metaphorical. ${ }^{285}$ If one claims that this passage is metaphorical, it would mean that defilement is not literal and the use of the purity language is secondary. However, it is explicitly and implicitly stated in the OT that the land of Israel is holy due to God's presence in the midst of it (Num 35:34). If the land can be holy, then it can be defiled. Almost a century ago, Hoffmann understood that impurity in the context of grave sins is to be understood as an idea opposite to holiness. ${ }^{286}$

Defilement of the land in the context of Lev 18:24-30 is not ritual, but rather, moral; these impurities defile the land on which they are committed, and the sinner literally and, as a result, the land, is permanently degraded in status. ${ }^{287}$ The ultimate result is exile of the people. ${ }^{288}$ Both types of impurity's perceived effects result from actual physical processes and as such are real. A ritual impurity is perceived as impermanent contagion coming out of real, physical processes which affect people and certain objects within their reach. A moral impurity is perceived as permanent contagion coming out of

\footnotetext{
${ }^{284}$ Klawans, “The Impurity of Immorality in Ancient Israel,” 32-33.

${ }^{285}$ André and Ringgren, "טמא," TDOT, 5:337-38; Milgrom, Leviticus 1-16, 37; Neusner, The Idea of Purity in Ancient Judaism, 15.

${ }^{286}$ Hoffmann, Das Buch Leviticus, 1:303-4.

${ }^{287}$ Klawans, Impurity and Sin in Ancient Judaism, 33.

${ }^{288}$ Klawans, Impurity and Sin in Ancient Judaism, 34.
} 
real, physical processes that affect people, the land, and the sanctuary. A ritual impurity is conveyed by direct and indirect physical contact, while a moral impurity is transmitted to the land by the sins that take place on it. All three sins that defile the land morally include direct contact with the land. ${ }^{289}$

Second, it is implied by scholars that moral impurity involves secondary use of purity terminology. Levine termed it, "applied concepts of purity," Schwartz referred to a "transformation," and Wright spoke of "metaphorization." ${ }^{290}$ However, no detailed analysis has been provided to establish precisely the nature of the secondary use of purity terminology in regard to moral impurity. ${ }^{291}$ It was commonly assumed that moral impurity is a secondary use of purity terminology, but yet, this secondary usage occurs in prophetic and so-called Deuteronomistic texts which are considered, in the perspectives of these scholars, ${ }^{292}$ to be chronologically earlier traditions than Priestly sources. As such, they should use the primary use of impurity terminology, but yet, they do not. This means, then, that it is uncertain which usage came first, and as a result, it cannot be

\footnotetext{
${ }^{289}$ Klawans, Impurity and Sin in Ancient Judaism, 35, $175 \mathrm{n} 86$.

${ }^{290}$ Levine, Leviticus, 134; Schwartz, "Selected Chapters of the Holiness Code," xii; Wright, "The Spectrum of Priestly Impurity,” 163.

${ }^{291}$ Klawans, Impurity and Sin in Ancient Judaism, 34.

${ }^{292}$ The works of these scholars show extensive use of the historical-critical method and its various approaches, such as source, form, and redaction criticism. These are just some of their works that prove this. David P. Wright, "Historical Criticism: A Necessary Element in the Search for Religious Truth," Sunstone 16 (1992): 28-38; Levine, Leviticus; Levine, Numbers 1-20, 1; Baruch A. Levine, Numbers 2136, AB 4A (New York: Doubleday, 2000), 2; Baruch J. Schwartz, "The Bearing of Sin in the Priestly Literature," in Pomegranates and Golden Bells: Studies in Biblical, Jewish, and Near Eastern Ritual, Law, and Literature in Honor of Jacob Milgrom, eds. David P. Wright, David Noel Freedman, and Avi Hurvitz (Winona Lake, IN: Eisenbrauns, 1995); Baruch J. Schwartz, “The Prohibitions Concerning the 'Eating' of the Blood in Leviticus 17," in Priesthood and Cult in Ancient Israel, eds. Gary A. Anderson and Saul M. Olyan, JSOTSup 125 (Sheffield: JSOT Press, 1991); Schwartz, "Selected Chapters of the Holiness Code."
} 
assumed that purity terminology was used metaphorically in Lev $18 .{ }^{293}$ This is not to say that metaphorical and figurative use of purity terminology is nonexistent in the OT, but is just an observation that in Lev 18:24-30, purity language was used in a literal way, not metaphorically or figuratively. When ritual impurity terminology is used metaphorically or figuratively to express the sinfulness of the Israelites or to illustrate righteousness or atonement, there is always an explicit or implied comparison between ritual impurity or purity on the one hand, and sinfulness and righteousness on the other. ${ }^{294}$

Establishing a distinction between the two kinds of impurities leads to the question of their inter-relatedness. In other words, is there a single system that encompasses both or does each impurity form its own system? Mary Douglas, as an anthropologist, claimed that there is a unifying system that encompasses both impurities. ${ }^{295}$ Building on Douglas's work, Wright suggested that all defilement-creating conditions in the priestly legislation have the same conceptual family, and as such, the whole purity system, ritual and moral, in his words tolerated and prohibited, has a moral basis and rationale. ${ }^{296}$ Klawans's critique of Wright's claim is substantial and well taken. To get to the point of claiming that these two impurities belong to the same conceptual family with the same morally informed foundation, Wright argued that (1) purity/impurity terminology is interchangeable between the two impurities, (2) they share the loci of pollution (the sanctuary), (3) there are similar ways of removing that pollution

\footnotetext{
${ }^{293}$ Klawans, Impurity and Sin in Ancient Judaism, 35.

${ }^{294}$ For references, see Klawans, Impurity and Sin in Ancient Judaism, 35-36.

${ }^{295}$ Neusner, The Idea of Purity in Ancient Judaism, 138.

${ }^{296}$ Wright, “The Spectrum of Priestly Impurity,” 170-73.
} 


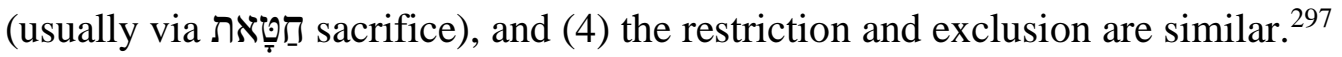

Klawans also noted that a search for the single symbolic system is not called for by the text itself. He explained that various rituals have the task of reminding Israelites of some greater purpose. Certain activities related to the Sabbath remind Israelites either of the Exodus from Egypt (Deut 5:14-15) or the creation of the world (Exod 20:10-11). The tassels on their garments served to remind the people to obey God's commandments (Num 15:37-41). The Pentateuch had a way to communicate that certain rituals served to remind them of some greater purpose, but the texts do not have any indication that impurity laws were to serve as behavioral reminders of morally defiling effects of sin. ${ }^{298}$

In addition, Klawans also noted that Wright emphasized that the use of impurity language associated with sin, moral impurity, involves metaphorization which is a secondary application of language originally used in the context of ritual defilement. ${ }^{299}$ Subsequently, Wright argued that morality is the foundation of the whole system, and that ritual impurity symbolizes sin. This means, then, that ritual defilement serves to symbolize its own metaphorization. The circularity present in this proposal is selfcontradictory. ${ }^{300}$

The sharp distinction Klawans proposed does not mean that these two impurities are totally separate. They are distinct, but yet analogous, conceptions of contagion. They overlap, but they do that with other systems in the OT such as the sacrificial system, the

\footnotetext{
${ }^{297}$ Wright, “The Spectrum of Priestly Impurity,” 164.

${ }^{298}$ Klawans, Impurity and Sin in Ancient Judaism, 37.

${ }^{299}$ Wright, "The Spectrum of Priestly Impurity,” 162-64.

${ }^{300}$ Klawans, Impurity and Sin in Ancient Judaism, 37.
} 
legal system of law and justice, cultic laws, and the calendar. If one were to look for a unifying system for all other systems, it might be the entire religion of Israel. Thus, due to the fact that the differences between two impurities outweigh the similarities, it is fair to take the two impurities on their own terms. ${ }^{301}$

When it comes to the terminology, Klawans agreed with Wright that the use of adjectives, "ritual" and "moral," attached to the word "impurity" in order to differentiate these two impurities, is problematic. They do not appear in OT texts, nor in post-biblical Jewish literature. ${ }^{302}$ Some scholars simply refused to use any additional terminology than just impurity. ${ }^{303}$ The danger of using ritual and moral is that whatever is associated with the latter will always be considered with more attention than with the former. However, since the OT uses the same terminology to describe two distinct impurities, researchers need to supply descriptive terminology in order to lessen the confusion related to this concept. ${ }^{304}$ Adopting a terminology not used by the biblical authors to explain biblical concepts is necessary and unavoidable in regards to many concepts. ${ }^{305}$

The terminology that defines these two kinds of impurities does not imply that these two types of impurity are opposing or mutually exclusive. Rather, the intention is to highlight the fact that there are two distinct impurities, one of which is more associated

${ }^{301}$ Klawans, Impurity and Sin in Ancient Judaism, 37.

${ }^{302}$ Wright, "The Spectrum of Priestly Impurity," 151-52n3.

${ }^{303}$ Sanders, Jewish Law from Jesus to the Mishnah, 192; Neusner, The Idea of Purity in Ancient Judaism, 1-2.

${ }^{304}$ Klawans, Impurity and Sin in Ancient Judaism, 22.

${ }^{305}$ The term Trinity was never used in the Bible even though biblical texts contain many statements about this concept. Millard J. Erickson, Christian Theology, 2nd ed. (Grand Rapids, MI: Baker Academic, 2013), 172. 
with sin (in terms of moral faults) than the other. A ritually impure person is excluded from particular rituals and prevented from entering sacred precincts. ${ }^{306}$ A ritually impure person regains his or her ritual purity in part ritually, by the means of sacrifice, sprinkling, washings, and bathing, but in some cases, rituals are not sufficient. One may remain ritually impure until evening after ritual purification (Lev 15:5). Thus, the completion of the process of regaining ritual purity in part is conditioned by the passage of time. However, ritual is a useful description, much more so than cultic ${ }^{307}$ and levitical, ${ }^{308}$ since ritual frequently plays an important role in this process. ${ }^{309}$ Ritual is also an integral part of achieving moral purity, as well as also making this term imperfect for reflecting this type of impurity. However, Klawans suggested the use of the adjectives "ritual" and "moral" to describe impurity in the best way possible, but not in perfect terms. These adjectives attached to the noun "impurity" express both the inter-relatedness of the two impurities and also their differences. They refer to the same concept of impurity, which consists of two types ${ }^{310}$ with two distinctive natures.

${ }^{306}$ Klawans, Impurity and Sin in Ancient Judaism, 22.

${ }^{307}$ Cultic is less suitable simply because the cult plays an important role in both types of impurity. Klawans, Impurity and Sin in Ancient Judaism. Wright suggested that cultic would be used to refer to the impurities that take place as by-products of particular sacrificial procedures. David P. Wright, "Unclean and Clean," ABD 6:732.

${ }^{308}$ This term is misleading in two ways: (1) both ritual and moral impurities are articulated not only in the book of Leviticus, but in other books, as well, and (2) neither ritual nor moral impurity is particularly concerned with Levites, but with all Israelites. Klawans, Impurity and Sin in Ancient Judaism, 23; Wright, "The Spectrum of Priestly Impurity," 152-53.

\footnotetext{
${ }^{309}$ Klawans, Impurity and Sin in Ancient Judaism, 22-23.

${ }^{310}$ Klawans, Impurity and Sin in Ancient Judaism, 23.
} 


\section{Thomas Kazen}

Thomas Kazen is a representative of the school that equates ritual and moral impurity. ${ }^{311}$ He noted that "purity is a ritual concept but the purity language is used in the OT with reference to sinful behavior." ${ }^{312}$ For this and reasons that will be presented below, Kazen initially claimed that the unifying factor of ritual and moral impurity is the notion of disgust as stated in the following quotation: "All three phenomena for which impurity language is used in Leviticus - dietary laws, contact-contagion, and certain types of immorality — share common traits that can be related to the primary emotion of human disgust at objectionable substances, being applied secondarily to these phenomena alike." ${ }^{313}$ Kazen arrived at this conclusion by applying a bio-psychological approach to the moral and ritual texts. This approach in Kazen's work, as in all other approaches of cognitive science of religion, refers to human cognition. However, he placed the emphasis on the emotional aspect of cognition, rather than on rational mental activities. ${ }^{314}$ Kazen took Antonio Damasio's work as a foundation in this process. Contrary to the traditional Western paradigm based on Descartes' famous saying, Cogito, ergo sum, which assumed that mind is separate from matter and rationality is opposite to emotion, Damasio claimed that bodily sensations and emotions are an integral part of the human mind. In conducting neurobiological research, he found that the mind is in constant

\footnotetext{
${ }^{311}$ Thomas Kazen, Jesus and Purity Halakhah: Was Jesus Indifferent to Impurity?, ConBNT 38 (Winona Lake, IN: Eisenbrauns, 2010), 209-14, 216-18.

${ }^{312}$ Kazen, Jesus and Purity Halakhah, 200.

${ }^{313}$ Kazen, "Dirt and Disgust," 64.

${ }^{314}$ Thomas Kazen, Issues of Impurity in Early Judaism, ConBNT 45 (Winona Lake, IN: Eisenbrauns, 2010), 13.
} 
interaction with the rest of the organism. He concluded, "It does not seem sensible to leave emotions and feelings out of any overall concept of mind." ${ }^{315} \mathrm{He}$ also said that the "mind derives from the entire organism." 316 Therefore, emotions are crucial in human reasoning, judgment, and behavior. ${ }^{317}$ Focusing on the emotions and avoiding the division between morality and ritual, Kazen's latter work shows that he added two more major emotions to the emotion of disgust, namely fear and the sense of justice, which underlie the concept of impurity. ${ }^{318}$ Thus, these three emotions form the background for all impurities, rituals, and morals.

Kazen noted that purity language is used in three different groups of laws—clean and unclean animals, bodily transferable contact-contagion, and serious immorality. ${ }^{319} \mathrm{In}$ scholarly works, clean and unclean animals are placed into either ritual or moral laws. ${ }^{320}$ Noting the overlap between these three groups of laws and not acknowledging the separation between the last two allowed Kazen to integrate the first and most problematic group of texts into a single-nature understanding of impurity in the OT. ${ }^{321}$ The fact that these three groups of laws overlap in the OT and that, in Kazen's understanding, they

\footnotetext{
${ }^{315}$ Antonio R. Damasio, Descartes' Error: Emotion, Reason, and the Human Brain (New York: Putnam, 1994), 158.

${ }^{316}$ Damasio, Descartes' Error, 225.

${ }^{317}$ Damasio, Descartes' Error, 245-52.

${ }^{318}$ Kazen, Issues of Impurity in Early Judaism, 16-17.

${ }^{319}$ Kazen, Issues of Impurity in Early Judaism, 17.

${ }^{320}$ Kazen, "Dirt and Disgust," 44.

${ }^{321}$ Kazen, "Dirt and Disgust," 44.
} 
have a common origin enforced Kazen's claim of a single-nature of impurity. ${ }^{322}$

Kazen also excluded the metaphorical interpretation of impurity on two grounds:

the use of the metaphor in the scholarly works is inconsistent ${ }^{323}$ and human language

itself is very prone to be metaphorized.

The distinction [between literal and metaphorical] often becomes artificial. Although "metaphorical" generally refers to the use of language in a secondary or transferred sense, while "literal" refers to a primary use, literal expressions can be metaphorized and metaphorical language at times literalized. At a deep level, human language and thought are metaphorical throughout, including our moral imagination. ${ }^{324}$

Kazen's reasons for eliminating metaphor from the discussion on impurity are not sound. First, the inconsistent metaphorical and literal use of purity/impurity language by scholars does not mean that the distinction between ritual and moral impurity does not exit. Rather, the solution can simply be found in defining these two terms than in eliminating the possibility of separation between ritual and moral impurity. ${ }^{325}$ Second, Kazen's understanding of metaphor is based on the works of George Lakoff and Mark Johnson, ${ }^{326}$ whose totalizing claims on metaphor are to be taken with caution. ${ }^{327}$ Lam's evaluation of Lakoff's and Johnson's understanding of metaphor seems to be on point:

Lakoff and Johnson claim that metaphorical patterning has a deeper cognitive basisthat "metaphors as linguistic expressions are possible precisely because there are

\footnotetext{
${ }^{322}$ Kazen, "Dirt and Disgust," 47-49. It has to be stressed that the common origin argument is heavily dependent on the ANE texts rather than on biblical texts.

${ }^{323}$ Kazen, "Dirt and Disgust," 45.

${ }^{324}$ Kazen, "Dirt and Disgust,” 64.

${ }^{325}$ Lam, "Metaphorical Patterning," 117.

${ }^{326}$ G. Lakoff and M. Johnson, Metaphors We Live By (Chicago: University of Chicago Press, 1980); G. Lakoff and M. Johnson, Philosophy in the Flesh: The Embodied Mind and Its Challenge to Western Thought (New York: Basic Books, 1999); Mark Johnson, Moral Imagination: Implications of Cognitive Science for Ethics (Chicago: University of Chicago Press, 1993), 32-77.

${ }^{327}$ Lam, "Metaphorical Patterning," 117.
} 
metaphors in a person's conceptual system." Thus they posit the existence of "metaphorical concepts"--cognitive structures of the form [TARGET DOMAIN] IS [SOURCE DOMAIN] that are thought to give rise to linguistic instantiations of the metaphor. The assumption is that, since these patterns are so apparent and pervasive in language, it must be the pattern that is primary, not the linguistic expressions that give evidence of it. ${ }^{328}$

It seems very arbitrary to single out just one aspect of the human being - the emotional, ${ }^{329}$ - and disregard all others, such as the rational and the social, which contribute greatly in conceptualizing an idea as complex as morality. ${ }^{330}$ It also has to be emphasized that Kazen's model is limited in terms of its theoretical foundation to Charles Darwin's evolutionary theory.

\section{Summary of Scholarly Research on Impurity}

The review of the history of interpretation shows certain tendencies and developments in the studies of impurity in the OT. The pioneers of this study in modern times, David Hoffmann and Adolf Büchler, followed, conceptually and terminologically, the classical, bipartite division of impurity to ritual and moral which was already articulated in Jewish sources, spanning from Talmudic and medieval rabbinic literature, Philo, and the early rabbinic sages.

Hoffmann recognized that moral impurity originates from sinful behavior such as eating forbidden foods, idolatry, and various sexual sins for which atonement is not available except on the Day of Atonement. This impurity defiles the sinner's body and is

\footnotetext{
${ }^{328}$ Lam, "Metaphorical Patterning," 23. For a more thorough critique of Lakoff's and Johnson's understanding of metaphor, see sources cited in Lam, "Metaphorical Patterning," 23 n33.

${ }^{329}$ Kazen, "Dirt and Disgust," 52.

${ }^{330}$ Lam, "Metaphorical Patterning," 116.
} 
not symbolic, but real, implying God's rejection of the one who commits it. Based on Lev 18:24-30, this defilement also defiles the land and causes the exile of the people. Ritual impurity is temporal and can be removed by ablutions. As Lev 11-15 and Num 19 convey, it originates from human corpses, certain animal carcasses, bodily flows, and leprosy. Hofmann perceived this impurity as a symbolic one, symbolizing sin.

Büchler assigned different terminology to the same two natures of impurity by using levitical instead of ritual, and religious or spiritual instead of moral impurity. He noted that ritual impurity is impermanent contagion. Except for the different terminology he used for these two impurities and the fact that moral impurity is not contagious, his work is similar to Hofmann's work. Both Hoffmann's and Büchler's works missed drawing a distinction between the defilement that arises from unintentional and intentional moral impurity and they do not discuss the difference between minor and major ritual/levitical defilements.

Gedalyahu Alon added a new component to the purity studies, namely, the role of geographical boundaries to which purity laws were applied. "Minimalists" restricted these laws to the sphere of the Temple and priests, while the "maximalists" claimed that they are applicable to all of Israel. However, isolating only the geographical element related to the purity/impurity laws is insufficient to understand them properly.

Jacob Neusner proposed the evolutionary development of moral impurity out of one's unfitness in the holy community. Under the influence of Alon, he suggested that purity/impurity itself is a single nature concept and can be interpreted in two ways: as a metaphor of morality elsewhere in the Hebrew Bible and in the Priestly texts through which specific laws are related to the Temple. However, Neusner's interpretation of 
biblical texts shows that he was not able to preserve these two descriptions on the purity/impurity laws. In addition, Douglas correctly noted the inconsistency of taking some parts of a single system and ascribing to them different meanings in different contexts. Neusner's work has received a lot of substantial criticism.

The contribution of Mary Douglas to the study of ritual and impurity from a theoretical and anthropological standpoint is well known and substantial, but she was not concerned about making a clear distinction between ritual and moral impurity; because of that, some scholars claimed that she also assumed the single nature of impurity. This is strengthened with the statements found throughout her works that would lead one to deduce that she understood impurity as a single nature phenomenon, but there are also statements in her works which point to the fact that she understood impurity to be a twonature phenomenon. Klawans's remark that she was much more nuanced than scholars who make such claims based on her works regarding impurity seems to be correct.

Hyam Maccoby recognized a basic distinction between ritual and moral impurity with ritual purity having limited validity for Israelites only, and moral purity having universal validity for all of humanity. In addition, he believed that moral purity has precedence over ritual purity in case they conflict. He emphasized the fact that mortality through the birth and death cycle, which is related to all ritual impurity, stands as the background of ritual laws and that they guard the temple from the entire cycle of mortality.

Jacob Milgrom's treatment of impurity is not clear as might have been expected. Essentially, he endorsed ritual and moral impurity distinction. However, his treatment of 
ritual impurity is more consistent and systematic than treatment of moral impurity which he, at times, interpreted as metaphorical.

Tikva Frymer-Kensky produced one of the most systematic and complete treatments of impurity in modern times. Building from the classical division to ritual and moral impurity which both defile individuals, temple, and land, she added subdivisions to both of them. She divided ritual impurities into major and minor ones. Major impurities are caused by death, leprosy, bodily discharges, and childbirth, while minor impurities result in contact with impure things, things that are defiled by the persons having a major impurity, and persons themselves under major impurity. This impurity is contagious in its nature, not sinful or dangerous by default, but it can lead to sin and danger. Moral impurity is related to forbidden activities which provoke God's punishment of kērēt or the punishment expressed by "he shall bear his penalty." She understood that a distinction to the sacred and profane is foundational for Israelite cosmology. First, God is holy and his presence made the temple, camp, and land holy, and the latter three must maintain their holiness. Frymer-Kensky believed that pollution takes place via direct contact, but also aerially. At times, Frymer-Kensky used different terminology to refer to these impurities, for example, "pollution beliefs" and "dangerous beliefs," rather than classical terms, but she more frequently used the classic terms ritual and moral impurity.

Building on the work of the previous scholars mentioned above, in great part Frymer-Kensky, David P. Wright accepted the fact that some impurity comes out of natural conditions and some results out of sinful situations. In addition, he endorsed two classes of ritual impurities, major and minor. He also assigned to them a defiling force and approved the fact that this impurity is not sinful. Wright's systematization is based on 
the (1) means of cleansing, (2) extent of pollution, and (3) communicability of pollution. His division is more detailed and consists of four classes of major and six classes of minor impurity. Wright divided impurity that is caused by sinful activities into (1) intentional and (2) unintentional. The unintentional impurity defiles the outer altar and holy place depending on social status, while intentional sins defile the most holy place aerially. The unintentional are expiable via sacrifice, while the intentional are not expiable but punishable by kārēt. The idea Wright introduced in comparison to FrymerKensky's was totally new terminology to refer to these two impurities, tolerated and prohibited, but he himself acknowledged that these terms are also problematic. Wright can also be credited for being much more detailed in his systematization of impurity.

Basing his research on the works of the previous scholars mentioned above who had already advanced systematization and understanding of impurity, especially in the works of Hoffmann and Frymer-Kensky, Jonathan Klawans produced the most elaborate and systematic, up-to-date research on impurity. He is currently the most ardent proponent of the traditional division of impurity into ritual and moral. Along with the previous scholarly research, Klawans agreed that ritual impurity (1) arises from natural and unavoidable conditions, (2) is not sin, and (3) conveys impermanent contagion via direct contact. Moral impurity on the other hand, (1) arises from grave sin, (2) does not defile by direct contact, (3) leads to long-lasting, if not permanent, contagion, and (4) unlike ritual impurity which can be addressed and remedied via purification ritual, is rectified by atonement, punishment, or by refraining from committing it.

Klawans noticed that purity/impurity terminology also confirms traditional

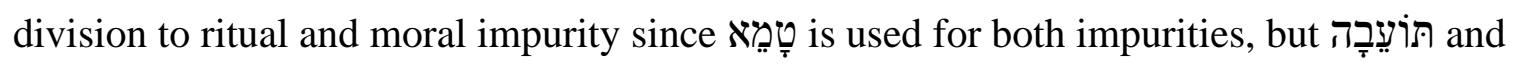


חָָנָך are used exclusively for moral impurity. Moral impurity defiles the one who performs it, the sanctuary, and the land. Ritual impurity never defiles the land, nor is derived from the land, but defiles the sanctuary and humans. The idea that Klawans brought to the discussion on impurity is that both impurities, ritual and moral, are real. In addition, he endorsed the metaphorical use of purity/impurity language in biblical texts, but not to the extent scholars usually assume. In addition, the use of a metaphorical or figurative interpretation of certain texts brings more confusion than clarity to the discussion due to various theories on metaphor itself.

Klawans also stated that besides the fact that these impurities are distinct, they are an analogous conception of contagion as a part of the entire system of Israelite religion. These two impurities are not mutually exclusive, but rather, the emphasis is on the fact that impurity consists of two natures, each of which has unique characteristics and features. Aware of the deficiencies of all terminology suggested in the previous research, Klawans chose ritual and moral impurity, not as perfect terms to denote these two impurities, but as what are the least confusing and misleading.

Thomas Kazen was a firm proponent of a single nature of impurity. Driven by the methods of bio-psychology, he suggested that the notions/emotions of disgust, fear, and sense of justice stand in the background of both ritual and moral impurity. Informed by research in the area of bio-phycology which proposes the equal role of emotions along with reason in the decision-making process, Kazen concluded that these three emotions underline the concept of impurity as a single nature phenomenon.

After review of the development of scholarly opinions on impurity in the OT and before proceeding to study moral impurity specifically, the present study seeks to 
emphasize some more specific points mentioned in the scholarly dialog on the topic, namely, the following subheading examined and expanded some crucial scholarly claims regarding impurity.

\section{Remarks on Sin and Impurity: Insights from the Present Research}

Some scholars have arrived at profound insights that impact the understanding of impurity in the Pentateuch. These statements are cited below and, when needed, refined. Following the works of Kurtz, ${ }^{331}$ Rendtorff, ${ }^{332}$ and Milgrom, ${ }^{333}$ Gane brought to attention an accurate and helpful point that further strengthens the standpoint of modern כפר מטאת A sacholarship on the existence of two distinct impurities: "Aviding for physical ritual impurity results in physical ritual purity (טהר). Forgiveness (סלח) is not needed, because contacting a bodily impurity does not, by itself, constitute a moral fault."334 The following subheadings, "טלחר,"טר"," test the correctness of this claim.

\section{סָלָח}

The verb סָלָ, "to forgive"335 occurs twenty times in the Pentateuch and was

${ }^{331}$ Kurtz, Offerings, 416-17, 420.

${ }^{332}$ R. Rendtorff, Leviticus, BKAT 3/3 (Neukirchen-Vluyn: Neukirchen, 1992), 176, 216-17.

${ }^{333}$ Milgrom, Leviticus 1-16, 255-56, 760.

${ }^{334}$ Gane, Cult and Character, 199.

${ }^{335}$ Gerhard von Rad, Old Testament Theology, trans. D. M. G. Stalker (Louisville: Westminster John Knox Press, 2001), 2:757-58; J. P. J. Olivier, "סָלָח," NIDOTTE 3:258-61. 
never required for contracting ritual impurity. As a search for this verb, provided in the following table, proves,${ }^{336}$ contracting ritual impurity status does not create moral impurity. This point is further strengthened by the way ritual impurity comes into existence. That is, ritual impurity is undesirable, but it remains a part of the current human nature and the created world since the Fall into sin (Gen 3). In most cases, it is unavoidable and cannot be prevented.

The first two columns of Table 3 provide the biblical reference where סָלָ is used in the context with the terms for sin. The middle two columns show the additional noun/s and verb/s that convey the concept of sin found in the same pericope. The last two columns demonstrate the nature and expiability of the impurity under consideration.

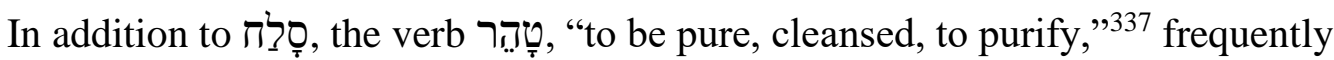
occurs in impurity contexts to convey the elimination of the effects of impurity on humans. ${ }^{338}$ The verbal forms of טָּה occur fifty-four times in the Pentateuch. ${ }^{339}$

\footnotetext{
${ }^{336}$ The verbal form of סָלָ occurs twenty-seven more times in the OT along with four remaining derivatives (three nouns, Ps 130:4, Dan 9:9, and Neh 9:17, and one adjective, Ps 86:5). None of these refers to ritual, but moral impurity.

${ }^{337}$ Richard E. Averbeck, “טהר," NIDOTTE 2:332; F. Maass, “טהר," TLOT 3:482.

${ }^{338}$ Wright, "Unclean and Clean," 6:737.

${ }^{339}$ Nonverbal forms occur eighty-one times (sixty-nine adjectives and twelve nouns). Adjectives can be grouped into four semantic domains: (1) natural (dietary) cleanness: Gen 7:2 (2x), 8 (2x); 8:20 (2x), Lev 20:25, Deut 14:11, 20, (2) physical quality of material items (gold): Exod 24:10; 25:11, 17, 24, 29, 31, $36,38-39 ; 28: 14,22$, 36; 30:3, 35 (perfume); 31:8; 37:2, 6, 11, 16-17, 22-24, 26, 29; 39:15, 25, 30, 37; Lev 24:4, 6, (3) ritual cleanness of humans, things, places, animals: Lev 4:12;6:11; 7:19; 10:10, 14; 11:3637, 47; 12:4. 5. 6; 13:7, 13, 17, 35, 37, 39-41; 14:2, 4, 23, 32, 57; 15:8, 13; 20:25; Num 6:9; 9:13; 18:11, 13; 19:9, 18-19; Deut 12:15. 22; 15:22; 23:11, and (4) moral cleanness of humans: Num 5:28. Thus, out of sixty-nine adjectives, sixty-eight of them refer to ritual impurity, while one instance (Num 8:21) refers to moral impurity.
} 
Table 3. The verb סָלָ in the Pentateuch

\begin{tabular}{|c|c|c|c|c|c|c|c|}
\hline \multirow[b]{2}{*}{$\begin{array}{c}\text { Biblical } \\
\text { Reference }\end{array}$} & \multirow[b]{2}{*}{ Sin Terms } & \multicolumn{2}{|c|}{ Word Type } & \multicolumn{2}{|c|}{$\begin{array}{l}\text { Nature of } \\
\text { Impurity }\end{array}$} & \multicolumn{2}{|c|}{ Expiability } \\
\hline & & $\begin{array}{l}\text { Additional } \\
\text { Noun/s }\end{array}$ & Additional Verb/s & Ritual & Moral & Yes & No \\
\hline \multirow{2}{*}{ Ex 34:9 } & 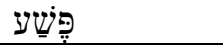 & & & & \multirow{2}{*}{$\mathrm{X}$} & \multirow{2}{*}{$\mathrm{x}$} & \\
\hline & חטאת & & & & & & \\
\hline Lev 4:20 & & חטאת v. 14 & $\begin{array}{l}\text { אשם ,עשה, שטגה v. } 14 \\
\text { חטא v. } 14\end{array}$ & & $\mathrm{X}$ & $\mathrm{x}$ & \\
\hline Lev 4:26 & חטאת & $\begin{array}{l}\text { שטגאה v. } 22 \\
\text { חטאת v. } 23 \\
\text { חטאת v. } 26\end{array}$ & $\begin{array}{l}\text { אשם ,עשה, חטא, v. } 23 \\
\text { חטא, v. } 23\end{array}$ & & $\mathrm{X}$ & $\mathrm{x}$ & \\
\hline Lev 4:31 & חטאת & חטאת v. 28x2 & 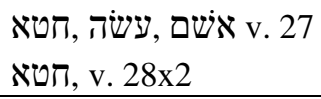 & & $\mathrm{X}$ & $\mathrm{x}$ & \\
\hline Lev 4:35 & חטאת & & חטא v. 35 & & $\mathrm{X}$ & $\mathrm{x}$ & \\
\hline Lev 5:10 & חטאת & $\begin{array}{l}\text { חטאת v. 6x2 } \\
\text { חטאת v. } 10\end{array}$ & $\begin{array}{l}\text { חטא v. } 5 \\
\text { חטא v. } 7 \\
\text { חטא v. } 10\end{array}$ & & $\mathrm{X}$ & $\mathrm{x}$ & \\
\hline Lev 5:13 & חטאת & & $\begin{array}{l}\text { חטא v. } 11 \\
\text { חטא v. } 13\end{array}$ & & $\mathrm{X}$ & $\mathrm{x}$ & \\
\hline Lev 5:16 & 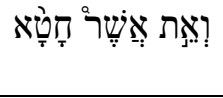 & מעל v. 14 & $\begin{array}{l}\text { חטא ,מעל v. } 14 \\
\text { חטא v. } 16\end{array}$ & & $\mathrm{X}$ & $\mathrm{x}$ & \\
\hline Lev $5: 18$ & שגגה & & 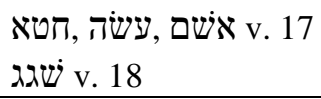 & & $\mathrm{X}$ & $\mathrm{x}$ & \\
\hline Lev 5:26/6:7 & 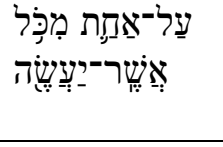 & 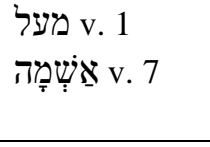 & $\begin{array}{l}\text { חטא ,מעל v. } 1 \\
\text { חטא v. } 4 \text {, חטא vש } 4\end{array}$ & & & & \\
\hline Lev 19:22 & x2 חטאת x & & חטא v. 4x2 & & $\mathrm{X}$ & $\mathrm{x}$ & \\
\hline Num 14:19 & עון & & 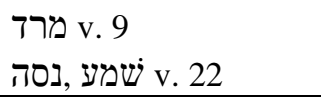 & & $\mathrm{X}$ & $\mathrm{x}$ & \\
\hline Num 14:20 & & & & & $X$ & $\mathrm{x}$ & \\
\hline Num 15:25 & שגגה x2 & שגגה v. 24 & עשה, עשה ,שגה v. 22 & & $\mathrm{X}$ & $\mathrm{x}$ & \\
\hline Num 15:26 & שגגה & & שגה v. 22 & & $\mathrm{X}$ & $\mathrm{x}$ & \\
\hline Num 15:28 & & $\begin{array}{l}\text { שגגה v. } 29 \\
\text { שגגה v. } 29\end{array}$ & $\begin{array}{l}\text { חטא v. } 28 \\
\text { חשגא vשו v. } 29 \\
\text { עשה v. } 29\end{array}$ & & $\mathrm{X}$ & $\mathrm{x}$ & \\
\hline Num 30:6 & חטאת, Lev 5:6 & & חטא Lev 5:5 & & $\mathrm{X}$ & $\mathrm{x}$ & \\
\hline Num 30:9 & חטאת, Lev 5:6 & & חטא Lev 5:5 & & $\mathrm{X}$ & $\mathrm{x}$ & \\
\hline Num 30:13 & חטאת, Lev 5:6 & & חטא Lev 5:5 & & $\mathrm{X}$ & $\mathrm{x}$ & \\
\hline Deut 29:19 & 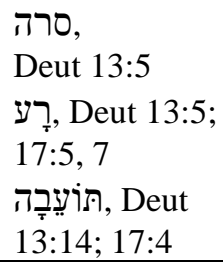 & & Negation + סָלָח & & $\mathrm{X}$ & & $\mathrm{x}$ \\
\hline
\end{tabular}


However, contrary to סָלַח which is exclusively used in moral impurity contexts,

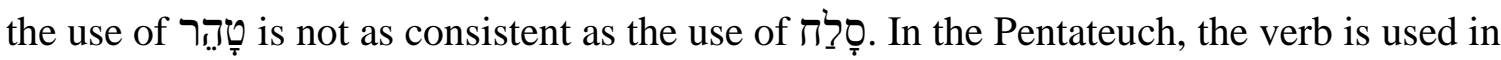
the context of both ritual and moral impurity. The following table (Table 4) lists all the texts where the verbal form of טָּה refers to the state of the person or object when purity is achieved in the Pentateuch. The first column contains the references and the second, the number of uses in each of those references. The next two columns in the middle divide the references in regard to the impurity they refer to. The last two columns show whether an object of the verb is a human being, the sanctuary, or other objects.

Results of the search on these two verbs shows that the purity/impurity terminology that conveys the elimination of the effects of impurity from humans is consistent, but still has certain exceptions. That is, the use of סָלָ decisively shows that forgiveness was never needed for ritual impurity, and a ritually impure person never received it in the Pentateuch or the rest of the OT. Accordingly, the uses of the verb סָלָ in the Pentateuch and the rest of the OT clearly emphasize a difference between the two impurities, moral and ritual.

The use of טָלָח טָָה is not as consistent as that is to the purity that is the result of ritual and/or moral impurity being eliminated from humans and inanimate objects in the Pentateuch. Statistics show that טָָָ deals with ritual impurity more frequently. Speaking in numbers, טָָ refers to the purity from the effects of ritual impurity in twenty-one out of twenty-five of contexts when it appears with the terms of impurity in the Pentateuch. However, three out of four of the remaining four contexts are 
Table 4. The verbal forms of טָָָּ in the Pentateuch

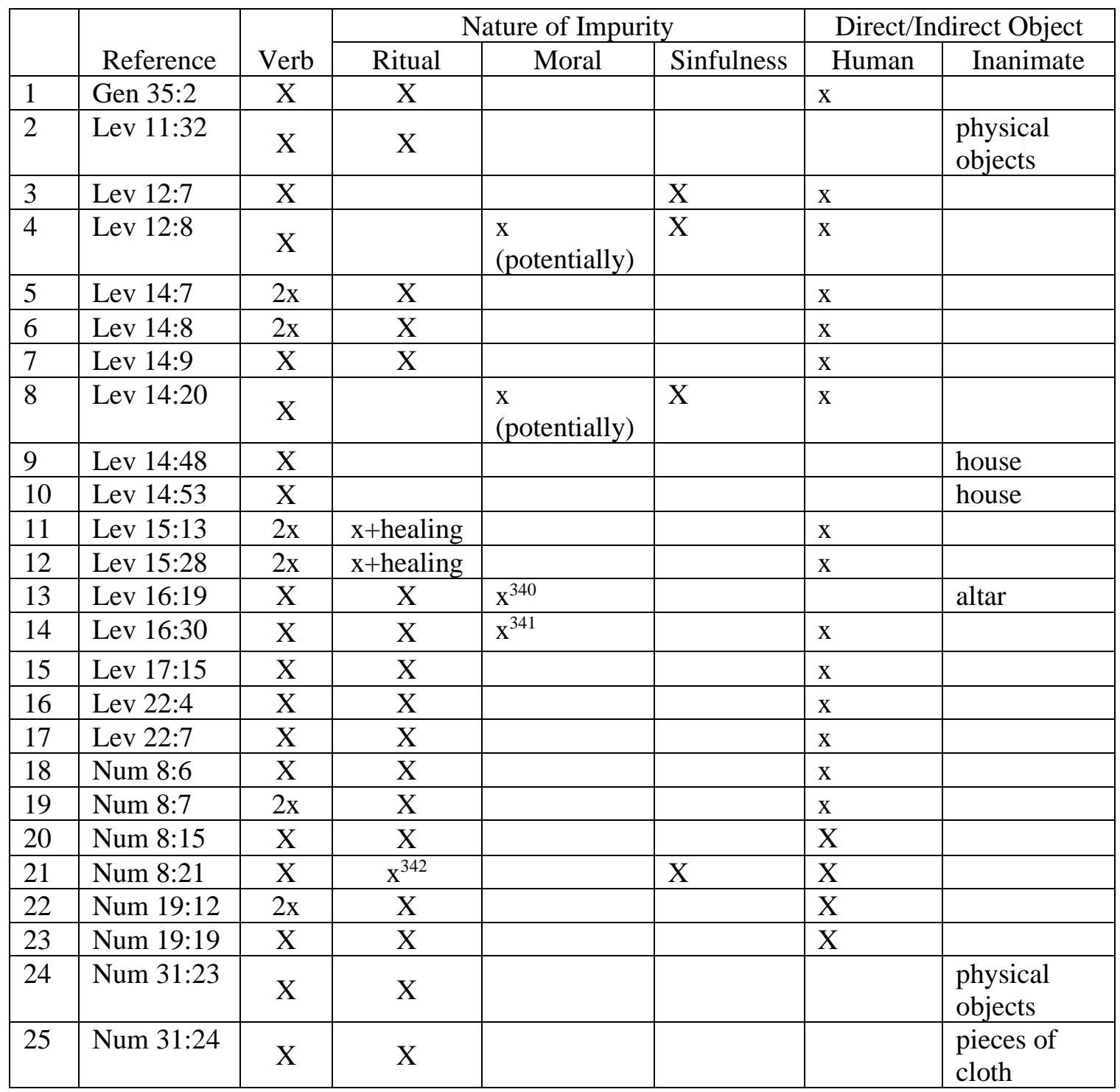

${ }^{340} \mathrm{Gane}$, Cult and Character, 230.

${ }^{341}$ Gane, Cult and Character, 39.

${ }^{342}$ Based on the use of the hithpael form of the verb חָז by this verb and form undeniably refers to the cleansing from ritual impurity. Milgrom, Numbers, 65 and see excursus 48. 
debatable. In Lev 12:7-8 and 14:20, the moral aspect of purity is just potentially present. It is not mentioned in the text. In Lev 16:19, ritual and moral impurity are removed from the sacrificial altar, which cannot have moral responsibility, but can just be clean or unclean. Lev 16:30 remains the only true exception since טָָה refers to the moral purity of the Israelites. ${ }^{343}$

In the rest of the OT, the use of טָָ is more frequently found in contexts where it refers to the cleansing of both ritual and moral impurity. That is, forty verbal forms refer to both ritual and moral purity which, contrary to the uses in the Pentateuch, have the greater number of occurrences related to moral impurity. There are thirty-two derivatives of the root טָָָ that are divided into two nonverbal forms, adjectives and nouns. Nouns occur five times and in four occurrences, they refer to ritual purity (Ezek 44:26; Neh 12:45; $1 \mathrm{Chr} 23: 28 ; 2 \mathrm{Chr} 30: 19)$ while one of them does not belong to purity language (Ps 89:44, translated as "splendor"). Adjectives occur twenty-seven times and refer to ritual (1 Sam 20:26; Isa 66:20; Ezek 22:26; 36:25; 44:23; Mal 1:11; Job 14:4; 17:9; 28:19; Eccl 9:2; Ezra 6:20; 2 Chr 30:17) and moral impurity (Hab 1:13; Psa 12:6; Ps 19:9; 51:10; Job 14:4; 17:9; 28:19; Prov 15:26; Prov 22:11; 30:12). In addition, some adjectives refer to ritual purity (Zech 3:5; Job 28:19; $1 \mathrm{Chr} 28: 17 ; 2 \mathrm{Chr} 3: 4 ; 2 \mathrm{Chr}$ 9:17; 13:11). These statistics show that the use of the root טָָה is more complex in the rest of the OT than in Pentateuch. The meanings that are attached to this term and the conditions they refer to are much broader. However, the rationale for this broader meaning of the verb in the rest of the OT exceeds the scope of this study and will not be explained here.

${ }^{343}$ Gane, Cult and Character, 39. 
It seems that the verb that refers to removal of the negative effects of impurity from humans points to the existence of two kinds of impurities. סָלָ is used exclusively to convey the removal effects of moral impurity from humans, while טָָה effects removal in the contexts where ritual impurity affected humans or inanimate objects and once where both impurities are involved (Lev 16:30).

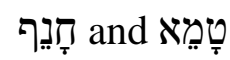

In the following quotation, Klawans highlighted two terminological points that also stress the difference between ritual and moral impurity: "Although the term impure (טָמֵאא) is used in both contexts, the terms abomination (תועבה) and pollute (חנף) are used with regard to the source of moral impurity, but not with regard to the sources of ritual impurity. $" 344$

First, in surveying the terminology mentioned in this quotation, Klawans noticed

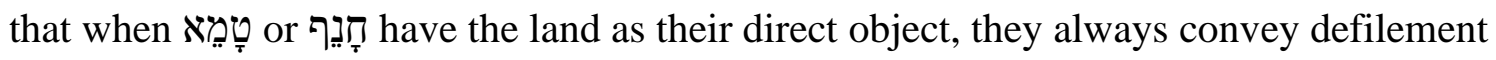
by moral impurity. The land never acquires defilement by ritual impurity. The following displays the texts where the verb טָָמָ conveys moral defilement of the land (Table 5).

The verb חָָנָר is used only once in the Pentateuch to convey the defilement of the land (Num 35:33). The nature of this defilement is moral.

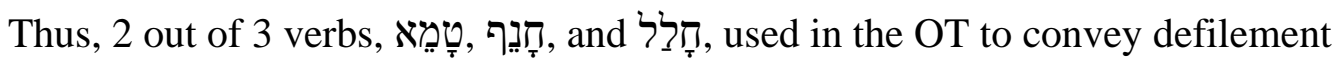
are employed to express defilement in the Pentateuch. The use of these verbs shows that

\footnotetext{
$55-56$.

${ }^{344}$ Klawans, Impurity and Sin in Ancient Judaism, 26; Klawans, Purity, Sacrifice, and the Temple,
} 
Table 5. The verb טָָמָא in relation to the land in the Pentateuch

\begin{tabular}{|l|l|l|l|c|c|}
\hline & \multirow{2}{*}{ Reference } & \multirow{2}{*}{ Terminology } & \multicolumn{2}{c|}{ Word Type } & \multicolumn{2}{c|}{ Nature of Impurity } \\
\cline { 3 - 6 } & Various & Verb & Ritual & Moral \\
\hline Lev 18:25 & & & $\mathrm{X}$ & & $\mathrm{X}$ \\
\hline Lev 18:27 & & & $\mathrm{X}$ & & $\mathrm{X}$ \\
\hline Lev 18:28 & & & $\mathrm{x}$ & & $\mathrm{X}$ \\
\hline Num 35:34 & & & $\mathrm{X}$ & & $\mathrm{X}$ \\
\hline Deut 21:23 & & $\mathrm{x}$ & & $\mathrm{X}$ \\
\hline
\end{tabular}

the land never received ritual, but always moral defilement. The reason why Klawans did not examine what kind of defilement is conveyed by the third verb that conveys defilement, the verb חָלָל, is because it never has land as a direct object in the Pentateuch. The only time דָלָל conveys defilement of the land is in the prophetic text of Jer 16:18, where the verb conveys defilement of the land by moral impurity.

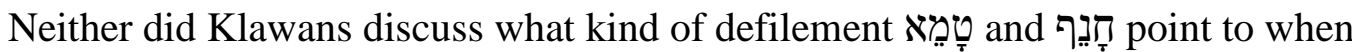
they involve humans or the sanctuary. Those statistics are provided in Table 6 . The first column indicates references where טָָָָא is used in the Pentateuch. The second column follows the use of the verbs. The third and fourth columns are both divided into two to present the nature and direct object of impurity.

The verb טָָָָא can apply to either of the impurities, as can be observed in Table 6. The majority of direct objects affected by the defilement communicated by טְָָָָ are humans rather than the sanctuary. Out of ninety-three uses, humans were affected eightynine times, while the sanctuary was affected three times. Once the entire camp was affected. 
Table 6. The verb טֵָָָָא in relation to humans and sanctuary

\begin{tabular}{|c|c|c|c|c|c|}
\hline \multirow[b]{2}{*}{ Reference } & \multirow[b]{2}{*}{ Terminology } & \multicolumn{2}{|c|}{ Nature of Impurity } & \multicolumn{2}{|c|}{ Object of Impurity } \\
\hline & & Ritual & Moral & Human & Sanctuary \\
\hline Gen 34:5 & & & $\mathrm{x}$ & $\mathrm{X}$ & \\
\hline Gen 34:13 & & & $\mathrm{x}$ & $\mathrm{X}$ & \\
\hline Gen 34:27 & & & $\mathrm{x}$ & $\mathrm{X}$ & \\
\hline Lev 5:3 & & $\mathrm{x}$ & & $\mathrm{X}$ & \\
\hline Lev 11:24 & $2 x$ & $\mathrm{x}$ & & $\mathrm{X}$ & \\
\hline Lev 11:25 & & $\mathrm{x}$ & & $\mathrm{X}$ & \\
\hline Lev 11:26 & & $\mathrm{x}$ & & $\mathrm{X}$ & \\
\hline Lev 11:27 & & $\mathrm{x}$ & & $X$ & \\
\hline Lev 11:28 & & $\mathrm{x}$ & & $X$ & \\
\hline Lev 11:31 & & $\mathrm{x}$ & & $X$ & \\
\hline Lev 11:39 & & $\mathrm{x}$ & & $\mathrm{X}$ & \\
\hline Lev 11:40 & $2 \mathrm{x}$ & $\mathrm{x}$ & & $\mathrm{X}$ & \\
\hline Lev 11:43 & $2 x$ & $\mathrm{x}$ & & $X$ & \\
\hline Lev 11:44 & & $\mathrm{x}$ & & $\mathrm{X}$ & \\
\hline Lev 12:2 & $2 \mathrm{x}$ & $\mathrm{x}$ & & $\mathrm{X}$ & \\
\hline Lev 12:5 & & $\mathrm{x}$ & & $X$ & \\
\hline Lev 13:3 & & $\mathrm{x}$ & & $X$ & \\
\hline Lev 13:8 & & $\mathrm{x}$ & & $\mathrm{X}$ & \\
\hline Lev 13:11 & & $\mathrm{x}$ & & $\mathrm{X}$ & \\
\hline Lev 13:14 & & $\mathrm{x}$ & & $\mathrm{X}$ & \\
\hline Lev 13:20 & & $\mathrm{x}$ & & $\mathrm{X}$ & \\
\hline Lev 13:22 & & $\mathrm{x}$ & & $\mathrm{X}$ & \\
\hline Lev 13:25 & & $\mathrm{x}$ & & $X$ & \\
\hline Lev 13:27 & & $\mathrm{x}$ & & $\mathrm{X}$ & \\
\hline Lev 13:30 & & $\mathrm{x}$ & & $\mathrm{X}$ & \\
\hline Lev 13:44 & $2 \mathrm{x}$ & $\mathrm{x}$ & & $X$ & \\
\hline Lev 13:46 & & $\mathrm{x}$ & & $\mathrm{X}$ & \\
\hline Lev 13:59 & & $\mathrm{x}$ & & $\mathrm{X}$ & \\
\hline Lev 14:46 & & $\mathrm{x}$ & & $X$ & \\
\hline Lev 15:5 & & $\mathrm{x}$ & & $X$ & \\
\hline Lev 15:6 & & $\mathrm{x}$ & & $X$ & \\
\hline Lev $15: 7$ & & $\mathrm{x}$ & & $\mathrm{X}$ & \\
\hline Lev 15:8 & & $\mathrm{x}$ & & $X$ & \\
\hline Lev 15:10 & $2 x$ & $\mathrm{x}$ & & $\mathrm{X}$ & \\
\hline Lev 15:11 & & $\mathrm{x}$ & & $X$ & \\
\hline Lev 15:16 & & $\mathrm{x}$ & & $X$ & \\
\hline Lev 15:18 & & $\mathrm{x}$ & & $X$ & \\
\hline Lev 15:19 & & $\mathrm{x}$ & & $X$ & \\
\hline Lev 15:21 & & $\mathrm{x}$ & & $X$ & \\
\hline Lev 15:22 & & $\mathrm{x}$ & & $X$ & \\
\hline Lev 15:23 & & $\mathrm{x}$ & & $\mathrm{X}$ & \\
\hline Lev 15:24 & $2 \mathrm{x}$ & $\mathrm{x}$ & & $X$ & \\
\hline Lev 15:27 & $2 x$ & $\mathrm{x}$ & & $X$ & \\
\hline Lev 15:31 & & $\mathrm{x}$ & & & $X$ \\
\hline
\end{tabular}


Table 6-Continued.

\begin{tabular}{|c|c|c|c|c|c|}
\hline Lev 15:32 & & $\mathrm{x}$ & & $X$ & \\
\hline Lev $17: 15$ & & $\mathrm{x}$ & & $X$ & \\
\hline Lev 18:20 & & & $\mathrm{x}$ & $X$ & \\
\hline Lev 18:23 & & & $\mathrm{x}$ & $X$ & \\
\hline Lev 18:24 & $2 x$ & & $\mathrm{x}$ & $X$ & \\
\hline Lev 18:30 & & & $\mathrm{x}$ & $X$ & \\
\hline Lev 19:31 & & & $\mathrm{x}$ & $X$ & \\
\hline Lev $20: 3$ & & $\mathrm{x}$ & & & $X$ \\
\hline Lev 21:1 & & $\mathrm{x}$ & & $X$ & \\
\hline Lev $21: 3$ & & $\mathrm{x}$ & & $X$ & \\
\hline Lev 21:4 & & $\mathrm{x}$ & & $X$ & \\
\hline Lev $21: 11$ & & $\mathrm{x}$ & & $\mathrm{X}$ & \\
\hline Lev $22: 5$ & $2 x$ & $\mathrm{x}$ & & $\mathrm{X}$ & \\
\hline Lev 22:6 & & $\mathrm{x}$ & & $\mathrm{X}$ & \\
\hline Lev 22:8 & & $\mathrm{X}$ & & $X$ & \\
\hline Num 5:3 & & $\mathrm{x}$ & & & camp \\
\hline Num 5:13 & $2 x$ & & $\mathrm{x}$ & $X$ & \\
\hline Num 5:14 & $2 x$ & & $\mathrm{x}$ & $X$ & \\
\hline Num 5:20 & & & $\mathrm{x}$ & $X$ & \\
\hline Num 5:27 & & & $\mathrm{x}$ & $X$ & \\
\hline Num 5:28 & & & $\mathrm{x}$ & $\mathrm{X}$ & \\
\hline Num 5:29 & & & $\mathrm{x}$ & $X$ & \\
\hline Num 6:7 & & $\mathrm{x}$ & & $X$ & \\
\hline Num 6:9 & & $\mathrm{x}$ & & $\mathrm{X}$ & \\
\hline Num $6: 12$ & & $\mathrm{x}$ & & $\mathrm{X}$ & \\
\hline Num 19:7 & & $\mathrm{x}$ & & $X$ & \\
\hline Num 19:8 & & $\mathrm{x}$ & & $\mathrm{X}$ & \\
\hline Num 19:10 & & $\mathrm{x}$ & & $\mathrm{X}$ & \\
\hline Num 19:11 & & $\mathrm{x}$ & & $\mathrm{X}$ & \\
\hline Num 19:13 & & $\mathrm{x}$ & & & $X$ \\
\hline Num 19:14 & & $\mathrm{x}$ & & $X$ & \\
\hline Num 19:16 & & $\mathrm{X}$ & & $\mathrm{X}$ & \\
\hline Num 19:20 & $2 x$ & $\mathrm{x}$ & & & $\mathrm{X}$ \\
\hline Num 19:21 & & $\mathrm{x}$ & & $X$ & \\
\hline Num 19:22 & $2 x$ & $\mathrm{x}$ & & X & \\
\hline Deut $24: 4$ & & & $\mathrm{x}$ & $X$ & \\
\hline
\end{tabular}

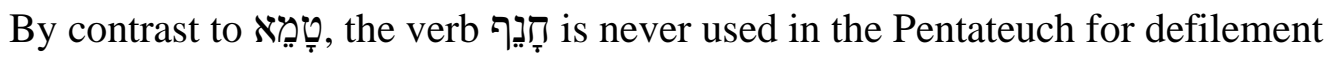

that affected either humans or the sanctuary. However, the verb חָלבל is used in nine texts in the Pentateuch to denote defilement as the following table displays. 


\section{חָלבל}

While the verb טָָָָ remains the key verb to convey the process of defilement in the Pentateuch, חָלָל is also used, less frequently, to refer to defilement. Milgrom שטמֵָא explained this semantic domain overlap in terms of confusion in the $\mathrm{H}$ texts that use and interchangeably. ${ }^{345}$ However, the present study understands this semantic overlap as a common phenomenon in $\mathrm{BH}$. The following table regarding the defilement of the land communicated through חָּלָ should be understood thus: the first column of the table shows references where חָלָל is used in the Pentateuch. The second column lists the use of the verbs. The third and fourth columns are both divided into two to present the nature and direct objects of impurity (Table 7).

Table 7. The verb חָּל in relation to humans and sanctuary

\begin{tabular}{|l|c|c|c|c|c|}
\hline & \multirow{2}{*}{ Reference } & Terminology & \multicolumn{2}{|c|}{ Nature of Impurity } & \multicolumn{2}{l|}{} \\
\cline { 3 - 6 } & & Ritual & Moral & Human & Sanctuary \\
\hline Lev 19:29 & & & $\mathrm{x}$ & $\mathrm{X}$ & \\
\hline Lev 21:4 & & $\mathrm{x}$ & & $\mathrm{X}$ & \\
\hline Lev 21:9 & $2 \mathrm{x}$ & & $\mathrm{x}$ & $\mathrm{X}$ & \\
\hline Lev 21:12 & & $\mathrm{x}$ & & $\mathrm{X}$ & $\mathrm{X}$ \\
\hline Lev 21:15 & & & $\mathrm{x}$ & $\mathrm{X}$ & \\
\hline Lev 21:23 & & $\mathrm{x}$ & & & $\mathrm{X}$ \\
\hline Lev 22:9 & & $\mathrm{x}$ & & & $\mathrm{X}$ \\
\hline Lev 22:15 & & $\mathrm{x}$ & $\mathrm{x}$ & & holy gifts \\
\hline Num 18:32 & & $\mathrm{x}$ & $\mathrm{x}$ & & holy gifts \\
\hline
\end{tabular}

${ }^{345}$ Milgrom, Leviticus 1-16, 37-38, 229-30. 


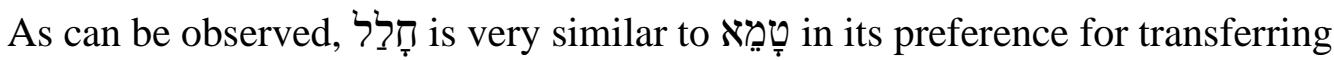
both ritual and moral defilement to humans and sanctuary.

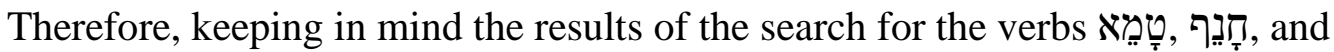
חָלָ presented above, Klawans's claim that the land never contracts ritual defilement is correct. The only defilement that the land can be affected with is moral defilement. However, the use of these verbs when their direct objects are humans or the sanctuary shows that they can refer to either type of defilement. In addition, the search showed that humans are more frequently affected with both kinds of defilement than the sanctuary is.

$$
\text { תָּעָבָדה }
$$

The second claim from Klawans's quotation is that nָּעָדה nevers to ritual impurity. The following shows that Klawans's claim that טָָָָ is used in both contexts,

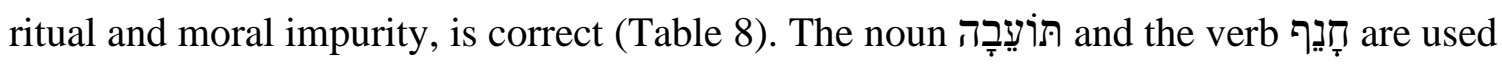
exclusively for moral impurity.

It has to be emphasized here that îעיערה in Gen 43:32, 46:34 and Exod 8:22[26] conveys meaning/s that were part of the Egyptian cultural, religious, moral, and social context and order, rather than Israelite's ideological context. Scholars are not certain of the exact meaning of תiֹ עִבָרה in these texts. Most of them claim that the issue was essentially related to both ritual and moral contexts. ${ }^{346}$ However, the most thorough study

\footnotetext{
${ }^{346}$ Thomas B. Dozeman, Exodus, ECC (Grand Rapids, MI: Eerdmans, 2009), 228; Kenneth A. Mathews, Genesis 11:27-50:26, NAC 1B (Nashville: Broadman \& Holman, 2005), 791-92; Michael A.

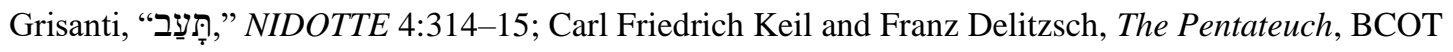
(Grand Rapids, MI: Eerdmans, 1952), 1:361-62.
} 
Table 8. The noun תiֹ in in the Pentateuch

\begin{tabular}{|l|l|l|l|c|c|}
\hline \multirow{2}{*}{ Reference } & \multirow{2}{*}{ Terminology } & \multicolumn{2}{c|}{ Word Type } & \multicolumn{2}{c|}{ Nature of Impurity } \\
\hline & & Noun & Verb & Ritual & Moral \\
\hline Gen 43:32 & & & & & $\mathrm{x}$ \\
\hline Gen 46:34 & & & & & $\mathrm{x}$ \\
\hline Ex 8:22 [26] & & & & & $\mathrm{x}$ \\
\hline Lev 18:22, 26-27, 29-30 & illicit sex, sodomy & & & & $\mathrm{x}$ \\
\hline Lev 20:13 & homosexuality & & & & $\mathrm{x}$ \\
\hline Deut 7:25-26 & idolatry & & & & $\mathrm{x}$ \\
\hline Deut 12:31 & child sacrifice & & & & $\mathrm{x}$ \\
\hline Deut 13:15 & illicit worship & & & & $\mathrm{x}$ \\
\hline Deut 14:3 & unclean animals & & & & $\mathrm{x}$ \\
\hline Deut 17:1 & unfit sacrifice & & & & $\mathrm{x}$ \\
\hline Deut 17:4 & Idolatry & & & & $\mathrm{x}$ \\
\hline Deut 18:9,12 & Necromancy & & & & $\mathrm{x}$ \\
\hline Deut 20:18 & sins of the nations & & & & $\mathrm{x}$ \\
\hline Deut 22:5 & sexes mixing clothes & & & & $\mathrm{x}$ \\
\hline Deut 23:18 & prostitution money & & & & $\mathrm{x}$ \\
\hline in temple & & & & \\
\hline Deut 24:4 & remarrying a woman & & & & $\mathrm{x}$ \\
\hline Deut 25:16 & dishonest scales & & & & $\mathrm{x}$ \\
\hline Deut 27:15 & idolatry & & & & $\mathrm{x}$ \\
\hline Deut 32:16 & idolatry & & & & $\mathrm{x}$ \\
\hline
\end{tabular}

on the meaning and origin of תוֹעָדָה has been done by A. S. Yahuda, who noted that the word is mainly related to sinful and criminal contexts that are in sharp opposition to Egyptian gods. ${ }^{347}$

The following statement by Milgrom is partially correct but misleading: "The distinction between moral and physical impurity is indicated not only by the terms for the causes of the sanctuary's pollution (tum ' $\bar{a}$ versus hẹt $t^{\prime}$ ) but by the consistent use of the

${ }^{347}$ A. S. Yahuda, The Language of the Pentateuch in Its Relation to Egyptian (London: Oxford University Press, 1933), xxxii, 4, 75, 95. It is also documented that the Egyptian influence on the biblical texts is very low. Bernd U. Schipper, "Egyptian Influences on the Biblical Text," Bible Odyssey, released 8 Nov 2017, http://www.bibleodyssey.org/places/related-articles/egyptian-influences-on-the-biblical-text. 
two different verbs that describe the effect of the purgation: physical impurity is purified (țāherr); moral impurity is forgiven (nislah)." 348

Based on this statement, one is led to believe that there is a consistent terminological usage of two sets of terms for ritual or moral impurity. That is correct for the second pair of terms טָלָח טָָ as as it was demonstrated above, ${ }^{349}$ with Lev 16:30 being the only exception. However, consistency of uses cannot be claimed for the first

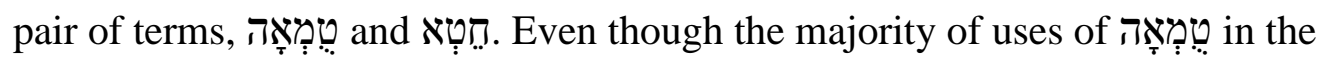
Pentateuch, nineteen out of twenty, ${ }^{350}$ refers to ritual impurity, טְְׁמָ in Num 5:19 refers to moral impurity. In addition, the nominal derivative of דָָּ and its derivative חִָּ is not the only term for moral impurity. Besides חֶ, there are four more nominal derivatives

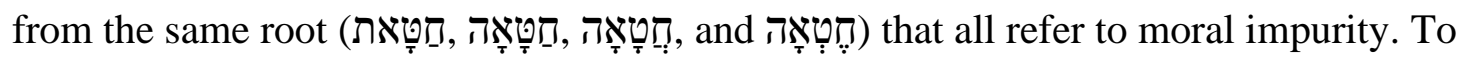
this, one could add other terms that convey moral impurity, such as which the present study is limited. However, the number of terms, including their verbal and nominal derivatives, that refer to moral impurity is even higher, which makes Milgrom's claim highly questionable.

\section{Conclusion}

After having analyzed the findings of scholarly research on impurity compared with Pentateuchal texts that deal with impurity and the additional terminological search

\footnotetext{
${ }^{348}$ Milgrom, Leviticus 1-16, 857.

${ }^{349}$ See Table 3 on page 97 of the present study.

${ }^{350}$ Lev $5: 3 ; 7: 20-21 ; 14: 19 ; 15: 3,25-26,30-31 ; 16: 16,19 ; 18: 19 ; 22: 3,5 ;$ Num 19:13.
} 
presented here, the present study arrived at the following conclusions. The position of the majority of scholars on the topic in regard to the first question that permeates the discussion, that is, whether there are one or two types of impurity, seems to be correct. The research presented in the present study, comprised of a variety of insights derived from Pentateuchal texts and a terminological/contextual/intertextual analysis of the passages where certain terms for sin are used, showed that there is a substantial difference between two types of impurity, ritual and moral. The key features of these two impurities which emphasize the differences between them were recently formulated by Klawans. Building his own system on the works of Hoffmann, Büchler, and FrymerKensky, he substantially expanded the understanding of the concept and strengthened the weak points of their research to frame the most comprehensive and detailed understanding of impurity to the present time.

However, Klawans' system also lends room for some modification. Two points in which it can be modified were noted in the present study. First, there is no division into intentional and unintentional in moral sins in Klawans's system, but rather, he recognized that moral sins are only murder, idolatry, and illicit sex, and they are always intentional. The second point coming from this oversight is that by not dividing moral sins into intentional and unintentional, he understood that moral impurity is a direct consequence of these grave sins, which is in sharp contrast with texts like Lev 4:1-5 and Num 15:2229 that speak about unintentional sins which are also moral in nature.

The second question regarding the relationship between these two types of impurity generated a considerable amount of research, but unfortunately did not produce a unified position. At this point, I suggest the following descriptions to reflect the 
relationship between ritual and moral impurity as an attempt to bring more clarity and precision to this lengthy discussion.

(1) Origin of impurity: Both kinds of impurity are sinful because they originate from the Fall into sin portrayed as the disobedience of the first couple in Eden (Gen 3). This Fall resulting from disobedience that made humanity susceptible to specific condition of GHS which is discussed on pp. 399-407 of the present study. This condition of humanity is foundational to both ritual and moral impurity. Ritual impurity essentially represents the effects of the Fall on the natural world, including humans, while moral impurity represents its effect on the human mind (as being a set of cognitive faculties including consciousness, perception, thinking, judgement, language and memory, and also including the spiritual aspect of it), thus paving the way for potential intentional and unintentional activity by humans against God's laws. Ritual impurity finds its expressions in the physical domain of human existence-reproduction, various physical diseases, contact with the dead — while moral impurity is exclusively related to the human mindperforming activities that oppose God's laws. Kiuchi, following Wenham, ${ }^{351}$ has postulated an understanding of ritual impurity accepted in the present work that it symbolizes an "aura of death.",352

(2) Nature of impurity: (a) Both of these impurities are real. They are perceived effects coming out of actual physical processes. Both impurities, as a result of certain activities or events, defile humans, physical entities, and the land. There are perceived

\footnotetext{
${ }^{351}$ Gordon J. Wenham, “Why Does Sexual Intercourse Defile (Lev 15:18)?,” ZAW 95 (1983): 434.

${ }^{352}$ Kiuchi, Purification Offering, 63. Wenham modified Douglas's theory of normality and wholeness as a norm of holiness. Douglas, Purity and Danger, 63-71.
} 
effects of a defilement by both impurities, mostly impermanent defilement caused by ritual impurities, and more severe defilement caused by moral impurity. Defiled individuals, in the case of ritual impurity, must refrain from contacting holy things or, in the case of moral defilement, are subject to punishment. Thus, both impurities bring effects of legal and social consequences. "Real" is not the same as "physical," but both of these impurities are ontologically abstract realities. Ritual impurity is often represented as physical and results from natural sources or events like child birth and human corpses. Numerous texts warn against direct contact between the ritually impure and the pure or especially the holy (Lev 7:20-21; 15:31;22:3-7; 21:1-4;22:3-7), an indication that the primary goal of these texts was to maintain and bring awareness of a required separation to be kept between ritual impurity and the holy. On the one hand, violating any of God's laws, which were given to prevent direct contact between the impure and the holy, constitutes moral rather than ritual impurity. On the other hand, being in or contracting a state of ritual impurity never generates moral impurity. Moral impurity is more serious in its consequences than ritual impurity since it results from the violation of God's laws, some of which include breaking the laws that are related to ritual impurity, and the rest represent guidelines for social and religious relationships within ancient Israel.

(3) Modes of defilement: Both kinds of impurities are contagious. Ritual impurity defiles humans and physical entities including the sanctuary via direct or indirect contact, but contracting ritual impurity by humans does not constitute moral impurity or sin as long as the divinely prescribed procedures for cleansing various types of ritual impurity are followed. Moral impurity defiles humans, the sanctuary, and the land in its entirety, but not certain physical entities as ritual impurity does. Humans are defiled by moral 
impurity by breaking God's laws. Defilement of the sanctuary by moral impurity takes place through the sacrificial blood offered by the sinner that is brought into the sanctuary. The land is defiled by moral impurity performed in/on it by covenantal people.

(4) Effects of impurity: Ritual impurity results in mostly impermanent defilement with no punishment. However, if ritual impurity was not dealt with or was brought in contact with the holy, it could trigger terminal punishment since that activity represents ignoring God-given guidelines regarding ritual impurity, and thus constitutes moral impurity or violating God's laws. Moral impurity brings more severe conditions and punishment of and upon the sinner which sometimes includes degradation of status. By breaking God's laws, the sinner is considered guilty, liable for punishment, and in need of forgiveness. Some moral impurities make a sinner irrevocably liable to $k \bar{a} r \bar{e} t^{353}$ or in some instances, he or she is allowed to live, but at a lower status. The remedy for both defilements was given by God so that individuals affected by any type of impurity could get rid of it, and in most of cases, experience no status degradation. If the remedy is not utilized in regards to some ritual and all moral impurity then one faces permanent degradation which, in other words, is death or exile if the land is affected.

(5) Remedy for impurity: Ritual impurity can be lessened by lapse of time and/or rites of purification. The remedy for some ritual impurity also requires a sin offering, but never forgiveness. Moral impurity always required a sin offering/atonement, prerequisite to forgiveness, but in some cases it resulted in the terminal punishment of kārēt.

Cleansing, which involved a sin offering, took place on the Day of Atonement. The most

${ }^{353}$ The concept of kārēt is explored in chapter four of the present study. 
severe remedy was exile and took place in case the land was defiled. In order to maintain their moral purity, humans could refrain from committing morally impure acts in the first place and follow God's procedures for private and annual cleansing of the sanctuary. Cleansing of the land was uniquely achieved by the shedding of the intentional killer's blood onto it.

(6) Terminological details: In addition to the previous characteristics derived from Pentateuchal texts in totality, the terminology used in purity/impurity contexts confirms the existence of two types of impurity. The crucial and most important difference is that removal of the effects of ritual impurity never requires סָלָ, forgiveness, but is always used in contexts that involve the effects of moral impurity. This consistent use of points to the fact that being ritually impure does not constitute the moral defilement of an individual. Another verb used to express removal of the effects of impurity is טָָָָ; it is always used in ritual impurity context. The only exception is its use in Lev 16:19. 30 which seems to be reasonable in that particular context. The term that always refers to

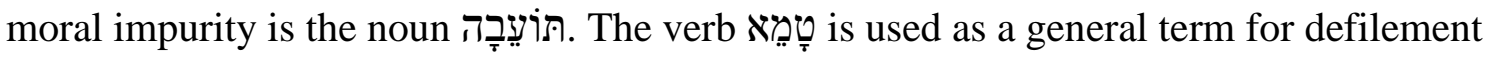
of humans, sanctuary, and physical entities by impurity in both ritual and moral contexts. However, טָָמָא never conveys ritual impurity to the land; it only conveys moral impurity.

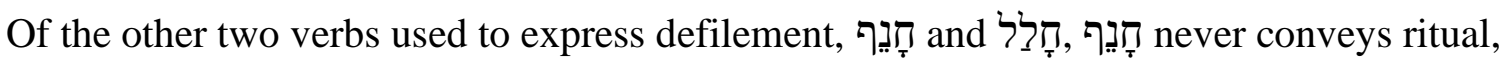
but always moral defilement of the land; it is never found in the contexts of defilement of humans, sanctuary, or other physical entities. The verb חָלָל, on the contrary, conveys both ritual and moral defilement of humans, sanctuary, or other physical entities, but never defilement of the land. Thus, the terminology that conveys removal of impurity is 
consistent where סָָלָ is used in moral and טָּה in ritual contexts with the exception of Lev 16:30. The terminology that conveys defilement is not consistent since טֵֵָׁ conveys

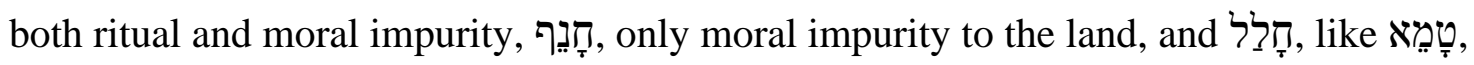
conveys ritual and moral defilement, but unlike טָָמָ , never conveys defilement of the land.

People who are in a covenantal relationship with God should not take part in moral impurity and should follow God's guidelines to deal with ritual impurity. However, since both ritual and moral impurities were impossible to avoid in the state of human affairs in ancient times, God prescribed regulations and remedies so the people could retain a relationship with him even though they found themselves affected by one, or the other, or both types of impurity.

\section{Moral Impurity/Sin in the Pentateuch}

This subheading opens the second part of chapter 2 which focuses on moral impurity. With a broad, yet foundational understanding of impurity in the OT, I focus on the three specific terms for sin in the Pentateuch in the second part of this chapter. A brief introduction of these terms and understanding in the scholarly debates precedes their full analysis. These three terms occur in the most relevant passages in the Pentateuch that deal exclusively with moral impurity. The importance of these terms is also seen in the fact that they are found in crucial texts that scholars refer to as they form their understanding of atonement.

\section{Relevant Terms for Moral Impurity in the OT}

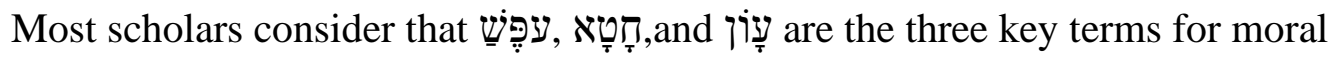


impurity in the OT due to the frequency these terms are used in comparison to others.

Some consider them to be generic terms for $\sin .{ }^{354}$ Some also consider the root

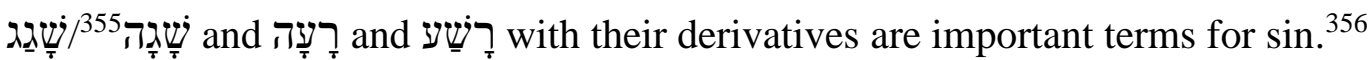

However, the current study is limited to the terms

First, these three terms were never used to refer to ritual impurity expressed through the root טָָמָא. They were used in certain contexts where derivatives of the root טֵָָׁא were used (Lev 5:1-13; Num 5:5-31; Num 6, 19; Deut 21:22-23), but they never refer to ritual impurity. No pericope of all these provides grounds for claiming that , דָָ

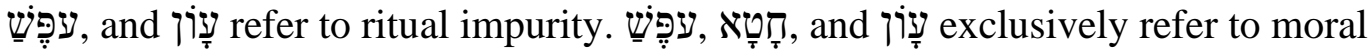
impurity.

The terms reserved for moral impurity, עָטָא

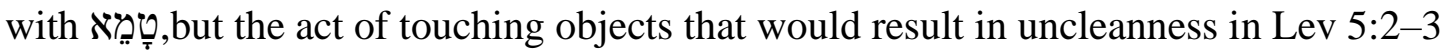
was not problematic, but postponing/forgetting the cleansing ritual was. The sin was not acquiring defilement, but disregarding the prescribed procedures to deal with it was.

${ }^{354}$ Knierim, "חטח," TLOT 1:410.

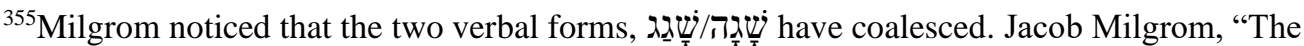
Cultic שגגה and Its Influence in Psalms and Job,” JQR 58 (1967): 116; Milgrom, Leviticus 1-16, 242. Also, "But biconsonantal roots that expanded into geminates and lamed-he are attested frequently"

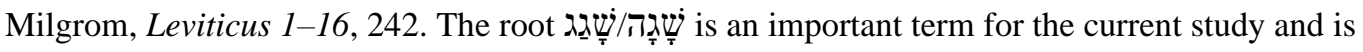

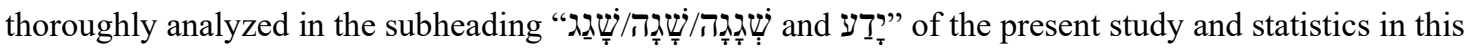
chapter rely on the findings presented in that subheading.

${ }^{356}$ Sklar, "Sin,” 2:298; Youngblood, “A New Look,” 202; Cover, "Sin, Sinners,” ABD 6:32;

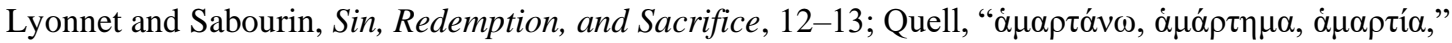
TDNT, 1:270-71; Robinson, "Terminological Study," 112. For additional list of works see Lam,

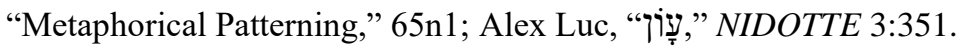


Thus, this sin was moral and not ritual in its nature. ${ }^{357}$

Sin in Num 5:5-31, potential adultery, is referred to by עָ in v. 15. ${ }^{358}$ Though Gane presented arguments that this sin could include both ritual and moral defilement by the woman, ${ }^{359}$ he ultimately concluded that "in any case, adultery involves both physical ritual impurity that is forbidden and is therefore morally wrong, because it was incurred with the wrong party (cf. Lev 18:20 of man defiling himself with his neighbor's wife)." ${ }^{360}$ The emphasis in this case is on moral impurity since the sin in the first place was in breaking one of the commandments from the Decalogue.

Accidental annulment of the Nazirite's vow in Num 6 is the most challenging case. That is, the circumstance that annuls the Nazirite's vow is introduced in 6:9. The Nazirite obtains defilement by corpse contact of a person who suddenly dies in his

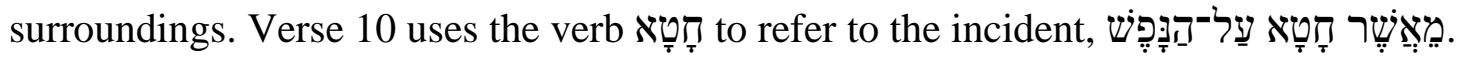
Thus, it seems that the act of incurring ritual impurity constitutes moral sin. The verb דִָָ along with nominals However, Gane was correct when he said that this incident has to be treated as unintentional moral sin because it represented the violation of God's commandment regarding the Nazirite status: "Here sin is objective: Corpse impurity has simply occurred through adverse circumstances, thereby violating the divine prohibition, without any

${ }^{357}$ Gane, Leviticus, Numbers, 119.

${ }^{358}$ Philip J. Budd, Numbers, WBC 5 (Nashville: Thomas Nelson, 1984), 64; Milgrom, Numbers: $38-39$.

${ }^{359}$ Gane, Leviticus, Numbers, 522-23.

${ }^{360}$ Gane, Leviticus, Numbers, 523. 
failure of intention, carelessness, vigilance, or memory on the part of the Nazirite (cf. Lev 5:2-4)." 361 The fact that the person under Nazirite vow was involved in the incident and was not in any case responsible for the violation of God's commandment regarding his Nazirite status makes this sin a moral one. ${ }^{362}$

The sin in Num 19:13, 20 is moral in nature since it resembles the sin in Lev 5:23. Numbers 19 supplements Lev 5:2-3 by the addition of the sinner's attitude of not wanting to submit himself or herself to the prescribed purification procedure. The sin is not referred to as acquiring ritual defilement, but as the neglect of purification procedures. It differs from the sin in Lev 5:2-3 because it represents intentional disobedience rather than an inadvertent or forgetful act. ${ }^{363}$

The sin in Deut 21:22-23 is moral defilement of the land, not ritual. The removal of the corpse might also be initiated in order to prevent the community or the land from accruing the curse applied to the criminal. ${ }^{364}$

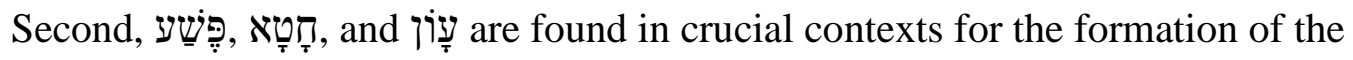
atonement doctrine. All of them are used in Lev 16:21 to describe the sins that were cleansed from the most holy place by the blood of the bull for the priests and the Lord's goat, and confessed by the high priest over the head of the scapegoat, thus "loading" it

\footnotetext{
${ }^{361}$ Gane, Leviticus, Numbers, 534.

${ }^{362}$ Milgrom, Leviticus 1-16, 357.

${ }^{363}$ Gane, Leviticus, Numbers, 664.

${ }^{364}$ Carl Friedrich Keil and Franz Delitzsch, The Pentateuch, BCOT (Grand Rapids, MI: Eerdmans, 1952), 3:150-51; Eugene H. Merrill, Deuteronomy: An Exegetical and Theological Exposition of Holy Scripture, NAC 4 (Nashville: Broadman \& Holman, 1994), 296; John H. Walton, Victor H. Matthews, and Mark W. Chavalas, "Deuteronomy," in IVPBBCOT (Downers Grove, IL: InterVarsity Press, 2000), 194.
} 
with the sins from the sanctuary, and that goat subsequently takes them away from the Israelites' camp. This part of the ritual of the Day of Atonement is considered the second and final phase of the cleansing of Israel's sins, removing them from the sanctuary and

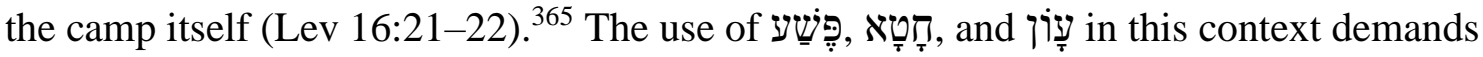
research as to their meaning. However, the meaning of excluded from separate searches on these terms that follow, but is suggested in the subheading "Interpretation of Leviticus 16:21" because it depends on separate findings on these terms.

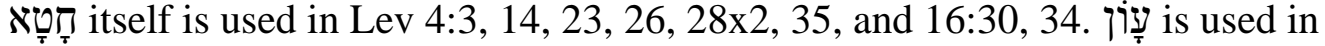
Exod 28:38, ${ }^{366}$ Lev 5:1, 17, 10:17 and 16:22. Besides the statistics that demonstrate that these three terms are the most frequent terms for sin in the Pentateuch, the fact that they are found in crucial atonement contexts separates them from others.

The aim of this subheading "Relevant Terms for Moral Impurity in the OT" is to show that Pentateuchal texts do not provide support for the claim that each of the three terms for sin, intentional/unintentional or expiable/inexpiable (forgivable/unforgivable) sins. ${ }^{367}$ Based on the analysis presented in this study, all three terms refer to intentional/unintentional and expiable/inexpiable or forgivable/unforgivable sins.

In order to demonstrate this, I am going to examine two characteristics concerning

\footnotetext{
${ }^{365}$ Gane, Cult and Character, 274-77.

${ }^{366}$ Rodríguez, "Substitution in the Hebrew Cultus," 133.

${ }^{367}$ Against Gane, Cult and Character, 292-300.
} 


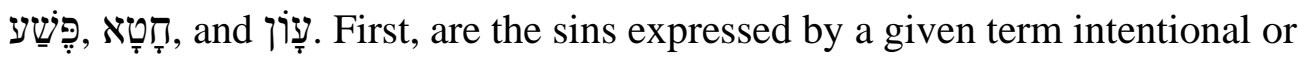
unintentional? In other words, by what extent do biblical texts reveal the mental state of the sinner who commits commits a sin articulated by these terms? In other words, are or inexpiable?

In order to answer to these two questions, I will study חָטָׁ applying the terminological/contextual/intertextual approach. This approach extracts the data about each sin from its immediate and wider literary context. This approach refers to the study of the terms within the context in which a sin was committed. The presence or absence of some sort of capital or other punishments ${ }^{368}$ contributes to the final answers. This approach includes the contexts in which respective terms for sins are syntactically or conceptually related to verbs/phrases that describe punishment for them.

The first step of the terminological/contextual/intertextual approach includes a basic analysis of the phrase contexts and they differ according to the subject of the verb the sinner is the subject of second context, God is the subject of

\footnotetext{
${ }^{368}$ For a more detailed study on who executes capital punishment, see Sklar, Sin, Impurity, Sacrifice, Atonement, 18-20.

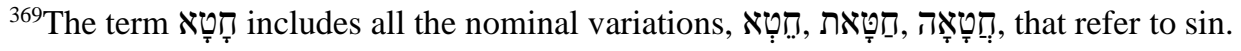

${ }^{370}$ Sklar, Sin, Impurity, Sacrifice, Atonement, 20.
} 
context, a third party, neither the sinner nor the one wronged, is the subject of the verb. ${ }^{371}$

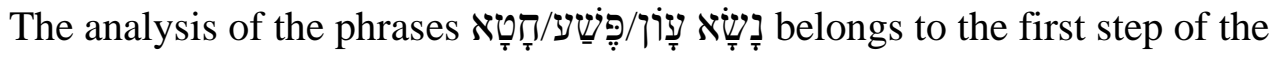
terminological/contextual/intertextual approach since their meaning affects the meaning

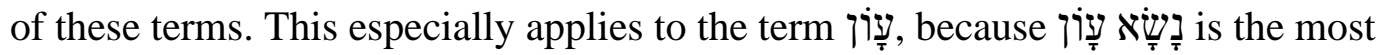

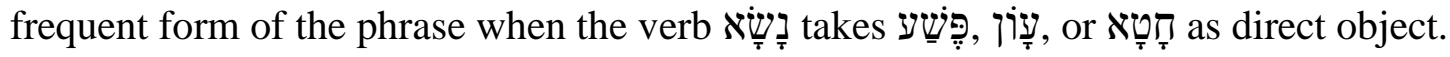
The first step will include occurrences of the phrase within the Pentateuch. The second step of the terminological/contextual/intertextual approach is the

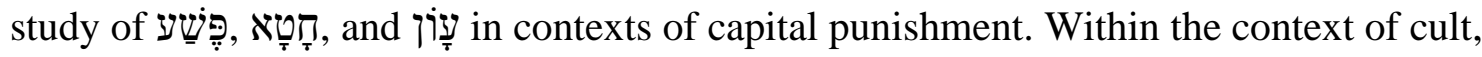
capital punishment ${ }^{372}$ points to inexpiable and unforgivable $\sin ^{373}$ and is expressed through a number of verbs and phrases. The verbs that serve as an umbrella for the various modes of execution of capital punishment are ${ }^{374}$ הרבג מיז מוּר

${ }^{371}$ Sklar, Sin, Impurity, Sacrifice, Atonement, 20.

${ }^{372}$ Punishments that do not include death are mutilation (Deut 25:11-12), application of the talionic principle (Lev 24:19-20), flogging (Deut 22:18) with restrictions to forty strokes (Deut 25:1-3). Intercourse with an aunt by marriage or a sister-in-law makes the culprits עִּרִירִ, usually interpreted as childless (20:19-21). Raymond Westbrook, "Punishments and Crimes (OT and NT)," ABD 5:555. However, not being a capital punishment hints towards the expiable nature of the sins for which these punishments were executed. Gundmundur Olaffson eloquently suggested that the childlessness in Lev 20:20-21 is another way of saying that the culprits will die, which removes this sin from the list of sins punishable by non-capital punishment and treats it as an unforgivable and inexpiable sin. Gudmundur Olaffson, "The Use of $n s$ ' in the Pentateuch and Its Contribution to the Concept of Forgiveness" (PhD diss., Andrews University, 1993), 177.

${ }^{373}$ Donald J. Wold, "The Meaning of Biblical Penalty Kareth" (PhD diss., University of California, 1978), 254; Schwartz, "The Bearing of Sin," 13; Gane, Cult and Character, 200-201.

${ }^{374}$ It seems that the choice of the verbal stem points to two potential executors of the death

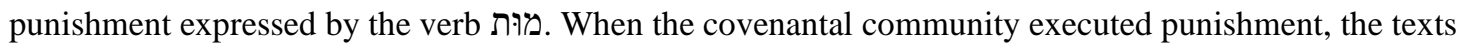
used hophal of מוּת (Exod 31:14, 15; 35:2; Lev 19:20; 20:2, 9, 10, 11, 12, 13, 15, 16, 27, 24:16, 17, 2; 27:29; Num 1:51;3:10, 10, 38;15:35; 18:7; 35:16, 17, 18, 21,31) while the texts use qal of when the Lord is the executor of it (Exod 28:35, 43; 30:20, 21; Lev 8:35; 10:2, 6, 7, 9; 15:31; 16:2, 12; 22:9; Num 4:15, 19, 20; 14:37; 17:25 [10], 28 [13]; 18:3, 22, 32. Sklar, Sin, Impurity, Sacrifice, Atonement, 13-14.

${ }^{375}$ Gen 20:4; Exod 4:23; 13:15; 22:24; 32:27; Lev 20:16; Num 25:5; Deut 13:9. 
There are several modes of execution of capital punishment. The first mode is stoning and is expressed via verbs רָָג (Lev 20:2, 27; 24:14, 16, 23; Num 15:35-36; Deut 21:21) and (Exo 19:13; Deut 13:11 [10]; 17:5; 22:21, 24). The second one is burning, expressed via the verb שָָׁרף (Gen 38:24; Ex 10:6; Lev 20:14; 21:9). The third mode is execution by the sword (Exod 22:24; 32:27-29; Deut 13:15). The verb נָכָָה also refers to the act of killing as a form of capital punishment (Lev 26:21, 24). ${ }^{376}$ Finally, the verb ריָָה is used once to denote divine destruction in war in Exod 15:4. Even though the verb is not mentioned, it is most likely that this sort of capital punishment operates in

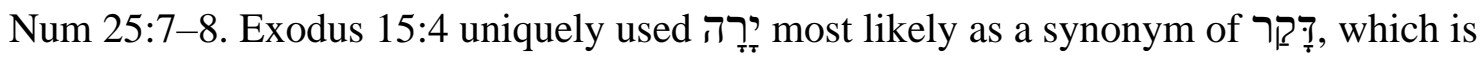
the technical verb for killing by piercing with a spear or sword. ${ }^{377}$ Sin punished by ירָה was never referred to by the terms is not articulated (Lev 20:9, 10, 11, 12, 13, 15, 15; 24:17, 21) ${ }^{378}$ However, the use of the verb מוּ indicates some form of capital punishment for the cases where it is not specified.

In the third step of the terminological/contextual/intertextual approach, and

\footnotetext{
${ }^{376}$ The verb נָָכָ is included in this search due to the fact that it is conceptually, like its synonym, linked with the verb Rationale behind the Homicide Law in Numbers 35:30-34," in Searching the Scripture: Andrews University Seminary Emerging Scholars Pay Tribute to Their Professors, ed. Slaviša Janković (Berrien Springs, MI: Andrews University, Theological Seminary, Old Testament Department, 2017), 84.

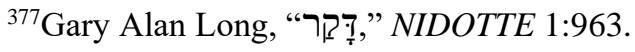

${ }^{378}$ Sklar, Sin, Impurity, Sacrifice, Atonement, 14.
} 
various understandings of the kārēt punishment, the following subheading presents the arguments for the understanding adopted in the present work.

The fourth step of the terminological/contextual/intertextual approach traces the

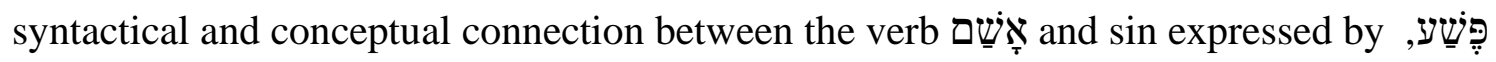

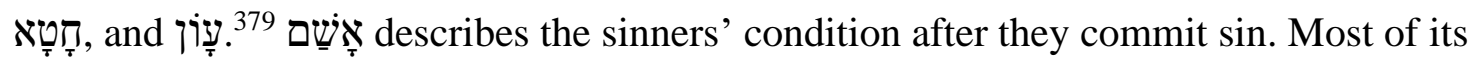
51 occurrences within the Pentateuch are found in the book of Leviticus, especially chapters 4 and 5 which discuss atonement for intentional and unintentional sins.

There are four proposals for the meaning of the term nd they are a ${ }^{380}$ analyzed on pages $288-313$ in the present study. At this point, this study accepts that "to suffer guilt's consequences" is the least problematic meaning of Wָ in the crucial context of Leviticus 4 and 5.

\section{Cut Off (Kārēt) Punishment ${ }^{381}$}

This punishment was frequently prescribed for various sins in the OT. ${ }^{382}$ Milgrom $^{383}$ and Hobson ${ }^{384}$ offer a list of sins punishable by kārēt, but both of them either

\footnotetext{
${ }^{379}{ }^{37}$ iָ is also considered as a punishment for the sin. Leviticus 1-16, 33; Gane, Leviticus, Numbers, 119; Sklar, Sin, Impurity, Sacrifice, Atonement, 13.

${ }^{380}$ The first three are as follows: (1) to be guilty, (2) to realize guilt, and (3) to feel guilt. Sklar, Sin, Impurity, Sacrifice, Atonement, 25.

${ }^{381}$ This punishment is known as kārēt in Judaism. G. Thomas Hobson, "Cut off (One's) People: Punitive Expulsion in the Torah and in the Ancient Near East" (paper presented at the Annual Meeting of the Biblical Law of the SBL, San Francisco, CA, 24 November 2011), 1.

${ }^{382}$ Sklar, Sin, Impurity, Sacrifice, Atonement, 15.

${ }^{383}$ Milgrom, Leviticus 1-16, 457.

${ }^{384}$ Hobson, "Cut off (One's) People."
} 
omit, ${ }^{385}$ or fail to differentiate between, certain sins. ${ }^{386}$ Therefore, in the following list, which is based on the list suggested by these two scholars, I have made adjustments accordingly:

1. Failure to be circumcised: Gen 17:14.

2. Eating leavened bread during Passover: Exod 12:15, 19.

3. Unauthorized production of sacred incense: Exod 30:33.

4. Unauthorized production of sacred anointing oil: Exod 30:38.

5. Profaning the Sabbath: Exod 31:14.

6. Eating sacrificial meat in a state of uncleanness: Lev 7:20-21.

7. Eating blood: Lev 7:27; 17:10; 17:14.

8. Eating sacrificial fat: Lev 7:25.

9. Slaughtering an animal outside of the authorized sanctuary and as a sacrifice to God: Lev 17:4.

10. Sacrificing an animal outside of the authorized sanctuary and as a sacrifice to God: Lev 17:9.

11. Committing "any of these abominations" listed in Lev 18 (according to v. 29), including incest, sacrifice to Molech, sex during menstruation, homosexual intercourse, and bestiality.

12. Eating sacrificial meat that has been left over until the third day: Lev 19:8.

${ }^{385}$ Milgrom missed including the sin of brother-sister incest, (Lev 20:17), sex during menstruation (Lev 20:18), and priests' approaching the holy gifts in the state of uncleanness (Lev 22:3); Milgrom, Leviticus 1-16, 242-43.

${ }^{386}$ Hobson did not differentiate between slaughtering (Lev 17:4) and sacrificing (Lev 17:8-9) an animal outside of the authorized sanctuary, and not afflicting oneself (Lev 23:29) and abstaining from work (Lev 23:30) on the Day of Atonement. 
13. Offering children to Molech: Lev 20:3-5.

14. Patronizing mediums and wizards: Lev 20:6.

15. Brother-sister incest: Lev 20:17.

16. Sex during menstruation: Lev 20:18.

17. Approaching sacred gifts that have been dedicated to $\mathrm{YHWH}$, while one is in a state of uncleanness: Lev 22:3.

18. Failure to afflict oneself during Yom Kippur: Lev 23:29.

19. Failure to keep the Passover without an adequate excuse: Num 9:13.

20. Sinning "with a high hand," that is, deliberately "despising the word of YHWH”: Num 15:30-31.

21. Failure to cleanse oneself with holy water after defilement due to contact with a dead person: Num 19:13, 20.

Sklar has summed up the debate on the meaning of kārēt by asking two main questions: (1) Of what does the penalty consist?, and (2) Who executes the penalty? ${ }^{387}$ These two questions are discussed below, respectively.

\section{Of What Does Kārēt Consist?}

In response to the first question, biblical scholars have proposed at least four meanings of kārēt: (1) excommunication from the covenantal community, ${ }^{388}$

${ }^{387}$ Sklar, Sin, Impurity, Sacrifice, Atonement, 15.

${ }^{388}$ Budd, Leviticus, 122; René Péter-Contesse, Lévitique 1-16, CAT 3A (Genève: Labor et Fides, 1993), 119; John I. Durham, Exodus, WBC 3 (Nashville: Thomas Nelson, 1987), 406; Hobson, "Cut off (One's) People," 1. 
(2) premature death, ${ }^{389}$ (3) extinction of lineage, ${ }^{390}$ and (4) punishment in the afterlife. ${ }^{391}$

The first proposal, excommunication from the covenantal community, is mainly supported by the fact that the person deserving kārēt is said to be "cut off from his/her people," which is interpreted as excommunication from the covenantal community.

Pentateuchal texts seem to lend the most substantial support for the second proposal, premature death. There are at least five arguments of support for the second proposal:

(a) This is supported by some texts that seem to equate kārêt with premature death (Exod 31:14; ${ }^{392}$ Num 4:18-20 $0^{393}$ ). These texts suggest that kārēt and premature death are synonymous. ${ }^{394}$ I found that Exod 31:15 and 35:2 in relation to Exod 31:14 also point to the fact that $k \bar{a} r \bar{e} t$ and premature death are synonymous.

In addition to Exod 31:14 and Num 4:18-20 that Sklar quoted, the following textual pairs further confirm that $k \bar{a} r \bar{e} t$ refers to the premature death of the sinner: Gen 17:14=Exod 4:24; Lev 17:4=Exod 32:27, Deut 13:5, 9, 10, 17:5-6; Lev 20:3, 5=20:2, 4;

${ }^{389}$ Wenham, The Book of Leviticus, 125, 242; Porter, Leviticus, 139.

${ }^{390}$ Wold, "The Meaning of Biblical Penalty Kareth," 1-45, especially 4-5. Wold's suggestion was followed Wright, The Disposal of Impurity, 164n2; Milgrom, Numbers, 406-7; Gane, Cult and Character, 145; Wright, The Disposal of Impurity, $164 \mathrm{n} 2$.

${ }^{391}$ Wenham, The Book of Leviticus, 242. Milgrom found that this understanding of kārēt was anticipated by earlier exegetes. Milgrom, Numbers, 407.

392،Therefore, you are to observe the Sabbath, for it is holy to you. Everyone who profanes it shall surely be put to death; for whoever does any work on it, that person shall be cut off from among his people."

${ }^{393}$ V. 18: "Do not let the tribe of the families of the Kohathites be cut off from among the Levites. 19 But do this to them that they may live and not die when they approach the most holy objects: Aaron and his sons shall go in and assign each of them to his work and to his load; 20 but they shall not go in to see the holy objects even for a moment, or they will die."

${ }^{394}$ Sklar, Sin, Impurity, Sacrifice, Atonement, 16. 
Lev 20:6=Exod 22:18, Lev 20:27; Num 19:13=Lev 15:31. The sins in these texts are the same, but the punishment is either kārèt or premature death, which suggests that either $k \bar{a} r \bar{e} t$ refers to premature death or refers to premature death with potential further punishment.

(b) This is supported by three contexts where human beings are the direct object of the verb כָָּרת which refers to premature death (Gen 41:36, ${ }^{395}$ Deut 12:29, ${ }^{396} 19: 1$ ). These texts are not legal texts, but they reflect a specific semantic preference in the Bible. The same semantic choice can be detected also when animals are the direct object (Gen 9:11; Exod 8:9; Lev 26:22).

(c) Through the use of other verbs that regularly refer to premature death of human beings, the context of some laws points to kārēt as premature death (Lev 23:29, Num 19:13). Therefore, Lev 23:30 helps explain the prohibition in v. $29 .{ }^{397}$ Thus, based on the present study's research, the public or private nature of sin is insignificant in determining the mode of punishment; however, a sinner's attitude can be determinative. ${ }^{398}$ This is particularly applicable in this case. Furthermore, Lev 7:20; 10:12; 12:4; 15:31 shed light on the meaning of kārēt in Num 19:13.That is, those who

\footnotetext{
${ }^{395}$ Gordon J. Wenham, Genesis 1-15, WBC 1 (Nashville: Thomas Nelson, 1987), 195; Gordon J. Wenham, Genesis 16-50, WBC 2 (Nashville: Thomas Nelson, 1994), 394, 25.

${ }^{396}$ Merrill, Deuteronomy, 227-28.

${ }^{397}$ Hartley, Leviticus, 388; Henry T. C. Sun, “An Investigation into the Compositional Integrity of the So-Called Holiness Code (Leviticus 17-26)" (PhD diss., The Claremont Graduate University, 1990), 360,372 .

${ }^{398}$ Contra Milgrom, Milgrom, Leviticus 23-27, 2024-25.
} 
intentionally bring impurity in contact with God's holy sanctuary experience premature death.

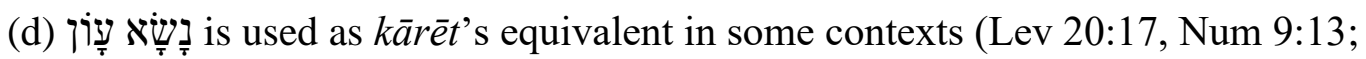

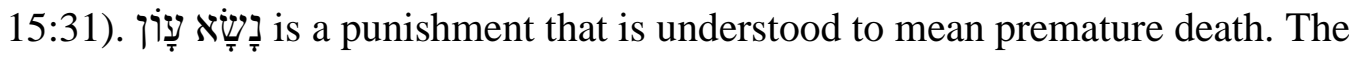
arguments for such an interpretation are presented below. Consequently, based on this semantic equivalence, kērētt may refer to premature death of the sinner.

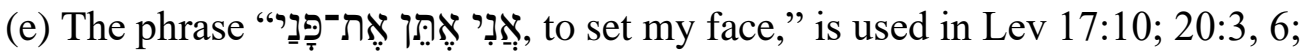
26:17 along with kārêt and suggests the type of punishment implied. According to the interpretation suggested in the present study regarding Lev 20:3, namely that it is a subcase of the case introduced in v. 2, this text points to premature death as a punishment for the idolater. Such a conclusion is possible since the same kind of punishment is explicitly stated in v. 2 for the same sin. Moreover, the death penalty and $k \bar{a} r \bar{e} t$ are equivalent in this case. However, Lev 20:6 provides more certainty that $k \bar{a} r \bar{e} t$ actually refers to premature death. Specifically, based on Exod 22:18 and Lev 20:27, the sin of necromancy is punishable by premature death. Leviticus $26: 17$ also points in the same direction. It describes Israel's defeat at the hands of its enemies, which is understood as a reversal of v. 7 and describes Israel's victory over its enemies. The defeat in both verses includes (1) killing Israel's enemies "by the sword" in v. 7 and killing Israelites in v. 27, and (2) God as executioner. ${ }^{399}$ Based on the intertextual evidence, in three out of four of these texts that contain double punishment, the phrase "to set my face," and kārēt are equivalent. The implied punishment seems to be premature death.

\footnotetext{
${ }^{399}$ Milgrom, Leviticus 17-22, 2307.
} 
The third proposal can be taken as complementary to the second and finds support in Num 4:18-20, which states that Kohathites are cut off from the tribe of Levi. This means that this particular lineage of the tribe of Levi would be terminated. The same principle seems to be operating in Lev 20:20-21, where the sinner's lineage is terminated because of sin. Even though kārēt is not mentioned as a punishment for illicit sexual deeds in these texts, the parallel laws in Lev 18:14, 16 that deal with the same sins are understood in Lev 18:29 as punishable by kārēt. ${ }^{400}$

The fourth proposal finds textual support in Lev 20:2-3, which requires the double punishment of stoning and being cut off. Wenham noticed that death in the OT is referred to as "sleeping with one's fathers" $(1 \mathrm{Kgs} 1: 21)$ and "being buried with the fathers" (1 Kgs 14: 31), which could imply an afterlife judgment. In that case, being cut off would mean the eternal annihilation of the sinner. ${ }^{401}$ Milgrom argued that another phrase, "to be gathered to one's kin/fathers," is an opposite idiom of kārēt and suggests a reunion of the deceased after earthly life. ${ }^{402}$

Thus, based on the above points, the intertextual connections suggested in the present study and the points noted by Sklar, it can be concluded that kārēt primarily refers to the premature death of the sinner and possibly includes two additional more severe components, termination of their lineage and eternal death. However, since Donald Wold addresses the last two additional punishments in his research on the nature of kārēt, his method and interpretation will be evaluated below.

\footnotetext{
${ }^{400}$ Sklar, Sin, Impurity, Sacrifice, Atonement, 16-17.

${ }^{401}$ Wenham, The Book of Leviticus, 242.

${ }^{402}$ Milgrom, Numbers, 407.
} 


\section{Donald Wold on the Kārēt Punishment}

Wold suggested that $k \bar{a} r \bar{e} t$ refers to one's extirpation and/or the extirpation of his/her line of descendants, which may occur simultaneously along with or subsequent to the premature death that was carried out either by God or the covenantal community. Thus, the biblical kārēt resembles curse formulae found throughout ANE literature, and is "a conditional divine curse of extinction." ${ }^{403}$ This view has been adopted by many modern scholars of biblical cult, such as Milgrom, ${ }^{404}$ Wright, ${ }^{405}$ and Gane. ${ }^{406}$

The present study argues against Wold's conclusions which are problematic due to the shortcomings of his methodology. As stated in his introduction, his work heavily relies on extra-biblical sources conceptually, ideologically, and linguistically. Although such information may be profitable for understanding biblical texts, it may also obstruct the biblical presentation of topics and concepts, especially if such sources are given preference over biblical texts. The present work finds that Wold allowed the extrabiblical material to guide and greatly influence his understanding of biblical topics on the afterlife, which consequently influenced his understanding of kārēt punishment.

Wold stated that his methodology would include two steps: (1) an analysis of expressions paradigmatically and syntagmatically associated with the verb כָָּ in various $k \bar{a} r \bar{e} t$ formulae in order to form a stable matrix whose dimensions can construct an exegetical model and (2) this matrix would be rooted in the conceptual field of ideas

\footnotetext{
${ }^{403}$ Wold, "The Meaning of Biblical Penalty Kareth," 252.

${ }^{404}$ Milgrom, Leviticus 1-16, 457.

${ }^{405}$ Wright, The Disposal of Impurity, 164n2.

${ }^{406}$ Gane, Cult and Character, 145, 201.
} 
derived from the P source of the OT and extra-biblical sources. ${ }^{407}$ The three expressions

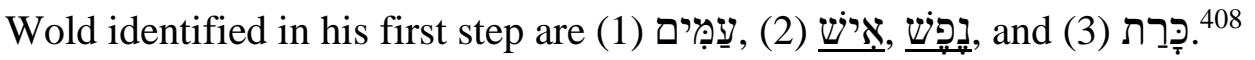

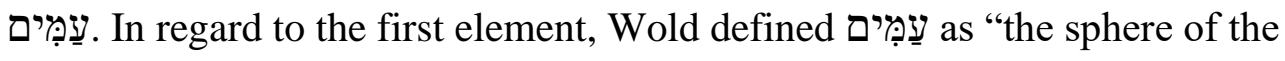
individual's existence. It designates the social entity from which one is cut off, whether from the nation Israel, the cultic community (עדה), one's own family, etc." ${ }^{409}$ Wold

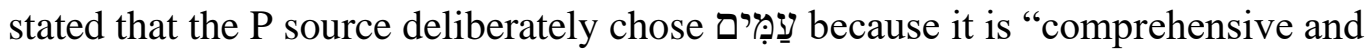
equivocal. ${ }^{\circ 10}$ This semantic broadness led Wold to extend the meaning of this word to connote the afterlife. However, the initial step towards this understanding of עִִַ̣ים came from G. Driver's and John Miles' observation in regard to the Nabataean uses of $\underline{\underline{\underline{y}} \text { as }}$ ancestors. ${ }^{411}$ Wold also relied on the opinions of scholars of his time who held that the phrases "to sleep with one's fathers," "buried with his fathers," and "to be gathered to one's kin" refer to a place called "community of souls" whose existence is in the afterlife. ${ }^{412}$ This claim suffers from at least two problems.

First, the dissertation research of Eriks Galenieks demonstrated that the beliefs of

${ }^{407}$ Wold, "The Meaning of Biblical Penalty Kareth," v.

${ }^{408}$ Wold, "The Meaning of Biblical Penalty Kareth," 6-7.

${ }^{409}$ Wold, "The Meaning of Biblical Penalty Kareth," 12.

${ }^{410}$ Wold, "The Meaning of Biblical Penalty Kareth," 12.

${ }^{411}$ Godfrey R. Driver and John C. Miles, The Babylonian Laws (Oxford: Clarendon Press, 1968), $1: 118$.

\footnotetext{
${ }^{412}$ Wold, "The Meaning of Biblical Penalty Kareth," 9.
} 
Wold's time, which are currently accepted ${ }^{413}$ are not biblically supported, but rather, rest on evidence found in extra-biblical sources. All sixty-six passages in which שֶׁאוֹ is mentioned in the OT are "poetic synonyms of the grave," which denies the possibility of human conscious existence after death ${ }^{414}$ Galenieks further stated:

Sheol means no more than the place of the dead or simply the grave in general, where the dead bodies or corpses return to become the dust of the earth (Gen 2:7;3:19). On the other hand, the fact that not even one of the sixty-six references to the term Sheol contains any indication that Yahweh would somehow try to communicate with the dead is strikingly clear and does not need to be commented on." 415

Second, the fact that the OT evinces little interest in the topics of death and afterlife is one argument against Wold's conclusions regarding kārēt. This is not to say that the OT does not speak about death in connection with the afterlife, but rather, it defines it in a very limited way (see e.g., Gen 5:24; Num 16:33; 1 Sam 2:6; 28:8-19; 2 Kgs 2:11; Isa 26:19; Ezek 37:1-14; Prov 12:28). ${ }^{416}$ The OT's focus is on the present life, so it emphasizes the covenant relationship between God and human beings. ${ }^{417}$ In his dissertation research, Jan Sigvartsen stated: "The overall impression from a study of the TaNaKh passages relating to the afterlife is that death was not considered the start of the

\footnotetext{
${ }^{413}$ Richard C. Steiner, Disembodied Souls: The Nefesh in Israel and Kindred Spirits in the Ancient Near East, with an Appendix on the Katumuwa Inscription, ANEM 11 (Atlanta: SBL Press, 2015), 2.

${ }^{414}$ Eriks Galenieks, "The Nature, Function, and Purpose of the Term Sheol in the Torah, Prophets and Writings" (PhD diss., Andrews University, 2005), 582, 612.

${ }^{415}$ Galenieks, "The Nature, Function, and Purpose," 582, 598.

${ }^{416}$ Jan Åge Sigvartsen, "The Afterlife Views and the Use of the Tanakh in Support of the Resurrection Concept in the Literature of Second Temple Period Judaism: The Apocrypha and the Pseudepigrapha" (PhD diss., Andrews University, 2016), 1.

${ }^{417}$ Sigvartsen, "The Afterlife Views and the Use of the Tanakh," 2-3.
} 
next life, but the end of the present." ${ }^{418}$ He also added that "the lack of obvious religious burial rites in the Hebrew Bible may further suggest a lack of interest in the afterlife among religious leaders." ${ }^{419}$ Finally, Sigvartsen found that "the Hebrew Scriptures do not present a fully developed, or rather, a complete, comprehensive, and detailed description of the afterlife." 420

In the light of Sigvartsen's and Galenieks' research, especially of the latter's exegesis of the pertinent biblical texts (which is also the method used throughout this work) Wold's inclusion of extra-biblical notions of the afterlife cannot be accepted. Subsequently, the impact such a notion has on the noun עַפְִּים and ultimately the term kārēt invalidates Wold's conclusions.

נִפֶּש , אִישׁ. In regard to the second element, building on the definition of Daniel Lys, Wold concluded that נֶֶֶֶ represents "the whole person but surely this was not an abstraction for the ancient Hebrew. Of significance to the $k \bar{a} r \bar{e} t$ formulae is the fact that the Israelite's identity and existence was linked to his name and to his children." ${ }^{421}$ While this is true throughout the OT, it is also true that every individual is responsible for his/her sin and for his/her own existence. Even more, Deut 24:16 states that "fathers shall not be put to death for their sons, nor shall sons be put to death for their fathers; everyone

${ }^{418}$ Sigvartsen, "The Afterlife Views and the Use of the Tanakh," 1-2.

${ }^{419}$ Sigvartsen, "The Afterlife Views and the Use of the Tanakh," 2.

${ }^{420}$ Sigvartsen, "The Afterlife Views and the Use of the Tanakh," 3.

${ }^{421}$ Wold, "The Meaning of Biblical Penalty Kareth," 14. See also Daniel Lys, Nèphèsh: Histoire de l'âme dans la révélation d'Israël au sein des religions proche-orientales, ÉHPR 50 (Paris: Presses Universitaires de France, 1959), 161-62. 
shall be put to death for his own sin." ${ }^{\text {422 }}$ Thus, the claim that kärēt formulae refer to one and exclude the other semantic domain of the word iֶֶֶ is certainly a possible use in certain contexts, but further research is needed. Such research is lacking in Wold's work. He rooted his transition from the former limited understanding of upheld throughout his study in the quote of Josef Schrabert, who stated that "wie נפפ im hebräischen Text, so kann auch $\psi v \chi \eta ́$ di ganze person meinen, etwa in der

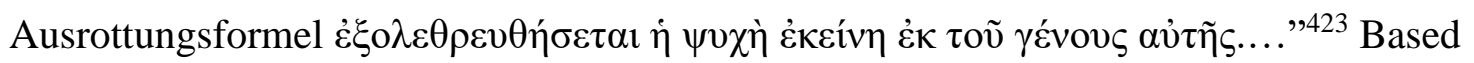

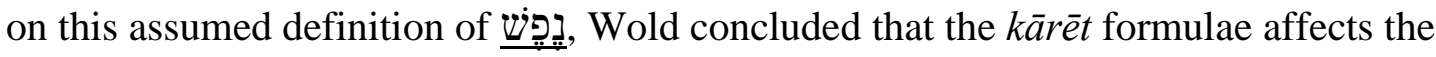
person and his/her progeny. The present research does not find the method used to arrive at such an understanding of נִֶֶ as sound.

פכָּרָת In regard to the third element, to which Wold devoted most attention and space in his study, he studied the verb כָּרָ in the context of its Akkadian and WestSemitic background. He stated:

In this section we hope to establish a Gattung for the kareth formula by means of comparative linguistic analysis. Etymologically, karath is cognate to Akkadian karätu, "to cut off, cut down." To date, our search of the Akkadian sources had turned up no examples of karātu with either napištum or awilum as its object so as to provide an exact parallel to the biblical kareth formula with the verb karātu. However, we do find a counterpart to karat nefesh with the verb nakāsu, a synonym of karātu, in the expression napištam nakāsu. By studying the paradigmatic semantic field of this idiom in the Akkadian literature and by comparing the usage of a network of West-

\footnotetext{
${ }^{422}$ Emphasis mine.

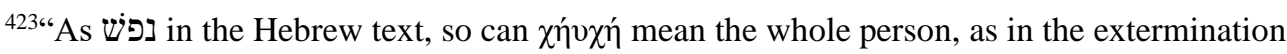

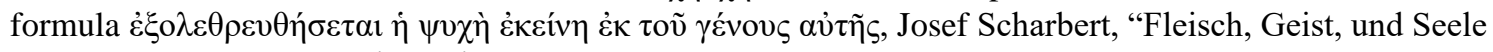
in der Pentateuch-Septuaginta," in Wort, Lied und Gottesspruch: Beiträge zur Septuaginta: Festschrift für Joseph Ziegler, ed. Josef Schreiner, FB 1 (Würzburg: Echter Verlag, 1972), 126, 130.
} 
Semitic terms which mean "to cut off" it is possible to establish a Gattung for the biblical kareth penalty. ${ }^{424}$

Based on linguistic and conceptual similarities between kārêt formulae in the OT and in Akkadian and West-Semitic texts, Wold concluded that kārēt punishment is "conditional divine curse formulae." 425 The initial step Wold utilized in his quest for the meaning of kārēt punishment was deriving its meaning from comparative Semitic examples. ${ }^{426}$ Wold then analyzed the crux interpretum texts in the OT, namely the texts that contain double punishment, $k \bar{a} r \bar{e} t$, and premature death. These texts are Exod 31:14, Lev 18:18, 15, 17, 21, 23, 22; 20:3, 5, 6; Num 15:30. ${ }^{427}$ Leaving aside the potential irregularities of Wold's linking of comparative insights to biblical texts, the present study focuses on the reasons he offered against the understanding that kārēt formulae always predominantly refer to premature death, regardless of the fact that premature death is stated along with it. He proposed three reasons.

First, "stylistically, the Priestly Source is noted for its terseness in the legal portions so that a circumlocution like the ambiguous kareth formula for the death penalty at the very last comes as a surprise. ${ }^{" 428}$ This claim is only partially correct, that is, terseness is a general feature of biblical literature as a whole and applies to certain but definitely not to all texts. It has been demonstrated throughout the present work that terseness was not the primary guide that led biblical author/s to generate the biblical text

\footnotetext{
${ }^{424}$ Wold, "The Meaning of Biblical Penalty Kareth," 15.

${ }^{425}$ Wold, "The Meaning of Biblical Penalty Kareth," 16-17.

${ }^{426}$ Wold, "The Meaning of Biblical Penalty Kareth," 17.

${ }^{427}$ Wold, "The Meaning of Biblical Penalty Kareth," 47.

${ }^{428}$ Wold, "The Meaning of Biblical Penalty Kareth," 47.
} 
as it stands. In many instances a phrase or a word is repeated for rhetorical purposes in order to emphasize certain topic/s, maintain legal precision, or follow structure. To this can be added that many laws themselves were repeated with modifications along with exact verbatim repetitions. Repetitions are specifically present in the legal texts that speak about curses. ${ }^{429}$ For the same reason, kārèt formulae were repeated after a premature death penalty in order to emphasize the seriousness of the consequences for certain sins. In addition to the specific weaknesses against Wold's second and third reason against single punishment kārēt formulae, the arguments against terseness presented here are also applicable to those arguments.

Second, "logically, since the meaning of מות יומת is clear, the addition of the kareth formula in the aforementioned cases is tautologous and leads to confusion rather than clarification." 430 This claim is refuted by numerous instances of repetition of the same or equivalent/synonymous expressions in legal as well as narrative texts of the OT. For instance, Num 15:31 abounds with synonyms that are not needed. Lev 1-7 is filled with unnecessary repetition.

Third, "exegetically, to accept the synonymy of the expressions for death and the

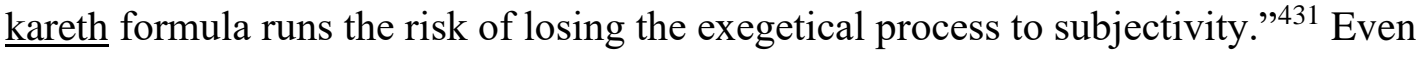
though this risk is possible, the repetition of the same concepts through different words is

\footnotetext{
${ }^{429}$ Milgrom, Leviticus 1-16, 147, 204, 392, 401, 429-30, 542, 653, 656 etc.; Wenham, The Book of Leviticus, 58-59, 89, 157, 198, 230, 267, 276, 291, 328, 374, 410, 449, 456, 458; Michael Dean Hildenbrand, Structure and Theology in the Holiness Code, BIBAL Dissertation Series 10 (North Richland Hills, TX: BIBAL, 2004), 11, 38. See also page 588, especially fn. 91, on repetition in the present study.

${ }^{430}$ Wold, "The Meaning of Biblical Penalty Kareth," 48.

${ }^{431}$ Wold, "The Meaning of Biblical Penalty Kareth," 48.
} 
well recognized and accepted. ${ }^{432}$ Removing the risk of losing exegetical objectivity in the texts that include such phenomena is achieved by a careful analysis of the definitions in context.

Thus, terseness, style, and logic should not be made a decisive factor for interpretation. Rather, one should take into consideration the entire context of the Pentateuch/OT.

In addition to those points of critique to Wold's double punishment of texts that contain premature death and $k \bar{a} r \bar{e} t$ punishment, the following arguments can be mentioned:

1. kārēt never appears after any case of expected kārēt punishment (see Num $16,{ }^{433} 35: 32-26,{ }^{434}$ Lev $\left.10,{ }^{435} 24^{436}\right)$, but premature death does.

2. The syntactical position of kārēt is not static in the texts causing chronological confusion. Sometimes it precedes other punishments (Lev 20:17; 23:29; Num 4:18; 9:13; 19:13), sometimes it follows them (Exod 31:14, Lev 17:10; 20:3, 5, 6), and sometimes it appears in triple punishment texts where it is repeated twice (Num 15:31).

3. Wold's methodological shortcomings may suffer from uncontrollably

${ }^{432}$ Hildenbrand, Structure and Theology, 4, 11. 129-30.

${ }^{433}$ Breaking the commandment against sancta encroachment Deut 16-18. Milgrom, Numbers,

${ }^{434}$ Breaking the commandment against work on the Sabbath found in Exod 16:23-29; 20:8-10, $31: 13-16 ; 35: 2$ and others.

${ }^{435}$ Breaking the commandment regarding the incense found in Exod 30:9. Levine, Leviticus, 5859; Gane, Leviticus, Numbers, 188. 166.

${ }^{436}$ Breaking the commandment against curing the Lord found in Exod 22:28. Levine, Leviticus, 
applying insights from the ANE context onto biblical texts without establishing sound methods and control of the correspondence between the two literary, conceptually, and ideologically similar, but yet totally differently worldviews, which has continued unabated since the 1960s ${ }^{437}$ Establishing a defensible method is still a demanding and difficult task. Although current scholarship finds some overlaps between ANE and OT exist, few scholars are able to find a proper method of comparison and analysis. ${ }^{438}$

4. A valid question to ask is this: What is the difference between death and kāre $\bar{e} t$ in reference to the afterlife? The sins deserving of premature death as a punishment are intentional and brazen sins, where the sinner shows an attitude of defiance against God. The death penalty assumes that a sinner deserving of this punishment automatically loses the benefits of the afterlife based on his/her own choice.

5. Death is the primary punishment in kārēt cases outside of legal texts (Deut $12: 29 ; 19: 1)$.

In conclusion, Wold's study is inordinately influenced by an Akkadian and WestSemitic worldview and suffers from a limited analysis of certain linguistic similarities. That $k \bar{a} r \bar{e} t$ punishment in the OT refers to punishment in the afterlife is based on an ANE construct that is more fully developed in ANE literature than in the OT. Therefore, in not denying the existence of vague understanding of the afterlife concept in the OT, Wold's proposal cannot be accepted by this study since it is not supported by the biblical evidence and suffers from methodological unsoundness.

\footnotetext{
${ }^{437}$ Samuel Sandmel, "Parallelomania," JBL 81 (1962).

${ }^{438}$ Noel Weeks, "Problems with Comparative Method in OT Studies," JETS 62 (2019).
} 


\section{Who Administers the Kārēt Penalty?}

In an attempt to provide an answer to the second question, key scholars of biblical cult have suggested that $k \bar{a} r \bar{e} t$ is carried out by God himself, ${ }^{439}$ and they have identified three points in support of this conclusion. First, there are texts which explicitly state that God executes kārēt punishment such as Lev 17:10; 20:3, 5, 6. ${ }^{440}$ Second, as Wenham noticed, many of the sins punishable by kārēt are secret sins, and only God could know them (Lev 7:20). ${ }^{441}$ Third, in regards to Wold's classification of sins punishable by kārēt into six categories, specifically sacred time, substance, failure to perform purification ritual, illicit worship, illicit sex, and blasphemy, ${ }^{442}$ Milgrom noted that "all fall within the category of religious law not civil law; that is, they are deliberate sins against God not against man." ${ }^{\prime 43}$ He further reasoned that "as the cardinal postulate of the Priestly legislation is that sins against God are punishable by God and not by man (Milgrom 1970a: 5-8), it follows that the punishment of kārēt is executed solely by the deity." ${ }^{\prime 44}$ The first two points support the fact that at least in some instances God executes $k \bar{a} r \bar{e} t$. The third point may require some adjustments. First, Milgrom's claim that all sins punishable by kārēt are sins against God may benefit from more analysis. It does not

${ }^{439}$ Levine, Leviticus, 241-42; Milgrom, Numbers, 405-8; Milgrom, Leviticus 1-16, 424, 457-60; Donald J. Wold, "The Kareth Penalty in P: Rationale and Cases," SBLSP 1 (1979): 24; Wenham, The Book of Leviticus, 125, 241.

${ }^{440}$ Sklar, Sin, Impurity, Sacrifice, Atonement, 18.

${ }^{441}$ Wenham, The Book of Leviticus, 241.

${ }^{442}$ Wold, "The Kareth Penalty in P," 3-24.

${ }^{443}$ Milgrom, Numbers, 406.

${ }^{444}$ Milgrom, Leviticus 1-16, 457. 
provide the grounds for the argument that God executes the punishment in the event of such sins. As stated in the present study, under the subheading Legal System of Ancient Israel in chapter three, God is the originator, source, and giver of BL. This means that violation of any of those laws makes the violator liable to God. Even if a person suffers due to the sin of another person, the sin committed is ultimately against God. Thus, Milgrom's constructing a false dichotomy between religious and civil laws ${ }^{445}$ does not remove foundational and underlying responsibility of the law breaker to God himself.

Second, some sins deserving of kērēt, according to Milgrom's and Wold's lists, are punished by a human party, as explicitly stated in Exod 31:14. ${ }^{446}$ Milgrom assumes that two punishments are implied here, as in Lev 20:2-3. The first punishment is death at the hand of the covenant community, followed by kārēt at the hand of God. ${ }^{447}$ While Sklar accepted the possibility that a double punishment may be possible but not necessary in Lev 20:2-3, ${ }^{448}$ he claimed that that is not the case here because the role of the Hebrew

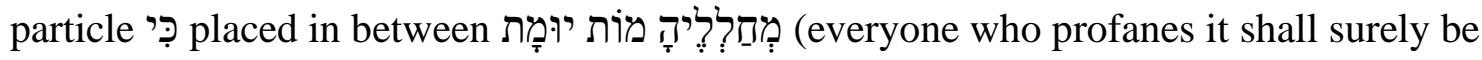
put to death) and (for whoever does any work on it, that person shall be cut off from among his people) suggests that one clause interprets the other: $k \bar{a} r \bar{e} t$ is carried out by the act of capital punishment. ${ }^{449}$

\footnotetext{
${ }^{445}$ Kenneth Bergland, "Reading as a Disclosure of the Thoughts of the Heart: Proto-Halakhic Reuse and Appropriation between Torah and the Prophets" (PhD diss., Andrews University, 2018), 88-97.

${ }^{446}$ Sklar, Sin, Impurity, Sacrifice, Atonement, 19.

${ }^{447}$ Milgrom, Numbers, 407-8.

${ }^{448}$ The analysis of Lev 20:1-5 suggested in the sixth chapter of this work also suggested that kārēt refers to death penalty in the first place.

${ }^{449}$ Sklar, Sin, Impurity, Sacrifice, Atonement, 19.
} 
Sklar also pointed to another passage that consists of similar lexical and conceptual elements, Num 15. Numbers 15:27-31 discusses forgivable and unforgivable sins, of which the latter is punishable by kārett. This passage is immediately followed by the episode of a man who was found collecting sticks on the Sabbath (v. 32). The covenant community inquired of the Lord and asked how they should treat the violator. God affirmed kārēt punishment, which was carried out by the covenant community and consisted of stoning the Sabbath-breaker outside the camp (v. 35). In the passage beginning in Num 15:31, immediately following the passages that prescribed kārēt for high-handed sin, v. 35 illustrates what kārēt looks like. It states that it is premature death carried out by a human party. ${ }^{450}$ In addition to these two texts, the following texts on idolatry laws in Lev 20:1-5, 6; Deut 13, and 17 prescribe that idolater/s are punished by

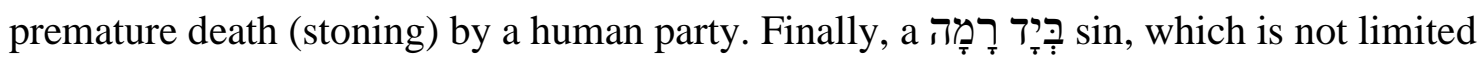
to any type of sin, but rather, is defined by the sinner's attitude (see Num 35:32-36; Sabbath breaking), is also punishable by premature death at the hand of the covenant community. Thus, the claim that God is the only one who administers punishment for sins punishable by kārēt is not confirmed by the biblical texts.

In conclusion, based on these biblical texts, it can be inferred that the kārēt punishment is carried out by both God and the covenantal community and not solely by God. Due to the nature of the sins in question, it is possible that God implemented this punishment more frequently than the covenantal community.

\footnotetext{
${ }^{450}$ Sklar, Sin, Impurity, Sacrifice, Atonement, 20.
} 


\section{Summary and Conclusions}

Kärēt punishment predominantly refers to the premature death of the sinner. The sins that invoked the punishment of premature death themselves represent sins that are motivated by a desire to defy and reject God. As such, premature death as punishment affects the sinner's status in the afterlife and prevents him/her from receiving the advantages of afterlife that are presented in a limited manner in comparison to the ANE texts and the NT. Wold's study, which argues that kārèt punishment refers to the sinner's status in the afterlife, is heavily informed by an Akkadian and West-Semitic worldview and based on a limited analysis of linguistic similarities. His proposal that kārēt punishment in the OT refers to the punishment in the afterlife is based on an ANE construct that is developed more fully in ANE literature than in the OT texts. Therefore, in not denying the existence of a limited presentation of the concept of afterlife in the OT, Wold's proposal is not supported by the biblical texts. In addition, his conclusions also suffer from methodological unsoundness. Finally, according to the biblical texts and in contradistinction to Milgrom's conclusions, God and the covenant community administer $k \bar{a} r \bar{e} t$ punishments. However, due to the secret nature of these sins, it is reasonable to suggest that God administers this punishment more than humans. The current study first presents the key points of the previous scholarly research on each term that precedes this study within the limits of the Pentateuch.

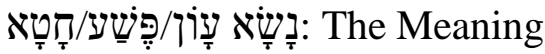

The analysis of the terms 
generated a considerable amount of research. ${ }^{451}$ Most scholars have studied these phrases

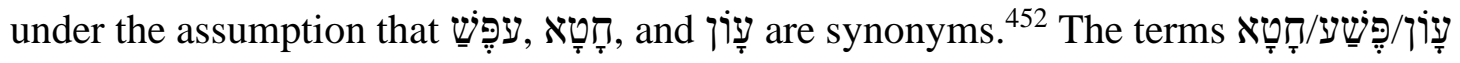
נָשָׁ are found in two contexts: (1) forgiveness for sin or (2) consequences for sin: punishment. Studies have maintained these two functions of the phrase for a long time, but this dichotomy was challenged by Baruch J. Schwartz in recent times. ${ }^{453}$

\section{Schwartz's Interpretation of}

Schwartz noted that there are two key reasons that have led scholars to arrive at the dual understanding, forgiveness for sin or punishment, of the phrase: (1) in the metonymic use of the terms for sin in the Hebrew Bible, they refer to both the act itself and its consequence and (2) the verb נְָָׁ has two different figurative meanings, "to forgive" and "to suffer, endure." This resulted in two contrasting translations of the verb depending on the context, "to forgive sin" or "to suffer punishment." Other ANE languages seem to affirm this point further. ${ }^{454}$

Schwartz proposed that the phrase does not have two different meanings, but

\footnotetext{
${ }^{451}$ Walther Zimmerli, “Zur Vorgeschichte von Jesaja LIII,” in Congress Volume: Rome, 1968, eds. G. W. Anderson, et al., VTSupp 17 (Leiden: Brill, 1969), 236-44; Walther Zimmerli, Ezekiel 1: A Commentary on the Book of the Prophet Ezekiel, Chapters 1-24, Hermeneia 8 (Philadelphia: Fortress Press, 1979), 1:116-18, 302-14; W. H. C. Propp, Exodus 19-40, AB 2A (New York: Doubleday, 2006), 448-50; Schwartz, "The Bearing of Sin," 3-21. $8-10$.

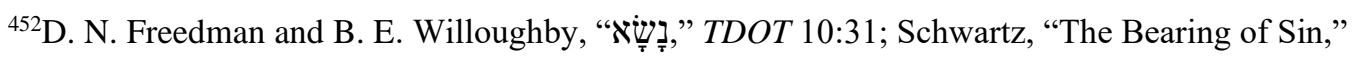

${ }^{453}$ Schwartz, "The Bearing of Sin," 8 . He also cited the most important proponent of this understanding such as Zimmerli, "Zur Vorgeschichte von Jesaja LIII," 236-44; Milgrom, Leviticus 17-22, 1488-90; Rodríguez, "Substitution in the Hebrew Cultus," 132; Janowski, Sühne als Heilsgeschehen, 36, 253; Levine, Leviticus, 26; Knierim, Die Hauptbegriffe für Sünde im Alten Testament, 73-91; Kiuchi, Purification Offering, 50-51; Milgrom, Leviticus 1-16, 339.

${ }^{454}$ Schwartz, "The Bearing of Sin," 8, 10.
} 


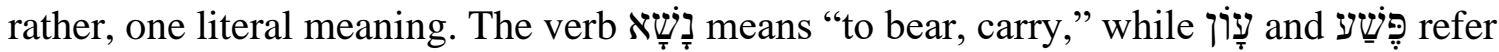
to sin, so the phrase means "to bear, carry sin or carry off, take away, remove." As being a figure of speech that refers to the wrongdoing as an object rather than an event or an action, the phrase was used in two distinct ways. Schwartz understood the phrase as a figure of speech that conceives sin as an object, a load rather than an event or action. First, it was used to convey the sinner's carrying of sin as a burden which might end in suffering the consequences if there are any. Thus, if a sinner bears sin, he or she may suffer the consequences if there are any related to it. In this usage, the phrase is a metaphor for the sinner's unrelieved guilt and should be translated as "to bear, carry sin." In other words, it is an indirect way of saying that the sinner deserves punishment and never represents punishment itself. ${ }^{455}$

If somebody else bears the load, then the sinner is relieved of it and its consequences if there are any. In this usage, the phrase is a metaphor for the sinner's relief from guilt and should be translated as "to carry off, take away, remove sin." Thus, the phrase has only one meaning, but two uses. ${ }^{456}$ The former use of the phrase (just נִשְָׁא חָטָא

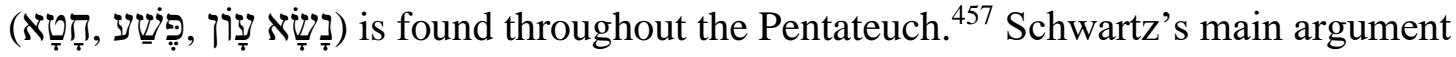
for establishing the two uses of the same phrase is in changing the subject and the

\footnotetext{
${ }^{455}$ Schwartz, "The Bearing of Sin," 8-9, 10.

${ }^{456}$ Schwartz, "The Bearing of Sin," 8-9, 10.

${ }^{457}$ Schwartz, "The Bearing of Sin," 9.
} 
execution of some sort of punishment or release from it. ${ }^{458}$

The use of the phrase in one or another context is characterized by changing subject. If the sinner is the subject then the phrase refers to his or her liability, whereas if someone else other than the sinner is the subject, it refers to relief from the liability. ${ }^{459} \mathrm{In}$ the latter usage, the sin, as a weight, is not transferred to another party so that the individual would bear the sin instead of the sinner, but rather, it does not weigh upon anyone. Schwartz stated: "It has disappeared.",460

Schwartz ardently upheld the fact that the verb "to bear, carry" - and the choice of the subject of the phrase would point to one of the two possible uses. In his opinion, the meaning of "to forgive ( $\sin$ )" or "to suffer punishment" is not a semantic domain of the verb

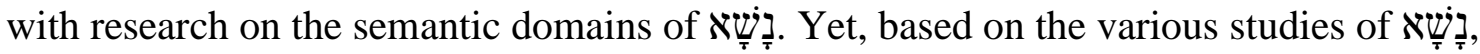
gathered together by Olaffson, ${ }^{461}$ the consensus was reached that the basic meaning for the verb נָָָָׁׁא is "to lift," "to carry," or "to take." The meaning "to forgive" was not considered as a semantic domain of

\footnotetext{
${ }^{458}$ Schwartz, “The Bearing of Sin,” 10.

${ }^{459}$ Schwartz, “The Bearing of Sin,” 10.

${ }^{460}$ Schwartz, "The Bearing of Sin," 10.

${ }^{461}$ The history of scholarly research on the verb נָׁשָ can be grouped into two approaches: (1) Lexical Listings, and (2) Semantic-Theological studies. Five major representatives of the former approach are (1) G. Gesenius, (2) J. Fuerst, (3) F. Brown, S. R. Driver, and C. A. Briggs, (4) L. Koehler and W. Baumgartner, and (5) W. L. Holladay. The major scholars of the latter approach are F. Stolz, N. Freedman and B. E. Willboghby, J. J. Stamm, R. Knierim, W. Zimmerli, R. N. Whybray. Gundmundur Olaffson conveniently examined all of these studies as a part of his doctoral research. Olaffson, "The Use of $n s$ " in
} the Pentateuch," 19-51. 
In addition to the basic meaning, the studies of expressed in two ways, literal or metaphorical. ${ }^{462}$ The emphasis is placed on the former one, whereas the latter was almost totally ignored. Finally, these studies showed a lack of importance and the meaning of the idiomatic uses of particular phrases encompassing the verb נִָָֹ The outcome of the approaches noted in those studies was that "no one has suggested the existence of a homonymous root for the concept of forgiveness, even though they seem to suggest that the concept of forgiveness is more or less 'appended' to the root rather than being an integral part of it." 463 These studies are uniform in understanding the concept of forgiveness as "removal of sin, guilt, transgressions, or wrongdoing." ${ }^{464}$ Knierim, Stolz, Zimmerli, Freedman, and Willoughby pointed to the substitutionary aspect of forgiveness. ${ }^{465}$ Knierim, Holladay, Freedman, and Willoughby indicated the aspect of forgiveness in personal relationships. ${ }^{466}$ Knierim, Freedman, and

\footnotetext{
${ }^{462}$ For the validity of these two basic types of meanings, see Osborne, The Hermeneutical Spiral, 83-93; Kaiser, Toward an Exegetical Theology, 59-60, 87-88; J. Cheryl Exum, “"Whom Will He Teach Knowledge?": A Literary Approach to Isaiah 28," in Art and Meaning: Rhetoric in Biblical Literature, eds. David J A Clines, et al., vol. 19 of JSOTSup, eds. David J A Clines, et al. (Sheffield: JSOT Press Department of Biblical Studies The University of Sheffield, 1982), 114; J. Kenneth Kuntz, "The Contribution of Rhetorical Criticism to Understanding Isaiah 51:1-16," in Art and Meaning: Rhetoric in Biblical Literature, eds. David J A Clines, et al., vol. 19 of JSOTSup, eds. David J A Clines, et al. (Sheffield: JSOT Press Department of Biblical Studies The University of Sheffield, 1982), 157; Lam, "Metaphorical Patterning," 32-54, 415-37. For a common approach throughout the ancient Near East, see Othmar Keel, The Symbolism of the Biblical World: Ancient Near Eastern Iconography and the Book of Psalms, trans. Timothy J. Hallett (Winona Lake, IN: Eisenbrauns, 1997), 9, 171, 201.

${ }^{463}$ Olaffson, "The Use of $n s{ }^{\prime}$ in the Pentateuch," 53.

${ }^{464}$ Olaffson, "The Use of $n s ́$ ' in the Pentateuch," 52-53.

${ }^{465}$ Knierim, Die Hauptbegriffe für Sünde im Alten Testament, 52-53, 221-22; N. Freedman, B. E. Willoughby, and Heinz-Josef Fabry, "נשא,," TWAT 5:632-37; Zimmerli, Ezekiel 1, 1:164; F. Stolz, "נשא," THAT 2:113-14.

${ }^{466}$ Knierim, Die Hauptbegriffe für Sünde im Alten Testament, 52; William Lee Holladay, A Concise Hebrew and Aramaic Lexicon of the Old Testament (Grand Rapids, MI: Eerdmans, 1971), 246; Freedman, Willoughby, and Fabry, "נשא," TWAT, 5:636-37.
} 
Willoughby gave limited evidence for the "to care," "to support" aspect of the verb .

Two characteristics of Schwartz's work that become obvious in the following part of the present research: (1) no analysis of נָָָׁ semantic domains and (2) source-driven division of the Pentateuch. The first caused him to go with the basic lexical meaning of the verb and not notice the nuances of meaning contained in the semantic domains of the verb. The second characteristic caused him not to conduct a source-driven understanding of atonement, thus eliminating the insights on the topic that can be gained outside of $\mathrm{P}$.

He isolated 22 occurrences ( 21 texts) of the phrase/s and one additional text in the Priestly tradition that captured the consequential meaning of the phrase derived 5 arguments that confirm this meaning of the phrase (see Table 9). ${ }^{468}$

As the table above shows, Schwartz joined Lev 7:18 and Lev 19:8 in one text due to the close similarity of the two texts. The phrase texts since they all belong to P, but it does appear in other texts of the Pentateuch. I will first analyze Schwartz's research on texts that also include

First, these 22 texts are comprised of 3 types of cases of which (1) some do not state any punishment, (2) some include capital punishment prescribed by human or divine agency, and (3) some involve kārēt punishment, explicitly or implicitly prescribed.

\footnotetext{
${ }^{467}$ Knierim, Die Hauptbegriffe für Sünde im Alten Testament, 51; Freedman, Willoughby, and Fabry, "נשושא," TWAT, 5:632.

${ }^{468}$ Schwartz, "The Bearing of Sin," 12.
} 


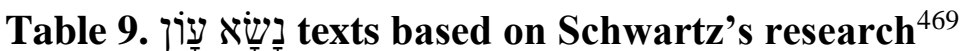

1. Exod 28:43 - Aaron and his sons when they fail to wear the proper undergarments as they approach the altar.

2. Lev 5:1 - A potential witness in a trial who refuses to testify.

3. Lev 5:17 - A person who has unknowingly sinned and possibly violated "the holy things of Yhwh" (qodšê yhwh).

4. Lev 7:18 - A person who eats from the šĕlāmîm -offering on the third day (first day $=$ day of offering)

5. Lev 17:16 - A person who eats from an animal that either died on its own or was killed by other animals and who does not then properly cleanse himself.

6. Lev 19:17 - A person who does not reprove his neighbor and thereby "lifts (nāśá') onto him (the neighbor) sin (hêt')."

7. Lev 20:17 - A man who "takes" his sister or half-sister and, presumably, has sexual relations with her.

8. Lev 20:19 - A man who has sexual relations with his maternal or paternal aunt. 9. Lev 20:20 - A man who has sexual relations with his uncle's wife.

10. Lev 22:9 - Priests who do not obey the instructions about keeping themselves ritually clean.

11. Lev 22:16 - "Nonpriests who inadvertently eat of the sacred gifts, having thus been caused to 'bear sin' through the negligence of the priests." v. 15
12. Lev 24:15 - A person who curses his god. 13. Num 5:31 - A wife whose husband suspects her of adultery and who undergoes the prescribed ritual under the supervision of the priest.

14. Num 9:13 - A person who does not make the paschal offering without a good reason.

15. Num 14:34 - The generation of adults who were too fearful to enter Canaan after hearing the report of the scouts.

16. Num 18:1 - Aaron, his sons, and his ancestral house with respect to sins against the sanctuary (miqdāš); only Aaron and his sons with respect to sins connected to the priesthood (kěhunnâ).

17. Num 18:22 - Israelites who draw near to the Tent of Meeting.

18. Num 18:23 - The Levites for any offenses connected with the service of the Tent of Meeting.

19. Num 18:32 - The Levites when they fail to take the best of the donations (tithes) that they receive to pass on to the priests.

20. Num 30:16 - A husband who, after hearing about his wife's vows and obligations, later nullifies them.

21. Num 15:30-31 - Any person who acts defiantly, deliberately transgressing any commandment, thus spurning God

Based on the fact that some cases do not include potential punishment and some warrant it, Schwartz concluded that the phrase is a metaphor for the commonality related to all these texts, that is, being guilty. ${ }^{470}$

\footnotetext{
${ }^{469}$ Schwartz, "The Bearing of Sin,” 10-12.

${ }^{470}$ Schwartz, "The Bearing of Sin," 12-13.
} 
Second, if sin bearing and punishment were coextensive, it would be expected that either one or the other, but not both, would be mentioned in one single context. This not being the case signals that the punishment and the bearing of sin are two distinct phenomena, that is, sin bearing is culpability, liability, and guilt, whereas punishment may or may not follow. ${ }^{471}$

Third, in some cases, bearing sin can be remedied ([2] $]^{472}$ Lev 5:1; [3] Lev 5:17; [11] Lev 22:9 and possibly [6] Lev 19:17, and perhaps [20] Num 30:16), thus pointing to it as only being the state of culpability and not the punishment itself. ${ }^{473}$

Fourth, Schwartz found additional confirmation for his position in the fact that the

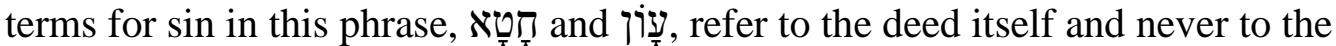
punishment since in 19/21 cases, they are sins of commission, deeds. However, he did notice that eight cases ([1] Exod 28:43; [2] Lev 5:1; [5] Lev 17:16; [6] Lev 19:17; [10] Lev 22:9; [14] Num 9:13; [18] Num 18:23, and [20] Num 30:16) appear to be omissions, "but in every one of them, the negligence involved is tantamount to the commission of an offence. ${ }^{, 44}$ He listed Num 9:13 as the only exception to this point since it is a performative command in $\mathrm{P}$ which includes kārēt punishment. ${ }^{475}$

Fifth, Schwartz found that in four cases ([2] Lev 5:1; [4] a) Lev 7:18; [5] Lev 17:16, and [10] Lev 22:9), bearing sin is the precise equivalent for being impure in the

\footnotetext{
${ }^{471}$ Schwartz, "The Bearing of Sin,” 13.

${ }^{472}$ Numbers in square brackets refer to Table 9.

${ }^{473}$ Schwartz, "The Bearing of Sin," 13.

${ }^{474}$ Schwartz, "The Bearing of Sin," 13.

${ }^{475}$ Schwartz, "The Bearing of Sin,” 13.
} 
immediate and proximate cases. He stated: "This analogy too confirms that the sin that is borne is a metaphor for a condition, not the penalty that is its outcome." ${ }^{476} \mathrm{He}$ noticed that a bearing metaphor is reinforced when one realizes that impurity and sin are associated with the same prepositions as they relate to human beings. Consequently, impurity is occasionally "upon" the sinner (Lev 7:20, 22:3, Num 19:13) as is bloodguilt "upon" sinners ([7] Lev 20:17; [8] Lev 20:19; [9] Lev 20:20). As individuals are "in their impurity" (Lev 15:31; 18:19), they can also be "in their sin" (Lev 26:39; Num 27:3; Ezek $3: 18 ; 33: 6)$. In case (13), Num $5: 31$, bearing sin is opposite to being cleansed of sin. In case (20), Num 30:16, the text states that the wife's sin is borne just as her vow/oath is upon her. ${ }^{477}$

Sixth, he noticed that in two cases ([2] Lev 5:1 and [3] Lev 5:17), the offender's bearing of his $\sin$ is a counterpart of realizing his or her guilt (wָשָׁ). Sin-bearing, like 

\section{Critique of Schwartz's Interpretation of עָּוֹ}

Milgrom produced the most extensive critique of this view. The starting point of his argument was that behavioral terms extend the consequential meaning so that the phrase can be translated as punishment or God lifts his punishment. Milgrom found that this phenomenon is found in the Akkadian phrases hitam naš $\hat{u}$, arnam našû, šertam naš $\hat{u}$ (CAD N 11/2:103, 104, 108). Thus, he rejected Schwartz's first consequential meaning

\footnotetext{
${ }^{476}$ Schwartz, "The Bearing of Sin," 14.

${ }^{477}$ Schwartz, "The Bearing of Sin," 14.

${ }^{478}$ Schwartz, "The Bearing of Sin," 14.
} 
and provided more arguments for Schwartz's second meaning of "carry" or "removing sin. $" 479$

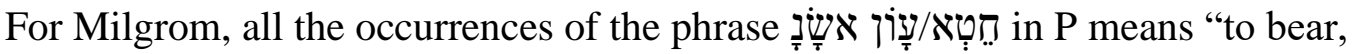
suffer punishment," ${ }^{480}$ while in $\mathrm{H}$, it means "to carry off, remove sin or forgive." ${ }^{481}$ It does not mean to carry a sin as if it were a weight, but refers to its consequences.

Milgrom first focused on proving that in all the cases ([2] Lev 5:1; [3] Lev 5:17; [6] Lev 19:17) that Schwartz classified as having no punishment, the phrase actually does

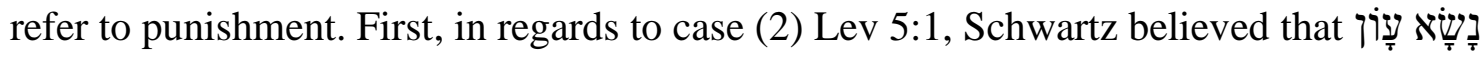
from v. 1 is parallel to וְ וָאָשָׁ in vv. 2, 3, and 4. This interpretation has a long history ${ }^{482}$ and was noticed as early as in the Qumran texts (CD 9.10-12). ${ }^{483}$ Milgrom claimed that

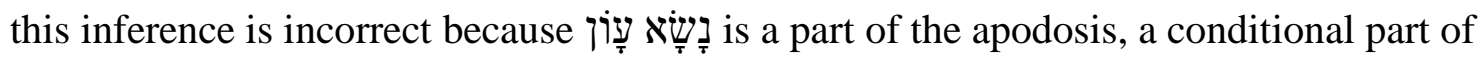
the law introduced in v. 1, while וְ וָָָ belongs to the protasis of the subcases of this law detailed in vv. 2, 3, and 4. ${ }^{484}$ In most instances in Biblical Hebrew (hereafter BH), the protasis of these conditional statements begin with either ’ִ̣, and then the apodosis follows. ${ }^{485}$ Subcases of the protasis are emphatically introduced by iw at the beginning of

${ }^{479}$ Milgrom, Leviticus 17-22, 1488.

${ }^{480}$ Milgrom, Leviticus 17-22, 1488.

${ }^{481}$ Milgrom, Leviticus 1-16, 295.

${ }^{482}$ Noth, Leviticus, 44; Rodríguez, "Substitution in the Hebrew Cultus," 90; Hoffmann, Das Buch Leviticus, 1:197-98.

${ }^{483}$ Milgrom, Leviticus 1-16, 295-96.

${ }^{484}$ Milgrom, Leviticus 17-22, 1488-89.

${ }^{485}$ Bruce K. Waltke and M. O’Connor, An Introduction to Biblical Hebrew Syntax (Winona Lake, IN: Eisenbrauns, 1990), 636-37. 
each law in vv. 2, 3, and 4, ${ }^{486}$ emphasizing their dependence on the protasis in v. 1 . The apodosis actually begins in 5 b. ${ }^{487}$

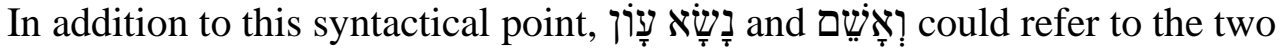
mutually inclusive parts of the same process, namely the sinner's realization that he has

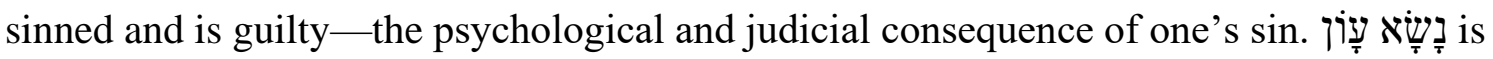
mentioned in the protasis and would apply to all following cases in vv. 2, 3, and 4, whereas וְָָ is added in the apodosis to add the subjective aspect of the same process

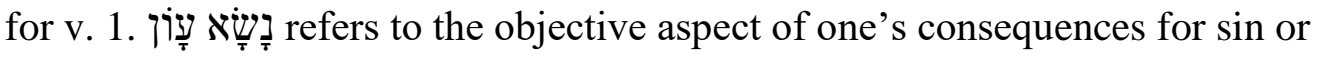

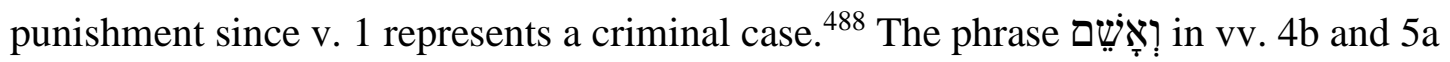
could refer to the sinner's subjective realization of his or her condition of guilt. It also

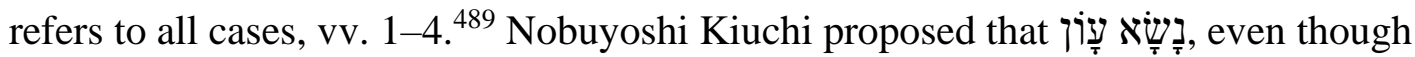
mentioned only in v. 1, applies to all the following cases in vv. 2, 3, and 4. The culprit in v. 1 faces two penalties, one for not testifying about the truth, and other for withholding testimony. 490

Second, regarding the case in (3) Lev 5:17, Milgrom rightfully pointed to the fact that the law explicitly states that the sin was expiated with a reparation offering, but an expensive ram as a fine is a stark penalty rather than a remedy. He listed Lev 5:6, 19,

\footnotetext{
${ }^{486}$ Milgrom, Leviticus 17-22, 1488-89.

${ }^{487}$ Milgrom, Leviticus 1-16, 344-45.

${ }^{488}$ Porter, Leviticus, 41; Péter-Contesse, Lévitique 1-16, 86.

${ }^{489}$ Milgrom, Leviticus 1-16, 295.

${ }^{490}$ Nobuyoshi Kiuchi, Leviticus, AOTC 3 (Nottingham: Apollos, 2007), 100.
} 


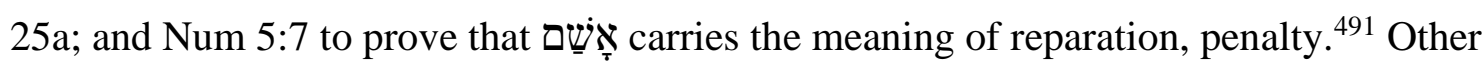

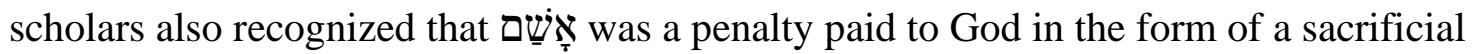
offering in this pericope. ${ }^{492}$

Third, regarding case (6), Lev 19:17, Milgrom agreed that punishment is not explicitly mentioned in this case, but that does not mean that it is not implied. He went on to say that none of the cases ([4a] Lev 7:18; [4b] Lev 19:8; [8] Lev 20:19; [12] Lev 24:15; [13] Num 5:31; [16] Num 18:1; [18] Num 18:23, and [20] Num 30:16) mention punishment, but the punishment is implied in all these texts. ${ }^{493}$ Schwartz himself agreed that punishment is also implicit in (4a) Lev 7:18 and (8) Lev 20:19, as well as in others ([5] Lev 17:16 and [7] Lev 20:17). Thus, Lev 7:18 rules that those who do not uphold

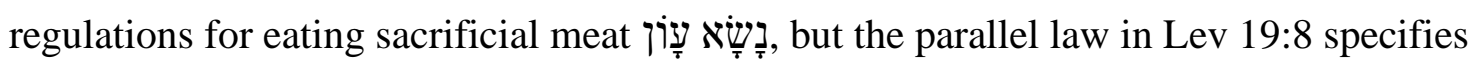
the kārēt punishment for this sin. Milgrom stated: "H (Lev 19:8) explains the נָשָׁא עָּוֹן in 7:18 (P) means kareth." ${ }^{494}$ Not agreeing that this is the characteristic of the two sources, other scholars also noticed that these two texts illuminate each other, thus suggesting that 7:18 does indeed imply the kārēt punishment. ${ }^{495}$

It has been noted that the change in person and style in Lev 20:19a and 19b could

${ }^{491}$ Milgrom, Leviticus 17-22, 1489.

${ }^{492}$ Richard E. Averbeck, “"ָָָָָ," NIDOTTE 1:550; Eugene Carpenter and Michael A. Grisanti,

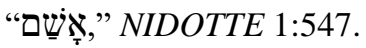

${ }^{493}$ Schwartz, "The Bearing of Sin," 12.

${ }^{494}$ Milgrom, Leviticus 17-22, 1489.

${ }^{495}$ Wenham, The Book of Leviticus, 125; Kiuchi, Leviticus, 353; Levine, Leviticus, 129-30, 44. Noth believed that punishment would follow if the sin was committed intentionally. Noth, Leviticus, 63. 
suggest that this law is an appendix. ${ }^{496}$ Milgrom agreed with Michael Hildenbrand that the change of person is rather an attempt to distinguish this prohibition from all the others within its literary context by its content, style, and vocabulary. ${ }^{497}$ Hildenbrand noted that this prohibition is the only one in the pericope, consisting of vv. 17-21, that does not

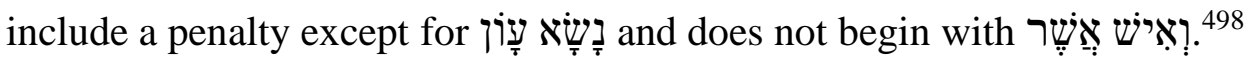

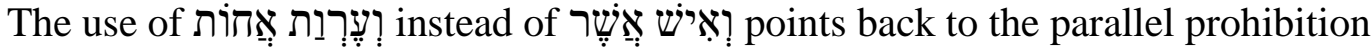
in Lev 18:12-13 where this phrase begins eleven laws (vv. 7, 8, 9, 10, 11, 12, 13, 14, 15, 16, 17). Another signal that Lev 20:19 builds on Lev 18:12-12 is the noun שִָׁר, translated as blood relative. שִשָׁi is used 4 times in Lev 18 (vv. 6, 12, 13, 17) and only used in v. 19 of Lev 20. Milgrom believed, in this regard, that H edited the list in Lev 20 using the list in Lev $18 .{ }^{499}$ Hildenbrand saw it as a combination of Lev 18:12-13 with the

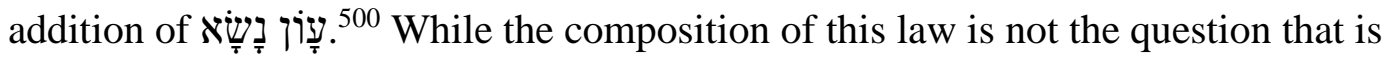
pursued in the current study, it is evident that Lev 20:19 heavily relies on the parallel law in Lev 18:12-13 which, in contrast to Lev 20:19, does legislate the punishment of kārēt via Lev 18:24-30 that serves a concluding epilogue of the chapter codifying the kârèt

\footnotetext{
${ }^{496} 19 \mathrm{a}$ uses apodictic style in contrast to casuistic style used in previous and following verses and second person whereas 19b reverts to the third person. David Daube, Studies in Biblical Law (Cambridge: The University Press, 1947), 80-81.

${ }^{497}$ Hildenbrand, Structure and Theology, 160-61; Milgrom, Leviticus 17-22, 1756.

${ }^{498}$ Hildenbrand, Structure and Theology, 159.

${ }^{499}$ Milgrom, Leviticus 17-22, 1756.

${ }^{500}$ Hildenbrand, Structure and Theology, 160.
} 
punishment for committing the sins listed in the preceding verses. ${ }^{501}$ Therefore, Lev 20:19 does imply severe punishment as do sins in Lev 18 and in the preceding and following verses of Lev 20:19. Schwartz himself agreed that the death penalty must be inferred for the laws of the entire pericope of Lev 20:17-21 because it is mentioned in vv. $9-16.502$

Milgrom rightfully noted that case (12) Lev 24:15 is followed by a death penalty emphatically expressed by ממוֹת יוּמָת in v. 16 which clearly means that the penalty for such a sin is death. ${ }^{503}$ Even though this law seems clear in terms of punishment for this

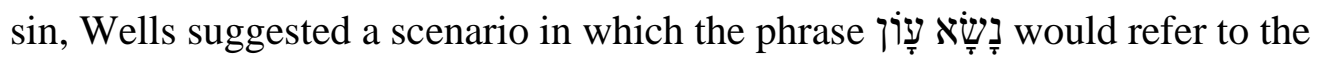
unspecified punishment for cursing one's god other than the God of Israel. Wells stated that it is difficult to argue that there is an additional liability in this law, but he saw a possibility that this law may be referring to a god other than the God of Israel. Thus, the law could be applied in two different contexts and could imply distinct liabilities. In case the context includes cursing the God of Israel, the punishment would be death, but in case the context includes cursing some other deity, then the liability would be unspecified, which would make the punishment in this law similar to the punishment in Lev 5:1, 17; 17:16; Num 5:31; and 30:15, some sort of wait-and-see unknown punishment. ${ }^{504}$ The

\footnotetext{
${ }^{501}$ Wenham, The Book of Leviticus, 260; Milgrom, Leviticus 17-22, 1582; Gane, Leviticus, Numbers, 321; Kiuchi, Leviticus, 338-39.

${ }^{502}$ Schwartz, "The Bearing of Sin," 13.

${ }^{503}$ Milgrom made a difference regarding the mode of punishment execution between cursing or pronouncing God's name, namely, execution by God himself or the community, respectively. Milgrom, Leviticus 17-22, 1489.

${ }^{504}$ Bruce Wells, "Liability in the Priestly Texts of the Hebrew Bible," SL 5 (2012): 21-22.
} 
present study rejects this proposal based on the fact that Leviticus used the phrase 8 times in 7 texts (Lev 4:22; 21:7; 12:8, 17, 21-22; 24:15) and the addition to the pronominal suffix 3 MSS never changed the referent of the phrase, that is, it is always the God of Israel. ${ }^{505}$ It would also be unlikely that BL would be concerned with protecting other gods than the God of Israel. This would contradict the entire thrust of the biblical monotheistic faith and put emphasis only on the God of Israel. Biblical legislation shows unfriendliness towards other gods including death penalties for serving or enticing others to serve them (Exod 23:13, 24; Lev 20:1-5; Deut 13; 17:1-7). ${ }^{506}$ In addition, the punishments in 5:1,17; 17:16; Num 5:31; and 30:15 are not wait-and-see, but are rather

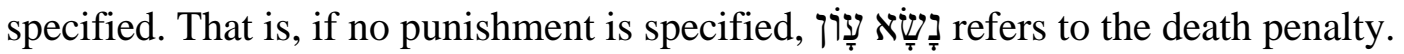

Case (13) Num 5:31 also contains the punishment. That is, convicted women are condemned to childlessness (vv. 22, 27). Milgrom stated: "Her punishment is equivalent to "ărîrî." biblical texts (Gen 20:9; 26:10; 39:9b) that in the Bible, as well as in ANE, ${ }^{508}$ adultery was considered a crime against the husband, but also against deities. As such, it was treated by religious and civil laws. ${ }^{509}$

${ }^{505}$ Accordance Bible Software, version 10.0 (Altamonte Springs, FL: OakTree Software, 2012).

${ }^{506}$ Roy E. Gane, Old Testament Law for Christians: Original Context and Enduring Application (Grand Rapids, MI: Baker, 2017), 243.

${ }^{507}$ Milgrom, Leviticus 17-22, 1489.

${ }^{508}$ The technical term, “a great sin," was used throughout the ANE to qualify sin. Four ninth century marriage documents from Egypt use this phrase to label adultery. Multiple documents from Babylonia also qualify adultery as "great sin." This sin always offends both the husband and deities in the ANE. Milgrom, Numbers, 348-49.

${ }^{509}$ Milgrom, Numbers, 348-49. 
Milgrom proposed two reasons why a suspected adulteress was not judged by a human court. First, she was not apprehended by man, and thus there were no witnesses to the woman's sin. There are four indicators in v. 13 to show this: (1) "unbeknown to her husband," (2) "she keeps secret," (3) "without being apprehended," and (4) "and there is no witness against her." This further means that an unapprehended criminal is not subject to the jurisdiction of the human court. These kinds of crimes are punishable by God only with no need for human mediation. ${ }^{510}$

Second, the technical term for adultery, naaf, found in Decalogue 20:13, Lev 20:10[4x], Deut 5:17, is absent in a suspected adulteress pericope even though the text describes her infidelity in four ways. The author of this pericope perhaps intentionally refrained from relating a legal term naaf to suspected adultery because he wanted to disconnect this woman's fate from the death penalty imposed for adultery by a human court. The intention was to emphasize the fact that punishment in this case comes from God himself, and was not a human jurisdiction. ${ }^{511}$

The punishment itself reflects what is known in the OT as a measure-for-measure principle and refers to a more precise retribution that would fit the crime one commits. Thus, a human court could not do any more than put the apprehended adulteress to death, but God sentenced an unapprehended adulteress to a more suitable punishment. That is, since she agreed to receive forbidden seed, she was doomed to sterility for the rest of her

\footnotetext{
${ }^{510}$ Milgrom, Numbers, 349-50.

${ }^{511}$ Milgrom, Numbers, 349-50.
} 
life. ${ }^{512}$ She was not put to death and could live out her life, but was doomed by God to childlessness. ${ }^{513}$ The final punishment in case the woman was proven to be guilty is also debatable. Gane's observation that the text is silent in regard to the punishment if the women confessed her sin discredits Milgrom's claim that the ritual's purpose was to encourage the woman's confession. ${ }^{514}$

Perhaps her confession can protect her from the public humiliation of being involved in the ritual itself, punished by a prolapsed uterus, and eventually being punished by the death penalty. Milgrom believed that her full punishment could be sterility, ${ }^{515}$ perhaps a prolapsed uterus, ${ }^{516}$ and a childless life ${ }^{517}$ which was perceived in the OT as curse from God. ${ }^{518}$ In addition, if she had been proven guilty, her husband

\footnotetext{
${ }^{512}$ Milgrom, Numbers, 350. For a fuller treatment and questions that this pericope generates, see Jacob Milgrom, "The Case of the Suspected Adulteress, Numbers 5:11-31: Redaction and Meaning," in The Creation of Sacred Literature: Composition and Redaction of the Biblical Text, ed. Richard Elliott Friedman, UCPNES 22 (Berkeley, CA: University of California Press, 1981), 69-75.

${ }^{513}$ Milgrom, Leviticus 17-22, 1758.

${ }^{514}$ Gane, Leviticus, Numbers, 524. Contra Milgrom, Numbers, 350.

${ }^{515}$ Milgrom, Leviticus 17-22, 1758.

${ }^{516}$ Tikva Frymer-Kensky, "The Strange Case of the Suspected Sotah (Numbers V 11-31)," VT 34 (1984): 18. For an additional interpretation of the nature of woman's punishment, see Gordon J. Wenham, Numbers: An Introduction and Commentary, TOTC 4 (Downers Grove, IL: Inter-Varsity, 1981), 84; Frymer-Kensky, "The Strange Case of the Suspected Sotah," 20-1. R. K. Harrison suggested scenarios where the effect of the curse could be fatal for a woman if she was proven to be liable for adultery. Receiving the curse upon herself would result in her death. R. K. Harrison, Numbers, WEC (Grand Rapids, MI: Baker, 1992), 111-13.

${ }^{517}$ Milgrom, Numbers, 350. Followed by Gane, Leviticus, Numbers, 526; Frymer-Kensky, "The Strange Case of the Suspected Sotah," 18.

${ }^{518}$ Kiuchi, Leviticus, 378.
} 
would have had the right to divorce her. ${ }^{519}$

The hint that the death penalty might be involved if she was proven to be liable in this case is found in the inclusion of the עִּרִירי element of this punishment. Milgrom recognized that the punishment of the woman in Num 5:31 is equivalent to עִִּרִירִ punishment legislated in Lev 20:20, she would not be able to have children.

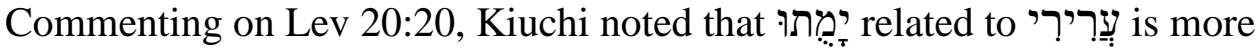
particular than it might seem. That is, dopמְת does not refer to a natural death, but rather, describes the consequences of violating God's laws or ordinances. Leviticus uses the qal stem of the verb מוּת to refer to the death punishment when humans carry it out (8:35; $10: 2,6-7,9 ; 15: 31 ; 16: 1-2,13) .{ }^{521}$ Some texts are excluded from this claim for valid reasons. The death of an animal in Lev 11:39 is excluded due to the non-human subject. However, it is unknown why Kiuchi did not include Lev 22:9 in the list since the text uses the qal stem of מוּת and refers to the death of the human being due to punishment for violating God's regulations regarding the sanctity of the sanctuary. Leviticus 21:11 is a true exception to this since it uses the qal of the verb מוּת and refers to a human who has died for unknown reasons. ${ }^{522}$ However, with Lev 21:11 most likely being the only exception, Kiuchi's claim that death is viewed as punishment for violating God's laws in

${ }^{519}$ Levine, Numbers 1-20, 202.

${ }^{520}$ Milgrom, Leviticus 17-22, 1489.

${ }^{521}$ Kiuchi did not count texts where the qal infinitive absolute of מוּת was followed by hophal imperfect (Lev 20:2, 9, 10, 11, 12, 13, 15, 16, 27; 24:16, 17, 27:29).

${ }^{522}$ Kiuchi stated that death in this text is not natural, but rather, results from the violation of God's commandments. For more detailed interpretations, see Kiuchi, Leviticus, 395-96. 
the book of Leviticus potentially emphasizes the presence of death as the punishment

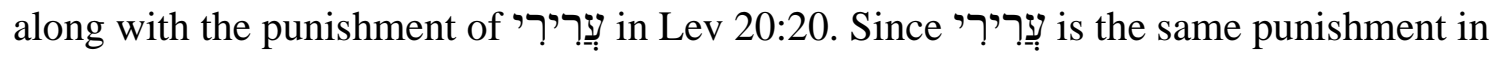
Num 5:22, 27 and in agreement with death as the punishment for adultery elsewhere in the OT (Lev 18:20, 28; 19:20; 20:10-21; Deut 22:22-27), could include the death penalty in the course of time if the suspected adulteress were proved liable for the adultery.

Olaffson pointed that it is not clear if the phrase "to die childless" in Lev 20:2021 refers to the inability to have children or if their efforts to have children together would be unsuccessful because they will both die. In the context of the pericope and the punishments presented for illicit sexual behaviors the latter alternative is more suitable. ${ }^{524}$ Regardless of the fact that the nature of punishment is still a matter of debate, it is nonetheless certain that punishment is envisioned in Num 5:31.

The two additional cases (16) Num 18:1 and (18) Num 18:23 are similar, and none of them contains any explicit penalty. However, Num 18 deals with two dominant concerns that were anticipated in prior legislation: (1) laws concerning the purity of the sanctuary, its interior space and contents, including the priesthood, and (2) laws for the support/compensation for the priests and Levites and their families. The law of (16) Num 18:1 belongs to the first concern and is specifically related to Exod 29:1-37; Lev 8-10; Num 3-4, and 8:5-26, while the law of (18) Num 18:23 is embedded in the second

\footnotetext{
${ }^{523}$ Brichto and Harrison also pointed out the fact that punishment for adultery in OT narratives is infertility combined with the death sentence. Herbert Chanan Brichto, "The Case of the Śōtā and Reconsideration of Biblical 'Law, " HUCA 46 (1975): 66; Harrison, Numbers, 113.

${ }^{524}$ Olaffson, "The Use of $n s s^{\prime}$ in the Pentateuch," 177.
} 
concern. The specific issue of these laws in Num 18 covers the duties of the priests and Levites. ${ }^{525}$

The former are responsible for preserving the purity of the sanctuary and its contents by not allowing encroachment, which could have been done by priests' entering it in the state of impurity (Lev 22:3) $)^{526}$ or by allowing a disqualified priest-blemished (Lev 21:23), inebriated (Lev 10:9), unwashed (Exod 30:20), improperly dressed (Exod 28:43) - to officiate at the altar or enter the sanctuary. Priests are the only ones who could prevent some among them from entering the Most Holy place (Num 18:7) or if the high priest entered it without proper safeguards (Lev 16:2). ${ }^{527}$ The priest had access to the outer area of the Sanctuary and was punished by death if he encroached on the Sanctuary or allowed a non-Levite to commit such an offense (Num 18:3) ${ }^{528}$ In the light of the greater responsibility of the priesthood to guard the Sanctuary, the Most Holy, and the altar and the fact that the Levites who guarded the outside of the sanctuary would receive the death penalty if they failed, it is very difficult to claim that the punishment for priests would not be death, as well. ${ }^{529}$ In addition to this, the fact that previous legislation associated with potential violations envisioned in Num 18:1 stipulates kārēt (Lev 22:3; Lev 21:23- הָלָלד) or the death penalty (Lev 10:9; Exo 30:20; Exo 28:43; Lev 16:2, and Lev

${ }^{525}$ Levine, Numbers $1-20,435$.

${ }^{526}$ Levine, Numbers $1-20,435-36$.

${ }^{527}$ Milgrom, Numbers, 146.

${ }^{528}$ Levine, Numbers 1-20, 441; Milgrom, Numbers, 147. For a more precise analysis of what specifically guards priests and Levites, see Milgrom, Numbers, 147, 424.

${ }^{529}$ John H. Walton, Victor H. Matthews, and Mark W. Chavalas, "Numbers," in IVPBBCOT (Downers Grove, IL: InterVarsity Press, 2000), 153-54; Milgrom, Numbers, 147; Milgrom, Leviticus 17$22,1489$. 
cf. v. 7) for the culprit also emphasizes the responsibility of the priests and Levites in relation to preventing its defilement. Case (18) Num 18:23 portrays the same phenomenon of implied punishment. That is, the punishment for an encroaching Israelite is death (Num 18:22), whereas the punishment for the Levite who failed to prevent this is

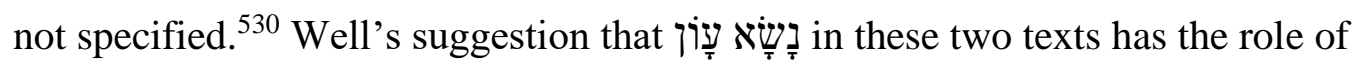
designating who bears liability ${ }^{531}$ would be redundant in the light of the beginning of the verse, where Aaron was introduced and addressed.

Case (20) Num 30:16 is a law that regulates the annulment of a woman's vows and oaths. The law states that if a husband does not annul his wife's vow or oath within the next 24 hours of hearing it, ${ }^{532}$ but annuls it afterwards, he will נָּשָׁ her her he vow/oath is not honored. Milgrom deduced from Num 30:6 that not fulfilling a vow or oath causes punishment for the culprit. That is, the unfulfilled vows or oaths are punished by $\operatorname{God}^{533}$ or in this case, forgiven by him. Wells admitted again that it is difficult to argue for any additional liability, as he did in relation to Lev $24: 15$, and the clarity of the

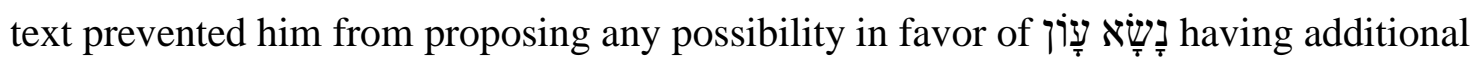
liability over punishment. He is right thought that the nature of punishment is not

\footnotetext{
${ }^{530}$ Milgrom, Leviticus 17-22, 1489.

${ }^{531}$ Wells, "Liability in the Priestly Texts," 30-31. Wells did acknowledge that death punishment in these two texts, as well as others.

${ }^{532}$ Milgrom, Numbers, 254; Levine, Numbers 21-36, 433.

${ }^{533}$ Milgrom, Leviticus 17-22, 1489.
} 
specified; ${ }^{534}$ it is unknown and God implements it. ${ }^{535}$

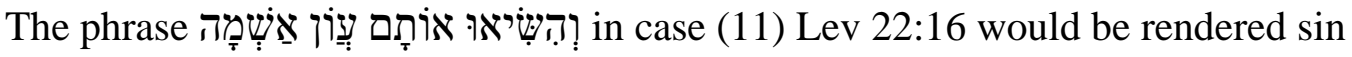
of guilt/reparation, which makes no sense. Rather, עָ iָ in this context, refers to punishment of guilt/reparation. ${ }^{536}$

In addition, Milgrom found Schwartz's proposal that bearing sin is a counterpart of being impure incorrect. ${ }^{537}$ The preposition bet is the bet of means, thus changing the translation of the texts which Schwartz translated from "in the sin" into "by means of (sin)" (Lev 26:39; Num 27:3; Ezek 4:17; 18:17, 19; 20; 33:6, and so on). ${ }^{538}$ Others also recognized that the bet of means or cause ${ }^{539}$ is a more accurate use/meaning of the preposition in these texts. ${ }^{540}$

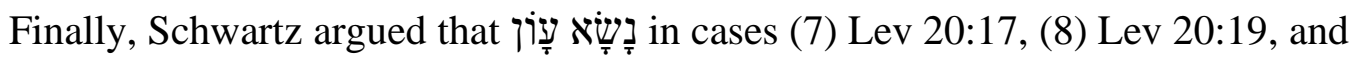

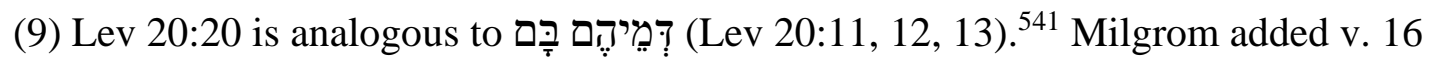
since this law also contains

${ }^{534}$ Wells, "Liability in the Priestly Texts," 23.

${ }^{535}$ Milgrom, Numbers, 43, 254.

${ }^{536}$ Kiuchi, Leviticus, 407; Milgrom, Leviticus 17-22, 1489; Levine, Leviticus, 150; Levine, Numbers 21-36, 345; Budd, Numbers, 299; Dennis R. Cole, Numbers, NAC 3B (Nashville: Broadman \& Holman, 2000), 464.

${ }^{537}$ Schwartz, "The Bearing of Sin," 14.

${ }^{538}$ Milgrom, Leviticus 17-22, 1489.

${ }^{539}$ Waltke and O'Connor, An Introduction to Biblical Hebrew Syntax, 198.

${ }^{540}$ Milgrom, Leviticus 1-16, 946; Milgrom, Leviticus 17-22, 1489; Levine, Leviticus, 98; Kiuchi, Leviticus, 284-85.

${ }^{541}$ Schwartz, "The Bearing of Sin," 14.

${ }^{542}$ Milgrom, Leviticus 17-22, 1489. 
condition in Lev 20:11, 12, 13 and 16, but rather, provides the reason why the culprits are punished by the death penalty. Therefore, Milgrom stated, it cannot be analogous with

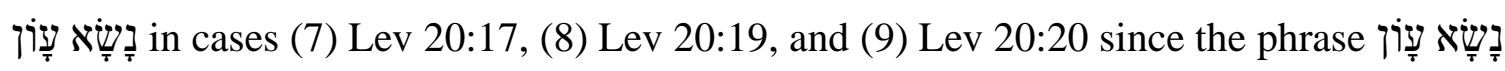
has a role of a declaratory formula in these texts. ${ }^{543}$ Its role is to express that the culprits will be punished.

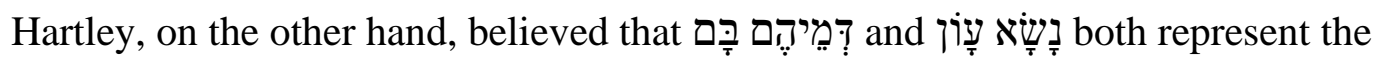
declaratory formula in these laws. Their function is to underscore the certainty that the punishment will be executed. The death penalty qualified by the declaratory formula

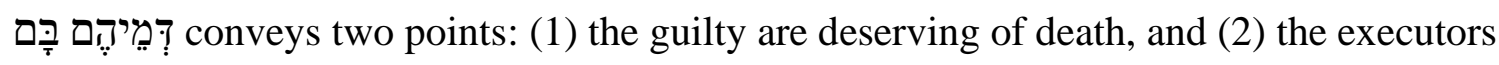
of the penalty are not responsible for shedding blood. ${ }^{544}$

It is also possible that the structure of the law in case (7) Lev 20:17 points to the

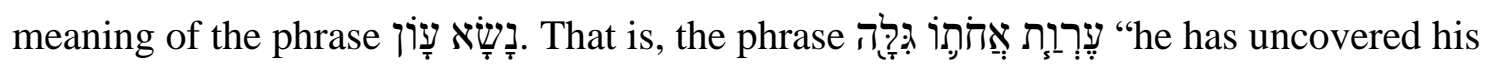

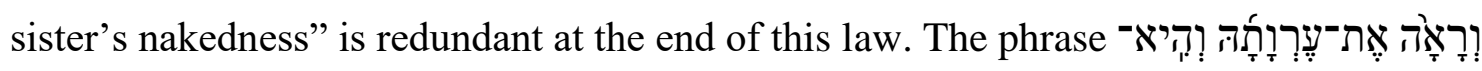
"he sees her nakedness and she sees his nakedness” conveyed this

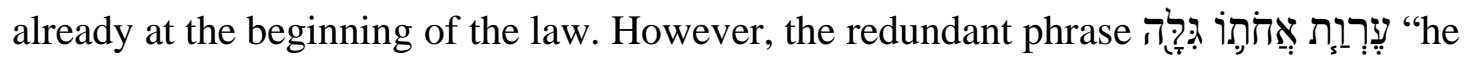

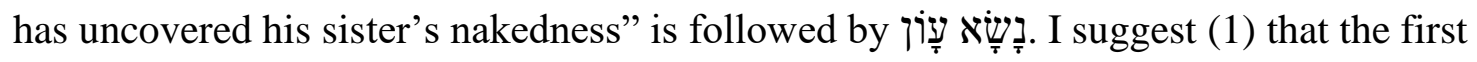

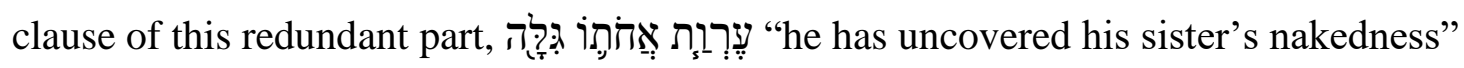
summarizes the entire law without punishment, and (2) that the second clause, the phrase

\footnotetext{
${ }^{543}$ Hartley, Leviticus, 330-31; Milgrom, Leviticus 17-22, 1754.

${ }^{544}$ Hartley, Leviticus, 331.
} 


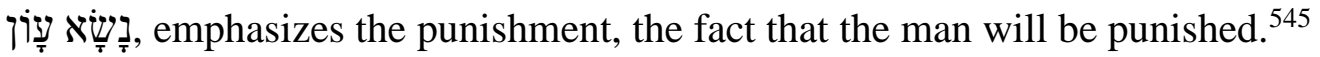

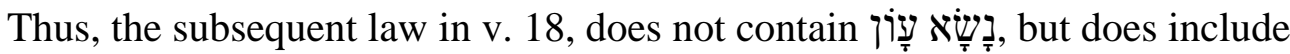

kārēt punishment; v. 19 does not state the exact penalty, but does have 20

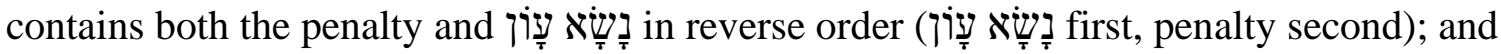

v. 21 contains just the penalty. It seems that the author was not concerned about

establishing a consistent pattern. Hildenbrand and Hartley presented a detailed study on

the laws contained in Lev 20:17-21 ${ }^{546}$ and agreed on two points: (1) the inconsistency in

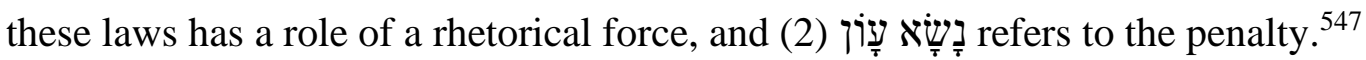

Based on the well supported proposal that some sort of death penalty is implied in

all the laws in 20:17-21 and the structure of the law in v. 17, it might be that the author of

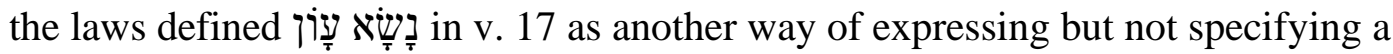

serious penalty that applies to all the laws in this pericope. Thus, wherever the penalty is

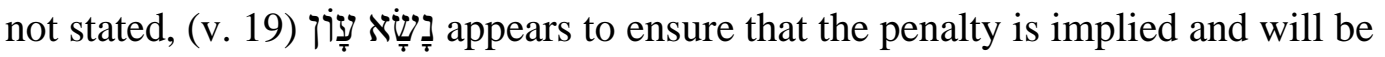

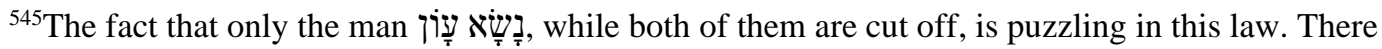
are valid explanations for this. First, Gane's quotation sheds light on the process of law administration in ancient Israel which was implemented by males. "In ancient Israel, legal matters were normally administered by males, and dependent females came under their legal protection and jurisdiction (cf. Num 30). Men initiated marriage and divorce proceedings (e.g., Deut 24:1-4) and also charges of sexual misconduct, which could lead to capital punishment (cf. 22:13-21)." Second, Milgrom pointed out that LXX and Peshita read the plural "they" to refer to the punished ones as v. 19 reads plural. Milgrom, Leviticus 17-22, 1754. Both of them would be punished by the same punishment as it is stated in v. 19 for a

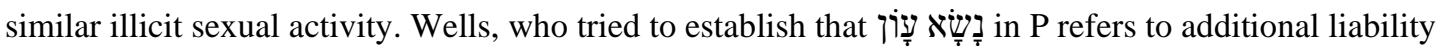
separated from the punishment, was not able to find any additional liability that one was to bear, but the one stated in v. 17, that is, cut off. Wells, "Liability in the Priestly Texts," 17-18.

${ }^{546}$ Hildenbrand eloquently proved through a detailed structural study that Lev $20: 17-21$ is a distinct pericope. Hildenbrand, Structure and Theology, 160.

${ }^{547}$ Hartley, Leviticus, 330-31; Hildenbrand, Structure and Theology, 160-61.
} 
executed. In the cases where it shows up along with the penalty (v. 20), it emphasizes that the penalty will be executed.

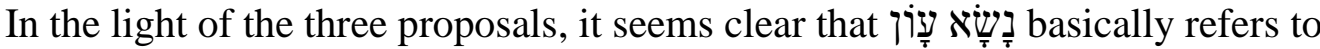
the punishment. It has two roles: sometimes it ensures that the punishment will be executed, and sometimes it refers to the implied punishment.

Schwartz also supported his claim that נָשָָׁא עָוֹץ refers to the bearing of the sin as a load by quoting Ezek 16:58 and 23:35. as the object of נִשָׁ makes no sense unless the punishment for these sins is implied. ${ }^{549}$ In reference to Ezek 16:58, Keil and Delitzsch noted that "the perfect נְשָׁאתִים indicates that the certainty of the punishment is just as great as if it had already commenced." 550 They held that the same idea of punishment is projected in 23:35. ${ }^{551}$ A recognized Ezekiel

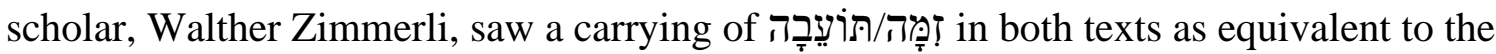
punishment for these sins. ${ }^{552}$ The claim that the punishment is implied in these texts is strengthened even more by the historical and literary context of Ezek 16:53-63 which presupposes the destruction of Jerusalem. ${ }^{553}$

${ }^{548}$ Schwartz, "The Bearing of Sin," $14 n 46$.

${ }^{549}$ Milgrom, Leviticus 17-22, 1490.

${ }^{550}$ Carl Friedrich Keil and Franz Delitzsch, Biblical Commentary on the Prophecies of Ezekiel, BCOT 23 (Grand Rapids, MI: Eerdmans, 1952), 1:230.

${ }^{551}$ Keil and Delitzsch, Biblical Commentary on the Prophecies of Ezekiel, 1:332.

${ }^{552}$ Zimmerli, Ezekiel 1, 1:352, 491.

${ }^{553}$ William H. Brownlee, Ezekiel 1-19, WBC 28 (Waco, TX: Thomas Nelson, 1998), 244; Leslie C. Allen, Ezekiel 20-48, WBC 29 (Waco, TX: Thomas Nelson, 1998), 50; Moshe Greenberg, Ezekiel 1-20, AB 22 (Garden City: Doubleday, 1983), 294; Moshe Greenberg, Ezekiel 21-37, AB 22A (New York: Doubleday, 1997), 490. 


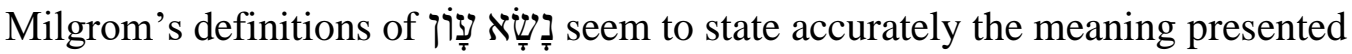

in Lev 20, but is overstated when studied in the context of the entire Pentateuch: ${ }^{554}$

$n \bar{a} s \bar{a}^{-}$' ' $\bar{a} w \hat{o} n$ is a nonexpiable, irremediable divine sentence. In all cases where the punishment is not stated, it is forthcoming-irrevocably. In the theological terms, perhaps one might say the punishment (usually mwt or kārèt, see above) expiates for the sin (explicitly, m. Yoma 8:8), but the punishment itself is unavoidable. ${ }^{555}$

Gane pointed to a critical weakness of Schwartz's proposal on the second use of

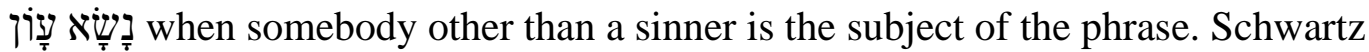

proposed that the liability disappears when transferred to someone else. ${ }^{556}$ Following

Claus Koch, Gane rightly pointed to the fact that there has to be a transfer of the

liability/punishment from the sinner to the other party who receives the sinner's

liability/punishment, making the sinner free of liability, forgiven. The Pentateuchal texts

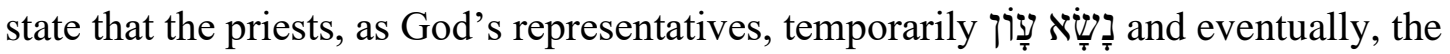

high priest confesses עָּוֹ, transferring it over to the scapegoat. ${ }^{557}$

In conclusion, even though Schwartz's proposal that the term

refers to the state of guilt, thus representing consequential bearing of $\sin$, is an eloquent attempt to suggest fresh meaning to the phrase. However, the weaknesses it contains make it indefensible so the traditional understanding of the phrase consisting of two meanings: "to forgive" and "punishment," still remains a better option. That the

\footnotetext{
${ }^{554}$ This meaning is challenged by texts like Exod 34:7; Num 14:18-19, 34.

${ }^{555}$ Milgrom, Leviticus 17-22, 1489-90.

${ }^{556}$ Schwartz, "The Bearing of Sin,” 10; Gane, Cult and Character, 103.

${ }^{557}$ Klaus Koch, "עון," TDOT 10:559; Gane, Cult and Character, 103-4.
} 
behavioral terms extend a consequential meaning so that the phrase can be translated as "punishment" or "God lifts his punishment" is well attested to in the Pentateuch/OT.

Schwartz's first point that some texts do not include punishment is not correct as was suggested above. Punishment is implied, explicitly or implicitly, in all the texts as it has been shown above.

Second, the texts of the Pentateuch prove that the terms for sin, especially עָוֹ, refer to all three elements a sinful situation causes: an act, guilt, and punishment. Thus, one, two, or even all three elements are coextensive in the texts. Schwartz himself admitted that in 17 out of 22 occurrences, the phrase assumes punishment, either

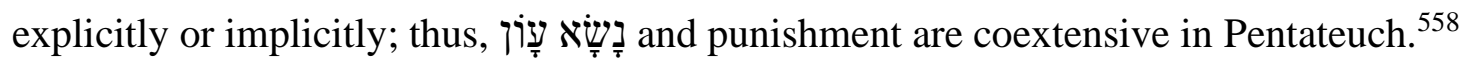

Third, punishment is included in all texts, but it is not capital in every text.

Fourth, the terms for sin combined with the verb נָָָׁ refer to the sin as an act, but also to punishment. They do that in the texts that speak of the sin of commission and omission. Schwartz himself realized that there are texts that deal with the sins of commission, and yet, are punished by capital punishment. Taking gị as a term for sin only and always does not make sense because punishment is an obvious meaning in a number of texts.

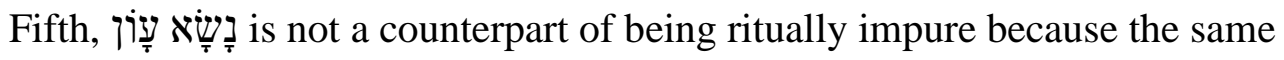
preposition, جִ̣, has different meanings in Pentateuchal, as well as in other OT texts.

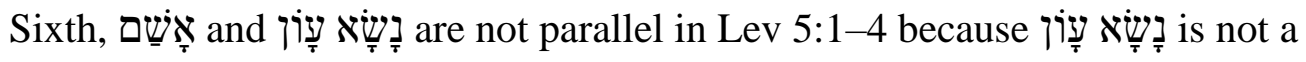

\footnotetext{
${ }^{558}$ Schwartz, "The Bearing of Sin,” 12-13.
} 


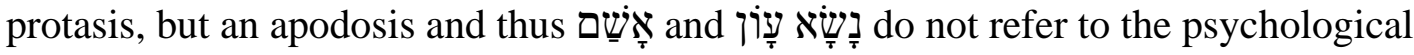
component of the process. Sins in vv. 1 and 4 and 2-3 are radically different.

The proximity of the phrase with punishment in the majority of cases in Priestly tradition (17/22 times is based on Schwartz's interpretation, but in reality, in all cases as

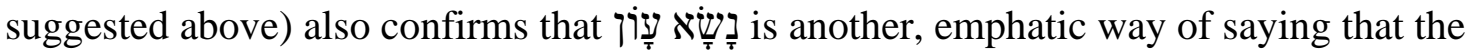
sinner is being punished. It has to be emphasized that the punishment is not necessarily capital. The reason why some texts contain both explicit punishment and matter of rhetorical effect.

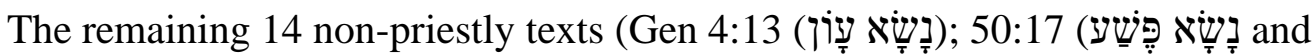

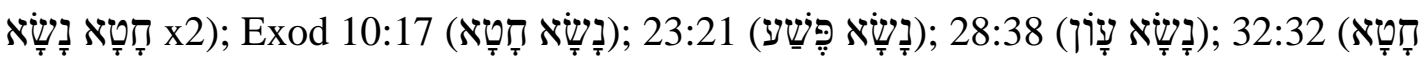

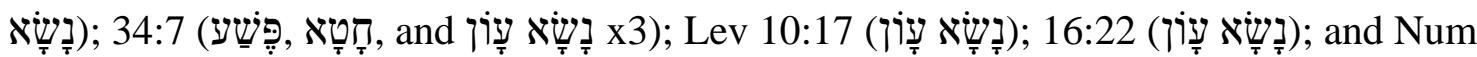

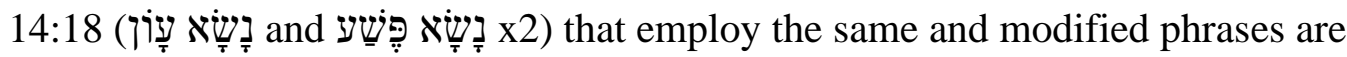
discussed in the first part of this subheading. Two meanings of the phrase that are employed in those texts are the same, "to punish" if the sinner is the subject of the phrase or "to forgive" in case other than the sinner is the subject of it.

\section{Insights from Olaffson's Work on on כָשָָׁא עָוֹן}

These aspects of the verb נָָָׁׁ that went unnoticed by the previous lexical listings prior to Olaffson's research are fully recognized in the lexicons published subsequent to Olaffson's dissertation defense in 1993. In particular, DCH, in addition to recognizing the main points Olaffson discovered, also clearly lists that "to suffer punishment for," or "to 
forgive," "to pardon,"559 "to be forgiven of"

HALOT and NIDOTTE listed both of these meanings as a semantic domains of the verb נ. ${ }^{561}$ In addition, all these lexicons provide ANE background for the meanings they suggested.

I am referring to Olaffson's work here to provide rationale for the claim that the meanings "to forgive" and "to suffer punishment" are included in the semantic domains of the verb נָָָּ domains of seems to be the most complete way to find out the meaning of the word/verb within the biblical literature. Examining the distribution of that

All the morphological, syntactical, and contextual evidence seems to point to a single, very flexible and neutral root which is fairly evenly distributed throughout of all the OT, without any significant difference noted between individual books and sections. ... No noticeable development was detected in the OT writings relating to time, authorship, or sources. ${ }^{562}$

The diversity of basic groups of passages, cultic and non-cultic. As it is used in the rest of the OT, the Pentateuch also uses נִָָֹ in a literal (45 times or 27.2\%) and metaphorical (124 times or

${ }^{559}$ DCH 5, s.v. "נשיא."

${ }^{560}$ DCH 5, s.v. "נשיא."

${ }^{561}$ HALOT, s.v. "נשטא", Victor Hamilton, "נש:א," NIDOTTE 3:161-65.

${ }^{562}$ Olaffson, "The Use of $n s s^{\prime}$ in the Pentateuch," 121. For details on the distribution of נָָ Olaffson, "The Use of $n s '$ in the Pentateuch," 79-120. 
$72.8 \%$ ) sense. These two shades of meaning, along with the others, are not discernable by a characteristic pattern, but are rather solely dependent on the context. ${ }^{563}$

Olaffson delineated 5 categories of נְִָָ uses in the Pentateuch. The two most common aspects of expressions indicating (3) utilization of tools or parts of the human body and (4) interpersonal relations are quite frequent. Finally, there is (5) dealing with sin and wrongdoings. ${ }^{564}$ The last one is of special interest to this study, along with the 4th one since it occasionally represents the context for the 5 th one.

When which depend on who the subject of נָשָׁ was. The subject may either be (1) the sinner himself/herself or (2) someone else who bears the sinner's $\sin { }^{565}$ In regard to the fact that the context suggests different meanings depending on who the subject of the phrase was, Knierim asked a valid question:

Liegen hier zwei verschiedene Vorgänge zugrunde, so dass die Konformität der Bezeichnung rein zufallig und darum unsere herkommlich verschiedene Ubersetzung der vorgange sachlich richting ist? Oder Druckt die Wendung beidemal vor allen den gleichen Grundvorgang der Wendung, sondern nur asu dem Zusammenhang erschlossen werde kann? ${ }^{566}$

${ }^{563}$ Olaffson, "The Use of $n s s^{\prime}$ in the Pentateuch," 120-21.

${ }^{564}$ Olaffson, "The Use of $n s s^{\prime}$ in the Pentateuch," 123.

${ }^{565}$ Olaffson, "The Use of $n s ́$ in the Pentateuch," 169.

${ }^{566}$ Are there two different processes underlying this so that the conformity of the designation is purely coincidental and therefore, our traditionally different translation of the process is objective? Or does the phrase in both cases equalize, above all, the same basic process of the phrase, but can only be deduced from the context? Personal translation. 
Sinner Is the Subject of נָָשָׁא עָּוֹן

There are 19 texts in which the sinner נָָָּ his her her own sin. They demonstrate that the sinner who commits sin/wrongdoing either knowingly or inadvertently has to bear it (see Table 10).

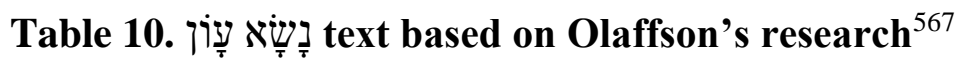

\begin{tabular}{|c|c|c|c|c|c|}
\hline \multicolumn{6}{|c|}{ נֵשָׁא עָוֹן with own wrongdoings } \\
\hline $\begin{array}{l}\text { 1. Wrongdoing } \\
\text { Sin General }\end{array}$ & $\begin{array}{r}\text { 2. Cultic } \\
\text { Eating }\end{array}$ & $\begin{array}{l}\text { 3. Cultic } \\
\text { Clothing }\end{array}$ & $\begin{array}{l}\text { 4. Sexual } \\
\text { Relations }\end{array}$ & $\begin{array}{l}\text { 5. Attitudes and } \\
\text { Actions } \\
\text { Towards God } \\
\text { and Holy } \\
\text { Things }\end{array}$ & $\begin{array}{l}\text { 6. Attitudes } \\
\text { and } \\
\text { Actions } \\
\text { Towards } \\
\text { Others }\end{array}$ \\
\hline $\begin{array}{l}\text { 1. Lev } 5: 1 \\
\text { "Now if a person } \\
\text { sins after he } \\
\text { hears a public } \\
\text { adjuration to } \\
\text { testify when he is } \\
\text { a witness, } \\
\text { whether he has } \\
\text { seen or otherwise } \\
\text { known, if he } \\
\text { does not tell it, } \\
\text { then he will bear } \\
\text { his guilt." } \\
\text { 2. Lev } 5: 17 \\
\text { "Now if a person } \\
\text { sins and does } \\
\text { any of the things } \\
\text { which the LORD } \\
\text { has commanded } \\
\text { not to be done, } \\
\text { though he was } \\
\text { unaware, still he } \\
\text { is guilty and } \\
\text { shall bear his } \\
\text { punishment." }\end{array}$ & $\begin{array}{l}\text { 1. Lev 7:18 } \\
\text { 2. Lev 19:8 } \\
\text { 3. Lev 22:16 } \\
\text { 4. Lev 22:9 } \\
\text { 5. Num 18:32 } \\
\text { 6. Lev 17:16 }\end{array}$ & 1. Exod 28:43 & $\begin{array}{l}\text { 1. Lev 20:17 } \\
\text { 2. Lev 20:19 } \\
\text { 3. Lev 20:20 } \\
\text { 4. Num 5:31 }\end{array}$ & $\begin{array}{l}\text { 1. Lev 24:15 } \\
\text { 2. Num 14:34 } \\
\text { 3. Num 18:22 } \\
\text { 4. Num 9:13 }\end{array}$ & $\begin{array}{l}\text { 1. Lev 19:17 } \\
\text { 2. Gen 4:13 }\end{array}$ \\
\hline
\end{tabular}

${ }^{567}$ Olaffson, "The Use of $n s s^{\prime}$ in the Pentateuch," 176. 
The ultimate consequence of such bearing is death. ${ }^{568}$ Olaffson's research showed that the difference between the deed and its consequences is not clear, thus confirming that the findings of the previous scholars on the topic such as Knierim and others ${ }^{569}$ seem

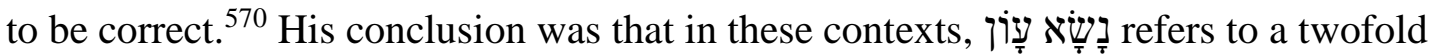
picture which includes that the one who commits sin acted against God and as a consequence, has to bear the effects of his or her actions. This bearing involves "Eingeständnis eigener Schuld und Einsicht in die Strafe-acknowledgement of one's guilt and insight into punishment." ${ }^{, 571}$ The phrase indicates (1) the sinner's responsibility for his or her sin and (2) the impending punishment that the sin assumes. In 3 out of 19 contexts, the punishment is not capital, even though it might become that (Lev 5:1, 17; 19:17), while in 16 out 19 contexts, the punishment is capital whether explicitly stated (11 times) or implicitly indicated or based on intertextuality (5 times). ${ }^{572}$ " $n \bar{a} s \bar{s}^{\mathrm{a}}$ 'âwon, can state the consequences for a number of different wrongdoings. When it does, it often takes the place of a specific punishment. That is, the expression can be used to mean that a person will be punished without specifying the exact nature of the punishment."573

${ }^{568}$ Olaffson, "The Use of $n s s^{\prime}$ in the Pentateuch,” 173.

${ }^{569}$ See page $144-146$ of the present study.

${ }^{570}$ Olaffson, "The Use of $n s s^{\prime}$ in the Pentateuch," 174.

${ }^{571}$ Freedman, Willoughby, and Fabry, "נשטא," TWAT, 5:633.

${ }^{572}$ For a detailed table that reflect this statistic, see Olaffson, "The Use of $n s '$ in the Pentateuch," 176.

\footnotetext{
${ }^{573}$ Wells, The Law of Testimony, 161.
} 


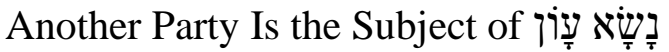

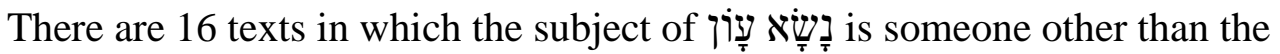
sinner. In 11 of them, a human being is subject of the verb, whereas God was the subject in 4 of them and in 1 of them, an animal is the subject. ${ }^{574}$ Table 11 contains all the texts.

The texts will be commented on as grouped in Table 11. Thus, the texts in which the subject of an animal is the subject of the phrase, and finally, the texts wherein God or divine beings are the subject.

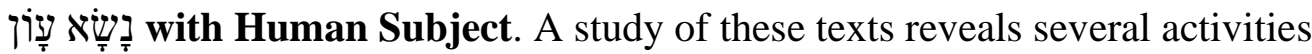

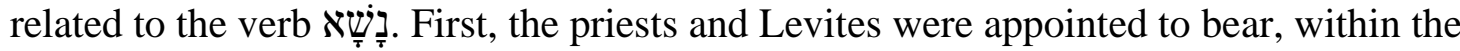
confines of the sanctuary, the wrongdoings of the people and priesthood against the

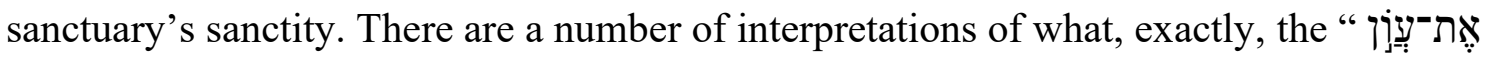

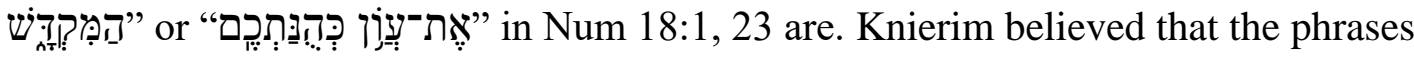
point to every conscious or unconscious act done by the people against the sanctuary or the priesthood. ${ }^{575}$ This means that if a non-Levite tried to enter the sanctuary, divine anger would break out against both the Levites and non-Levites who attempted to enter the sanctuary, violating its sanctity. God would hold the priests responsible for preventing

\footnotetext{
${ }^{574}$ Olaffson started off by saying that there are eighteen of these passages, but in reality, there are sixteen. Two of them have the phrase used twice in them, Gen 50:17 and Num 18:1. Olaffson, "The Use of $n s^{\prime}$ in the Pentateuch," 179.

${ }^{575}$ Knierim, Die Hauptbegriffe für Sünde im Alten Testament, 242. Philip J. Budd thought that it referred to "the penalty for all ritual errors," which would mean that the priests were fully responsible for every aspect of priestly ministry. Budd, Numbers, 205.
} 
Table 11. Someone else but the sinner is the subject of

\begin{tabular}{|c|c|c|c|}
\hline \multicolumn{4}{|c|}{ Someone Else Other Than the Sinner Bears Sin } \\
\hline \multicolumn{4}{|c|}{ Human Being } \\
\hline $\begin{array}{l}\text { General Functions of the } \\
\text { Priests }\end{array}$ & Transport by Eating & Canceled Vow & General Wrongdoings \\
\hline 1. Num $18: 1 \mathrm{x} 2$ & 1. Lev 10:17 & 1. Num 30:15 & 1. Gen 50:17 x2 \\
\hline $\begin{array}{l}\text { So, the LORD said to } \\
\text { Aaron, "You and your sons } \\
\text { and your father's household } \\
\text { with you shall bear the guilt } \\
\text { in connection with the } \\
\text { sanctuary, and you and your } \\
\text { sons with you shall bear the } \\
\text { guilt in connection with } \\
\text { your priesthood." } \\
\text { 2. Num 18.23 }\end{array}$ & $\begin{array}{l}\text { Why did you not eat } \\
\text { the sin offering at } \\
\text { the holy place? For } \\
\text { it is most holy, and } \\
\text { He gave it to you to } \\
\text { bear away the guilt } \\
\text { of the congregation, } \\
\text { to make atonement } \\
\text { for them before the } \\
\text { LORD. }\end{array}$ & $\begin{array}{l}\text { But if he indeed } \\
\text { annuls them after } \\
\text { he has heard them, } \\
\text { then he shall bear } \\
\text { her guilt." }\end{array}$ & $\begin{array}{l}\text { Thus, you shall say to } \\
\text { Joseph, "Please forgive, I } \\
\text { beg you, the transgression } \\
\text { of your brothers and their } \\
\text { sin, for they did you } \\
\text { wrong. And now, please } \\
\text { forgive the transgression of } \\
\text { the servants of the God of } \\
\text { your father." And Joseph } \\
\text { wept when they spoke to } \\
\text { him. }\end{array}$ \\
\hline $\begin{array}{l}\text { Only the Levites shall } \\
\text { perform the service of the } \\
\text { tent of meeting, and they } \\
\text { shall bear their iniquity; it } \\
\text { shall be a perpetual statute } \\
\text { throughout your } \\
\text { generations, and among the } \\
\text { sons of Israel they shall } \\
\text { have no inheritance. }\end{array}$ & & & $\begin{array}{l}\text { 2. Exod 10:17 } \\
\text { Now therefore, please } \\
\text { forgive my sin only this } \\
\text { once, and make } \\
\text { supplication to the LORD } \\
\text { your God, that He would } \\
\text { only remove this death } \\
\text { from me. }\end{array}$ \\
\hline $\begin{array}{l}\text { 3. Exod 28:12 } \\
\text { You shall put the two stones } \\
\text { on the shoulder pieces of the } \\
\text { ephod, as stones of } \\
\text { memorial for the sons of } \\
\text { Israel, and Aaron shall bear } \\
\text { their names before the } \\
\text { LORD on his two shoulders } \\
\text { for a memorial. }\end{array}$ & & & $\begin{array}{l}\text { 3. Num } 14: 33 \\
\text { Your sons shall be } \\
\text { shepherds for forty years in } \\
\text { the wilderness, and they } \\
\text { will suffer for your } \\
\text { unfaithfulness, until your } \\
\text { corpses lie in the } \\
\text { wilderness. }\end{array}$ \\
\hline
\end{tabular}

${ }^{576}$ Olaffson, "The Use of $n s s^{\prime}$ in the Pentateuch," $180-82$. 
Table 11—Continued.

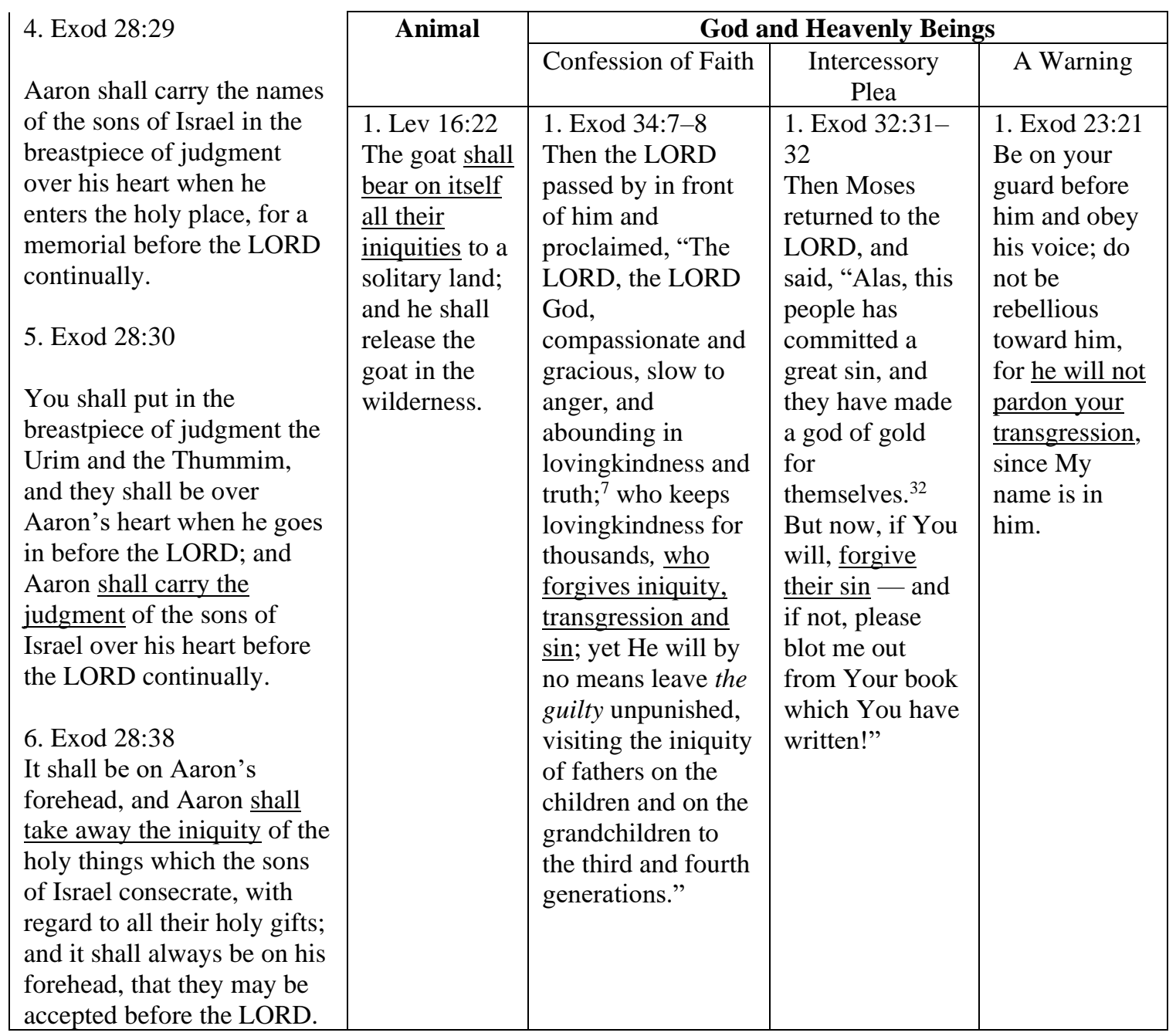

an attempt of a non-priest or Levite to encroach on a priestly prerogative. ${ }^{577}$ In the context of the rebellion in Num 17, the regulations in Num 18:1, 23 are the assurance to the rest of the people that they would be released from the consequences for the violation of the sanctuary's sanctity. The culprit would be punished, but the rest of the people would be released from the punishment. Keil and Delitzsch emphasized the nuance of

${ }^{577}$ Gane, Leviticus, Numbers, 652; Milgrom, Numbers, 146, 155, 423-24. 
this interpretation, that the Levites and priests were to take upon themselves and remove the guilt brought upon the sanctuary by the sins of the people and their holy gifts (Exod 28:38), "contaminated" by the giver's sinfulness. ${ }^{578}$

The next group of texts from Exod 28 that discuss the various parts of the priestly garments and their function in the sanctuary services seems to support this point. There is in v. 12 a description of two stones engraved with the names of the sons of Israel that were fastened to Aaron's shoulders. Verse 29 mentions the breastplate and the stones, but this time, each tribe had its name engraved on a stone. The high priest would "bear their names" on his shoulders and heart as he entered God's presence as their representative ${ }^{579}$ and substitute. ${ }^{580}$

The entire chapter of Exod 28 in general, and especially v. 30, which talks about the Urim and Thummim in the breastplate and v. 38 that speaks about the golden plate on Aaron's forehead, point to the fact that the carrying process is related to the people's wrongdoings. The function of the former one is for Aaron "to bear the judgments" of the people over his heart, and of the latter, that he may "bear their iniquity" before the Lord.

In light of the inseparable connection between sin and its punishment in Ancient Israel, these two phrases are almost synonymous. Judgment related to the Urim and Thummim is the result of the people's wrongdoings, whereas the iniquities associated with the golden plate caused that judgment. By bearing these articles, Aaron identified

${ }^{578}$ Carl Friedrich Keil and Franz Delitzsch, The Pentateuch, BCOT (Grand Rapids, MI: Eerdmans, 1952), 2:315-16.

${ }^{579}$ Keil and Delitzsch, The Pentateuch, 2:195; Milgrom, Leviticus 1-16, 54; Douglas K. Stuart, Exodus, NAC 2 (Nashville: Broadman \& Holman, 2006), 609, 611.

${ }^{580}$ Olaffson, "The Use of $n s '$ in the Pentateuch," 185. 
himself with the people's wrongdoings as he entered God's presence on the people's behalf. He symbolically carried the people's wrongdoings on his body before the Lord. These articles signified the mediating aspect of the high priestly office, along with a substitutionary character..$^{581}$

Olaffson found confirmation for this interpretation of the articles from Exod 28 in Lev 10:17. That is, the priest was to eat the sin offering (Lev 6:19 [26]), but Eleazar and Ithamar failed to do that, and Moses rebuked them for not performing their priestly duties properly. Eating had a symbolic meaning of acceptance and/or relationship, and even identification with someone. ${ }^{52}$ Thus, when the priest ate the sacrifice, he symbolically made it part of himself, taking upon himself its function to נָָָָ of the people into the sanctuary to make atonement on behalf of the congregation. He became a substitute for the sinners and literally carried their wrongdoing in his body. ${ }^{583}$ Thus, עָ נָשָׁ seems to be a significant element of the it. $^{584}$

Numbers 30:15 is the only text in the Pentateuch that explicitly spells out the alternative of a person This law treats the sanctity of vows and seems to be indirectly related to the cult. The key

${ }^{581}$ Olaffson, "The Use of $n s s^{\prime}$ in the Pentateuch," 187-88.

${ }^{582}$ Johannes Pedersen, Israel: Its Life and Culture (Atlanta: Scholars Press, 1991), 2:334.

${ }^{583}$ Olaffson, "The Use of $n s s^{\prime}$ in the Pentateuch," 190; Gerhard Hasel, "Studies in Biblical Atonement-I: Continual Sacrifice, Defilement//Cleansing, and Sanctuary," in The Sanctuary and the Atonement: Theological and Historical Studies, ed. Frank B. Holbrook (Silver Spring, MD: Biblical Research Institute, 1989), 103-6.

${ }^{584}$ Kiuchi, Purification Offering, 98-99. 
standard portrayed in the law is that regardless of the gender of the one who makes the vow, it has to be honored (v. 2). The husband of a married woman can annul or confirm her vow (v. 13). In case he decides the former, he has to do it within a certain time limit, and the Lord would forgive (סָלָ) the wife (v. 12). If he did that outside of the time

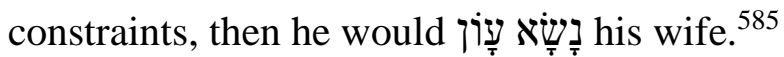

The similar point is found in the following 2 passages (Gen 50:17 x2, Exo 10:17) in the Pentateuch which are not related to the cult. All 3 times the wrongdoer/s plead with

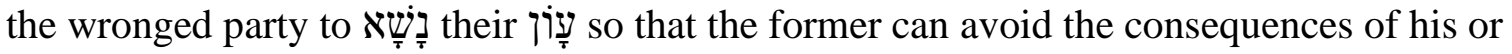
her actions. In Gen 50:17, Joseph's brothers asked him to bear the wrongdoing they had done to him from their relationship so that there would not be any obstacle or threat to their relationship. It was evident that neither the wrong nor its effects could be revoked,

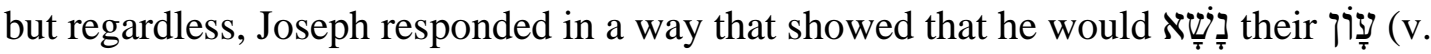
21). He comforted them, spoke kindly to them, and obliged himself to provide for their

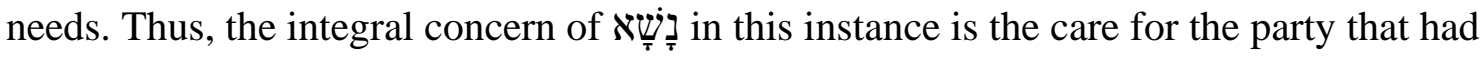
committed the wrong. ${ }^{586}$

The context of Exod 10:17 is the eighth plague due to Pharaoh's opposition to God's instructions. After his command in v. 16, Moses and Aaron were summoned before Pharaoh. He admitted his sin and pleaded for forgiveness. He asked Moses to כָשָָָׁא הַטְׁאת so that the consequences of his sin, the eighth plague, could be removed from

\footnotetext{
${ }^{585}$ Olaffson, "The Use of $n s^{\prime}$ in the Pentateuch," 191-92.

${ }^{586}$ Olaffson, "The Use of $n s '$ in the Pentateuch," 192-93.
} 
Egypt. Subsequently, Moses prayed to God and God removed (נְָָָׁא) the locusts. ${ }^{587}$

The inference from both of these texts is that the entire process of removing the effects of the wrongdoing is based entirely on the goodwill of the wronged party towards the wrongdoer. The final outcome is that the guilty party is freed from the consequences of his or her actions while the wronged party or the substitute takes on the burden of wrong.

Finally, no removal or carrying of the wrongs of others on their behalf is involved in the last passage, Num 14:33, but rather the emphasis is on the communal sharing of the consequences of wrong actions. The context of Num 14 is the reaction of the people of Israel on the report the spies brought about the Promised Land. The people grumbled against Moses (v. 2-3) and the whole congregation called for the stoning of Joshua and Caleb as they suggested that the people should follow God's leadership (v. 10). This attitude translates into rejection of a covenantal relationship (Deut 31:20) and rejection of God's leadership (v. 4). Even though they were forgiven (v. 20), they were not allowed to enter the Promised Land. ${ }^{588}$ They received a mitigated punishment.

In particular, out of the 5 groups ${ }^{589}$ involved in the incident, all of them were affected differently. In the sense of bearing the consequences of their actions, special emphasis was placed on 3 groups of people: (1) the 10 spies who caused grumbling;

${ }^{587}$ Olaffson, "The Use of $n s '$ in the Pentateuch," 193.

${ }^{588}$ Olaffson, "The Use of $n s s^{\prime}$ in the Pentateuch,” 195.

${ }^{589}$ The first group consists of the ten spies and the second, of the remaining two spies. Those who were twenty years of age of older when they left Egypt belong to the third, while those younger than twenty at the time of the Exodus belong to the fourth group. Finally, the fifth group consists of priest and Levites. Olaffson, "The Use of $n s$ ' in the Pentateuch," 196. 
(2) the grumbling crowd; (3) the faithful spies, Joshua and Caleb; (4) the descendants of the grumblers, and (5) the priests and Levites. The first two groups cut themselves from the covenant by their own free choice. The 10 spies, as the initiators of the grumbling, died shortly after the incident (14:36-37). The grumblers lost their inheritance suffering, just a less severe punishment. Even though not having negative effects in the incident, but still being a part of the corporate body of Israel, the third group also suffered consequences. That is, their entrance into the Promised Land was delayed; ultimately, they received fulfillment of the promise. They had to bear the consequences by remaining with the wrongdoers in the wilderness until the whole generation died. The younger generation did not become co-guilty with the older one, nor was the older generation released from their guilt, but rather, the younger generation became co-sharers of the consequences.

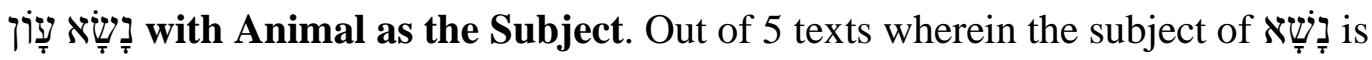
an animal, ${ }^{590}$ only 1 is directly related to the removal of sins in the sanctuary, Lev 16:22. The meaning and function of "the goat for Azazel" is hotly debated in scholarly research ${ }^{591}$ with no consensus in sight. Wenham seemed to propose inclusive and general evaluation on the question: "Whatever we understand by Azazel, there is a little doubt about the total meaning of the ceremony ... it all comes back to the same idea: that sin is exterminated from Israel." 592

\footnotetext{
${ }^{590}$ Gen 37:25, 45:23 x2; Num 23:24; Lev 16:22.

${ }^{591}$ Wright, The Disposal of Impurity, 21-30.

${ }^{592}$ Wenham, The Book of Leviticus, 235.
} 
The main concern of the current research is which sins are dealt with in this ritual. Does the goat for Azazel bear away unconfessed $\operatorname{sins}^{593}$ or the totality of the confessed sins of the Israelites? ${ }^{594}$ Rodríguez argued for the latter alternative, which seems to be supported by the straightforward reading of Lev $16 .{ }^{595}$ I addressed this question below in greater detail on page 376-79 of the present study.

Lev 16 explicitly states that the high priest confesses the accumulated sins from the sanctuary and potentially the ones that the priest himself bears over the head of the goat for Azazel, thus transferring them to it so that the goat could bear them away from the camp into the wilderness. In this way, the sins of the people were removed from the sanctuary (v. 20) and the camp. ${ }^{596}$ Olaffson further claimed three points regarding the Azazel goat ritual: (1) forgiveness is nowhere mentioned in connection with the Day of Atonement ritual, (2) the goat for Azazel was not killed, nor was its death a part of sanctuary symbolism, and (3) the goat was not a sacrifice prepared for Azazel. Its only role in the ritual was the one of a vehicle of transport for the sins of Israel from a populated area to a place they cannot threaten Israelites. ${ }^{597}$ Thus, Olaffson saw the עָוֹן נָשָׁא of the goat for Azazel as purely removal with no traces of the concept of forgiveness. This conclusion is heavily influenced by the interpretation of the ritual itself and will be discussed at multiple occasions of the present study.

\footnotetext{
${ }^{593}$ Milgrom, Leviticus 1-16, 1040.

${ }^{594}$ Rodríguez, "Substitution in the Hebrew Cultus," 117.

${ }^{595}$ Rodríguez, "Substitution in the Hebrew Cultus," 117-20.

${ }^{596}$ Olaffson, "The Use of $n s s^{\prime}$ in the Pentateuch,” 201.

${ }^{597}$ Olaffson, "The Use of $n s s^{\prime}$ in the Pentateuch," 201-2.
} 


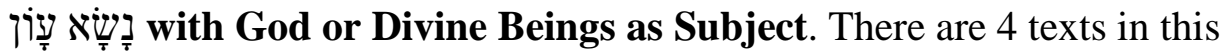

category. Two of them are liturgical declarations or possibly confessions of faith ${ }^{598}$ and are focused on God's character (Exod 34:6-7; Num 14:18). One is part of an intercessory prayer (Exod 32:31-32) and one is a form of a warning (Exod 23:31). ${ }^{599}$

Scholars usually refer to Exod 34:6-7 as a "Sinaitic theophany"600 which appears to be the basis for other liturgical confessions frequently used in the OT. ${ }^{601}$ This text is propositional in its nature. It is not concerned with God's acts, but rather, with his character. ${ }^{602}$ The key part of this passage is " above, scholars considered the three key terms for sin in the OT to convey universality or totality of sin and not just a specific nuance that each of these terms could refer to ${ }^{604}$ In

${ }^{598}$ Robert C. Dentan, “Literary Affinities of Exodus XXXIV 6f,” VT 13 (1963): 37.

${ }^{599}$ Olaffson, "The Use of $n s '$ in the Pentateuch," 202.

${ }^{600}$ Dawn Elizabeth Waring, “The Nature of Yahweh's Relationship with His People: A Literary Analysis of Exodus 32-34" (PhD diss., Fuller Theological Seminary, 1985), 169-88.

${ }^{601}$ At least eight passages show lexical connection with Exod 34:6-7: Num 14:18, Neh 9:17, Pss 86:5; 103:8; 145:8, Joel 2:13, Jonah 4:2, and Neh1:3. R. W. L. Moberly, At the Mountain of God: Story and Theology in Exodus 32-34, JSOTSupp 22 (Sheffield: JSOT Press, 1983), 128-31.

${ }^{602}$ Dentan, "Literary Affinities," 48; G. Ernest Wright, "The Divine Name and the Divine Nature," Perspective 12 (1971): 177; W. Ross Blackburn, The God Who Makes Himself Known: The Missionary Heart of the Book of Exodus (Downers Grove, IL: Apollos, 2012), 153.

${ }^{603}$ Exod 34:6-7 is one of the texts in the OT that poses the problem associated with the relationship between God's mercy and his righteousness. Blackburn, The God Who Makes Himself Known,

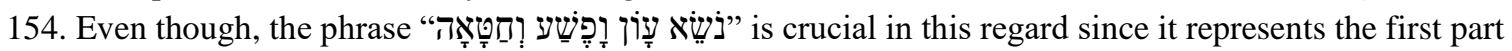
of the equation. The debate on that topic will not be included here because it goes beyond the scope of this study.

${ }^{604}$ Knierim, Die Hauptbegriffe für Sünde im Alten Testament, 233; Johannes Pedersen, Israel: Its Life and Culture (Atlanta: Scholars Press, 1991), 1:414. 
other words, this triad refers to all sins. The whole phrase literally refers "to the one who carries/removes sin."

The use of a participle of נָָָָָָ is noteworthy since it "as a verbal adjective the participle tends to describe a state of affairs rather than to present a bare event" or "a continuing state of affairs." ${ }^{606}$ Accordingly, God is presented as constantly bearing the sin of his people, subjecting himself to its consequences. As a result of this, the people continue to live and enjoy God's guidance and protection. ${ }^{607}$ On the other hand, God's bearing of people's sin does not include annulment of the consequence nor declaration of people's innocence. This is confirmed in the account of the spies. ${ }^{608}$ Although, Moses

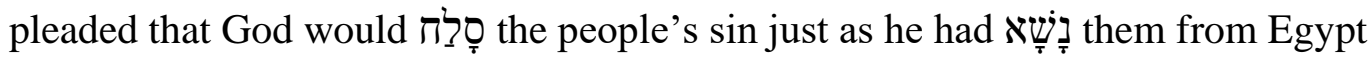
onward $^{609}$ and God did not forgive them, they had to suffer the consequences of their sin.

On the other hand, God's bearing of the people's sin involves the participation and support of the one who bears sin in the sinner's suffering. ${ }^{610}$ God's direct speech in v. 11 reveals the attitude of the people that caused them to reject him. It reads: "The LORD said to Moses, 'How long will this people spurn Me? And how long will they not believe in Me, despite all the signs which I have performed in their midst?"' All the piel uses of

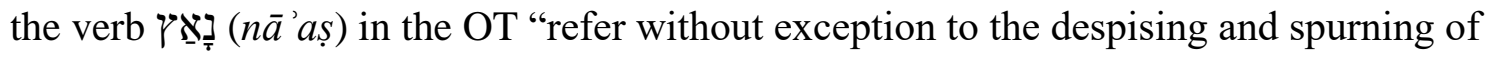

\footnotetext{
${ }^{605}$ Olaffson, "The Use of $n s s^{\prime}$ in the Pentateuch," 208.

${ }^{606}$ Waltke and O’Connor, An Introduction to Biblical Hebrew Syntax, 614, 626.

${ }^{607}$ Olaffson, "The Use of $n s s^{\prime}$ in the Pentateuch," 208-9.

${ }^{608}$ Sklar, Sin, Impurity, Sacrifice, Atonement, 84-85.

${ }^{609}$ Olaffson, "The Use of $n s s^{\prime}$ in the Pentateuch," 210.

${ }^{610}$ Olaffson, "The Use of $n s s^{\prime}$ in the Pentateuch," 209.
} 
God or something sacred to him. The contexts suggest that the action is regarded as tantamount to rejection of the whole covenant relationship." ${ }^{611}$

Thus, God's pronouncement of judgment over the people did not happen as a result of an arbitrary unleashing of his temper, but rather, it was an expression of an unavoidable outcome of the people's decision to reject him. Moses interceded not because injustice was done toward people by God or that God acted arbitrarily in his

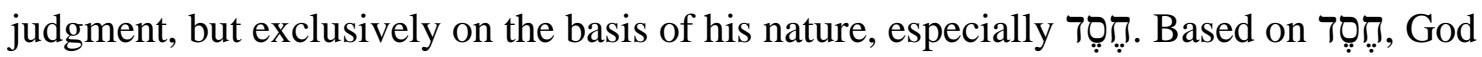
is able to preserve a relationship that he has already created. The passage does not indicate that forgetting or removing the consequences is a part of the concept of forgiveness. It seems to be a more relational experience in which the forgiving party removes the barrier that hinders the relationship with the forgiven party in order to restore or maintain it. Sakenfeld seemed to be on point when she commented on forgiveness in this context:

[Forgiveness] has to do with the preservation of the fundamental covenantal relationship rather than simply with eliminating some particular act of punishment (e. g. Jer $5: 1,7 ; 31: 34 ; 50: 20) \ldots$ Forgiveness is understood basically as preservation of the community, and this preservation need not be precluded or even cheapened by the punishment of the community while the relationship is being continued. ${ }^{612}$

The last text where God is the subject of the danger of rebelling against God's angel which God promised to send to guard them as they wandered in the desert. The identity of the angel mentioned in this narrative is closely associated to God himself. This narrative contains God's announcement that his

\footnotetext{
${ }^{611}$ Katharine Sakenfeld, The Meaning of Hesed in the Hebrew Bible: A New Inquiry (Missoula, MT: Scholars Press, 1978), 321.

${ }^{612}$ Sakenfeld, The Meaning of Hesed in the Hebrew Bible, 327.
} 
name would be in this angel (v. 21). Douglas Stuart noticed multiple references which provide the ground for the inference that a name can mean presence or identity (Exod 20:24; Num 6:27; Deut 18:19-20; 2 Sam 7:13; I Kgs 8:16; 2 Kgs 21:7; Jer 7:10-12.) In addition, the phrases "what he says," referring to the angel's words, and "all that I say," (v. 22) referring to God's words, are treated syntactically as synonymous. ${ }^{613}$ In the same venue, Gerhard von Rad suggested that the angel was "the personification of Yahweh's assistance to Israel" and it is frequently impossible to make a difference between God himself and the angel of the Lord. ${ }^{614}$ Rebellion against this angel is paralleled with the

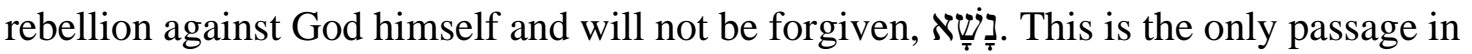

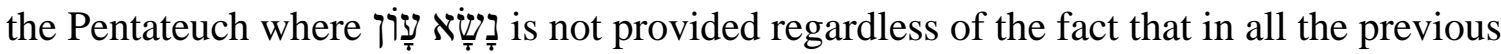

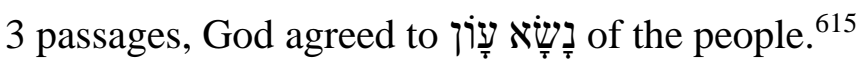

There is another passage in Deut 29:20 where סָלָח is used and forgiveness is not granted. Here a law regulates the punishment for an idolater who exhibits a rebellious attitude toward the God of Israel that leads to worshipping other gods. ${ }^{616}$ The reason why

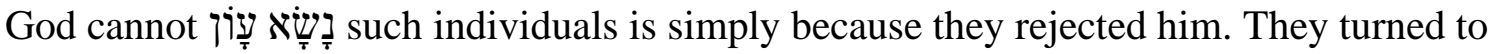

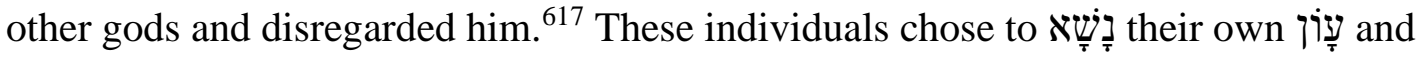

\footnotetext{
${ }^{613}$ Keil and Delitzsch, The Pentateuch, 2:152; Stuart, Exodus, 544-45; John H. Walton, Victor H. Matthews, and Mark W. Chavalas, "Exodus," in IVPBBCOT (Downers Grove, IL: InterVarsity Press, 2000), 103-4; Alan R. Cole, Exodus, TOTC 2 (Downers Grove, IL: IVP Academic, 2008), 190.

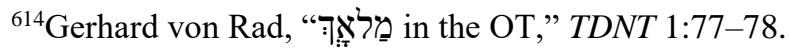

${ }^{615}$ Olaffson, "The Use of $n s ́$ in the Pentateuch," 213.

${ }^{616}$ Olaffson, "The Use of $n s s^{\prime}$ in the Pentateuch," 213-15.

${ }^{617}$ Olaffson, "The Use of $n s s^{\prime}$ in the Pentateuch," 215.
} 
die. ${ }^{618}$ Thus, open, conscious, and intentional rebellion also belongs to the group of sins that are punishable by various sorts of capital punishment for which forgiveness is not available.

Olaffson's research on the meaning of is the semantic domain of the phrase. He did not see the forgiveness element in Lev 16:22, but as it was pointed out at the beginning of the previous subheading, this ritual activity sealed the forgiveness process that had begun in the sinner's private and daily sacrifices.

It is noteworthy to mention that neither Schwartz nor Olaffson emphasized any difference if the נָָָָׁׁ was used with different terms for sin, but they both took these to refer to be sin in general. ${ }^{619}$

\section{Conclusion on the Study of}

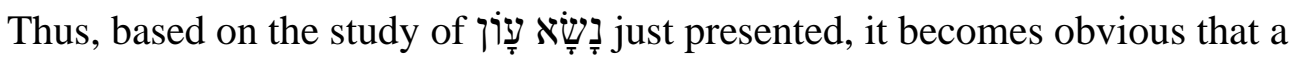
human being, animal/s, or God can be the subject of the verb נָָָּ when it is associated with sins of others. The key principle that proceeds from this study is that whoever commits sin/does not live in accordance with God's revealed standards is guilty and must bear, נָּשָׁא consequences for it, which includes punishment. Ultimately, that person suffers death. The punishment is fixed in most cases where sinners

However, because God is presented as a loving God in the OT, some incidents

\footnotetext{
${ }^{618}$ Olaffson, "The Use of $n s s^{\prime}$ in the Pentateuch," 216.

${ }^{619}$ Olaffson, “The Use of $n s s^{\prime}$ in the Pentateuch,” 173, 179-80.
} 
that involve sin are repairable. Thus, priests and Levites are appointed and are able to נָשָָׁא עָוֹוֹ of the people, thus releasing them from the consequences that would result in their death. When a priest officiated a sin offering on behalf of someone else, he ate the meat of the offering, thus making it part of himself, whereas in other cases, he would function as a substitute for the people by wearing stones in his vestments along with the golden plate on his forehead. In this way, he carried the sins of the people and provided for their acceptance before God.

A unique ritual on the Day of Atonement included sending the goat for Azazel, into the wilderness, loaded with the forgiven sins of the people that were accumulated in the sanctuary. This activity on a yearly basis sealed the forgiveness process that began on a daily basis in the experience of the sinner.

A husband could provide forgiveness for the obligation of the vow made by dependents of his home by taking the responsibility of the vow on himself. The wronged

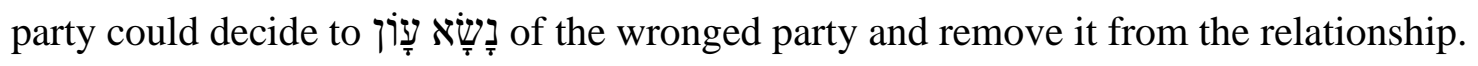

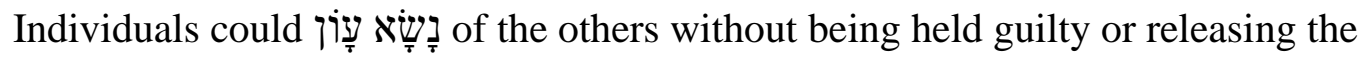
wronged party from his or her punishment. Finally, individuals could be instrumental in removing the consequence of the others' sin by taking them to God in prayer who is the ultimate sin bearer. Conclusively, these tests show that forgiveness is one of the semantic

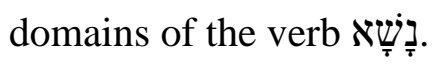

\section{The Root}

Based on the major lexicons and dictionaries, with slightly different outcomes, the root mith its derivatives is most frequently associated with the concept of sin in the 
OT. The term occurs $591,{ }^{620} 593,{ }^{621} 595,{ }^{622}$ or even $605^{623}$ times in the OT. This statistic makes זחט stand out from all other terms that refer to sin and indicate that it is the most important term for the concept of $\sin$ in the OT. ${ }^{624}$

The basic, literal meaning of the verb דָָ is “to miss (a mark)," but, apart from a few exceptions, the root is only used figuratively in religious contexts. The term marks particular acts such as crimes or errors, and for that reason, is considered a general or comprehensive term for $\sin { }^{625}$ It conveys a sin or error of a person against another person or a person against God. ${ }^{626}$ Quell has pointed out that this word is preferred to other words because "this root conveyed a clear, objective picture to the mind, with no reference to motive, or to the inner quality of the sinful behavior." 627

This characteristic of the term results from the fact that the verbal form is frequently utilized in various formulaic usages that refer to various sort of errors. Thus, the verb is found 30 times in the context of individual sins with the characteristic phrase, "I have sinned," in confessions after (sacral or profane) legal sentencing (Josh 7:20; 1

\footnotetext{
${ }^{620}$ Youngblood, “A New Look,” 202.

${ }^{621}$ Luc, "חט," NIDOTTE 2:87.

${ }^{622}$ Knierim, "חשט," TLOT 1:406; Cover, "Sin, Sinners," ABD 6:32.

${ }^{623}$ Accordance Bible.

${ }^{624}$ Robinson, "Terminological Study," 119; Knierim, "“טח," TLOT 1:410; Porùbčan, Sin in the

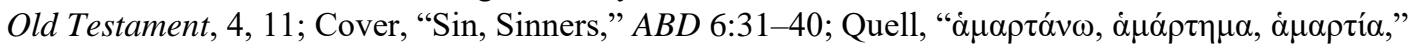

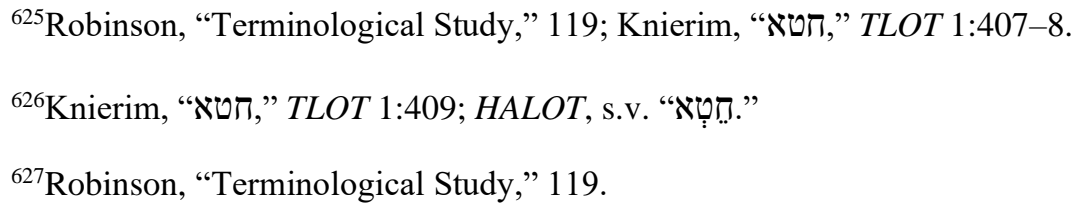
TDNT, 1:267. 
Sam 15:24; 2 Sam 19:21; 24:10; Ps 41:5; 51:6) or in the affirmation of innocence following an indictment (Judg 11:27; 1 Sam 24:12). It is also found 24 times in the context of communal confessions with the reoccurring phrase, "We have sinned," in rites of penance or prayers of repentance and the communal laments (Num 14:40; 21:7; Judg 10:10, 15; 1 Sam 7:6; 12:10; Jer 3:25; 8:14; 14:7, 20; Dan 9:5ff; Neh 1:6). It is also used in the cases of the indictment or verdict formulae within both profane and sacral procedures, as well as in dictions to disclose an error or justify the sentence (Exod 32:30; Num 23:23; Deut 9:16, 18; Jer 40:3; Hos 10:9). ${ }^{628}$

There are about 15 nominal forms of the root which refer to various settings and all sorts of errors including legal, cultic, and social ones (2 Sam 12:13; Jer 16:10; Hos 8:13; Gen 41:9; Lev 16:16; Mic 3:8; Ps 59:4; 32:5; Lam 4:22; Ps 51:4; Jer 36:3; Ps 85:3; Isa 44:22). Some significant usages are related to two other roots, מִּּת paired with the verb or punishment. In the case of forgiveness, the representative bears the (Exod 34:7 and Gen 50:17; Exod 32:32; 1 Sam 15:25), while in the case of punishment, it is the sinners themselves who bear it (Lev 19:17; 22:9; 20:20). ${ }^{630}$ When paired with the verb מוּת , the term refers to the sins that are punishable by death (Deut $21: 22 ; 22: 26 ; 24: 16 ; 2$ Kgs 14:6; Ezek 18:4, 20; Amos 9:10). ${ }^{631}$

\footnotetext{
${ }^{628}$ Knierim, "“ט," TLOT 1:408.

${ }^{629}$ Knierim, "“ט,," TLOT 1:408.

${ }^{630}$ Knierim, "חט," TLOT 1:408.

${ }^{631}$ Knierim, "“ט,," TLOT 1:409-10.
} 
Based on the variety of contexts and usages of the term, Knierim more specifically suggested that the term refers to the act of sinning per se as the following quotation shows: 'For the rejection of a behavior as 'error,' it is basically inconsequential whether a deed occurs consciously or unconsciously. In a great many passages, such a distinction plays no role whatsoever. Neither the motive nor the attitude is characterized, but the fact as such." $" 632$

Knierim also suggested that the error expressed by some specific commandment, but rather, affects the relationship of a man toward another man or God. He claimed this based on the fact that the term is used to express sins or crimes against the ban (1 Sam 14:33ff.), adultery (2 Sam 12:13) or another sexual offense (Lev 20:20), theft (Gen 31:36), crimes against innocent blood (2 Kgs 21:17), against Yahweh's anointed (1 Sam 24:12), idolatry (Deut 12:29f.), social misdeeds (Mic 3:8; 6:6-8, etc.). The term was frequently used in so-called profane-legal spheres as in

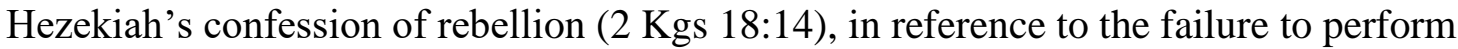
professional duties by Pharaoh's baker and butler (Gen 40:1), and other instances (Gen 42:22; 43:9). Knierim thus concluded: "Beside the known impossibility of strictly distinguishing between the profane and the sacral realms, these usages of the term indicate that the discussion of "sin" applies to all areas of life and was in no way limited only to the religious sector." 633

Based on the meanings appropriate for certain texts in the OT where חָָ was

\footnotetext{
${ }^{632}$ Knierim, "הט," TLOT 1:409.

${ }^{633}$ Knierim, "חט," TLOT 1:409.
} 
translated with English "sin" or in some legal contexts with the English words "crime, negligence," Gnana Robinson also noted that the term "indicated both intentional and unintentional sins.. ${ }^{934}$ Along the same lines, while observing that the term refers to unwitting sin in some instances, Ryder noted a frequent use of the term to convey both intentional and unintentional sins, as the following quotation shows: "While the word is overwhelmingly used of conscious and voluntary sins, there are a few instances in the ritual code where it seems to refer to 'unwitting sin,' and is rendered 'sin-offering' (e.g. in Lev 4:5). ${ }^{9635}$ Based on the entire OT, Ryder also noted the following regarding the moral versus rare, literal uses of חָז: “The hundreds of examples of the word's moral use require that the wicked man 'misses the right mark because he chooses to aim at a wrong one', - that is, there is no question of an innocent mistake or of the merely negative idea of 'failure'." ${ }^{636}$ Martens also noted that this term denotes both intentional and unintentional sins. ${ }^{637}$ Milgrom did the same thing. ${ }^{638}$

Thus, based on the variety of uses of this term in the OT, Rolf Knierim suggested the following overall meaning of the root חט in the OT: "The theological character of the understanding of 'error' is therefore not only grounded in the meaning of the word, formally and psychologically only minimally developed, but in terms of whether and how

${ }^{634}$ Robinson, “Terminological Study,” 120.

${ }^{635}$ Smith, The Bible Doctrine of Sin and of the Ways of God with Sinners, 17.

${ }^{636}$ Smith, The Bible Doctrine of Sin and of the Ways of God with Sinners, 17.

${ }^{637}$ Elmer A. Martens, "Sin, Guilt," in Dictionary of the Old Testament: Pentateuch, eds. T. Desmond Alexander and David W. Baker, IVPBD 1 (Downers Grove, IL: InterVarsity Press, 2003), 765.

${ }^{638}$ Milgrom, Leviticus 1-16, 229, 320, 1034. 
Yahweh views a misdeed. In this sense 'error' has the same weight as all other types of 'sin."',639

The Nature of דָָּ Sins in Leviticus and the Rest of the Pentateuch

As was set out at the beginning of this chapter, by applying a terminological/contextual/intertextual approach, I intend to address two questions in the study of Tָָּ sins in Leviticus and the rest of the Pentateuch in the present study. The first question is to find out whether second question is to explore whether

\section{Intentionality and Expiability Associated to חָ Sins}

Out of 86 instances of nouns derived from the root חט in the book of Leviticus the term refers 25 times to sin or error. Of those 25 uses, ${ }^{640}$ the term refers to both intentional $(4: 3,14,23,26,28 \times 2,35,5: 6 \times 2,10,13 ; 16: 30,34,19: 17,22 \times 2 ; 20: 20 ; 22: 9$, $24: 15 ; 26: 18,21,24,28)$ and unintentional $(4: 3,14,23,26,28 \times 2,35 ; 16: 30,34)$ sin or error. The rest of the 61 uses of the nominal derivatives of חָָָ refer to the sin offering $(4: 3,8,14,20,21,24,25,29 \times 2,32,33 \times 2,34 ; 5: 6,7,8,9 \times 2,11 \times 2,12 ; 6: 10[17]$, $18[25] \times 2,23[30] ; 7: 7,37 ; 8: 2,14 \times 2 ; 9: 2,3,7,8,10,15,22 ; 10: 16,17,19 \times 2 ; 12: 6,8$;

${ }^{639}$ Knierim, "“ט,," TLOT 1:410.

${ }^{640}$ The nominal חֶט wa was was used four times $(19: 17 ; 20: 20 ; 22: 9 ; 24: 15)$ and the remaining twenty-one times $(4: 3,14,23,26,28 \times 2,35 ; 5: 6 \times 2,10,13 ; 16: 30,34,22 \times 2 ; 26: 18,21,24,28)$. 
$14: 13 \times 2,19,22,31 ; 15: 15,30 ; 16: 3,5,6,9,11 \times 2,15,25,27 \times 2 ; 23: 19) .{ }^{641}$ The statistics on the nominal uses of דָָָ in Lev 16 reflect the understanding that two nominal uses of this term in verses 16,21 refer to the sin offering, rather than to sin itself. ${ }^{642}$

The study of verbal uses of the term exhibit the same result as the use of the nominal forms. Of 30 verbal forms in Leviticus, 25 refer to the activity of sinning; the verb speaks of intentional sinning 21 times $(4: 2,3 \times 2,14,22,23,27,28 \times 2,35,5: 1,5,6$, $7,10,11,13,[6: 2] 21,[6: 3] 22,[6: 4] 23 ; 19: 22)$, while it refers to unintentional sinning 14 times $(4: 2,3 \times 2,14,22,23,27,28 \times 2,35 ; 5: 15,16,17)$. In the remaining 5 usages $(6$ : [19] $26 ; 8: 15 ; 9: 15 ; 14: 49,52)$, the verb has different meanings. ${ }^{643}$

These statistics confirm that the root חָָּ was used in Leviticus to refer to both intentional and unintentional sins. This claim is strengthened later when applying the terminological/contextual/intertextual approach. That is, the sins expressed by חָָָ are both expiable and inexpiable. The intentionality of a given sin, but not exclusively its intentionality, impacts whether it is expiable or inexpiable. The first step of the terminological/contextual/intertextual approach established that the certain verbs that point to a capital punishment of the sinner confirm that $\sin$.

\footnotetext{
${ }^{641}$ Accordance Bible.

${ }^{642}$ The arguments for this decision are presented in the subheading "William H. Shea Proposal" of the current study.

${ }^{643}$ Accordance Bible.
} 


\section{Capital Punishment ${ }^{644}$ and}

The first set of contexts relates to capital punishment expressed through six

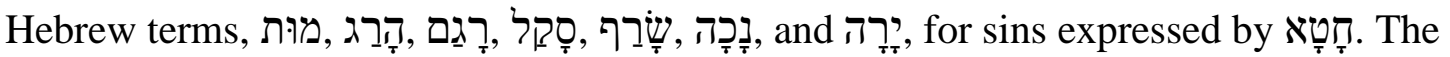
מדוֹת מטָא are found in 8 texts in the Pentateuch (Exod 10:17 [death refers to punishment that does not include biological death]); Lev 20:20; 22:9; Num 18:22, 32; 19:13 ([refers to human carcass]); 27:3; Deut 21:22; 22:26; 24:16). These statistics shows that the verb מוּת, when it refers to capital punishment, is related to the to capital punishment. A syntactical connection between מָּזָ מוּת is found in all these texts. The following presents the references (Table 12):

In the capital punishment contexts, דָָּ always refers to intentional sin. The fact that capital punishment was associated with חָָָ sin suggests that in these cases, such a sin was considered as an inexpiable one.

The Pentateuch uses the verb הָָרג to express punishment for various sins in eight texts (Gen 20:4: adultery, kidnapping; Exod 4:23; 13:15: refusal to obey God; Exod 22:24: affliction of a widow or orphan; Exod 32:27: idolatry; Lev 20:16: sodomy; Num 25:5: idolatry; Deut 13:9: idolatry). The syntactical or conceptual connection between the

\footnotetext{
${ }^{644}$ For a more comprehensive study on capital punishment and understanding the input from rabbinic sources, see Hyman E. Goldin, Hebrew Criminal Law and Procedure: Mishnah: Sanhedrin, Makkot (New York: Twayne, 1952), 18-37; Aryen Amihay, "Capital Punishment," OEBL 1:93-97; Trevor W. Thompson, "Punishment and Restitution," OEBL 2:433-46.
} 
מצוּת The term 12. The

\begin{tabular}{|c|c|c|c|c|c|c|}
\hline & Reference & Sin & Punishment & Expiable & Inexpiable & Intention \\
\hline 1 & Lev 20:20 & Illicit sex & $\begin{array}{c}\text { Death } \\
\text { Lev 20:20 }\end{array}$ & & $X$ & $\mathrm{x}$ \\
\hline 2 & Lev 22:9 & $\begin{array}{l}\text { Failure to guard } \\
\text { the sanctuary }\end{array}$ & $\begin{array}{c}\text { Death } \\
\text { Lev 22:9 }\end{array}$ & & $X$ & $\mathrm{X}$ \\
\hline 3 & Num $18: 22$ & $\begin{array}{l}\text { Touching the } \\
\text { sanctuary }\end{array}$ & $\begin{array}{c}\text { Death } \\
\text { Num 18:22 }\end{array}$ & & $\mathrm{x}$ & $\mathrm{x}$ \\
\hline 4 & Num $18: 32$ & $\begin{array}{l}\text { Profaning } \\
\text { offerings }\end{array}$ & $\begin{array}{c}\text { Death } \\
\text { Num 18:32 }\end{array}$ & & $\mathrm{x}$ & $\mathrm{X}$ \\
\hline 5 & Num 27:3 & unspecified & $\begin{array}{c}\text { Death } \\
\text { Num 27:32 }\end{array}$ & & $\mathrm{X}$ & $\mathrm{x}$ \\
\hline 6 & Deut 21:22 & unspecified & $\begin{array}{c}\text { Death } \\
\text { Deut 21:22 }\end{array}$ & & $\mathrm{x}$ & $\mathrm{x}$ \\
\hline 7 & Deut 22:26 & rape & $\begin{array}{c}\text { Death } \\
\text { Deut 22:26 }\end{array}$ & & $\mathrm{x}$ & $x$ \\
\hline 8 & Deut $24: 16$ & unspecified & $\begin{array}{c}\text { Death } \\
\text { Deut } 24: 16\end{array}$ & & $\mathrm{X}$ & $\mathrm{X}$ \\
\hline
\end{tabular}

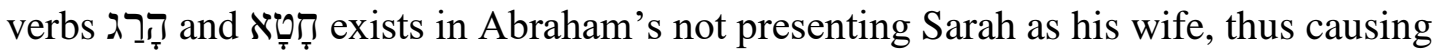
potential adultery or kidnapping (Gen 20:4) and in the Golden Calf incident (Exod $32: 27)$.

In the first event, God used the verb taking Abraham's wife Sarah for himself. The act could have resulted in adultery, as well as in kidnapping (Gen 20:6).

The connection between הָטָטא verbal and nominal forms of The verb is used in Exod 32:30, 31, 33 to express performing an idolatrous act while the 
noun is used in $32: 21,30 \times 2,31,32,34$ for the same cause. ${ }^{645}$

The verb רָגָ is used in Lev 24:14 to refer to the punishment of the sin of cursing

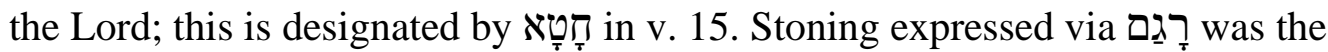
prescribed mode of capital punishment in Num 15:35-36 for breaking the Sabbath, but

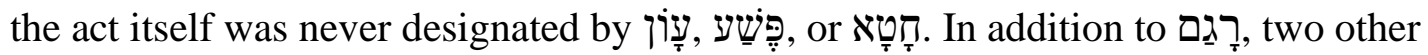
verbs were used to express punishment for this sin. מוּת was repeatedly used in Exod 31:14 and 35:2 to refer to the punishment for Sabbath breaking. Kārēt was also a mode of capital punishment related to the breaking of the Sabbath (Exod 31:14).

Stoning expressed with סָקל for sinning that is designated with iָ is re. That is, Exod 19:13 (refusal to obey God's instructions), Deut 13:10 (idolatry); 17:5 (idolatry), and 22:21, 24 (sexual promiscuity) all use סָק to express a mode of capital punishment for various sins. However, it is only Deut 22:21, 24 that portrays that the sin of sexual promiscuity could imply the

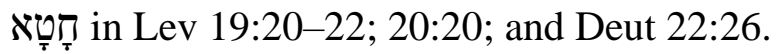

Burning $^{646}$ as a capital punishment is expressed through the verb שָָָׁרף. The narratives in Gen 38:24 and Lev 10:6 and laws in Lev 20:14; 21:9; and Deut 22:21 all

\footnotetext{
${ }^{645}$ Num 25:5 and Deut 13 use הָרָ to express capital punishment for idolatry, but idolatry is not specified as a חָּ $\sin$ in these two texts. An individual idolater was killed by a spear in Num 25:5, while Deut 13:10 and the parallel law for idolatry in Deut 17:5 mention stoning as a mode of capital punishment. The corporate idolatry act of the entire city is punished by sword: Deut 13:15. Idolatry is expressed by רָָָה and תוֹעָרָה

${ }^{646}$ Burning was a rare mode of capital punishment reserved for the most serious sexual crimes. John H. Walton, "Genesis," in Genesis, Exodus, Leviticus, Numbers, Deuteronomy, vol. 1 of ZIBBCOT, ed. John H. Walton, 5 vols. (Grand Rapids, MI: Zondervan, 2009), 127; Mathews, Genesis 11:27-50:26, $722-23$.
} 
state that burning was used to punish the sin of illicit fire for the altar in Lev 10:6, and illicit sexual acts in the remaining texts. The verb but Lev 10:6.

The verb נָכָָה is is syntactically connected to in in text, Lev 26:24, which is illuminating regarding the nature of דָָּ $\sin$. In the contexts involving capital punishment discussed in this subsection, the term Tָָּ refers to intentional sin, unwillingness to obey God. The imposition of capital punishment included in this text alludes that this sin is inexpiable and unforgivable. ${ }^{647}$ The verb ירָיה is never used to express punishment for the sin designated by חָָָ.

\section{Kārēt and}

The second group of contexts examines the connection between $k \bar{a} r \bar{e} t$ and

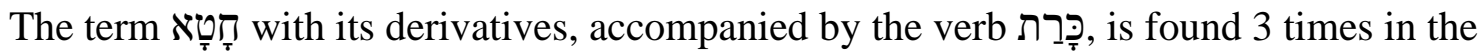
Pentateuch, namely in Num 9:13: neglect of the Passover; and 19:13, 20: not purifying $\operatorname{him} /$ herself. Of these texts, the syntactical connection between $k \bar{a} r \bar{e} t$ and the nominal of గ̦ exists only in Num 9:13 (see Table 13).

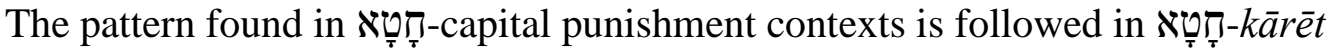
contexts. The term Tָּ refers to intentional sin. In addition, the nature of the punishment, $k \bar{a} r \bar{e} t$, suggests that this sin is an inexpiable one.

${ }^{647}$ Milgrom, Leviticus 23-27, 2309-15. 
Table 13. The term

\begin{tabular}{|c|c|c|c|c|c|c|}
\hline & Reference & Sin & Punishment & Expiable & Inexpiable & Intention \\
\hline 1 & Num 9:13 & $\begin{array}{l}\text { Avoiding } \\
\text { Passover }\end{array}$ & $\begin{array}{l}k \bar{a} r \bar{e} t \\
\text { Num 9:13 }\end{array}$ & & $\mathrm{x}$ & $\mathrm{x}$ \\
\hline 2 & Num 19:13 & $\mathrm{n} / \mathrm{a}$ & $\mathrm{n} / \mathrm{a}$ & & & \\
\hline 3 & Num 19:20 & $\mathrm{n} / \mathrm{a}$ & $\mathrm{n} / \mathrm{a}$ & & & \\
\hline
\end{tabular}

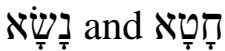

The third context provided insight into the connection between חָטָ and

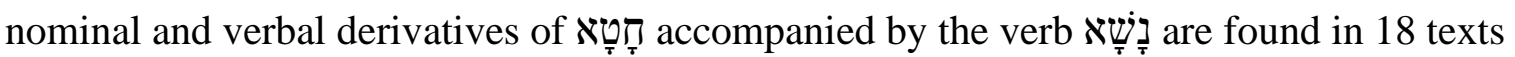
in the OT. The term is syntactically connected to the verb 1 in 11 texts. Table 14 displays all the occurrences.

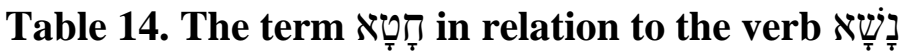

\begin{tabular}{|c|c|c|c|c|c|c|c|}
\hline & Reference & Sin & Punishment & Expiable & Inexpiable & Unintentional & Intention \\
\hline 1 & Gen 50:17 & Kidnapping & $\begin{array}{c}\text { Death } \\
\text { Deut } 24: 7\end{array}$ & forgive & $\mathrm{x}$ & & $\mathrm{X}$ \\
\hline 2 & Exod 10:17 & $\begin{array}{l}\text { Not obeying } \\
\text { God's word }\end{array}$ & $\begin{array}{c}\text { Death } \\
\text { Num } \\
\text { 15:30-31 }\end{array}$ & forgive & $\mathrm{x}$ & & $\mathrm{x}$ \\
\hline 3 & Exod 32:32 & Idolatry & $\begin{array}{c}\text { Death } \\
\text { Deut }\end{array}$ & forgive & $\mathrm{x}$ & & $\mathrm{x}$ \\
\hline 4 & Exod $34: 7$ & Unknown & $\mathrm{n} / \mathrm{a}$ & forgive $n / a$ & $\mathrm{n} / \mathrm{a}$ & $\mathrm{n} / \mathrm{a}$ & $\mathrm{n} / \mathrm{a}$ \\
\hline 5 & Lev 19:17 & Hatred & & punishment & & & $\mathrm{x}$ \\
\hline 6 & Lev 20:20 & Illicit sex & $\begin{array}{l}\text { Death; } \\
\text { childless }\end{array}$ & punishment & $\mathrm{x}$ & & $\mathrm{x}$ \\
\hline 7 & Lev 22:9 & $\begin{array}{c}\text { Charge over } \\
\text { sanctuary }\end{array}$ & & punishment & $\mathrm{x}$ & & $\mathrm{x}$ \\
\hline 8 & Lev $24: 15$ & Cursing God & Death & punishment & $\mathrm{x}$ & & $\mathrm{x}$ \\
\hline 9 & Num 9:13 & $\begin{array}{c}\text { Not } \\
\text { attending } \\
\text { Passover }\end{array}$ & כָּרַת & punishment & $\mathrm{x}$ & & $\mathrm{x}$ \\
\hline 10 & Num 18:22 & $\begin{array}{c}\text { Coming } \\
\text { close to the } \\
\text { tent }\end{array}$ & Death & punishment & $\mathrm{x}$ & & $\mathrm{x}$ \\
\hline 11 & Num 18:32 & $\begin{array}{l}\text { Profaning } \\
\text { holy gifts }\end{array}$ & Death & punishment & $\mathrm{x}$ & & $\mathrm{x}$ \\
\hline
\end{tabular}


Scholars have widely accepted that נָשָׁא הָטָּאת in Gen 50:17 to mean "to

forgive." ${ }^{648}$ Schwartz's proposal that the sin disappears if it is carried away by someone else other than the sinner is problematic in $\mathrm{P}$ since the trajectory of sin from the sinner to the sanctuary/priest is extensively elaborated in the cultic context. However, his proposal seems to fit the texts outside of P, but only if the phrase "forgive." Jacob was dead and Joseph was in the position to get his revenge and punish his brothers who had committed a horrific sin towards him. This context strongly suggests that 11:27-50:26 $)^{649}$ described the religion of the patriarchs in a very limited manner. ${ }^{650}$ Thus, the contrast of priestly detailed treatment of sin and lack of it in the patriarchal narratives makes the vanishing of sin, if forgiven, plausible. If not forgiven, sinners would still

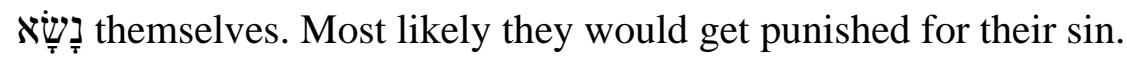

\footnotetext{
${ }^{648}$ Robert Alter, Genesis (New York: W.W. Norton, 1996), 305; Mathews, Genesis 11:27-50:26, 925-26; Claus Westermann, Genesis 37-50: A Commentary, trans. John J. Scullion (Minneapolis: Augsburg, 1986), 204; Kenneth O. Gangel and Stephen J. Bramer, Genesis, HOTC 1 (Nashville: Broadman \& Holman, 2002), 375; Wenham, Genesis 16-50, 490; Victor P. Hamilton, Genesis 18-50, NICOT 1B (Grand Rapids, MI: Eerdmans, 1980), 703; Nahum M. Sarna, Genesis = [Be-reshit]: The Traditional Hebrew Text with the New JPS Translation, JPSTC 1 (Philadelphia: Jewish Publication Society, 1989), 350; Keil and Delitzsch, The Pentateuch, 2:411-12.

${ }^{649}$ William Sanford LaSor, David Allan Hubbard, and Frederic William Bush, Old Testament Survey: The Message, Form, and Background of the Old Testament (Grand Rapids, MI: Eerdmans, 1982), 15-18, 32-43; Tremper Longman and Raymond B. Dillard, An Introduction to the Old Testament, 2nd ed. (Grand Rapids, MI: Zondervan, 2006), 53. For a different view on the division of the patriarchal narratives in Gen 11:27-50:26 and the further references, see Longman and Dillard, An Introduction to the Old Testament, 59-61; Wenham, The Book of Leviticus, 256-64; Wenham, Genesis 16-50, 167-70, 343-45. Gleason L. Archer, A Survey of Old Testament Introduction, Rev. and exp. ed. (Chicago: Moody Press, 2007), 155.

${ }^{650}$ They prayed (Gen 25:21) and built altars and offered sacrifices (Gen 12:7; 22:9; 35:1), but there is no special reference to the location of these rites, no official priesthood, nor established cult. The distinctiveness of their religion can be seen in their conception of God and close personal relationship with him. LaSor, Hubbard, and Bush, Old Testament Survey, 46.
} 
The 3 remaining texts state that God himself (Exod 10:17-18; 34:6-7) נָשָָׁא חָטָָ

of various human beings or his angel does not

There is no indication in these texts about what happen with the sins in case God bears them. Most likely, they vanish away as Schwartz proposed.

Texts 1-4 were all also commented above in the present study and were based on the analysis provided on these pages. I adopted the view that the phrase texts the subject of the sin is not the one who committed the sin, but rather, someone else is "to forgive."

The texts 5-11 were all commented above in the present study and based on the investigation proposed on these pages, I agree with the idea that the phrase in these texts refers to the explicit or implicit verb or noun "punish or punishment."

The sins that Tָָָ refers to in these texts, when they are syntactically connected to the verb

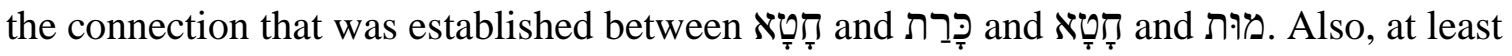
one of the sins listed in the Table 14 is an unintentional one; the rest are intentional ones. Thus,

אָָׁשָם

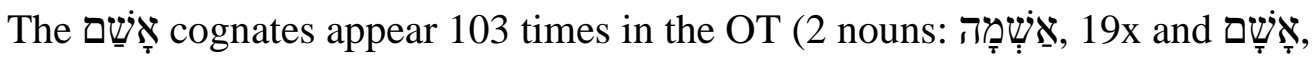
46x, the adjective

${ }^{651}{ }^{1}$ Leviticus 1-16, 243. 
times, of which the books of Leviticus and Numbers use

nine times. The concentration of the term meanings for these forms should be sought in these two books. The meaning of reparation offering is attached to two nominal derivatives. Twenty-nine of thirty-three occurrences of the nominal $\underset{\sim}{\underset{w}{W}}{ }^{652}$ refer to the offering as well as 2/4 occurrences of the

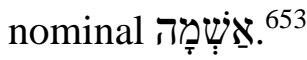

Of special interest for the present study is the verbal form of Wָ since it expresses the outcome the sinners' experience after committing a sin. ${ }^{654}$ The nominal form of the same root refers to the guilt sacrifice that remedies the wrong, the wrong itself, and the penalty for the wrong. Thus, both the nominal and verbal derivatives of Wִ represent a punishment for the wrong. ${ }^{655}$ However, the verbal form is analyzed here because it represents the sinners' initial condition or state after they have committed $\sin ;{ }^{656}$ the approach set out in this study examines whether the punishment is applied for both intentional and unintentional sins.

${ }^{652}$ Lev 5:6-7, 15-16, 18-19; 6:6, 17; 7:1-2, 5, 7, 37; 14:12-14, 17, 21, 24-25, 28; 19:21-22; Num $6: 12 ; 18: 9$. Different meanings are associated with the noun in the following texts: Gen 26:10: guilt; Num 5:7, 8x2: wrong. Scholars consider this nominal as a technical term for restitution/reparation offerings.

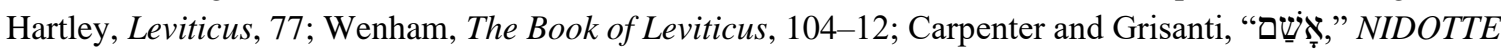
1:547. Based on the statistics presented where the noun refers to the offering, 29/33 occurrences, that claim seems to be justified.

${ }^{653}$ Lev 4:3, 5:24 [6:5]. The other two occurrences in Lev 5:26 [6:7] and 22:16 are used adjectively and mean "guilty."

\footnotetext{
${ }^{654}$ Sklar, Sin, Impurity, Sacrifice, Atonement, 24.

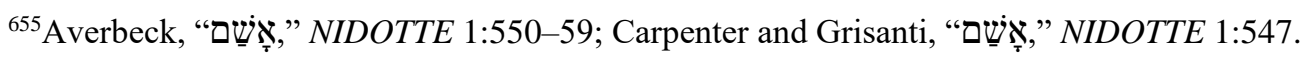

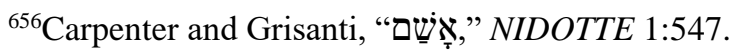


The verbal form of the term Wָ is used thirteen times in the Pentateuch, eleven times in Lev 4-5 (4:13, 22, 27; 5:2, 3, 4, 5, 17, 19x2, 23), and 2 in Num $5(5: 6,7)$. There are four proposals of what the verb means: (1) "to be/become guilty, to incur guilt, to be/to become liable for guilt," (2) "to feel guilt," (3) "to realize guilt," and (4) "to suffer guilt's consequences. ${ }^{.657}$ Arguments for each of these meanings are analyzed on pages 288-313 of the present study, but at this point, it is important to notice that the texts of the Pentateuch make a syntactical connection between the verb חָטָא in two passages, a set of pericopes in Lev 4-5 and Num 5. The verses with syntactical interaction between these two terms in Lev 4 are vv. 13-21, 22-26, 27-28; 5: 5:2, 3, 4, 5, 17, 19x2, 5:23 [6:4], and Num 5:6, 7 .

Since it is important to establish the nature of the sin for which one experiences Wִ all these pericopes need to be addressed. It is important to state that Lev 4 deals with both intentional and unintentional sins, as are the ones in the second and third pericopes in Lev 5 (vv. 14-16, 17-19), while the ones listed in the first and the last pericopes of Lev 5 (vv. 1-4, 20-26 [6:1-7]) are intentional. ${ }^{658}$

The unintentionality of the sins is indicated the fact that verbs that refer to the activity/action of sinning are adverbially modified by the nominal prepositional phrase

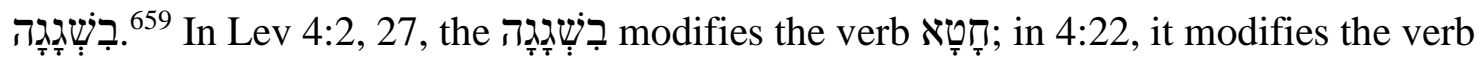

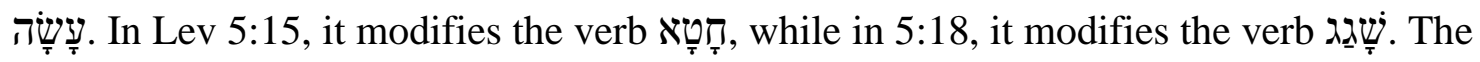

\footnotetext{
${ }^{657}$ Sklar, Sin, Impurity, Sacrifice, Atonement, 25.

${ }^{658}$ Wells, The Law of Testimony, 64.

${ }^{659}$ Sklar, Sin, Impurity, Sacrifice, Atonement, 24.
} 


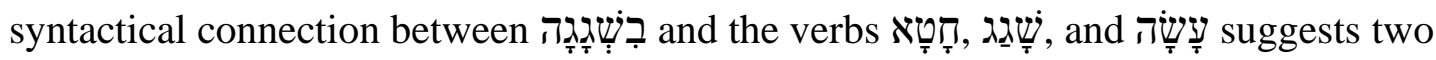

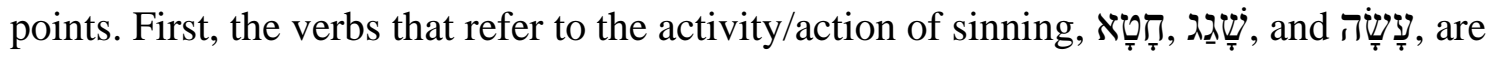
interchangeable. This claim is reinforced below as I comment on the pericopes of Lev 4-

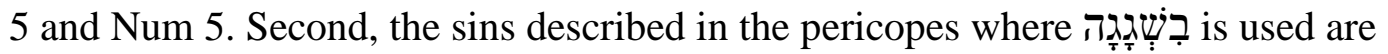
unintentional. The topic of intentionality and unintentionality is examined in greater detail on pages $271-313$ of the present study, but at this point it is sufficient to state that the sins in these pericopes are either intentional or unintentional.

Lev 4: The first pericope in ch. 4, vv. 3-12, is included here even though it does not contain the verbal form of שָָׁ because the nominal form of this term causes the same effect on the people. That is, a sin of the high priest brings verbal forms that refer to the activity/action of sinning in this pericope are חָָ in vv. 2, 3x2, and בִשְׁגָגָּה in v. 2. In v. 2, the verbal form of which is infinitival as is of $\sin$ in v. 3 .

There is a cluster of verbs in vv. 13-21 that express the activity of sinning, and a single noun, חָטָָאת, that refers to the act of sinning. In v. 13, the whole congregation experiences שָָָׁ However, in v. 14, the act of sinning expressed by the verb שָָָׁ in in v. 13 is labeled as

${ }^{660}$ Milgrom, Leviticus 1-16, 231; Hannah S. An, "The Delayed Recognition of Sin in the Sacred

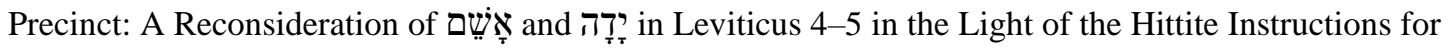
Priests and Temple Officials (CTH 264)" (PhD diss., Princeton University, 2014), 31. 


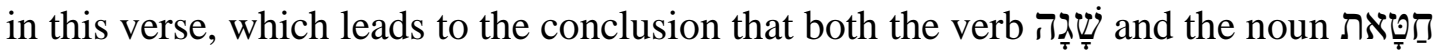
produce the to refer to the activity/action of sinning in this pericope because of which, the doer

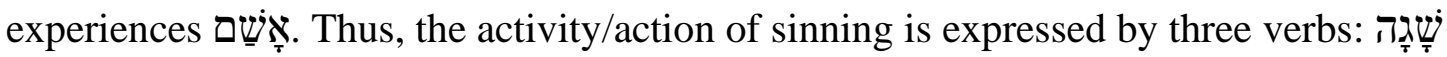

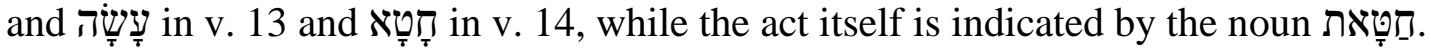

In the pericope of the leader in vv. 22-26 the verbal

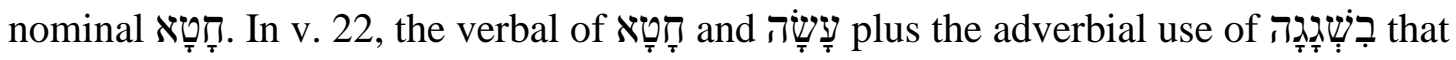

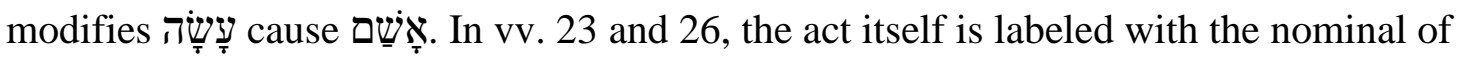
חָָּ Thus, the same cluster of terms that defines the activity of sinning (the verbal of

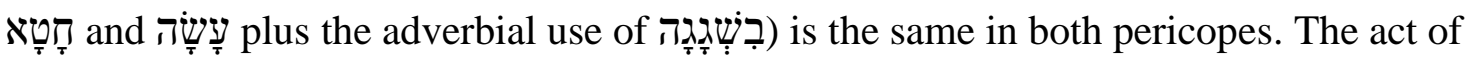
sinning is also defined with the nominal חָָּ in both pericopes.

The pericope of the commoner in vv. 27-31 shows that same pattern that was identified in the pericope that presents the sinning of the whole congregation (vv. 13-21) and the leader (vv. 22-26). That is, in v. 27, the text uses the verbal of modified by the double adverbials בִּשְָׁגרָה causes the doer to experience express the activity of sinning while the nominal of the same term is used to describe the act committed.

The pattern that emerges out of these four pericopes is that the activity/action of sinning is expressed by the three verbs: שָָָָָָָׁה

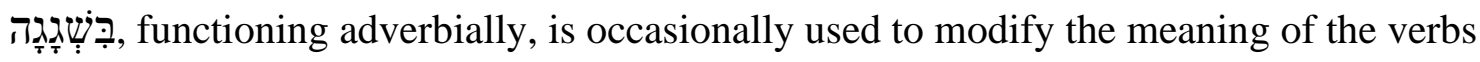




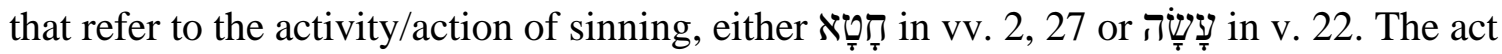
of the sin committed is always labeled with the nominal of Tָּ (vv. 14, 23, 26, 28x2, 35). The outcome of the activity/action that are expressed by these verbs and the verbal constructions cause the doer to experience wָ, mainly the verbal form of the term (vv. 2 [verbal use of nominal], 13, 22, 27).

Lev 5: There is a consensus among scholars regarding the pericopes division in Lev $5^{661}$ and the element of intention and lack of it as regards the sins listed. Milgrom, for instance, stated that Lev 5 consists of four pericopes and provided his own interpretation of these sins. Thus, vv. 1-13 (graded sin offering) refer to intentional sin in v. 1 and sins of forgetfulness in vv. 2-4; 14-16 (sacrilege against sancta) refer to unintentional, inadvertent sin; 17-19 (suspected sacrilege against sancta) refer to unintentional, inadvertent sin; and 20-26 (sacrilege against the oath) refer to intentional sin. ${ }^{662}$ The

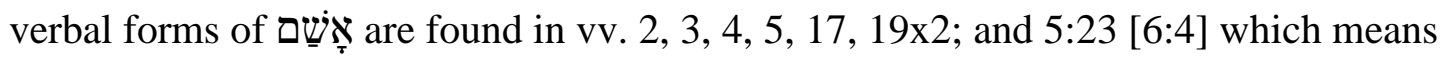
that it is a consequence of sin in all of these pericopes but 5:14-16.

The verbs used in the first pericope, vv. 1-13, only use the verbal of Tָָּ to describe the activity/action of committing the $\sin (\mathrm{vv} .5,6,7,10,11,13)$. The act of $\sin$ is expressed through the nominal of Tָּ (vv. 5, 6x2, 10, 13).

The second pericope, vv. 14-16, uses the verb חָטָ in two verses, vv. 14 and 16,

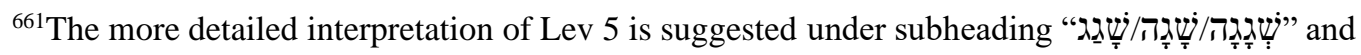

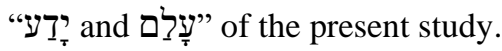

${ }^{662}$ Milgrom, Leviticus 1-16, 292-93, 314, 319; Keil and Delitzsch, The Pentateuch, 2:315; Kiuchi, Purification Offering, 99-101, 112-15; Rooker, Leviticus, 116-26; Gane, Cult and Character, 117-23, 132-35; Sklar, Sin, Impurity, Sacrifice, Atonement, 24.
} 
to refer to the activity/action of sinning. The verbal form is modified by the adverbial use

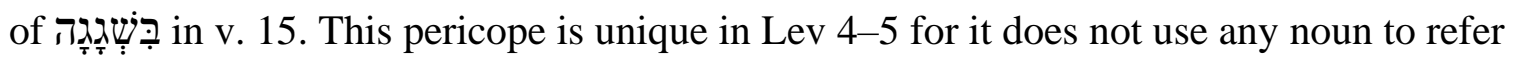
to the act of sin, nor it uses the verb אָָׁ. Based on the pattern from the previous pericopes in Lev 4 and 5, it is reasonable to claim that the act of sin in this pericope is also

The verbal forms that refer to the activity/action of sinning in the next pericope,

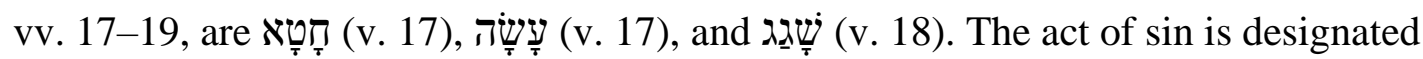

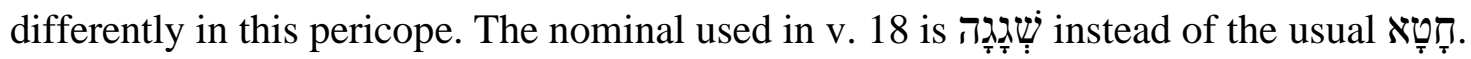

The last pericope, v. 20-26 [6:1-7], uses the verb חָטָ (vv. 20, 22 [6:21], 23 [6:6]) and עָעָָׁה (v. 26) to denote the activity/action of sinning. The nominal form to designate the act of $\sin$ is missing in this pericope.

Two of the pericopes in Lev 5, vv. 14-16 and 5:20-26 [6:1-7], use an additional verbal form of the root מָעַע to designate further the activity/action of sinning and also use the nominal derivative of the same root to describe the act of sin. These two pericopes are unique because the sins that they deal with are directed toward God. In other words, this sin constitutes a sacrilege. ${ }^{663}$ In the first case, it is directed toward God's holy things. In the second case, sacrilege consists of misusing God's name in an oath. ${ }^{664}$

The pattern that surfaces out of the four pericopes in Lev 5 is very similar to the one that was identified with the pericopes of Lev 4. That is, the activity/action of sinning

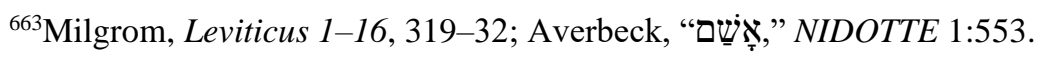

${ }^{664}$ Milgrom, Leviticus 1-16, 320, 345-56; Gane, Cult and Character, 132-35.
} 
is expressed by the three verbs

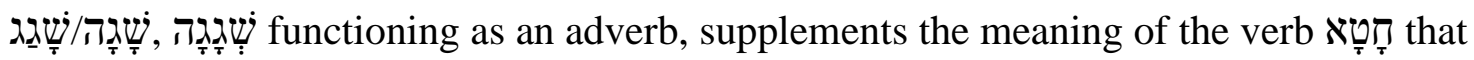
refers to the activity/action of sinning in $\mathrm{v}$. 15 . The act of the sin committed is expressed

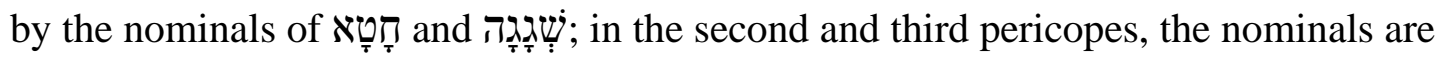
omitted (vv. 14-16, 20-26 [6:1-7]). The outcome of the activity/action that are expressed

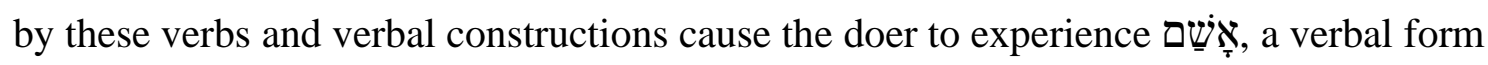
of the term א்ָָׁ (vv. 2, 3, 4, 5, 17, 19 x2, 23 [6:4]).

Num 5: Compared to the previous pericopes, Num 5:6-7 shows a limited use of both verbal forms to refer to an activity/action of sinning. The only verbal form that is used in this pericope derives from the root עָשָׁ (vv. 6, 7), whereas other pericopes

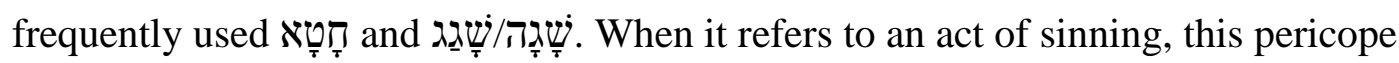
utilizes the usual nominal derivative of דָּ (v. 6, 7) in agreement with pericopes in Lev 4 and in contrast to the pericope in Lev 5, vv. 17-19, that used the nominal derivative of

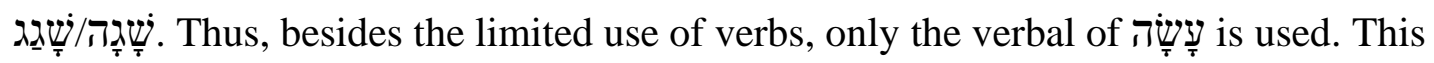
pericope follows the previous pericopes in Lev $4-5$ in using the usual term, the nominal of ${ }^{0}$, to refer to an act of sin.

The analysis of the contexts when חָָ designates sins that causes sinner demonstrates that חָָָ refers to intentional and unintentional sins. However, both intentional and unintentional sins are expiable. These texts do not propose any sort of capital or non-capital punishment that would imply that these sins would be inexpiable. On the contrary, Lev 4-5 laid out the way for a sinner to receive expiation for their sins. 
Conclusion on the Study of Tָּ

Based on insights from the studies that have been done in the history of interpretation on the term presented here, it is accepted that a sinful act. In many instances, the term itself does not specify whether the sin is intentional or unintentional, whereas some texts show that it can refer to both types of sins. The focused analysis conducted in the present study demonstrated that sins designated with the term Tָָּ also signify intentional and inexpiable sins in the Pentateuch. That has been verified by the syntactical or conceptual connection between

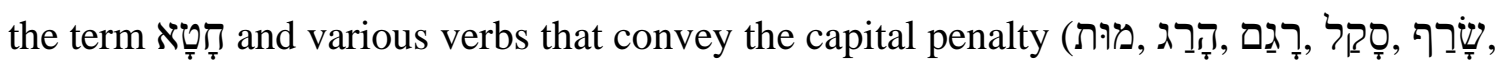
נָכָָ) and the punishment of kārēt.

The sins referred to by the phrase inexpiable and or are expiable mainly intentional. The analysis of Tָָּ and and contexts showed that the sins that cause the sinner to be implication of the fact that חָָּ refers to expiable and inexpiable sins is that it describes forgivable and unforgivable sins.

Finally, in expressing the concept of sin, this term is not limited to the particular aspect or context of human life but rather is found in all of them: legal, cultic, and social. Having provided the evidence that this term carries the same meaning/s in the book of

\footnotetext{
${ }^{665}$ This phrase refers to the use of the verb נָָָָ with both nominal derivatives of the root

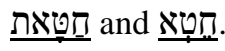


Leviticus and in the Pentateuch, the present study agrees with the claim that rofers to unintentional and expiable sins or errors, but based on pieces of evidence presented above, it also suggests that חָָ also refer to intentional and inexpiable sins in the book of Leviticus and in the Pentateuch.

\section{The Root עָ as a Key Term for Sin in the OT}

By contrast with the term חָָ which is used in a variety of contexts, עָּ is mostly used in religious and ethical settings. ${ }^{666}$ Its plural form has been recognized as a "summary word" that encompasses all sins against God ${ }^{667}$ Based on the fact that the term is used in the confession of the high priest in Lev 16:21 for sins that were removed from the most holy and is the only term repeated in Lev 16:22, Milgrom claimed that עi is the key term used to convey "the totality of offences against the deity that the high priest then transfers to the scapegoat." $" 668$

It is still dispute whether עָּ originates from the Hebrew root 'wh (עוה) or the Semitic root attested in Arabic 'awa ${ }^{669}$ However, scholars mainly believe that the Hebrew $w h$ is the root of ${ }^{670}$ Statistics on the occurrences of עָ coincide with those

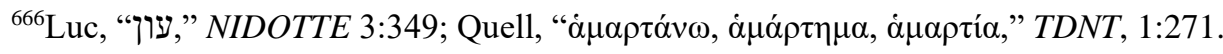

${ }^{667}$ Luc, "עוך," NIDOTTE 3:349; Carl Schultz, "עָוֹדָ," TWOT 2:650.

${ }^{668}$ Milgrom, Leviticus 1-16, 25, 1043.

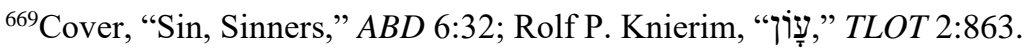

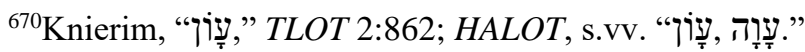


of חָָּ in that that there are several proposals, ranging from $229,{ }^{671} 227^{672}$ to $231^{673}$ nominal occurrences in the OT. The metonymic uses of the term exemplify the affiliation between "sin," "guilt" and "punishment" in biblical thought, ${ }^{674}$ since עָ can mean any or all of these three meanings in a single verse. ${ }^{675}$ Knierim coined a phrase, "dynamistic holistic thought," pointing that עָּ ivi is a term of motion that basically conveys a process of movement to emphasize the relatedness between the act and its consequence that is embedded in the meaning of the term. ${ }^{676}$ Von Rad employed the phrase, "synthetic view of life," to refer to the same phenomenon. ${ }^{677}$

עָ can refer to a conscious activity related to verbal forms, assuming that the verb derives from 'wh (עוה) (1 Kgs 8:47; Jer 3:21; 9:4; Ps 106:6; Job 33:27; Prov 12:8; Esth 1:16; Dan 9:5), as well as nominal forms (Gen 44:16; Num 14:19; Josh 22:20; 1 Sam 25:24; 2 Sam 3:8; Isa 22:14; Jer 11:10). Yet, multiple references also show that עָוֹן represent unconscious and unintended activity (Gen 15:16; 19:15; Lev 22:16; Num 18:1, 23; 1 Sam 14:41 LXX; 20:1; 2 Sam 14:32; 1 Kgs 17:18; Isa 6:7). In addition, some uses emphasize the relationship between a deed and its consequence (Gen 4:13; Deut 19:15; 2

${ }^{671}$ Cover, "Sin, Sinners," ABD 6:32.

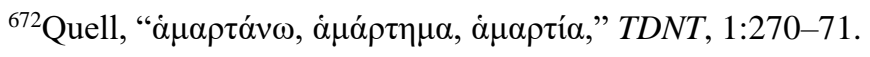

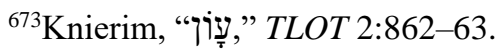

${ }^{674}$ Joseph Lam, “The Concept of Sin in the Hebrew Bible,” $R C$ 12.3-4 (19 February 2018).

${ }^{675}$ Cover, "Sin, Sinners," ABD 6:32; Schultz, “עָָׁדי", TWOT 2:650.

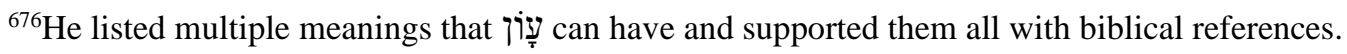

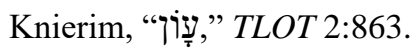

${ }^{677} \mathrm{Rad}$, Old Testament Theology, 1:264-65. 
Kgs 7:9; Isa 5:18; Ps 25:11; 31:11). Some texts emphasize the totality of sin without interest in clarifying the type of sin (Deut 19:15; Amos 3:2; Ps 103:3). There are also

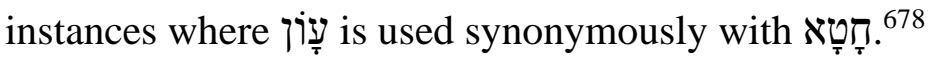

Finally, since עָּז refers to both a deed and its consequence, then the consequential-volitional element is not essential because the consequence often occurs unknowingly or unintentionally. Knierim noted that "the emphasis on consciousness does not characterize the term, then, but lies in the nature of the - always historically conditioned - context that makes the issue of guilt comprehensible (Gen 3; Hos; Jer; Ezek)." ${ }^{\prime 679}$ Thus, the general implication is that עָּ can express both intentional and unintentional sins, and it is the context that clarifies whether the sin expressed by עָ belongs to the former or latter category. ${ }^{680}$ After presenting the key points related to the term עָּוֹן from scholarly discussions, the present study focuses on the Pentateuch.

The Nature of עָּז Sins in Leviticus and the Rest of the Pentateuch

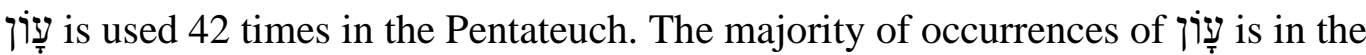
books of Leviticus (18x) and Number (12x). The books of Genesis (4x), Exodus (6x), and

\footnotetext{
${ }^{678}$ Knierim, Die Hauptbegriffe für Sünde im Alten Testament, 19-20, 50-54. followed by Schwartz, "The Bearing of Sin," 8n17. Gane noticed the following in the case of sin in Lev 5:1, 5-6: "A witness who sins (verb עטא) by failing to give required testimony bears his עון, 'culpability,' unless/until he confesses what he has sinned (verb חחטא) and bring a purification offering for the sin he has sinned

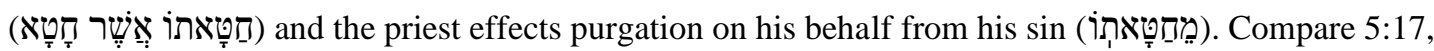
where sinning (verb חון (שטא) also results in bearing." Gane, Cult and Character, 294.

${ }^{679}$ Knierim, "עָָּוֹן," TLOT 2:864.

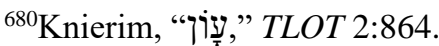


Deuteronomy (2x) show low frequency of עָ usage. ${ }^{681}$ The general meaning/s suggested by scholarly research that the term עָ covers a sinful act and its consequence, along with the guilt for the sin, seems to be operating in the book of Leviticus and the wider literary context of the Pentateuch. The following tables list the עָ occurrences, demonstrating that the term in the Pentateuch refers to (1) sinful act, (2) punishment as a consequence for a sinful act, and (3) guilt or liability for a sinful act. The application of the terminological/contextual/intertextual approach with the questions set out at the beginning of this chapter is also applied in the further analysis of עָָּ

\section{Intentionality and Expiability Associated to עָּ Sins}

It is challenging to determine precisely the meaning of עָּ Sometimes, all three components of sin are in view — an act, guilt, and punishment. It is very likely that it is a matter of emphasis of one or the other. Thus, the following paragraphs are not intended to suggest the firm meanings of עָּ but rather, to point to the emphasis on specific meanings of the term in certain texts. In addition, I will seek to determine whether עָוֹן refers to intentional or unintentional sin and whether עָּ is expiable or inexpiable sin.

עָּ Sinful Act

There are at least four contexts where עָ wiֹ was used six times to refer to intentional and inexpiable sin. This suggestion points to the use of the term עָ when it refers to the sinful act. The following table shows the references (see Table 15):

\footnotetext{
${ }^{681}$ Accordance Bible.
} 


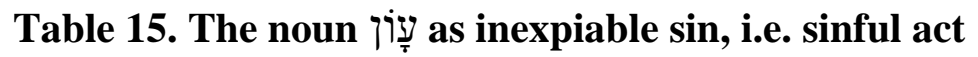

\begin{tabular}{|c|c|c|c|c|c|c|c|}
\hline & Reference & Sin & Punishment & Expiable & Inexpiable & Intentional & Intentional \\
\hline 1. & Lev $26: 39 \times 2^{682}$ & Various sins & Death, exile & & $\mathrm{x}$ & $\mathrm{x}$ & $X$ \\
\hline 2. & Lev $26: 40 \times 2^{683}$ & Various sins & Death, exile & & $\mathrm{x}$ & $\mathrm{x}$ & $\mathrm{X}$ \\
\hline 3. & Lev 26:41 $61^{684}$ & Various sins & Death, exile & & $\mathrm{x}$ & $x$ & $X$ \\
\hline 4. & Lev $26: 43^{685}$ & Various sins & Death, exile & & $\mathrm{x}$ & $\mathrm{x}$ & $X$ \\
\hline
\end{tabular}

The occurrences in Table 15 demonstrate that עָּ is perceived as an inexpiable sin. All these עָָּ occurrences have in common the fact that they refer to sins punished by capital punishment and exile. It is worthy to note that these texts do not provide details about the act of sin itself, but rather a general idea of sin is in view.

The severity of the punishment for these sins suggests that they are inexpiable. As being a background of all the texts in the Table 15, exile represents God's most severe punishment for people's sins. The intentionality of the sins portrayed in this chapter can be suggested on the basis of verbs used to refer to Israel's sins and thematic contrasts.

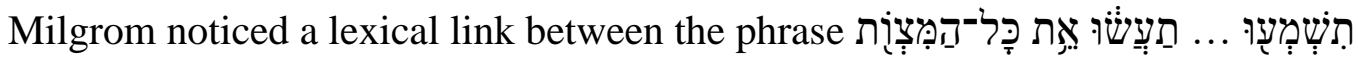

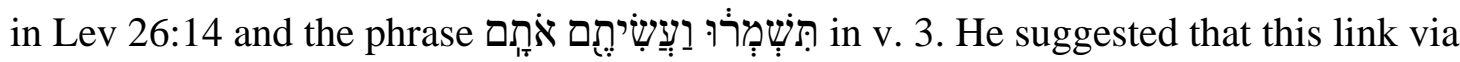

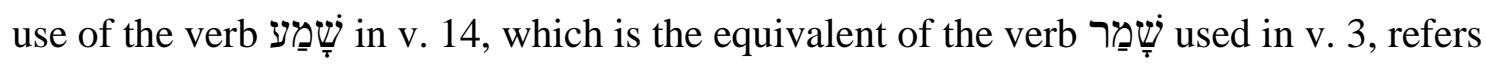

\footnotetext{
${ }^{682}$ The term עָ עָ can take on two potential meanings in this text. The one favored by Milgrom is "iniquity." Milgrom, Leviticus 23-27, 2273, 2327. However, Milgrom referred to this iniquity as sins. Milgrom, Leviticus 23-27, 2327. This meaning is followed by many other scholars. Gane suggested culpability as other meaning. Gane, Leviticus, Numbers, 454.

${ }^{683}$ Milgrom, Leviticus 23-27, 2273, 2330-31.

${ }^{684}$ Milgrom, Leviticus 23-27, 2274, 2333.

${ }^{685}$ Milgrom, Leviticus 23-27, 2274. Gane understood the term עָּ refers to culpability in this text. Gane, Leviticus, Numbers, 455.
} 
to the negation of the heading of the previous "blessings" section. Both verbs used in vv.

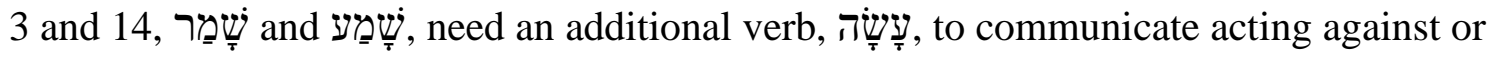

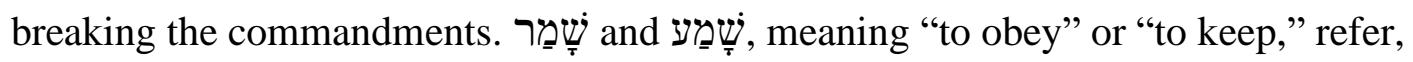
rather, to physical passivity, while עָָָָׁׁה conveys the action of breaking the commandments. ${ }^{686}$

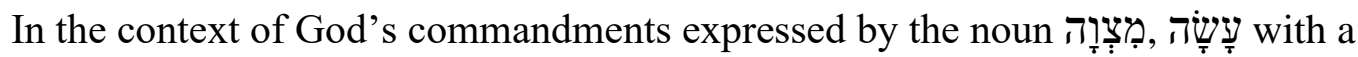
human subject always refers to intentional and conscious activity (Ex 15:26; Lev 4:2, 13, 22,$27 ; 5: 17 ; 22: 31 ; 26: 3,14,15 ;$ Num 15:22, 39, 40; Deut 5: 31; 6:1, 25; 7:11; 8:1; $11: 22 ; 13: 18 ; 15: 5 ; 19: 9 ; 27: 10 ; 28: 1,13,15 ; 30: 8 ; 31: 5) .{ }^{687}$ The same pattern is detected

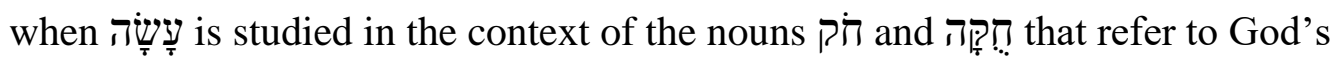
commandments (Exod 15:26; 18:20; Lev 16:29, 34; 18:4, 5; 19:37; 20:8, 22-23; 25:18; 26:3; Num 9:3, 12, 14; Deut 4:1, 5, 6, 14; 5:1, 31; 6:1, 24; 7:11; 11:32-12:1; 16:12; 17:19; 26:16; 27:10). ${ }^{688}$ In some contexts, עִשָָׁ also refers to intentional activity (Lev 18:4-5, 26; 19:37; 20:22; 25:18; 26:15).

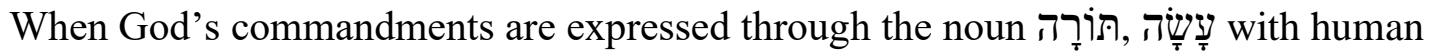
subject also refer to intentional and conscious activity (Exod 18:20; Num 5:30; 6:21;

\footnotetext{
${ }^{686}$ Milgrom, Leviticus 23-27, 2304.

${ }^{687}$ This principle also apply to the uses when God is subject of the verb עָש்ָָׁ (Exod 20:6; Deut $5: 10)$.

${ }^{688}$ Several texts do not follow this pattern, but do not negate it. In Lev 6:22 עָָָָָׁ means "to offer a

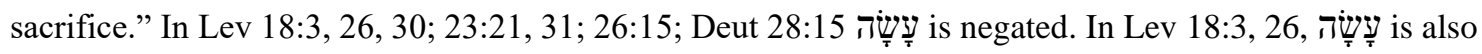
negated and חק refer to the statutes of Egyptian's and Canaanite's societies of which some were most likely religious.
} 
15:29; Deut 17:11, 19;27:26; 28:58; 29:29; 31:12; 32:46). In the context of the verb צָָּ the verb עָשָָָׁa always expressed intentional activity (Lev 8:4-5, 34, 36; 9:6-7; 16:34; $\left.24: 23 ; 25: 21^{689}\right)$.

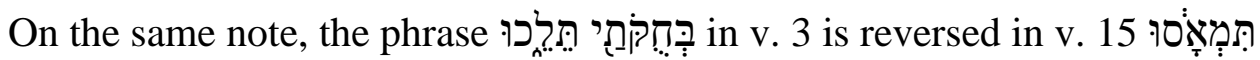

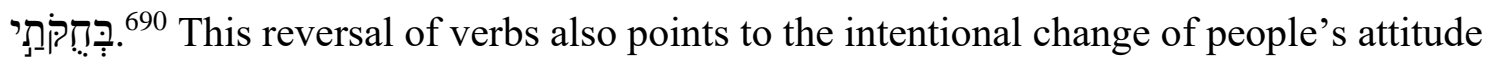
towards God's commandments. The verb מָָ is critical in this verse since it points to an intentional, willful rejection or refusal in various contexts. ${ }^{691}$ God promised blessings for people's willingness to follow God's commandments and curse/punishment if they decide to refuse, reject, despise and not do them.

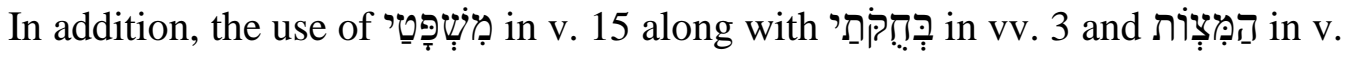
14 , adds a legal notion of the sins associated with the activities elaborated in these texts. The use of all 3 terms that refer to the totality of Israel's legislative system ${ }^{692}$ further hints at the totality of their sins or illegitimate status/condition.

Another hint concerning the nature of the sins implied in this chapter is found in

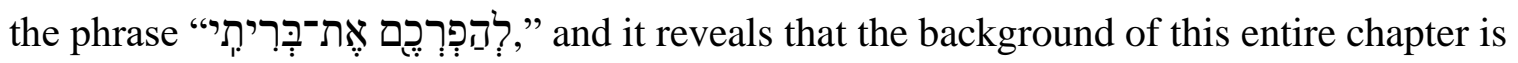
the Sinaitic covenant, including all of its stipulations. ${ }^{63}$ The stipulations of the Sinaitic

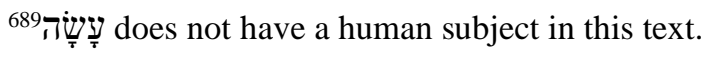

${ }^{690}$ Milgrom, Leviticus 23-27, 2304.

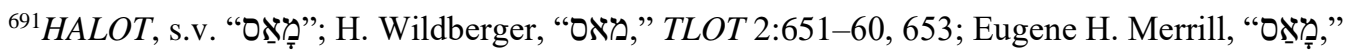
NIDOTTE 2:826-27.

${ }^{692}$ Milgrom, Leviticus 23-27, 2305.

${ }^{693}$ Roy E. Gane, "Leviticus,” in Genesis, Exodus, Leviticus, Numbers, Deuteronomy, vol. 1 of ZIBBCOT, ed. John H. Walton, 5 vols. (Grand Rapids, MI: Zondervan, 2009), 323; Milgrom, Leviticus 2327, 2305. 
covenant encompass cultic, legal, and moral laws. ${ }^{694}$ Consequently, it is to be expected that the sins referred to by the term עָּ include a variety of inexpiable sins in this context. The sins implied here are unlikely to be unintentional sins since God would provide atonement for those sins via the cult. These texts do not contain clues about nor describe the act of sin. Biblical accounts of the exile of the kingdom of Judah testify that individuals within covenant people retained their brazen rebellious and in doing so died (Jer 52, Lamentations). The point from Lev 26:39-41, 43 and later texts about exile is that עָָּ can refer to intentional brazen inexpiable sin.

\עָ as Punishment

The present study suggests that two texts with עָ emphasize the punishment (Lev $18: 25 ; 22: 16)$. Scholars are divided on the meaning of עָ in 18:25. Snaith and Milgrom suggested that the עָ should be translated by "sin" as becomes obvious from their translation of Lev 18:25. ${ }^{695}$ The majority of scholars stressed punishment in the pericope of v. 25, assuming punishment as the translation of yָiָ, based on the fact that 18:24-30, as a conclusion of the law collection presented in ch. 18, would speak about punishments

\footnotetext{
${ }^{694}$ Shalom M. Paul, Studies in the Book of the Covenant in the Light of Cuneiform and Biblical Law, VTSupp 18 (Leiden: Brill, 1970), 28-29, 34; Nahum M. Sarna, Exodus = [Shemot]: The Traditional Hebrew Text with the New JPS Translation, JPSTC 2 (Philadelphia: Jewish Publication Society, 1991), 117-50; Joe M. Sprinkle, Biblical Law and Its Relevance: A Christian Understanding and Ethical Application for Today of the Mosaic Regulations (Lanham, MD: University Press of America, 2006), 51; Raymond Westbrook and Bruce Wells, Everyday Law in Biblical Israel: An Introduction, 1 st ed. (Louisville: Westminster John Knox Press, 2009), 12.
}

${ }^{695}$ Snaith, Leviticus and Numbers, 126; Milgrom, Leviticus 17-22, 1515, 1580. 
as a consequence of breaking the laws just presented. ${ }^{696}$ The literal translation of the phrase would be "I have visited, punished its sin" as recognized and verbalized by some scholars, but its meaning undeniably points to the punishment of the people via punishment of the land. This literary tendency to emphasize punishment in the case of disobedience at the conclusion of a group of laws was noticeable in the ANE texts and followed in the OT. ${ }^{697}$

There is no such disagreement related to the meaning of Lev 22:16. That is, key scholars agree that עָ should be translated as punishment in this text. ${ }^{698}$

Like the texts that emphasize the act of sin, meaning of עָּ, these texts do not contain clues about nor describe the act of sin. Emphasis on the punishment component of the term makes the nature of sin (intentional or unintentional) insignificant.

\section{עָּ as Sin/Guilt/Punishment}

The term was used 8 times to express all three components of $\sin (\operatorname{Lev} 5: 1,17$;

$7: 18 ; 10: 17 ; 17: 16 ; 19: 8 ; 20: 17,19)$. The precise or emphasized meaning/s is a matter of interpretation, than based on solid, textual clues. Contrary to the uses of עָָּ when it refers

\footnotetext{
${ }^{696}$ Keil and Delitzsch, The Pentateuch, 2:418; A. Noordtzij, Numbers, BSC (Grand Rapids, MI: Zondervan, 1983), 189; Levine, Leviticus, 123-24; Rooker, Leviticus, 249; John H. Walton, Victor H. Matthews, and Mark W. Chavalas, "Leviticus," in IVPBBCOT (Downers Grove, IL: InterVarsity Press, 2000), 133; Gane, Leviticus, Numbers, 321; Kiuchi, Leviticus, 338-40; Jay Sklar, Leviticus: An Introduction and Commentary, TOTC 3 (Downers Grove, IL: Inter-Varsity Press, 2014), 239-40.

${ }^{697}$ Wenham, The Book of Leviticus, 260; W. H. Bellinger, Leviticus and Numbers, UBCS (Peabody, MA: Hendrickson, 2012), 113-14; Gane, "Leviticus," 323.

${ }^{698}$ Milgrom, Leviticus 17-22, 1869-70; Kiuchi, Leviticus, 407; Noordtzij, Numbers, 224; Wenham, The Book of Leviticus, 296n10; Snaith, Leviticus and Numbers; Levine, Leviticus, 150; R. K. Harrison, Leviticus: An Introduction and Commentary, TOTC (Downers Grove, IL: Inter-Varsity Press, 1980), 215.
} 
to sin as an act or punishment, these texts do provide details about and describe the act of sin. That is, the act for which one is guilty and punished is described in detail.

Schwartz suggested that in all of these texts, the phrase refers to the guilt or consequential bearing. ${ }^{699}$ Bruce Wells approved of Schwartz's findings, but furthered the dialogue by limiting his work to the category of consequential sin-bearing, or as he termed it, 'a wōn-clause, in the OT. ${ }^{700} \mathrm{He}$ proposed that the phrase "point[s] to a liability that is in addition to the general liability for having committed an act that these texts consider sinful." ${ }^{\text {701 }}$ The fact that discredits Well's proposal is the inability to identify what that additional liability would be in some texts. ${ }^{702}$

Schwartz and Wells both reduced the meaning of the phrase to the consequential meaning only. The part of Schwartz's list of the Leviticus texts with the consequential meaning of the phrase differs from the list suggested here due to the fact that the list of

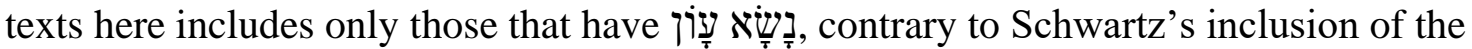
other two terms for sin,

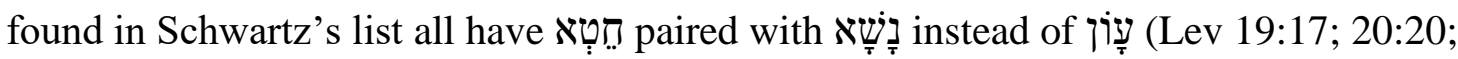
$22: 9 ; 24: 15)$.

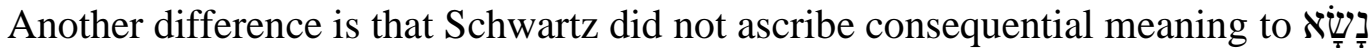

${ }^{699}$ Schwartz, "The Bearing of Sin," 12-13.

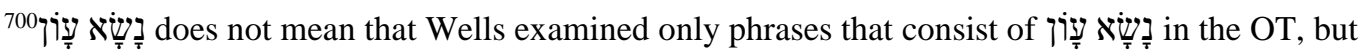

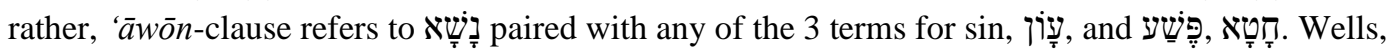
"Liability in the Priestly Texts," 1.

${ }^{701}$ Wells, "Liability in the Priestly Texts," 1, 13, 15.

${ }^{702}$ Wells, "Liability in the Priestly Texts," 16, 18, 21, 23. 
עָוֹ in Lev 10:17, but rather, a carrying, bearing away, or removing the sin from the sanctuary, not from the sinner. ${ }^{703}$ Finally, Lev 18:25 does not have the verb

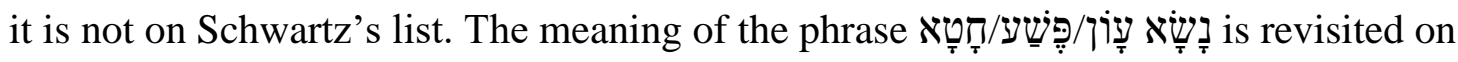
pages $139-85$ above of the present study. However, at this point, it is important to note that other scholars recognized that עָּוֹ in these Leviticus texts point to sin as an act and guilt. In order for עָּוֹ to have consequential meaning, the subject of the phrase always human. ${ }^{704}$

This group of texts contains sins of various kinds. It is evident that the majority of them are intentional and inexpiable, but some of the intentional ones are expiable. In addition, except for Lev 10:17, the texts provide clues that describe the sin in details.

\section{Capital Punishment and עָּוֹ}

The order of verbs that refer to capital punishment is the same as in the section of

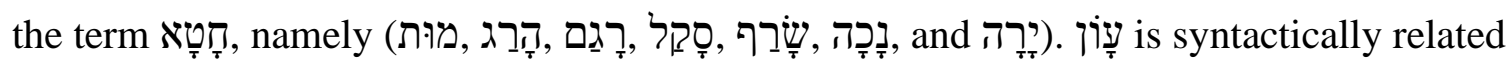
to the verb מעוּת once in the Pentateuch, in Exod 28:43. It is debatable what the actual nature of the sin in this ordinance was, ${ }^{705}$ but it is inevitable that the punishment/consequence was death. ${ }^{706}$ iָiֹ is never associated with the term of In

${ }^{703}$ Schwartz, "The Bearing of Sin," 16.

${ }^{704}$ Schwartz, "The Bearing of Sin," 10.

${ }^{705}$ Keil and Delitzsch: "either through disobedience to these instructions, or, what was still more important, through such violation of the reverence due to the holiness of the dwelling of God as they would be guilty of, if they entered the sanctuary with their nakedness uncovered." Keil and Delitzsch, The Pentateuch, 2:205-6.

\footnotetext{
${ }^{706}$ Keil and Delitzsch, The Pentateuch, 2:205-6; Wells, "Liability in the Priestly Texts," 29.
} 
two contexts, Gen 4:8 and Lev 20:16, הָרג is used to express a capital punishment for the

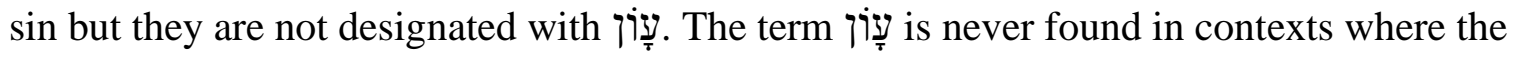
term רָגָ or are used to communicate punishment for sin.

The term may also be associated with שָָָׁרָ in the contexts of various sexual misconducts. Various texts use שָָָׁרָ to designate the mode of punishment for sexual misconducts that are defined by the term זָָנָה (Gen 38:24: adultery; Lev 21:9: illicit sex;

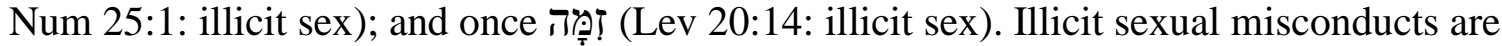
also defined as עָ in Lev 20:17, ${ }^{707} 19,{ }^{708}$ and $20 .{ }^{709}$ The law in v. 17 deals with illicit marriage and sex. The text in v. 19 refers to a potential double sexual misconduct. First, it refers to an illicit sexual relationship with one's mother's or father's sister. Second, it potentially refers to adultery since the sister referred to in the law might have been married. They are not married since the usual verb that refers to marriage but rather just have illicit sex. The law in v. 20 undoubtedly refers to adultery, illicit sex with one's uncle's wife. ${ }^{710}$ The term עָ is used in a metonymic way in all these three laws to refer to sin, guilt, and its punishment. Thus, certain sexual misconducts initiate

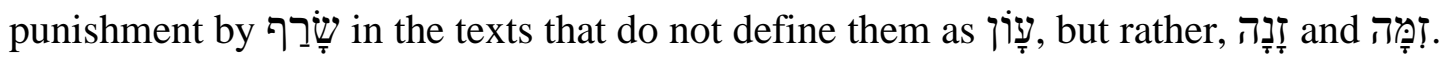

${ }^{707}$ Milgrom, Leviticus 17-22, 1763; Wells, “Liability in the Priestly Texts," 18-19.

${ }^{708}$ The marital status of his aunt is ambiguous, but the law might imply that the aunt was married.

${ }^{709}$ The illicit sexual deeds in Lev 20-21 are considered as עָ vị via the parallel laws in Lev 18:14, 16 that deal with the same sins. The sins in Lev 18 are designated as עָָּוֹ 18:25.

${ }^{710}$ Wells, Liability in the Priestly Texts, $20-21$. 
However, these sexual misconducts are defined by עָiָin other texts of the Pentateuch. As a result, it is plausible to state that שָָָׁרָ is used as a mode of punishment for sins.

The term עָ עָוֹן is never syntactically associated with the verb נָכָה in the Pentateuch. There are only 2 out of 3 contexts where נָָָָה of the Pentateuch (Isa 57:17; Jer 30:14). Neither is associated to the term ריָרה in the sense of punishment.

Kārēt and עָָּ

The term עָּוֹ is syntactically related with the verb 3 contexts in the Pentateuch. The following table (Table 16) provides the references of those contexts:

Table 16. The verb $k \bar{a} r a t$ and

\begin{tabular}{|c|l|l|l|c|c|c|c|}
\hline & Reference & \multicolumn{1}{c|}{ Sin } & Punishment & Expiable & Inexpiable & Intentional & Unintentional \\
\hline 1 & Lev 19:8 & $\begin{array}{l}\text { Illicit eating } \\
\text { of sacrifice }\end{array}$ & $\begin{array}{l}\text { Death } \\
\text { Lev 19:8 }\end{array}$ & & $\mathrm{x}$ & $\mathrm{x}$ & \\
\hline 2 & Lev 20:17 & Illicit sex & $\begin{array}{l}\text { Death } \\
\text { Lev 20:17 }\end{array}$ & & $\mathrm{x}$ & $\mathrm{x}$ & \\
\hline 3 & Num 15:31 & $\begin{array}{l}\text { Defiant sin, } \\
\text { despising } \\
\text { God's word }\end{array}$ & $\begin{array}{l}\text { Death } \\
\text { Num 15:31 }\end{array}$ & & $\mathrm{x}$ & $\mathrm{x}$ & \\
\hline
\end{tabular}


The nature of kārèt punishment for all three of these sins points to the fact that they are inexpiable and unforgivable sins. The presence of the intention is unquestionably explicit in Lev 20:17 711 and Num 15:31. ${ }^{712}$ One could technically argue for negligence in the case of Lev 19:8 since a person or the participants in the offerer's feast could fail to handle the sanctified offering meat properly. The full responsibility for handling the peace offering is on the offerer and/or the participants in the offerer's feast, not on the priests. ${ }^{713}$ The offerer could have forgotten the day the sacrifice was offered and then eat from it on the third day and serve it to his guests, or by not checking with the participants of this feast, if they fulfill the prerequisites of ritual purity to participate in the feast (Lev 7:19-20), just to name some potential compromising situations. The full responsibility lies on the offerer or his invitees.

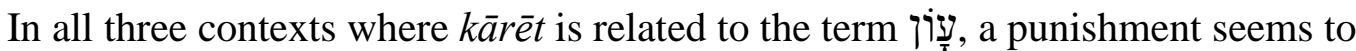
be implied in the term. In other words, this connection points to the punishment to which a person is liable because the term עָiֹimmediately defines these sins. ${ }^{714}$ Milgrom stated that the term עִ עִ and añet are equivalents here. ${ }^{715}$ The sins in these texts are intentional and inexpiable.

\footnotetext{
${ }^{711}$ The use of the verb לָקז, which is frequently used to denote forming of a marital relationship in the Pentateuch, suggests that the law discusses the situation of a person marrying his full sister which includes illicit sexual intercourse. Milgrom, Leviticus 17-22, 1763; Wells, "Liability in the Priestly Texts," 18-19.

${ }^{712}$ Milgrom, Numbers, 125; Cole, Numbers, 252-53; Keil and Delitzsch, The Pentateuch, 3:103.

${ }^{713}$ Rooker, Leviticus, 256; Milgrom, Leviticus 17-22, 1622-23; Gane, Leviticus, Numbers, 155.

${ }^{714}$ Levine, Numbers 1-20, 398; Milgrom, Leviticus 17-22, 1488-90, 1622-23.

${ }^{715}$ Milgrom, Leviticus 17-22, 1622.
} 
עָּוֹן and בָשָא

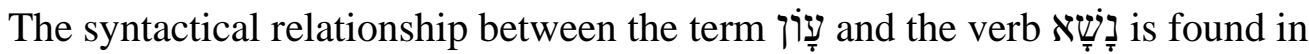
twenty contexts in the Pentateuch. Table 17 provides the list of references:

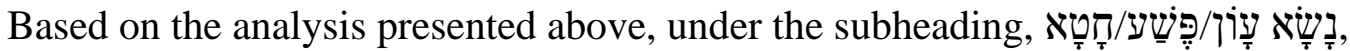
on pages 139-85 of the present study, the meanings associated with the phrase depend on the subject of the phrase. When the sinner is the subject of the phrase, that is,

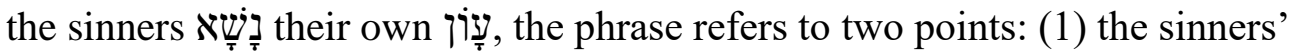
responsibility for their sin, and (2) the impending punishment that the sin assumes. That the act of sin has occurred is implied in this use. Accordingly, stating the consequences for a number of different sins, the phrase takes the place of a specific punishment without explicitly stating the exact nature of it. ${ }^{716}$

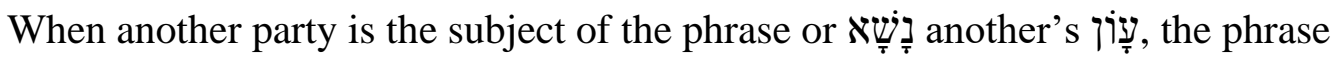
ultimately implies forgiveness. Thus, in some of the texts from Table 17, the phrase עִעוֹן נָשָָׁא refers to punishment (Gen 4:13; Exod 28:43; Lev 5:1, 17; 7:18; 10:17; 17:16; $19: 8 ; 20: 17,19 ; 22: 16 ;$ Num 5:31; 14:34), while in others, it implies forgiveness (Exod 28:38; 34:7; Lev 16:22; Num 14:18-19; 18:1, 23; 30:15). ${ }^{717}$

\footnotetext{
${ }^{716}$ See page 172 of the present study. Olaffson, "The Use of $n s ́$ ' in the Pentateuch," 176; Wells, The Law of Testimony, 161.

${ }^{717}$ For a more detailed interpretation of the texts that convey punishment, see Olaffson, "The Use of $n s^{\prime}$ in the Pentateuch," 170-78. For a more detailed interpretation of the texts that convey forgiveness, see Olaffson, "The Use of $n s$ ' in the Pentateuch," 179-216.
} 


\section{Table 17. The relationship of}

\begin{tabular}{|c|c|c|c|c|c|c|c|}
\hline & Reference & Sin & Punishment & Expiable & Inexpiable & Intentional & Unintentional \\
\hline 1. & Gen $4: 13^{718}$ & Murder & $\begin{array}{l}\text { Death, } \\
\text { mitigated, } \\
\text { but not } \\
\text { death }\end{array}$ & $\mathrm{x}$ & & $\mathrm{x}$ & \\
\hline 2. & Exod 28:38 & Study this & & & & & \\
\hline 3. & Exod 28:43 & $\begin{array}{l}\text { Not } \\
\text { wearing } \\
\text { priestly } \\
\text { robe }\end{array}$ & $\begin{array}{l}\text { Death } \\
\text { Exod 28:43 }\end{array}$ & & $\mathrm{X}$ & $\mathrm{x}$ & \\
\hline 4. & Exod 34:7 & Unknown & Unknown & $\mathrm{n} / \mathrm{a}$ & $\mathrm{n} / \mathrm{a}$ & $\mathrm{n} / \mathrm{a}$ & $\mathrm{n} / \mathrm{a}$ \\
\hline 5. & Lev 5:1 & $\begin{array}{l}\text { Failure to } \\
\text { testify }\end{array}$ & 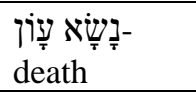 & $\mathrm{x}$ & & $\mathrm{x}$ & \\
\hline 6. & Lev 5:17 & $\begin{array}{l}\text { Disobeyin } \\
\text { g God's } \\
\text { word }\end{array}$ & 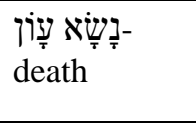 & $\mathrm{x}$ & & & $\mathrm{x}$ \\
\hline 7. & Lev 7:18 & $\begin{array}{l}\text { Illicit } \\
\text { eating of } \\
\text { sacrifice }\end{array}$ & 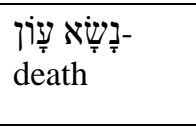 & & $\mathrm{X}$ & $\mathrm{x}$ & \\
\hline 8. & Lev 10:17 & Unknown & 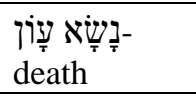 & $\mathrm{n} / \mathrm{a}$ & $\mathrm{n} / \mathrm{a}$ & $\mathrm{n} / \mathrm{a}$ & $\mathrm{n} / \mathrm{a}$ \\
\hline 9. & Lev 16:22 & Unknown & 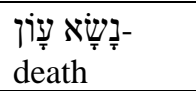 & $\mathrm{n} / \mathrm{a}$ & $\mathrm{n} / \mathrm{a}$ & $\mathrm{n} / \mathrm{a}$ & $\mathrm{n} / \mathrm{a}$ \\
\hline 10. & Lev 17:16 & $\begin{array}{l}\text { Fail to } \\
\text { purify }\end{array}$ & נָשָָׁא עָוֹוֹן & $\mathrm{n} / \mathrm{a}$ & $\mathrm{n} / \mathrm{a}$ & $\mathrm{x}$ & \\
\hline 11. & Lev 19:8 & $\begin{array}{l}\text { Illicit } \\
\text { eating of } \\
\text { sacrifice }\end{array}$ & Cut off & & $\mathrm{x}$ & $\mathrm{x}$ & \\
\hline 12. & Lev 20:17 & Illicit sex & Cut off & & $\mathrm{x}$ & $\mathrm{x}$ & \\
\hline 13. & Lev 20:19 & Illicit sex & 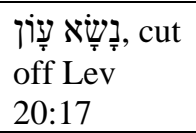 & $\mathrm{x}$ & & & $\mathrm{x}$ \\
\hline
\end{tabular}

${ }^{718} \mathrm{~A}$ brief history of the interpretation of the meaning of yij in this text is provided in the Claus Westermann's Commentary with the most influential suggestions for it. Scholars were divided into two groups, those who translate עָ as sin in this text, and those who translate it as punishment. Westermann's solution points to the fact that (1) Hebrew עָ describes an event which can include both sin and punishment and (2) it is the context that places the stress on one or the other potential meaning. The outcome of these two inferences is that none of these two groups is totally incorrect nor totally correct. Westermann suggested that these two meanings for the Hebrew עָ are not mutually exclusive, but rather, complimentary, and the context determines which of them is stressed in a given text. Along with von Rad and Koch, Westermann believed that Gen 4:13 stressed the punishment meaning. Claus Westermann, Genesis 1-11: A Commentary, trans. John J. Scullion (Minneapolis: Augsburg, 1984), 309; Gerhard von Rad, Genesis, rev. ed., OTL (Philadelphia: Westminster Press, 1972), 107. This view is later affirmed by subsequent scholars like Kenneth Mathews, Genesis 1-11:26, NAC 1A (Nashville: Broadman \& Holman, 1996), 276; Schultz, "עָָָָ," TWOT 2:650-51. 
Table 17-Continued.

\begin{tabular}{|c|c|c|c|c|c|c|c|}
\hline 14. & Lev 22:16 & $\begin{array}{l}\text { Illicit } \\
\text { eating of } \\
\text { sacrifice }\end{array}$ & 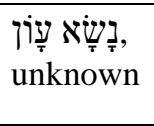 & & & & \\
\hline 15. & Num 5:31 & $\begin{array}{l}\text { Potential } \\
\text { adultery }\end{array}$ & Death & & $\mathrm{x}$ & $\mathrm{x}$ & \\
\hline 16. & Num 14:18 & Unknown & Unknown & $\mathrm{n} / \mathrm{a}$ & $\mathrm{n} / \mathrm{a}$ & $\mathrm{n} / \mathrm{a}$ & $\mathrm{n} / \mathrm{a}$ \\
\hline 17. & Num $14: 34$ & $\begin{array}{l}\text { (Bad } \\
\text { testimony) } \\
\text { multiple } \\
\text { sins }\end{array}$ & $\begin{array}{l}\text { Staying in } \\
\text { the desert }\end{array}$ & $\mathrm{x}$ & & & $\mathrm{x}$ \\
\hline 18. & Num $18: 1 \times 2$ & Unknown & Unknown & $\mathrm{n} / \mathrm{a}$ & $\mathrm{n} / \mathrm{a}$ & $\mathrm{n} / \mathrm{a}$ & $\mathrm{n} / \mathrm{a}$ \\
\hline 19. & Num 18:23 & Unknown & Unknown & $\mathrm{n} / \mathrm{a}$ & $\mathrm{n} / \mathrm{a}$ & $\mathrm{n} / \mathrm{a}$ & $\mathrm{n} / \mathrm{a}$ \\
\hline 20. & Num 30:15 & $\begin{array}{l}\text { Annulling } \\
\text { wife's } \\
\text { vow }\end{array}$ & Unknown & $\mathrm{n} / \mathrm{a}$ & $\mathrm{n} / \mathrm{a}$ & $\mathrm{x}$ & \\
\hline
\end{tabular}

עָּוֹן

The connection between these two terms exists in two pericopes, Lev 5:1-13 and 5:17-19. The phrase designates the sin and points to its punishment in v. 1. The  governs all four cases in vs. $1-4 .^{719}$ As a result, one of the sins that produces sinner is

In the same manner, the sin and its punishment are expressed by the phrase נִשָָׁ in v. 17. That sin further causes the sinner to experience אָשָׁ (vv. 17, 19). The sin of this pericope, like that in the previous one, is intentional and expiable.

${ }^{719}$ Wells, The Law of Testimony, 66; Milgrom, Leviticus 1-16, 314. 
Conclusion on the Study of עָוֹֹ

The previous research showed that עָּוֹ occurs mainly in religious and ethical settings and refers to intentional and unintentional sin in the OT. The verbal form of עָָּ, from the root, from which the noun עָּוֹ is apparently derived, refers to both a conscious activity and unconscious or unintended activity in the OT. Some nominal uses emphasize the relationship between a deed and its consequence. עָ עָ can be used synonymously with חָטָָא Pentateuch. The occurrences of the noun עָi in the Pentateuch demonstrate that the term is used in a metonymic way to exemplify the affiliation between "sin," "guilt," and "punishment," as the previous scholarly research has shown.

The present research also agrees that it is difficult to determine whether the term refers to any or all the elements of the sinful event, the act of sin, and/or guilt and/or punishment, since in the majority of the texts, they overlap. A study of the texts where refers to an act of sin demonstrated that it refers to intentional and inexpiable sins. When עָּ emphasizes punishment, then inference on what kind of sins it refers to is insignificant. The texts that convey metonymic use of this term encompass a variety of intentions. In other words, עָ refers to both intentional and unintentional sins. In addition, some intentional sins, besides the unintentional ones, are expiable. It has also been noticed that the texts that potentially imply only one meaning, sinful act or punishment, do not provide the descriptions nor designation about the sinful act, but emphasis is rather on the general idea of sin. To the contrary, when all three possible meanings are implied, the text provides details about and designates that particular sin. 
When עָ is studied with the intent to establish whether the sin it refers to is intentional or unintentional and expiable or inexpiable, the Pentateuchal texts provide hints that עָ aside from Lev 10:17; 16:21-22; and 22:16, always refer to intentional and both expiable and inexpiable sin. עָ as inexpiable and intentional sin results in capital punishment via its association with the verbs that convey this kind of punishment, such as שָׁרָף but is never used in the contexts where the punishment is conveyed via

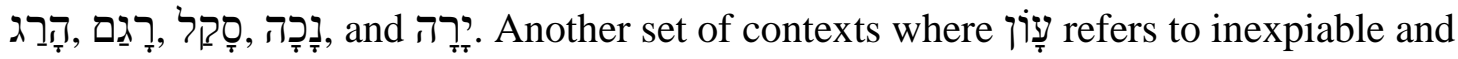
intentional sin is when it is associated with kārèt punishment. It has to be mentioned that

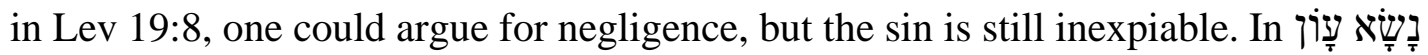
contexts, the term refers to punishment or forgiveness. Sins that caused punishment are both intentional and inexpiable. However, some intentional sins are expiable, in addition to the unintentional sins which are mostly expiable. The punishment is not capital even

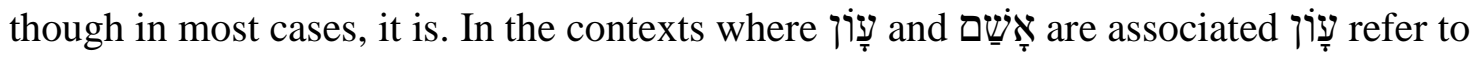
intentional and expiable sin. The fact that עָּ refers to both expiable and inexpiable sin implies that עָּ sins are forgivable or unforgivable.

The term עָּ rarely explicitly expresses unintentional sin in the book of Leviticus. The only exceptions could be Lev 10:17; 16:21-22; and 22:16, where the contexts do not indicate whether intentional or unintentional sins, or both, are in view. It is very likely that עָָּ refers to unintentional sin in these instances. An analysis of Lev 16:21 will be provided below after all three terms for sin have been analyzed. Lev 10:17 seems to imply the metonymic use of the term, referring to the three components of sin: act, guilt, and punishment. 
This understanding of עָּ also does not coincide with Gane's understanding that עָ refers to culpability in Leviticus $1-16 .{ }^{720}$ The research just presented suggests that it refers to any sinful element, including sin, guilt, and punishment, and sometimes all of them.

\section{The Root}

The term is used 134 times in the OT including 41 verbal forms (40 times in qal and 1 time in niphal) and 93 nominal forms. The commonly accepted meaning of the term is "dispute, rebellion," based on the understanding of Exod 22:8 suggested by L. Köhler. Knierim found Köhler's exegesis untenable based on the fact that the term refers to various sins that cannot be classified as dispute or rebellion such as Gen 31:36: Jacob's potential theft of Laban's gods; Gen 50:17: the act of Joseph's kidnaping by his brothers; 1 Sam 24:10-14: David's potential murder of Saul; Prov 28:24: the act of a son's robbing his parents; Amos 1:3, 6, 9, 11, 13; 2:1:various criminal acts, and other texts. ${ }^{721}$

Knierim, noting that the exegesis of Exod 22:8[9] does not support dispute or rebellion, stated that the assumption of a dispute in this case "rests on inconsistent and self-contradictory exegesis of the verse." ${ }^{, 722} \mathrm{He}$ suggested that translating the nominal

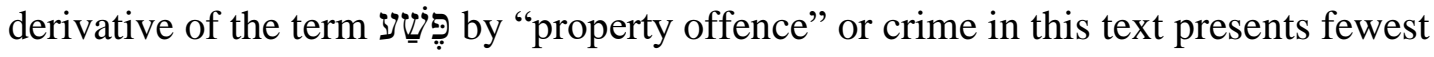

\footnotetext{
${ }^{720}$ Gane, Cult and Character, 294.

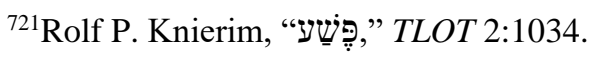

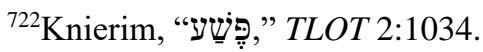


difficulties. In addition, it is supported by Deut 22:1-3, which is considered to be the oldest exegesis of Exod 22:8. ${ }^{723}$

He also suggested that the verbal form of this term should be translated with "to break with,"724 rather than with "to rebel." Knierim justifiably questioned whether the verb in $2 \mathrm{Kgs} 8: 20,22$ "refers to a basic process of completed disengagement from a social union or only to the process of rebellion, of protest against the union, whether successful or not. Consequently, the definition of the term must involve a distinction between (completed) separation and (attempted) rebellion." The context of this text,

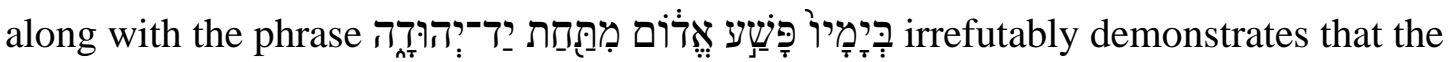
separation was achieved, which further leads to the conclusion that this act was a type of removal of property. Thus, he preferred "to break with," over "to rebel." The apparent incongruity of the former translation is found when the term is accompanied by the

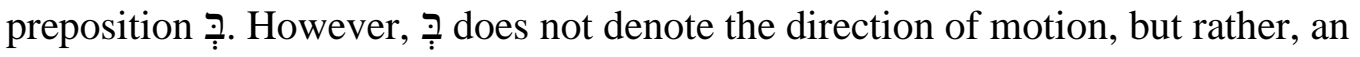
association. The association of the term with the preposition עַ is unique and may denote secondary usage and, having in mind circumstances, may be translated with "to suffer revolt." $" 725$

Based on these remarks, Knierim suggested that nominal forms of formal category that is comprised of various types of personal and material crimes described by the verbs such as "to rob," "to steal," "to lay hand on," and so on, whose

\footnotetext{
${ }^{723}$ Knierim, “עשฺֶָׁ," TLOT 2:1035.

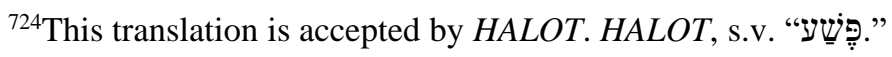

${ }^{725}$ Knierim, “雨”, TLOT 2:1035.
} 
meaning is not included in the semantic range of legal technical term for crimes that were subject to legal penalties."726 The verbal forms, implying some sort of loss, removal of a segment of a state structure, are to be translated with "to break with," "to break away from," "to behave criminally," or "to suffer loss, crime, breach" depending on the literary contexts. ${ }^{727}$

Based on the meanings he derived from researching both nominal and verbal forms of

Whoever commits peša ' does not merely rebel or protest against Yahweh, but breaks with him, takes away what is his, robs, embezzles, misappropriates it. Although it always implies conscious behavior, the term per se does not describe the attitude, but the criminal act that consists in removal of property or breach of relationship. As a result, in the OT, the most serious aspect of the sin phenomenon is the offense as a breach, but not "the revolt of the human will against the divine will." 728

Knierim, followed by Seebass, ${ }^{729}$ indicated a profound implication due to the fact that the term was used in a variety of distinctive contexts: "Finally, then, peša 'does not mean "sin." For just as surely as the term has a theological dimension, the OT is in general interested in speaking of 'sin' in such a way as to call deeds and procedures by their proper names." 730

H. Seebass suggested a more neutral translation, "offence,"731 than Knierim's

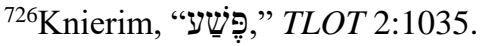

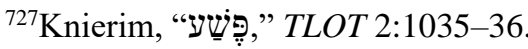

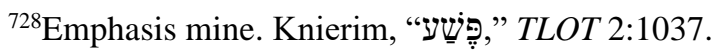

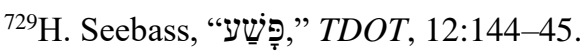

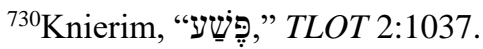

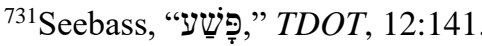


"crime." Lexically, Seebass's suggestion is more plausible and precise since "crime" is a limiting word by associating it to criminal law only ${ }^{732}$ However, it has to be indicated that in Knierim's treatment of this term, he did not limit it to criminal law only, but rather, recognized various contexts in which it is found. Thus, the issue of the translation might be related to Knierim's unsuitable choice of the word, rather than misunderstanding what the term/concept meant. In addition, Knierim's procedure of deriving the meaning from one text and attempting to prescribe it to all subsequent contexts where the term is used shows insensitivity for the context and may lead into an inaccurate representation of what the term refers to. However, his suggestion of translating פֶָ as "crime" does not seem inaccurate in biblical uses of the term.

Seebass's suggestion is more inclusive and also suits the context, but it is informed by his analysis of all OT texts which, on the other hand, includes reading into Exod 22:8[9] what is actually not there. Deciding which of these two suggestions is more accurate does not affect the core of the questions dealt with in the present study and will be left open.

The essential difference between the crime and offence is found in the fact that crime is always violation of the law and is punishable by it, while some offences are not punishable by law. ${ }^{733}$ Carrol has recognized that חָטָ and

The part that is crucially important for the present study is the fact that there is a

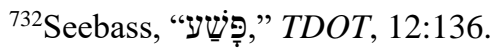

${ }^{733}$ For a more in-depth analysis on crime, see pages $251-66$ of the present study.

${ }^{734}$ R. P. Carroll, “Rebellion and Dissent in Ancient Israelite Society,” ZAW 89 (1977): 181.
} 
solution regarding Exod 22:8 [9] which does not include any of the punishment that Would indicate that that this case is an example of lex talionis being applied to a false testimony ${ }^{735}$ which does not include a terminal penalty, that would classify this sin as inexpiable. With the review of the scholarly research on the term Pentateuch follows.

The Nature of

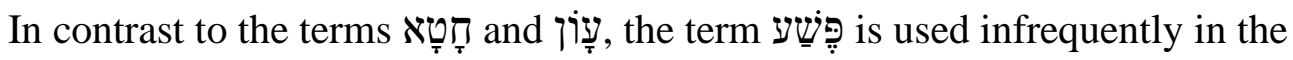
Pentateuch. The nominal form of the term is used 2 times in Leviticus and 7 more times in the rest of the Pentateuch (Genesis, 2x; Exodus, 3x; and Numbers, 1x) to make a total of 9 occurrences. ${ }^{736}$ The verbal form is not used in the Pentateuch, but occurs for the first time in $1 \mathrm{Kgs} 8: 50 .^{737}$

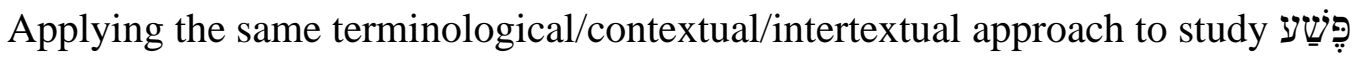

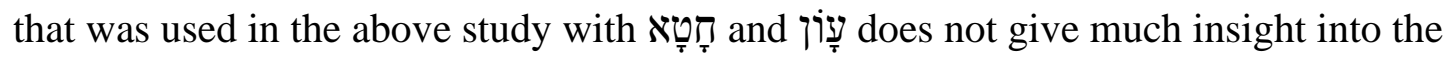
meaning of this term as it did with the previous two terms due to the fact that less frequently used term in the Pentateuch.

\footnotetext{
${ }^{735}$ Wells, The Law of Testimony, 143-44.

${ }^{736}(G e n$ 31:36; 50:17; Ex 22:9; 23:21; 34:7; Num 14:18). Accordance Bible.

${ }^{737}$ Accordance Bible.
} 


\section{Capital Punishment and}

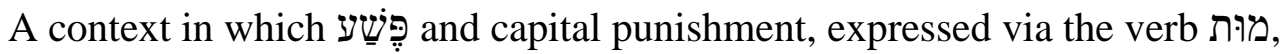
occur together is not detected in the Pentateuch. The syntactical connection can be established in two out of six contexts where these two terms occur together outside of the Pentateuch (2 Kgs 1:1; 3:5; Isa 53:12; 66:24; Ezek 18:28, 31). Both of them are found in the book of Ezekiel. However, these texts will not be considered here because they do not belong to the Pentateuch.

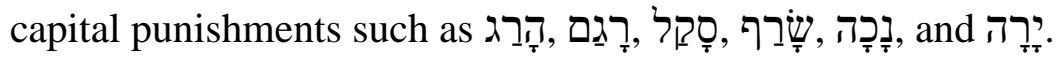

\section{$K \bar{a} r \bar{e} t$ and}

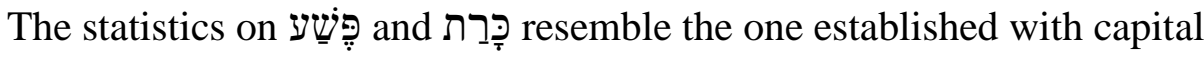
punishment and outside of the Pentateuch (1 Sam 24:12; Isa 50:1; Ps 37:38), the syntactical association between them might be potentially established in Ps 37:38 based on the literary devices

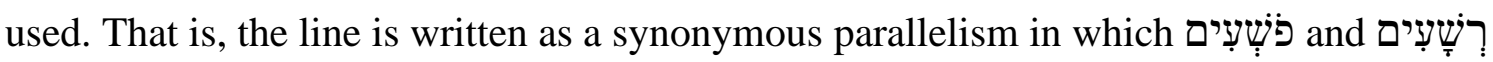
are a lexical pair. However, this text does not belong to the Pentateuch, so the potential insights from it are not considered as the meaning of Hebrew Bible.

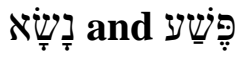

There are four contexts in the Pentateuch in which a syntactical relationship between 
established in this study where the term is analyzed against certain elements provided in a given context such as the activity the term refers to, the sort of punishment it invokes, and whether the sin is expiable/inexpiable and intentional/unintentional (Table 18).

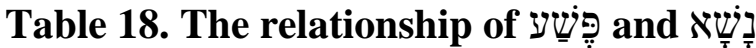

\begin{tabular}{|c|l|l|l|c|c|c|c|}
\hline & \multicolumn{1}{|c|}{ Reference } & Sin & Punishment & Expiable & Inexpiable & Intentional & Unintentional \\
\hline 1 & Gen 50:17x2 & Kidnapping & Death & & $\mathrm{x}$ & $\mathrm{x}$ & \\
\hline 2 & Exod 23:21 & Unknown & Many & & $\mathrm{x}$ & $\mathrm{n} / \mathrm{a}$ & $\mathrm{n} / \mathrm{a}$ \\
\hline 3 & Exod 34:7 & Unknown & Unknown & $\mathrm{x}$ & & $\mathrm{n} / \mathrm{a}$ & $\mathrm{n} / \mathrm{a}$ \\
\hline 4 & Num 14:18 & Unknown & Unknown & $\mathrm{x}$ & & $\mathrm{n} / \mathrm{a}$ & $\mathrm{n} / \mathrm{a}$ \\
\hline
\end{tabular}

Out of four contexts in which 50:17 provides explicit insights for the points sought in the analysis pattern set in this study for sin terminology. The action of Joseph's brother towards him involves accountability for several crimes such as kidnapping, breach of the kinship covenant, and forced usurpation of the father's privilege of selling a family member into slavery. ${ }^{738}$ The context explicitly suggests that the sin of Joseph's brothers was intentional, and later legislative material found in the Pentateuch requires the death penalty for their most obvious sin of kidnaping (Exod 21:16). It is an inexpiable and unforgivable sin. However, all those sins were forgiven (Gen 50:19-20).

The other three texts are actually descriptions of God's dealing with the sins of his people. Two of those three contexts speak of God's willingness to forgive the sins (Exod 34:7; Num 14:18), while in one, it is stated that God will not forgive them (Exod 23:21).

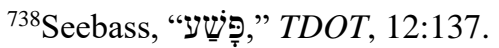


It should be noted that the terminology does not give grounds for an undisputed definition or nature of the sins represented by the term פִּשֶׁ.

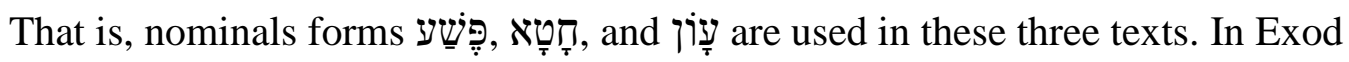
23:21 where it states that God will not forgive the people's sin, the term used is which represents the activity of the verb מָָר which, in piel, means "to make bitter" or in Hiphil, "to cause bitterness, grief." Pentateuch point to a willful decision of someone to make someone else's life bitter by physically attacking/hurting or physically forcing him or her to perform various physical activities (Gen 49:23; Exod 1:14). ${ }^{740}$ The context of the Hiphil use of מָָר in Exod 23:21 can include various activities that make/cause God to feel/be bitter.

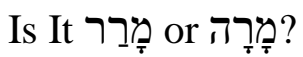

Rolf Knierim's suggestion that the verbal form in this text was probably derived from another root, מָָרָ, "to rebel"741 that points to a more intense intentionality of its subject reflects the understanding commonly accepted by the English Bible translations ${ }^{742}$ that

${ }^{739}$ HALOT, s.v. "מרר."

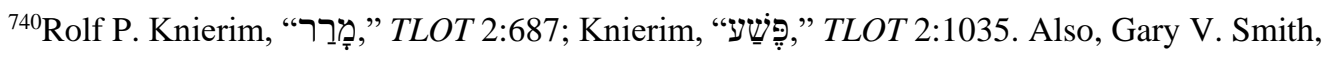
“"מרר," NIDOTTE 2:1103-4; A. S. Van Der Woude, "TLOT 3:1363; Eugene Carpenter and Michael

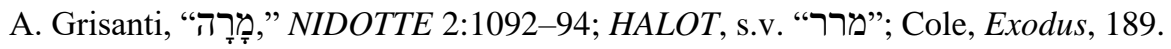

\footnotetext{
${ }^{741}$ HALOT, s.v. "מרה."

${ }^{742} \mathrm{NASB}, \mathrm{NRSV}, \mathrm{ESV}, \mathrm{NET}, \mathrm{NIV}, \mathrm{NLT}$.
} 
emendation of the MT's מָָרָ iñ in into possible under the assumption, favored by the contexts of their uses, that these two roots are equivalents

While the meaning is in little doubt (however, see Rashbam, ibn Ezra), the vocalization is uncertain. The MT Hiph il tammēr appears to be influenced by Aramaic (GKC $\$ 67 \mathrm{~g}, \mathrm{y})$ and assumes the root $m r r$, which ordinarily means "to be bitter" (so Symmachus). However, Sam (tmry), LXX, Aquila, Tgs. and Syr read the Hiphil of mry "rebel," as the context dictates. So we should probably vocalize *temer (GKC §67y) or *tāmèr (assuming a root mrr is equivalent to $m r y$; cf. GKC $§ 77 \mathrm{e}$ ). ${ }^{743}$

However, the uses of מָּר מָרָה do not completely support the claim that the sin of שֶּש expressed by any of these two verbs is unforgivable. The majority of these contexts testify that פֶּשׁׁע could refer to inexpiable/unforgivable sin. However, out of five מָּרָ contexts in the Pentateuch, ${ }^{744}$ Num 20:24 and 27:14 point to the complexity of such sins. That is, the act of בָָרָרה can refer to the sin that requires punishment, in this case, a ban from entering the Promised Land which also included premature death, and in this sense might be regarded as implying inexpiable/unforgivable sin. However, at the same time, textual hints in Num 20:24, 27:14 and the treatment of Moses and Aaron in rest of OT suggest that the treatment of their sin was exceptional and not considered inexpiable/unforgivable regardless of the premature death of both of them.

\footnotetext{
${ }^{743}$ Propp, Exodus 19-40, 136.
}

${ }^{744}$ First, Moses addressed the sons of Israel by using the participle of מָרָרה in Num 20:10. Second, Moses' and Aaron's sin of not obeying God's command at the water of Meribah was described as a קָָָׁ act in Num 20:24; 27:14. Third, Israel's disobedience of God's commands to go and occupy the Promised Land in Deut 1:26; Deut 9:23 or not to go to occupy it in Deut 1:43 was described by the verb מָָרָ. Fourth, the rebellious attitude of the son of Israel in Deut 9:7, 24; 31:27 is expressed by מָָרָ. Fifth, the rebellious son is described by the participle of מָָרָ in Deut 21:18, 20. 
Closer Look at Num 20:10 and

Num 20:24; 27:14

Two contrasting contexts are Num 20:10 and Num 20:24; 27:14. In the first, Moses addressed the sons of Israel as "rebels," while God never addressed them in such a way in this context, but rather, in the latter two texts, God defined Moses' and Aarons' behavior at the Meribah incident as being act of מָָרָ $1{ }^{745}$ Moses' and Aaron's sin was not considered rebellion in the sense of breaking with or separating from God, but rather, expression of their GHS and weakness, since they were "honored in their deaths with all the status and dignity afforded the great patriarchs of Israel." ${ }^{, 46}$ However, it is clear that capital punishment elsewhere implies that these sins were inexpiable/unforgivable in other contexts.

The act of מָּרָ in the third set of contexts always implies capital punishment, thereby indicating inexpiability/unforgiveness of these sins. It should be noted that the main reason for their rebellion, recognized to be disobedience, ${ }^{747}$ was fear ${ }^{748}$ of the Amorites and later, their arrogance ${ }^{749}$ (Deut 1:26, 43; 9:23). ${ }^{750}$ The emphatic presence of

${ }^{745}$ Cole, Numbers, 327-38. For a potential background of Moses' sin, see Milgrom, Numbers, 452.

${ }^{746}$ Cole, Numbers, 340 . See also other valid arguments suggested by Tigay and Merrill related to Moses' burial and details related to it. Jeffrey H. Tigay, Deuteronomy $=$ [Devarim]: The Traditional Hebrew Text with the New JPS Translation, JPSTC 5 (Philadelphia: Jewish Publication Society, 1996), 336-38; Merrill, Deuteronomy, 453-54.

${ }^{747}$ Merrill, Deuteronomy, $75-76$.

${ }^{748}$ Duane L. Christensten, Deuteronomy 1:1-21:9, revised, WBC 6A (Nashville: Thomas Nelson, 2001), 31, 182.

${ }^{749}$ Merrill, Deuteronomy, 86.

${ }^{750}$ It is the fear of the Canaanites that prevented the sons of Israel from beginning to occupy the Promised Land, not their desire to break with or separate from God, which would have indicated a desire to rebel. Their zeal to fight the Amorites in 1:43, regardless of God's revealed will not to, reflects their arrogance, but also a desire to recompense for their previous disobedience and disbelief by appeasing him 
fear also points to the fact that they did not necessarily wanted to break with or rebel against God, but they allowed fear to inform their behavior and decisions, rather than the mighty deeds of God on their behalf. Therefore, the nature of their rebellion is not desire to break with God because of who he was, but rather, they disobeyed his orders because they were afraid. This does not change the final result of their choice which was capital punishment as stated in 14:29, 32, 35, but it does shed light on the nature of their rebellion. In other words, it was instigated by fear, rather than a mere desire to separate from God. The same can be said regarding Deut 9:7, 24; 31:27, which include many incidents, such as at Taberah (Num 11:1-3), Massah (Exod 17:1-7), Kibroth-hattavah (Num 11:31-35), Kadesh-barnea (Num 14-15; cf. Deut 1:19-40) and others. The fear for their physical existence can be added to the background of their rebellion. ${ }^{751}$ Their rebellion was not motivated by their desire to break with or separate from God because they do not want him as a leader, but rather by fear originating from their disbelief in what God can do.

These מָרָר contexts describe the attitude of the Israelites during their journey after the Exodus from Egypt, and they included capital punishments, but the texts do not provide much clarity as to who, exactly, was punished. They do show that not all the

in order to withdraw his punishment over them. The actual account of the event referred to in Deut 1:26 is found in Num 13-14 and the activity of the sons of Israel is never described by the term מָרָ in these two chapters. Even more emphatic words used in chapter 14 to refer to their activity and character such as

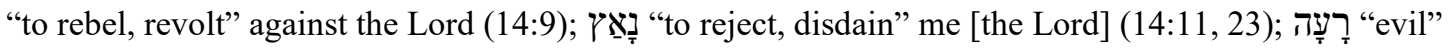
congregation who are gathered together or to grumble against Me (27,35); עָבָר "to transgress" the commandment of the Lord (14:41) should include the fact that the underlying factor of their behavior was fear. It is explicitly stated two times in 14:9 that a driving force behind their rebellious disobedience to God was fear. Having seen all the miraculous acts of God, the sons of Israel should not have developed such a fearful attitude.

\footnotetext{
${ }^{751}$ Stuart, Exodus, 390.
} 
participants of certain events were punished. Christensen captured this by stating that "the long history of Israel's perfidy underscores that they would not be standing in the plains of Moab to renew their covenant but for the grace of God."752 This provides grounds for the claim that God punished those who deserved punishment and spared those who did not.

The final context of Deut 21:18-21 could be used to claim that rebellion in the sense of wanting to separate from God because of who he was, in contrast to the previous two sets of contexts. This context contains references to a young man's continuous behavior against God's commandments, particularly the fifth. ${ }^{753}$ The rebellious attitude of his persistent breaking of God's commandment, even though he was warned not to do so (the negated form of the verb שָָמָע is repeated 2 times in v. 18 and 1 time in v. 20) shows that the son wanted to break with God.

These points of the מָָרָ contexts demonstrate that there is no solid textual ground

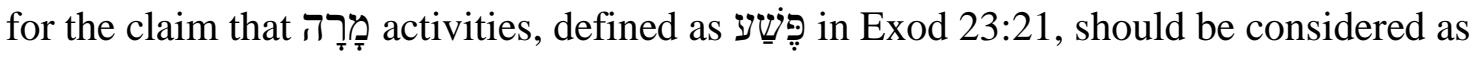
inexpiable/unforgivable sin.

Moreover, it is probable that Exod 23:21 should be read with מָָרָרה and not, since this verb refers to the bitter, resentful attitude of the sons of Israel. In the following quotation, John I. Durham emphasized the broader context of Exod 23:21 that confirms

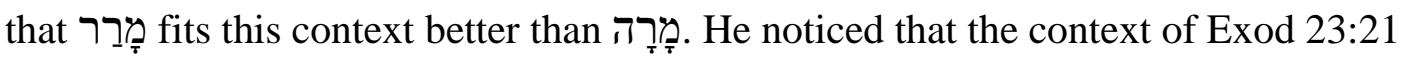

\footnotetext{
${ }^{752}$ Duane, Deuteronomy 1:1-21:9, revised: 187.

${ }^{753}$ Gane, Old Testament Law for Christians, 259-60.
} 
stresses the totality of Israel's journey which, in turn, does not favor the rebellion sense

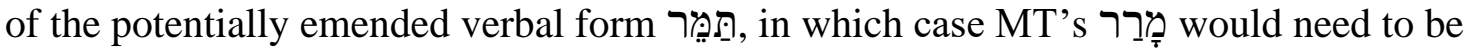
changed to מָרָרה. Rather, the verb reveals Israel's wrong attitude towards God:

This is why the messenger's guidance can be trusted: his guidance is Yahweh's guidance into the land "made ready," the gift of which will fulfill the second half of the covenant promise of progeny and land. Exodus begins with an account of the first half of this promise, and ends, at least in its narrative sequence, with the anticipation of the fulfillment of its second half. Paying close attention to the Presence of Yahweh's messenger and listening to his voice is equal to paying close attention to Yahweh's Presence and listening to Yahweh's voice. They must not "resent" or "be bitter against (מרר) the "messenger's" guidance and counsel, because to do so will bring punishment authorized by Yahweh, whose "name" (שמר = "Presence") is "within him" (בקרב).

The use of מָָרבר makes more sense if the diachronic element of the text is taken into consideration since at the point the warning in Exod 23:21 was stated, many events of Israel's rebellious acts were still in the future. Later, this attitude, in some cases of their journey, would grow into מָרָָ, rebellion, while in some cases, it remained just a wrong, provoking attitude toward God.

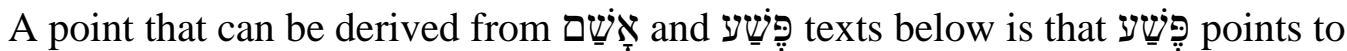
intentional and planned activities. It is noteworthy that the rebellious son in Deut 21:1821 is described with the participial form in v. 20, which conveys a definite decision of the subject to continue with his attitude of rejection and rebellion. As such, these activities have the potential of being considered as unforgivable sins. The doer actually does not want forgiveness.

Continuing to describe the nature of God, Exod 34:7 includes the full triad of

\footnotetext{
${ }^{754}$ Durham, Exodus, 335.
} 


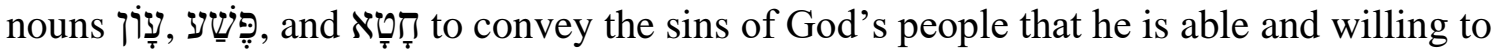
forgive his people. The semantic domain of uncertain from this text. It may refer to either intentional or unintentional sins. However, the text does indicate that and since the term covers both intentional and unintentional sins in the Pentateuch, it seems reasonable to accept the proposal of Knierim and others ${ }^{755}$ that when this triad is found, it points to the totality of sin without strictly assigning particular meaning to any of them. ${ }^{756}$ In other words, פֶּ can refer to both expiable and inexpiable sin, as well as intentional and unintentional sin with the context determining which meaning is intended depending on the context. The wider literary context of this text is idolatry recorded in Exod 32, but the lexical link between idolatry and In addition, the text portrays the forgiving trait of God's character which includes forgiving sin in its totality.

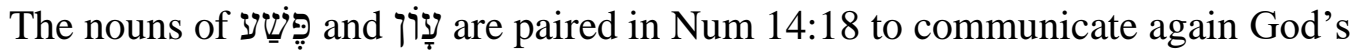
willingness to forgive his people's sins. Even though the noun חָטָ is omitted in this text, it heavily relies on Exod 34:7 through multiple lexical and topical similarities. ${ }^{757}$ However, even though God forgave people's sin of rebellion against him, they were

\footnotetext{
${ }^{755}$ Stuart, Exodus, 717. The same idea is implied in Keil's comment on Lev 16:21. Keil and Delitzsch, The Pentateuch, 2:402-3. Also, Harrison, Leviticus, 175-76; Luc, "הטח," NIDOTTE 2:88.

${ }^{756}$ Knierim, "“ט,," TLOT 1:410.

${ }^{757}$ God promised that he would forgive people's sins and he reminded the people of the need to be obedient in order to see his miracle of driving multiple nations before them. Cole, Numbers, 232.
} 
punished with the mitigated penalty of not entering the Promised Land. As with the previous text, the wider literary context of this text is rebellion recorded in the previous verses, but the lexical link between rebellion and addition, the text depicts the forgiving characteristic of God's character which involves forgiving sin in its totality.

\section{草 and}

That sin expressed by the noun testimony in Lev 5:20-26 [6:1-7]. False testimony is mentioned six times in the OT, two times in the Decalogue (Exod 20:16; Deut 5:20), two times in the Covenant code (Exod 22:6-8 [7-9]; 23:1-3), once in Lev 5:20-26 [6:1-7]; and once in Deut 19:16-21. ${ }^{758}$ False testimony seems to be a part of the law of deposit in Exod 22:6-8 [22:7-9]. Exodus 22:68 [7-9] portrays a situation where one person deposits his or her belongings for safekeeping with another person. When those belongings are missing, the law implies two potential situations: (1) The belongings could have been stolen from the receiver and the thief has been apprehended, or (2) no third party has been involved which further implies two additional scenarios: (1) The receiver illegally appropriated some of the belongings and perhaps falsely alleged that they were stolen, or (2) the receiver claims the purported owner never deposited his/her belongings to the receiver or not in the amount/s they claim. The guilty party in the first scenario is the receiver, whereas the

\footnotetext{
${ }^{758}$ Wells grouped the texts in a different way. Wells, The Law of Testimony, 134.
} 
purported owner is liable in the second. ${ }^{759}$ The law focuses on the first of the two scenarios, namely that the receiver misappropriated the belongings of the owner. ${ }^{760}$ Verse 7 [8] states that in order to determine the receiver's guilt or innocence, he/she must go to Elohim for a decision. This part of the law could have been referring to the judicial oath or divine oracle, and the punishment ${ }^{761}$ is spelled out at the conclusion of v. $9 .^{762}$ However, there is an expansion of the list of possible belongings in v. 9 before the penalty is stipulated to other kinds of property including cattle and clothing. It is obvious that the punishment for this illicit treatment of other's belongings does not include any sort of capital punishment. Instead, the punishment in both scenarios, when a thief is identified, or the receiver or depositor is found guilty, is double the worth of the belonging/s. ${ }^{763}$ The term However, the hint that designation for all these illicit activities is [6:1-7] causing sin in Exod 22:6-8 [7-9] causes אָָׁ in Lev 5:20-26 [6:1-7] lead to the conclusion that

${ }^{759}$ Wells, The Law of Testimony, 141-42.

${ }^{760}$ Wells, The Law of Testimony, 142.

${ }^{761}$ On the punishment issue, see Bruce Wells, "Exodus," in Genesis, Exodus, Leviticus, Numbers, Deuteronomy, vol. 1 of ZIBBCOT, ed. John H. Walton, 5 vols. (Grand Rapids, MI: Zondervan, 2009), $141-42$.

\footnotetext{
${ }^{762}$ It is more likely that this part of the law refers to the divine oracle. Wells, The Law of Testimony, 142.

${ }^{763}$ Wells, The Law of Testimony, 142-44.
} 
בֶּ but are expiable and forgivable.

The specific issue in this law is that the defendant takes a false oath. The following statement from Milgrom reflects his careful reading and accurate interpretation of the function of the phrase, "and then he swears falsely," in v. 22: "This clause does not specify a discrete wrong. Rather, it applies to all of the preceding cases: not only has the offender wronged his fellow but he has denied it under oath." ${ }^{" 764}$ Commenting on the possible misdeeds listed in v. 21-22, Wells identified 3 of them: "Lying about property of another that was not lost and then discovered, but that was taken in some other way; extorting property from another; and lying about the property of another that was lost."765 That is, the defendant is accused of having in his possession an item that most likely belongs to the person who claims it. The defendant denies the charge under oath, but later decides to confess his misdeed and restore it to its owner. Of the first misdeeds, the first one undoubtedly is dealt with in the law of deposit in Exod 22:6-8 [7-9]. Milgrom recognized that "the bailee laws of Exod 22:6-12 are subsumed under piqqādôn and represent no new category."766 Thus, the same misdeed that are designated by Exod 22:2-8 [7-9] are contained in Lev 5:20-26; in the case of the latter text, a new element is the oath and the fact that they are treated as sins against God, but in both cases,

\footnotetext{
${ }^{764}$ Milgrom, Leviticus 1-16, 337

${ }^{765}$ Wells, The Law of Testimony, 139.

${ }^{766}$ Milgrom, Leviticus 1-16, 367; Toorn, Sin and Sanction in Israel and Mesopotamia, 19.
} 
they are expiable and forgivable. Accordingly, sins in the Pentateuch.

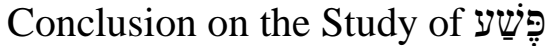

Based on the biblical texts, it seems that terms like property offence, crime, or simply offence fit better what verbal forms, implying some sort of loss, are to be translated with "to break with," "to break away from," "to behave criminally," or "to suffer loss, crime, breach," depending on the literary context. The nominal form refers to various acts that are described with the verbs such as "to rob," "to steal," "to lay hands on," and so on, whose meaning is not included in the semantic range of legal, social, and ethical. It is used in parallel with עָָּוֹ

Within the limits of the Pentateuch, $k \bar{a} r \bar{e} t$ punishment. A study of insights into the nature of the sins it refers to. That is, in Gen 50:17, שֶֶׁׁ refers to intentional sin that deserves the death penalty, but the sin was forgiven. Other texts include Exod 34:7 and Num 14:18, where God stated that he would forgive Exod 23:21, where God said that he would not forgive it. These texts, however, do not give undisputed guidelines regarding the nature of the sins expressed by

Exodus 23:21 includes clues to state that God or his angel does not forgive sin because the sinner does not ask for or want forgiveness. In Exod 34:7, God assures that he will forgive 
way as inexpiable sin. Thus, it seems preferable to accept the proposal that the triad used here

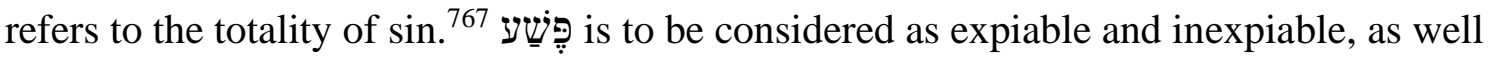
as intentional and unintentional sin. Determining which type of $\sin$ is in view depends on the immediate and broader literary context.

Numbers 14:18 is an allusion to Exod 34:7 with the omission of Tָּ God declares that he will forgive

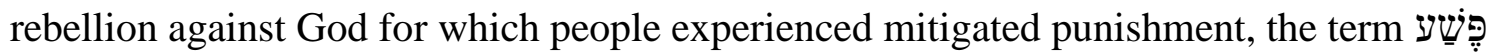
is never associated with the rebellion in Num 14. The most solid clue that intentional, but yet expiable sin is found in the fact that a sinner experiences 5:20-26 for the list of sins of which one is expressed by פֶּ described in detail in Exod 22:8. This is also intentional, but yet expiable sin.

\section{Conclusion on the Study of}

Based on the research conducted in the present study which included an application of the terminological/contextual/intertextual approach on the three key terms for sin in the Pentateuch, it has been demonstrated that own distinct characteristics by which they refer to the concept of sin. However, at the same time, they often semantically overlap. The present study suggests three implications

\footnotetext{
${ }^{767}$ The meaning/function of this triad in Lev 16:16, 21 is closely examined under the subheading, "Interpretation of Lev 16:21" and "William H. Shea's Proposal," of the present study.
} 
about these terms regarding their (1) intentionality and (2) expiation/forgiveness of the sins expressed by them.

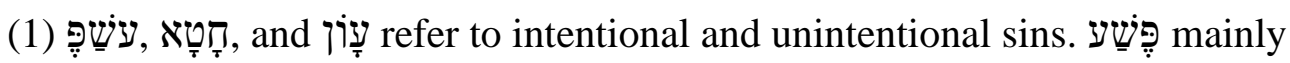
refers to intentional sin (4/6 times) except in two accounts of theophany events in Exod 34:7 and Num 14:18, where it potentially covers unintentional sins because it is used in

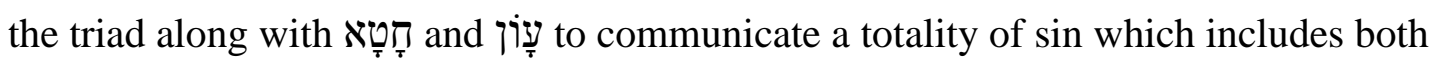
intentional and unintentional sins. Outside of these special events, it always refers to intentional sin.

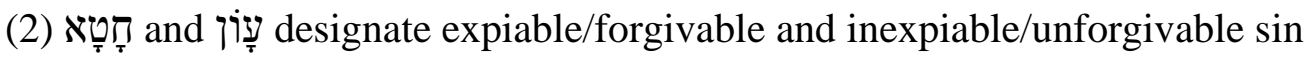
whereas פֶּ expresses an inexpiable/unforgivable sin.

(3) On the one hand, in some contexts, all of them refer to expiable/forgivable sins, while on the other hand, in some contexts, they all designate inexpiable/unforgivable sins.

With this in mind, Gerhard von Rad could not be more correct when he reflected upon his own terminological study and stated, "As can be well understood, as far as terminology went, Israel had very varied ways of expressing what she understood by sin, for of course there were very many ways in which she met the phenomenon of sin. ... But such a statistical review, even if were prosecuted in much more details, would still come far short of disclosing what is the heart of the matter for theology."768

\footnotetext{
${ }^{768} \mathrm{Rad}$, Old Testament Theology, 1:263.
} 
Terminology that expresses ritual and moral impurity does not give grounds for the claim that חָטָׁא, give grounds for the claim that טָָמָא can express one of the two types of impurity,

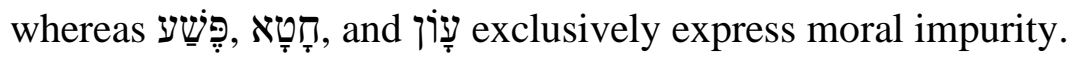

The current study agrees with Lam, who defined sin in the OT as follows: "Sin denotes personal wrongdoing, which in biblical terms has to do either with actions (moral or cultic) that violate the will of God (i.e., sin as an act), or with the human condition resulting from such behavior (i.e., sin as a state-encompassing the ideas of sinfulness and guilt). ${ }^{{ }^{769}}$ This definition basically conveys a conceptual understanding of sin. It is comprehensive, but yet refers to the main components of which sin is composed: (1) it is a wrongdoing, (2) it can come out of a state or activity, and (3) it can be moral or cultic/ritual in its nature.

\section{Ontology of Impurity}

As was established in chapter two, ritual and moral impurity are conceptual entities. As such, impurity is emptied of cognitive and motor skills characteristic of live entities, such as motion, thinking, and instinct. Maccoby and Milgrom assigned some sort of literal material nature to impurity, such as gas, miasma, radiation, or electricity. ${ }^{770}$ Gane, on the contrary, endorsed J. Porter's, appealing but yet misleading, assertion on the nature of moral impurity: "In the priestly theology, sin is an objective, quasi-physical

\footnotetext{
${ }^{769}$ Lam, "Metaphorical Patterning," 8.

${ }^{770}$ Maccoby, Ritual and Morality, 19-22, 169; Milgrom, Leviticus 1-16, 257.
} 
thing-hence, even if committed inadvertently, its consequences cannot be avoided — and so not sharply distinguished from defilement or uncleanness."

In Gane's understanding, impurity is a conceptual, but yet quasi-physical entity with the ability to behave like a living and, to some extent, an intelligent entity, namely, to travel from one point to another. Gane stated that "because the defilement in question is conceptual, it can have an effect through space in the sense that it causes a change of state to occur at a distance."772 $\mathrm{He}$ also stated that

words such as "miasma" or "ray" may be helpful as metaphors for explaining to the modern mind a dynamic that that connects objects located at some distance from each other, provided it is clear that in our ritual context they do not refer to literal physical substances subject to physical constraints in the material world, such as the time it takes for miasma or even radiation to spread. ${ }^{773}$

These quotations from Gane contain serious contradictions. First, the concept does not possess a physical quasi-physical quality to it. It is a mental construct and, as such, is purely abstract. It does not even look like a miasma or ray that could be characterized as quasi-physical entity. Schwartz stated the following about ritual impurity which at rare occasions can have physical characteristics "though invisible, it is believed to be quite real; though amorphous it is substantive."774 This can be applied with more force to moral impurity. Second, biblical metaphors are rooted in well-known and established realities that operate within physical limitations. For instance, the metaphor of

${ }^{771}$ Porter, Leviticus, 37; Gane, Cult and Character, 159.

${ }^{772}$ Gane, Cult and Character, 160.

${ }^{773}$ Gane, Cult and Character, 160.

${ }^{774}$ Baruch J. Schwartz, "Leviticus," in The Jewish Study Bible, eds. Adele Berlin and Marc Zvi Brettler, 2nd ed. (Oxford: Oxford University Press, 2014), 230. 
load is used in the OT to represent sin. However, this metaphor of load that portrays that sin produces a pressure on the sinner's shoulders that is a well-known reality and possesses physical limitations. A load referred to in this metaphor is a purely abstract entity without any physical or quasi-physical component to it and cannot jump from one sinner to another or travel to the sanctuary. The assumption that any sort of physical or quasi-physical component is related to it would greatly diminish if not eliminate the symbolism of the concept of impurity in the defilement of the sanctuary aspect of the biblical sacrificial system. 


\section{CHAPTER 3}

\section{INSIGHTS FROM MODERN LEGAL SYSTEMS AND BIBLICAL LAW ON INTENT AND EXPIABILITY/INEXPIABILITY IN THE PENTATEUCH}

The second part of the first section is covered in this chapter. A taxonomy of crime is necessary in order to develop a basic conceptual framework and take part in a more productive dialogue concerning the nature of sins. The purpose of this subheading is twofold. First, it introduces fundamental concepts of modern legal systems which assist in clarifying concepts used in scholarly dialogue on the topic and present study. Second, it provides a rationale for using simple, yet biblically informed, legal terminology. The subsequent part of the present study shows that these fundamental concepts were present, but judging from the records, more implicit in the biblical legislative corpuses. The following interrelated concepts are vital for a meaningful conversation on sin: (1) mens rea and actus reus, (2) types of wrongs, (3) intent or mental state/s, (4) negligence, and (5) ignorance.

\section{Mens Rea and Actus Reus}

The following quotation presents two basic elements of which a crime consists: "A fundamental principle of Criminal Law is that a crime consists of both a mental and a physical element. Mens rea, a person's awareness of the fact that his or her conduct is 
criminal, is the mental element, and actus reus, the act itself, is the physical element."1

An act is not considered a crime if any of these two elements is missing. ${ }^{2}$

Mens rea is considered to be the internal side of the committed wrong. ${ }^{3}$ Mens rea

refers to the mental process of the offender associated with the wrong he/she committed.

It is also called intent or culpability. ${ }^{4}$ Mens rea or intent is sometimes equated with

motive, but motive is a slightly different concept ${ }^{5}$ and will be discussed below.

\section{Types of Wrongs}

Modern legal systems ${ }^{6}$ recognize two types of these wrongs which lead to harm:

(1) torts or civil wrong and (2) crimes. ${ }^{7}$ Some add one more type called moral wrongs,

\footnotetext{
${ }^{1} B L D$, 8th ed., s.v. "Mens Rea." See also Norman M. Garland, Criminal Law for the Criminal Justice Professional, 2nd ed. (New York: McGraw-Hill, 2009), 61; George P. Fletcher, Basic Concepts of Criminal Law (Oxford: Oxford University Press, 1998); Garland, Criminal Law for the Criminal Justice Professional (2009), 61; “Actus Reus and Mens Rea,” Google, https://www.google.com/\#q=actus+reus+and+mens+rea.

${ }^{2}$ Garland, Criminal Law for the Criminal Justice Professional (2009), 61.

${ }^{3}$ Fletcher, Basic Concepts of Criminal Law, 112.

${ }^{4}$ Garland, Criminal Law for the Criminal Justice Professional (2009), 66.

${ }^{5}$ Garland, Criminal Law for the Criminal Justice Professional (2009), 67.

${ }^{6}$ I agree with Westbrook's definition of modern law: "By modern law I mean law based upon the Common Law or Civil Law traditions, as mediated by the Enlightenment of the eighteenth century and consequently characterized by restless innovation. The two traditions have been carried, in part by imperialism and in part by their own intellectual force, to virtually every corner of the globe. Today they are the basis, directly or indirectly, of the legal systems of most of the member states of the United Nations and of international law. The only other widely prevalent legal traditions are conservative systems: local customary law and religious law." Raymond Westbrook, "The Character of Ancient Near Eastern Law," in A History of Ancient Near Eastern Law, eds. Raymond Westbrook and Gary M. Beckman, Handbook of Oriental Studies, Section 1: The Near and Middle East 72/1 (Leiden: Brill, 2003), 1:1.

${ }^{7}$ Fletcher, Basic Concepts of Criminal Law, 77; Westbrook and Wells, Everyday Law in Biblical Israel, 69; Kenneth W. Simons, "The Crime/Tort Distinction: Legal Doctrine and Normative Perspective," WLJ 17 (2008): 719-32; Kenneth W. Simons, "Deontology, Negligence, Tort, and Crime," BULR 273 (1996): 273-99; Anthony Phillips, Essays on Biblical Law, JSOTSup 344 (London: Sheffield Academic Press, 2002); Westbrook, "The Character of Ancient Near Eastern Law," 1:1.
} 
which may actually be objects of both civil and criminal proceedings, but not all moral wrongs are classified as crimes or torts. This is due to the fact that criminal law does not seek to punish thoughts or moral character, but just acts or omissions that cause social harm. ${ }^{8}$ Therefore, the first two concepts will be presented below.

The definition of tort and crime suggested by biblical scholar Raymond Westbrook resembles the definitions of the tort ${ }^{9}$ or crime ${ }^{10}$ found in modern legal literature and sources. He defines the tort as follows: "A tort is conceived of purely as a personal wrong against the victim. The initiative for proceeding against the tort-feasor (guilty party) is solely in the hands of the victim, and the role of the court is to compensate the victim for any harm caused him."11 The following quotation compliments Westbrook's definition of tort: “A tort is a legal wrong committed against a person or property independent of contract. A tort is either an intentional act that causes damage to legally protected interest, or the breach of a legal duty that is the proximate cause of harm to a legitimate interest of another."12 The tort can be an intentional or unintentional act, but is, by rule, a personal wrong towards another person. In addition, the initiation of a

${ }^{8}$ Garland, Criminal Law for the Criminal Justice Professional (2009), 58.

${ }^{9}$ ERLA, s.v. "Torts and Religious Organizations"; David Partlett, "Torts," OEBL 2:407; "Tort," Wikipedia, released 17 July 2017, https://en.wikipedia.org/wiki/Tort; Dan B. Dobbs, The Law of Torts, HSer (St. Paul, MN: West Group, 2000), 5; Westbrook and Wells, Everyday Law in Biblical Israel, 69; Fletcher, Basic Concepts of Criminal Law, 77; Garland, Criminal Law for the Criminal Justice Professional (2009), 56. The crime required the "taking from possession and carrying away of a thing with the intent permanently to deprive the owner of his property." Fletcher, Basic Concepts of Criminal Law, 79.

\footnotetext{
10“Crime,” Wikipedia, released 17 July 2017, https://en.wikipedia.org/wiki/Crime.

${ }^{11}$ Westbrook, "Punishments and Crimes (OT and NT)," 5:548.

${ }^{12}$ ERLA, s.v. "Torts and Religious Organizations"; Dobbs, The Law of Torts, 3.
} 
legal procedure depends on the victim. Compensation to the victim is regulated by legal institutions.

The nature of a crime is different, as Westbrook's definition ${ }^{13}$ of it shows: "A crime, by contrast, is conceived of as a wrong to society, in which the harm to the particular victim is incidental — indeed, there may be no specific victim at all. The initiative is in the hands of the state, which may proceed irrespective of the victim's wishes; and the purpose is to punish the offender." ${ }^{\prime 14}$ Even though an individual can also be harmed in the event of a crime and initiate retaliation, it is the state that is the primary party which prosecutes and sanctions the offender. ${ }^{15}$

It has been recognized that certain acts can fall into both of these two basic categories, crimes and torts, both in biblical and MLS. ${ }^{16}$

As was mentioned above, the two legal terms crucial for examining both types of wrongs, torts and crimes, are intent and negligence. Modern legal systems recognize the difference between intentional and negligent wrongs, but disagreement appears when it comes to the definition or the implications of these two types of liability. It is also assumed that intentionally committing a wrong is worse than committing it negligently

\footnotetext{
${ }^{13}$ Westbrook's definitions of crime, as his definition of tort, also resemble definitions of crime found in legal literature and sources. See BLD, 8th ed., s.v. "Crime"; Paul Bergman and Sara J. BermanBarrett, The Criminal Law Handbook: Know Your Rights, Survive the System (Berkeley, CA: Nolo Press, 1997), 24/22; Fletcher, Basic Concepts of Criminal Law, 77. For a more in debt discussion on definition and nature of tort and crime, see Simons, "Deontology, Negligence, Tort, and Crime," 273-99.

${ }^{14}$ Westbrook, "Punishments and Crimes (OT and NT)," 5:548; Dobbs, The Law of Torts, 5. Also, Moshe Greenberg, "Crime and Punishment," IDB 1:733.

${ }^{15}$ Garland, Criminal Law for the Criminal Justice Professional (2009), 56.

${ }^{16}$ Westbrook, "Punishments and Crimes (OT and NT)," 5:548; Fletcher, Basic Concepts of Criminal Law, 57.
} 
and bears higher responsibility. The key to separating these two ways of committing a crime is the factor of knowledge, desire, commitment, or likelihood of execution. ${ }^{17}$ In order to do so, legal systems have established four types of wrongs that are associated with a certain level of responsibility. ${ }^{18}$ As will be noticed below, the level of responsibility grows along with the level of consciousness/awareness or knowing the one who does something wrong.

The process of establishing responsibility in the event of committed wrong starts with the possibility of accident where the level of responsibility is the lowest and progresses to negligence, intention, and bad motive, with a gradual increase of responsibility with each new possibility. ${ }^{19}$ Accident has the lowest possible level of responsibility of the actor. By rule, "accidents are possible only where there is a conceptual gap between the action and the consequence. This is the case with regard to homicide, battery, and arson but not true relative to rape, larceny, and burglary." ${ }^{20}$ The subsequent possibility is the negligent act where the level of responsibility is higher. Negligence is closely related to accident and differs from it in the fact that the actor has the ability to avoid harm by exercising due care-acting reasonably or nonnegligently. ${ }^{21}$ The concept of negligence is discussed below in more detail.

A major conceptual divide exists between accident and negligence on one hand,

\footnotetext{
${ }^{17}$ Fletcher, Basic Concepts of Criminal Law, 112.

${ }^{18}$ Fletcher, Basic Concepts of Criminal Law, 113.

${ }^{19}$ Fletcher, Basic Concepts of Criminal Law, 113.

${ }^{20}$ Fletcher, Basic Concepts of Criminal Law, 113.

${ }^{21}$ Fletcher, Basic Concepts of Criminal Law, 113.
} 
and intent and bad motives on the other. The matter of intent assumes the second highest level of responsibility and can exist independently prior to actions, as well as in the actions themselves. In other words, an actor comes to the point where he/she intends to perform the criminal act which later translates into an actual criminal act. The intention of performing the act is formed before the action confers upon it its particular quality as a criminal act. ${ }^{22}$ The act of the bad motive represents the highest level of responsibility. Motive refers to the emotions which prompt a person to perform an act. ${ }^{23}$ Motives form a basis for distinguishing between various levels of bad intentional conducts. These levels of bad intentions make a difference between various types of certain crimes, the most notable being homicide and theft. ${ }^{24}$

\section{Intent or Mental State/s in the MLS}

Modern legal systems have various definitions of mens rea, but a consensus has been reached on the following four types. In the past, legal systems used to employed various phrases that consisted of the adjective plus the noun "intent" to refer to a specific mental state or mens rea. The three most common are (1) special intent which refers to the consequences which surpass the performing a criminal act itself, (2) a general intent which refers to the actual act of a crime, and (3) transferred intent that holds an actor liable even if he/she did not intend the consequences of the act. ${ }^{25}$ However, it has been

\footnotetext{
${ }^{22}$ Fletcher, Basic Concepts of Criminal Law, 121.

${ }^{23}$ Garland, Criminal Law for the Criminal Justice Professional (2009), 67.

${ }^{24}$ Garland, Criminal Law for the Criminal Justice Professional (2009), 124.

${ }^{25}$ Garland, Criminal Law for the Criminal Justice Professional (2009), 67.
} 
noted that these phrases, along with the others ${ }^{26}$ used in the legal system are confusing and complicated. ${ }^{27}$ Thus the following four phrases ${ }^{28}$ that describe the way an act has been realized began to be used more frequently:

1. Acting with Purpose. This mental state consists of two subcategories. With respect to the result of conduct, "the perpetrator's voluntary will is to act in a certain way or produce a certain result." 29 With respect to attendant circumstances, "the perpetrator is aware of conditions that will make the intended crime possible." ${ }^{30}$ In other words, the perpetrator's voluntary wish is to act in a certain way or construct a certain result.

2. Acting knowingly. This mental state consists of two subcategories. With respect to the result of conduct, "the perpetrator commits an act aware that it is practically certain that his or her conduct will cause a certain result." ${ }^{31}$ With respect to attendant circumstances, "the perpetrator commits an act aware that his or her actions are criminal or that attendant circumstances made an otherwise legal act a criminal one." ${ }^{32}$ Accordingly, the perpetrator acts knowing well that his/her behavior will cause a certain result.

${ }^{26} B L D$, 8th ed., s.v. "Intent"; William C. Burton, BLT (1998), s.v. "Intent"; A Dictionary of Modern Legal Usage, 2nd ed., s.v. "Intent."

${ }^{27}$ Garland, Criminal Law for the Criminal Justice Professional (2009), 67; DMLU, s.v. "Intent."

28“"Model Penal Code," Wikipedia, released 2709 2018, https://en.wikipedia.org/wiki/Model_Penal_Code,

${ }^{29}$ Norman M. Garland, Criminal Law for the Criminal Justice Professional, 4th ed. (Dubuque, IA: McGraw-Hill Education, 2017), 71.

${ }^{30}$ Garland, Criminal Law for the Criminal Justice Professional (2017), 71.

${ }^{31}$ Garland, Criminal Law for the Criminal Justice Professional (2017), 71.

${ }^{32}$ Garland, Criminal Law for the Criminal Justice Professional (2017), 71. 
3. Acting recklessly ${ }^{33}$ This mental state is explained in the following way: "The perpetrator voluntarily ignores a substantial and unjustified risk that a certain circumstance exists or will result from the reckless conduct." ${ }^{34}$ Emphasis in this state is on the perpetrator's ignorance of the fact that his/her reckless conduct will result in certain circumstances.

4. Acting negligently ${ }^{35}$ This mental state is defined in the following way: "The perpetrator should be aware that a substantial and unjustifiable risk exists or will result from the negligent conduct. ${ }^{36}$ In other words, acting negligently refers to the perpetrator's failure to know that his/her negligent conduct results in certain circumstances.

\section{Negligence ${ }^{37}$}

A closely related term to the concept of intent is negligence. Black's Law

Dictionary $(B L D)$ defines it as follows: "The negligence is failure to exercise the standard of care that a reasonably prudent person would have exercised in a similar situation; any conduct that falls below the legal standard established to protect others against

\footnotetext{
${ }^{33}$ Reckless conduct is equated with adverted conduct in legal literature. Kenneth W. Simons, "When is Negligent Inadvertence Culpable?: Introduction to Symposium, Negligence in Criminal Law and Morality," CLP 5.2 (2011): 98.

${ }^{34}$ Garland, Criminal Law for the Criminal Justice Professional (2017), 71.

${ }^{35}$ Negligence is paralleled with inadvertent act in legal jurisprudence. Simons, "When is Negligent Inadvertence Culpable?," 98.

${ }^{36}$ Garland, Criminal Law for the Criminal Justice Professional (2017), 71. http://study.com/academy/lesson/mens-rea-definition-types-requirement-examples.html

${ }^{37} \mathrm{On}$ the arguments for objective and subjective negligence, see Fletcher, Basic Concepts of Criminal Law, 117-20; Simons, "When is Negligent Inadvertence Culpable?"; Joseph Raz, "Responsibility and the Negligence Standard," OJLS 30 (2010): 1-18; Nils Jansen, "Duties and Rights in Negligence: A Comparative and Historical Perspective on the European Law of Extracontractual Liability," OJLS 24 (2004): 443-69.
} 
unreasonable risk of harm, except for conduct that is intentionally, wantonly, or willfully disregardful of other's rights." ${ }^{38}$ As such, "negligence in law ranges from inadvertence that is hardly more than accidental to the sinful disregard of the safety of others." ${ }^{\prime 39}$

Kenneth Simons concluded the following concerning negligence:

The conscious choice of a reckless actor can be culpable even though the choosing actor almost never is aware of, much less consciously chooses, all of the morally and legally relevant features of his act. Thus, the actor need not be aware of the illegality, or even the immorality, of his act, in order to deserve blame and punishment; nor must he believe that the risk he is running is unjustifiable. ${ }^{40}$

As such, negligence refers to an unintentional activity, but at the same time it is considered as culpable carelessness. ${ }^{41}$ Modern jurisprudence classifies thirty types of negligence, ${ }^{42}$ some of which even blur the lines between negligence and intention. Types such as wanton negligence, willful negligence, and the combined terms of willful and wanton negligence all depend on awareness, consciousness, and/or the voluntary nature of the activity. In other words, they depend on the intention of a doer. ${ }^{43}$ That is why legislative theorists state that "negligence is indeed a surprisingly complex and pluralist concept." ${ }^{44}$

An example of negligence is found in the law which regulates safety in the event

${ }^{38} B L D$, 8th ed., s.v. "Negligence."

${ }^{39}$ Patrick Devlin, The Enforcement of Morals (London: Oxford University Press, 1965), 36.

${ }^{40}$ Simons, "When is Negligent Inadvertence Culpable?," 112.

${ }^{41} B L D$, 8th ed., s.v. "Negligence"; Brent A. Strawn, "Intention," $O E B L$ 1:433-46.

${ }^{42} B L D, 8$ th ed., s.v. "Negligence."

${ }^{43}$ Strawn, "Intention," 1:443; François Lareau, "The Distinction between Conscious Negligence and Recklessness," revised 2 December 2001, http://www.lareau-law.ca/article-consciousnegligence.html.

${ }^{44}$ Simons, "When is Negligent Inadvertence Culpable?," 98. 
of building a new house. Deuteronomy 22:8 requires the construction of a parapet on the roof of a new house to prevent someone falling down and potentially suffering death. Having someone falling down from his roof and consequently dying is not the homebuilder's intention, but is a possible outcome. Not building the railing would be an act of negligence. This is also similar to the law of goring ox ${ }^{45}$ when it went its ways and gored someone to death, but the owner is not liable (Exod 21:28). However, if the owner knew that the ox was a gorer and the individual was warned, then the owner is liable (Exo 21:29).

\section{Inadvertence}

A sub-category of negligence is inadvertence. Inadvertence is defined as "a fault resulting from not paying attention; a mistake caused by an oversight."46 Inadvertence may result from the following four flaws: (1) motor control (e.g., clumsiness), (2) cognition (e.g., stupidity or short attention span), (3) conation (e.g., weakness of will), and (4) motivation (e.g., character flaws such as selfishness or indifference). ${ }^{47}$ The concept of inadvertence as a sub-category of negligence emphasizes the fact that negligence is intentional conduct, ${ }^{48}$ especially flaws (3) and (4).

Weakness of will is an especially important concept for the overall understanding

${ }^{45}$ Strawn, "Intention," 1:443.

${ }^{46}$ A Dictionary of Modern Legal Usage, 2nd ed., s.v. "Inadvertence; inadvertency.”

${ }^{47}$ Simons, "When is Negligent Inadvertence Culpable?," 108. For a more detailed analysis of these flaws, see Douglas Husak, "Negligence, Belief, Blame and Criminal Liability: The Special Case of Forgetting," CLP 5 (2011): 199-218; Michael S. Moore and Heidi M. Hurd, "Punishing the Awkward, the Stupid, the Weak, and the Selfish: The Culpability of Negligence," CLP 5 (2011): 147-98; Holly M. Smith, "Non-Tracing Cases of Culpable Ignorance," CLP 5 (2011): 115-46.

${ }^{48}$ Frank Jackson, “Weakness of Will,” Mind 93 (1984): 2-4, 6. 
of inadvertence. It refers to a conflict between practical thought and action. ${ }^{49}$ In other words, an agent is intentionally doing something he/she knows is wrong. The concept has a long tradition in the philosophical and lately, psychological conversation. ${ }^{50}$ The first mention of this topic appeared in Plato's Protagoras (352b-356c) and Aristotle's Nichomachean Ethics 7 (2-3) who both referred to Socrates who denied the existence of akrasia $^{51}$ or weakness of will. ${ }^{52}$ In Socrates' understanding, "no one who either knows or believes that there is another possible course of action better than the one he is following will ever continue on his present course." 53

The history of interpretation of this concept portrays two major points that permeate the dialogue. First, the concept of weakness of will has moved from being deeply puzzling and denied in antiquity to being considered as a common component of human experience in the present. Philosophers who, following Socrates, questioned this concept understood that that free intentional act that opposes one's better judgement is

\footnotetext{
${ }^{49}$ Christine Tappolet, "Weakness of Will," IEE 9:5412; HDE, s.v. "Weakness of Will."

${ }^{50}$ Jackson, "Weakness of Will," 1; Byron Williston, review of Weakness of Will from Plato to the Present, ed. Tobias Hoffmann, NDPR (2008, 3 September), https://ndpr.nd.edu/news/weakness-of-willfrom-plato-to-the-present/; Tappolet, "Weakness of Will," 9:5412.

${ }^{51}$ Akrasia is considered a moral state that refers to the lack of mastery. Generally, English uses the noun "incontinence" to translate it. Tappolet, "Weakness of Will," 9:5413. "A literal translation of the Greek term 'akrasia' might be "powerlessness,' signifying 'being overcome by desire' and a consequential loss of self-control." Richard Reilly, "Plato and Augustine on Human Weakness," Cithara 18.2 (1979): 48; Sarah Stroud, "Weakness of Will," The Stanford Encyclopedia of Philosophy, Spring 2014, http://plato.stanford.edu/entries/weakness-will/ 655.

${ }^{52}$ R. M. Hare, "Weakness of Will," EncEth 3:1789; Gerard J. Hughes, "Weakness, Moral," NDCE

${ }^{53}$ Protagoras 358b-c. For a more detailed work on classical conceptions of akrasia and their relations to the present debates, see Christopher Bobonich and Pierre Destrée, Akrasia in Greek Philosophy: From Socrates to Plotinus, PA 106 (Leiden: Brill, 2007).
} 
feasible. This view is now widely accepted.$^{54}$ Second, initially being a moral problem that used to be discussed in moral philosophy, weakness of will is now understood as a failure of practical rationality and has moved into the domain of moral psychology and more generally, in the philosophy of action. ${ }^{55}$

Besides being an object of philosophical debates, weakness of will is widely debated among Christian thinkers too. Along with Socrates who was the first among philosophers to mention this concept, the apostle Paul expressed diametrically different opinion on the weakness of will. He actually endorsed the theoretical possibility of it as an inevitable reality for fallen humanity. ${ }^{56}$ Gerard J. Hughes conveniently summed up Christian understanding as follows: "The shortest way with the problem of moral weakness is to assert roundly that there is nothing here that requires explanation. It is simply a fact about ourselves that we are able to act against our sincerely held moral principles, with full knowledge and full deliberateness." ${ }^{57}$ This view is widely accepted today and is also well argumented in philosophical and psychological debates. ${ }^{58}$

\footnotetext{
${ }^{54}$ Even though some moral philosophers such as R. M. Hare still deny the possibility of this concept, or Alison McIntyre who understood weakness of will as strong desires that are imperfectly directed and one can learn how to share their desires so that in the course of time. Reilly, "Plato and Augustine on Human Weakness," 48.

${ }^{55}$ Tappolet, "Weakness of Will," 9:5413; Stroud, "Weakness of Will”; Yujian Zheng, "Interpretational Paradox, Implicit Normativity, and Human Nature: Revisiting Weakness of Will from a Perspective of Comparative Philosophy," DJCP 16 (2017): 145.

${ }^{56}$ Williston, review of Weakness of Will from Plato to the Present (ed. Hoffmann).

${ }^{57}$ Hughes, "Weakness, Moral,” NDCE 655; Gerard J. Hughes, "Weakness, Moral,” WDCE, 655. On the fine difference between the classical Greek understanding of the akrasia and Christian moral weakness, see Reilly, "Plato and Augustine on Human Weakness," 48-69.

${ }^{58}$ Tappolet, "Weakness of Will," 9:5419-20; Sarah Stroud, "Weakness of Will and Practical Judgement," in Weakness of Will and Practical Irrationality, eds. Sarah Stroud and Christine Tappolet (Oxford: Oxford University Press, 2003), doi:10.1093/0199257361.003.0006.
} 
The most influential work on the weakness of will was done by Thomas

Aquinas. ${ }^{59}$ Denis J. M. Bradley noted that "whereas for Aristotle, agents do not choose to act incontinently, for Thomas they do. However, they do not choose the action as such but rather the passion that is its proximate cause or psychological support."60

From this basic study of the weakness of will concept one thing becomes obvious: weakness of will is an intentional and free act of an agent. The reasons why people decide to act contrary to their judgment may be rooted in their passions, desires, and bodily appetites ${ }^{61}$ but they do not deny the fact that one acts intentionally and willfully. Thus, intentionality for at least one reason, weakness of will, is embedded in the concept of inadvertence.

\section{Ignorance}

Biblical scholars frequently used this concept in the process of defining sin in important texts of the Pentateuch ${ }^{62}$ which requires that it, too, be defined. A Dictionary of Modern Legal Usage defines ignorance as follows: "Ignorance implies a total want of knowledge in reference to the subject matter." ${ }^{\circ 3}$ Glanville Williams defined it as follows: "Ignorance is lack of true knowledge, either (1) because the mind is a complete blank or

${ }^{59}$ Williston, review of Weakness of Will from Plato to the Present (ed. Hoffmann).

${ }^{60}$ Williston, review of Weakness of Will from Plato to the Present (ed. Hoffmann).

${ }^{61}$ Jackson, "Weakness of Will," 2; Reilly, "Plato and Augustine on Human Weakness," 48. For more elaborate study of the potential weaknesses, see J. C. B. Gosling, The Weakness of the Will (Problems of Philosophy) (London: Routledge, 1990), 186-94.

${ }^{62}$ Milgrom, Leviticus 1-16, 228-29; Milgrom, "The Cultic שגגה and Its Influence in Psalms and Job,” 115-18; Kiuchi, Purification Offering, 25-31; Harrison, Leviticus, 173.

${ }^{63}$ A Dictionary of Modern Legal Usage, 2nd ed., s.v. "Mistake.”; Glanville Llewelyn Williams, Criminal Law: The General Part, 2nd ed. (London: Stevens, 1961), 151-52. 
(2) because it is filled with untrue (mistaken) knowledge on a particular subject. The first variety, lack of knowledge without mistaken knowledge, may be called simple ignorance. The second variety, lack of true knowledge coupled with mistaken knowledge, is mistake." ${ }^{64}$ It is a conscious and intentional act, but is opposed to the law because of the doer's misconceptions regarding the matter. ${ }^{65}$

It is evident, at least at the level of written records, that modern jurisprudence is much more complex, comprehensive, and precise in understanding the concept of intent. Terminology of the legal collections of the OT was not as extensive and precise as the terminology utilized in modern legal systems. ${ }^{66}$ A look at the definitions of some legal terms used in modern legislative systems would suffice to support this claim. For instance, BLD has 31 different types of act entries: ${ }^{67} 61$ crime entries (crime accompanied by other terms is not included in this number of types), ${ }^{68} 19$ of the intent entries, ${ }^{69} 19$ intention entries, ${ }^{70}$ and 64 of the property entries. ${ }^{71}$ The legal terms such as crime and/or criminal law do not exist in OT texts. ${ }^{72}$

Even though the term intention is not present in the legal corpus of the OT and is

${ }^{64} D M L U$, s.v. “Mistake.”; Williams, Criminal Law, 151-52.

${ }^{65} B L D, 8$ th ed., s.v. "Ignorantia."

${ }^{66}$ Gordon J. Wenham, “Law,” NBD (1996), 674.

${ }^{67} B L D, 10$ th ed., s.v. "Act."

${ }^{68} B L D, 10$ th ed., s.v. "Crime."

${ }^{69} B L D, 10$ th ed., s.v. "Intent."

${ }^{70} B L D, 8$ th ed., s.v. "Intention."

${ }^{71} B L D, 8$ th ed., s.v. "Property."

${ }^{72}$ Goldin, Hebrew Criminal Law and Procedure, 11. 
not as precisely defined as it is in modern legislative systems, some phrases irrefutably point to the presence or absence of intention related to some forbidden activities. As shown above, this claim is valid for the laws that cover various aspects of human life in ancient Israel. Table 19 is a simple representation of the relationship between the basic types of wrongs, their consequences, and the consciousness/awareness of the one doing them:

Table 19. The assessment of the sinful act

\begin{tabular}{|c|c|c|c|}
\hline Types of wrongs & $\begin{array}{c}\text { Consciousness/ } \\
\text { awareness }\end{array}$ & $\begin{array}{c}\text { Unconsciousness/ } \\
\text { Unawareness }\end{array}$ & Intentionality \\
\hline Accident & Act & Consequences & no \\
\hline Negligence & $\begin{array}{c}\text { act, consequences- } \\
\text { by some extent }\end{array}$ & Consequence & yes, no \\
\hline Intent & act, consequences & & yes \\
\hline Bad Motive & act, consequences & & yes \\
\hline
\end{tabular}

\section{Conclusion}

Like any other activity that breaks certain sets of laws, sin that in the Bible refers to breaking the biblical legal corpus, including the Decalogue, consists of two elements: (1) the internal/psychological, called mens rea or intent or mental state, and (2) the outward/physical part, called actus reus or an act itself.

The biblical legal corpus resembles modern jurisprudence in recognizing two basic types of offences, torts that refer to the wrong towards an individual and crimes that refer to the wrong towards society when the individual may or may not be affected. It has to be emphasized that the biblical legal corpus does not employ specific terms to refer to 
torts or crimes. However, the biblical legal corpus contains these two types of offences conceptually.

Legal jurisprudence has recognized four ways in which an act can be committed. First, a person can purposely act in a certain way to bring about a certain outcome. Second, a person can knowingly act in certain way to bring about certain outcome. Third, the perpetrator ignores the fact that his/her reckless conduct will produce certain outcomes. Fourth, the perpetrator does not know that his/her conduct results in certain circumstances.

Negligence is wrong based on the failure of one to exercise certain laws that prevent harming other people. By definition, negligence is unintentional, unwilful activity, but certain forms of negligence are undoubtedly intentional conducts and sanctioned as such. The concept of inadvertence as a part of negligence points to the presence of intention in negligent conduct. Intentionality stems from weakness of will.

Ignorance is a product of two elements of the mental state. First, ignorance takes place a result of one not knowing the law, or second, having a wrong perception of it.

The review of these definitions from modern legal jurisprudence that biblical scholars frequently use to discuss the concept of sin was needed in order to proceed into a meaningful dialogue with secondary literature.

\section{Legal System of Ancient Israel}

In contrast to the modern legal system, ${ }^{73}$ the legal system of ancient Israel

\footnotetext{
73“"Modern legal systems generally classify wrongful acts as crimes and civil delicts (torts) and approach them in different ways." Westbrook and Wells, Everyday Law in Biblical Israel, 69.
} 
reflected the basic concepts and categories of her ANE neighbors' tripartite division: (1) offences against a hierarchical superior, especially a king or a god, that called for disciplinary action; (2) morally grave offences against another individual that called for revenge ${ }^{74}$ and (3) offenses against the interests of an individual involving less moral culpability, for which the remedy was compensation. ${ }^{75}$ However, this tripartite division is an external scholarly assessment of the BL, rather than a division that comes out of the law since BL does not make the distinction between the law collections. ${ }^{76}$ Even though scholars of the BL have reached some sort of consensus on the similarities and differences of ANE law collections and the legislative corpus between ancient Israel, this is still a highly controversial topic..$^{77}$

There are several similarities and differences that are widely accepted. First, ANE law collections are older than BL. Second, ANE law collections come out of royal jurisprudence and represented the voice of the establishment. They existed from ancient times and have been innovated as new circumstances arose or through administrative order issued by the ruler. BL collections do not reflect circles sympathetic to the king. Third, in Israel, to the contrary, God was portrayed as the author of the legislative system.

\footnotetext{
${ }^{74}$ Even though the society was an agent in solving these types of offences they cannot be compared to modern law of crimes. Westbrook, "Punishments and Crimes (OT and NT)," 5:549.

${ }^{75}$ Westbrook and Wells, Everyday Law in Biblical Israel, 69-70. This type of offense is comparable to modern law of torts. Westbrook, "Punishments and Crimes (OT and NT)," 5:548-49; Martin J. Selman, "Law," in Dictionary of the Old Testament: Pentateuch, eds. T. Desmond Alexander and David W. Baker, IVPBD 1 (Downers Grove, IL: InterVarsity Press, 2003), 505.

${ }^{76}$ Selman, “Law," 507.

${ }^{77}$ Westbrook and Wells, Everyday Law in Biblical Israel, 70; Samuel Greengus, Laws in the Bible and in Early Rabbinic Collections: The Legal Legacy of the Ancient Near East (Eugene, OR: Cascade Books, 2011); Westbrook, "Punishments and Crimes (OT and NT)," 5:546-56.
} 
He was also considered as divine and the ideal king of justice. His role was to maintain equity and protect the poor and oppressed. ${ }^{78}$ In this sense, God is also the ultimate judge. ${ }^{79}$ Fourth, in accord with ANE law collections, BL was not legislation in the modern sense since these texts present just a small fraction of the law and assumed the knowledge of the rest. ${ }^{80}$

The third and the fourth points are especially relevant for the present study. In regard to the fact that God is portrayed as a king in Israel who gives the laws, it is important to know that his kingship over ancient Israel was based on the divinecovenant. ${ }^{81}$ The primary way of speaking about a special relationship between God and ancient Israel is in the context of the covenant. ${ }^{82}$ The law was given in the context of an established covenantal relationship (Exod 19-14) and therefore, in breaking the law, one is liable and accountable to God. ${ }^{83}$ Moshe Greenberg profoundly stated: "In the biblical view, the law is the command of God; hence violation of it is rebellion against God's will

\footnotetext{
${ }^{78}$ Westbrook, "Punishments and Crimes (OT and NT)," 5; Selman, "Law"; Huiping Hu, "Codes as Constitution: The Development of the Biblical Law-Codes from Monarchy to Theocracy" (PhD diss., Durham University, 2009); Michael LeFebvre, "Legal Institutions," OEBL 1:433-46; Anthony Phillips, Ancient Israel's Criminal Law: A New Approach to the Decalogue (Oxford: Blackwell, 1970); Gane, Old Testament Law for Christians. On different conceptions of kingship in Ancient Near East and the difference to God's kingship in Ancient Israel, see Hu, "Codes as Constitution," 140-42, 170-72.

${ }^{79}$ LeFebvre, “Legal Institutions,” 1:536; Gane, Old Testament Law for Christians, 120.

80، The biblical codes, like their cuneiform counterparts, were not legislation in the modern sense. Their text was not interpreted by the courts as authoritative (except perhaps at the very end of the biblical period); far from being comprehensive, it presented only a small fraction of the law and assumed knowledge of the rest." Westbrook, "Punishments and Crimes (OT and NT)," 5:546; Hu, "Codes as Constitution," 2-10.

${ }^{81}$ Phillips, Ancient Israel's Criminal Law, 3-13; Hu, "Codes as Constitution," 175; LeFebvre, "Legal Institutions," 1:132-34; Greenberg, "Crime and Punishment," IDB 1:734-35. For a scholarly discussion on the role of Decalogue for BL, see Phillips, Essays on Biblical Law, 2-48.

${ }^{82}$ LeFebvre, "Legal Institutions," 1:131.

${ }^{83}$ Phillips, Ancient Israel's Criminal Law, 3; Pauline A. Viviano, "Covenant," OEBL 1:132-33.
} 
- i.e. crime is $\sin .{ }^{94}$ Studying legal institutions in Ancient Israel, Michael LeFebvre said, "Notwithstanding the resulting complexities, there is one consistent ideal behind these institutions that helps explain them: the conviction that Yahweh was Israel's true lawgiver and judge. ${ }^{85}$

The BL separated itself from ANE law collections by uniquely integrating various law regulations into one legal collection. regarding the ANE legal corpuses, Shalom Paul stated: "There is a complete separation of secular and religious law: dinn (law), kibsu (moral rules), and parșu (religious orders) are never combined in a single corpus. Legal rules, moreover, have no didactic purpose; they do not serve as a goal for pedagogic instruction. ${ }^{966}$ Basing her study on the analysis of Moshe Greenberg's work on the relationship between biblical and ANE law collections, Ruxandria Pădure stated: "In the theory referring to the Biblical law, the idea of the transcendence of the law becomes clearer. Here, God is not just the guardian or the judge, He is the very source of the law, and the latter is the expression of His will." ${ }^{87}$ As such, BL expresses the will of Yahweh. Frank Crüsemann noted that "the basic notion that Israelite law is direct divine utterance is not at all common in the ancient world." ${ }^{88}$ This fact is foundational for the claim that

${ }^{84}$ Greenberg, "Crime and Punishment," IDB 1:734.

${ }^{85}$ LeFebvre, "Legal Institutions," 1:536.

${ }^{86} \mathrm{Paul}$, Studies in the Book of the Covenant, 8-9. This is also noted by Umberto Cassuto, $A$ Commentary on the Book of Exodus, trans. Israel Abrahams (Jerusalem: Magnes Press, 1997), 263; Kaufmann, The Religion of Israel, 171. Also, Greenberg, "Crime and Punishment," IDB 1:734.

${ }^{87}$ Ruxandra Pădure, "Comparison between the Biblical and the Near Eastern Laws," SJHS 3.4 (2011): 237. Ruxandra Pădure's analysis of Greenberg's work on the relationship between biblical and ANE law collections brought up several other significant distinctive features of BL that separate it from ANE law collections. Pădure, "Comparison between the Biblical and the Near Eastern Laws," 233-37.

${ }^{88}$ Frank Crüsemann, The Torah: Theology and Social History of Old Testament Law, trans. Allan W. Mahnke (Minneapolis: Fortress Press, 1996), 15. 
"instruction" or "teaching," rather than "law" in the majority of cases, reflects better the sense of what tôrâ is. ${ }^{89}$

In addition, M. J. Selman stated that "many parallels exist between the laws of the OT and those from the rest of the ancient Near East, though no laws have been found so far that are identical in form in both Israel and Mesopotamia." ${ }^{90}$ Biblical Law experts resist claims that the laws found in the Pentateuch are identical to the laws of ANE law collections, but rather speak of mutual similarity between the two collections. ${ }^{91}$ Selman has noted two extreme views of the law that are not necessarily contradictory if put in the right perspective.

Scholars have suggested two opposed views of the function of BL. First, working out of the realization of the close connectedness between the commandments and covenant and the fact that revelation of the commandments was a salvific event, Gerhard von Rad viewed the law as a form of gospel. This implication is based on the fact that covenant was completed at a time when Israel had had no chance to exhibit its obedience to the law. ${ }^{92}$ Thus, the law had a salvific role. Complementary rather than contrary to this is the inference of W. Zimmerli and H. D. Preuss. They noted that besides blessings, covenant laws also contain curses. Zimmerli noted that the validity of divine law that assumes threatening judgments is embedded in Israel's election. Preuss discredited the

${ }^{89}$ Selman, "Law," 509.

${ }^{90}$ Selman, "Law," 506.

${ }^{91}$ Shalom E. Holtz, "Reading Biblical Law," in The Jewish Study Bible, eds. Adele Berlin and Marc Zvi Brettler, 2nd ed. (Oxford: Oxford University, 2014), 2206-7.

${ }^{92} \mathrm{Rad}$, Old Testament Theology, 1:193. 
law's ability to save by emphasizing Israel's inability to obey the laws. ${ }^{93}$ The law had a legal, obligatory function.

Selman believed that von Rad's, on the one hand, and Zimmerli's and Preuss's view, on the other, can be seen as complementary if viewed in the context of God's covenant with Israel which implies that the law is not law per se, but rather, serves for God's larger purpose for Israel. The laws given to Israel as a nation redeemed from slavery (Ex 20:1-2; Deut 5:6; cf. Deut 1:1-4:43) in order to preserve and shape their newly won freedom and provide further opportunities to commune with him as they journeyed from Egypt. ${ }^{94}$ Thus, both of these functions, salvific and legal, are obligatory as valid elements of the covenant.

These distinctive features of the BL are crucial since the present study views BL as a whole. Breaking any regulation of BL assumes the liability of the one doing it and accountability to God himself. ${ }^{95}$ This further means that breaking any regulation requires offering a sin and/or reparation sacrifice and making restitution when needed.

Regarding the claim that BL is different than modern legislative systems, Bernard S. Jackson conveniently outlined the manner in which modern scholars have related ancient biblical codes to modern legal systems. It is factual that both ancient and modern legal codes, common and civil traditions, consist of the three principal parts of legal

\footnotetext{
${ }^{93}$ Walther Zimmerli, Gottes Offenbarung: Gesammelte Aufsätze zum Alten Testament, TBü 19
} (München: C. Kaiser, 1963), 271; Horst Dietrich Preuss, Old Testament Theology (Louisville: Westminster John Knox, 1995).

${ }^{94}$ Selman, "Law," 509. 138.

${ }^{95}$ Helmer Ringgren, Israelite Religion, trans. David E. Green (Philadelphia: Fortress Press, 1966), 
source, statute, precedent, and doctrine. Jackson concluded that

ancient phenomena corresponding to these modern institutions are certainly to be found. But once discovered they are all too readily invested with the particular attributes of their modern counterparts. Moreover, such identifications sometimes suggest inappropriate lines for further investigation. Much effort has been misapplied in seeking to determine such questions as whether ancient "codes" are restatements of custom or reform (i.e. consolidating or reforming statutes); whether they are comprehensive or merely collections of "difficult cases" (i.e. codes or miscellaneous provisions acts); whether they are "official" or "private" (i.e. statute or doctrine). ${ }^{96}$

The similarities between biblical and modern law do exist since they share some shared features when basic concepts and terminology of the two systems are compared. ${ }^{97}$ However, the differences are more numerous, which is a signal against applying a conceptual understanding regarding similar laws from modern, legal understanding to related or similar laws of the ancient legal corpus. ${ }^{98}$ Rather, they should be studied separately first, and then similarities should be discussed/compared. This principle also applies to the use of modern, legal terminology which, in the case of this study, is related to the concept of intention in reference to some crimes. Instead of applying already preconceived terminology of intent and related subconcepts such as inadvertence and negligence, fresh terminology is needed that is defined by the study of the laws themselves and to the extent the laws provide.

\footnotetext{
${ }^{96}$ Bernard S. Jackson, "From Dharma to Law," AMJCL 23 (1975): 491. For a more detailed analysis of the influence of modern legal terminology on ancient legal systems and the inadequacy of applying the concept of the former to the latter, see Hu, "Codes as Constitution," 2-12.

${ }^{97}$ Richard H. Hiers, Justice and Compassion in Biblical Law (New York: Continuum, 2009); Jackson, "From Dharma to Law," 491; Westbrook, "The Character of Ancient Near Eastern Law," 1:1-2.

${ }^{98}$ Gane agreed with Christine Hayes on the fact that "the relationship between OT law and modern categories of law is complex." Gane, Old Testament Law for Christians, 27; Christine Elizabeth Hayes, What's Divine about Divine Law?: Early Perspectives (Princeton, NJ: Princeton University Press, 2015), 3 , $12,14-53$.
} 


\section{Intent or Mental State/s in Biblical Law}

The term intent or mental state/s is never used in the OT and most likely was not in use in Ancient Israel (Early Judaism and rabbinic texts). ${ }^{99}$ "On the contrary, all of them frequently employed a rich selection of concepts and expressions to refer to state of mind that a person had when he or she performed a given action." ${ }^{100}$ Another difficulty in studying intent/mental states is spelled out in the following quotation by Brent A. Strawn: "The notion of intention is controversial given the difficulty of determining internal dispositions (solely) on the basis of external factors." ${ }^{101}$ Strawn captured the core difficulty in determining the nature of intent in legal cases. Intent, as such, takes place in a very private domain, namely, the human mind, but its nature is established based on external factors, physical activities. Yet, it is obvious that intent plays a crucial role in BL, and some of these laws provide textual hints into the mental state of a potential human agent. ${ }^{102}$

Greenberg recognized that BL provide bases for establishing both types of guilt, objective and subjective:

The notion of objective guilt, which still operates in the realm of cult and taboo, has but faint echoes in the penal laws of the Bible. As a rule, it is the subjective factor, the mind of the doer, which is determinant in evaluating the nature of the offense. The laws distinguish clearly between murder, on the one hand, and homicide through negligence or accident, on the other. Bodily injuries inflicted deliberately and with premeditation are treated differently from those inflicted in the sudden heat of passion. The religion of Israel heightened both the awesome sanctity of all that

${ }^{99}$ Aurelian Botica, The Concept of Intention in the Old Testament, Philo of Alexandria and the Early Rabbinic Literature: A Study in Human Intentionality in the Area of Criminal, Cultic and Religious and Ethical Law, PHSC 9 (Piscataway, NJ: Gorgias Press, 2011), 2.

${ }^{100}$ In addition, for a selected terminology on intent, see Botica, Concept of Intention, 2-3.

${ }^{101}$ Strawn, "Intention,” 1:433. Also Botica, Concept of Intention, 1n2, especially.

${ }^{102}$ Botica, Concept of Intention, 1; Strawn, “Intention,” 1:434. 
touched upon God - an objective datum - and the importance of the individual's moral choice - a subjective datum; these laws illustrate the dilemma that may arise out of the class of the two. ${ }^{103}$

Analyzing intention in the present study is limited to so-called "action" cases, ${ }^{104}$ that is, the cases in which the wrong is not limited to an inward offense, but is accompanied by the physical act, as well. An individual may sin either by committing a sinful action or by failing to perform an act that the law required. The criterion of intention is equally important in criminal and cultic laws. ${ }^{105}$

\section{Intent or Mental State/s in Criminal Law}

The notion of intent is first mentioned in the Decalogue. Exodus 20:17 uses the

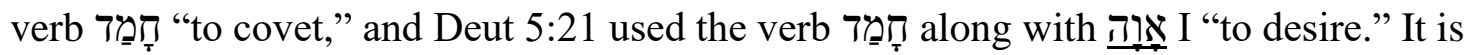

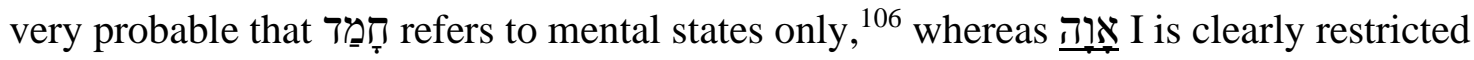

${ }^{103}$ Greenberg, "Crime and Punishment,” IDB 1:734.

${ }^{104}$ Bernard S. Jackson started off his study on intention with the claim that "numerous texts in the early history of law suggest that the ancients were concerned with the problem of liability for mere intention, that is, the imposition of liability upon a person solely because of the intention he has formed in his mind, and without reference to any external act by which such intention may be projected into practice." Thus, he introduced the conceptual division between action (criminal and cultic scenarios) and non-action (coveting, devising evil) cases. The latter cases do not necessarily exclude the physical act and its consequential impact, but rather, the emphasis is on the fact that biblical authors perceived the offense consisting not just of the physical act, but also of inward trespass. Bernard S. Jackson, Essays in Jewish and Comparative Legal History, SJLA 10 (Leiden: Brill, 1975), 202ff. Also, Botica, Concept of Intention, 6.

${ }^{105}$ Botica, Concept of Intention, 51.

${ }^{106}$ Some scholars related this text with Mic 2:1-2 in which the verb hāmad involves action besides feelings. Thus, the semantic domain of the verb can include action, as well, so the verb encompasses the feelings that precede the act and the act itself follows those feelings. However, in this particular text, the former is encapsulated since including the latter would mean overlapping with other commandments against stealing, adultery, and so on. Patrick D. Miller, The Ten Commandments (Louisville: Westminster John Knox Press, 2009), 389-90. 
just to the mental states. ${ }^{107}$ The key law is the one of homicide. ${ }^{108}$

Exod 21:12-14: The first mention of this law is in Exod 21:12-14, and the offender's intent candidly affects the gravity of the punishment. That is, the opening clause of the law, the protasis, states that the punishment in case of a person's hitting another person which ends in the death of the latter is the death of the former. ${ }^{109}$ This introductory statement is a generic case of intentional homicide. ${ }^{110}$ This would be typical example of a well-attested concept in the OT, lex talionis or talionic retribution.

However, vv. 13 and 14 further provide immediate qualifications. If the murder was not premeditated, ${ }^{111}$ but the event was "an act of God," then it is classified as an unintentional homicide, and the offender can flee to the appointed place for sanctuary (Exod 21:13). If it was a premeditated, ${ }^{112}$ then the offender has no right for refuge (Exod 21:14). He suffers capital punishment. The issue associated with this law is the fact that the law does not specify who performs the execution of the punishment. The place of

\footnotetext{
${ }^{107}$ Botica, Concept of Intention, 453-56; Jackson, Essays in Jewish and Comparative Legal History; Strawn, "Intention," 1:434-35.

${ }^{108}$ Strawn, "Intention," 1:435; Botica, Concept of Intention, 15.

${ }^{109}$ Strawn, "Intention," 1:435; Botica, Concept of Intention, 14.

${ }^{110}$ Botica, Concept of Intention, 15.

${ }^{111}$ The absence of the verb צִדָדָ demonstrates the fact that there was no premeditation. Strawn, "Intention," 1:435; Sarna, Exodus, 122, 252n33. Sarna cited other texts on murder which also point to the lack of premeditation. Linguistic pointers toward the unintentional acting in these additional texts are different, but solid and widely accepted in the scholarly dialog. Strawn, "Intention," 1:436-37. The

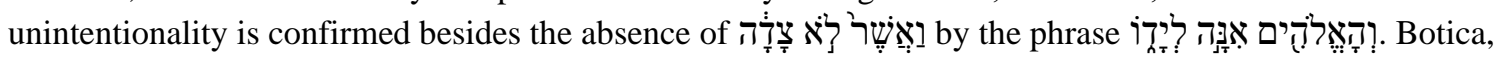
Concept of Intention, 17.

${ }^{112}$ The verb murder. Strawn, "Intention," 1:436. Even more, this verb in the OT often conveys "an attitude of purposeful disregard for laws and morality, or of presuming to exert a role or authority against the divine will." Botica, Concept of Intention, 19. He provides more references.
} 
refuge for unintentional manslayers is discussed later in Num 35:9-34 and Deut 4:41-43; and 19:1-13. ${ }^{113}$ Premediating can be understood as "scheming" to fit the context of a crime. ${ }^{114}$ Another term, עָּרם I, is used in v. 14 to strengthen the intent idea behind this crime and it refers to the attitude of deceit as a result of prior intention. ${ }^{115}$ The role of the court and judges is also not specified in Exod 21:12-14, but is stipulated in Num 35:9$28 .^{116}$

The homicide law in Exod 21:12-14 contains clear pointers for the presence of intent, and even more premeditation of a criminal act. All the pointers in this law come close to the descriptions of similar crimes in the MLS.

Num 35:9-34: In contrast to Exod 21:13-14 where the details of the homicide are lacking, Num 35:9-34 includes a series of specific circumstances under which the crime happened, along with tools/means included in it. A basic division between two sets of circumstance related to the crime is that the former points to an unintentional homicide, while the latter points to an intentional one. ${ }^{117}$ The switch in content is followed by the use of a literary pointer, the particle אִ, that also separates the cases (vv. 16, 22).

Concerning intentional homicide, in the first set of texts, vv. 17-18, the manner of committing the crime was striking and it was performed by the use of the objects (v. 16-

${ }^{113}$ Strawn, "Intention," 1:436.

${ }^{114}$ Botica, Concept of Intention, 20.

${ }^{115}$ Botica, Concept of Intention, 20.

${ }^{116}$ The study on the evolution of the law found in Exod 21:12-14 in the subsequent text of Num 35:9-34 is conveniently outlined in Botica's study and being irrelevant for the current study will not be discussed here. Botica, Concept of Intention, 22-30.

${ }^{117}$ Botica, Concept of Intention, 31. 
iron object, v. 17-stone, and v. 18-wooden object). In the second set of texts, vv. 2021 , the manner is conveyed by pushing, throwing at, or lying in wait, whereas the state of mind is communicated by the use of hatred and enmity. ${ }^{118}$

Regarding unintentional homicide, vv. 22-23 state that the manner related to this act was through "suddenness, not seeing," while the mental state is expressed by "no enmity nor personal enmity, no malice aforethought, no intent to hurt."119

Thus, the terminology that is used to point to the intent of a murder such as premeditation, plotting, lying in ambush or in wait and acting out of hatred or enmity is negated in the parts of the law that emphasize unintentional acting. ${ }^{120}$

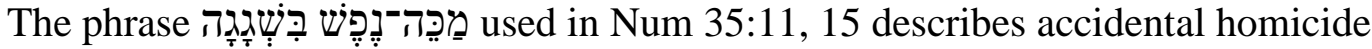
and Botica appropriately asked if it refers to the state of mind or only refers to the generic case of accident. Numbers 35:11 does not contain indications to answer this question. The terms used in the homicide contexts in the same fashion as wiשָגָגה

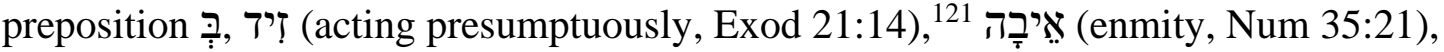

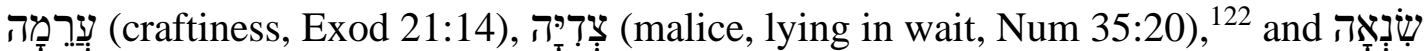
(hatred, Num 35:20) all possess a distinct mental/emotional connotation. ${ }^{123}$ Botica correctly concluded: "Perhaps, one could apply here the legal distinction between

\footnotetext{
${ }^{118}$ Botica, Concept of Intention, 32.

${ }^{119}$ Botica, Concept of Intention, 32.

${ }^{120}$ Strawn, "Intention," 1:437-38; Rolf P. Knierim, “שגג," TLOT 3:1303.

${ }^{121}$ This verb is not accompanied with the preposition $b e$.

${ }^{122}$ Botica, for some reason, missed including this term.

${ }^{123}$ Botica, Concept of Intention, 34-36.
} 
intention to harm (on the spur of the moment but not to kill), intention to kill (not foreplanned, but on the spur of the moment) and premeditation (planning to kill in

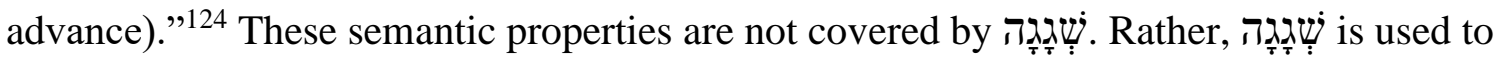
convey both accidental and unintentional activity. The context of Num 35 suggests that שִ refers to the unintentional and accidental nature of the act and is followed by the phrase ברבְליי-דַבַעת in order to emphasize the fact that it does not imply previous mental planning of the act. ${ }^{125}$ In other words, it is an accident which itself presumes unintentionality on the part of the human party involved.

The suggestion that the homicide law in Exod 21:12-14 contains clear pointers for the presence of intent and premeditation is even more expanded in the case of Num 35:9-34, where the text contains terms based on which, one can determine various levels of intent. In this regard, this law comes closer to the descriptions of similar crimes in the MLS.

Deut 4:41-42: The main concern of the short law in Deut 4:41-42 is the establishment of the cities of refuge, rather than particulars of homicide intentionality and unintentionality. It actually deals only with the latter. In this regard, it resembles the law in Josh 20. That is, this similarity in terms of content between the two texts is also extended to the realm of terminology. The phrase that is used to refer to unintentionality

\footnotetext{
${ }^{124}$ Botica, Concept of Intention, 36.

${ }^{125}$ Botica, Concept of Intention, 34-36. For a more specific meaning related to the terms describing intentional homicide where one can discern various levels of intent, see Botica, Concept of Intention, 36-38.
} 


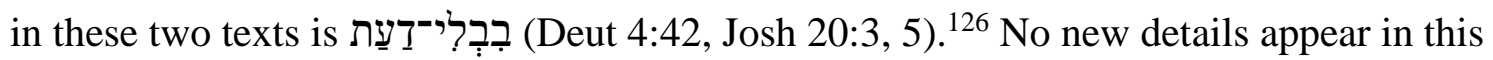
text that are not covered in the previous two texts.

Deut 19:1-13: A general statement concerning the mental state involved in unintentional homicide is found in v. 4 which states that the perpetrator did not have the

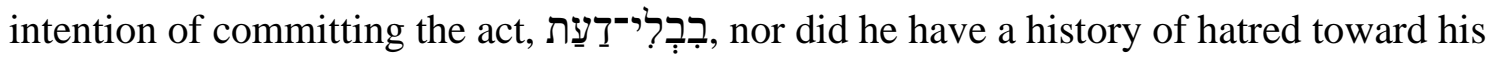
fellowmen, לאָ-ששנָא לו. Verse 5 provides details of the circumstances of the accident and object involved, slipping of a head from the axe handle as one swings to cut wood and striking his fellowman as he cuts wood in the forest. Intentional homicide is more precisely described in v. 11 . The manner of committing the crime was conveyed by lying in wait, attacking and striking, whereas the state of mind includes hatred. ${ }^{127}$

The analysis of the homicide laws in the Pentateuch demonstrates that the concept of intention is present in these laws even though the texts do not use the term intent/intention or mental states. The level of intention in homicide laws range from the law that has no specifications (Exod 21:12-14), but just states that the person who kills another person is to be executed, to the ones where there is a distinction between the intention to kill and premeditated intentionality to kill (Num 35:9-34). The laws of homicide require the death penalty for the intentional murderer. ${ }^{128}$ In the case of accidental, unintentional homicide, the laws of homicide do not require the death of the

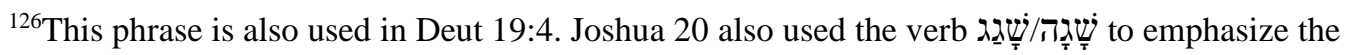
fact that the act is accidental, without mental planning.

${ }^{127}$ For a more detailed analysis of these two scenarios and a slight difference with other homicide laws, see Botica, Concept of Intention, 43-46.

${ }^{128}$ Botica, Concept of Intention, 48.
} 
killer, but protect him/her by making sure that he/she has valid legal investigation and protection if it is proven that he/she did not act intentionally. Not negating these insights of levels of intent, Botica plausibly stated: "Nevertheless, the understanding of intention in biblical criminal law is still basic. The observable/physical dimension is paramount." 129

However, even though determining the mental state was not an easy task due to the lack of a fuller list of explicit verbal indicators and their definitions, the legal corpus contains certain hints which indicate the existence of certain and specific verbal pointers. ${ }^{130}$

Other laws where intent plays an important role in determining the magnitude of punishment are related to various aspects of life in Ancient Israel. Some of these laws are the goring ox found in Exod 21:28-32, the thief breaking in found in Exod 22:2-3, injury of a pregnant women in a quarrel found in Exod 21:23-25, bodily injuries found in Lev 24:19-20, the malicious witness found in Exod 20:16; 23:1-3; Deut 5:20; 19:15-21, and sex between a man and a betrothed woman in Deut 22:23-27. ${ }^{131}$ The present study limits itself to the homicide law because intention is developed in these laws in the most comprehensive way.

\section{Intent or Mental State/s in Cultic Law}

The difficulty of determining intention in legal texts also appears in cultic texts.

\footnotetext{
${ }^{129}$ Botica, Concept of Intention, 49.

${ }^{130}$ Strawn, "Intention," 1:437-38.

${ }^{131}$ Strawn, "Intention,” 1:438-40; Botica, Concept of Intention, 9-50.
} 
The two key texts are Lev 4-5 and Num $15 .{ }^{132}$ Determining the nature of intent in Lev 45 and Num 15 requires understanding the semantics of nominal and verbal forms of the

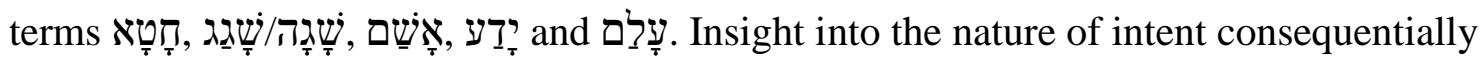
provides understanding of the nature of sins mentioned in these texts. In both passages,

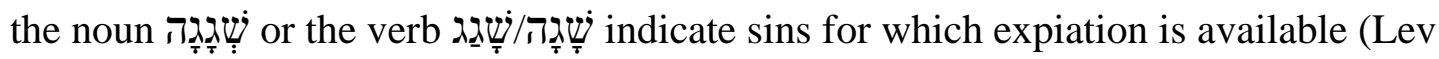

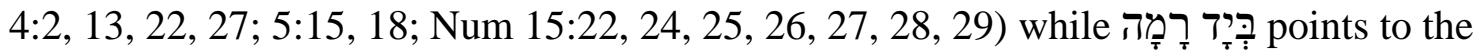
intentional sin which excludes the chance for expiation (Num 15:30-31), and this sin is denoted by עָּוֹן Scholars have understood that former terms refer to inadvertence, ${ }^{133}$ while the latter is associated with sins committed out of brazen opposition to God. ${ }^{134}$ The study of intent or mental state/s in criminal law demonstrated that the context of Num 35 suggests that the phrase בִּשְָׁגָגָה conveys accidental and thus, the unintentional nature of the act and is followed by the phrase בִבְלי־ in in order to emphasize that it does not imply previous mental planning of the act.

\section{Jacob Milgrom on Leviticus 4-5 and Numbers 15}

Milgrom's work and understanding of the nature of sin, and consequently, intent, outlined in Lev 4-5 and Num 15 is foundational and has immensely influenced most of

${ }^{132}$ Strawn, "Intention," 1:440-41.

${ }^{133}$ Botica, Concept of Intention, 69, 85.

${ }^{134}$ Caspar J. Labuschagne, "The Meaning of $b^{e} y \bar{a} d$ rāmā in the Old Testament," in Von Kanaan bis Kerala: Festschrift für J. P. M. van der Ploeg O.P. zur Vollendung des siebzigsten Lebensjahres am 4. Juli 1979, eds. J. P. M. van der Ploeg and W. C. Delsman, Alter Orient und Altes Testament 211 (Kevelaer, Germany: Butzon \& Bercker, 1982), 143; Milgrom, Leviticus 1-16. 
recent scholarship ${ }^{135}$ and encompasses all the crucial terms listed above. For that reason, it is analyzed in this section. He proposed that

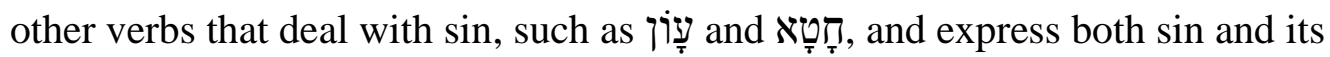
punishment. ${ }^{136}$ He summarized the meaning of nominal and verbal derivatives of the root אָ in cultic contexts as follows:

The cultic usages of the root ' 'sm are as follows: the noun ' $\bar{a} \check{s} \bar{a} m$ is the restitution for desecration by either composition or sacrifice and should be rendered "reparation" and "reparation offering," respectively. The verb 'ăšam is a stative. When it is followed by the preposition $l$ and a personal object it means "to incur liability to" someone for reparation; without an object, it refers to the inner experience of this liability, meaning "to feel guilt."137

In Milgrom's understanding, the meaning of the intransitive is supported by the technical noun which Milgrom held to mean “inadvertence." ${ }^{139}$ Before continuing further into the analysis of Milgrom's position on the nature of intent and sins in these chapters, I need to address the concept of inadvertence which was discussed on pages 258-61 above.

For Milgrom, inadvertence is an overarching criterion in all expiatory sacrifices. This is how he expressed it:

\footnotetext{
${ }^{135}$ Strawn, "Intention," 1:440-41; Gane, Cult and Character, 202; Sklar, Sin, Impurity, Sacrifice, Atonement, 24; Wells, The Law of Testimony. However, Milgrom's view was also heavily criticized and rejected by others. Hartley, Leviticus, 55, 58-59, 76-77; Kiuchi, Purification Offering; Knierim, "שגיג" TLOT 3:1303.

${ }^{136}$ Milgrom, Leviticus 1-16, 339.

${ }^{137}$ Milgrom, Leviticus 1-16, 339.

${ }^{138}$ An, "Delayed Recognition," 21.

${ }^{139}$ Milgrom, Leviticus 1-16, 228.
} 
Inadvertent wrongdoing may result from two causes: negligence or ignorance. Either the offender knows the law but involuntarily violates it or he acts knowingly but is unaware he did wrong. The former situation underlies the examples of accidental homicide-Num 35:16-18, 22-23; Deut 19:5-6 - and the latter is presumed by 1 Sam 14:32-34; Ezek 45:20; and such nonritual texts as 1 Sam 26:21; Prov 5:23; Job 6:24; 19:4. These two types of inadvertence have also been termed "error" and "accident" (Daube 1949). In either case, as the citations illustrate, unconsciousness of the sin and consciousness of the act are always presumed (contra Kiuchi 1987: 25-31), as recognized by the rabbis: "Scripture says biš ĕgāgâ implying the existence of consciousness" (b. B. Qam. 26b). By contrast, an unconscious wrong, when the offender is unaware of both his act and his sin, when he only suspects that he has done wrong, is expiated by a different sacrifice, the ' $\bar{a} \bar{s} \bar{a} m$ (see the NOTES on $5: 17-19) .{ }^{140}$

This quotation requires close analysis. First, based on the review of the legal concepts it is negligence that encompasses wrongs done inadvertently or ignorantly, and not inadvertence that encompasses wrongs done negligently or ignorantly. Negligence is a more complex and neutral concept in terms of intent involvement. It includes bothinadvertence, a wrong that can be done intentionally and unintentionally, and accident, where wrong is exclusively unintentional. Negligence assumes knowledge of the law as does inadvertence, but inadvertence, as a subcategory of negligence is a narrower concept related to the nature of the intent of a wrong act, ${ }^{141}$ while negligence includes other elements such the circumstance, level of damage, consequences... Milgrom seems to bypass the meaning of these concepts as they are defined by MLS and loaded them with the meanings based on his interpretation of Lev 4-5 and his understanding of sin. Loading precisely defined terms in MLS with incorrect meaning added even more confusion to the understanding of which sin/s is/are in question in Lev 4-5. He claimed

\footnotetext{
${ }^{140}$ Milgrom, Leviticus $1-16,228-29$.

${ }^{141}$ Simons, "When is Negligent Inadvertence Culpable?," 98, 107.
} 
that inadvertence precisely meets the condition of being conscious of the act, but not its sinfulness. ${ }^{142}$ One of the ways inadvertence takes place is by the weakness of will which is intentional activity and includes consciousness of its wrongness. I revisit this below in greater detail.

Second, Milgrom understood negligence when the offender knows the law, but involuntarily violates it. This is a very unlikely scenario since knowing the law and involuntarily breaking it is a contradictory scenario in itself. Knowledge of the law and still breaking it must include either intention of breaking it, regardless of knowing it or knowing the law and accidentally break it. I later suggest an additional way of how one can know the law and break it. Milgrom himself related the wrong of negligence to accidental homicide (Num 35), and it is to an accident, just one aspect of negligence, that

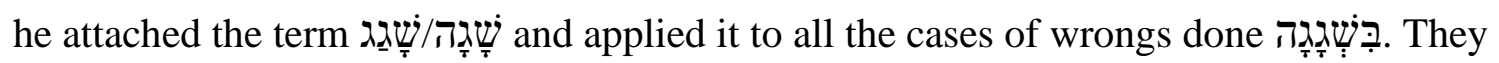
are always exclusively accidental wrongs. ${ }^{143}$ Thus, Milgrom's reducing negligence to accidental wrong only presents the obscure and incorrect use of the word that refers to the concept which includes wrongs done intentionally and unintentionally or accidentally.

However, there is another misuse of the legal terminology. Milgrom's quotation

\footnotetext{
${ }^{142}$ Milgrom, "The Cultic שגגה and Its Influence in Psalms and Job," 118. Milgrom's use of David Daube's terminology of "error" and "accident" does not fit the concepts he related to them since Daube defined error and accident as follows: "If there is a flaw in your plan, in your assumptions, but the act as such is executed as intended, without anything to upset it, we speak of error; whereas if the very act goes wrong, we speak of accident." David Daube, "Error and Accident in the Bible," RIDA 2 (1949): 189. Daube's error sounds like MLS's ignorance in the event of the misconception of the law by an individual and only partially fits Milgrom's negligence. In other words, it is not unintentional, but intentional activity. Daube's accident is an intentional act which an individual accidentally turns into an unplanned activity. It does correlate with Milgrom's understanding of ignorance. This also reflects Milgrom's loose use of terminology to define types of sins in Lev 4-6.
}

${ }^{143}$ Milgrom, Leviticus 1-16, 283, 488. 
above indicates that the he assumed that accidental nature of the wrong is done by both negligence and ignorance. As I discussed above, MLS theorists have recognized and endorsed the fact that inadvertent wrongs are not always unintentional or accidental. Thus, Milgrom misused his overarching concept of inadvertence in the same way that he misused the concept of negligence. That is, he reduced inadvertence to unintentional or accidental wrongs only. I come back to the use of MLS terminology as I conclude the analysis of Milgrom below.

Third, based on the quotation above, Milgrom defined ignorance as acting knowingly, but being unaware of the fact that one's acting is wrong. He did not explain how this scenario unfolds. This vague statement is explained by the definition of ignorance by MLS provided above. Ignorance results from not knowing the law or by a wrong perception of it. It is a conscious and intentional act, but a doer is unaware that his act is breaking the law since he either does not know the law or his perception of it is incorrect. This correlate with Milgrom's understanding of ignorance.

Milgrom cited two cases to show the sin of ignorance: 1 Sam 14:32-34 and Ezek 45:20. ${ }^{144}$ The case of 1 Sam 14:32-34 is of the warriors who ate meat with blood in it. However, this case does not look like ignorance, but rather, an intentional act due to their hunger and physical exhaustion. Verse 31 states that after the battle was over, "the people were very weary." Verse 34 also states that after Saul provided the solution, a big stone was installed so the people could use it to drain blood from the slaughtered animals for food, "all the people that night brought each one his ox with him and slaughtered it

\footnotetext{
${ }^{144}$ Non-ritual case includes 1 Sam 26:21; Prov 5:23; Job 6:24; 19:4, but are not analyzed here.
} 
there." The narrative presents a smooth transition from eating with the blood to going through a process of draining it from the animals and then eating it; it seems that they were familiar with the reasoning behind this prohibition, but still broke it since they were hungry and exhausted. Rather, this was intentional sin out of hunger and exhaustion. The context of Ezek. 45:20 does not provide any insights into the nature of sins that were to be atoned by the prince, except that the verb שָָָ was used to refer to the action of sinning. This is extremely insufficient to argue that the sin in these texts is one of ignorance.

The cases of ignorance are very much unlikely in the society of ancient Israel. In the light of covenantal obligations which included stipulations, laws, that Israelites obliged themselves to as they accepted a covenant with God and in the light of the texts such as Deut 24:8, 33:10, that Milgrom referred to in support of a plausible idea that the law was publicly taught in Ancient Israel. ${ }^{145}$ It is hard to imagine that the Israelites did

\footnotetext{
${ }^{145}$ That function of the priesthood was, as Milgrom said, "stressed in the later literature (2 Kgs 17:27b; Ezek 22:26; 44:23; Hag 2:11; Mal 2:7). It is also emphasized in H: ûlěhôrōt 'et-běnê yiśrā 'ēl 'ēt kol-hahuqqim 'ăšer dibber YHWH 'ălêhem běyad-mōšeh, ' and you must teach the Israelites all of the laws that the Lord has imparted to them through Moses' (10:11)" Milgrom, Leviticus 1-16, 52; Gane, Old Testament Law for Christians, 33, 117. Contrasting the mysterious character of the Babylonian temple program, Milgrom stated that "that the priests must teach their lore to the Israelites" that is diametrically different from the Mesopotamian religion systems. Milgrom, Leviticus 1-16, 52. The following quotation provides insights into the limited and mysterious nature of the Mesopotamian temple program: "The ritual which you perform, (only) the qualified person shall view. An outsider who has nothing to do with the ritual shall not view (it); if he does, may his remaining days be few! The informed person may show (this tablet) to the informed person. The uninformed shall not see (it) - it is among the forbidden things of Anu, Enlil, and Ea, the great gods" (ANET 336a; for the Egyptian equivalent, see the NOTE on 1:2). Milgrom, Leviticus 1-16, 52. Finally, as Milgrom noted again: "Furthermore, the recurring refrain in $\mathrm{P}$ is wayyō'mer YHWH 'el-mōšeh lē'mōr dabbēr 'elběnê yiśrā'èl 'The Lord spoke to Moses, saying: Speak to the Israelites' (e.g., 1:1-2; 4:1; 7:22;11:1;12:1;15:1). The torah of the Lord is, therefore, not an esoteric doctrine, stored in the Temple archives and available solely to the elite priesthood (see also the NOTE on 'to them,' 1:11). Hence, the Lord's commandments compose the curriculum of the priest-teachers, so to speak, in Israel's schoolhouse. Its purpose is to reduce the incidence of impurity in Israel so that holiness, the sphere of God, can expand beyond the sanctuary." Milgrom, Leviticus 1-16, 52.
} 
not know the majority of the law. To the contrary, due to the nature of the law ${ }^{146}$ it is expected that the Israelites would be quite familiar with it. ${ }^{147}$ Shalom M. Paul noted that each member of the community, then, has a dual responsibility: to observe the law personally and to see that the law is observed by the group. Each must see that justice is executed and that all crimes are punished - otherwise the community and its members are threatened with dire consequences. ... Law becomes the single most important factor in the life and destiny of Israel." 148

Even if the public impact of the law on individual court cases was less direct than that of modern statutory law ${ }^{149}$ and because it was available to any Israelites, parties involved in the case could settle the matter without involvement of the third-party. ${ }^{150}$ All these insights into the role and status of the law in ancient Israel suggest that the cases of ignorance were significantly reduced. Not that they would never happen, but such importance and inclusion of the law in public life and exposure to it reduced the chance for these kinds of violations.

Fourth, Milgrom surprisingly equaled the wrong of negligence with "error" and ignorance with "accident," as can be observed from the quotation above. ${ }^{151}$ However, as

\footnotetext{
${ }^{146}$ The covenantal stipulations were public and normative. John H. Walton, Ancient Near Eastern Thought and the Old Testament: Introducing the Conceptual World of the Hebrew Bible (Grand Rapids, MI: Baker Academic, 2006), 293, 297; Phillips, Essays on Biblical Law, 51-52. Gane stated that "Moses commanded the priests and elders to read 'this law' (torah; possibly Deuteronomy) to the assembled Israelites every seven years at the Festival of Boots (Deut 31:19-13)" Gane, Old Testament Law for Christians, 33. Based on Deut 17:18-20, the future king was to have his own copy of the law and read it so he could learn and follow it. Gane, Old Testament Law for Christians, 33.

${ }^{147}$ Paul, Studies in the Book of the Covenant, 38-39.

${ }^{148}$ Paul, Studies in the Book of the Covenant, 38; See also Greenberg, "Crime and Punishment," IDB 1:733-34.

${ }^{149}$ Michael LeFebvre, Collections, Codes, and Torah: The Re-Characterization of Israel's Written Law, LHB/OTS 451 (New York: T \& T Clark, 2006), 47.

${ }^{150}$ Bernard S. Jackson, Wisdom-Laws: A Study of the Mishpatim of Exodus 21:1-22:16 (Oxford: Oxford University Press, 2006), 29.

${ }^{151}$ These terms are borrowed from David Daube. Daube, "Error and Accident in the Bible," 189.
} 
he explicitly stated in the quotation, negligence is conceptually an accident in his understanding. He related ignorance to "accident," which is a totally different concept than ignorance. ${ }^{152}$

Fifth, Milgrom suggested that common to both ways of breaking the law is unconsciousness of the sin and consciousness of the act. This part of the statement is the most critical point of Milgrom's evaluation of sin and consequently, in the notion of

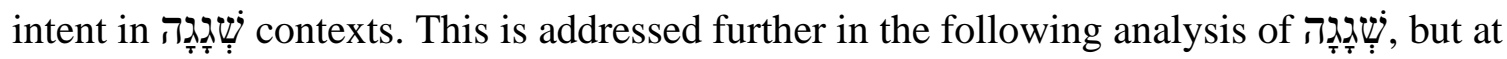
this point, I want to emphasize the major weakness of this interpretation.

Putting aside Milgrom's inaccurate use of MLS's legal terminology, perhaps he did not intend it to be used with the precision with which it was presented in this work, but his interpretation of $\sin$ in Lev 4-5 downsized the types of sins that can be forgiven through the sin offering to sins that are always accidentally or unintentionally committed where a sinner is never aware at the time that he is committing sin. The sinner becomes aware only later that the activity of which he is conscious is sinful.

Such an understanding of sin excludes the major class of sin which is sin committed out of GHS and weakness. The concept of GHS is conceptually identical (or close) to the concept of weakness of will, and as noted above, this concept is debated in the major works of philosophy back to Socrates, Plato, and others, and is widely accepted within Christianity from its beginnings. Sin resulting from GHS may be sin committed in full consciousness and knowledge by sinners which, by consciously committing it, they

\footnotetext{
152“"1. An unintended and unforeseen injurious occurrence; something that does not occur in the usual course of events or that could not be reasonably anticipated. 2. Equity practice. An unforeseen and injurious occurrence not attributable to mistake, negligence, neglect, or misconduct." $B L D$, 8th ed., s.v. "Accident." Mistake is a form of ignorance. DMLU, s.v. "Mistake."
} 
break God's law. This sin is intentional activity where there is consciousness of its

meaning and consequences. This type of $\sin$ is missed by some modern commentators, ${ }^{153}$

but some admit that this type of sin has to be taken into consideration. ${ }^{154}$ Averbeck stated

regarding sin in Lev 4-5: "It probably has the sense of someone straying from the

commands of the Lord (see 4:2b) whether unintentionally or because they were tempted

to do so and followed their temptations." $" 155$

\section{אַָָׁ}

The meaning of the verb Wָ is crucial. Scholarly proposals on the meaning of

this term are various, and Sklar conveniently summarized and critiqued them. ${ }^{156}$ As

mentioned above, there are four proposals for the verb's meaning: (1) "to be/become

guilty, to incur guilt, to be/to become liable for guilt," (2) "to feel guilt," (3) "to realize

guilt," and (4) “to suffer guilt's consequences." "157

\footnotetext{
${ }^{153}$ The key representatives are Jacob Milgrom, Roy E. Gane, David P. Wright, and Jay Sklar whose works are extensively evaluated in the present study.

154“'In many cultic passages, especially in Lev 4, the term בשגגה, 'inadvertently,' is joined to חטא, 'sin,' in order to restrict it to offenses committed out of ignorance or human frailty ( $4: 27 ; 5: 25[6: 6])$. In Num 15:22-31 a sin committed inadvertently is contrasted to one done with ביד רמה, 'a high hand,' i.e., a deliberate, defiant action. An inadvertent sin may be committed in total ignorance, such as unknowingly eating food that has become unclean (cf. Ps 19:13[12]). It also includes offenses that one commits accidentally or out of negligence or because of a weak will. Thus חטא בשגגה, 'to sin inadvertently,' includes transgressions other than those done in ignorance." Hartley, Leviticus, 55. "It is commonly held that agah denotes both complete ignorance as well as an imperfect knowledge or advertence." P. P. Saydon, "Sin-offering and Trespass-offering," CBQ 8 (1946): 394; Eichrodt, Theology of the Old Testament, 2:161.

${ }^{155}$ Averbeck, "חַטְָאת," NIDOTTE 2:94.

${ }^{156}$ Sklar, Sin, Impurity, Sacrifice, Atonement, 25-41.

${ }^{157}$ Sklar, Sin, Impurity, Sacrifice, Atonement, 25.
} 


\section{To Be/Become Guilty, To Incur Guilt, To Be/To \\ Become Liable for Guilt}

The traditional meaning "of Wָ has been understood as the objective statement of guilt." ${ }^{158}$ First, as noted below, limiting שָָָׁ to objective meaning creates difficulty in Lev 4-5 since the transition between vv. 13-14 is expressed by the conjunction ? whereas transition between vs. $22-23$ and $27-28$ is expressed by a different particle, או The most natural meaning for $1 \boldsymbol{\aleph}^{159}$ "or" is not possible using the traditional meaning since it produces the following translation: "If anyone sins, and is guilty or is told what their sin is, then he or she shall bring an offering." 160 This reading requires a different translation for ix since, in this case, sinners are guilty and required to bring a sacrifice before they even know they have sinned. ${ }^{161}$ The difficulty is augmented even more due to the assumption that the sinner is not aware of the sinfulness of their sin in these chapters. ${ }^{162}$

It has to be noted that Sklar reasoned under the assumption that the sin in these

\footnotetext{
${ }^{158}$ Péter-Contesse, Lévitique 1-16, 71; Janowski, Sühne als Heilsgeschehen; Toorn, Sin and Sanction in Israel and Mesopotamia, 92; Levine, Leviticus, 22-23; Paul Joüon, "Notes on Lexicographie Hébraique," Bib 19 (1938): 455; Rolf P. Knierim, “w్שָׁ," THAT 1:255.

159، ... i (319x), of whose occurrences 75 percent are in the Pentateuch. Its main function is to serve as a separator of alternatives in either main or subordinate clauses. The latter usage is especially noticeable in legislative narrative, where it introduces an alternative or an exception to the rule being stated. In Lev 13:47-49 it appears 10x." Allan Harman, "Particles," NIDOTTE 4:1035. "Other than waw, the only coordinating conjunction established in Hebrew is i 'or,' used to join alternatives. It is alleged that $p$ 'and then' is to be found in Hebrew. The coordinator או is found separating alternatives in main clauses ... and, more often, in subordinate clauses ... subordinate clauses are common in legal materials where the precision of או is desired." Waltke and O'Connor, An Introduction to Biblical Hebrew Syntax, 654.

${ }^{160}$ Sklar, Sin, Impurity, Sacrifice, Atonement, 30. 23.

${ }^{161}$ Of the notable scholars in this field, Baruch A. Levine held this position. Levine, Leviticus, 22

${ }^{162}$ Sklar, Sin, Impurity, Sacrifice, Atonement, 30.
} 
texts is unknown to the sinner. This detail prevents him from allowing a subjective sense of exclusion of the objective sense.

The other translations are not troubled by the natural translation of iא as "or" since sinners either (1) recognize their sin and subsequently feel guilty or their sin was made known to them, (2) they simply realize their sin or their sin was made known to them, or (3) they realize their sin because of suffering or their sin was made known to them. Subsequently, after recognizing in their sin in some way, the sinners bring the sacrifice or begin the process of rectifying their $\sin .^{163}$

Second, Sklar noted that reading Lev 5:23 also does not make sense if it is

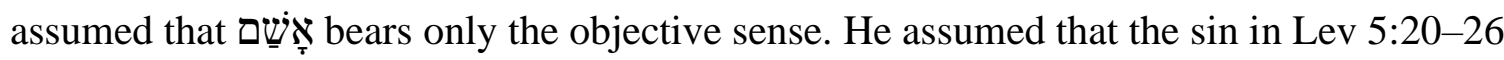
is intentional and that the sinners are aware of it, which further means that they know that they are guilty from the outset. Excluding the subjective element of text with the objective sense only poses a problem of insufficiency of objective guilt to motivate the sinner to bring the sacrifice. ${ }^{164}$ I return to this text and the solution to it below as I analyze Milgrom's “to feel guilt” translation.

\section{Bruce Wells' Suggestion}

Wells' explanation of is not new in terms of the verb's meaning per se: he retained an objective sense of it "to be/become guilty," but his suggestion is new in that

\footnotetext{
${ }^{163}$ Sklar, Sin, Impurity, Sacrifice, Atonement, 31.

${ }^{164}$ Sklar, Sin, Impurity, Sacrifice, Atonement, 31-32.
} 
he proposed that sinners basically do not need to be aware of their sin in order for it to be extirpated, and consequently, forgiven. Gane expressed the same understanding of sin in Lev 5:17-19. Sinner never knew nor recalled their sin. ${ }^{165}$ Wells' view of אָָׁ is not based on the study of this verb in the Pentateuch or OT, but is totally informed by the ANE text, specifically the Mesopotamian $\breve{S} u r p u$ incantations, and then applied to Lev 45. Unlike Milgrom who tried to establish the meaning of biblical and ANE texts, Wells mainly relied on the $\breve{S} u r p u$ incantations. He rightly

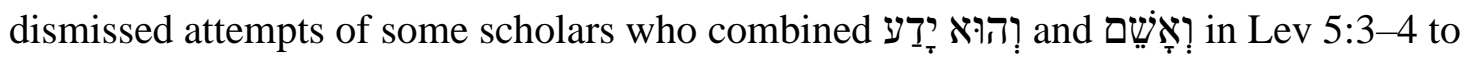
claim that sinners acquire knowledge of their sin, become guilty, and subsequently offer

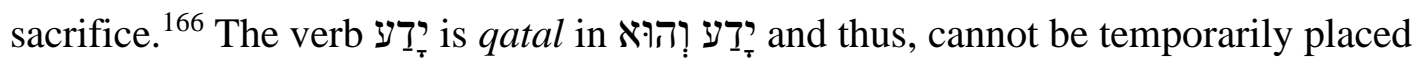

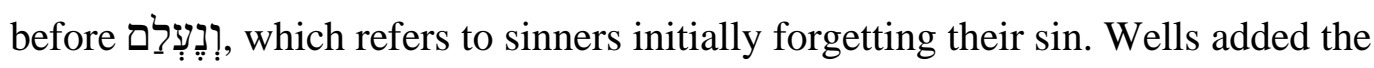
argument from Lev 4 where he also thought that the "knowledge [of sin] never precedes the guilt and the guilt sometimes does the prompting without knowledge ever being acquired." ${ }^{\prime 67}$ He did recognize two alternatives in Lev 4:22-23 and 27-28, but limiting Tָ th the objective sense only prevented him from seeing that there is no knowledge of sin in the first alternative, but rather, the guilt itself is the only motivator for the sinner to offer sacrifice. Knowledge of $\sin$ is not needed at all. ${ }^{168}$ This argument is heavily

\footnotetext{
${ }^{165}$ Gane, Leviticus, Numbers, 133.

${ }^{166}$ Paul Heinisch, Das Buch Leviticus (Bonn: P. Hanstein, 1935), 30-31; Karl Ellinger, Leviticus, HAT 4 (Tübingen: Mohr, 1966), 55. Gordon J. Wenham proposed a similar view. He claimed that the sinners confessed their sin and offered sacrifice after being smitten by their conscience. Wenham, The Book of Leviticus, 93, 86.

${ }^{167}$ Wells, The Law of Testimony, 67.

${ }^{168}$ Wells, The Law of Testimony, 68.
} 
influenced by the understanding that which is in contradiction to the conceptual and literary reading of Lev 4 suggested in this work.

Wells declared the subjective-psychological sense (feelings of guilt or remorse, pangs of conscience) as an anachronistic claim that it was unlikely for the ancients to identify guilt in this way. ${ }^{169}$ Rather, the person would experience some tangible signs of being guilty of sin or of suffering divine punishment. ${ }^{170}$

Wells stated that this kind of attitude is demonstrated in the belief of Job's three friends as they witnessed his experience of great misfortune and severe physical pains. As Job did not know what his sin was, so the ancients did not know their sin when struck with physical sufferings. Wells demonstrated this by using the $\check{S} u r p u$ incantations. There, he pointed out "that there was a way for a person, usually someone who was ill, to go to a priest and obtain pardon for sin and relief from its effects, even if the person had no inkling what sin he or she may have committed." ${ }^{171}$ Wells then cited M. J. Geller's observation on the case of a sick person who visited the priest due to their sickness: "Since the patient does not know the exact nature of his transgression, the incantation priest recites an exhaustive list of 95 possible personal misdemeanours, presumably hoping to include the relevant sin." 172 Wells concluded that "it is then assumed that if the

${ }^{169}$ Wells, The Law of Testimony, 68-69.

${ }^{170}$ This argument is based on Raymond Westbrook, Studies in Biblical and Cuneiform Law, CahRB 26 (Paris: Gabalda, 1988), 27-30.

${ }^{171}$ Wells, The Law of Testimony, 68.

${ }^{172}$ M. J. Geller, “The Šurpu Incantations and Lev V.1-5,” JSS 25 (1980): 182. 
offending sin is included in the recitation and the proper ritual performed, people will receive the pardon and relief they seek. Also included in the $\breve{S} u r p u$ texts is a section indicating that a person can ask "for some omen or sign confirming his guilt, or identifying his exact sin." ${ }^{173}$ Wells' final conclusion was that "this is the context in which to understand the term 'āšam Leviticus 4 and 5." "174 This would translate into the following scenario: A person would experience some kind of misfortune, Wells suggested sickness, losing a loved one, or other sort of suffering, which could make him think that he was guilty and incite him to seek out a priest in order to perform ritual involving a purification offering. Thus, it was not knowledge of sin, but the onset of the guilt that triggers the entire process. ${ }^{175}$

The contextual and conceptual difference between pagan religions of ANE and the one of ancient Israel is considerably immense, ${ }^{176}$ as is the difference between the roles of the priest in these two religion systems ${ }^{177}$ which call for detailed work in potentially establishing the connection and mutual influence. The context of the sick person from $\breve{S} u r p u$ texts does not resemble any context in the OT.

There are three well-taken points in Well's understanding of wָ wָ and Lev 5:1-4. First, upholding the objective sense of

${ }^{173}$ Wells, The Law of Testimony, 68; Geller, “The Šurpu Incantations,” 182.

${ }^{174}$ Wells, The Law of Testimony, 68.

${ }^{175}$ Wells, The Law of Testimony, 69.

${ }^{176}$ Milgrom, Leviticus $1-16,42-43$.

${ }^{177}$ Milgrom, Leviticus 1-16, 52-57; Hector Ignacio Avalos, "Illness and Health Care in Ancient Israel: A Comparative Study of the Role of the Temple” (PhD diss., Harvard University, 1991). 
condition is obviously present in this verb. Second, the point that the ancients experienced guilt in a tangible way is also a well-taken point. However, it has to be mentioned that Milgrom and others have already stated that physical, along with psychological, suffering is a part of the sinner's being אָ, as was discussed above. ${ }^{178}$ Third, Wells rightly noted that the phrase וְהוּא יָיבע should be understood as a pluperfect and refers to the knowledge of the sin that was subsequently forgotten prior to the experience of exaggerated, and not supported by the OT. The main concern of Wells' suggestion is an unconvincing lexical and conceptual connection between these two texts.

First, a proper method of inferring insights from ANE texts to the biblical texts has been highly debated over the last 150 years, resulting in two totally opposing positions. One camp is recognizable for overemphasizing parallels (parallelomania) ${ }^{179}$ between the two texts corpuses and another one for downplaying them (parallelophobia). ${ }^{180}$ The right direction for arriving at a sound comparative method is a middle ground proposed by William W. Hallo, termed a "contextual method," that seeks to observe both the similarities, as well as differences between the two texts. ${ }^{181}$ William

\footnotetext{
${ }^{178}$ Jacob Milgrom, Cult and Conscience: The Asham and the Priestly Doctrine of Repentance, SJLA 18 (Leiden: Brill, 1976), 76.

${ }^{179}$ Sandmel, "Parallelomania," 1-13.

${ }^{180}$ R. Ratner and B. Zuckerman, "AA Kid in Milk'?: New Photographs of KTU 1.23, Line 14,” HUCA 57 (1986): 15-60, especially 52.

${ }^{181}$ William W. Hallo, “Compare and Contrast: The Contextual Approach to Biblical Literature," in The Bible in the Light of Cuneiform Literature: Scripture in Context III, eds. William W. Hallo, Bruce William Jones, and Gerald L. Mattingly, Ancient Near Eastern Texts and Studies 8 (Lewiston, NY: Mellen Press, 1990), 1-30; William W. Hallo, "Biblical History in Its Near Eastern Setting: The Contextual Approach," in Scripture in Context: Essays on the Comparative Method, eds. C. D. Evans, W. W. Hallo,
} 
Younger correctly stated that "the best comparative studies recognize that the literature of the ancient Near East was produced not only out of a particular culture but also out of a larger literary tradition, and that comparison with other literature that is similar within that tradition — serving the same purpose, using the same structure, or referring to the same subject—reveals certain aspects of a text that might remain hidden." 182 This method seeks to expose what is traditional, conventional, or generic in a story in order to lessen the conjectural element in historical analysis, or the subjective element in literary criticism. A balanced evaluation of the evidence is comprised of four closely linked lines of assessment: (1) linguistic, (2) geographic, (3) chronological, and (4) cultural (not necessarily in this order). ${ }^{183}$ In addition, this method cautions that there is a degree of uncertainty in the interpretative process. ${ }^{184}$

In terms of the comparative approach, Wells followed Meir Malul by accepting the "historical compassion approach," which seems to be a better alternative than the "typological comparison approach," since the former looks for the correspondence between two societies that share common geographical and historical settings in contrast to the latter that compares geographically and historically unrelated societies. ${ }^{185}$

and J. B. White, PTMS 34 (Eugene, OR: Pickwick, 1980), 1-12; William W. Hallo, The Book of the People, BJS 225 (Atlanta: Scholars Press, 1991), 17-23.

${ }^{182}$ K. Lawson Younger, "The 'Contextual Method': Some West Semitic Reflections," in Archival Documents from the Biblical World, ed. William W. Hallo, COS 3 (Leiden: Brill, 1997), xxxvii.

${ }^{183}$ Younger, "The 'Contextual Method"”, xxxvii.

${ }^{184}$ Younger, "The 'Contextual Method"”, xli.

${ }^{185}$ Wells, The Law of Testimony, 6; Meir Malul, The Comparative Method in Ancient Near Eastern and Biblical Legal Studies, AOAT 227 (Neukirchen-Vluyn: Neukirchener, 1990), 13; Claus Westermann, The Structure of the Book of Job: A Form-Critical Analysis, trans. Charles A. Muenchow (Philadelphia: Fortress Press, 1981), 33; Paul Maxwell and John Perrine, "The Problem of God in the Presence of Grief: Exchanging 'Stages' of Healing for ‘Trajectories' of Recovery,” JSFSC 9.2 (2016): 192. 
However, Wells excluded most literary and contextual links from his method, ${ }^{186}$ which is crucial for establishing the fact that the $\check{S} u r p u$ incantations and Lev 4-5 share the same characteristics, thus justifying their comparison. This would be essential, as Hallo's “contextual approach" suggests, in order to establish ground for comparing two texts from different geographical, cultural, and chronological settings and is required to

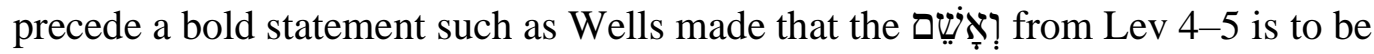
understood in the same context where the sick find healing in $\breve{S} u r p u$ incantations. In addition, Wells' work focuses on similarities only neglecting the importance of considering contrasts which is contrary to Malul's understanding of the "historical comparison approach." 187

Second, it is problematic to take the assumptions of Job's friends which were never explicitly spelled out in the OT nor defined as a common way of sinners' realization of their unknown or forgotten sin and use them to interpret the technical text of Lev 4-5, the only text besides Num 15 that resolves the situation in which a person sinned. These assumptions were proven to be totally wrong later in the book of Job. ${ }^{188}$ There is a need to establish more solid connections between the two texts in order to have

${ }^{186}$ Wells, The Law of Testimony, 9-10.

187، This pre-assumption of some historical link between the Old Testament and the ancient Near East is, of course, justified in principle. After all, the Old Testament grew up in the same cultural, linguistic, and historical context of the ancient Near East, and it is only natural to expect to find similarities and parallelisms here and there, as well as significant contrasts." Malul, The Comparative Method in Ancient Near Eastern and Biblical Legal Studies, 34.

${ }^{188}$ Scholars mainly deny any sin on Job's part in the book of Job. Robert L. Alden, Job, NAC 11 (Nashville: Broadman \& Holman, 1993), 409; John H. Holbert, "The Rehabilitation of the Sinner: The Function of Job 29-31," ZAW (1983): 237; John E. Hartley, "Job,” NIDOTTE 4:781. Some believe that Job committed sin during his sickness as he was questioning God, but not before it. Lynne B. Newell, "Job: Repentant or Rebellious?," VT 46 (1984): 315. 
one influence over the other. The nature of these two texts is totally different; this is reflected in the use of different literary genres. Job, for the most part, belongs to wisdom literature that deals with concepts and notions, ${ }^{189}$ while Leviticus, for the most part, is legal/cultic law. Belief that sufferings, physical or psychological, can come on people because of their sin is definitely a part of ANE and the biblical worldview, but singling it out as the only way by which sinners realize that they have committed sin and need to offer a sacrifice would be a matter of arbitrary, subjective opinion and forced interpretation, rather than a textually proven assessment. If that were true, it would greatly dispute the sophisticated and intellectual cognition the ancients had.

This inexhaustive list of serious weaknesses in Wells' comparative method that is reflected in his interpretation of Lev 4-5 led me to dismiss his suggestion that wָ refers to the physical pain caused by the sinners' sin, which actually motivates sinners to offer sacrifice rectifying the situation in which they find themselves. His work shows a poor connection between the contexts of Šurpu incantations and Lev 4-5 in order to infer insights from the former and apply them to the latter.

\section{"To Realize Guilt"}

Kiuchi proposed that the sinners are unaware of their $\sin$ in Lev $4,{ }^{191}$ but he allowed for "or" as the meaning

\footnotetext{
${ }^{189}$ Lawrence Boadt, "Wisdom, Wisdom Literature," EDB 1380-82; Roland E. Murphy, "Wisdom in the OT," ABD 6:925-26, 928; C. Hassell Bullock, An Introduction to the Old Testament Poetic Books (Chicago: Moody Publishers, 2007), 19-78, especially 29-34.

${ }^{190}$ Kiuchi, Purification Offering, 31-34. Also followed by Hartley, Leviticus, 44-45, 72-73.

${ }^{191}$ Kiuchi, Purification Offering, 25-31.
} 
for ik, which introduces two alternative ways in which sinners realize their sin. Sinner are told their sin after the particle, but it was the way sinners learn about their sin before it is described by Since the consciousness of sin is missing in the verb שגה, it must be expressed through דָ. ${ }^{192}$ Kiuchi's suggestion also provides a persuasive reading of the texts in Lev 4-5 since it solves the difficulty that, chronologically, sinners are not aware of their sins or they forget them until the inference that sinners realize their sin that is told to them by others, and subsequently bring the sacrifice. Sklar first critiqued Kiuchi's suggestion that אָָׁשָם can refer to the suffering caused by sin which leads to the realization of the sin. In this case, expresses the result of sin, rather than the lack of realization itself. However, Sklar did, in a way, uphold Kiuchi's proposal by stating that sinners could realize their sin, which would subsequently lead them to feel guilty. This point of Sklar's critique is fully informed by Milgrom's understanding of consequential meaning of it ${ }^{193}$ and is not convincing. As such, it opens up the possibility for the inclusion of both realization of sin and feeling guilt in the semantic domain of

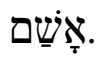

Sklar's second point of criticism of Kiuchi's suggestion is that the translation, "to realize sin," creates an unreasonable reading of Lev 4:3: "If the high priest sins so as to

\footnotetext{
${ }^{192}$ Kiuchi, Purification Offering, 31.

${ }^{193}$ Sklar, Sin, Impurity, Sacrifice, Atonement, 33.
} 
make people realize their guilt." ${ }^{, 194}$ First, Kiuchi never excluded the notion that this text, due to the infinitival idea, meaning leshmat, "causing guilt to the people,"195 assumes some sort of consequences on the people because of the high priest's sin, but rather noted the fact that when the high priest commits sin, the entire people, besides him, is in his words, "the people realize guilt." Behind Kiuchi’s proposal that leshmat ${ }^{197}$ means "so that the people realize guilt" stands his subjective and objective understanding of אָ, meaning that they realized their guilt and are guilty, which correlates with the experience of the high priest himself. ${ }^{198}$ Sklar's criticism is informed by Milgrom's idea that not the objective. Second, the correlation between the high priest's sin and the experience of guilt of the people is a well-established interpretation of this text: ${ }^{199}$ it is thus expected that the high priest's sin has an impact on, and is eventually noticed by, the people. Thus, this point of criticism essentially depends on whether one allows for the

${ }^{194}$ Sklar, Sin, Impurity, Sacrifice, Atonement, 34.

${ }^{195}$ Kiuchi, Purification Offering, 126; Kiuchi, Leviticus, 88.

${ }^{196}$ Kiuchi, Leviticus, $92-93$.

${ }^{197}$ Kiuchi seems to disagree with himself on the meaning of ${ }^{2}$ in Lev 4:2 since he seems to allow for both senses of wָז , and yet denies the objective one in this text. Kiuchi, Purification Offering, 126; Kiuchi, Leviticus, 88, 92-93, 95-96. However, his position is generally that wָ is comprised of both senses. Kiuchi, Purification Offering, 33-34.

${ }^{198}$ Kiuchi, Leviticus, 92-93.

${ }^{199}$ Milgrom, Leviticus 1-16, 231-32; Snaith, Leviticus and Numbers, 41; Noordtzij, Numbers, 57; Noth, Leviticus, 38; Levine, Leviticus, 20; Wenham, The Book of Leviticus, 97; Gane, Cult and Character, 81. Sklar himself included Sklar, Sin, Impurity, Sacrifice, Atonement, 41; Sklar, Leviticus, 110. 
encompass in a subjective and objective sense or only in the subjective, which makes it highly inadequate.

\section{"To Feel Guilt"}

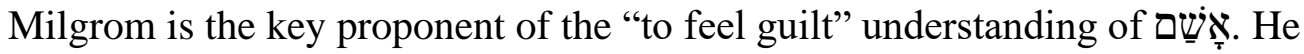

proposed the following meaning of אָ: "When it is followed by the preposition $l$ and a personal object it means "to incur liability to" someone for reparation; without an object, it refers to the inner experience of this liability, meaning "to feel guilt.","200 It either conveys that the guilt is incurred by someone in the former or to the sinner's psychological experience of guilt in the latter case, but he denied that the root contains the reference to sinners' realizing their sin. Milgrom displayed an inconsistency of his own reasoning since he stated that one of the ways sinners realize their sin is on their own. ${ }^{201}$ Chronologically, this happens before sinners are told of their sin, before ? in v. 13 or i in vv. 22 and 27. The subjective-psychological component of augmented by the consequential sense of it. Milgrom explained the subjective-

${ }^{200}$ Milgrom, Leviticus 1-16, 339.

201،'The subsequent cases certify that remorse for ('āšām) and knowledge of (yāda') one's error are prerequisites for the purification offering (see on vv 13-14, 22-23). Yet surprisingly, neither term is found in the case of the high priest. Moreover, the text does not even state that his error was committed inadvertently! The latter objection is removed once it is realized that the factor of inadvertence is expressly given in the previous verse, the heading for the entire chapter. But what of the missing remorse and knowledge? There is no choice but to infer that these things are taken for granted (Keter Torah). Because the high priest performs most of his rituals in the privacy of the tent-shrine, only he can inform himself of his error. And once discovered, it is inconceivable that he would not feel remorse." Milgrom, Leviticus 116, 232. "The individual who errs either finds out the nature of his error on his own or ('ô) someone else informs him of it." Milgrom, Leviticus 1-16, 243-44. "Either the chieftain discovers his error (and regrets it) or someone else informs him." Milgrom, Leviticus 1-16, 247. Also, Milgrom, "The Cultic שגגה and Its Influence in Psalms and Job," 117; Jacob Milgrom, Studies in Cultic Theology and Terminology, SJLA 36 (Leiden: Brill, 1983), 117. 
psychological sense in the following way:

Wrongdoing creates guilt and fear of punishment, and, conversely, suffering reinforces the presence of guilt feelings because it is interpreted as punishment for $\sin$. Thus it is logical to expect that a language that, as observed, will express the consequential syndrome of sin-punishment by a single word will also have at least one root in its lexicon to express another consequential relationship, that which exists between sin-punishment and guilt feelings. This root, I submit, 'šm. ${ }^{202}$

Milgrom limited אָ in cultic texts, when used as an intransitive verb, to the subjective sense only:

In the cultic and legal texts, however, where metaphors are eschewed, a precise term would be essential to pinpoint the existence of guilt: it is the verb 'āšam. Thus, contrary to usual translations, 'āšam without an object does not refer to a state of guilt; rather, in keeping with its consequential meaning, it denotes the suffering brought on by guilt, expressed now by words such as qualms, pangs, remorse, and contrition. 'āšam would then mean to be conscience-smitten or guilt stricken, and henceforth it will be rendered as "feel guilt." 203

Sklar critiqued the essence of the arguments in both Milgrom's quotations. First, Milgrom assumed that punishment and guilt feelings without providing valid arguments for such a claim. Sklar correctly stated that just because it is logical for a word with a certain meaning to exist in a given language does not necessarily mean that that word actually exists in that language. ${ }^{204}$ Second, Milgrom also saw the need of a word in cultic and legal texts that would convey the notion of guilt and proposed that that word is not provide any substantial proof for such a claim. Sklar correctly pointed out that the

\footnotetext{
${ }^{202}$ Milgrom, Leviticus 1-16, 343.

${ }^{203}$ Milgrom, Leviticus 1-16, 343. Emphasis mine.

${ }^{204}$ Sklar, Sin, Impurity, Sacrifice, Atonement, 38.
} 
proof for this meaning of contexts. $^{205}$

Kiuchi noticed that Milgrom's line of thinking to come to this subjectiveconsequential understanding of reasonable to assume that sinners are aware of the sinfulness of their act, even while planning it, since the sin in Lev 5:22 is intentional but Milgrom proposed that "only the element of remorse fits we '̄ašem here." ${ }^{206}$ Sinners feel guilt and, therefore, begin the process of rectifying their sin, v. 23.

Second, if one applied the objective sense, "be guilty," the protases in Lev 4-5 would lose their prescriptive function since the objective sense of שָָָׁ, "to be/become guilty," is an external assessment of the sinners' condition that is alienated from the sinners' own internal assessment of themselves. This is further confirmed by the fact that the term immediately precedes the bringing of the sacrifice or the beginning of the rectifying process of the sinners' $\sin ^{207}$

However, the understanding of creates an inconsistent reading of Lev 4-5. This limited view of שָ as a subjectivepsychological-consequential sense especially affects the protases in Lev 4:3, 13-14, 22$23,27-28 ; 5: 3-5,17,23$.

Lev 4:3. In this text, the community becomes $ָ$ w̦ by the high priest's $\sin$. The

\footnotetext{
${ }^{205}$ Sklar, Sin, Impurity, Sacrifice, Atonement, 38-39.

${ }^{206}$ Milgrom, Leviticus 1-16, 344.

${ }^{207}$ Kiuchi, Purification Offering, 32.
} 
prepositional phrase

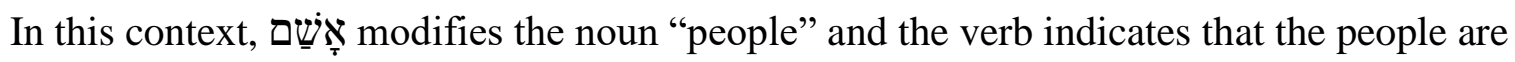
endangered because of the high priest's sin. Applying his consequential understanding of

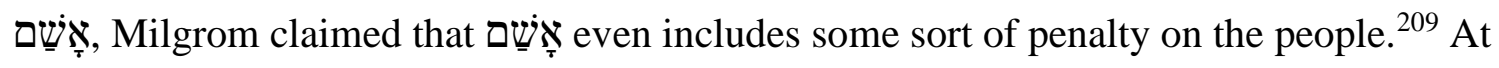

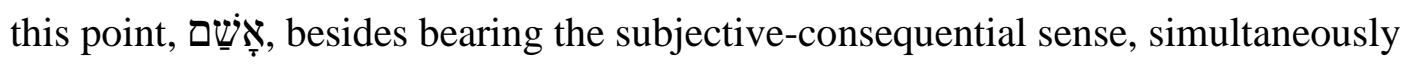
conveys the objective fact that the people are guilty for an unknown reason.

Sklar, noting the sameness of ritual and sacrifice in the first two subcases (vv. 312 and 13-21) which would imply the same sort of guilt, critiqued Milgrom for changing a consequential understanding of אָָ in v. 3, "to the detriment (of the people)," into a subjective one in v. 13, "they feel guilty." The understanding of in the two subcases. ${ }^{210}$

Milgrom excluded the consciousness of sinfulness of the act from Lev 5:17, 23 because sinners are aware of their sin and guilt before 17, they are unaware of their sin and thus, cannot realize it. ${ }^{211}$ Milgrom proposed that in 5:17, the sinner was unaware of both his sin along with its sinfulness and therefore, אָשָָׁ refers to the sinner's "suspecting that he has done wrong." 212 This sin turns out to be the

\footnotetext{
${ }^{208}$ Milgrom, Leviticus 1-16, 231.

${ }^{209}$ Milgrom, Leviticus 1-16, 231.

${ }^{210}$ Sklar, Sin, Impurity, Sacrifice, Atonement, 36-37.

${ }^{211}$ Milgrom, Leviticus 1-16, 342-43; Milgrom, "The Cultic שגגה and Its Influence in Psalms and Job," 117n11.

${ }^{212}$ Milgrom, Leviticus 1-16, 342.
} 
sin against God like the sin in vv.14-16. ${ }^{213}$ Milgrom connected the subcases in vv. 14-19 and 20-26 [6:1-7] as being the laws that treat sins against God. The former treats sacrilege against sancta and the latter deals with sacrilege involving oaths. ${ }^{214}$ This was Milgrom's starting point for arriving at the subjective-psychological-consequential sense of wָשָׁ. Accordingly, it can only refer to the state of remorse.

The fear of unknown sins is a well-known concept in ANE people. Hence, sinners suffer either mentally or physically, which make them conclude that they must have committed a sin. Yet, despite the ancient's fear of unknown sin, the law assumes an objective fact that a person committed a sin. The law does not envision the situations in which sinners suspect that they have committed wrong, but rather, states that sinners committed sin and subsequently feel guilty. Kiuchi correctly stated that "when he [the sinner] feels guilty, he [the sinner] knows what the sin was." ${ }^{215}$ Sinners are undeniably aware of their sin and guilt before even feeling guilty. Accordingly, wָin includes consciousness of sin by the sinner. Sklar noted similar weakness. That is, Milgrom's psychological sense, "to feel guilt," inadequately accounts for the fact that sinners cannot feel guilt for the sin they do not know. In addition, Milgrom's psychological or physical suffering as an element of for it. ${ }^{216}$

213“"The law of Lev 5:17-19 is thus the legal formulation of the psychological truth that he who does not know the exact cause of suffering imagines the worst: he affronted the Deity; he has trespassed on His sancta and "incurred liability to the Lord" (v. 19)" Milgrom, Leviticus 1-16, 332.

\footnotetext{
${ }^{214}$ Milgrom, Leviticus 1-16, 320.

${ }^{215}$ Kiuchi, Purification Offering, 33.

${ }^{216}$ Sklar, Sin, Impurity, Sacrifice, Atonement, 37-38.
} 
Finally, it is highly questionable whether the realm of conscience can be separated so finely from the realm of consciousness. ${ }^{217}$ Hartley argued that this precision is not the customary manner of expression in the Hebrew Bible:

While Milgrom has made an excellent point, nevertheless, אשם has an objective usage for a person's ethical/legal culpability, rather than for a person's existential feelings. In that Hebraic thought tends not to make strict categorical distinctions, it is possible that both of these meanings are present in some occurrences of the verb; a person who is guilty and accountable before God would also experience the stirring of guilt in his conscience, awaking him to his need to take the steps to expiate his wrongdoing. ${ }^{218}$

In 5:23, sinners are aware of their sin expressed by the Hebrew term מָָּ from the

outset. This term was used previously in v. 14 and since the Pentateuch does not define it, nor does the rest of the Bible, Milgrom studied it in the rabbinic texts, and in similar contexts within ANE texts to find its meaning and applied it to v. $23 .{ }^{219}$ Based on all these three sources, Milgrom proposed that

${ }^{217}$ David Daube, Ancient Jewish Law: Three Inaugural Lectures (Leiden: Brill, 1981), 123ff.

${ }^{218}$ Hartley, Leviticus, 76-77.

${ }^{219}$ Milgrom particularly studied the ANE Instructions for Priests and Temple Officials (CTH 264). Milgrom, Leviticus 1-16,353. This Hittite text provides "a full range of biblical ma al" by treating a variety of sancta trespasses. Milgrom, Leviticus 1-16,353-56. However, Milgrom's comparative work is critiqued in depth by An, who claimed that his understanding of wָw was based on his interpretation of Lev 5:17-19 in the ANE literature and applied it to all other places in Lev 4-5. An, "Delayed Recognition," 23. An critiqued Milgrom's methodology of working with the English translation of Hittite texts since it "does not fully capture the rich details of the conception of sin and the consequent legal proceedings," since his presentation is limited to the "hierarchy of penalties for sancta trespass among the Hittites." An, "Delayed Recognition," 23. She found out that he pointed to the differences and disregarded striking similarities between the two texts. Finally, she suggested that Milgrom's work on the priests and temple officials (CTH 264) needs a thorough reassessment in light of recent work of Ada Taggar-Cohen on the same text that demonstrated a complex compositional relatedness of this text to earlier sections. In other words, a more comprehensive perspective of literary features and the underlying ritual system in the Hittite text is necessary if one wants to compare these two texts. An, "Delayed Recognition," 23; Ada TaggarCohen, Hittite Priesthood, THeth 26 (Heidelberg: Winter, 2006), 33-139. 
sacrilege against sancta or sacrilege involving oaths. ${ }^{220}$ Sinners, in v. 23 , are aware of their sin subjectively and objectively, but it seems reasonable to think that only after they experience the consequential aspect of wָָ (pangs of their consciousness) is their subjective and objective experience of guilt placed in the right context and they fully understand their $\sin .^{221}$ This scenario of a $\sin$ in v. 23 resonates with sin out of the weakness of will. People sin regardless of the fact that they know that they are sinning against God. This would mean that Milgrom's proposal that sinners are fully aware of their guilt even while planning their sin is not correct. ${ }^{222}$

A simple inclusion of the objective sense of אָ along with the subjective solves the inconsistent reading of Lev 4-5. Sinners sin, know that they are guilty, experience the feelings or pangs of guilt, realize the full scope of their sin, and decide to undergo the necessary steps to rectify their sin. A limiting שָָָׁ to subjective-psychologicalconsequential sense of שָׁw to "feel guilt" is a contradictory choice in this context.

Lev 4:13-14, 22-23, 27-28. One of the problems with these texts was caused by the attempt to amend the opening of the vv. 23, 28 that starts with the Hebrew particle based on the fact that v. 14 begins with the conjunction ?, instead causing וְ to be translated objectively "to be, become guilty." 223 The particle introduces an alternative to

\footnotetext{
${ }^{220}$ Milgrom, Leviticus 1-16, 320.

${ }^{221}$ Kiuchi, Purification Offering, 32.

${ }^{222}$ Kiuchi, Purification Offering, 32.

${ }^{223}$ Kiuchi, Purification Offering, 33-34.
} 


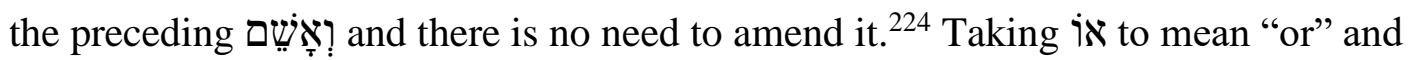
excluding consciousness of sin from though they do not know their sin. On the contrary, sinners are fully aware that their act is sinful before they offer a sin offering or proceed to rectify their $\sin .^{225}$ They become aware of their act's sinfulness in two ways, on their own which is contained in the verb אֵַָׁם (they suffer the pangs of their consciousness or feel guilt, subsequently recall their sin and realize that they are guilty), or they are informed about their sin by someone else. The Hebrew particle iw undeniably separates two different ways of sinners' cognition about their $\sin (\operatorname{Lev} 4: 22-23,27-28){ }^{226}$

This separatedness does not disappear nor diminish because of the fact that that the transition in v. 14 is expressed through the conjunction ? instead of iא, since ? is frequently used to separate two different/contrasting items in the Pentateuch, especially in conditional phrases or alternative cases as this one is. ${ }^{227}$ Commenting on Lev 4:14, Milgrom himself confirmed the two ways of sinners' learning of their sin in Lev 4:22-23 and 27-28: "The individual who errs either finds out the nature of his error on his own or ('ô) someone else informs him of it." ${ }^{228}$ Again, Milgrom confirmed that the same

${ }^{224}$ Toorn, Sin and Sanction in Israel and Mesopotamia, 92.

${ }^{225}$ Milgrom, "The Cultic שגגה and Its Influence in Psalms and Job," 116.

${ }^{226}$ Toorn, Sin and Sanction in Israel and Mesopotamia, 92.

${ }^{227}$ Also, HALOT, s.v. "I”; BDB, s.v. “"." See Gen 26:11, Exod 20:10, 17; 21:16, 17; Lev 21:14; 22:23, 24 and Job 31:13, 16, 26; Prov 29:9; Jer 44:28 outside of the Pentateuch. See also Lev 1:2, 10 where ? and is are interchangeable.

${ }^{228}$ Milgrom, Leviticus 1-16, 243. 
principle operates in vv. 23-24 as he commented on v. 23: "Either the chieftain discovers his error (and regrets it) or someone else informs him." ${ }^{229} \mathrm{He}$ and Kiuchi, ${ }^{230}$ by not reading ? with the meaning of "or," totally missed the point about two alternative ways of realizing sin, which also means that Instead he erroneously stated: "Here [v. 14] the temporal sequence is reversed, wě 'assemm $\hat{u}$ wěnôdĕ 'à 'and they feel guilt when [the wrong] becomes known': the second verb precedes the first in time." ${ }^{231}$ Milgrom explained this by saying, "But as the community as a whole has erred there can be no 'or'; the communal guilt results from the eventual discovery of the error by the community itself." ${ }^{, 232}$ The temporal sequence reversal is syntactically unlikely since both verbs are weqatals meaning the action conveyed by the second verb temporally follows the action conveyed by the first verb. The temporal reversal is clearly implied in Lev 5:3-4, 17-18, since all רִיָ verbal forms are qatal, pluperfects which is not the case in Lev 4:13-14.

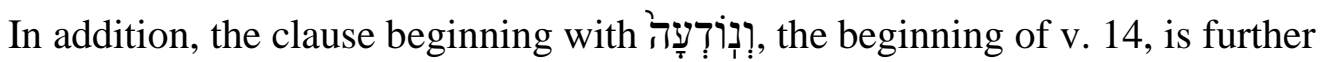

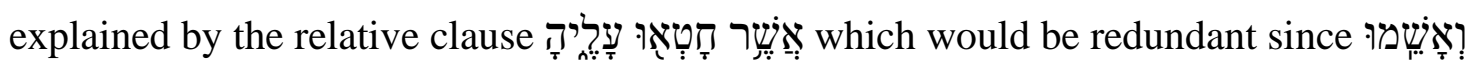

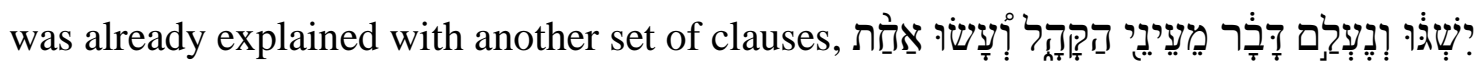

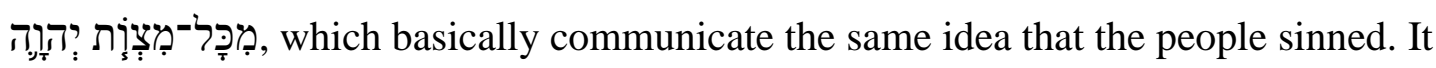
makes more sense to view the clause that opens v. 14 , וֹנוֹדְעָה , as an alternative way of

\footnotetext{
${ }^{229}$ Milgrom, Leviticus 1-16, 247.

${ }^{230}$ Kiuchi, Purification Offering, 33-34.

${ }^{231}$ Milgrom, Leviticus 1-16, 243.

${ }^{232}$ Milgrom, Leviticus 1-16, 243-44.
} 
realizing sin since the text would be redundant if the וְנְוֹדְעָה were temporarily transported

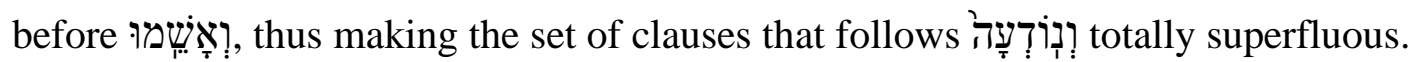

This would go against the subsequent two subcases in Lev 4:22-23, 27-28, which use the same verbs and temporal sequence, but also use the particle i which definitely separates the two alternatives. Thus, instead of emending " אi "or" in different ways ${ }^{233}$ in vv. 23 and 27 that produce a smooth reading, one should note and apply a regular "or" meaning for ? and uphold two alternative ways of realizing sin by the sinner in the last three subcases in Lev 4.

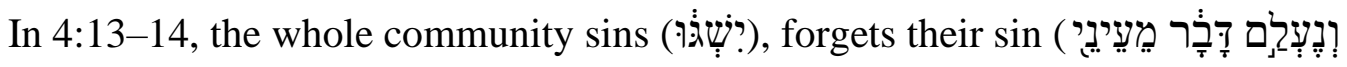

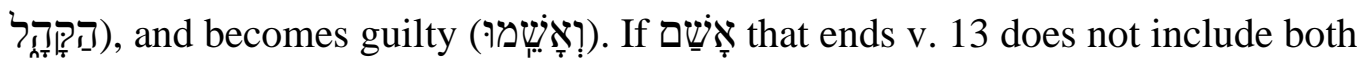
subjective and objective meanings, but rather, just the subjective as proposed by Milgrom, ${ }^{234}$ Sklar, ${ }^{235}$ and Gane, ${ }^{236}$ the text would be irrational and Sklar's critique would be well taken. This scenario would have sinners bringing the sacrifice for a sin they do not even know. To the contrary, the context suggests that אָָׁ should include both semantic meanings of

\footnotetext{
${ }^{233}$ For the alternative translations of ix in v. 23 and 28 see Sklar, Sin, Impurity, Sacrifice, Atonement, 30.

${ }^{234}$ Milgrom, Leviticus 1-16, 342-43.

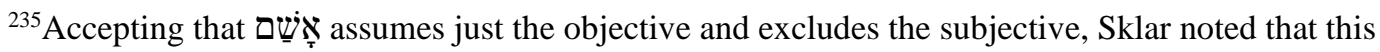
reading is senseless in 4:13,22, 27: "This is because the sin is hidden from the sinner; as a result it would make no sense to say that 'if anyone sins, and is guilty or is told what their sin is, then he or she shall bring an offering', for in the first instance the sinner is not aware of their sin and would thus not even know to bring a sacrifice." Sklar, Sin, Impurity, Sacrifice, Atonement, 30.

${ }^{236}$ Gane, Cult and Character, 205, 211n58.
} 
scenario would be in place. The people sinned, forgot their sin, subsequently remembered it (through feelings or pangs of guilt, subjective-consequential element of אָָָׁ), realized

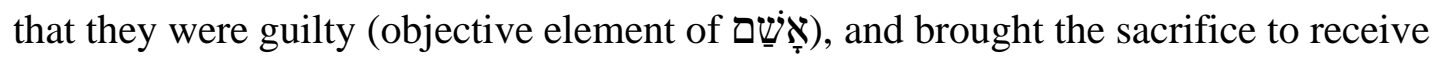
forgiveness. In addition, before the point when the text proceeds with the procedure to address their sin, that is, to bring the sacrifice (וְהקְְרָיבוּ), the opening clause of v. 14 that

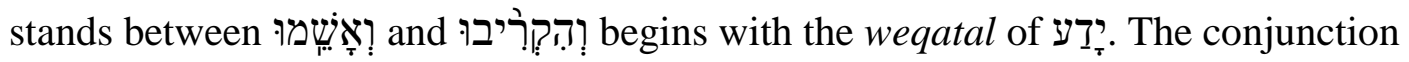
introduces another and totally different way in which the sin is being objectively realized. Someone else lets the people know that they sinned since they are not aware of their sin at all. This reading suggests two types of $\sin$. The first type of sin is done both intentionally or unintentionally, subsequently forgotten, and eventually remembered, while the second type of sin is unknown to the people. They need somebody else to tell them.

This reading of protases in Lev 4 suggests that and the subjective sense without excluding the consequential component of the subjective sense. Only allowing the verb the immediate context of Lev 4 provides a credible reading of the text.

\section{“To Suffer Guilt's Consequences"}

Following K. van der Toorn, ${ }^{237}$ Sklar adopted the idea that translated as "to suffer guilt's consequences" based on the fact that terms for sin in

\footnotetext{
${ }^{237}$ Toorn, Sin and Sanction in Israel and Mesopotamia, 92.
} 
general have a consequential meaning. He stated that " "שָׁw is often explicated with the description of the punishment it describes." In addition, he suggested that this is confirmed by the uses of שָָׁ outside of the Pentateuch (Psa 34:22 [21]; Hos 10:2; 14:1[13:16]; Isa 24:6; Jer 2:3). ${ }^{238}$ These texts are not commented on, for the latter argument is dismissed since, in essence, it is an old hermeneutical mistake called root fallacy.

Sklar claimed that this translation of 4:22 to $4: 23$ and from vv. 27 to 28 since it allows for the "or" translation of the particle iא. It fits the context well in which the sinners are initially not aware of their sin, but subsequently, learn of it when they experience guilt's consequences, both physical and psychological, which was common in ANE. Sklar cited another text outside the Pentateuch to support this particular point (2 Sam 21:1). In addition, this translation does well with Lev 5:23 since sinners, struck by guilt's consequences, decide to rectify their sin. Finally, this translation introduces the same sort of suffering for both subcases in Lev 4:3-12 and 13-21 since the sin is the same in both cases and necessitates that the effect of it be the same, as well. ${ }^{239} \mathrm{He}$ then concludes that "the most appropriate translation for

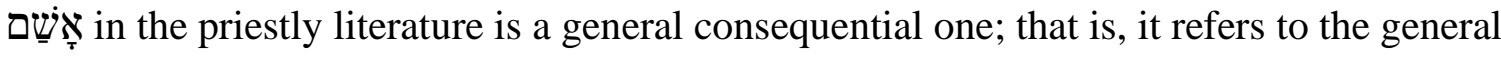
consequences brought on by the guilt of sin and may be translated with 'to suffer guilt's consequences. ${ }^{240}$

\footnotetext{
${ }^{238}$ Sklar, Sin, Impurity, Sacrifice, Atonement, 39.

${ }^{239}$ Sklar, Sin, Impurity, Sacrifice, Atonement, 40-41.

${ }^{240}$ Sklar, Sin, Impurity, Sacrifice, Atonement, 41.
} 
This proposal does contribute to the debate since it provides a smooth reading of the transitional particles in vv. 3, 13-14, 23-24, and 27-28. However, it excludes the notion of the objective sense after sinners come to realize their sin. This detail is crucial for an even more natural reading of the transitional particle in these verses.

\section{Conclusion on אָשָָׁ}

The solution I propose is that both aspects, subjective-psychologicalconsequential and objective, are contained in the verb above, my understanding of Michael A. Grisanti's observation: “ [It] signifies the state in which the perpetrator finds himself as a result of his offense." ${ }^{241}$ Knierim augmented this understanding by stating that "the double usage — from a modern perspective — of the one root 'šm (see 3a) apparently relates to a common foundation assumed in all aspects from judgment of guilt to resolution of guilt: it is the obligation, the duty, the liability, that results from incurring guilt.."242 ${ }^{242}$ is a multifaceted verb encompassing basically all the proposed translations: (1) to be/become guilty, (2) to realize guilt, (3) to feel guilt, and (4) to suffer guilt's consequences. These meanings are not mutually exclusive, but rather, complementary. The context is a determining factor if both or one particular sense is to be a preferred meaning. Inclusion of both of these factors, the subjective-psychologicalconsequential and objective sense of the verb שָׁ expressed in the four ways of

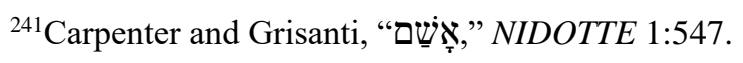

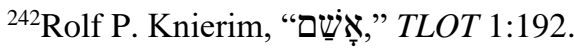


translating it, and the literary and grammatical flow of the texts provides the most satisfactory and consistent reading of Lev 4-5. The contexts in Lev 4-5 suggest that the terms would be open to take on any, some, or even all of these meanings since choosing only certain meanings does not provide satisfactory nor consistent reading. The struggle of choosing the right translation remains since at least four different English translations were suggested in the history of research of this term. However, "to be/become guilty" remains the least misleading translation since it embodies all the others and it remains the most basic meaning of the term in the context of legal/moral standing. ${ }^{243}$

This understanding of one of the suggested understandings/translations of

First, it chronologically places sinners' recognition of the sinfulness of their sin before they offer sacrifice or make confession in Lev 5:1-5, 17, which is obvious in Lev $4: 3,13-14,23-24$, and 27-28. Sinners are always fully aware of their sin before offering sacrifice.

Second, it provides the rationale of how sinners who are aware of their sin are motivated to rectify their sin in Lev 5:23. Besides being objectively and subjectively aware of their sin, sinners also experience the consequential aspect of consciousness), and their objective and subjective experience of guilt is placed in the right context; they fully understand their sin.

Third, this chronology of activities where sinners' awareness of their sin before they begin to rectify it is preserved and upheld by the recognition of the temporal

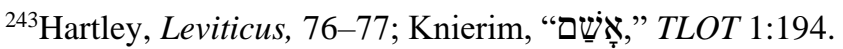


sequence of activities in Lev 4-5 is expressed by wayiqtol and weqatal verbs and of the pluperfect sense of qatal verbs. ${ }^{244}$

Fourth, it recognizes that the two different ways by which sinners become aware of their sin, which are obvious in Lev 4:23-24, 27-28, can apply in the other translations in Lev 4:3, 13-14 by understanding the Hebrew particle iw in the most natural way as "or" and understanding the Hebrew conjunction ? to mean "or," as well as is one of its frequent meanings in the Pentateuch and the Hebrew Bible. ${ }^{245}$

Fifth, the presence of two different ways for sinners' recognition of their sin also

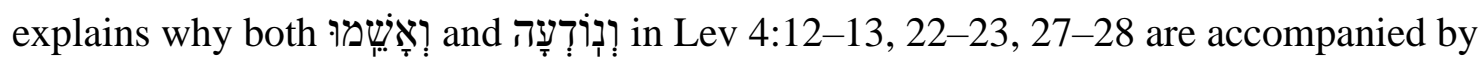
additional clauses that basically communicate that sinners have committed $\sin$. This is not the case in Lev 5:5, 17, 23, where only communicate the act of sinning. The only exception is a short reference to in $v .23$.

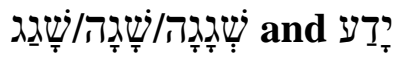

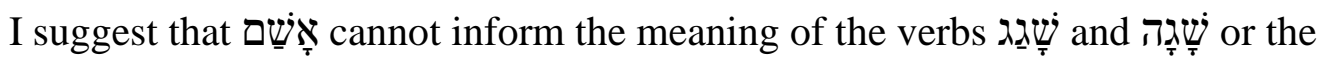

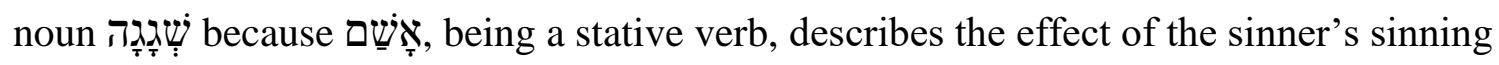

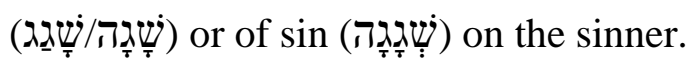

\footnotetext{
${ }^{244}$ The only exception is Lev 5:24, where the yiqtol instead of wayiqtol verb comes after qatal verbs to express the pluperfect sense.

${ }^{245}$ Also, HALOT, s.vv. "או, I"; BDB, s.v. "ר." See Gen 26:11, Exod 20:10, 17; 21:16, 17; Lev 21:14; 22:23, 24 and Job 31:13, 16, 26; Prov 29:9; Jer 44:28 outside of the Pentateuch. See also Lev 1:2, 10 where ? and is are interchangeable.
} 
These two roots are crucial for determining the nature of sins in Lev $4-5^{246}$ and affect the meaning of have coalesced. ${ }^{247}$

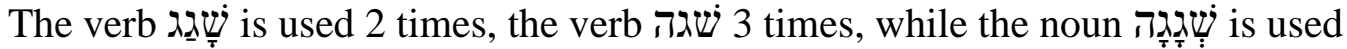
15 times in the Pentateuch. ${ }^{248}$ The basic meaning of the verb is "to err, to lead astray." 249 The root conveys activities that are done unintentionally and intentionally in the OT. ${ }^{250}$ Scholars have generally understood בִּשְָׁגָגדה adverbially as "unintentionally, unwittingly, inadvertently."251

Based on the study presented below, שִשָגָגדה is a generic term for sin, like עִָּ , referring to the intentional or unintentional act as confirmed by the use of this term in Lev 4-5. However, it does not refer to brazen or high-handed sin. That is, it is used in contexts where sinners know that they have sinned (Lev 4:2, 3 [through v. 2], 22, 27; 5:14-16, 17-19; Num 15:24, 25x2, 26, 27, 28, 29; 35:11, 15), as well as in the ones where they do not know (Gen 43:12; Lev 4:2, 3 [through v. 2], 27; 5:17-19; 22:14; Num $15: 24,25 \times 2,26,27,28,29)$.

${ }^{246}$ Kiuchi, Purification Offering, 24.

${ }^{247}$ Milgrom, "The Cultic שגגה and Its Influence in Psalms and Job," 116; Milgrom, Leviticus 116, 242. Also, "But biconsonantal roots that expanded into geminates and lamed-he are attested frequently." Milgrom, Leviticus 1-16, 242.

${ }^{248}$ Accordance Bible.

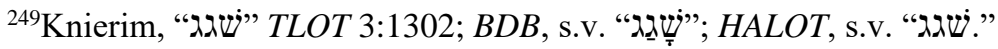

${ }^{250}$ Botica, Concept of Intention, 35n59; Saydon, "Sin-offering and Trespass-offering," 394-95.

${ }^{251}$ Milgrom, Leviticus 1-16, 228-29, 264-65; Kiuchi, Purification Offering, 21, 25, 31; Botica, Concept of Intention, 67; Levine, Leviticus, 19; Sklar, Sin, Impurity, Sacrifice, Atonement, 24. 
Determining the difference between the consciousness of an act and its sinfulness is crucial for the meaning of provide arguments for such distinction.

The verbal form of the term עָָָּ occurs 10 times in the Pentateuch (Lev 4:13; 5:2, 3, 4; 20:4 [x2]; Num 5:13; Deut 22:1, 3, 4), and its basic meaning is "to be concealed, hidden.. ${ }^{253}$ This indicates the lack of knowledge. ${ }^{254}$

Based on his proposal that

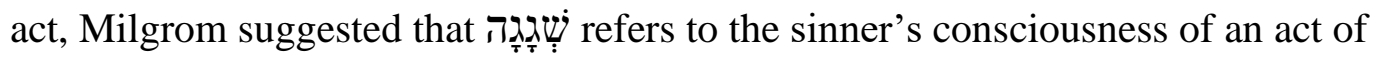
sinning, but not its sinfulness ${ }^{255}$ or that he is unaware of both. ${ }^{256}$ With some adaptations, Hartley, ${ }^{257}$ Hill, ${ }^{258}$ and Kiuchi ${ }^{259}$ have all accepted Milgrom's proposal. Knierim, ${ }^{260}$ Rendtorff, Seidl, Schenker, and Janowski, on the other hand, have rejected Milgrom's

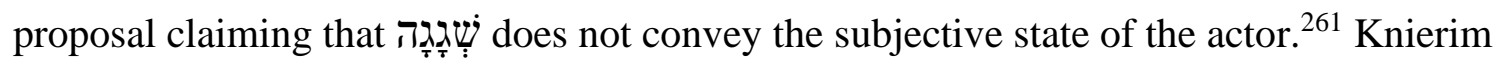

${ }^{252}$ Kiuchi, Purification Offering, 26.

${ }^{253}$ HALOT, s.v. "עלם."

${ }^{254}$ Wells, The Law of Testimony, 65.

${ }^{255}$ Milgrom, Studies in Cultic Theology and Terminology, 117nn11,13.

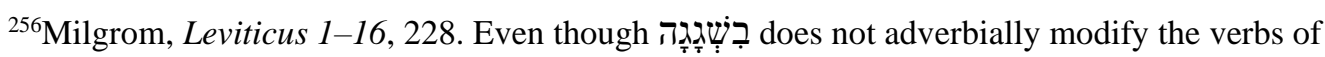

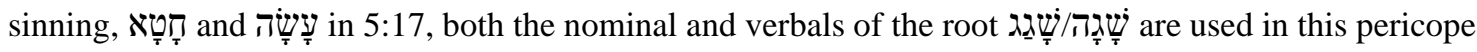
to describe sin in v. 18. This makes Milgrom's claim that sinners in this pericope are not aware of their act, nor of its sinfulness. The terms

${ }^{257}$ Hartley, Leviticus, 59.

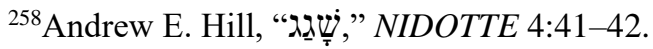

${ }^{259}$ Kiuchi, Purification Offering, 25-27.

${ }^{260}$ Knierim, "שגג" TLOT 3:1303.

${ }^{261}$ Botica, Concept of Intention, 68. 
suggested that if sinners are cognizant of their sin or not is to be deduced from the

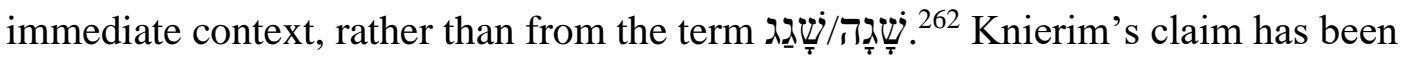
confirmed in the present study. The literary, grammatical, and syntactical contexts prove to be crucial in determining the nature of the sin conveyed by this and all other nouns.

Kiuchi's observation that a meaning of a word should be distinguished from information or a situation inferred from the context agrees with the overall method utilized in this study. ${ }^{263}$ The context is the primary determinant of the word meaning. ${ }^{264}$ Accordingly, it is important to determine whether the consciousness of the act and

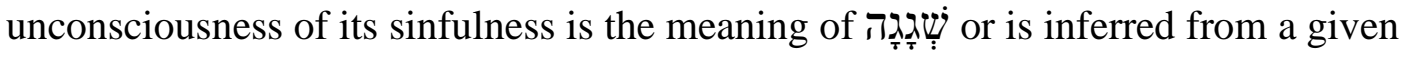
context.

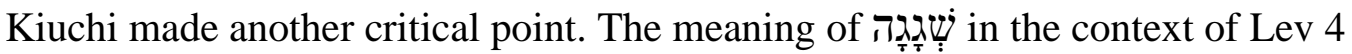
suggests the existence of commands, God's prohibitions, which means that an act can be defined as sinful only in the context of prohibitions. Thus, Kiuchi proposed that refers to the unconsciousness of sinfulness of an act, rather than consciousness of an act. $^{265}$ The distinction between consciousness of an act and its sinfulness is crucial for the

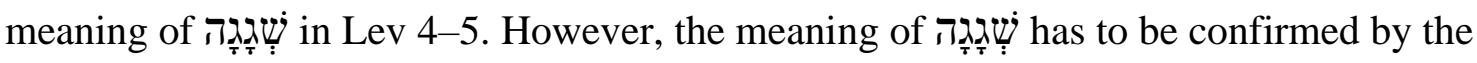

${ }^{262}$ Knierim, "שגיג" TLOT 3:1303.

${ }^{263}$ Kiuchi, Purification Offering, 26.

264، A determinative function to context, that is, the context does not merely help us understand meaning, it virtually makes meaning." Silva, Biblical Words and Their Meaning, 139; Osborne, The Hermeneutical Spiral, 97.

${ }^{265}$ Kiuchi, Purification Offering, 26. 
immediate context. Two key texts that illuminate the meaning of this term are Lev 5:1719 and $4: 13$.

Lev 5:17-19. Milgrom found the argument for his claim that שָָׁ refers to the consciousness of the act but not its sinfulness in the absence of שִָָׁ from the protasis of this subcase. The sinner has sinned, but is not aware of this. The missing element of the

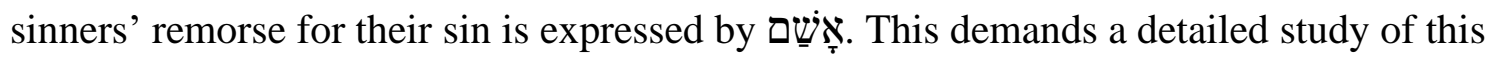
subcase.

The protatis in v. 17 introduces the activity of sinning with two clauses. In all other protasis in Lev 4-5, this pattern presents two alternative ways of sinning. That pattern is overruled in this pericope by its grammar, syntax, and literary structure. The

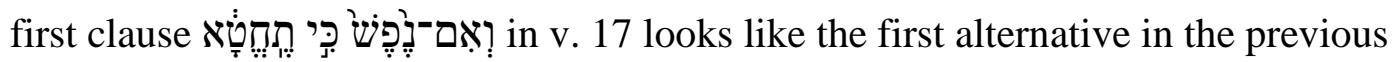

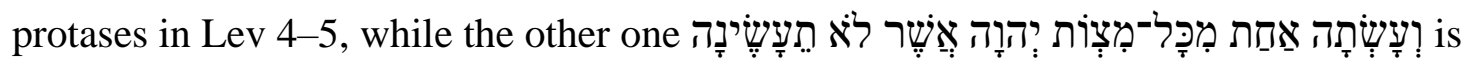
like the second contrasting alternative of the same verse. However, two times in this text, it is stated that sinners did not know that they had sinned. The first לאיריָיזע is reference to

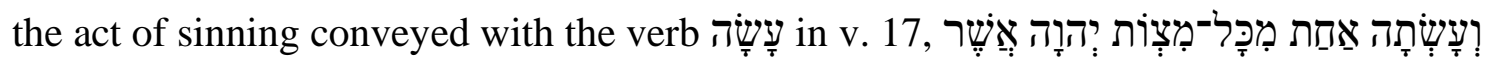

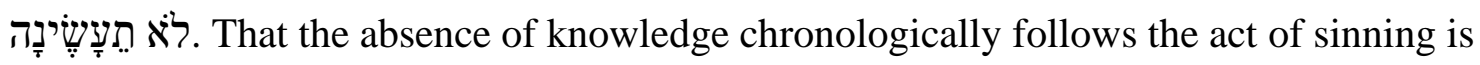

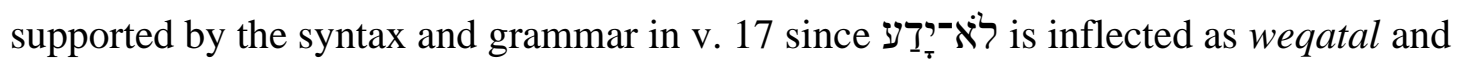

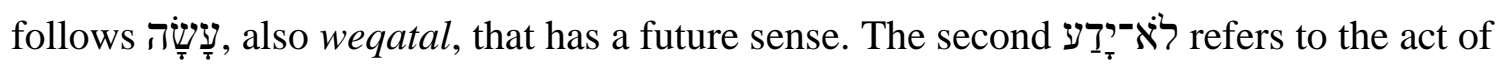

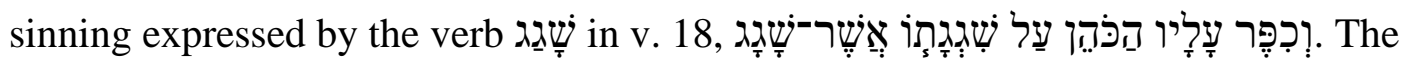

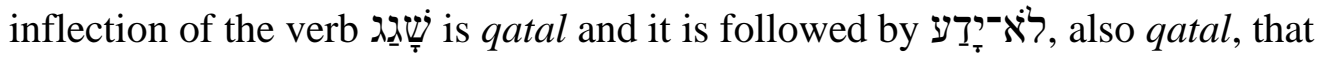

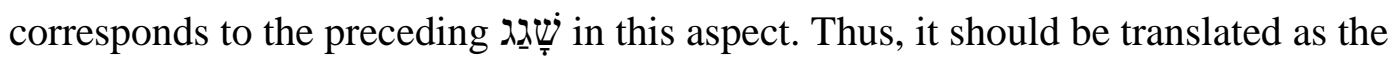


pluperfect, "he had not known." Accordingly, the short relative clause,

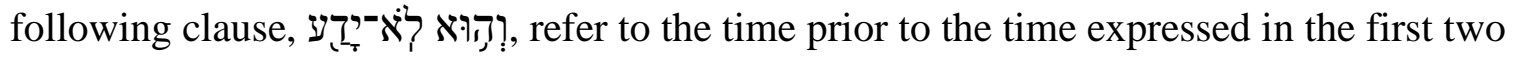

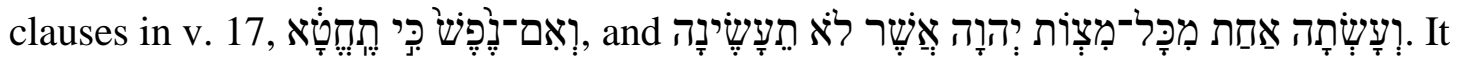
refers to the time of committing the sin, also potentially including the time prior to it. The

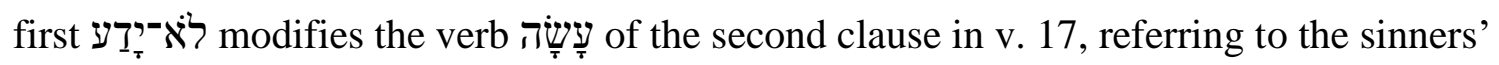
לאיָיזָע

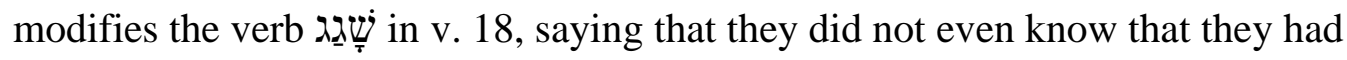
committed $\sin$. This sin is a sin out of ignorance, where sinners never knew that they had sinned, neither before nor after the act. Accident is not possible here regardless of the

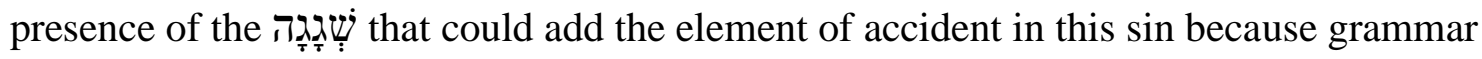
and syntax point to the ignorance. The present study assumes that this scenario of sinning has been very limited in Israel due to the nature of BL that conditioned Israel's good acquaintance with it. However, it is uniquely addressed here.

The use of verbs that denote the activity of sinning in this pericope demonstrates

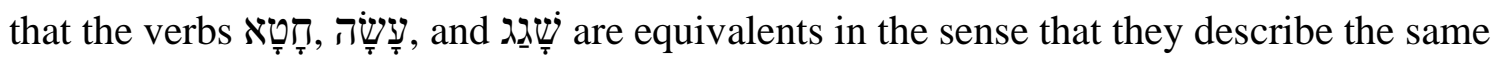
act of sinning in this pericope, although from different perspectives. The sinning that is שִ שָגֵג in v. 18. The noun used to denote the sin expressed by all these three verbs is regards usage of terms, this pericope is the most complex and proves that in sin terminology, both the verbs that express the activity of sinning and nouns that label the act of sinning are interchangeable and possess multiple meanings.

The above interpretation of 5:17-19 confirms that Milgrom and Kiuchi are both 
partially correct in their understanding of what the sinner has been aware of in this pericope. Milgrom is right that לאיזיָיזע refers to the sinner's unconsciousness of an act, ${ }^{266}$ but so is Kiuchi that the sinner is unconscious of the act's sinfulness. ${ }^{267}$ Intention is not important here since sinners do not know that they have sinned as the verb עָָָָ that is modified by לאיָיָָע in v. 17 suggests, nor did they know that their activity represents

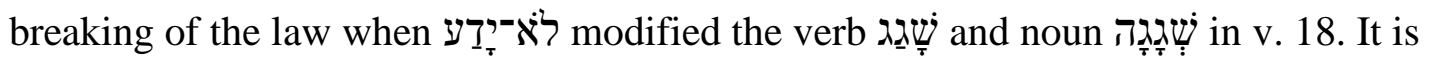
likely that the intention is involved, if not based, on the use of the verb on the verb עָשָׁ which refers to the intentional activity, in this case, of breaking God's commandments, ${ }^{268}$ but they did not know the law.

The grammar and syntax of this pericope have an advantage over the literary structure that has been in accordance with the grammar and syntax in all other protases in Lev 4-5. The context, grammar, and syntax of 17-19 annulled the established literary structure.

Lev 4:13. This verse separates itself from the rest of the verses in Lev 4 due to the

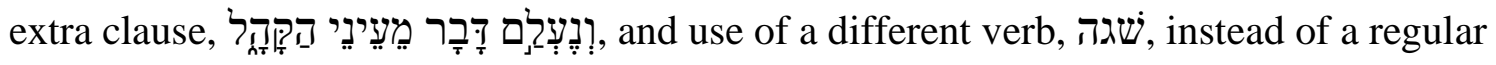
TָT to denote the act of sinning. This clause is the key for the proper reading of the protasis. All the other subcases contain two verbs that convey the activity of sinning at the beginning of their pericopes, vv. 2, 22, 27, and these verbs are

\footnotetext{
${ }^{266}$ Milgrom, Cult and Conscience, 9.

${ }^{267}$ Kiuchi, Purification Offering, 26.

${ }^{268}$ Milgrom, Leviticus 23-27, 2304.
} 
meaning of the construction consisting of the verb עִ מָן an and the preposition is attached to the noun or pronoun is well established and refers to the lack of knowledge (Lev 5:2, 3, 4; Num 5:13) as presented below.

That consciousness of an act or unconsciousness of its sinfulness are not contained in the verb שָָָָ in this pericope is evident from syntactical, grammatical, and conceptual standpoint. Syntactically, the verb שגנה is a predicate of an opening clause of

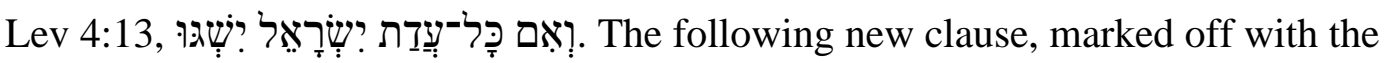

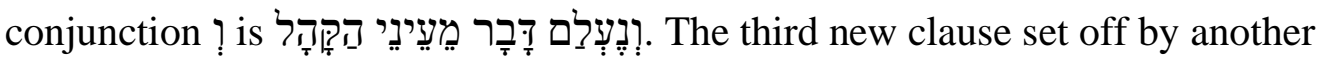

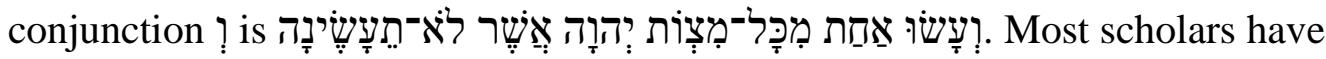
understood that these clauses follow each other chronologically and have the second clause modify the first one, which means that the conjunction ? is taken to mean "and." In that case, the two clauses are translated as "now if the whole congregation of Israel commits error and the matter escapes the notice of the assembly," and Milgrom's understanding that the clause שִגנה modifies the verbults in the claim that שָָָׁ refers to the consciousness of act of sinning, but unconsciousness of its

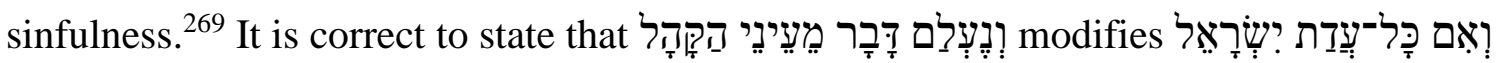

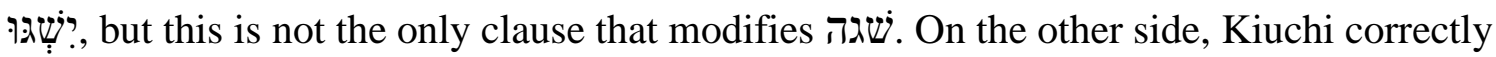

\footnotetext{
${ }^{269}$ Milgrom, Leviticus 1-16, 242. It is surprising that Milgrom totally excluded the verb עָש்ָָׁ from his comments in Lev 4. Milgrom, Leviticus 1-16, 246-47, 251, 264-65. It is surprising since he devoted considerable attention to this verb in various other contexts in his three volume commentary, basically correctly claiming that עָָׁׁ conveys intentional activity. Milgrom, Leviticus 17-22, 1522, 1582; Milgrom, Leviticus 23-27, 2292-93, 2304.
} 


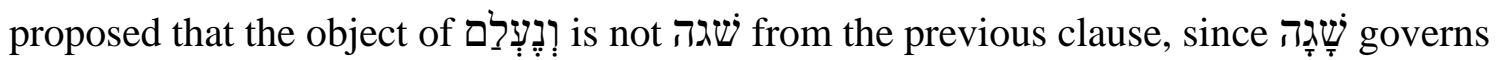

a separate clause, but rather, רְִָָ. However, he then erroneously suggested that it is

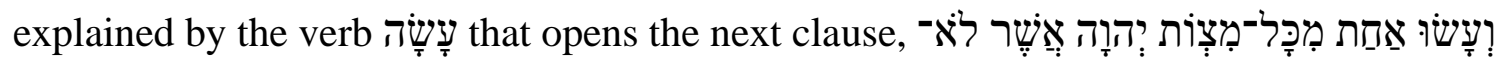

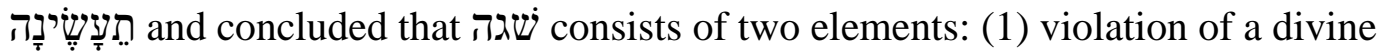

prohibition, and (2) hidden nature of the act. ${ }^{270}$

If the general understanding of this protasis is accepted, then the clause

is redundant since it just repeats what has been conveyed

already by the verb שגה and in the main casuistic statement, the protasis in v. 2. I suggest

that Kiuchi's first point is correct, but suggest that the syntax of the three clauses points

to the double nature of the act of sinning. That is, along with the clause

three clauses constitute the first sentence, v. 13, that is followed by the second sentence

${ }^{270}$ Kiuchi, Purification Offering, 27-28.

271" A clause is the syntactic combination of a subject and predicate.... The two clauses together constitute a sentence, ... When a sentence consists of only one clause it is called a 'simple sentence'; when it consists of more than one clause it is called a "compound" or 'complex' sentence, depending on how the clauses within the sentence are joined." Waltke and O'Connor, An Introduction to Biblical Hebrew Syntax, 69. Before defining these three types of clauses, it is helpful to introduce general understanding of the sentence. Francis I. Andersen defined the sentence in BH as follows: "A sentence is a grammatically selfcontained construction," meaning that "the grammatical functions of all constituents in a sentence may be described in terms of relationships to other constituents in the same sentence." Francis I. Andersen, The Hebrew Verbless Clause in the Pentateuch, JBLMS 14 (Nashville: Abingdon Press, 1970), 20. In addition, Andersen also noticed that "Grammatical completeness ... may prove as hard to establish as completeness of thought." Francis I. Andersen, The Sentence in Biblical Hebrew, JLSP 231 (The Hague: Mouton, 1974), 22. Waltke defined a simple sentence as "consisting of grammatical elements that cannot exist apart from their syntactical connection with each other and that together constitute a unified utterance." Waltke and O'Connor, An Introduction to Biblical Hebrew Syntax, 79. Waltke defined the compound sentence as containing multiple "verbs, with the single subject and the single adverbial modifier, follow each other with only the conjunctions to join them." Waltke and O'Connor, An Introduction to Biblical Hebrew Syntax, 79. The complex sentence consists of at least two clauses, the second of which is subordinate to the first, usually a relative clause, and modifies that subject of the first clause. Waltke and O'Connor, $A n$ Introduction to Biblical Hebrew Syntax, 79. 


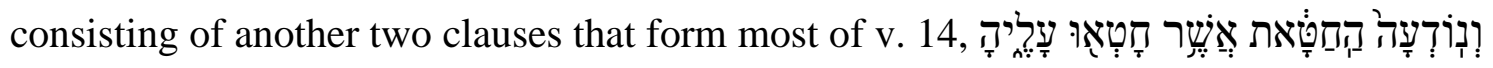

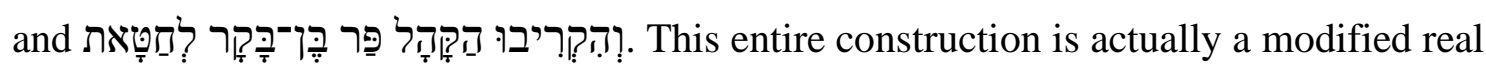
conditional clause ${ }^{272}$ that functions as a protasis which describes the subcase of the entire community's sinning. The understanding of the particle $?{ }^{273}$ which connects all of these clauses and the two sentences, is crucial in this text in order to grasp the full meaning of what the sentences convey.

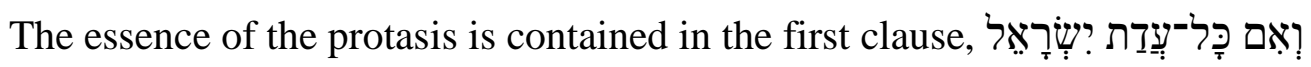

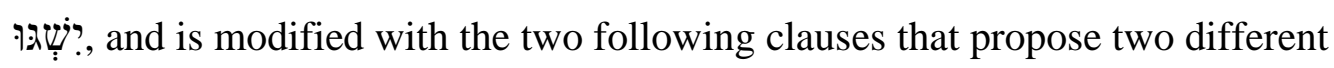
alternatives. The verbs that govern these four clauses is the opening yiqtol and three weqatal that follow. This grammatical and syntactical construction is regularly used in $\mathrm{BH}$ to convey succession of thought ${ }^{274}$ which is the case in this construction. The first

\footnotetext{
${ }^{272}$ Waltke and O'Connor, An Introduction to Biblical Hebrew Syntax, 636-37. “Any two clauses, the first of which states a real or hypothetical condition, and the second of which states a real or hypothetical consequence thereof, may be taken as a conditional sentence." Thomas Oden Lambdin, Introduction to Biblical Hebrew (New York: Scribner's Sons, 1971), 276.

${ }^{273}$ The particle ! is a macrosyntactic sign. "Macrosyntactic signs are words, particles, and expressions which serve ... to mark out the major divisions of a text. ... The speaker inserts such macrosyntactic signs in order to highlight for the hearer the beginning, transitions, climaxes, and conclusions of his address. .... Even if the spoken (colloquial) language is the essential sphere of such macrosyntactic signs, nevertheless its influence can be also observed in the literary, fixed linguistic forms, such as we encounter in the Bible, especially in contexts involving dialogue." Wolfgang Schneider and Oskar Grether, Grammatik des Biblischen Hebräisch: Ein Lehrbuch (München: Claudius-Verlag, 1974), 261. The particle ! can also be used at different syntactic levels, thus, besides the macrosyntactic or intersentential level, it is often used on the interclausal level. Waltke and O'Connor, An Introduction to Biblical Hebrew Syntax, 79.

${ }^{274}$ Waltke stated that "scholars are agreed that the we in the wəqatalt construction usually (though not always) signifies succession (temporal or logical), but they are not agreed about the meaning of the suffix conjugation in this construction." Waltke and O'Connor, An Introduction to Biblical Hebrew Syntax, 523.
} 


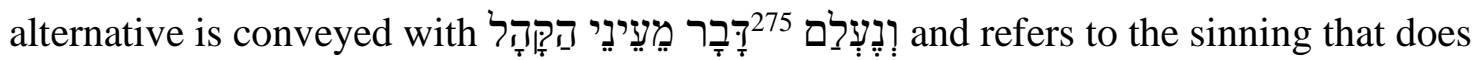
not come out of awareness or intention. ${ }^{276}$ The second alternative is expressed by ועָשׁוּ The first argument that this clause represents an alternative to the previous clause is found in the fact that regardless of the very large

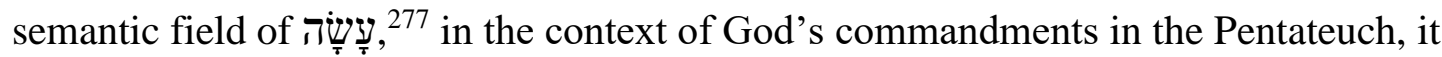
refers to the intentional activity of breaking them whatever that might be (Ex 15:26; 20:6; Lev 4:13, 22, 27; 5:17; 26:14-15; Num 15:22, 40; Deut 5:10; 6:25; 15:5; 27:10; 28:1, 15; 30:8; 31:5). Aside from Lev 4-5, this verb is used in Lev 26:14-15 which clearly refers to the intentional activity of sinning, breaking God's commandments. The second argument is found in the semantics of these two clauses. The first clause points to the unawareness of the sinner that he/she has sinned, while the second clause conveys intentional activity of sinning. Thus, having established the contrastive nature of these two clauses based on the meaning of the words from their immediate context and considering grammar and syntax of conditional clauses, the conjunction ? that connects these two clauses, that modifies the opening clause of the protasis, is best understood as

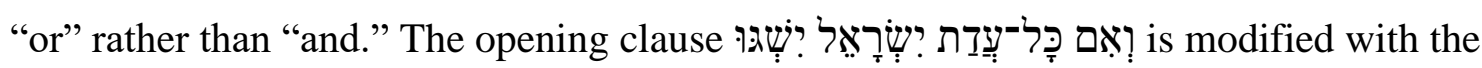

\footnotetext{
${ }^{275}$ Kiuchi's remark that this word is definite, referring to something, is implausible since it does not have the definite article and is syntactically unsupported since it belongs to the clause that modifies the opening clause of the protasis introducing the first alternative of the way the activity of sinning took place.

${ }^{276}$ Rooker's claim that this clause refers to initial hiddenness of the act lacks grammatical and

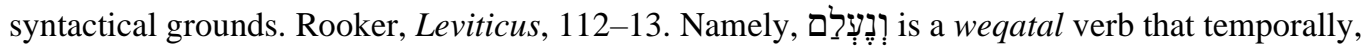

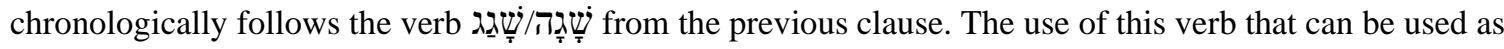
a pluperfect is found in Lev 5:2-4, but there, עָָָלָ is not inflected as weqatal, but as qatal.

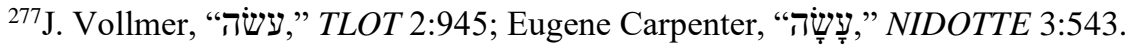




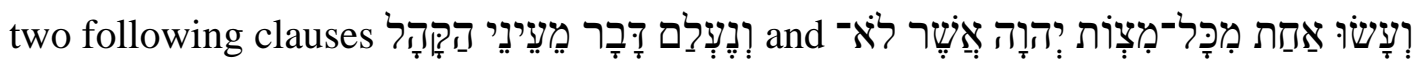

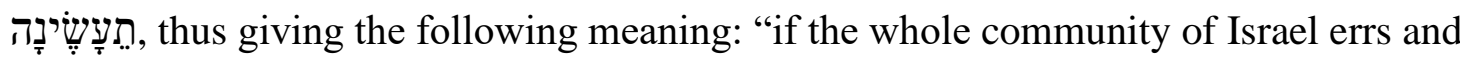
the matter escapes the notice of the community (unknowingly or in a hidden way) or they do any of the Lord's commandments that are not to be done, and they are guilty." In other words, two ways of sinning expressed through this protasis are (1) unconsciousunintentional (out of ignorance or accident), and (2) intentional-non-brazen.

This interpretation of Lev 4:13-14 suggests that the verb שגה in this context is equivalent to the verb שגנה Trom the first clause of v. 13 that conveys the activity of sinning is replaced by the verb חָָ in v. 14 that refers to the same act of

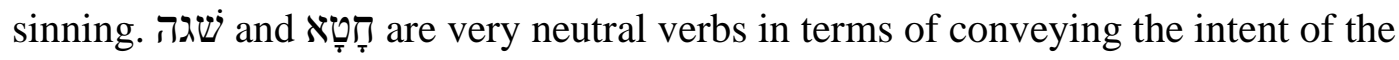
activity they refer to, which means that they can refer to both intentional or unintentional activities. As such, שִגה iָi include the sinners' awareness of the act's sinfulness in case of intentional sin. In that case, sinners are aware of their act, as well.

The remaining protases in Lev 4:2-3, 22-23, 27-28 do not have an עלם element

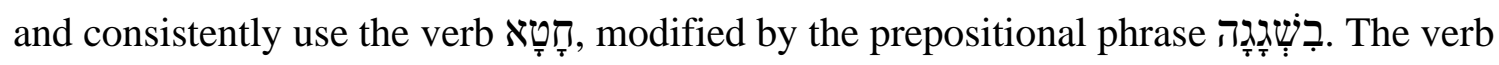
חָָטָ gets more nuanced meaning in vv. 2-3, 22-23, and 27-28. It is the noun that brings out nuances contained in the verb חָָ. Before analyzing these protases, it is

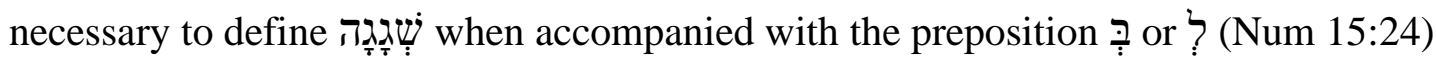


because this prepositional phrase frequently modifies the verbs חָּטָא, נָכָה אָכַל 281 or .and 355 and Num 15-in Lev 4

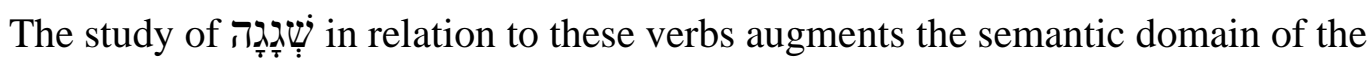

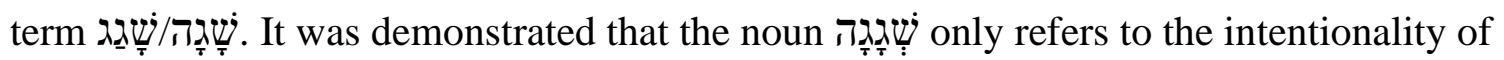
the activity, but unawareness of the activity's sinfulness in the context of Lev 5:17-19. However, the phrase בִּשְָׁגָגדה conveys some additional nuances to the nature of sins or the activity of sinning.

\section{בִשְָׁגָָה}

As in Lev 4:13, the protasis in Lev 4:2, 27, 5:15; and Num 15:27, 28, ${ }^{283}$ where

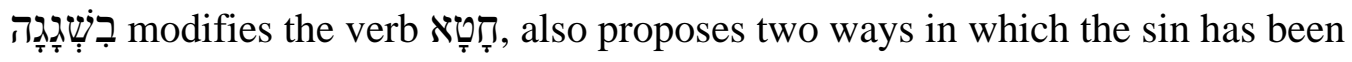
committed. Milgrom and others are right 284 "that the verb $h \bar{a} t \underline{\bar{a}}$ ' can cover the entire range of $\sin$ from accidental misdemeanors ... to deliberate crimes. ${ }^{, 285}$ In addition to the

\footnotetext{
${ }^{278}$ Lev 4:2, 27, 5:15; Num 15:27.

${ }^{279}$ Num 15:28.

${ }^{280}$ Lev 4:22, Num 15:24, 26, 29.

${ }^{281}$ Lev 22:14.

${ }^{282}$ Num 35:11, 15.

${ }^{283}$ The nominal of functions as a verb.

${ }^{284}$ For further list of scholars see Gane, Cult and Character, 292nn30-35.

${ }^{285}$ Milgrom, Leviticus 1-16, 320.
} 
modifying verb חָטָָ, the phrase modifies the verb עָשָָׁ in Lev 4:22 and Num 15:26, 286

29.

In Lev 4:2, the protasis consists of two clauses, but the opening clause, בִשְָׁגָגה potentially points to both intentional or unintentional sinning. The notion of intentionality

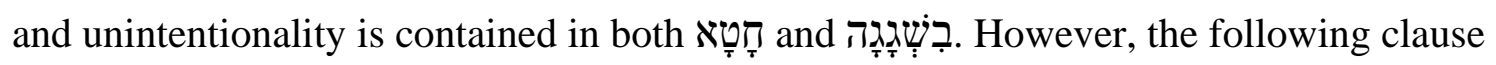

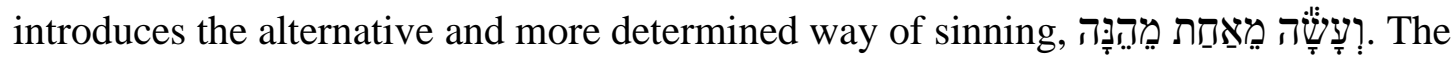
verb עָשָׁi in the context of God's commandments points to intentional activity. The contrastive nature of these two clauses, based on their meanings, suggests that the conjunction ?̣ should be translated as "or" and the verb דָָָ is understood to refer to unintentional sinning in order to avoid a mere repetition of the same meaning in the following clause. Thus, the two clauses should be translated as "when a person sins unintentionally in regards to any of the Lord's commandments or does any them:" The very same pattern is seen in 4:27 with infinitival inflection of עָָָָׁה in contrast to weqatal in Lev 4:2.

The context of Lev 5:15 is vague since

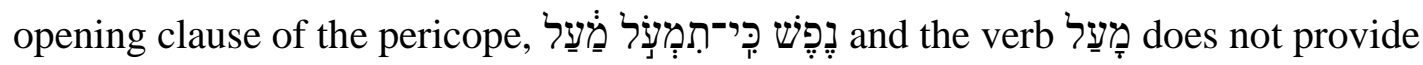

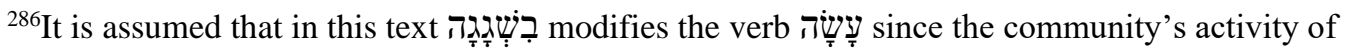
sinning is expressed by it in v. 24 . $22-23$.

${ }^{287}$ This clause implies sinning against all divine commandments. Kiuchi, Purification Offering,
} 
many insights into the intentionality or unintentionality of the activity. ${ }^{288}$ The use of to very particular, intentional sthat it often refer sPentateuch demonstratethe ni sins of disloyalty, mainly towards $\operatorname{God}^{290}$ (Lev 26:40; 31:16; Deut 32:51), and sometimes, to other human beings (Num 5:12,27). Theoretically, sacrilege can be committed intentionally and unintentionally. However, the second, contrasting clause

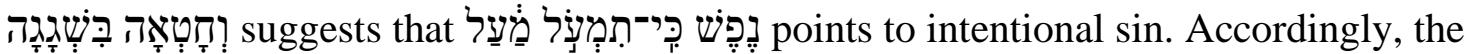
pattern of two alternative ways of sinning exists in this pericope. All three terms

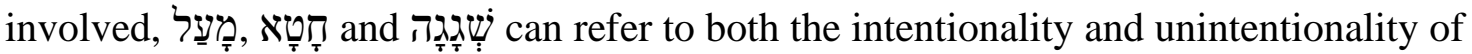
the committed activity.

Lev 22:14. This text does not provide any new insights into the meaning of

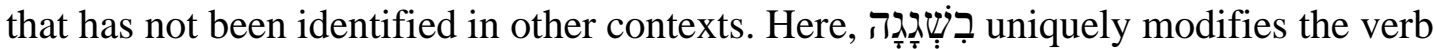

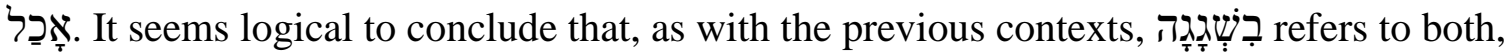
intentionality and unintentionality.

In Num 15:27, the protasis is simple, consisting of one clause,

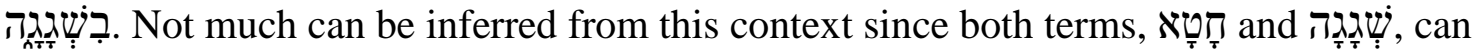
refer to the intentionality and unintentionality of the committed activity. However, the

\footnotetext{
${ }^{288}$ Levine, Leviticus, 30; Milgrom, Leviticus 1-16, 320.

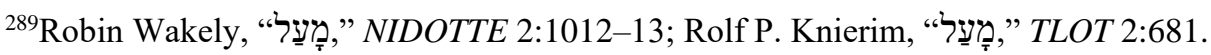

${ }^{290}$ Milgrom's claim that מָעָ constitutes a sin against God in all of its occurrences is broad and
}

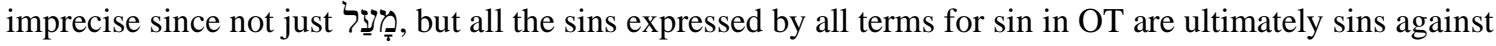
God. Milgrom, Leviticus 1-16, 345-46. Sometimes, a human party directly suffers the consequences of

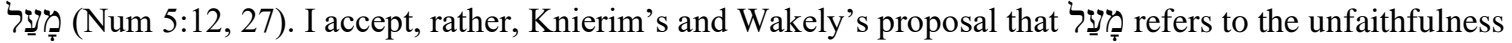

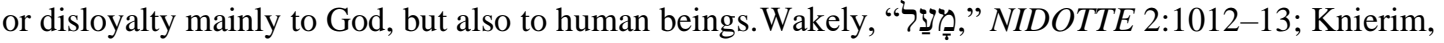

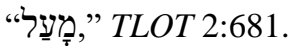


major casuistic statement of this legal case further confirms the presence of the elements of intentionality and unintentionality related to this sin.

The protasis in 15:22

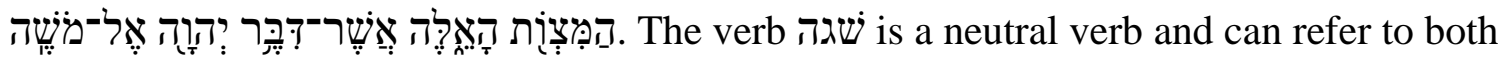
intentional and unintentional activity, while refers to intentional generally activity. Milgrom rightly stated that עָשָָָׁ predicates active violation. ${ }^{293}$ Thus, two alternative ways are potentially present in the major protasis which covers the subcases in 15:27-29. The trend noted in Num 15:1-16, as a literary context of Num 15:22-31, strongly suggests that this chapter introduces innovations. The requirements for the sacrifices in 15:22-31 were also modified. ${ }^{294}$ Num 15:22-31 does not contain a subheading, which means that it belongs to the previous section, vv. 17-21, and ultimately, the opening section, vv. $1-16,{ }^{295}$ which also says that dependence of this section to the entire chapter assumes the context of commandments. Within this context of expanding legislation, the verb שגה is more specified, as in Lev 4, to convey breaking God's commandments hypothetically, intentionally, or unintentionally. The verb עָשָָׁה

291"The language of Num 15-kol-hammișwôt ...kol-'ăšer șiwwâ any of the commandments ... anything that [the Lord] has enjoined' (vv 22, 23) - must be understood literally: the word kol-embraces all of the commandments, positive and negative, performative and prohibitive." Milgrom, Leviticus 1-16, 265.

${ }^{292}$ Milgrom did not give details on the meaning of the verb עָשָׁ in the context of Num 15:22-26 and its importance for the interpretation of this passage other than saying that the verb is used as a technical term for the entire process of offering a sacrifice. Milgrom, Leviticus 1-16, 265-66. This is in contrast to his detailed analysis of this verb in the context of Lev 26:14 that provided him with appropriate and valid insights into the meaning of this text.

\footnotetext{
${ }^{293}$ Milgrom, Leviticus 1-16, 265.

${ }^{294}$ Levine, Numbers 1-20, 395-96.

${ }^{295}$ Milgrom, Leviticus 1-16, 265.
} 
governs the second clause that introduces the alternative way of sinning and, if not modified in the immediate context, it refers to intentional sinning. Nothing in this particular context indicates that עָשָָׁ should be taken as pointing to unintentional sinning. In addition, the protases of significantly longer subcases in Lev 4 all contain two alternative ways of sinning which is not the situation here, most likely due to the considerably abbreviated nature of the texts of these subcases, with emphasis on the sacrificial innovation and not on the precise ways of sinning. Accordingly, the protasis in v. 22 governs all others found in vv. 24 and 27, but not 30 since the subcase in v. 30 uses

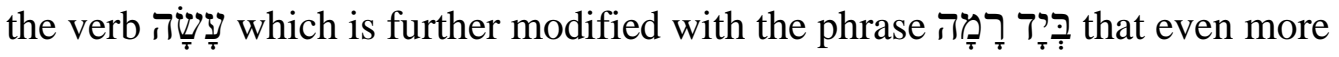
intensifies the intentional nature of sinning presented in this subcase. In addition, it is punishable by capital punishment. The data from the immediate context confirm that the major protasis does not cover the subcase in vv. 30-31.

Thus, the major protasis that introduces two alternative ways of sinning in v. 22 applies to the first two subcases in vv. 24-26 and 27-29. It does not cover the last subcase in vv. 30-31 due to the specific, brazen nature of sin it deals with.

That the terms דָטָ and are being used equally is proven by their

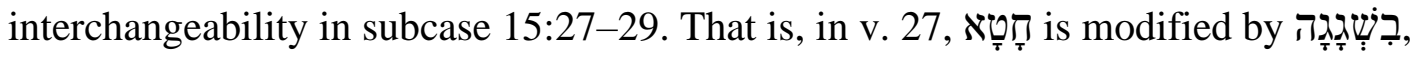

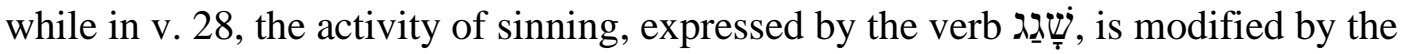
nominal phrase This relatedness and interchangeability proves that these terms generally share

\footnotetext{
${ }^{296}$ Levine, Numbers 1-20, 395-96.
} 
the same semantic range if not also modified by the immediate context. Both terms refer to the intentionality and unintentionality of the committed activities.

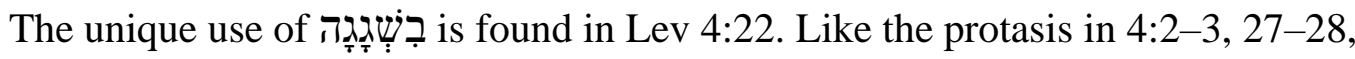
this one consists of two clauses that introduce two alternative manners of sinning. The

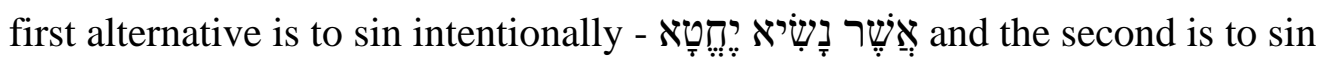

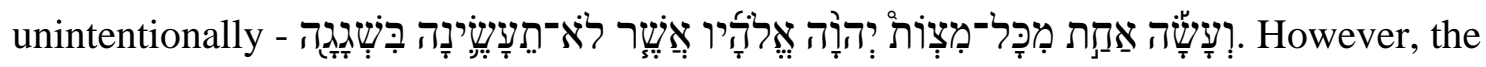
verbs used in previous protasis to refer to the intentionality and unintentionality exchanging place. That is, in 4:2-3, 27-28; 5:17, רָטָט

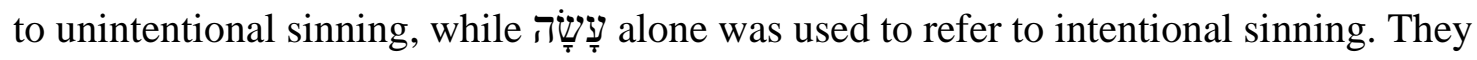
exchanged places here. However, the text still portrays two alternative ways of sinning, and the fact that the verbs exchanged their established places in the protasis structure does not affect the meaning of any of the clauses based on the fact that both convey intentionality and unintentionality in their semantic range. It is based on the fact

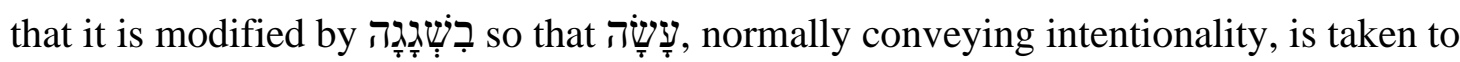
communicate unintentionality in this context, while

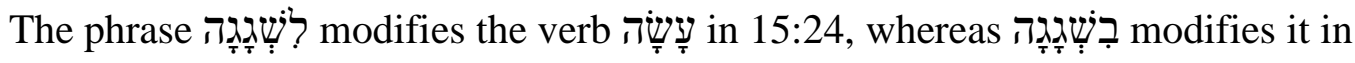
Num 15:26, 29. The preposition ${ }^{297}$ is uniquely attached to שִשְָָג in v. 24 to mark either

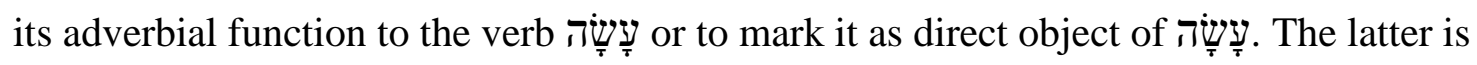
more probable since עָָָָָָi inflected as passive and when inflected as such, is used to

\footnotetext{
${ }^{297}$ This is ? of manner, often used in this way to form "such phrases as lārōb 'abundantly' and lātōhar 'clearly.'” Waltke and O'Connor, An Introduction to Biblical Hebrew Syntax, 206.
} 
refer to the impersonal subject (Lev 7:9; 18:30; Deut 13:14; 17:4), which does fit this

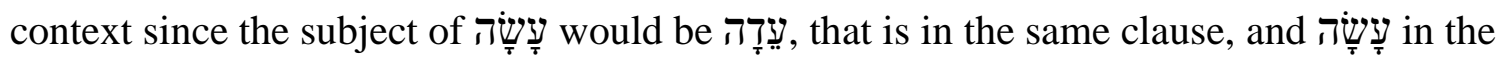
following clause, assuming the same subject is active.

ברשְׁגָגָה is used adverbially in Num 15:26, 29 to refer to the way the act of sinning has been committed. In v. 26, it stands on its own in a verbless clause referring to the sin of the community. The fact that שִָָׁגָגi is subject of the niphal passive form of the verb עִ עָָׁה in the protasis that introduces the subcase of the community in v. 24 reveals that modifies the verb בִשְׁגָגָה by that verb in v. 24 . In v. 29, the phrase modifies the verb שָָָׁ which is contained in the text, the ending of the verse.

The subcases in vv. 22-26 and 27-29 are sharply contrasted with the subcase in vv. 30-31. The activity of killing is more closely defined by the adverbial phrase that even more intensifies the intentional nature of this activity. In addition, it is punishable by capital punishment, with no chance for the doer to received atonement and forgiveness. As was established earlier, this attitude of sinning is called "brazen sin"; then it is not just intentional in performing an illegal act, but intent on annihilating the party on the opposite side.

The phrase has been used more specifically in Num 35:11, 15, where it modifies the verb נָכָָה, which in this context, means "to kill,"298 that refers to the act of homicide, the activity of killing another human being. The analysis of this law that has been done

\footnotetext{
${ }^{298}$ Milgrom, Numbers, 292-93.
} 
on pages 272-78 of this study shows that בְשָָָׁגָה has been used to convey both the accidental and the unintentional activity of a human being that unfortunately resulted in the death of another human being. The intentional killing is defined in vv. 16-21 with the terms that convey prior planning of murder, while those terms are juxtaposed with another set of terms in the section that describes unintentional killing in vv. 22-24. Thus,

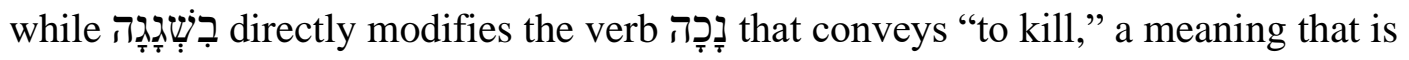
informed by another set of verbs in vv. 22-24, they all point to the fact that the act of homicide took place accidentally and unintentionally. Accordingly, the context of Num

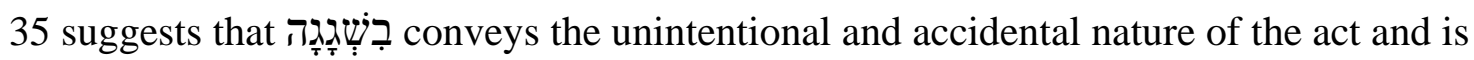

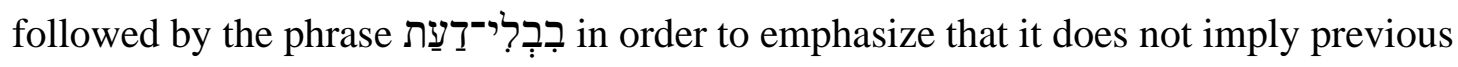
mental planning of the act. ${ }^{299}$

\section{עָשָׁi: Pattern of Uses in the Pentateuch}

Before concluding the analysis of Lev 4-5, the present study examines the pattern of uses of the verb ע்ָָׁ since some parts of this analysis may be questioned by the claim that עָשָׁ and the verbs of sinning in these chapters refers to the same verbal activity.

It is well documented that עָָָָ's semantic range is vast. ${ }^{300}$ Due to its semantic flexibility, עָשָׁ often gets its meaning in a given context and can include a variety of

\footnotetext{
${ }^{299}$ Botica, Concept of Intention, 34-36. For a more specific meaning related to the terms describing intentional homicide where one can discern various levels of intent, see Botica, Concept of Intention, 36-38.

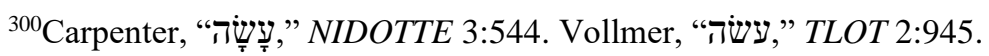


verbal activities. ${ }^{301}$ Carpenter noted the pattern in Gen $1-11$ that when God is subject of

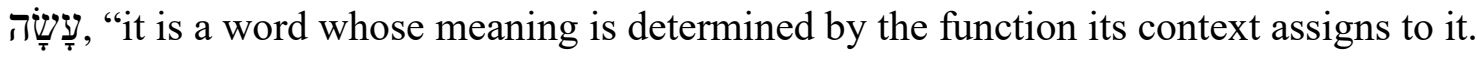
In itself it simply indicates activity of whatever kind its context demands, making/doing. ${ }^{302}$ The same principle is detected with עָָָ and a human subject. ${ }^{303}$ The present study also identified the same עָָָָ uses in BL texts and narratives. The context remains the key factor for determining the meaning of this verb.

in the Contexts of Verbs that Express the Activity of Sinning

In order to provide a more specific semantic range of עָָָׁ I identified and examined the texts which contain the identical syntactical structures where the verbs and the verbs of sinning are found in the same context like the one found in Lev 4-5. The texts are listed in Table 20.

Semantically, the statistics are indecisive. The texts can be divided into two groups: cultic laws (Exod 29:36; Lev. 4:2, 13, 22, 27; 5:10, 17; 6:3; Num 6:11; 15:22;) and narratives (Gen 20:6, 9; 39:9; Exod 5:16; 32:31; Num 32:23; Deut 9:16, 18; 20:18). Some of these texts contain both patterns of uses, such as when the verbs of sinning precede and follow the verb עָשָָׁ

More certainty is detected in the 10 texts where עָשָ precedes the verb of sinning

\footnotetext{
"עשה", TLO1mer, 2:946.

302Carpenter, "עָשָָָׁ", NIDOTTE 3:544.

${ }^{303}$ Carpenter, "עָעָשָה" NIDOTTE 3:546.
} 
Table 20. The verb עָָָׁ and the verbs of sinning

\begin{tabular}{|c|c|c|c|c|c|}
\hline & Activity (עָשָׁi) & Intention & Activity (sinning) & Intention & Sem. Overlap \\
\hline Gen. 20:6 & $\begin{array}{l}\text { 1, Taking Sarah } \\
\text { v. } 2-3\end{array}$ & yes & 2, חָָָ, sex & No & No \\
\hline Gen 20:9 & 1, Lying v. 5 & yes & 2, חָָ, unknown & No & no \\
\hline Gen 39:9 & 1, Sex v. 7,12 & no & 2, 2 గָָ adultery & No & yes \\
\hline Exod 5:16 & $\begin{array}{l}\text { 1, Making bricks } \\
\text { v. } 16 \\
\end{array}$ & no & $\begin{array}{c}2, \text { Chet, out-turn, } \\
\text { norm }\end{array}$ & No & no \\
\hline Exod 29:36 & $\begin{array}{l}\text { 1, Offering } \\
\text { sacrifice }\end{array}$ & yes & 2, חָָָ, purify & Yes & yes, partially \\
\hline Exod 32:31 & 2, Making idol & yes & 1, חָָָ, idolatry & Yes & yes, partially \\
\hline Lev 4:2 & 2, Breaking the law & yes & $\begin{array}{l}\text { 1, חָָ , breaking } \\
\text { the law }\end{array}$ & No & yes, potentially \\
\hline Lev 4: 13 & 2 , Breaking the law & yes & $\begin{array}{l}\text { 1, שגה, breaking } \\
\text { the law }\end{array}$ & No & yes, potentially \\
\hline Lev 4: 22 & 2, Breaking the law & no & 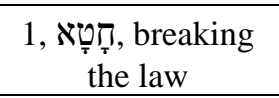 & Yes & yes, potentially \\
\hline Lev 4: 27 & 2, Breaking the law & yes & $\begin{array}{l}\text { 1, חָּ̦, breaking } \\
\text { the law }\end{array}$ & No & yes, potentially \\
\hline Lev 5:10 & $\begin{array}{l}1, \text { Offering } \\
\text { sacrifice }\end{array}$ & yes & 2, דָטָא, oath, vow & Yes & no \\
\hline Lev 5: 17 & 2 , Breaking the law & no & 1, חָָָ & Yes & yes, potentially \\
\hline Lev $5: 22[6: 3]$ & $\begin{array}{l}\text { 1, Various } \\
\text { activities }\end{array}$ & yes & חָָטָא , & Yes & yes \\
\hline Num 6:11 & $\begin{array}{l}\text { 1, Offering a } \\
\text { sacrifice }\end{array}$ & yes & חדָטָא 2, & No & no \\
\hline Num 15:22 & 2, Breaking the law & yes & 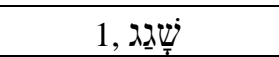 & No & yes, potentially \\
\hline Num 32:23 & 1, Helping to take & yes & 2, חָָ lying & Yes & no \\
\hline Deut 9:16 & 2, Making idol & yes & 1, חָָ, idolatry & Yes & yes, partially \\
\hline Deut 9:18 & $\begin{array}{l}\text { 1, Making idol, } \\
\text { idolatry }\end{array}$ & yes & 2, דָטָ, idolatry & Yes & $\begin{array}{c}\text { yes, Inf. } \\
\text { Complementing } \\
\text { verb }\end{array}$ \\
\hline Deut 20:18 & 1, Teaching & yes & 2, חָָּ, idolatry & No & yes, partially \\
\hline
\end{tabular}

in cultic laws (Exod 29:36; Lev 5:10, 22 [6:3]; Num 6:11) or narrative (Gen 20:6, 9; 39:9, Exod 5:16; Num 32:23; Deut 20:18). Semantically, שָָָׁ overlaps with the verbs of sinning in $4 / 10$, while in $6 / 10$, it does not. In cultic texts, the statistics are even, $2 / 4$ for semantic overlap and 2/4 for semantic distinctiveness. Semantic distinctiveness is more 
emphasized in the narrative texts $4 / 6$ in contrast to the overlap in $2 / 4$ texts. ${ }^{304}$

Less certainty is found in the 9 texts when the verbs of sinning precede עָ עָ עָ in cultic laws (Lev 4:2, 13, 22, 27; 5:17; Num 15:22) or narrative (Exod 32:31; Deut 9:16, 18). There is only one text, a narrative one, where עָשָָָׁ unquestionably overlaps with the verb of sinning (Deut 9:18) while the statistics in all other texts are uncertain. This uncertainty is reflected in the fact that in all 6 cultic law texts where the verb of sinning precedes עָשָָׁ (Lev 4:2, 13,22, 27; 5:17; Num 15:22), there is the potential that these two verbs might overlap semantically. In the $2 / 3$ narrative texts, the verb עָָָָ semantically overlaps with the verb of sinning in part only, while only once (Deut 9:18) did they overlap certainly.

These statistics demonstrate that certainty of the semantic overlap of the verb עָשָׁה and the verbs of sinning when they occur in the same context is very low. In other words, the statistics of use do not provide grounds for the claim that עָָׁׁ and the verbs of sinning refer to the same activity. A given context remains the final determiner as to whether this is the case or not.

Does עָשָׁ Refer to the Same Activity as the Preceding Verb?

In order to add more precision to the uses of עָָָָ the present study followed the same syntactical pattern that is used in Lev 4-5, namely, that of any verb that is followed

\footnotetext{
potential.

${ }^{304}$ The certainty of semantic overlap in one (Gen 39:9) is high, while in the other (Deut 20:18),
} 


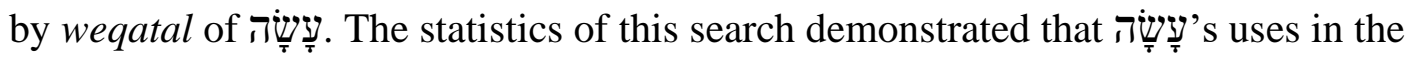
books of Exodus, Leviticus, and Numbers demonstrate that the verbs preceding עִשָָָׁ do not semantically conflate with it in 61 out of $63^{305}$ texts without considering Lev 4:2, 13, 22; 5:17. Two exceptions are Exod 20:9 and 32:31. In the former text, עָשָָׁ is semantically conflated with the verb עָבָָ and does not reveal additional particulars

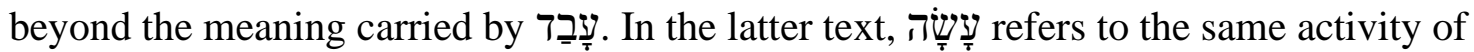
sinning as חָָטָ does, but it explains exactly what the sin was. These statistics on עָשָָׁ do not prevent the interpretation of it in Lev 4-5 that claims that עָָָׁ refers to the intentional activity except when the text explicitly marks it as unintentional activity. Second, there is a law possibility that עָָָָ semantically merges with the verbs of sinning and there is almost no possibility that it coalesces semantically with the verbs in the constructions as in Lev 4-5, that is, a verb followed by the weqatal of עָש்ָ.

\section{Conclusion on בִשְגָגָָה}

The literary context, grammar, syntax, and lexical terms of Lev 4:2, and 27 point to the existence of two alternative ways of sinning, intentional and unintentional. בִשְׁגָגָה that modifies חָָָ clarifies that this verb refers to unintentional sinning, while the verb עִ עָ expressed intentional, but non-brazen sinning.

${ }^{305}$ Exodus $1: 21 ; 4: 21,30 ; 5: 9 ; 7: 10-11 ; 10: 25 ; 12: 28,48 ; 14: 4 ; 17: 6 ; 18: 24 ; 20: 9 ; 23: 22 ; 25: 11$,

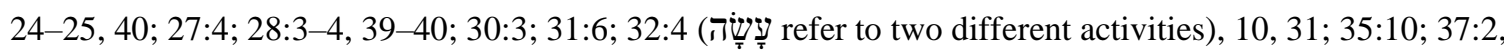
11-12, 26; 39:1, 32; Lev 9:7, 16; 10:7; 16:9, 15, 24, 34; 19:37; 20:8, 22; 22:31; 25:18, 21; 26:3; Num 5:30;

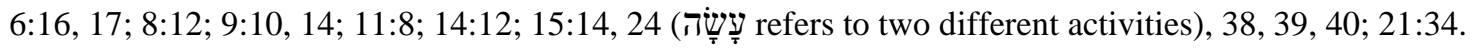


The same contextual elements of Lev 5:15 also point to the same conclusion. That

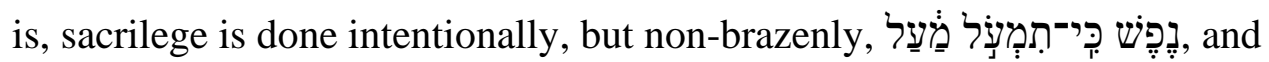

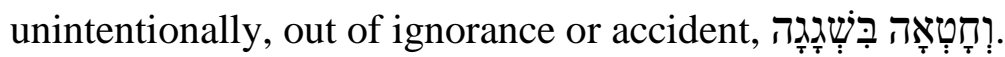

There are two foundational points that are inferred from בְִּשָגָָגה contexts. First, Num 15:22-31 and its immediate context suggests that the semantic range of the phrase

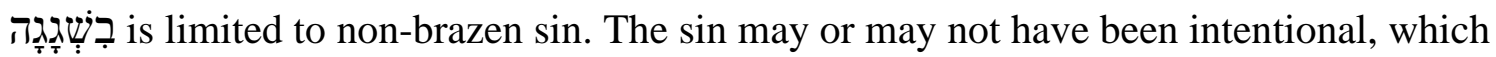
consequently includes the accidental nature of the act when it was committed, act, but the activity was not expression of a brazen attitude. The sin stands in sharp contradiction to

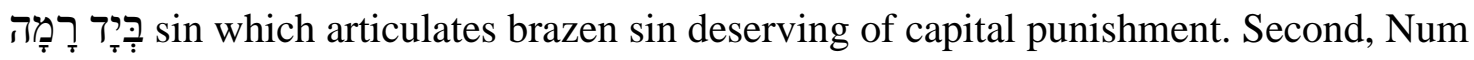
35:11, 15 and its immediate context suggests that the semantic range of the phrase includes activities committed as a result of accident with no intentionality included on the sinner's part.

Based on the use of בִּשְָׁגָגָה it Num 15:22-31 and 35:11, 15, I suggest that this phrase refers to accidental sinning and nonbrazen sinning. If the immediate context of the phrase does not provide arguments for a different nuance of meaning, this is the meaning that should be assumed by the phrase בְְִָָׁגָגָ, including in Lev 4-5.

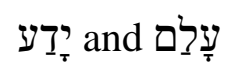

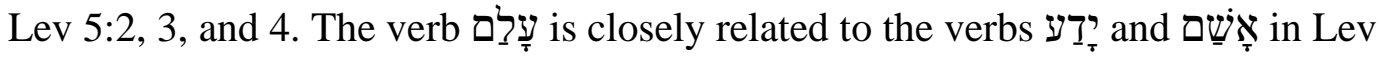

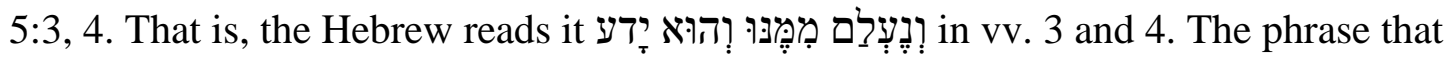
conveys the absence of knowledge is immediately followed by the phrase that expresses the presence of knowledge. Wells logically asked the following question: "The question 
then becomes whether the presence of knowledge (weh $\hat{u} y \bar{a} d a$ ) chronologically precedes the absence of knowledge ('it is hidden from him, though he knew') or whether it follows the absence of knowledge ('it is hidden from him, but then he comes to know')."306

Accepting the latter option means that the person involved was not conscious of his sin. On the other hand, accepting the former option means that the person involved had knowledge of his sin, was aware of it, but consequently lost knowledge of it. He forgot about it. There are at least two valid reasons why the latter option fits the literary context and syntax of the text better. ${ }^{307}$

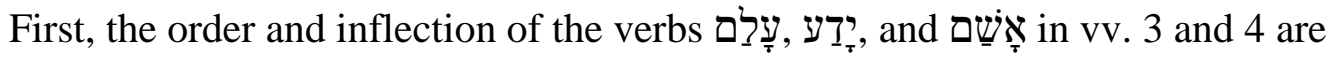

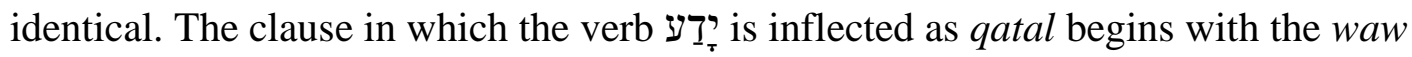
conjunctive and is positioned between two clauses that begin with waw consecutives and

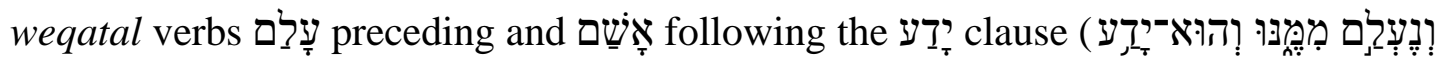

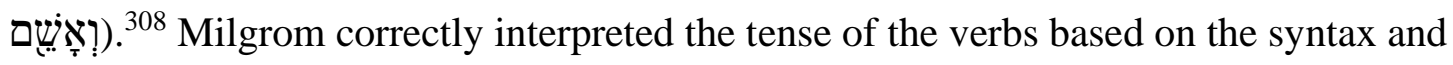
grammar: "A verb in the perfect between two perfects governed by waw consecutives has the force of a pluperfect, giving the reading that originally he knew that he had become impure but subsequently he forgot (Tg. Ps.-J.)." ${ }^{309}$ The same construction with the same

${ }^{306}$ Wells, The Law of Testimony, 65.

${ }^{307}$ Wells, The Law of Testimony, 65.

${ }^{308}$ Wells, The Law of Testimony, 65-66. The verb situation. "Waw-relative suffix forms used after a suffix form do not take on that conjugation's perfective aspect. Rather, in that connection waqatalt signifies either a consequent (logical and/or chronological) situation (without aspect, in future time) to the one represented by $q t l$ or an epexegetical situation (with an imperfective aspect in past or present time)." Waltke and O'Connor, An Introduction to Biblical Hebrew Syntax, 530.

${ }^{309}$ Milgrom, Leviticus 1-16, 298-99. 
tense is found in Lev 13:6, 32 and in a reversed way, in Lev 26:44. Thus, contextually and syntactically, the clause known." 310

Such a translation finds support in v. 2 where

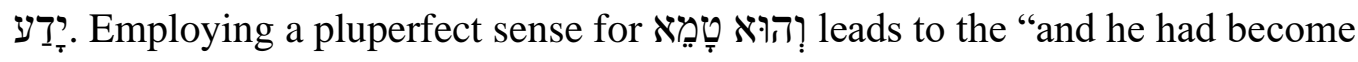
unclean" and logically fits the context better than the future tense that would yield, "and

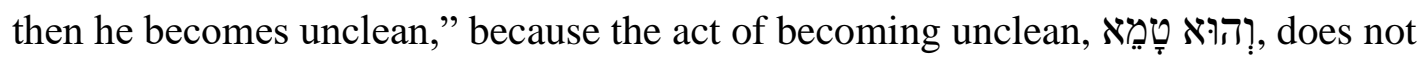

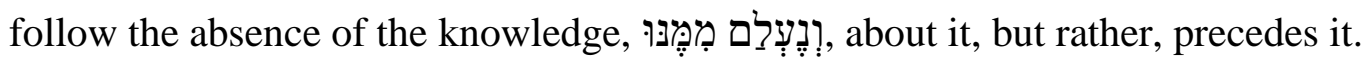
Accordingly, the act of possessing the knowledge in vv. 3 and 4 is also unlikely to follow the absence of the knowledge about it, but rather, precedes it. ${ }^{312}$ All aspects of this sentence, the grammar, syntax, and logical sequence of actions, favor this understanding.

Second, all vv. 1-4 form protases of which the apodosis is found in vv. 5-6 where the confession is introduced as the remedy for the sins previously portrayed. There are two characteristics related to the sins listed in vv. $1-4$. They are either public offenses, ${ }^{313}$ vv. 1, 4, or forgotten failures to prevent defilement spreading and eventually defiling the sanctuary, ${ }^{314}$ vv. $2-3$. All these particular sins affect other people and potentially, God's

\footnotetext{
${ }^{310} \mathrm{Wells}$, The Law of Testimony, 66.
}

311"In a verbless clause of classification in which the predicate refers to a general class of which the subject is a member, the two parts of the clause generally occur in the order predicate-subject. Clauses of classification answer the question, What is the subject like?'" Waltke and O'Connor, An Introduction to Biblical Hebrew Syntax, 132.

${ }^{312}$ Wells, The Law of Testimony, 66.

${ }^{313}$ Herbert Chanan Brichto, The Problem of "Curse" in the Hebrew Bible, JBLMS 13 (Philadelphia: Society of Biblical Literature, 1968), 42-45; Milgrom, Leviticus 1-16, 229.

${ }^{314}$ Milgrom, Leviticus 1-16, 232. 
sanctuary. I suggest that this is one of the reasons why they are separated from the sins in Lev 4 where the text does not treat cases in which the sin is forgotten, but presumably dealt with them immediately after it was committed. As such, they require confession since they are publicly done, vv. 1, 4, or the public/community is affected or endangered by them, vv. 2-3.

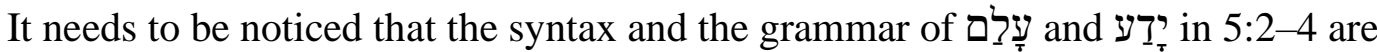

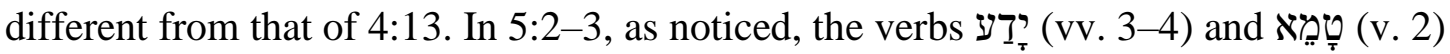
are inflected as qatal which is best interpreted as pluperfect. In contrast, in 4:13 the verb is weqatal and follows the flow of the text. It refers to the activity taking place after the activity expressed by the verb שגה, or here, it describes it. Thus, context, including grammar and syntax, proves to be determinative of the meaning of the words.

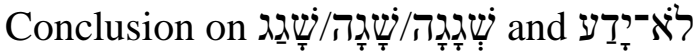

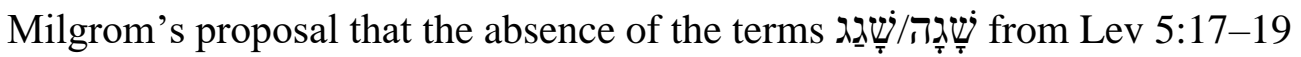

proves that this term refers to the sinner's consciousness of act is disproved by a fresh

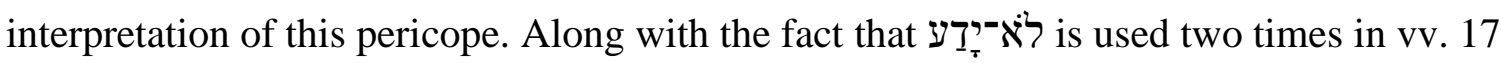

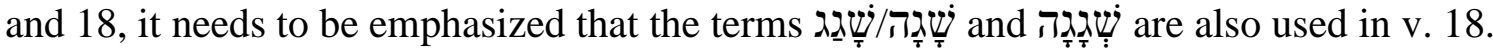

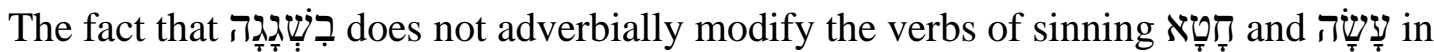

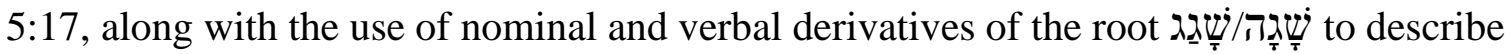
sin in v. 18 , does not disprove Milgrom's claim that sinners in this pericope are not aware of their act nor its sinfulness. However, this claim is not based on the fact that does not modify the verbs of sinning in the protasis, thus conveying the sinners' 


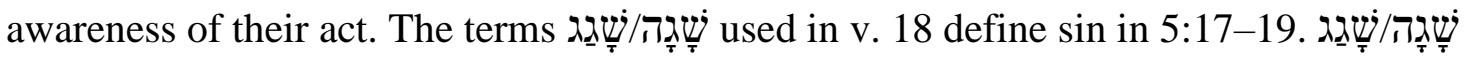
are used as generic terms for sinning and for sin like חָָָ and its derivatives. The use of

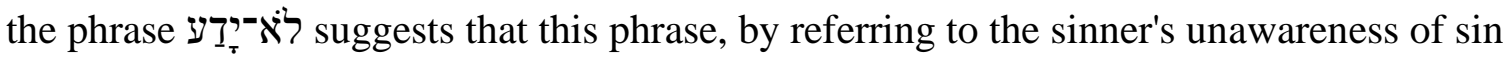
prior to, after, and consequently during the act, delineates a totally unique and new type of $\sin$ in Lev 4-5; a sin out of ignorance. The sinner intentionally commits an act, but not knowing the law, they are unaware that they have sinned. Consequently, they are not aware of the sinfulness of their act. This argument disproves Milgrom's postulate that the

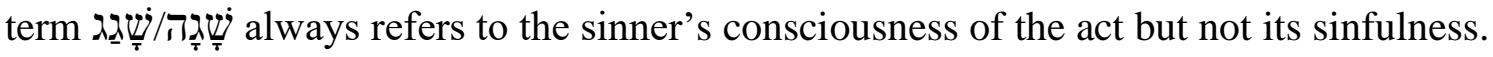

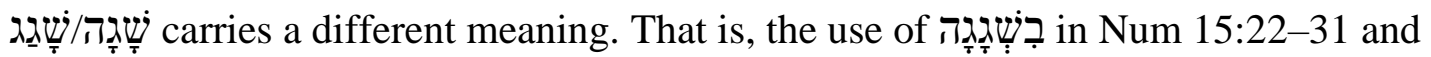
$35: 11,15$ suggests that the term refers to accidental and nondefiant sinning.

Finally, the uses of this term in Lev 4-5 determine the final semantic nuance of

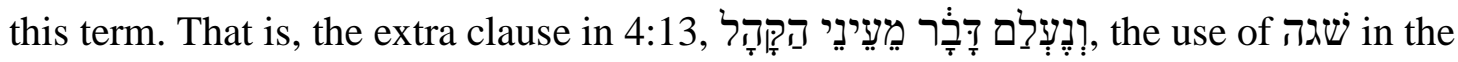
major casuistic statement instead of the regular syntax of this pericope signals that the whole protasis in 4:13-14 should be read as

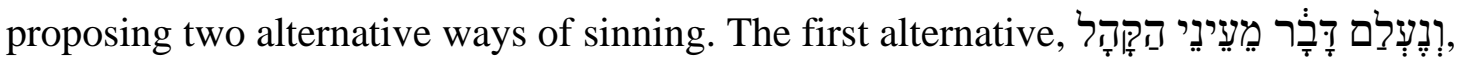
conveys unintentional sin out of ignorance or accident, while the second one,

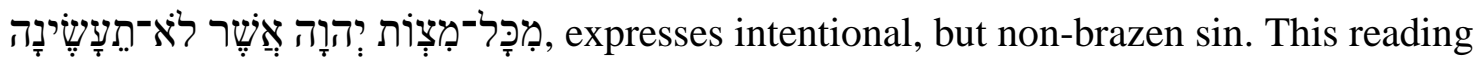
implies שגה in a major, introductory statement does not refer to consciousness of the act, nor to its sinfulness; rather, it is used as a general verb for sinning like potential of referring to all possible ways of sinning.

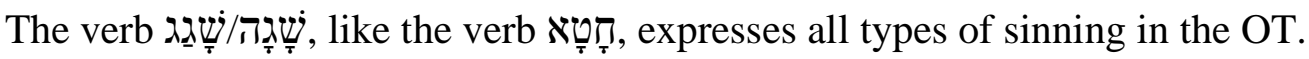


The immediate and wider context of each use clarifies whether the verb is used in a generic way or conveys some specific way of sinning.

Based on the understanding of crucial terms in Lev 4-5 and Num 15, Tָָ,

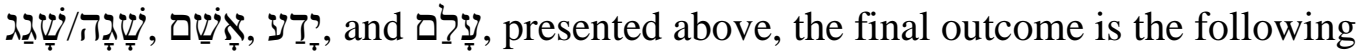
interpretation of the nature of sins and intent in the respective chapters.

The four subcases in Lev 4 all assume two alternative ways of sinning: unintentional, accidental, and potentially out of ignorance, and intentional, but nonbrazen. The next four subcases in Lev 5:1-4 are intentional, but non-brazen sins that were forgotten and eventually remembered. The pericope of Lev 5:14-16 is unique for that reason, separated from subcases in Lev 4, because it deals with sins against the sancta. However, in terms of the nature of sinning due to the use of a general verb theoretical potential, the pericope assumes the same types of sins as are in Lev 4, unintentional, accidental, or out of ignorance and intentional but non-brazen. Leviticus 5:17-19 is another unique type of sinning that is only well-established here, and that is a sin of ignorance. The final pericope in Leviticus, 5:20-26 [6:1-7], encompasses exclusively intentional, but non-brazen sins. Numbers 15:22-31 deals with two types of sinning. The first is described in vv. 22-29 and are non-brazen sins which may include all types of non-brazen sins defined in Lev 4-5. The second is brazen sin that includes the full intention of the sinner, along with the attitude of rejecting God's personality and authority. 


\section{Expiable and Inexpiable Sins in the OT}

Any sort of capital punishment or $k \bar{a} r \bar{e} t^{315}$ seems to be the determinative factor in dividing sins into expiable and inexpiable. In addition, the phrase נָָָָ frequently points to capital punishment, which further means that it refers to inexpiable sin. Finally, Wָ normally points to expiable sin, but it is conditioned by sinners' following the procedure to be forgiven, namely offering a sacrifice, applying blood on appropriate parts of the sanctuary, and taking necessary steps toward the restitution for their sin. אָׁ includes some sort of punitive consequences for sinners who forget their sin or are not aware of it in order to make them remember their sin and take necessary actions to avoid punishment for it. These punitive consequences could eventually lead to capital punishment if the sinner refuses to offer the appropriate sacrifice and be forgiven. In addition, some sins that deserve capital punishment like eating the meat of a peace offering while impure in Lev 7:20 are forgivable if committed accidentally or out of ignorance and the sinner offers sacrifice and make necessary restitutions. If they refuse to offer sacrifice, the capital punishment that is stated in that particular law, which is kārēt, applies. This is also confirmed by Lev 17:11 that the atoning blood ransoms sinner's life, which implies that the sinner's life is in danger when his/her sin is unresolved. ${ }^{316}$ In the chapter "Numbers 15:22-31 and the Spectrum of Moral Faults," Gane reviewed previous work on the kinds of sin in the OT and endorsed Adrian Schenker's

\footnotetext{
${ }^{315}$ Wold, "The Meaning of Biblical Penalty Kareth," 254; Schwartz, "The Bearing of Sin," 13; Gane, Cult and Character, 200-201; Milgrom, Leviticus 1-16, 457-60.

${ }^{316}$ Sklar, Sin, Impurity, Sacrifice, Atonement, 42-43.
} 
understanding, however, he modified it by adding two additional qualifications. ${ }^{317}$ The entire debate on this topic involves the two comparative laws of the sin offering: Lev 4-5 and Num 15:22-31.

Gary A. Anderson has argued that Num 15:22-31 encompasses two kinds of sin, expiable inadvertent and inexpiable high-handed, that cover the entire spectrum of moral sins. ${ }^{318}$ The outcome of this interpretation, as Anderson himself stated, is that any sin committed advertently (intentionally) results in capital punishment: "This text singles out for special emphasis two facts: first, all sins committed inadvertently require sacrificial atonement; and, second, any sin that is committed advertently results in the banishment of the person in question." ${ }^{\text {"319 }}$ Anderson related the second group of sins with the minority of sins of an "egregious nature" that are associated with the cult or ritual. ${ }^{320}$ This division and its rationale is disproven by the texts since Lev 4-5 and Num 15 encompass both intentional and unintentional sins and both are forgivable as suggested in the present study.

Milgrom, following rabbinic tradition, proposed that expiable deliberate sins (Lev

${ }^{317}$ In the first qualifications, Gane suggested that Lev 5:1, 5-6; 5:20-26 [6:1-7], and Num 5:5-8 have to be taken into consideration in order to specify "non-defiant deliberate" sins that can be expiated through purification (sin) and reparation offerings after voluntary confession and necessary reparation. In the second qualification, Gane basically claimed that these kinds of sins can be undetectable by human beings, but God addresses them. Roy E. Gane, "Numbers 15:22-31 and the Spectrum of Moral Faults," in Inicios, Paradigmas y Fundamentos: Estudios Teológicos y Exegéticos en el Pentateuco, ed. Gerald A. Klingbeil, Serie Monográfica de Estudios Bíblicos y Teológicos de la Universidad Adventista del Plata 1 (Libertador San Martín: Editorial Universidad Adventista del Plata, 2004), 154-55.

${ }^{318}$ Gary A. Anderson, "The Interpretation of the Purification Offering (תאטח) in the Temple Scroll (11QTemple) and Rabbinic Literature," JBL 111 (1992): 30-31.

\footnotetext{
${ }^{319}$ Anderson, “Interpretation,” 30.

${ }^{320}$ Anderson, "Interpretation," 31.
} 
5:5, Num 5:7) require voluntary confession in order to reduce them to the category of inadvertent, expiable sins. He assumed that Num 15:30-31 does not allow sacrificial expiation only for the unrepentant sinner. ${ }^{321}$ Gane rightfully critiqued this view based on the fact that Num 15:30-31 does not prescribe confession to provide expiation through repentance. The specific cases of intentional, but expiable sins in Lev 5:20-26 and Num 5:6-8 do not provide enough grounds for the claim that all other deliberate sins can be expiated. ${ }^{322}$ In addition, the absence of capital punishment significantly dissociates $\sin$ in Lev 5:20-26 and Num 5:6-8 from the one in Num 15:30-31. In addition, contrary to Gane in regard to premeditation, ${ }^{323}$ it is very possible that the blasphemer acted with premeditation during the brawl (Lev 24:10-14,23). Why would one, in the middle of a fierce, physical fight, curse God but not his immediate enemy whom he fights with and is most likely overpowered by? It is very possible, keeping in mind the background of this man, ${ }^{324}$ that he spoke out of his attitude of rebelliousness to God.

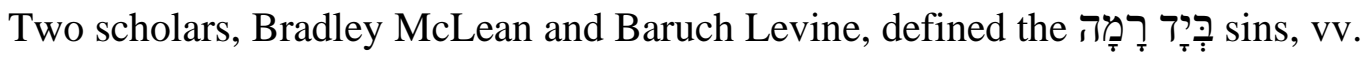
$30-31$, as premeditated to distinguish them from the ones that are unpremeditated. ${ }^{325}$

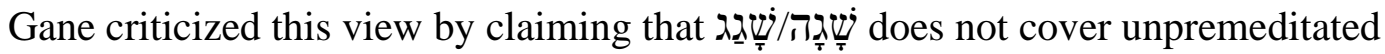
deliberate sins and that intent is not crucial in defining a sin as expiable or inexpiable. ${ }^{326}$

${ }^{321}$ Milgrom, Leviticus 23-27, 2449.

${ }^{322}$ Crüsemann, The Torah, 318.

${ }^{323}$ Gane, "Numbers 15:22-31," 152.

${ }^{324}$ Keil and Delitzsch, The Pentateuch, 2:453; Milgrom, Leviticus 23-27, 2106-7.

${ }^{325}$ Bradley H. McLean, "The Interpretation of the Levitical Sin Offering and the Scapegoat," SR 20 (1991): 348. Levine, Numbers 1-20, 398.

${ }^{326}$ Gane, "Numbers 15:22-31," 152. 


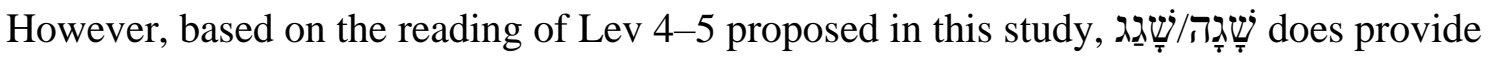
sufficient data for determining whether the sinner acted with intent or not. Intention only, along with unintentionality, is present in all four subcases in Lev 4; 5:1-4, 14-16, 17-19, 20-26. Gane is convincing that in the end, intent itself does not necessarily define whether the sin is expiable or inexpiable.

Gane also found Angel Rodríguez's and Mark Rooker's interpretation of Num 15:30-31 untenable. They, like Milgrom, proposed that subsequent repentance reduces deliberate sin to inadvertent and thus, expiable. ${ }^{327}$ Beside good points of this interpretation, ${ }^{328}$ Gane criticized this approach, as well. First, Gane correctly noted that allowance for the expiation of some deliberate sins does not warrant expiation of all deliberate sins. ${ }^{329}$ This is evident in light of the fact that capital punishment is related to some deliberate sins. Second, Gane's second point was informed by the ADH of the sanctuary, which means that inexpiable sins reach the sanctuary through the air automatically as they are committed. He noted that Rodríguez's and Rooker's claim that any deliberate sin of which the sinner repents is expiable through the sacrifice, based on the fact that in Lev 16:16, 21, rebellious sins, the Day of Atonement. They, in Gane's understanding, missed seeing that removal of these sins from the sanctuary does not imply that the sinner who committed them

\footnotetext{
${ }^{327}$ Rodríguez, "Substitution in the Hebrew Cultus," 148-49; Rooker, Leviticus, 53-55, 219.

${ }^{328}$ Gane, "Numbers 15:22-31," 152-53.

${ }^{329}$ Gane, "Numbers 15:22-31," 153.
} 
experienced expiation. ${ }^{330}$ In light of the study of the term Sins do not refer to sins inexpiable through sacrifice. They are expiable through the sacrifice at least by being part of the list of sins in Lev 5:20-26. This critique of Gane

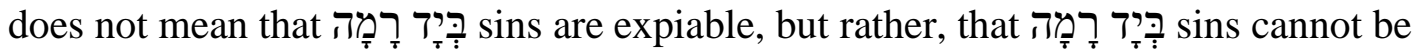
associated with the term may refer to expiable sins. Third, Gane also noticed that since all sins can be expiated in Rodríguez's and Rooker's interpretation if the sinner repents, this leaves no room for inexpiable sins. ${ }^{331}$ I have also supported this claim with the fact that capital punishment speaks for the inexpiability of some sins.

Anthony Phillips suggested that expiable deliberate sins in Lev 5 are different

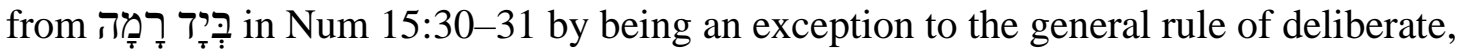
inexpiable sins. Basically, these sins are undetectable and expiable on the basis that the sinner themselves admit them. Leviticus 5:20-26 had the purpose of encouraging the sinner to do so. ${ }^{332}$ Gane rightfully corrected Phillips' proposal by reminding that Num 15:30-31 does not state that this kind of sin is necessarily detectable by human agents, but does state that the sinner experiences capital punishment administered by God. ${ }^{333}$ Thus, Phillips' suggestion, regardless of its appeal and possibly presence in the function of the law by endorsing one of the main roles of the BL to make covenant people

${ }^{330}$ Gane, "Numbers 15:22-31," 153.

${ }^{331}$ Gane, "Numbers 15:22-31," 153.

${ }^{332}$ Phillips, Essays on Biblical Law, 257; Anthony C. Phillips, "The Undetectable Offender and the Priestly Legislator," JTS 36 (1985): 148, 150.

${ }^{333}$ Gane, "Numbers 15:22-31,” 154. 
intrinsically and ethically sound, is disproven by the text.

Gane's own interpretation of the discrepancy between Lev 4-5 and Num 15 agrees with Schenker's understanding of this subject. Schenker understood that there are two types of deliberate sins, and it is the sinner's attitude that differentiates them. Those committed in open, rebellious attitude towards God's rulership and those that are deliberate, but are not committed rebelliously. He proposed that Num 15:22-31 contrasts the least serious types of sin, vv. 22-29, and the most serious types, vv. 30-31. This passage does not deal with the sins in between these two types. ${ }^{334}$

Gane first supplemented this view with the claim that Lev 5:1, 5-6; 5:20-26, and Num 5:5-8 specify exactly which non-defiant deliberate sins can be expiated through sin and reparation offerings after voluntary confessions and necessary reparations. ${ }^{335}$ Second, Gane suggested that the sins are ultimately against God himself. They may not be detected by humans, but God is able to see them. While Gane's latter point is profoundly correct, the former one needs modification. That is, it is too restrictive to delimit the nondefiant deliberate sins to those found in Lev 5:1, 5-6 and 5:20-26 due to the fact that the Pentateuch lists many other sins that are deliberate, but non-defiant and thus, expiable. The list in Lev 5:20-26 is especially not concerned with the exact examples of misappropriation of the property as such, but rather, encourages individuals to confess to having sworn a false oath. Exodus 21:37-22:12 and Lev 19:11-13 list many other variations of sins that are some form of misappropriation of another's property and are

\footnotetext{
${ }^{334}$ Gane, "Numbers 15:22-31," 154; Adrian Schenker, "Das Zeichen des Blutes und die Gewißheit der Vergebung im Alten Testament: Die sühnende Funktion des Blutes auf dem Altar nach Lev 17.10-12," MTZ 34.3 (1983): 205.

${ }^{335}$ Gane, "Numbers 15:22-31," 155.
} 
deliberate, but yet expiable. ${ }^{336}$ Thus, Lev 5:1, 5-6 and 5:20-26 is taken to be a representative procedure with regards to any kind of sin against another's property that would include taking an oath before God and not only the sins that are expiable, regardless of being deliberate, but non-defiant.

The outcome of Gane's study is that there are 3 kinds of sin: (1) inadvertent sins represented in Num 15:22-29, (2) intentional defiant sins represented in Num 15:30-31, and (3) intentional non-defiant sins represented in Lev 5:1, 5-6; 5:20 [6:1-7] and Num 5:5-8. Two of these kinds, the first and the third, can be expiated through the sacrificial system, while the second cannot.

Gane's study divides intentional sins into two categories: (1) those committed defiantly with the intent to break with God and (2) those that are not done with such an attitude; this division is correct. I came to the same conclusion, but differ with him in the selection of texts used to prove this. Based on the interpretation suggested in the present study that the protasis in Lev 4-5 and Num 15:22-31 all except of Num 15:30-31, present two alternative ways of sinning, intentional and unintentional, I suggest that nonbrazen, intentional, as well as unintentional sins are found in both Lev 4-5 and Num 15:22-29.

It has to be added that this distinction cannot be supported by the terminological study of the terms for sin that this study is limited to since they are used interchangeably in the Pentateuch as I verified above. Rather, the texts in which these categories of sin are found classify them as such in two ways. First, the verb שָָָׁ is used to mark both unintentional and intentional sin in the procedure which discusses the expiation of these

\footnotetext{
${ }^{336}$ Phillips, Ancient Israel's Criminal Law, 138, 189; Levine, Leviticus, 33.
} 
sins as in Lev 4:13 and Num 15:22. The adverbial use of the nominal derivative also used for the same purpose as in Lev 4:2, 22, 27; 5:15; 22:14 and Num 15:26, 27; 35:11, 15. ${ }^{337}$ Second, Num 5:5-8 indicates that some intentional sins can be expiated by the use of the verbal and nominal forms of מָעָ which can refer to both intentional and unintentional sins. Regardless of being intentional, these sins are expiable. Third, the general and all-encompassing verb חָָָ used throughout Lev 4-5 refers to both intentional and unintentional sinning and is defined by the context.

This view is implied by Keil and Delitzsch who expanded the category of expiable sins to inadvertent and deliberate:

But sinning "in error" is not merely sinning through ignorance (vv. 13, 22, 27, 5:18), hurry, want of consideration, or carelessness (Lev. 5:1, 4, 15), but also sinning unintentionally (Num 35:11, 15, 22, 23); hence all such sins as spring from the weakness of flesh and blood, as distinguished from sins committed with a high (elevated) hand, or in haughty, defiant rebellion against God and His commandments. ${ }^{338}$

The methodology and arguments for arriving at this understanding of types of sin by Keil and Delitzsch are different from those presented in the current study. Gane's

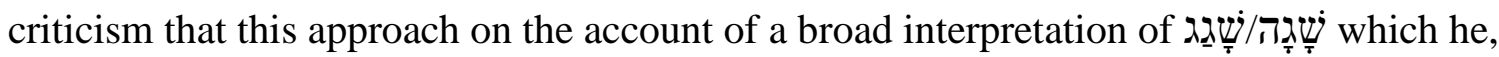
with a majority of scholars, held to refer to inadvertence ${ }^{339}$ is not valid since this

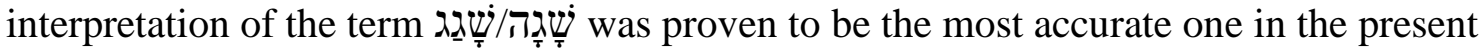
study. Consequently, this division of sins is proven to be the most accurate.

\footnotetext{
${ }^{337}$ The same pattern is found in Josh 20:3, 9.

${ }^{338}$ Keil and Delitzsch, The Pentateuch, 2:303.

${ }^{339}$ Inadvertence in Gane's and other scholars' understanding never includes intentionality. Gane, "Numbers 15:22-31," 151.
} 


\section{Sins}

It is shown already in the preceding subheading that there is general agreement

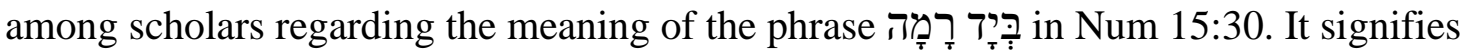
inexpiable, unforgivable sin, and scholars have rightfully come to that conclusion. ${ }^{340}$

This phrase refers to the activity done deliberately, presumptuously. ${ }^{341}$ Caspar Labuschagne noted that based on texts such $1 \mathrm{Kgs}$ 11:26ff, Mic 5:8, Deut 32:27, and Exod 17:11, the phrase has military origin: "The origin of the expression is without any doubt the physical gesture of the raised hand, with or without a weapon in it, which indicates that one is triumphantly determined to fight and win." The phrase conveys the attitude of readiness to fight and the will to prevail. Besides this argument, Labuschagne also noted three additional arguments to understand the phrase in this way: (1) in the remaining two occurrences of the phrase in Exod 14:8 and Num 33:3b, the human party, people of Israel, is the subject of the sentence, and thus, the phrase describes the posture or attitude of the people signifying their determination to fight and will to prevail in the given situation; (2) the Exodus of Israel from Egypt account contains the element of Israel's readiness for the battle as they were leaving Egypt; and finally (3) Israel left Egypt organized as a military unit, mustered in their tribal hosts. ${ }^{342}$ These pieces of

\footnotetext{
${ }^{340}$ Milgrom's thought that this sin can also be expiated if the sinner repents, confesses, and makes appropriate restitution. Milgrom, Leviticus 1-16, 370; Milgrom, Leviticus 17-22, 2449. However, the following denied expiation of this type of sin. Keil and Delitzsch, The Pentateuch, 2:303; Schenker, "Das Zeichen des Blutes und die Gewißheit der Vergebung im Alten Testament," 205; Phillips, "The Undetectable Offender," 148; McLean, "The Interpretation of the Levitical Sin Offering," 348; Anderson, "Interpretation," 19, 30-31; Hartley, Leviticus, 1xix-1xx.

${ }^{341}$ Labuschagne, "The Meaning of $b^{e} y \bar{a} d$ rāmāa," 143; Botica, Concept of Intention, 88-89.

${ }^{342}$ Labuschagne, "The Meaning of $b^{e} y \bar{a} d$ rāmā," $146-47$.
} 
evidence suggest that the phrase refers to the deliberate, intentional activity of the subject which it modifies. Labuschagne cautioned that "in Num 15:30 the expression has a weakened meaning: 'deliberately,' but it is not impossible that here also it still retains something of its original force and connotes the idea 'ready to commit rebellion,' 'defiantly"' ${ }^{343}$ Based on the fact that v. 30 expresses a personal affront to $\operatorname{God}^{344}$ and that

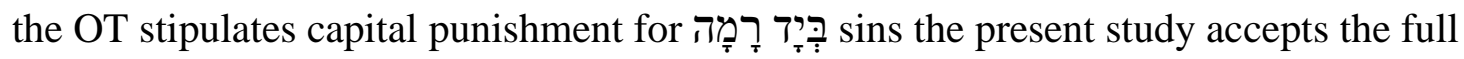
force meaning of this phrase. Applied to this context, the phrase conveys the fact that a

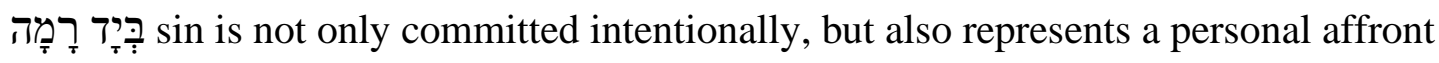
against God, rebellion against his personality, his authority, and his covenant. ${ }^{345}$

All these points show that the OT does provide certain guidelines for identifying intentional, brazen sin. However, Num 15 does not relate this kind of sin to any of the three key terms for sin in the OT.

\section{Intentional and Unintentional Sins in the OT}

There are two types of sins in the OT, intentional and unintentional. I divided the former group into non-brazen and brazen intentional sin. The former is expiable through the sacrificial system and cult, while the latter is not, but the sinner suffers terminal punishment.

In the case of intentional sin, sinners are totally aware of both elements of sin:

${ }^{343}$ Labuschagne, "The Meaning of $b^{e} y \bar{a} d$ rāmā,, 148.

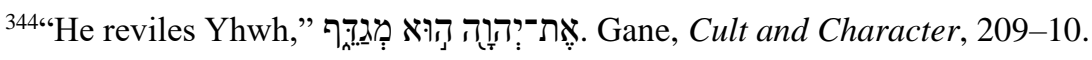

${ }^{345}$ Gane, Cult and Character, 209. Adolf Büchler, Studies in Sin and Atonement in the Rabbinic Literature of the First Century (New York: Ktav, 1967), 307-8, 456; Porter, Leviticus, 37. 
(1) that they perform certain activity, and (2) that that activity breaks God's law; they are committing sin. This intentionality can come out of sinner's GHS and weakness and out of an attitude to deny God, his personality, and authority.

I deliberately abstain from using any of the mass of adjectives such as wanton, defiant, deliberate, inexpiable, done wittingly... that refer to intentional sin, but limit myself to a simple "intentional sin" that comprises two distinct types: (1) non-brazen sin, coming out of GHS and weakness, on the one hand, and (2) brazen sin, the desire to deny and break with God on the other. Scholars have usually attached these adjectives to sins that are intentional, but not inexpiable/unforgivable, and my decision to abstain from using them aims to avoid a potential misunderstanding that intentional sin is inexpiable/unforgivable. ${ }^{346}$ The analysis of texts I proposed confirms the fact that

\footnotetext{
${ }^{346}$ Compare the following quotations from Milgrom's commentary with my emphasis added. " $\mathrm{P}$ holds that the sanctuary is polluted by Israel's moral and ritual violations (4:2) committed anywhere in the camp (but not outside) and that this pollution can and must be effaced by the violator's purification offering and, if committed deliberately, by the high priest's sacrifice and confession (16:3-22)." Milgrom, Leviticus $1-16,48$. Indeed, there are only four passages in $\mathrm{P}$ in which confession (hitwaddâ) is explicitly required, and each case deals exclusively with deliberate $\sin (5: 1-4 ; 16: 21 ; 26: 40$; Num 5:6-7). Milgrom, Leviticus 1-16, 301-2. But what function does confession serve? Why must contrition of the heart be augmented by the confirmation of the lips? Confession must, then, play a vital role in the judicial process. Because it occurs only when deliberate sin is expiated by sacrifice, the conclusion is inevitable: confession is the legal device fashioned by priestly legislators to convert deliberate sins into inadvertences, thereby qualifying them for sacrificial expiation. Milgrom, Leviticus 1-16, 301-2. Milgrom contradicts himself greatly in the following quotation that qualifies deliberate sins as inexpiable and unforgivable: "In the Priestly laws, however, there is no sacrificial expiation for capital crime or, for that matter, for any deliberate violation. The presumptuous sinner is banned from the sanctuary because he 'acts defiantly (béya $d$ rāmâ) ... reviles the Lord ... has spurned the word of the Lord and violated his commandment' (Num 15:30-31; contrast vv. 24-29)." Milgrom, Leviticus 1-16, 710. Also, see Noorditzij's limitations to define the intention of the sinner in statements on Lev 4:3-12 where he clearly defined sin as unintentional only:. "If the high priest sinned by doing 'what was forbidden in any of the Lord's commands' (v. 2; cf Gen 29:26; 34:7; 2 Sam 13:12), i.e., if he unintentionally transgressed an express prohibition (cf. Lev 5:17) - for sins committed 'defiantly,' and thus deliberately, there was only one penalty, viz., death (Num 15:30) - he thereby brought guilt on the people." Noordtzij, Numbers, 57. Compare his comments on Lev 5:20-26 where he refrains from expressing the type of this sin: "These verses (MT 5:20-26) no longer deal with the unintentional violation of what belonged to the Lord, but rather with unlawful appropriation of what one knew to belong to one of his countrymen." Noordtzij, Numbers, 72-73. Emphasis mine. In addition, see his inability to include this pericope in his comparison of Lev 4-5, that in his words present unintentional sins, and Num 15:30, which discuss intentional sin. Noordtzij, Numbers, 55.
} 
intentional, non-brazen sins are expiable/forgivable, as are unintentional ones.

In the instance of unintentional sin, sinners are totally aware of only one element of the sin: that they have intentionally done a certain activity, but not the sinful element, that that activity breaks God's law, and that they are thereby committing sin. Unintentional sins are always expiable/forgivable, but yet, some do include diminished punishment.

I also intentionally refrain from using a variety of adjectives that refer to unintentional sin such as negligent, unwitting, or inadvertent because the majority of them present a complex definition attached to them by MLS that do not or just partially match the descriptions of sins in the Pentateuch. As was shown in the case of Milgrom's work on Lev 4-5 and Num 15, applying these strictly defined terms of MLS to sins as they are described in the Pentateuch produces incoherence between the terminology and the concepts they are supposed to signify. In order to avoid miscommunication and terminological confusion, I use the simple term, "unintentional sin," meaning "out of ignorance" or "by accident." This terminology comes out of the interpretation of Lev 4-5 and Num 15 presented in the current study and provide more comprehensive descriptions of sins such as homicide laws (Exod 21:12-25, Num 35:9-34), but they are attached to specific sins and are not introduced as allencompassing and comprehensive legal cases that cover sin in general like Lev 4-5 and Num 15. Table 21 demonstrates these sin types visually, while Table 22 demonstrates the

\footnotetext{
${ }^{347}$ Gane, Sklar, and Hartley have the same understanding of sin types, but based on a different methodology which I suggest is not consistent, since all of them, except Hartley, do not see any sort of intentional sin in Lev 4. Gane, "Numbers 15:22-31," 154; Sklar, Sin, Impurity, Sacrifice, Atonement, 4244; Hartley, Leviticus, 55.
} 
Table 21. Sin's expiability/inexpiability

\begin{tabular}{|c|c|c|}
\hline $\begin{array}{c}\text { Unintentional } \\
\text { (Accident, ignorance) }\end{array}$ & $\begin{array}{c}\text { Intentional but non-brazen } \\
\text { (GHS/weakness) }\end{array}$ & $\begin{array}{c}\text { Intentional brazen } \\
\text { (Desire to break with God) }\end{array}$ \\
\hline Expiable, forgivable & Expiable, forgivable & Inexpiable, unforgivable \\
\hline
\end{tabular}

Table 22. The sinner's awareness

\begin{tabular}{|l|c|c|c|c|}
\hline & \multicolumn{2}{|c|}{ Unintentional } & \multicolumn{2}{c|}{ Intentional } \\
\cline { 2 - 5 } & Accident & Ignorance & Non-brazen & Brazen \\
\hline Intent to act & Yes & Yes & Yes & Yes \\
\hline Intent to sin & No & No & Yes & Yes \\
\hline
\end{tabular}

separation of a sinner's awareness in relation to these sin types:

This simple terminology allows for inclusion of all other sins in the Pentateuch some of which are thoroughly described, but also the ones that lack context that would define them under all-encompassing legal cases of Lev 4-5 and Num 15. Thus, sin in the Pentateuch is simply described as expiable/forgivable and inexpiable/unforgivable which does not correlate with another simply division of sins as intentional and unintentional because some intentional, but non-brazen sins are expiable/forgivable, as some unintentional sins for which the sinner chooses not to offer sacrifice are not. The sacrificial system offered a way of reconciliation with God to any sinner for the majority of sins, but it was God only who granted forgiveness. In other words, any sinner could offer a sacrifice for any sin, but God was the one who decided whether the sin would be forgiven or not.

Some intentional sins are inexpiable/unforgivable in the OT due to the fact that the sinner is punished by capital punishment either by God or a human agency. These are 
sins (Num 15:30-31). ${ }^{348}$ Some intentional sins are expiable/forgivable, but expiation of them is conditioned by obedience to divine regulations of bringing a sacrifice for them. This same principle is also applicable to the cases of unintentional sin (Lev 4-5). If the sacrifice is not offered, then the sinner who commits intentional expiable/forgivable and unintentional expiable/forgivable sins experiences terminal punishment. Thus, the status of expiable/forgivable or inexpiable/unforgivable sins in great part rests on the sinner's response. The terminology is not helpful in determining whether a sin belongs to one or another category, but context is.

\section{Interpretation of Leviticus 16:21}

Leviticus 16:21 is a known, twofold, interpretative crux, and scholars rightfully relate it to Lev 16:16. First, the crux is the function of the prepositional phrase lekol and the second one is the interpretation of the Hebrew terms used in these texts. Gane has collected major scholarly proposals on how to interpret it, and he himself proposed a solution to both the cruxes. ${ }^{349}$

Milgrom made a difference between the last two terms which are the same in both

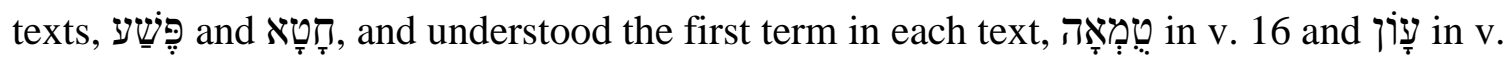
21, as encompassing the latter two. ${ }^{350}$ Rolf Rendtorff proposed a similar interpretation.

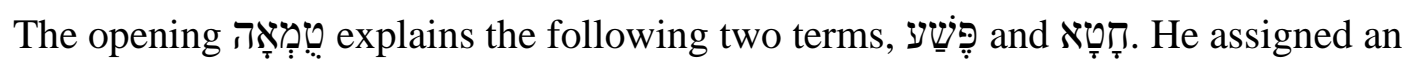

\footnotetext{
${ }^{348}$ Based on the canonical understanding of the plan of salvation, especially by the input of the NT, this type of sin may be forgiven by God through Jesus Christ. This would be an anti-typical augmentation of the typical OT sacrificial system in Jesus Christ and forgiveness could be achieved through it.

${ }^{349}$ Gane, Cult and Character, 285-91.

${ }^{350}$ Milgrom, Leviticus 1-16, 1033-34, 1044.
} 
explicative meaning to the ? attached to שֶֶּ, "impurities - that is, brazen sins and other sins." ${ }^{, 351}$ Gane criticized this approach because assigning an explicative meaning to the ? "raises the suspicion of circular reasoning." 352 It implies that טְְִׁ includes moral sins, and vice versa. Even though present in a limited number of texts, these two terms

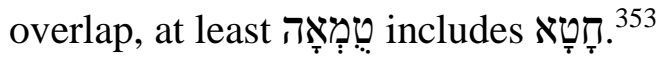

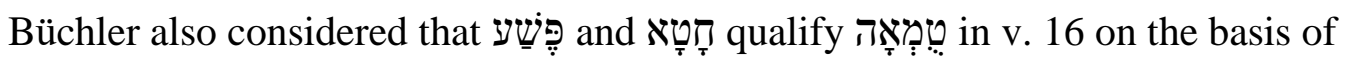

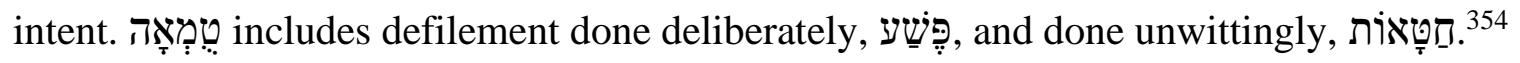
Noting that the ? impacts the interpretation he proposed, he stated that all three terms are synonyms and that, in v. 21 , they refer to the same evils from a different perspective. ${ }^{355}$ Thus, moral and ritual sins are equal in this interpretation.

Kiuchi took Büchler's route, but still, in arguing in a reversed order that moral

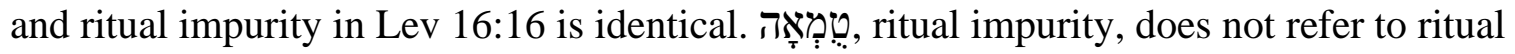
impurities themselves, but is rather, a moral fault that originates from breaking laws concerning ritual impurity. Consequently, חַּט

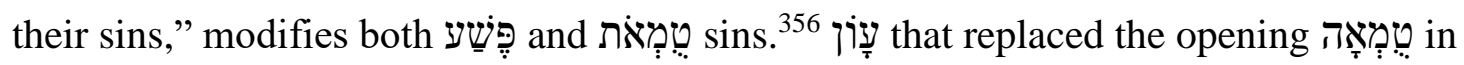

${ }^{351}$ Rendtorff, Leviticus, 3:220.

${ }^{352}$ Gane, Cult and Character, 287.

${ }^{353}$ This was demonstrated under the subheading Relevant Terms for Moral Impurity in the OT of the present study.

${ }^{354}$ Büchler, Studies in Sin and Atonement (1967), 265.

${ }^{355}$ Büchler, Studies in Sin and Atonement (1967), 267.

${ }^{356}$ Kiuchi, Purification Offering, 154-55. 
v. 21 refers to a guilt/consequence of the ritual and moral impurity. Based on the same

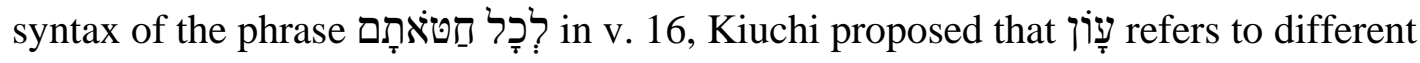

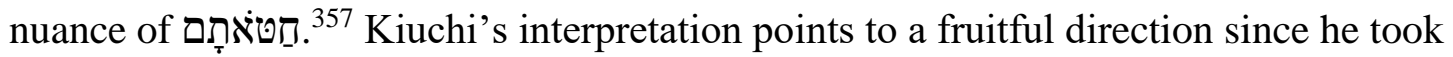
into account what none of the previous scholars did, the fact that

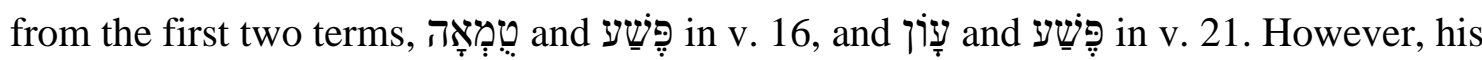

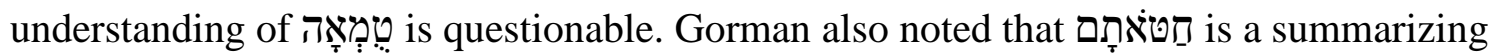
term, but with the meaning of "sin." This term, then, encompasses sins expressed by the previous two terms. ${ }^{358}$

Schwartz has given proper attention to the fact that ! attached to

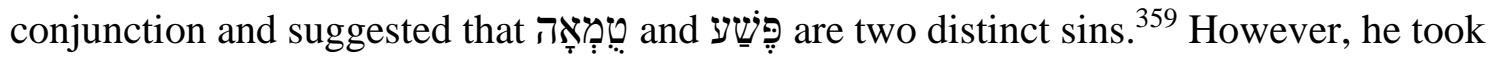
חטּאתָם these two texts point to two types of sin, ritual and moral impurity, with the addition of a

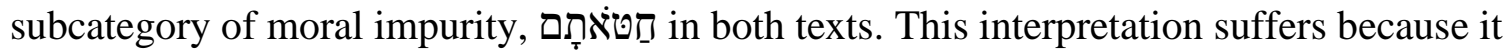
is based on the assumption that שֶׁ are inexpiable/unforgivable sins. Based on the same

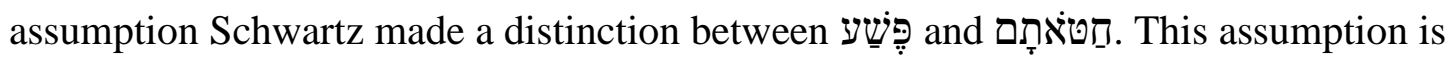
proven to be unsupported by texts.

\footnotetext{
${ }^{357}$ Kiuchi, Purification Offering, 155-56, 188n57.

${ }^{358}$ Frank H. Gorman, The Ideology of Ritual: Space, Time and Status in the Priestly Theology, JSOTSup 91 (Sheffield: JSOT Press, 1990), 82.

${ }^{359}$ Schwartz, "The Bearing of Sin," 6-7, 17.

${ }^{360}$ Schwartz, "The Bearing of Sin," 18.
} 


\section{Gane's Proposal on Function of the Prepositional Phrase ?ִכְל}

Gane also proposed his own interpretation of these two texts. He first criticized

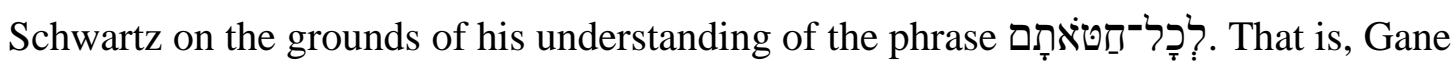

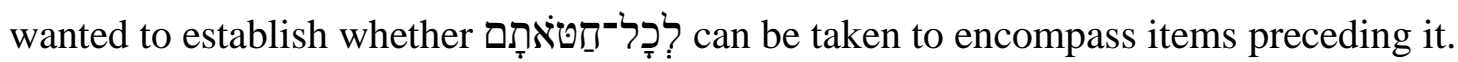
He established the fact that two patterns of uses of lekol occur. First, "elsewhere in Leviticus, when לכל (lit., "to all") is placed just before a final item in a list, if this item includes all of the previous terms in its semantic range, it is a summarizing category, as in 11:42." Second, "if the final item following לכל does not include all of the previous ones, it represents a separate item to which the list is extended, as in v. 46." ${ }^{361}$

Based on these two patterns, Gane proposed that summarizing item, but rather, a separate item added to the list. ${ }^{362} \mathrm{He}$ added another

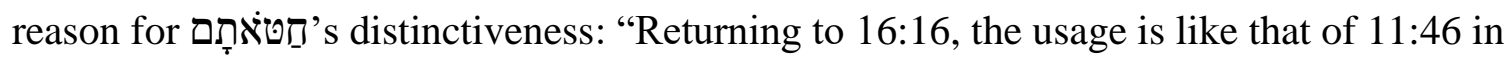
that הטטאתם , לכל , the final item following cannot be an overall summarizing category

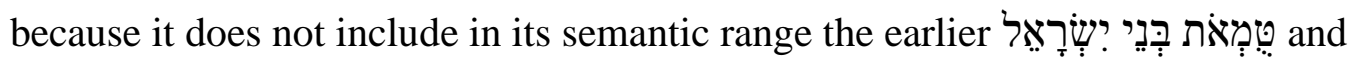
363

Gane's first pattern of uses of כּ is well supported in contrast to the second one. That is, Lev 11:46 differs significantly from Lev 16:16, 21 since in the former, the

${ }^{361}$ Gane, Cult and Character, 289.

${ }^{362}$ Gane, Cult and Character, 289.

${ }^{363}$ Gane, Cult and Character, 289. Also, the form טִpְמאת should be without dagesh forte of the preposition $\min$ in the initial ט. See Lev 16:16; Ezek 36:25, 29. 
conjunction ? is attached to the כל, which is not the case in the latter. Thus, it is natural that the ? introduces another new item in the list. However, that is not the case in Lev 16:16, 21. Consequently, the inferences from Lev 11:46 to Lev 16:16, 21 are not justifiable since they are grammatically and syntactically different.

Regarding his second argument, Gane is partially correct. That is, in reference to

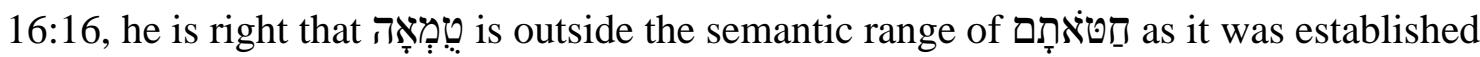
under the subheading, "Relevant Terms for Moral Impurity in the OT," in the present

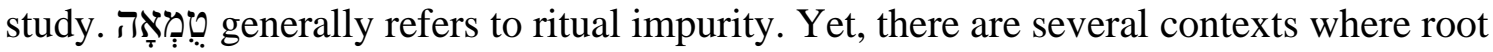

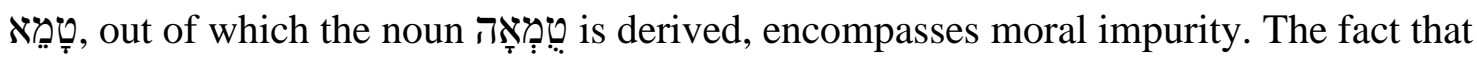
חַטּאתָם "Impurity in the OT in Modern Studies, Jonathan Klawans" of the present study. Yet, it does not affect the interpretation of 16:16 because the last item in the list is not טְִִּ but

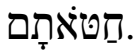

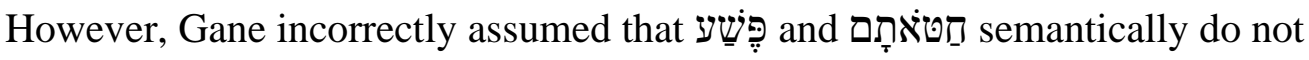
overlap. Applying the terminological/contextual/intertextual method for studying sin established in the present study demonstrated that they do semantically overlap.

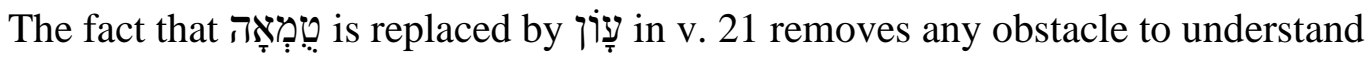

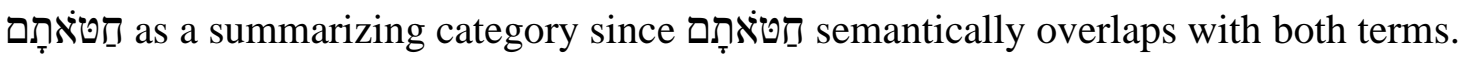

The findings of the present study confirm that three key terms for sin, and activities. There are a considerable number of scholars who consider these three terms as 
complimentary to describe sin in its totality when they are found in the same context. ${ }^{364}$

\section{Gane's Proposal on the Interpretation of Hebrew Terms}

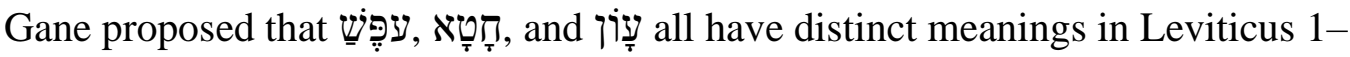
16, and others have followed him. ${ }^{365}$ This claim is based on the use of these terms in various parts of the OT. ${ }^{366}$

Attempting to be more specific on the nature of the חָטָאתם sins, Gane suggested that the He listed the 3 following types of sin that חָָָ refers to: (1) expiable, non-defiant sins, including inadvertent sins (Lev 4:3, 14, 23, 26, 28), (2) sins of forgetting to perform a duty to God (Lev 5:6), and (3) some deliberate sins (Lev 5:6, cf. v. 1; Num 5:6-7; also

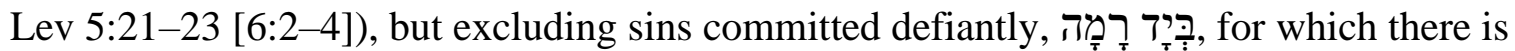
no opportunity for expiation, but rather, the sinner suffers kārēt punishment. ${ }^{367}$ This view of the $\sin$ in Leviticus and the rest of the Pentateuch will be evaluated below, and it will be suggested that the חָָ in Leviticus and the rest of the Pentateuch refers to expiable and inexpiable, as well as intentional and unintentional sins.

First, it is necessary to note that Gane based his claims about חָָּ on the

\footnotetext{
${ }^{364}$ Sklar, "Sin," 2:298; Knierim, "חט," TLOT 1:410. For a more extended list of sources, see Gane, Cult and Character, 285n1.

${ }^{365}$ Wells, "Liability in the Priestly Texts," 5.

${ }^{366}$ Gane, Cult and Character, 292-98.

${ }^{367}$ Gane, Cult and Character, 292.
} 
Pentateuchal ritual laws only. However, it seems that Gane restricted the term Pentateuchal ritual laws to the Leviticus texts and Num 5:6-7, even though the term occurs in the texts of the entire Pentateuch, and not just Leviticus and Num 5:6-7. Gerald A. Klingbeil suggested the list of ritual texts in the Pentateuch that covers the entire corpus of the Pentateuch. This list emphasizes the fact that ritual texts in the Pentateuch are spread over chs. 1-23 in the book of Leviticus, as well as in the entire Pentateuch. ${ }^{368}$ Singling out some Leviticus texts and Num 5:6-7 as the only Pentateuchal ritual texts is not hermeneutically sound since these texts are some, but not all, the Pentateuchal ritual texts. Inclusion of all Pentateuchal ritual texts would bring a significantly different definition of $\operatorname{Tin}$ in the Pentateuchal ritual texts. It is attested that Num 9:13 is a ritual text, ${ }^{369}$ dealing with exceptions in regards to Passover regulations. These details, demonstrating the syntactical connection between the and the verb מוּר הָטא refers the inexpiable, intentional sin (Num 9:13 and Lev 22:9, respectively), which was shown in more detail earlier (pp. 194-98).

Second, Gane excluded Lev 26:18, 21, 24, 28 from Pentateuchal ritual law texts most likely because he agreed with Levine that this section does not belong to legal or ritual texts, but is rather considered as the climax of the entire book of Leviticus. ${ }^{370}$ Levine himself, however, claimed that ch. 26 is the epilogue of the Holiness code. ${ }^{371}$

\footnotetext{
${ }^{368}$ Klingbeil, Bridging the Gap, 245-52.

${ }^{369}$ Klingbeil, Bridging the Gap, 250.

${ }^{370}$ Gane, Leviticus, Numbers, 451.

${ }^{371}$ Levine, Leviticus, 182.
} 
Milgrom also held this position about ch. $26 .^{372}$

Singling out chs. 1-6 in Leviticus and Num 5:6-7 would not be viable hermeneutics even if one accepted the presence of two priestly sources, $\mathrm{H}$ and $\mathrm{P}$, in the book of Leviticus. That is, both of these two sources are tightly connected and frequently intermingled in terms of content and form. It is suggested that $\mathrm{H}$, the latter source, was a redactor of $\mathrm{P}$, the earlier source. In terms of ritual texts, it is attested that both of these sources dealt with the same laws. At this point, it is vital to emphasize that both of them deal with the same ritual laws. Milgrom showed that the law concerning the ingestion of meat of the offering found in Lev 7:18 ${ }^{373}$ (P source) was reworked in Lev 19:7-8 (H source). Accordingly, both sources contain ritual texts that deal with the same laws. ${ }^{374}$ This law is just one that is worked out in both sources. ${ }^{375}$

This close connectedness of $\mathrm{P}$ and $\mathrm{H}$ in content suggests that both of them should be considered if one studies rituals laws in the Pentateuch. In other words, the presence of two sources should not prevent one from deriving implications from each of them to form a functionally integrated system. ${ }^{376}$ The same principle is applicable to many given

${ }^{372}$ Milgrom, Leviticus 23-27, 2304.

${ }^{373}$ Wright, "The Spectrum of Priestly Impurity,” 162.

${ }^{374}$ Milgrom, Leviticus 1-16, 13-35; Henry T. C. Sun, "Holiness Code,” ABD 3:254-57.

${ }^{375}$ Milgrom, Leviticus 17-22, 1615-19.

${ }^{376}$ This point was eloquently demonstrated by Gane on the functional, systematic nature of Leviticus 16. Gane, Cult and Character, 31-42. 
elements of a broader religious system of Ancient Israel. ${ }^{377}$ This suggestion points to the fact that Lev 26:18, 21, 24, 28 should be taken into consideration when one studies the nature of the TָT $_{\text {sin }}$ in Leviticus. In addition to the first point above, this reasoning would also create a very different understanding of חָָָ sin than the one Gane proposed. That is, scholars have recognized that the punishments in Lev 26 are God's response to the sins of his people, and that their unresponsiveness to those punishments represents people's stubbornness to God's dealing with them. ${ }^{378}$ The term דָָָ is used in all these texts to refer to their sins. The context indisputably suggests that these sins are both brazen intentional and inexpiable sins.

Third, Milgrom ${ }^{379}$ and others ${ }^{380}$ correctly claim that sin in Lev 5:1 is an intentional sin. In his monograph "The Problem of "Curse" in the Hebrew Bible," Herbert Brichto noted that the institution of public proclamation, 'ālâ, of eliciting information regarding the status of property, commission of crime, and so on was common in ANE and Israel. ${ }^{381}$ In Israel, 'âlâ took the form of a conditional imprecation

\footnotetext{
${ }^{377}$ It should be noted that some basic premises of the atonement process are not taken from $\mathrm{P}$ or $\mathrm{H}$, but rather, belong to the wider literary context of the entire OT. Milgrom for instance, confirmed the fact that God will abandon his sanctuary if not cleansed by quoting Lam 2:7; Ezek 11:22; 2 Kgs 18:4. Milgrom, Leviticus 1-16, 258-59. The meaning of כְִֶּ, in Milgrom's system is also taken from poetic parts of the OT. Jacob Milgrom, “Atonement in the OT," IDBSup 78.

${ }^{378}$ Levine, Leviticus, 186-89; Rooker, Leviticus, 315-19; Gane, Leviticus, Numbers, 452-53; Keil and Delitzsch, The Pentateuch, 2:473-76.

${ }^{379}$ Milgrom, Leviticus 1-16, 295.

${ }^{380}$ Noordtzij, Numbers, 63; Snaith, Leviticus and Numbers, 48; Noth, Leviticus, 44; Kiuchi, Leviticus, 99; Sklar, Sin, Impurity, Sacrifice, Atonement, 80; Gane, Cult and Character, 146.

${ }^{381}$ Brichto, The Problem of "Curse," 42. Also followed by Walton, Matthews, and Chavalas, "Leviticus," 123; Wells, The Law of Testimony, 20-21; Milgrom, Leviticus 1-16, 293. For alternative views see Hartley, Leviticus, 68-70.
} 
against the perpetrator of a crime, and against accessories after the fact and witnesses withholding material evidence. In addition, it requires the awareness that every adjuration involves a contingent curse. Brichto suggested that the translation of the 'âla in Lev 5:1, which has the lexical form qôl 'âlâ, would be "a public summons backed by a contingent curse.” Besides Lev 5:1, which is one of the key 'ālâ texts Brichto referred to in the OT, he also listed Prov 29:24 and Judg 17:2. ${ }^{382}$ Milgrom listed more texts dealing with the 'àlâ, along with examples of it from the ANE contexts, and rabbinic and historical sources. $^{383}$

Fourth, uses of nominal and verbal derivatives of the root דָָ show a different nature of $\operatorname{Tr}$ sin. Of 25 uses of nominal derivatives of דָטָ when it refers to sin, it describes intentional sin 14 times, and it refers to either unintentional (4:3, 14, 23, 26, $28 \times 2,35)$ or $\sin$ in general (Lev 16:30, 34) 9 times. Two times the context is not clear where intentional or unintentional sin is in view. Of 30 verbal uses of the term Tָטָ⿻ there are 25 uses when the verb refers to the activity of sinning; 11 times it is in designate intentional $(5: 1,5,6,7,10,11,13,[6: 2] 21,[6: 3] 22,[6: 4] 23 ; 19: 22)$, whereas 14 times, it is designated unintentional sinning $(4: 2,3 \times 2,14,22,23,27,28 \times 2,35 ; 5: 15,16,17)$.

Having established this, Gane's definition of the sin in Leviticus 1-16 seems not to be supported by the Pentateuchal texts. This term is defined in the wider context of the book of Leviticus and the Pentateuch as intentional

\footnotetext{
${ }^{382}$ Brichto, The Problem of “Curse," 42-43.

${ }^{383}$ Milgrom, Leviticus $1-16,294$. For possible scenarios of this case, see Noordtzij, Numbers, 64; Hartley, Leviticus, 68-72.
} 
and unintentional, as well as expiable and inexpiable. In addition, isolating only the uses of חָָ from ch. 1-24 of the book of Leviticus and deducing the meaning for this term only from them is hermeneutically unsound.

With regard to the term contrast to expiable דֶָּ Gin rests on two erroneous arguments. First, the term is mentioned only 2 times in the Pentateuchal ritual law (Lev 16:16, 21). This term is never used to denote any $\sin$ in the book of Leviticus. Second, the serious

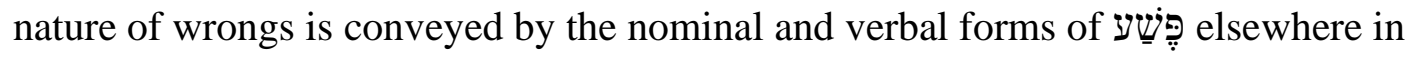
$\mathrm{OT}^{384}$

In regards to Gane's first point, it is important to note again that the Pentateuchal ritual law is limited to Leviticus in Gane's interpretation. However, since the use of שֶׁשׁׁע is quite limited in the Pentateuch, Gane's understanding of it would stand the test even if all Pentateuchal ritual law texts had been considered since outside of Lev 16:16, 21, is never used differently in the Pentateuch. All other uses are found in the narrative sections of Genesis, Exodus, and Numbers, and one legal text in Exod 22:9. Considering all these usages radically changes the understanding of $\underset{\nu}{285}{ }^{385}$

Regarding Gane's second point, it is significant to observe that the understanding of

\footnotetext{
${ }^{384}$ Gane, Cult and Character, 295-96.

${ }^{385}$ On the meaning of study.
} 
of the OT and not the Pentateuch. The verbal form of שֶׁ, out of which the idea of breaking with God was derived which points to the most severe sin in the OT, is never used in the Pentateuch. All the contexts where the nominal form of פֶּ is used in the Pentateuch were discussed above and they confirmed that פֶּ is not inexpiable sin, but to the contrary is expiable sin in the Pentateuch and in the rest of the OT. The latter claim was demonstrated by scholarly research above, as well. This hermeneutical unsoundness that can be detected in this point was already mentioned in the present study. Barr called it root fallacy, and it refers to the belief that in biblical Hebrew, there is a root meaning that is effective throughout all the variations of a given root, and as such, is taken as a part of the actual semantic value of any form of that root. ${ }^{386}$ Study of the applying the terminological/contextual/intertextual approach brought a totally different understanding of the term. That is, it covers intentional and unintentional sin which is both expiable and inexpiable.

The most ambiguous meaning of עָּ ivi found in Lev 16:21 where context does not provide a clue as to which of the 3 potential meanings or all three is intended. Scholars have suggested various proposals on the meaning of עָ in in these two texts. Milgrom

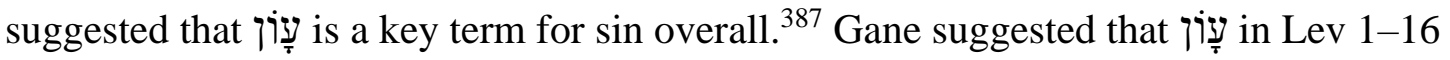
refers to culpability. ${ }^{388} \mathrm{He}$ stated that it can stand for "any part of the process of wrongful

\footnotetext{
${ }^{386}$ Barr, Semantics, 100.

${ }^{387}$ Milgrom, Leviticus 1-16, 25, 1043.

${ }^{388}$ Gane, Cult and Character, 294, 299-300.
} 
act-blame-punishment, whether the act is intentional or not." ${ }^{389}$ However, he suggested that its meaning is restricted to culpability in the sense of consequential liability to punishment which the offender must bear, the understanding formulated by Schwartz. ${ }^{390}$ However, based on the evidence presented in the current study, עָּ does not refer to any specific sin in terms of being intentional/unintentional or expiable/inexpiable, but rather,

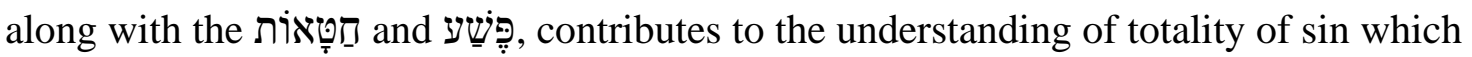
was intended to be conveyed in this text.

As was suggested above, a fair interpretation of Lev 16:21 would imply that

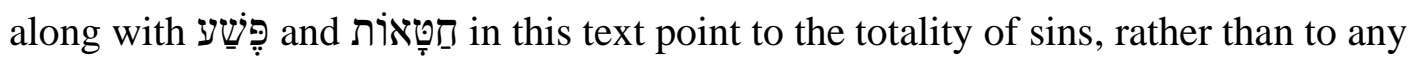
specific $\sin$.

Some theologians have suggested that even though each of these three terms has particular meaning, not much attention should be placed on the differences in their meaning since they were used as synonyms. ${ }^{391}$

The research of these terms presented above demonstrates that the following quotation by Rolf Knierim summarizes a fair approach when it comes to the precise meaning of these terms: "Even though this triad is formulaic and systematically expresses the mass of all possible errors, one may not simply view the three terms in the triad as synonyms. Each disqualifies 'sin' in its own way. Nevertheless, where they are used

\footnotetext{
${ }^{389}$ Gane, Cult and Character, 294.

${ }^{390}$ Gane, Cult and Character, 298.

${ }^{391}$ Georg Fohrer, History of Israelite Religion (Nashville: Abingdon Press, 1972), 193-94.
} 
together as a formula, they are intended to represent all other terms for ' $\sin . ", 392$

Crüsemann suggested that the repetition of "all" (all) in this chapter (vv. 16, 17, 21, 30,

34 ) in connection with a variety of important terms for sin emphasizes the

comprehensiveness of the atonement and the elimination of the nation's sins. ${ }^{393}$ Other

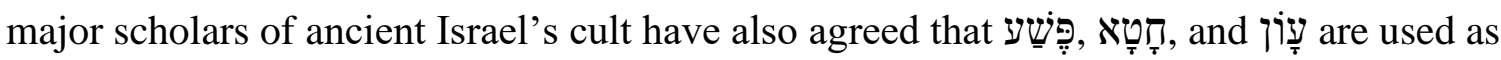

synonyms. ${ }^{394}$ This triad was frequently used in the OT to refer to the totality or

completeness of sin (Exod 34:7; Lev 16:21; Job 13:23; Ps 32:5; Isa 59:12; Ezek 21:24

[29]; Dan 9:24). ${ }^{395}$

\section{William H. Shea's Proposal}

William Shea proposed a viable proposal for the understanding of this verse. In

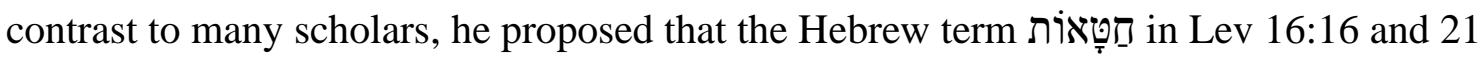
does not refer to the sins, but rather to the sin offerings of the sons of Israel. ${ }^{396} \mathrm{His}$ proposal is semantically possible since the term is found in both singular (Lev. 4:3, 8, 14, 20-21, 23-26, 28-29, 32-35; 5:6-13; 6:17, 25, 30; 7:7, 37; 8:2, 14; 9:2-3, 7-8, 10, 15, $22 ; 10: 16-17,19 ; 12: 6,8 ; 14: 13,19,22,31 ; 15: 15,30 ; 16: 3,5-6,9,11,15,25,27$;

19:22; 23:19) and plural (Lev. 16:16, 21, 30, 34; 26:18, 21, 24, 28) forms to refer to both

\footnotetext{
${ }^{392}$ Knierim, "אטח," TLOT 1:410.

${ }^{393}$ Gane, Cult and Character, 39; Crüsemann, The Torah, 314.

${ }^{394}$ Schwartz, "The Bearing of Sin,” 8n16.

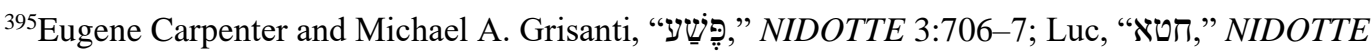

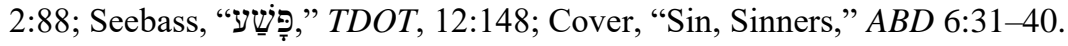

${ }^{396}$ William H. Shea, "Literary Form and Theological Function in Leviticus," in The Seventy Weeks, Leviticus, and the Nature of Prophecy, ed. Frank B. Holbrook, Daniel \& Revelation Committee Series 3 (Hagerstown, MD: Review and Herald, 1986), 159.
} 
sins and sin offerings. Shea's syntactical and contextual approach to study which meaning is intended in context is hermeneutically very sound. However, limiting the data of research to Lev 16 in the first part of his method, which he called "a direct lexical approach," disturbs his hermeneutical soundness and is unnecessary. The plural is

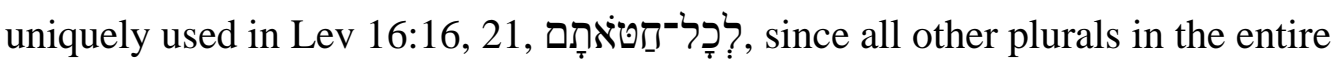

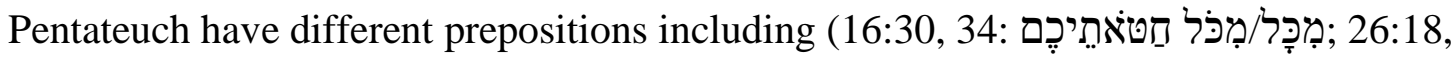

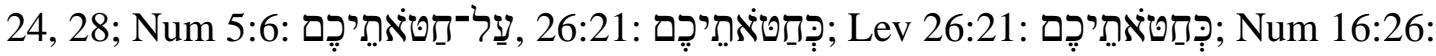

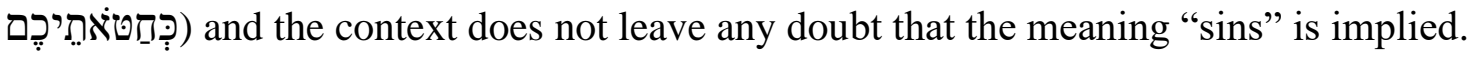
However, one could ask whether the number of the noun affects its semantic choice in a given context. Thus, while this argument is a good starting point, a more elaborate approach is needed to establish such a claim.

The second part of Shea's method is more complex since he examined the

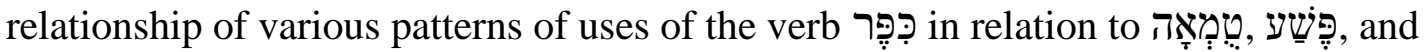

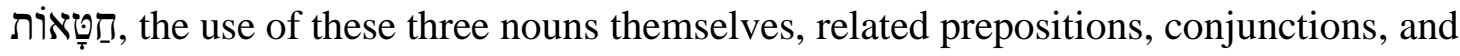
adjectives. I will examine Shea's most relevant arguments for the present study.

\section{Related Nouns}

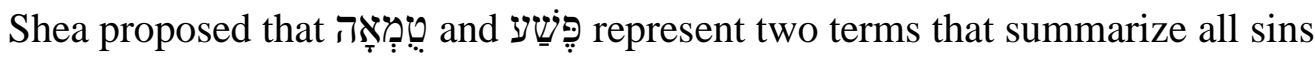
discussed in Lev 1-15. The former covers sin in Lev 1-7, while the latter represents uncleanness in Lev 11-15. This inference makes תח redundant. It would just provide another shade of meaning for the term

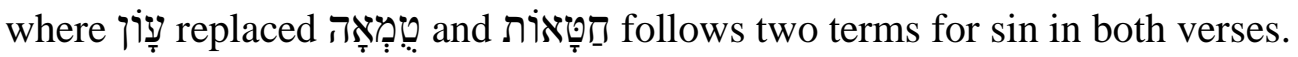


Redundancy is even more intense since all these terms would refer to moral sins. ${ }^{397}$

Shea's recognition, that in ion redundant if taken to mean sin like the previous two terms in vv. 16 and 21, is logical. A semantic overlap between demonstrated in the present study, ${ }^{398}$ thus it would not be surprising if the author intentionally used semantic overlaps of the terms. In terms of intent, all refer to intentional and unintentional sins, and in terms of expiability, the former two

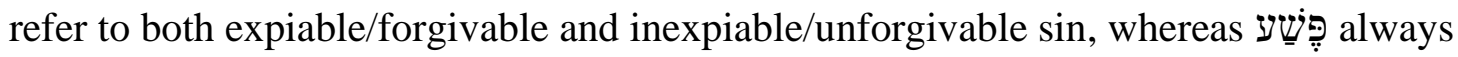
refers to expiable sin. Thus, on the one hand, all of them refer to expiable/forgivable sins, while on the other hand, all of them designate inexpiable/unforgivable sins.

\section{Related Prepositions}

Shea's argument based on the use of prepositions ?ִ כל כל when they modify the noun that is modified by the preposition ? 4 times in vv. 3, 5, 16, 21 and 2 times by the prepositions מִ̣ in 16:30, 34. Based on these uses, he identified the pattern that Tָטָ refers

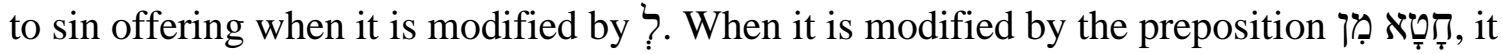
signifies $\sin .{ }^{399}$ With the delimitations to Lev 16 , this argument is without weaknesses and it remains without weaknesses when one examines these two constructions in all of Leviticus.

\footnotetext{
${ }^{397}$ Shea, "Literary Form," 160-61.

${ }^{398}$ See pages $187-250$ of the present study.

${ }^{399}$ Shea, "Literary Form," 162.
} 
That is, Leviticus (vv. 4:3, 14, 20, 32, 33; 5:6, 7, 8, 11; 7:37; 9:2, 3; 12:6, 8; 23:19). The meaning of sin is never intended by this grammatical construction. When דָָ is modified by the preposition מִ̣, it refers to sin in 4 other occurrences $(4: 26 ; 5: 6,10 ; 19: 22)$. In another 4 occurrences, מִ̣ never modifies the sin offering directly. In 3/4 occurrences, it modifies the noun "blood" that is in a construct relationship with "sin offering" (4:25, 34: 5:9). In one instance in 9:10, it modifies "sin offering" directly, but that one occurrence is actually highly questionable since the author of Leviticus did not have any other choice but to use מ̣ן to modify "sin offering" as a secondary, indirect object. The clause reads

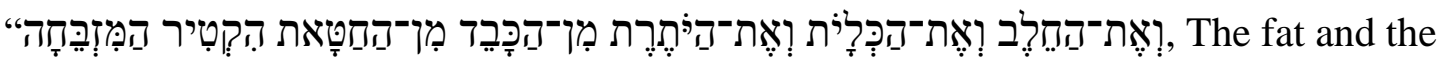
kidneys and the lobe of the liver of the sin offering, he then offered up in smoke on the altar."

When all the other five patterns of uses of חָטָ are taken into consideration in Leviticus, the statistics still greatly favor Shea's arguments, but some grammatical constructions should be acknowledged. Thus, when דָטָ is accompanied by the direct object marker, it refers to the sin offering in $21 / 21$ occurrences $(4: 8,29 ; 8: 2,14 ; 9: 7,8$, $15 ; 10: 16,17,19 ; 14: 13,19,31 ; 15: 15,30 ’ 16: 6,11 \times 2,15,25,27)$. This grammatical construct never refers to sin. When sin offering in 3/4 occurrences $(6: 10$ [6:17]; $7: 7 ; 14: 13)$, while in 1/4 (26:21) occurrences, it signifies sin. When חָָָ is modified by a definite article, it refers to the sin offering in 3/4 occurrences $(4: 21 ; 6: 18$ [25]; 9:22) and to sin in 1/4 (4:14) instances. When דָטָ stands without any modifiers, it refers to sin offering in $12 / 14$ occurrences, while in 2/14 
occurrences, it refers to sin. In addition, out of 86 nominal uses in Leviticus, חָָָ refers to sin offering 61 times, which leaves 25 times for the meaning of sin. This statistic still supports Shea's argument. These 4 additional patterns of use greatly favor Shea's suggestion.

Statistics of the 5th pattern does not favor Shea's proposal, since when associated with the preposition iַ it refers to sin offering 4/13 times $(4: 33,29,33 ; 8: 14)$, while in $9 / 13$ times $(4: 3,28,35 ; 5: 6,13 ; 19: 22 ; 26: 18 ; 24,28)$, it designates sin. However, עַ never modifies in Lev 16, thus not greatly affecting his proposal.

\section{Related Conjunction}

It is most likely that this argument and the following are Shea's strongest arguments for his proposal. This argument is based on the use of the conjunction ?. That

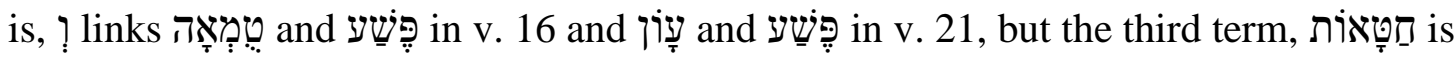
preceded by the preposition $\zeta$ a and the adjective פּל term in the row, to be connected with the previous two in order to form a triad or triplet, then it would be necessary for it to be preceded by ?, like the second term always is. ${ }^{400}$

\section{Related Adjective}

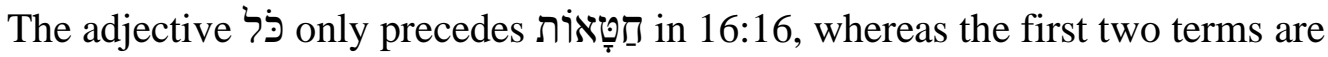
modified by the preposition מִ. Shea stated: "If the meaning of the latter word is 'sin offerings' rather than 'sins,' then that meaning could encompass very well all of that

\footnotetext{
${ }^{400}$ Shea, "Literary Form,” 163.
} 
which has been treated from the former two categories through their sacrifices. In this case the term would not be simply another category of evil." 401

The distinction between the first two and the third term is threefold: (1) the first two terms are modified by the preposition מִ̣, while

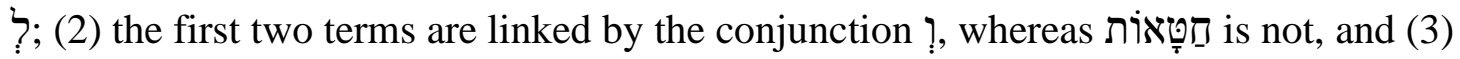

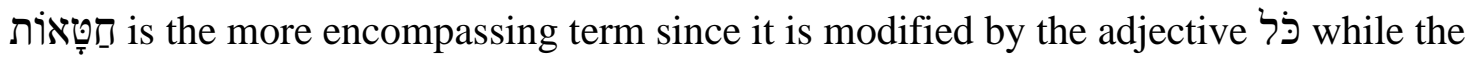

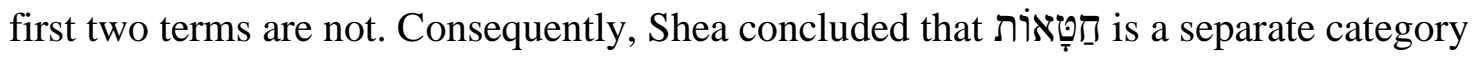
with a distinct or specific meaning than the former two. ${ }^{402}$

Shea proposed that a similar syntactical relationship is also found in v. 21 where

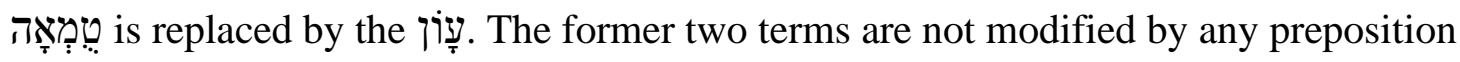
while חַטָָּאוֹ retains its ? preposition. The former two are modified by the direct object

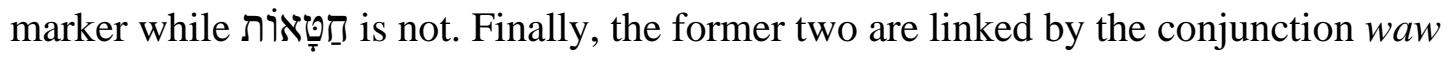

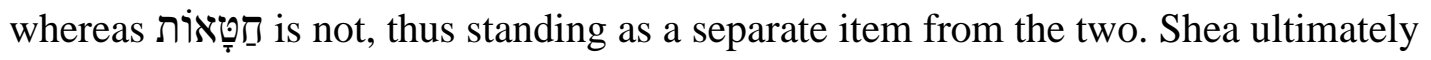
proposed: "Our conclusion from these considerations is that it is possible that our word could be translated as 'sin offerings' in Leviticus 16:16, 21 rather than 'sins.",403

The order of the arguments Shea used to support his proposal is followed by the growth of their probability and accuracy. The first argument based on the inference that פֶּ

\footnotetext{
${ }^{401}$ Shea, "Literary Form,” 163.

${ }^{402}$ Shea, "Literary Form," 163.

${ }^{403}$ Shea, "Literary Form," 164.
} 
two terms semantically overlap. The second one, based on the use of the prepositions ?

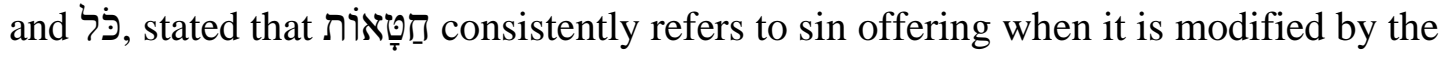
preposition ?? , and sin when it is modified by the preposition remains valid and solid even when tested within all of Leviticus, which makes Shea's second argument firm. The third argument, based on the use of the conjunction, is highly convincing. That is, the first two terms in both texts are linked with the conjunction ?, while the third term is modified by the preposition ? grammatically and conceptually separate it from the previous two. Building a triad of terms that would refer to the conceptually same phenomenon would imply the use of the conjunction ? as is the case with the second term. The fourth argument is the most

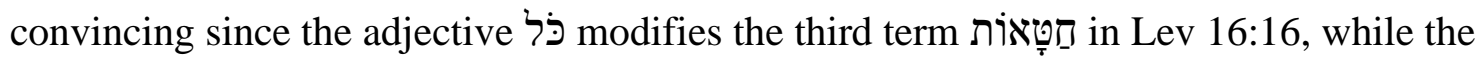
first two terms are modified by the preposition מִ̣. The first two terms, in this case, would refer to sin that was dealt with via all the sin offerings offered for them.

Thus, to summarize, there is a threefold distinction between these terms: (1) the

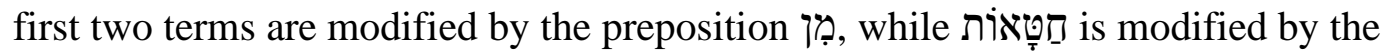
preposition ?, (2) the first two terms are linked by the waw conjunction, whereas

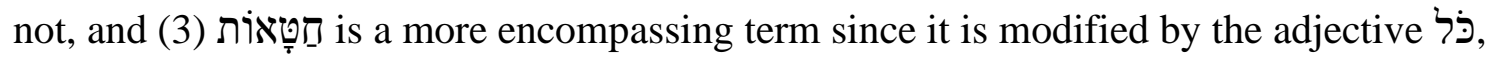
while the first two terms are not, which makes Shea's proposal take better account of the biblical context and meaning.

The syntax in 16:21 is little bit different, but it still greatly favors the grammatical

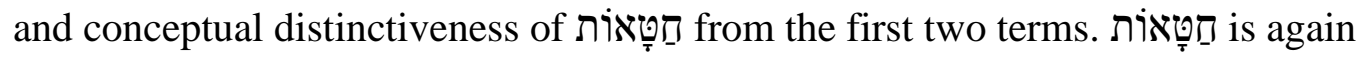


modified by a preposition ? not modified by any preposition, but rather, are accompanied by a direct object marker

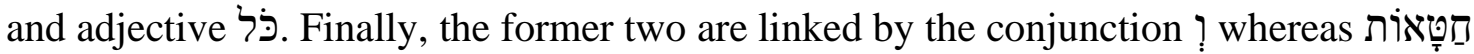
is not, thus standing as a separate item from the two.

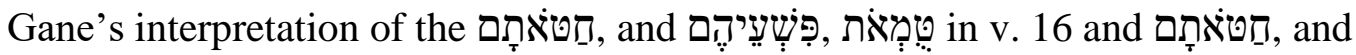

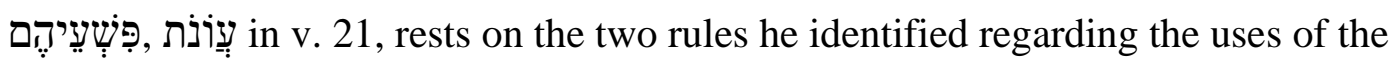
prepositional phrase לְכָל Moskala recognized that כלּל alone "is a very relative word" and establishing its precise meaning depends on the context. ${ }^{404}$ Adding the preposition ? to it makes it even more complicated.

Building on Milgrom's remark on the use of this phrase, ${ }^{405}$ Gane established his first rule regarding לְכָל לְכָל (1) is placed before the final word in the list and (2) the final item includes all of the previous terms in its semantic range, then it is a summarizing word. An example of this is Lev 11:42. ${ }^{406}$ In his second rule, Gane stated that the adjective לְכָ introduces a separate item or category when (1) it is placed before the final word in the list and (2) it presumably does not include, semantically, all the previous items. An example of this is Lev 11:46. Common for both rules is that the לָכָ is always placed before the last item in the list and in order to be a summarizing word, the last word has to include all the previous items in the list semantically or to be a separate

\footnotetext{
${ }^{404}$ Jiri Moskala, "The Laws of Clean and Unclean Animals of Leviticus 11: Their Nature, Theology, and Rationale (An Intertextual Study)" (PhD diss., Andrews University, 1998), 240.

${ }^{405}$ Milgrom, Leviticus 1-16, 668, 683. See also Kiuchi, Leviticus, 201.

${ }^{406}$ Gane, Cult and Character, 289.
} 
item or category, the last word does not semantically include all the previous terms in the list.

The outcome of these rules is that the הטּזאת in vv. 16 and 21 is a separate, rather than summarizing item in the list. In other words, it is just another term for sin like the previous two. Gane stated that the use of פ̇ל followed by the phrase לְכָ in v. 16 resembles the use of this construction in Lev 11:46 since

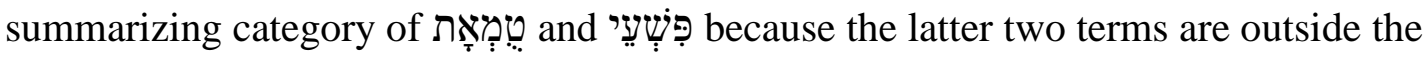
semantic range of the former clearly do not include משעים

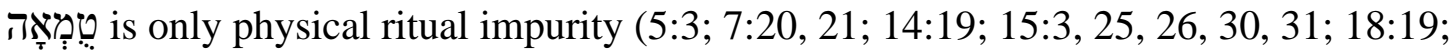

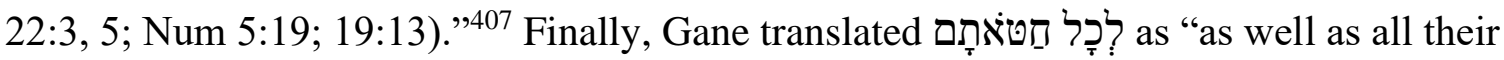
sins. ${ }^{\prime 408}$

Kiuchi, on the other hand, introduced another syntactical rule that takes the meaning of this phrase to be totally different than the one Gane suggested. He stated that לְכָל basically means "with respect to all," ${ }^{409}$ which, based on the present study, is a step in the right direction. The preposition ? has a function of specifying what precedes it, ${ }^{410}$

${ }^{407}$ Gane, Cult and Character, 289.

${ }^{408}$ Gane, Cult and Character, 289.

${ }^{409}$ Kiuchi, Purification Offering, 187n50. See also BDB, s.v. "ל”; Harry M. Orlinsky, ed. Notes on the New Translation of the Torah (Philadelphia: Jewish Publication Society of America, 1969), 30. 1976), 49.

${ }^{410}$ R. J. Williams, Hebrew Syntax: An Outline, 2nd ed. (Toronto: University of Toronto Press, 
while כּל conveys the totality of what follows it. Kiuchi suggested thus that לכָל a a a whole functions to specify what precedes it from a different viewpoint." ${ }^{411}$ A simple, yet consistent, rule can be established based on Kiuchi's definition of this prepositional phrase: when לְכָל is attached to the noun at the end of a summative list, whether accompanied by modifiers or not, it always specifies those preceding nouns in the list from a different perspective. Pentateuchal texts that support this rule include the following: Gen 9:10; Exod 14:28; 26:2; 27:3; 36:9; Lev 5:4; 11:42; 13:12; 22:5; Num $3: 25,26 ; 4: 31,32$; and Deut $22: 3$. This rule is foundational to the syntactical and grammatical analysis of Lev 16:16, 21 that follows below.

The present study also finds Gane's translation unjustifiable for the following reasons: First, the structure of Lev 11:42 differs from the one in Lev 16:16. The preposition ạp does not precede any terms in the list in the former, while it precedes the first two terms and is absent before the last term in the latter text. Thus, these two texts cannot be compared at the syntactical level in order to derive a valid syntactical rule. The present study agrees with Gane that in Lev 11:42, the phrase לִ ְָל is placed before the summarizing term, but the syntax of this verse is different than the one in Lev 16:16 and thus, not valid to make a general rule for uses of לְכָל. The exact syntactical/grammatical construction found in Lev 16:16 never replicates itself in the Pentateuch.

A study of the uses of כּל לְל followed by phrase, similar to the one in Lev 16:16, 21, points to the rule that does not favor Gane's conclusion. Namely, the uses of כi in the

\footnotetext{
${ }^{411}$ Kiuchi, Purification Offering, 187n50.
} 
Pentateuch followed by phrase לְכָ demonstrate that when לְכָל is placed before a summarizing term, it is never preceded by the conjunction ? (see Gen 9:10; Exod 35:24, 36:1; Lev. 11:42, 13:12; 22:5, Num 4:32, 5:9, 14:29, 18:15; Deut 3:13). On the other

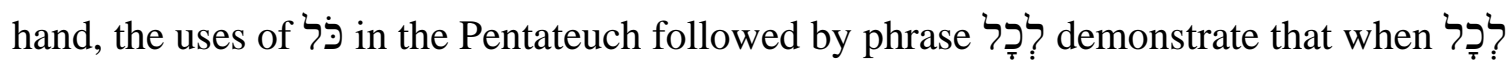
is placed before a separate term, it is always joined with the conjunction ? (see Gen 1:30; 2:20; 9:10; Exod 35:21; Lev. 11:46, 22: 18; Num 4:27, 18:9; Deut 19:15; 29:1[2], 34:1112). Since לְכָל in both Lev 16:16 and 21 is not joined with the conjunction ?,,it does not mark a separate item, but the term that somehow is related or summarizes both the previous terms.

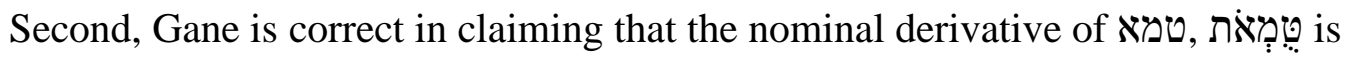

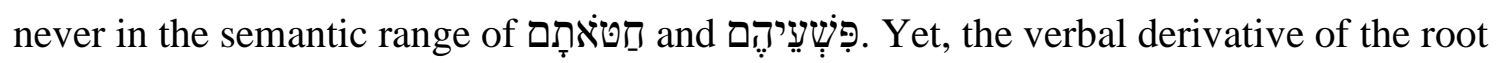
טמא frequently refers to moral impurity as the present study provided textual evidence for in subheading טָָנָא refers to moral defilement in Lev 18:20, 23, 24, 30, 31; 20:3; Num 5:13, 14, 20, 27, 28, 29, Deut 24:4. Textual proof that vמאה refers to moral impurity does not exist in the Pentateuch, but inasmuch as it originates from the root טמא that does refer to moral impurity, this eliminates the exclusively ritual nature of פְְִּמאת This is in spite of the fact that the text never defines it as moral in nature. However, the understanding that claim nor need טְּאתָם related to sin offering was offered for certain ritual impurity (Lev 12-15). 
Third, Gane's second rule states that the last word in the list that follows לִכָל does not semantically include all the previous terms. Gane found that the use of לְכָ in Lev 16:16 resembles the one in Lev 11:46. The present study agrees with Gane that in the latter text, לְכָ has the role of marking a separate item. However, in Lev 11:46, לְכָל is preceded by the conjunction ?, while it is not in Lev 16:16 and 21. The presence or the רִכְל conveys adding another item to the list of items as it is in Lev 11:46, while its absence points to the fact that the word following it is not just another item in the list, but rather, is related to all the items previously listed from a different viewpoint (as noted in the rule by Kiuchi).

An additional argument for the interpretation of Lev 16:16, 21, where the first two terms are considered to express totality and completeness of the concept of sin, can be confirmed by the fact that these terms semantically overlap. In addition, distinct term always keeps its final position, thus pointing to the fact that it is separate in both texts.

Shea's proposal is supported by more solid arguments and rests on the more detailed methodology. Therefore, this study accepts Shea's proposal as a more probable

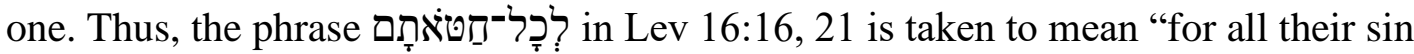
offerings," instead of a variety of other suggestions such as "as well as all their sins,"412

${ }^{412}$ Gane, Cult and Character, 290. 
and "including all their sins" 413 and others.

This translation also correlates with the trajectory of sins presented in the present study. Shea expressed it in the following way:

Such a translation strongly indicates that the Day of Atonement sin offering ritual functioned to cleanse the sanctuary from only the confessed sins of the penitent Israelites. That is, it functioned to remove the sins that had been confessed and transferred to it by means of the sin offerings that had been offered previously during the year. ${ }^{414}$

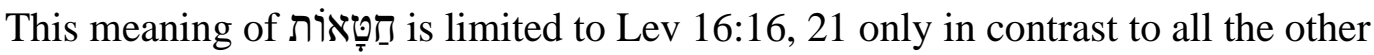
places where it is a part of the triad equal to all other terms that, as a grammatical and syntactical composition, designates totality or comprehensiveness of sin. Besides the arguments presented in the present study, חָטָטאוֹת in Lev 16:16, 21 separates itself syntactically, grammatically, and contextually from all other uses in the texts where it is an equal part of the triad. The terms are separate grammatical and syntactical units in all other texts (Exod 34:7; Lev 16:21; Job 13:23; Ps 32:5; Isa 59:12; Ezek 21:24 [29]; and

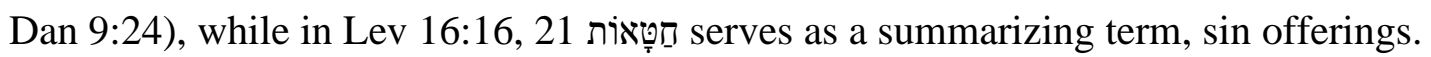

\footnotetext{
${ }^{413}$ Milgrom, Leviticus 1-16, 689.

${ }^{414}$ Shea, "Literary Form," 165.
} 


\section{CHAPTER 4}

\section{THE MEANING OF כִֶֶּּ IN PENTATEUCH}

Having established the concept of sin, the present study transitions to its second section, which also consists of two parts. I first present major scholarly suggestions on the concept of atonement and then, based on a thorough analysis of this concept which primarily consists of the examination of the uses of the Hebrew verb Pentateuch, evaluate them in order to suggest a new proposal on the understanding of atonement in the Pentateuch.

\section{The Meaning of פְִּ : Review of Scholarly Research}

The Hebrew root atonement ${ }^{1}$ and it has generated a considerable amount of research ${ }^{2}$ regarding its etymology. However, there is no scholarly consensus regarding its origin. Philologists

${ }^{1}$ Sidney O. Hills, "A Semantic and Conceptual Study of the Root KPR in the Hebrew Old Testament with Special Reference to the Accadian Kuppuru” (PhD diss., Johns Hopkins University, 1954), 1.

2Janowski, Sühne als Heilsgeschehen, 1-26; F. Maass, "כפר," TLOT 2:624-35; Baruch A. Levine, In the Presence of the Lord: A Study of Cult and Some Cultic Terms in Ancient Israel, SJLA 5 (Leiden: Brill, 1974), 56-114; Milgrom, "Atonement in the OT," 78-83; Kiuchi, Purification Offering, 94; Wright, The Disposal of Impurity, 291-99; Schwartz, “The Prohibitions," 34-66, (p. 51n3); Richard E. Averbeck, "כפר," NIDOTTE 2:681-701; Gane, Cult and Character, 106-43; Sklar, Sin, Impurity, Sacrifice, Atonement, 1-9. The references for the previous research can be found in Maass, "כפר,, TLOT 2:624-25; Sklar, Sin, Impurity, Sacrifice, Atonement, 1; Levine, In the Presence of the Lord, 123-27. 
have established two alternatives, both well supported from Semitic cognates, which are well attested to in the scholarly dialogue. ${ }^{3}$ The first proposal is that the Hebrew related to the Arabic kaffara, and the other relates it to the Akkadian kuppuru. In its base (I) stem, kafara means "cover, conceal, deny, disbelieve, be ungrateful," while in the intensive (II) stem (kaffara) it means “conceal, annul, expiate, do penance." The Akkadian kapāru refers to "wipe off, smear on" in the base (B) stem and "wipe off, clean, rub, ritually purify" in the intensive (D) stem, kuppuru. ${ }^{4}$

Milgrom was correct in his assertion that the basic idea of both etymologies is "to rub." In the case of Arabic, it is "to rub on," that is, "to cover" or "to rub off," that is, "to wipe" in Akkadian. ${ }^{5}$ Thus, Milgrom established that from the point of etymology:

"Because a substance may either be "rubbed on" or "rubbed off," the derived meanings, “cover" and "wipe," may be complementary and not contradictory." ${ }^{6}$ Richard E. Averbeck also stated that these two along with the meaning of "to ransom," are not mutually exclusive. ${ }^{7}$ The dispute of whether kaffara or kuppuru is to be taken as a starting point to determine the foundational meaning of the Hebrew lengthy debates. Some scholars tried to determine its meaning by examining the usage and internal OT evidence and concluded that the etymology is not decisive. ${ }^{8}$

\footnotetext{
${ }^{3}$ Milgrom, Leviticus 1-16, 1080.

${ }^{4}$ Milgrom, Leviticus 1-16, 1080; Averbeck, “כפרפ," NIDOTTE 2:681-82.

${ }^{5}$ Milgrom, Leviticus 1-16, 1080.

${ }^{6}$ Milgrom, Leviticus 1-16, 1080.

7'Averbeck, "כפר," NIDOTTE 2:683-84.

8Averbeck, “כפר," NIDOTTE 2:682.
} 
The difficulty of relating the Hebrew the polysemous nature of the root $k p r$ in all Semitic languages. ${ }^{9}$ In addition, insights from comparative studies are also confusing since, as Milgrom stated, both cognates contain the same idea, "to rub." The Arabic kafara, I stem, does not correspond to the Hebrew רֶֶ, piel, and the Akkadian kuppuru, D stem. The Akkadian D stem means "to wipe" and always in the sense of "to wipe off, wipe away," not "to wipe on or smear on.", Furthermore, making the etymology even more complicated is the fact that in addition to the meaning "to cover," the Arabic kafara has the same meaning "to expiate" that corresponds to the Akkadian D stem, "to remove, to erase." ${ }^{11}$ Finally, the Akkadian D stem is repeatedly used in medical and ritual texts. It seems that the Akkadian cognate corresponds more closely to the Hebrew contexts. ${ }^{12}$ However, many still heavily rely on the comparative and etymological evidence. $^{13}$

The question that also impacted the debate on the atonement communicated by this verb. The scholars of the 19th and the beginning of the 20th centuries argued that

\footnotetext{
${ }^{9}$ Benno Landsberger, The Date Palm and Its By-Products According to the Cuneiform Sources, AfO 17 (Graz, Austria: Weidner, 1967), 30-34; Paul V. Mankowski, Akkadian Loanwords in Biblical Hebrew (Winona Lake, IN: Eisenbrauns, 2000), 71.

${ }^{10}$ Averbeck, “כפר," NIDOTTE 2:684.

${ }^{11}$ Levine, In the Presence of the Lord, 126; An Arabic-English Lexicon: Derived from the Best and the Most Copious Eastern Sources, s.v. "كَبَّرَ"

${ }^{12}$ Averbeck, "כפר," NIDOTTE 2:684.

${ }^{13}$ Averbeck, “כפר," NIDOTTE 2:682.
} 
refers to the covering over the sin or the sinner. ${ }^{14}$ Some recognized the connection

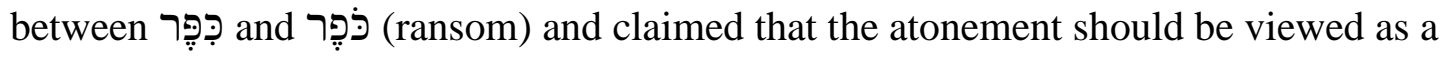
payment of the ransom or appeasement that results from it. ${ }^{15}$ Some also viewed the as a symbolic dedication of the worshiper's life to the holy. ${ }^{16}$ Regardless of these differences in the understanding of atonement, scholars agreed on the fact that indicates the repairing of the relationship between God and humans that was interrupted by $\sin .{ }^{17}$ Sklar's following statement explains this claim:

That this is plausible understanding of it is used in sin contexts to describe taking care of the negative effects of sin in order to bring about reconciliation between the sinner and the Lord. For this reason, it is often said that a person is forgiven after atonement has been effected of their behalf: "And the priest shall make atonement for [the leader] in regard to his sin, and he shall be forgiven" (Lev 4:26b). ${ }^{18}$

However, this understanding of atonement becomes problematic because used in contexts where sin was never committed, indicating that no forgiveness is needed

${ }^{14}$ Yitzhaq Feder, "On kuppuru, kippēr and Etymological Sins that Cannot be Wiped Away," VT 60 (2010): 537. The notable proponent of this view is Johann Jakob Stamm, Erlösen und Vergeben im Alten Testament (Bern: A. Francke, 1940), 61-66; Kurtz, Offerings, 67-71; Ellinger, Leviticus, 71. For a more complete list, see Janowski, Sühne als Heilsgeschehen, 20-22, 99-100; Schwartz, "The Prohibitions," $54 \mathrm{n} 2$.

${ }^{15}$ Johannes Herrmann, Die Idee der Sühne im Alten Testament: Eine Untersuchung über Gebrauch und Bedeutung des Wortes kipper (Leipzig: J. C. Hinrichs, 1905), 99, 101-2; Herbert Chanan Brichto, "On Slaughter and Sacrifice, Blood and Atonement," HUCA 47 (1976): 19-55, especially 26-27, 34-35; Adrian Schenker, "kōper et expiation," Bib 63.1 (1982): 32-46. For a more complete list see Sklar, Sin, Impurity, Sacrifice, Atonement, 46nn8-13, especially.

${ }^{16}$ Janowski, Sühne als Heilsgeschehen, 185-276; Hartmut Gese, “The Atonement,” in Essays on Biblical Theology (Minneapolis: Augsburg, 1981), 93-116.

${ }^{17}$ Hills, "A Semantic and Conceptual Study,” 287; Frank H. Gorman, Divine Presence and Community: A Commentary on the Book of Leviticus, ITC (Grand Rapids, MI: Eerdmans, 1997), 16; Gane, Cult and Character, 106; Sklar, Sin, Impurity, Sacrifice, Atonement, 2.

${ }^{18}$ Sklar, Sin, Impurity, Sacrifice, Atonement, 2-3. 
in contexts like these, but rather, purification. Some such cases are the birth of a child where a new mother receives רִִּ where "sanctuary" is the indirect or direct object of this verb (Lev 16:16, 20, respectively). ${ }^{19}$

As a result of the problems caused by translating some contexts, some scholars, relying on the Akkadian kapāru, have suggested that should be translated as "to purify, purge, effect purgation." 20

Two studies that began to turn the attention from the Arabic kaffara to Akkadian kuppuru are G. B. Gray's Sacrifice in the Old Testament: Its Theory and Practice ${ }^{21}$ and S. V. Driver's articles in the Journal of Theological Studies. ${ }^{22}$ There are four principal

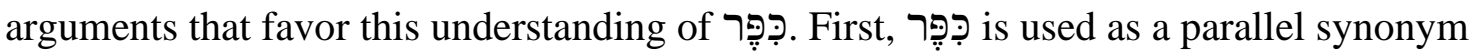
in biblical poetry with māḥ̂a "to wipe" (Jer 18:23b) and hēsîr "to remove" (Isa 27:9), suggesting that it refers "to purge." ${ }^{, 3}$ Second, Priestly texts often use words for

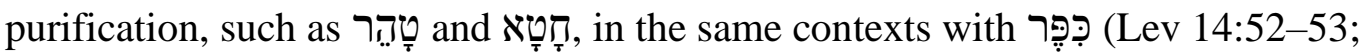
16:30...). ${ }^{24}$ Third, this understanding of

\footnotetext{
${ }^{19}$ Jay Sklar, "Sin and Impurity: Atoned or Purified? Yes!," in Perspectives on Purity and Purification in the Bible, eds. Baruch J. Schwartz, et al., LHB/OTS 474 (New York: T\&T Clark, 2008), 22.

${ }^{20}$ Feder, "On kuppuru, kippēr and Etymological Sins," 537.

${ }^{21}$ George Buchanan Gray, Sacrifice in the Old Testament: Its Theory and Practice (Oxford: Clarendon Press, 1925), 67-76.

${ }^{22}$ Godfrey R. Driver, "Studies in the Vocabulary of the Old Testament V," JTS 34 (1933): 34-38; Godfrey R. Driver, "Studies in the Vocabulary of the Old Testament II," JTS 32 (1931): 255n20.

${ }^{23}$ Milgrom, Leviticus 1-16, 1080; Averbeck, “כפר,," NIDOTTE 2:687.

${ }^{24}$ Milgrom, Leviticus 1-16, 1080; Averbeck, "כפר,, NIDOTTE 2:687.
} 
committed, but emphasis is on the ritual purification. ${ }^{25}$ Fourth, the Akkadian kapāru, in the D stem is not just similar to

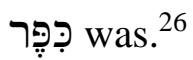

The proponents of this understanding of פִ̣ do not claim that it should always be translated as "to purify," since, as with kaffara, there are contexts where this understanding is not functional. Thus, they kept the translation "to expiate/atone" in some contexts and "to purify" in others. However, the decision of which understanding to apply to a given text is not an easy task. The works of certain notable scholars in the area of Ancient Israel cult have proved this to be the case. ${ }^{27}$

\section{כָ: B: Baruch A. Levine}

In attempting to separate these two understandings of רֶֶֶ, Baruch A. Levine

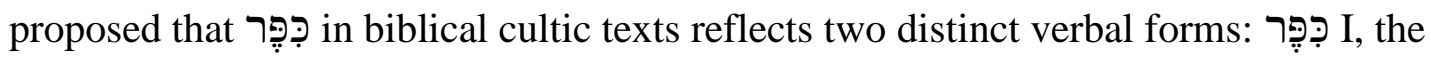
primary piel form derived from the Akkadian kuppuru, and denominative from the nominal כְֶּּ (ransom, expiation gift). ${ }^{28}$ Levine held that means "to purify" 29 when it is followed by a direct object or "to make expiation" when it

\footnotetext{
${ }^{25}$ Sklar, Sin, Impurity, Sacrifice, Atonement, 4.

${ }^{26}$ Sklar, Sin, Impurity, Sacrifice, Atonement, 4.

${ }^{27}$ Sklar, Sin, Impurity, Sacrifice, Atonement, 4.

${ }^{28}$ Levine, In the Presence of the Lord, 67.

${ }^{29}$ Levine, In the Presence of the Lord, 60.
} 


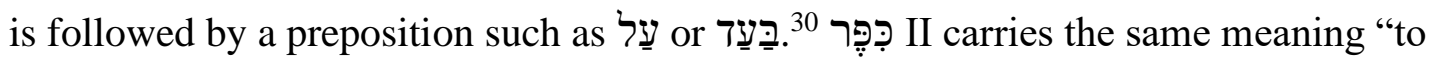
expiate," but the additional element that differentiates the "to make expiation" meaning of I with the prepositions and כִּפְָּ II is the fact that primarily, as with as Levin understood it, possesses a functional or technical sense and means "to perform

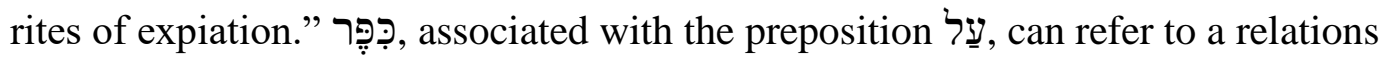
process and means "to perform rites of expiation with respect to" places, persons, and so on. It points to the fact that the indirect object, marked by the preposition עַ is a beneficiary of the rite's effects, and no physical contact is implied. An example of this sense is Lev 16:33: "and make atonement for the holy sanctuary, and he shall make

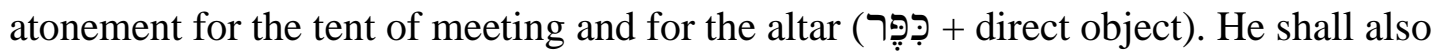
make atonement for the priests and for all the people of the assembly (עַ + + + sanctuary compartments all received physical action resulting in their purification, while no physical action was directly performed over the Israelites. They were just beneficiaries of the expiation..$^{32}$

עִ עַל can also refer to a spatial process and means "to perform rites of expiation in proximity to or upon" sacrificial animal, places, persons, and so on. This process implies physical contact or, at least, proximity. In Levine's understanding, the

\footnotetext{
${ }^{30}$ Levine, In the Presence of the Lord, 64-65.

${ }^{31}$ Levine, In the Presence of the Lord, 67.

${ }^{32}$ Levine, In the Presence of the Lord, 64-65.
} 
expiation rites do not automatically produce purification, but rather, God himself is the one who accomplishes it. ${ }^{33}$ The $\mathrm{I}$ in cultic texts refers to the separation or riddance of impurity from individuals. ${ }^{34}$ In regards to the kopper, Levine saw it as (1) the payment made for the purpose of "erasing or "wiping away" guilt incurred by the offense," 35 and (2) “a substitute for a life (Exod 30:12, Isa 43:3), one's own or another's (Prov 21:18)."36 In cultic texts, it becomes an expiatory payment. ${ }^{37}$ Finally, kopper refers to substitution in light of Lev 17:11. ${ }^{38}$

Averbeck seems to be correct when he observed, "Do we really have the same vb. reflecting two different original derivations that have fallen together? At least historically, one of them must have been antecedent to the other." ${ }^{39}$ In addition, this

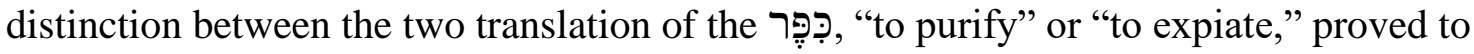
be untenable in Levine's own interpretation of certain Priestly texts. Levine implied that the expiation in Lev 4:20 has the meaning of cleansing, (כִֶֶֶֶּ I) rather than ransom II). ${ }^{40}$ Assuming that the כִֶֶּ: I meaning is operating in this text can be maintained even though there is no major impurity involved in this legislation. Levine applied

${ }^{33}$ Levine, In the Presence of the Lord, 65.

${ }^{34}$ Levine, In the Presence of the Lord, 63.

${ }^{35}$ Levine, In the Presence of the Lord, 61.

${ }^{36}$ Levine, In the Presence of the Lord, 62.

${ }^{37}$ Levine, In the Presence of the Lord, 62.

${ }^{38}$ Levine, In the Presence of the Lord, 69.

${ }^{39}$ Averbeck, “כפר," NIDOTTE 2:688.

${ }^{40}$ Levine, Leviticus, 23. 
because he understood sinfulness as a form of impurity ${ }^{41}$ and thus, his distinction still stands the test even though the context of Lev 4 is inadvertent sin. The following statement demonstrates this:

The Akkadian kuppuru, which corresponds to the Hebrew רֶֶ, means "to wipe off, burnish, cleanse." In cultic terms, this means that expiation is conceived as cleansing, as wiping away impurity, contamination, and, by extension, sinfulness itself. Levitical texts use the verb כִֶֶּ to express the concept that through expiation, one is "wiped clean" of impurities that adhere or cling to a person, infect him, we might say. ${ }^{42}$

However, the element of an inadvertent sin found in the context of Lev 4 strongly suggests that the expiation should be understood as ransom, rather than cleansing. ${ }^{43}$

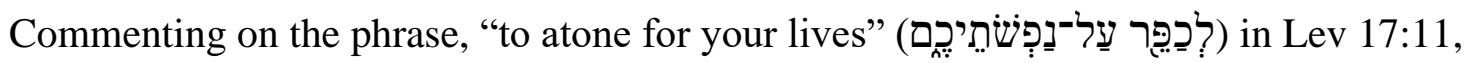
Levine stated that expiation in this text refers to atonement based on the כฺָּ as the following quotation shows: "Literally, this formula means "to serve as kofer (ransom) for your lives." God accepts the blood of the sacrifices in lieu of human blood." ${ }^{\text {44 }}$ This form of atonement is carried by Levine's כִכְֶָ II and is allowed only in the case of inadvertence. ${ }^{45}$ Lev 4 exactly fits this context since the sin involved is the one of inadvertence. It seems that one or the other understanding needs to be eliminated or perhaps both are operative in this text.

\footnotetext{
${ }^{41}$ Levine, Leviticus, 105.

${ }^{42}$ Levine, Leviticus, 23.

${ }^{43}$ Sklar, Sin, Impurity, Sacrifice, Atonement, 5.

${ }^{44}$ Levine, Leviticus, 115.

${ }^{45}$ Levine, Leviticus, 115.
} 


\section{כִּ:ְ: Jacob Milgrom}

Milgrom delineated four meanings of the verb is found. ${ }^{46}$ In the first context, כְִֶּ is associated with the sin offering, which in Milgrom's atonement theory cleanses the sanctuary rather than a worshiper, and it is to be translated exclusively as "to effect purgation."47

In the second group of texts, רְִֶּ bears a meaning of "to rub on" However, Milgrom claimed that this meaning for cultic texts since the only two examples of this use, paschal lamb and scale-diseased person, come from the texts where a sin offering was not used (Exod 12:27; Lev 14:18, $20,29,31) .{ }^{50}$ The only potential proof text of this use is Num $16: 46-47,{ }^{51}$ but this understanding of

In the third group of texts that deal with averting God's wrath, כִֶֶּ is based on the kōper principle (Exod 30:12-16). This meaning includes the notion of substitution; the guilty party is substituted by the innocent party or their ransom. ${ }^{52}$

In the fourth context, כִּ has a more abstract or figurative notion of "atone" or

\footnotetext{
${ }^{46}$ Milgrom, Leviticus 1-16, 1079-84; Milgrom, "Atonement in the OT," 78-81.

${ }^{47}$ Milgrom, Leviticus 1-16, 1080-81.

${ }^{48}$ Milgrom, Leviticus 1-16, 1081-82.

${ }^{49}$ Milgrom, "Atonement in the OT," 80.

${ }^{50}$ Milgrom, Leviticus 1-16, 1081.

${ }^{51}$ Milgrom, “Atonement in the OT," 80.

${ }^{52}$ Milgrom, Leviticus 1-16, 1082. See Sklar for the clarification of Milgrom's quotation he used in his Sin, Impurity, Sacrifice, Atonement, 47n15.
} 
"expiate" (Lev 16:10, 21; 17:11). "The meaning here is that the offerer is cleansed from his impurities/sins and becomes reconciled, 'at one,' with God.” Milgrom further stated that "Such is also the kippēr role of all of the other sacrifices whose blood is not daubed on the altar's horns like the hatță 't." He stated that this meaning is also found in 'ôla (Lev 1), minhâa (Lev 2), millu' '̂̀m (Exod 29:33), and 'āšām (Lev 5:16, 18, 26) offerings. ${ }^{53}$

Regardless of Milgrom's more elaborate contextual work, he relied heavily on the comparative texts, and his interpretations of texts, like Levine's, also show tensions. That is, Num 35:31-33 states that no act of bloodshed, except the shedding of the murderer's own blood. Milgrom stated that the כִֶֶּ in this text refers to the ransom principle, ${ }^{54}$ which is in accordance with vv. 31-32, but the text clearly speaks about the pollution of the land through the shedding of blood (דָנָּף,

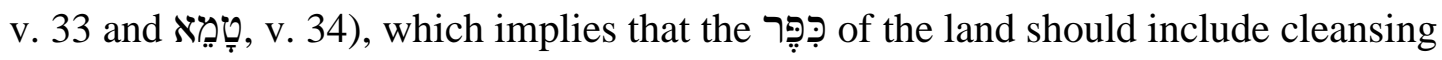
element as well. ${ }^{55}$ Milgrom emphasized moral defilement alone in this text. ${ }^{56}$

\section{רֶ: Jay Sklar}

Sklar proposed that this tension can be solved by understanding that כִּ includes both conceptions: purification and ransom. ${ }^{57} \mathrm{He}$ has suggested this by demonstrating that

\footnotetext{
${ }^{53}$ Milgrom, Leviticus 1-16, 1083.

${ }^{54}$ Milgrom, Leviticus $1-16,1082$.

${ }^{55}$ Sklar, Sin, Impurity, Sacrifice, Atonement, 6.

${ }^{56}$ Milgrom, “Atonement in the OT," 81.

${ }^{57}$ Sklar, Sin, Impurity, Sacrifice, Atonement, 187. Sklar, “Sin and Impurity,” 18.
} 
כִֶֶּ in the contexts of sin requires both elements, ransom and purification. Ransom delivers the guilty party, the sinner, from the punishment of his/her sin while purification is needed in this context to cleanse the sanctuary that was automatically defiled by the sinner's $\sin .{ }^{58} \mathrm{He}$ stated that purification is needed in the contexts of ritual impurity to purify the individuals from their impurity or consecrate them for a certain ministry, while ransom is required in cases of major ritual impurities since those individuals would defile the sanctuary or, in the context of consecration, need ransom on account of the "general impurity of the people relative to the holy."59

\section{כִֶֶּ: Roy Gane}

Gane's study on the כִֶֶּּ formulae confirmed F. Maass's claim that in the context of a sin offering, " "כִֶֶּּ always indicates the goal of activity rather than prescribing a specific physical activity." 60 Gane also noted that another point that separates Hebrew כִֶֶּ? and Akkadian kuppuru is the physical act by which the goal of the verb is accomplished. Generally, Akkadian kuppuru in ritual contexts includes physical wiping of the objects or person from evil which was removed which is rarely the case in biblical corpus. ${ }^{61}$ Gane proposed that

${ }^{58}$ Sklar, Sin, Impurity, Sacrifice, Atonement, 183-85.

${ }^{59}$ Sklar, Sin, Impurity, Sacrifice, Atonement, 185-86.

"כ0 Maass, "כפר," TLOT 2:626; Gane, Cult and Character, 192.

${ }^{61}$ Gane, Cult and Character, 192; Wright, The Disposal of Impurity, 291-92. This point is also affirmed in Yitzaq Feder's recent article where he proposed, besides this claim that lexically and syntactically Akkadian kuppuru and Hebrew established based on the 1) identification of common misconstruals of this evidence, and 2) comparison of 
indicating that evil has been removed from the offerer. This fact suggests that

includes a purgatory element in reference to the offerer. ${ }^{62}$ Gane moved the dialogue on the meaning of

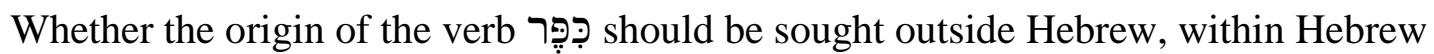
as a denominative of the noun כָָָּּר "ransom" or "compository payment" (see e.g., Exod 30:11-16) or both, it seems impossible to explain the semantic range of without allowing for the possibility that some meanings of the word are derived by extension or metaphorical usage, a factor that diminishes the relevance of etymology. ${ }^{63}$

S. R. Driver suggested that: "it does not greatly signify, in explaining it, whether we start from the idea of covering over or from that of wiping out: in either case, the idea which the metaphor is intended to convey is that of rendering null and inoperative." ${ }^{\prime 4}$

Having in mind the variety of usages of agree that there is no English word that encompasses all of them. ${ }^{65}$ Biblical usages of in the ritual texts and non-ritual texts indicate that some sort of obstacle has been removed from the offerer or relationship between the two parties. ${ }^{66}$ Gane affirmed Driver's claims that atonement in its entirety. The sequence of activities related to sin and reparation offerings

the kuppuru/kippēr relationship to the largely analogous case of Akkadian salāhu ("sprinkle") and Hebrew sālaḥ ("forgive"). Feder, "On kuppuru, kippēr and Etymological Sins," 537-38, 535.

${ }^{62}$ Gane, Cult and Character, 193.

${ }^{63}$ Gane, Cult and Character, 193-94.

${ }^{64}$ S. R. Driver, "Propitiation,” DBDL 4:128.

${ }^{65}$ Driver, "Propitiation,” DBDL 4:131; Hills, “A Semantic and Conceptual Study,”287-91; David P. Wright, "Day of Atonement," ABD 2:72-73; Gane, Cult and Character, 194.

${ }^{66}$ Gane, Cult and Character, 194-95. 
confirms this, since the priest performs God (Lev 4:20, 26, 31, 35; 5:16, 18, 26. Accordingly, כִֶּ must precede atonement and

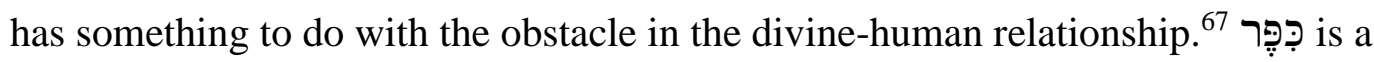
prerequisite for forgiveness ${ }^{68}$ However, God is the one who grants forgiveness, not the rite itself. ${ }^{69}$ Finally, Gane correctly stated that "the nature of the כפר in a given sacrifice depends, of course, upon the goal of that ritual. ${ }^{70}$

\section{רֶֶ: Yitzhaq Feder}

Feder elaborated even more on the point already noted by Gane that the Akkadian kuppuru conveys a concrete use versus purely abstract meaning of the Hebrew stated: "The Akkadian uses of kuppuru refer specifically to the physical act of purifying by means of wiping a person or object with a purificatory substance. Occasionally, this verb can be used to refer to the rite as a whole, but it is never used as a general term meaning 'to purify. ${ }^{, 71}$ The Hebrew function of a ritual, instead of to any specific physical act (e.g. Lev. 4:20, 26, 31, 35; 5:6, 10). In addition, the majority of cultic uses of רכּ a are related to sin offering contexts

\footnotetext{
${ }^{67}$ Gane, Cult and Character, 194.

${ }^{68}$ Levine, Leviticus, 23; Averbeck, "כפר,," NIDOTTE 2:683; Gane, Cult and Character, 50, 80, 82-83, 92, 100, 150, 154, 162, 194, 196, 204.

${ }^{69}$ Levine, In the Presence of the Lord, 65-66; Levine, Leviticus, 23-24; Gane, Cult and Character, $51-2$.

${ }^{70}$ Gane, Cult and Character, 65.

${ }^{71}$ Feder, “On kuppuru, kippēr and Etymological Sins," 538.
} 
where the central act is the daubing and sprinkling of blood. However, this ritual is fairly different from the rubbing rites described by the Akkadian term. That the Hebrew best understood as referring to the abstract effect of the ritual is reinforced by the vast

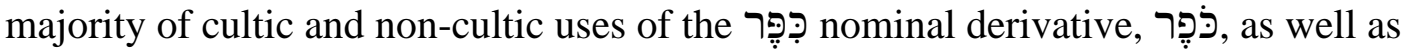
verbal uses. ${ }^{72}$ Feder concluded: "Thus, the non-cultic and cultic sources are in accord that kipperr refers to the abstract effects of a person's actions ('to appease,' 'to expiate'), not a concrete action such as that described by kuppuru ('to rub, wipe')." ${ }^{\prime 73} \mathrm{He}$ correctly stated that none of the

Feder also pointed to the fact that scholars never proposed that the meaning of the Hebrew סִָ should be informed by the Akkadian salāhu. This is peculiar since salāhu is frequently used in ritual texts to refer to aspersions with water or other liquids, usually for the purpose of purification and the notion that ritual cleansing provides compellingly enough ground for the proposal that this term is a "concrete etymological predecessor to the Heb. term's sense 'to forgive,' deriving perhaps from the notion that the person is thereby cleansed of guilt." ${ }^{p 5}$ It is exactly in these contexts that the Hebrew ợ appears (Lev 4:26, 31, 35; 5:10, 13, 16, 18, 26). This is never proposed since the Hebrew סָלָ in

\footnotetext{
72،"In non-cultic sources, one finds כפר derivatives in reference to placating anger (e.g. Gen 32:21; Exod 32:30; Num 25:13; Prov 16:14) or expiation of sin (e.g. 2 Sam 3:14; Isa 6:7). A distinct subgroup of the latter category pertains to the expiation of blood-guilt (e.g. Exod 21:30; Num 35:33; Deut 32:43). Since the two basic contexts which govern these various forms are 1) appeasement of anger, and 2) compensation for guilt, one can hardly ignore the semantic continuity which connects these forms with cultic kippeer." Feder, "On kuppuru, kippēr and Etymological Sins," 538.

${ }^{73}$ Feder, "On kuppuru, kippēr and Etymological Sins," 538.

${ }^{74}$ Feder, "On kuppuru, kippēr and Etymological Sins," 539.

${ }^{75}$ Feder, "On kuppuru, kippēr and Etymological Sins," 543.
} 
both cultic and non-cultic contexts always refer to the abstract sense "to forgive." Very

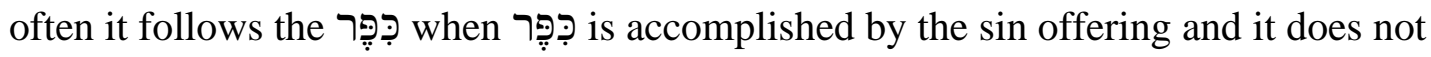
appear in contexts where ritual impurity is implied. ${ }^{76}$ Both, Akkadian kuppuru and salāhu

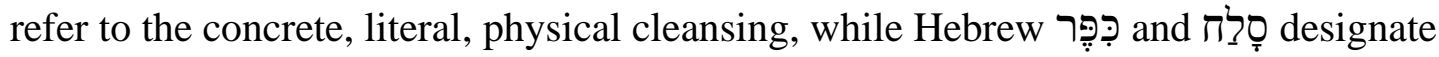
abstract effects of the terms whose etymological origin is not definite.

Feder himself proposed that "it seems clear that the only lexicographically prudent approach requires an analysis of kippēr primarily, and perhaps exclusively, on the basis of the inner-Biblical evidence." Feder's suggestion was anticipated three decades ago, since Gorman, in 1990, suggested the same method for a proper understanding of of meaning that must be determined in each case by its specific ritual context."77 This seems to become the scholarly consensus after countless attempts to relate various ANE cognates. The present study attempts to begin this process by analyzing contexts in the Pentateuch. Before proceeding to this task, the present study introduces a critical element in the

\section{Various States of the Creation}

In order to understand properly deals with human beings and inanimate objects, their states needs to be addressed. 543.

${ }^{76}$ Gane, Cult and Character, 123ff. Also, Feder, "On kuppuru, kippēr and Etymological Sins,"

${ }^{77}$ Gorman, The Ideology of Ritual, 173. 
Creation, including people, physical objects, and places, is defined by four states. They can be holy, profane, pure, and impure, and as such, these states can be viewed as two pairs of opposites: holy versus profane, and pure versus impure. Further, even though impure is opposite to holy, profane is its antonym. Finally, these states are often combined with each other, forming four possible pairs. An entity can be profane and pure, profane and impure, holy and pure, but not holy and impure. ${ }^{78}$ The following quotation explains the pairs of state:

"Profane and pure" is a neutral and basic state since it lacks dynamic elements of holiness and impurity. Most laws that talk about becoming holy or impure assume a person or object starts with this combined state. Being profane and impure is the concern of most of purity legislation. "Holy and pure" is the state of most persons, object, and places considered holy. Only the last, ostensibly contradictory pairing of holiness and impurity demands attention. While this is not an expected or desired state, it is legitimate, even demanded, in case of purgation offerings. ${ }^{79}$

It has to be emphasized that the holy and impure state appears in a very limited way. Namely, it is the priesthood, sanctuary, and sin offering that can encompass both of these mutually exclusive states.

\section{Duality of Human Nature}

The Creation account separates humanity from the rest of creation. The two Hebrew nouns that define human nature as God created them, צְִֶּם point to two basic aspects of human nature. Regardless of the semantic overlaps between them, צֶלֶם emphasizes concrete, while

\footnotetext{
${ }^{78}$ David P. Wright, "Holiness (OT),” ABD 3:246.

${ }^{79}$ Wright, "Holiness (OT)," ABD 3:247.
} 
former aspect includes the outward, physical, while the latter emphasizes the inward, moral, spiritual, mental resemblance between human beings and God, which establishes the duality ${ }^{80}$ of human beings as perceived by the OT. However, the use of these two nouns in the Creation account suggests that the human being as a whole, including these two components, is created in God's image. ${ }^{81}$ This duality of human beings is an important observation in light of the fact that human impurity in the OT corresponds to it. That is, ritual impurity, as one aspect of GHS, finds its expression in the outward, physical component of human nature, while moral impurity, as another aspect of GHS, finds its expression in the inward, moral, spiritual element of human nature.

\section{Human Sinfulness}

Besides these four basic states, human beings exclusively experience additional state of sinfulness. ${ }^{82}$ Scholars use various phrases such as "universal sinfulness of the human race," 83 "basic sinfulness," 84 "the rebellious disposition of humanity"85 "common

\footnotetext{
${ }^{80}$ Duality does not refer to dualism, as the well-known term that refers to the belief that human beings consist of two separate entities: material and mortal body and immaterial immortal soul. It is based on the premise that "there are two irreducible, substances in the universe (i.e., matter vs. nonmatter; body vs. soul)." The beginning of such a perception of reality is credited to "Plato's doctrine of the sensible and the intelligible worlds, which the Hellenistic Jewish exegete Philo of Alexandria adopted." Bennie R. Crockett Jr., "Dualism," EDB 358. See also Aecio E. Cairus, "The Doctrine of Man," in HSDAT, ed. Raoul Dederen, CRS 12 (Hagerstown, MD: Review \& Herald, 2000), 212-13, 223-26.

${ }^{81}$ Richard M. Davidson, "The Nature of Human Beings from the Beginning: Genesis 1-11," in "What are Human Beings that You Remember Them:" Proceedings of the Third International Bible Conference NOF Ginosar and Jerusalem June 11-12, 2012, ed. Clinton Wahlen (Silver Spring, MD: Review and Herald, 2015), 18. See also Cairus, "The Doctrine of Man," 212-13.

${ }^{82}$ Kurtz, Offerings, 422.

${ }^{83}$ Kurtz, Offerings, 134

${ }^{84}$ Hartley, Leviticus, 18, 24.

${ }^{85}$ Leigh M. Trevaskis, Holiness, Ethics and Ritual in Leviticus, HBM 29 (Sheffield: Sheffield Phoenix Press, 2011), 206.
} 
human sinfulness," 86 and "general sinfulness" $" 87$ to refer to it. Kurtz coined an eloquent term for it: "the sinful habitus, which is inherent in human nature generally." 88

The OT proposes that "things began as perfect from God's hand and then grew steadily worse through man's sinfulness." ${ }^{89}$ The understanding of GHS was a commonly shared concept by other ANE cultures..$^{90}$

The following lines from Sumerian religious texts demonstrate this claim. "Never has a sinless child been born to its mother, ... a sinless workman has not existed from of old" (ANET, 590, lines 102-3)." An Akkadian incantation for pacifying an angry deity uses similar reasoning: "Who is there who has not sinned against his god? Who that has kept the commandment for ever? All humans who exist are sinful." 91

Cover noted that "rhetorical questions of this sort were popular forms of expression for this universally acknowledged dogma, reminding the gods that they should not expect too much." Some of them follow: "Mankind, as many as there are, Which one of them comprehends his faults? Who has not transgressed, and who has not committed sin? Which one understands the way of the god?"92 "Whoever was there so on his guard

${ }^{86}$ Maass, "טהר," TLOT 3:485.

${ }^{87}$ Kiuchi, Purification Offering, 46; Kurtz, Offerings, 36; Mathews, Genesis 1-11:26, 164; Wenham, The Book of Leviticus, 63, 95, 148-49.

${ }^{88}$ Kurtz, Offerings, 205.

${ }^{89}$ Thorkild Jacobsen, “The Eridu Genesis,” JBL 100 (1981): 529. Followed by G. J. Wenham, "Cain and Seth," NIDOTTE 4:454.

${ }^{90}$ W. G. Lambert, “DINGIR.ŠÀ.DIB.BA Incantations,” JNES 33.3 (1974): 305.

${ }^{91}$ Lambert, "DINGIR.ŠÀ.DIB.BA Incantations,” 281-83, lines 132-43; Marie Joseph Seux, Hymnes et Prières aux Dieux de Babylonie et d'Assyrie, LAPO 8 (Paris: Le Cerf, 1976), 207, lines 12-14.

${ }^{92}$ Erich Ebeling, Die Akkadische Gebetsserie “Handerhebung," DAWBIO 20 (Berlin: AkademieVerlag, 1953), 72-73, lines 8-11; Seux, Hymnes et Prières aux Dieux de Babylonie et d'Assyrie, 170. 
that he did not sin? Whoever was so careful that he did not incur guilt?"93 "Where is the wise person who has not transgressed and [committed] an abomination? Where is he who has checked himself and thus not ba[ckslid]?"94 Egypt literature also reflects the same concept: "Say not:' I have no wrongdoing.",95

The OT abounds with statements that show a similar attitude about human nature. ${ }^{96}$ Biblical scholars of various genres of biblical literature recognized and confirmed the concept of general sinfulness of human nature. ${ }^{97}$ David Daube proposed that BL is formed with GHS in the background. This does not mean that BL condones sin in any form, but is aware that it deals with "fallible people." 98 This concept is also

\footnotetext{
${ }^{93}$ W. G. Lambert, "Three Literary Prayers of the Babylonians," AfO 19 (1959-1960): 57, lines 105-6; Seux, Hymnes et Prières aux Dieux de Babylonie et d'Assyrie, 176.

${ }^{94}$ Stephen Langdon, Babylonian Penitential Psalms to Which are Added Fragments of the Epic of Creation from Kish in the Weld Collection of the Ashmolean Museum OECT 6 (Paris: Geuthner, 1927), 23, lines $15-18$.
}

${ }^{95}$ John H. Walton, Victor H. Matthews, and Mark W. Chavalas, "Psalms," in IVPBBCOT (Downers Grove, IL: InterVarsity Press, 2000), 532.

${ }^{96}$ Cover, "Sin, Sinners," ABD 6:33.

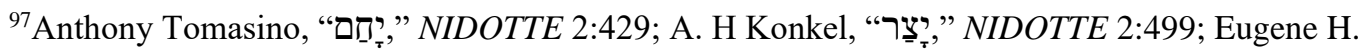

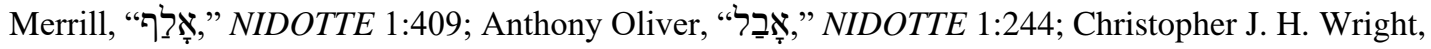
"אֶ:," NIDOTTE 1:513; John N. Oswalt, "Rest," NIDOTTE 4:1129; Elmer A. Martens, "Numbers,"

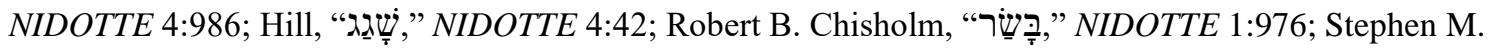

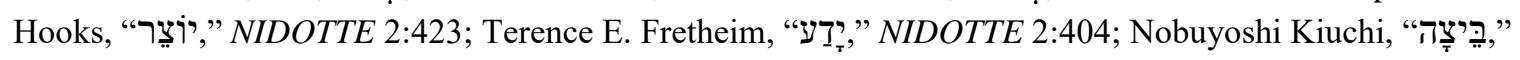

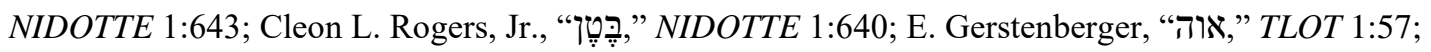

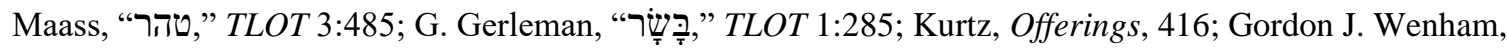
"Genesis," in New Bible Commentary: 21 st Century Edition, eds. G. J. Wenham, et al. (Downers Grove, IL: Inter-Varsity, 1994), 44; Walter C. Kaiser, "Exodus," in The Expositor's Bible Commentary: GenesisNumbers, vol. 2 of The Expositor's Bible Commentary: With the New International Version of the Holy Bible, ed. Frank E. Gaebelein (Grand Rapids, MI: Zondervan, 1990), 333-560; Keil and Delitzsch, The Pentateuch, 2:283, 302-3, 339; Keil and Delitzsch, The Pentateuch, 3:115-16, 431.

98“"By concessions to sinfulness we do not mean exhortations that one should forgive and help the transgressor, as God forgives and helps him. Such exhortations are in no way intended to legalize sin. Nor do we mean the mere fact that in Judaism, as everywhere, law proper is not co-existensive with morality or whatever ideal order may prevail. Certainly all codes, including the Jewish, since they deal with fallible human beings, are severely limited in their repression of evil and promotion of good; one could not, for 
extensively debated outside of biblical studies. ${ }^{99}$ Reflecting on biblical ritual and purity

laws, Childs stated:

At the heart of the biblical laws lies a profound sense of human sinfulness as a powerful destructive force which calls forth forms of institutional protection in an effort to check its power. Although the concept of sin in the Old Testament at times seems almost mechanical, when viewed as a whole, sin remains basically an offence against the God of the covenant. ${ }^{100}$

Gen 1-11 contains the account of the human fall (Gen 3:1-8), ${ }^{101}$ understood to be the introduction of sin into the perfect world. Even though no term for sin is mentioned in the Fall account of Gen 3, this text is the best representation of what $\sin$ is. ${ }^{102}$ Cover stated: "Sin ruptured the relationship between the creator and the creature, and set in motion a series of consequences which, if unchecked, would eventuate in the 'death' of the individual sinner." ${ }^{" 103}$ A multitude of expressions of human sinfulness, that is, sins by

example, impose the death-penalty for each and every kind of fraud or oppression. But we would not in general, because a lawgiver remains within these limitations, speak of a deliberate giving in to sin. For that, the lawgiver has to be aware of, even concerned about, the shortcomings of his code. What we mean, then, is conscious building into the law, the full recognition by the lawgiver, in spheres where in principle he would want to enforce the ideal order, of institutions or practices in conflict with it - the kind of thing Jesus declared to have happened in the case of divorce, tolerated by Moses 'for the hardness of your heart."' David Daube, "Concessions to Sinfulness in Jewish Law," JJS 10 (1959): 1.

${ }^{99}$ Marc A. Clauson, "Human Nature and the Christian," GFP (2015): 7-21, esp. 8-9.

${ }^{100}$ Childs, Old Testament Theology, 87. A similar understanding was suggested by Phyllis A. Bird: "Canonically, the understanding of human nature expressed or implied in the laws, wisdom literature, narratives, prophetic texts, and other genres of the Hebrew Scriptures may be viewed as commentary on the creation texts... The Bible's first statement concerning humankind remains the normative statement that governs all others." Phyllis A. Bird, “'Bone of My Bone and Flesh of My Flesh,"” ThTo 50 (1994): 525, 527.

${ }^{101}$ Eugene H. Merrill, "Fall of Humankind," NIDOTTE 4:637; Wright, "Unclean and Clean," 6:739; Ringgren, Israelite Religion, 109-11; Jiri Moskala, "Origin of Sin and Salvation according to Genesis 3: A Theology of Sin," in Salvation: Contours of Adventist Soteriology, eds. Martin F. Hanna, Darius W. Jankiewicz, and John W. Reeve (Berrien Springs, MI: Andrews University Press, 2018), 120.

${ }^{102}$ Moskala, "Origin of Sin and Salvation," 122.

${ }^{103}$ Cover, "Sin, Sinners," ABD 6:38. 
humanity, further caused God's judgment. ${ }^{104}$ First, the couple was expelled from the garden of Eden because of their $\sin { }^{105} \mathrm{R}$. Van de Walle captured the progression of evil: "Sin increased and evil action multiplied during primeval history: Cain murdered his brother, the sons of god fornicated with the daughters of man, the hubris of those who, built the Tower of Babel is a collective transgression parallel to the eating of the fruit and followed by a parallel lasting punishment, i.e. the confusion of tongues." ${ }^{106}$

Later almost all of creation was destroyed, and God granted Noah and his family a new beginning (Gen 6:5-7). However, the statement in Gen 8:21 witnesses that the catastrophic event did not alter the fundamental human problem, that is, the intrinsic sinfulness of humanity. ${ }^{107}$

The OT texts by some extent define the concept of GHS. First, it affects all human beings (Gen 8:21; Prov 20:9; Eccl 7:20, 29). ${ }^{108}$ Second, it is inherited and a permanent, life-long condition (Ps 51:7 [51:5]; 58:4 [58:3]; Isa 48:8; Job 15:14; 25:4; 14:1, 4; Isa 6:1-7). ${ }^{109}$ Three, it includes the inclination or determination of human mind

\footnotetext{
${ }^{104}$ Davidson, "The Nature of Human Beings," 28-29.

${ }^{105}$ Wright, "Unclean and Clean," 6:739.

${ }^{106}$ René Van de Walle, “The Sin in the Garden and Sinfulness of the World,” IJT 18 (1969): 140.

${ }^{107}$ Cover, "Sin, Sinners," ABD 6:33; Wenham, New Bible Commentary, 56, 65; Wenham, Numbers, 18.

${ }^{108}$ Kurtz, Offerings, 134; Niels-Erik A. Andreasen, "Death: Origin, Nature, and Final Eradication," in HSDAT, ed. Raoul Dederen, CRS 12 (Hagerstown, MD: Review and Herald, 2000), 321-22; Richard G. Swinburne, “Original Sinfulness," NZSTR 27 (1985): 249-50.

${ }^{109}$ Tomasino, "יחיזם," NIDOTTE 2:429; Cover, "Sin, Sinners," ABD 6:33; Moskala, "Origin of Sin and Salvation," 129, 132-33; Van de Walle, "The Sin in the Garden," 141-42; Swinburne, "Original Sinfulness," 235-48.
} 
towards sin (Gen 6:4; 8:21; Deut 31:21). ${ }^{110}$ Four, it involves the experience of

death/mortality (Gen 2:16-17; 3:14-19, 22-23). ${ }^{111}$

David R. Blumenthal provided a convenient definition: "Sinfulness is a very deep

dimension of human existence and dealing with it calls upon all our spiritual, intellectual,

emotional, and moral resources - even when we recognize that ceasing to sin is the base

line of repentance."112

Several events in the Pentateuch show that the consciousness of GHS caused

God's people or individuals not to approach God and have direct communication with

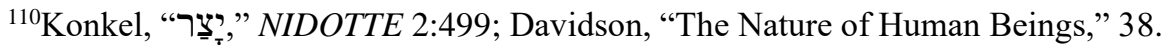

${ }^{111}$ Scholars' opinions on when death became reality for humanity are opposed. A number of them think that it entered creation following the sin of the first couple. Kurtz, Offerings, 134; Keil and Delitzsch, The Pentateuch, 1:105; Wenham, The Book of Leviticus, 90; "Genesis," in SDABC, ed. Francis D. Nichol, CRS 1 (Washington, DC: Review and Herald, 1976), 225; Wright, "Unclean and Clean," 6:739; Gerleman,

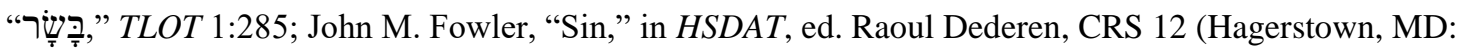
Review and Herald, 2000), 253; Cairus, "The Doctrine of Man," 206. For the basic arguments that God did not intend death to be a part of his creation, but is a punishment for human sin, see Eun-Jung Kim, "Reconsidering Eternal Life in the Old Testament: The Idea of Resurrection Rooted in the Torah" (PhD diss., The Southern Baptist Theological Seminary, 2015), 130-34; Cairus, "The Doctrine of Man," 217; Fowler, "Sin," 253; Andreasen, "Death," 318; Kent Harold Richards, "Death," ABD 2:109; Randall W. Younker, "A Look at Biblical and Ancient Extra-Biblical Perspectives on Death," JATS 16 (2005): 31-32. Cairus neatly stated: "The Paradise narrative explains the rise of death and affliction in the world through man's disobedience." Cairus, "The Doctrine of Man," 206. He also noted multiple ways the OT emphasizes that death is the penalty for human sin: "Death as the penalty for sin is emphasized throughout the Scriptures. The unrepentant soul 'person' will die (Ezek 18:4), will be 'cut off' (Ps 37:9, 34) or destroyed

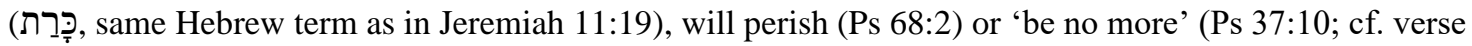
20)." Cairus, "The Doctrine of Man," 218. Arguments presented by scholars in this line of reasoning seem to be more biblically informed than those of the other group who claim that death was a part of original creation. Sarna, Genesis, 18-19; Lloyd R. Bailey, Biblical Perspectives on Death (Philadelphia: Fortress Press, 1979), 4, 109; Bernard L. Ramm, The Christian View of Science and Scripture, 1st ed. (Grand Rapids, MI: Eerdmans, 1954), 233; Karl Rahner, On the Theology of Death (New York: Seabury Press, 1973), 34; John Goldingay, Old Testament Theology: Israel's Gospel, Old Testament Theology, 3 vols. (Downers Grove, IL: IVP Academic, 2003), 1:120; Terence E. Fretheim, God and World in the Old Testament: A Relational Theology of Creation (Nashville: Abingdon Press, 2005), 77. For a further exposition of the argument related to the former understanding of death, see Lazarus Castang, "A Comparative Analysis of the Origin and Divine Causation of Death in Ancient Near Eastern Literature and in the Old Testament" (PhD diss., Andrews University, 2011), 100-29.

${ }^{112}$ David R. Blumenthal, "Repentance and Forgiveness," Crosscurrents, released 18 Nov 2018, http://www.crosscurrents.org/blumenthal.htm. 
him or to feel fatally endangered in God's presence (Exod 20:19, Isa 6). ${ }^{113}$ Thus, a human being can potentially embody two conditions that both point to their mortality. First, mortality through general sinfulness, and second, as a punishment for a particular sin. ${ }^{114}$

The Apocryphal books extensively reflect on GHS in the books of 2 Esd, Wis, and Sir taking the OT traditions of the Fall, the Mosaic law, and the moral teachings of the prophets as their source materials. According to them sin began in Eden, but is attributed variously either to Eve (Sir 25:24), Adam (2 Esd 3:21-22), or Satan (Wis 2:2324). ${ }^{115}$ Later on, Judaism and Christianity, based on the OT texts developed their own beliefs about the sinfulness of human nature. ${ }^{116}$ Christianity, especially, has a long tradition of debates on the GHS. ${ }^{117}$

\section{Sinfulness as Reflected in Human Experience}

Günter Röhser recognized a distinction between the act of sin and the state of sin in his Metaphorik und Personifikation der Sünde, ${ }^{118}$ conveying more precision regarding

\footnotetext{
${ }^{113}$ Kurtz, Offerings, 36; Trent C. Butler, Isaiah, HOTC 15 (Nashville: Broadman \& Holman, 2002), 57; John N. Oswalt, The Book of Isaiah: Chapters 1-39, NICOT (Grand Rapids, MI: Eerdmans, 1986), 182-83. Judges 13:21 can also be considered as one of the texts. I suggest that the awareness of his own sinfulness forms the backdrop for Manoah's fear of dying after seeing God and the temporary lack of sanity expressed in his statement that they would die because of the intense feelings of unworthiness characteristic for the context of theophany throughout the OT.

${ }^{114}$ Kurtz, Offerings, 134.

${ }^{115}$ David G. Clark, “Apocrypha: Theology,” NIDOTTE 4:404.

${ }^{116}$ Gerstenberger, "אוה," TLOT 1:56.

${ }^{117}$ Darius W. Jankiewicz, "Sin and Human Nature: Historical Background," in Salvation: Contours of Adventist Soteriology, eds. Martin F. Hanna, Darius W. Jankiewicz, and John W. Reeve (Berrien Springs, MI: Andrews University Press, 2018), 91-118.

${ }^{118}$ Günter Röhser, Metaphorik und Personifikation der Sünde: Antike Sündenvorstellungen und Paulinische Hamartia, WUNT II/25 (Tübingen: J. C. B. Mohr, 1987), 73. Followed by Glen S. Martin, Exodus, Leviticus, Numbers, HOTC 2 (Nashville: Broadman \& Holman, 2002), 243.
} 
the different the stages of the human experience of sin. On one the hand, the activity of sinning can be both a conscious and responsible act of human free will and choice; ${ }^{119}$ on the other hand, it can be unconscious or unintentional. ${ }^{120}$ The state of sin can further be understood in two different ways: (1) the state of having sinned, and (2) the human inclination to commit sin. ${ }^{121}$ The former is also referred to as guilt. While the state of having sinned is a specific one in the sense that it is a result of a particular sin being committed, the human inclination to commit sin, along with other characteristics of GHS, is ever present in human experience as it was shown above.

\section{Burnt Offering: A Solution for General Human Sinfulness}

As such, human sinfulness needs to be addressed in the divine-human relationship. Any form of it, the act or the state of sin, represents an obstacle in divinehuman relationship. The offering fitting to overbridge GHS, the ever-present inclination to commit sin, and other characteristics of GHS in a divine-human relationship is burnt offering. Kurtz identified clear textual support for the difference between burnt and sin offering: "Sinfulness tied to burnt and well-being offerings. Also, sin offering does not deal with this since the sin is specifically mentioned." ${ }^{22}$ The development of the burnt offering constructed from biblical texts confirms this role of the burnt offering.

Its antiquity is well established by biblical texts (e.g., Gen 8:20; 22:2, 7, 8, 13;

\footnotetext{
${ }^{119}$ Eichrodt, Theology of the Old Testament, 2:383.

${ }^{120}$ Cover, "Sin, Sinners," ABD 6:35.

${ }^{121}$ Lam, “Metaphorical Patterning," 107.

${ }^{122}$ Kurtz, Offerings, 177.
} 
Exod 10:25; 18:12; Num 23:15; Judg 6:26; 13:16; 1 Sam 7:9; 1 Kgs 18:38; 2 Kgs 3:27;

10:24; Job $1: 5 ; 42: 8) .{ }^{123}$ The burnt offering is considered to encompass initially the purposes of expiation and propitiation. ${ }^{124}$ This function is retained to some extent after the coming of the entire sacrificial system (Lev 9:7; 14:15, 17: 16:24). However, the regulation of the cult assigned specialized expiation to the sin and reparation offerings. ${ }^{125}$ They were introduced to mend the divine-human relationship when the human party interrupted that relationship by committing certain kinds of sins. The burnt offering may have retained the function of entreating God and included a wide range of motives such as homage, thanksgiving, appeasement, and expiation, as the OT narratives recount. ${ }^{126}$ Schwartz's comment on the motives standing behind the offering of the burnt offering is even more specific: "They [gift offerings, Lev 1-3] could be made at will—in fulfillment of vows, at private visits to the sanctuary, in supplication in times of distress, in gratitude for deliverance from danger or harm, or simply in a spontaneous urge to pay homage to God." 127 Wenham summed up all these motives in the following way: "In these phrases the general aim of the sacrifice is indicated. It is that the offerer may be accepted (rātsāh) by God. Peace with God is the goal of sacrifice."128

\footnotetext{
${ }^{123}$ Milgrom, Leviticus 1-16, 143. For additional pieces of evidence for the antiquity of the burnt offering, see the same source.

${ }^{124}$ Milgrom, Leviticus 1-16, 144.

${ }^{125}$ Milgrom, Leviticus 1-16, 144; Gary A. Anderson, "Sacrifice and Sacrificial Offerings," $A B D$ 5:880-81.

${ }^{126}$ Milgrom, Leviticus 1-16, 144.

${ }^{127}$ Schwartz, "Leviticus,” (JSB), 196.

${ }^{128}$ Wenham, The Book of Leviticus, 54. Emphasis mine.
} 
The introduction of the cult assumed specific directions for the burnt offering to be offered in the morning as the first and in the evening as the last offering of the day (Exod 29:38-42; Num 28:3-8). Exodus 29:42 states that the burnt offering was to be offered continually (tâmīd) and as such, it symbolized the deity's presence among and in relationship with the covenant people. ${ }^{129}$ It was included in many festivals and special days (the New Moon, each day of the Feast of Passover, the Feast of Weeks, the Feast of Booths, the Day of Atonement). ${ }^{130}$ The phrase, "burnt offerings and peace offerings," is used as a merism to represent the entire sacrificial system. ${ }^{131}$ Hartley stated that "the frequent presentation of whole offerings enabled the covenant community, despite the human proneness to sin, to maintain fellowship with the holy God."132

I agree with Hartley and Klingbeil that the burnt offering specifically retained the purpose of atoning GHS which would enable the offerer to worship in God's presence regardless of the unfavorable state of his/her general sinfulness. Kurtz also stated that "burnt offering atones for sinfulness, while sin and guilt offering atone for particular $\sin { }^{133}$ In this way, it serves constantly to provide reconciliation between God and sinful human beings. ${ }^{134}$ Some rabbinic sources seem to be in accord with the claim that the purpose of the burnt offering, among others, was to deal with sinful thoughts, ${ }^{135}$ that is,

\footnotetext{
${ }^{129}$ Anderson, "Sacrifice," 5:878.

${ }^{130}$ Hartley, Leviticus, 17-18.

${ }^{131}$ Anderson, "Sacrifice," 5:878.

${ }^{132}$ Hartley, Leviticus, 88.

${ }^{133}$ Kurtz, Offerings, 352.

${ }^{134}$ Hartley, Leviticus, 88-89.

${ }^{135}$ Milgrom, Leviticus 1-16, 175, 858.
} 
the ever-present inclination to commit sin.

\section{Neglect of GHS in Scholarly Works on Atonement}

Leading scholars of ancient Israel's cult and particularly, of the book of Leviticus did not include the concept of GHS in their understanding of atonement. When they infrequently used the noun "sinfulness," they referred to the state of sin after a sin had been committed.

In his monumental three-volume commentary on Leviticus of more than 2700 pages, Milgrom rarely used the noun "sinfulness"136 or the adjective "sinful." 137 When he did, it was a reference to the state of an individual or humanity who had committed sin or a sin as an act. He never used these terms to refer to a state of human sinful nature as described above. There is one reference that most likely is an exception, where, he possibly referred to human sinful nature. ${ }^{138}$ Milgrom never considered human sinful nature in his understanding of atonement, and that seems to be a lapse in his hermeneutics, bearing in mind that atonement of human beings is one of the key topics in the book of Leviticus.

Wright advanced the concept of human sinfulness to some extent in his Anchor

${ }^{136}$ Milgrom, Leviticus 1-16, 177, 705.

${ }^{137}$ Milgrom, Leviticus 23-27, 2015, 2178, 2275, 2307, 2341, 2459; Milgrom, Leviticus 17-22, 1372, 1490, 1498, 1577, 1633, 1649, 1676; Milgrom, Leviticus 1-16, 175, 317, 342, 357, 662, 705, 711, $858,868,1005$.

${ }^{138}$ Commenting on the element of demonic in the OT, he seems to be making a claim that impurity consists of moral mistakes humans make, but are also caused by human physical weakness. He does not use the term sinfulness, but infirmity, as the following quotation shows: "To be sure, the demons disappeared from the official religion, but not the demonic - it continued in man. Impurity was now given an added component: moral failing as well as physical infirmity." Milgrom, Leviticus 1-16, 766. Milgrom's use of the term "physical infirmity" is limited to menstrual infirmity only in the second and third volumes of his Bible Anchor Commentary on Leviticus. 
Bible Dictionary article "Unclean, Clean." ${ }^{139}$ His basic understanding of human sinfulness seems to be contradictory. Basically, in his interpretation of Gen $2-3$, becoming sinful is a desirable condition for humans. He called it "growing-up:"

Before eating the woman and man are like children: without wisdom or knowledge, sexually immature, unashamed of nakedness, immortal (i.e., as children who are not entirely cognizant of their mortality), and not responsible for or aware of sin. After eating the couple becomes wise and knowledgeable, sexually mature (in the J story only after the eating does the subject of reproduction come up, 3:16, and naming the woman Eve "life," the "mother of all the living" occur, v 20), ashamed of their nakedness, mortal, and sinful. This suggests that the latent reason for the pair's expulsion from the garden is their acquisition of a mature, mortal, human nature. ${ }^{140}$

Eating forbidden fruit slightly changed human condition, causing women's pregnancy to be painful and men's agricultural activity to be more difficult. ${ }^{141}$ The major and key difference in the human condition that eating from the Tree of Knowledge of good and evil brought was the separation between humans and animals due to a newly acquired divine knowledge, wisdom, discernment after they ate from it. ${ }^{142}$ Since God did not want humans to possess this knowledge, he banished them from the Garden of Eden. ${ }^{143}$ This explains why the concept of human sinfulness is totally absent in his other works dealing with

${ }^{139}$ Wright, "Unclean and Clean," 6:729-41.

${ }^{140}$ Wright, "Unclean and Clean," 6:739.

${ }^{141}$ David P. Wright, "Holiness, Sex, and Death in the Garden of Eden," Bib 77 (1996): 315; David P. Wright, "Sex and Death in the Garden of Eden," Sunstone (1998): 34.

${ }^{142}$ Wright, "Holiness, Sex, and Death," 319-20; Wright, "Sex and Death," 35.

${ }^{143}$ Wright, "Holiness, Sex, and Death," 319-20; Wright, "Sex and Death," 36.

${ }^{144}$ The following works never include the noun "sinfulness" nor the adjective "sinful." David P. Wright, "Purification from Corpse-Contamination in Numbers XXXI 19-24," VT 35 (1985), 213-23; Wright, "The Gesture of Hand Placement"; David P. Wright, "The Hermeneutics of Ritual Innovation: Hand Placement in Leviticus 24" (paper presented at the Annual Meeting of the Biblical Law of the SBL, Atlanta, GA, 23 November 2015); Wright, The Disposal of Impurity. 
be taken into consideration. In his interpretation of the Fall in Gen 2-3, the human condition was not degraded, but on the contrary, had progressed. ${ }^{145}$

Even though Schwartz's area of expertise is wide, some of his work related to atonement presented an influential contribution to the topic. However, he did not use the noun "sinfulness" in his works related to the topic of atonement. ${ }^{146}$ Gane also infrequently used the noun "sinfulness"147 or the adjective "sinful" 148 in his Cult and Character. Uses of both words do not refer to the state of GHS, but always to a state of committing a sin.

Gane's detailed analysis of human nature in Leviticus portrays it in a series of disparities - alive vs. dead, holy vs. common, pure vs. impure, and male vs. female. His introductory remarks on human nature resonate with the understanding of human nature offered in the present study. That is, humans are mortal, not inherently holy, and prone to commit moral faults. This is in contrast to God who is eternal, holy, pure, and just. Realization of this fundamental difference between God and humans is important in the context of "the protection and positive growth relationship between the radically different

\footnotetext{
${ }^{145}$ For a contrasting view on the degrading condition of humanity after eating of the forbidden fruit related to nudity, see Akua Darkoa Frimpong, "Purity and Impurity: Menstruation and Its Impact on the Role of Akan Women in the Church" (PhD diss., Vrije Universiteit, 2011), 98-99. Also on the basic debate of menstruation potentially being a result of eating forbidden fruit, see Frimpong, "Purity and Impurity," 115-18. For the arguments for menstruation being a result of the curse from the creation account, especially Gen 3:16, see Janice Delaney, Mary Jane Lupton, and Emily Toth, The Curse: A Cultural History of Menstruation, rev. ed. (Champaign, IL: University of Illinois Press, 1988), 37.

${ }^{146}$ Schwartz, "Leviticus," (JSB); Schwartz, "The Bearing of Sin."

${ }^{147}$ Gane, Cult and Character, 50, 142, 316.

${ }^{148}$ Gane, Cult and Character, 150 (2x), 154, 239, 297, 336, 352.
} 
divine and human party." ${ }^{\prime 49}$ He published this study a full decade after publishing his Cult and Character, which might be reflected in the exclusion of this aspect of human nature from his understanding of the atonement. Certainly, if the human being, defined as such, wants to approach God, some sort of mediation is needed, even if no particular sin is committed by the human party. Gane's atonement articulated in his Cult and Character does not address this element of GHS. In Gane's understanding of atonement, at least as expressed in his Cult and Character, human beings are in need of atonement only when they commit sin or contract defilement. Gane did not show much concern for a disadvantage of GHS as being constant impediment on human part in divine-human interactions aside from being represented in the states of ritual or moral impurity. "Physical ritual impurities, on the other hand, are generated by an existing human state of mortality that must be kept separate from Yhwh." ${ }^{150}$ It is not certain if Gane's understanding of mortality is the same concept as GHS as described in the present study.

In his article, "Sin and Impurity: Atoned or Purified? Yes," Sklar never used the terms sinfulness and used the adjective "sinful" only once to refer to moral impurity. ${ }^{151}$ The foundation for this article is his dissertation, and in it, Sklar dealt extensively with ritual and moral impurity, but never discussed nor defined the concept of human sinfulness.

\footnotetext{
${ }^{149}$ Roy E. Gane, "The Nature of the Human Being in Leviticus," in "What are Human Beings that You Remember Them?" Proceedings of the Third International Bible Conference NOF Ginosar and Jerusalem June 11-21, 2012, ed. Clinton Wahlen (Silver Spring, MD: Review and Herald, 2015 ), 43.

${ }^{150}$ Gane, Cult and Character, 201.

${ }^{151}$ Sklar, "Sin and Impurity," 27. He did not include this concept in Jay Sklar, "Sin and Atonement: Lessons from the Pentateuch," BBR 22 (2012): 467-92.
} 


\section{Conclusion}

Both of these points regarding the state of creation, the four basic states of creation, and the additional state of sinfulness associated with creation, particularly of human beings, are important for a proper understanding of objects and particularly human beings, are frequently recipients of These states define human beings, and physical entities thus need to be considered in the process of developing the understanding of

The concept of human sinfulness underlines both conditions related to the human experience of sin, the act, and the state. Human sinfulness is a permanent condition of all human beings which needs to be addressed in any study of divine-human interaction.

While major scholars of ancient Israel cult devoted adequate attention to the four states of creation when they researched was totally ignored. This concept did not seem to have an impact in the process of their formation of the רֶֶּ

Having established the neglect of the concept of GHS in the works of major scholars of the Ancient Israel cult and the states applicable to human beings and other

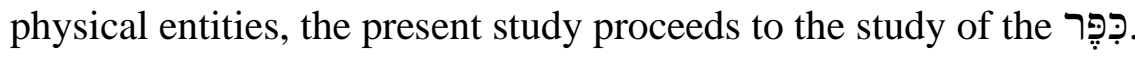

\section{The Meaning of $ר$ כִ iִ in the Pentateuch}

The frequent use of the verb 
gathering insights to form the meaning/s this verb conveys. ${ }^{152}$ Inferences from cognate languages or etymological considerations are not conclusive. ${ }^{153}$ For this reason, the current study proceeds to suggest the meaning of כִֶֶּּ based on its uses in the Pentateuch and pointers found in the relevant contexts.

The present study of understanding of this verb. First, the uses of internal syntactical structure demonstrate that the verb is used with the direct object or without any object, and with the indirect object (with the preposition analysis of these contexts is conducted in the same order in the present study. Second, since the application of blood is frequently used in כִֶֶּ contexts, the analysis includes examination of (1) the origin of blood in a given context, which reveals (2) the type of offering the blood was obtained from, that further disclosed (3) who the offerer was, ${ }^{154}$ (4) the reason for offering, and (5) the location the blood was applied to. These elements are often absent in non-cultic contexts and therefore, are not included in the analysis. In other words, כִֶּ in non-cultic contexts is often achieved without some or all the

\footnotetext{
${ }^{152}$ The verb is used 78 times in the Pentateuch 74 times of which in piel, 2 times in pual, 1 time each in qal and hithpael. Personal search, Concordance. By addressing various weaknesses of studying Hebrew "כְִֶּּ against Akkadina kuppuru, Feder also suggested studying the biblical corpus. Feder, "On kuppuru, kippēr and Etymological Sins," 544.

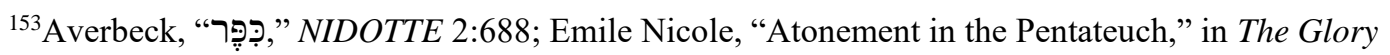
of the Atonement: Biblical, Historical \& Practical Perspectives: Essays in Honor of Roger R. Nicole, eds. Charles E. Hill and Frank A. James III (Downers Grove, IL: InterVarsity Press, 2004), 47.

${ }^{154}$ The sacrificial process is comprised of two parts. In the initial part, the offerer is a person who owns, brings, lays his hand on, and slaughters, if animal, a sacrifice. The second part of sacrificial process begins after the sacrifice is handed to an officiating priest or, in the case of the animal, is slaughtered. From this point on the owner of the animal is not involved in the sacrificial process, but the entire process through to its end, is solely the responsibility of the officiating priest.
} 
elements listed in the second step. Third, the analysis focuses on identifying certain Hebrew verbs in of a given ritual. Some texts, mostly non-ritual texts, will not contain data to answer these questions raised in steps two and three. Before proceeding with the analyze Lev 17:11 to test whether this text can be taken as a foundational text for the meaning of blood application by which כִֶֶּ is achieved.

\section{Analysis of Leviticus 17:11: The Role of Blood and}

Leviticus 17:11 is one of the critical texts that sheds light on the role of blood in the sacrificial process by which history of interpretation. It is enclosed by the two prohibitions concerning blood consumption in vv. 10 and v. 12 and forms the center of this pericope, Lev 17:10-12, providing a rationale for the prohibition. ${ }^{155}$ Scholars traditionally held that this text is unique "in that it explicitly assigns sacrificial blood the function of ransoming human life, ${ }^{, 156}$ including blood obtained from the sin offering. ${ }^{157}$ Gane noted that some scholars

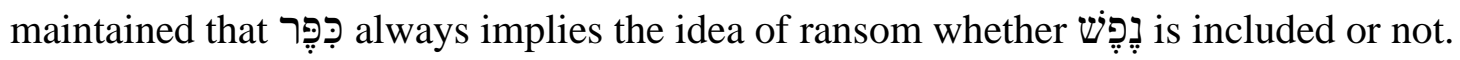
He also eloquently challenged this idea with the fact that ransom is not a possible

\footnotetext{
${ }^{155}$ Milgrom, Leviticus 17-22, 1469, 1472.

${ }^{156}$ Gane, Leviticus, Numbers, 304.

${ }^{157}$ Kiuchi, Purification Offering, 101; Sklar, Sin, Impurity, Sacrifice, Atonement, 163; Gane, Cult and Character, 170-71.
} 
understanding of (Lev 16:16, 18). ${ }^{158}$

Milgrom, however, claimed that blood manipulation in Lev 17:11 is associated with the well-being offering only. ${ }^{159}$ In addition, this text poses a question as to whether substitution can be inferred in the sacrificial ritual. ${ }^{160}$ Due to the critical importance of this text for the כִֶֶּ process, the grammatical and theological analysis of the present study includes four elements to understand properly the meaning of this text. The proper understanding of these four elements is necessary for a sound interpretation of the entire text. The first element is the meaning of the כִ in this text. The second element is related to the type/s of sacrifice by whose blood

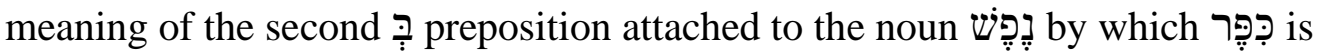
accomplished. The fourth element is examining whether substitution.

\section{Leviticus 17:11: The Meaning of the רִֶֶּּ}

A consensus exists among scholars regarding the first element. Leading scholars of the ancient Israel cult recognized that כִִּ refers to ransom in this text. ${ }^{161}$ This is

${ }^{158}$ Gane, Leviticus, Numbers, 304.

${ }^{159}$ Milgrom, Leviticus 17-22, 1474-75.

${ }^{160}$ Kiuchi, Purification Offering, 101.

${ }^{161}$ Wenham, The Book of Leviticus, 115; Rodríguez, "Substitution in the Hebrew Cultus," 244-57; Kiuchi, Purification Offering, 106-7; Levine, Leviticus, 115; Milgrom, Leviticus 1-16, 707-8; Milgrom, Leviticus 17-22, 1474; Schwartz, "The Prohibitions," 17, 55n1; Gane, Leviticus, Numbers, 303; Gane, Cult and Character, 170. 


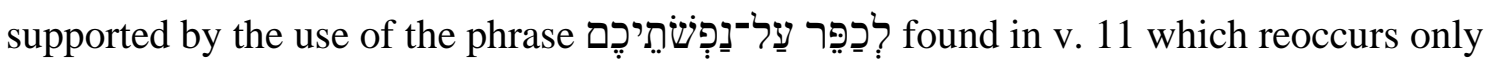

two more times (Exod 30:15-16; Num 31:50). Both occurrences of this phrase mean "to

ransom your lives." Milgrom noted that this is especially explicit in Exod 30:15-16:

Moreover, the verb kipper must be related to the expression found in the same pericope kōper napšô 'a ransom for his life' (Exod 30:12). The same combination of the idiom kopper nepeš and the verb kippēr is found in the law of homicide (Num 35:31-33). Thus in these two cases, kippēr is a denominative from kopper, whose meaning is undisputed: "ransom" (cf. Exod 21:30). Therefore, there exists a strong possibility that all texts that assign to kipperr the function of averting God's wrath have kopper in mind: innocent life spared by substituting for it the guilty parties or their ransom. ${ }^{162}$

Sklar has compellingly suggested that the concept of ذֶָּּ informs the concept of

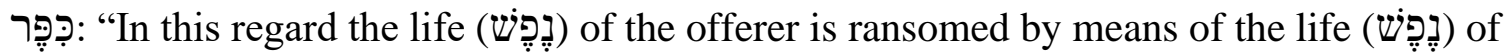
the animal, which is a payment that the offended party (the Lord) has agreed to (and indeed, provided), which is less than the penalty the offerer originally expected (viz. their own life), and which both rescues the offerer and restores peace to their relationship with the Lord."163

This definition of כְִֶּ is based on Sklar's extensive research of the term is, "Sklar used two steps to define koper. The first step is to search for the meaning by an exegetical analysis of the texts where koper is found, and the second is to compare koper with other terms in its semantic field."

\footnotetext{
${ }^{162}$ Milgrom, Leviticus 1-16, 707-8.

${ }^{163}$ Sklar, Sin, Impurity, Sacrifice, Atonement, 173-74.

${ }^{164}$ Janković, "The Rationale," 101. Sklar labeled the first step the concept-oriented approach
} where he studied ذָ within its own context. He was aware of the major weakness of this approach: distinguishing the actual lexical sense of the word from concepts that are present in any given context in which a word is used. Sklar, Sin, Impurity, Sacrifice, Atonement, 48. The second step Sklar named was the field-oriented approach which included an analysis of the two other nominal forms of two verbs with a 
texts: "(1) there is a guilty party, (2) there is an injured party, (3) the guilty party is being rescued, (4) peace is being established to the damaged relationship between the guilty and injured party, and (5) the guilty party is totally dependent on the reaction of the injured party and on the acceptance or rejection of the koper." 165

"Sklar identified two more roots that, along with their derivatives, share the same meaning and contexts with the term koper. The first root is $p \bar{a} \underline{d} \bar{a} h$, along with its four derivatives ( $p^{e} \underline{d} u y i m, p^{e} \underline{d} u \underline{t}$, pidyom, and pidyon)... The second root is $g \bar{a}$ 'al and its derivatives $g^{e^{\prime}} u l l a \bar{h}$ and go 'el. Regardless of the overlap in meaning in some contexts, there are cases in which the meaning of koper differs from the meaning of the terms..."166 The contexts with these two roots show slight different semantic nuances that

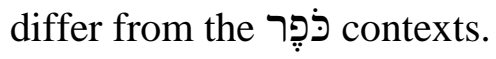

That is, in some In others, the person who redeems has the automatic right to do so and does not need approval from the person who possesses the person or object that is being redeemed. In these contexts, "redemption" or "to redeem" makes more sense, since in כָּפְ contexts, the party that does the ransoming needs and depends on the acceptance of כฺָּ by the party to

similar semantic field, $p \bar{a} \underline{d} \bar{a} h$ and $g \bar{a}$ al. Other forms could be considered in this analysis, but these two occur in contexts that are the most similar to koper. Sklar, Sin, Impurity, Sacrifice, Atonement, 61.

${ }^{165}$ Janković, "The Rationale," 101. For some insignificant exceptions to this pattern in some texts which Sklar detected, see Sklar, Sin, Impurity, Sacrifice, Atonement, 48-64.

${ }^{166}$ Janković, "The Rationale," 103. For the insignificant differences, see Sklar, Sin, Impurity, Sacrifice, Atonement, 62-66. 
whom the wrong has been done. Some contexts with very similar to that of פּ. ${ }^{167}$

The conclusion that comes out of this understanding of

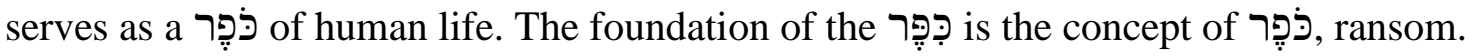
The broken relationship between God, as an injured party, and the sinner, as a wrong party, is resolved by God's acceptance of animal's blood-life as ransom for the offerer's blood-life. The decision as to whether to accept the ransom or not rests solely on the wronged party, God.

\section{Leviticus 17:11: The Type/s of Sacrifices}

The second element generated considerable debate among scholars. It is traditionally understood that this text proposes a rationale for the function of blood of all animal sacrifices. ${ }^{168}$ Milgrom and Brichto argued that this text explains the function of the blood of the well-being sacrifice only. ${ }^{169}$ The answer to this question significantly impacts the understanding of

Milgrom first established that the offerer envisaged in Lev 17:11 is guilty of a capital offence and therefore, the sacrificial blood they offer serves as their ransom. ${ }^{170} \mathrm{He}$

\footnotetext{
${ }^{167}$ For more details on the findings of these two steps see Sklar, Sin, Impurity, Sacrifice, Atonement, 61-67.

${ }^{168}$ Füglister, "Sühne durch Blut," 197; Kiuchi, Purification Offering, 101; Sklar, Sin, Impurity, Sacrifice, Atonement, 174; Rodríguez, "Substitution in the Hebrew Cultus," 241.

${ }^{169}$ Jacob Milgrom, “A Prolegomenon to Leviticus 17:11,” JBL 90 (1971): 93-103. Slightly modified in Milgrom, Leviticus 1-16, 706-13; Brichto, “On Slaughter and Sacrifice,” 19-28.

${ }^{170}$ Milgrom, Leviticus 1-16, 708.
} 
found three lines of evidence for arriving at this conclusion. First, Milgrom stated that "in a legal context, moreover, nepeš specifically connotes capital crime or punishment (e.g., Exod 21:23; Lev 24:15; Deut 19:21), and expressions compounded with it often imply that life is at stake (e.g., Judg 5:18; 12:3; 1 Sam 19:5)." ${ }^{171}$ Second, he further confirmed

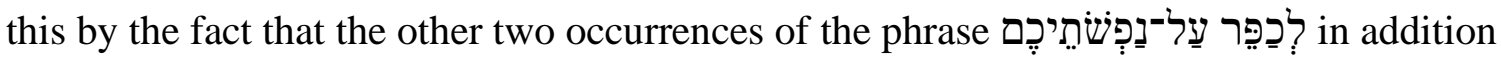
to v. 11, have capital punishment in view, namely census (Exod 30:11-16; Num 31:48). ${ }^{172}$ Third, Milgrom noted that the verb רכּ in Exod 31:11-16 "must be related to the expression found in the same pericope kōper napšô 'a ransom for his life' (Exod 30:12). The same combination of the idiom kōper nepeš and the verb kippēr is found in the law of homicide (Num 35:31-33)."173

Second, he argued that the sacrifice in this pericope is a nonexpiatory, well-being offering, supporting this in two points. ${ }^{174}$ First, he understood the phrase "you will not eat blood" as a reference to eating the meat with blood in it. ${ }^{175}$ The only sacrifice of which the offerer would eat is the well-being offering; thus, Lev 17 deals with this offering. Second, noting that 17:10-14 consists of two laws (vv. 10-12, and vv. 13-14) which form a unity, Milgrom inferred that "because the second deals with wild animals— hunted, obviously, for their meat and not for sport ( $\breve{a}$ šer ye' $\bar{a} k \bar{e} l)$ — the first law undoubtedly also speaks of the flesh of edible animals; these, however, are not game but

\footnotetext{
${ }^{171}$ Milgrom, Leviticus 1-16, 707.

${ }^{172}$ Milgrom, Leviticus 1-16, 708.

${ }^{173}$ Milgrom, Leviticus 1-16, 708.

${ }^{174}$ Milgrom, Leviticus 1-16, 708-9.

${ }^{175}$ Milgrom, Leviticus 1-16, 709.
} 
domestic animals, which, according to H, must be sacrificed at the altar." ${ }^{\prime 176}$ The only meat from the altar that the offerer is permitted to eat is of the well-being offering. ${ }^{177}$

Milgrom showed awareness in claiming that the well-being offering only in view in Lev 17:11 creates two crucial problems. First, the well-being offering would have an expiatory role which contradicts the fact that it "never functions as a kippūr." 178 The expiatory sacrifices in Leviticus are sin, guilt, and burnt offering. Second, in Milgrom's opinion, the sin that needs to be expiated is a capital offense against God. The following quotation depicts his course to get to this claim:

As noted, lěkappēr 'al-nepeš must mean that the Israelite is guilty of a capital offense against God, and unless he brings sacrificial blood to the altar, he is subject to the death penalty. In the Priestly laws, however, there is no sacrificial expiation for capital crime or, for that matter, for any deliberate violation. The presumptuous sinner is banned from the sanctuary because he "acts defiantly (b̌ey $\bar{a} d r \bar{a} m \hat{a})$... reviles the Lord ... has spurned the word of the Lord and violated his commandment" (Num 15:30-31; contrast vv. 24-29). ${ }^{179}$

Milgrom found the resolution for both of these contradictions in the opening law of this chapter, Lev 17:3-4. He first argued that the "animal slaughter is murder except at an authorized altar (vv. 3-4)." "180 This is further confirmed in 17:4a. Milgrom stated that the law "ordains that any Israelite who slaughters a sacrificial animal (for its meat) without bringing it to the Tabernacle altar as an offering of well-being, dām yēhašè $l \bar{a}$ ' $\hat{\imath} S$ hahû' dām šāpāk 'blood guilt shall be reckoned to that man: he has shed blood' (v

\footnotetext{
${ }^{176}$ Milgrom, Leviticus 1-16, 709.

${ }^{177}$ Milgrom, Leviticus 1-16, 709.

${ }^{178}$ Milgrom, Leviticus 1-16, 709.

${ }^{179}$ Milgrom, Leviticus 1-16, 710.

${ }^{180}$ Milgrom, Leviticus 1-16, 710; Milgrom, Leviticus 17-22, 1474.
} 
4ba). ${ }^{" 181}$ Finally, he found the support for this claim in the fact that

the idiom šāpāk dām is the well-attested accusation of murder (in P, Gen 9:6; Num 35:33; so in all sources: e.g., narrative, Gen 37:22; 1 Sam 25:31; 1 Kgs 2:31; 2 Kgs 21:16; 24:4; legal, Deut 19:10; 21:7; wisdom, Prov 1:16; 6:17; prophetic, Isa 59:7; Jer 22:3, 17; esp. Ezek 16:38; 18:10; 22:3, 4, 6, 9, 12) and the niphal of $h \breve{s} b$ "be reckoned," is the declaratory statement in $\mathrm{P}$ and $\mathrm{H}$ for designating a cultic act as either acceptable or unacceptable to God (Lev 7:18; Num 18:27, 30; cf. Ps 106:31). ${ }^{182}$

Second, Milgrom proceeded to conclude that "the blood ransoms the offerer's life and clears him of the charge of murder." ${ }^{183}$ Accordingly, his resolution is that the wellbeing offering atones in terms of ransoming the offerer who is guilty of murder, that is, unauthorized killing of an animal.

Milgrom's thesis that Lev 17 is limited to the well-being offering which atones as a ransom was extensively critiqued by Kiuchi, Gane, and Sklar.

In the first place, Milgrom's interpretation depends on v. 10 being restricted to the well-being offering. ${ }^{184}$ Yet, the text seems to be more inclusive since the phrase

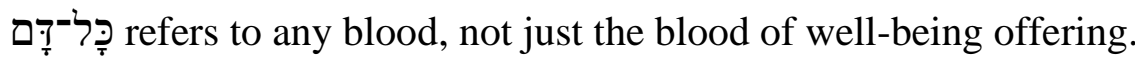

Milgrom's comment on this phrase in Lev 17:10 seems to contradict his thesis in great measure.

Since the blood of game is the topic of the next law (vv. 13-14), one might argue that "any blood" in this verse refers to only sacrificial animals. The rabbis, however, claim that this blood prohibition is total: it includes nonsacrificial animals as well (Sipra Ahare, par. 3:3; b. Ker. 4b). This view is corroborated by the occurrence of the same phrase in another attestation of the blood prohibition (7:27), which contains the added

\footnotetext{
${ }^{181}$ Milgrom, Leviticus 1-16, 710.

${ }^{182}$ Milgrom, Leviticus 1-16, 710.

${ }^{183}$ Milgrom, Leviticus 1-16, 710-11; Milgrom, Leviticus 17-22, 1474.

${ }^{184}$ Sklar, Sin, Impurity, Sacrifice, Atonement, 177.
} 
words lā ôp wĕlabběhēmâ 'of birds and beasts', a phrase intended to include every nonsacrificial category: game, blemished animals, and carcasses. ${ }^{185}$

However, Milgrom made a difference between the phrases where they refer to "eating meat with blood" and which refer to "eating over blood,"186 that is, some form of illicit practice such as divination or soothsaying (Lev 19:26). ${ }^{187}$ Even this seems unlikely for two reasons.

First, there is a lexical difference when "eating meat with blood" is intended or when "eating over blood" is intended. In the former phrase, blood is syntactically linked with the adjective כּ כ or with and without direct object marker, but blood remains the direct object of the verb אָָָ as it is in Lev 17:10, 12, while the latter phrase places the preposition עַ before

Second, blood is related to worship in vv. $1-9$, but it seems that the shift takes place from v. 10 where it is emphasized that blood has an atoning role. ${ }^{188}$ For that reason, it seems unlikely that, lexically, the very general regulation ${ }^{189}$ regarding the handling of

\footnotetext{
${ }^{185}$ Milgrom, Leviticus $17-22,1470-71$.

${ }^{186}$ Milgrom, Leviticus 17-22, 1471.

${ }^{187}$ Milgrom, Leviticus $17-22,1490-91$.
}

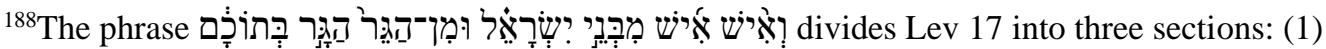
illegitimate sacrifice (vv 2-9), (2) handling blood (vv 10-14), and (3) eating from an animal's carcass (vv 15-16). Hartley, Leviticus, 264-65. Hartley emphasized the difference between topical and literary

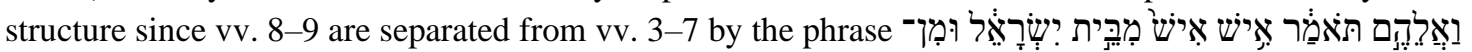

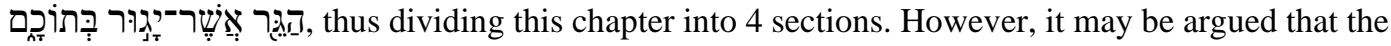

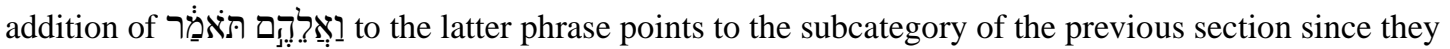
both deal with sacrifices, while 10-14 deals with blood. Even though, for a different overall conclusion, Milgrom correctly understood that vv. 8-9 belongs to the previous section, vv. $1-7$, due to this expanded dividing formula. Milgrom, Leviticus 17-22, 1475.

${ }^{189}$ Kiuchi, Purification Offering, 102. 
blood in v. 11 should be limited to the well-being offering in vv. 3-7. Finally, v. 8

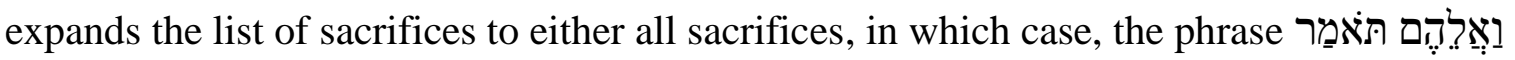
functions as a merism referring to all sacrifice, ${ }^{190}$ or just the peace sacrifices. The former alternative makes more sense in light of the overarching topic in vv. 3-9, that is, illegitimate sacrifice. ${ }^{191}$

Sklar noted two reasons that suggest that a general tone of blood consumption prohibition in v. 10 was transferred to v. 11. First, based on v. 11a, blood contains life which cannot be factual of the animals offered as a well-being offering only, but for all animals, not just sacrificial ones, and even more unlikely for the well-being offering. Second, based on v. 11b, God himself as the owner of life, prescribed an atoning role to the blood. It is not to be eaten. ${ }^{192}$ Consequently, v. 11 states two reasons that stand behind this prohibition: (1) the blood of animals contains its life and cannot be consumed, and (2) the animals' blood can be used only to make atonement on the altar.

Besides postulating that the general language in v. 11 does not warrant the conclusion that the context of this text should be well-being offering, ${ }^{193}$ Kiuchi pointed to another inconsistency with Milgrom's thesis. That is, v. 4 prescribes a kārēt penalty for the one guilty of slaughtering the animal except at the altar. The same punishment is also prescribed for blood consumption in v. 10. However, no remedy is given for these sins in Lev 17. Kiuchi correctly stated:

\footnotetext{
${ }^{190}$ Milgrom, Leviticus 17-22, 1467.

${ }^{191}$ Kiuchi, Purification Offering, 102; Hartley, Leviticus, 138.

${ }^{192}$ Sklar, Sin, Impurity, Sacrifice, Atonement, 177.

${ }^{193}$ Kiuchi, Purification Offering, 101.
} 
If the offerer brought a sacrificial animal to the sanctuary and slaughtered it, this act would constitute a totally legitimate act. It is not a sin; he has not committed a murder. In other words, vv. 3-4 do not imply any capital offence to be expiated, and there is no reason to mention the fact that the blood may not be consumed. On the other hand, if the offerer killed his animal outside the sanctuary this passage offers no ritual remedy. In either case the comment in Lev 17:11 is irrelevant on Milgrom's interpretation. ${ }^{194}$

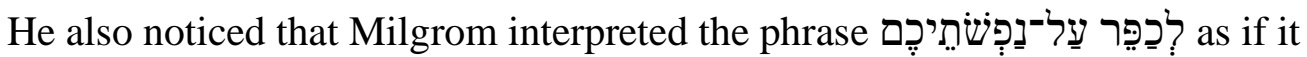
implies a capital offense partly by the meaning of the independent noun נִֶֶּ and partly by analogy with Exod 30:11-16 and Num 31:48ff. He found it methodologically incorrect to infer that the use of the identical phrase implies the identical offense. To argue that the same offence. The context of Lev 17 does not provide a basis for this suggestion. ${ }^{195}$ Being an offering that includes blood application, the well-being offering seems to be an expiatory offering based on Lev 17:11. Kurtz was correct regarding the expiatory role of a well-being offering when he stated that "if the sprinkling of blood in connection with

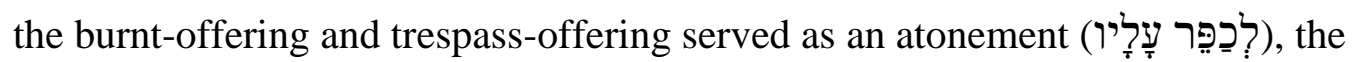
sprinkling of the blood of the peace-offering, which was performed in precisely the same way, must necessarily have had the same significance."196

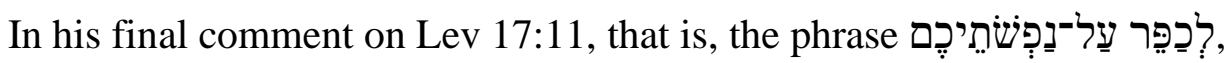
Milgrom raised two more points against the traditional understanding of this text:

Why should the blood of the hatța 't and ' $\bar{a} \bar{s} \bar{a} m$, the exclusive expiatory sacrifices brought for inadvertent wrongs, ransom the offerer's life? What capital crime has he

\footnotetext{
${ }^{194}$ Kiuchi, Purification Offering, 102-3.

${ }^{195}$ Kiuchi, Purification Offering, 102-3.

${ }^{196}$ Kurtz, Offerings, 74.
} 
committed to warrant the forfeit of his life? In particular, as I argued thirty years ago (Milgrom 1970), is the new mother, whose 'ōlâ and hatțāt offerings expressly expiate on her behalf (wěkipper 'ālêhā, 12:7, 8), deserving of death because she had a baby ${ }^{197}$

There are two underlying assumptions in this quotation which are incorrect. The first assumption is related to the first two questions, and it is that one's life is never at risk in the case of inadvertent sin. Based on Lev 4-5 and Num 15:22-29, which both state that סָלָח is and possible for inadvertent sin, it would be more correct to say that one never has to face death punishment in case of inadvertent sin. Inadvertence does not

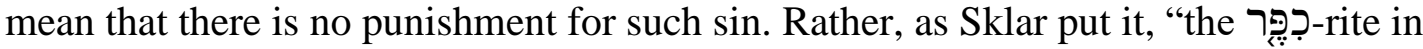
contexts of inadvertent sin is characterized by the ransoming of the sinner, that is, the giving of a legally legitimate ransom payment (כฺֶָּ) that acts as a mitigated penalty.

Within this context, forgiveness functions as an expression of agreement to and acceptance of the ransom payment (כֶּ).,"198

The second assumption is that the new mother is not at risk after having a baby. Based on the overall understanding of ritual impurity, she seems to be at risk because her impurity is considered severe and requires of capital punishment for not following God's regulations for ritual cleansing (Lev 15:31, Num 19:13, 20). ${ }^{199}$ According to Milgrom, the goal of the רִִּ in Lev 12 was to remove

\footnotetext{
${ }^{197}$ Milgrom, Leviticus 17-22, 1475.

${ }^{198}$ Sklar, Sin, Impurity, Sacrifice, Atonement, 178-79.

${ }^{199}$ Gane, Cult and Character, 175-76.
} 
impurity from the new mother and bring her back to the state of purity. ${ }^{200}$

Brichto, like Milgrom, argued that Lev 17:11 should be restricted to a well-being offering and that the slaughter of a domestic animal anywhere else but at the tabernacle constitutes a murder. ${ }^{201}$ However, Brichto uniquely understood

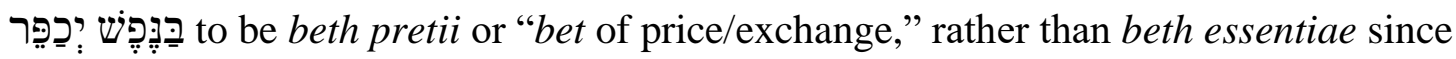
this preposition is often interchanged with תַח in talionic formulas. ${ }^{202}$ Accordingly, a general prohibition against blood eating in v. 10 is not limited to a well-being offering, but refers to burnt, sin, and reparation sacrifices that all have an atoning function. ${ }^{203}$

\section{Leviticus 17:11: The Nature of the Preposition

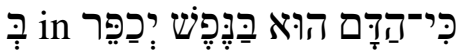

The third element includes answering a fundamental question: What is the nature

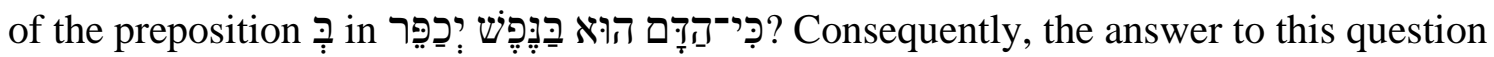
also sheds light on the referent of the noun נֶֶֶ, the animal that is offered, or the offerer who offers it.

There are three proposals regarding the nature of the preposition $\underset{?}{?}$. First, if $\underset{?}{\stackrel{\vartheta}{i}}$ is beth pretii, the noun נֶֶֶֶ refers to the offerer's life as opposed to the life of the sacrificial animal. The whole phrase is translated as "it is the blood that makes atonement for one's

\footnotetext{
${ }^{200}$ Gane, Leviticus, Numbers, 221-22, 224.

${ }^{201}$ Brichto, “On Slaughter and Sacrifice," 24.

${ }^{202}$ Brichto, "On Slaughter and Sacrifice," 28.

${ }^{203}$ Sklar, Sin, Impurity, Sacrifice, Atonement, 177; Schwartz, "The Prohibitions," 44-45.
} 


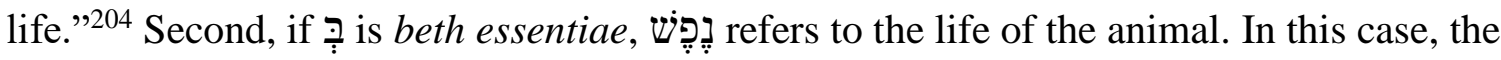
phrase is translated as "it is the blood, as life, that effects expiation."205 Third, if ᄁִ is beth instrumentii, נֶֶֶ also refers to the life of the animal. In this case the phrase is translated as "for it is the blood that makes atonement, by reason of/means of the life."206

\section{Beth Pretii}

If $\underset{?}{?}$ is beth pretii, the preposition is translated with the English preposition "for/in exchange of," and it occurs in contexts where one item is given for/in exchange of the other. To support this understanding of $\underset{?}{\mathfrak{i}}$, scholars usually point to the interchangeability

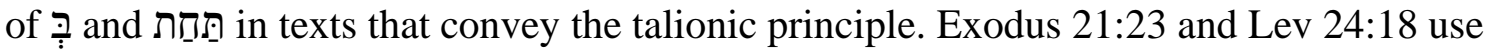

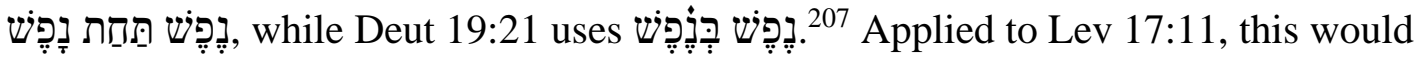
mean that the blood of the animal is given for/in exchange of/in place of the offerer's life. The animal's blood-life becomes the substitute for the offerer's blood-life. This understanding would further indicate that the animal's blood-life serves as a substitution in place of the offerer's blood-life. ${ }^{208}$

\section{7.}

${ }^{204}$ NIV, Henri Cazelles, Le Lévitique (Paris: La Sainte Bible, 1958), 84-85; Noordtzij, Numbers,

${ }^{205}$ JPSV, Füglister, "Sühne durch Blut," 145. For a more extensive list, see Sklar, Sin, Impurity, Sacrifice, Atonement, 169n20.

${ }^{206} \mathrm{RSV}$, NASV, Adalbert Metzinger, "Die Substitutionstheorie und das Alttestamentaliche Opfer mit besonderer Berücksichtigung von Lv 17:11," Bib 21 (1940): 270-72; Janowski, Sühne als Heilsgeschehen, 245; Paul Garnet, "Atonement Constructions in the Old Testament and the Qumran Scrolls," EvQ 46 (1974): 139; Kurtz, Offerings, 71-72; Hartley, Leviticus, 261; Kiuchi, Purification Offering, 105-6. For a more extensive list of authors who held this understanding of be, see Sklar, Sin, Impurity, Sacrifice, Atonement, 169n21.

${ }^{207}$ Cazelles, Le Lévitique, 85n[1]; Brichto, “On Slaughter and Sacrifice,” 28.

${ }^{208}$ Sklar, Sin, Impurity, Sacrifice, Atonement, 170. 
There are four points of critique of this understanding of $\underset{?}{\mathfrak{p}}$. First, the appeal to the use of $\underset{?}{\dddot{T}}$ in talionic formulas (Deut 19:21) is not decisive because the only use of this phrase in priestly literature does not use פִּחת (Lev 24:18). ${ }^{209}$ Second, the formulas

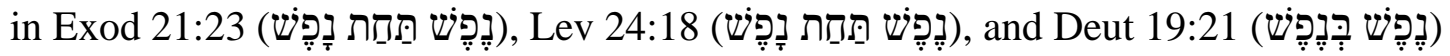

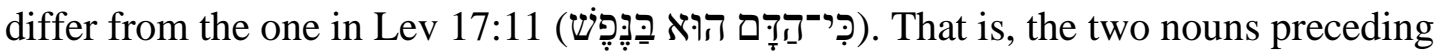
and following the preposition are the same in the former formula and different in the latter one. where since beth essentiae and beth instrumenti are also compatible with the idea of substitution. ${ }^{211}$ Fourth, נִפֶ in v. 11 most likely refers to the life of the sacrificial animal

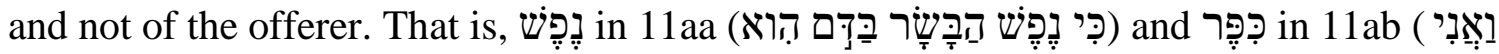

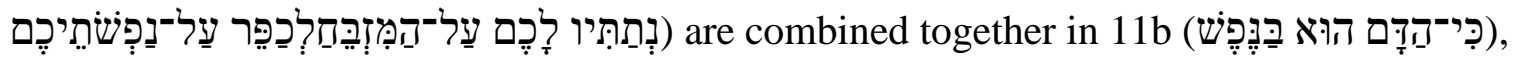
implying that the נִֶֶ in $11 \mathrm{ab}$ is the same as the one in $11 \mathrm{aa}$, that is, of the animal. ${ }^{212}$ Kiuchi, via Janowski, also noted chiasmus of נֶֶֶ and in in 11aa and in $11 \mathrm{~b} .{ }^{213}$ Even though this understanding of the preposition $\underset{?}{\mathfrak{p}}$ in Lev 17:11 is grammatically and semantically possible none of the arguments scholars presented seems to be strong

\footnotetext{
${ }^{209}$ Füglister, "Sühne durch Blut,” 145.

${ }^{210}$ Janowski, Sühne als Heilsgeschehen, 244.

${ }^{211}$ Sklar, Sin, Impurity, Sacrifice, Atonement, 170.

${ }^{212}$ Schwartz, "The Prohibitions," 46-48.

${ }^{213}$ Janowski, Sühne als Heilsgeschehen, 244; Kiuchi, Purification Offering, 105.
} 
enough, especially when keeping in mind that נֶֶֶ refers to the sacrificial animal.

\section{Beth Essentiae}

The following quotation is educational on the beth essentiae:

This old, rather unclear expression probably means that the noun introduced by the belongs to the essence (in the broad sense) of the thing which is being talked about, or it may point to the function of the preposition as a link between the subject and predicate of an equational clause. The expressions Beth of identity and pleonastic Beth are also found. ${ }^{214}$

In other words, what follows the preposition $\underset{?}{\mathfrak{p}}$, beth essentiae, is equivalent to or

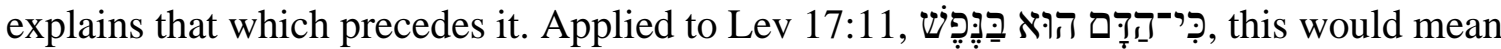
that blood is equated with life. There are three arguments to support beth esssentiae.

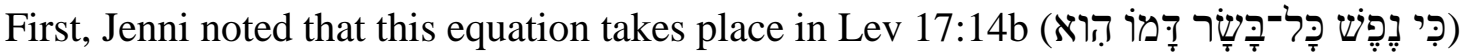
and informs the understanding of both i⿱: in v. 11a and 11b. Accordingly, 11a, נִֶֶּ

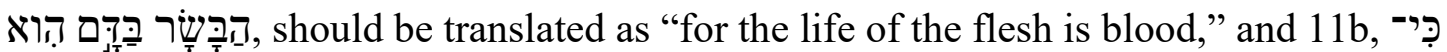

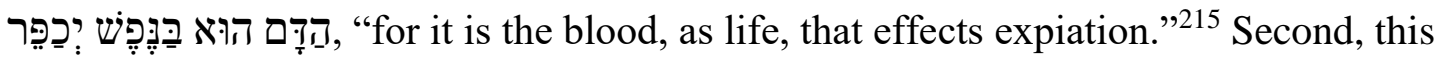

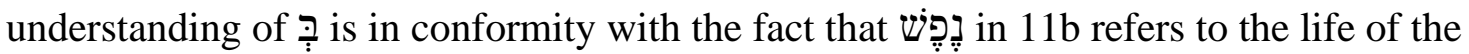
sacrificial animal. Third, the idea of substitution is implied due to the ransom meaning of the

\footnotetext{
${ }^{214}$ Paul Joüon and T. Muraoka, A Grammar of Biblical Hebrew, 2nd ed. (Roma: Editrice Pontificio Istituto Biblico, 2006), 462n10.

${ }^{215}$ Ernst Jenni, Die Präposition Beth, vol 1 of Die Hebräischen Präpositionen (Stuttgart: W. Kohlhammer, 1992), 84.

${ }^{216}$ Schwartz, "The Prohibitions," 56-57. Schwartz did not apply this understanding of anywhere else but in Lev 17:11. Sklar, Sin, Impurity, Sacrifice, Atonement, 171.
} 
Accordingly, beth essentiae is a viable option from the grammatical standpoint. It is consistent with the understanding that נֶֶֶ in $11 \mathrm{~b}$ refers to the life of the sacrificial animal. It fits the ransoming nature of כִֶֶּ: in this text. It has to be added that the equation of life and blood in Lev 17:14b does not exclude the possibility that $\underset{?}{?}$ could also be beth instrumentii. $^{217}$

\section{Beth Instrumentii}

The beth instrumentii is the most widely accepted understanding of $\underset{?}{\mathfrak{T}}$ in Lev 17:11b. ${ }^{218}$ The preposition $\underset{:}{\mathfrak{i}}$ indicates the instrument with which or the means by which something is done. ${ }^{219}$

The primary support for the beth instrumentii emanates from the fact that $\underset{?}{?}$ is mainly instrumental when it is syntactically linked to the verb כְִּּ (Gen 32;21; Exod 29:33; Lev 5:16; 7:7; 19:22; Num 5:8; 35:33; 1 Sam 3:14; Isa 27:9; Prov 16:6) except in the two texts in which it is locative (Lev $6: 23 ; 16: 17,27) .{ }^{220}$ The other two arguments coincide with the same argument presented in favor of beth essentiae. It is consistent with the understanding that נֶֶֶֶ in $11 b$ refers to the life of the sacrificial animal and to the

${ }^{217}$ Sklar, Sin, Impurity, Sacrifice, Atonement, 172.

${ }^{218}$ See footnote that begins with RSV, NASV in the present study.

${ }^{219}$ Waltke and O'Connor, An Introduction to Biblical Hebrew Syntax, 197; Wilhelm Gesenius, Gesenius' Hebrew Grammar, ed. E. Kautzsch, trans. A. E. Cowley (Oxford: Oxford University Press, 1910), 380; Jenni, Die Präposition Beth, 118-49.

${ }^{220}$ Kiuchi, Purification Offering, 105; Milgrom, Leviticus 1-16, 706; Milgrom, Leviticus 17-22, 1478; Schwartz, "The Prohibitions," 47; Füglister, "Sühne durch Blut," 145-46n11. 
ransom nature of the כִִּ Rodríguez viewed beth pretii as a form of beth essentiae. ${ }^{221}$

\section{Conclusion on the Preposition ִㅜ:}

To summarize, from the grammatical stand point, the preposition ᄁִ̣ in Lev 17:11b could be any of the following options: beth pretii, beth essentiae, or beth instrumentii. However, two last alternatives, beth essentiae and beth instrumentii, are favored since they agree with the understanding that the referent of נֶפֶ in $11 \mathrm{~b}$ is the life of the sacrificial animal. Of the last two, beth instrumentii seems to have stronger grammatical

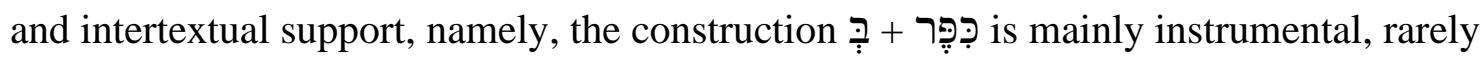
locative, but never beth essentiae. ${ }^{222}$

Sklar noted that either of the last two options, beth essentiae or beth instrumentii, basically conveys the same meaning to Lev $17: 11$. He stated:

Indeed, whether one states that blood atone by the means of the life it contains, or whether one states that the blood atones as life, it is clear that the atoning function of the blood is grounded in its relation to the life of the animal, that is, the blood is able to atone because of the life it contains. ${ }^{223}$

Thus, Sklar suggested the following translation of Lev 17:11: "For the life of flesh is in the blood, and I myself have bestowed it to you upon the altar to ransom your lives,

\footnotetext{
${ }^{221}$ Rodríguez, "Substitution in the Hebrew Cultus," 249; Gesenius, Gesenius' Hebrew Grammar, 380. However, Rodríguez's emphasis on the beth pretii rests on an incorrect argument. That is, the absence of $3 \mathrm{~ms}$ pronominal suffix on the noun follows the general tone of vv. 10-11. In addition, כִּ attached to נִפְְש does not always refer to human life (Gen 9:4). Finally, the last point discredits Rodríguez's understanding that the beth pretii should be translated "in exchange for the person," thus referring to the life of the offerer, whose life is saved at the cost of the sacrificial animal's. Rodríguez, "Substitution in the Hebrew Cultus," 250, 256. These irregularities in Rodríguez's argumentation diminish the strength of his suggestion. Beth pretii is not the best solution in this verse.

${ }^{222}$ Sklar, Sin, Impurity, Sacrifice, Atonement, 173.

${ }^{223}$ Sklar, Sin, Impurity, Sacrifice, Atonement, 173.
} 
for it is the blood that ransoms by means of/as the life."224

\section{Leviticus 17:11: Probability of the Idea of Substitution}

As emphasized above, the idea of substitution is widely recognized and affirmed in Lev 17:11 and it does fit the two choices that are favored by the grammar and syntax of the text. The life of the sacrificial animal takes the place of the offerer on the altar. ${ }^{225}$ As argued above, inadvertence related to a sin does not mean that the life of the sinner was not endangered. As Kiuchi stated, "it seems arbitrary to hold that the sin in Exod 30: 12ff. put a person's life in jeopardy whereas the sin in Lev 4-5 does not." ${ }^{226}$ As it was argued on pages 395-96 of the present study, the life of a person is always in need of ransom from death from the point of committing sin and receiving forgiveness. ${ }^{227}$ Kiuchi has shown that

uncleanness, which symbolizes death or the aura of death, is ascribed not only to corpses or carcasses but to things and persons which have contact with them. The same is true for an inadvertent sin. Though it does not deserve the death penalty, the sinner is regarded as being in the realm of death. ... Because if nothing is done to uncleanness or sin that will lead to a person's death, so it could be posited that a sacrifice indeed saves the life of a sinner or an unclean person, and that the exchange of נֶפֶּ in Lev 17: 11b should be understood in this sense. ${ }^{228}$

Thus, it is more correct to say that sinners do not experience death because of the

\footnotetext{
${ }^{224}$ Sklar, Sin, Impurity, Sacrifice, Atonement, 173. An almost identical rendering of this text is suggested by Milgrom: "For the life of the flesh is in the blood and I have assigned it to you upon the altar to ransom (kpr) your lives, for it is the blood that ransoms by means of life." Milgrom, Leviticus 1-16, 417.

${ }^{225}$ Rodríguez, "Substitution in the Hebrew Cultus," 259-60; Kiuchi, Purification Offering, 107.

${ }^{226}$ Kiuchi, Purification Offering, 107-8.

${ }^{227}$ Kiuchi argued this based on the conceptual relationship between Purification Offering, 96-7.

${ }^{228}$ Kiuchi, Purification Offering, 108-9.
} 
privilege of כִֶּּ that ransoms their lives by moving them from the aura of death and the forgiveness that God bestows on them. Kiuchi is also correct in suggesting that the term death penalty should be avoided in the context of inadvertent $\sin$ in Lev 4-5, since neither the phrase ממוֹת יוְָּת nor the kārêt penalty is mentioned in these chapters, which further points to the fact that these sins do not deserve the death penalty. ${ }^{229}$ Actually, none of a variety of capital punishments is implied in Lev 4-5.

Finally, as argued above, the idea of substitution is present in Lev 17:11 because in itself, it includes the idea of a substitution and because the sacrificial animal instead of the offerer is slaughtered at the altar in the sanctuary. ${ }^{230}$

\section{Conclusion on Lev 17:11}

The analysis above confirms the fact that the most compelling understanding of Lev 17:11 is a traditional one which argues that this text encompasses general theological principles which apply to all atoning sacrifices; the life-blood of the sacrificial animal, as

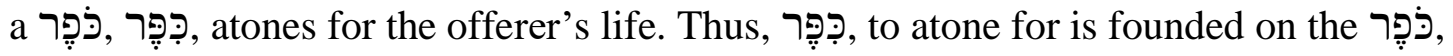
rather than on other suggestions, including "to cover," since it avoids misconceptions related to all other suggestions. This understanding of Lev 17:11 is based on the following four points. First, serves as a פּפָ of human life. God accepts the animal's life-blood as a ransom instead of the offerer's life-blood. כִֶֶּּ ransoms in Lev 17:11 based on the Tֶּר This insight is

\footnotetext{
${ }^{229}$ Kiuchi, Purification Offering, 107-8.

${ }^{230}$ Kiuchi, Purification Offering, 108-9.
} 
supported by the ever-present unfavorable status of human beings before God due to their sinfulness. Consequently, humans constantly need atonement. ${ }^{231}$ Second, based on the fact that a general prohibition against blood eating in v. 10 is not limited to a well-being offering, but refers to burnt, sin, and reparation sacrifices that all have an atoning function, the present study accepts the traditional understanding that Lev 17:11 envisions all sacrifice by whose blood

Third, although all three alternatives, beth pretii, beth essentiae, or beth instrumentii, are

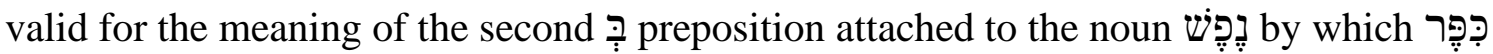
is accomplished, beth essentiae and beth instrumentii are favored since they agree with the understanding that the referent of נֶֶֶ in $11 \mathrm{~b}$ is the life of the sacrificial animal and have stronger grammatical and intertextual support. Fourth, the fact that כִֶֶּ in itself includes the idea of substitution and because the sacrificial animal instead of the offerer is slaughtered at the altar in the sanctuary, the idea of substitution is implied in Lev 17:11.

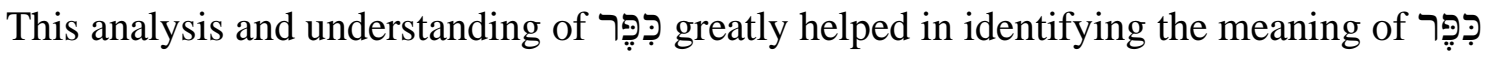
in some vague contexts below.

\section{רִִּ with the Direct Object Marker}

Two potential meanings found in three texts emerge when direct object marker in the Pentateuch (Gen 6:14; Lev 16:20, 33). The first one is "to cover" or "to rub on" (Gen 6:14) and the verb is in qal stem. This use corresponds to

\footnotetext{
${ }^{231}$ See the following subheadings in the present work: Various States of the Creation, Duality of Human Nature, Human Sinfulness, Sinfulness as Reflected in Human Experience, Burnt Offering: A Solution for General Human Sinfulness, and Neglect of GHS in Scholarly Works of Atonement.
} 
Akkadian B stem kapāru. ${ }^{232}$ This is identical to the Arabic kaffaru as stated above. The second meaning is "to rub off, wipe, purify" (Lev 16:20, 33), and the verb is in piel stem which corresponds to the Akkadian D stem kuppuru. ${ }^{233}$ These two meanings are based on their literary contexts and are confirmed by their correspondence with ANE languages.

\section{Non-Cultic Contexts}

Regarding Gen 6:14, commentators believed that the hapax legomenon כฺָּ is to be translated with "bitumen," and the verb referred to the sealing of the bark outside and inside to make it watertight. 234 כָּפ is uniquely used in this way in the $\mathrm{OT}^{235}$ and this understanding is well confirmed from ANE lexical, conceptual, and contextual correspondence where Hebrew כָּפְ corresponds with the Akkadian kupru, "bitumen," that is used in the Hebrew and Akkadian flood stories. ${ }^{236}$ Harold R. Cohen emphasized a critical point that proved that "to smear" 237 is the foundational meaning of the Akkadian kaparu that corresponds to the Hebrew רֶֶ:

The parallels from Atrahasis, however, are somewhat closer than those usually cited from the eleventh tablet of the epic of Gilgamesh, since the former demonstrate the use of the bitumen for caulking the boat, obviously what is implied in Gen 6:14 as

\footnotetext{
${ }^{232}$ Chaim Cohen, Biblical Hapax Legomena in the Light of Akkadian and Ugaritic, SBLDS 37 (Missoula, MT: Scholars Press, 1978), 33-34; Milgrom, Leviticus 1-16, 1080.

${ }^{233}$ Milgrom, Leviticus 1-16, 1080.

${ }^{234}$ Keil and Delitzsch, The Pentateuch, 1:142; Sarna, Genesis, 52; Mathews, Genesis 1-11:26, 364; Victor P. Hamilton, Genesis 1-17, NICOT 1 (Grand Rapids, MI: Eerdmans, 1980), 281.

${ }^{235}$ Usually, OT uses the nominal ḥēmār for pitch, bitumen (Gen 11:3, 14:10, Exod 2:3). Sarna, Genesis, 52; Hamilton, Genesis 1-17, 281.

${ }^{236}$ Cohen, Biblical Hapax Legomena, 33.

${ }^{237}$ For further debate on this meaning see Cohen, Biblical Hapax Legomena, 53-54; CAD, K:17889.
} 
well. Furthermore, in context outside the flood story, Akkadian kupru is often used with its denominative verb kapāru "to smear" and this too is precisely the case in Gen $6: 14 .^{238}$

However, Gen 6:14 is the only place in the OT where the verb כָָּ is used in the qal stem with the meaning of "to smear, rub on, cover." Therefore, it is misleading to think that the piel verbal form is a denominative of כָָּ since, in this single instance, the noun was used with the verbal root that is in qal not piel. ${ }^{239}$ Avoiding the erroneous linguistic concept (habit) called "root fallacy," one should not take the meaning of qal of כָּפ and apply it to the piel stem Pentateuch and in the entire OT. As Averbeck stated, "Linguistically the same root in a different stem is a different word." 240 The same syntax pattern between the use of qal of כָ in Gen 6:14 and piel in Gen 32:20 241 does not change this since the argument can be made that, in the latter text, the רִּ can be translated as "to wipe clean"242 that corresponds to the Akkadian D stem.

Based on contextual insights from Gen 6:14, along with comparative insights that are lexically, contextually, and conceptually controlled, the qal of פָָ means "to cover, smear on, rub on." In addition, this meaning should not be transported onto the piel stem

${ }^{238}$ Cohen, Biblical Hapax Legomena, 33-34.

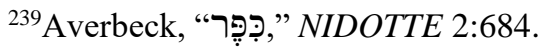

${ }^{240}$ Averbeck, “רפְּ," NIDOTTE 2:685.

${ }^{241}$ In both texts, the verb is followed by a direct object (the ark and the face of Esau, respectively),

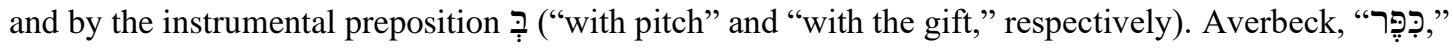
NIDOTTE 2:684.

${ }^{242}$ Pedersen, Israel: Its Life and Culture, 2:361-62; Milgrom, Leviticus 1-16, 1084. 
of the same verb, but rather one should seek hints from the immediate context to determine the most plausible meaning of the piel uses.

\section{Cultic Contexts}

The piel form of כִֶֶּּ is found in Lev 16:20, 33. The direct recipients of these two texts are the most holy place, the holy place and the sacrificial altar since they are all presided over by the direct object marker, and the last two are joined with the waw conjunction. The context of these texts is the Day of Atonement.

It is important to note that the first blood application that these objects receive by which the 16:16. Verses 14-15 state that blood for the blood application to achieve from the sin offerings of both the priest/s and the people, and v. 16 confirms that hְִָּּ has to do with ritual and moral impurities of the people of Israel as a whole, the priestly tribe

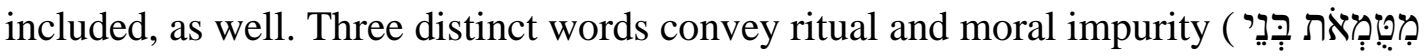

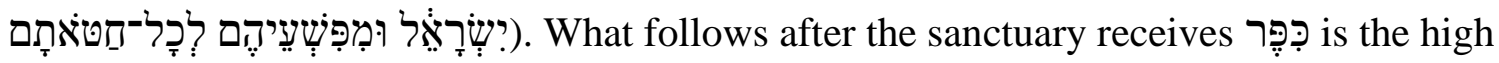
priest's laying on of hands on and confessing the sins of the sons of Israel over the goat for Azazel to transfer those impurities onto it (16:21). Scholars have generally reached a consensus that the laying on of hands in Lev 16:21 means the transfer of sins from the high priest to the Azazel goat. ${ }^{243}$ Two points derived from the

\footnotetext{
${ }^{243}$ Kurtz, Offerings, 98; Koch, “עון," TDOT, 10:559; Hartley, Leviticus, 20, 241; Kiuchi, Purification Offering, 113; Milgrom, Leviticus 1-16, 638, 1040-45; Gane, Leviticus, Numbers, 196, 27374; Gane, Cult and Character, 57-8, 103-4, 161; Wright, "The Hermeneutics of Ritual Innovation," 7. Kiuchi also added the idea of substitution. Kiuchi, Purification Offering, 118-19.
} 
suggest that the verb in this context should be translated "to cleanse" in terms of the sin removal from the sanctuary to outside the camp.

First, the blood of the high priest's and people's sin sacrifices was applied to the tree compartments of the sanctuary, on and in front of mercy seat, in the first compartment, and on the altar. The sins were absorbed by that application of the sacrificial blood and transferred to the high priest himself and then, from the high priest to the Azazel goat. ${ }^{244}$ They were relocated, removed from the sanctuary onto the Azazel goat, thus leaving the sanctuary clean.

Second, the meaning of sanctification when the recipients of it are physical, inanimate objects. The sanctuary as an inanimate object cannot commit, but just receive ritual and moral impurity onto itself. $^{245}$ The context is clear in Lev 16; the sanctuary compartments are being rid of the impurity of the people of Israel, thus implying purgation/cleansing. ${ }^{246}$ The sins were cleansed, removed, and the sanctuary is clean again. Scholars agree that כִ כִ in the context of Lev 16, when the compartments of the sanctuary are the recipients of it, refers to purgation. ${ }^{247}$

\footnotetext{
${ }^{244}$ Milgrom, "Sacrifices and Offerings, OT," 767; Gorman, The Ideology of Ritual, 81. Milgrom stated that sin offering blood defiles those who handle it, in this case, the high priest. Milgrom, "Sacrifices and Offerings, OT," 767.

${ }^{245}$ Milgrom, Studies in Cultic Theology and Terminology, 67-69; Gane, Leviticus, Numbers, 96; Gane, Cult and Character, 50.

${ }^{246}$ Gorman, The Ideology of Ritual, 73.

${ }^{247}$ Milgrom, Leviticus 1-16, 1009-59; Hartley, Leviticus, 65; Gane, Leviticus, Numbers, 272; Gane, Cult and Character, 82-3; Kiuchi, Purification Offering, 129, 146; Kiuchi, Leviticus, 301; Averbeck,

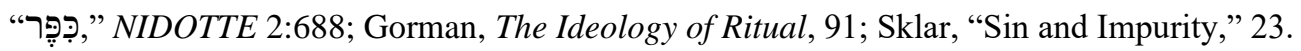




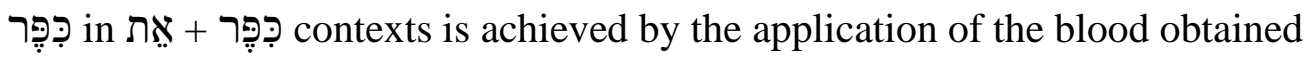

from the priests' and people's sin offering onto the most holy place, the holy place, and the sacrificial altar. Verses 20, 33 and the immediate context of Lev 16 suggest that the meaning of

\section{Wִִּּ Without Object Marker}

There are three texts where even though syntactically, the noun/s following the verb constitute its direct object (Gen 32:20 [21]; Lev 16:32; Deut 32:43). They will be treated under separate subheadings based on their contexts.

\section{Non-Cultic Contexts}

Scholars have ascribed multiple meanings to the verb רִּ such as "to cover,"248 "to purify, wipe off,"249 "to remove," 250 or "to appease"251 in Gen 32:20 [21]. ${ }^{252}$ Relying on Godfrey R. Drivers's linguistic comparative work, Levine concluded that "to wipe off' is the best meaning in this context. The present Jacob sent had a role of wiping off the wrath from Esau's face. In addition, Levine noted that Prov 16:14, "The wrath of a

\footnotetext{
${ }^{248}$ Mathews, Genesis 11:27-50:26, 554.

${ }^{249}$ Milgrom, Leviticus 1-16, 1082.

${ }^{250}$ Gane, Cult and Character, 194.

${ }^{251}$ Keil and Delitzsch, The Pentateuch, 1:303.

${ }^{252}$ Some suggest "to appease." Keil and Delitzsch, The Pentateuch, 1:303. Some, on the other hand, incorporate multiple meanings in this context. Pedersen, Israel: Its Life and Culture, 2:361; Gerhard, Genesis: 313-14; Hamilton, Genesis 18-50, 326.
} 
king is like messenger of death, but a skillful man will wipe it off," supports this meaning

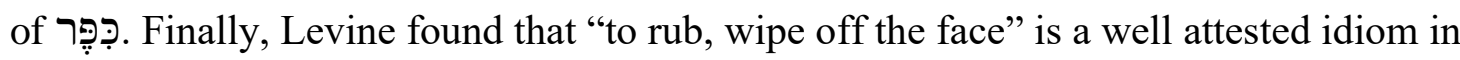
Akkadian and Aramaic texts. ${ }^{253}$ However, Yitzhaq Feder has recently suggested that in this context cannot be interpreted in a concrete sense, "to wipe off." The idiom "to rub, wipe off the face" is not an idiom at all since it is used in actual situations where a baby rubs his/her face. Thus, it is not an idiom but rather describes actual activity. ${ }^{254}$ On the other hand, Claus Westerman translated Esau's face will prevent him from seeing Jacob's guilt. ${ }^{255}$ The context undoubtedly suggests that the does not contain hints to the precise meaning of the verb. Both of these alternative meanings could fit the context of Gen 32:20 [21] but never in a concrete sense of real “wiping off” or "covering” Esau's face, but rather, in an abstract, immaterial sense of "to assuage." ${ }^{257}$ The face is used to represent anger or negative emotions in a common case of metonymy where the face is substituted with the emotions it represents. ${ }^{258}$ Two points are certain in this context: כִֶֶּּ precedes and lays the foundation for the reconciliation between the two brothers and conveys activity that is purely immaterial, abstract. Thus, it

\footnotetext{
${ }^{253}$ Levine, In the Presence of the Lord, 60-61. Milgrom also noted Akkadian parallels of the idiom "to wipe off the face." Milgrom, "Atonement in the OT," 81.

${ }^{254}$ Feder, “On kuppuru, kippēr and Etymological Sins,” 539-40.

${ }^{255}$ Westermann, Genesis 1-11, 510.

${ }^{256}$ Gane, Cult and Character, 194.

${ }^{257}$ Feder, “On kuppuru, kippēr and Etymological Sins,” 539-40.

${ }^{258}$ Feder, “On kuppuru, kippēr and Etymological Sins," 539-40.
} 
is best understood as "to assuage" or "to appease."

The text in Deut 32:43 is one of the several texts that relate כִכֶֶֶ with the land as its direct object. Defilement of the land is dealt in a very limited number of texts in the OT (Lev 18:25, 28; 20:22 by sexual immorality, Num 35:33-34 by murder, Deut 21:23 by letting the human corpse hang overnight). ${ }^{259}$ The same applies to the which is mentioned only in a single text (Num 35:33), and there is no prescribed ceremony for the רכָ כitual of the land. ${ }^{260}$ Milgrom's claim regarding the limited defiling force of the blood points in the right direction: "Blood never defiles, except if spilled illicitly (Num 35:33-34); otherwise it only purifies and sanctifies (e.g.,16:19)."261

The critical question in the context of land defilement is whether the land is defiled ritually or morally, and this question is partly answered on page 78 of the present study. Klawans clearly stated: "Indeed, in biblical law or narrative the land is never a source of or a means of transmitting ritual defilement. Rather, the land suffers a noncontagious degradation. The ultimate result of this defilement, if it remains unchecked, is the exile of the land's inhabitants. ${ }^{262}$ Milgrom also interpreted the defilement of the land in terms of being moral in its nature. ${ }^{263}$ The idiom šāpak dām is the well-attested accusation for murder in Gen 9:6 and Num 35:33, as it is in other biblical

\footnotetext{
${ }^{259}$ Milgrom, “Atonement in the OT," 81; Klawans, Impurity and Sin in Ancient Judaism, 33.

${ }^{260}$ Milgrom, "Atonement in the OT," 81.

${ }^{261}$ Milgrom, Leviticus 1-16, 749. The exception to this rule is Lev 6:20 [27] where the blood of the sin offering which is legitimately slaughtered defiles. Gane, Cult and Character, 91.

${ }^{262}$ Klawans, Impurity and Sin in Ancient Judaism, 30.

${ }^{263}$ Milgrom, "Atonement in the OT," 81; Milgrom, Leviticus 17-22, 1438. Gane also seems to side with Milgrom in believing that the land defilement is moral in nature. Gane, Leviticus, Numbers, 795-96.
} 
genres, and undoubtedly is a moral sin (genres such as narrative, Gen 37:22; 1 Sam 25:31; 1 Kgs 2:31; 2 Kgs 21:16; 24:4; legal texts, Deut 19:10; 21:7; wisdom texts, Prov 1:16; 6:17; prophetic texts, Isa 59:7; Jer 22:3, 17; Ezek 16:38; 18:10; 22:3, 4, 6, 9, 12). ${ }^{264}$ Leviticus 18:25, 28; 20:22, Num 35:33-34, and Deut 21:23; 32:43 all refer to moral sins as the defiling agency which produces non-contagious defilement. Paul Garnet accurately stated that "Yahweh's wrath against the polluted land, however, is clearly a metaphor for punishing Israel through the land for her corporate sin in tolerating evil in her midst (cf. Deut 21:9)."265

The claim that the nature of land defilement is moral is strengthened by the commandment in Num 5:1-4 that urges Israelites to send away people who were the source of defilement (lepers and persons with a discharge) or who had contracted some sort of defilement (unclean because of a dead person). The presence of those individuals in the land did not defile the land, but rather, the commandment seeks to prevent their stay in the camp and potential spreading of the contagion in the camp, and eventually, to the sanctuary. The commandment does not envision danger of land defilement, but of the people, sanctuary, and holy things.

This trend that the defilement of the land should be considered to be moral in its

\footnotetext{
${ }^{264}$ Milgrom, Leviticus 1-16, 710.

${ }^{265}$ Garnet, “Atonement Constructions," 142.
} 
nature is also adopted in the Qumran ${ }^{266}$ and tannaitic literature. ${ }^{267}$

These insights regarding the land defilement leave even fewer clues regarding the meaning of were ritual, then at least the only text that mentions contain very limited, but still some, guidelines regarding the murderer's blood onto the ground would in some way the fact that the land defilement in Num 35:33 were ritual in nature, the ritual procedure for the כִּפֶּ of the land would not be applicable to other contexts (Lev 18:25, 28; 20:22; Deut 21:23, 32:43). However, the fact that the defilement of the land is always moral in nature (Lev 18:25, 28; 20:22; Num 35:33-34; Deut 21:23) leaves no clues concerning the meaning of the כִֶֶּּ in this text. None of the most frequent alternatives for the meaning of

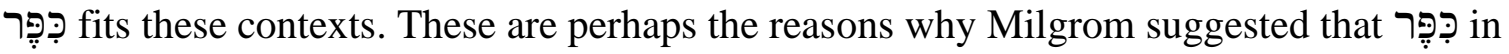
the context of the land refers to "general moral expiation."268 The current study also accepts this understanding.

\footnotetext{
${ }^{266}$ Klawans, Impurity and Sin in Ancient Judaism, 88-89. Klawan's interpretation of 1QS VIII that discusses that defilement of the land is preceded by E. P. Sanders, Paul and Palestinian Judaism: A Comparison of Patterns of Religion, 40th anniversary ed. (Minneapolis: Fortress Press, 2017), 302-3; A. R. C. Leaney, The Rule of Qumran and Its Meaning: Introduction, Translation, and Commentary (Philadelphia: Westminster Press, 1966), 217; Michael Newton, The Concept of Purity at Qumran and in the Letters of Paul, SNTSMS 53 (Cambridge: Cambridge University Press, 1985), 48; Paul Garnet, Salvation and Atonement in the Qumran Scrolls, WUNT 3 (Tübingen: Mohr, 1977), 66-67.

${ }^{267}$ Klawans, Impurity and Sin in Ancient Judaism, 120-21, 126-27.

${ }^{268}$ Milgrom, “Atonement in the OT,” 81; Milgrom, Leviticus 1-16, 1083.
} 


\section{Cultic Contexts}

The emphasis of Lev 16:32 is on the legitimacy of the high priest to perform כִֶֶּּ on the Day of Atonement along with the importance of being dressed in proper vestments, ${ }^{269}$ iִ iִ is used here in a very general way. However, the waw consecutive attached to the opening verb כִֶֶּ in Lev 16:33 has a copulative force ${ }^{270}$ and makes verbal activity of the רִִּּ conceptually and temporally related to the preceding verse, v. 32. In Lev 16:33, כִִּ takes the direct object, the three compartments of the sanctuary. Thus, based on the syntactical and conceptual relationship, the inferences one finds in Lev

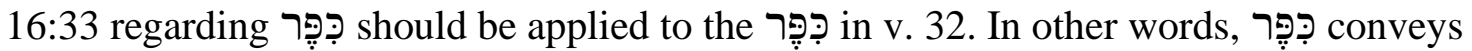
purgation in this verse, as it does in v. 33.

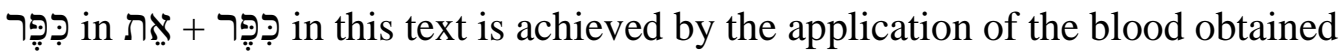
from the priests' and people's sin offering onto the most holy place, the holy place and the sacrificial altar. The syntactical and grammatical connection of v. 32 to v. 33 and the immediate context of Lev 16 suggest that the meaning of sanctuary in its totality.

\section{רִֶֶּ with Prepositions}

The prepositions used to express the indirect object of the verb כִֶֶּ are are and

\footnotetext{
${ }^{269}$ Milgrom, Leviticus 1-16, 1057.

${ }^{270}$ All the כִִּ verbal forms with the waw consecutive in Lev 16 have the same role $(16: 6,11,16$,
} 17, 18, 24, 32, 33). A resulting nuance is also present in vv. 16 and 17. Waltke and O'Connor, An Introduction to Biblical Hebrew Syntax, 547-48. 
עַ. The instances with both

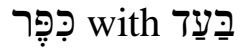

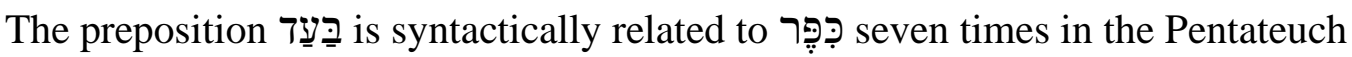
(Exod 32:30; Lev 9:7x2, 16:6, 11, 17, 24) as the following table displays. The analysis of texts is divided to cultic and non-cultic contexts (see Table 23).

\section{Table 23. The preposition}

\begin{tabular}{|c|c|c|c|c|c|}
\hline Ref. & Stem & Aspect & Type of impurity & Benefiter & Lexical construction \\
\hline Exod 32:30 & piel & Imperfect & Sin text/sinf. implied & Human & 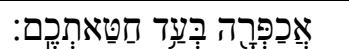 \\
\hline Lev 9:7x2 & $\begin{array}{l}\text { 1. piel } \\
\text { 2. piel }\end{array}$ & $\begin{array}{l}\text { 1. Imperative } \\
\text { 2. Imperative }\end{array}$ & $\begin{array}{l}\text { 1. sinfulness } / \text { sin poten. } \\
\text { 2. sinfulness } / \text { sin poten. }\end{array}$ & $\begin{array}{l}\text { 1. human } \\
\text { 2. human }\end{array}$ & 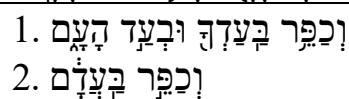 \\
\hline Lev 16:6 & piel & Perfect & sin/sinf. Implied & Human & 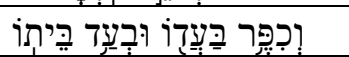 \\
\hline Lev 16:11 & piel & Perfect & sin/ sinf. Implied & Human & 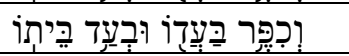 \\
\hline Lev 16:17 & piel & Perfect & sin/ sinf. Implied & Human & 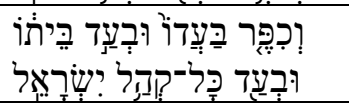 \\
\hline Lev 16:24 & piel & Perfect & sin/ sinf. Implied & Human & 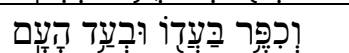 \\
\hline
\end{tabular}

\section{Non-Cultic Contexts}

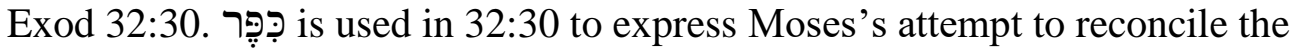
Israelites and God after their act of idolatrous worship (Exod 32:19-20). Milgrom, one of the strongest voices of "to purge" translation for רִִּּ correctly stated that conveys ransom in this context: "This kippēr must be sharply distinguished from that of the sanctuary. In the latter instance, the impurities are purged to keep them from provoking the indwelling God to leave. In the ransom cases, however, kippēr has the immediate goal 
of preventing the divine anger from incinerating innocent and guilty alike."271

The manipulation. However, the Levites killed three thousand individuals among the people, most likely the initiators and those directly involved in idolatry and resisted being corrected. Those who committed idolatry but later became sorry for their sin waited to see the resolution of their case as Moses wanted to intercede for them on the mountain. ${ }^{272}$ Moses attempted to achieve community. However, God's response in vv. 33-34 followed by his activity towards the

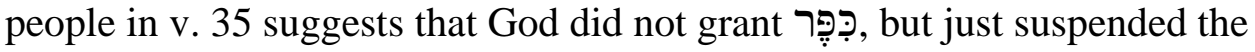

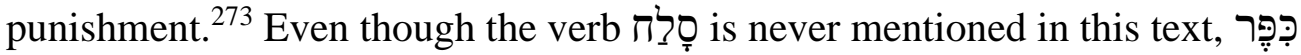
undoubtedly implied it. ${ }^{274}$ However, as was forgiveness a temporary stage.

\section{Cultic Contexts}

Lev 9:7. The context of Lev 9:7 is the inauguration of the sanctuary. ${ }^{275}$ Observing

${ }^{271}$ Milgrom, Leviticus 1-16, 1082.

${ }^{272}$ Stuart, Exodus, 684; Peter Enns, Exodus, NIVAC (Grand Rapids, MI: Zondervan, 2000), 577; Durham, Exodus, 432-33.

${ }^{273}$ Sarna, Exodus, 210; Stuart, Exodus, 684; Enns, Exodus, 577-78; Durham, Exodus, 432-33.

${ }^{274}$ Sarna, Exodus, 209; Stuart, Exodus, 684-85.

${ }^{275}$ Gane, Leviticus, Numbers, 177. 
that neither $\sin ^{276}$ nor forgiveness ${ }^{277}$ is mentioned in Lev 9 along with the fact that it is very unlikely that Aaron's sin offering is related to his sin with the golden calf in Exod $32,{ }^{278}$ Milgrom abandoned the meaning of "to wipe off, purge" for the one in this verse, and suggested "to atone." In this context, in Milgrom's opinion, it refers to the reconciliation between God and the individual/community. ${ }^{279} \mathrm{He}$ accurately stated that "the more inclusive rendering is clearly implied here," suggesting "to atone."280

Why reconciliation was needed between Aaron and his sons, on one the hand, and God, on the other, is not indicated in Milgrom's comments on Lev 9:7 as there is no comment on the meaning of after their 7-day consecration time period began, Aaron and his sons underwent a complex and rigorous process of consecration; it is very unlikely that כִֶֶּּ had to deal with a sin Aaron or his sons had committed, but rather, Milgrom indicated reconciliation. The intense 7-day consecration process could theoretically prevent Aaron and his sons from breaking the law, but they were still

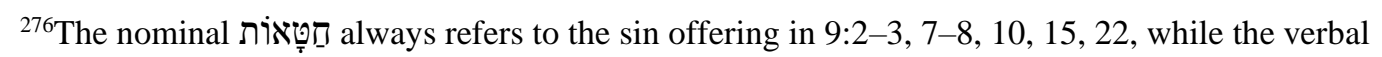
form of דָָּ (9:15) does not convey the activity of sinning, but rather, "to offer a sacrifice." Gane repeatedly understood that text of Lev 9. Gane, Cult and Character, 66, 123; Kiuchi, Purification Offering, 109.

${ }^{277}$ Kiuchi, Leviticus, 169.

${ }^{278}$ Liane Merquis Feldman, "Ritual Sequence and Narrative Constraints in Leviticus 9:1-10:3," JHS 17 (2017): 20. However, the more compelling reason why this is unlikely can be found in the fact that Moses's intercession brought atonement of Aaron's and the people's sin. Milgrom, Leviticus 1-16, 1083; Hartley, Leviticus, 148. In other words, the sin offerings Aaron offered during his seven-day time period of consecration

\footnotetext{
${ }^{279}$ Milgrom, Leviticus 1-16, 578.

${ }^{280}$ Milgrom, Leviticus 1-16, 578.

${ }^{281}$ Feldman, "Ritual Sequence," 1.
} 
humans burdened with permanent, ever present GHS ${ }^{282}$ translated in their tendency to sin and being mortal. "To atone," as the meaning of than "to wipe off." Due to the nature of GHS, it cannot be purified from the humans, but rather be atoned for in order to be tolerated by God. Metaphorically, "to cover" is also possible meaning of God. The present study prefers "to atone" since it is the verb that in the piel stem conveys immaterial activity, which better fits the dynamics of the reconciliation between humans and God that takes place on an immaterial level. In contrast, the meaning, "to cover," can be used as referring to a material activity which is not contained in the piel stem, but rather qal (Gen 6:14) and a limited number of piel contexts (Lev 16:20, 33 and 16:32 via v. 33, respectively). The figurative meaning "to cover" brings a misconception in the mind of the reader as if sin can be covered and thereby hidden from God. Rather, God accepts humans as they are on the basis of the sacrifice they offer. Nothing can preclude (cover, hide, remove) God from seeing human sinfulness. He chooses to accept it based on the atonement achieved through a sacrifice.

In addition, the use of the verb בָכָָ "to cover," is frequently used in the rest of the OT with the figurative meaning in reference to the sins, ${ }^{283}$ but never in the Pentateuch. Out of 47 uses of

\footnotetext{
${ }^{282}$ Hartley, Leviticus, 18; Rooker, Leviticus, 152; Gane, Leviticus, Numbers, 179-80. Kiuchi referred to the state of creation before the common becomes holy. He termed it the state of uncleanness. He clarified that that state is sinfulness. Kiuchi, Purification Offering, 42-44; Kiuchi, Leviticus, 168-69; Wenham, The Book of Leviticus, 148.

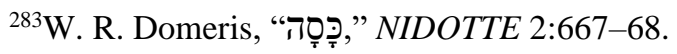


11) and three have the meaning "to hide" (Gen 18:17, 37:26; Deut 13:8), while all the rest have the literal meaning "to cover" (Gen 7:19-20; 9:23; 24:65; 38:14-15; Exod 8:6; 10:5, $15 ; 14: 28 ; 15: 5,10 ; 16: 13 ; 21: 33 ; 24: 15-16 ; 26: 13 ; 28: 42 ; 29: 13,22 ; 40: 34 ;$ Lev. 3:3, 9, $14 ; 4: 8 ; 7: 3 ; 13: 12-13 ; 16: 13 ; 17: 13 ;$ Num 4:5, 8-9, 11-12, 15; 9:15-16; 16:33, 42; Deut 22:12; 23:13). כָָּסָה is never used in reference to sins in the Pentateuch.

in this context is achieved by the application of the blood obtained from the priests' and the people's sin offerings, burnt offerings, and the people's peace offering on the sacrificial altar. The offerers are both the priests and the people. Since Lev 9 does not mention ritual or moral impurity, רִּ deals with the GHS of the offerers.

Lev 16:6, 11, 17, 24. Texts in Lev 16 contain a syntactical construction: כִֶֶּּ referring to Aaron and his household in vv. 6, 11, 17, 24 while the people of Israel are included in vv. 17, 24. The last part of v. 15, "and bring its blood inside the veil and do with its blood as he did with the blood of the bull, and sprinkle it on the mercy seat and in front of the mercy seat," confirms that the blood applied to those items was the same blood obtained from the people's and Aarons' sin offering, as stated in v. 14. It cleanses the sanctuary. ${ }^{284}$ Milgrom's point that persons other than the subject, but when the subject wishes to refer to himself he must use b̆ 'ad (e.g., 9:7; 16:6, 11, 24; Ezek 45:22)."285 This is not confirmed by Lev 9:7 and 16:6, 11, 24. Aaron does not refer to himself only, but also to all the whole people, as

${ }^{284}$ Milgrom, Leviticus 1-16, 1009-59; Kiuchi, Purification Offering, 129, 146; Gorman, The

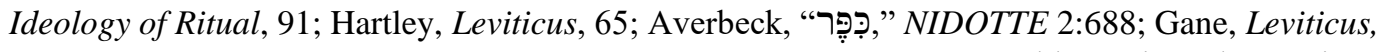
Numbers, 272; Gane, Cult and Character, 82-3; Kiuchi, Leviticus, 301; Sklar, "Sin and Impurity," 23.

${ }^{285}$ Milgrom, Leviticus 1-16, 255. 
already noticed by Janowski ${ }^{286}$ and Kiuchi. ${ }^{287}$

Analogous to the previous ritual in Lev 9, the ritual in Lev 16 does not disclose that any particular sin is committed by Aaron or the people in the immediate context, but in contrast to the ritual in Lev 9, the ritual of Lev 16 deals with the cleansing of the sanctuary compartments from the sins committed by both Aaron and the people (Lev 16:16-20, 33). The (vv. 6, 11, 17) and burnt offering (v. 24). The preposition פֵַ is is best translated as "on behalf of or for." ${ }^{288}$ Accordingly, Aaron and the people are offerers - not direct, but rather, indirect or final recipients of כִִּ ${ }^{289}$

The the people because it was their sins from which the sanctuary was Milgrom's comment on Lev 16:17 reflects the same conclusion: "The waw introduces the purpose of the high priest's rites in the shrine, thereby making it similar in function to wěkipper in v 16, which stated the purpose of the high priest's rites in the adytum."290

Thus, the following pattern can be detected. When and/or the people, the texts always use the preposition $(16: 6,11,17,24)$ and the reference is to the cleansing of the sanctuary on their behalf. The same pattern is detected

\footnotetext{
${ }^{286}$ Janowski, Sühne als Heilsgeschehen, 188n23.

${ }^{287}$ Kiuchi, Purification Offering, 88-89.

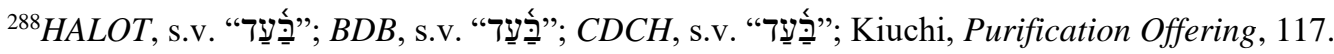

${ }^{289}$ Kiuchi, Leviticus, $168-69$.

${ }^{290}$ Milgrom, Leviticus 1-16, 757.
} 
in non-cultic texts, Exod 32:30. The sacrifices from which the blood was obtained do change. That is, in all other texts except v. 24, the blood is obtained from the sin offering, while in v. 24, it was obtained from the burnt offering. The blood of the sin offerings was used to cleanse the sanctuary's compartments, but the blood of the burnt offering was offered only on the sacrificial altar. Its blood was not used to cleanse the sanctuary. However, object of this verb.

This means that One goal is the cleansing of the sanctuary on behalf of Aaron and the people $(16: 6,11$, $17,24)$ and it is achieved by the application of the blood obtained from Aaron's and people's sin offerings. The other goal is achieved through the offering of Aaron's and the people's burnt offerings (16:24) and does not deal with sins. They were already 16), and their sins were sent away from the camp on Azazel's goat (v. 22). The present study suggests that the second goal of כְִֶּ is to atone for GHS of Aaron and the people of Israel whom he represents in God's presence. This exclusive goal of the by the burnt offering. As established above, GHS is an ever-present condition causing human beings to be in constant need of two goals when it is syntactically associated with the preposition cleansing of the sanctuary from the committed sins which simultaneously bring ultimate רִּ to those who committed those sins (Aaron, the priests, and the people), and (2) it atones for Aaron's and the people's GHS whom he represents in God's presence. 


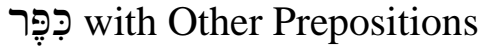

There are two more prepositions that are syntactically associated with the verb

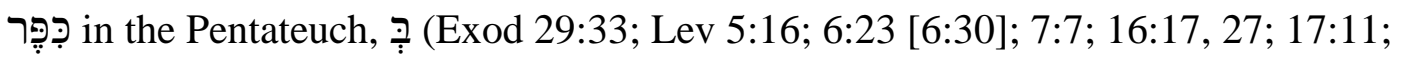
19:22; Num 5:8) and ?? (Num 35:33; Deut 21:8x2).

\section{Non-Cultic Contexts}

Two texts, Num 35:33 and Deut 21:8, contain the construction ? + + Nợ 35:33, in regards to the כִֶֶּּ of the land, gives no clues as what means in this text. As discussed on p. 445 of the present study, none of the most frequent meanings, "to wipe off" or "to cover," or others fit this context. It seems that כִֶֶּּ should be understood here as Milgrom suggested as "general moral atonement." The preposition ? marks the agent of a passive verb. ${ }^{291}$

The construction ? + + + is used two times in Deut 21:8, and the context suggests that people of the nearest city to the place the murder took place. ${ }^{292}$ This can partly be inferred by the lexical choice for the meaning of the preposition. ? marks the indirect

\footnotetext{
${ }^{291}$ Waltke and O'Connor, An Introduction to Biblical Hebrew Syntax, 210n84; Joüon and Muraoka, A Grammar of Biblical Hebrew, 456.

${ }^{292}$ Wright's interpretation "that the rite is a reenactment of the murder which transfers bloodguilt from the inhabited land and the people to an innocuous locale" seems to be well supported. David P. Wright, "Deuteronomy 21:1-9 as a Rite of Elimination," CBQ 49 (1987): 393-94; Tigay, Deuteronomy, 472, 475, 476; Gane, Cult and Character, 61-62.
} 
object in this text with a datival goal. ${ }^{293}$ This text is considered non-cultic, In other words, the killing of the red heifer is not sacrifice since it is not sacrificed on the sacrificial altar, nor does the ritual include a gesture in the direction to the sanctuary as the Num 19 ritual does (v. 4) ${ }^{294}$ However, the guilt elimination does not seem to include the entire semantic range of רִּ in this context. Since the people of the closest city provided the animal that served to reenact the murder and atone for the people's guilt of murder, the red heifer served as their ransom. Milgrom summarized כֶֶָּּ in this context as follows: "In cases in which the murderer is unknown, the community closest to the corpus delicti must disavow complicity by breaking a heifer's neck over a perennial stream so that its blood is washed away. In this case the heifer serves as the substitute for the slain and a ransom for the suspected community.” Accordingly, meanings: (1) it atones the guilt of the people of the city closest to the place of murder and (2) it ransoms the people of the closest city for their suspected guilt.

\section{Cultic Contexts}

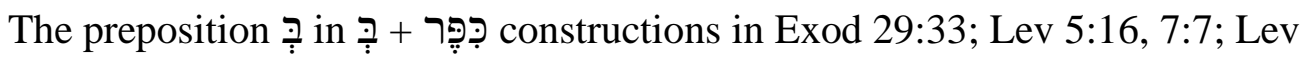

17:11b; 19:22 and Num 5:8 is beth instrumenti, conveying the means by which the רִּ has been achieved. ${ }^{295}$ Exodus 29:33 lays out the details concerning the consecration of

\footnotetext{
293“'The goals here include a thing made." Waltke and O'Connor, An Introduction to Biblical Hebrew Syntax, 209.

${ }^{294}$ Gane, Cult and Character, 61. Additional argument can be found in Wright, "Deuteronomy 21:1-9," 390-92; Tigay, Deuteronomy, 473.

${ }^{295}$ Kiuchi, Purification Offering, 89-90; Milgrom, Leviticus 1-16, 706-7; Milgrom, Leviticus 1722, 1478; Gane, Cult and Character, 130, 137, 262.
} 
the sanctuary, altar, and priesthood. This text demonstrates that

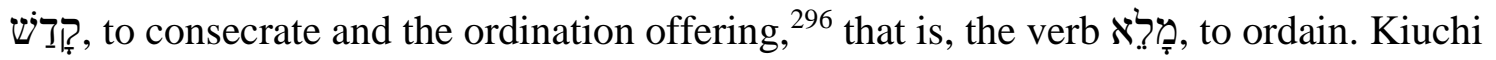
suggested, among others, that

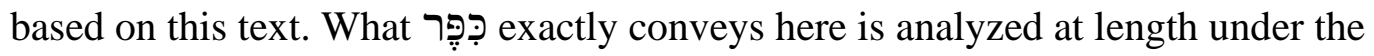
subheading, "The Consecration of the Priests: Aaron and His Sons," on pp. 492-96 of the present study. The blood in the applied differently. Blood from the sin offering was applied on the altar's horns and its base. Blood from the burnt offering was applied around the altar. Blood from the ordination offering was applied to Aaron's and his sons' right ears, the thumbs of their right hands, on the big toes of their right feet, and blood, along with the anointing oil, was sprinkled on their garments. Finally, the rest of the blood was applied around the altar. Moses was officiating at the entire ritual and offered all the sacrifices.

Leviticus 5:16 shows that noted that the כִֶֶּּ achieved by the reparation offering, along with the burnt offering, the well-being offering, and the ordination offering refers to the general expiation. ${ }^{299}$ This text also exhibits a syntactical relationship between the offering and the verb סָלָ.

\footnotetext{
${ }^{296}$ Kiuchi, Purification Offering, 95.

${ }^{297}$ Kiuchi, Purification Offering, 97-8.

${ }^{298}$ Milgrom, Leviticus 1-16, 709; Gane, Cult and Character, 143.

${ }^{299}$ Milgrom, Leviticus 1-16, 331, 1083.

${ }^{300}$ Hartley, Leviticus, 80; Gane, Cult and Character, 194.
} 
offering. ${ }^{301}$ It atones for the offerer since he/she has committed sin. Gane compellingly noted the abstract nature of this process by stating that this removes reme hindrance that prevents the divine-human relationship. ${ }^{302}$ However, this atonement, removal of the hindrance, is based on the concept of ransom, as discussed in the analysis of Lev 17:11. God accepts ransom in the form of the animal's life-blood instead of the offerer's lifeblood, and the offerer is atoned for, which includes the removal of the hindrance from their relationship with God. The reparation offering is offered in the cases of offences which includes literal/quantifiable debt. ${ }^{303}$ These offences include misappropriation of the

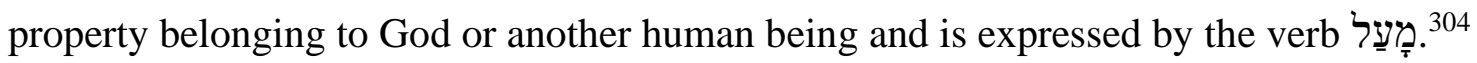
The property is restored first, along with a $20 \%$ (one fifth) penalty, and then blood from this offering is applied around the altar ( $\operatorname{Lev} 7: 2)$.

The construction of $\underset{ְ}{\mathfrak{y}}+$ + כִ in Lev 6:23 [6:30] and 16:17, 27 is beth loci and marks the location of the verbal action. ${ }^{305}$ Like the previous group of texts where $\underset{:}{*}$ functions as beth instrumenti, this group of texts where $\underset{?}{?}$ acts as a beth loci also does not lend much insight into the meaning of רִִּ

The construction $\underset{?}{\mathfrak{y}}+$ in Lev 7:7 is a part of the regulation regarding the part of the sacrificial animal that belongs to the priest. The officiating priest who performs the

\footnotetext{
${ }^{301}$ Gane, Cult and Character, 130; Milgrom, Leviticus 1-16, 410.

${ }^{302}$ Gane, Cult and Character, 196.

${ }^{303}$ Gane, Cult and Character, 66.

${ }^{304}$ Gane, Leviticus, Numbers, 132.

${ }^{305}$ Kiuchi, Purification Offering, 89-90; Milgrom, Leviticus 1-16, 706-7; Gane, Cult and Character, 137.
} 
ritual that achieves sameness of the reparation and sin offering is limited to which part of the sacrificial animal belongs to the priest. The phrase, "there is one law for them," does not imply generalization $^{306}$ since the difference between the two sacrifices is implied in the blood application of the two offerings. With the reparation offering blood is applied around the altar, while with sin offering, it is applied to the altar's horns (Lev 7:2). The offerer is not stated since chapters 6-7 focus on the details regarding the sacrificial process that concern the priesthood, rather than the laity; this is reversed in chs. $1-5 .^{307}$

The only new element inferred from Lev 19:22 and Num 5:8 is found in the latter text which regulates to whom the restitution of the defrauded property will be given if the person of a defrauded property dies and leaves no kinsman. It belongs to the officiating priest. $^{308}$

Finally, the analysis above of the role of $\underset{i}{\mathfrak{i}}$ in Lev 17:11b confirmed that be is beth essentiae or beth instrumentii. The blood in this text is obtained from all sacrifices, as it is traditionally believed that this is what the text deals with. This further implies that this text is achieved for situations where sin in the sense of act (sin and reparation offering) was or was not involved (burnt and well-being offering). The general language of this text suggests that it is a general statement ${ }^{309}$ and the offerer and the exact way

\footnotetext{
${ }^{306}$ Milgrom, Leviticus 1-16, 410.

${ }^{307}$ Milgrom, Leviticus 1-16, 382.

${ }^{308}$ Milgrom, Leviticus 1-16, 382; Gane, Leviticus, Numbers, 520.

${ }^{309}$ Kiuchi, Purification Offering, 105-6.
} 
blood is applied to the altar (around the altar or on the altar's horns) remains unspecified.

This text depends on the previous material in Lev 1-7 for the ritual flow of each sacrifice.

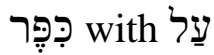

This grammatical construction of everything analyzed so far is the most

frequently used in the Pentateuch. It occurs 56 times, always in cultic contexts. A detailed study of all occurrences is not necessary since the current study accepts that עַ of advantage is operative in 47 of them ${ }^{310}$ as scholarly research shows. However, some texts in particular, Exod 29:36-37; 30:10; Lev 8:15; 14:53; and16:10,16, 18 do require a detailed analysis since the meaning of the construction in them is debated and affects the meaning of בִֶּּ The only non-cultic context of these is Lev 14:53.

Milgrom has postulated the following proposition regarding the רֶֶּ followed with עַ and other prepositions that accompany it:

When the object is nonhuman, For example, all three usages are attested to in the purging of the adytum on the Day of Purgation (Lev 16:16, 20), and they must be understood literally, for the kipper rite takes place on ('al) the kapporet and on the floor before it, in (b) the adytum, or it can be said that the entire room ('et) is purged (kipper; cf. also 6:23; 16:10, 33; Exod 30:10), (Janowski 1982: 185 n. 5, who claims that kipper 'al always means "expiate for," must entertain the absurd idea that sancta [and the scapegoat, 16:10] are capable of sinning [see Milgrom 1985d: 302-4].) (11 $^{311}$

When the object of kipper is a person, however, it is never expressed as a direct object, but requires the prepositions 'al or be 'ad. Both signify "on behalf of" (16:6, $24,30,33$; Num 8:12, 21), but they are not entirely synonymous. The difference is that 'al can only refer to persons other than the subject, but when the subject wishes

${ }^{310}$ Cultic contexts include: Exod 30:15-16; Lev 1:4; 4:20, 26, 31, 35; 5:6, 10, 13, 16, 18, 26 [6:7]; $8: 34 ; 10: 17 ; 12: 7-8 ; 14: 18-21,29,31 ; 15: 15,30 ; 16: 30,33-34 ; 17: 11 ; 19: 22 ; 23: 28$; Num. 5:8; 6:11; 8:12, 19,$21 ; 15: 25,28 ; 17: 10-11[16: 46-47], 28: 22,30,29: 5,31: 50$. The only non-cultic context is Num 25:13.

${ }^{311}$ Gyung-Yul Kim, "The Hattat Ritual and the Day of Atonement in the Book of Leviticus" (PhD diss., University of Pretoria, 2013), 26. 
to refer to himself he must use bě ad (e.g., 9:7; 16:6, 11, 24; Ezek 45:22). This distinction is confirmed by Job 42:8: "Offer a burnt offering for yourselves (bě 'adkem) and Job, my servant, will intercede on your behalf ( 'ălêkem)" (Milgrom 1970b). This means the purgation rite of the hatta ${ }^{\prime} t$ is not carried out on the offerer, but only on his behalf. ${ }^{312}$ Milgrom translates the former with "to effect purgation for" and "to effect purgation on" for the latter. ${ }^{313}$

I first highlight what is correct and then, the assertions that are partially or totally incorrect. First, Milgrom correctly stated that אֶּ never marks the object of object is human. Second, his criticism of Janowski ${ }^{314}$ is valid since the present study also maintains the idea that the nature of רפְִּ 's object affects its meaning, and that that inanimate object is not capable of committing sin. Third, Milgrom is right that the עַל + construction means "on behalf of or for" when the object is human. It refers to advantage. ${ }^{315}$

First, Milgrom's claim that the preposition עֵת and the direct object marker "must be understood literally" is misleading, since his literal meaning of עַ and refers only to their spatial, locational sense, which singles out one meaning from their multiple meanings. The instrumental meaning is a possibility in Lev 16:10, which makes more sense since the goat for Azazel's role was to receive the sins on itself and take them away from the camp, and that was just part of the crucial blood manipulation in the sanctuary. Accordingly, the instrumental sense of

\footnotetext{
${ }^{312}$ Milgrom, Leviticus 1-16, 255.

${ }^{313}$ Kim, "The Hattat Ritual," 26.

${ }^{314}$ That Janowski also noted the sameness of Janowski, Sühne als Heilsgeschehen, 231-32.

${ }^{315}$ Waltke and O'Connor, An Introduction to Biblical Hebrew Syntax, 217.
} 
would have a more precise meaning and fitting choice in this context, since it would refer to the specific role of this goat and not the entire process.

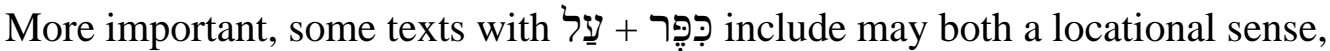

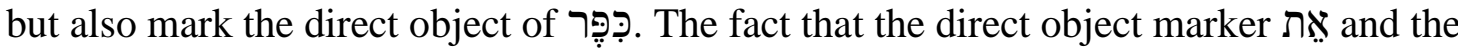

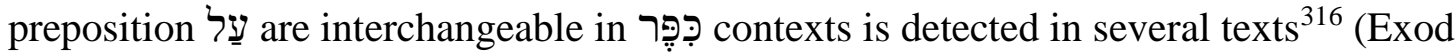
29:36=Lev 8:15, Exod 13:19=Lev 5:22, Lev 3:3, 9, 14; 7:3=Lev 4:8, Lev 16:20 =v. 33, also in Lev 4:14, 5:5, 22, 24, 7:12, 8:9 עַ functions as which disproves Milgrom's claim that עַ should be understood literally as referring to spatial, locational meaning. Accepting the fact that these two prepositions are sometimes equivalents removes the illogical reading of Lev 16:16. If a spatial, locational sense of עַ is accepted the beginning of this verse should read, "thus he shall purge on the sanctuary."317 Taking in 16:16 to function as the direct object marker of כִֶֶּּ harmonizes this verse with Lev 16:20 in which כִֶֶּּ is associated with אֶּ to the express logical translation, "when he has finishes purging the sanctuary," the sense of a direct object. Both texts refer to the cleansing of the sanctuary. Regardless of claiming that עַ must be translated "literally,"

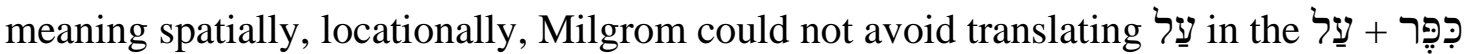

\footnotetext{
${ }^{316}$ This has been noted by Joshua Vis which I came across after I submitted my dissertation. Joshua M. Vis, "The Purgation of Person through the Purification Offering," in Sacrifice, Cult, and Atonement in Early Judaism and Christianity: Constituents and Critique, eds. Henrietta L. Wiley and Christian A. Eberhart., RBS 85 (Atlanta: SBL Press, 2017), 33-34.

${ }^{317}$ Kiuchi also noted this incongruity. However, he noted that עַ can also function as a direct object marker, but missed applying this inference to other texts where that is the case as is done in the present study. Rather, he suggested that there is no difference between resulted in the conclusion that
} 
construction in Lev 16:16 as a direct object marker. ${ }^{318}$ Texts in Lev 14:53 319 and 16:18 ${ }^{320}$

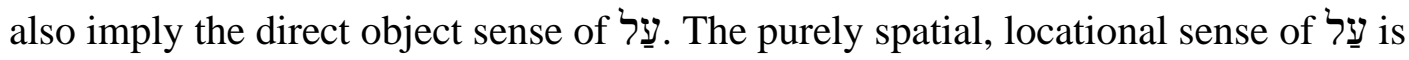
definitely found in Exod 30:10 as Milgrom claimed, but not in all other text cited.

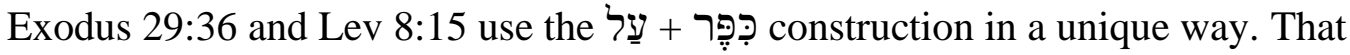
is, both functions, spatial and locational indicator, and direct object marker, of the preposition עַ are found in these two corresponding texts, the former being prescriptive, and the latter being descriptive. The first clause of v. 36 is a transitional clause. The noun

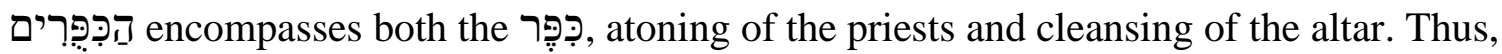
the temporal infinitive of the עִ בִּפְּר construction,

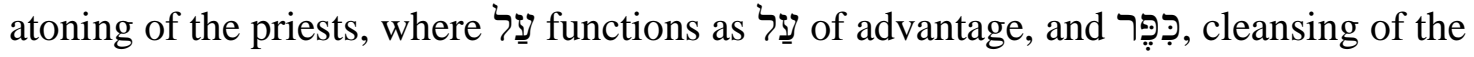
altar, where עַ functions as the direct object marker.

To confirm his literal locational sense of $\underset{?}{\text { Ta }}$ to mean "in," he cited only one text, Lev 6:23, which is definitely the correct meaning. He could also have cited 16:17, 27. However, other texts that have the

upholds the crucial difference of the nature of Purification Offering, 89-90, 92-93.

${ }^{318}$ Milgrom, Leviticus 1-16, 1009-10.

${ }^{319}$ Not recognizing that עַ הֵת are equivalents in the Milgrom supplied the following translation of the beginning of this verse which retains the spatial, locational sense of עַy,., "Thus he shall perform purgation upon the house," instead of a more logical and fluid, "Thus he shall purge/cleanse the house," with the direct object sense of עַ Milgrom, Leviticus 1-16, 829.

\footnotetext{
${ }^{320} \mathrm{He}$ took the similar route for translating this text: see Milgrom, Leviticus $1-16,876$.
} 
instrumental sense: Exod 29:33; ${ }^{321}$ Lev 7:7; ${ }^{322}$ and Num 5:8. ${ }^{323}$ Thus Milgrom's postulate regarding the preposition $\underset{?}{\mathfrak{T}}$ 's spatial, locational sense is not textually proven and excludes the instrumental sense that is the natural choice in more texts than the spatial, locational.

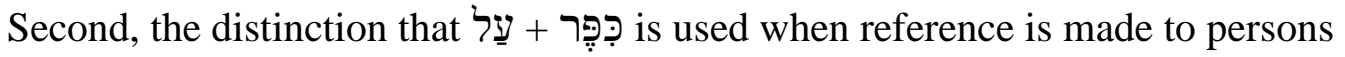
other than the subject and that disproved by Lev 9:7; 16:6;11;24 where is used and the texts refers to Aaron

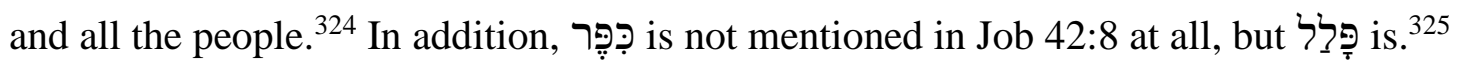
The use of a different verb does not mean that certain structural patterns cannot be established and applied to different contexts that include different verbs, but a passing note, as Milgrom did, is not sufficient to make a sound case. More texts that contain the same structural pattern need to be cited with verbs that contain the same verbal type.

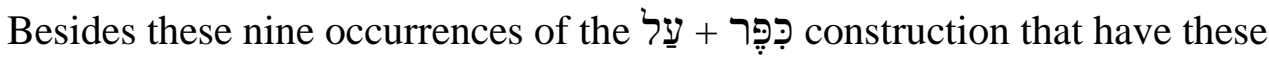
specific meanings, the rest of the 47 occurrences (Exod 30:15, 16; Lev 1:4; 4:20, 26, 31, $35 ; 5: 6,10,13,16,18,26$ [6:7]; 8:34; 10:17; 12:7, 8; 14:18, 19, 20, 21, 29, 31; 15:15, 30;

\footnotetext{
${ }^{321}$ Milgrom, contradicting himself, affirmed the instrumental sense of the preposition $\underset{?}{9}$. Milgrom, Leviticus 1-16, 528, 534, 540-41, 707-8.

${ }^{322}$ Milgrom's translation, "it shall belong to the priest who performs expiation therewith," again shows that he was not able to avoid the instrumental sense of ?ִ̣, again contradicting himself here. Milgrom, Leviticus 1-16, 380-81. Emphasis mine.

${ }^{323}$ In this text, Milgrom again affirmed the instrumental sense of the preposition ᄁִ.. Milgrom, Leviticus 1-16, 707-8.

${ }^{324}$ Kiuchi, Purification Offering, $88-89$.

${ }^{325}$ Piel: judge, execute judgment, expect (H7136); פָּל (pālal I B), hithpael: pray (Prayer:

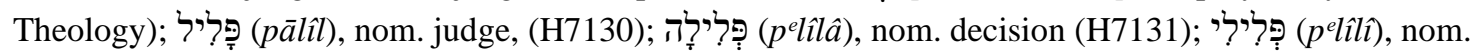

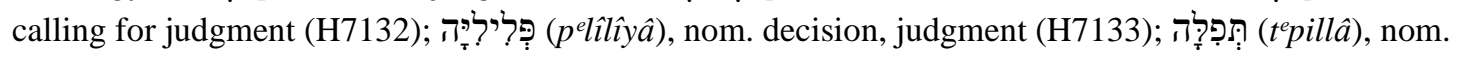

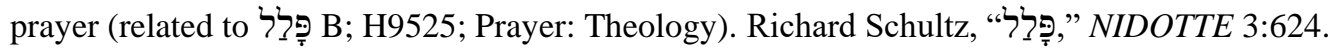


$16: 30,33,34 ; 17: 11 ; 19: 22 ; 23: 28 ;$ Num $5: 8 ; 6: 11 ; 8: 12,19,21 ; 15: 25,28 ; 16: 46,47$;

$25: 13 ; 28: 22,30 ; 29: 5 ; 31: 50)$ provide a large variety of ways in which

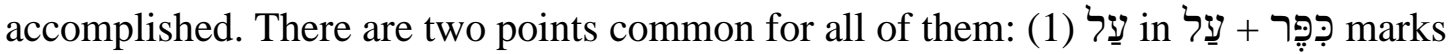
the indirect object that receives the advantage of the verb it is associated with, and (2) the

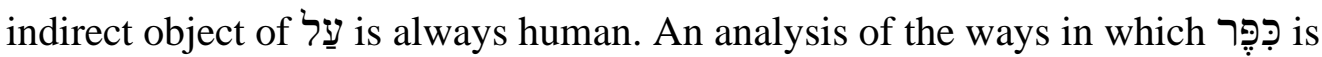

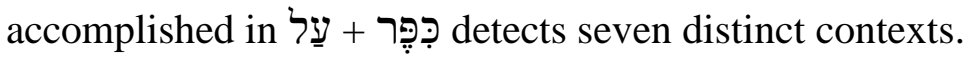

First, in a significant number of texts, through a sin offering only, which means that the blood is obtained from this offering (Lev 4:20, 26, 31; 5:6, 11; 10:17;12:7, 8; 15:15, 30;16:10,16, 18). Most of these texts imply that the offerer is somehow associated with ritual (Lev 12:7-8; 15:15, 30) or moral (Lev 4:20, 26, 31) impurity or that רִִּּ atones for GHS (Lev 10:17). Location of the blood application in this context is prescribed in Lev 4 and depends on the offerer's societal status. In the case of the priest or the entire community, it takes place either in the first compartment of the sanctuary (blood is sprinkled in front of the veil that separates the two compartments, applied on the horns of the incense altar, and the rest is poured out at the base of the sacrificial altar) or on the sacrificial altar (blood is applied on its horns and the rest is poured out at its base).

Second, 1:4; Num 28:30), implying that the blood is obtained from this offering. These contexts do not relate any impurity to the offerer and thus, GHS. The blood is applied around the sacrificial altar regardless of the societal status.

Third, in in 
only in some texts (Lev 5:13,18,26;19:22; Num 5:8). The procedure of making a reparation offering was presented in Lev 7:1-7. The blood obtained from this offering is applied around the altar regardless of societal status, just like the burnt offering. These texts always relate moral impurity to the offerer who makes this sacrifice. They come to

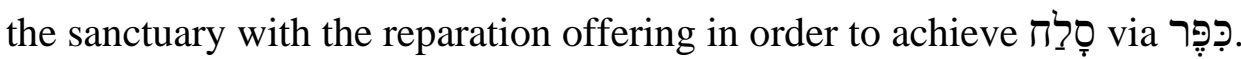

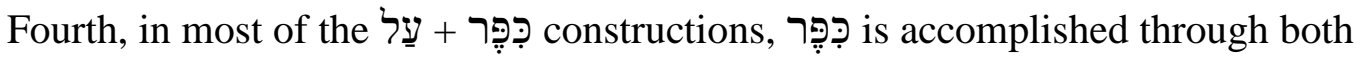
sin and burnt offering (Exod 29:33, 36, 37; Lev 8:15, 34; 10:17, 16:10, 16, 18, 30, 33, 34; 23:28; Num 8:12, 21; Num 15:25, 28; 28:22, 30; 29:5). Based on their contexts, these texts can be divided into groups: (1) consecration ritual, (2) cleansing ritual, and (3) forgiveness ritual. All of them are analyzed below under the subheading concepts, and for that reason, they are not analyzed here.

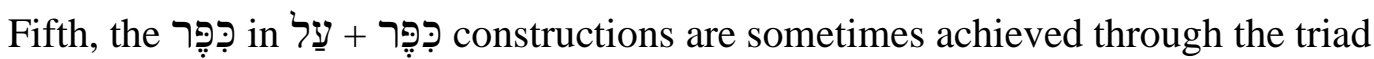
of sin, burnt, and reparation offering (Lev 14:18, 19, 20, 21, 29, 31; Num 6:11). These are also comprehensively analyzed below under the subheading and for that reason they are not analyzed here.

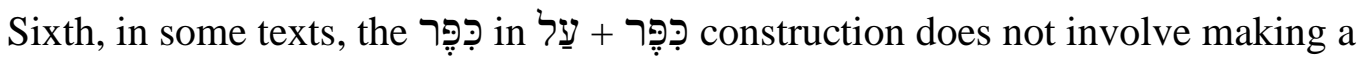
sacrificial offering, but rather, (1) bringing the money to the sanctuary (Exod 30:15-16), (2) Aaron's mediation with the censer and incense among the people (Num 17:11-12 [16:46-47]), (3) killing an Israelite and Midianite woman (Num 25:13), or (4) bringing articles of gold and other valuable items (Num 31:50).

Seventh, some texts totally depend on other texts for the ways in which achieved (Exod 30:10). 


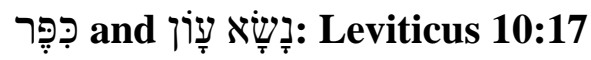

Eating of the sin offering meat by the officiating priest in the context of offering the sin offering is an inseparable element of the כִֶֶּּ on the behalf of the offerer and is

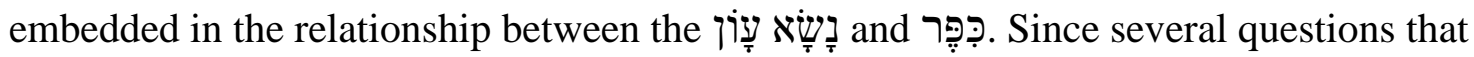

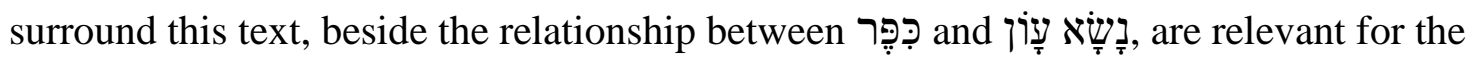
present study, they are all studied here.

\section{The Meaning of Priests' Eating of Sin Offering Flesh}

That is, Lev 6:19 [26], 22 [29] and 7:6 state that an officiating priest receives and is obligated to eat the remaining flesh of sin offering when he offers it on behalf of another Israelite. The meaning of this ritual has also generated a significant amount of attention by scholars. ${ }^{326}$ Two key questions that permeate the scholarly discussions concerning the ritual gesture of the priests' eating of the flesh of the outer altar sin offering are (1) does this gesture contribute to the expiation process, and (2) if it does, whether it plays an additional or simultaneous role in the process of expiation $?^{327}$

\section{Does Eating of the Sin Offering Flesh Contribute רֶֶ?}

As to the first question, the history of the interpretation of the sin offering shows that the majority of scholars who stripped the priests' eating of the edible sin offering flesh of any expiatory significance claim that sin offering flesh is just a priest's reward

${ }^{326}$ Levine, In the Presence of the Lord, 103-4; Gane, Cult and Character, 91-105; Wright, The Disposal of Impurity, 132-35; Kurtz, Offerings, 228-30; Rodríguez, "Substitution in the Hebrew Cultus," 130-36; Kiuchi, Purification Offering, 46-52.

${ }^{327}$ Gane, Cult and Character, 91; Milgrom, Leviticus 1-16, 624. 
for his ministry. ${ }^{328}$ This was Milgrom's position initially, but an extensive scholarly dialogue made Milgrom change his position on the meaning of this ritual gesture in the course of his scholarly career. ${ }^{329}$

This was irrefutably one of the reasons, but not the only, nor the major one. ${ }^{330} \mathrm{I}$ trace the change of Milgrom's understanding of this activity since it includes relevant arguments for the position that eating of the sin offering is crucial in the pִ̣ process.

He used to follow A. Ehrlich who suggested a different meaning of Lev 10:17b, namely, "and he has given it to you for bearing the responsibility of the community by performing purgation rites on their behalf before the Lord." נָשָָׁא would not refer to the priests' bearing the sins of the people, but rather, to bearing the responsibility of the entire community through their performing of expiatory rites on their behalf before the Lord. The flesh of edible חָטָטאת, based on such an understanding of this verse, would be just a reward or wage for the priests' service. ${ }^{332}$ Two arguments are crucial for the change of Milgrom's opinion on both of these points.

${ }^{328}$ Kurtz, Offerings, 228; Janowski, Sühne als Heilsgeschehen, 239n272; Kiuchi, Purification Offering, 47, 51; Jacob Milgrom, "Two Kinds of Hațtā't," VT 26 (1976): 333-34. For a more elaborate list of proponents of this view see Kiuchi, Purification Offering, 47n33, especially.

${ }^{329}$ Milgrom, “Two Kinds of Hatṭā' t,” 333-34; Milgrom, Leviticus 1-16, 261-64.

${ }^{330}$ Rad, Old Testament Theology, 1:248; Rodríguez, "Substitution in the Hebrew Cultus,” 131.

${ }^{331}$ Arnold B. Ehrlich, Randglossen zur Hebräischen Bibel: Textkritisches, Sprachliches und Sachliches (Leipzig: J. Hinrichs, 1908-14), 2, 37; A. W. Knobel, Die Bücher Exodus and Leviticus (Leipzig: S. Hirzel, 1880); Wright, The Disposal of Impurity, 133; Milgrom, Leviticus 1-16, 623. Others also follow this interpretation of eating of the 58. Leviticus, 51.

${ }^{332}$ Wright, The Disposal of Impurity, 133; Milgrom, “Two Kinds of Hatṭā t,” 333-34; Porter, 
First, he recognized that the praxis of the elimination of impurity by the means of ingestion was known in some cultures. ${ }^{333}$ Yet, the argument streaming out of the comparison of the two geographically distant cultures is quite methodologically unsound.

Second, a natural next step for Milgrom was to reconsider his understanding of the function of edible חַטָּאת, which he used to think was a priestly reward for their service. ${ }^{334}$ The change of his opinion on this point seems to be adequately established in contrast to the first point. He pointed to Rodríguez's dissertation ${ }^{335}$ where the following quotation by Knierim is found as the initial source for his change of opinion:

Eine Übertragung auf den 'āwōn Begriff ist aber kaum möglich; denn "Verantwortung" ist ein wertneutraler, unqualifizierter Begriff. Das aber ist bei 'āwōn nie der Fall. 'āwōn ist immer qualifiziert. In den gennanten Stellen (Numb 18:1. 23; Ezek 18:19) wird man darum nś' 'āwōn nicht allgemein mit "verantwortlich sein," sondern mit "für die ‘āwōnōt verantwortlich sein, sie zu tragen haben" übersetzen. ${ }^{336}$

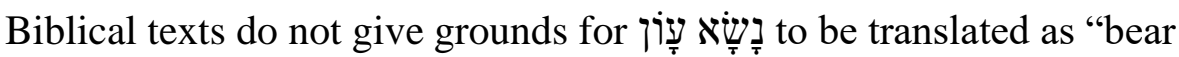

responsibility" since responsibility is value-neutral and unqualified term. On the contrary,

\footnotetext{
${ }^{333}$ In his previous works he used to claim that such a ritual gesture was never known in the Ancient Near East. Milgrom, "Two Kinds of Hatțā't," 333-34. Later, supposedly upon more extensive research, he claimed that such praxis was known in other cultures such as Hinduism and in England. Milgrom, Leviticus 1-16, 624. Such cases did not exist in ancient Greece. Parker, Miasma: Pollution and Purification in Early Greek Religion, 283. Milgrom also cited a slightly different case found in the incantation tablet from Nimrud, Iraq, tablet number ND.5577 found in the ruins of the Ezida Temple, in a pit in N.T. 12 in 1956, where the sick man ate dough which evidently absorbed his illness and thereby eliminated it from his body, bringing his health back. E. E. Knudsen, “An Incantation Tablet from Nimrud,” Iraq 21 (1959): 54-55, 59. In this case, it is an inanimate object, not another human being, that absorbs the illness, not an impurity, from the sick man's body.

${ }^{334}$ Wright, The Disposal of Impurity, 133n22.

${ }^{335}$ Rodríguez, "Substitution in the Hebrew Cultus," $134 \mathrm{n} 2$.

${ }^{336}$ Knierim, Die Hauptbegriffe für Sünde im Alten Testament, 220. Cited in Rodríguez, "Substitution in the Hebrew Cultus," 134. My translation: "A transfer [of the meaning] to the 'āwōn term is hardly possible however. For responsibility is a value-neutral, unqualified term. Yet this is never the case with 'āwōn. 'āwōn is always qualified. In the mentioned places (Num 18:1, 23; Ezek 18:19) nś' 'āwōn will therefore not be generally translated as "be responsible," but as "be responsible for the 'āwōnōt, to have to carry them." Kiuchi also follows Knierim on this. Kiuchi, Purification Offering, 50-51.
} 
, עִּוֹנֵת is always a qualified term and should be translated as "to be responsible for the to have to carry them." Thus, it seems that the priests are not merely to bear "responsibility," but "responsibility for the sins of the Israelites," which they would take upon themselves via ingesting the flesh of the edible sin offering.

Milgrom himself discovered additional and very critical points to support his newly accepted position. If the flesh of the edible sin offering were just to be a reward for their ministry, then Moses's anger at Aaron's sons would be difficult to explain. Leviticus 10:17-18 actually encloses the requirement of eating the sin offering flesh, which would further indicate that there is an expiatory significance in that ritual gesture ${ }^{337} \mathrm{He}$ also correctly noted that the frequency of eating of the sin offering flesh by the priests would be much higher than burning it up outside the camp. Two sets of stipulations found in the Pentateuch would most likely happen rarely in the life of Israel, that is, the case of the anointed priest committing a sin that would put the entire community, including himself, (Lev 4:3-21) and the annual cleansing of the sanctuary on Yom Kippur (Lev 16:27) in jeopardy. In all other instances the priest would eat the flesh of the sin offering. ${ }^{338}$

The priest had to eat, at least a part of, the sin offering flesh and/or by the help of his fellow priests. Milgrom found that rabbis in their dictum also confirmed this (Sipra, Shemini 2:4b; Pesah 59b; Yoma 68b; Yebam 40a, 90a). He also rightfully pointed out the fact that cultic legislation demands that laypersons burn the rest of their sacrifices which

\footnotetext{
${ }^{337}$ Wright, The Disposal of Impurity, 133n22.

${ }^{338}$ Milgrom, Leviticus 1-16, 637.
} 
they were not able to eat for the duration of the holy feasts: the Passover (Exod 12:10a, 12b; 23:18, 34:25; Num 9:12; Deut 16:4), the thanksgiving offering (Lev 7:15; 22:30), the well-being offering (Lev 7:17; 19:6), the ordination offering (Lev 8:32; Exod 29:34the priests were still lay persons here). Absence of such an implicit command in regards to sin offering flesh points to the fact that the priest had to eat its flesh in order to complete the process of expiation. ${ }^{339}$

\section{Incident in Lev 10}

The scholars who stripped the priests' eating of the sin offering flesh of any expiatory value point to the fact that the priests' not eating of the sin offering flesh in the incident in Lev 10 did not invalidate the people's sin offering. ${ }^{340}$ However, Lev 10:19 suggests that failure to follow the ritual procedure was not an accident, but rather, a deliberate decision by Aaron. ${ }^{341}$

The rationale for the failure to follow the ritual procedure is stated in the text, but at least two valid responses were suggested, besides others which are not defensible. ${ }^{342}$ First, Aaron possibly felt that he and his sons were not worthy of ingesting the flesh of the sin offering since they were the object of severe condemnation by God, ${ }^{343}$ or the death

\footnotetext{
${ }^{339}$ None of the sets of instructions concerning expiatory sacrifices, namely the cereal offering offered as a sin offering, sin offering and reparation offering (Lev 6:9, 11, 19, 22; 7:6; 10:12-13, 17-18) include the rule about burning their leftovers. They obviously had to be eaten. Milgrom, Leviticus 1-16, 638.

${ }^{340}$ Ellinger, Leviticus, 139; Kiuchi, Purification Offering, 47; Gane, Cult and Character, 92.

${ }^{341}$ Milgrom, Leviticus 1-16, 635-36; Gane, Cult and Character, 92.

${ }^{342}$ Milgrom, Leviticus 1-16, 636.

${ }^{343}$ Gane, Cult and Character, 92.
} 
of Nadab and Abihu before the Lord-within the sanctuary, ${ }^{344}$ contaminated both the sin offering by severe impurity, making it unsafe for the priests to ingest it, and the entire sanctuary which needed immediate cleansing. ${ }^{345}$

Gane added that the sole incident in which the priest did not eat the meat of the sin offering or in other words, did not follow ritual procedures in exceptional and unique circumstances, does not give grounds for the claim that eating of the sin offering meat does not have an expiatory role. ${ }^{346}$

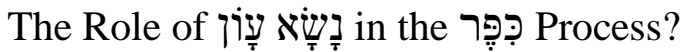

Regardless of the weaknesses of Ehrlich's view, he seems to be right in his understanding of the verb נשיא in the sense of "bear" rather than "remove," since Knierim noticed that the Hebrew does not make a terminological distinction between bearing consequences of one's actions and bearing them for someone else. He claims that "dieser Wechsel des Trägers wird nicht durch eine andere Begrifflichkeit, sondern nur durch

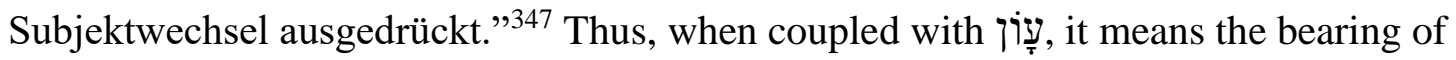
culpability, and this immediately asks for the response to the question: "What happens to the priest as a result of bearing the people's culpability?"348

Schwartz's work on how the priest is freed from bearing the people's culpability

${ }^{344}$ Milgrom, Leviticus 1-16, 600.

${ }^{345}$ Milgrom, Leviticus 1-16, 639.

${ }^{346} \mathrm{Gane}$, Cult and Character, 92.

347، This change of the bearer is not expressed by a different terminology, but only by change of subject." Knierim, Die Hauptbegriffe für Sünde im Alten Testament, 53.

${ }^{348}$ Gane, Cult and Character, 101. 
is helpful. That is, as it was presented on p. 197 of the present study, based on his study of the phrase נִשֶָ and its equivalents ${ }^{349}$ in the Pentateuch, he strongly argued against the traditional understanding that in the contexts dealing with the consequences or forgiveness of sin, these phrases do not convey two distinct meanings, that is, suffer punishment or forgive sin, respectively. Rather, they were employed to express metaphorically the objective fact of legal guilt in terms of bearing or carrying sin, conceiving the wrongdoing as an object to be dragged around as a burden. ${ }^{350}$ The first usage identified by Schwartz is a sinner who himself bears his own sin, and these phrases indicate that he/she deserves and may suffer the consequences, if there are any. In this case, it is a metaphor of sinner liability/culpability. The second usage is associated with the situations when another party, God or other human being, bears the sinner's burden; that is, it does not rest on the sinner's shoulders anymore. In this case the phrases are a metaphor for the sinner's release from his/her liability/culpability. Thus, the phrases do not have two different meanings, but rather two different uses with only one meaning. ${ }^{351}$ Schwartz's study shows that the two uses of these phrases differ not only by their subject, but also by the sense in which they employ נשא. In case of a consequential bearing of sin, the sinner carries it, which may kill him/her by human or divine agency if it remains unsolved. If someone else bears the sinner's sin, the second party does not bear

\footnotetext{
${ }^{349}$ The two equivalents are נשא חטא a נשא פשע. Schwartz, "The Bearing of Sin," 8.

${ }^{350}$ Schwartz, "The Bearing of Sin,” 15; Gane, Cult and Character, 102.

${ }^{351}$ Schwartz, "The Bearing of Sin," 9-15.
} 
it for it disappears. In this case נשיא means "carry off, take away, remove."352

Following this pattern and keeping in mind the fact that the carriers of $\sin$ in Lev

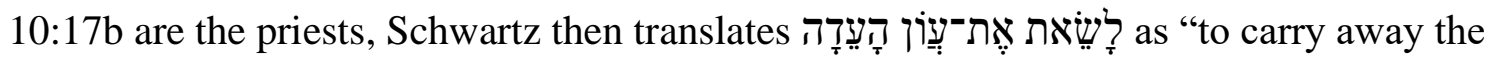
transgressions of the community." ${ }^{\circ 353}$ The priests take away the culpability of the people so that the people do not carry it. In spite of the strength of his arguments, Schwartz's study fails to explain adequately how culpability, transferred to someone else from the sinner who is liable for it, simply disappears. The consequences for the secondary sinbearer are not explicitly stated, but that does mean that the secondary sin-bearer does not, at least temporarily, carry them. ${ }^{354}$

Koch claims that the priests were to remove עָּוֹ from Israel or from the sanctuary, bear it as God's representatives, and by virtue of their own inherent quality, render it harmless (Exod 28:38; Lev 10:17; Num 18:1, 23). ${ }^{355}$ Koch believed that the priest's inherent quality, which makes them immune to culpability of the people, is divinely derived holiness conferred on the priests and their vestments at their consecration ceremony. ${ }^{356}$ Koch also found that the high priest, through confession and laying on of hands on the head of the scapegoat, transfers the culpability onto it so that the scapegoat is now the one who bears the culpability (Lev 16:21f). ${ }^{357}$ Contrary to Schwartz's

\footnotetext{
${ }^{352}$ Schwartz, "The Bearing of Sin," 10.

${ }^{353}$ Schwartz, "The Bearing of Sin," 16.

${ }^{354}$ Gane, Cult and Character, 103.

${ }^{355}$ Koch, "עון," TDOT 10:559.

${ }^{356}$ Koch, “עון," TDOT 10:560.

${ }^{357}$ Koch, “עון," TDOT 10:559.
} 
understanding of the meaning of these phrases based on the points presented by Koch, it could be argued that these phrases do have distinct meanings, that is, (1) to suffer punishment or (2) to forgive sin.

W. Zimmerly made a difference between bearing sin with God himself as a subject, which is found in non-cultic contexts, and cultic usage in which the priests ingest the sin offering flesh. ${ }^{358}$ It seems that the fact of God's bearing sin without an after-effect on him would potentially pave the path for the possibility of the priest's bearing another person's עָ עָ in order to achieve expiation that is prerequisite to divine forgiveness. ${ }^{359}$ The

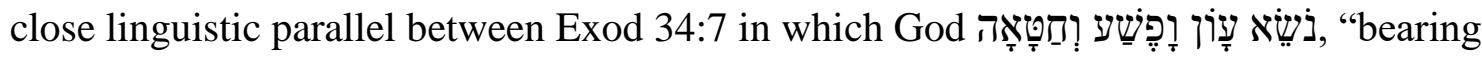
iniquity and transgression and sin," and Lev 10:17, in which the priest bears confirm this possibility. Consequently, the priest's eating of the sin offering flesh also conveys his participation in the process of God's granting forgiveness to the sinner. ${ }^{360}$

\section{How Is Sin Offering Both Holy and Impure?}

A number of scholars have denied any expiatory significance to the ritual of priestly eating of sin offering meat ${ }^{361}$ based on the claim that the sin offering is holy (Lev 6:18 [25], 22 [29]; 10:17). They have not accepted the potential impure status of the sin offering flesh. ${ }^{362}$ In other words, impurity and holiness cannot coexist in the sin offering.

${ }^{358}$ Zimmerli, “Zur Vorgeschichte von Jesaja LIII,” 239.

${ }^{359}$ Gane, Cult and Character, 104.

${ }^{360}$ Gane, Cult and Character, 104.

${ }^{361}$ Kurtz, Offerings, 240; Dillmann and Ryssel, Die Bücher Exodus and Leviticus, 463-64, 517.

${ }^{362}$ Noordtzij, Numbers, 79-80; Kurtz, Offerings, 228-30, 240-41; Dillmann and Ryssel, Die Bücher Exodus and Leviticus, 463-64; Budd, Leviticus, 116; Kiuchi, Purification Offering, 119. 
Based on Lev 4:20, 26, 31, 35, Dillmann claimed that expiation was achieved with no further aid by the priest's eating of sin offering flesh. Eradication of sin is not needed after forgiveness is granted. Nevertheless, this claim disregards important supplementary regulations of the sin offering sacrifice found outside of Lev 4, namely in Lev 6:19 [26], 22 [29]; 10:17; and 16:26-28. Based on these texts, eradication of sin, after forgiveness has been granted, is a required element of the expiation process and is accomplished either via eating of the sin offering flesh by a priest or burning it outside of the camp. ${ }^{363}$ It has been rightfully argued that sacrificial regulations found in Lev 1-5 are written from the offerer's perspective and Lev 6-7 from the priest's perspective, which explains why a priest's eating of the sin offering is not listed among other sin offering regulations in Lev $4 .{ }^{364}$ The complete range of the sin offering regulations found in the OT includes eradication of sin, as well as forgiveness.

In addition, Milgrom pointed out that the priest's ingestion of sin offering flesh becomes even more crucial due to the fact that sin offering was associated with impurity. The priest was the embodiment of holiness, while to the contrary, was the embodiment of impurity. An occasion of the priest's consuming the sin offering delivers an insightful theological statement, that is, "holiness has swallowed impurity, life can defeat death." 365 The priest's invulnerability to impurity stands in apparent contrast to the sanctuary's vulnerability to any form of it. As long as he is within that same sanctuary,

\footnotetext{
${ }^{363}$ Milgrom, Leviticus 1-16, 624-25; Wright, The Disposal of Impurity, 133.

${ }^{364}$ Gane, Cult and Character, 91-92; Milgrom, Leviticus 1-16, 134.

${ }^{365}$ Milgrom, Leviticus 1-16, 638.
} 
the priest is resistant to impurity. As soon as he leaves it, his immunity is revoked. Thus, Milgrom reasoned: "Impurity pollutes the sanctuary, but it does not pollute the priest as long as he serves God in the sanctuary." 366

Milgrom finally pointed to the fact that the laws of impurity (Lev 11-15) intentionally follow the incident of Nadab and Abihu. This speaks about the seriousness of impurity since the entire tent had to be cleansed after this incident, but at the same time, it speaks for the fact that, through uninterrupted service of the priests, holiness is more powerful than impurity. ${ }^{367}$

Kiuchi also further noted that it would be inadequate to assume that the congregation somehow defiled the sanctuary in the context of Lev 9 before the sin offering ritual. ${ }^{368}$ In addition, he recognized that the plain sense of the preposition $ל$ in (Lev 10:17b) "to bear/remove" is that of purpose, ${ }^{369}$ conveying that the eating of

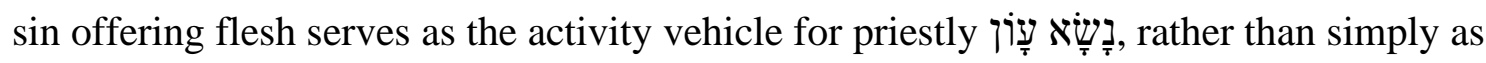
a prerequisite for the earlier bearing of officiating responsibility. ${ }^{370}$ This means that the sin offering retains its holiness besides the fact that it contains impurity.

\section{Does Sin Offering Refer to the Sin Offering Flesh or the Entire Sacrifice?}

Kiuchi echoed the claim of Kurtz, who agreed with Hoffman that the phrase "he

\footnotetext{
${ }^{366}$ Milgrom, Leviticus 1-16, 638-39.

${ }^{367}$ Milgrom, Leviticus 1-16, 639.

${ }^{368}$ Kiuchi, Purification Offering, 50.

${ }^{369}$ Kiuchi, Purification Offering, 48.

${ }^{370}$ Gane, Cult and Character, 101.
} 
has assigned it to you" does not refer to the eating of the sin offering flesh, but to the entire sin offering. ${ }^{371} \mathrm{He}$ arrived at this conclusion by claiming that Lev 6:19 [26]; 6:23 [30] sin offering refers to the whole offering, not just flesh of it. ${ }^{372}$ Janowski also claimed that "to remove iniquity of the community," clarified by "to effect purgation on their behalf," refers to the priestly mediatory role for Israel through effecting expiation for them via sin offering as a whole. ${ }^{373}$

However, in this context, it does not refer to the entire sin offering ritual, which would include blood application, but rather, to the flesh of the sin offering, the remainder of the sacrificial animal, which can be eaten. Here, החטשת is accompanied by the direct object marker which makes it the direct object of the verb אכל as the Hebrew text shows. Also, at this point of the event in Lev 10, נתן לכם could not refer to God's assigning the victim to the priest so they could apply blood to the altar since the animal was already God's property by the time of the blood application and he, consequently, assigned the flesh to the priests Lev $6: 10[17] ; 7: 32,34,36 .{ }^{374}$ It is not the entire sin offering in question here, but rather, the flesh portion of it which God allotted to the priest. Contrary to Kurtz's understanding, Gane presented a structural analysis of Lev $10: 17 \mathrm{~b}$ where he found that the first part of the bipartite structure begins with the

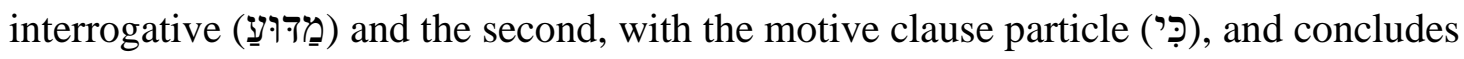

\footnotetext{
${ }^{371}$ Hofmann, Der Schriftbeweis, 2:281. Cited in Kurtz, Offerings, 242.

${ }^{372}$ Kiuchi, Purification Offering, 48.

${ }^{373}$ Janowski, Sühne als Heilsgeschehen, 239n272.

${ }^{374}$ Gane, Cult and Character, 95.
} 


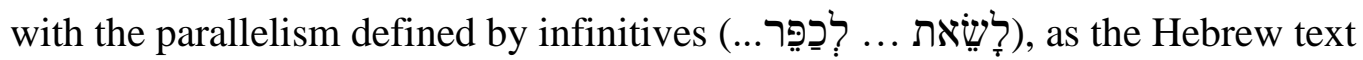
shows. $^{375}$

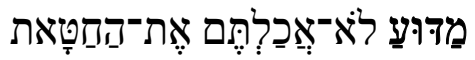

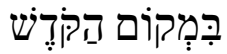

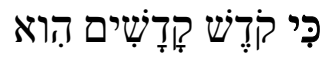

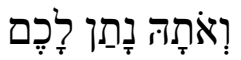

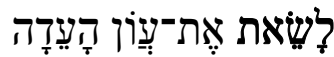

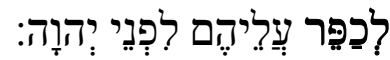

In addition, there is also chiastic correspondence between the two parts of the

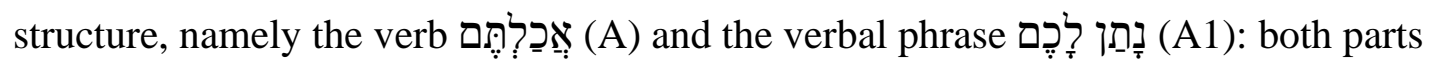
contain a verb and a second-person address referring to the priests, and the noun הַקדת

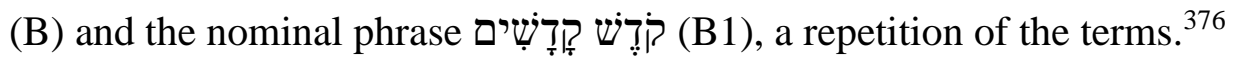

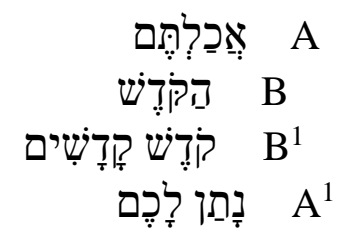

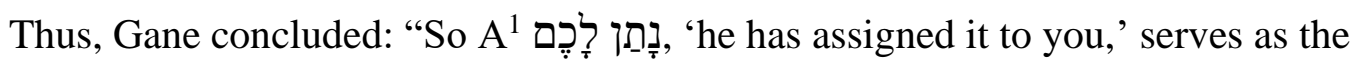

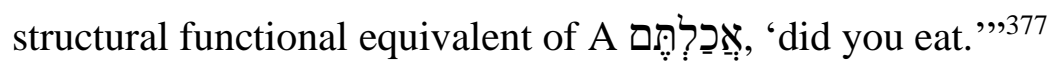

Finally, Gane found another chiasm in the opening texts of the two parts of the

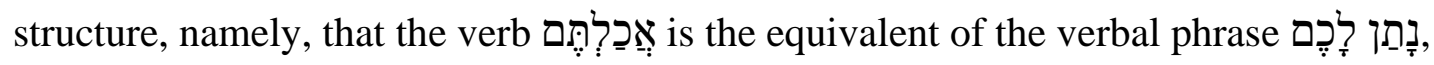

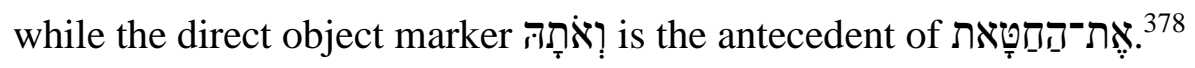

\footnotetext{
${ }^{375}$ Gane, Cult and Character, 94.

${ }^{376}$ Gane, Cult and Character, 94.

${ }^{377}$ Gane, Cult and Character, 94.

${ }^{378}$ Gane, Cult and Character, 95.
} 


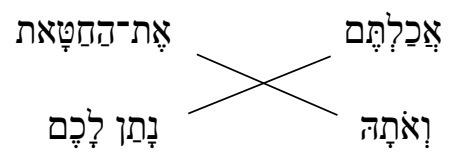

Thus, it seems plausible that the last part of the verse is related to the eating of the sin offering flesh. The context of the text makes it clear that the eating of the sin offering is in question here, so repetition of the verb אָכָ is not necessary. ${ }^{379}$

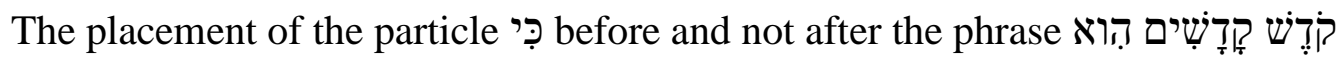
does not support the claim that this part of the verse affirms the holy status of the sin offering due to its contribution to the expiation process. It has been suggested that its holy status is determined by the place of its ingestion, that is, within the tent of meeting. ${ }^{380}$ However, it seems that besides other cultic objects that are not inherently holy, ${ }^{381}$

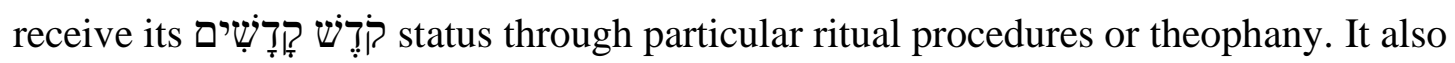

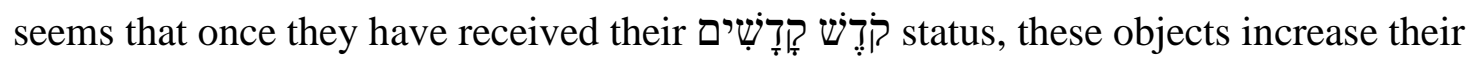
holiness via contact with the holy tabernacle. ${ }^{382}$

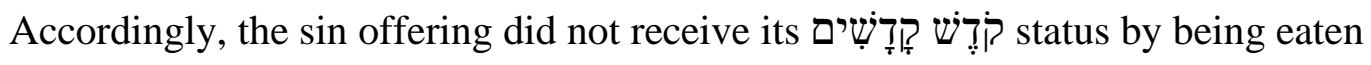

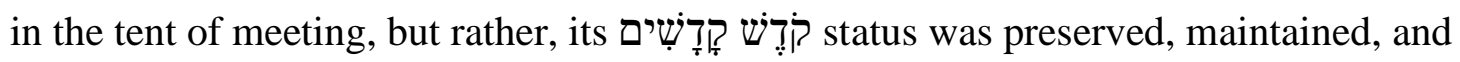

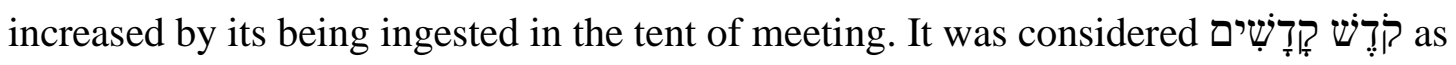
soon as it was devoted to the Lord; God has assigned it with that status. This is

\footnotetext{
${ }^{379}$ Gane, Cult and Character, 95.

${ }^{380}$ Gane, Cult and Character, 95.

${ }^{381}$ Tabernacle and the most holy furniture and offerings. Wright, "Holiness (OT)," 3:244.

${ }^{382}$ Wright, "Holiness (OT)," 3:244.
} 
particularly emphasized in Exod 30:10 3 atas and Num 18:19. The initial קדש קדשים of the sin offering was assigned to it even before the tent of meeting (ritual spatiality) existed.

קדֶֶׁש This is also true for the outer, sacrificial altar recorded in Exod 29:37: the status of the outer altar was achieved by the rites of consecration.

The guidelines in Exod 30:22-29 suggest that the tent of meeting itself including the ark of the covenant, the table and all its utensils, the lampstand and its utensils, the altar of incense, the altar of burnt offering with all its utensils, and the basin with its

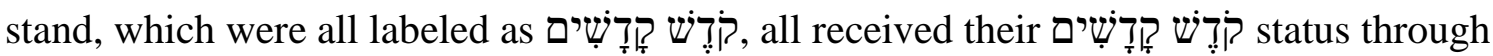
the consecration service-ritual procedures performed by Moses (Exod 40).

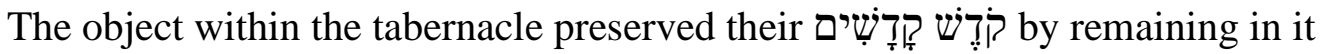
and its courtyard. The initial sanctification of the tabernacle was consummated by God's arrival into the most holy place and continuance of the sanctifying effect of the tabernacle was also conditional on God's presence in the most holy place. ${ }^{384}$

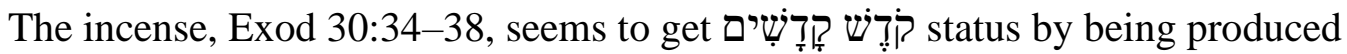
following particular procedures God has revealed. The same applies to the bread of presence, based on ritual procedures for its production found in Lev 24:9.

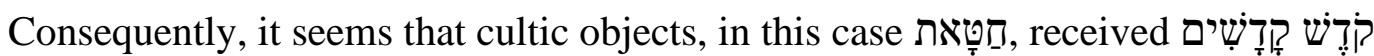
status through particular ritual procedures they would undergo directed by God and

\footnotetext{
${ }^{383}$ The entire process of expiation on the Day of Atonement was summed under one, collective sin offering and is labeled "sin offering" in this text. Gane, Cult and Character, 20.

${ }^{384}$ Wright, "Holiness (OT)," 3:245.
} 
preserved and potentially increased their status by remaining in the holy tabernacle.

Some correctly maintain both elements, that is, the sin offering flesh was a

compensation to the priests for their service, but also essential to the expiation process. ${ }^{385}$

\section{How Does Eating of the Sin Offering Flesh Contribute to the Pִֶֶּּ Process: Simultaneously or Separately/Additionally?}

Besides some scholars who did not see any expiatory significance in the priest' eating of the sin offering flesh, ${ }^{386}$ some who accept the expiatory function of the priest'

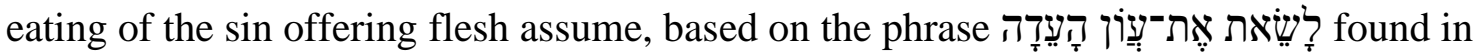
Lev 10:17, that this ritual activity actually removed of the evil absorbed in the sin offering flesh. ${ }^{387}$

Y. Kaufmann suggested that the priest's eating and incinerating the sin offering flesh are alternative ways of eliminating impurities. ${ }^{388}$ Milgrom followed this, as well, but suggested that the rationale for the two types of elimination of the sin offering flesh was due to the amount of impurity accumulated in it as the following quotation shows:

By requiring that the hatt $\bar{a}^{\prime} t$ be eaten, Israel's priests were able to affirm that the power to purge the sanctuary does not inhere in a ritual but is solely dependent on the will of God. Moreover, they backed up their conviction by their act: they ate the hatt $\bar{a}^{\prime} t$ and were willing to suffer the consequences if their conviction proved wrong.

${ }^{385}$ Gane, Cult and Character, 94-95; Levine, Leviticus, 62; Milgrom, Leviticus 1-16, 622-25, 635-40; Snaith, Leviticus and Numbers, 56, 80; Yitzhaq Feder, Blood Expiation in Hittite and Biblical Ritual: Origins, Context, and Meaning, WAWS 2 (Atlanta: Society of Biblical Literature, 2011), 70-71.

${ }^{386}$ Noordtzij, Numbers, 79, 114-15.

${ }^{387}$ Keil and Delitzsch, The Pentateuch, 2:355; Milgrom, Leviticus 1-16, 623-25, 637-39; Budd, Leviticus, 156; Levine, Leviticus, 62-63.

${ }^{388}$ Gane, Cult and Character, 97; Yehezkel Kaufmann, תולדות האמונה הישראלית [Toldot HaEmunah HaYisraelit The Religion (Belief) of Israel], 4 vols. (Jerusalem: Bialik, 1937-56), 1:568. Strongly opposed understanding by Snaith, Leviticus and Numbers, 56, 80. 
Yet their faith was not without its limits: the hațta 't prescribed for the deep pollution of the sanctuary, when its blood was brought into the shrine, continued to be burned. The pollution incurred by Israel's brazen sins and impurities, which had infested the very seat of the Godhead in the Holy of Holies ... was just to lethal to be ingested. ${ }^{389}$

The outer altar sin offering contained a low level impurity and was safe for the priests to ingest it, while the outer sanctum sin offering, which supposedly contained Israel's brazen sins and impurities which penetrate to the holy of holies, was too harmful for the priest to ingest. ${ }^{390}$ This claim by Milgrom also conveys the change of his opinion on the transferability of impurity, since he previously held that impurity was not transferable to the sin offering and that it was just as a reward to the priests for their ministry. ${ }^{391}$

However, Gane correctly noted that there is a weakness in the claim that the reason for not eating the sin offering flesh of a higher-level impurity was because of the priest's fear, due to limitations of their faith. ${ }^{392}$ Based on the principle that the priests could not benefit from their own expiatory sacrifices, ${ }^{393}$ the outer sanctum sin offering flesh could not be eaten even though their blood sometimes was only applied to the outer altar and not to the outer sanctum (Exod 29:14; Lev 8:17; 9:11). ${ }^{394}$

Gane also pointed to the fact that the inner-sanctum sin offering on the behalf of

${ }^{389}$ Milgrom, Leviticus 1-16, 637.

${ }^{390}$ Wright, The Disposal of Impurity, 132-33.

${ }^{391}$ Gane, Cult and Character, 97; Milgrom, Leviticus 1-16, 637.

${ }^{392}$ Gane, Cult and Character, 97-98.

${ }^{393}$ Milgrom, “Two Kinds of Hatțā’t," 337; Rodríguez, "Substitution in the Hebrew Cultus," 13536; Hasel, "Studies in Biblical Atonement-I," 103.

${ }^{394}$ Milgrom, Leviticus 1-16, 264. 
the community on the Day of Atonement (Lev 16) was not eaten, but burned up outside of the camp even though the high priest was not included in the offering party, contrary to the regular outer sanctum sin offering in Lev 4:12-21. The high priest performed a separate sacrifice for himself and his household. The fact that he did not eat the sin offering flesh of the community's sacrifice points to the fact that, potentially, the "consumption of the purification offering flesh serves to involve the officiating priest in the process by which Yhwh extends forgiveness to the offerer." 395

Before expanding this proposal, Rodríguez's unique interpretation of the priest's eating of the sin offering flesh should be mentioned here. Rodríguez claimed that the priest's eating of the sin offering flesh of the edible sin offering is equivalent to the sprinkling of the outer sanctum sin offering blood. ${ }^{396}$ His claim results from the fact that the outer sanctum sin offering ritual contains a sevenfold sprinkling in front of the veil, while the priests ingest the outer altar sin offering flesh. Gane stated that Rodríguez's understanding that these two ritual activities as equivalent was based on the fact that, in Lev 9:8-11, the inauguration offering on behalf of Aaron (and his sons) involved only the application of the blood to the outer altar, but yet, was incinerated outside the camp. Gane did not provide a reference from Rodríguez's work for such a claim. ${ }^{397}$ The blood was not sprinkled inside the tent of meeting, but the sin offering flesh was properly burned up

\footnotetext{
${ }^{395}$ Gane, Cult and Character, 98; Rodríguez, "Substitution in the Hebrew Cultus," 135-36; Milgrom, "Sacrifices and Offerings, OT," 766.

${ }^{396}$ Gane, Cult and Character, 98; Rodríguez, "Substitution in the Hebrew Cultus," 133-35; Milgrom, "Sacrifices and Offerings, OT," 766; Wright, "The Spectrum of Priestly Impurity," 133n22.

${ }^{397}$ Gane, Cult and Character, 99.
} 
instead of eaten. ${ }^{398}$ On the other hand, the sin offering of the community was also offered at the outer altar with no sprinkling in the tent of meeting but, it was Nadab's and Abihu's tragic death that caused it not to be eaten (Lev 10:16-20). Otherwise, the priest would have eaten it, since Moses expected it to be eaten by the surviving priest. ${ }^{399}$

Gane claimed that eating or not eating the sin offering flesh was not due to the presence or absence of sprinkling of the blood in the outer sanctum, but rather, if the offerer was a priest or layperson. The reason for the incineration rather than eating of the priest's inaugural sin offering is based on the principle that a priest who officiates at his own expiatory sacrifice cannot benefit from it. ${ }^{400}$ Gane stated that the rule in 6:23[30] which states that no sin offering of which blood was brought into the Tent of meeting may be eaten by the priest excludes the priestly ingestion of outer sanctum or inner sanctum sin offering flesh. It does not, as Rodríguez assumed, say that every outer altar sin offering must be eaten. According to Gane, the sin offering flesh was not necessarily to be eaten by the priest according to the regulation in Lev 6:23[30], but because Moses thought that it should be, as the following quotation shows: "When Moses cites this rule in 10:18 to assert that the priests should have eaten the inaugural offering of the community because its blood was not brought inside the sanctuary, he is saying that an

\footnotetext{
${ }^{398}$ Gane, Cult and Character, 98; Rodríguez, "Substitution in the Hebrew Cultus,” 135-36.

${ }^{399}$ Gane, Cult and Character, 99.

${ }^{400}$ Rodríguez, "Substitution in the Hebrew Cultus," 135-36; Snaith, Leviticus and Numbers, 56; Milgrom, "Two Kinds of Hatțā't," 337; Hasel, "Studies in Biblical Atonement-I," 103.
} 
outer altar (not outer sanctum) purification offering of the community (not of the priests) should be eaten." ${ }^{401}$

These two arguments are unsound. First, one of the crucial differences between the two types of sin offering is the absence or presence of the blood sprinkling inside of the sanctuary. The first two cases in Lev 4:2-21, for the high priest and the entire people, include sprinkling of blood inside of the outer sanctum, and the sacrifice is incinerated outside the camp, while the last two cases in Lev 4:22-35, the leader or a commoner, do not include it, and the officiating priest eats the flesh of the sin offering.

Milgrom's rationale for the comprehensiveness of the regulation in Lev 6:23[30] and its impact on Lev 10:17 is sound:

Some commentators feel that this rule applies only to the previously mentioned purification offerings (4:1-21; Ibn Ezra, Ramban), but its generalized formulation argues for greater comprehensiveness. This rule also explains Moses' rebuke of Aaron for not eating the purification-offering goat sacrificed on the day the regular Tabernacle cult was initiated (10:17): even though the goat was brought by the community - in a previously cited case the community's purification offering was not eaten but was incinerated $(4: 13-21)$ - because its blood was daubed on the outer altar and not taken inside the Tent (9:9 [see the NOTE], 15), it should have been eaten by the priests." 402

Neither of the two reasons Gane proposed above-(1) that the absence or presence of blood sprinkling is not the crucial difference between outer altar and outer sanctum sin offering and (2) that Lev 6:23[30] does not imply that every outer sanctum sin offering must be eaten-diminishes the principle that the priests do not eat the meat portion of their sin offerings because they cannot benefit from their own sacrifice. Even

\footnotetext{
${ }^{401}$ Gane, Cult and Character, 99.

${ }^{402}$ Milgrom, Leviticus 1-16, 407.
} 
more, the present study upholds that the priest, by bearing the sin of the leader and the commoner, is integrated in the process of סָלָ on the behalf of the offerer.

Is Eating of Sin Offering Flesh a Way of Eradication of the חסטָָאת?

In his dissertation on the disposal of impurity, Wright pointed to the fact that the priest's eating of the edible sin offering cannot be taken as equivalent to the burning of the outer sanctum חָטָָאת; ${ }^{404}$ he found support for this claim in Lev 10:17, which states that the purpose of eating the edible sin offering is (1) bearing of the iniquity of the congregation and (2) doing expiation for them before the Lord. ${ }^{405}$ Wright suggested that "had the concession to eat not been given to the priests, the carcass would have been burned like the sanctuary-priestly hatțā 't.",406

Gane suggested further support for the claim that the priests participate with God in bearing the culpability of the people. He based his claim on the syntax of Lev 10:17 which discusses the purpose of God's assigning the sin offering flesh to the priests as the Hebrew text shows:

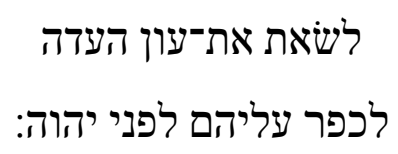

${ }^{403}$ Rodríguez, "Substitution in the Hebrew Cultus," 131, 133.

${ }^{404}$ Budd, Leviticus, 117; Snaith, Leviticus and Numbers, 80.

${ }^{405}$ Wright, The Disposal of Impurity, 132.

${ }^{406}$ Wright, The Disposal of Impurity, 133. 
That is, the preposition $ל+$ infin. cstr. + reference to the community in (העדה/pron. suff. הם-) strongly conveys the impression that the two ideas are intended, to be synonymous. ${ }^{407}$ Thus, the priests' eating of the sin offering flesh is necessary for the priests to remove the iniquity from the people in order to effect כִֶֶּּ on behalf of the people. Even though the priests' offering of the sacrifices in Lev 9:7, 15 made a vital contribution to the overall process of from the people until Lev 10:17b where this aspect of expiation is accomplished by the priests' eating of the sin offering flesh. ${ }^{408}$

It has to be emphasized that the priests' eating of the sin offering flesh is not essential for the achievement of the expiation/atonement in every kind of sacrifice. The outer altar offerings of the priests and the outer sanctum offerings are incinerated, rather than eaten, and they also accomplish expiation/atonement of impurity on behalf of the offerer, while in the sacrifices which the priests offer for the benefit of others, a special kind of priestly participation by eating the sin offering flesh is added in achieving expiation/atonement. ${ }^{409}$

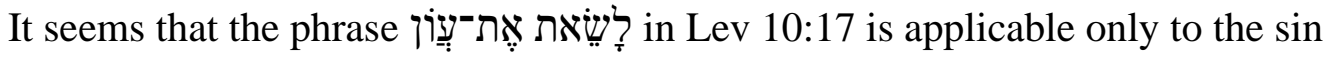
offering for moral impurity. In cases of outer-altar sin offering for severe ritual

${ }^{407}$ Olaffson, "The Use of $n s s^{\prime}$ in the Pentateuch," 263; Ángel Manuel Rodríguez, "Transfer of Sin in Leviticus," in The Seventy Weeks, Leviticus, and the Nature of Prophecy, ed. Frank B. Holbrook, Daniel and Revelation Series Committee 3 (Hagerstown, MD: Review and Herald, 1986), 187; Gane, Cult and Character, 99.

${ }^{408}$ Gane, Cult and Character, 99; Gane, Leviticus, Numbers, 194-95.

${ }^{409}$ Gane, Cult and Character, 99-100; Gane, Leviticus, Numbers, 190, 194-95. 
impurities, where presumably no עָ would be involved, the remaining sin offering flesh would have a function of a priestly reward only. ${ }^{410}$

Lev 10:17 conveys double identification by the priests. By eating of the sin offering flesh, the priests serve as a mediatorial bridge between the people and God: 1) by taking their iniquity, they identify with the people (Lev 5:1), and 2) by removing their iniquity, they identify with God (Exod 34:7). ${ }^{411}$ Consequently, Rodríguez's claim is textually established that the sprinkling of the blood of the sin offering inside the sanctuary (Lev 4:2-21) and the priest's eating of the sin offering flesh (Lev 4:22-35) have the same function of transferring sin from the offering to the sanctuary or the officiating priest, respectively, is textually established.

\section{Summary of Leviticus 10:17}

Based on the more comprehensive study of the Pentateuch texts, the eating of the sin offering flesh does contribute to the

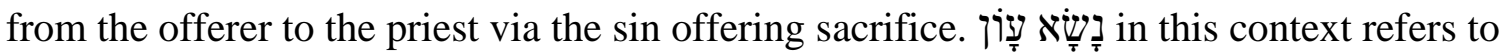
the priest's bearing of the leader's or commoner's moral impurity, instead of the latter bearing their own. The sin offering sacrifice has the unique feature of being holy and impure at the same time. The impurity that it received from the offerer does not nullify its holy status. The incident in Lev 10 in which the priest did not eat the sin offering of the people did not annul the basic regulation that eating of the sin offering flesh is imbedded

\footnotetext{
${ }^{410}$ Gane, Cult and Character, 100.

${ }^{411}$ Gane, Cult and Character, 100.
} 
in the but also more important, an integral part of the רכฺָּ process and, as such, cannot be understood as a way of eradicating the sin offering animal.

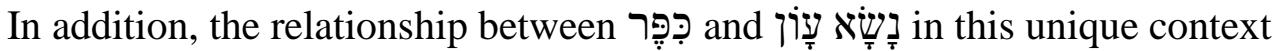
suggests that the latter is crucial in achieving the syntactical relation between the two infinitives that introduce both verbs.

Accordingly, the sin, burnt, and peace offerings which were offered by the priest on behalf of the people (Lev 9:15-16, 18-21). The blood was applied around the altar. The specific reason why these sacrifices were offered was to conclude the eight-day-long process of the consecration of the priests and the institution of the sanctuary by offering sacrifices in it for the first time. Ritual or moral impurity terminology is not found in the chapter, suggestive of the absence of any of the two possible impurities. I suggest that כֶֶָּ in this context deals with the GHS of the people.

\section{רֶֶֶֶ and Conceptually Related Concepts}

There are five other verbs that appear in

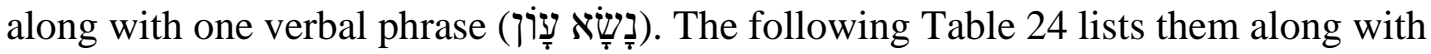
references and stems. The analysis begins with the texts in which כִֶֶּ: is related to two other verbs, Exod 29:33, 36-37; Lev 8:15; Lev 14:49-53; 16:19, 30; Num 8:21; Lev 12:7-8; 15:13, 28; Num 6:11, and then resumes in the following order Lev 4:20, 26, 31, 35; 5:10, 13, 16, 18, 29 [6:7]; 12:7-8; 19:22; Num 15:25, 26, 28; Lev 1:4; and 10:17. 
Table 24. The verb

\begin{tabular}{|c|c|c|c|c|c|}
\hline 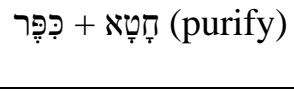 & 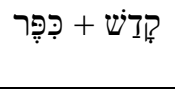 & טָהִר + כִּפְּר & 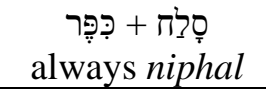 & 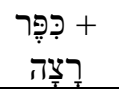 & 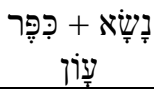 \\
\hline $\begin{array}{c}\text { Exod } \\
\text { 29:36 piel + } \\
\text { mashah }\end{array}$ & $\begin{array}{c}\text { Exod } \\
\text { 29:33 piel }\end{array}$ & $\begin{array}{c}\text { Lev } \\
12: 7 \text { qal } \\
8 \text { qal }\end{array}$ & $\begin{array}{c}\text { Lev } \\
4: 20,26,31,35\end{array}$ & $\begin{array}{c}\text { Lev } \\
1: 4 \\
\text { niphal }\end{array}$ & $\begin{array}{c}\text { Lev } \\
\text { 10:17 qal }\end{array}$ \\
\hline $\begin{array}{c}\text { Lev } \\
\text { 8:15 piel }\end{array}$ & $\begin{array}{c}\text { Exod } \\
29: 36 \text { piel } \\
+ \text { mashah } \\
\end{array}$ & $\begin{array}{c}\text { Lev } \\
\text { 14:20, qal } \\
53 \text { qal (v. 48) } \\
\end{array}$ & $\begin{array}{c}\text { Lev } \\
5: 10,13,16,18, \\
26[6: 7] \\
\end{array}$ & & \\
\hline $\begin{array}{c}\text { Lev } \\
\text { 14:49 piel } \\
52 \text { piel }\end{array}$ & $\begin{array}{c}\text { Exod } \\
\text { 29:37 piel }\end{array}$ & $\begin{array}{c}\text { Lev } \\
15: 13 \text { qal (v. 15) } \\
28 \text { qal (v. 30) }\end{array}$ & $\begin{array}{c}\text { Lev } \\
19: 22\end{array}$ & & \\
\hline \multirow[t]{2}{*}{$\begin{array}{c}\text { Num } \\
8: 21 \text { hithpael } \\
(\mathrm{v} .12,19,21)\end{array}$} & $\begin{array}{c}\text { Lev } \\
\text { 8:15 piel }\end{array}$ & $\begin{array}{c}\text { Lev } \\
\text { 16:19 piel } \\
\text { 30 Piel, qal }\end{array}$ & $\begin{array}{c}\text { Num } \\
15: 25,26,28\end{array}$ & & \\
\hline & $\begin{array}{c}\text { Lev } \\
\text { 16:19 piel }\end{array}$ & $\begin{array}{c}\text { Num } \\
\text { 8:21 piel } \\
\text { (v. 12, 19, 21) }\end{array}$ & & & \\
\hline $\begin{array}{c}\text { Num } \\
\text { 31:19, 20, } 23 \\
\text { hithpael, } \\
\text { excluded }\end{array}$ & $\begin{array}{l}\text { Num } \\
6: 11 \text { piel }\end{array}$ & $\begin{array}{c}\text { Num } \\
31: 23,24 \\
\text { hithpael } \\
\text { excluded }\end{array}$ & & & \\
\hline
\end{tabular}

The following pages demonstrate that Hartley's following statement can be seen as correct:

Sometimes another verb in the [כפר] context emphasizes an aspect accomplished by כפר or an attending result: "be clean" (qal 12:7, 8; 14:20, 53; cf. Num 8:21) or "cleanse" (piel 16:30), נסלח לו, "be forgiven" (4:20, 26, 31, 35; 5:10, 13, 16, 18, 26[6:7]; 19:22), קדּ (piel) "sanctify, consecrate" (8:15; 16:18-19; Exod 29:33, 36, 37; Num 6:11), and (piel) "purge, de-sin" (8:15; 16:18-19; Exod 29:36). ${ }^{412}$

In such contexts, ritual activities that achieve רכָ deal with certain aspects related to the ritual participants who contribute to the overall goal of those rituals. cases represents a sub-ritual, that is, is just a part to reach the overall goal expressed by

\footnotetext{
${ }^{412}$ Hartley, Leviticus, 64.
} 
the other verbs. These contexts are analyzed below.

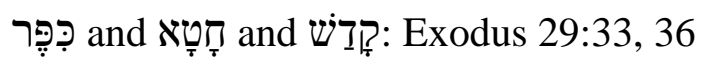

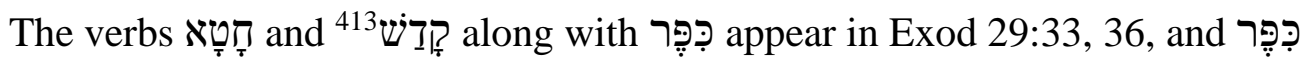

with 2 Tִ , only in v. 37. The context is the consecration of the priests, Aaron and his

sons, and the sacrificial altar.

\section{The Consecration of the Priests: Aaron and His Sons}

Exodus 29:1 makes it clear what the main purpose of its ritual is: "Now this is what you shall do to them to consecrate them to minister as priests to Me." However, at the same time, it does not make any mention of ritual or moral impurity in reference to the priests or the altar. This means that the priests were profane and pure before the ritual of their sanctification began, which is in accordance with Wright's assertion that most of ritual laws deal with such a state of human beings. ${ }^{414}$ Milgrom also correctly stated that the priests were profane at this point of the ritual ${ }^{415}$ and that they did not offer sin offering to purge themselves, but the altar. ${ }^{416}$ Only ritually clean people could participate in public or familial cultic functions. ${ }^{417}$

\footnotetext{
413“'In Hebrew the simple verb form focuses attention on the pivotal change that occurs when the 'not-holy' becomes 'holy."” Baruch A. Levine, "The Language of Holiness: Perceptions of the Sacred in the Hebrew Bible," in Backgrounds for the Bible, eds. Michael Patrick O'Connor and David Noel Freedman (Winona Lake, IN: Eisenbrauns, 1987), 244. Also, Wright. Wright, "Unclean and Clean," 6:735.

${ }^{414}$ Wright, "Holiness (OT)," 3:247.

${ }^{415}$ Milgrom, Leviticus 1-16, 545.

${ }^{416}$ Milgrom, Leviticus 1-16, 279. This is incorrect since the noun in v. 33 of which only the priests could eat.

${ }^{417}$ Averbeck, "טָּהָ," NIDOTTE 2:337.
} 
Accordingly, the priests to which I return after presenting the flow and certain details of the consecration ritual. The רִֶֶּ of the priests is accomplished in two phases.

As vv. 33-34 state, the first phase of consecration was accomplished through the ordination offering, not the sin offering, since that is the only sacrificial meat that the priests ate. ${ }^{418}$ It is not specified who provided the sacrificial animal, but the text states that Moses offered the sacrifice with the priests acting as the offerers since they laid their hands on the sacrificial animal and ate the sacrificial meat. The blood from the ordination offering was applied “on the lobe of Aaron's right ear and on the lobes of his sons' right ears and on the thumbs of their right hands and on the big toes of their right feet, ${ }^{, 419}$ and the rest was sprinkled around the altar (vv. 19-20).

Second, Moses was to take blood that was on the altar and anointing oil and sprinkle the mixture on Aaron and his sons and their garments in order to consecrate them (v. 21). Two points of difference between the emerge as the instructions are compared: (1) blood that was sprinkled on the priests and their garments was obtained from the sin and burnt offering (vv. 10-14, 15-20, respectively) in contrast to the blood that was obtained from the ordination offering, and (2) the mixture of blood was applied on the priests and their garments without specifying the spot on their bodies, in contrast to the blood of the ordination offering whose blood

\footnotetext{
${ }^{418}$ Milgrom, Leviticus 1-16, 227-28, 529-30, 534-35; Hartley, Leviticus, 115.

${ }^{419} \mathrm{NASB}$
} 
was applied on the lobes of the priests' right ears, the thumbs of their right hands, and on the big toes of their right feet.

Keeping in mind the fact that the ever-present characteristic of human sinfulness was also the priests' disadvantage in God's presence, the present study essentially agrees with Hartley who made a general statement regarding the sacrifice of the consecration ritual in Exod 29: "These sacrifices daily cleansed the priests from the pollution of human sinfulness. This period of separation brought to completion the consecration of these men to the priestly task. ${ }^{420}$ In the same vein, Kurtz explained the difference between dealing with sin or GHS:

For the forgiveness of sin, or justification, might be defined in precisely the same way. And the definition is all the more inappropriate here, from the fact that the sinoffering had regard not to sinfulness in general, or to the sinful habitus, which is the object exterminated in the case of sanctification, but to certain acts of sin, the extermination of which is effected not by sanctification, but by justification. ${ }^{421}$

Based on the four states related to creation and the fifth related to human beings and the flow of the ritual in Exod 29, the present study adds more nuances to this general statement. That is, the ordination offering solely served to change the profane and pure state of the priests into the holy. Holiness is not inherent with creation, but is imparted by God. ${ }^{422}$ As regards the ordination offering, that is, in his terms, "the Filling Ram," William H. Propp stated: 'It seems, therefore, that the rite simply raises one's state of

\footnotetext{
${ }^{420}$ Hartley, Leviticus, 115. See also Wenham, The Book of Leviticus, 148.

${ }^{421}$ Kurtz, Offerings, 232.

${ }^{422}$ Wright, "Holiness (OT)," 3:237.
} 
purity, making the impure pure and the already pure super-pure. ${ }^{423}$ Wright also came to the same conclusion regarding the ritual process of the sanctification of the priests in his ABD article on "Holiness, OT." 424

Milgrom incorrectly stated that the sin offering is not included in the priests, but was right in suggesting that the meaning of context and should be translated as "to atone." 425 The blood of the sin and burnt offering, along with anointing oil, was sprinkled on the priests and their garments (v. 21), which means that the sin offering was included in the process of consecration. Accordingly, cannot mean "to purify, to cleanse," since the priests' presence in the sanctuary implies their pure state, and the ordination offering was used to change their pure state into holy. Only clean people could participate in public or familial cultic functions. ${ }^{426}$ There is nothing on the priests that needs to be purified/cleansed. The only element that sin and burnt offering could deal with is the GHS, as Hartley suggested, but partially erroneously that it is related to all the sacrifices in the consecration ritual. The present study suggests that כִֶֶּּ brought about by sin and burnt offerings especially has to do with the GHS in accordance with the כִ ְִ function of both of these sacrifices (Lev 1, 4-5). In other words, כִֶֶּּ atones for ritual participants, which by being sinful human beings were naturally

\footnotetext{
${ }^{423}$ Propp, Exodus 19-40, 530-31. Followed by Arnold B. Ehrlich, The Pentateuch, vol. 1 of Mikrâ ki-Pheschutô: The Bible According to Its Literal Meaning (New York: KTAV, 1969), 193.

${ }^{424}$ Wright, "Holiness (OT)," 3:244. Milgrom incorrectly stated that the objective of ordination offering was purgation. Milgrom, Leviticus 1-16, 540-41.

${ }^{425}$ Milgrom, Leviticus 1-16, 540-41.

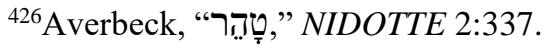


considered unacceptable in God's presence, protecting them to reside safely and perform various services in God's presence. The present study agrees with Milgrom that should be translated as "to atone for" in this particular context.

i⿱ process/ritual. ${ }^{427}$ It is just a phase, a subprocess of a broader consecration process/ritual within which it, by atoning for the GHS of the participants, enables and protects them to reside safely and perform other rituals in God's presence. Accordingly, it is distinct from consecration. Consecration implies a change of status in terms of the rite of passage.

\section{The Consecration of the Sacrificial Altar}

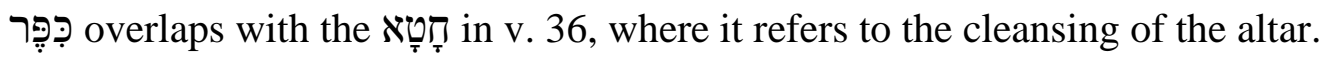

The infinitive The consecration of the priests which includes offering of multiple sacrifices depends on a properly operating sacrificial altar. For that reason, the consecration of the altar is interwoven in the ritual of priestly consecration. However, based on the flow of the ritual, the main emphasis is on the consecration of the priests, while the ritual for the consecration of the altar is briefly stated in vv. $36 \mathrm{~b}$ and 37.

Assuming that the sin offering purifies/cleanses the altar from sins and impurities on the behalf of the offerer, that is, the priests, Milgrom and Wright concluded that the blood of the sin offering applied to the altar purifies/cleanses it in order to prepare it for

\footnotetext{
${ }^{427}$ Kiuchi, Purification Offering, 96.

${ }^{428}$ Kiuchi, Purification Offering, 95. Contra Milgrom. Milgrom, Leviticus 1-16, 226.
} 
its consecration. ${ }^{429}$ However, at the same time, both of them understood that the verb חָָָ purifies the altar in v. 36 as a preparation for consecration. ${ }^{430}$ Milgrom correctly stated that "purging must precede consecration, not follow it."

Thus, two different verbs in the same verse have the same meaning. This tension that two different verbs are used in the same verse with the identical meaning is relatively easily resolved by realizing that these two verbs are synonyms. ${ }^{432}$ It is redundant, but still possible. However, the claim that the purification of the altar is a preparatory stage before its consecration is not warranted by the text, and thus, opens room for a different explanation.

Milgrom and Wright are inconsistent concerning the anointing of the altar. They held that the anointing of it is effected by the application of the anointing oil on it, which takes place at the beginning of each day of the 7-day-long ritual. ${ }^{433}$ The present study agrees with this since this is the most natural sequence of events related to the altar in Exod 29 and 40, and Lev 8. However, they also both viewed the altar as impure and in need of cleansing. The text never labeled the altar as being impure. It is, rather, in the

${ }^{429}$ Milgrom, Leviticus 1-16, 278-79; Wright, “Holiness (OT),” 3,244.

${ }^{430}$ Milgrom's translations of "to effect or to perform purgation" reflect his assumption that the blood of a sin offering purifies/cleanses what it is applied to, and thus, the altar as well. Milgrom, Leviticus $1-16,278-79,290,400,520-24,528-29,540-41,582-83,881,1036$. "The purgation sacrifice in particular cleanses and sanctifies the outer altar, readying it for ensuing sacrificial activity (Exod 29:36-37; Lev 8:15; Ezek 43:18-22, 25-26)." Wright, "Holiness (OT)," 3:244; Wright, "Unclean and Clean," 6:731.

${ }^{431}$ Milgrom, Leviticus 1-16, 523-24.

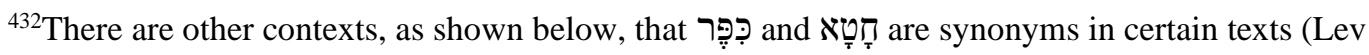
1). Milgrom, Leviticus 1-16, 1039-40, 884, 289-90.

${ }^{433}$ Milgrom, Leviticus 1-16, 290; Wright, “Unclean and Clean,” 6:731, 733. 
basic profane state. As such, it was anointed, which resulted in its consecration (Exod 40:11; Lev 8:11).

Following the four states related to creation, the altar is pure and profane at the beginning of the ritual, and since it is in this condition, it does not need to be purified. Its consecration is achieved by applying anointing oil on it, which takes place before the priests were anointed. However, later in the ritual, Exod 29:36 states that the altar needs to be cleansed, and the present study agrees with Milgrom and Wright that the altar's state changed during the ritual and needs to be purified/cleansed, but disagrees with by what and how it got defiled.

Milgrom asked valid questions: "Why is it [the altar] singled out, and what is its purpose?" ${ }^{434}$ or in another place “... the newly erected altar can hardly have become polluted; why then need it be purged? And why for seven days?" ${ }^{435}$ After correctly refuting several suggestions as to why the altar would need purification/cleansing, Milgrom suggested that the priests themselves, because of their proximity to it, defiled the altar by "unavoidable physical impurities (e.g., a nocturnal emission, 15:16-17)" and subsequently, their laying on of hands on the sin offering meant that they were making this offering to purify/cleanse the altar from their $\sin .{ }^{436}$ This reasoning is not possible based on the logic Milgrom himself proposed. Direct contact between impurities, even minor ones, and the sancta would cause the carrier of impurity to die. ${ }^{437}$ This translates to

\footnotetext{
${ }^{434}$ Milgrom, Leviticus 1-16, 520-21.

${ }^{435}$ Milgrom, Leviticus 1-16, 278-79.

${ }^{436}$ Milgrom, Leviticus 1-16, 522-23.

${ }^{437}$ Milgrom, Leviticus 1-16, 307-8, 930, 993, 1050.
} 
the immediate death of the priests. In addition, nocturnal emissions in married men, which Aaron was (Exod 6:23) and his sons ${ }^{438}$ most likely were, ${ }^{439}$ are very rare. ${ }^{440}$

Another assertion that invalidates this interpretation is the fact that Exod 29 does not mention defilement of the sanctuary, even though the priests were in its proximity as much as they were in the proximity of the altar. It never actually used any term for ritual and moral impurity in reference to the priests, altar, or sanctuary. In addition, if the sin of Aaron and his sons was the issue these sacrifices dealt with, then it would be expected that the blood of their sin offerings would be applied in the first compartment of the sanctuary before the veil as the regulations prescribe (Lev 4:3-12), and not on altar. However, that did not happen in Exod 29. Because of these points, the present study suggests another interpretation.

The altar needed to be cleansed from the priests' GHS. That is, vv. 10-12 and vv. 15-16 state that the priests laid their hands on the heads of both sacrificial offerings and their blood was applied on the altar's horns and the base in the case of the sin offering and around the altar in the case of the burnt offering. No ritual or moral impurity that was

${ }^{438}$ Eleazar was married based on Exod 6:25.

${ }^{439}$ It was commonly widespread in the Ancient Near East that people would marry very young and that custom is maintained even today. Roland de Vaux calculated that king Jehoiachin married at the age of 16, and Amon and Josiah at the age of 14. Roland de Vaux, Ancient Israel: Its Life and Institutions (Grand Rapids, MI: Eerdmans, 1997), 29.

440"'For males who have experienced nocturnal emissions the mean frequency ranges from 0.36 times per week (about once every three weeks) for single 15-year-old males to 0.18 times per week (about once every five-and-a-half weeks) for 40-year-old single males. For married males the mean ranges from 0.23 times per week (about once per month) for 19-year-old married males to 0.15 times per week (about once every two months) for 50-year-old married males." "Nocturnal Emission," Wikipedia, released 24 July 2018, https://en.wikipedia.org/wiki/Nocturnal_emission\#In_males; American Academy of Sleep Medicine, "Sexual Activity Reported In Dreams Of Men And Women," ScienceDaily, 15 June 2007, www.sciencedaily.com/releases/2007/06/070614085118.htm 
related to the priests is mentioned in this chapter. However, the fifth state of GHS related to humans remains a disadvantage for the priests in God's presence even during this ritual. Both of these sacrifices deal with the status of humans before God. The blood was offered on the altar to God in order to achieve this case cleanses the priests' GHS that defiled the altar, while at the same time, atoned for the priests' GHS, granting them the right to stay safely in God's presence regardless of their GHS.

In addition, Milgrom claimed that the blood of the sin offering has a prophylactic function. It was to protect the altar from future defilement. ${ }^{441}$ This statement is erroneous in its totality. The very purpose of the altar was to receive the impurity which is one of its fundamental functions (Lev 4:22-35), and it was not intended to be protected from it. The infinitive of sִֶֶּ should be understood as temporal, "when you atone for," and has a dual function in v. 36. It encompasses atoning for the priests and simultaneously cleanses the altar from the impurity.

To conclude, the sequence of the processes related to the priests' consecration is the following: (1) the priests were anointed (Exod 29:7) which resulted in (2) their ordination (Exod 29:9), then (3) the mixture of the blood of all sacrifices and oil was

441، The blood rites therefore had both a purgative and an apotropaic function. It is not too difficult to conclude that in Israel these rituals originally had the same dual purpose: to purge the altar of pollution and to protect it from future pollution." Milgrom, Leviticus 1-16, 279. It is very difficult to imagine that the application of the blood during this ritual protected the altar from future pollution against the laws in Lev $4: 22-35 ; 16: 18-19$, which all speak of the defilement of the altar and its cleansing. 
sprinkled on them רִֶֶּ for their GHS (Exod 29:10-12, 15-16, 19-21) which resulted in (4) their consecration $\left(\right.$ Exod 29:21). ${ }^{44}$

The blood in this ritual was obtained from three sacrifices: sin, burnt, and ordination offerings. The offerers of these sacrifices were Aaron and his sons, but since this was the introduction of the priestly ministry, Moses acted as the officiating priest. There are two reasons for offering these sacrifices. First, the sin and burnt offerings atoned for the priests' GHS and they were applied to the altar. Second, the ordination offering, along with sin and burnt offerings, ordained/consecrated the priests and was applied to the lobes of the priests' right ears, the thumbs of their right hands, and on the big toes of their right feet.

The chronological sequence of the processes related to the altar during the priests' consecration is the following: (1) the altar is being anointed (Exod 40:9-10; Lev 8:1011), which resulted in (2) the altar's consecration (Exod 40:9-10; Lev 8:10-11).

The blood for this ritual was obtained from sin, burnt, and ordination offerings. The offerers are the same as in the previous ritual, the priests. The reason was the cleansing of the GHS of the priests. The blood of sin and burnt offerings was applied according to the protocol established in Lev 1, 4, while the blood of the ordination offering was applied around the altar.

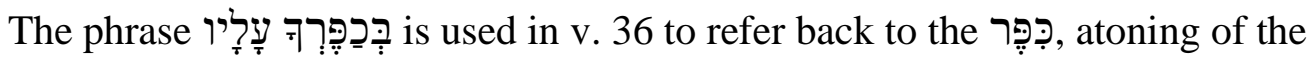

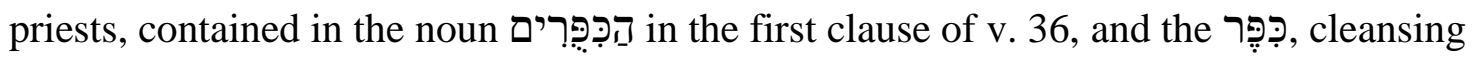

\footnotetext{
${ }^{442}$ Gane provided a more comprehensive flow of the ritual that is parallel to the flow of the ritual sequences mentioned here. Gane, Leviticus, Numbers, 162-65.
} 


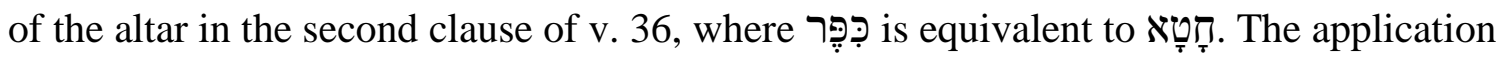
of the blood of all sacrifices achieved רִֶֶּ for the priests to protect them in God's presence as anointed representatives, while the altar's

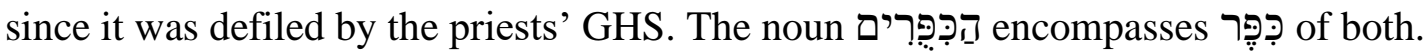
First, the cleansing of the altar is expressed by the verb חָטָ in v. 36 and synonymously by the temporal infinitive of the כִֶֶֶּּ. Second, the atoning of the priests is contained in the temporal infinitive of the entire ritual that was performed on behalf of the priests and the altar.

כִ done on the priests and the altar differs due to their different natures and status. Humans are sinful and need God's presence in order to prepare them for holy status. inanimate, is different than כִֶֶּּ for the priests, and refers to its cleansing. are synonyms in this case. ${ }^{443}$ Anointing with oil consecrates the altar, and it functioned as an authorized altar from the beginning of the ritual. Based on the anointing of the altar that Lev 8:11 places before the anointing of the priests, it can be assumed with Milgrom that Lev 8:11 and Exod 40:9-13 assume that this first initial anointing of the altar was also meant between the sequences of Exod 29:7a and 29:7b. ${ }^{444}$ The altar in this context

\footnotetext{
${ }^{443}$ There are other contexts, as shown below, that 1). Milgrom, Leviticus 1-16, 290, 882-83, 1039-40.

${ }^{444}$ Milgrom also provided a compelling explanation of the altar's double anointing and the form of the second one. Milgrom, Leviticus 1-16, 515.
} 
needed

that was transferred to it during the 7-day consecration ritual for the priests.

This is the first time in my analysis of כִֶֶּּ that I encountered the phenomenon of

the dual function/meaning of the same ritual activity, in this case, blood manipulation.

This phenomenon is well established in biblical rituals ${ }^{445}$ and in this case, the GHS of the priests is transferred to the altar by the blood application and at the same time, the blood application purifies the altar. This is in agreement with the biblically-based principle that most of the laws deal with entities that are profane and pure as contrasted to the state of holiness and impurity. ${ }^{446}$

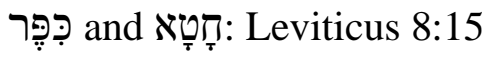

There are certain differences between the ritual flow in Exod 29 and Lev 8, and Milgrom conveniently discussed them. ${ }^{447}$ However, the ritual flow is essentially the same. The priests were first anointed (Exod 29:7, 21; Lev 8:12) ${ }^{448}$ in order to be ordained

\footnotetext{
${ }^{445}$ Gorman noticed that through blood application on the Day of Atonement, blood absorbs sins that were located in the sanctuary and thus, cleanses it (Lev 16:16). The same blood serves to consecrate the altar in the following ritual sequence (Lev 16:19). Gorman, The Ideology of Ritual, 82, 87-89; Gane, Cult and Character, 5. It was emphasized before that the high priest, as a handler of the sin offering blood, also gets defiled by the sins he absorbed. Accordingly, the sins are carried by both the blood of the sin offerings and the high priest himself, and are later transferred to the Azazel goat. In the meantime, the same blood consecrates the altar.

${ }^{446}$ See p. 400 in the present study.

${ }^{447}$ Milgrom, Leviticus 1-16, 545-49.

${ }^{448}$ In Lev 8, anointing is mentioned in v. 12 and results in Aaron's consecration, while Exod 29:7 does not state that Aaron is consecrated after being anointed because Exod 29 seems to present consecration as complete only after both blood and oil were sprinkled on Aaron. I agree with Milgrom's understanding that this is a more sensible sequence, but disagree with him that the priest has to be purified before being consecrated; I rather propose that Aaron has to be כִֶֶּ, atoned for in the sense of protected before being consecrated. Milgrom, Leviticus 1-16, 545.
} 
(Exod 29:19-21; Lev 8:12), ${ }^{449}$ and sprinkled with the mixture of blood of all offerings from the altar and oil (Exod 29:21; Lev 8:12, 30) $)^{450}$ in order to be consecrated (Exod 29:21; Lev 8:12, 30). ${ }^{451}$ Though present, the differences do not seem to affect the basic ritual processes and their essence. Accordingly, everything that was said regarding the

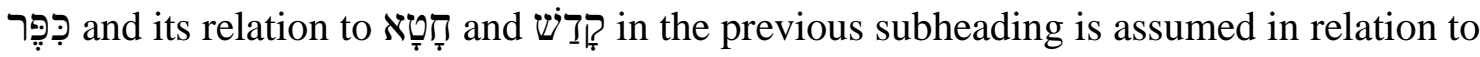
the ritual of Lev 8.

There is a significant difference between Exod 29:36-37 and Lev 8:15 in the use of prepositions. That is, חָטָא is syntactically related to the preposition עַל Exod 29:36, while עַ is replaced by the direct object marker in Lev 8:15. As suggested in the analysis

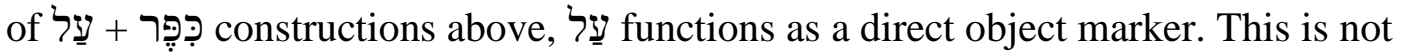
established based on the interchangeability of the two particles in these two texts, but the same pattern is detected in other texts as shown above.

The sameness of the sequence of ritual processes in Exod 29 and Lev 8 in relation to the consecration of the priests and the altar suggests the same relationship between

\footnotetext{
${ }^{449}$ They were daubed with the blood of ordination offering together in Exod 29:20, while in Lev 8:23-24, separately. Milgrom, Leviticus 1-16, 545.

450“'Aaron is not sprinkled together with his vestments, his sons, and their vestments (v. 30) because he has already been sanctified by the anointment oil (v. 12). Yet Exod 29 insists that he be sprinkled together with his vestments, his sons, and their vestments (v 21) for it is this aspersion with blood and oil that simultaneously sanctifies Aaron and his sons." Milgrom, Leviticus 1-16, 545. The sprinkling rite precedes the consecration of the elevation offering in Exod 29:21-26, while the order is reversed in Lev 8:30, 25-26. Milgrom, Leviticus 1-16, 545. I follow Milgrom who favors the Exodus' more logical ritual flow with small modifications as proposed above.

${ }^{451}$ Lev 8:12 declares Aaron sanctified/consecrated by the anointing of oil only, but then in v. 30, it follows Exodus in stating that now both Aaron and his sons along with their vestments were anointed and consecrated by sprinkling the mixture of the blood from the altar with oil. Exodus 29 insists that sprinkling all the priests along with their vestments takes place at the same time, and then declares them consecrated/sanctified. Milgrom, Leviticus 1-16, 545.
} 


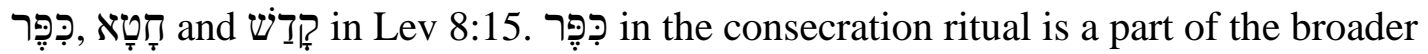
sanctification process/ritual. ${ }^{452}$ Consecration, as a broader process/ritual, includes the phase, subprocess, which atones human participants enabling and protecting them to reside safely and perform other rituals in God's presence. Lev 8:15 as they did in Exod 29:36 ${ }^{453}$ and they refer to the cleansing of the altar.

The sameness of the ritual also implies the same inferences regarding the origin of the blood, sacrifices included, the identity of the offerer, location of the blood application, and its function. It is plausible that through the laying on of hands and the application of the blood of these two sacrifices, the priests' GHS was transferred to the altar from which it later needed to be removed in the sense of purified/cleansed.

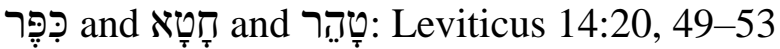

There are two sets of stipulations in Lev 14. The first passage presents the ritual for purification after צָרָעַָ person is healed, vv. 1-32, whereas the second passage deals

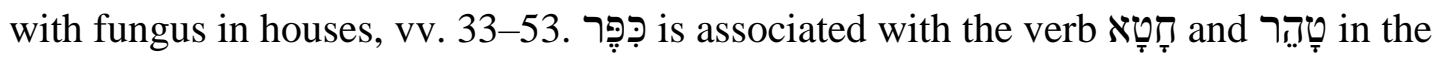
second and טָּרָ in the first one.

Lev 14:1-32. There is a sequence of appearances of טָּר on the first, seventh, and eighth day (vv. 8, 9, 20) that mark various levels of cleanness that the צִ person

${ }^{452}$ Kiuchi, Purification Offering, 96.

${ }^{453}$ Because the purpose of the ritual process is consecration, the preposition ? is used in the sense of instrumental, "by means of," rather than ? of purpose. Wenham, The Book of Leviticus, 135; Kiuchi, Purification Offering, 129. Contra Gorman who equated כְִֶּ not just with the cleansing but also with consecration. Gorman, The Ideology of Ritual, 87. 
obtains during the ritual in the first passage. רฺֶָּ , which appears in vv. $18,19,20$, is achieved by various means in this ritual. The first syntactical connection between and טoָָ is mentioned in v. 20. However, previously in v. 18, application of the blood of the reparation offering and oil on צִָָָּ person's lobe of the right ear, thumb of the right hand, and big toe of the right foot. In v. 19, by the priest's offering of a sin and burnt offering on behalf of the affected person. The

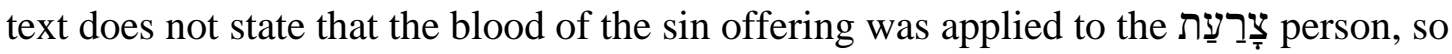

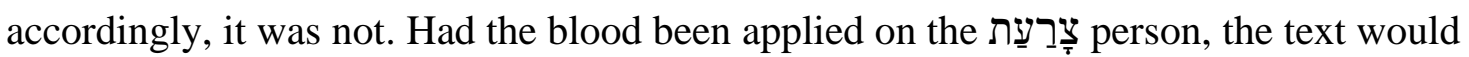
indicate that, since it would be a different use of the sin offering blood as it was in the case of the reparation offering in vv. 12-18. In v. 20, on the eighth day, the priest's offering of the burnt and grain offerings finalizes the ritual of cleansing of the צִבעַעת person. Again, the text does not state that the blood of these two offerings was applied to

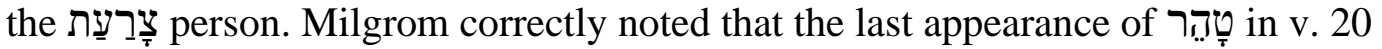
"signifies the completion of the process," which reinstates the healed and now purified

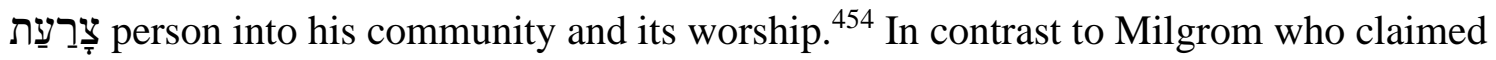
that the presence of טָָה in these verses does not play an essential role, but only refers to the effects of the sacrifices, טָָה in is essential and signifies a newly acquired and

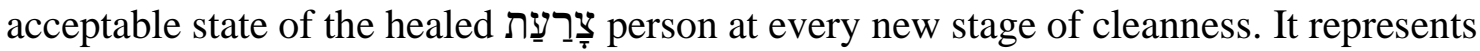

\footnotetext{
${ }^{454}$ Milgrom, Leviticus 1-16, 859.

${ }^{455}$ Milgrom, Leviticus 1-16, 858-59.
} 
the pinnacle of the cleansing and restoring process. ${ }^{456}$

This text presents 3 basic semantic domains of the verb טָָה that are analogous to

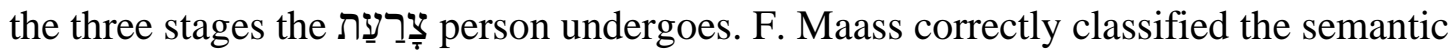
domains of the verb טָָהָ: "In the OT, thr refers to physical, ethical, and religious (cultic) purity. $" 457$ This text exemplifies all three of them.

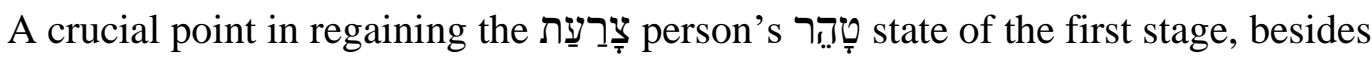
the two birds' ritual, is restoration of his physical health (v. 3). The priest examines him

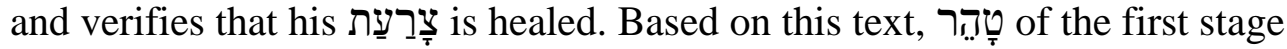
includes/refers to physical health. After the priest verifies that he is healthy and performs

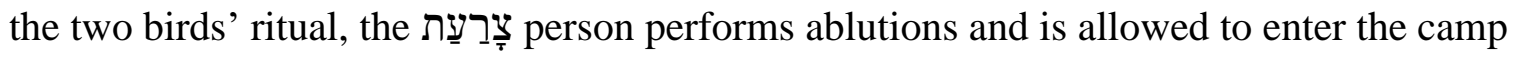
(vv. 7-8). However, he still remains unclean in the sense that he is not allowed to enter his tent. In other words, he can still defile other persons or objects by direct touch or by

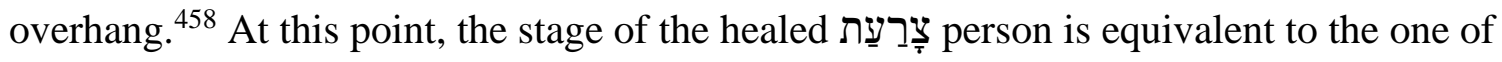
the new mother when she delivers a son, the defiled person at the beginning of his/her purification period. The צָבָעַ person still

${ }^{456}$ Gane, Leviticus, Numbers, 247-48. The same sequence of ritual activities is presented in the subcase of this pericope, vv. 21-31, for the צִּרָָּ person whose means are insufficient.

${ }^{457}$ Maass, “טהר," TLOT 3:483.

${ }^{458}$ Milgrom, Leviticus 1-16, 983; Hannah K. Harrington, The Impurity Systems of Qumran and the Rabbis: Biblical Foundations, SBLDS 143 (Atlanta: Scholars Press, 1993), 32. 
contaminates by direct contact and must wait seven days for the next stage of his/her purification. ${ }^{459}$

The second stage of טָָָּ refers to the ritual purity as indicated by the seven-day period of abstinence from directly touching or overhanging other persons or objects. The passage of seven days along with shaving of all of his hair, washing his clothes and body makes the צָרָעָת person ritually pure (v. 9). At this point he can come into his tent and does not transmit any defilement any more. He is ritually clean. ${ }^{460}$

The third stage of טָּ refers to moral/ethical purity. The ablutions that were present in the ritual of the first and second day are not present in the eight-day ritual, but the set of sacrifices which guilt, sin, and burnt offering are achieving כִֶֶֶּ for him (vv. 18-20) are. כִֶֶּּ is mentioned only in the third stage of ritual and refers to the moral

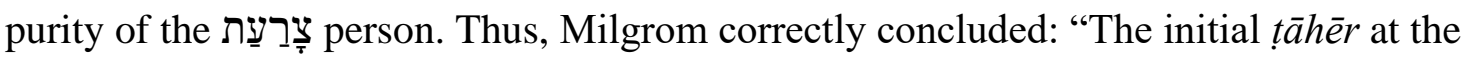
end of the first day admits him to the camp (v 8); the second, to his tent (v. 9); and the third, to his God (v. 20). The first two are preceded by ablutions that, as pointed out (vv. $8,9)$, execute the rites of passage." ${ }^{461}$ Even though he did not comment on how, Maass recognized that some sort of guilt was present in the situations where no fault is explicitly mentioned in the text, such as Lev 12, $15 .{ }^{462}$ This element was missed by Milgrom and

${ }^{459}$ Milgrom, Leviticus $1-16,842-43$.

${ }^{460}$ Milgrom, Leviticus 1-16, 844.

${ }^{461}$ Milgrom, Leviticus 1-16, 859. Also followed by Averbeck, “טָָּרָ," NIDOTTE 2:337.

${ }^{462}$ Maass, "טהר," TLOT 3:483. He also noted that the rest of the OT explicitly understands the purification as moral in its nature. Maass, "טרהר," TLOT 3:485. 


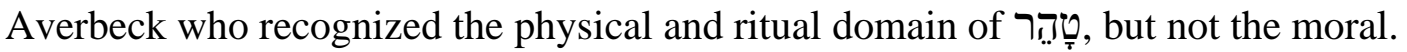

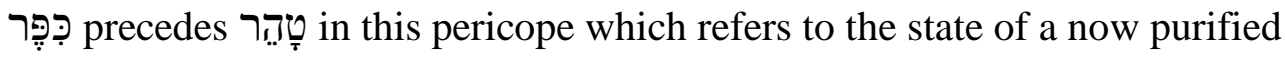
person as he/she passes from one level of cleanness to the next. This sequence of verbs leads to the conclusion that פִּפֶֶּ is a means or a part of the process of achieving that is, reinstating one into טָָה condition that is acceptable for the community of God's people.

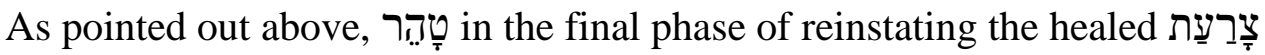
person that consists of כִֶֶֶּּ that is achieved by offering the reparation offering, by application of the oil, and by offering the sin, burnt, and grain offerings. The ritual instructions in v. 11 which include placing the affected person "before the Lord at the doorway of the tent of meeting," that is, inside the tabernacle, ${ }^{463}$ implies that the person is not in an impure state anymore because his coming in an impure state to the confines of the sanctuary would initiate his death as the punishment for making contact between impure and holy. He is טָָה from his uncleanness at the point that he is brought to the sanctuary. The reason for the ritual of the eighth day which results in his restoration into the community cannot be impurity from צִּרַָת, but rather, is comprised of multiple reasons.

First, the guidelines of ritual in the third pericope present an innovative use of the blood of the reparation offering. Instead of dashing it on the sides of the altar, as Lev 7:2 prescribes, the priest applied it on the healed צָָָָּת persons' lobe of the right ear, thumb

\footnotetext{
${ }^{463}$ Milgrom, Leviticus $1-16,850-51$.
} 
of the right hand, and big toe of the right foot, which resembles the body parts to which Moses applied blood from the ram of ordination during the consecration of the priests (Lev 8:23-24). ${ }^{464}$ This unique application of the blood of the reparation offering, among other reasons, ${ }^{465}$ makes it a key offering in the ritual. ${ }^{466}$ כִ achieved by it, due to its similarity with the ordination offering and the change of status of the individuals that are involved in the ritual, enables the transition from the צִָָָּ person, outcast, to a clean, healthy person, full member of his/her community. ${ }^{467}$ As Hartley noted, "it indicates that a radical change has taken place in the person's status before God. Now that this person is being restored to the community, it is imperative that his whole being be consecrated to God, his ears to hear God's word and his hands and feet to do God's will."468

Second, the צָּרָָת person might have done a sin for which he/she was punished by God with the ${ }^{469}$ צָבָעַע or he/she might have sinned during the duration of the Sin offering in this ritual deals with those sins. An additional reason for making the sin

\footnotetext{
${ }^{464}$ Hartley noted other similarities as well. Hartley, Leviticus, 194.

${ }^{465}$ Milgrom, Leviticus $1-16,850-51$.

${ }^{466}$ Milgrom, Leviticus 1-16, 850-51; Kiuchi, Leviticus, 256.

${ }^{467}$ Milgrom, Leviticus 1-16, 852-53.

${ }^{468}$ Gorman, The Ideology of Ritual, 173; Hartley, Leviticus, 197-98.

${ }^{469}$ Both, Milgrom and Hartley assumed that the affected person did some sort of sin against the holy (Lev 5:15-17). Milgrom, looking at other biblical accounts in which individuals were punished with leprosy due to their encroaching upon sancta (Num 12:9; 2 Kings 5:27; 2 Chron 26:18-21), concluded that the affected person did the same sin. Milgrom, Leviticus 1-16, 820-22; Milgrom, Cult and Conscience, 8081. Followed by Wright, "Unclean and Clean," 6:736. Hartley claimed that reparation offering is required because of transgressing the holy property which, in this case, is the affected person himself since, as Hartley stated, "the disease marred a person who bears the very image of God (Gen 1:27; Ps 8:6[5]) and separated him from free access to God at the central sanctuary." Thus, a reparation offering is needed to fully restore a person recovered from a deadly skin disease. Hartley, Leviticus, 196-98.
} 
offering is found in the fact that all skin disease, characterized by the fact that the body of a person affected "is wasting away," and as such, is strongly associated with death in the OT. ${ }^{470}$ Because of the processes taking place in the leper's body, Kurtz stated that a leper was "a living death, the destruction of all the vital powers, a dissolution and putrefaction even in the living body, a death before death; so that, as Spencer says, the leper was a ‘walking tomb." ${ }^{471}$ Miriam’s leprosy reflects this idea (Num 12:12). ${ }^{472}$

The sin offering also had a ransoming role, since the healed צִבעַעת person was given a new life and was required to ransom it (Exod 22:28-29; 34:19-20). ${ }^{473}$ Milgrom stated:

The bodily impurities enumerated in the impurity table ... focus on four phenomena: death $(4,5,7,11)$, blood $(2,3,8)$, semen $(3,10)$, and scale disease (1). Their common denominator is death. Vaginal blood and semen represent the forces of life; their loss — death ... In the case of scale disease, this symbolism is made explicit: Aaron prays for his stricken sister, "Let her not be like a corpse" (Num 12:12). Furthermore, scale disease is powerful enough to contaminate by overhang, and it is no accident that it shares this feature with the corpse (Num 19:14). The wasting of the body, the common characteristic of all biblically impure skin diseases, symbolizes the death process as much as the loss of blood and semen. ${ }^{474}$

Even though the set of sacrifices offered on the eighth day all have distinctive functions, they collectively contribute to a healed צָּרעַת person's reconciliation with God

\footnotetext{
${ }^{470}$ Feldman, Biblical and Post-Biblical Defilement and Mourning, 34; Milgrom, Leviticus 1-16, 820, 995-96. Also, Gorman, The Ideology of Ritual, 162.

${ }^{471}$ Kurtz, Offerings, 417.

${ }^{472}$ Gane reminded me of this text in the course of my research. See also Richard M. Davidson, "The Living Death: Typology of Leprosy and Its Cleansing," in Festschrift Honoring Merling Alomía, ed. Benjamin Rojas, et al. (Lima, Peru: Peruvian Union University, 2015), 45-58.

${ }^{473}$ Stuart, Exodus, 522.

${ }^{474}$ Milgrom, Leviticus 1-16, 999.
} 
and his/her full restoration into the community. ${ }^{475}$ The blood for this ritual was obtained from reparation, sin, and burnt offerings. The offerer of these sacrifices was the priest (v. 11-20), but they were offered on the behalf of the affected person (v. 10). All the blood of the other sacrifices was applied to the locations in the previously established procedures (Lev 1-5), except for the modified blood application of the reparation offering on a person's lobe of the right ear, thumb of the right hand, and big toe of the right foot, instead of around the altar.

Lev 14:33-53. The verb Tָָּ is used in vv. 49, 52 to refer to the cleansing of the house affected by fungus by the ritual of the two birds that resembles the ritual of the first

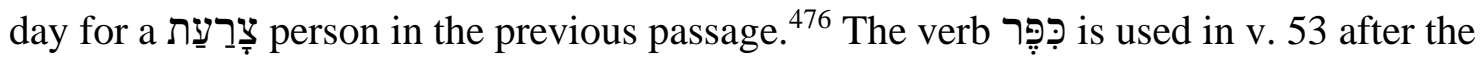
priest lets the live bird free outside the city into the open field to finalize the ritual of

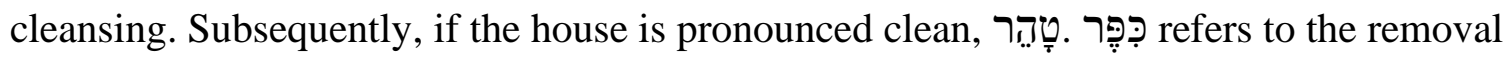
of the fungus from the house ${ }^{477}$ and is a part of the process of achieving טָהָר status for the house as was the case in the previous passage in regards to the צִּרָּת person. No moral impurity is mentioned nor assumed in this case.

The priest is the officiant in this context. The birds involved in the cleansing process are not labeled as sacrifice, but the blood obtained from one of them, along with the water, the other live bird, and other ritual items, was directly sprinkled on the house. The live bird would then be let go, thus completing the cleansing of the house. The

\footnotetext{
${ }^{475}$ Richard E. Averbeck, "Sacrifices and Offerings," NIDOTTE 4:1003; Kiuchi, Leviticus, 257.

${ }^{476}$ Milgrom, Leviticus 1-16, 864; Gane, Leviticus, Numbers, 248.

${ }^{477}$ Gane, Leviticus, Numbers, 249-50.
} 
function of this ritual was the cleansing of the house from ritual impurity.

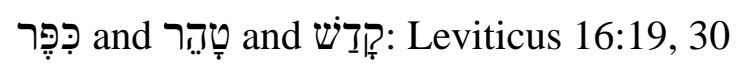

The triad of verbs is conceptually related in vv. 18-19 while v. 30 mentions

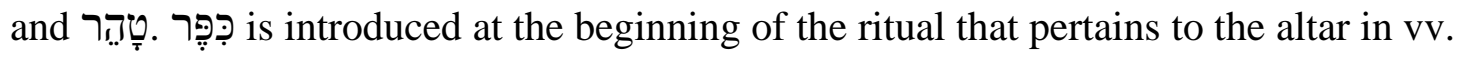
18-19, which is contrary to the majority of ritual requirements that include כִ כִ mentioned at the end of the ritual procedures. This leads to the conclusion that

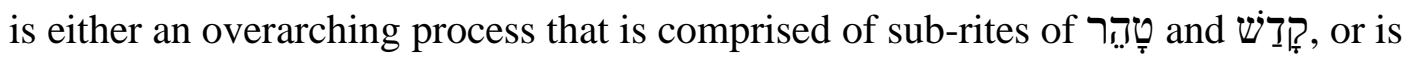
identical to these two sub-rites. That is supported by the fact that the direct object/beneficiary is the same with

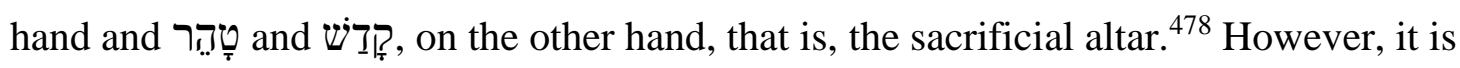
very unlikely to equate

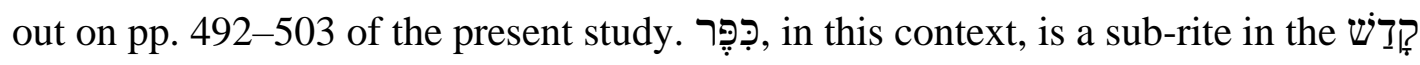
process as it was in Exod 29:36-37. The same sequence of ritual activities related to the sacrificial altar in this pericope is found in Exod 29:36-37, although different verbs are used, state that there are two blood applications. The first one, daubing on the altar's horns, is recorded in v. 18. The second one, sevenfold sprinkling, is recorded in v. 19. The role of

\footnotetext{
${ }^{478}$ Kiuchi, Purification Offering, 96-97.

${ }^{479}$ Milgrom, Leviticus $1-16,1036$.
} 
the dual blood application was to cleanse and reconsecrate the altar. ${ }^{480}$ iִ כִ v. 18 is equivalent to טָָהר in v. 19. ${ }^{481}$ It refers to both blood applications with two different effects on the altar as was the case with the blood application during the sacrificial altar consecration in Exod 29:36-37 and Lev 8:15. The first blood application cleanses the altar in v. 18 and is achieved by daubing the blood of the sin offerings on the altar's horns. The second blood application reconsecrates the altar ${ }^{482}$ by sevenfold sprinkling of the blood on the altar. ${ }^{483}$

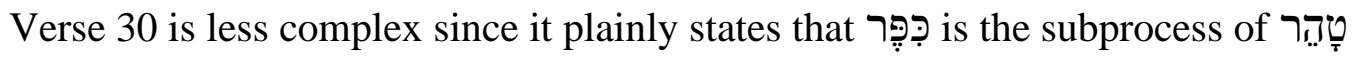

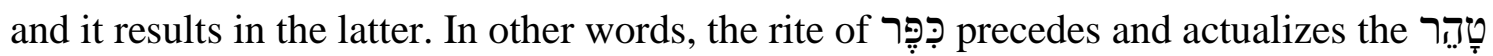
state of the people. ${ }^{484}$ It is obvious that this טָָהר does not refer to a literal cleansing, even though the main purpose of the Day of Atonement ritual was to cleanse the sanctuary. The sanctuary is polluted by people's ritual and moral impurities; thus, the people also are being cleansed morally or spiritually through their self-denial and abstaining from work. In other words, all the people reconcile with the Lord through the cleansing of the sanctuary and in participating self-denial and abstaining from work. ${ }^{485}$

רִּ in Lev 16:18-19, 30 is achieved by the blood of sin offerings of the priests

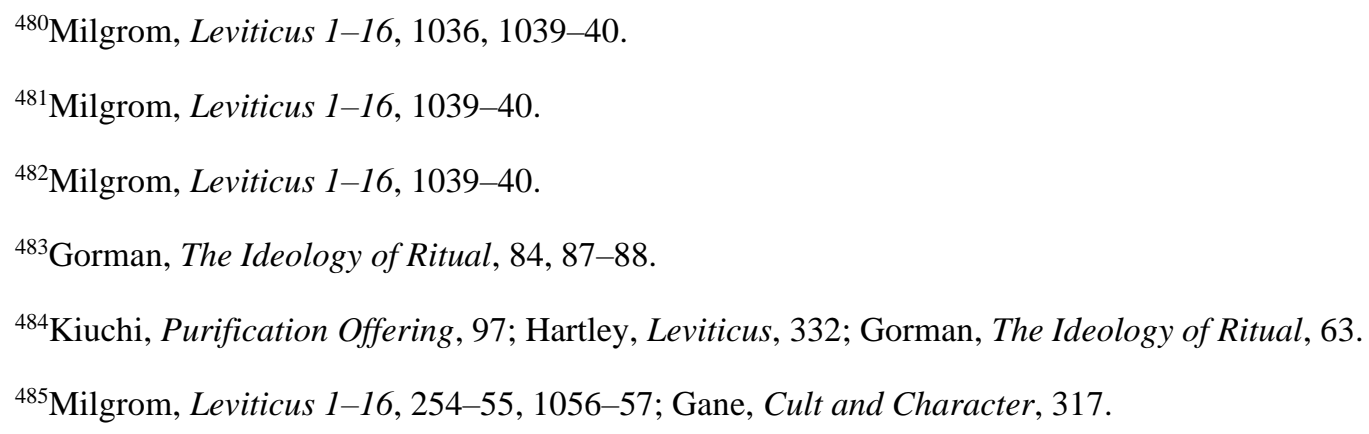


and the people. The offerer is exclusively the high-priest. However, one of the sin offerings was from and for the people. The reason for this ritual was the cleansing of the sanctuary, including the sacrificial altar that eventually results in the cleansing of the people. The cleansing and reconsecration of the altar includes the application of the blood on the altar's horns and sprinkling on it (vs. 18-19). The cleansing of the people originated from the cleansing of the sanctuary, as well, which is achieved by the sprinkling of the blood on and in front of the ark cover.

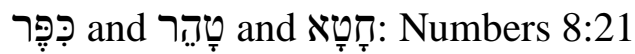

Numbers 8 presents the installation of the Levites so that they can perform previously assigned duties. The previous texts in Numbers first present the Levites as the ones who have replaced the Israelite first-born $(3: 11-13,40-51)$ and have been assigned the duty of guarding (3:14-39) and removing (1:1-33) the tabernacle. ${ }^{486}$ The verb expresses the desired state of the Levites (vv. 6, 7, 1, 5, 21). Milgrom noticed that the repetition of טָָ in v. 21, which is the end of the ritual, forms an inclusion with this verb in v. 6, which marks the beginning of the ritual. ${ }^{487}$ The installation of the Levites is essentially different ${ }^{488}$ from that of the priests in Exod 29, 40 and Lev 8 since the priests

\footnotetext{
${ }^{486}$ Milgrom, Numbers, 61.

${ }^{487}$ Milgrom, Numbers, 306.

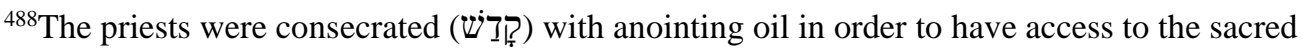
objects and officiate at the alter and in the tabernacle. On the other hand, the Levites were purified (טָּר) in order to be able to transport the dismantled tabernacle and its sacred objects after the priest covered them, but they did not have access to the sanctuary nor were allowed to officiate at the altar. Milgrom, Numbers: 61; Timothy R. Ashley, The Book of Numbers, NICOT 4 (Grand Rapids, MI: Eerdmans, 1993), 169; Levine, Numbers 1-20, 273. In addition, the main officiant of the ritual in the priestly consecration is Moses while Aaron leads most of the ritual activities in the Levites' purification. Milgrom, Numbers, 61. 
were sanctified while the Levites were purified. However, the use of adds to the meaning of this purificatory ritual. ${ }^{489}$

Based on v. 6, the first level of טָָָ is achieved by three ritual activities: (1) sprinkling of the water of purification (מָי חָטָּאת) onto the Levites, (2) complete shaving of their bodies, and (3) washing their clothes. On the one hand, some scholars understood

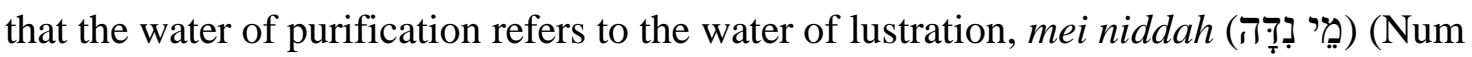
19:9) that is used to purify the person who incurred corpse defilement. ${ }^{490}$ On the other hand, "other scholars allow uncertainty to remain since no specific ritual of mixing the water with some other element is delineated in the context of 8:5-22."491 The current study agrees with the latter view. Ceremonial cleanness is the goal of the section in vv. $5-8^{492}$ because the Levites themselves were considered as an offering to God. ${ }^{493}$ Based on the flow of the entire ritual of the Levites' installation, ${ }^{494}$ Milgrom was right in stating that bathing in v. 7 cleansed Levites from minor impurities, but incorrectly

\footnotetext{
${ }^{489}$ The meaning of the verb in v. 19 is not included in this part of the current research since it refers to the activity of the Levites after their installation.

${ }^{490}$ Milgrom, Numbers, 62; Budd, Numbers, 93; Gane, Leviticus, Numbers, 555. An opposing position is held by Levine, Numbers 1-20, 274-75.

${ }^{491}$ Cole, Numbers, 149. The following are some of them Ashley, Numbers, 170; Levine, Numbers 1-20, 274-75, 464; George Buchanan Gray, A Critical and Exegetical Commentary on Numbers, ICCHSONT 4 (New York: Scribner's Sons, 1903), 79.

${ }^{492}$ Ashley, Numbers, 169-70.

${ }^{493}$ Cole, Numbers, 149; Levine, Numbers 1-20, 274.

494، The ceremonial installation of the Levites involved several ritual acts: (1) purification via sprinkling of the 'water of cleansing,' (2) shaving of the body, ${ }^{200}$ (3) washing of clothes, (4) selection of sacrificial animals, (5) presentation of the Levites before the Israelites at the Tent of Meeting, (6) laying on of hands, (7) presentation of Levites to Yahweh as a wave offering, (8) sacrifice of the bull of the sin offering then the bull of the burnt offering for Levite atonement, (9) presentation to Yahweh as a wave offering." Cole, Numbers, 148-49.
} 
claimed that the function of the water of purification and the sin offering was to "cleanse them of severe impurities that impinged on the sanctuary and polluted its altar." ${ }^{\prime 45}$ This understanding requires an adjustment since severe ritual impurity required seven days of time to pass by, and lustration with the water of purification on the third and seventh day in order to be removed from the person defiled by it (Num 19:11-12). The ritual portrayed in Num 8:5-26 does not mention or assume seven-day time passage, which leads to the conclusion that the ritual impurities implied concerning the Levites' ritual impurity are not major, but rather minor ones.

Milgrom also understood that the Levites were presented as an elevation offering to God in v. $11,{ }^{496}$ but missed realizing that it would be unlikely that they would have any kind of ritual impurity on themselves carried over to v. 12 to be purified by the achieved by the offering of the sin and burnt offerings. ${ }^{497} \mathrm{He}$ was also inconsistent in his comments on v. 8 that sin offering cleansed severe ritual impurities from the Levites, ${ }^{498}$ but in commenting on v. 12, he limited the cleansing function of the sin offering to "moral cleansing" and purging of the sanctuary. ${ }^{499}$

Based on the ritual flow outlined in v. 21, there are four stages of the Levites' installation: (1) purification of the Levites, (2) presenting them as an elevation offering,

\footnotetext{
${ }^{495}$ Milgrom, Numbers, 63.

${ }^{496}$ Milgrom, Numbers, 62.

${ }^{497}$ Cole, Numbers, 151.

${ }^{498}$ Milgrom, Numbers, 62.

${ }^{499}$ Milgrom, Numbers, 63.
} 
(3) performing cleanness is expressed by טָָה in v. 7, which is definitely the semantic scope of this term,

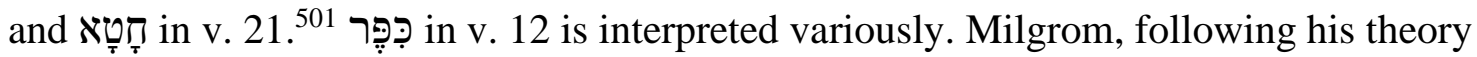
that the sin offering cleanses the sanctuary, claimed that it was "to purge the sanctuary of the impurities caused by any of the Levites' moral (and physical) lapses." 502 However, the text does not imply or mention any moral sin committed by the Levites. Budd suggested a more viable option "to give protection" from divine wrath. ${ }^{503}$ כְִֶּ does not deal with any moral sin of the Levites, which is in accordance with the text and the flow of the ritual, but rather, atones for the Levites, enabling them to perform certain duties safely in the sanctuary. In a similar vein, Levine suggested ransom," because the phrase לִכַפַּר עַל is often associated with the notion of ransom (Exod 30:15; Lev 17:11). ${ }^{504}$ The complementary suggestions by Budd and Levine fit the ritual flow since at the point כִֶֶּ is performed on the behalf of the Levites in v. 12, they are ritually clean and no sin is associated with them. The study of the states of creation and human sinfulness presented in the present study confirms this understanding of

The sequence of verbs in v. 21 correctly reflects a natural progression of the

${ }^{500}$ Cole, Numbers, $153 \mathrm{n} 214$, especially.

${ }^{501}$ Hithpael of in all other instances in the Pentateuch refers to the cleansing from ritual impurity (Num 19:12-13, 20; 31:19-20, 23).

\footnotetext{
${ }^{502}$ Milgrom, Numbers, 63, 369-71.

${ }^{503}$ Budd, Numbers, 93.

${ }^{504}$ Levine, Numbers 1-20, 276-77.
} 


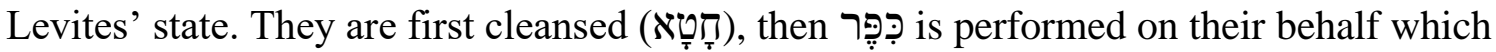

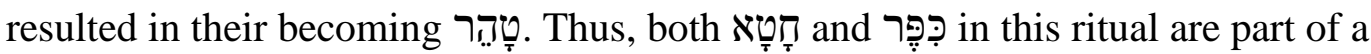
broader process of becoming טָָָָ.

כִ is achieved by the offering of the sin and burnt offerings made by the priest. The offerers were the Levites since they laid hands on the sacrificial animals (v. 12). The reason for the offerings was installation/enabling of the Levites for the service in the sanctuary. The blood of the sin and burnt offerings was applied according to the protocol established in Lev 1, 4.

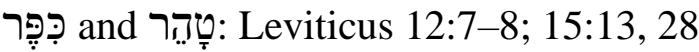

Lev 12:7-8. Leviticus 12 emphasizes the fact that the mother is ritually impure (טָמֵא) for seven + thirty-three days if she delivers a son (v. 2-4) or fourteen + sixty-six days if she delivers a daughter (v. 5). For the first seven, in the case of a boy, or fourteen days, in the case of a daughter, her ritual impurity is of the same force as menstrual impurity, which means that it is communicable by the contact. The force of her impurity is being reduced during the last thirty-three or sixty-six days, and it is not communicable, yet, she is restricted from contacting the holy and entering the sanctuary (v. 4) ${ }^{505}$ During this period, the mother is gradually healed from childbirth and totally cleansed, which means that normal discharge after the childbirth that lasted for two to six weeks had totally ceased. ${ }^{506}$ The verb טָהר is used two times in vv. 7 and 8 to convey the mother's

\footnotetext{
${ }^{505}$ Noordtzij, Numbers, 132; Gane, Leviticus, Numbers, 221-22.

${ }^{506}$ Noth, Leviticus, 98.
} 
pure state. Thus, the final goal of the ritual is mother's reaching the state of purity. The

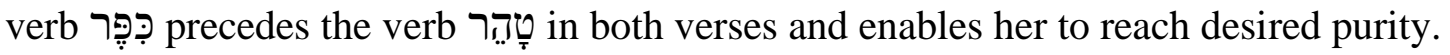
Scholars have reached a consensus that the mother has regained her ritual purity when she is able to make her offerings in the sanctuary. ${ }^{507}$ Milgrom's comment is explanatory here: "Now that forty (or eighty) days have elapsed and she has brought her requisite sacrifices to the sanctuary, she is purified completely and is eligible to make contact with sacred objects." ${ }^{508}$

There is no indication in the text that the mother was involved in any moral impurity. ${ }^{509}$ The verb סָלָ which marks the resolution of moral impurity contexts is not used in this chapter. ${ }^{510}$ Thus, the text of Lev 12 indicates that just before offering burnt and sin sacrifices, the mother has reached a pure state again and was not involved in any kind of moral impurity. Following Milgrom's influential hypothesis that the sin offering purges the sanctuary and its part, scholars have accepted the fact that the purifies the sanctuary/altar from the mother's impurity which reached the altar from a

\footnotetext{
${ }^{507}$ Porter, Leviticus, 95; Wenham, The Book of Leviticus, 186-87; Milgrom, Leviticus 1-16, 75960. Levine, Leviticus, 74; Hartley, Leviticus, 168-69; Gane, Leviticus, Numbers, 221-22.

${ }^{508}$ Milgrom, Leviticus 1-16, 759-60. There many more instances where Milgrom made it clear that the mother is ritually pure at the time she offers sacrifices. "That these sacrifices are brought after the impurity has totally disappeared is irrefutable proof that their function is not apotropaic or medicinal." Milgrom, Leviticus 1-16, 756. Also, "Nevertheless, the fact that the parturient is purified by the action of both sacrifices ( $\mathrm{vv} 7 \mathrm{a}, 8 \mathrm{~b})$ indicates that the purpose of the burnt offering, like that of the purification offering, is expiatory (see the NOTE on "effect expiation," $v 7$ ), but it addresses other matters than pollution.” Milgrom, Leviticus 1-16, 757-58.

${ }^{509}$ Porter, Leviticus, 94; Milgrom, Leviticus 1-16, 759-60; Hartley, Leviticus, 168-69; Rooker, Leviticus, 184; Gane, Leviticus, Numbers, 221-22; Richard S. Hess, "Leviticus," in The Expositor's Bible Commentary: Genesis-Leviticus, vol. 1 of The Expositor's Bible Commentary, rev. ed., ed. Tremper Longman III and David E. Garland (Grand Rapids, MI: Zondervan, 2008), 689.

${ }^{510}$ Milgrom, Leviticus 1-16, 759-60; Gane, Leviticus, Numbers, 221-22.
} 
distance. ${ }^{511}$ Gane, in contrast, claimed that impurity: "The goal/meaning of the ritual procedure is to remove physical ritual impurity from the woman so that she is ritually pure, not to remove moral fault from her in preparation for divine forgiveness (contrast 4:20, 26, 31, 35). So her hatta 't is a "purification offering." ${ }^{512}$ Gane himself stated that the defiled person would reach the status of ritual purity before the point he/she comes to the sanctuary to offer the sacrifice. ${ }^{513}$ This claim conflicts with an opening statement in v. 6: "When the days of her purification are completed," 514 she is allowed come to the sanctuary. This implies that she had fully reached the state of ritual purity as established above. N. H. Snaith and A. Noordtzij viewed the sin offering as purificatory, but it is unclear whether they refer to the purification of the sanctuary or the mother. ${ }^{515}$

Keil suggested that the mother's burnt and sin offerings purify her from "uncleanness in which the sin of nature had manifested itself" in the delivery and prevented her from going to the sanctuary and the fellowship of God. In addition, he said the main reason for the offerings was the "sin which had been indirectly manifested in

\footnotetext{
${ }^{511}$ Milgrom, Leviticus 1-16, 759-60; Wenham, The Book of Leviticus, 186-87; Walton, Matthews, and Chavalas, "Leviticus," 130.

${ }^{512}$ Gane, Leviticus, Numbers, 221-22. Followed by Hess, "Leviticus," 689.

513“'So the contagion of physical ritual impurity is already removed before sacrificial hand leaning is performed, which makes it difficult to maintain that this gesture defiles animals by physical contact in the same way that people defile objects and other people while their sources of impurity are active (cf. Lev 15:4-12, 26-27)." Gane, Cult and Character, 55.

${ }^{514}$ This phrase refers to the completion of the purificatory process the mother goes through. Milgrom, Leviticus 1-16, 755-56.

${ }^{515}$ Snaith, Leviticus and Numbers; Noordtzij, Numbers, 133.
} 
her bodily condition." ${ }^{516}$ Uncleanness from Keil's first quotation and sin from the second seem to refer to general human sinful condition and its representation, respectively.

Levine also viewed that this rite handles the sinfulness of the mother since, in his opinion, כִֶֶּּ followed by the indirect object (preposition followed by the direct object marker does, but rather removes sinfulness from the offerer. ${ }^{517}$ A. Noordtzij, J. R. Porter, and Mark Rooker are more particular in their

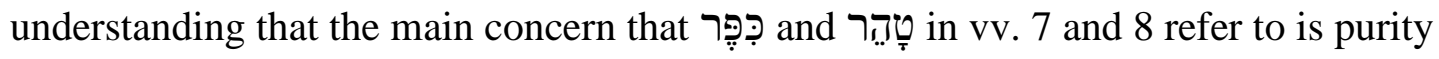
from "the issuance of blood." 518

Based on the foundational sinful condition of humans that has been explored on pages 400-14, the present study agrees that the most compelling reason for the mother's obligation to offer burnt and sin offering is this severe ritual impurity as a manifestation of GHS that is associated with the loss of blood that is associated with death. As argued on page 405, death is the underlying idea and significant expression of GHS. As such, it interrupted the relationship of the mother with the community and God. Thus, כְִֶּ brought about by the burnt and sin offering is best understood as being comprised of two elements. The first element is ransom for two reasons. The first reason is that the mother was involved in the event in which GHS was manifested in the most vivid way. During the childbirth and period of her ritual impurity, she experienced blood loss and constant

\footnotetext{
${ }^{516}$ Keil and Delitzsch, The Pentateuch, 2:376-77.

${ }^{517}$ Levine, Leviticus, 74, 24.

${ }^{518}$ Noordtzij, Numbers, 131; Porter, Leviticus, 94; Rooker, Leviticus, 184-85.
} 
discharge from her body. Both of these are signs of death and decay. Milgrom was informative again:

Moreover, in the Israelite mind, blood was the archsymbol of life (17:10-14; Deut 12:23; cf. chap. 11, COMMENT C). Its oozing from the body was no longer the work of demons, but it was certainly the sign of death. In particular, the loss of seed in vaginal blood (see the NOTE on "at childbirth," v. 2) was associated with the loss of life. Thus it was that Israel - alone among the peoples - restricted impurity solely to those physical conditions involving the loss of vaginal blood and semen, the forces of life, and scale disease, which visually manifested the approach of death. ${ }^{519}$

The second reason is articulated by Levine's remark that "in ancient times, concern for the welfare of mother and child was most often expressed as the fear of destructive, demonic, or antilife forces" ${ }^{520}$ in ANE texts contemporaneous with biblical times,${ }^{521}$ which testifies to the fact that childbirth was perceived as a threatening and risky time for both mother and child in the ANE. One or even both could die. Both of these facts led to the conclusion that the mother was in close contact with death and, having survived this experience, she was asked to offer burnt and sin offerings in order to redeem herself.

A second element community and worship to God. Reinstatement was needed due to the fact that the mother was, in a way, excluded from society due to her specific experience of child birth and severe ritual impurity that was associated with it. This element resembles the

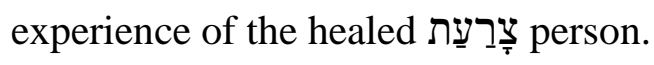

\footnotetext{
${ }^{519}$ Milgrom, Leviticus 1-16, 766.

${ }^{520}$ Levine, Leviticus, 249, 282n1.

${ }^{521}$ The OT does not present a threat for the mother and child from demons.
} 
כִּ was achieved by burnt and sin offerings brought by the new mother.

However, the focus of this text was not on the sacrificial procedures and it depends greatly on the previously established procedures for sacrificial offering in Lev 1,4 . The reason for the set of offerings was "the issuance of blood" that followed childbirth.

Lev 15:13, 28. These verses stand as conclusions of two passages that deal with the abnormal discharges from genital organs in men (15:2-15) and women (15:25-30).

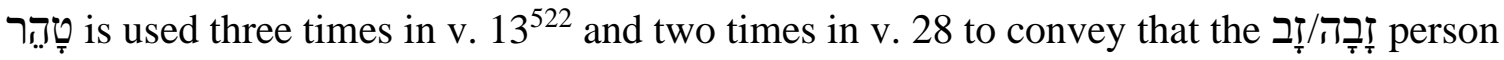
achieved the pure state. ${ }^{523}$ In support of the ownership theory of the sacrificial handleaning, Gane accurately stated that "the contagion of physical ritual impurity is already removed before sacrificial hand-leaning is performed, which makes it difficult to maintain that this gesture defiles animals by physical contact in the same way that persons defile objects and persons while their sources of impurity are active (cf. Lev 15:4-12, 26-27)."524 Milgrom also argued: "Clearly, physical impurity is removed by ablution: 'he shall launder his clothes [and] bathe in water' (15:8 inter alia)."525

The fact that the pָזָרָה person achieves the state of purity informs the

\footnotetext{
${ }^{522}$ The first טָׁה undeniably refers to the physical health of the zāb person. Milgrom, Leviticus 116, 675; Gane, Leviticus, Numbers, 260.

${ }^{523}$ Levine, Leviticus, 95; Wright, "The Spectrum of Priestly Impurity,” 156; Gorman, The Ideology of Ritual, 116, 164; Gane, Leviticus, Numbers, 260; Gane, Cult and Character, 55.

${ }^{524}$ Gane, Cult and Character, 55.

${ }^{525}$ Milgrom, Leviticus 1-16, 329-30, 756. And again: "That this severe "menstrual" impurity is terminated by immersion is nowhere stated either for the parturient or for the menstruant. But as all statements regarding the duration of impurity automatically imply, if they do not explicitly affirm, that it must terminate with ablutions (see the NOTE on "he shall be impure until evening," 11:24b), the mere statement that the period of the parturient's severer impurity lasts seven (or fourteen, v. 5) days assumes that this period is terminated by ablutions. The same holds true for the menstruant (see the NOTE on bĕniddātāh, 15:19). Besides, if a minor impurity such as seminal discharge requires ablution (15:16), all the more so the major genital discharges." Milgrom, Leviticus 1-16, 746.
} 
understanding of כִּפְּ in vv. 14 and 28 . That is, the ritual chronologically takes place

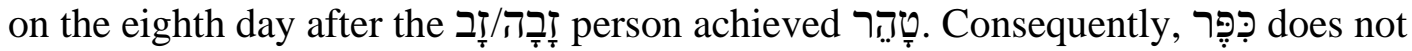
purify the זָָָָהת/זָ person from ritual impurity since they are already ritually pure at this point of the ritual. Rather, and ransoms his/her life. Experiencing constant genital discharge from the body was perceived as a severe ritual impurity; the זָָָָה/זָ person, in a way, experienced death and decay in a similar way as the new mother.

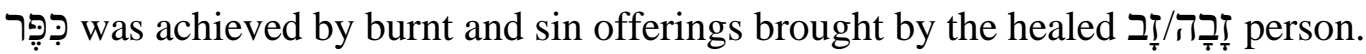
Here, also, the focus was not on sacrificial procedures and this text depends greatly on previously established procedures for sacrificial offering in Lev 1, 4. The priest officiated the sacrificial offering and the reason for the set of offerings was the זָזָה person's abnormal genital discharge.

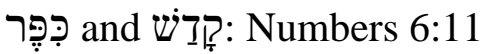

In this context, previous cases analyzed above. The text clearly state that the Nazirite has sinned (v. 11, verb obtained unintentionally through a person who suddenly died in the Nazirite's proximity. Through such incident, the Nazirite becomes ritually defiled (v. 9, טָָָָא usual ritual purification from the corpse defilement of sprinkling by the purification waters on the third and the seventh days as prescribed in Num 19:11-12,17-19. On the same day, the Nazirite also had to shave off his hair (v. 9) as an outward sign of the 
removal of his Nazirite status. ${ }^{526}$ After being purified from the ritual impurity through the lustrations on the third and seventh days, on the eighth day, the Nazirite had (1) to offer the sin and burn offerings, (2) reconsecrate his hair for a new term, and (3) to offer the reparation offering.

The fact that the Nazirite had to go through these rituals on the eighth day makes Milgrom's inference that "the Nazirite's contamination is sinful and is to be avoided" 527 accurate. The Nazirite's defilement is sinful for two reasons. First, based on his current state "he [the Nazirite] is holy (Num 6:5, 8) and contamination of holiness is a serious sin." ${ }^{, 528}$ Second, his exceptional holy nature stems from the vow by which the Nazirite entered this temporary state of holiness (vv. 2-8). Through the corpse defilement, this vow was broken, thus annulling their previous days of Nazirite status (vv. 6-10).

כִִּ in this case atones for the Nazirite's sin as a preparation for his new term of Nazirite status. The ritual impurity has been removed by the regular sprinkling of the water of purification on the third and seventh days in addition to shaving the Nazirite's head. burnt offering (v. 11). It is then followed by the Nazirite's reconsecration for the new term.

כִ was achieved by burnt and sin offerings brought by the Nazirite. The text does not focus on the sacrificial procedure; thus, it wholly depends on previously

\footnotetext{
${ }^{526}$ Gane, Cult and Character, 278.

${ }^{527}$ Milgrom, Leviticus 1-16, 357-58.

${ }^{528}$ Milgrom, Leviticus $1-16,254-55,357-58$.
} 
established procedures for sacrificial offering in Lev 1, 4. The priest officiated the sacrificial offering and

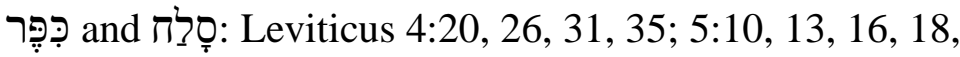 26 [6:7]; 19:22; Numbers 15:25, 26, 28}

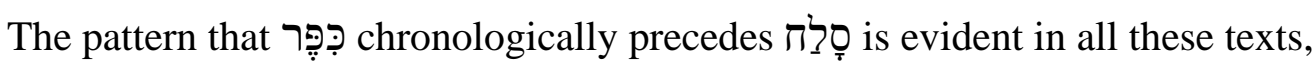
except in Lev 5:6 where However, the regulations applying to the same cases in vv. 10 and 13 maintain the usual

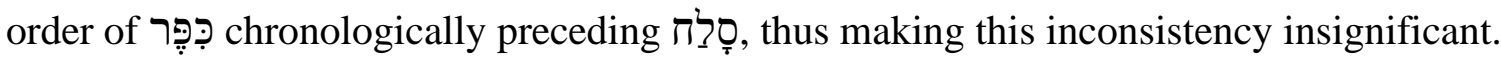

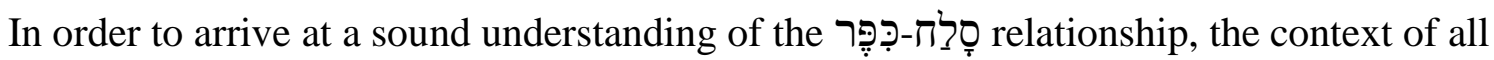
these texts has to be taken into consideration and the context is coherent and clear; the human party has sinned and is required to offer a sin or reparation offering.

The most elaborate text of those in the Pentateuch is Lev 4, since it contains the most detailed description of the sin offering ritual. In the event of moral impurity, the one who commits it is required to offer a sin offering. This consists of the offerer's bringing the sacrificial animal to the doorway of the tent of meeting, laying his/her hand on its head, and slaughtering it.

Subsequently, the priest would dip his finger in the blood obtained from the sacrificial animal and apply the blood on various objects of the sanctuary, depending on the social status of the offerer. In cases 1 (high priest/priest) and 2 (a whole community) in Lev 4, he would sprinkle some of the blood seven times in front of the veil that separates the two compartments inside of the tent and apply some of it to the horns of the altar of incense, located in the first compartment of the tent, and pour out the rest of it at the base of the sacrificial altar (vv. 6-7, 16-18). The remainder of the sacrificial animal 
that is not burned on the sacrificial altar (hide, flesh, legs and entrails, vv. 11, 20) ${ }^{529}$ is taken out of the camp to a clean place and incinerated (vv. 12, 21). ${ }^{530}$

The steps are slightly different in cases 3 (a leader) and 4 (a commoner). The activities are identical up to the point of the blood application, but in these two cases, the priest applies some of the blood on the horns of the sacrificial altar and pours the rest of it at the base of the same altar (vv. 25, 30, 34) ${ }^{531}$ Besides a different location of the blood application, the regulations for cases 3 and 4 miss stating that the remainder of the sacrificial animal is incinerated outside the camp. However, further regulations for the sin offering in Lev 6:19 [26], 22 [29] state that the officiating priest is obliged to eat the remaining flesh of sin offering.

The stipulations of the sin offering differ in the types of the required animal ${ }^{532}$ and that is properly explained by the social status of the offerer. ${ }^{533}$ Offerings of both types of

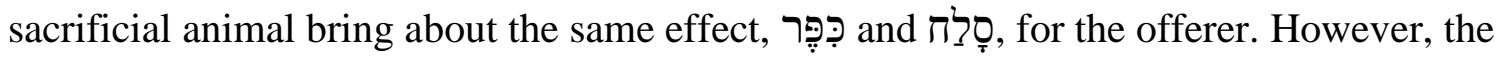
location of the blood application is more substantial difference between the two sets of instructions. That is, the blood is applied inside the tent in cases 1 and 2 with certain parts of the animal being incinerated outside the camp, while the blood in cases 3 and 4 is

\footnotetext{
${ }^{529}$ All the fat that covers the entrails along with kidneys is offered on the sacrificial altar (vv. 8-10, 19).

${ }^{530}$ For a more complete list of activities related to cases 1 and 2 in Lev 4, see Gane, Leviticus, Numbers, 99.

${ }^{531}$ For a more complete list of activities related to cases 3 and 4 in Lev 4, see Gane, Leviticus, Numbers, 101-2. respectively.

${ }^{532} \mathrm{~A}$ bull for cases 1 and 2, and a male goat and a female goat or a lamb in cases 3 and 4 ,

${ }^{533}$ Milgrom, Leviticus 1-16, 307-8.
} 
applied only outside the tent, on the sacrificial altar, with the priest being required to eat the meat of the sacrificial animal. Again, the different activities bring about the same effect, סָלָּח for the offerer.

The texts from Lev 5:10, 13, 16, 18, 26 [6:7] belong to four distinct pericopes: 5:1-13, 14-16, 17-19 and 5:20-26. Schwartz accurately claimed that "the cases [Lev $5: 1-4]$ aim to counter the notion that duties weaken with time and eventually cease to exist ("forget it and it will simply go away")." 534 Gane has plausibly proved that 5:1-13 is a continuation of the sin offering regulations, with special emphasis on the sin offering's having the function of אָָָׁ, some sort of reparation for the sin committed. ${ }^{535}$ This pericope assumes the offering of a sin offering as prescribed in Lev 4:27-35. ${ }^{536}$ The sins in Lev 4:27-35 are expiable/forgivable, regardless of the fact that they were intentional.

As it was established in the present study, Lev 5:14-16 envisions two alternative ways of sinning, intentional non-brazen and unintentional, based on the two distinct classes included in the protasis of this case. In terms of the nature of sin, it envisions sin against sancta and its sacrificial procedure depends on the ones laid out in Lev 7:1-7, in addition to the possibility embedded in this pericope, v. 15 , to use monetary payment instead of an actual sacrificial animal. ${ }^{537}$ The pericope in Lev 7:1-7 introduces a set of regulations for a reparation offering that was offered in cases when an individual

\footnotetext{
${ }^{534}$ Schwartz, “Leviticus,” (JSB), 215.

${ }^{535}$ Gane, Leviticus, Numbers, 118-19.

${ }^{536}$ Milgrom, Leviticus 1-16, 408-9, 438; Gane, Leviticus, Numbers, 121, 132.

${ }^{537}$ Milgrom, Leviticus 1-16, 408-9, 438; Gane, Leviticus, Numbers, 132-33.
} 
committed a sin that would involve some sort of literal, measureable debt that could be restituted to another party. ${ }^{538}$ The procedure for the reparation offering in great part resembles the one for a sin offering with a notable difference in treating the sacrificial blood that was dashed on the sides of the outer altar, instead of applying it on its horns, thus resembling the treatment of the blood in burnt or well-being offering. ${ }^{539}$ Certain procedural differences are affected by the fact that this set of instructions is placed in the section of sacrificial procedures that are meant for priests (Lev 6:1 [6:8]-7:7), rather than the laity (Lev 1-5). Milgrom reasoned plausibly:

If it is indeed the case that the one liable for a reparation offering was expected to bring its monetary equivalent to the sanctuary, it should occasion no surprise that the procedure for the sacrifice of the reparation offering should be given here in the administrative unit addressed to the priests (chaps. 6-7) rather than in the didactic order addressed to the laity ... Once the lay offerer purchases the requisite ' $\bar{a} \bar{s} \bar{a} m$ animal from the priest, the latter makes certain that the proper sacrificial procedure is followed. ${ }^{540}$

Milgrom noted that the expiatory value of this sacrifice does not resemble the one of the sin offering, "to purge," but rather refers to general expiation. ${ }^{541}$ However, regardless of the different procedures for the two offerings, ${ }^{542}$ they bring about the same

${ }^{538}$ Rooker, Leviticus, 122; Gane, Leviticus, Numbers, 132.

${ }^{539}$ See Milgrom endorsing Rodríguez's suggestion that the phrase " can refer to the entire procedure with the difference in blood application stated in this pericope. Milgrom, Leviticus 1-16, 409-10; Rodríguez, "Substitution in the Hebrew Cultus," 160; Gane, Leviticus, Numbers, 132.

${ }^{540}$ Milgrom, Leviticus 1-16, 409.

${ }^{541}$ Milgrom, Leviticus 1-16, 410.

${ }^{542}$ Milgrom's view on Lev 7:7 allows for both interpretations of the phrase "the reparation offering is like the sin offering," that is (1) the phrase refers to the specific regulation of eating of sacrificial meat that is the immediate context of this text, and (2) the phrase refers to the entire ritual except of blood application. Milgrom, Leviticus 1-16, 408-9. Rodríguez proposed a strong support for the latter view. Rodríguez, "Substitution in the Hebrew Cultus," 160. 
result,

It is established in the present study that Lev 5:17-19 involves unintentional sin either out of ignorance or by accident. Besides certain linguistic differences, especially in the protasis of the two subcases, 5:17-19 resembles 5:14-16. Accordingly, it depends for its sacrificial procedure on the ones laid out in Lev $7: 1-7 .{ }^{543}$ In addition, there is the possibility embedded in this pericope in v. 18 , and in the additional clarification in $\mathrm{v} .15$, of using a monetary payment instead of an actual sacrificial animal.

Contrary to the previous three pericopes, Lev 5:20-26 implies only intentional, non-brazen sins. However, since these sins were committed under oath before God, ${ }^{544}$ they depend for their sacrificial procedure on the ones laid out in Lev $7: 1-7 .{ }^{545}$ Here also, there is the possibility embedded in this pericope in v. 25 , and in the additional clarification in v. 15, of using a monetary payment instead of an actual sacrificial animal.

The sexual misconduct in Lev 19:22 is undoubtedly intentional, but regardless of

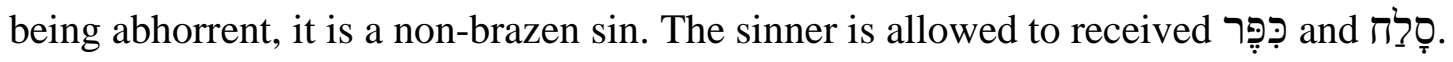
The sinner who commits such a sin of adultery would be penalized by the capital punishment and the same punishment would be implemented to the girl if she consented rather than was raped (Lev 22:23-27). However, the girl in this law is a slave ${ }^{546}$ and because of her non-free status, this sin is not punishable by capital punishment. Gane

\footnotetext{
${ }^{543}$ Milgrom, Leviticus 1-16, 408-9, 438; Gane, Leviticus, Numbers, 132.

${ }^{544}$ Milgrom, Leviticus 1-16, 438; Gane, Leviticus, Numbers, 134.

${ }^{545}$ Milgrom, Leviticus 1-16, 408-9, 438; Gane, Leviticus, Numbers, 132.

${ }^{546}$ Baruch J. Schwartz, "A Literary Study of the Slave-Girl Pericope: Leviticus 19:20-22," in Studies in Bible II: 1986, ed. Sara Japhet, ScrHier 31 (Jerusalem: Magnes Press, Hebrew University, 1986):
} 245-46. 
captured the plausible rationale of this sin:

Although violation of a designated slave woman is not a capital offense, it is immoral activity offensive to God, violating the spirit of the seventh commandment of the Decalogue, which prohibits adultery (Ex. 20:14). Thus, a man who commits this wrong must sacrifice a reparation offering ('ašam, the so-called "guilt offering") to the Lord. ${ }^{547}$

Milgrom's understanding that the reparation offering was always offered for the cases of sacrilege either through illicit contact with sancta in 5:14-19 and/or misappropriation of other's property under misuse of God's name in a false oath in 5:20-26 $6^{548}$ adds even more gravity to this sin. The requirement for the reparation offering upholds the sanctity of the marriage covenant and as such, it constitutes a sacrilege even under the two disrupting conditions which, in this case, are the facts that (1) this is a marriage of a slave woman, and (2) it is not consummated. ${ }^{549}$

The pericope in Num 15:22-29 modifies the sin offering procedure in Lev 4:5$13,{ }^{550}$ but the two points are unchanged: (1) the protasis encompasses two alternative ways of sinning, and (2) the sinner first receives כִֶֶּ: and is forgiven, implying that they follow the sacrificial procedure $(5: 16,18,29[6: 7])$.

As established under the subheading "Moral Impurity/Sin in the Pentateuch" of this study, punishments for sin are always included in the contexts when the sinner breaks

${ }^{547}$ Milgrom, Leviticus 1-16, 338-39.

${ }^{548}$ Milgrom, Leviticus 1-16, 345-46, 365-73.

${ }^{549}$ Milgrom, Leviticus 17-22, 1672-75; Gane, Leviticus, Numbers, 339.

${ }^{550}$ The relationship and differences between the procedures regarding the sin offering in Lev 45:13 and Num 15:22-31 are not the concern of the present study. For potential resolutions see Milgrom, Leviticus 1-16, 264-68; Roy E. Gane, "Loyalty and Scope of Expiation in Numbers 15," ZABR/JANEBL 16 (2010): 249-50. 
God's commandments. The punishment for various sins cannot be related to certain Hebrew terms for sin since they are frequently used as equivalents in the Pentateuch and OT. Authors of biblical books did not use them in a strict, technical manner, but rather, in a general one referring to a broad-spectrum of breaking the commandments. It is the context which often contains punishment that suggests whether a certain sin is expiable/forgivable or inexpiable/unforgivable. Punishment also cannot be established based on the sinner's intention, since both basic types of sin, intentional, but not brazen sins, and unintentional sins, are expiable/forgivable. I have suggested that inexpiable/unforgivable sins are those for which the texts stipulate capital punishment in

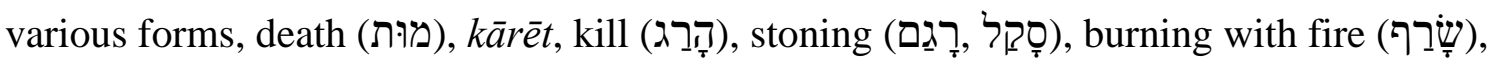

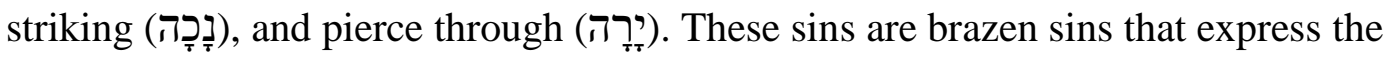

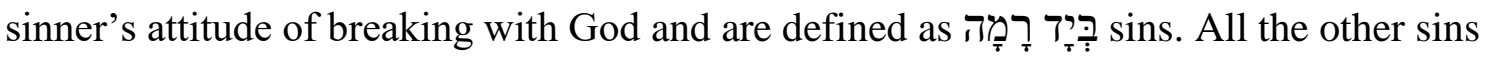
are expiable/forgivable. No capital punishment is associated with the sins enumerated in Lev 4-5 and Num 15:22-29. In addition, all these texts portray that forgiveness is available to the sinner. The meaning of Lev 17:11 fits these contexts perfectly since the sinner is guilty before God and yet, receives forgiveness. implied is the fact that the sin the sinner committed has been transferred to the sanctuary. 


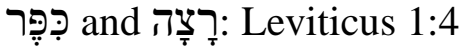

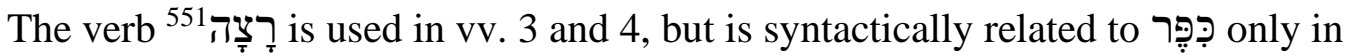

the latter verse. Milgrom correctly noted a difference between the two uses of רָצָה:

Whereas the latter is dependent on the unblemished condition of the animal, the "acceptance" in this verse [v. 4] relates to the hand-leaning rite. The two dative suffixes attached to this and the following verb, רִֶֶּ, both mean "for, on behalf of," thereby emphasizing the indispensability of the hand-leaning by the offerer himself in his quest for "acceptance" and "expiation" (see below). ${ }^{552}$

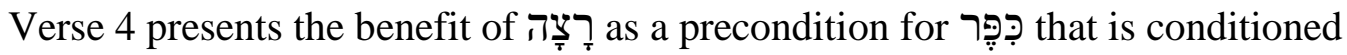

by the laying on of hands, while v. 3 requires that the sacrifice be a male, without defect, and offered in the sanctuary (vv. 3,10). רָָָ thus connects four prerequisites in vv. 3 and 4 that the offerer was required to do in order to receive רֶֶ, (1) the unblemished (2) male sacrifice (3) offered in the sanctuary and (4) the offerer's laying on of hands on the head of the sacrificial animal. Chapter 1 does not relate ritual nor moral impurity to the offerer. ${ }^{553}$ However, Levine correctly noticed: "Proximity to God was inherently dangerous for both the worshiper and the priests, even if there had been no particular ofference to anger Him. The favorable acceptance of the 'olah signaled God's willingness to be approached and served as a kind of ransom, or redemption, from divine wrath." 554 It is not clear from Levine's quotation what would create this danger from God

\footnotetext{
${ }^{551}$ The root רָָּ has two verbal and corresponding nominal meanings: "to be accepted" and "an acceptance" and "to desire" and "a desire." However, only the former meaning is found in the Pentateuch. Milgrom, Leviticus 1-16, 150; Rooker, Leviticus, 86.

${ }^{552}$ Milgrom, Leviticus $1-16,153-54$.

${ }^{553}$ Levine, Leviticus, 6; Porter, Leviticus, 19; Balentine, Leviticus, 23.

${ }^{554}$ Levine, Leviticus, 7.
} 
for the offerer in the latter's approach to God. As has been suggested multiple times in the current study, it is the GHS that generates this danger for the offerer in God's presence and thus, inherently sinful human and a holy God possible and safe. ${ }^{555}$ The foundational principle behind atonement brought by the misunderstood the meaning of the כִֶֶּ in this context since they ascribed to it the role of purifying from both ritual and moral impurity ${ }^{557}$ which is not supported by the text. These scholars have considered, explicitly or implicitly, the two radically different contexts of Lev 1 and 4 as the same and suggested the same meaning for not provide grounds for such inference.

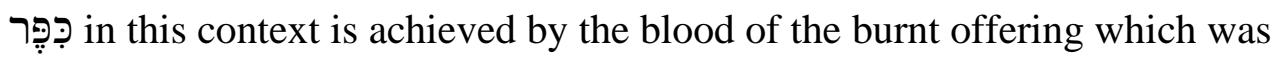
offered by the priest on behalf of the offerer. The blood was applied around the altar. There is no specific reason why this sacrifice was offered. Ritual or moral impurity terminology is not found in the chapter suggestive of the absence of either of the two possible impurities. The only element that the foundation based on which atoning is possible.

\footnotetext{
${ }^{555}$ Wenham, The Book of Leviticus, 57; Bellinger, Leviticus and Numbers, 20.

${ }^{556}$ Sklar, Sin, Impurity, Sacrifice, Atonement, 163; Kiuchi, Leviticus, 56-57.

${ }^{557}$ Milgrom, Leviticus 1-16, 65-66; Gerstenberger, Leviticus, 27-28; Gane, Leviticus, Numbers, 67-68; Tidball, The Message of Leviticus, 39-40; Kenneth A. Mathews, Leviticus: Holy God, Holy People, Preaching the Word series (Wheaton, IL: Crossway Books, 2009), 30-31; Sklar, Leviticus, 90; Wenham, The Book of Leviticus, 57. Wenham's interpretation is the most contradicting since he explicitly stated in one spot that "this is the clearest clue to the purpose of the burnt offering to be found in the Levitical law. It atones for the worshipper's sins," and in other spot that "the burnt offering does not remove sin or change man's sinful nature, but it makes fellowship between sinful man and a holy God possible." Wenham, The
} Book of Leviticus, 57, 58. 
Milgrom's translation of these texts accurately reflects what has been

communicated in the Hebrew: " If his offering is a burnt offering from the herd, he shall offer a male without blemish. He shall bring it to the entrance of the Tent of Meeting, for acceptance on his behalf before the Lord. ${ }^{4} \mathrm{He}$ shall lean his hand on the head of the burnt offering, that it may be acceptable [accepted] on his behalf, to expiate [atone] for him.."558

\section{Milgrom's and Gane's Understanding of Atonement and Its Relation to the Hebrew Preposition מִ̣}

The most updated debate on the nature of atonement is the one between Milgrom and Gane ${ }^{559}$ Citing just these two studies in a limited way does not intend to disregard several more theories such as those of Rodríguez, ${ }^{560}$ Kiuchi, ${ }^{561}$ and other scholars who contributed greatly to the understanding of atonement. ${ }^{562}$ This debate contains elements that the present study agrees and disagrees with, so for that reason, both are presented and critiqued in a limited way in order to highlight the differences and similarities between them. This process portrayed the theory suggested in this study. The preposition included here because it emphasizes one of the crucial differences between these two

${ }^{558}$ Milgrom, Leviticus 1-16, 133.

${ }^{559}$ Christian A. Eberhart, "Cult and Character: Purification Offerings, Day of Atonement, and Theodicy: A Review," JBL 125 (2006): 573-76; Baruch H. Schwartz, "Cult and Character: Purification Offerings, Day of Atonement, and Theodicy: A Review," AUSS 45.2 (2007): 267-72; William K. Gilders, "Cult and Character: Purification Offering, Day of Atonement, and Theodicy: A Review," CBQ 69 (2007): $116-18$.

${ }^{560}$ Rodríguez, "Substitution in the Hebrew Cultus."

${ }^{561}$ Kiuchi, Purification Offering; Kiuchi, Leviticus.

${ }^{562}$ Levine, In the Presence of the Lord, 63-67; Philip P. Jenson, Graded Holiness: A Key to the Priestly Conception of the World, JSOTSup 106 (Sheffield: JSOT Press, 1992), 155-60; Sklar, Sin, Impurity, Sacrifice, Atonement; Hartley, Leviticus; Rendtorff, Leviticus, vol. 3. 
theories and helps inform the concept of atonement presented in this study. Milgrom's and Gane's treatments of the preposition ậ are analyzed in a separate subheading after the basic components of their atonement theories are presented and evaluated.

\section{Milgrom's Theory of Atonement}

Milgrom innovatively suggested that it is not the offerer who benefits from

but rather, the sanctuary. ${ }^{563}$ This claim rests on five assumptions. First, means "to cleanse, purge." $" 564$ Second, impurity is always removed from sinners before they offer a sin offering. Ritual impurity is removed by ablutions, whereas moral impurity is removed by repentance. ${ }^{565}$ Third, the sanctuary is defiled aerially. A major impurity defiles the sacrificial altar, while a forgivable moral impurity, depending on the socio-religious status of the offerer, defiles the holy and the most holy places. Unforgivable sin, regardless of who commits it, defiles the most holy place and is cleansed on the Day of Atonement. ${ }^{566}$ Fourth, the blood of the sin offering was never applied directly to human beings and therefore, the sin offering never purges the offerers from their sins, but rather, the sanctuary to which it is applied. ${ }^{567}$ Fifth, when the object of כִִּּ is inanimate, it is accompanied by a direct object marker, and when the object is

\footnotetext{
${ }^{563}$ Milgrom, “Atonement in the OT," 78-79; Milgrom, Leviticus 1-16, 255-56.

${ }^{564}$ Milgrom, “Atonement in the OT," 78-79; Milgrom, Leviticus 1-16, 255-56.

${ }^{565}$ Milgrom, Leviticus 1-16, 255.

${ }^{566}$ Milgrom, Leviticus 1-16, 257.

${ }^{567}$ Milgrom, Leviticus 1-16, 255.
} 
human, then it is modified by the prepositions עַ or 568

All these claims are erroneous. The general error of Milgrom's theory is a/the mechanistic view of atonement expressed through רִִּ which, in cultic contexts, is achieved within the limits of physical activities. In other words, the blood of the sin offering touches entities that need it. A detailed study of the atonement in the present study demonstrated that Milgrom's understanding of not supported by biblical texts and worldview. It also blurs the lines between magic and biblical faith within which God directly acts to bring change rather than the performance of certain ritual activities. The benefits of ritual is not achieved by the performance of the ritual itself, but by God's involvement and acting based on his commitment/promise that he will act if the human party follows his guidelines to perform a given ritual.

First, the understanding of the concept of sin, the semantics of the present study, and other inferences derived from biblical texts led to the conclusion that atonement expressed through ransom of sacrificial blood/life and not on cleansing. Second, ritual impurity was usually remedied by the passage of time and it vanished with no sin offering needed, but in some cases, a sin offering was needed after the passage of time, which in this case, does not cleanse the offerers, but rather, atones for them. Moral impurity remained on the offerers until they received atonement and were forgiven. Forgiveness for sin takes place after the

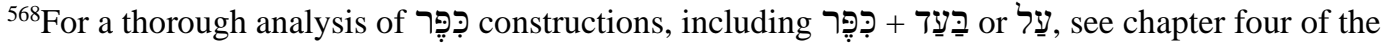

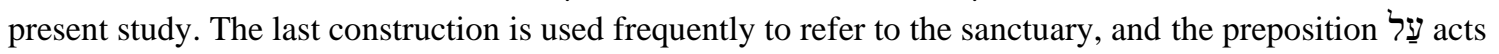

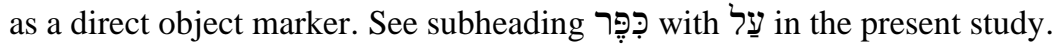


כִִּ ritual was performed, signaling that the offerers were still affected with their sin. Repentance is needed in the process of forgiveness, but it is never said to remove sin from the sinner. Third, the ADH is extensively disproved in chapter five of the present study. A part of this hypothesis is disproved by the understanding of sin presented in chapter two of the present study, while other parts are disproved by a close study of the grammatical, semantical, and syntactical peculiarities of the passages upon which this theory rests. Fourth, the blood of the sin offering is infected by the offerers' sin and therefore, is not applied onto them, but rather, to the sanctuary where the sin is stored until the Day of Atonement. It is on this day when the sanctuary, in its totality, would be cleansed, not at the time when the offerers offer their sacrifice. ${ }^{569}$ Milgrom's fifth point is

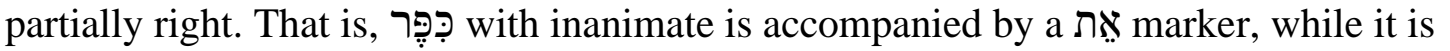

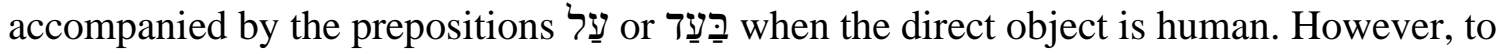
claim that the offerers do not directly receive the benefits of overemphasizes the role of the prepositions in the process of forming an understanding on such a comprehensive concept as atonement. In addition, it opposes the outcome of the rest of the sin offering ritual where the offerers are forgiven only after they offer a sin offering and receive atonement. Gane correctly concluded that the benefit of in the case of inanimate objects, and indirect in case of human objects. ${ }^{570}$ Building on Gane's point, the present study proposes that the essential difference between the two

\footnotetext{
${ }^{569}$ Gane convincingly argued for a two-phase atonement, contrary to Milgrom's one-phase atonement. Gane, Cult and Character, 267-84.

${ }^{570}$ Gane, Cult and Character, 108.
} 
constructions of receive cleansing due to their inanimate nature and therefore, are marked with

Human objects, on the other hand, receive atonement that is based on ransom due to the constant disadvantage of GHS and sin (understood as a violation of God's laws). Many scholars of cult have successfully criticized Milgrom's theory lately, ${ }^{571}$ so this study refrains from analyzing all the points of his theory.

\section{Gane's Theory of Atonement and Understanding of}

The critical point of concern of Gane's theory is the identity of the object who received ר.ֶ. Hasel, ${ }^{572}$ Rodríguez, ${ }^{573}$ and Zohar ${ }^{574}$ already responded to this question in the same way as Gane, claiming that it is the offerer who was cleansed in the sin offering ritual, but Gane supplied additional arguments to strengthen this position.

First, Gane adopted the concept that the blood applications in Lev 4 and 16 are different because they were performed on different occasions and the former cleanses the offerer, while the latter cleanses the sanctuary, thus forming two phases of atonement,

\footnotetext{
${ }^{571}$ Levine, In the Presence of the Lord, 63-67; Jenson, Graded Holiness, 155-60. Also see entire works of Rodríguez, "Substitution in the Hebrew Cultus"; Rodríguez, "Transfer of Sin in Leviticus," 132 33, 137; Kiuchi, Purification Offering; Kiuchi, Leviticus; Zohar, "Repentance and Purification"; Roy E. Gane, Ritual Dynamic Structure, GD 14 (Piscataway, NJ: Gorgias Press, 2004); Gane, Cult and Character.

${ }^{572}$ Hasel, "Studies in Biblical Atonement-I," 99.

${ }^{573}$ Rodríguez, "Transfer of Sin in Leviticus," 132-33, 137.

${ }^{574}$ Zohar, "Repentance and Purification," 612-13.
} 
daily and yearly. ${ }^{575}$ In this, Gane's theory resembles that of Rodríguez ${ }^{576}$ which was also accepted by Zohar ${ }^{577}$ and Hasel. ${ }^{578}$ Second, Gane adopted limited automatic defilement only for cases of Molech worship and wanton neglect to purify oneself from corpse contamination. ${ }^{579}$ Third, Gane suggested a unique but yet not clearly articulated defilement of the sanctuary, while Rodríguez, Zohar, and Hasel clearly stated that the transfer of sin from the offerer to the sin offering happens via laying on of hands. ${ }^{580}$ Gane's understanding of this ritual gesture is multifaceted. His basic interpretation of the laying on of hands is as follows: "When hand-leaning is performed, it identifies the offerer/owner of the victim, to whom the benefits of the sacrifice accrue, within the context of transferring the offering material from the offerer to the deity." 581

Gane's hybrid theory encompasses the meanings of several theories. First, the ritual gesture expresses ownership of the offerer over the animal. Based on the following quotation by Gane that both types of laying on of hand/s "signifies a (different) kind of identification that is involved in transfer, ${ }^{, 582}$ so that two more elements can be derived.

${ }^{575}$ Gane, Cult and Character, xx, 6, 123-25, 127, 154, 160, 241, 274-84.

${ }^{576}$ Rodríguez, "Substitution in the Hebrew Cultus," 125-26; Rodríguez, "Transfer of Sin in Leviticus," 189-91.

${ }^{577}$ Zohar, "Repentance and Purification," 613.

${ }^{578}$ Hasel, "Studies in Biblical Atonement-I," 97-100; Gerhard Hasel, "Studies in Biblical Atonement-II: The Day of Atonement," in The Sanctuary and the Atonement: Theological and Historical Studies, ed. Frank B. Holbrook (Silver Spring, MD: Biblical Research Institute, 1989), 120.

${ }^{579}$ Gane, Cult and Character, 156, 157, 296, 299.

${ }^{580}$ Rodríguez, "Transfer of Sin in Leviticus," 180-88; Hasel, "Studies in Biblical Atonement-I," 94-96; Zohar, "Repentance and Purification,” 612-13; Rodríguez, "Transfer of Sin in Leviticus,” 126-31.

${ }^{581}$ Gane, Cult and Character, 56.

${ }^{582}$ Gane, Cult and Character, 245. 
Second, it represents identification of the offerer and the sacrificial animal. Third, it contributes to the transfer. However, it is not clear whether the transfer refers to the transfer of sin to the sacrificial animal or transfer of the animal to the Lord. Thus, the use of one hand signifies transfer of the animal from the offerer to God, while use of two hands as, in the case of the scapegoat (with simultaneous confession), transfers moral sins to the goat. ${ }^{583}$ However, as stated in the introduction of the present study, Gane's understanding of the ritual gesture seems to be identical to the position of Bähr, ${ }^{584}$ but his application of the OT offerings to the sacrifice of Jesus Christ in the NT reveals that he goes beyond Bähr's position by including the idea of transfer of sin and substitution. ${ }^{585}$ First, as mentioned previously, this study agrees with the claim that the offerer

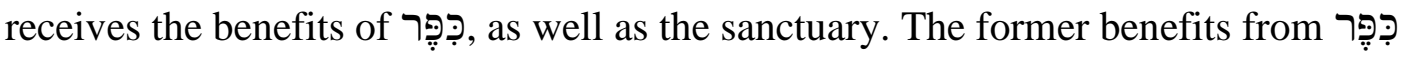
achieved by daily sacrifices (Lev 4-5), while the latter, through yearly sacrifices (Lev 16). Consequently, this study accepts a two-phase atonement, daily and yearly. Second, based on the study in chapter five of the present study, ADH in is not supported by biblical texts. Third, the meaning/function of the laying on of hand/s as transfer of sin and substitution, suggested by Rodríguez, Hasel, Zohar and others, ${ }^{586}$ deserves to be explored further. The new idea that the present study suggests is that GHS could have also been transferred so the ever sinful offerer can be atoned for in the presence of the holy God.

\footnotetext{
${ }^{583}$ Gane, Cult and Character, 245.

${ }^{584}$ Page 3-4 in this study. Also, Knierim, Text and Concept in Leviticus 1:1-9, 37-40.

${ }^{585}$ Gane, Leviticus, Numbers, 68-69.

${ }^{586}$ See introduction of the present study, p. $3 \mathrm{fn} .7$.
} 
Milgrom's and Gane's Debate on the

Understanding of the Preposition

The understanding of the preposition used by both Milgrom and Gane to confirm their understanding of who receives the

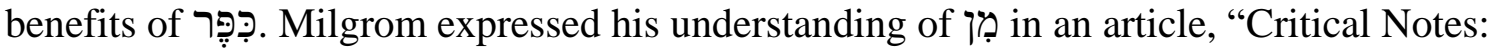
The Preposition מִט in the Pericopes,"587 as response to Gane’s which he expressed in Cult and Character: Purification Offerings, Day of Atonement, and Theodicy and a subsequent article, "Privative Preposition $\min$ in Purification Offering Pericopes and the Changing Face of 'Dorian Gray." ,588 This study agrees and disagrees with both theories, but basically accepts Milgrom's causative meaning of מ̣̂ and consequently, disagrees with Gane's privative, but yet, as stated earlier, disagrees with Milgrom's claim that this understanding of offerer never receives the benefits of to be taken to have privative, "from, of," or causative "because of, on account of, for" meaning.

That is, both Milgrom and Gane held that the role of prepositions in the formation of their atonement theories was decisive. ${ }^{589}$ As demonstrated in the study of the כִֶּּ

\footnotetext{
587Jacob Milgrom, “Critical Notes: The Preposition מִ̣ in the חטשאת Pericopes,” JBL 126 (2007): $161-63$.

${ }^{588}$ Roy E. Gane, "Privative Preposition 27 in Purification Offering Pericopes and the Changing Face of 'Dorian Gray,'” JBL 127 (2008): 209-22.

${ }^{589}$ Milgrom, “Atonement in the OT," 255; Gane, Cult and Character, 108; Gane, "Privative Preposition," 210.
} 
construction in the present study, Milgrom's understanding of prepositions is erroneous on several grounds. ${ }^{590}$ Milgrom did not include the preposition מִ̣ in his emphasis of prepositions. Gane, on the other hand, focusing particularly on pạ, overemphasized and overlooked some basic assertions regarding it which he considered decisive in a pursuit of his question as to who was the object of רִֶּ:

The present study affirms that Milgrom correctly claimed that the preposition should be understood as causative and thus translated "because of, on account of, for." Against Gane's privative meaning, “from, of," Milgrom listed 4 arguments. First, he rightfully stated that מ̣̣ cannot be understood as privative in the cases of individuals of Lev $12,13-14$, and 15 because they are ritually pure when they come to sanctuary. This argument represents Milgrom's partly inaccurate reading of Gane, since Gane himself understood that the ritual impurity is not on them, but rather, that "the sacrificial process removes residual impurity from her." ${ }^{591}$ Because some sort of ritual impurity is on them, Milgrom's argument is on point since texts do not mention the concept of residual ritual impurity. Milgrom claimed that Gane's privative meaning is not supported by these texts. Second, Milgrom rightfully criticized Gane's privative interpretation of מִ in Lev 15:15b because "purgation (כפר) is not offered "from," but "for, because of"—“his flow" (15:15); "her impure flow" (15:30);

\footnotetext{
${ }^{590}$ See evaluation of Milgrom's claims on the use of prepositions under the subheading עֵ in the present study.

${ }^{591}$ Gane, Cult and Character, 113. Even though this quotation refers to the parturient, Gane applies this role to the sacrificial process in all ritual impurity texts he lists (Lev 14, 15). Gane, Cult and Character, 116.
} 
"his impurity" (14:19a), which contaminated the altar." Third, the preposition ạִ and are interchangeable, synonyms which subsequently mean that pִ̣ receives a causative meaning from עַ עַ עַל is never partitive. ${ }^{592}$ Fourth, Milgrom criticized Gane for the claim that "the חטאהת brought by the bodily impure or the inadvertent sinner absorbs the impurity; the priest brings the impure blood of the חטאת to the altar, and the holiness of the altar wipes out the impurity. ${ }^{593}$ Milgrom dismissed Gane's claim for two reasons. First, the impure blood of the sin offering was not allowed on the altar. This is incorrect since the high priest in Lev 16:18 applies that same blood by which he cleanses the sanctuary to the sacrificial altar to cleanse it. Thus, the impurity is on the altar as it is in the sanctuary, and the high priest cleanses it from both places, Lev 16:16-19. Second, Milgrom criticized Gane because of the claim that the sin offering blood in Lev 6:27-28 is impure. The fact that the holy is immune to impurity within the sanctuary confines is a biblically informed conclusion. ${ }^{594}$ Milgrom himself held that the priests are immune to impurity, and their immunity to impurity stems from their holiness. ${ }^{595}$ However, contradicting himself, Milgrom stated that "the sanctuary itself is not immune to impurity." ${ }^{, 596}$ It is unknown why he stated that the priesthood is immune to impurity based on the fact that they are sanctified and the sanctuary is not even though it was

\footnotetext{
${ }^{592} \mathrm{An}$ oppositional sense context related to this preposition does not fit this context. Waltke and O’Connor, An Introduction to Biblical Hebrew Syntax, 216-19.

${ }^{593}$ Milgrom, "Critical Notes," 162; Gane, Cult and Character, 176-81.

${ }^{594}$ Rodríguez, "Substitution in the Hebrew Cultus," 217-18. Kiuchi, Purification Offering, 162.

${ }^{595}$ Milgrom, Leviticus 1-16, 1050-51.

${ }^{596}$ Milgrom, Leviticus $1-16,1050-51$.
} 
sanctified before the priests and served as the environment where the priests were sanctified. Contradicting himself even more, Milgrom stated: "On the contrary, it is the continuous pollution of the sanctuary by Israel's moral and physical impurity that mandates its indispensable purgation by means of the חטאת offering." ${ }^{597}$ The present study totally agrees with this quotation of Milgrom. However, the claim that the sanctuary is not immune to impurities is totally disproved by the Pentateuchal texts since the impurities are stored in the sanctuary during the entire year. This makes his critique of Gane contradictory and unacceptable. It has to be added that this immunity of the sanctuary and priesthood to impurity is temporary and not permanent, since both entities have to be cleansed of it once a year, on the Day of Atonement. This is exactly assumed in Milgrom's last quotation. Thus, this argument is incorrect since the holy objects inside the sanctuary confines, including sanctuary itself, were immune to impurity, and Gane's claim remains valid. Milgrom was right in his claim that super-sanctity cannot eradicate impurity, so the altar's sanctity cannot wipe out impurity. Rather, it stays on the altar until the Day of Atonement when the altar, along with the sanctuary, is cleansed.

Based on his fourth critique, Milgrom's fifth critique of Gane is incorrect: "Gane engages in two paradoxes: In his view, not only is the .... blood that is daubed on the most sacred altar impure (above), but on Yom Kippur the .... blood changes its nature from a pollutant to a purifier; erstwhile impure blood now purifies the entire sanctuary and its sancta." ${ }^{, 598}$ As affirmed in the present study, this phenomenon is paradoxical but firmly

\footnotetext{
${ }^{597}$ Milgrom, Leviticus 1-16, 622-23, 840-41, 1042-43, 1048-49.

${ }^{598} \mathrm{Gane}$, Cult and Character, 230-33.
} 
rooted in an all-inclusive and comprehensive reading of the Pentateuchal texts. A slight correction should be supplied to this quotation that the blood that purifies was not impure, but rather, pure blood. No hands were laid on the animals from which this blood was obtained inasmuch as not laying on of hand/s was performed over those sacrificial animals. Thus, the blood used on the Day of Atonement was pure and thus, able to cleanse the sanctuary.

The present study proposes that מ̣ן should always be translated with a causative sense in the texts where Gane identified a privative sense (Lev 4:26; 5:6, 10; 14:19; $15: 15,30)$. The most convincing argument for such a proposal is the fact that the offerer, especially the offerers previously affected by ritual impurity, do not need to be cleansed from anything. They are ritually clean and do not need removal of ritual impurity or residual impurity that remain after the ritual impurity is healed. The residual impurity assumption is never mentioned or discussed in Pentateuchal texts. The offerers loaded with moral impurity cannot receive cleansing from it since moral impurity is a conceptual, rather than physical or quasi-physical entity. Such offerers need atonement based on ransom because they broke God's law and are in the state of guilt before God with the punishment lingering. The only potential exception where the present study would agree with the partitive sense is $16: 16,34$ because the object receiving inanimate, the sanctuary. The inanimate entity, being ontologically different than human entity, can receive cleansing. The human entity needs atonement based on ransom.

An additional reason against a privative sense of the preposition this sense of uses. Separation is determined by space or time. These two concepts of space and time 
are unrelated to מ̣ in the contexts Gane studied. The only major Hebrew Grammar that defines the privative sense of מִן is Waltke and O'Connor's grammar, but that definition does not fit contexts that Gane referred to. They proposed: "The preposition is a privative marker, that is, it marks what is missing or unavailable (\#\# 22-23)." ${ }^{, 59}$ This is not to say that the privative sense cannot be related to the texts dealing with impurity, but the privative sense of מ̣ן has to be established on another basis such as the preposition's syntactical relationship with the verb and its meaning. ${ }^{600}$ The meaning of כְִֶּ presented in the present study does not give grounds that the privative meaning would be assigned to input from the immediate and broader context for a proper meaning. The causative sense, on the contrary, is well explained in major Hebrew grammars, ${ }^{601}$ and it correlates with the

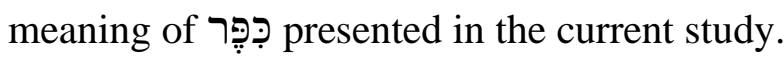

Milgrom is right to say that atonement is not "from" impurity, the privative sense of מִן, but rather "because of, on account of, for" impurity, the causative sense of it. Gane's privative sense can be maintained if atonement is understood as being cleansing, an idea of כִֶֶּּ that is not supported by the research presented in this study. The offerers do not need cleansing, but rather atonement for their impurity based on ransom.

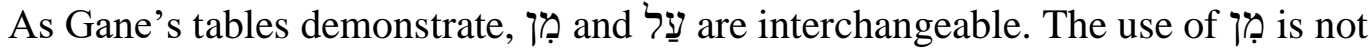

\footnotetext{
${ }^{599}$ Waltke and O’Connor, An Introduction to Biblical Hebrew Syntax, 214.

${ }^{600}$ Waltke and O'Connor, An Introduction to Biblical Hebrew Syntax, 411.

${ }^{601}$ Joüon and Muraoka, A Grammar of Biblical Hebrew, 460; Gesenius, Gesenius' Hebrew Grammar, 382-83; Waltke and O'Connor, An Introduction to Biblical Hebrew Syntax, 212-15.
} 
consistent as Gane's tables demonstrate. ${ }^{602}$ Overall, it is missing in $16 / 44$ formulas that he identified. $5 / 8$ contexts are related to ritual impurity, 10/17 are related to moral impurity, and $1 / 19$ contexts is related to both impurities. ${ }^{603}$ It is also critical to note, as Gane's tables ${ }^{604}$ show that in Lev 4-5, the preposition is consistently interchangeable with the preposition עַע. The fact that it is missing so many times is not to say that the text did not assume it, but that it says that the text did not place emphasis on it. These reasons make it unsafe to rely on one of the multiple meanings of מִ̣ that are inconsistently and interchangeably used in critical atonement texts such as Lev 4-5.

\section{Conclusion:}

כִּ was etymologically traced to two cognate roots, the Akkadian D (intensive) stem from the verb kapāru, kuppuru and Arabic intensive kaffara from the verb kafara. The meanings established by this comparison are "to cleanse, remove" or "to cover." Another frequent meaning of כִֶֶּ is “to ransom." However, a sharp distinction between meanings established on the comparative evidence is not solid since the Arabic kafara, I stem, does not correspond to the Hebrew רֶֶּ, piel, or the Akkadian kuppuru, D stem. The Akkadian D stem means "to wipe" and always in the sense "to wipe off, wipe away," not "wipe on or smear on." In addition, the Arabic kafara has the same meaning of "to expiate" that corresponds to the Akkadian D stem, "to remove, to erase." This semantic

${ }^{602}$ Gane, Cult and Character, 110-11, 113, 124.

${ }^{603}$ The remaining four contexts are sanctification (Exod 29:36-37, Lev 8:15) and one with reparation offering (Lev 19:22). Gane, Cult and Character, 110-11, 121.

${ }^{604}$ Gane, Cult and Character, 124. 
overlap of cognate alternatives makes this evidence unsound.

Regardless of the fact that relying on the comparison with Akkadian and Arabic cognates is unsound, some theologians still believe that "to cover" is the correct meaning of the Hebrew meaning is "to ransom." The key problem related to the "to cover" sin meaning is the fact that in some contexts, sin is not included at all, but כִֶֶּ refers more to the cleansing. Proponents of the "to cleanse" meaning realize that this meaning is not applicable to all contexts and thus, accept the "to atone, expiate" meaning for some contexts. However, the predominant meaning for the latter group of scholars is "to cleanse." Baruch A. Levine, Jacob Milgrom, Jay Sklar, Roy E. Gane, and Yitzhaq Feder have expanded the research on the meaning of this verb. This study partially agrees with all of them on the point that multiple meanings, but yet differs with all of them in what its meaning is in particular contexts. The present study, unlike any of the studies mentioned, took into consideration the fact that the underlying condition of human beings is GHS and the fact that with it. The uniqueness of this study is also found in the fact that it suggested the meaning of

Before analyzing constructions, the present study examined the concept of the GHS of human nature and demonstrated that, surprisingly, this concept is neglected in the studies of atonement. The present study demonstrated that GHS is a critical human characteristic in the biblical understanding of human nature. It originated from the fall of humanity in the Garden of Eden when the first couple disobeyed God's commandment 
and, since then, affects every human being. Influential scholars have recognized and accepted the concept of GHS as being inseparably related to human beings in the Bible. It affects all aspect of human life, including those related to humans' cognitive, as well as those related to their physical existence. Surprisingly, critical scholars of ancient Israel cult did not include this concept in their study of atonement. They simply ignored it and it does not affect the process of atonement. The present study demonstrates that GHS, like ritual and moral impurity, is real but at the same time, in the majority of cases, an abstract entity. General human sinfulness is foundational for both impurities, ritual and moral. Both of them stem from GHS and ritual impurity in a small number of cases, and is represented in terms of physical appearance. However, ritual impurity is atoned for only after the physical aspects of it have disappeared (healed, certain amount of time elapsed...).

Grammatical and syntactical variations associated with the Hebrew verb the Pentateuch reflect the semantic complexity of the term. There are several points of difference of כָָּ usage in the Pentateuch which were noted in the present study that were referred to in the study of the occurrences where כִֶֶּּ is syntactically associated with various prepositions or where it is not accompanied by any complement. This study also agreed that Lev 17:11 is a foundational text for the meaning of כִֶֶּ: and that, in this text, it means "to ransom," which is based on the sacrificial blood that is applied onto the altar. Sacrificial blood represented the life of animal that was terminated on behalf of the offerers as a ransom for the sin they committed or sinfulness they were affected with as they relate to God. The inevitable consequence of such an understanding of רכָ in Lev 17:11 is that sacrifice also serves as the offerers' substitute. Thus, 
two foundational functions; it ransoms the offerers and substitutes for them. In addition, the present study adopts the concept related to Lev 10:17 that eating of the sin offering flesh does contribute to the

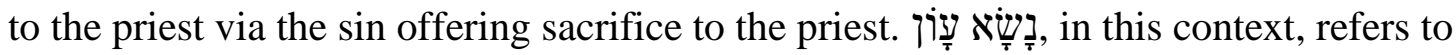
the priests' bearing the leader's or commoner's moral impurity instead of them. The sin offering sacrifice has the unique feature of being holy and impure at the same time.

The first construction analyzed in this study is There are two contexts within which this construction is found. The verb is used only once in basic qal stem in the non-cultic context in the Pentateuch and then it conveys the concrete meaning of rubbing of the bitumen onto the wood of the ark to make it watertight. This is the only qal and only concrete use of the term. All the other occurrences are in piel and they always refer to the abstract effects that cultic context, in Lev 16:20, 32, and it means "to remove," in the sense of cleansing. Impurity is involved in these texts, and object, that is, sanctuary.

The constructions where object marker also appears in cultic and non-cultic contexts. Of the former, two occurrences convey different meanings. Genesis 32:20 [21] carries the meaning "to appease," while Deut 32:43 is best understood as "to atone for, expiate." The cultic occurrence in Lev 16:33, due to its syntactical relationship with Lev 16:20, 32, also conveys the meaning of "to remove," in the sense of cleansing. Impurity is involved in 
this text, and

When to atonement, but it was of a temporary nature (Gen 32:30). Impurity is heavily integrated into this context. In cultic contexts, Lev 16:34, the term is best translated as "to atone for." Impurity is not involved in these

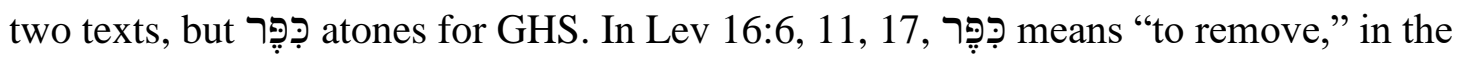
sense of cleansing. Impurity is involved in these texts and an inanimate object, that is, the sanctuary.

The construction ? + + + i⿱ 35:33 and Deut 21:8. In both of these texts, incorporates the idea of ransom.

Two meanings are detected with $\underset{?}{\text { Tִ }}+$ constructions and they are both found in cultic contexts (Exod 29:33, Lev 5:16; 6:23[30]; 7:7; 16:17, 27; 17:11; 19:22; Num 5:8). All the texts include impurity, either from context or implied, but the function of this construction is either to communicate instrumental usage, indicating the agent by which the כִּפֶּ was achieved in Exod 29:33; Lev 5:16; 7:7; 17:11; 19:22; Num 5:8, or indicating the location where the כִִּ was accomplished in Lev 6:23[30]; 7:7; 16:17, 27.

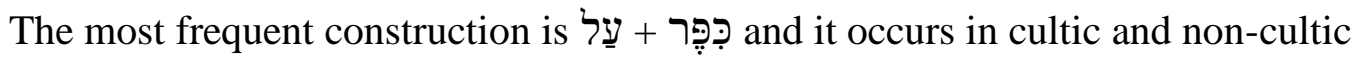
contexts. In 47/56 of occurrences, the preposition עַ carries the meaning of advantage in Exod 30:15-16; Lev 1:4; 4:20, 26, 31, 35; 5:6, 10, 13, 16, 18, 26 [6:7]; 8:34; 10:17; 12:7$8 ; 14: 18-21,29,31 ; 15: 15,30 ; 16: 30,33-34 ; 17: 11 ; 19: 22 ; 23: 28 ;$ Num. 5:8; 6:11; 8:12, 
19,$21 ; 15: 25,28 ; 17: 10-11[16: 46-47] ; 25: 13$ [the only non-cultic context]; 28:22, 30;

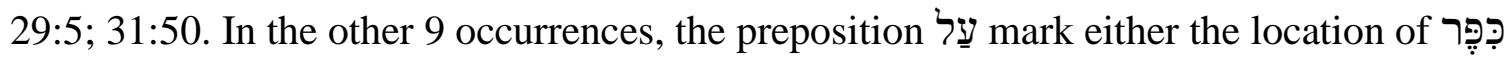
accomplishment in Exod 29:36; 30:10; Lev 8:15, or the instrument in Lev 16:10, or as a direct object marker in Exod 29:27; Lev 14:53; 16:16, 18. In Exod 29:36, עַ carries a double function of direct object marker and location. Of the last 9 occurrences, only Lev 14:53 is a non-cultic context.

רֶּ a also appears in context with other concepts such as to cleanse (గָ), sanctify

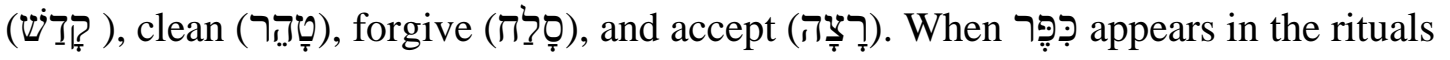
whose goal is to reach these outcomes, כִֶֶּּ is a part of a bigger, major ritual. It has limited function within the major ritual to assist the accomplishment of the major ritual.

Thus, when it appears along with חָָָ and the priests' GHS in v. 33, and cleanses the altar in v. 36. When it appears in Tָּ contexts in Lev 8:15, it also atones for the priests' GHS. Ritual or moral impurity is not included in these texts. The basis for this atonement is ransom.

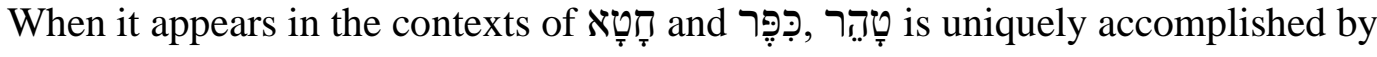
the reparation offering in Lev 14:20 and refers to the reinstatement of the healed צִּעַעת

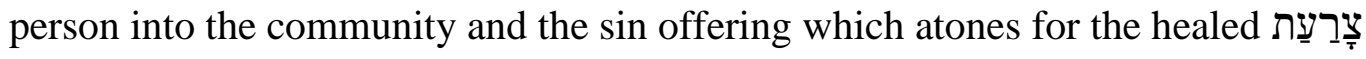
person's GHS. Potentially moral impurity might have been included here, but no ritual impurity. In Lev 14:53, it refers to the removal of ritual impurity in the sense of cleansing it from the infected house.

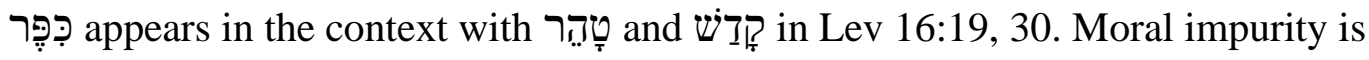


definitely included in these contexts and cleansing.

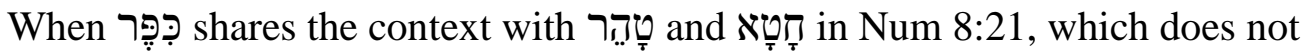
include impurity, it refers to the atonement of the Levites' GHS. In the context with in Num 6:11, רִֶֶּ refers to atonement for the Nazirite's sin to prepare him for the new term of Nazirite status. Ransom is again the basis upon which atonement is possible in this context.

The most frequent contexts in which כִִֶּּּ is related to some other concepts is when it is related to סָלָ in Lev 4:20, 26, 31, 35; 5:10, 13, 16, 18, 26 [6:7];19:22; and Num 15:25, 26, 28. All these are cultic contexts and all of them involve moral impurity.

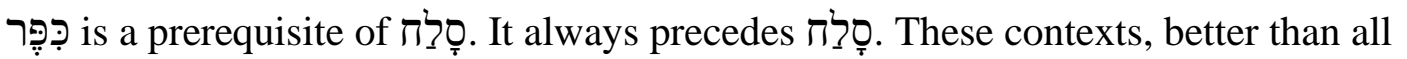
others, show that כִֶֶּ conveys atonement and is based on the ransom. The offerer receives סָלָ based on the sacrifice he/she offers.

Finally, כִּ appears in the contexts where the offerer receives acceptance before God in Lev 1:4. No impurity is involved in this context, so רֶֶֶ atones for GHS. Again the basis of this atonement is ransom in the form of sacrifice.

The context of the atonement of which כִִּ is a part, as was implied by the discussion on which implies that a relationship between God and a human party was broken. The reconciling act is actually a bestowing of God's grace toward humans, followed by their 
willingness to return to God. ${ }^{605}$ The second element is expiation, which implies that the human party feels guilt in the face of the law because of his/her sin and God's wrath that follows the act of sin. The human party needs to overcome these. Removal of the feelings of guilt and God's wrath is what expiation does. The human party gives up his/her sin while God gives up his wrath. ${ }^{606}$ In the actualization of both of these elements, reconciliation and expiation, God's initiative is crucial and always precedes the response of the human party. ${ }^{607}$ In other words, However, God is never subject nor object of the verb, ${ }^{608}$ even though the process involving כִֶֶּּ is prescribed by God. Completion of the atonement process is sealed by God's direct involvement in this process by granting forgiveness, ${ }^{609}$ or other benefits such as acceptance, sanctification.

Both cultic and non-cultic contexts in the Pentateuch confirm that understood as achieving abstract effects on both human and inanimate entities. Milgrom allowed for ransom to be foundational for include averting God's wrath. רִִֶּ as such, encompasses the substitution, as well. This study understands that כִֶֶּּ always has this function, either in the contexts of moral impurity, some cases of severe ritual impurity, and in the cases of GHS. The analysis of

\footnotetext{
${ }^{605}$ Hills, “A Semantic and Conceptual Study,” 9-10.

${ }^{606}$ Hills, “A Semantic and Conceptual Study,” 11-14.

${ }^{607}$ Hills, “A Semantic and Conceptual Study," 14.

${ }^{608}$ Garnet, “Atonement Constructions,” 148.

${ }^{609}$ Gane, Cult and Character, 195.
} 
contexts showed that some contexts give certain guidelines as to what meaning could convey, but some contexts do not provide any guidelines, but only rely on the already-elaborated meaning. This study agrees that the foundational text that informs almost all contexts is Lev 17:11. There the verb is presented to ransom on the basis of the sacrificial blood that is applied onto the altar. In addition, based on Lev 10:17, the present study adopted the fact that eating of the sin offering flesh does contribute to the

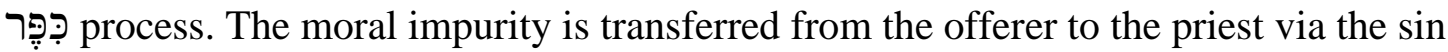

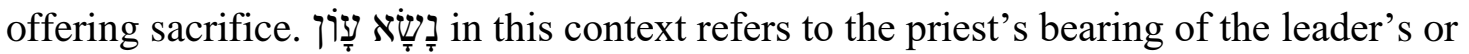
commoner's moral impurity instead of them. The sin offering sacrifice has the unique feature of being holy and impure at the same time.

There is no English word that encompasses the complex semantic and conceptual range of the Hebrew in the present study with the presence of the constant disadvantage of GHS related to human beings as they interact with the divine, the English verb to atone and the noun atonement are proposed in the present study as the best, though far from perfect, choice to represent the Hebrew כִֶֶּּ This choice of "atonement" is driven by the fact that the strict sense of at-one-ment is always present in human relationship due to human sin (ritual and moral) and GHS. The word atonement, in its conceptual rather than strict sense, is used to include both meanings, atonement and substitute, of the verb רִֶֶּ, and also, all its related conceptual outcomes or results, such as

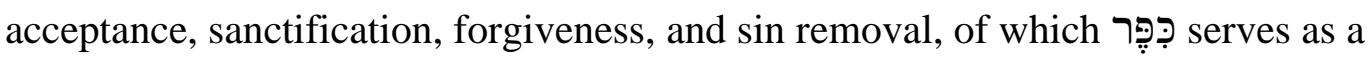
prerequisite. 
Based on the evaluation of limited parts of Milgrom's and Gane's atonement theories, the present study concludes that both theories are informed by the incorrect understanding of כִֶֶּּ which they interpreted as referring to cleansing in ritual texts. This understanding reflects a literal sense of the verb which is impossible in the contexts of impurity that is strictly an abstract conception when it is dealt with in כִֶֶּ contexts. The present study demonstrated that כִֶֶּּ is best understood to refer to atonement based on ransom and to be translated as "to atone for" when the direct/indirect object is human or "to remove" when the direct/indirect object is inanimate. This understanding of רִֶֶּ is in sharp contrast to the meaning proposed by Milgrom and Gane. The inaccurate and inappropriate translation of "to cleanse," but not the understanding behind this terminology, is also adopted by Rodríguez, ${ }^{610}$ and occasionally, Hasel. ${ }^{611}$ Contrary to both Milgrom and Gane, who held that proposes that refers to atonement based on ransom. In agreement with Gane and contrary to Milgrom, the present study affirms that the offerers were atoned for during the daily offering, while the sanctuary was cleansed during the Day of Atonement by yearly offerings. Atonement that the offerer received included a transfer of his/her sin from himself/herself to the sacrificial animal and through the blood application to the sanctuary. Milgrom's claim that the offerers are cleansed from their impurity prior their

\footnotetext{
${ }^{610}$ Ángel Manuel Rodríguez, "Sacrificial Substitution and the Old Testament Sacrifices," in The Sanctuary and the Atonement: Theological and Historical Studies, ed. Frank B. Holbrook (Silver Springs, MD: Biblical Research Institute, 1989), 132-33, 137. 33, 137.

${ }^{611}$ Hasel, "Studies in Biblical Atonement-I,” 99, 104; Rodríguez, "Sacrificial Substitution,” 132 -
} 
coming to the sanctuary is just partially correct. That is, ritual impurity for which one was required to offer a sacrifice was healed, but the moral impurity, which was also potentially present with the offerers and demanded offering a sacrifice. This moral impurity was still on them and needed to be dealt with. Milgrom's argument that the blood of the sin offering was never directly applied on human beings, thus affirming that the sanctuary, rather than the offerer, was cleansed during the offering of the sin offering does not mean that they were never direct beneficiaries of informed by a certain understanding of 4-5 explicitly states that the offerers are freed from their sin after they offer their sacrifice and receive therefore, invalid. Consequently, with Gane and contrary to Milgrom, the present study affirms the understanding that atonement consists of two phases. In the first phase, impurity is transferred to the sanctuary via the blood of the offering as stated in Lev 4, while on the Day of Atonement, the impurity was removed from the sanctuary by the blood of the sacrifice, as stated in Lev 16. Contrary to both Milgrom and Gane, the present study demonstrated that the $\mathrm{ADH}$ is not defensible in the light of Pentateuchal texts. In opposition to Milgrom and clarifying Gane, this study affirms that the transfer of impurity into the sanctuary takes place during the daily sacrifice via the laying on of hand/s on the head of the sacrificial animal. The animal receives the offerer's impurity, and the priest, by applying its blood in the sanctuary, in the case of the priest or the entire community, transfers it to the most holy place. In the case of a leader or a commoner, the priest applies the blood to the sacrificial altar and eats the flesh of the sin offering, 
receiving it in this way on (in) himself. This direction of impurity transfer is explicitly stated in Lev 4, where impurity via blood application is stored in the sanctuary, and in Lev 16, where it is taken outside of the sanctuary. The impurity is on the offerers as they come to offer sacrifice in Lev 4. They thereby get rid of it and it is present in the sanctuary as Lev 16 states. Further, the impurity is removed from there on the Day of Atonement. 


\section{CHAPTER 5}

\section{AUTOMATIC DEFILEMENT OF THE SANCTUARY}

The second part of the second section of the present study examines the theory closely related to atonement, that is, $\mathrm{ADH}$. This part consists of the analysis of the piel stem, the infinitive construct, the perfect, the semantics of טָָָָ along with the literary structure of related texts. The findings on all these concepts suggest that this theory is not supported by Pentateuchal texts.

\section{Automatic Defilement: The Hypothesis}

The ADH of the sanctuary is based on the interpretation of 3 Pentateuchal texts:

Lev 15:31; 20:3, and Num 19:13, 20. Jacob Milgrom was the first one to introduce it into main-stream scholarship and since then, this hypothesis has encountered valid opposition both in his time, ${ }^{1}$ and afterwards. ${ }^{2}$ However, it is still, in a slightly refined form, accepted

${ }^{1}$ Maccoby, Ritual and Morality, 165-81; Hartley, Leviticus, 213; Wenham, The Book of Leviticus, 221; Wenham, Numbers, 145; Rodríguez, "Substitution in the Hebrew Cultus"; André and Ringgren, "טמא," TDOT, 5:337. It must be noted that Baruch A. Levine claimed that ritual defilement of the sanctuary happened via direct contact of an impure person with the holy entities, based on his interpretation of Lev 12:4 and 15:31. However, he also believed, based on Lev 15:31, that one can morally defile the sanctuary by neglecting to follow the purification procedures listed in Lev 15:1-30. In addition, in his interpretation of Lev 20:3, he was not clear as to whether the installment of the pagan cult objects or objects within or near the sanctuary defile it ritually or morally, but his pointing to the very act of disobedience of God's commands most likely points to the moral defilement of the sanctuary. Levine's interpretation of Num 19:13, 20 shows that he principally held that ritual defilement of the sanctuary takes place via direct contact, but allows for automatic defilement by moral sins by not following the purifying procedures given by God. Thus, it can be said that Levine differentiated between ritual defilement of the sanctuary, which takes place via direct contact of the contaminated person and holy entities, and moral defilement which resembles Milgrom's automatic defilement hypothesis. Levine, Leviticus, 74, 92, 98, 136, 
and advocated by some of his students ${ }^{3}$ and other scholars. ${ }^{4}$ Gane's defense of a modified form of this hypothesis is the most recent one. ${ }^{5}$ The following portion of this study examines the validity of grammatical, syntactical, and semantical choices utilized by the proponents of this hypothesis to establish it or still consider it valid.

Each text is peculiar in its own way. Thus, Lev 15:31 utilizes the preposition ִํ: (ㄱ) followed by the piel infinitive construct (טטָמָא) to express defilement of the sanctuary as the Hebrew texts demonstrates:

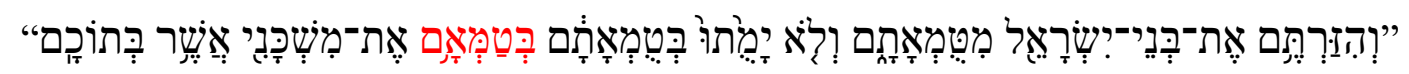

Lev 20:3, employs the preposition (למען) followed by the piel infinitive construct

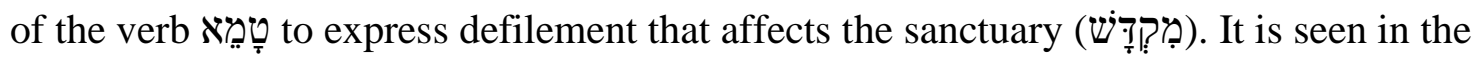
following Hebrew text:

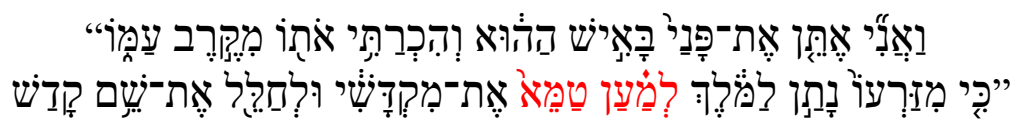

249; Levine, Numbers 1-20, 457. Milgrom's ADH, on the other hand, is more restrictive. His interpretation of Lev 15:31; 20:3; and Num 19:13, 20 avoids allowing any sanctuary defilement via direct contact. Milgrom, Leviticus 1-16, 257, 309, 887, 993, 1005; Milgrom, Numbers, 161-62, 445; Jacob Milgrom, "Impurity is Miasma: A Response to Hyam Maccoby," JBL 119 (2000): 729.

${ }^{2}$ Tidball, The Message of Leviticus, 167-68; Rooker, Leviticus, 206; Klawans, Purity, Sacrifice, and the Temple, 54, 71.

${ }^{3}$ Wright, The Disposal of Impurity, 19n10; Gane, Cult and Character, 144-62. Wright, "Unclean and Clean," 6:732.

${ }^{4}$ Sklar, Leviticus, 204; Feder, Blood Expiation, 93-96.

${ }^{5}$ Gane, Cult and Character, 144-62, especially 156, 160, 162. 
Num 19:13. 20, utilizes the piel perfect of the verb (טָָָָָא) to express defilement of the sanctuary:

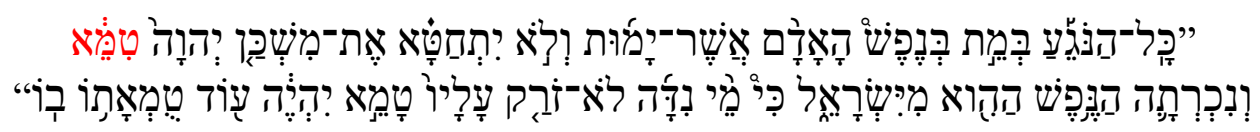

However, regardless of their peculiarities, these texts share common features. In order to analyze the grammatical/syntactical choices that led certain scholars to interpret these texts to refer to automatic defilement, it is necessary to present relevant particulars regarding the stem, aspect, and verb (טָָָָ) used in these texts. The following section is relevant for all three texts since all of them use the same stem, piel and the same verb,

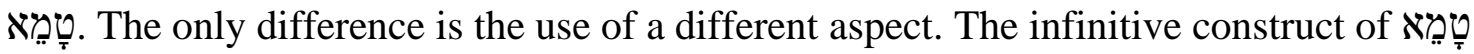
is used in Lev 15:31 and 20:3, while Num 19:13, 20 use the perfect. I first explore the stem, aspect, and the semantic range of the verb טָָמָא. With the conclusions on these three points, I address additional specific peculiar issues of each text that will be mentioned as they are analyzed. These two steps of analysis provide an extensive spectrum of evidence that all these texts imply defilement of the sanctuary through direct contact, rather than automatic defilement.

\section{Piel Stem and טָמָא}

The research of the piel stem shows that Hebrew linguists greatly debated over the its meaning/s. Piel Hebrew verbs can fit into a number of legitimately distinct semantic categories, resulting in the claim that no single notion or semantic category 
underlies all of them. ${ }^{6}$ Prior to Albercht Goetze's groundbreaking study on the Akkadian D stem, ${ }^{7}$ Hebrew linguists thought that the piel stem principally signified an intensification of a meaning of a given root. ${ }^{8}$ In addition, the use of some Hebrew verbs indicated a causative nuance of the stem with two sub-nuances: (1) declarative, and (2) estimative. A denominative meaning was also detected with other verbal roots. ${ }^{9}$ Thus, key Hebrew grammars list a total of 5 distinct meanings for the piel: (1) intensive, (2) causative, (3) declarative, (4) estimative, and (5) denominative. ${ }^{10}$

The most recent influential postulate on the cohesive meaning of the piel has been suggested by Bruce Waltke and M. O'Connor. They proposed that "Piel tends to signify causation with a patiency nuance, and hiphil causation notion with an agency nuance. The two types of causation form differ from one another with reference to the status of the subject being acted upon by the main verb, that is, the voice associated with the undersubject or secondary subject."11 John Beckman, who critiqued Waltke's and O'Connor's proposal, simplified this statement in the following way:

The D stem describes an action with a passive undersubject, meaning that the focus is on the undersubject (the direct object) being put into a new state, without regard to the process that the subject is doing to bring about that new state. The undersubject is

${ }^{6}$ Joüon and Muraoka, A Grammar of Biblical Hebrew, 143-44.

${ }^{7}$ Albrecht Goetze, “The So-called Intensive of the Semitic Languages,” JAOS 62 (1942): 1-8.

${ }^{8}$ Gesenius, Gesenius' Hebrew Grammar, 141.

${ }^{9}$ Waltke and O'Connor, An Introduction to Biblical Hebrew Syntax, 396; Joüon and Muraoka, A Grammar of Biblical Hebrew, 144-45.

${ }^{10}$ Waltke and O'Connor, An Introduction to Biblical Hebrew Syntax, 396-97; Gesenius, Gesenius' Hebrew Grammar, 141-43; Joüon and Muraoka, A Grammar of Biblical Hebrew, 144-45; Carl Brockelmann, Hebräische Syntax (Neukirchen: Kreis Moers, 1956), 35-36; Carl Brockelmann, Grundriss der Vergleichenden Grammatik der Semitischen Sprachen, 2 vols. (Hildesheim: G. Olms, 1961), 508-10.

${ }^{11}$ Waltke and O'Connor, An Introduction to Biblical Hebrew Syntax, 355. 
passive because it is not described as doing anything; instead, it is passively entering a new state as a result of the action of the subject. ${ }^{12}$

Waltke's and O'Connor's proposal is built upon the work of Ernst Jenni who claimed that piel is always factitive or resultative, never intensive. If a qal stem of a given verb expressed a state (a stative, intransitive verb), then piel of that same verbal root is factitive. As such, piel brings a totally passive undersubject, without regard to the process, into the state depicted by a given verb. ${ }^{13}$ As opposed to the hiphil where the focus is on causing the progress of an action, piel focuses on causing the change of the state. ${ }^{14}$ Jenni lists about 100 verbs of this type. ${ }^{15}$ For example, גדל meaning "to be great" in qal stem changes to "to cause, declare, or consider to be great" in the piel stem. ${ }^{16}$ The qal verbal form is intransitive, which is an additional feature that separates it from the piel form which is. ${ }^{17}$

Alternately, if the qal stem of a given verbal root conveys the process (a fientive, transitive verb), then piel of the same verb is resultative. ${ }^{18}$ It conveys the idea of causing the object to be in the state that results from the action indicated by the qal verb. ${ }^{19}$ For

\footnotetext{
${ }^{12}$ John Charles Beckman, "Toward the Meaning of the Biblical Hebrew Piel Stem" (PhD diss., Harvard University, 2015), 79.

${ }^{13}$ Waltke and O'Connor, An Introduction to Biblical Hebrew Syntax, 398-99, 400-401.

${ }^{14}$ Ernst Jenni, Das Hebraische Pi 'el: Syntaktisch-Semasiologische Untersuchung einer Verbalform in Alten Testament (Zürich: EVZ-Verlag, 1968), 41.

${ }^{15}$ Jenni, Das Hebraische Pi 'el, 20-21.

${ }^{16}$ Jenni, Das Hebraische Pi 'el, 41.

${ }^{17}$ Waltke and O’Connor, An Introduction to Biblical Hebrew Syntax, 355-58.

${ }^{18}$ Waltke and O'Connor, An Introduction to Biblical Hebrew Syntax, 398-99, 404.

${ }^{19}$ Jenni, Das Hebraische Pi 'el, 126-27; Waltke and O'Connor, An Introduction to Biblical Hebrew Syntax, 400.
} 
instance, חלק means "to divide" in the qal stem and "to cause to be in a divided state" in piel. ${ }^{20}$ Piel's factitive or resultative meanings are identical, and different labels indicate different meanings of qal stem, not piel. Waltke and O'Connor acknowledged that detecting the difference between the process meaning of a verb in qal and the factitive/resultative meaning in piel is difficult, and they did not set any criteria to detect it. $^{21}$

Beckman noticed that the main weakness of Waltke's and O'Connor 's theory is the fact that most occurrences of qal and piel verbs do not provide evidence for the distinction between verbs that convey process and those that express a factitive meaning. Also, a process meaning is attached to more piel occurrences than those that are factitive/resultative. ${ }^{22}$

Beckman himself concluded that a potentially productive way of coming to the cohesive meaning of piel stem, along with latest linguistic progresses, may provide the needed tools to arrive at a viable solution. These progresses are seen in the works of

\footnotetext{
${ }^{20}$ Jenni, Das Hebraische Pi'el, 126-27.

${ }^{21}$ Beckman, "Toward the Meaning," 80.

${ }^{22}$ For additional arguments that dispute Waltke's and O'Connor's proposal, see Beckman, "Toward the Meaning," 246-48.
} 
Golovko, ${ }^{23}$ Hopper and Thompson, ${ }^{24}$ Kulikov, ${ }^{25}$ and $\mathrm{Li},{ }^{26}$ all of whom noted that the same verbal forms are used with multiple meanings such as intensive/pluralic and factitive/causative in a variety of languages. ${ }^{27}$ In other words, they all suggest inclusion of the variety of meanings for certain stems since the majority of verbs utilize them. Beckman preferred Kouwenberg's hypothesis ${ }^{28}$ which is, on one hand, more flexible and inclusive of the variety of meanings piel conveys, but on the other hand, less systematic. ${ }^{29}$ Based on this theory, the presence or absence of intensity along with the high semantic transitivity laid a foundation for the preferred use of piel over qal for

${ }^{23}$ Golovko V. Evgeniy, "On Non-Causative Effects of Causativity in Aleut," in Causatives and Transitivity, ed. Bernard Comrie and Maria Polinsky (Philadelphia: John Benjamins, 1993), 385-90.

${ }^{24}$ Sandra A. Thompson and Paul J. Hopper, "Transitivity in Grammar and Discourse," Language 56 (1980), 251-99.

${ }^{25}$ Leonid I. Kulikov, "Causatives," in Language Typology and Language Universals: An International Handbook, ed. Martin Haspelmath, et al., 2 vols., Handbooks of Linguistics and Communication Science 20 (New York: Walter de Gruyter, 2001), 886-98.

${ }^{26}$ Fengxiang Li, "An Examination of Causative Morphology from a Cross-Linguistic and Diachronic Perspective," in Papers from the 27th Regional Meeting of the Chicago Linguistic Society, 1991, Part 1: The General Session, eds. Lise M. Dobrin, Lynn Nichols, and Rosa M. Rodriguez (Chicago: Chicago Linguistic Society, 1993), 344-59.

${ }^{27}$ Beckman, "Toward the Meaning," 35.

${ }^{28}$ Kouwenberg argued that the Semitic D stem began in Proto-Semitic with D-stem verbs derived from adjectives that indicated intensity (e.g., adjective "very wide" $\rightarrow$ D "to be/become/make very wide"). Over time, this developed into a productive mechanism whereby intensive D-stem verbs were formed from G-stem verbs directly, rather than from intensive adjectives. Since intensity is a component of verbal plurality, the meaning of the D stem in some verbs broadened to indicate non-intensive types of verbal plurality, such as action on multiple objects (e.g., 'to kiss multiple people'). Since intensity is also a component of high semantic transitivity, the meaning of the D stem in other verbs came to be associated with high transitivity. Because a factitive meaning connotes high transitivity, the D stem, in particular, became preferred over the $\mathrm{G}$ stem for factitive meanings, so non-intensive factitive meanings (e.g., "to make wide") were lost by the G stem and gained by the D stem. Due to the lack of a contrast with a nonintensive factitive $\mathrm{G}$ stem, the factitive $\mathrm{D}$-stem lost its original intensive meaning (e.g., D "to make very wide" $\rightarrow$ "to make wide"). Beckman, "Toward the Meaning," 211. See also N. J. C. Kouwenberg, Gemination in the Akkadian Verb, SSN 32 (Assen: Van Gorcum, 1997), 98-100, 445-50; N. J. C. Kouwenberg, The Akkadian Verb and Its Semitic Background, LANE 2 (Winona Lake, IN: Eisenbrauns, 2010), 282-87.

\footnotetext{
${ }^{29}$ Beckman, "Toward the Meaning," 251.
} 
various types of verbal plurality for some verbs or high semantic transitivity for other verbs. $^{30}$

Waltke's and O'Connor's claim that the stative and process meaning of the verbs in qal corresponds to the factitive/resultative of the same verbs in piel is examined below. The evaluation of Waltke's and O'Connor's claim that if the verb is stative in qal, then it is factitive in piel, and Beckman's claim that this is not accurate follows.

Beckman's critique of Waltke's and O'Connor's work includes an analysis of seven factitive verbs to investigate whether their stative meaning in qal corresponds to

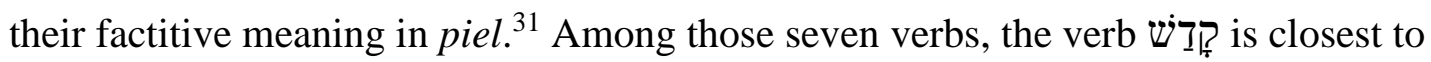
טָָָ, and thus the following analysis, deals with only these two verbs.

First, both verbs are metaphorical and abstract in their meaning. They do not refer to concrete, material processes, but rather, to those that are conceptual, metaphorical, and abstract.

Second, טָָמָא is always stative in qal and means "to be/become defiled/unclean" (Lev 5:3; 11:24-28, 31-36, 39-40; 12:2, 5; 13:14, 46; 14:36, 46; 15:4-11, 16-24, 27, 32; $17: 15 ; 18: 20,23,25,27 ; 19: 31 ; 22: 5-6,8 ;$ Num $6: 12 ; 19: 7-8,10-11,14,16,20-22)$. It never takes a direct object. ${ }^{32}$ It either conveys that an entity is already in or has entered the defiled state. In this respect, it behaves, according to Beckman, like the qal of קָin in

${ }^{30}$ Beckman, “Toward the Meaning," 248.

${ }^{31}$ Beckman, "Toward the Meaning," 89.

${ }^{32}$ In some טָָָָ contexts, is present, but is never syntactically related to this, but always to some other verb (Lev 11:28, 33, 40; 14:36, 46; 15:10, 16; 18:25, 27; Num 6:12; 19:8, 10, 20). 
its 11 occurrences, ${ }^{33}$ which correlates with Waltke's and O'Connor's theory of piel. It always refers to the state.

Third, in all 25 piel occurrences, טָָָָ encompasses a factitive meaning, "to make defiled/unclean or declare/pronounce somebody/something defiled/unclean" (Gen 34:5, 13, 27; Lev 11:44; 13:3, 8, 11, 15, 20, 22, 25, 27, 30, 44, 59; 15:31; 18:28; 20:3, 25; Num $5: 3 ; 6: 9 ; 19: 13,20 ; 35: 34$; Deut 21:23). According to Beckman, 68/75 occurrences of the piel of $\underset{w}{\mathbb{Z}}$, do not provide evidence for the distinction between a resultative and a process meaning. ${ }^{34}$ Therefore, these texts are not helpful in determining the accuracy of Waltke's and O'Connor's theory. Beckman's claim that the remaining seven occurrences (Exod 19:10; ${ }^{35}$ Jer 17:24, 27; ${ }^{36}$ Ezek 44:19; Job 1:5; ${ }^{37} 2$ Chr 29:17[2x]) point to process is accurate because the texts he cited do convey the passage of time related to the process of sanctification. Ezekiel 44:19 still remains problematic since this text, in contrast to the other six, does not include nor point to any temporal complement related to the process of sanctification. However, there is a crucial point regarding the verb $\underline{\underline{T}} \underline{\underline{T}}$ that also applies to טֵָָׁא in their piel contexts, both verbs are always accompanied by other verb/s by which the

${ }^{33}$ Beckman, "Toward the Meaning," 91.

${ }^{34}$ Beckman, "Toward the Meaning," 92.

35، ... as Yadin has correctly noted (1983: 1.223), the three-day purification imposed for the Temple city is modeled after the Sinaitic purification consisting of ablutions, laundering, and sexual abstinence (Exod 19:10-15).” Milgrom, Leviticus 1-16, 969.

${ }^{36}$ The text explicitly mentioned that at least one verbal activity achieves the holiness of the Sabbath by not carrying a burden through the gates of Jerusalem on the Sabbath day.

${ }^{37}$ Based on this text, Job's sanctification of his children after their feast days consisted of at least one verbal activity, offering burnt offerings. 


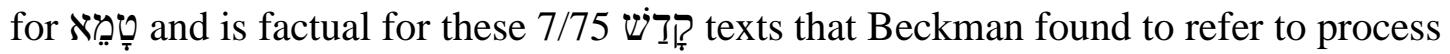

meaning, and for the 68/75 texts that, in Beckman's assessment, do not provide evidence to distinguish between a resultative and process meaning. ${ }^{38}$

It is also important to note that these 7 texts that do not follow the pattern suggested by Waltke and O'Connor are found outside of the Pentateuch, which also points to the current unproductiveness of the effort to diachronically nor synchronically come to the unified stem meaning at the level of the entire OT text. The more sound method utilized in this study is to be aware of the key theories that attempted to find unified stem meaning and test these theories through the study of verbal roots on a caseby-case study. A potential proposal of a unified stem meaning resembles a root fallacy where one root meaning is enforced in to all of its occurrences.

Thus, this study agrees with Muraoka's and Joüon's statement regarding the piel stem:

The question how the function of Piel in relation to other conjugations, notably Qal, should be defined still remains one of the major challenges facing Hebrew and Semitic linguistics. In the present state of our knowledge, we can only point to a number of fairly distinct meaning categories into which some verbs seem to fit. Others, an uncomfortably large number, still defy such categorisation. Nor can we suggest, without doing violence to all the evidence available, a single notion or meaning category which can be said to underlie all those "nuances." 39

Subsequently, the part of Waltke's and O'Connor's theory that claims that piel is

\footnotetext{
${ }^{38}$ Of the piel texts, $22 / 40$ includes the process of sanctification and all of them contain or are based on other texts that deal with the same topics and imply other verbal activities to achieve the process of sanctification (Exod 13:2; 20:8, 11; 28:3, 41; 29:1, 27, 33, 36-37, 44; 30:29-30; 40:9-11, 13; Lev 8:10-12, $15,30 ; 16: 19 ; 21: 8,25: 10 ;$ Num $6: 11 ; 7: 1$; Deut $5: 12)$. The $18 / 40$ occurrences do not refer to the process meanings, but rather, to a declarative one (Gen 2:3; Exod 19:10, 14, 23; 31:13; Lev 20:8; 21:15, 23; 22:9, 16, 32; Deut 32:51).

${ }^{39}$ Joüon and Muraoka, A Grammar of Biblical Hebrew, 143-44.
} 
always factitive if qal of the same verb is stative is valid in the case of טָָָא within the limits of the Pentateuch, but it is not complete. The study of the uses of טָָָָ in the Pentateuch demonstrated that certain pattern of uses is consistent with this verb. That is, it is always accompanied by other verbs through which its meaning onto the direct object it modifies is achieved. This second point has not been noted by Waltke and O'Connor and Beckman and is presented below.

\section{Aspect: Grammatical Considerations on the Use of the Infinitive Construct and the Perfect}

The infinitive construct is used in Lev 15:31 and 20:3 but only in the former text is it preceded by the preposition $\underset{?}{\text { ?. On }}$ On the contrary, the perfect is used in Num 19:13, 20.

\section{Infinitive Construct: A Temporal Use}

Hebrew grammarians have discovered that in nominal use the infinitive construct either mainly stands alone or is preceded by the preposition $? \cdot{ }^{40}$ Even though a pronominal suffix is attached to the infinitive construct to express a subject (a nominal use) in Lev 15:31, it is preceded by the preposition $\underset{?}{?}$ which is not typical. As stated above, when ? precedes the nominal use the infinitive construct, it is not preceded by any complement. The proponents of $\mathrm{ADH}$ took the preposition be in this text to be beth instrumenti, most likely of human instrument/agent, ${ }^{41}$ and thus translated with the

\footnotetext{
${ }^{40}$ Waltke and O'Connor, An Introduction to Biblical Hebrew Syntax, 601; C. H. J. van der Merwe, Jackie A. Naudé, and Jan H. Kroeze, A Biblical Hebrew Reference Grammar, BLH 3 (Sheffield: Sheffield Academic Press, 1999), 151; Joüon and Muraoka, A Grammar of Biblical Hebrew, 401-2.

${ }^{41}$ Merwe, Naudé, and Kroeze, A Biblical Hebrew Reference Grammar, 286-87; Waltke and O’Connor, An Introduction to Biblical Hebrew Syntax, 197.
} 


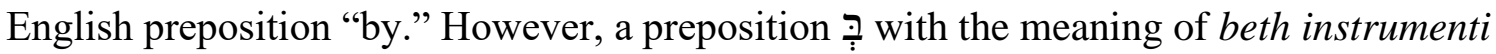

is, by rule, attached to a regular noun and not the verb/verbal noun. ${ }^{42}$

In addition, even though the infinitive construct can be preceded by many

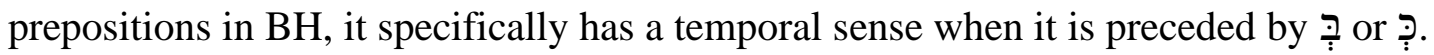

This pattern is frequent and well attested in the $\mathrm{BH} .{ }^{43}$ The difference between the two

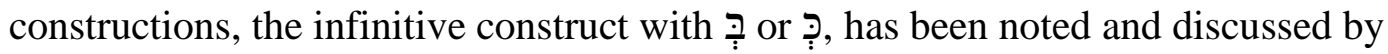

Hebrew grammarians. ${ }^{44}$ Margaretha Folmer summarized the meaning of both

grammatical constructions in the two following quotations:

Clauses with $\underset{+}{+}+$ cstr. inf. indicate an immediately preceding time (tight when', 'as soon as', 'the moment') (instantaneous action; slight anteriority), that is to say the time of the event referred to by the cstr. inf. is the same as the time of the event referred to by the main verb. The construction with 3 is relatively frequent with verbs of perception ('to see', 'to heat' etc.), which often occur in combination with an instantaneous action ('the moment she heard her brother, she went to the door' or 'the moment he saw the news, he rang his sister'). Clauses with $\underset{?}{\mathfrak{p}}+\mathrm{cstr}$. inf indicate temporal proximity of the event referred to by the cstr. inf to the event referred to by the main verb, that is to say the point in time of the event referred to by the main verb is included in the time of the event referred to by the cstr. inf ('when they were on holiday, their cat had five kittens'). ${ }^{45}$

\footnotetext{
${ }^{42}$ Merwe, Naudé, and Kroeze, A Biblical Hebrew Reference Grammar, 286-87; Waltke and O’Connor, An Introduction to Biblical Hebrew Syntax, 197.

${ }^{43}$ Merwe, Naudé, and Kroeze, A Biblical Hebrew Reference Grammar, 286; Waltke and O’Connor, An Introduction to Biblical Hebrew Syntax, 196, 205, 604. Besides, having the temporal be attached to the infinitive construct can also have a causal sense. However, a causal sense makes the sentence highly awkward and, in this case, the subject is separated from the infinitive construct instead of being attached to it as it is in Lev 15:31. Waltke and O'Connor, An Introduction to Biblical Hebrew Syntax, 604.

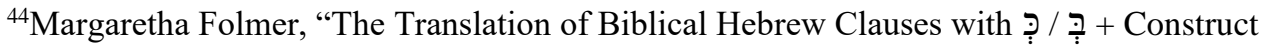
Infinitive in Targum Onqelos," AS 11 (2013): 114-15.

${ }^{45}$ Folmer, "The Translation of Biblical Hebrew Clauses," 115. Waltke and O'Connor noticed the same thing: "The construction occurs with every preposition, but most frequently with $\supseteq$ and $\ni$, especially with a temporal sense. With the infinitive construct, $\supseteq$ denotes in general the temporal proximity of one event to another, $\supset$ more specifically the more immediately preceding time.” Waltke and O’Connor, An
} 
Folmer stated that the difference between these two constructions cannot at times be discerned. ${ }^{46}$ While the difference between the two constructions goes beyond the scope of, and is not crucial for, this study since only the second one is used in Lev 15:31, the fact that both of these constructions, especially the second, convey the temporal meaning of the infinitive construct and not the instrumental is critical. It points to the fact that Lev 15:31 implies a temporal, rather than an instrumental sense. Analysis of the verb טָמָא further disputes the validity of an instrumental translation/interpretation.

\section{Infinitive Construct as Finite Verb}

No complement precedes the infinitive construct in Lev 20:3; thus, it functions as a finite verb. As any other transitive finite verb, it governs a noun or a pronoun in the accusative and the subject of the action conveyed by it is nominative. ${ }^{47}$ In the majority of cases, determining whether an action expressed by the infinitive construct is in the nominative or the genitive is impossible. ${ }^{48}$ Joüon and Muraoka have suggested that "as a rule the subject of the action must be considered as being in the nominative: this is the construction in primitive Semitic, and in some cases the vocalisation indicates the

Introduction to Biblical Hebrew Syntax, 604. Temporal character of the Infinitive Construct with be was noted by Gesenius. Gesenius, Gesenius' Hebrew Grammar, 347.

${ }^{46}$ Folmer, "The Translation of Biblical Hebrew Clauses," 115.

${ }^{47}$ If its subject is in the genitive, the infinitive construct would generally function as a noun in socalled nominal use. Joüon and Muraoka, A Grammar of Biblical Hebrew, 402.

${ }^{48}$ Joüon and Muraoka have criticized Waltke and O'Connor for postulating that the distinction between these two uses of the infinitive construct can be attained by the inferences from two texts only:

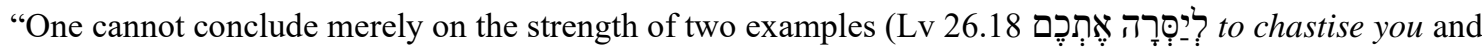

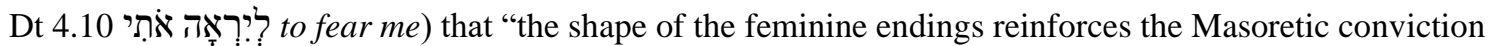
that such forms are not construct” (WO, Syntax, p. 611, n. 38).” Joüon and Muraoka, A Grammar of Biblical Hebrew, 402. 
nominative." ${ }^{49}$ Elisha Qimion has postulated that "in BH, the nouns governed by an infinitive follow it, while in Aramaic and in Qumranic Hebrew the opposite order is attested for objects. ${ }^{50}$ This proposal is effective in the Pentateuch (Gen 3:24; 4:2, 11; $8: 21 ; 13: 16 ; 14: 17 ; 19: 19 ; 21: 8 ; 22: 10 ; 24: 48 ; 25: 22 ; 27: 30 ; 31: 19 ; 34: 7,14 ; 37: 12$; 40:20; 41:9; 42:9; 44:22; 49:33; 50:2, 7, 14; Exod 2:15; 5:2; 6:13, 27; 10:4, 26; 12:23; $14: 12 ; 16: 3 ; 29: 33 ; 30: 15 ; 33: 20 ; 36: 1 ; 38: 27$; Lev 7:38; 10:11, 17; 20:3; 21:21; 26:15; Num $3: 7-8 ; 4: 30 ; 7: 5 ; 8: 11,15,19,22 ; 9: 7 ; 11: 11,14 ; 13: 17 ; 16: 9,28,31 ; 18: 6 ; 20: 21$; $21: 4,32 ; 22: 18 ; 24: 1,13 ; 34: 29 ; 36: 2$; Deut $2: 31 ; 3: 24 ; 4: 2 ; 5: 15,25,29 ; 6: 2,19,24-25$; $8: 18 ; 9: 5 ; 10: 8,12-13 ; 11: 13,22,32 ; 12: 5 ; 13: 18 ; 14: 23 ; 15: 5 ; 17: 19 ; 18: 16 ; 19: 9 ; 21: 16$; $25: 7,11 ; 26: 12 ; 28: 1,12,15,58 ; 29: 18,29 ; 30: 6,16,20 ; 31: 12-13,24 ; 32: 45-46)$. Thus,

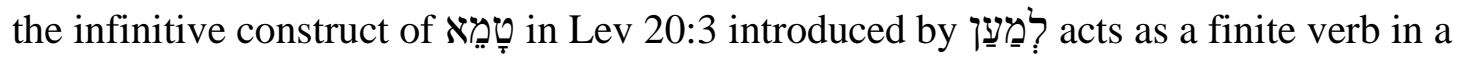
resultative clause. This is typical grammatical construction in $\mathrm{BH} .{ }^{51}$

\section{The Perfect}

The texts in Num 19:13, 20, to the contrary, use the perfect instead of the infinitive construct. It is well established by Hebrew grammarians that the perfect functions to express events or states that are perceived as complete whether they belong to a determinative past, present, or future time. ${ }^{52}$ It should not be perplexing that both

\footnotetext{
${ }^{49}$ Joüon and Muraoka, A Grammar of Biblical Hebrew, 402.

${ }^{50}$ Elisha Qimron, The Hebrew of the Dead Sea Scrolls, HSS 29 (Atlanta: Scholars Press, 1986), 74; Waltke and O'Connor, An Introduction to Biblical Hebrew Syntax, 610-11.

${ }^{51}$ Waltke and O'Connor, An Introduction to Biblical Hebrew Syntax, 637.

${ }^{52}$ Joüon and Muraoka, A Grammar of Biblical Hebrew, 332-37; Gesenius, Gesenius' Hebrew Grammar, 309-13; Waltke and O'Connor, An Introduction to Biblical Hebrew Syntax, 485-91.
} 
verses, vv. 13 and 20, use the perfect form since it has been well established that the completed action expressed by the perfect of active, fientive verbs ${ }^{53}$ is frequently used to refer "to resulting perfect state in future relative to the speaker." Waltke and O'Connor labeled it the "future perfect." 54 Gesenius compared this perfect with the Latin futurum exactum. This perfect represents the action or state "as existing in the future in a completed state (futurum exactum)..."55 Joüon and Muraoka reminded us that when the perfect is used in this way, the "domain of the future is indicated by the context, usually by a previous verb." They labeled this the perfect "relative preterite." 56 Thus, the defiling expressed by the perfect of טָָׁא in Num 19:13, 20 is a future event that is projected as if it had been completed in the future.

\section{Semantics: The Verb טָָָָָא}

By form and meaning, טָָָָָא is, in most cases, a stative verb and in the same way as participles, one of the standard uses of stative verbs in $\mathrm{BH}$ is to describe a state. ${ }^{58}$ Determining whether a verb is stative or active is a complex task in BH. Some stative verbs are ambiguous and could be treated as having both an active, inchoative sense (to

${ }^{53}$ Piel of טָָמִא is such type of a verb since, in this text, it takes a direct object.

${ }^{54}$ Waltke and O'Connor, An Introduction to Biblical Hebrew Syntax, 490.

${ }^{55}$ Gesenius, Gesenius' Hebrew Grammar, 313.

${ }^{56}$ Joüon and Muraoka, A Grammar of Biblical Hebrew, 335.

${ }^{57}$ The future tense is introduced in v. 12 with the imperfect of ${ }_{\mathfrak{N}} \tilde{T}_{\tau}$.

${ }^{58}$ Waltke and O'Connor, An Introduction to Biblical Hebrew Syntax, 370-71; Stuart Alan Creason, "Semantic Classes of Hebrew Verbs: A Study of Aktionsart in the Hebrew Verbal System" (PhD diss., University of Chicago, 1995). 
enter into a state), or a stative sense, including when they encompass a stative sense (e.g., to maintain the state).${ }^{59}$ Aaron Koller stated that "sometimes it is difficult to tell if the ambiguity is present because of the participle form or because of foe semantics of the verb itself." However, the third masculine singular for of the verb טָמָָא has an $\bar{a}-\bar{e}$ vowel pattern, which is a consistent characteristic of the stative verbs in $\mathrm{BH} .{ }^{60}$ As such, it refers to a quality or characteristic of an object. ${ }^{61}$

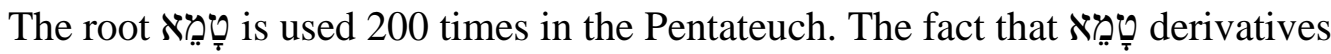
are found 150/200 times in Leviticus, thus distributing $1 / 4$ of occurrences in the rest of the Pentateuch, confirms the fact that the book of Leviticus is crucial material for students of this concept. The verbal forms of טָָָָא are analyzed in each book of the Pentateuch starting with the book with the least number of occurrences and ending with the book with most. The total number of verbal forms in the Pentateuch is $114 .^{62}$

The use of טָָמָא in the Pentateuch demonstrates that it is a binary verb. In other words, in terms of syntactic transitivity, טָָמָא appears as transitive and intransitive verb.

\footnotetext{
${ }^{59}$ Aaron Koller, "Diachronic Change and Synchronic Readings: Midrashim on Stative Verbs and Participles,” JSS 57.2 (2012): 268, 278-80; Creason, “Semantic Classes,” 73.

${ }^{60}$ Creason, "Semantic Classes," 2.

${ }^{61}$ Joüon and Muraoka, A Grammar of Biblical Hebrew, 116-20; Waltke and O'Connor, An Introduction to Biblical Hebrew Syntax, 367-71; Creason, "Semantic Classes," 2; Joüon, "Notes on Lexicographie Hébraique." Paul Joüon, and T. Muraoka claimed that "the transitivity and intransitivity are syntactic phenomena, which do not affect the vocalisation of verbs." Joüon and Muraoka, A Grammar of Biblical Hebrew, 115n9.

${ }^{62}$ Accordance Bible.

63“"Syntactic transitivity is a binary property of a verb as it is used in a particular clause: a verb is either transitive or intransitive, depending on whether or not it has a direct object. A transitive verb has a direct object, whereas an intransitive verb does not." Talmy Givón, Syntax: A Functional-Typological Introduction, 2 vols. (Philadelphia: John Benjamins, 1984-90), 1:109. Via Beckman, "Toward the Meaning," 17.
} 
In all piel occurrences, טָָׁמאץ is transitive, and in the majority of the occurrences, it is accompanied by אָת (Gen 34:5, 13; Lev 11:44; 13:3, 8, 11, 15, 20, 22, 25, 27, 30, 44;

$15: 31 ; 18: 28 ; 20: 3$; Num 5:3; 19:13, 20; 35:34; Deut 21:23), whereas in four texts, missing; however, טָָָָ in all occurrences modifies a noun in a given clause (Gen 34:27; Lev 13:59; 20:25; Num 6:9). In terms of semantic transitivity, טָָמָא also behaves variably, ${ }^{64}$ but, being mainly a stative verb, טֵָָׁא is generally low in semantic transitivity. ${ }^{65}$

Two characteristics related to the verb טָָָָ emerged from the analysis of its uses in the Pentateuch conducted below: (1) It always depends on the other verb/s (verbal actions), mentioned or assumed in the given or surrounding texts in order to achieve the meaning it conveys. טָָמָא is always accompanied by verbs of touching, carrying, sitting, eating, etc. in order to show the actual manner of how an entity contracts טָָָָא status, and (2) consequently, contracting the state of טָָָָ always includes some sort of physical contact between the entity transmitting and contracting impurity.

\section{טָָָּ in Genesis}

In the book of Genesis, all 3 verbal forms of טָָָָא always refer to Dina's unclean state caused by Shechem's sexual intercourse with her $(34: 5,13,27)$. Dina's defiled state

\footnotetext{
64"Semantic transitivity refers to the extent to which the subject of the clause affects the direct object. Whereas syntactic transitivity is binary, semantic transitivity comes in multiple levels. A clause can have high semantic transitivity (greatly affects the object), low semantic transitivity (little or no effect on the object), or be somewhere in between." Beckman, "Toward the Meaning," 22.

${ }^{65}$ Thompson and Hopper, “Transitivity in Grammar and Discourse," 252.
} 
was attained by Shechem's lying with her, v. 2. Dina's state expressed by the verb טָָָָא actually achieved by the other verbal action, that is, to have intercourse. ${ }^{66}$ Both characteristics pointed out above, the use of helping verbs and contact between the two entities, are present in the affair of Dina's defilement.

\section{in Deuteronomy}

Out of 10 occurrences of the root of טָָמָא in the book of Deuteronomy, only 2 verbal forms ${ }^{67}$ are found in 21:23 and 24:4. The first text discusses leaving the dead body on the tree overnight, which consequently defiles the land, while the second discusses the sending away of a wife, thus forcing her to defile herself by having an intercourse with another man. ${ }^{68}$ The same pattern is detected. The defiled status in these two instances is accomplished by other additional verbal activities which include contact between two entities.

${ }^{66}$ The nature of this defilement is puzzling. Generally, certain moral acts such as various sexual behaviors (Lev 18:27), eating impure food (Lev 20:22-26), and practicing idolatry (Deut 12:1-4) form a combination of reasons that can make Gentiles both ritually and morally impure. Jonathan Klawans, "Notions of Gentile Impurity in Ancient Judaism," AJSR 20 (1995): 290-91.

${ }^{67}$ The 8 remaining adjectival derivatives always refer to the individuals who have/have not contracted various sorts of defilement $(12: 15,22 ; 15: 22 ; 26: 14)$ or to the animals that are unclean by their nature $(14: 7,8,10,19)$. Accordance Bible.

${ }^{68}$ For an in-depth analysis of Deut 24:1-4, see Richard M. Davidson, Flame of Yahweh: Sexuality in the Old Testament (Peabody, MA: Hendrickson, 2007), 389-405, especially pp. 395-98. 


\section{טָמָא in Numbers}

The term טָָמָא occurs 37 times in the book of Numbers ${ }^{69} 24$ of which are verbal forms. Three distinct uses emerge out of these occurrences. טֵָָָָא refers to: (1) the people who obtained a defiled status and can defile other entities by being in close proximity to or touching them $(5: 3 ; 6: 9 ; 19: 7,8,10,11,13,14,16,20 \times 2,21,22 \times 2),(2)$ people being/not being defiled by prohibited acts $(5: 13,14 x 2,20,27,28,29 ; 6: 7,12)$, and (3) land defilement by murder/shedding of blood (35:34).

The first text of Group 1, people who obtained a defiled status and can defile other entities by being in close proximity to or touching them, is found in 5:3 which is an extension of God's command initiated in v. 2. That is, to put outside the camp all who are leprous, have a discharge, and everyone who is unclean through contact with a corpse so that they do not defile the camp because God lives among them. In which manner does the defilement of their camp take place? A logical place to find the answer to this question is to examine the regulations regarding these 3 potential ways of contracting defilement. First, the leprosy regulations found in Lev 13-14 are quite vague in this regard. However, there are at least two convincing and instructive sets of clues that help to delineate the mode of defilement. The regulations in 13:45-46 would suggest that defilement by the leper takes place through the contact. That is, it is prescribed, among other things, for lepers to, cry out "unclean, unclean," most likely when they encounter an

\footnotetext{
${ }^{69}$ Adjectival forms occur in eleven texts and they always refer to individuals (5:2; 9:6, 7, 10; $19: 13,17,19,20,22)$, or things that have/have not contracted various sorts of defilement (19:15), or to animals that are unclean by their nature (18:15). Two nominal derivatives are found in 5:19 and 19:13. Accordance Bible.
} 
undefiled person, clearly to avoid contact with undefiled persons, as understood by noted scholars of the Hebrew Cult. ${ }^{70}$ The continuation of the leprosy regulations found in chap. 14 , for the case of leprosy on the house also contains a clue about how the actual defilement takes place. In vv. 46-47, it states that all who enter the house, sleep, or eat in it while it is quarantined contract the defilement. Scholars call this defilement "the defilement by overhang," based on Num 19:14-15. ${ }^{71}$ However, if the house is considered as a whole, the floor of the house on which one would undeniably have to step, making contact with it in order to enter it, could be seen as the source of the defilement for the one entering the house. The same applies to the door of the house as well. ${ }^{72}$ Indisputably, other verbs are present in this way of transmitting defilement, as well as the contact of the entity transmitting and receiving defilement. Second, the regulations for various genital/bodily discharges found in Lev 15 convey the same idea. Verses 15:4-12, 18-24, $26-27$, through the use of verbs of touching, ${ }^{73}$ siting upon, spitting by the defiled one on a clean person, riding in the saddle, emission of semen, lying with a menstruating woman, lying on the bed, demonstrate that the defilement is transmitted through contact with the object that was defiled by the impure person. Third, the regulations concerning defilement by the human corpse found in Num 19:11, 13, 16 are straightforward, since they state that defilement through the human corpse takes place through contact. Potential

${ }^{70}$ Milgrom, Leviticus 1-16, 806; Gane, Leviticus, Numbers, 238.

${ }^{71}$ Milgrom, Leviticus 1-16, 875; Gane, Leviticus, Numbers, 249.

${ }^{72}$ This is not a crucial point of this essay and it will not be elaborated on in greater detail. It is assumed that defilement could takes place in both ways, by overhang and by contact.

${ }^{73}$ The verb נָגֵָ is the most frequently used in this chapter, ten times, in all of Leviticus. Chapter 11 follows with seven occurrences. Some entities always get defiled when touched by the defiled person. Accordance Bible. 
defilement by overhang is found in 19:14-15. The defilement of the sanctuary mentioned in vv. 13 and 20 will be analyzed below in a separate subheading.

The verbal form of טָָָָא is also found in procedures for the termination of the Nazirite vow, v. 6:9. The idea is that his holy status will be interrupted due to contact between the Nazirite and a human corpse ${ }^{74}$ or if they find themselves in a house with a person who suddenly dies. ${ }^{75}$ The adverbial use of the prepositional phrase עַ + personal pronoun (3ms, referring to the Nazirite) suggests the existence of contact between the person who suddenly dies and the Nazirite disputing the defilement of overhang.

The account of the cleansing water which involves slaughtering the red heifer includes multiple action verbs to describe the priest' $\mathrm{s}^{76}$ and his assistants ${ }^{97}$ involvement in the ritual process which defiles all of them $(19: 7,8,10)$. There are opposite opinions as to the subject of the verbs "to deliver," "to take out," and "to slaughter." Some claim that the subject of all these verbs is someone else than Eleazar, the officiating priest, ${ }^{78}$ while some consider Eleazar as the subject of the verbs "to deliver" and "to take out," or the subject of the verb "to slaughter" is elliptical. ${ }^{79}$ However, even if Eleazar is not the

${ }^{74}$ Levine, Numbers 1-20, 215; Gane, Leviticus, Numbers, 534.

${ }^{75}$ Levine, Numbers 1-20, 222.

${ }^{76}$ The priest, at least, takes the heifer's blood and sprinkles it (v. 4), throws cedarwood, hyssop, and crimson material into the fire in which the heifer is burning (v. 6).

${ }^{77}$ The first assistant burns the heifer (v. 8). The second assistant gathers up the ashes of the heifer, and deposits them outside the camp in a clean place (v. 9).

${ }^{78}$ Ashley, Numbers, 365.

${ }^{79}$ Levine, Numbers $1-20,461$. 
subject of any of these verbs, and even if the priest mentioned in v. 6 is not Eleazar, ${ }^{80}$ based on v. 4, he is indisputably the one who takes and sprinkles the red heifer's blood. In other words, taking and sprinkling the red heifer's blood renders him defiled. Thus, regardless of who performs the activities expressed by "to deliver," "to take out," and "to slaughter," the text declared the priest and his assistant/s, defiled. The text is also clear that all the participants get in touch with in various ways with the red heifer during the process of preparing the water of cleansing.

The rest of the red heifer account, vv. 11, 13, 14, 16, 20x2, 21, 22x2, where occurs, shows that contact between the entities transmitting and receiving defilement

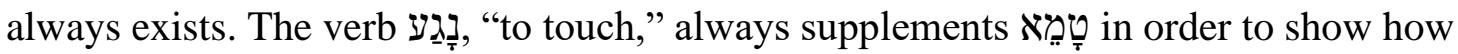
the defilement takes place (vv. 11, 13, 16, 21, 22). The text of v. 22 is very straightforward in stating that defilement takes place through contact. The potential defilement of overhang is found in v. 14, which was discussed above. Verse 20 is a general statement and does not mention the way one contracts defilement, most likely because the manners of defilement were explained multiple times before and after it, that is, through contact. In two verses of this section, vv. 13 and 20, טָמָָא affects the sanctuary. Those who do not purify themselves after being defiled through contact with the dead defile the tabernacle of the Lord. These verses will be analyzed in greater detail later.

The texts of Group 2, people being/not being defiled by prohibited acts, are found in chaps. 5 and 6. Chapter 5 deals with the law of a suspected adulteress, and טָָָָא in this text refers to the potentially defiled condition contracted from intercourse outside

${ }^{80}$ Milgrom, Numbers, 159. 
marriage $(5: 13,14 x 2,20,27,28,29)$. The nominal derivative of the root used in vv. 13, 20, and 29 to indicate the sexual act, in this case outside of marriage boundaries, which causes the defilement of the woman. The verbal derivative of the root שָָָׁ is also found in v. 13 and in addition, in v. 19. Both nominal and verbal derivatives of the root מָעָל, which also refers to marital infidelity, appear in v. 12 to introduce the issue the law deals with. The root also appears in v. 27 in the conclusion of the law. A woman contracts impurity through illicit sexual intercourse which includes contact between the two involved in the act.

The Nazirite vow regulations prohibit individuals who take the vow from going to dead members of their family (6:7. 12). Scholars settled that the phrase "go near the dead" refers to contact between the Nazirite and his dead family member. ${ }^{81}$

The only text in Group 3, the defilement of the land by murder/shedding of blood, is found in 35:34. This text is a part of the concluding remarks, vv. 30-34, on the homicide law imbedded in the law of the cities of refuge found in Numbers 35:6-34. This law states that the presence of the murderer in the land defiles it. A murderer becomes the source of defilement by the fact that he kills, sheds the blood of another human being, and was in contact with the dead. In addition, v. 33 states that the shedding of blood defiles the land. The only way the land could be kept holy is by eliminating, shedding the blood of the murderer. If the community is neglectful in not eliminating the murderer (v. 30) or accepting a ransom for the murderer (v. 31) or approving a manslaughterer who

\footnotetext{
${ }^{81}$ Levine, Numbers 1-20, 215; Milgrom, Numbers: 45; Gray, A Critical and Exegetical Commentary on Numbers; Vaux, Ancient Israel: Its Life and Institutions, 56.
} 
leaves the city of refuge (v. 32), he also is responsible for the defilement of the land by allowing the defilement to spread in the land. In addition to mutual contact between the murderer, the victim's blood, and the victim's dead body and the land, defilement is also transmitted by people's sins in regards to the crime of murder, that is, by not eliminating the murderer (v. 30) or accepting a ransom for the murderer (v. 31) or by having a manslaughterer leave the city of refuge (v. 32). ${ }^{82}$ The analysis of the טָָָ texts in Numbers, including all the 3 categories delineated in this book, confirms the fact that defilement is achieved by some other verbal activities which always include some sort of contact between the entity which transmits and the entity receiving defilement.

\section{טָמָא in Leviticus}

Leviticus uses טָָמָמא the most frequently. ${ }^{83}$ The verbal forms are used 85 times out of 150 occurrences and they refer to various manners by which the defilement is contracted. Unlikely to the 3 groups identified in the book of Numbers, the book of Leviticus contains the 2 following groups: (1) the entities that obtained a defiled status and can defile other entities by being in close proximity to or touching them $(5: 3 ; 12: 2 \times 2$, $5 ; 13: 3,8,11,14,15,20,22,25,27,30,44 \times 2,46,59 ; 14: 36,46 ; 15: 4 \times 2,5,6,7,8,9$, $10 \times 2,11,16,17,18,19,20 \times 2,21,22,23,24 \times 2,27 \times 2,31,32 ;)$, (2) people being defiled by prohibited acts $(11: 24 \times 2,25,26,27,28,31,32 \times 2,33,34 \times 2,35,36,39,40 \times 2,43 \times 2$, $44 ; 17: 15 ; 18: 20,23,24 \times 2,25,27,28,30 ; 19: 31 ; 20: 3,25 ; 21: 1,3,4,11 ; 22: 5 \times 2,6,8)$.

\footnotetext{
${ }^{82}$ For a more detailed analysis of the law of homicide see Janković, "The Rationale," 79-104.

${ }^{83}$ Adjectives occur forty-seven times (Lev 5:2; 7:19, 21; 10:10; 11:4-8, 26-29, 31, 35, 38, 47; $13: 11,15,36,44-46,51,55 ; 14: 40-41,44-45,57 ; 15: 2,25-26,33 ; 20: 25 ; 22: 4 ; 27: 11,27)$ and nominals eighteen times (Lev. 5:3; 7:20-21; 14:19; 15:3, 25-26, 30-31; 16:16, 19; 18:19; 22:3, 5).
} 
The pattern attested in the books of Genesis, Deuteronomy, and Numbers is also attested in the book of Leviticus. Exceptions do exist, but there is substantial explanation for each of them.

Based on the present research, of all these 85 occurrences of טֵַָׁ in Leviticus, there are few instances where טָָמָא is not accompanied by other verb/s to convey the manner by which defilement took place. However, the inclusion of other verbs to accomplish defilement is implied.

The text of Lev 11:43, 18:25, 28 do not contain the verb/s which would convey the manner of defilement, but it should be remembered that many verbs in the previous verses of these two chapters (touch, carry, fall [corpse on some other entity], and eat) indisputably convey the manner by which defilement takes place (Lev 11:31-36swarming things, 18:6-24, 27, 30-various sexual acts).

There are two issues in Lev 20:25. First, the verb טָָמָא refers to the distinction which should be kept by the Israelites between clean and unclean animals. A detailed explanation of this distinction is found in chap. 11. Second, the verb טָָָָ is used in this text to describe defilement by various unclean animals by which Israelites should not be infected. It has been recognized that טָָמָא the way one gets defiled by these animals is also explained in chap. 11 in details.

Leviticus 21:1. 3-4 does not state the manner of defilement (i.e., the process of

${ }^{84}$ Milgrom, Leviticus 1-16, 684. 
defiling), but it is anticipated that defilement by the corpse would assume various contacts with it. ${ }^{85}$

Leviticus 15:31 and 20:3 will also be commented on later in this study under separate subheadings.

\section{Semantics of טָָָָּ: Summary}

The foregoing analysis of the uses of טֵָׁא in the Pentateuch demonstrates that the two claims proposed regarding this verb are accurate. First, טְָָָ always depends on the other verb/s mentioned or assumed in the given or surrounding texts to achieve the condition it conveys. These verbs are verbs of touching, carrying, sitting, eating, etc., in order to show the manner by which an entity contracts טֵָָָא status. Second, building on the first finding, contracting the state of טֵָׁא always includes some sort of contact between the entities transmitting and contracting impurity or a defiling process takes place if both the source and recipient of impurity are inside the same, enclosed space.

The concept of delay is one of the unavoidable concepts to be addressed when one studies the ADH. Therefore, this concept will be presented and analyzed below.

\section{The Concept of Ellipsis}

The so-called concept of delay fashioned by Milgrom was another point of debate among scholars and rests upon another concept, that is, the concept of ellipsis. Elliptical interpretation refers to the absence of essential clauses in the biblical text, in this case cultic legislation, which were well established and known within this body of biblical

\footnotetext{
${ }^{85}$ Gane, Leviticus, Numbers, 372; Milgrom, Leviticus 17-22, 1814.
} 
texts. Maccoby's ellipsis, an essential but yet missing clause in Lev 15:31, 20:2 and Num $19: 13,20$, is "if impure person touches sancta"; 86 he claims that this ellipsis streams out of texts like Lev 7:20-21, 12:4, and 22:3-7, which undoubtedly convey the fact that the defilement of the holy entity takes place through direct contact with the impure entity. ${ }^{87}$ Outside of these texts, Maccoby also cited Lev 5:4 as an obvious example of ellipsis, in this case, "if he breaks his vow." 88

Milgrom claimed that this is not a real ellipsis, and his critique of Maccoby on this particular text ${ }^{89}$ is highly controversial due to his claim that the legist (the author)

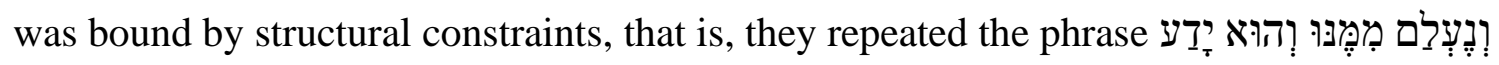
in v. 4 as they did in vv. 2-3. If, as Milgrom agreed with many other scholars, Lev 5:1-4 is comprised of a unit of 4 cases of apodosis, then the legists' striving to follow structural consistency would lead them to use the same phrase in v. 1 as well, which they did not. In addition, it would also have led them to the same phrase in all three verses, 2, 3, and 4,

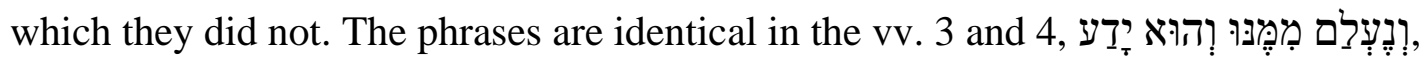

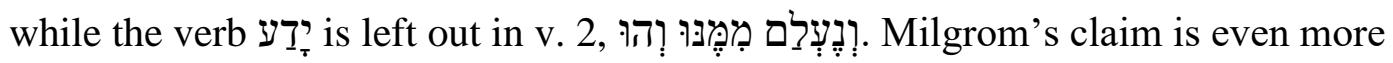
controversial due to the fact that vv. 2 and 3 refer to the similar topic, defilement, in v. 2 , by carcass, and in v. 3 , by human. Thus, it would be natural to have the same phrase in

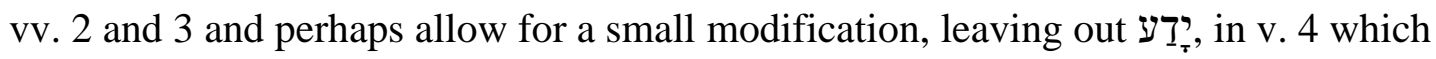

\footnotetext{
${ }^{86}$ Maccoby, Ritual and Morality, 174.

${ }^{87}$ Maccoby, Ritual and Morality, 170, 190n2.

${ }^{88}$ Maccoby, Ritual and Morality, 173-74.

${ }^{89}$ Milgrom, “Impurity is Miasma,” 729.
} 
deals with a new topic, a rush oath. Thus, it seems that the legists were not bound by structural constraints when it came to this phrase because they left out the phrase in v. 1 and used it in vv. 4, which is the structural and thematic counterpart of v. 1, and they used different phrases in vv. 2 and 3 which are structural and thematic counterparts.

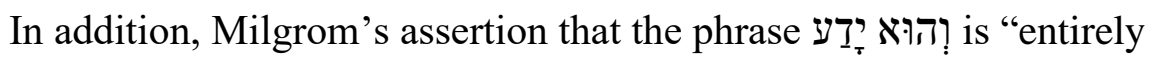

superfluous" $" 90$ is also not substantial since repetition, even though not desired as much in conventional writing, was essential in Ancient Near Eastern written materials in order to emphasize certain facts. ${ }^{91}$ Milgrom made an accurate comment when he stated that the

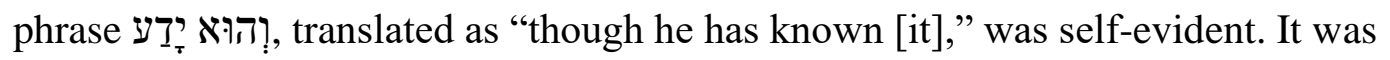
therefore eliminated."92 That is exactly what Maccoby was also pointing out, but referred to it as an ellipsis. This study does not deal with the structure of Lev 5:1-4, but rather, notes the flaws of Milgrom's comment on the structure related to the use of the phrase mentioned above by the legist. Milgrom's own suggestions of ellipsis in Lev 11:27-28, $31,32,39$, and 40 regarding the ablutions are convincing, ${ }^{93}$ while those in Lev 9:8, 12 , 15, 18 and 16:11, 15 are a matter of unsettled debate among scholars, and are informed by Milgrom's theory of atonement. It is obvious that although the concept of ellipsis is

\footnotetext{
${ }^{90}$ Milgrom, "Impurity is Miasma," 729.

${ }^{91}$ Repetition is a structural element in historical narratives. John Sailhamer, The Pentateuch as Narrative: A Biblical-Theological Commentary (Grand Rapids, MI: Zondervan, 1992), 25. It is considered to be the most powerful means in biblical texts. J. P. Fokkelman, "Genesis," in The Literary Guide to the Bible, eds. Robert Alter and Frank Kermode (Cambridge: Belknap Press of Harvard University Press, 1987), 46. Its task is to emphasize what is important, remind the listener of the previous steps or actions, or sometimes, simply to impress. Laurence A. Turner, Genesis, RNBC (Sheffield: Sheffield Academic Press, 2000), 15.

${ }^{92}$ Milgrom, "Impurity is Miasma," 729.

${ }^{93}$ Milgrom, "Impurity is Miasma," 730.
} 
common and present in biblical cultic/legal material, the potential elliptical claims have to be confirmed by and clearly stated in other biblical texts. In this case, biblical cultic/legal material favors Maccoby’s understanding.

\section{The Concept of Delay}

Milgrom assumed that a lapse of time, a delay between the actual moment of defilement of a person and the time he/she becomes aware of his/her defiled status makes the impurities grow from a non-sinful, minor one into a major, sinful one, thus defiling the sanctuary from afar. Normally, simple day ablutions would eliminate non-sinful defilements, but since there is a delay in dealing with them, the impurities grow into major ones requiring the sacrifice $(5: 6-13) .{ }^{94}$ Maccoby already noted that the text which would verify this concept of delay as a deciding factor, whether the defilement is sinful or not, is nonexistent in biblical cultic legislation. ${ }^{95}$ I agree with Milgrom that the concept of delay is a valid concept, as I agree with Maccoby concerning elliptical interpretation. However, the consequence of the delay is different in my understanding, namely, the requirement of the sacrifice might be for the unintentionality of the person who initially contracted impurity and did not immediately handle it properly. In that way, the defilement would have grown, not due to a delay itself, but because it would be transmitted and spread in the camp, thus increasing the risk of a defiled person's, unaware of his/her status, entering the sanctuary and defiling it. The transmission of impurity could continue uncontrollably until ultimately, the entire camp becomes

\footnotetext{
${ }^{94}$ Milgrom, "Impurity is Miasma," 730. Milgrom cites Lev 11:28, 31-40 to support one day time limit to deal with the defilements. Milgrom, Leviticus 1-16, 298.

${ }^{95}$ Maccoby, Ritual and Morality, 174.
} 
defiled. ${ }^{96}$ Thus, delay does not make minor defilements grow from small ones into major ones, but gives room for neglected defilement to be transmitted uncontrollably in the camp via contact and finally, to defile the sanctuary and the entire camp. In addition, a simple neglect to purify constitutes violation of divine commandments.

In his response to Maccoby's remarks, Milgrom stated that the concept of delay can be derived from other references, but he cited one single text, Lev 17:16, based on which he claimed that delay is dangerous, not because the defiled person can enter the sanctuary in his/her impure state, but because neglect to purify himself/herself is sinful and punishable. ${ }^{97}$ It is true that disobedience to be purified falls into the domain of moral impurity, as Milgrom claimed, but on the other hand, it is also true that during the delay, the defiled person could unintentionally, and unaware of his/her defiled state, enter the sanctuary and defile it through direct contact. Thus, one could accept both scenarios, moral impurity of neglecting to follow God's procedure for dealing with the defilement and entering the sanctuary in a defiled state, since they are both possible and not mutually exclusive. Texts where individuals in their defiled state came into the direct contact with the holy entities and consequently died do exist in the Pentateuch (Lev 10:1-2; Num 16:16ff, etc.) or were forbidden to come in contact with holy entities (Lev 7:20; 12:4, etc.), while there is not a single text that clearly supports ADH.

\section{Leviticus 15:31}

Leviticus 15:31 is a conclusion to the laws on genital impurities found in Lev

\footnotetext{
${ }^{96}$ Wenham, Numbers, 145.

${ }^{97}$ Milgrom, “Impurity Is Miasma,” 730.
} 
15:1-30 and can be translated/interpreted in two distinct ways as the following translation shows: "Thus you shall keep the people of Israel separate from their uncleanness, so that they do not die in their uncleanness 1. by defiling my tabernacle that is in their midst or 2. when they defile my tabernacle that is in their midst." The interpretational and grammatical crux of this verse is the meaning of the infinitive construct preceded by the preposition Эุ̣. The first translation assumes an instrumental sense of the infinitive construct and is favored by automatic defilement proponents. The second translation conveys a temporal one and it disputes this hypothesis. Both options, respectively, will be discussed below.

\section{Instrumental Sense: "by Defiling My Tabernacle That Is in Their Midst"}

Based on the first possible translation, the proponents of the ADH believe that it is the negligence of the Israelites to implement procedures found in Lev 15:1-30 or chaps. $11-15,{ }^{98}$ prescribed to handle genital (chap. 15) or all impurities listed in chs. $11-$ 15 , which cause defilement of the sanctuary from a distance. In this case, the death penalty is triggered by moral fault. ${ }^{99}$ In other words, the sin represented in this case is intentional disobedience to the divine laws for purification listed in chap. 15 or chaps. 11-15. An individual affected by these impurities does not need to come to the sanctuary, in other words to come into a direct contact with it, in order to defile it for they defile it from the distance. Their punishment is not based on potentially bringing their ritual

\footnotetext{
${ }^{98}$ Balentine, Leviticus, 124; Milgrom, Leviticus 1-16, 945.

${ }^{99}$ Jacob Milgrom, "The Paradox of the Red Cow (Num. XIX)," VT 31 (1981): 71; Kiuchi, Purification Offering, 124. Followed by Gane, Cult and Character, 145.
} 
impurities into a direct contact with the holy entities, sanctuary in this case, but rather, their punishment is initiated by their neglect to undergo divinely prescribed purification rituals.

This interpretation agrees with the first translation of the third clause in 15:31 mentioned above, where the infinitive construct of the Hebrew verb טָָמָ, preceded by the preposition $\underset{?}{\mathfrak{7}}$, is taken to function as a noun in the so-called nominal use of the infinitive construct. The logical subject in this grammatical construction is expressed by the pronominal suffix attached to a given noun or a personal name. ${ }^{100}$

\section{Temporal Sense: "When They Defile My Tabernacle That Is in Their Midst"}

Based on the second possible translation of the third clause in Lev 15:31, it has been argued that the individual comes in their impure state to the sanctuary and via direct contact with the holy entities, in this case, the sanctuary, defiles them. The exact source of defilement is a matter of an ongoing debate. Some scholars believe that this text warns against ritual defilement of the sanctuary, ${ }^{101}$ while some believe that defilement originates out of moral impurity, ${ }^{102}$ that is, the neglect to follow procedures for ritual purification. In any case, this interpretation is based upon the second, temporal translation which seems more plausible from the grammatical, syntactical, and semantic standpoint.

${ }^{100}$ Folmer, "The Translation of Biblical Hebrew Clauses," 116.

${ }^{101}$ Hoffmann, Das Buch Leviticus, 1:430; Maccoby, Ritual and Morality, 170; Rodríguez, "Transfer of Sin in Leviticus," 173-76; Hannah K. Harrington, The Purity Texts, CQS 5 (New York: T \& T Clark International, 2004), 71-72, 78; Kazen, Issues of Impurity in Early Judaism, 57; Charlotte Elisheva Fonrobert, Menstrual Purity: Rabbinic and Christian Reconstructions of Biblical Gender, Contraversions (Stanford: Stanford University Press, 2000), 19; Frymer-Kensky, "Pollution, Purification," 403.

${ }^{102}$ Brichto, “On Slaughter and Sacrifice,” 33; Kiuchi, Purification Offering, 61. 
As noted above, the first translation translates the third clause of this text with "by defiling my tabernacle," indicating an instrumental nuance of the clause, while the second as "when they defile my tabernacle" points to the temporal, conditional sense. The second translation gives room for the other consequential meaning of this clause, entrance of the impure person into the sanctuary and defiling it via direct contact. This interpretation is preferred by some theologians. ${ }^{103}$ As shown above, a number of the Pentateuchal texts explicitly confirm the notion that the defilement of the sanctuary happens through direct contact (Lev 7:20;10:1-2; 12:4).

This claim is further verified by the analysis of all 22 constructions of the infinitive construct, preceded by $\underset{?}{\mathfrak{7}}$, found in Leviticus $(4: 27 ; 10: 9 ; 12: 6 ; 15: 23,31 ; 16: 1$, $17,23 ; 18: 28 ; 19: 9 ; 20: 4 ; 22: 16 ; 23: 22,39,43 ; 24: 16 ; 26: 26,35,43,44 ; 27: 21)$. That is, all of them convey a temporal sense (Lev 4:27; 10:9; 12:6; 15:23, 31; 16:1, 17, 23; 18:28; $19: 9 ; 20: 4 ; 22: 16 ; 23: 22,39,43 ; 24: 16 ; 26: 26,35,43,44 ; 27: 21)$. In addition, all occurrences of the infinitive construct preceded by $\underset{?}{?}$ when it is syntactically related to the noun that refer to the sanctuary (משכן) retain a temporal sense (Exod 40:36; Lev 15:31; Num $1: 51 ; 9: 19,22)$. To scrutinize this statistics more, the exact same grammatical construction as it is in this text, $\underset{?}{?}+$ infinitive construct + Nֵ, is found in 17 texts in Leviticus $(6: 13$ [20]; 7:16, 36, 38; 15:23[꾸 acting as direct object marker], 31; 16:30; $18: 28 ; 19: 9 ; 20: 4 ; 22: 16 ; 23: 12,22[\mathrm{x} 2], 39,43 ; 24: 16$ [no direct object marker]) and these texts express temporal sense, too.

\footnotetext{
${ }^{103}$ Maccoby, Ritual and Morality, 173; Kiuchi, Purification Offering, 61, 155; Péter-Contesse and Ellington, A Translator's Handbook on Leviticus, 238.
} 


\section{Leviticus 20:3}

A law of Lev 20:1-5 prescribes the procedure for an individual who offers any of their children to Moloch as a sacrifice. Verse 3 crucially states that "I myself [God] will set my face against them, and will cut them off from the people, because they have given of their offspring to Moloch, defiling my sanctuary and profaning my holy name." According to $\mathrm{ADH}$, defilement of the sanctuary in this case also takes place from distance, and the mere act of offering one's offspring to Moloch defiles the sanctuary. Again, a practitioner of this prohibited worship does not need to come to the sanctuary, that is, come in contact with it, in order to defile it.

As mentioned above, Lev 20:3 also utilizes the infinitive construct, but preceded by the separable preposition למען. With knowledge concerning the piel stem, the infinitive construct aspect, and the semantics concerning the verb טָָמָָ, I specifically focus on the two particulars of this text: the meaning and function of the preposition and the structure of the law. These two items are included in the analysis of this text since they contribute greatly to its proper understanding.

The Form, Meaning, and Function of ?ִּ ?

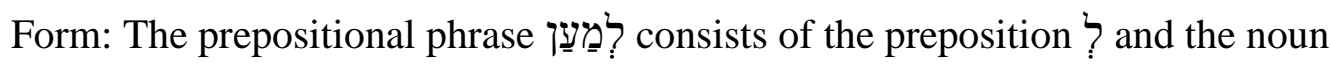

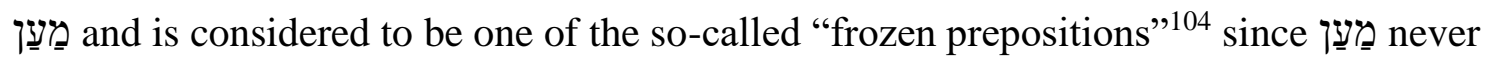
occurs without $?$ (270 times). ${ }^{105}$ Meaning: Scholars have reached a consensus on the

\footnotetext{
${ }^{104}$ Waltke and O'Connor, An Introduction to Biblical Hebrew Syntax, 91.

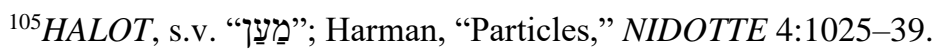


meaning of this phrase. It is usually translated as "for the sake of, on account of, to the intent or in order that," conveying both purpose and intention, but without the sense of causation. $^{106}$

Function: In $\mathrm{BH}$, “the main clause expresses a situation, and the subordinate clause either a purpose (final or telic clause) or a consequence (result clause), ${ }^{\prime 107}$ and both of these types of clauses, normally including the infinitive construct, are governed

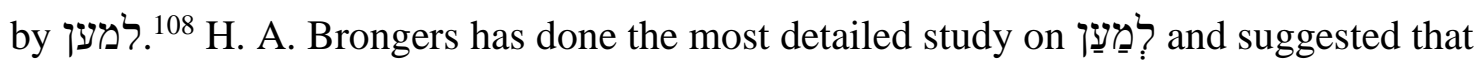
syntactically, it governs a result clause in a few cases (Lev 20:3; 2 Kgs 22:17; Amos 2:7). He noted that the particle is sometimes elliptical in sense and a paraphrase is necessary: "the consequence of which will be." 109 It has to be highlighted that the level of certainty in classifying purpose and consequence is sometimes low. The context is critical for the precise sense of given grammatical constructions and particles. ${ }^{110}$

Brongers' and Joüon and Muraoka's insights are crucial regarding the function of לִמַעַַ in Lev 20:3. First, commenting on its function in this text, Brongers emphasized that

\footnotetext{
${ }^{106}$ Waltke and O'Connor, An Introduction to Biblical Hebrew Syntax, 91, 511, 637-41, 694; Allan

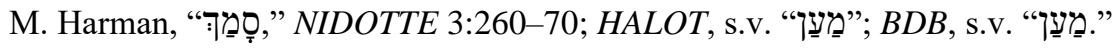

${ }^{107}$ Waltke and O'Connor, An Introduction to Biblical Hebrew Syntax, 91, 637.

${ }^{108}$ H. A. Brongers, "Die Partikel לִַַַ in der Biblisch-Hebräischen Sprache," in Syntax and Meaning: Studies in Hebrew Syntax and Biblical Exegesis, eds. C. J. Labuschagne, et al., OtSt 18 (Leiden: Brill, 1973), 84-96; Waltke and O'Connor, An Introduction to Biblical Hebrew Syntax, 91; Joüon and Muraoka, A Grammar of Biblical Hebrew, 357. Via Johannes F. Diehl, Die Fortführung des Imperativs im Biblischen Hebräisch, AOAT 286 (Münster: Ugarit-Verlag, 2004), 342-60.

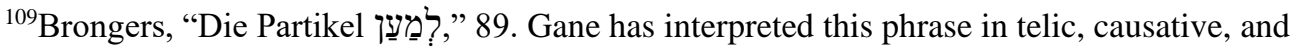
resultative senses. He stated: "It is this effect on the sanctuary, which does not depend upon the sinner's direct contact with sacred places or things, for which he/she receives punishment." Gane, Cult and Character, 148.

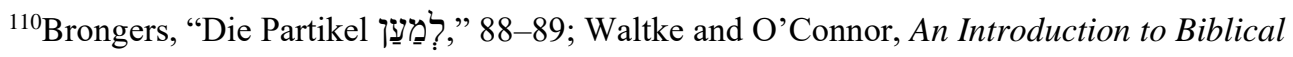
Hebrew Syntax, 91, 637; Joüon and Muraoka, A Grammar of Biblical Hebrew, 357, 595.
} 
es ist klar, dass es sich in diesen Stellen nicht um die Absiht, sonders um di Folge des Verfahrens handelt. Es ist z.b. fraglich, ob die Israeliten, als sie darangingen ihre Kinder dem Moloch zu opfern, dabei bewusst die Absicht hatten das Heiligtum Jahwes zu verunreiningen und seinen Namen zu entweihen. So eit werden sie ihre Überlegungen bestimmt nicht getrieben haben. Andererseits ist es auch keine Frage, dass infolge dieser Verfehlung Jahwe aufs tiefste gekränkt wurde. ${ }^{111}$

Second, Joüon and Muraoka have noted that לִ conveys a consequential or resultative sense in the context that discusses "the effect of a punishable act which is an offence against God rather than about its aim." ${ }^{112}$ They have cited Lev 20:3; Num 25:4; Deut $4: 25 ; 30: 12-14$ to show consequential or resultative sense. ${ }^{113}$ Thus, in this particular

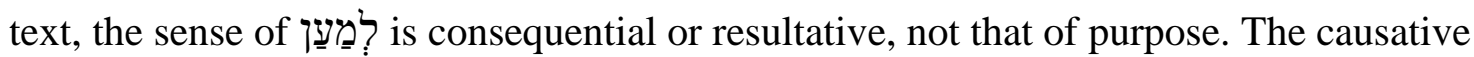
sense is never included in the preposition למען.

\section{Literary Structure of the Law}

According to the majority of modern scholars, the law consists of two scenarios. The first is contained in vv. 2-3 which implies that the idolater's act is known and both the community and God punish them. This case includes a double punishment, death by stoning and divine kārēt. With the fact that the idolater experiences premature death by human agency in v. 2, the divine punishment is taken to mean either extinction of the

\footnotetext{
111"It is clear that these verses are not about intention, but rather, about the results of the process. For example, it is questionable whether the Israelites, as they began to sacrifice their own children to Moloch, consciously intended to defile the sanctuary of Yahweh and to desecrate his name. They would not have driven their considerations so far. On the other hand, there is no question that, as a result of this

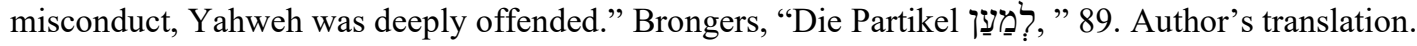

${ }^{112}$ Joüon and Muraoka, A Grammar of Biblical Hebrew, 598.

${ }^{113}$ Joüon and Muraoka, A Grammar of Biblical Hebrew, 405, 596, 598.
} 
lineage ${ }^{114}$ or punishment in the afterlife. ${ }^{115}$ Otherwise, v. 3 is understood as an explanation of v. 2 in the sense that the stoning to death by human agency represents God's opposition to this act. ${ }^{116}$ In the second scenario, vv. 4-5, the idolater's act is also known, but the community fails to punish him/her so consequently, God punishes them. It can be said that this is a standard, scholarly understanding of this law. ${ }^{117}$ Gane's explanation of divine punishment in a potential double punishment in the first scenario is eloquent and profound:

Divinely administered "cutting off" goes beyond capital punishment. When someone deserves more than one death penalty, human justice is stymied. It makes no difference whether an individual murders one or six million; the malefactor has but one life to give for his crime(s). But God can do plenty more: He can make the punishment fit the crime by seeing to it that the sinner's line of descendants, from which he has contributed to another deity, becomes extinct so that he is not even history. It is terrifying to face the prospect of being forgotten and unmissed. God can also deny the offender a positive afterlife. Either way, he is "cut off from his people." 118

This explanation was also accepted by Milgrom ${ }^{119}$ and is based on Donald Wold's dissertation research which is analyzed in the subheading "Donald Wold on the Kārēt Punishment" of this study. This explanation is not accepted here due to numerous

\footnotetext{
${ }^{114}$ Wold, "The Meaning of Biblical Penalty Kareth," 1-45, especially 4-5. Wold's suggestion was followed by the most influential scholars of Ancient Israel cult. Wright, The Disposal of Impurity, 164n2; Milgrom, Numbers, 406-7; Gane, Cult and Character, 145.

${ }^{115}$ Wenham, The Book of Leviticus, 242. Milgrom found that this understanding of kareth was anticipated by earlier exegetes. Milgrom, Leviticus 17-22, 1733; Milgrom, Numbers, 407; Hartley, Leviticus, 337-38.

${ }^{116}$ Keil and Delitzsch, The Pentateuch, 2:426-27.

${ }^{117}$ Wenham, The Book of Leviticus, 278; Levine, Leviticus, 136-37; Hartley, Leviticus, 333-41; Budd, Leviticus, 290-92; Milgrom, Leviticus 17-22, 1729; Gane, Cult and Character, 145; Gane, Leviticus, Numbers, 362; Kiuchi, Leviticus, 372-73; Sklar, Leviticus, 255.

${ }^{118}$ Gane, Leviticus, Numbers, 362.

${ }^{119}$ Milgrom, Leviticus 1-16, 459-60.
} 
methodological and conceptual fallacies of Wold's work.

Alfred Cholewinski has proposed a notable literary structure (see Table 25) which reflects the two scenarios type of the law. ${ }^{120}$

Table 25. Literary structure of Lev 20:2-5

\begin{tabular}{|c|c|c|}
\hline \multirow{4}{*}{ A } & $\mathrm{A} \beta$ & \multirow{4}{*}{ 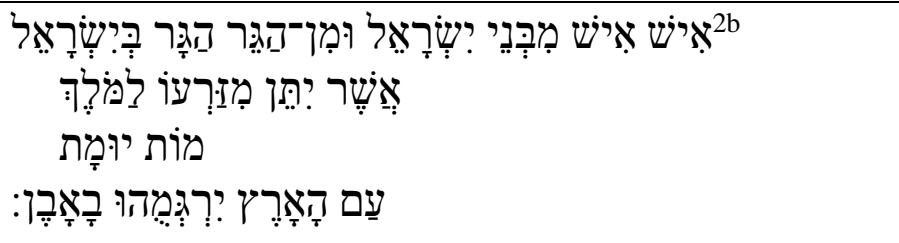 } \\
\hline & $\Gamma$ & \\
\hline & $\Gamma$ & \\
\hline & B & \\
\hline \multirow[b]{2}{*}{ B } & $\mathrm{A} \alpha$ & 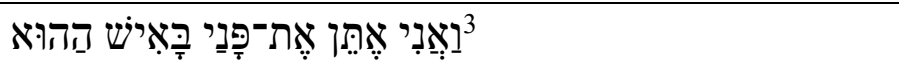 \\
\hline & B & 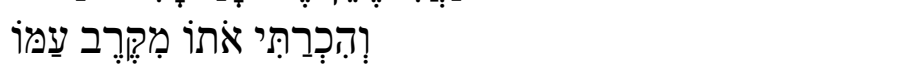 \\
\hline \multirow[b]{2}{*}{$\mathrm{C}$} & $\mathrm{b} \alpha$ & 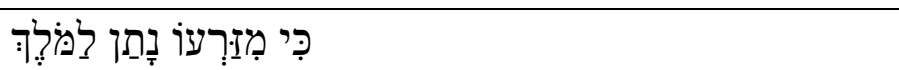 \\
\hline & $\beta-\delta$ & 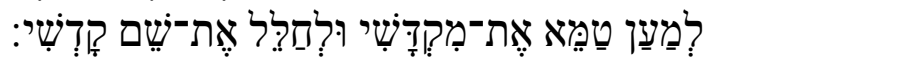 \\
\hline \multirow{3}{*}{$\mathrm{A}^{1}$} & $\mathrm{a} \alpha$ & 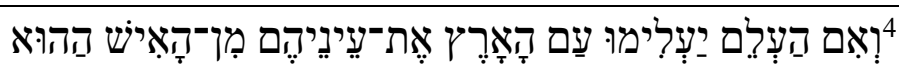 \\
\hline & $\beta$ & 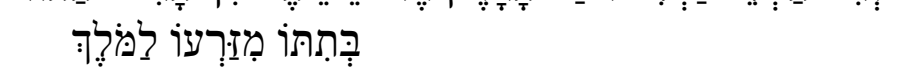 \\
\hline & b & 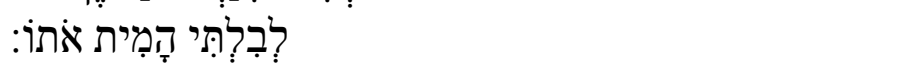 \\
\hline \multirow{3}{*}{$\mathrm{B}^{1}$} & $5 \mathrm{a}$ & 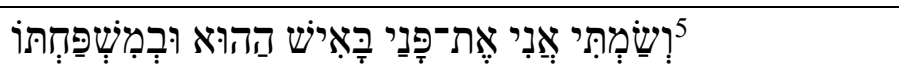 \\
\hline & $\mathrm{B} \alpha$ & 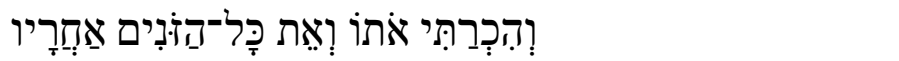 \\
\hline & B & 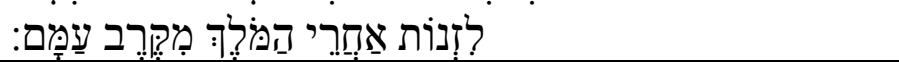 \\
\hline
\end{tabular}

However, this understanding of the law runs into internal conceptual inconsistencies. First, v. 2 states that the punishment for the act of idolatry is premature death. It is administered by the people who stone the idolater. This is well-established punishment for idolatry in Pentateuchal narratives (Exod 32:27) and legal texts

${ }^{120}$ Alfred Cholewinski, Heiligkeitsgesetz und Deuteronomium: Eine Vergleichende Studie, AnBib 66 (Rome: Biblical Institute Press, 1976), 55-56. 
(Deut $13: 5,9,10,15 ; 17: 5-6)$. If the punishment for idolatry in v. 2 stipulated by God is premature death by stoning, then the same punishment should be imposed in v. 5 . The only difference in vv. 4-5 and v. 2 is the attitude of the people which affects the mode of execution, but the nature of sin remains the same, implying that the nature of punishment should be the same as well: a premature death. The copulative ? that connects the opening verb in v. 5 with v. 4 also suggests that the punishment implied in v. 4 coordinates with the punishment implied in v. $5 .^{121}$ Therefore, it is reasonable to expect that the same punishment is in view in the people's punishing the idolater in v. 2, and God's punishing the idolater in v. 5-premature death.

Second, based on vv. 4-5, God administers punishment himself when people refuse to punish the idolater which points to the possibility that in v. 3 people do not punish the idolater. Keeping in mind the fact that vv. 4-5 discuss the people's refusal to impose punishment, a valid alternative is that they do not know about the act of idolatry in v. 3 and consequently are not able to punish idolater.

Third, the fact that the idolater is also punished by God himself in v. 3 and experiences premature death makes the subcase in vv. 4-5 superfluous. The people cannot disregard or fail to punish the idolater, even if they considered it, since they are already punished by God in v. 3 .

Fourth, taking v. 3 to be additional punishment to the one in v. 2 makes vv. 4-5 redundant and superfluous. The punishments in vv. 2 and 3 were also puzzling for Julius

\footnotetext{
${ }^{121}$ Waltke and O’Connor, An Introduction to Biblical Hebrew Syntax, 540.
} 
Wellhausen. ${ }^{122}$ It is very unlikely that God's punishment for idolatry in v. 3 did not mean premature death because this is a standard punishment for this sin. It would also be very unlikely that this law focused on punishment that did not affect the idolater immediately, premature death, but rather, implied afterlife punishment.

On the other hand, some scholars have proposed convincingly that this law actually consists of three scenarios. In v. 2, the people know about the idolatrous act and punish the idolater; in v. 3, they do not know about it and are not able to punish him/her so God does it, and in v. 4, the people refuse to punish the idolater and again, God does it. Thus, v. 3 is taken to refer to a separate subcase, not as an explanation of v. 2 or additional punishment to the one in v. 2. In this case v. 2, is the basic casuistic statement, while vv. 3 and 4-5 are the subcases, additional alternatives to the basic law. Thus, in v. 3 the idolater and his/her act is secret, and since nobody knows it and is thus not able to be sanctioned, God himself intervenes to punish him/her. This interpretation is not new since it was already known in rabbinic literature, ${ }^{123}$ as well as among some modern scholars. ${ }^{124}$ Ibn Ezra stated already:

״ואני אתן את פני באיש ההוא. אם היה בסתר ויש אומרים כי טמאו לחללית זרען:125

\footnotetext{
${ }^{122}$ Julius Wellhausen, Die Composition des Hexateuchs und der Historischen Bücher des Alten Testaments, 3rd ed. (Berlin: G. Reimer, 1899), 156.

${ }^{123}$ Ibn Ezra, "Ibn Ezra on Leviticus," Sefaria: Ibn Ezra on the Pentateuch, trans. Jay F. Shachter, https://www.sefaria.org/Ibn_Ezra_on_Leviticus.20.3.1-2?lang=bi.

${ }^{124}$ Don DeWelt, Leviticus, BSTS (Joplin, MO: College Press, 1975), 333; George Bush, Notes, Critical and Practical, on the Book of Leviticus: Designed as a General Help to Biblical Reading and Instruction (New York: Dayton \& Newman, 1843), 215; Noordtzij, Numbers, 209-10; Rodríguez, "Transfer of Sin in Leviticus," 174-75.

${ }^{125}$ Ibn Ezra, "Ibn Ezra on Leviticus," 20:3. "I will turn My anger against that man if the crime was committed in secret. Some people say that this denotes destruction of his progeny (posterity)."
} 
This statement implies the ellipsis, "if he does it secretly," in v. 3 in order to avoid the inconsistencies listed above. The alternative sense of v. 3 may be hinted at if the opening ? which can legitimately be understood as a coordinative particle "or," as explained on p. 602 of the present study, thus introducing an alternative to the previously stated rule. This alternative reading of $?$ is also noted in the works of Yosef Isaak Bekhor Shor. ${ }^{126}$ The assumption that v. 3 addresses that the act of idolatry could have been committed secretly is a well-established alternative in other BLs regarding idolatry. The same phrase that Ibn Ezra suggested in his reading of v. 3, the preposition $\underset{?}{\mathfrak{y}}$ followed by the noun סֶת ${ }^{127}$ is explicitly utilized in Deut 13:6 and 27:15, adverbially presenting a secret act of idolatry. Thus, it is already introduced in the BL that idolatry can be open, public, and secret in its nature.

Wells' detailed treatment of the law of testimony in Exod 22:6-8 demonstrate that not all details of the potential situation are explicitly spelled out in biblical legal texts. Sometimes even the crucially important details are not mentioned. For instance, the law of testimony in Exod 22:6-8 is missing crucial details that should precede v. 8. Two scenarios are implied in the second subcase, v. 7, if the thief is not found: (1) the receiver illegally appropriated some of the belongings and perhaps falsely alleged that there were stolen, or (2) the receiver claims that the purported owner never deposited his/her belongings with the receiver or not in the amount/s claimed. The guilty party in the first

\footnotetext{
${ }^{126}$ Milgrom, Leviticus 17-22, 1733.

${ }^{127}$ This phrase also introduces other serious sin in Deut 27:24, hitting/killing a neighbor secretly.
} 
scenario is the receiver, whereas the purported owner is liable in the second. ${ }^{128}$ However, none of that is spelled out in the law, but the law simply focuses on the first of the two scenarios, namely that the receiver misappropriated the belongings of the owner. ${ }^{129}$

Keeping in mind the crucial importance of the missing parts in Exod 22:6-8, it is not atypical that Lev 20:3 does not contain, but still implies ellipsis "if he does it secretly." Biblical laws do not always provide all the background and sometimes, crucial details regarding the particular law, but they are to be assumed in order for the law to make sense.

The next illuminative point is the use and the meaning of the phrase, "from the midst of one's people," that is used in vv. 3 and 5. As in these two verses, the phrase is syntactically related to the punishment of kārett. This grammatical construct is used 11 times in the Pentateuch (Exod 31:14; Lev 17:4, 10; 18:29; 20:3, 5, 6, 18; 23:30; Num 15:30; Deut 2:16). The phrase is syntactically related to the verb כָּר in 9 out of 11 occurrences (Exod 31:14; Lev 17:4, 10; 18:29; 20:3, 5, 6, 18; Num 15:30), whereas in 2 of them, the verbs (Dev 23:30) and 2:16) are used. In at least 7 of 11 of these texts, the phrase refers to premature death (Exod 31:14; Lev 17:4, 20:3, 5, 6; 23:30; Deut 2:16). This claim in relation to Exod 31:14 rests on the fact that breaking the Sabbath in Num 15:32-36 is punished by premature death, stoning. Idolatry in Lev 17:4 is also punishable by death based both on Pentateuchal narratives (Exod 32:27) and legal texts (Deut 13:5, 9, 10, 15; 17:5-6). As explained above, based on Lev 20:2, 4, idolatry in

\footnotetext{
${ }^{128}$ Wells, The Law of Testimony, 141-42.

${ }^{129}$ Wells, The Law of Testimony, 142.
} 
$20: 3,5$ is also punishable by premature death. Necromancy dealt with in Lev 20:6 is also punishable by premature death (Exod 22:18; Lev 20:27). Two times the verb כָָָּ is replaced by other verbs and combined with the phrase, "from one's people." The verb אָבָ is used in Lev 23:30, while מוּר is used in Deut 2:16. Both of these verbs clearly convey premature death. ${ }^{130}$ All these texts unanimously present premature death as an immediate and primary punishment. All these sins are intentional and epitomize direct opposition to God's will expressed in covenantal laws. In addition, only Exod 31:14 (Sabbath breaking) and Lev 20:2-5 (Molech worship) may be detectable by the public, while all the others are secret. These two are punished by premature death. Thus it is reasonable to assume that all texts that use the phrase, "from the midst of one's people" along with verbs מָבד or imply premature death as punishment for the sins they refer to. It would be logical that individuals who committed these sins would be eliminated from the covenantal community since doing all these sins negate core values and policies that the covenant with God includes. ${ }^{131}$ Since the sins listed in those 7 texts are punishable by premature death, it is reasonable to expect that this punishment is envisioned for the sins in the 4 remaining texts for which other texts do not prescribe premature death (Lev 17:10; 18:29; 20:18; Num 15:30).

The analysis of the texts that contain a shorter phrase, "cut off from one's people" (without "the midst"), show the same results (Gen 17:14; Exod 30:33, 38; Lev. 7:20, 21,

${ }^{130}$ Milgrom, Leviticus 23-27, 2024-25; Sklar, Sin, Impurity, Sacrifice, Atonement, 13-14.

${ }^{131}$ Contra Milgrom's statement: "In contrast to the death penalty inflicted by man (yûmat) or God (yāmût), kārēt is not necessarily directed against the person of the sinner. He may live a full life or an aborted one." Milgrom, Leviticus 1-16, 347. It is very paradoxical that individuals who commit these sins would be allowed to reside within a covenantal community. 
$25,27 ; 17: 9 ; 19: 8 ; 23: 29 ;$ Num $9: 13)$. They all utilize the same niphal stem pointing that this could be the so-called "divine passive." In other words, God administers premature death in cases like this. All these sins are intentional and secret and negate core values and regulations that a covenant with God includes. It is reasonable to expect that those who commit them would also be punished by premature death. Keeping in mind the gravity of these sins, it is also reasonable to include punishment that goes beyond premature death like some scholars suggest, ${ }^{132}$ but premature death remains the primary punishment.

Finally, kārēt and מוּר are presented as equivalents in Exod 31:14=Num 15:3236; Lev 20:3=Lev 20:2, 4; Num 4:18=4:19-20, which further confirms the fact that kāret in the first place refers to premature death. Wold, followed by Milgrom, Schwartz, and Gane, believed that this law consists of only one case and is interpreted in v. 3 to convey punishment that would go beyond mere death, but was referring to annihilation of one's line of descendants. ${ }^{133}$ Attractive as it is and potentially possible, this interpretation cannot be based on this text.

With this reading of the law, it is logical that only v. 3 expresses fear for sanctuary defilement since being undetected, the idolater can freely come to the sanctuary and defile it. In that case, the idolater's death would be immediate. Verses 2 and 4-5 do not express such fear since in v. 2, the idolater is punished and subsequently prevented

\footnotetext{
${ }^{132}$ Milgrom, Leviticus 1-16, 346-48.

${ }^{133}$ Wold, "The Meaning of Biblical Penalty Kareth," 251-55; Milgrom, Leviticus 1-16, 457-60; Schwartz, "The Bearing of Sin,” 13; Gane, Cult and Character, 145, 201.
} 
from defiling the sanctuary, whereas in vv. 4-5, God punishes them and prevents defilement.

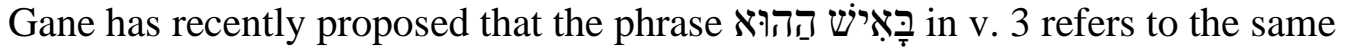
person in v. 2, and thus, forms one case, vv. $2-3$. However, the same phrase is also used in v. 5 and by this logic, the case in vv. $4-5$ should also be considered as belonging to the case presented in vv. 2-3. That is highly unlikely since v. 4 undeniably introduces a new subcase. Thus, the claim that the phrase,

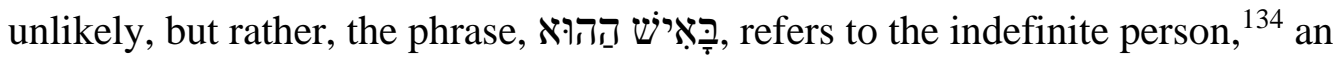
impersonal subject, ${ }^{135}$ any man. This is further confirmed by the prescriptive nature of this law ${ }^{136}$ and the fact that the prescriptive texts are goal-oriented. ${ }^{137}$ Prescriptive texts do not imply any particular individual, but rather, any or every individual of the covenant community. The definite article does not modify the nominal phrase, אִיש אִ̣, that introduces an implied subject of this law. In addition, Gesenius stated that the repetition of a single word, in this case wִיש expressed the entirety or the distributive sense,

${ }^{134}$ Milgrom, Leviticus 1-16, 664.

${ }^{135}$ Gane, Old Testament Law for Christians, 89.

${ }^{136}$ Gane, Cult and Character, 22; Baruch A. Levine, "Ugaritic Descriptive Rituals," JCS 17 (1963): 105-11; Baruch A. Levine, "The Descriptive Tabernacle Texts of the Pentateuch," JAOS 85 (1965): 307-18; William W. Hallo, "Offerings to the Temple Gates at Ur," HUCA 38 (1967): 17-58; David W. Baker, "Leviticus 1-7 and the Punic Tariffs: A Form Critical Comparison," ZAW 99 (1987): 193; A. Rainey, "The Order of Sacrifices in Old Testament Ritual Texts," Biblica 51 (1970): 485-98. Interestingly, Rainey classified Lev 1-7 as descriptive. See Rainey, "The Order of Sacrifices," 486-87.

${ }^{137}$ Knierim, Text and Concept in Leviticus 1:1-9, 64-67, 90; Robert E. Longacre, An Anatomy of Speech Notions, PPPT 3 (Lisse, Netherlands: Peter de Ridder Press, 1976), 199-206; Baker, "Leviticus 17," 192-93. 
thus it includes every man ${ }^{138}$ who offers his children to Moloch as introduced in v. 2. The implied person in this law is not a particular man, but rather any or every man, and דָאִישט ההוּץ does not convey that the person in vv. 2 and 3 were the same, but rather, points to any person who offers his/her children to Moloch as introduced in v. 2. Waltke and O'Connor noticed that the sameness of a person is expressed in a different way, namely, " הוא" precedes a personal name only in the post-exilic books and has the force of "the same' without special emphasis."139

This reading of the law, the inclusion of the implied phrase Cholewinski's literary structure.

\section{Numbers 19:13, 20}

These two texts belong to two different pericopes. The first pericope, vv. $1-13$, is primarily concerned with the preparation of a mixture for purifying human beings and other objects defiled by the human corpse, while the second, vv. 14-22, provides more details and introduces the specific conditions of defilement through direct contact and through the proximity of human beings and other objects to the human corpse. ${ }^{140}$ Similar to Lev 15:31, these texts also point out that the neglect of utilizing the procedures to treat ritual impurity causes defilement of the sanctuary based on the stative nature of the root טָמֵא that I suggested above. Num 19:13, 20 do not refer to the action of contracting ritual

\footnotetext{
${ }^{138}$ Gesenius, Gesenius' Hebrew Grammar, 395.

${ }^{139}$ Waltke and O’Connor, An Introduction to Biblical Hebrew Syntax, 301.

${ }^{140}$ Levine, Numbers 1-20, 457; Milgrom, Numbers, 161-62.
} 
impurity by the sanctuary, but rather, just state that the sanctuary will be defiled. In other words, these texts do not convey the mode or the way in which the sanctuary would be defiled, but just conveys that it will be defiled.

These texts do not contain issues that have not been studied and resolved above. That is, the initial study of stem and aspect along with the semantic and usage patterns of the verb טָָמָ suggest that these texts do not support ADH. First, the piel stem of the verb טֵָׁ brings a totally passive undersubject, without regard to the process, into a certain state. The verb טָָמָא is always accompanied with other verbs through which its meaning in relation to the undersubject/direct object is achieved.

In addition, the use of the perfect aspect might appear confusing since the perfect is used to convey a future event. Still, it is well established by Hebrew grammarians that the perfect aspect is frequently utilized to convey a result in a future time as a completed event or state. However, it is possible that the qatal form in the flow of other wayiqtol forms could refer to the activity that took place before the initial wayiqtol form. The qatal form would, in this case, function as a pluperfect tense, referring to an action that took place at a time earlier than the time in the past already referred to. In that case, the immediate context ultimately assists in arriving at a correct decision on the sense of a given qatal form. In the case of Num 19:13, 20, the context favors the former alternative.

\section{Summary: Automatic Defilement Hypothesis}

Based on the findings in the area of stem, aspect, and the semantics and patterns of use of the verb טָָמָ used in Lev 15:31; 20:3 and Num 19:13, 20, this study suggests that $\mathrm{ADH}$ is not justifiable. 
First, the part of Waltke's and O'Connor's theory that piel is always factitive if qal of the same verb is stative is valid in the case of טָָׁ within the limits of the Pentateuch. In other words, piel brings a totally passive undersubject, without regard to the process, into the state depicted by an adjective. By utilizing a method specifically developed to examine Waltke's and O'Connor's theory of piel, Beckman's research did not provide sufficient evidence to disprove it when applied to the verbs that convey

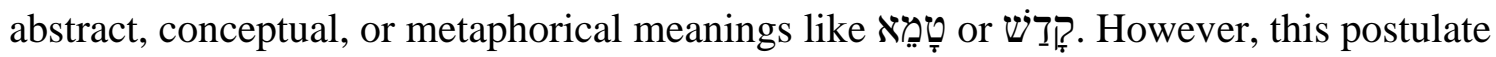
regarding piel is not complete. Second, building on this, the present study has detected a twofold pattern of טָָָָ uses in the Pentateuch. This verb is always accompanied with other verbs through which its meaning onto the undersubject/direct object it modifies is achieved, and physical contact between the entity transmitting and contacting impurity is always included. Third, the verbal aspects of טָָָמא in the contexts of Lev 15:31; 20:3 and Num 19:13, 20 contain nuances that do not lend support for the ADH. All these three points are reinforced as I focus on the issues pertaining to each of these texts and propose their interpretation.

\section{Interpretation of Leviticus 15:31}

Building on the arguments just presented, the present study focuses on the more subtle grammatical, syntactic, and semantic irregularities. The seriousness of these oversights showed that the instrumental sense "by defiling my tabernacle that is in their midst" is not justifiable, consequently making ADH unsustainable.

First, $\mathrm{ADH}$ disregards established grammatical rules related to the Infinitive

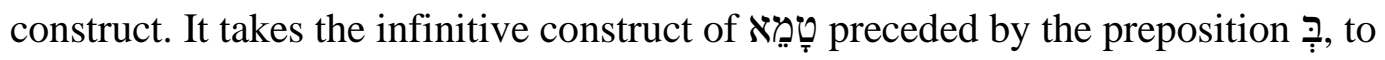


function as a noun which is not typical. Rather, the preposition $\underset{?}{\mathfrak{7}}$ is attached to the infinitive construct when it is used nominally. In addition, the preposition $\underset{?}{\mathfrak{p}}$ with the meaning of beth instrumenti, is by rule attached to a regular noun and not the verb/verbal noun. Finally, when used nominally, the infinitive construct either stands alone or is preceded by the preposition ?.

Second, ADH takes the infinitive construct of the verb טָמֵָ as a finite, active verb. Based on the analysis of the טָָָָ occurrences in the Pentateuch presented in this study, this is problematic due to the fact that טָָָָא is a stative verb when intransitive. Statistics on טָָָא syntactic and semantic transitivity. However, it was also established that when intransitive, טָָָָא is stative, not a finite, active verb.

Third, defilement expressed by טָמָא is never an action encapsulated within the semantic range of the verb טָָָָָא itself. It conveys a defiled state of a particular entity which is achieved by the use of some other verb/s or is its inherited state. It always depends on the other verbal actions, found along with טָָָָָ or in the surrounding texts, to achieve the meaning it conveys. Some of the verbs, like to touch, to carry, to sit, to eat, and so on, are used in order to convey the actual manner of how an entity contracted status.

Fourth, contracting the state of טֵָָָא always includes some sort of physical contact between the defiled and profane entity in order to transmit defilement from the former to the latter or both entities, source and recipient of the impurity, are inside a closed space. 
Fifth, the concept of ellipsis, as a foundational concept for the concept of delay, does exist in the biblical cultic and legal texts. This fact is well recognized by both camps of the ADH. The same applies to the concept of delay. However, the delay to undergo prescribed procedures to handle impurity does not enable it to grow from minor into major, but rather causes the defilement of the entire camp and the tent of meeting via an uncontrollable transmission within the covenant community.

In light of these grammatical, syntactical particularities found in Lev 15:31 and the semantics along with the patterns of use of the verb טָָָָ the instrumental translation followed by the proponents of this hypothesis contains significant grammatical irregularities. These substantial oversights imbedded in the process of forming the instrumental translation of this text make this translation highly unconvincing, which subsequently discredits the entire hypothesis.

In addition, this translation/interpretation is in sharp contrast with the rabbinic understanding of these texts. That is, as noted by both camps of modern interpreters, rabbis viewed that the defilement of the sanctuary occurs via direct contact between the impure and profane entity. ${ }^{141}$ Interestingly, it was demonstrated that the preference for the instrumental $^{142}$ or the temporal translation/interpretation ${ }^{143}$ is distributed equally among English translations of the Bible.

On the other hand, the temporal sense "when they defile my tabernacle that is in

\footnotetext{
${ }^{141}$ Milgrom, Numbers, 445; Maccoby, Ritual and Morality, 167; Rodríguez, "Transfer of Sin in Leviticus," 173-74n7.

${ }^{142}$ ESV, NASB, NET, NRSV.

${ }^{143} \mathrm{ASV}, \mathrm{KJV}, \mathrm{NKJV}$.
} 
their midst," does not conflict with grammatical, syntactic, and semantic rules.

First, the temporal interpretation considers that the infinitive construct +

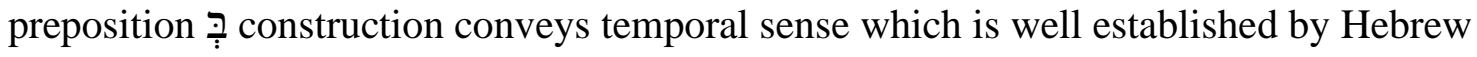
grammarians. Second, the piel of the verb טָָָָָא is considered as a stative verb in this text since it is intransitive. In addition to the factitive understanding of piel with this particular verb, the temporal interpretation agrees with the pattern of uses of טָָמָא established in this study. Third, the present study demonstrated that טָָמָא strictly follows a certain pattern of use in the Pentateuch. That is, it is always accompanied with other helping verbs that

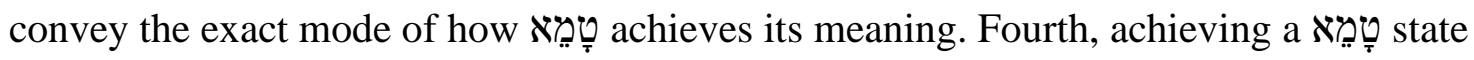
always includes contact between the defiling and profane entities. Fifth, the concept of ellipsis and delay that are part of the debate of defilement transmission do not override the temporal sense. These two concepts do exist in the Pentateuch. When they are interpreted within the Pentateuchal corpus without imposing preconceived ideas upon the texts that imply elliptical statements, they support the temporal sense. Based on the patterns of use of טָָָא , the ellipsis "if impure person touches sancta" is implied in this text. Also, delay does not mean that a minor impurity grows into a major one if there is the case of delay in handling them, but rather, makes room for the defilement of the entire camp and the tent of meeting via uncontrollable transmission of impurity among the covenantal community. Finally, as showed above, the temporal sense is accepted in rabbinic literature.

This study showed that Hebrew grammarians have proposed well-established rules in the area of grammar and syntax as well as the semantics of the verb טָָמָא, which 
are highly helpful to determine the most plausible meaning of Lev 15:31. The present study attempted to incorporate these rules onto Lev 15:31 and arrived at the conclusion that the instrumental sense is less plausible than the temporal. It actually results from significant grammatical, syntactic, and semantical irregularities. The temporal sense in Lev 15:31, on the other hand, does not collide with grammatical or syntactical rules or the semantic sense of the verb טָָָא. It has to be admitted that the temporal sense in Lev 15:31 does not provide the way the defilement actually takes place, but just proposes a potential defiled state of the sanctuary in the future. However, the manner by which the sanctuary gets defiled is very explicitly specified in the Pentateuch (Lev 10:1-2; 12:4). In other words, defilement takes place through direct contact as a part of pטָמָא patterns of use in the Pentateuch, as demonstrated in the present study.

\section{Interpretation of Leviticus 20:3}

Besides the understanding of stem, aspect, and semantic features of טָָָָא , two issues challenge ADH in this text: (1) the meaning and function of the preposition that connects the first two and last clause, and (2) the structural and conceptual inconsistencies under the assumption that this law consists of two, instead of three cases.

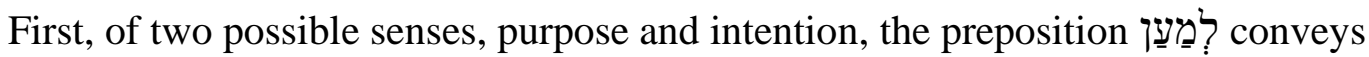
the resultative sense in this text. It never conveys the causative sense in order to provide grounds for the interpretation that offering one's children to Moloch itself defiles the sanctuary, as the proponents of ADH imply. Rather, this preposition conveys the fact that offering one's children to Moloch results in defiling the sanctuary. As Brongers suggested, the best translation of it would be "the consequence of which will be." This 
understanding is in accordance with the understanding of piel stem, the aspect of the infinitive construct, and patterns of uses of טָָָָ in the Pentateuch. As established above, piel brings a totally passive undersubject, without regard to the process, into a certain state. The infinitive construct acts as a finite verb in this text because it is transitive in a resultative clause. The infinitive construct is frequently used in resultative clauses in $\mathrm{BH}$

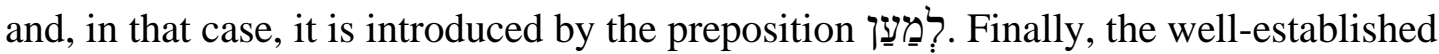
pattern of טָָָָ uses in the Pentateuch points to the fact that this verb always requires another helping verb to achieve its meaning. All these insights suggest that an additional activity is implied between the first two and the third clause of this text as the preposition introducing the third clause points to. Based on the established pattern of uses of טָָָמָָ in the Pentateuch, that additional activity would imply direct contact between the idolater and the sanctuary through his/her coming to the sanctuary.

Second, the structure of the law in Lev 20:1-5 faces significant internal conceptual inconsistencies if it is assumed that it consists of two cases, vv. 2-3, and vv. 4-5. Cholewinski suggested the most detailed structure of this passage that assumes two cases. In that case, v. 3 represents the additional punishment to death by stoning in v. 2, understood to be either extinction of the lineage or punishment in the afterlife. Staying within the limits of this text only, the first inconsistency is the disparity of punishments for the same sin. That is, in v. 2, the punishment for idolatry is death by stoning, while in v. 4, it is either extinction of the lineage or punishment in the afterlife. Death by stoning is standard punishment for idolatry. A second inconsistency is that the people cannot disregard the idolater in v. $4-5$, if they experience premature death in v. 3 as a part of God's administering punishment upon them. Verses 4-5 are superfluous in this case. 
Finally, if God punishes the idolater only when the covenant community does not, as was evident in vv. 4-5, then this fact points to the claim that God in v. 3, punishes because people do not know that the act of idolatry took place amongst them. These inconsistencies led scholars to propose that v. 3 represent the separate subcase of the law, implying the ellipsis, "if he does it secretly." In that case, ? is not used as a conjunctive “and," but coordinative particle "or." As Wells' work on the law of testimony shows, in some BLs, significant details are left out, but yet assumed. In addition, the use of the phrase, "from the midst of one's people," as well as "from one's people," accompanied

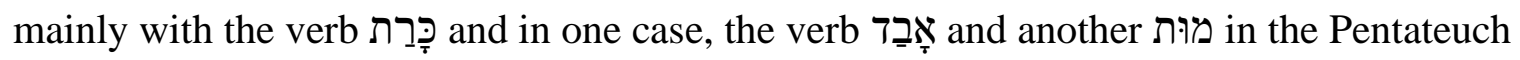
convincingly prove that premature death is an implied punishment in those contexts. The

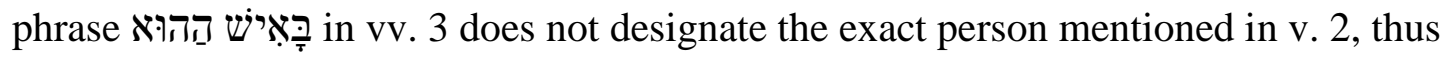
connecting these two verses into one unit, but rather, it refers to any person who commits idolatry. This phrase is also mentioned in vv. 4 and 5, and it is impossible that the very

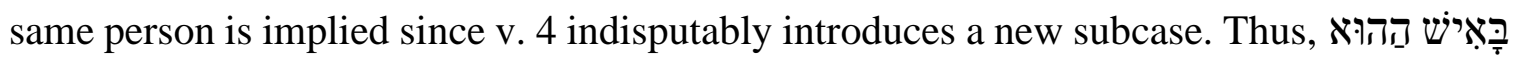
refers to an impersonal, indefinite individual who commits idolatry. Cholewinski's persuasive literary structure is not affected by the inclusion of the implied elliptical phrase רֶֶֶֶֶ.

Accordingly, the understanding of the stem, aspect, and semantic influences of טָָָא conceptual inconsistencies under the assumption that this law consists of two, rather than three cases does not support ADH. Verse 3 is a separate case in which implied ellipsis, "if he does it secretly," resolves internal conceptual inconsistencies of a two-subcase, literary 
structure, thus allowing the idolater to come to the sanctuary and defile it through direct contact since the covenant community does not know it and is not able to prevent it.

$$
\text { Interpretation of Numbers 19:13, } 20
$$

Building on the findings regarding the stem, aspect, and semantic of טָָמָ along with established patterns of its use in the Pentateuch, this study suggests that an interpretation that more carefully understands the grammatical, syntactical, and semantic insights related to the texts in Num 19:13, 20 indicates that ADH is not textually supported.

The piel stem of the verb טָָמָא is factitive. It brings a totally passive direct object into the certain state without regard to the process. The perfect aspect is frequently utilized to convey result in future times as a completed state. The verb טָָמָ is always accompanied by other verbs through which its meaning onto the direct object it modifies is achieved. Accordingly, these insights regarding stem and aspect utilized in Num 19:13, 20 along with the semantics and patterns of uses of טָָׁׁ in the Pentateuch do not support ADH. Rather, these texts speak of the result that will take place in the future. The exact mode of how this result is achieved in indicated by the pattern uses of טָָמָָ, namely via direct contact. 


\section{CHAPTER 6}

\section{LAYING ON OF HAND/S: A CONTEXTUAL APPROACH}

The third section of the present study explores the ritual theory that would correlate with findings on the meaning/function of the ritual activity of laying on of hand/s. This theory was primarily needed to offer a vocabulary, and to some extent, a conceptual framework that is necessary for interpreting ritual activity such as laying on of hands. The second part of the third section and this chapter is an evaluation of the arguments against the Transfer and/or Substitution Theory and suggestions of the arguments from the present study for its validity.

\section{Ritual Theory}

Establishing a conceptual framework based on approaches of the most often consulted scientific disciplines in ritual studies ${ }^{1}$ in order to apply them to the biblical ritual texts is not the goal of the present study. The trend just explained is articulated by Wright, currently one of the most influential scholars of biblical ritual texts, who

\footnotetext{
${ }^{1}$ Since ritual is imbedded in the larger concept of human existence, the study of ritual is interdisciplinary in its nature and often encompasses multiple scientific disciplines such as sociology, anthropology, study of religion, literary criticism, study of theatrical performance, and psychology. Gorman, The Ideology of Ritual, 8; Frank H. Gorman, "Ritual Studies and Biblical Studies: Assessment of the Past, Prospects for the Future," Semeia 67 (1994): 13, 20. Klingbeil added philosophy, the study of intellectual history, history of religion later renamed to comparative religions, and sociobiology. Klingbeil, Bridging the Gap, 23; David P. Wright, "The Study of Ritual in the Hebrew Bible," in The Hebrew Bible: New Insights and Scholarship, ed. Frederick E. Greenspahn, JSTFC 4 (New York: New York University Press, 2008), 120.
} 
correctly described the present trend in biblical studies, including the study of biblical ritual texts, in their quest for the conceptual framework: "Biblical studies thrives on the application of models and methods developed outside the discipline, especially those from the social sciences. This is particularly true in the study of ritual.",2 On the one hand, scholars of biblical ritual texts use the scientific disciplines that study ritual which are undeniably closely related to the study of human experience of ritual and as such can shed light on the topic. On the other hand, these scientific disciplines are established on the presuppositions that are opposite to the presuppositions found in biblical texts. ${ }^{3}$ Accordingly, the biblical text is a safeguard from incorporating elements that collide with the claims found in biblical ritual texts, as well as with their broader literary context into the ritual theory of biblical ritual.

Being totally opposite in its approach, the intention of this study was to identify data from the biblical texts that would inform ritual theory and recommend the meaning of cultic rituals in the Pentateuch. Biblical scholars usually create a conceptual framework based on some combination of multiple disciplines and then apply it to biblical texts. ${ }^{4}$ By establishing a conceptual framework based solely on biblical texts,

\footnotetext{
${ }^{2}$ Wright, "Ritual Theory, Ritual Texts," 195. Wright listed some of the most recent works that used the socio-theoretical approach that mainly focuses on the application of this approach to cultic ritual, specifically sacrifice. These are Gane, Cult and Character; Gilders, Blood Ritual in the Hebrew Bible; Gruenwald, Rituals and Ritual Theory in Ancient Israel; Klawans, Purity, Sacrifice, and the Temple; Klingbeil, Bridging the Gap; Sklar, Sin, Impurity, Sacrifice, Atonement.

${ }^{3}$ Klingbeil, Bridging the Gap, 23-44, especially 43.

${ }^{4}$ Gorman, The Ideology of Ritual; Gruenwald, Rituals and Ritual Theory in Ancient Israel; Gane, Cult and Character; Klingbeil, Bridging the Gap, 23.
} 
ritual texts for the particular mechanics of the ritual, and others texts for broader elements of a conceptual framework, the possibility of importing conceptual components that are foreign to the biblical texts or world view is decreased.

The two ritual theories that the present research finds to be in concurrence with the method utilized here are those of Gorman and Gane. In his quest for the meaning of ritual texts in the OT, Gorman placed emphasis on the conceptual, ideological, and theological framework of Pentateuchal rituals. The present study also contributed in that direction, especially in regard to the concept of sin and atonement. Gane emphasized the sufficiency of biblical texts to provide meaning for rituals introduced in the Pentateuch. Both theories are based on Gorman's and Gane's doctoral research.

In his doctoral dissertation, Ritual Dynamic Structure, Gane eloquently succeeded in preserving the biblical text as ultimate and decisive data for the elements of the conceptual framework for his ritual theory, regardless of a considerable inclusion of the insights from the comparatives studies ${ }^{5}$ and systems science. ${ }^{6}$ Two postulates of Gane's ritual theory are that (1) ritual, as performed by human beings, consists of human activity and, as such, should be viewed as a human activity system ${ }^{7}$ and that (2) the texts, in this case biblical ritual texts, are the only and sufficient access to biblical rituals in order to retrieve their function/meaning. ${ }^{8}$ These two points are simple, but yet, foundational for

${ }^{5}$ Gane, Ritual Dynamic Structure, 13-114, 199-326.

${ }^{6}$ Gane adapted the General Systems Theory of Brian Wilson for examining human activity systems. B. Wilson, Systems: Concepts, Methodologies, and Applications (Chichester, West Sussex: Wiley, 1984); Gane, Cult and Character, 7-9. For more details on systems of science, see George E. Mobus and Michael C. Kalton, Principles of Systems Science (New York: Springer, 2015).

${ }^{7}$ Gane, Ritual Dynamic Structure, 26-35.

${ }^{8}$ Gane, Cult and Character, 4. 
the analysis of biblical ritual texts. The second point generated considerable debate and is presented in the following subheading before presenting Gane's ritual theory.

Wright, on the other hand, has recently articulated the three main issues that prevent the application of socio-theoretical approaches to biblical rituals. All of them are based on the fact that biblical ritual is not observable, but rather, can only be examined based on their textual representation. It is important to note that the basis for Wright's conclusions regarding the ritual are cultic rituals in the Pentateuch which he clearly delineated from non-cultic rituals. ${ }^{9}$ However, the majority of the general claims that he made regarding ritual in the Bible cannot be applied to Pentateuchal cultic ritual which is explained below. These three issues are (1) insufficiency of the text to communicate the meaning of the ritual, (2) genre of the text, and (3) redactional work of the text.

\section{Insufficiency of Ritual Texts}

Wright claimed that the necessity for the data source for biblical ritual to be a text is philosophically and phenomenologically problematic because it includes the equivocal use of the term ritual in relation to its source, that is, the text. The term ritual is used to refer to both prescriptive and descriptive ritual texts. He pointed out that none of these two types of ritual texts is equivalent to the actual performance of the ritual itself, but that instead, they describe or prescribe the ritual. ${ }^{10}$

\footnotetext{
${ }^{9}$ Wright stated: "It should be kept in mind that cultic ritual (as found in PH) is a sub-category of ritual. The cult includes practices and phenomena associated with temples or sanctuaries, such as sacrifice, holiness, purity, priesthood, and festivals. A student interested in ritual in the Bible broadly should look beyond the cult and beyond PH." Wright, "Ritual Theory, Ritual Texts," 196. However, he significantly resorted to the non-cultic ritual to establish his claims, such as Gen 4, 29; Deut 16; Job 29-30; Ezek 44:917, rather than studying cultic rituals. Wright, "Ritual Theory, Ritual Texts," 199, 213.

${ }^{10}$ Wright, "Ritual Theory, Ritual Texts," 197.
} 
Building on this inference, Wright further postulated that "these texts, even the most detailed of them, do not contain enough information for a reconstruction of performances." However, Wright himself responded to the unsustainability of this claim:

Nonetheless, prescriptions for actual ritual performances (e.g., Hittite, Akkadian, or Ugaritic ritual texts) often assume and depend on the background knowledge of performers. They prescribe only enough detail to activate this background knowledge. But this is exactly the problem with real prescriptive texts. The more they seek to prescribe actual practice, the less detail they may contain, rendering them almost impenetrable in terms of sociological analysis.

The fact that ritual texts assume a certain acquaintance of the ritual performers to the ritual points to the fact that the emphasis of the biblical ritual texts was not on the ritual performance, but rather, these texts were designed to carry out certain goal/s as is usually stated in biblical cultic ritual texts. Both types of biblical ritual texts, prescriptive or descriptive, sometimes lack essential details, but they rarely lack goal formulas. A considerable number of performance elements of which the performance act consists, beyond the prescribed or described account of them, rest on the participants/performers themselves of the performance act. In other words, they are not written down, but rather, uniquely involved and played out as properties of the performers/participants themselves. However, the prescribed or described account of the performance act conveys and contains the basic notion/message/lesson/goal.

The same issue informed Knierim's understandable doubt regarding the soundness of applying Victor Turner's ritual theory to the biblical text: "Turner's interpretations are the result of field studies of actually observed ritual performances. His text describes and interprets those performances. But while a prescriptive text about a ritual [i.e., like a PH text] will probably also reveal its hermeneutical system to a certain extent, it must not $e$ silentio be presumed to be descriptive of actual performance, not 
only because there is-as in our biblical texts-no evidence for it but also because even such description represents an interpretive distancing vis-à-vis the performance." ${ }^{\prime 11}$ Also, ... "the prescription of a ritual in a text is not identical with the description of an observed ritual, let alone with a performed ritual itself." ${ }^{12}$

Thus, Wright's concern that "the distance of text, phenomenologically and practically, from actual performance is almost enough to thwart sociological analysis" is totally accurate. However, realization of this fact does not detain one from studying the ritual, since biblical cultic ritual texts were ideologically shaped to provide data for a theological analysis, rather than a sociological one. Thus, the texts, prescriptive and descriptive, remain the primary analytical sources from which a researcher obtains insights into the meaning and purposes of a given biblical cultic ritual. Instead of realizing this, Wright considered this as an insufficiency for extrapolating a full meaning of ritual texts: "In these cases, extracting or modulating aspects of theoretical approaches and application to biblical ritual texts becomes more the study of a literary motif in the text than of real-world social phenomena."13

Constructing his own theory upon B. Wilson's profound study of human activity systems, ${ }^{14}$ Gane endorsed an apparent fact that ritual is "an activity system.." ${ }^{15}$ As Wilson pointed out, "the goal/raison d'être defining such a system is to accomplish a particular

\footnotetext{
${ }^{11}$ Knierim, Text and Concept in Leviticus 1:1-9, 19.

${ }^{12}$ Knierim, Text and Concept in Leviticus 1:1-9, 19-20.

${ }^{13}$ Wright, "Ritual Theory, Ritual Texts," 199.

${ }^{14}$ Wilson, Systems.

${ }^{15}$ Gane, Cult and Character, 12.
} 
transformation through an activity process." ${ }^{\prime 16}$ Thus, it is not the activities themselves that define the system, since they themselves are meaningless and prone to various or multiple meanings, ${ }^{17}$ but it is the goal that determines which actions are vital for accomplishing a desired change and how are they performed. ${ }^{18}$ These insights confirm that a sociological interpretation of the biblical ritual texts should be taken as a secondary tool in order to shed additional light on the meaning of the ritual, since these texts are not written from a sociological perspective with emphasis on the performance, but rather, are goal-informed and goal-shaped. The primary approach remains the theological one. ${ }^{19}$ In other words, God instituted rituals with certain goal imbedded in their textual representation.

The claims Wright pointed to disclose that his goal in studying biblical cultic ritual texts is a reconstruction of the ritual performance which is a valid enterprise, but totally neglects the fact that biblical ritual texts were not written to be a "script" for ritual performance. The fact that insight into a given biblical cultic ritual is conveyed by the

\footnotetext{
${ }^{16}$ Wilson, Systems, 16, 26; Gane, Cult and Character, 12. Gane found that this claim is in agreement with what is found in many biblical ritual texts. He pointed to one of them: "We found earlier that Lev 16:16 expresses the goal of special purification offerings: to purge the inner sanctum from ritual impurities and moral faults. The goal is to effect transformation (purging) through activities, namely, by sprinkling blood (vv. 14-15)." Gane, Cult and Character, 12.

${ }^{17}$ Gane made a difference between pure activity, as Staal considered them, and intrinsic activity in his quest for the boundaries and meaning of the ritual activity. Gane, Ritual Dynamic Structure, 3-5; Frits Staal, Rules Without Meaning: Ritual, Mantras, and the Human Sciences, TSR 4 (New York: P. Lang, 1989), 131. The first refers to the physical causes and effects only. Staal elevated the rules as a determinative factor for ritual boundaries and meaning. Staal, Rules Without Meaning, 132. The second, established by Gane, points to the activity that goes beyond the physical causes and effects. In other words, it refers to the task that operates at the cognitive level and is a matter of belief. Gane, Ritual Dynamic Structure, 3-5. The same principle is also hinted at in Wright's study of Hittite ritual. Wright, "The Study of Ritual in the Hebrew Bible," 129.
}

${ }^{18} \mathrm{Gane}$, Cult and Character, 12. Interestingly, Wright has found this to be operative factor in Hittite ritual texts. Wright, "The Study of Ritual in the Hebrew Bible," 128.

${ }^{19}$ For a totally different emphasis rather than theological, see Lester L. Grabbe, Leviticus, OTG (Sheffield: JSOT Press, 1993), 74. 
text itself is an advantage since it preserves the critical function of a given ritual which is its goal, rather than all the absent secondary elements which are prone to modifications. Thus, Wright's point that both prescriptive and descriptive ritual texts in the OT do not provide a full explanation of the ritual performance and are not subject to sociological analysis is well noted and undeniably accurate. However, this accurate assessment is out of context, since none of these two points stands in the ideological fabric of the production and the purpose of these texts.

\section{Genre Is an Impediment in Ritual Texts}

Wright also pointed to another issue that makes prescriptive and descriptive biblical ritual texts insufficient for sociological analysis: the fact that ritual is featured in various genres in the OT. He stated the following regarding the Pentateuchal rituals:

As for the Priestly-Holiness writings in particular, the corpus has generally been understood to encode actual cultic practice at some particular point in Israelite or Jewish history or directly prescribe practice that is to be performed. This may misapprehend the genre. There are a number of indications that the portrayals of ritual in $\mathrm{P} \mathrm{H}$ are academic abstractions or idealizations that significantly transcend practice.

However, Pentateuchal ritual texts still retain emphasis on the ritual goal in various genres, rather than presenting themselves for sociological analysis and performance. Historical peculiarities do not necessarily include a significant amount of "hermeneutically transforming sources, creatively filling in gaps, and inventing events and details. In doing this, the writers no doubt built on the customs prevailing at the time of their writing," as Wright assumed ${ }^{20}$ Wright's quotation raises the question of what ritual he had in mind. There is not a single ritual text from the OT he referred to that

\footnotetext{
${ }^{20}$ Wright, "Ritual Theory, Ritual Texts," 200-201.
} 
demonstrates this source transformation, gaps filling, or events or details inventing. ${ }^{21}$

Lester L. Grabbe correctly noted that the book of Leviticus does not provide full

prescriptive/descriptive descriptions for a ritual performance in the smallest detail. ${ }^{22}$

However, Knierim has proven that biblical ritual prescriptions are composed, in a way as to regulate the essential steps of valid performance so that the rituals can accomplish their intended purposes/goals. $^{23}$

Knierim delineated 4 points that expose the incompleteness of biblical ritual texts: ${ }^{24}$

1. They do not include all actions that must, of practical necessity, be performed. The text's presentation is selective and serves its interpretation of activities according to its perspective.

2. They control activities at various levels of detail, often sketching flows of activities with broad strokes, without providing finer points of performance at the lowest hierarchical levels.

3. The order in which activities are presented in a ritual prescription does not always indicate the chronological sequence of their performance.

4. A ritual activity paradigm may be subject to adaptation in different contexts. ${ }^{25}$

Gane subsequently importantly concluded the following:

When the biblical text provides the overall goal of a ritual (e.g., Lev 4:31b), gaps in our knowledge regarding details of physical actions, such as the precise manner of slaughter or removal of suet, do not pose a serious problem for the interpretation of the

\footnotetext{
${ }^{21}$ Wright, "Ritual Theory, Ritual Texts," 199-202. He did describe Lev 25 and Num 35 as examples of "highly idealized, utopian, and impractical practices."

${ }^{22}$ Grabbe, Leviticus, 38, 74. Grabbe himself proposed that which is highly incorrect in the light of the fact that the majority of ritual texts contain explanation of ritual. Grabbe, Leviticus, 74.

${ }^{23}$ Knierim, Text and Concept in Leviticus 1:1-9, 31, 65, 94-97, 98-106.

${ }^{24}$ Knierim, Text and Concept in Leviticus 1:1-9, 89, 64-67, 90.

${ }^{25}$ Gane, Cult and Character, 22.
} 
overall function/meaning of the ritual, provided that we are content with the meaning supplied by the text. ${ }^{26}$

Knierim recognized the difference of ritual interpretation when one studies a prescriptive text which differs significantly from the descriptive text of the same ritual and the fact that both texts differ from the interpretation of a performed ritual. ${ }^{27}$ Not realizing these limitations, modern interpreters of ritual text are prone to the danger of importing elements from their own world view into the interpretation of a given ritual that are not based on the actual experience of a given ritual. ${ }^{28}$

\section{Textual Redaction Is an Impediment in Ritual Texts}

This argument rests on two points. First, the presence of redaction strata in the Pentateuch presents its own way of how concepts and topics are portrayed. This issue is heavily informed by historical-critical presuppositions, and thus, it is more a matter of interpretation, than a valid argument. Second, the extent of redactional work in Pentateuchal texts is a subject of extensive debate and does not necessarily include a conflicting stance or direction on a given concept as Wright assumed. ${ }^{29}$

The recent works of Yoel Elitzur, Ian Young, Robert Rezetko, and Martin Ehrensvärd have suggested that a sharp distinction between Classical/Standard BH and

\footnotetext{
${ }^{26}$ Gane, Cult and Character, 22.

${ }^{27}$ Knierim, Text and Concept in Leviticus 1:1-9, 19-20.

${ }^{28}$ Gane, Cult and Character, 22.

${ }^{29}$ Wright, "Ritual Theory, Ritual Texts,” 209-10.
} 
Late BH suggested by Avi Hurvitz ${ }^{30}$ is not well argued and consequently, cannot be a solid basis for dating the biblical books. ${ }^{31}$ It has to be taken into account that this sharp distinction between two language strata within the biblical canon is foundational for understanding that the Pentateuch consists of various literary sources, ${ }^{32}$ and being subject to a totally opposite view, it cannot be taken as a valid argument. Young's overall conclusion is that the different language strata suggested by Hurvitz were a coexisting style of language. ${ }^{33}$ Overall, the five pillars of Documentary Hypothesis and the hypothesis in totality have been heavily disputed in the past and continue to be disputed in the present, as well as. ${ }^{34}$ Thus, these two issues are rather a matter of interpretation affected by certain presuppositions than real textual issues. As soon as one understands that biblical ritual texts are created with a specific goal and first lend themselves to theological interpretation rather than sociological or any other, these issues vanish.

\footnotetext{
${ }^{30}$ Avi Hurvitz, A Linguistic Study of the Relationship between the Priestly Source and the Book of Ezekiel: A New Approach to an Old Problem, CahRB 20 (Paris: J. Gabalda, 1982); Avi Hurvitz, "The Language of the Priestly Source and Its Historical Setting: The Case for an Early Date" in Proceedings of the Eighth World Congress of Jewish Studies, Jerusalem, August 16-21, 1981 (Jerusalem: World Union of Jewish Studies, 1983), 5:83-94; Avi Hurvitz, "Dating the Priestly Source in Light of the Historical Study of Biblical Hebrew a Century after Wellhausen,” ZAW 100.Suppl. (1988): 88-99.

${ }^{31}$ Yoel Elitzur, "Diachrony in Standard Biblical Hebrew: The Pentateuch vis-à-vis the Prophets/Writings," JNSL 44 (2018), 81-101. See also Ian Young, "Biblical Texts Cannot Be Dated Linguistically," HS 46 (2005): 341-51; Ian Young, Robert Rezetko, and Martin Ehrensvärd, Linguistic Dating of Biblical Texts: An Introduction to Approaches and Problems, vol. 1 of Linguistic Dating of Biblical Texts (London: Equinox, 2008); Ian Young, "Is the Prose Tale of Job in Late Biblical Hebrew?," VT 59 (2009): 606-29.

${ }^{32}$ Milgrom, Leviticus 1-16, 1-13.

${ }^{33}$ Young, "Is the Prose Tale of Job in Late Biblical Hebrew?," 606, 629.

${ }^{34}$ Umberto Cassuto, The Documentary Hypothesis and the Composition of the Pentateuch: Eight Lectures (Jerusalem: Magnes Press, 1961); Archer, Survey, 71-138; Moshe Weinfeld, The Place of the Law in the Religion of Ancient Israel (Leiden: Brill, 2004), 16-74.
} 


\section{Frank Gorman}

Frank Gorman has accurately noticed the lack of research regarding the conceptual, ideological, and theological framework of Pentateuchal ritual texts in earlier studies. In the past, these studies focused on the analysis of the texts by employing various approaches, such as literary criticism, form criticism, and tradition historical criticism, rather than on the meaning of the ritual. Gorman also noticed that these studies did not try to reconstruct the ritual system. ${ }^{35}$ In contrast, the work of Jacob Milgrom, Baruch Levine, Menahem Haran, and Gordon Wenham attempted to explicate the larger conceptual framework of the ritual system in order to understand it better. Their goal was to uncover the meaning of the ritual. ${ }^{36}$

With a similar goal in mind and in order to contribute towards a fuller understanding of the ritual system as described in the Pentateuch, the present study focuses on two neglected yet critical components of the Pentateuchal ritual system: sin and atonement. This is not to say that scholars have not researched these two concepts. On the contrary, scholars have made significant efforts to understand them, as the present work demonstrates, but they often overlooked important nuances in regard to both sin and atonement. In addition, the scholars used methods that have been questioned of late, and for valid reasons. Therefore, this work attempts to pinpoint the weaknesses of previous studies on sin and atonement, especially in relation to method and interpretation, and to identify their impact on certain meanings attached to the laying on of hands.

\footnotetext{
${ }^{35}$ Gorman, The Ideology of Ritual, 7.

${ }^{36}$ Gorman, The Ideology of Ritual, 8-9.
} 
In addition to Gane's ritual theory, which deals with a variety of technical elements in an attempt to identify the meaning of ritual that the present work adopts, I also find Gorman's work helpful in decoding biblical ritual. That is, Gorman emphasized the importance of the social context of the ritual, and thus attempted to form a system of beliefs that are helpful in identifying what the ritual achieves or what it communicates. Gorman affirmed that ritual is a form of communication. He stated:

Ritual is viewed as a symbol system and rituals are viewed as symbolic statements or encoded performances that act out or dramatize an already existing social message. Ritual symbols have a referential quality that points to a meaning that exists outside the rituals themselves. In order to understand rituals, one must break their symbolic code and determine their linguistic message. Generally, this means translating the non-verbal into the verbal, the irrational into the rational, activity into language. ${ }^{37}$

He identified four key characteristics of communication in biblical ritual. The basic postulate of Gorman's ritual theory is that ritual "brings about a change in the state of being or status of one or more of these areas and/or to make a declaration about the state of being or status in one or more of these areas." ${ }^{38}$ First, ritual affects the state of being or status of an individual involved in it, such as transition from one state of being or status to another. Second, rituals affect the entire society, not just an individual, and they are performed in order to preserve the well-being of the entire society. This point is reflected in the fact that there are two basic types of rituals in the Pentateuch that have the role of preserving or maintaining social well-being and reestablishing it when it is broken. The ultimate goal of the ritual is to prevent the breakdown of social order and

\footnotetext{
${ }^{37}$ Gorman, "Ritual Studies and Biblical Studies," 23.

${ }^{38}$ Gorman, "Ritual Studies and Biblical Studies," 37.
} 
well-being. ${ }^{39}$ Third, biblical ritual affects the state of the natural world God created and its order, or in Gorman's words, the cosmos. Through ritual, humans participate in maintaining the divinely created order. Fourth, ritual communicates how a certain social group perceives divine-human interaction. For example, the most developed ritual of sacrificial offerings always takes place "before God" or "at the door of the tent of meeting." Therefore, sacrificial ritual processes are performed in the presence of God, in relation to deity. Gorman accurately emphasized that all four of these areas are interrelated and interdependent. ${ }^{40}$ Moreover, Gorman noticed that sin and defilement are crucial in biblical ritual. Rituals are often enacted in order to maintain or restore situations disturbed by sin or defilement. ${ }^{41}$

According to many scholars, Milgrom has produced the most significant work on biblical rituals in the twentieth century. ${ }^{42}$ In his analysis, he extensively used insights from comparative ANE texts, biblical texts, and Judaic sources. In addition, he has made significant progress towards a better understanding of the biblical ritual system in both its details and its larger conceptual structures and categories. However, his research did not focus on theoretical issues involving ritual. ${ }^{43}$ In contrast, Klawans has demonstrated various theoretical and methodological questions in relation to Milgrom's work on ritual

${ }^{39}$ Gorman, "Ritual Studies and Biblical Studies," 37.

${ }^{40}$ Gorman, "Ritual Studies and Biblical Studies," 38.

${ }^{41}$ Gorman, The Ideology of Ritual, 42.

${ }^{42}$ Jacob Milgrom, Studies in Levitical Terminology: The Encroacher and the Levite (Berkeley, CA: University of California, 1970); Milgrom, Cult and Conscience; Milgrom, Studies in Cultic Theology and Terminology; Milgrom, Leviticus 1-16.

${ }^{43}$ Gorman, "Ritual Studies and Biblical Studies," 28. 
and moral purity, and sacrifice. ${ }^{44}$ Consequently, although Milgrom's work will continue to be valuable, it does not lack possibilities for refinement.

Regardless of the recent advancements in the study of biblical ritual, no study, including Milgrom's, has conducted a systematic analysis of sin, which is a basic concept embedded in ancient Israel's religion. Furthermore, the topic of atonement has raised more interest among scholars but, as stated in chapter five of the present study, their research is mostly informed by insights from ANE texts. The present study offers an indepth study of both sin and atonement based primarily on biblical texts.

The present study is essentially attempting to identify the meaning/function of laying on of hand/s on the sacrificial animal in the Pentateuch. This ritual gesture is a part of a broader religious context of biblical religion. As was established in the introduction, the present study focuses on two specific components of this broader religious context of biblical religion, sin and/or GHS which is human disadvantage in divine-human interaction and atonement. The former precedes the laying on of hands, while the latter follows it in the sacrifices defined in Lev 1-5:26 [6:7].

Therefore, the Pentateuch portrays human beings as inherently sinful, which this study refers to as GHS, and at times ritually and morally impure. All three features that the Pentateuch associates with humans are discussed above on pages 400-14 in the present work. In contrast, God is holy and dwells in the tabernacle. ${ }^{45} \mathrm{He}$ is the one who shaped all aspects of ancient Israel with his laws. ${ }^{46}$ Consequently, such a disparity

\footnotetext{
${ }^{44}$ Klawans, "Ritual Purity."

${ }^{45}$ Gorman, The Ideology of Ritual, 11.

${ }^{46}$ Gorman, The Ideology of Ritual, 43.
} 
between God and humans necessitates some sort of mediation in order to provide a context for safe divine-human interaction. Biblical texts assign this mediatory role to the ritual of offering various sacrifices.

The offerer offers his/her sacrifice for different reasons to provide a context for safe divine-human interaction. For example, if a burnt or grain offering is presented, the offerer seeks acceptance. A well-being offering was offered for multiple reasons, such as thanksgiving (Lev 7:12-15), fulfilment of a vow (Lev 7:16), or freewill/voluntary offering (Lev 7:16). In the case of a sin or reparation offering, the offerer seeks forgiveness. In any of these cases, the offerer is always in an underprivileged state because of his/her GHS; therefore he/she needs to be atoned before God. The offerer's underprivileged state becomes even more deteriorated if he/she has violated any of God's commandments. In order to identify the meaning/function of laying on of hands, the present study conducted a detailed study of both of these components of biblical religion, $\sin / \mathrm{GHS}$, and atonement.

\section{Roy Gane}

Gane further singled out 7 basic premises of his theory. He found solid textual support for each of these presuppositions. The guiding principle in Gane's analysis was this question: Where does the meaning of a given ritual reside? Two potential domains are (1) prescribed or described physical activity or (2) the interpretation of these activities as found in the texts. ${ }^{47}$ The development of Gane's theory showed that the

\footnotetext{
${ }^{47}$ Gane, Cult and Character, 4.
} 
function/meaning is to be found in the latter. ${ }^{48}$

\section{Ritual Actions and Substances Do Not Have Inherent Meaning}

Gane has recognized that Pentateuchal ritual texts confirm the fact that ritual actions do not have a fixed, inherent meaning. He relied on Staal's work where he demonstrated that "a given ritual can have more than one meaning., ${ }^{\text {" } 99}$ Pentateuchal cultic texts confirm this semantic multifacetedness of ritual activities. ${ }^{50}$ Gane detected multiple examples:

In the outer sanctum of the Israelite sanctuary, the high priest sprinkles blood seven times "before the veil" as part of purification (חטאת) offerings on behalf of himself and of the community, respectively (Lev 4:6, 17). During the special Day of Atonement purification offerings he sprinkles blood seven times in the inner sanctum (16:14-15), the outer sanctum (v. 16b-abbreviated), and on the altar in the courtyard (v. 19). Although 4:6, 17 does not state the meaning of its sevenfold sprinklings, 16:16a explains such aspersions in the inner sanctum as effecting purgation (rpk) of this area from the impurities and moral faults of the Israelites. Later in the same ritual, however, v. 19 attributes another meaning to the sevenfold sprinkling on the outer altar: to (re)consecrate (vdq) it. Thus, the same activity carries two related, but distinct functions in the same ritual. ${ }^{51}$

Thus, the same ritual activity in Lev 16:16 and 19 have different meanings. The seven-fold sprinkling cleansed the sanctuary and reconsecrated the altar, respectively.

Gane did not assign any particular meaning in this quotation to the first activity, the high priest's sprinkling before the veil in Lev 4:6, 17, since it is not stated. However,

${ }^{48}$ Gane, Cult and Character, 24.

${ }^{49}$ Staal, Rules Without Meaning, 127-29, 131, 134, 330; Gane, Cult and Character, 4.

${ }^{50}$ Rudolph González proved the this premise, also operated in laying on of hands contexts in the NT. Rudolph González, "Laying-on of Hands in Luke and Acts: Theology, Ritual, and Interpretation" (PhD diss., Baylor University, 1999), 6-7; Gilders, Blood Ritual in the Hebrew Bible, 10, 81-82.

${ }^{51}$ Gane, Cult and Character, $4-5$. 
based on the fact that the sinner in both cases left the sanctuary forgiven and that the sanctuary in Lev 16:16 is cleansed "from the impurities of the sons of Israel and because of their transgressions in regard to all their sins," (מִטְְמָאת חטּאתחם ), one can conclude that in Lev 4, the sprinkling had a function of transferring the sins involved in the atonement process to the most holy place. This would expand even more the semantic multifacetedness of a single ritual activity. I begin to introduce here and highlight later on the fact that the context of ritual activity also plays a role in determining the meaning of a given ritual activity which was also emphasized by Gane.

Gane endorsed Staal's insight that the meaning of the ritual activity is assigned to it from sources like culture or religious authority ${ }^{52}$ and made a profound statement: "Recognizing that ritual actions have no inherent meaning aids ritual analysis by sparing us the trouble of searching for some 'holy grail' of essential meaning and by keeping us from unjustifiably importing meaning from one context to another because we incorrectly assume that the function of identical actions must be the same. ${ }^{.53}$

\section{Ritual Consists of Activity and Attached Meaning}

Gane did not follow Staal completely in his understanding of the ritual activity meaning. Gane's critique of Staal is directed towards Staal's claim that, based on the fact that activities are intrinsically meaningless, rituals are meaningless, too. ${ }^{54}$ Gane proposed that "physical activities alone do not constitute ritual or set it apart from nonritual

\footnotetext{
${ }^{52}$ Gane, Cult and Character, 5.

${ }^{53} \mathrm{Gane}$, Cult and Character, 6.

${ }^{54}$ Staal, Rules Without Meaning, 433.
} 
activity. $" 55$ He correctly insisted that there has to be some kind of meaning attached to the ritual that sets it apart from other non-ritual activities.

Even if a ritual is "fossilized" in the sense that its meaning has been lost, the tradition of performing it as a ritual is remembered because at some time in the past it was believed to do something over and above the physical cause and effect of its activities. If an activity system was never believed to have any kind of "efficacy," whether religious, magical, social, or otherwise, I would not regard it as a "ritual," at least not in the full sense of the word. ${ }^{56}$

Accordingly, physical activities and meaning attached to them are two basic and essential components of a ritual ${ }^{57}$ which necessitates that a ritual be symbolic in its nature. ${ }^{58}$ This symbolic nature of rituals was emphasized already in the first century BC by Rabbi Hillel. ${ }^{59}$ Gane correctly concluded that "in ritual a nonmaterial entity (e.g., sin) can be treated as if it belongs to the material domain so that it can be subject to physical interaction and manipulation."

The attached meaning for Pentateuchal ritual texts where one finds otherwise incoherent and meaningless ritual activities is found in the Israelite religious system. Gane delineated 3 basic inferences stemming from the Israelite religion as it attaches meaning to cultic rituals: (1) "the religious system can assign different meanings to a

\footnotetext{
${ }^{55}$ Gane, Cult and Character, 7.

${ }^{56}$ Gane, Cult and Character, 7.

${ }^{57}$ Gane, Ritual Dynamic Structure, 18-23, 50-60.

${ }^{58}$ Gane, Cult and Character, 7.

${ }^{59}$ Zeitlin, "The Semikah Controversy," 244.
} 
given activity...,"60 (2) "a given activity can carry more than one meaning at the same time...,"61 (3) "different activities can carry the same meaning...,"62 and (4) "we are as dependent on a ritual tradition to provide us with meanings at every stage of development as we must rely on that tradition for rules governing performance of activities." ${ }^{93}$

In the context of an Ancient Israelite system of rituals, the only asset one can use to potentially retrieve a meaning of a given ritual is the biblical text. Pentateuchal cultic ritual texts themselves present God as the authority who prescribes ritual activities and assigns meanings to them. ${ }^{64}$ For instance, applying blood to the altar had no inherent efficacy and itself could be understood as an incoherent and meaningless activity. However, in the context of Pentateuchal cultic ritual texts, this becomes a ritual activity and the activity that is said to achieve atonement exclusively prescribed by God. ${ }^{65}$ In Pentateuchal cultic ritual texts, God prescribes various ritual roles to various physical objects which otherwise would not necessarily have them. God designated the outer altar

60“'For example, aside from the different functions of blood aspersions in Lev 16:14-16, 19 (see above), the suet of a well-being offering is presented to YHWH as an wִ. "food gift" (3:3-5, 9-11, 1416), but the suet of a purification offering is not (e.g. 4:8-10, 19, 26, 31, 35)." Gane, Cult and Character, 8; Milgrom, Leviticus 1-16, 161-62; Rendtorff, Leviticus, BKAT 3/1 (Neukirchen-Vluyn: Neukirchen, 1985), 65; cf. Rendtorff, Leviticus, 3:188.

61"For example, an officiating priest's privilege and duty of eating purification offering flesh (6:19, 22; Engl. vv. 26, 29) can simultaneously function as appropriation of his agent's commission for carrying out a transaction between YHWH and the offerer (7:7) and contribute in some way to expiation (10:17). It is not necessary to argue for one of these functions to the exclusion of the other." Gane, Cult and Character, 8.

62“"Thus a grain offering can function as a sin offering sacrifice (5:11-13) in place of a living creature (cf. vv. 6-10)." Gane, Cult and Character, 8. This particular point is based on Kiuchi, Purification Offering, 113.

${ }^{63}$ Gane, Cult and Character, $8-9$.

${ }^{64}$ Knierim, Text and Concept in Leviticus 1:1-9, 6.

${ }^{65}$ Rodríguez, "Substitution in the Hebrew Cultus," 242; Gane, Cult and Character, 9. 
as the place where the priests would apply sacrificial blood (Lev 17:11). ${ }^{66}$ The same but more limited function was assigned to the incense altar (Exod 30:10).

\section{Inadequacy of a Structural Approach in Identifying Ritual Meaning}

Two significant approaches of interpreting rituals are dynamistic and structural. The former "approach attributes the effectiveness of a ritual to the power of the particular symbols and actions of which it is comprised. The symbols themselves are understood to convey power and bring about result." ${ }^{, 67}$ This approach does not correlate with the ritual ideology presented in the Pentateuchal cultic ritual texts. It tends to isolate the symbols from the larger context of a given ritual and diminished variety, richness, and ambivalence of many common symbols. ${ }^{68}$

The latter is proposed by Jenson who found the dynamistic approach unsatisfactory. He stated the strengths of this approach:

Instead of an atomistic approach, it is preferable to begin with the movement and structure of the sacrificial ritual as a whole, since this larger context should determine the primary significance of the individual symbols. symbols. The value of a structural approach is that it looks for patterns at the level of the complete ritual. ${ }^{69}$

Gane agreed that "the advantage of such a structural methodology is that it takes into account the fact that rituals are hierarchical systems of activity in which individual activities are included and shaped by higher level goals to which they are intended to

\footnotetext{
${ }^{66}$ Gane, Cult and Character, 9.

${ }^{67}$ Jenson, Graded Holiness, 151. For more details on this approach, see A. Bertholet, Das Dynamistische im Alten Testament (Tübingen: Mohr, 1926).

${ }^{68}$ Jenson, Graded Holiness, 151; Victor W. Turner, The Forest of Symbols: Aspects of Ndembu Ritual (Ithaca, NY: Cornell University Press, 1970), 28-30.

${ }^{69}$ Jenson, Graded Holiness, 151; Gane, Cult and Character, 10.
} 
contribute. ${ }^{, 70}$ However, the major strength of this structural approach over the dynamic one becomes its weakness in light of the fact that activities do not have an inherent meaning, as Staal established. Taking the ritual as a whole or certain part of it as a starting point for deriving its meaning does not make a difference. Gane provided an excellent example to represent this dynamic. ${ }^{71}$ The activities themselves do possess an inherent meaning. As established above, ritual system is an activity system, it is defined by its goal. It is the goal that separates a ritual system from other activity systems. ${ }^{72}$ Jenson himself recognized that a structural approach cannot provide a full explanation of a ritual and a historical approach may be more appropriate when anomalies occur since "there is a conservative tendency in the cult to preserve actions and symbols when their original function has ceased."73 In addition, symbols can gain a different meaning in a new context or the meaning of the individual symbol may transcendent the specific purposes of a ritual. ${ }^{74}$

Gane claimed that the historical approach cannot overcome the weaknesses of a structural approach since diachronic information does not assist in setting the boundaries

${ }^{70}$ Gane, Cult and Character, 10.

${ }^{71}$ For example, suppose we observe a man washing his feet outside a religious shrine on a hot day. Is he (a) cooling himself, whether or not he enters the shrine, (b) making sure that he will not soil the carpet in the shrine when he enters, (c) ritually purifying himself preparatory to worship, or (d) engaging in a core act of worship? Even if we continue to watch the man's subsequent behavior, without knowing how his actions fit into his world view, we will remain unsure whether his actions constitute a complete activity system or belong to a larger activity system, let alone whether they are ritual in nature and, if so, what they might mean. How can we even begin to employ a structural approach, unless we import one or more a priori assumptions that invalidate our analysis from the outset, when we do not know whether we are looking at the top or the bottom of a ritual or a nonritual activity hierarchy? Gane, Cult and Character, 11.

\footnotetext{
${ }^{72}$ Gane, Cult and Character, 12.

${ }^{73}$ Jenson, Graded Holiness, 152.

${ }^{74}$ Jenson, Graded Holiness, 152.
} 
of the activity and its symbolic meaning. In other words, a diachronic approach would be effective only if the researcher were able to talk to the ritual participants, which in the case of ancient rituals, is impossible. The time element itself does not warrant a more complete interpretation of the activity system. Another structuralist, Douglas Davis, suggested that certain ritual forms provide meaning within a given context. He stated that "by contrast we presuppose that the form the rites took, their symbolic patterning, itself gives the meaning, though it is necessary to view the rites within the wider context of the idea of covenant as already indicated above."75 Accordingly, the covenant is undeniably a conceptual element that provides a worldview of the Ancient Israelites. The covenant conditioned God's presence among Israelites by the observance of his laws, especially those related to cult that regulated the ritual system. However, Gane rightfully noted that unless functions/meaning of ritual forms are not explained or understood, at least to a certain degree, a principal covenant context generally supplies a satisfactory interpretation of a ritual that conveys specific meaning. ${ }^{76}$

\section{The Meaning/Function of a Ritual Is the Goal Assigned to Its Activity System}

It is obvious that a ritual is "an activity system."77 As mentioned in the context of Wright's claim that the textual nature of a biblical ritual reflects its inadequacy as a source for sociological analysis, a ritual, as an activity system, is a goal-informed system.

\footnotetext{
${ }^{75}$ Douglas Davies, “An Interpretation of Sacrifice in Leviticus,” ZAW 87 (1977): 392.

${ }^{76}$ Gane, Cult and Character, 13.

${ }^{77}$ Gane, Cult and Character, 12.
} 
In other words, it is the goal, rather than the activities themselves, ${ }^{78}$ that determines the meaning of such a system along with the choice of activities needed to accomplish this goal. Gane accurately captured this point: "The goal defines the activities that are included and the way they are performed."79 The hierarchical structure that is characteristic for any activity system is apparent in ritual, as well. A biblical cultic ritual consists of smaller systems that constitute components that compose larger, more complex systems. ${ }^{80}$ The prime importance of the goal is reflected at each hierarchical level of ritual activity.

“In B. Wilson's study of nonritual human activity systems, he points out that the goal/raison d'être defining such a system is to accomplish a particular transformation through an activity process. So, it is not the activities that define the system, but rather, the goal determines which activities are necessary to achieve the desired change." 81 That which sets ritual apart is the fact that it is "action believed to be efficacious" through "symbolic relationship" to some supposed transcendental reality. The goal defines the

\footnotetext{
${ }^{78}$ Activity is meaningless and prone to various or multiple meanings. Gane made a difference between pure activity, as Staal considered them, and intrinsic activity in his quest for the boundaries and meaning of the ritual activity. Gane, Ritual Dynamic Structure, 3-5; Staal, Rules Without Meaning, 131. The first refers to physical causes and effects only. Staal elevated the rules as a determinative factor for ritual boundaries and meaning. Staal, Rules Without Meaning, 132. The second, established by Gane, points to the activity that goes beyond the physical causes and effects. In other words, it refers to the task that operates at the cognitive level and is a matter of belief. Gane, Ritual Dynamic Structure, 3-5. The same principle is also hinted at in Wright's study of Hittite ritual. Wright, "The Study of Ritual in the Hebrew Bible," 129.

${ }^{79}$ Gane, Cult and Character, 13.

${ }^{80}$ For instance, the activity of blood application consists of two other, pre-requisite and postrequisite, activities. "An activity may be pre-requisite to another activity that fulfills the goal, or it may be post-requisite. For instance, slaughtering an animal (4:29) is pre-requisite to application of its blood to the horns of the altar (v. 30a), following which pouring out the remaining blood at the base of the altar is postrequisite disposal (v. 30b)." Gane, Cult and Character, 13.

${ }^{81}$ Wilson, Systems, 16, 26; Gane, Cult and Character, 12.
} 
activities that are included and the way that they are performed. ${ }^{82}$

\section{A "Ritual" Is an Activity System with a Special Kind of Goal}

Scholars, biblical ${ }^{83}$ and from other scientific disciplines,${ }^{84}$ have offered numerous definitions of ritual. The question of if and how a ritual should be separated from other human activity is still unsettled. ${ }^{85}$ The present study, with Gane, accepts that a difference between ritual and non-ritual activity does exist. Monica Wilson noticed that non-ritual activity, also called ceremony, "is an appropriate and elaborate form of expression of feeling, but ritual is believed to be efficacious." ${ }^{86}$ Regardless of the fact that ritual is situated in a ceremony, the latter is not crucial for ritual's effectiveness. Wilson also emphasized even more on the further difference between ritual and ceremony: "Both ritual and ceremonial have a function in rousing and canalizing emotion, but ritual, by relating its symbols to some supposed transcendental reality, affects people more deeply than a ceremony, which some will describe as "mere play-acting." 87 Turner and E. M. Zeusse also affirmed these two characteristics of ritual: (1) belief that it is efficacious through (2) symbolic association "to some supposed transcendental reality,"

${ }^{82}$ Gane, Cult and Character, 14.

${ }^{83}$ Gorman, The Ideology of Ritual, 19; Gruenwald, Rituals and Ritual Theory in Ancient Israel, 2; Gane, Cult and Character, 15; Klingbeil, Bridging the Gap, 18.

${ }^{84}$ Jan Plavoet listed twenty-four different definitions produced since 1909, starting with van Gennep, through 1991, with David Parkin. Platvoet, "Ritual in Plural and Pluralistic Societies," $42-45$. Klingbeil, Bridging the Gap, 14. Also see Catherine M. Bell, Ritual Theory, Ritual Practice (New York: Oxford University Press, 2009).

\footnotetext{
${ }^{85}$ Gruenwald, Rituals and Ritual Theory in Ancient Israel, 1-36.

${ }^{86}$ Monica Wilson, "Nyakyusa Ritual and Symbolism,” AA 56 (1954): 240.

${ }^{87}$ Wilson, "Nyakyusa Ritual and Symbolism,” 240.
} 
differentiat[ing] it from non-ritual activity or ceremony. ${ }^{88}$ Gorman also affirmed that ritual consists of symbolic actions and added that ritual symbolism derives its meaning from the cultural system of a particular human group or nation. ${ }^{89}$ Distinguishing ritual from a kind of sign language, Gane emphasized another element that separates ritual and non-ritual activity. That is, a ritual "is believed to do something that changes reality in a way that goes beyond the constraints of cause and effect that operate in activities belonging to the mundane physical world that are susceptible to manipulation by the performers. ${ }^{, 90}$ Since the ritual dealt with in the present work is religious, as such, it includes a belief in a deity. God sought to be reached and communicated with in the Pentateuch, and the rest of the Bible is inaccessible unless he chooses to make himself accessible. Therefore, M. Douglas emphasized the necessity of incorporating so-called "non-Newtonian physics" in the scientific analysis scholars utilize to study biblical cultic ritual. This is needed due to the fact that God is presented as spiritual and thus noncorporeal, which assumes that he is omnipresent, invisible, and possessing the knowledge of the future. These powers or attributes are not available to the human creature, but God can bestow some of them to certain humans. ${ }^{91}$

\footnotetext{
${ }^{88}$ Victor W. Turner, The Ritual Process: Structure and Anti-Structure, LHML (New York: Aldine de Gruyter, 1995), 105-6; E. M. Zeusse, "Ritual," ER 12:7833. For a further debate on the difference between ritual and non-ritual activity, see Ronald L. Grimes, Ritual Criticism: Case Studies in Its Practice, Essays on Its Theory, SCR 52 (Columbia, SC: University of South Carolina Press, 1990), 12; David P. Wright, Ritual in Narrative: The Dynamics of Feasting, Mourning, and Retaliation Rites in the Ugaritic Tale of Aqhat (Winona Lake, IN: Eisenbrauns, 2001), 12-14; Bell, Ritual Theory, 74, 90-91.

${ }^{89}$ Gorman, The Ideology of Ritual, 22-23.

${ }^{90}$ Gane, Cult and Character, 15.

${ }^{91}$ Mary Douglas, "Holy Joy: Rereading Leviticus: The Anthropologist and the Believer," CJ 46 (1994): 7.
} 
Gane eloquently noticed another dimension of biblical cultic ritual. Regardless of the interrelated and complex relationship between biblical ritual texts and their system of beliefs articulated in the Bible to the extent that it may be believed that a ritual enactment affects states of individual, society, cosmos, and deity, as Gorman proposed, ${ }^{92}$ Gane emphasized that ritual effects result from the interaction with the otherworldly. He stated that "not only is its meaning acted out as potent dramatic expression, it is also believed to result in transformation that nonritual activity cannot achieve." ${ }^{93}$ As an example of this, Gane referred to the sin offering that purges the Pentateuchal sanctuary. The ritual goal in this context is not achieved by the natural physical result of its activities. More precisely, applying the blood to the parts of the sanctuary physically does not cleanse it, but on the contrary, makes it physically dirtier. Gane put it as follows:

Non-physical pollution, consisting of ritual impurities and moral faults, is purged from the sanctuary of supramundane YHWH on behalf of the Israelites (vv. 16, 1819,33 ). While the activities themselves do not produce this goal through physical cause and effect as they would be expected to in ordinary life, they serve as a vehicle for transformation that takes place on the level of symbolic meaning. ${ }^{94}$

Thus, the symbolism of these activities that achieved the goal of the sin offering was integrated in the conceptual system that required belief. The effectiveness of ritual and its rules assumed a belief in God's existence, the fact that the pollution that needed to be removed was real, and that prescribed ritual actions do carry out the desired transformation. ${ }^{95}$

\footnotetext{
${ }^{92}$ Gorman, The Ideology of Ritual, 37-38.

${ }^{93}$ Gane, Cult and Character, 17.

${ }^{94}$ Gane, Cult and Character, 17.

${ }^{95}$ Gane, Cult and Character, 17.
} 


\section{The Aid of Systems Theory Concepts in the Interpretation of Israelite Rituals}

In his doctoral research, Christopher E. Queen explored the period of the history of religious studies when it was believed that the "'science of religion,'

$\underline{\text { Religionwissenschaft, as Max Miller and his early disciples chose to call it, }{ }^{, 96} \text { would }}$ emerge with its own distinctive methodology and establish theoretical principles. He noted that these unrealistic expectations started to fade away during the 1970s. The major agreement recognized among the scholars of the time was that "the study of religion is an interdisciplinary enterprise which cannot afford to exclude contributions from any quarter." 97 This agreement originated from the fact that religion itself is a complex phenomenon as Ninian Smith accurately described it:

[T] he study of religions is in principle multi-dimensional — dealing not just with doctrines and myths, but also with rituals, experiences, institutions, ethics, iconography and so on. Maybe a major focus will be on texts, though this has been an exaggerated emphasis in the past. A consequence of all this is the need to study the dimensions of religion via various disciplines - history, philology, sociology, anthropology, history of ideas, art history, psychology of religion, and so on. Thus the study of religion is in principle multi-disciplinary. ${ }^{98}$

Since then, various methods and theoretical principles were employed in the study of religion and always with their own deficiencies. Queen delineated four major methods: (1) personalism, (2) functionalism, (3) historicism, and (4) reductionism. ${ }^{99}$ Queen found that the general system theory, which Gane modified to suit his project of studying the

\footnotetext{
${ }^{96}$ Christopher Scott Queen, "Systems Theory in Religious Studies: A Methodological Critique" (PhD diss., Boston University, 1986), 275.

${ }^{97}$ Queen, "Systems Theory in Religious Studies," 275.

${ }^{98}$ Queen, "Systems Theory in Religious Studies," 275-76.

${ }^{99}$ Queen, “Systems Theory in Religious Studies,” 11, 68-237, 247-51.
} 
rituals, transcends disciplinary boundaries via its thematization by the four principles, the principle of integration, adaptation, emergence, and hierarchy. He concluded that each of these principles - Integration, Adaptation, Emergence, and Hierarchy — has been interpreted as an "invariant" characteristic of open systems at all levels of the natural-cognitive hierarchy. Each of these principles may be applied, with valuable results, we have argued, to the resolution of methodological problems which bedevil the social sciences, the humanities, and religious studies: personalism, functionalism, historicism, and reductionism. Each of the systems principles may be seen as a theoretical foundation or context for certain specialties which constitute the interdisciplinary field of religious studies and theology: phenomenology and hermeneutics (Integration), the social sciences as they are applied to religion (Adaptation), the comparative history of religions (Emergence), and the philosophy of religion and systematic theology (Hierarchy). ${ }^{100}$

However, Queen warned "that each of the systems principles — and by implication, each of the respective subdisciplines of religious studies and theology-is susceptible to distortion by overemphasis." 101 Thus, grounding one's methodological approach and theoretical principles upon the general systems theory, as Gane did, with the awareness of potential distortions caused by overemphasis, should supplement understanding of biblical cultic ritual preserved in the limited textual form. Queen's final remark regarding the role of systems theory in religious studies favors its responsible use:

The contribution of systems theory in religious studies, both in its experiments and applications to date, and in its heuristic potential for future development, lies in its unique ability to integrate the findings of many disciplines, to respect the worlds of meaning which they purvey, and to place all of this in a non-dogmatic, but irreducible Context that is the source of religious experience. ${ }^{102}$

${ }^{100}$ Queen, "Systems Theory in Religious Studies,” 282.

${ }^{101}$ Queen, "Systems Theory in Religious Studies," 282. The overemphasis by each principle is reflected in the following way: Integration-solipsism and/or idealism, Adaptation-behaviorism and/or determinism, Emergence-optimism and/or utopianism, Hierarchy-totalitarianism and/or mysticism. Queen, "Systems Theory in Religious Studies," 283. For more in-depth explanation of the overemphasis see Queen, "Systems Theory in Religious Studies," 283-94.

${ }^{102}$ Queen, "Systems Theory in Religious Studies," 294. 
Gane's extensive use of the general systems theory in his dissertation project shows a careful and responsible use of this theory in his quest to understand the biblical cultic ritual. Gane delineated 6 prominent properties of ritual activity systems as a result of his utilization of the general systems theory in his analysis of ritual: (1) a function or a ritual is equal to its meaning and is achieved by carrying out its goal of transformation. Both the goal and the function/meaning of the ritual are supplied by the text. This is the basic function of biblical cultic ritual, even though others like the social are certainly involved. As I emphasized above, this is the key one; ${ }^{103}$ (2) by being its driving force, the goal defines the ritual and its boundaries since the ritual activities contributed to its goal; ${ }^{104}$ (3) ritual brings out a physical transformation which supersedes the natural physical results, but rather, is a vehicle for achieving a higher level of transformation; ${ }^{105}$ (4) ritual efficacy and rules assume the acceptance of religious belief into which a ritual is integrated. The ritual system of Ancient Israel interacts with the wider conceptual and cultural environment of Israel's society. Thus, biblical cultic ritual is a part of Israelite religion instituted by God; ${ }^{106}$ (5) ritual is hierarchically structured, encompassing smaller

\footnotetext{
${ }^{103}$ Gane, Cult and Character, 19-20; Gruenwald, Rituals and Ritual Theory in Ancient Israel, $198-99$.

${ }^{104}$ Gane, Cult and Character, 19-20; Gane, Ritual Dynamic Structure, 34-5, 60-1, 92-6; Wilson, Systems, 26-31.

${ }^{105}$ Gane, Cult and Character, 19-20; Wilson, Systems, 15-16, 25-42; Gane, Ritual Dynamic Structure, 33-49, 60-61.

${ }^{106}$ Gane, Cult and Character, 19-20; Julia M. Norlin and Wayne A. Chess, Human Behavior and the Social Environment: Social Systems Theory, 3rd ed. (Boston: Allyn and Bacon, 1997), 31-33.
} 
systems that constitute it. ${ }^{107}$ These smaller systems are distinct ${ }^{108}$ and the ritual as a whole achieves its goal only if performed in its entirety in a proper order: ${ }^{109}$ and (6) The importance of the goal is translated into the smaller systems which also bring about transformation. ${ }^{110}$

Some of them were identified prior to Gane's work, while some were introduced by him. ${ }^{111}$ Gane used a potential problematic statement ${ }^{112}$ in Lev 16:25 to show the presence of these properties in one ritual sequence. That is, it states that the high priest is to burn the suet of the sin offering, expressed in the singular, regardless of the fact that two sin offerings are assumed in this text. The collective nature of the noun "suet" refers to the complex of actions consisting of both sacrifices, separate and smaller ritual system activities, that are interwoven and subsequently merged when their blood was simultaneously applied to the sacrificial altar (vv. 18-19). Thus, "the singular simply acknowledges the unity at a higher level of systems hierarchy."113

\footnotetext{
${ }^{107}$ Gane, Cult and Character, 20; Staal, Rules Without Meaning, 101. For a more general perspective on ritual hierarchy, see John P. Van Gigch, Applied General Systems Theory, 2nd ed. (New York: Harper \& Row, 1978), 66. 31.

${ }^{108}$ Gane, Cult and Character, 20; Norlin and Chess, Human Behavior and the Social Environment,

${ }^{109}$ Gane, Cult and Character, 20.

${ }^{110}$ Gane, Ritual Dynamic Structure, 37-38, 42-48; Wilson, Systems, 31-35.

${ }^{111}$ Gane, Cult and Character, 19-20.

${ }^{112}$ Gane, Cult and Character, 20; Noth, Leviticus, 126; Ellinger, Leviticus, 216.

${ }^{113}$ Gane, Cult and Character, 20.
} 


\section{The Biblical Text Provides Instructions for Physical Performance and Interpretations of Activities}

Since scholars began studying biblical ritual texts more intensively after the 1950s, some crucial characteristics of these texts emerged. David W. Baker compared Lev 1-7 to the Punic Marseille and Carthage Tariffs ${ }^{114}$ and suggested that ritual texts in general belong to the universal genre of procedural texts previously established by Robert E. Longacre. ${ }^{115}$ Longacre established the fact that the two key characteristics of these texts are (1) prescription, and (2) a chronological framework, and as a result, these texts are goal-oriented. ${ }^{116}$ I agree with Gane, who suggested that all biblical ritual texts are goal-oriented. Baruch Levine and William W. Hallo have delineated two basic ritual text types in the OT, prescriptive and descriptive, the former telling how rituals ought to be done, and the latter, how ritual performances were actually performed. ${ }^{117}$ The prescriptive texts generally begin with conditional clause followed by clauses governed by the verbs in perfect consecutive or imperfect aspect. The descriptive texts usually begin with the verbs in imperfect consecutive or perfect aspect, referring to the sequence of activities performed at one point in time. ${ }^{118}$

Building on the previous works, Knierim showed a more precise literary classification of biblical ritual texts by identifying a subgenre of procedural law, namely

\footnotetext{
${ }^{114}$ Baker, "Leviticus 1-7," 189.

${ }^{115}$ Longacre, An Anatomy of Speech Notions, 197-231, especially 199-206.

${ }^{116}$ Baker, "Leviticus 1-7," 192-93.

${ }^{117}$ Levine, "Descriptive Tabernacle," 307-18; Hallo, "Offerings to the Temple Gates at Ur," $17-$ 58; Baker, "Leviticus 1-7," 193; Rainey, "The Order of Sacrifices," 485-98; Gane, Cult and Character, 21.

${ }^{118}$ Rainey, "The Order of Sacrifices," 495.
} 
"case law." He also suggested that the purpose of the texts that utilized case law genre is to standardize the vital steps of ritual performance in order to achieve the intended purpose/s. ${ }^{119}$ Again, Knierim is one more scholar who noticed that the key component of biblical ritual text is the goal which is so important that it determines the structure of these texts. $^{120}$

Gary Anderson affirmed that biblical ritual texts contain the instructions for physical performance of activities, ${ }^{121}$ but also noticed that they also contain the interpreted goals of these activities. ${ }^{122}$ Knierim accurately suggested that "we speak about the writers' transformation of a concept into a text, not into an action, and interpret the concept of an observed text, not of an observed performance." ${ }^{123}$ He made a difference between the textual representation of a prescribed ritual and a description of an observed ritual which increases even more as one is involved in a ritual performance. ${ }^{124}$ Gane's warning that not realizing these limits in a ritual analysis increases the possibility of importing "a priori elements from our own world view into our interpretation of ritual meaning" is well taken. The interpretation of a given ritual, represented by either prescriptive or descriptive text, by a ritual text is crucial in order to determine its meaning.

\footnotetext{
${ }^{119}$ Knierim, Text and Concept in Leviticus 1:1-9, 31, 65, 94-97, 98-106. Gorman, The Ideology of Ritual, 25-27.

${ }^{120}$ Knierim, Text and Concept in Leviticus 1:1-9, 89, 64-67, 90.

${ }^{121}$ Anderson, "Sacrifice," 5:884.

${ }^{122}$ Anderson, "Sacrifice," 5:883.

${ }^{123}$ Gane, Cult and Character, 23; Knierim, Text and Concept in Leviticus 1:1-9, 17-18.

${ }^{124}$ Gane, Cult and Character, 23; Knierim, Text and Concept in Leviticus 1:1-9, 19-20.
} 


\section{Gaps: The Peculiarity of Ritual Texts}

Scholars noted that biblical ritual texts contain conceptual "gaps." ${ }^{\text {"25 }}$ In the context of biblical ritual texts, the conceptual "gaps" refer to the lack/silence of texts regarding the meaning of certain ritual activities expressed in them or omission/s of certain ritual activities that should be included in certain rituals. Gilders especially emphasized and dealt with this peculiarity of biblical ritual texts and suggested a simple, but yet not precisely defined solution. He stated that when a reader encounters gaps, "the interpreter must fill gaps with information derived from other sources in order to make sense of them."126

$\mathrm{He}$, being himself a reader-response criticism proponent, ${ }^{127}$ followed a known reader-response literary critic, Wolfgang Iser, who claimed that readers inevitably experiences "gaps" in the text they read and variously fill those gaps in order to arrive at a coherent understanding of the meaning of the text. Assigning this role to the readers assumes that they play a vital role in constituting the meaning of any text. ${ }^{128}$ The critical question is defining the scope of the term "source/s." Most of the time, the source/s in Gilders' work is limited to the biblical canon, assuming various traditions and sources in the biblical text, or even biblical texts in its entirety. ${ }^{129}$

\footnotetext{
${ }^{125}$ Milgrom, Leviticus 1-16, 816, 983; Gane, Cult and Character, 23; Gilders, Blood Ritual in the Hebrew Bible, 19, 22-23, 36, 58, 67, 183.

${ }^{126}$ Gilders, Blood Ritual in the Hebrew Bible, 35.

${ }^{127}$ Gilders, Blood Ritual in the Hebrew Bible, 9-10.

${ }^{128}$ Wolfgang Iser, "The Reading Process: A Phenomenological Approach," in Reader-Response Criticism: From Formalism to Post-Structuralism, ed. Jane P. Tompkins (Baltimore: Johns Hopkins University Press, 1980), 50-69.

${ }^{129}$ Gilders, Blood Ritual in the Hebrew Bible, 19, 22-23, 36, 58, 67, 183.
} 
This correlates with the approach in this study with two modifications. First, the present study does not accept the presence of various and multiple traditions/sources that biblical texts are comprised of. Second, this study set limits to the books of the Pentateuch in its quest to understand the laying on of hands. However, Gilders' work shows that the term "source/s" also includes text outside the biblical canon, as he laid out that the situatedness of the reader of his "interpretative community" which consists of the works of biblical scholars who apply modern critical-historical methods to the biblical text. ${ }^{130}$ Rabbinic tradition is clearly one of the sources Gilders used. ${ }^{131}$ This part of his gap-filling methodology does not correlate with the presuppositions of the present study, since it attributes the biblical texts greater authority than all other useful sources to understand biblical topics.

\section{Laying on of Hands: Texts}

The gesture of laying on of hands was common in the ANE and Mediterranean context, including Ancient Israel, as a part of that milieu. ${ }^{132}$ The study of Egyptian, Mesopotamian, Greco-Roman, and post-exilic Jewish and rabbinic sources unanimously demonstrates that laying on of hands was used in various contexts with various meanings.

Egyptian sources use laying on of hands to convey purification, resurrection,

${ }^{130}$ Gilders, Blood Ritual in the Hebrew Bible, 9-10.

${ }^{131}$ Gilders, Blood Ritual in the Hebrew Bible, 127.

${ }^{132}$ Mattingly, "The Laying on of Hands on Joshua," 24-172; Rodríguez, "Substitution in the Hebrew Cultus," 20-74; González, "Laying-on of Hands in Luke and Acts," 31-101; Clayton David Robinson, "The Laying on of Hands, with Special Reference to the Reception of the Holy Spirit in the New Testament" (PhD diss., Fuller Theological Seminary, 2008), 56-81; Wright, "The Gesture of Hand Placement." 
deification, empowerment, transfer, or sometimes, just as a method to transpose an entity. ${ }^{133}$ Mesopotamian sources contain multiple uses of laying on of hands. ${ }^{134}$ Ras Shamra Texts contain The Legend of King Keret, Plate 7, which points to the transfer meaning of this ritual gesture. ${ }^{135}$ In the myth of Inanna's Descent, Enlil and Ninlil both contain the idea of transfer of sickness or misfortune to another entity. ${ }^{136}$ Laying on of hands is not included in these two texts, but transfer and substitution are. James Moyer's dissertation demonstrated that the Hittite texts also contain multiple references to the idea of transfer ${ }^{137}$ and substitution. ${ }^{138}$ Some of the texts like the Substitute King rituals, the Ritual of Mastigga, and several healing rituals do not include laying on of hands.

However, some rituals include laying on of hands that convey symbolical transfer, like the Ritual of Askhella. Moyer's and Wright's dissertation research demonstrated that

\footnotetext{
${ }^{133}$ González, "Laying-on of Hands in Luke and Acts," 31-40; Robinson, "The Laying on of Hands," 56-61.

${ }^{134}$ González, "Laying-on of Hands in Luke and Acts," 40-43.

${ }^{135}$ D. Winton Thomas, ed., Documents from Old Testament Times, HTB 85 (New York: Harper \& Brothers, 1961), 118-21; González, "Laying-on of Hands in Luke and Acts," 42-43.

${ }^{136}$ For a more extended treatment of these texts and references, see Rodríguez, "Substitution in the Hebrew Cultus," 21-4.

${ }^{137}$ James Carroll Moyer, "The Concept of Ritual Purity among the Hittites" (PhD diss., Brandeis University, 1969), 56, 66, 86, 96-97, 127, 129, 133, 136-37, 140, 144. See also Wright, The Disposal of Impurity, 32-34.
}

${ }^{138}$ Moyer, "The Concept of Ritual Purity among the Hittites,” 34, 36, 66-67, 86, 119, 135. 
transfer and substitution were dominant ideas in Hittite and Mesopotamian texts. ${ }^{139}$ Ugaritic literature contains examples of the Royal Substitution rituals. ${ }^{140}$ The concept of substitution was also spread in Babylonian and Assyrian religion. ${ }^{141}$

In Classical Greco-Roman sources, laying on of hands was employed in healing rites, conveying a blessing, giving a charge, or stating a curse, in sacrificial rites, as well as in a few other contexts. ${ }^{142}$ In post-exilic Jewish and rabbinic sources, laying on of hands was used to convey ordination, transfer, blessing, and healing. ${ }^{143}$

As indicated in the introduction, the focus of the present study is to identify the meaning/function of this gesture in the Pentateuch. The phrase two times in the Pentateuch, ${ }^{144}$ mainly in cultic contexts. Being performed in the cultic context does not imply the same meaning of this gesture. Table 26 shows twenty-two occurrences of the laying on of hands.

It is inevitable that some sort of relationship is envisaged in the gesture of laying on of hands. Kiuchi has correctly stated that "it appears natural to assume that the

${ }^{139}$ Moyer, "The Concept of Ritual Purity among the Hittites"; Wright, The Disposal of Impurity.

${ }^{140}$ For a more in-depth analysis of these texts with references, see Rodríguez, "Substitution in the Hebrew Cultus," 21-73; Robinson, "The Laying on of Hands," 56-61.

${ }^{141}$ S. H. Hooke, "The Theory and Practice of Substitution," VT 2 (1952); Wright, The Disposal of Impurity, 37-38.

${ }^{142}$ González, "Laying-on of Hands in Luke and Acts," 43-51. For the contexts outside of these categories, see González, "Laying-on of Hands in Luke and Acts," 51-54; Robinson, "The Laying on of Hands," 43-56. Hands," 61-72.

${ }^{143}$ González, "Laying-on of Hands in Luke and Acts," 73-87; Robinson, "The Laying on of

${ }^{144}$ The remaining three occurrences found outside of the Pentateuch are 2 Chron 29:23, Ps 37:24, and Amos 5:19. 


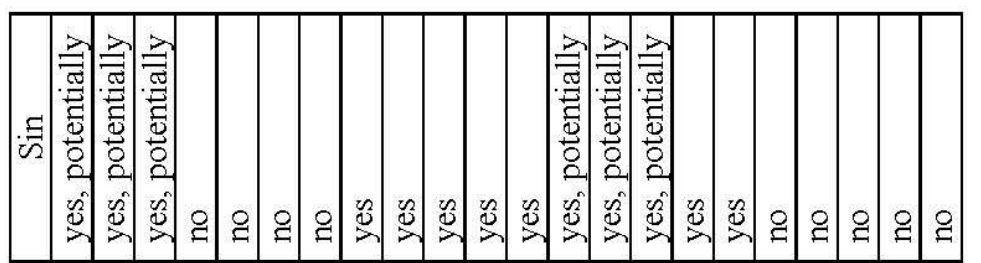

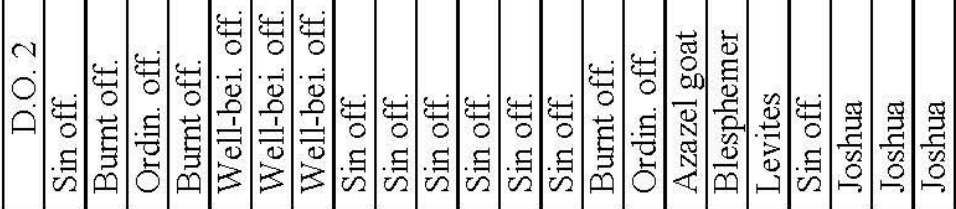

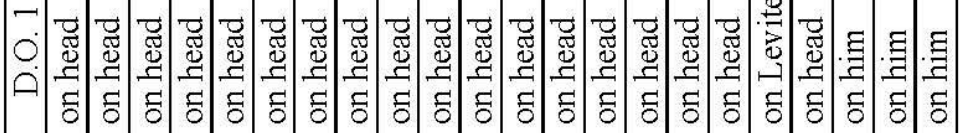

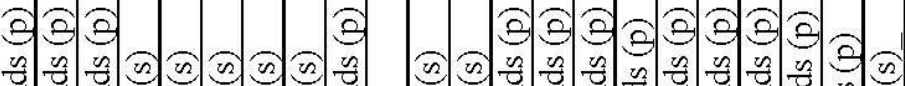

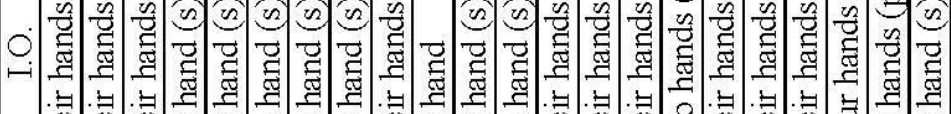
븡

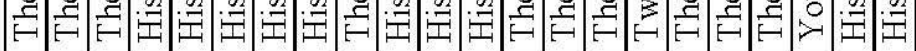

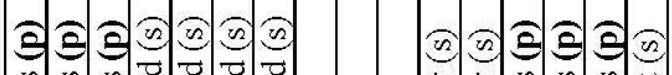

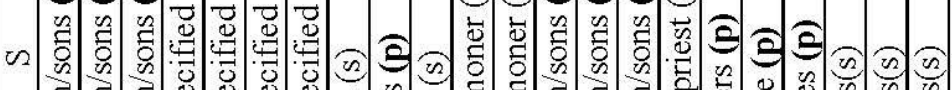

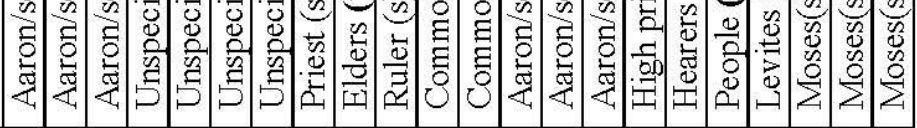

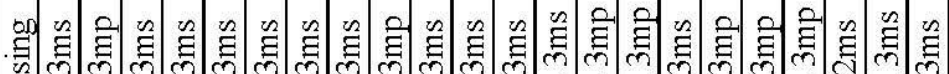

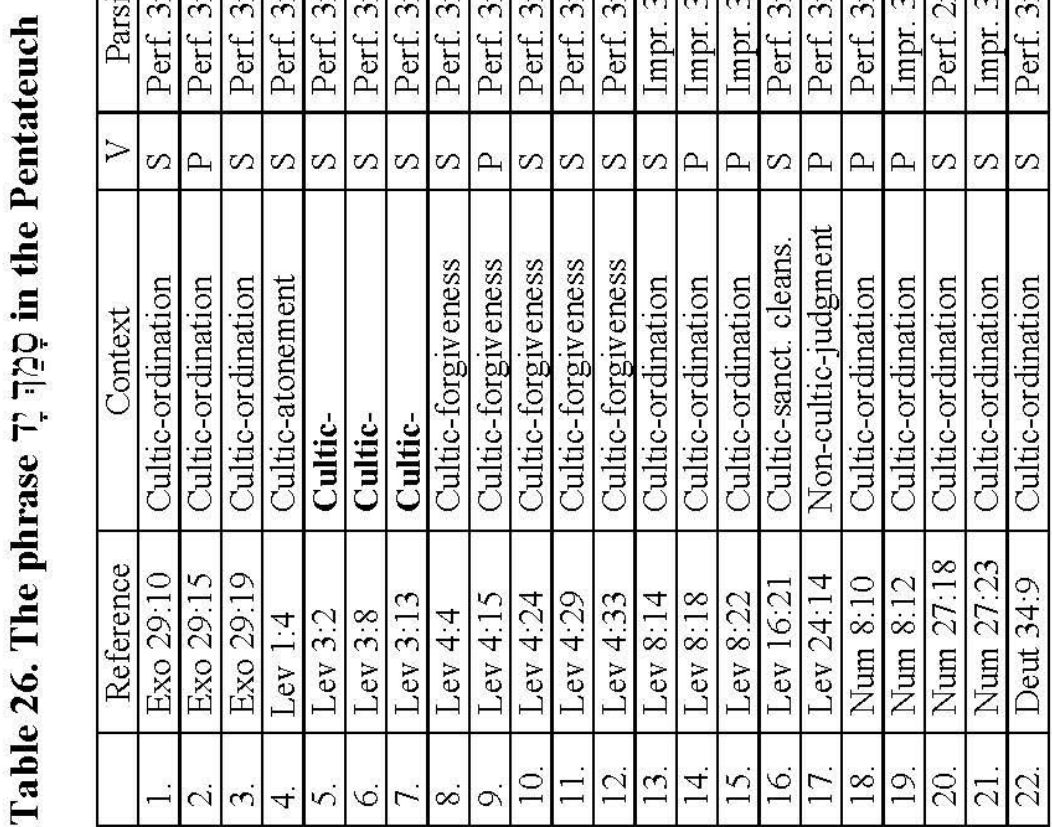


gesture expresses some relationship between the offerer and the sacrificial animal."145 However, the specific explanation of its meaning is found only in Lev 1:4 and 16:21. In part, Gilder was right when he stated that "the great variety of explanations of the handpressing gesture again indicate the problem of trying to interpret an uninterpreted gesture. ${ }^{146}$ Various interpretations have been associated with Lev 1:4 and the latter was often excluded from the discussion due to its irrelevancy with the fact that the Azazel goat was not considered a sacrifice. ${ }^{147}$

Two issues are embedded in identifying the meaning/function of this gesture. First, it seems that laying on of hand/s is missing in at least 5 texts where it is expected to be included (Lev 1:10-11; Lev 9, 16, 23; and Num 28-29). The second issue is the form of the gesture and its impact on the meaning/function of this gesture. Was it performed with one or both hands? Both issues, respectively, are dealt with below.

\section{Leviticus 1:3-4}

This text was analyzed in the context of רִִּ with a different goal. Here this text is juxtaposed with the texts that utilize the same topical, syntactical, and grammatical constructions in order to identify pointers that assist the meaning laying on of hand/s. Kiuchi affirmed Milgrom's inference concerning the datival sense of the pronominal suffix attached to the noun רִ in v. 3. This is based on the valid analogy with Lev 22:19-20 where it is stated that the same grammatical construction was used to highlight

\footnotetext{
${ }^{145}$ Kiuchi, Purification Offering, 152. See also Gilders, Blood Ritual in the Hebrew Bible, 82.

${ }^{146}$ Gilders, Blood Ritual in the Hebrew Bible, 75-76.

${ }^{147}$ Kiuchi, Purification Offering, 152.
} 
the same points. That is, the burnt offering will be accepted if it is a male and without

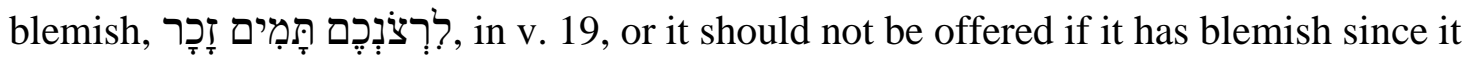

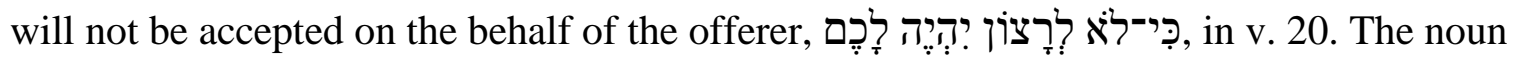
accompanied with the pronominal suffix refers to the offerer in these texts, as well as in Lev $1: 3 .^{148}$

He also noted that the verbal forms of רָצָ are used in Lev 22:25 and in Lev 1:4. In addition to this, two additional points that connect these two passages are similar. First, both of them discuss the acceptance or rejection of the sacrificial animal. Second, both utilize the same grammatical pattern. Thus, based on the context of 22:19-25, it can be inferred that the meaning of the phrase לא ירִָצּוּ לָכָם in v. 25 is the same as the one in

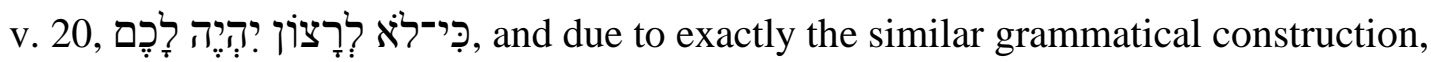
except that the verbal negation accompanies the verbs in Lev 22:20, 25, Kiuchi correctly suggested that the same meaning is implied in Lev 1:4. ${ }^{149}$

בִצִּוֹן connotes the idea of substitution of the offerer with his/her sacrifice receives substantial textual support. The offerer and his/her sacrifice are considered as one. In other words, acceptance of the offerer is conditioned by the acceptance of his/her animal. The inference is that the animal acts as the offerers substitute. Both Milgrom's and Kiuchi's translation point to the organic and conceptual unity of Lev 1:3-4 via term רָָּה/רָצוֹן

\footnotetext{
${ }^{148}$ Kiuchi, Purification Offering, 158.

${ }^{149}$ Kiuchi, Purification Offering, $158-59$.
} 
v. 3, the emphasis is on the offerer who will be accepted if his/her sacrifice is a male, without blemish, and offered in the sanctuary whereas in v. 4, the emphasis is placed on the sacrificial animal that will not be accepted if the offerer does not lay his/her hands on its head.

The rejection of the offerer and the sacrifice are perceived as identical in these two verses. The substitutionary function of the sacrifice is confirmed by Lev 7:18 which states that "if any meat from a peace offering is eaten on the third day, the man who

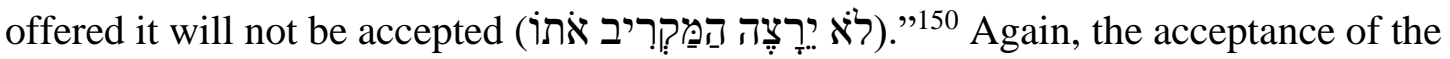
sacrificial animal is tightly related to the acceptance of the offerer. If the offerer violates the rules regarding the well-being offering, he/she will not be accepted and as a result, he/she invalidates the sacrifice itself so the sacrifice is not accepted. ${ }^{151}$ The sacrifice is invalidated and consequently, rejected retroactively.

Consequently, Kiuchi concluded: "Then the fact that the imposition of a hand in Lev 1:4a is mentioned between the bringing of the sacrifice (v .3b) for acceptance on behalf of the offerer and the declaration that the sacrifice will be accepted on his behalf shows that the meaning of the imposition of a hand is implied in וְנִרְָָה לוֹ 'it will be accepted on his behalf ${ }^{\prime} .152$

Thus, the laying on of hand/s in regard to the burnt offering consists of two foundational components: 1) it facilitates the substitutionary relationship between the

\footnotetext{
${ }^{150}$ Kiuchi, Purification Offering, 159.

${ }^{151}$ Milgrom, Leviticus 1-16, 420-21.

${ }^{152}$ Kiuchi, Purification Offering, 159.
} 
offerer and the sacrificial animal and 2) it is a prerequisite for the offerer's atonement.

\section{Omission or Abbreviation}

Some biblical ritual texts omit certain ritual activities. In the case of the laying on of hands in cultic contexts, it is consistently mentioned in the majority of contexts (Exod 29:10, 15 ,19; Lev 1:4; 3:2, 8, 13; 4:4, 15, 24, 29, 33; 8:14, 18, 22; 16:21; 24:14; Num 8:10,12; 27:18, 23; Deut 34:9), but not all (Lev 1:10; 7:1-7; 9:8, 12, 15, 16, 18; 16:6, 9, $11,15,24 ; 23: 8,12,18,19,27,36,37,38$; and Num 28-29). This calls for the explanation of its absence from these texts. One explanation would be that these texts purposely omitted laying on of hands because it was not needed in those contexts, while another would be that the texts rely on the previous established regulations of these ritual activities. The present study seeks to find a rationale for the omissions of laying on of hand/s in the texts listed above on case-by-case basis, taking into consideration the wider religious context of the Ancient Israel faith.

Grounding his arguments on the understanding that laying on of hands/s has different meanings/functions - one hand conveys the ownership of the offerer over their animal, and both hands has a different meaning/function-Milgrom proposed that this gesture was not prescribed/performed in regards to public/communal calendric sacrifices because it was unnecessary. In other words, the owner was obvious, the whole community or the offerer holds the offering in their hands. ${ }^{153}$ The two exceptions are Lev 4:15 and 16:21. ${ }^{154}$ In order to provide a rationale for these exceptions, Milgrom stated

\footnotetext{
${ }^{153}$ Milgrom, Leviticus $1-16,151-52$.

${ }^{154}$ Milgrom, Leviticus 1-16, 153; Gane, Cult and Character, 54-55.
} 
that the latter is not even an exception since the laying on of hands was included in the ritual $^{155}$ inasmuch as the laying on of both hands on the Azazel, which meant transfer, was included. ${ }^{156}$ The former is not a public/communal sacrifice, but was offered for the sins of "individual members of the community." 157 Milgrom's classification of the sin offering in Lev 4:14-21 as not a public/communal one contradicts a realistic reason why it could have been offered, which would classify it as public/communal. That is, Milgrom himself envisioned that the priest's sin in Lev 4:3-12 could affect the entire community, ${ }^{158}$ in which case, both the priest as the initiator of sin and the community as participants in sin were expected to offer a sin offering. On this matter, Gane rightfully questioned Milgrom's division of sacrifices into private non-calendric sacrifices such as Lev 1-5 and public/communal calendric sacrifice such as Lev 16, 23; 16:21, 23, and Num 28-29. He suggested a simpler, but yet questionable solution of keeping the distinction between non-calendric sacrifices that require laying on of hand/s, in which case there would be only one, Lev 4:14-21, and public/communal calendric sacrifices that do not require this gesture (Num 28-29). This division compromises the clear distinction between private non-calendric and public/communal calendric sacrifices. However, Gane's observations of the flaws of Milgrom's division of sacrifices into private non-calendric and public/communal calendric are also not consistent. The current

\footnotetext{
155"The hand-leaning rite is also missing from the Yom Kippur ceremonies (see 16:11, 15) and must be similarly taken for granted. Perhaps its absence there is to accentuate the special and different function of the hand-leaning performed on the live goat (see the NOTE on "he shall slaughter," 16:11)." Milgrom, Leviticus 1-16, 579. Emphasis mine.

${ }^{156}$ Milgrom, Leviticus 1-16, 638, 1023.

${ }^{157}$ Milgrom, Leviticus 1-16, 153.

${ }^{158}$ Milgrom, Leviticus 1-16, 231-32.
} 
study suggests that the laying on of hands was performed in both private and public sacrifices which include (Lev 1:10, 9, 23; Num 28-29), but it was not performed in Lev 16 for specific reasons which are discussed below.

\section{Leviticus 1:10-11}

The absence of the laying on of hands in this text never attracted the attention of scholars since it is obvious that Lev 1:10-13 is an abbreviated pericope and included this gesture. Milgrom's reasoning regarding this pericope is in this direction. It is sufficient and well taken.

The sacrificial procedure is repeated, but in an abbreviated form. The omissions are expendable or can be otherwise accounted for. The hand-leaning and flaying can be omitted because in the bovine pericope their prescriptions contain the word 'ólâ (vv $4 a, 6 a)$, thereby indicating that these rites apply to all burnt offerings and not just to the bull (Abravanel; cf. Sipra, Nedaba 4:6). The priest's presentation, hiqrîb (v 5), has been incorporated into a new clause that has been added to the text (see at v 13). Finally, v 7 is deleted in its entirety lest one conclude that each new animal required additional wood and stoking. ${ }^{159}$

\section{Lev 1:14; 5:7-10, 14:22, 1}

Laying on of hands is never prescribed when a sacrificial animal was a bird (עוֹף), either turtledove (תקוֹר) or pigeon (יוֹנָה), (Lev 1:14, 5:7, 12:6, 8; 14:22, 15:14, 29; Num 6:10). The question arises whether this is an omission, abbreviation, or something else. A bird was an option for offering in case of burnt (Lev 1:14), sin (Lev 12:6, 8, 14:22, 30$31 ; 15: 14,29$; Num 6:10), and reparation offering (Lev 5:7, 11). The fact that GHS is human constant disadvantage in God's presence which was dealt with by the burnt

\footnotetext{
${ }^{159}$ Milgrom, Leviticus 1-16, 163.
} 
offering, and that sin was the primary problem that was resolved by the sin and reparation offering helps clarify whether the absence of laying on of hands in relation to the bird sacrifice was an omission, abbreviation, or something else. The most logical explanation was offered by Milgrom in his following quotations:

"Finally, the absence of hand-leaning in the procedure for the 'ōlâ of birds may also be due to the same circumstance: the bird is carried in the offerer's hands, so handleaning occurs automatically (see the COMMENT on vv 14-17). Thus the handleaning rite seems not to be required whenever the offering could be carried by hand, as in the cases of the ' $\bar{a} \bar{s} \bar{a} m$ money, the cereal offering, and the burnt offering of birds. ${ }^{160}$

Milgrom's explanation, also followed by Wright, assumes that the absence of laying on of hand/s in relation to a bird offering was not due to an omission or abbreviation, but rather, the offerer would hold the animal in his/her hand, thus perform laying on of his/her hand on it automatically. The present study accepts such an explanation as valid since on all three occasions when a bird offering was allowed, the reason was either GHS or sin and the bird sacrifice accomplished the same goal as when any other prescribed sacrificial animal was offered. Milgrom also noticed that "if a declaration accompanied the hand-leaning to specify the purpose of the sacrifice, it was a discrete, independent act (contra Péter 1977)."161

Some crucial regulations that would normally apply to sin offering are missing if a sin offering was a bird, such as (1) requirement of an unblemished shape, (2) animal gender regulation, ${ }^{162}$ (3) the exact place of offering, (4) acceptance statement is missing,

\footnotetext{
${ }^{160}$ Milgrom, Leviticus 1-16, 151.

${ }^{161}$ Milgrom, Leviticus $1-16,151$.

${ }^{162}$ Hartley, Leviticus, 23.
} 
and (5) atonement statement is missing. Of all of these points, only point 2 requires further explanation while all the other points are not questioned. They are assumed to be binding in the sacrificial process regardless of the type of sacrificial animal.

\section{Leviticus 9:8, 12, 15, 16, 18}

It is significant to note with Milgrom that the eighth day of priestly consecration is not like the previous seven days, which served "as millu' 'im, the investiture of the priesthood (chap. 8), and the consecration of the sanctuary (8:10-12) whereas the eighth day serves an entirely different purpose - the inauguration of the public cult conducted by its newly invested priesthood.",163

The sacrificial altar had a special place in the ritual of the eighth day. Milgrom's insights are again valid. He noticed that the emphasis in this chapter is on the procedures that are directly related to the sacrificial altar:

The concentration of the entire chapter is upon the altar, as demonstrated by the curtailed description of the sacrificial procedure, which omits nearly every rite that is unrelated to the altar (e.g., the hand-leaning) but includes every rite involving the altar, even the most minute (e.g., the disposition of the suet pieces, vv 19-20), climaxed by the unique theophany upon the altar (vv 23-24). ${ }^{164}$

Based on these insights that are derived from the texts, the present study believes, with Milgrom, that the laying on of hands was performed in this ritual. Milgrom rightfully ascribed its omission in the text, as well as the omission of all other rites unrelated to the altar, to the intention of the writer to stress the sacrificial altar that

\footnotetext{
${ }^{163}$ Milgrom, Leviticus 1-16, 571.

${ }^{164}$ Milgrom, Leviticus 1-16, 571.
} 
ultimately culminated in God's theophany on it. ${ }^{165}$ Gane's attempt to find support for the absence of laying on of hand/s in the calendric sacrifices in $2 \mathrm{Chr}$ 29:22 ${ }^{166}$ is challenged by the fact that this chapter is descriptive, rather than prescriptive text. In addition, like Lev 23 and Num 28-29, it is very abbreviated.

This emphasis in Lev 9 is placed on the altar, which correlates with the interpretation of the consecration of the priest in Exod 29 and Lev 8, as seen in the present study, where the emphasis was placed on the priests. Like in Exod 29:36-37, the verb כִֶֶּ in this context would refer to the cleansing and consecration of the altar and the atoning of the priests and people from their GHS (Lev 9:7). ${ }^{167}$

\section{Leviticus 16:6, 9, 11, 15, 24}

Gane proposed two reasons why the laying on of hands was not performed in the Lev 16:6, 9, 11, 15, 24 ritual. First, Gane built upon a valid observation that this text is prescriptive and not abbreviated as other passages and yet omits the laying on of hands on the burnt and sin offerings offered on the Day of Atonement. Second, Gane claimed that the laying on of hand/s is not needed since there is no ambiguity regarding the identity of the offerer in public/communal calendric sacrifices. The latter argument is based on the division of sacrifices into private non-calendric and public/communal calendric ones, placing the ritual of Lev 16 into the latter group.

The present study agrees with Gane's first argument and holds it sufficient for the

\footnotetext{
${ }^{165}$ Milgrom, Leviticus 1-16, 571.

${ }^{166}$ Gane, Cult and Character, 54n34.

${ }^{167}$ Wenham, The Book of Leviticus, 148.
} 
claim that the laying on of hands on the burnt and sin offerings before the sending away of the goat for Azazel was not performed nor needed. The second argument is not solid since it rests on the division of sacrifices that is unsustainable, as shown above in the subheading Omission or Abbreviation and discussed below under the subheading, Leviticus 23:8, 12, 18, 19, 27, 36, 37, 38 and Numbers 28-29.

Milgrom, on the other hand, believed that the laying on of hands was performed on the Day of Atonement and "must be similarly taken for granted." He justifies its absence from the text by the intention of the writer to emphasize "special and different function of the hand-leaning performed on the live goat." 168 The fact that the regulations of Lev 16 are prescriptive and detailed overrules Milgrom's argument.

It is important to note that the burnt and sin offering of the priests and people before the sending away of the goat for Azazel had a totally different function than regular, daily burnt and sin offerings, including the burnt offerings offered right after the goat for Azazel was sent away from the camp. It is clearly indicated in Lev 16:16 that this combination of offerings was primarily to remove sin from the sanctuary, which is never said for any other regular, daily offerings. Thus, having a totally different goal from other regular, daily sacrifices, this set of sacrifices on the Day of Atonement did not need laying on of hands in contrast to others that did.

\section{Leviticus 23:8, 12, 18, 19, 27, 36, 37, 38}

and Numbers 28-29

Milgrom and Gane followed Tannaites' claim (Sipra, Nedaba 4:2; m. Menaḥ.

\footnotetext{
${ }^{168}$ Milgrom, Leviticus 1-16, 579.
} 
9:8-9; t. Menah. 10:9-10; b. Menah. 92b) that laying on of hands was not performed on the calendric sacrifices offered at communal public feasts such as Lev 23 and Num 2829. ${ }^{169}$ Milgrom stated:

The Tannaites exempt the public sacrifices from hand-leaning except for the bull brought by the 'édâ (4:15) and the scapegoat (16:21) (m. Menah. 9:7). The latter, as noted above, falls into a different category of hand-leaning, and the former can hardly be called public: it is brought for the aggregate sins committed by the individual members of the community. ${ }^{170}$

Gane's two arguments for the absence of laying on of hands in Lev 16:6, 9, 11, 15,24 ritual, as discussed in the previous section, are also applied to the public/communal sacrifices of Lev 23: 8, 12, 18, 19, 27, 36, 37, 38 and Num 28-29. Regardless of Gane's remark that laying on of hands could have been performed on sacrifices during the public communal feasts, ${ }^{171}$ he favored the possibility that it was not. ${ }^{172}$ First, Gane based his position on the fact that the gesture was not prescribed in relation to burnt and sin offerings offered on the Day of Atonement. ${ }^{173}$ Gane's second argument stems from the understanding that the laying on of hands conveys ownership. The first argument is well taken and valid for the context of Lev 16, but is not methodologically sound to be used as an argument for Lev 23 because the Day of Atonement had a special and unique role within the sacrificial system. The second

\footnotetext{
${ }^{169}$ Milgrom, Leviticus 1-16, 153; Gane, Cult and Character, 54-55.

${ }^{170}$ Milgrom, Leviticus 1-16, 153.

171"I have found no evidence that hand-leaning is required in calendric sacrifices. It is true that most prescriptions for such sacrifices are severely abbreviated (e.g., Lev 23; Num 28-29), which seems to allow for the possibility that hand-leaning was performed, even though it is not mentioned." Gane, Cult and Character, 54.

${ }^{172}$ Gane, Cult and Character, 54-55n34.

${ }^{173}$ Gane, Cult and Character, 54.
} 
argument is based on the interpretation of laying on of hands.

However, the omission of the laying on of hand/s in the extremely abbreviated sacrificial regulations in Lev 23 and Num 28-29 does not necessarily confirm that the gesture was omitted. It is actually reasonable that the gesture was performed in both of these texts since the priests were the representatives of the people in public communal feasts. However, being prescriptive in nature, these texts rely on the previously established regulations in Lev 1-7 and thus, would include laying on of hands.

Gyung-Yul Kim noted that other crucial ritual activities, such as blood application, skinning of the animal, and so on were not mentioned in these two texts, but it is impossible that they were omitted. In addition, Kim also noted that these texts focus on the sacrificial items in a very limited way and omit instructions for the sacrificial procedures. ${ }^{174}$ His arguments correlate with the proposal of this study that these texts relied on Lev 1-7 for their sacrificial procedures in regards to both offerer and priest.

Based on the principles identified in the analysis of these texts in which the laying on of hand/s is omitted, I suggest that the laying on of hand/s was also implied in Lev 5:6, 15-16, 18, 25 [6:6], 12: 6-7, 14; 15:13, 19, 25; 19:20-22; Num 6:16; 15:24, 27.

\section{Leviticus 7:1-7-Reparation Offering}

One would also expect that the laying on of hand/s would be included in the prescription for the reparation offering in Lev 7:1-7, but it is not. The exclusion of the laying on of hand/s in this sacrifice is because the reparation offering of a ram could be converted into a money payment $(5: 15,18,25$ [Engl. 6:6]), which would be further

\footnotetext{
${ }^{174} \mathrm{Kim}$, "The Hattat Ritual," 107.
} 
handed directly to the priest. ${ }^{175}$ In addition, the absence of the laying on of hands in this text is justified by the point of view. That is, the regulations in Lev 1-5 are written from the point of view of the donor, while the regulations in Lev 6-7 are written from the point of view of the priest. ${ }^{176}$ The laying on of hands is not mentioned in any of the regulations in Lev 6-7. If, however, a ram were offered, the laying on of hand/s would have been performed. ${ }^{177}$

\section{Form of Laying on of Hands: Singular vs Plural vs Dual and Pressure or No Pressure}

Along with the meaning/function, the form of the gesture has been a matter of extensive debate. One of the first attempts to establish the form of it is credited to René Péter who suggested that there were two forms of this gesture and that the form affected the meaning of the gesture. ${ }^{178}$ Péter understood that laying on of one hand that occurs only in sacrificial contexts refers to "identification of the offerer with the animal," while the laying on of two hands appears in non-sacrificial contexts (Lev 16:21; 24:14; Num 8:10 (?); 27:18 (LXX), 23; Deut 34:9) and signifies transfer. ${ }^{179}$ Subsequently, Wright produced the next significant study of the gesture with the inclusion and support of insights from ANE literature. He accepted Péter's division of the gesture to the two forms that imply two different meanings, but he suggested different meanings for both forms:

\footnotetext{
${ }^{175}$ Gane, Cult and Character, 54.

${ }^{176}$ Milgrom, Leviticus 1-16, 117.

${ }^{177}$ Gane, Cult and Character, 63.

${ }^{178}$ Péter, “L'imposition des mains," 48-55.

${ }^{179}$ Péter, "L'imposition des mains," 52.
} 
This one-handed form of the gesture in sacrifices is best explained as ritually attributing the animal to the offerer; it indicates that the entire sacrificial rite pertains to him or her, even though others (priests and other auxiliaries) participate in making the offering later in the rite. ${ }^{180}$

The gesture performed with only one hand conveys the offerer's ownership of a sacrificial animal. It highlights the offerer's ownership of the sacrificial animal over the other assisting participants. ${ }^{181}$ The two-hand gesture demonstrates who or what is the result of the ritual action. ${ }^{182}$

Examining the sacrificial contexts, Péter and Wright noticed that the texts are consistent in using the singular, iדי? used in sacrificial contexts. They considered the forms where the subject is plural as a distributive plural, which means that each individual included in the subject lays one hand on the animal's head.

Recently, Calabro has challenged this theory and suggested that "the gesture uniformly employed both hands in the period before the Babylonian exile as well as in the Second Temple period." 183 Calabro found that this proposal is well confirmed by postbiblical sources ${ }^{184}$ which always used the plural of the noun "hand" in sacrificial

\footnotetext{
${ }^{180}$ Wright, "Hands, Laying of," 3:47.
}

${ }^{181}$ Gane has also articulated the acceptance of this meaning: "In the Israelite sacrificial system, the cases in which the biblical text specifies leaning one hand on the head of a victim correspond to those in which the identity of the offerer, to whom ownership of the victim is attributed and therefore to whom the benefits of the sacrifice accrue, would need to be indicated." Gane, Cult and Character, 62.

${ }^{182}$ Wright, "Hands, Laying of," 3:47.

${ }^{183}$ David Calabro, "A Reexamination of the Ancient Israelite Gesture of Hand Placement," in Sacrifice, Cult, and Atonement in Early Judaism and Christianity: Constituents and Critique, eds. Henrietta L. Wiley and Christian Eberhart, RBS 85 (Atlanta: SBL Press, 2017), 100, 111.

${ }^{184}$ Calabro, "A Reexamination,” 109-10. 
contexts. ${ }^{185}$ In proposing his hypothesis, besides the MT, he took into consideration the readings of the DSS and the LXX. The former witness contains texts of Lev 1:4; 3:2; 4:4; $16: 21 ; 24: 14$, and Num $8: 10 ; 27: 18$. Regardless of being fragmentary, the possible nominal reconstructions follow the MT reading. ${ }^{186}$ The latter witness consistently follows the MT except in Lev 3:2, 8, 13 and Num 27:18, where instead of the singular, the LXX utilizes the plural of the noun "hands."

Based on this difference between the LXX and the MT in Lev 3:2, 8, 13 and Num 27:18, Calabro suggested that the LXX variant reflects an earlier plural reading. This is how he explained this divergence of the LXX witness: "This textual variant in the LXX is not consistently carried through, and it could be explained as a sporadic attempt to harmonize the text with such passages as Lev 16:21; Num 27:23; and Deut 34:9, where the gesture is definitely two-handed. But it is also possible that the LXX variant reflects

\footnotetext{
${ }^{185}$ Philo Judaeus' De specialis legibus states: “Then the person bringing the offering must wash $\underline{\boldsymbol{h i s}}$ hands and lay (them) on the victim's head. After this, one of the priests must take (it) and slaughter (it), while another holds a vessel underneath, and after catching some of the blood, he must go in a circle around the altar and sprinkle (it) thereon .... In the hands laid on the animal's head there happens to be the clearest pattern of blameless actions, and of a life not burdened by things that incur accusation, but rather (a life) in harmony with the laws and ordinances of nature ... so that as soon as he does the laying on of hands, he can speak boldly out of a pure conscience and say thus: "These hands have neither taken a gift to do injustice, nor (taken) the proceeds of robbery and greediness, nor have they meddled with innocent blood." (Spec. 1.198-204)

Philo agrees with Mishnah: "All may perform hand placement, except for deaf-mute people, insane people, minors, blind people, foreigners, slaves, agents, and women. Hand placement is $a$ secondary commandment, (performed) on the head and with both hands. (The animal) is slaughtered on the spot where hand placement is performed, and the slaughtering follows the hand placement in immediate succession." (m. Menah. 9:8)

The Tosefta and Talmud Bavli also state that two hands are included: "How does one lay (his hands on the sacrificial animal)? The sacrificial animal stands to the north, its face to the west, and he lays (his hands on the animal) to the west, his face to the west. He rests his two hands on the ridge of the horns of the sacrificial animal. He does not rest his hands on the sacrificial animal's back, nor does he rest his hands one on top of the other, nor does anything intervene between the (two) hands and the horns." (t. Menah. 10:12"' b. Yoma 36a).

${ }^{186}$ Variants have different spellings of the $2 \mathrm{~ms}$ pronominal suffix in Num 27:18. Calabro, "A Reexamination," 107-8.
} 
an earlier plural reading." ${ }^{187}$ Textual critics agree that the Pentateuch was the first portion of the OT that was translated into Greek sometime between the middle of the third and second centuries BCE. As such, it predates the Masoretic vocalization on the MT which took place roughly in 7th century CE. Accordingly, Calabro arrived at the conclusion that the LXX variant of Lev 3 which used plural hands represents the faithful transmission of the original reading.

However, he dismissed the fact that all the other texts, $6 / 10$ plus the LXX's

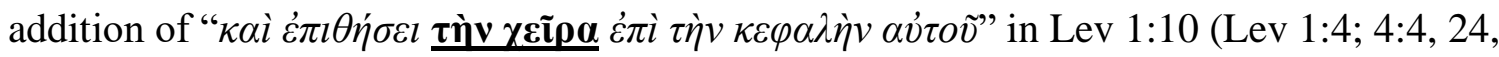
29, 33; Num 27:18), use the singular by arguing that "the fact that other portions of the Pentateuch have the singular 'hand' does not represent a challenge to this theory, since our current LXX text is most likely a composite of the efforts of many translators, even within individual books." ${ }^{\prime 188}$ However, a potential of the presence of multiple translators calls for equal treatment of all of them. In that case, there are more LXX translators who consistently followed the MT in using the singular of the noun "hand" than those who did not: $6+1 / 11$. This includes instances that are distributed in the same chapter, like Lev 4, in the same manner as the instances where the LXX translator/s changed the singular into the plural are distributed within one chapter, Lev 3 . The equation of $7 / 11$ instances where the LXX translator/s consistently and exactly followed the MT nominal number strongly opposes Calabro's suggestion. If all 24 texts that contain the laying on of hands are considered, the LXX's consistency in following the MT number of the noun "hand" is

\footnotetext{
${ }^{187}$ Calabro, “A Reexamination,” 108-9.

${ }^{188}$ Calabro, “A Reexamination,” 109n19.
} 
even greater. Accordingly, this argument is self-contradictory since even with the acceptance of multiple translators, within one book, the LXX translators still followed the MT in 20/24 places. In other words, the LXX translators followed the MT pointing in $83.3 \%$ and did not follow it in $17.7 \%$. The weight of the argument seems obvious in this case. Consequently, arguments to support Calabro's theory that the LXX in Lev 3:2, 8, 13 and Num 27:18 reflects original reading are insufficient.

In 12 other texts where the verb with a plural subject refers to "hand" in dual (Gen 27:23; 49:24: ${ }^{189}$ Exod 15:17; 17:12; ${ }^{190} 30: 19,{ }^{191} 21 ; 35: 25 ; 40: 31 ;{ }^{192} 7: 30$; Deut 21:6, $\left.7 ;{ }^{193} 34: 9\right)$, the two readings never differ in the number of the noun, that is, hand is always plural/dual. There is a disagreement with the number of subjects in the verbal forms in 3 texts (Gen 49:24; Exod 17:12; 30:19) and in Deut 21:7, ketiv of the MT has a singular verbal subject, but qere has the plural subject. The difference in the number of the verbal subject gives room for further research, as some rationale was suggested in the footnote of the listed texts but the nominal number is always consistent. In analyzing the nominal forms of "hand," when they are syntactically related to the verb (13 texts) as

\footnotetext{
${ }^{189}$ There is a disagreement in the verb's subject number, but not the noun. Namely, LXX has a singular verb and dual noun, whereas the MT has plurals/dual in both words.

${ }^{190}$ There are two syntactically related combinations of a verb and the noun "hand" in this text. In the first one, the LXX and the MT agree. They both have the verbal subject in the plural, and the noun "hand" in the plural/dual. For the second, the LXX has a plural for the verb's subject, contrary to the MT's singular, but "hands" are plural/dual in both variants. It is possible that the MT's singular was not meant to

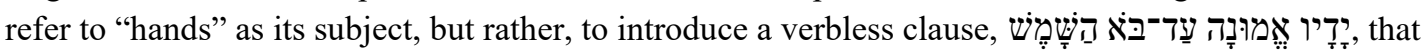
states what happened after Aaron and Hur supported Moses's hands.

${ }^{191}$ The LXX used the singular for the verb's subject, whereas the MT used the plural, but "hands" is plural/dual in both variants.

${ }^{192}$ The LXX is missing the translation of this text.

${ }^{193}$ The LXX used the plural for the verb's subject, whereas the MT used the singular ( $q$ 're suggests a plural reading), but the hands are plural/dual in both variants.
} 
well as other verbs (12 texts), it becomes obvious that the LXX is meticulously consistent with the MT.

Emanuel Tov noticed that number inconsistencies in the LXX can hardly be considered as the sign of an original reading because they can be explained as the presence of a variant or a non-variant. ${ }^{194} \mathrm{He}$ added that distinguishing between the two is uncertain even if the retroversion is possible. A correct retroversion should not be confused with the originality of the readings themselves. ${ }^{195}$ Tov also concluded:

Many of the changes in number in the translation derived from adaptations to the rules of the Greek language. Greek does not like combinations of a (collective) noun in singular with a plural verb nor, in fact, any incongruity of plural and singular forms. However, many harmonizations which were made in the LXX were also found in Hebrew manuscripts. ${ }^{196}$

However, the comparison of the LXX and the MT in 53 other texts (Table 27), ranging from Exodus to Numbers, that contain the singular of the noun "hand" shows deviations by the LXX that does not fit into Tov's description of LXX translational tendencies.

As the table above demonstrates, the LXX totally omitted 11/53 instances where the MT used the noun "hand." In the majority of those texts, the MT used "hand" idiomatically, as part of a phrase, so the LXX's omissions in those texts are not a concern (Exod 2:5, 16; 10:25; 16:3; 24:11; 35:29; 38:21; Lev 25:14; Num 2:17; 31:49; 35:25). Of the remaining 42 texts, the LXX changed the singular into the plural 16 times, including

\footnotetext{
${ }^{194}$ Emanuel Tov, The Text-Critical Use of the Septuagint in Biblical Research, 3rd ed. (Winona Lake, IN: Eisenbrauns, 2015), 169-78, especially 169-70.

${ }^{195}$ Tov, The Text-Critical Use of the Septuagint in Biblical Research, 170.

${ }^{196}$ Tov, The Text-Critical Use of the Septuagint in Biblical Research, 174.
} 
Table 27. LXX and MT singular agreement of the noun "hand"

\begin{tabular}{|c|c|c|c|c|c|c|c|}
\hline & \multirow[t]{2}{*}{ Reference } & \multicolumn{3}{|c|}{ MT } & \multicolumn{3}{|c|}{ LXX } \\
\hline & & verb & hand & $\begin{array}{l}\text { pron. } \\
\text { suff. }\end{array}$ & verb & hand & $\begin{array}{l}\text { pron. } \\
\text { suff. }\end{array}$ \\
\hline 1 & Exod 2:5 & $\mathrm{x}$ & $\mathrm{S}$ & $\mathrm{x}$ & $\mathrm{x}$ & omitted & omitted \\
\hline 2 & Exod 2:19 & $\mathrm{x}$ & $\mathrm{S}$ & $\mathrm{p}$ & $\mathrm{x}$ & omitted & omitted \\
\hline 3 & Exod 3:20 & $\mathrm{s}$ & $\mathrm{s}$ & $\mathrm{s}$ & $\mathrm{s}$ & $\mathrm{S}$ & omitted \\
\hline 4 & Exod 5:21 & $p$ & $\mathrm{~s}$ & $\mathrm{p}$ & $p$ & $\mathrm{P}$ & $\mathrm{P}$ \\
\hline 5 & Exod 7:5 & $\mathrm{s}$ & $\mathrm{s}$ & $\mathrm{s}$ & $\mathrm{s}$ & $S$ & omitted \\
\hline 6 & Exod 7:17 & $\mathrm{x}$ & $\mathrm{s}$ & $\mathrm{s}$ & $\mathrm{s}$ & $\mathrm{S}$ & $\mathrm{S}$ \\
\hline 7 & Exod 7:19 & $\mathrm{s}$ & $\mathrm{s}$ & $\mathrm{s}$ & $\mathrm{s}$ & $\mathrm{S}$ & $\mathrm{S}$ \\
\hline 8 & Exod 8:17 & $\mathrm{s}$ & $\mathrm{s}$ & $\mathrm{s}$ & $\mathrm{s}$ & $\mathrm{S}$ & omitted \\
\hline 9 & Exod 10:25 & $\mathrm{s}$ & $\mathrm{s}$ & $p$ & $\mathrm{~s}$ & omitted & omitted \\
\hline 10 & Exod 12:11 & $\mathrm{x}$ & $\mathrm{s}$ & $p$ & $\mathrm{x}$ & $\mathrm{P}$ & $\mathrm{P}$ \\
\hline 11 & Exod 13:3 & $\mathrm{s}$ & $\mathrm{s}$ & $\mathrm{x}$ & $\mathrm{s}$ & $\mathrm{S}$ & omitted \\
\hline 12 & Exod 14:8 & $\mathrm{x}$ & $\mathrm{s}$ & $\mathrm{x}$ & $\mathrm{x}$ & $\mathrm{S}$ & omitted \\
\hline 13 & Exod 14:16 & $\mathrm{s}$ & $\mathrm{s}$ & $\mathrm{s}$ & $\mathrm{s}$ & $\mathrm{S}$ & $\mathrm{S}$ \\
\hline 14 & Exod 14:21 & $\mathrm{s}$ & $\mathrm{s}$ & $\mathrm{s}$ & $\mathrm{s}$ & $\mathrm{S}$ & omitted \\
\hline 15 & Exod 14:26 & $\mathrm{s}$ & $\mathrm{s}$ & $\mathrm{s}$ & $\mathrm{s}$ & $\mathrm{S}$ & $\mathrm{S}$ \\
\hline 16 & Exod 14:27 & $\mathrm{s}$ & $\mathrm{s}$ & $\mathrm{s}$ & $\mathrm{s}$ & $\mathrm{S}$ & $\mathrm{S}$ \\
\hline 17 & Exod 14:31 & $\mathrm{x}$ & $\mathrm{s}$ & $\mathrm{x}$ & $\mathrm{x}$ & $\mathrm{S}$ & $\mathrm{X}$ \\
\hline 18 & Exod 15:20 & $\mathrm{s}$ & $\mathrm{s}$ & $\mathrm{s}$ & $\mathrm{s}$ & $\mathrm{S}$ & $\mathrm{S}$ \\
\hline 19 & Exod 16:3 & $\mathrm{x}$ & $\mathrm{s}$ & $\mathrm{x}$ & $\mathrm{x}$ & omitted & omitted \\
\hline 20 & Exod 19:13 & $\mathrm{s}$ & $\mathrm{s}$ & $\mathrm{x}$ & $\mathrm{s}$ & $\mathrm{S}$ & omitted \\
\hline 21 & Exod 23:31 & $\mathrm{s}$ & $\mathrm{s}$ & $\mathrm{p}$ & $\mathrm{s}$ & $\mathrm{P}$ & $\mathrm{P}$ \\
\hline 22 & Exod 24:11 & $\mathrm{s}$ & $\mathrm{s}$ & $\mathrm{s}$ & $\mathrm{s}$ & omitted & omitted \\
\hline 23 & Exod 28:41 & $\mathrm{s}$ & $\mathrm{s}$ & $p$ & $\mathrm{~s}$ & $\mathrm{P}$ & $\mathrm{P}$ \\
\hline 24 & Exod 29:29 & $\mathrm{s}$ & $\mathrm{s}$ & $\mathrm{p}$ & $\mathrm{s}$ & $\mathrm{P}$ & $\mathrm{P}$ \\
\hline 25 & Exod 29:33 & $\mathrm{s}$ & $\mathrm{s}$ & $p$ & $\mathrm{~s}$ & $P$ & $P$ \\
\hline 26 & Exod 32:4 & $\mathrm{s}$ & $\mathrm{s}$ & $p$ & $\mathrm{~s}$ & $\mathrm{P}$ & $\mathrm{P}$ \\
\hline 27 & Exod 32:15 & $\mathrm{x}$ & $\mathrm{s}$ & $\mathrm{s}$ & $\mathrm{x}$ & $\mathrm{P}$ & $\mathrm{S}$ \\
\hline 28 & Exod 32:29 & $p$ & $\mathrm{~s}$ & $p$ & $\mathrm{p}$ & $P$ & $P$ \\
\hline 29 & Exod 35:29 & $\mathrm{x}$ & $\mathrm{s}$ & $\mathrm{s}$ & $\mathrm{x}$ & omitted & omitted \\
\hline 30 & Exod 38:21 & $\mathrm{x}$ & $\mathrm{s}$ & $\mathrm{x}$ & $\mathrm{x}$ & omitted & omitted \\
\hline 31 & Lev 3:2 & $\mathrm{s}$ & $\mathrm{s}$ & $\mathrm{s}$ & $\mathrm{s}$ & $\mathrm{P}$ & omitted \\
\hline 32 & $\begin{array}{l}\text { Lev 3:8 } \\
\end{array}$ & $\mathrm{s}$ & $\mathrm{s}$ & $\mathrm{s}$ & $\mathrm{s}$ & $\mathrm{P}$ & omitted \\
\hline 33 & Lev 3:13 & $\mathrm{s}$ & $\mathrm{s}$ & $\mathrm{s}$ & $\mathrm{s}$ & $\mathrm{P}$ & omitted \\
\hline 34 & Lev 8:33 & $\mathrm{s}$ & $\mathrm{s}$ & $p$ & $\mathrm{~s}$ & $\mathrm{P}$ & $\mathrm{P}$ \\
\hline 35 & Lev 22:25 & $\mathrm{x}$ & $\mathrm{s}$ & $\mathrm{x}$ & $\mathrm{x}$ & $\mathrm{S}$ & $\mathrm{X}$ \\
\hline 36 & Lev 25:14 & $\mathrm{p}$ & $\mathrm{s}$ & $\mathrm{x}$ & $\mathrm{s}$ & omitted & $\mathrm{X}$ \\
\hline 37 & Lev 26:25 & $\mathrm{x}$ & $\mathrm{s}$ & $\mathrm{x}$ & $\mathrm{x}$ & $P$ & $\mathrm{X}$ \\
\hline 38 & Num 2:17 & $\mathrm{p}$ & $\mathrm{s}$ & $\mathrm{s}$ & $\mathrm{p}$ & omitted & omitted \\
\hline 39 & Num 3:3 & $\mathrm{s}$ & $\mathrm{s}$ & $p$ & $p$ & $\mathrm{P}$ & $\mathrm{P}$ \\
\hline 40 & Num 4:37 & $\mathrm{x}$ & $\mathrm{s}$ & $\mathrm{s}$ & $\mathrm{x}$ & $\mathrm{S}$ & $\mathrm{S}$ \\
\hline 41 & Num 4:45 & $\mathrm{x}$ & $\mathrm{s}$ & $\mathrm{s}$ & $\mathrm{x}$ & $\mathrm{S}$ & $\mathrm{S}$ \\
\hline 42 & Num 4:49 & $\mathrm{x}$ & $\mathrm{s}$ & $\mathrm{s}$ & $\mathrm{x}$ & $\mathrm{S}$ & $\mathrm{S}$ \\
\hline 43 & Num 5:18 & $p$ & $\mathrm{~s}$ & $\mathrm{~s}$ & $\mathrm{~s}$ & $\mathrm{~S}$ & $\mathrm{~S}$ \\
\hline 44 & Num 9:23 & $\mathrm{x}$ & $\mathrm{s}$ & $\mathrm{s}$ & $\mathrm{x}$ & $\mathrm{S}$ & $\mathrm{S}$ \\
\hline 45 & Num 10:13 & $\mathrm{x}$ & $\mathrm{s}$ & $\mathrm{s}$ & $\mathrm{x}$ & $\mathrm{S}$ & $\mathrm{S}$ \\
\hline 46 & Num 14:30 & $\mathrm{s}$ & $\mathrm{s}$ & $\mathrm{s}$ & $\mathrm{s}$ & $\mathrm{S}$ & $\mathrm{S}$ \\
\hline 47 & Num 20:11 & $\mathrm{s}$ & $\mathrm{s}$ & $\mathrm{s}$ & $\mathrm{s}$ & $\mathrm{S}$ & $\mathrm{S}$ \\
\hline
\end{tabular}


Table 27-Continued.

\begin{tabular}{|l|l|l|l|l|l|l|l|}
\hline 48 & Num 22:7 & x & s & p & x & P & P \\
\hline 49 & Num 24:24 & x & s & p & x & S & P \\
\hline 50 & Num 31:49 & x & s & p & & omitted & P \\
\hline 51 & Num 33:1 & x & s & p & x & S & P \\
\hline 52 & Num 33:3 & p & s & x & p & S & X \\
\hline 53 & Num 35:25 & x & s & x & x & omitted & X \\
\hline
\end{tabular}

Lev 3 texts (Exod 5:21; 12:11; 23:31; 28:41; 29:29, 33; 32:4, 15, 29; Lev 3:2, 8, 13; 8:33; 26:25; Num $3: 3 ; 22: 7)$. This is $38 \%$ of the occurrences. The LXX precisely follows the MT in the rest of 26 texts, $62 \%$. The verbal subject changed along with the noun in Exod 5:21 and $32: 29,2 / 42$ or $4.7 \%$. Contrary to the Tov's description, the LXX followed the MT once in Num 33:3 even though the "Greek does not like combinations of a (collective) noun in singular with a plural verb." ${ }^{197}$ Having proven that the incongruity of plural and singular forms in the LXX is even bigger than Tov presented, this adds even more: "As a result of these uncertainties, it is almost impossible to evaluate deviations in the LXX in many grammatical categories. Because many aspects of the translation techniques cannot be analyzed satisfactorily, no reliable variants can be reconstructed in these areas." $" 198$

Thus, Calabro's proposal that the LXX reading of Lev 3:2, 8, 13 represents an "original reading" is dismissed in the present study for two reasons. First, of 11 singular uses of the noun "hand" in texts where this noun is syntactically related to the verb the LXX and the MT agree in 6/11. In addition, the singular "hand" is used in a clause

\footnotetext{
${ }^{197}$ Tov, The Text-Critical Use of the Septuagint in Biblical Research, 174.

${ }^{198}$ Tov, The Text-Critical Use of the Septuagint in Biblical Research, 170.
} 
included in the LXX and not in the MT (Lev 1:14), which is a total of 7/11 times (i.e., $63 \%)$.

Second, when the singular of the noun "hand" is analyzed, the LXX follows the MT in 26/42 occurrences, 62\% (the MT contains 11 more occurrences which are excluded, since the LXX omitted the singular of the noun "hand," in the process of translating the phrases). The LXX changed the singular to the plural in 16/42 occurrences, $38 \%$.

Third, the LXX and the MT are in total agreement in their use of the plural of the noun "hand." This agreement is present in all 13 texts where the verb סֵַָٍ is syntactically related to the plural of the noun "hand." It also translates to 12 more texts where verbs other than ợמָּ are syntactically related to the plural of the noun "hand," that is, the LXX and the MT agree in all texts.

Calabro stated that "of course, neither of these observations constitutes proof that hand placement in the biblical period always involved two hands and not one." 199 This statement is confirmed by the analysis presented in the present study. The three points above show that Calabro's proposal is not sustainable in the present form. Based on the nature of its inadequacies the present study reasons that further research will not change this.

Going beyond the textual criticism arguments, Calabro further suggested that biblical data provide three further arguments to support his proposal of the "two hands" gesture. Calabro's first argument deals with the defective plural of the noun "hand" and

\footnotetext{
${ }^{199}$ Calabro, “A Reexamination,” 111.
} 
the second and third arguments deal with the number of the noun "hand" when the $3 \mathrm{mp}$ pronominal suffix is attached to it.

First, Calabro pointed out that the only text in which the noun "hand" is plural is Lev 16:21 and that it has defective writing of this noun, ידיו instead of stated that "if it were not for the explicit mention of 'two hands,' one would easily read the consonantal text's ידו as a reference to one hand." That led him to suggest that "this raises the possibility that ידו in the other passages is also a defective writing (such defective writings are actually quite common in this part of the Pentateuch) and that the vocalization as a singular in these passages is simply based on an ad hoc reading of the consonantal text." ${ }^{200}$ Consequently, this defective writing points to the plural of "hand."

To support this, he listed two more texts where the MT has defective writing. The first text is Num 27:18, where "hand" is in singular, but in v. 23, the MT changes it to a dual. The LXX translated the noun "hand" in both verses with the plural. Calabro might well be right on this point. In other words, the LXX's harmonization might point to the MT's haplography or an accidental mistake, ${ }^{201}$ and the LXX should be preferred reading.

The second text is Lev 9:22, where again, the consonantal text points to the singular, but the pointing to the dual. In the latter case, one ', either of the nominal plural ending or the initial consonant of the pronominal suffix, is missing. Calabro found the support for the two hands gesture in blessings to be well established "from the synagogue service at the time when the vowel points were added to the Hebrew text (around

\footnotetext{
${ }^{200}$ Calabro, “A Reexamination,” 111.

${ }^{201}$ J. Harold Greenlee, Introduction to New Testament Textual Criticism (Grand Rapids, MI: Eerdmans, 1964), 115.
} 
700 CE)." ${ }^{202}$ However, the pointing Calabro referred to is totally different from the potential pointing that the MT would have if it used plural. The plural of hands in never expressed by addition of masculine plural ending, as the form Calabro referred to used,

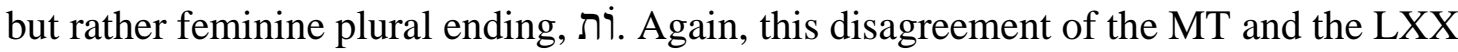
might be the MT's haplography or an accidental mistake, as in the case of Num 27:18.

Calabro's arguments are partially correct and they do not lend solid ground for the claim that LXX reading points to the MT's pattern in which its defective writing of the singular noun "hand" was its way to express dual of this noun. First, defective writing is clearly indicated at the time pointing was introduced and the inclusion of qere for all these texts which Calabro cited (Lev 9:22, 16:21 and Num 27:18) suggests dual form of the noun. However, all other 18 occurrences of the dual of noun "hand" are properly spelled, ידיו. So, this represent 18/21 examples of properly spelled dual of the noun "hand," which is $85.7 \%$, and 3/21 with defective writing for which Masoretic pointing supplies that they should have spelled as dual, which is $14.3 \%$. It is not impossible to claim that defective writing that includes the omission of such small letter like' can be the basis for the intent of the translator/s to convey certain pattern or interpretation ${ }^{203}$ but being a very minor and regular deviation ${ }^{204}$ it requires more thorough analysis and more solid arguments. This study totally disagrees with Calabro's suggestion that the defective

\footnotetext{
${ }^{202}$ Calabro, "A Reexamination," 111.
}

${ }^{203}$ Slaviša Janković, "The Textual Evidence of the Omission Found in the LXX Translation of Lev 16:14-15" (paper presented at the 2016 Midwest Region Meeting of the SBL, Bourbonnais, IL, 5-7 February 2016).

${ }^{204}$ Ernst Würthwein, The Text of the Old Testament: An Introduction to the Biblia Hebraica, 2nd ed., rev. and enl. (Grand Rapids, MI: Eerdmans, 1995), 111. 
use of plural of the noun "hand" point to the regular expression of the dual in the MT. He stated that "the usual method in pointing defectively written examples of the word T? "hand" in ritual hand gestures was to go with the singular in every case, except in specific instances where the dual was obvious."

Calabro's second and third points are well taken. In his second point he noted that the form ידיהם definitely presupposes the existence of plural form of "hands" ידים which

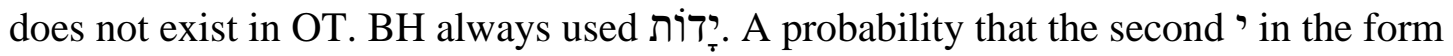
ידיהם might be the MT's mistake is refuted by Calabro's third point, namely, the plural form of body parts conflicts with the grammatical expression of the body parts in $\mathrm{BH}$. Body parts are usually expressed by dual. Calabro stated: "It is a lesser known, but nevertheless firmly established, aspect of Hebrew grammar that the words for body parts and other 'inalienably possessed' things, when bound to a plural genitive, tend to remain grammatically singular or dual, depending on whether the possessor is using one or two of them." ${ }^{205}$ This practically means that $\mathrm{BH}$ makes a reference to one hand of each participant, the pattern is to use a singular noun with a plural suffix attached to it, This would literally mean "their hand."

This study recognizes the complexity of the LXX and the MT number disparity concerning the noun "hand" which is complicated even more by the fact that grammatical patterns of uses of only one hand or both are sometimes overruled by the sameness of the context. For instance, this study claims that one hand is used in Lev. $1: 4 ; 3: 2,8,13 ; 4: 4$,

\footnotetext{
${ }^{205}$ Calabro, "A Reexamination," 113. For a more detailed explanation of this phenomenon, see Alan Henderson Gardiner, Egyptian Grammar: Being an Introduction to the Study of Hieroglyphs, 3rd ed. (Oxford: Griffith Institute, 2005).
} 
24, 29, 33 based on a consistent and explicit MT reading, and that potentially two hands of one person were involved in Exod 29:10, 15, 19; Lev 4:15; 8:14, 18, 22; 16:21; 24:14; Num $8: 10,12 ; 27: 18,23$; Deut $34: 9$ based on the patterns of use of the plural of the noun "hand" conducted on pp. 670-71. However, this delineation is potentially overruled in at least one text, Lev 4:15, since, based on the grammatical pattern, two hands were potentially used in this text, but Lev 4 in all other instances, vv. 4, 24, 29, and 33, used only one hand. Grammatical ambiguity related to the last set of texts where potentially two hands as well as one could have been used. The conclusion of the present study is that the form of gesture is insignificant and does not affect its meaning/function. This understanding of the form answers the valid question Kiuchi raised as to whether a difference in form implies a difference in symbolic meaning. ${ }^{206}$ The answer is "no." The biblical text confirms that there were two forms, but no different meanings. At this point, the presence of different forms remains a matter of further research in terms of discovering new manuscripts that contain the texts in question.

Calabro's reliance on post-biblical texts is highly questionable since these texts can hardly be used to reconstruct the form of the gesture that was introduced and prescribed several centuries before their time. These texts should, rather, be taken as an interpretation of Pentateuch material, rather than its equal. The interaction between these two materials should also be in the context of a precisely established method that would explicitly define interaction between them.

\footnotetext{
${ }^{206}$ Kiuchi, Purification Offering, 153; Gane, Cult and Character, 244-45; JoAnn Scurlock, "The Techniques of the Sacrifice of Animals in Ancient Israel and Ancient Mesopotamia: New Insights through Comparison, Part 1," AUSS 44 (2006): 25.
} 


\section{Pressure or No Pressure}

Rabbis commonly understood that the verb סָמַָ, when associated with hands, referred to the activity that includes pressure on the recipient of the action. ${ }^{207}$ Daube sustained this understanding by comparing the gesture of laying on of hands expressed by

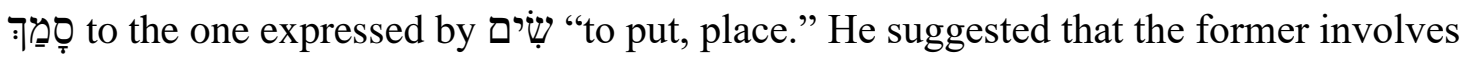
"vigorous leaning," whereas the latter is gentler in nature. ${ }^{208}$ However, Wright correctly argued that ợ might be idiomatic, without any indication that pressure is involved. The

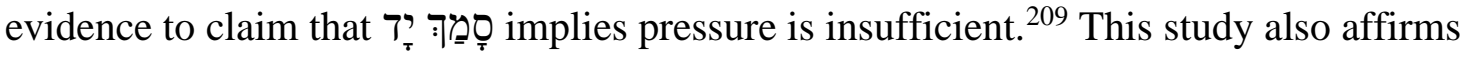
this claim.

\section{The Function/Meaning of Laying on of Hand/s}

As presented in the introduction of the current study, there are five major theories on the function/meaning of laying on of hand/s in the Pentateuch: (1) transfer/substitution theory, (2) identification/substitution theory, (3) consecration/dedication/presentation theory, (4) appropriation-ownership/designation theory, and (5) manumission theory. As their names disclose and as demonstrated in the introduction, there is a lot of overlap among them.

The quest for the function/meaning of this gesture is severely obscured by the fluidity and imprecision of terminology used, along with inaccurate conclusions resulting

\footnotetext{
${ }^{207}$ Milgrom, Numbers, 235.

${ }^{208}$ Daube, The New Testament and Rabbinic Judaism, 224-26.

${ }^{209}$ Wright, "Hands, Laying of," 3:37.
} 
from selective and incomprehensive reading of the texts. Transfer, substitution, and identification are often mutually paired and/or related to other theories. Transfer includes transmission of various elements such as evil, sin, authority, power, identity, and personality. Transfer of personality was associated with several slight modifications. ${ }^{210}$

\section{Critique of Theories}

This subsection deals with all other theories except the transfer/substitution and the appropriation-ownership/designation theory since they, as the most debated ones, are discussed separately below. The manumission theory is also not analyzed, since its only point of difference with the appropriation-ownership/designation theory is that in the former, the offerers renounced the right of property over the sacrifice, ${ }^{211}$ while in the latter, the offerers communicated ownership over their sacrifice.

\section{Identification/Substitution Theory}

Robinson proposed that the laying on of hand/s represents total and ontological identification of the offerers and their sacrificial animal. The animal, in a way, literally becomes the offerer. This nuance of identification/substitution theory is alien to the OT. The meaning/function of this ritual gesture is, rather, found in its symbolic interpretation. ${ }^{212}$ Rowley included symbolism in his interpretation of this gesture and

\footnotetext{
${ }^{210}$ Mattingly, "The Laying on of Hands on Joshua," 149-56; Kurtz, Offerings, 83.

${ }^{211}$ Eichrodt, Theology of the Old Testament, 2:165-66; Antonio Charbel, Zevah shelamim: Il sacrificio pacifico nei suoi riti e nel suo significato religioso e figurativo (Jerusalem: Commercial Press, 1967), 38n27; Merwe, "The Laying on of Hands in the Old Testament," 40; Vriezen, An Outline of Old Testament Theology, 263.

${ }^{212}$ Mattingly, "The Laying on of Hands on Joshua," 147.
} 
proposed that the offerers identify with their sacrificial animal in order that the death of the animal might symbolically remove any obstacle that separate them from God. ${ }^{213}$ Milgrom criticized this theory on the basis that it is magical and that a belief that death brings one closer to God is embedded in it. ${ }^{214}$ However, regardless of these non-biblically confirmed conceptions related to the identification theory, one can think that the offerers could symbolically perceive their offering as their own representative and/or substitute before God. The laying on of hand/s on the Levite had that meaning. ${ }^{215}$ This identification should not be understood as "identifying of," but rather, "identified with." ${ }^{216}$ However, this meaning/function cannot be the primary one due to the lack of explicit support from texts, especially in prevailing sacrificial contexts. It denies a crucial element of the sacrificial process which is sin/GHS that needs to be dealt with. No transfer is involved.

\section{Consecration-Separation/Dedication/Presentation Theory}

Rodríguez identified a valid weakness of this theory. He claimed that it would be more substantial if a priest performed a laying on of hand/s. He noted that the sinners come to the sanctuary to obtain forgiveness via their sacrifice and is not in the position to 1967), 133.

\footnotetext{
${ }^{213}$ Harold Henry Rowley, Worship in Ancient Israel: Its Forms and Meaning (London: S.P.C.K.,
}

\footnotetext{
${ }^{214}$ Milgrom, Leviticus 1-16, 151.

${ }^{215}$ Mattingly, “The Laying on of Hands on Joshua," 150.

${ }^{216}$ Péter, "L'imposition des mains," 53.
} 
consecrate/dedicate/present anything to God prior to being forgiven. ${ }^{217}$ His primary goal is to change his unfavorable status before God.

Mattingly incorrectly criticized Rodríguez on this point, arguing from the nonbiblical theory of sacrifice where a sacrifice is an offering or giving over of something to the realm of holy, God in this case. Mattingly argued that consecration had to be completed before the ritual ended and was a prerequisite to forgiveness. On this basis, he also criticized Rodríguez's point that the offerer cannot consecrate anything to God before obtaining forgiveness. ${ }^{218}$

First, Rodríguez's argument that the offerers first need to obtain forgiveness prior to being able to consecrate/dedicate/present something to God might be limiting the contexts of sacrificial offering only to those where the offerers make a sin or reparation offering. Leviticus 1-3 portrays situations of sacrificial offering in which sin was not included, yet all included a laying on of hand/s. However, the offerers would at all times bear their GHS that would put them in an unfavorable status before God which needed to be altered. This understanding of human nature and its constant unfavorable status before God negates the gift theory of sacrifice. If the offerers' sin was not dealt with by a sacrificial offering, then the sacrifice addressed their GHS. The offerer would admit their GHS and through the laying on of hand/s, transfer it to the animal that would, through its death, enable them to live and freely commune with God. Thus, Mattingly's critique of

\footnotetext{
${ }^{217}$ Rodríguez, "Substitution in the Hebrew Cultus," 205.

${ }^{218}$ Mattingly, "The Laying on of Hands on Joshua," 147.
} 
Rodríguez was based on a partially valid and unsustainable argument if all sacrificial contexts are taken into consideration.

Second, the process of consecration or sanctification is never in the domain of an ordinary individual in biblical legislation. It is always priests or Moses who sanctified the priests, who are involved in this process and never ordinary individual/s.

Third, it is God himself who consecrate/sanctifies in the OT. That fact is emphasized in any ritual which culminates in consecration/sanctification of an entity. The separation nuance of this theory is even less sustainable. Just the fact that a sacrificial animal is brought to the sacrificial altar is testament of the fact that it separated/set apart from the larger group for a special purpose. Laying on of hand/s would be redundant and as such, not needed.

Finally, Pentateuch legislation never uses the verbs of dedication with the offerer as a subject and sacrifice as a direct object in Lev 1-7. The only text where it is explicitly stated that sacrifices are dedicated to God is Lev 22:2-3. However, "holy gifts" refer to well-being offering ${ }^{219}$ of which the offerers would keep the most and give a thigh to the priest. The dedication theory is unsustainable.

Henry Preserved Smith argued that sacrifice itself is sacred based on the fact that its blood had cleansing power emanating from its sacredness. Thus, the offerers would partake of the sanctity of the sacrificial animal. ${ }^{220}$ The offerers would be purified via contact with the animal. Rodríguez noted a significant weakness of this proposal. The

\footnotetext{
${ }^{219}$ Hartley, Leviticus, 355. Wenham, The Book of Leviticus, 294. Milgrom, to the contrary, argued for the inclusive meaning of "the holy gifts" to include all sacrifices. Milgrom, Leviticus 17-22, 1729.

${ }^{220}$ Smith, "The Laying-on of Hands," 56-57.
} 
sacrificial animal is never sacred. It should be without blemish (Lev 1:3) to be

acceptable, ${ }^{221}$ but it becomes holy after it is offered, not before. The cleansing power of blood does not stem out of the animal's sacredness, but out of divine regulation (Lev

17:11).

\section{Key Misconceptions in Laying on of Hand/s Debate}

Calabro identified at least three reasons that prevent a correct interpretation of this gesture in scholarly debate concerning the laying on of hands. The current study fully agrees on the first, but disagrees with the second and third reasons.

First, previous researchers shared the assumption that the form of this gesture consistently correlate with its meaning/function. Foundational to this assumption is that there are two forms, one and two hands gestures, each of which has a distinct meaning. The one hand gesture conveyed the ownership or identification of the offerer, whereas the two hands gesture meant transfer or identification of its route, designation, partaking of sanctity of animal, substitution, designation. However, the emphasis on the two separate forms did not prevent overlaps between their meaning/function. ${ }^{222}$ Thus, the emphasis of some scholars on the form of the gesture did not bring clarity to its meaning/function.

Second, scholars usually assume that meanings/functions are mutually exclusive, which might not be the case. This is true since the history of interpretation shows that interpreters usually focus only on one or two, as in the case of two forms of gesture or interpretations and apply all others to them. However, this study disagrees with the

\footnotetext{
${ }^{221}$ Rodríguez, "Substitution in the Hebrew Cultus," 206.

${ }^{222}$ See Calabro's historical review table on the interpretation of both forms of the gesture. Calabro, “A Reexamination," 118-19.
} 
Calabro's background of this reason. That is, he followed Propp ${ }^{223}$ and Robertson Smith ${ }^{224}$ who proposed that there were two different understandings of the laying on of hands, the priestly author's one and the popular one. Calabro went on to state that "different people in the society likely held different interpretations of the same gesture. Some of those interpretations may have aligned with different social strata, religious viewpoints, and locations in space and time." OT texts do not support such a claim. On the contrary, sacrificial regulations in Lev 1-5 in chap. 1-3 do not refer to any specific social group within community, but rather, imply anyone in the society. An individual is given freedom within his/her financial means to choose the type of sacrificial animal. However, sacrifices had the same purpose in any case, acceptance and/or atonement. Thus, based on the texts, the presence of societal classes does not imply different interpretations of the same ritual. There are certain modifications of the sacrificial animal in Lev 4-6:7 based on social status, but the sacrifices always had the same meaning, forgiveness. In addition, given the fact that the two sets of sacrificial regulations were written for different audiences, Lev 6:8-7 also does not contain any hints that would indicate various interpretations of the sacrificial ritual. As stated above, they just clarify details that pertain to the priest personnel. Therefore, being unsupported by OT text, this background is rejected but the reason proposed based on this background is confirmed by the history of interpretation and is valid.

Third, Calabro stated that "many try to fit ancient practice within a framework of

${ }^{223}$ Propp, Exodus 19-40, 458.

${ }^{224} \mathrm{~W}$. Robertson Smith, Lectures on the Religion of the Semites, new ed., Burnett Lectures [Aberdeen University] 1888-89 (London: A. \& C. Black, 1894), 422. 
logical relationships that is characteristic of modern Western philosophy.” These logical relationships of Western philosophy are concepts like identification, designation, and attribution. However, it is questionable whether these concepts are exclusively constructs of Western philosophy. As Calabro stated, these constructs naturally emanate out of the logic of the sacrificial process.

The function of designation, for example, arises naturally from the direct contact involved in hand placement (which unambiguously points out the recipient) and from the fact that the gesture immediately precedes further ritual performance on the recipient. Likewise, since the protocol of sacrifice assumes that the animal receiving hand placement belongs to the one making the offering and is to be accepted on his behalf (Lev 1:2-4), the gesture would tend to carry an attributive function. ${ }^{225}$

The fact that they were not defined or stated in these texts does not mean that they were not present in people's perception of certain parts of the sacrificial offering process. It is true that the English verb "to identify," the noun "identification," and the adjective "identifiable" emerge in the time of modern Western philosophy in the English language, but at least a verb with the identical semantic range with which it is used in modern Western philosophy was in use as early as $350 \mathrm{AD} .{ }^{226}$ The verbs "to

${ }^{225}$ Calabro, “A Reexamination," 121.

${ }^{226}$ The origin of English verb "to identify" comes from possibly three sources: (1) Old Latin identitias plus Latin -ficiare, (2) the medieval Latin identificare, or (3) French identifier, from identité. The first English record was detected in 1769 with the meaning to "determine the identity of, recognize as or prove to be the same." The meaning "make one (with), associate (oneself), regard oneself as being the essence of" was detected in 1780. The sense of "serve as means of identification" is attested by 1886 . Etymonline, s.v. "Identify (v.)," released 17 Feb 2019, https://www.etymonline.com/word/ identify\#etymonline_v_1483. The noun "identification" was detected in the 1640s with the meaning of "treating of a thing as the same as another; act of making or proving to be the same," and it comes from French identification, probably from identifier. The psychological sense of "becoming or feeling oneself one with another" was detected in 1857 . The meaning "act or process of determining the identity of something" was found in 1859. The meaning "object or document which marks identity" is from 1947. Etymonline, s.v. "Identification (n.)," released 17 Feb 2019, https://www.etymonline.com/word/ identification\#etymonline_v_34531. Adjective "identifiable" was found 1804. Etymonline, s.v. "Identifiable (adj.)," released 17 Feb 2019, https://www.etymonline.com/search?q=Identifiable+. Also see Oxford English Dictionary, s.v. "Identify," released 17 Feb 2019, https://en.oxforddictionaries.com/ definition/identify. 
designate" 227 and "to attribute"228 also originate from Latin or French, languages that

were in use since the 4th century. This basic data proves that the use of these words

predates the dialogue of modern Western Philosophy. Calabro's assessment that terms

like identification, designation, and attribution are constructs of modern Western

Philosophy seems not to be correct, perhaps leaving this part of his research without

relevant references that would confirm this.

Building on these mainly inaccurate claims, Calabro suggested a methodology

that this study completely supports. "A close reading of the Hebrew texts, with careful

attention to words and phrases that are structurally aligned with descriptions of the

\footnotetext{
${ }^{227}$ The English verb "to designate" was formed either (1) as a back-formation from the noun "designation," (2) from the adjective "designate," or (3) from the Latin designatus. The first record with the meaning "to appoint or select for a particular purpose" was noted in 1791, whereas the meaning "to mark out or indicate" was noted in 1818. Etymonline, s.v. "Designate (v.)," released 17 Feb 2019, https://www.etymonline.com/word/designate\#etymonline_v_46758. The English noun "designation" originated either from the Old French designacioun or directly from the Latin designationem (nominative designatio), "a marking out, specification," noun of action from past participle stem of designare "mark out, devise, choose, designate, appoint," and was noted in the 16th century and on. Etymonline, s.v. "Designation (n.)," released 17 Feb 2019, https://www.etymonline.com/word/designation\#etymonline _v_29918. The English adjective "marked out, indicated" was formed from the Latin desegnatus, the past participle of designare "mark out, device, chose, designate, appoint." The meaning "appointed or nominated but not yet installed" dates from the 1640s. Etymonline, s.v. "Designate (adj.)," released 17 Feb 2019, https://www.etymonline.com/word/designate\#etymonline_v_46758. Also see Oxford English Dictionary, s.v. "Designation (n.)," released 17 Feb 2019, https://en.oxforddictionaries .com/definition/designation.

${ }^{228}$ The English verb "to attribute" comes from the Latin attributus, past participle of attribuere "assign to, allot, commit, entrust," and the first use is dated to 14th century with the figurative meaning "to attribute, ascribe, impute.” Etymonline, s.v. “Attribute (v.)," released 17 Feb 2019, https://www.etymonline .com/word/attribute\#etymonline_v_18918. The English noun "attribute" comes from the Latin attributum, "anything attributed," with the meaning "quality ascribed to someone, distinguishing mark (especially an excellent or lofty one)" in the late 14th century. Etymonline, s.v. "Attribute (n.)," released 17 Feb 2019, https://www.etymonline.com/word/attribute\#etymonline_v_18918. Another English noun, "attribution," originated from the Latin attributionem (nominative attributio) "an assignment, attribution," and the first use was dated to late 15 th century, referring to the "action of bestowing or assigning." Etymonline, s.v. “Attribution (n.)," released 17 Feb 2019, https:/www.etymonline.com/word/attribution\#etymonline _v_26708. The English adjective "attributable" was detected in the 1660s with the meaning of "ascribable, imputable." Etymonline, s.v. "Attributive (adj.)," released 17 Feb 2019, https://www.etymonline.com/word/ attributive\#tymonline_v_41854. Also see Oxford English Dictionary, s.v. "Attribute," released 17 Feb 2019, https://en.oxforddictionaries.com/definition/attribute.
} 
gesture, offers the most accurate method for disclosing ancient understandings of hand placement." In addition, taking into careful consideration the micro reading of the texts, I broaden the context of this gesture to a macro reading of the texts. In other words, I placed the laying on of hands in the context of the most common outcome of the sacrificial offering process, the atonement, and related it to the foundational background of any sacrificial offering, GHS or/and sin, as a constant human disadvantage before God. Calabro fell short in systematically following the methodology he suggested.

His starting point suggested a totally new meaning of the laying on of hands in Lev 1:4, "that it may be accepted for him to make atonement on his behalf." He stated that the way in which the animal mediates for the offerer is not a crucial point in this text. In other words, the focus is not on what the gesture does to the animal, but rather, the emphasis is on the fact that "the gesture's form is a similitude of atonement." He also adopted the meaning of "to cover" for the Hebrew verb רֶֶ? to propose that the laying on of hands on the animal's head is an "iconic symbol of "cover over" the sins of" the offerer. $^{229}$

This proposal is based on a subjective and selective reading of this verse. First, the act of atonement, as suggested in the present study, includes two basic parts which are the offerers' letting go of their sin by placing their hands on the sacrificial animal, and God's acceptance of that sin into his sanctuary and granting forgiveness to the offerers. The first part of it is represented by the animal's "recovering" of the offerers' sin. In other words, contrary to Calabro, the text does emphasize what the gesture does to the

\footnotetext{
${ }^{229}$ Calabro, “A Reexamination,” 121-22.
} 
sacrificial animal. The transfer of the offerers' sin onto the animal is crucial and thus, becomes an integral part of the atonement process. This does not diminish the emphasis on the atonement itself, but rather, explains it even more. Second, scholars rightfully refuted and largely abandoned the view that the Hebrew verb רכְִּּ means "to cover." Third, the context in Lev 1-3 is completely different from the one in Lev 4-6:7, since in the former, no sinful act was involved, whereas in the latter it was. Finally, this phrase is not mentioned in relation to any other sacrifice but burnt offering, which requires further investigation if it should be applied to all other sacrifices.

Building on the grammatical and syntactical parallels between " “

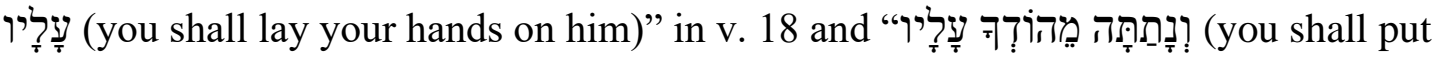
some of your power on him)" in v. 20 of Num 27, Calabro noticed that the transfer theory fits these contexts the best. He concluded that "the phrase נתן על contributes a distinctive nuance to the concept of transfer, indicating that what is transferred becomes like a material possession that one can wear (like a crown), rather than something that permeates the soul or the blood (the verb מלא 'fill' in Deut 34:9, of course, carries a different nuance).,"230

Calabro, then, proposed the interpretation of laying on of hands that nobody, to his knowledge, had previously the following: "On the basis of the passages from Numbers mentioned above, one could posit that hand placement is the 'gesture of פפקד,' a way of appointing a person or animal to a particular status or role. This function could

\footnotetext{
${ }^{230}$ Calabro, “A Reexamination,” 122.
} 
apply to all of the biblical attestations of hand placement." He came to this conclusion by noting that in Num 27:16, Moses asked God "to appoint, פקד" a man over the sons of Israel. Calabro stated that this sequence suggests that at least one function of the laying on of hands ritual was "to appoint" a person or a thing. He also cited Num 1:50; 3:10; 8:10; and Neh 7:1, where laying on of hands was performed on the Levites who were "appointed, to their offices. Finally, Calabro referred to Creason's work on the verb פפקד, where Creason defined its meaning as follows: "The verb's basic meaning is 'to assign a person or a thing to what the subject believes is its proper or appropriate status or position in an organizational order,' or more succinctly, 'to put some thing where it is supposed to be in the overall scheme of things." "'231

First, Calabro's proposal is not new by any means. It is virtually identical to the theory of consecration-separation/dedication/presentation that is presented in the history of interpretation in this study (see pp. 9, 11). Second in developing his proposal he ignored a basic step of a sound interpretation: root distribution. The verb פקד is found 144 times in the Pentateuch, plus 237 in the rest of the OT. The most significant use of the root occurs in the book of Numbers, 108/144. The occurrences and uses in other books are insignificant (Genesis, 11 times; Exodus, 18; Leviticus, 5; and Deuteronomy, 2) when compared to the one in Numbers. This statistic is not a warrant of any firm conclusions about the meaning of the root, but it does indicate that did not play a significant role in any other books but Numbers. Since most of the occurrences of the

\footnotetext{
${ }^{231}$ Stuart Creason, "PQD Revisited," in Studies in Semitic and Afroasiatic Linguistics Presented to Gene B. Gragg, ed. Cynthia L. Miller, SAOC 60 (Chicago: Oriental Institute of the University of Chicago, 2007), 30.
} 
laying on of hands occur in the book of Leviticus (15 times in 6 events), in contrast to Numbers (4 times in 2 events), Exodus ( 3 times in a single event), and Deuteronomy (1 time), it would be reasonable to examine Leviticus texts, rather than Numbers in order to find its meaning. This method is confirmed further by the fact that the only time פהקד is found in the book of Numbers in the context of the laying on of hands is in 27:16. In this context, the verb conveys the result or outcome of the laying on of hand/s, rather than the meaning/function of this ritual gesture which Moses will perform over Joshua. The verb is not mentioned in relation to the laying on of hands in Exod 29, Num 8, and Deut 34, which leave its only relation to this gesture in Num 27. It would be questionable to establish the meaning of the laying on of hands based on the connection of the verb פקד, and this gesture in one context, and not consider the other 22 contexts. Third, the verb פיקד is never used in Exodus and Leviticus with the meaning "to appoint." The meanings of פקד implied in Exodus are "to carefully watch over" (3:16), "to be concerned" (4:31), "to take care of" (13:19), "to punish" $(20: 5 ; 32: 34 ; 34: 7$,$) , and "to count, number"$ (30:12, 13, 14; 38:21, 25). ${ }^{232}$ The two meanings found in Leviticus are "to entrust" (Lev 5:23 [6:4]) $)^{233}$ and "to bring" (Lev 18:25:234 26:16). ${ }^{235}$ Thus, the meaning of פקד, "to appoint" does not appear at all in the books of Exodus and Leviticus that contain 18/23 laying-on-of-hands contexts. This statistic strongly demonstrates the flaws of Calabro's

\footnotetext{
${ }^{232}$ Stuart, Exodus, 123, 158, 326, 636, 688-89, 717, 770-71.

${ }^{233}$ Milgrom, Leviticus 1-16, 293, 327.

${ }^{234}$ Milgrom, Leviticus 17-22, 1515, 1580.

${ }^{235}$ Milgrom, Leviticus 23-27, 2272, 2305.
} 
analysis which is considered unsound in this study.

\section{Transfer/Substitution}

For the sake of clarity in the process of examining scholarly arguments on the meaning/function of the laying on of hands, I state here that the laying on of hand/s is best understood to convey transfer and/or substitution, and name my theory in accordance with its meaning/function, transfer, and/or substitution theory.

This is the most debated ${ }^{236}$ and the most frequent meaning of the laying on of hand/s in the oldest and recent studies. ${ }^{237}$ It is applicable to all contexts as long as the context is taken into consideration to determine what is being transferred to the sacrificial animal. $^{238}$

\section{Evaluation of the Points of Critique of the Transfer/Substitution Theory}

The total of 10 arguments against the transfer/substitution theory is presented in the introduction of the present study. Paterson recognized 5 at the beginning of the 20th century, while Wright collected 5 more at the end of the same century. All of them are evaluated below. Regardless of whether these arguments look impressive, they are the result of a selective reading of the texts. Scholars place an emphasis on some texts at the cost of disregarding others, which caused them to derive partially accurate inferences regarding the meaning/function of the gesture. Since some of them supplement each

\footnotetext{
${ }^{236}$ Mattingly, “The Laying on of Hands on Joshua,” 148.

${ }^{237}$ Hoffmann, Das Buch Leviticus, 1:84; Kiuchi, Purification Offering, 113; Calabro, “A Reexamination," 117.

${ }^{238}$ Calabro, “A Reexamination,” 117.
} 
other, those collected by Paterson are combined with the ones gathered by Wright in order to avoid repetitions as they are critically analyzed.

\section{The Death of the Victim Cannot be Vicarious}

The death of the victim could not have been vicarious, since sacrifice was not allowed for sins which merited death (Num 15:30), only for venial transgressions. This argument reflects a selective reading of texts. ${ }^{239}$ Scholars widely and rightfully recognized that the life of an individual Israelite who experiences sin or impurity and disregards the regulations mandated by God himself is terminated (Lev 15:31; Num 19:13, 20). Other texts also implied this, such as Lev 5:1-4. ${ }^{240}$ Instead of bearing his/her own sin and ultimately suffering its consequence of death, the Ancient Israelite was advised to transfer his/her $\sin / \mathrm{s}$ to the $\sin$ and/or reparation offering and receive forgiveness. Sins for which biblical legislation prescribes death are unforgivable/ inexpiable and the one who commits them is barred from the advantage of sacrificial atonement/forgiveness. Individuals liable for such sins would not get a chance to transfer their sin to appropriate offerings and receive forgiveness.

\section{Sacrifice Cannot be Holy and Impure}

The assumption that the imposition of hands involved a transmission of guilt is inconsistent, not only with other references to this practice, but also with the fact that the

${ }^{239}$ Paterson, “Sacrifice,” DBDL 4:340.

${ }^{240}$ Eichrodt, Theology of the Old Testament, 2:165; Wenham, The Book of Leviticus, 94-95; Rodríguez, "Substitution in the Hebrew Cultus," 149; Schwartz, "The Bearing of Sin," 8-10; Sklar, Sin, Impurity, Sacrifice, Atonement, 42. 
sacrificial flesh was treated as most holy, and might be eaten by the priest. ${ }^{241}$

J. C. Matthes criticism that this theory on the basis that the imposition of hands involved a transmission of guilt is inconsistent, not only with other references to this practice, but also with the fact that the sacrificial flesh was treated as most holy, and might be eaten by the priest. ${ }^{242}$ Rodríguez established the fact that holiness and sin, and I add GHS, can coexist in the same place at the same time. ${ }^{243}$ However, the inference that coexistence of sanctity and defilement is present in biblical texts was noted before by Rodríguez $^{244}$ and later by Milgrom and Gane. ${ }^{245}$ Sin offering in Lev 4-5:13 that specifically deals with sin is also considered holy. ${ }^{246}$ Kiuchi’s critique of Rodríguez's and the view of other scholars who believed this is not well taken. That is, he stated that "although it may be naturally envisaged that the חָָָּאת has something to do with the guilt, it is the priests who bear it, and not the concerning the sin offering in Lev 6:24-30 which states that the priest is to eat the flesh of the sin offering he officiates, it is accurate that the priest bears a sin that the sin offering dealt with in the third and fourth subcase in Lev 4, vv. 22-26 and 27-35. Yet, the same regulation also specifically states that the priest is not to eat the meat of the sin

${ }^{241}$ Paterson, "Sacrifice," DBDL 4:340.

${ }^{242}$ J. C. Matthes, “Der Sühnegedanke bei den Sündopfern,” ZAW 23 (1903): 109-13; Vaux, Ancient Israel: Its Life and Institutions, 416.

${ }^{243}$ Rodríguez, "Substitution in the Hebrew Cultus," 217-18; Kiuchi, Purification Offering, 162.

${ }^{244}$ Feldman, Biblical and Post-Biblical Defilement and Mourning, 63, 70.

${ }^{245}$ Milgrom, Leviticus 1-16, 406; Gane, Cult and Character, 178.

${ }^{246}$ Kiuchi, Purification Offering, 115.

${ }^{247}$ Kiuchi, Purification Offering, 115. 
offering that dealt with sin in the case of the first and second subcase in Lev 4, vv. 3-12 and $13-21$. In this case, sin is transferred to the sanctuary directly through the blood. ${ }^{248}$ This seems to be a common notion in ANE context. ${ }^{249}$ Kiuchi totally disregarded the fact that sometimes the priest bears the sin, while sometimes the sin is transferred directly onto the sanctuary. Second, Kiuchi stated that the priest bore guilt rather than sin, but admitted that 'the confusion of terms such as 'sin,' 'guilt,' and 'uncleanness' has obscured the whole issue of "transference of $\sin /$ guilt." 250 As it was established earlier, the terms for sin refer to all three stages of a sinful situation, an act, guilt, and its punishment. Metaphorical interpretation, which is undeniable in these contexts, would confirm that any of the three could be "borne" by the priest and refer to the obstacle between the offerer and God. In other words, the priest would carry all three of them. None of the two points of critique Kiuchi proposed against Rodríguez's work is substantial.

This is indeed validated by the texts which unanimously present these two entities coexisting in the physical place (sanctuary, Exod 29:44; 40:9-10= Lev 16:16), human (priests/Nazirite, Exod 29:33, 44; 40:13; Lev 8; Num $6=$ Lev 10:17), and animal bodies (sacrificial animals Lev 6:10 [6:17]; 6:18 [6:25] = 6:20 [6:27]). This point of critique seems to reflect selective, rather than careful and comprehensive reading of the texts.

${ }^{248}$ Rodríguez, “Transfer of Sin in Leviticus,” 190; Kiuchi, Purification Offering, 124.

${ }^{249}$ O. R. Gurney, Some Aspects of Hittite Religion (Oxford: Oxford University Press for the British Academy, 1977), 29.

${ }^{250}$ Kiuchi, Purification Offering, 115. 
Those three entities could coexist without affecting the holiness of the sanctuary, priests, Nazirite, or sacrificial animal.

Based on Lev 4:12, 6:23 [30], Rodríguez rightfully concluded: "The fact that the place where the burning occurred was a 'clean place' suggests that the flesh of the animal was holy. The flesh was also considered at the same time source of contamination (Lev $16: 18)^{251}$ since the person who burned it was 'to wash his clothes and bathe his body in water' before returning to the camp. ${ }^{\text {252 }}$ He was anticipated by Milgrom who also affirmed the paradox that the flesh of a sin offering animal is both holy and impure. Namely, it was deposited in a pure, clean place (Lev 4:12), as Rodríguez cited, and it was eaten by the priest and because its holy status is explicitly stated (Lev 6:19, 22, 10:17). ${ }^{253}$ Thus, the animal was both holy and impure at the same time.

This perplexing reality presented in biblical texts is possible only because God allowed it by delegating regulations that conveyed the coexistence of these three entities. Thus, the conclusion emerges that sin/impurity/sinfulness is not a threat or stronger than holiness, but rather, is under the control of holiness. ${ }^{254}$ Thus, transfer of sin/sinfulness to the sacrificial animal does not annul the holiness of the sacrifice.

\footnotetext{
${ }^{251}$ Rodríguez referred to Lev $16: 18$ in his dissertation to point to the fact that the flesh of the sin offering is impure and defiles entities it touches. This is mostly likely a typo since v. 28 of the same chapter actually stated that the sin offering flesh is impure and defiles the person who takes it out of the camp to burn it. Verse 18, rather, states that the blood of the sin offering has a cleansing effect on the sacrificial altar. See Rodríguez, "Substitution in the Hebrew Cultus," 218.

${ }^{252}$ Rodríguez, "Substitution in the Hebrew Cultus," 218.

${ }^{253}$ Milgrom, Leviticus 1-16, 239-40.

${ }^{254}$ Rodríguez, "Substitution in the Hebrew Cultus," 218.
} 


\section{Blood Manipulation Versus Slaughter}

The essence of this claim is that the central act of the sacrifice was not the act of slaughtering, but the manipulation of the blood which was presented to God. ${ }^{255}$ However, accepting this proposal does not diminish the fact that the sacrificial animal symbolically and substitutionally represents the offerer. Actually, the laying on of hands facilitates this understanding, since the sins were transferred onto the sacrificial animal via this gesture. Thus, this argument is an attempt to emphasize one ritual activity over other activities, which goes against the ritual theory accepted in the present study. Gane convincingly proved that ritual in its totality achieves its purpose. ${ }^{256}$ The transfer/substitution theory actually upholds the critical role of blood application in the sacrificial offering ritual since through it, the $\sin / \mathrm{s}$ that were carried by the offerer are transported to the sanctuary from where they are removed on the Day of Atonement (Lev 16:16, 21). The animal is symbolically the offerer's substitute that suffers punishment for his/her sin. Thus, the transfer/substitution theory organically correlates with and upholds the importance of blood application. It adds more importance and meaning to it.

\section{Substitution Theory Is Untenable}

Wright stated that the transfer/substitution theory as an explanation for the laying on of hands is informed by the substitution theory of sacrifice which, in his opinion, is untenable. ${ }^{257}$ This claim echoes the subjective and poorly supported claim. In order to

\footnotetext{
${ }^{255}$ Paterson, "Sacrifice," DBDL 4:340.

${ }^{256}$ Gane, Cult and Character, 67.

${ }^{257}$ Wright, "The Gesture of Hand Placement," 437-38.
} 
dismiss such an important and widely accepted theory of sacrifice, one would need to rely on extensive studies. Wright cited sources that do not provide in-depth research on the topic, along with two that do. ${ }^{258}$ However, scholars have proven and continue to prove that substitution was widely present in the ANE and in Ancient Israel. ${ }^{259}$ Thus, Wright's argument that the laying on of hand/s cannot mean transfer/substitution is refuted by the overwhelming amount of research that proved that this concept was firmly embedded in Ancient Israel and ANE texts. In addition, the study of the verb כִֶּּ in the present study strongly supports the idea that substitution was an integral part of the atonement conveyed via this verb in the Pentateuch. ${ }^{260}$

\section{Transfer/Substitution Theory Is Based on Lev 16:21}

Wright noticed that the main support of the transfer/substitution theory is the hand-laying in Lev 16:21. He was anticipated by Janowski who marshaled this argument in the second half of the twentieth century based on the three differences between laying on of hand in Lev 16:21 and other texts: (1) imposition of both hands on the head of the goat, (2) transference of materia peccans to the evil bearer, and (3) sending off of the

\footnotetext{
${ }^{258}$ Eichrodt, Theology of the Old Testament, 2:165-66; Milgrom, "Sacrifices and Offerings, OT," 764. Adalbert Metzinger and Roland de Vaux are valid sources on the topic, but still, only two out of many others with different perspectives. Roland de Vaux, Studies in the Old Testament Sacrifice (Cardiff: University of Wales Press, 1964), 29; Metzinger, "Substitutionstheorie und das Alttestamentaliche."

${ }^{259}$ Eichrodt, Theology of the Old Testament, 2:165-66; Médebielle, "Le Symbolisme du Sacrifice Expiatoire en Israel"; Médebielle, L'expiation dans l'Ancien et le Nouveau Testament; Médebielle, "Expiation," 3; Smith, "The Laying-on of Hands"; Rodríguez, "Substitution in the Hebrew Cultus," 20-74; Paterson, "Sacrifice," $D B D L$ 4:340-41. For more recent works that make reference to other older works, see Milgrom, Leviticus 1-16, 440-41; Mattingly, "The Laying on of Hands on Joshua," 58-63; González, "Laying-on of Hands in Luke and Acts," 31-87; Robinson, "The Laying on of Hands," 25-26.

${ }^{260}$ See pp. 391, 393, 418, 430-32, 435-37 of the present study.
} 
goat to the wilderness, are missing in sacrificial contexts. He concluded that the Scapegoat is not a sacrifice. ${ }^{261}$ These points are rightfully critiqued by Kiuchi ${ }^{262}$ and throughout the present work.

Wright assumed that hand placement in Lev 16:21, performed with two hands, is different from hand placement with one hand which is the procedure for other offerings. Hence, a difference in form suggests, a priori, a possible different meaning. He also claimed that the scapegoat is not a sacrifice; it is merely a rite of elimination and therefore, cannot be used to interpret the gesture of hand placement in sacrifices. ${ }^{263}$ This argument is refuted through extensive analysis of the form of this gesture under the subheading, "Form of Laying on of Hands: Singular vs Plural vs Dual" and "Pressure or No Pressure," of the present study and is not repeated here. ${ }^{264}$

Based on the inadequacy of the argument that the form affects the meaning/function of this gesture; this study accepts the proposition that Lev 16:21 can be taken as a model for the meaning in sacrifices. In addition, this text is not the only text that explicitly supports the transfer of sin via laying on of hands. Lev 4 clearly states that the sinner comes to offer his/her sacrifice "loaded" with his/her sin and goes away forgiven. It does not state what happens with sin borne by the sinner, but Lev 16:16 explicitly states that the sins are in the sanctuary, that is, in the most holy place. Having demonstrated that $\mathrm{ADH}$ is not textually supported, the transfer of sin is the logical

\footnotetext{
${ }^{261}$ Janowski, Sühne als Heilsgeschehen, 209-16, especially 215.

${ }^{262}$ Kiuchi, Purification Offering, 114-16.

${ }^{263}$ Wright, "The Gesture of Hand Placement," 437-38.

${ }^{264}$ See pp. $666-79$ of the present study.
} 
meaning/function of the laying on of hands in light of Lev 16:16, which attributes the sins in the sanctuary as the sins of the sons of Israel. Laying on of hands is the only ritual gesture that is performed in the constraints of the sanctuary that may indicate that the nature of the contact between the offerer and sacrificial animal is that of a transfer. All other contacts that the offerer makes with his/her sacrifice are conditioned by the cause and effect principle of the sacrificial process as set forth in the following paragraph.

Gane provided two slightly different lists of ritual activities related to burnt and sin offering, both of which contain two sets of sacrificial procedures: (1) the ones explicitly mentioned in the texts, and (2) the implicit ones. ${ }^{265}$ Regardless of which class a ritual activity belongs to, some of them can be viewed as pre-requisite or post-requisite activities. ${ }^{266}$ Gane was anticipated by Hubert and Mauss, and Turner, who termed these activities preliminary ones. ${ }^{267}$ Thus, the offerer's ritual purity, selecting ${ }^{268}$ and bringing the animal to the sanctuary, ${ }^{269}$ are necessary prerequisite activities for the sacrificial ritual to take place and are performed outside of the sanctuary. These ritual activities precede the laying on of hands. The cultic ritual law does not assign symbolic meaning to them, and it is unlikely that they had any symbolic meaning because they are necessary

${ }^{265}$ Gane, Leviticus, Numbers, 59; Gane, Cult and Character, 47-48.

${ }^{266}$ Gane, Leviticus, Numbers, 58.

${ }^{267}$ Henri Hubert and Marcel Mauss, Sacrifice: Its Nature and Functions, trans. W. D. Halls (Chicago: University of Chicago, 1964); Victor W. Turner, "Sacrifice as Quintessential Process: Prophylaxis or Abandonment?," HR (1977).

${ }^{268}$ Klawans, Purity, Sacrifice, and the Temple, 53, 56.

${ }^{269}$ Gane, Leviticus, Numbers, 58. 
activities for the ritual proper. They are conditioned by the cause and effect principle necessary for sacrificial procedure.

The ritual activities performed that follow the laying on of hands include slaying the animal; collecting the blood; presenting the blood to the outer altar; dashing the blood against the altar or applying it on the sacrificial altar's horns; pouring the remaining blood at the base of the sacrificial altar; dismembering the carcass; removing, presenting, and burning the suet or arranging the body pieces; washing, presenting, and burning the entrails and shins; and eating the meat. Gane suggested that of these, only laying on of hands and application of blood and suet to the sacrificial altar have no practical function in the ritual proper. ${ }^{270}$ Gane insightfully noted:

In terms of mere physical cause and effect, the collection of activities just listed is an inefficient way to feed a priest: leaning one hand on the head of an animal and applying its blood and suet to an altar have no practical function in the mundane sphere. Such "impracticality" is common in ritual because the goal of a ritual transcends what can be achieved through ordinary physical means alone. There is an important sense in which a ritual goal may be regarded as practical, but this involves a higher level of practicality, such as reestablishing good relations with a deity in order to receive his blessings instead of punishment. ${ }^{271}$

The principle of higher goals than those conditioned by the mere cause and effect principle is certainly true for both of these ritual activities. That is, the two activities referred to in the quotation are not necessary in the mundane sphere. They symbolically achieve goals that exceed the goals conditioned by the cause and effect principle. Therefore, it is expected and unavoidable that they are loaded with symbolic meaning. Limiting the laying on of hand/s to the meaning of ownership represents significantly

\footnotetext{
${ }^{270}$ Gane, Cult and Character, 48.

${ }^{271}$ Gane, Cult and Character, 48-49. See also Gane, Ritual Dynamic Structure, 43-44, 55, 58; Staal, Rules Without Meaning, 132.
} 
diminishing the symbolic meaning of this activity and undermines the contexts of sin or GHS that is associated in an unadvantageous way to sacrificial offering ritual. The meaning of transfer encounters well the fact that the sinner leaves the sanctuary free of his/her sin, in the case of the sin and reparation offering, and the fact that the sin is stored in the sanctuary and removed from there on the Day of Atonement. In the case of other sacrifices, laying on of hands symbolically facilitates transfer of GHS, thus enabling safe interaction between God and humans.

Scholars have already recognized that transfer is a valid meaning of this gesture regardless of the different contexts in which it was performed, such as the ordination of Joshua or the installation of the Levites or the incident of blasphemy (Lev 24:10-16; Num 8:10, 12; 27:18, 23; Deut 34:9). ${ }^{272}$ If transfer is an upheld meaning/function in two different contexts such as ordination and sin removal via the goat for Azazel, there is no reason that it would not be accepted in sacrificial contexts. The context remains the final determinant of what has been transferred and what the ultimate goal of a given ritual is as a whole. Rodríguez explained the interconnectedness and distinctiveness of sacrificial and goat-for-Azazel contexts in which the laying on of hands was practiced:

\footnotetext{
${ }^{272}$ Milgrom, Leviticus 1-16, 554-55, 1041; Gane, Cult and Character, 59. Wright radically changed his interpretation of the laying on of hands in Lev 24:10-16 in his recent paper read at an SBL meetings in 2015. Previously, in his article "The Gesture of Hand Placement in the Hebrew Bible and Hittite Literature" Wright adamantly rejected any presence of transfer from Moses to Joshua after the former laid his hands on the latter. At that time, he wrote that the only correct meaning of this ritual gesture is designation of who is the focus of ritual action, that is Joshua. This interpretation is informed by Wright's interpretation of laying on of hands in Lev 24:13-16, the blasphemer account. In his recent paper "The Hermeneutics of Ritual Innovation: Hand Placement in Leviticus 24" presented at the SBL meetings in Atlanta, GA in 2015, Wright stated that in both accounts, Lev 24:10-16; Num 8:10, 12; 27:18, 23; Deut 34:9, laying on of hands means transfer based on the interrelatedness of so-called PH (Priestly and Holiness codes) source to which these two accounts belong and Covenant Code (CC) and Deuteronomy (D). Wright, "The Gesture of Hand Placement," 435-36; Wright, "The Hermeneutics of Ritual Innovation," 7-10; Mattingly, "The Laying on of Hands on Joshua," 146-72.
} 
The only difference between the two cases [sacrificial and elimination contexts] is to be found in the nature of the relation which the laying on of hands produces. In the case of the scapegoat the relation is not one of sacrificial substitution in the sense that the animal bears the sin and penalty of the sinner. In the latter case we can speak

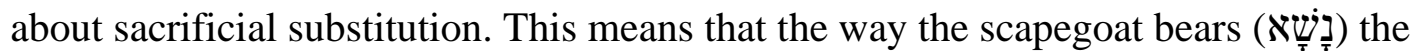
sin of the people is essentially different from the way the expiatory sacrifices bear the sin of the offerer. This is precisely what Lev 16:22 states: "The goat shall bear all

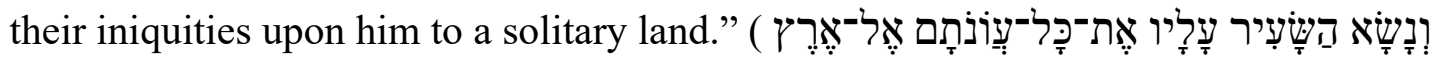

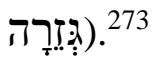

\section{Well-Being Offering Is Not an Expiatory Offering}

Wright stated that it is difficult to apply the idea of transfer of guilt in the case of the well-being offering since it is not an expiatory offering like sin and reparation offerings, and to a certain extent, the burnt offering. ${ }^{274}$ This inference reflects arguments based on selective reading of texts. Regulations in Lev 1 clearly state that the burnt offering, besides others, possesses an expiatory function which has been widely recognized (Lev 1:4). ${ }^{275}$ Thus, his argument then rests on the regulations of only wellbeing offerings. The expiatory function of the well-being offering was extensively analyzed in the current study as a part of the analysis of Lev 17:10-12 and is not repeated here. ${ }^{276}$ Since Lev 17:11 implies all animal sacrifices, they all have an expiatory function. ${ }^{277}$ Some of them are exclusively expiatory (sin and reparation offering), while

\footnotetext{
${ }^{273}$ Rodríguez, “Substitution in the Hebrew Cultus,” 220.

${ }^{274}$ Wright, "The Gesture of Hand Placement," 437-38.

${ }^{275}$ See subheading, "Burnt Offering: Solution for GHS," in the current study, pp. 408-11. Also see Rodríguez, "Substitution in the Hebrew Cultus," 225-26.

${ }^{276}$ See subheading, “Analysis of Leviticus 17:11: The Role of Blood and study, pp. 417-18. Also see Rodríguez, "Substitution in the Hebrew Cultus," 226-31.

${ }^{277}$ Vaux, Ancient Israel: Its Life and Institutions, 453; Gane, Cult and Character, 65, 196.
} 
others, besides being expiatory, also have other functions (burnt, grain, and well-being offerings). In addition, even though cultic legislation never required an offerer specifically to offer one of these two sacrifices for committing sin, the rituals that included these two sacrifices also represented a way of interaction with $\operatorname{God}^{278}$ and as such, these two sacrifices were expiatory as well, in a restricted way, but still expiatory. The foundational element that these two sacrifices of restricted expiatory function dealt with, besides the fact that they were primarily offered for reasons such as acceptance (Lev 1) or thanksgiving, vows, free-will (Lev 7:12, 16), is GHS, which presents a constant problem in divine-human interaction, but at the same time, is less complex than when an offerer commits sin.

\section{Laying on of Hand/s in Relation to Bird, Cereal Offering and the Identity of the Slayer}

Wright stated that if the laying on of hands means the transfer of guilt, it is then difficult to understand why it was not practiced on the purification or burnt offering commuted to a bird (Lev 1:14-17; 5:7-11). ${ }^{279}$ This claim was augmented by claims that a cereal offering also atones (Lev 5:11-13), but the cultic legislation never requires the laying on of hand/s on it, which then further implies there could be no idea of a penal substitution in this case. ${ }^{280}$

Second, in order to strengthen his proposal that the laying on of hand/s means

\footnotetext{
${ }^{278}$ Gane, Cult and Character, 49n11.

${ }^{279}$ Wright, "The Gesture of Hand Placement," 437-38.

${ }^{280}$ Paterson, "Sacrifice,” DBDL 4:340.
} 
ownership and not transfer, Wright rightfully observed that in some cases, the sacrificial process would involve other participants than the offerer. Gane adopted this argument to confirm the fact that the laying on of hands means ownership of the offerer over the animal. ${ }^{281}$ This argument is augmented by the claim that the victim was slain by the offerer, but in order to support the transfer/substitution theory, the sacrificial animal should have been put to death by the priest as God's representative.

\section{Wright's First Argument}

These two claims are actually Wright's first argument for the ownership theory of the laying on of hand/s. He stated that "this interpretation is confirmed by the fact that it makes sense of the lack of the gesture with birds and cereal offerings (Lev 1:14-17;2; 5:7-13)." ${ }^{282}$ Wright contributed the lack of laying on of hand in relation to the bird and cereal offering to the fact that they are small and carried by the offerers only, in their hands. ${ }^{283}$ Wright's arguments expressed in this quotation are partially correct, since the laying on of hands was never prescribed to be performed on the cereal offering in the OT and is missing in sacrifices that are reduced to a bird; turtledove, or pigeon. Wright found that in other ANE religions, the laying on of hands was performed over sacrifices that are not live animals, such as bread, cheese, grain products, wine, and other drinks,

\footnotetext{
281،The 'ownership' view of sacrificial hand-leaning is supported by the wording of Lev 1:4, the only place where the text interprets the gesture with one hand: 'He shall lean his hand' on the head of the burnt offering, that it may be acceptable on his behalf, to expiate for him. Here in the context of the burnt offering, acceptance on behalf of the offerer, rather than someone else, depends upon performance of handleaning. Even if another person leads the animal into the sanctuary courtyard, the gesture eliminates any possible doubt regarding the identity of the owner/offerer." Gane, Cult and Character, 63.

${ }^{282}$ Wright, "Hands, Laying of," 3:47.

${ }^{283}$ Wright, "Hands, Laying of,” 3; Milgrom, Leviticus 1-16, 151-52; Gane, Cult and Character, 63.
} 
slaughtered animals, meats, livers, and tray or baskets with food, ${ }^{284}$ but this practice is alien to the OT sacrificial system.

It should be emphasized that the absence of the laying on of hands in burnt, sin, and reparation offerings is missing only when the sacrificial animal is a bird due to practical reasons. Wright observed one reason why birds cannot be handled as quadrupeds: they are too small. In addition, it can be assumed that sacrificial birds, domesticated or not, would fly away if placed before the sacrificial altar to receive the laying on of hands. It could be argued that the offerer could have held a bird by the feet with one of his/her hands while performing laying on of hands with the other one. This method would leave the bird's wings free, allowing it to desperately flap. It can be argued that the offerer could have held his/her bird sacrifice in one hand and perform laying on of hands with the other one. However, cultic legislation does not prescribe that, but rather, omits this gesture.

Another inconsistency is found in Wright's argument regarding the size of the animal. That is, the bird would not be the only animal for which the offerer would not need assistance to bring it to the sanctuary. The only animal that the offerer would need help to bring it to the sanctuary would be a bull, since any adult should be able to bring a lamb or goat to the sanctuary.

However, Wright rightfully reasoned, similarly to Milgrom, that the same meaning is implied for the laying on of hands on sacrificial animals, quadrupeds, or carrying of the sacrificial bird. For Wright, this gesture conveys ownership. However, as argued in the present study, if the laying on of hands means transfer/substitution of

\footnotetext{
${ }^{284}$ Wright, "The Gesture of Hand Placement," 442-43.
} 
$\sin / \mathrm{s} / \mathrm{GHS}$, then that meaning could be ascribed to the bird offering in whatever capacity the bird was offered.

\section{Wright's Second Argument for Ownership} Theory and the Role of the Offerer

The argument that the laying on of hands removes any doubt in identifying the owner of the sacrificial animal is highly controversial for two reasons. First, no Pentateuch text mentions this scenario so it is an argument from silence. Nevertheless, it is totally logical to think that for practical reasons, other person/s besides or instead of the offerer could lead and bring the animal to the sanctuary. Yet, this argument is highly controversial since it is founded on exceptional cases. For instance, an animal could have been big and strong from the herd and an adult not be able to control it. Why would the offerer not be able to control it? In this case, it must be assumed that a domestic animal would strongly resist to being led by humans, something that is highly improbable. It could have happened that the offerer is physically weak, perhaps sick; he/she might not be able to lead such a strong animal. In that case, the offerer could wait to get well and then lead and bring the sacrifice animal to be offered in the sanctuary. It also could have happened that the offerer is physically weak due to age, not sickness. Supposedly, BL addressed fully grown, healthy adults in the first place. Contrary to this, an adult should be able to lead a young bull to the sanctuary, knowing that priestly personnel would be available there to assist further in holding, controlling the animal during the sacrificial process. In addition, it is highly improbable that such big animals would often be offered by an individual offerer. Also, one could also wonder why the offerer would not simply 
orally reveal that he/she is the offerer. ${ }^{285}$ These are just some of the scenarios, but I admit that all these arguments like Wright's, are from silence. The fact is that one could always argue in both directions. The gesture of the laying on of hands is not the only potential indicator of ownership. Cultic legislation concerning sacrifices provides much stronger indications in determining the owner and the beneficiary of the sacrifice.

Leviticus $1-5$ portrays a distinction between the activities which the offerer performs and the ones performed by the priest. Leviticus 1:1-9 can be used as an example. The subject is clearly the offerer since simple $3 \mathrm{~ms}$ verbal forms are used in 1:2 (to bring), 3 (to offer 2x, he might be accepted), 4 (to lay his hand), 5 (to slay), and 6 (to skin and cut into pieces) to highlight the involvement of the offerer. The antecedent of 3ms is introduced in v. 2 and it is expressed by $3 \mathrm{~ms}$ verbal forms but they are augmented by the nouns “Aaron's sons" or simply "the priest" in is v. 5 (to offer up, to sprinkle), v. 7 (to put fire on altar and arrange wood on fire), v. 8 (to arrange pieces of an animal), and v. 9 (to offer up in smoke). ${ }^{287}$

Some of the activities that are performed by the offerer still do not provide a clear indication as to who the offerer is, to whom the animal belongs, such as "to bring" $(1: 2)$ or "to offer" (1:3), but other activities besides the laying on of hands (1:4), such as to slay

\footnotetext{
${ }^{285}$ LaSor, Hubbard, and Bush, Old Testament Survey, 85.

${ }^{286}$ Both sexes are included by this noun. Milgrom, Leviticus 1-16, 145.

${ }^{287}$ The same pattern can be detected in the rest of Lev $1-5$.
} 
$(1: 5)^{288}$ and to skin and cut into pieces (1:6) certainly denote who the owner was.

Furthermore, the very next ritual step after the laying on of hands is slitting the sacrificial animal's throat.

It was claimed that the victim was slain by the offerer, but critiques of the transfer/substitution theory proposed that the sacrificial animal should have been put to death by the priest as God's representative. ${ }^{289}$ However, a much stronger rationale stands behind the cultic legislation that requires the offerer to slay his/her sacrificial animal.

Rooker also stated that "the worshiper had the responsibility of slaughtering the animal, apparently by cutting its throat." ${ }^{290}$ In addition, he recognized that "the worshiper was also responsible for skinning the animal and cutting it into pieces (1:6). ${ }^{291}$ The laws explicitly state that the offerer was to do that ${ }^{292}$ which would undoubtedly eliminate any confusion as to who the offerer was, and would do it in a much more meaningful way, especially in contexts that include moral impurity. Rooker's insights were anticipated by Rodríguez, who emphasized that the key reason for the assumption that the offerers were

\footnotetext{
${ }^{288}$ The offerer slaughters his/her sacrificial animal. This is indicated in the text of Lev $1-5$ and is accurately noted by Gane. "The sinner lays one hand on the head of the victim and then slaughters it. The priest puts some of its blood on the horns of the altar and pours out the rest of the blood at the base of the altar." Gane, Cult and Character, 21. Milgrom's belief that anyone could slaughter the animal is discredited by the fact that sacrificial regulations never mention anybody else doing this but the offerer. In addition, this is also assumed in the light of the regulations in Lev 5:5 and Num 5:7 that state that the offerer makes confession, with no hints about implying that another person is the subject of the verb "to bring" the sacrifice in Lev 5:6 or "to make restitution" in Num 5:7. Milgrom, Leviticus 1-16, 156.

${ }^{289}$ Paterson, "Sacrifice," DBDL 4:340.

${ }^{290}$ Rooker, Leviticus, 88 . The law concerning the sacrifices are consistent and emphatic that the offerer would perform the act of slaughter (Lev 1:5, 11; 3:2, 8, 13;4:4, 15, 24, 29, 33; 6:25; 7:2), and with it, began a series of activities where the offerer and the priest alternatively carried out responsibilities. LaSor, Hubbard, and Bush, Old Testament Survey, 85.

${ }^{291}$ Rooker, Leviticus, 89.

${ }^{292}$ Milgrom, Leviticus 1-16, 159.
} 
to slaughter the sacrificial animal is found in the fact that they transferred their sin onto it and therefore had to kill it. ${ }^{293}$ In that case, the sacrificial offering process would include at least two ritual activities that have exactly the same meaning and which would be highly questionable. Suggesting that the laying-on-of-hands function was to identify the owner of the sacrifice is unnecessarily limiting this crucial ritual activity and overlaps with other ritual activities included in the ritual process.

Thus, Wright's arguments are unsatisfactory because of (1) considering the cereal and the bird offering to belong to the same category in order to reason that the laying on of hands was not performed on these offerings because of their size, and (2) the sacrificial process contains stronger indicators of who the offerer of the sacrifice was other than the laying on of hands.

\section{Laying on of Hand/s and Confession}

Wright stated that the view of the transfer of sin or penalty by hand placement is usually accompanied by the view that a confession of guilt took place at the time of hand placement. There is no evidence, however, that confession took place at that time. The few examples of confession with a sacrifice placed the confession before the sacrifice is even brought (Lev 5:5; Num 5:7). ${ }^{294}$ This is an argument from silence. Cultic legislation does not include confession of sin in Lev 4 where one would expect it, but it does include it in Lev 5:5, which is a type of sin offering. Wright's suggestion that, in Lev 5:5 and

\footnotetext{
${ }^{293}$ Rodríguez, “Transfer of Sin in Leviticus,” 130.

${ }^{294}$ Wright, "The Gesture of Hand Placement," 437-38.
} 
Num 5:7, confession did not take place at the time of the laying on of hands is not supported by the text. ${ }^{295}$

Legislation in Lev 5:5 is significantly abbreviated in comparison to Lev 4, where the sacrificial process is explained in a temporal, chronological, and significantly more detailed manner. Regulations in Lev 5 perhaps emphasize confession and rely on Lev 4 for the exact sacrificial order, because the sins in vv. 1 and 4 are public and intentional, including certain damage to a fellow man, and as such, require public confession. ${ }^{296}$ Leviticus 4 does not contain hints that would point to their public and intentional nature, so perhaps they are private and the decision to offer sacrifice and receive forgiveness remains in the realm of the sinners' decision. If they decide to offer the sacrifice, the sacrificial process itself is a sort of confession, since they are moved to follow a divinely instituted mechanism to solve the problem of $\sin$ in their lives.

Gane suggested that the laying on of hands or handing the bird or grain offering to the priest served as an implicit confession. The priest did not need to know the exact nature of the offerer's sin. It is a matter between the offerer and God, so oral confession is not needed. ${ }^{297}$ In this vein, it is also reasonable to understand scholars who claim that making a sin offering would also include oral confession. ${ }^{298}$ Perhaps the confession

\footnotetext{
${ }^{295}$ Followed by Milgrom, Leviticus 1-16, 300-301; Gane, Leviticus, Numbers, 124-25.

296“'So it appears that verbal confession, demonstrating repentance and loyalty to the Lord by humbly acknowledging accountability to him, is needed to affirm that a deliberate $\sin$ is not defiant. With an inadvertent fault, there would be no question of possible defiance because the sinner would not even know that he or she was violating a divine command." Gane, Leviticus, Numbers, 125.

${ }^{297}$ Gane, Leviticus, Numbers, 125.

${ }^{298}$ Rodríguez, "Substitution in the Hebrew Cultus," 199-200; Noordtzij, Numbers, 66; Hartley, Leviticus, 21, 69.
} 
would not take place in the priest's presence, but would precede the sin and reparation offerings.

The regulation in Num 5:7 is also heavily abbreviated. It does not even mention a sacrificial animal, ${ }^{299}$ so it is logical that it would not mention the laying on of hands. Confession is explicitly mentioned for the same reason as it is mentioned in Lev 5:5-the public, intentional nature of the sins, including certain damage to a fellow man.

Any input from Lev 16:21 to rituals that are classified as sacrificial is disputed due to the belief that the goat for Azazel is not a sacrifice. However, having proven that the number of hands used in the laying on of hand/s gesture or its form essentially does not change its meaning/function, the present study points to the fact that the laying on of hands in this ritual can lend indications to the meaning of the laying on of hands in other contexts, especially those that are expiatory sacrifices. The fact that some scholars made a sharp distinction between Lev 16:21 and expiatory sacrifices, which Lev 5:5 and Num 5:7 definitely are, denying any sameness or correlation of meanings of common ritual activities between these two rites, shows their ignorance of the fact that the meaning of confession in Lev 16:21, nonsacrificial, and Lev 5:5 and Num 5:7, sacrificial, contexts is the same. Therefore, based on the fact that both of these supposedly different contexts contain the same ritual activities, the laying on of hand/s and confession, the present study accepts that the undisputed association of the confession of sins and the laying on of hands over the head of the goat for Azazel should be used a model for all expiatory sacrifices.

\footnotetext{
${ }^{299}$ Milgrom, Leviticus 1-16, 326-27, 337-38.
} 
Milgrom restricted the confession of sins only to intentional sins ${ }^{300}$ However, this claim faces serious problems in light of the fact that the high priest makes confession of the sins of the sons of Israel over the goat for Azazel on the Day of Atonement, and these sins are defined as "all the sins of the sons of Israel" (Lev 16:21, 30, 34). Confession does not seem to be limited to public, unintentional sins only, but rather, extends to all sins.

This claim is strengthened even more by a more explicit presence of the confession of sins in the rest of the OT (Ps 32:5; Prov 28:13; Dan 9:4, 20; Ezra 10:1, 11; Neh $1: 6 ; 9: 2-3)$. With the majority of scholars, I, believe that confession was an assumed element of sin and reparation offering ritual, ${ }^{301}$ however not in the presence of the priest or any other human being except when a human being incurred damage/loss because of the sin that the offerer committed. Milgrom, followed by many influential scholars, ${ }^{302}$ provided strong evidence from ANE literature and rabbinic texts for the presence of the confession of sins. ${ }^{303}$ Extrabiblical texts convincingly suggest that confession of sins was an integral part of the sin and reparation sacrifices.

${ }^{300}$ Milgrom, Leviticus 1-16, 300-303, 368-69.

${ }^{301}$ Kurtz, Offerings, 83; Merwe, "The Laying on of Hands in the Old Testament," 37-38; Eichrodt, Theology of the Old Testament, 2:161-62; Rodríguez, "Substitution in the Hebrew Cultus," 198-201; Noordtzij, Numbers, 66; LaSor, Hubbard, and Bush, Old Testament Survey, 154; Hartley, Leviticus, 1xx1xxi, 21, 69; Levine, Leviticus, 28; Rooker, Leviticus, 188-89. This list of scholars is not exhaustive.

${ }^{302}$ Schwartz, “Leviticus,” (JSB), 216; Wenham, The Book of Leviticus, 105, 109; Rooker, Leviticus, 119.

${ }^{303}$ Milgrom, Leviticus 1-16, 24-25, 298-99. See also Milgrom, Cult and Conscience, 106-14. Milgrom excludes confession in the context of inadvertences, that is Lev 4 . This study interprets Lev 4 as covering both intentional and unintentional sins which consequently led to the conclusion that confession was also part of Lev 4 ritual. 


\section{Arguments from Current Research}

Besides the points raised in the subheading, "Evaluation of the Claims against Transfer/Substitution Theory," that demonstrate that arguments against this theory reflect selective and uncomprehensive reading of the text, this study suggests additional arguments that support its validity. These arguments stem from the analysis of two concepts that are integrated in a broader context of Ancient Israel faith, as expressed in the Pentateuchal texts.

\section{Insight from Hamartiology}

The first section of this study demonstrated certain specifics of the concept of sin.

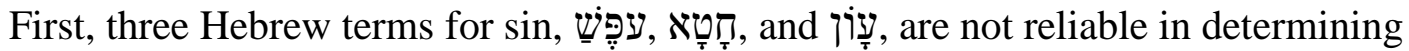
whether the sin is intentional or unintentional and expiable or inexpiable. They often semantically overlap and are used as synonyms. As such, these terms are not reliable for giving much insight into the nature of sin in terms of presence/absence of intent and expiability/inexpiability. Thus, context remains the decisive factor to this end.

Second, the first point is critical because scholars usually consider intentional, brazen, and inexpiable sin. However, a terminological analysis of the three

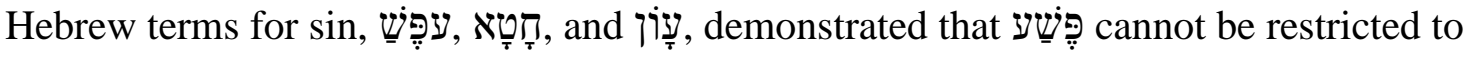
intentional, brazen, inexpiable/unforgivable sin. The present study demonstrates through the terminological/contextual/intertextual approach that iֶּ is mainly intentional and potentially also unintentional, but yet always expiable/forgivable sin.

Third, this point disproves the foundational assumption of ADH that inexpiable/unforgivable sin, uniquely defiles the sanctuary from a distance through the 
air. Being expiable, sin or reparation offering. Consequently, same way as other sins via the sacrificial offering process.

Fourth, in addition to the claim from a terminological study of the term it refers to intentional and potentially unintentional sin, the presence or absence of intent is not a reliable element to determine whether the sin is expiable or inexpiable. It is demonstrated in the present study that some intentional sins are expiable/forgivable as are unintentional ones, and expiable sins can invoke punishment if divine regulations to deal with a given sin are not followed. However, a terminological study of פֶּ itself does not provide grounds for establishing whether it conveys intentional inexpiable sin. Thus, it is the context, rather than the use of the term whether the sin is expiable or inexpiable.

Fifth, the proposed understanding of terms gave room for the unique interpretation of Lev 16:16, 21. Shea proposed certain arguments, some of which were disproved and some strengthened in the present study that the both lists of sins in these two texts, actually refers to sin offerings rather than to sins. The first two terms in the list refers to sins that were dealt with by the sin offerings.

Consequently, at least four facts invalidate basic and critical assumptions of

ADH: 1) three Hebrew terms for sin,

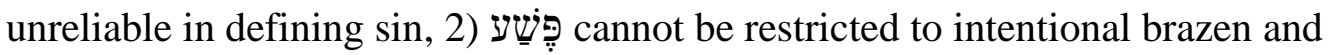
inexpiable/unforgivable sins which consequently challenges the key presumption of ADH that 
element in proclaiming a sinful activity inexpiable/unforgivable and provide ground to be classified as such sin, and finally 4) interpretation that nominal in Lev 16:16, 21 refers to the sin offering, rather than sin. These insights remove the most challenging critiques against transfer/substitution meaning/function of laying on of hands.

\section{Insights from the Concept of Atonement}

First, the understanding that element of the commonly believed atonement theory that assumes AD of the sanctuary. The sinner of experience capital punishment. This is not supported by biblical texts. The claim that there are sins for which forgiveness via sacrifice is not possible is correct, but these sins are never conveyed via the

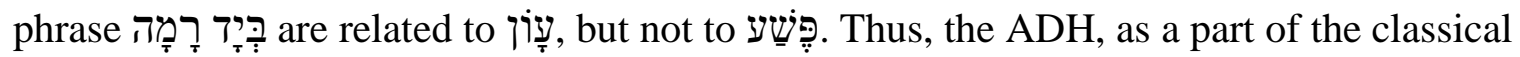
atonement theory, was redefined.

Second, scholars believe that through sacrifice, travels through the air and attaches itself to the sanctuary, particularly the most holy place. It is inescapable that possesses some kind of intelligence in order to land exactly where it is supposed to land, the most holy place. The present study understands that the concept of atonement is expressed by a highly abstract language that it also includes symbolism, but assigning these kinds of abilities to only a certain type of sin would be crossing the limits of the definition that biblical faith does not contain magic. In the atonement theory and understanding of sin presented in the present study, the movement of sin is highly 
controlled and limited. That is, the sin was transferred from the offerers to their sin offering and then through the blood of the offering into the sanctuary or through the blood onto the sacrificial altar in addition to the officiating priest via the eating of the sacrificial meat. The ADH assumes that offerer, glides through the camp and lands exactly in the sanctuary. If פֶּ sin were public, and presumably the sinner is deserving of capital punishment, as the proponent of ADH believes, כָּשׁ sin's entrance into the sanctuary does not make any sense. The sinner of fear of his sin's being a threat for the sanctuary.

Upon closer analysis of crucial texts used to support the AD theory, the present study demonstrates that this theory is untenable for multiple reasons. These reasons pertain to the areas of grammar lapses, the semantics of the verb טָָָָָ, and inconsistencies in the literary structure of related texts.

Third, the present study demonstrates that the foundational meaning of ransom, not cleansing. Even though the understanding of ransom defined in this study and the common understanding of this concept as defined in English dictionaries ${ }^{304}$ are similar to some extent, it has to be stressed that ransom in this study does not include legally negative connotations, but rather, the one that is informed by biblical texts. Thus,

\footnotetext{
${ }^{304}$ For instance, a bribe is defined as "a sum of money or something valuable that you give or offer to somebody to persuade them to help you, especially by doing something dishonest." Oxford Advanced Learner's Dictionary, s.v. "bribe," released 30 July 2015, http://www.oxfordlearnersdictionaries.com/ us/definition/american_english/bribe_1. For similar definitions see Oxford English Dictionary, s.v. "Bribe," released 9 April 2019, https://en.oxforddictionaries.com/definition/bribe; $B L D$, 8th ed., s.v. "Bribe"; $A$ Dictionary of Modern Legal Usage, 2nd ed., s.v. "Briber; bribee; bribe-giver; bribe-taker"; Burton, BLT (1998), s.v. "Bribe."
} 
ransom refers to a reconciliation of an interrupted relationship between a sinner (offending party), who broke God's law, and God (offended party), whose law has been violated. This reconciliation is achieved by God's acceptance of the ransom in the form of the life of the animal, instead of the sinner's life. In this case, the animal's life serves as a ransom for human life. A metaphor of removal, of sin with its punishment, encounters this part of the atonement process better than the metaphor of cleansing because the latter refers to total absence of the substance, an item that is being cleansed from the object that it resided on/in. This cannot be said of the connection of the sinner and their sin. Thus, the biblically informed understanding of ransom resembles the common definition of ransom in MLSs in the fact that there is some sort of payment to a law jurisdiction entity, which has not necessarily established a law, to help a law-breaker mend his/her situation that includes violating established law without considering the offended party. It differs in the fact that a biblical ransom fixes the relationship between a sinner and God which is defined by (1) laws that are given and enforced by God himself, and (2) God as the offended party who accepts a ransom in order for the reconciliation to take place.

The latter is possible in a very limited number of texts that separate themselves from other uses by a specific grammatical pattern: marker and the noun is modified by the direct object marker.

Fourth, the meaning of רכִֶֶּ as "to ransom" and the choice of English "to atone for" or "atonement" for it removes misleading connotations or senses of the two most common scholarly suggestions, "to cover" or "to cleanse," for רפֶּ that stems from concrete meaning of this verb which is not supported by biblical texts. In light of the 
ever-present and underlying GHS and a particular sin, the meaning, "to ransom," is supported in some context by rigorous examination of כִֶֶּ uses in the Pentateuch and by the overall interpretative framework found in the Pentateuch, which places emphasis on the symbolic, abstract meaning of atonement.

Fifth, the fact that such as acceptance, forgiveness, sanctification, or cleansing it always ransoms either the offerer's GHS or a particular sin that is transferred to the animal. The laying on of hand/s is a distinct ritual activity that facilitates this transfer to the sacrificial animal that eventually dies in the offerer's place.

In summary, the following facts established through the study of רִּ form an interpretative framework in which transfers/substitution is necessary and constitutes the

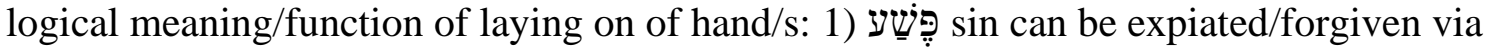
sacrifice; 2) possess faculties of an intelligent being such as traveling from the spot where it was

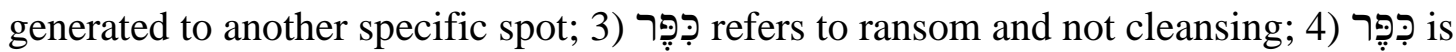
portrayed as a symbolic, abstract process for which the English word "atonement" is the most appropriate; and 5) divine-human relationships.

The arguments from hamartiology and atonement do not eliminate the fact that secondary functions of the laying on of hands could have been to express identification or convey the ownership of the animal. However, in light of the arguments mentioned above, the transfer/substitution remains the primary meaning/function for the laying on of 
hand/s. Transfer remains unspecified, since the element transferred is determined by a given context. However, the interpretative framework and a given context should also be taken into consideration to control the elements that are transferred, since in light of some contexts, some transfers are superfluous and redundant. 


\section{CHAPTER 7}

\section{SUMMARY AND CONCLUSION}

The foundation of this study was the interrelatedness of the concepts of sin and atonement with the ritual gesture of the laying on of hands as presented in the sacrificial offering regulations. Regardless of the long history of opposition to transfer/substitution as a suggested meaning/function of the laying on of hand/s, the research presented in the

present study suggests that this theory still possesses valid—and overwhelming — biblical support. The present research consisted of three major parts.

\section{The First Part}

The first part of the study included chapters two and three. Chapter two includes a general study of impurity in the OT including its key approach and weaknesses and ending in a more focused study of moral impurity, including specific Hebrew terms. Chapter three offers terminological definitions based on the MLS in order to examine the role of intent in the event of sin in the Pentateuch.

\section{Chapter 2}

\section{Approaches and Obstacles in the Study of Impurity}

I demonstrated in this chapter that OT hamartiology is perplexed with the fact that sin is often presented through (1) multiple metaphors, (2) an extensive plethora of 
Hebrew terms, and (3) the tendency of the OT to present it as a conceptual representation. A major weakness of all key approaches developed in OT hamartiology is root fallacy, a belief that the original, etymological meaning, which rests on the earliest use of the term/s, is a normative meaning for subsequent uses. The terminological approach is the most basic and needed element in OT hamartiology, but if it suffers from limiting sin to some terms, and all or the majority are included, then the study becomes superficial and literary insensitive. In addition, the contexts are usually insufficiently considered. The biblical-theological approach is also valuable since it tends to consider the historicalliteral element of biblical texts and organize the findings into a systematic/topical teaching. The key weakness of this approach is the immense number of imbalance definitions and text selectiveness. The metaphorical approach views impurity as just one term to denote the concept of sin and the meaning of "metaphor/metaphorical" is never defined by scholars. It does not seek to define the concept of sin, but rather, to find the metaphors by which impurity/sin is expressed. As such, it is the least utilized approach in scholarly debate. All these key approaches are not mutually exclusive and do overlap to some extent.

The approach utilized in the present study is named the terminological/contextual/intertextual approach and represents the way to avoid root fallacy and the weaknesses of key approaches and to incorporate their strengths. It attempts to collect statements on sin in the Pentateuchal texts paying attention to the context and literary particulars of the texts analyzed. In order to perform a thorough analysis of the texts, it set the limits on the number of terms being analyzed. 


\section{Impurity in Scholarly Debates}

This first part of the second chapter demonstrated that the division of impurity in the OT into ritual and moral is understood from the early beginnings of the study of this concept. Key scholars on the topic such as David Hoffmann, Alfred Büchler, Mary Douglas, Hyam Maccoby, Jacob Milgrom, Tikva Frymer-Kensky, David P. Wright, and Jonathan Klawans all confirmed the division into these two impurities. This bipartite division was articulated in early Jewish sources, spanning Talmudic and medieval rabbinic literature, Philo, and the early rabbinic sages. The two key proponents who viewed impurity as a single nature concept are Jacob Neusner and Thomas Kazen. However, Neusner was unsuccessful in preserving the two ways (metaphorical elsewhere in the Bible and literal in relation to Cult) of interpreting texts that speak of impurity, while Kazen's application of the bio-psychological approach onto moral and ritual texts is highly questionable. The history of research showed that moral impurity originates from sinful behavior, while ritual impurity originates from human corpses, certain animal carcasses, bodily flows, and leprosy, and as such, it symbolizes sin. It is unknown why they symbolize sin from the scholarly debate. The present study connects ritual impurities to sin via the potential of death that ritual impurities carry in themselves. The work of Frymer-Kensky, Wright, and Klawans are the most detailed and educational. Building on the bipartite division of impurity to ritual and moral impurity, Kensky-Frymer divided ritual impurity into minor and major, and concluded that these impurities are contagious, but yet, not sinful. Major impurities are caused by death, leprosy, bodily discharges and childbirth, while minor impurities result in contact with impure things, things that are defiled by persons under major impurity and persons under major impurity. Moral 
impurity refers to activities forbidden by God. She also believed that pollution of the sanctuary takes place in two ways, via direct contact and aerially. Wright's work is imbedded in Frymer-Kensky's study. He introduced a new terminology, tolerated for ritual and prohibited for moral impurity, which is heavily but yet, rightly criticized by Klawans. Finally, Klawans' work is the most up-to-date work on the topic and upholds the classical bipartite division. Along with the previous scholarly research, Klawans agreed that ritual impurity (1) arises from natural and unavoidable conditions, (2) is not sin, and (3) conveys impermanent contagion via direct contact. Moral impurity, on the other hand, (1) arises from grave sin, (2) is not defiled by direct contact, (3) leads to longlasting, if not permanent, contagion, and (4) unlike ritual impurity which can be addressed and remedied via purification ritual, is rectified by atonement, punishment, or refraining from committing it. He highlighted the fact that purity/impurity terminology also confirms the traditional division into ritual and moral impurity since טָָָ is used for

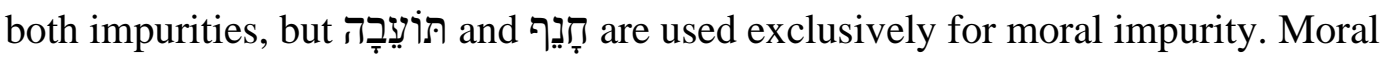
impurity defiles the one who performs it, the sanctuary, and the land. Ritual impurity never defiles the land, nor is derived from the land, but defiles the sanctuary and humans. Klawans innovatively introduced the fact that both impurities, ritual and moral, are real. In addition, he endorsed the metaphorical use of purity/impurity language in biblical texts, but not to the extent that scholars usually think of, claiming that use of metaphorical or figurative interpretation of certain texts brings more confusion than clarity to the discussion due to various theories on metaphor itself. 


\section{Further Insights on Impurity from the Present Study}

In expanding the works of these scholars, some other insights are present in the Pentateuch that further confirm the bipartite division between the two impurities. Removal of negative effects of ritual impurity never results in forgiveness (סְָָח), but predominantly, in 24/25 contexts, it does result in purification (טָָָרָ). In the Pentateuch, in 3/4 contexts, in Lev 12:7-8 and 14:20, purification is just potentially present, while in Lev 16:19, טָָָר deals with the ritual impurity. Thus, Lev 16:30 remains the only

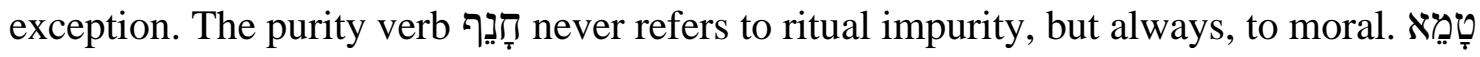
expresses both impurities and predominantly expresses defilement of humans and insignificantly, of the sanctuary and the entire camp. חָדָלָ is is even more flexible than in its preference to transfer both ritual and moral defilement to humans and the sanctuary.

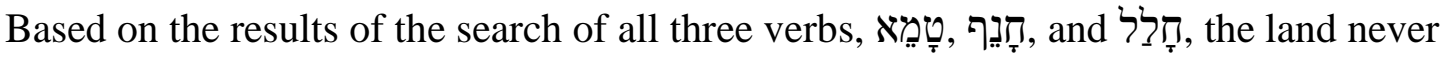
contracts ritual defilement, but always, moral. תוֹעָבדָה never refers to ritual, but always to moral impurity. Thus, a terminological analysis of purity verbs favors the bipartite division of impurity more than a single impurity approach.

Having established the division between ritual and moral impurity, the present study focuses on moral impurity expressed by atonement, especially in Lev 4-5; 16:16, 21. The present study established that

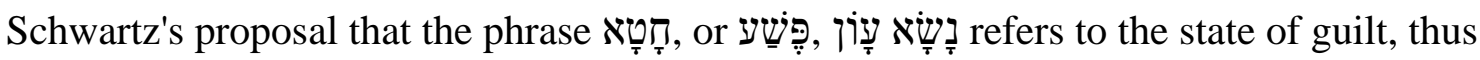
representing consequential bearing of sin, is an eloquent attempt to suggest a fresh meaning to the phrase. However, weaknesses embedded in it make it incapable of 
replacing the traditional understanding of the phrase consisting of two meanings, "to forgive" and "punishment."

By applying the terminological/contextual/intertextual method in studying the terms refer to unintentional and intentional sins. In terms of expiability, they all refer to expiable and inexpiable sins. The uses of these terms reveal that the emphasis of each term's preference to denote intentional or unintentional and expiable or inexpiable sin vary, but all of them at least sometimes refer to all these types of sin. Finally, these three terms are often used as synonyms and semantically overlap.

\section{Chapter 3}

\section{Legal Terminology}

In chapter three, this study consults MLS terminology in order to clarify its use in biblical studies. Consequently, it is demonstrated that biblical scholars usually misunderstood essential meaning of the terminology. The prime example is Jacob Milgrom who was followed by other biblical scholars. Contrary to Milgrom, it is negligence that encompasses wrongs done inadvertently or ignorantly, and not inadvertence that encompasses wrongs done negligently or ignorantly. Besides similarities to ANE law collections and certain unique characteristics of BL, its key uniqueness is crucial for the present study. That is, BL has its origin in God himself and consequently, breaking any regulation of BL assumes liability of the one doing it and accountability to God himself. 


\section{Intent in Legal and Cultic Texts}

Establishing intent, though difficult, is possible in legal texts, as well as in cultic texts. Homicide laws are an example of the most comprehensive display of various levels of intent in the former, while the latter is portrayed in Lev 4-5 and Num 15. Milgrom, in a way, determined how scholars perceive intent in cultic laws. He proposed that consequential meanings like other terms that deal with sin, such as express both, sin and its punishment. אָָָׁ, being an intransitive verb, is best understood if translated as "to feel guilty," which Milgrom supported by the use of the noun שִׁגָגָּ, which he understood to mean "inadvertence." A closer reading of his work reveals that שִשְָגָגi is limited to accident only, which is only partially true, and is applied to all cases of שִשָגָגדה Thus, unconsciousness of the sin and consciousness of the act is common for any breaking of the law in Milgrom's opinion and it impacted the role of intent in the process of breaking the law. Such an understanding of sin excludes the major class of sin which is sin committed out of GHS and weakness.

By examining the uses of wָשָ, it is established that both aspects, subjectivephysiological-consequential and objective, are contained in the verb אָָׁשָ. The context is the determining factor if both or one particular sense is to be a preferred meaning. The inclusion of both these factors, subjective-psychological-consequential and objective senses of the verb grammatical flow of the texts provide the most satisfactory and consistent reading of Lev 4-5. "To be/become guilty" remains the least misleading translation since it embodies all 
the others and remains the most basic meaning of the term in the context of legal/moral standing.

This understanding, one of the suggested understanding/translations of chronologically places the sinners' recognition of the sinfulness of their sin before they offer a sacrifice or make confession in Lev 5:1-5, 17 which is obvious in Lev 4:3, 13-14, 23-24, and 27-28. Sinners are always fully aware of their sin before offering a sacrifice. Second, it provides the rationale of how the sinners, who are aware of their sin, are motivated to rectify their sin in Lev 5:23. Besides being objectively and subjectively aware of their sin, the sinners also experience the consequential aspect of their consciousness), and their objective and subjective experience of guilt is placed in the right context, and they fully understand their sin. Third, this chronology of activities where sinners' awareness of their sin before they begin to rectify it is preserved and upheld by the recognition of the temporal sequence of activities in Lev 4-5 expressed by wayiqtol and weqatal verbs, and of the pluperfect sense of qatal verbs. Fourth, it recognizes two different ways by which sinners become aware of their sin which is obvious in Lev 4:23-24, 27-28 and in all other transitions in Lev 4:3, 13-14 by understanding that the Hebrew particle iw in the most natural way as "or" and understanding the Hebrew conjunction ? to mean "or," as one of its frequent meanings in the Pentateuch and the Hebrew Bible. Fifth, the presence of two different ways of the

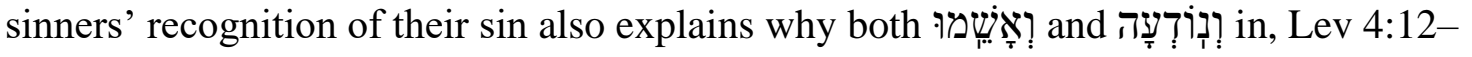
$13,22-23,27-28$, are accompanied by additional clauses that basically communicate that 
the sinner has committed sin. This is not the case in Lev 5:5, 17, 23, where only אָָׁשָ occurs, with no additional clauses to communicate the act of sinning. The only exception

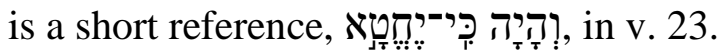

The study of בִשְָָׁגָגדה revealed that this term refers to the non-brazen nature of the sin (Num 15:22-29) and activities committed accidentally, with no intentionality included on the sinner's part. If the immediate context of the phrase does not provide arguments for a different nuance of meaning, this is the one that should be assumed.

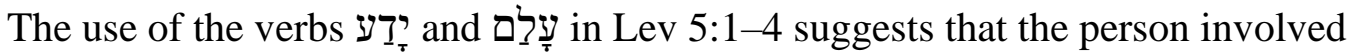
had knowledge of his sin, was aware of it, but consequently lost knowledge of it. Still, this understanding of $\sin$ in Lev 5:1-4 rests on the grammar utilized in the passage. These verbs are used in Lev 4:13, but the grammar does not support the understanding that is conveyed in Lev 5:1-4.

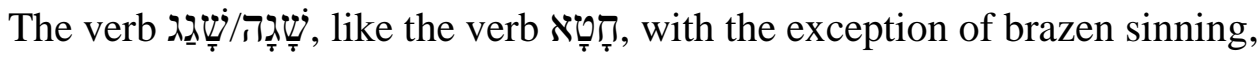
expresses all types of sinning in the OT. The immediate and wider context of each use clarifies whether the verb is used as a generic way, or whether it conveys some specific way of sinning.

\section{Leviticus 4-5: A Fresh Proposal}

The four subcases in Lev 4 all assume two alternative ways of sinning, unintentional accidental and potentially out of ignorance, and intentional, but non-brazen. The next four subcases in Lev 5:1-4 are intentional but non-brazen sins that were forgotten and eventually remembered. The pericope of Lev 5:14-16 is unique, and for that reason, is separated from the subcases in Lev 4 because it deals with the sins against 
the sancta. However, in terms of the nature of sinning, due to the use of a general verb Tָּ and a theoretical potential, the pericope assumes the same types of sins as are in Lev 4, unintentional accidental or out of ignorance, and intentional but non-brazen. Leviticus 5:17-19 is another unique type of sinning that is only well established here, and that is the sin of ignorance. The final pericope in Leviticus, 5:20-26 [6:1-7], encompasses the exclusively intentional, but non-brazen sins. Numbers 15:22-31 deals with two types of sinning. The first is described in vv. $22-29$ and are non-brazen sins which may include all types of non-brazen sins defined in Lev 4-5. The second, vv. 30-31, is brazen sin that includes the full intention of the sinner along with the attitude of rejecting God's personality and authority.

\section{Fresh Sin Classification}

As a result of such an understanding of terms and crucial texts concerning the intent related to sinful activities, the present study suggests that the death/capital punishment prescribed for sin makes it intentional, brazen sin, while all other sins to which other non-capital punishments are associated is unintentional or intentional, nonbrazen, and possibly, expiable. The former one is defined in the Pentateuch as " sin and it is always done in the sinner's full awareness of the activity and consciousness of the activity's being sinful. The latter can be done unintentionally and intentionally. The unintentional one is by accident or through ignorance, which implies awareness of the activity, but unconsciousness of the activity's being sinful. Intentional, non-brazen sin stems from GHS/weakness, where the sinner is fully aware of the activity of sinning and conscious of the activity's being sinful.

The research on moral impurity provides the following three points: First, Hebrew 
terms for moral impurity semantically overlap. Second, all of them, in terms of intent, refer to unintentional and intentional sins and in terms of expiability, refer to expiable and inexpiable sins. Third, these three terms are often used as synonyms. Fourth, Hebrew terms are consequently not helpful in determining the nature of sins but the context is. These points enable a plausible interpretation of Lev 16:16, 21. Some scholars have interpreted Others assigned specific meaning to each term. Gane produced the most comprehensive work concerning the two interpretative cruxes in these two texts in following the latter method. However, this study demonstrates that Gane's interpretation is not sound. In regard to the first crux, lekol does not introduce a new item in the list, but rather, encompasses the first two terms. Regarding the second crux, Hebrew terms cannot be taken as referring to specific sins for the above-mentioned reasons, that is, their semantic overlap and synonymous uses. Thus, besides conveying a comprehensiveness of sin which is confirmed by the present study, these terms could be understood to refer to the sins that could potentially be found in the sanctuary and are atoned for by the sin offerings which are always taken to be the meaning of the last term in the list,

\section{The Second Part}

This part also consisted of two chapters, four and five. A detailed and extensive study of the Hebrew verb includes the laying on of hand/s, is dealt with in chapter 4. An evaluation of the ADH, including critical grammatical issues involved in the text upon which this theory rests, is presented in chapter 5 . 


\section{Chapter 4}

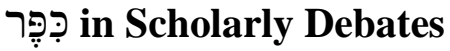

It has been established that widespread insight from comparative studies on the origin and meaning of the Hebrew verb רִּ , such as the Arabic kaffara or the Akkadian kuppuru, proved to be misleading, contrary to what was believed in the mid-20th century. First, stems in various languages do not correspond, but also overlap. The Hebrew and Arabic kaffara or Akkadian kuppuru have different meanings in the base and intensive stem. Yet, some uses show that sometimes they do semantically overlap. Second, scholars have proposed at least 4 ways (2) to ransom, (3) to purify, purge, and (4) to atone, expiate. Confronted with the variety

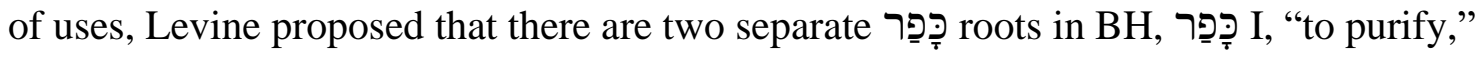
and כָָּ II, "to expiate," but his work reflected that he himself was not able to preserve this distinction as he interpreted texts. Milgrom was firm that pִֶֶּ predominantly means "to effect purgation" in a sin offering context. Less prominent meanings are "to cover," "to ransom," and "to atone, expiate." Sklar proposed that the verb encompasses both ideas, purging and ransom. Following previous scholarship, such as Driver, Gane moved

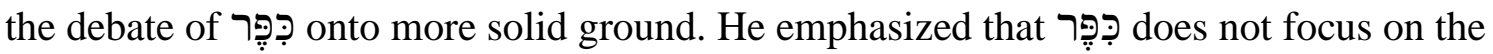
physical activity such as purging, which is emphasized in the Akkadian kuppuru context, but rather its goal, since the former is rare in biblical texts. He also insightfully noted that כִֶֶּּ takes place before forgiveness, which is the very final goal of offering a sin offering. Thus, כִִּ has something to do with the obstacle in divine-human relationships. Finally, he proposed that the nature of כִֶֶּּ in a given sacrifice is identified by the goal of that 
ritual. Feder's work is the most recent on the topic, and he proved that favored comparative input on the meaning of of the verb, and (2) 2 כִ has a wide range of semantic meanings in BH. He proposed, like Gane, that the meaning of

\section{Foundational Meaning of בִֶֶּּ}

The present study shows that major scholars of consideration for the fact of GHS of human beings in their formation of the meaning of this verb. GHS is a constant disadvantage of human beings when they interact with the divine, whether actual sin is involved or not, and as such, should be included in the formation of the understanding of foundational text for the meaning of כְִֶּ is the only text that explicitly explains it by detailing the role of blood in the sacrificial process, Lev 17:11.

First, examining the meaning of

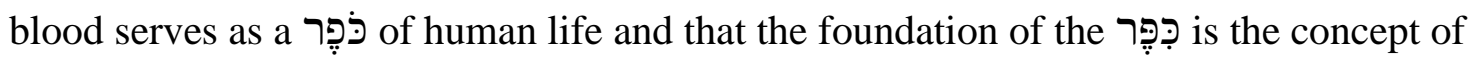
כָּפ a wrong party, is resolved by God's acceptance of the animal's blood-life as ransom for the offerer's blood-life. The decision of whether to accept the ransom or not rests solely on the wronged party, God. It is inescapable that the sacrificial animal serves as a substitute in the place of the offerer.

Second, asking to which sacrifices the regulations in Lev 17 refer in the present study affirmed that a general prohibition against blood eating in v. 10 is not limited to 
well-being offering but refers to burnt, sin and reparation sacrifice that all have atoning function.

Third, although all three alternatives, beth pretii, beth essentiae, or beth instrumentii, are valid for the meaning of the second ᄁִ preposition attached to the noun

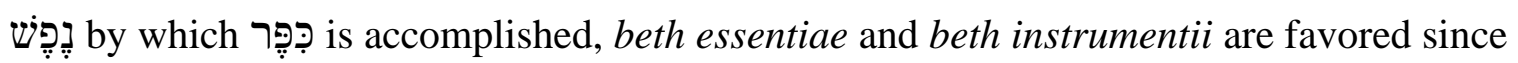
they agree with the understanding that the referent of iֶ $11 \mathrm{~b}$ is the life of the sacrificial animal and has stronger grammatical and intertextual support. Fourth, the fact that in in itself includes the idea of substitution and because the sacrificial animal is slaughtered at the altar in the sanctuary instead of the offerer, the idea of substitution is implied in Lev 17:11. This analysis and understanding of כִֶֶּּ greatly helped in identifying the meaning of רְְִּּ in some vague contexts below.

\section{Insights on}

The comprehensive analysis of the uses of modifiers in the present study brought the following results.

First, רְִֶּ has a concrete, literal meaning "to rub on, apply" only once in Gen 6:14, and then it is preceded by the direct object marker. This is also the only qal use of רכָ and non-cultic context in the Pentateuch. The same meaning is reflected in cultic contexts, even though

Second, when has various meanings such as "to appease, or atone, remove" that are derived from the contexts. 
Third, when רִֶֶּּ is accompanied by the preposition refers to atonement, but it was of a temporary nature (Gen 32:30). In cultic contexts, conveys two different meanings of "to atone for" and "to remove," in the sense of cleansing.

Fourth, ? + כִֶֶּּ is found two times and always in non-cultic texts with the meaning of "to atone for" and with the idea of ransom included.

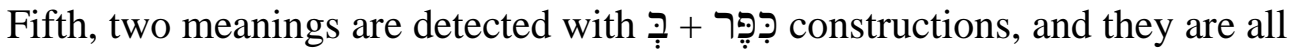
found in cultic contexts. All texts include impurity, either from context or implied, but the function of this construction is either to communicate the instrumental in the sense by

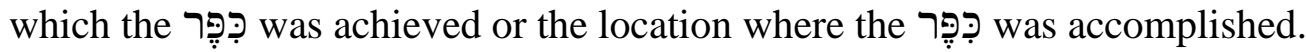

Sixth, the most frequent construction is cultic contexts. In 47/56 of occurrences, the preposition עַ carries the meaning of advantage, with only one non-cultic text. In the other 9 occurrences, the preposition marks either the location of Exod 29:36, עַל carries double function of marking the direct object marker and the location. Of the last 9 occurrences, only Lev 14:53 is a non-cultic context. The present study also analyzed the use of

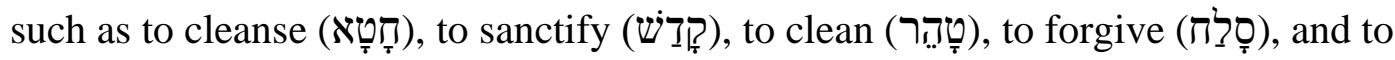

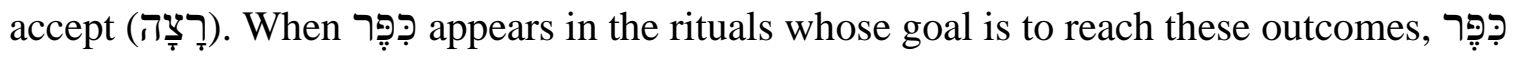
is a part of a bigger, major ritual. It has a limited function within the major ritual of assisting in the accomplishment of the major ritual. 


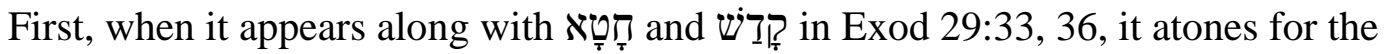
priests' GHS in v. 33, and cleanses the altar in v. 36. When it appears in דָָ contexts in Lev 8:15, it also atones for the priests' GHS. Ritual or moral impurity is not included in these texts. The basis for this atonement is ransom.

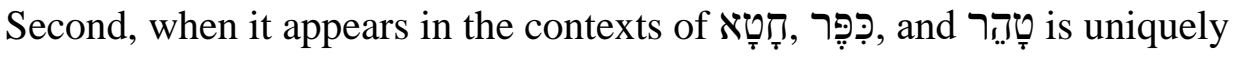
accomplished by the reparation offering in Lev 14:20 and refers to the reinstatement of the healed צָּרעַת person into the community and to the sin offering which atones for the healed צָרָעַ person's GHS. It is possible that moral impurity might have been included here, but not ritual impurity. In Lev 14:53, it refers to the removal of ritual impurity in the sense of cleansing it from the infected house.

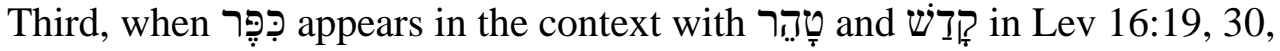
moral impurity is definitely included, and כִֶֶּ refers to its removal in the sense of cleansing.

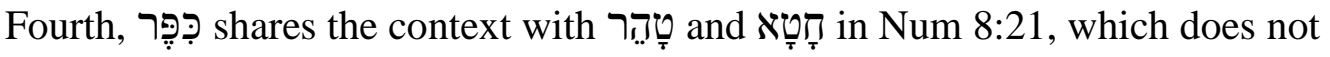
include impurity, and then refers to the atonement of the Levites' GHS. In the context

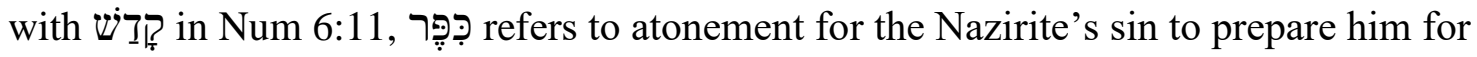
the new term of Nazirite status. Ransom is again the basis upon which atonement is possible in this context.

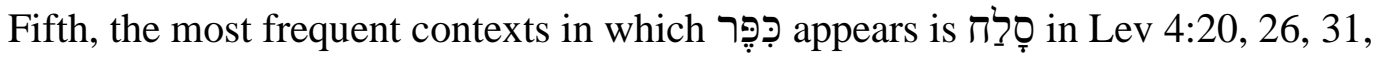
$35 ; 5: 10,13,16,18,26[6: 7] ; 19: 22 ;$ and Num 15:25, 26, 28. All these are cultic contexts

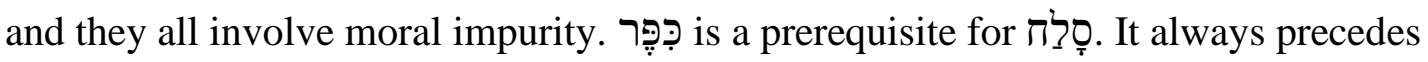

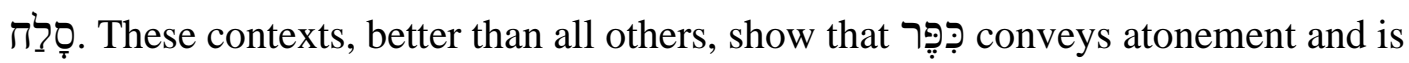


based on the ransom. The offerer receives סָלָ based on the sacrifice he/she offers.

Sixth, רִִּּ appears in the contexts where the offerer receives acceptance before God in Lev 1:4. This context implies the presence of GHS. Again, the basis of this atonement is ransom in the form of sacrifice.

Based on the contexts of the atonement of which כִִּּ is a part, it consists of two elements. The first element is reconciliation which implies that a relationship between God and a human party was broken. The reconciling act is actually an encounter of God's grace toward humans, followed by their willingness to return to God. The second element is expiation which implies that the human party feels guilt in the face of law because of his/her sin, and God's wrath that follows the act of sin. The human party needs to overcome these. Removal of the feelings of guilt and God's wrath is what expiation does. The human party gives up his/her sin while God gives up his wrath. In the actualization of both of these elements, reconciliation and expiation, God's initiative is crucial and always precedes the response of the human party. In other words, obstacle, whatever that might be.

However, God is never the subject or object of

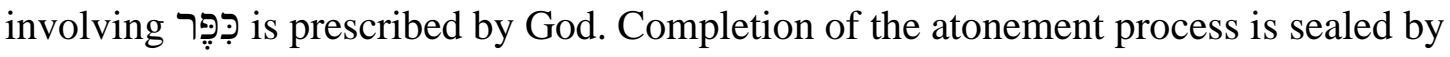
God's direct involvement in this process by granting forgiveness.

Both cultic and non-cultic contexts in the Pentateuch confirm that ṣִ should be understood as achieving abstract effects on both human and inanimate entities. Milgrom allowed for ransom to be foundational for include averting God's wrath. כִֶּ: as such encompasses substitution as well. This study 
understands that $ר$ רִּ always has this function, either in the contexts of moral impurity, some cases of severe ritual impurity, and in the cases of GHS. The analysis of contexts showed that some contexts give certain guidelines as to what the meaning could convey, but some contexts do not provide any guidelines, but solely rely on the already elaborated meaning. This study agrees that the foundational text that informs of almost all 1 çְִ contexts is Lev 17:11. There, the verb is presented as "ransom" on the basis of the sacrificial blood that is applied on the altar. The choice of a precise English word to translate the complex semantic range of the Hebrew present study proposed the English "to atone for" as the closest representation of what

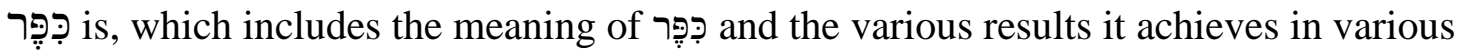
contexts.

\section{Chapter 5}

\section{Automatic Defilement Hypothesis}

The second part of the second section of the present study dealt with ADH. Based on the findings in the area of stem, aspect, and the semantics and patterns of use of the verb טָָמָא used in Lev 15:31; 20:3; and Num 19:13, 20, this study suggests that ADH is not supported by the Pentateuchal texts.

First, the part of Waltke's and O'Connor's theory that piel is always factitive if qal of the same verb is stative is valid in the case of טֵָָׁא within the limits of the Pentateuch. In other words, piel brings a totally passive undersubject, without regard to the process, into the state depicted by an adjective. By utilizing the method specifically developed to examine Waltke's and O'Connor's theory of piel, Beckman's research did 
not provide sufficient evidence for disproving it when applied to the verbs that convey

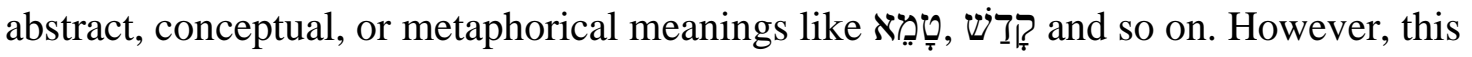
postulate regarding piel is not complete. Second, building on this, the present study detected a twofold pattern of טָָָָ uses in the Pentateuch. This verb is always accompanied with other verbs, through which its meaning onto the undersubject/direct object it modifies is achieved, and physical contact between the entities transmitting and contacting impurity is always included. Third, the verbal aspects of טֵָָׁא in the contexts of Lev 15:31; 20:3; and Num 19:13, 20 contain nuances that do not lend support for the $\mathrm{ADH}$. All these three points are reinforced as I focus on the issues pertaining to each of these texts and propose their interpretation.

\section{Leviticus 15:31}

Building on these three arguments just presented, the present study focuses on the more subtle grammatical, syntactic, and semantic irregularities found in Lev 15:31. It was demonstrated that the instrumental sense, "by defiling my tabernacle that is in their midst," is not justifiable, which consequently, makes ADH unsustainable.

First, the temporal interpretation considers that the infinitive construct +

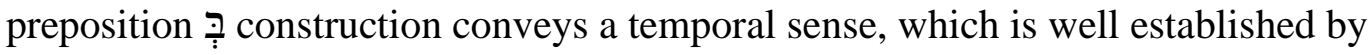
Hebrew grammarians. Second, the piel of the verb טָמָמא is considered as a stative verb in this text since it is intransitive. In addition to the factitive understanding of piel with this particular verb, the temporal interpretation agrees with the pattern of uses of טָָמִא established in this study. Third, the present study demonstrates that טָָמָא strictly follows a certain pattern of uses in the Pentateuch. That is, it is always accompanied with other 
helping verbs that convey the exact mode of how טָָמָא achieves its meaning. Fourth, achieving טֵָָָא state always includes contact between the defiling and profane entity. Fifth, the concept of ellipsis and delay that are part of the debate of defilement transmission do not override the temporal sense. These two concepts do exist in the Pentateuch. When they are interpreted within the Pentateuchal corpus without imposing preconceived ideas upon the texts that imply elliptical statements, they support a temporal sense. Based on the patterns of use of the ellipsis, "if an impure person touches sancta," is implied in this text. Also, a delay does not mean that a minor impurity grows into a major one if there in a case of delay to handle them, but rather, gives room for the defilement of the entire camp and the tent of meeting via the uncontrollable transmission of impurity among the covenantal community. Finally, as shown above, the temporal sense is accepted in rabbinic literature.

This study shows that Hebrew grammarians have proposed well-established rules in the area of grammar and syntax, as well as the semantics of the verb טָמָא which are very helpful in determining the most plausible meaning of Lev 15:31. The present study attempts to incorporate these rules into Lev 15:31 and arrives at the conclusion that the instrumental sense is less plausible than the temporal. It actually results out of significant grammatical, syntactic, and semantical irregularities. The temporal sense in Lev 15:31, on the other hand, does not collide with grammatical, syntactical rules or the semantic sense of the verb טֵָָָא. It has to be admitted that the temporal sense in Lev 15:31 does not provide the way defilement actually takes place, but just proposes a potentially defiled state of the sanctuary in the future. However, the manner of how the sanctuary gets defiled is very explicitly specified in the Pentateuch (Lev 10:1-2; 12:4). In other words, 
defilement takes place through direct contact as a part of טָָָא patterns of use in the Pentateuch as demonstrated in the present study.

\section{Leviticus 20:3}

An analysis of Lev 20:3 gave insights into an additional argument against the

ADH. First, the meaning and function of the preposition לִ לִַעַ that connects the first two and the last clause. Through two possible senses, purpose and intention, the preposition לִַַעַַ conveys a resultative sense in this text. It never conveys the causative sense in order to provide grounds for the interpretation that offering one's children to Moloch itself defiles the sanctuary, as the proponents of ADH imply. Rather, this preposition conveys that offering one's children to Moloch results in defiling the sanctuary. The translation, "the consequence of which will be," rightfully conveys its meaning. This understanding is in accordance with the understanding of the piel stem, the aspect of the infinitive construct, and the patterns of use of טָָָָא in the Pentateuch. As established above, piel brings a totally passive undersubject, without regard to the process, into a certain state. The infinitive construct acts as a finite verb in this text because it is transitive in a resultative clause. Infinitive Construct is frequently used in resultative clauses in $\mathrm{BH}$ and,

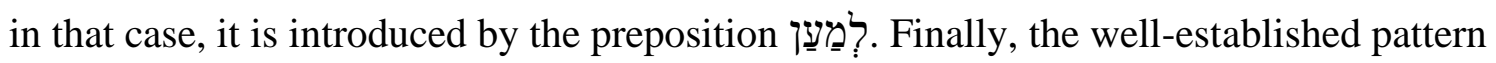
of טִָָָ uses in the Pentateuch points to the fact that this verb always requires another helping verb to achieve its meaning. All these insights suggest that an additional activity is implied between the first two and the third clause of this text as the preposition introducing the third clause indicates. Based on the established pattern of the uses of טָָָָא in the Pentateuch, that additional activity would imply direct contact between the idolater 
and the sanctuary through his/her coming to the sanctuary.

Second, Lev 20:1-5 faces significant internal structural and conceptual inconsistencies if it is assumed that it consists of two cases, vv. 2-3, and vv. 4-5. Staying within the limits of this text, the first inconsistency is a disparity of punishments for the same sin. That is, in v. 2, the punishment for idolatry is death by stoning, while in v. 4, it is either annihilation of the lineage or punishment in the afterlife. Death by stoning is standard punishment for idolatry. The second inconsistency is that the people cannot disregard the idolater in vv. 4-5 if they experience premature death in v. 3 as part of God's administering punishment upon them. Verses 4-5 are superfluous in this case. Third, if God punishes the idolater only when the covenant community does not, as it was evident in vv. 4-5, then this fact points to the claim that God, in v. 3, punishes because people do not know that the act of idolatry took place among them. These inconsistencies led scholars to propose that v. 3 represents the separate subcase of the law implying the ellipsis, "if he does it secretly." In that case, ? is not used as a conjunctive "and," but a coordinative particle "or." In addition, the use of the phrase, "from the midst of one's people," as well as "from one's people," accompanied mainly with the verb כָּרָת and in

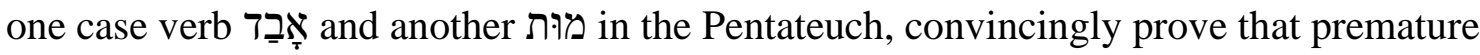

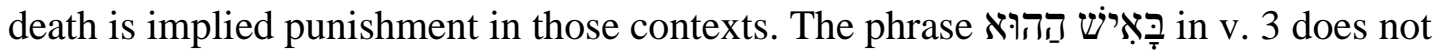
designate the exact person mentioned in v. 2 , thus connecting these two verses into one unit, but rather, it refers to any person who commits idolatry. This phrase is also mentioned in vv. 4 and 5, and it is impossible that the very same person is implied, since v. 4 indisputably introduces a new subcase. Thus, indefinite individual who commits idolatry. Cholewinski's persuasive literary structure is 
not affected by the inclusion of the implied elliptical phrase, בֶֶֶַַּ.

Accordingly, the understanding of stem, aspect, and semantic sense of טָָׁא, along

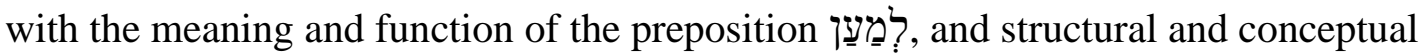
inconsistencies under the assumption that this law consists of two, rather than three cases does not support ADH. Verse 3 is a separate case in which the implied ellipsis, "if he does it secretly," resolves the internal conceptual inconsistencies of a two-subcase literary structure, thus allowing the idolater to come to the sanctuary and defile it through direct contact with it, since the covenant community does not know and is not able to prevent it. Again, arguments upon which ADH is proposed in regards to this text vanished.

\section{Numbers 19:13, 20}

Besides the already mentioned arguments, Num 19:13, 20 adds more arguments against the ADH. First, the piel stem of the verb טָָָָ is factitive. It brings a totally passive direct object into the certain state without regard to the process. Second, the perfect aspect is frequently utilized to convey a result in the future as a completed state. Third, the verb טָָמָא is always accompanied by other verbs through which its meaning on the direct object it modifies is achieved. Accordingly, these insights regarding the stem and aspect utilized in Num 19:13, 20, along with the semantics and patterns of use of טָָמָא in the Pentateuch, do not support ADH. Rather, these texts speak of the result that will take place in the future. The exact mode of how this result is achieved is indicated by the patterns of use of טָָָָ, namely via direct contact. 


\section{The Third Part}

The last part of the present study is presented in chapter 6 . This chapter encompasses the presentation of the ritual theory that would respect the data about the concept of sin and atonement suggested in the present study. In addition, it includes the evaluation of the critiques of transfer/substitution theory of the laying on of hand/s, along with arguments from the present study to confirm this theory.

\section{Chapter 6}

\section{Ritual Theory}

The present study has not focused on developing a ritual theory that would be based on the methods established by other disciplines such as sociology, anthropology, study of religion, literary criticism, study of theatrical performance, and psychology. Instead, this study looked for the ritual theory that correlates with the findings in the present study that were derived from biblical texts in order to provide a framework for the interpretation of the laying on of hand/s. The intention was to learn what the biblical texts have to offer about the laying on of hand/s. Such a ritual theory was found in the work of Roy Gane, who focused on the biblical text as the final and decisive factor in forming a conceptual and interpretative framework. Even though, Gane's and my interpretations on certain biblical texts, and ultimately the meaning of laying on of hands, significantly differ, the majority of my findings agree with his ritual theory and method he used to form it.

Led by sociological and anthropological methods, David P. Wright focused on the questions concerning ritual that are not dealt with in biblical texts. None of the three points he proposed are fully accurate. First, the claim that the texts do not lend sufficient 
data for proper interpretation assumes that ritual has to be observed in order to be interpreted properly. The point that both prescriptive and descriptive ritual texts in the OT do not provide a full explanation of the ritual performance and are not subject to sociological analysis is well noted and undeniably accurate, but still, his accurate assessment is out of context, since none of these two points stands in the ideological fabric of the production and purpose of these texts. Second, his point that the variety of genres enables a proper ritual interpretation is also misleading since the Pentateuchal ritual texts still retain emphasis on the ritual goal in various genres, rather than presenting themselves for a sociological analysis and performance. Third, a sharp conceptual distinction in the Pentateuch is not solidly established. Furthermore, recent research points to the unsustainability of establishing various literary strata within the Pentateuch based on literary features. Thus, Wright's arguments are not sustainable. Gane's ritual theory that also negates Wright's assumptions regarding the ritual interpretation was found to be in better agreement with biblical texts and therefore accepted in this study.

The main postulates of Gane's ritual theory are the following: (1) ritual actions and substances do not have an inherent meaning, but their meaning is established from sources like culture, religion, and immediate context; (2) ritual consists of activity and meaning that is attached to them in the text; (3) based on the second point, Gane was able to avoid weaknesses of structural, dynamistic, or historical approach, and focus on the meaning provided in the texts themselves, since these approaches are inadequate for identifying ritual meaning; (4) the meaning/function corresponding to the goal of a ritual is the goal, assigned to it by the activity system, that is, broader religious context of Ancient Israel; (5) a "ritual" is an activity system with a special kind of goal that is not 
subject to a physical cause and effect reaction, but rather, is symbolic, conveying that God intervenes through certain ritual physical processes; (6) systems theory concepts can aid in the interpretation of Israelite rituals because ritual in the Pentateuch, like in system theory, consists of sub-rituals; and (7) the biblical text, prescriptive or descriptive, provides instructions for physical performance and interpretations of activities, and remains foundational for determining a ritual's meaning/function. All these points of Gane's ritual theory are well supported by biblical texts, as demonstrated.

Conceptual gaps in the biblical ritual text are real. Some tried to solved by giving the reader freedom to fill them in based on other sources which, in the mind of the proponents of this approach, are even extra-biblical sources that are not affirmed by the present study. However, limiting the sources to biblical texts only, in this case, especially the Pentateuchal texts, provides a sound approach.

\section{Biblical Data Regarding Laying on of Hands}

Data from comparative studies confirms the fact that laying on of hand/s is found in a variety of contexts and meanings. The laying on of hand/s is recorded in 22 texts in the Pentateuch (Exod 29:10, 15 ,19; Lev 1:4; 3:2, 8, 13; 4: 4, 15, 24, 29, 33; 8:14, 18, 22; $16: 21 ; 24: 14 ;$ Num 8:10,12;27:18, 23; Deut 34:9) and 21 of them are performed in a cultic setting. It is widely accepted that this ritual gesture conveys the fact that some kind of relationship is established between the offerer and his/her sacrifice.

Besides these 22 texts where the laying on of hand/s is mentioned, there are at least 6 texts (Lev 1:10; 7:1-7; 9:8, 12, 15, 16, 18; 16:6, 9, 11, 15, 24; 23:8, 12, 18, 19, 27, $36,37,38$, and Num 28-29) where it is missing. The present study suggests that in Lev $1: 10 ; 7: 1-7 ; 9: 8,12,15,16,18 ; 23: 8,12,18,19,27,36,37,38$, and Num 28-29) the 
ritual gesture was performed and was omitted for valid reasons. An abbreviation is the reason for its absence in Lev 1:10 and 23:8, 12, 18, 19, 27, 36, 37, 38, and Num 28-29, where the focus is on the sacrificial altar, instead of on the priests in Lev 9:8, 12, 15, 16, 18 , or because of the point of view of the text, and allowance for converting the sacrifice into money that was handed to the priest. On the other hand, the present study recognizes that some texts contain hints that the laying on of hand/s was not performed in some contexts such as Lev 16:6, 9, 11, 15, 24 because Lev 16 is prescriptive and detailed text and as such, does not mention the laying on of hands on the burnt and sin offerings. In addition, the uniqueness of the sin and burnt sacrifices' function also points to the fact that the laying on of hand/s was not needed in this context.

Calabro correctly dismissed the presence of two forms of laying on of hand/s and proposed that the laying on of hand/s was always performed with both hands. However, his proposal was proven to be unsustainable upon closer study of his arguments and biblical texts. His argument relied on the partial and one-sided reading of other and later readings such as the LXX and the DSS. However, the review of his arguments shows multiple lapses at the level of statistics on the agreement and disagreement of the number of the noun "hand" in the MT, on one the hand, and the LXX and the DSS, on the other. In the context of unconvincing statistics, the claim of textual criticism that number disagreement can hardly be considered as a sign of an original reading does not stand. Except for some random cases within which hand disagreement is found in Lev 3:2, 8, 13, there is no pattern that could be established to support Calabro's proposal when the number of the noun hand is compared in the MT and the LXX. The two readings are more consistent than not. 
The present study fully recognizes the complexity of the number of the noun "hand" in the context of the laying on of hand/s and proposes that one hand is used in Lev $1: 4 ; 3: 2,8,13 ; 4: 4,24,29,33$ based on consistent the MT readings, and that two hands of one person were involved in Exod 29:10, 15, 19; Lev 4:15; 8:14, 18, 22; 16:21; 24:14; Num 8:10, 12; 27:18, 23; and Deut 34:9 based on the patterns of use of the plural of the noun "hand." This delineation is overruled in at least one text, Lev 4:15, since based on the grammatical pattern, two hands were used in this text, but in Lev 4, in all other instances, vv. 4, 24, 29, and 33, only one hand was used. Consequently, the conclusion of the present study is that the form of gesture is insignificant and does not affect its meaning/function since the texts do not provide enough evidence for a solid conclusion of the number of hands used. The same applies to the question of the presence of pressure during the hand leaning or not.

Calabro proposed that the laying on of hand/s appoints a person or animal to a particular status or role. However, his arguments were not solid. That is, the claim that the focus of the phrase "that it may be accepted for him to make atonement on his behalf" in Lev 1:4 is not on what the gesture does to the animal, but rather, the emphasis on the fact that "the gesture's form is a similitude of atonement" is supported by abandoned understanding of valid meaning of כִכֶֶ. Second, he confused contexts, since the set of sacrifices in Lev 1-3 is different from those in Lev 4-6:7. Finally, this phrase is related to the burnt offering only, and never to sin or reparation offerings. Building on the grammatical and syntactical parallels between "(you shall lay your hands on him) in v.

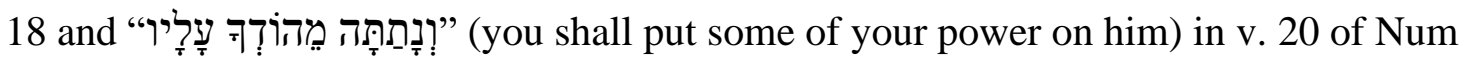


27, Calabro noticed that the transfer theory fits these contexts best, and then the material being transferred becomes the possession of the person to whom it was transferred. His reference point is the use of the verb פָּ in Num 27:16. However, Calabro disregarded the basic step in biblical interpretation, the use of the root. This root is used insignificantly outside of the book of Numbers. The only time on of hand/s is in Num 27:16. The verb never means "to appoint" in Exodus and Leviticus. These points demonstrate that Calabro's proposal is not sustainable.

A closer analysis of theories scholars have suggested showed that some of them are possible and some are not against the totality of the biblical text. Thus, identification is acknowledged that it does not happen at the ontological, but rather, the symbolic level is a possible meaning/function of this gesture. The consecrationseparation/dedication/presentation theory is not possible for several reasons. First, the offerers in most cases needed forgiveness in the first place or are ransomed before God because of their GHS. Second, common individuals cannot consecrate anything since this is in the domain of the priesthood. The separation nuance of this theory is even less sustainable because the fact that a sacrificial animal is brought to the sacrificial altar is testament of the fact that it is separated/set apart from the larger group for a special purpose. The laying on of hand/s was not needed for that purpose. Third, it is ultimately God himself who sanctifies in the OT. Finally, the Pentateuch legislation never uses the verbs of dedication with the offerer as a subject and sacrifice as a direct object in Lev 17. The only text where it is explicitly stated that sacrifices are dedicated to God is Lev 22:2-3. However, "holy gifts" refer to a well-being offering of which the offerer would keep the larger part and give a thigh to the priest. The consecration- 
separation/dedication/presentation theory does not provide enough evidence to be included as a viable meaning/function for the laying on of hand/s.

The possibility that the laying on of hand/s could encompass primary and secondary meanings/functions is possible. Identification does not seem to be a concept that emerged out of modern Western philosophy since it was noticed at the beginning of the Middle Ages and even in the times of the Church Fathers.

\section{Critique of Arguments against the Transfer/Substitution Theory}

Scholars have suggested ten arguments that invalidate the transfer/substitution theory, and each of them was analyzed in the present study. A general critique that applies to all of these arguments is that they are based on selective reading of texts. First, the fact that ignoring the divinely instituted regulations that deal with ritual or moral impurity results in capital punishment invalidates the claim that the death of the animal cannot have been vicarious, since a sacrifice was not allowed for sins which merited death (Num 15:30), only for venial transgressions. Instead of bearing their own sin and ultimately suffering the consequence of death, offerers could transfer their $\sin / \mathrm{s}$ to the sin and/or reparation offering and receive forgiveness. Second, biblical texts undeniably claim that the sin offering is holy, even though it receives the offerers' sins, which negate the critique that the sin cannot be transferred to a sacrificial animal since it was described as holy. Third, the fact that blood application was a critical ritual activity in the sacrificial offering process does not undermine the importance that the sacrificial animal symbolically and substitutionarily represents the offer. The transfer that takes place from the offerer to the sacrificial animal gives more importance to blood application, since the 
sin is transferred to the sanctuary in that way. Fourth, the substitution theory of sacrifice is a well-established phenomenon in ANE context and a part of the atonement theory proposed in the present study which refutes the claim that the transfer and/or substitution theory is based on a substitution theory of sacrifice that is untenable. Fifth, the claim that the transfer and/or substitution theory is based on Lev 16:21 assumes that (1) the form of ritual is different, and (2) the scapegoat is not a sacrifice. It was established that form does not affect the meaning/form of the gesture. In addition, transfer is implied in Lev 4, where offerers come to the sanctuary loaded with their sin and leave from it forgiven. Leviticus 16:16 explicitly states that the sins are in the sanctuary. Sixth, Lev 17:10-12 describes the well-being offering as an expiatory sacrifice that eliminates the critique that the well-being offering is not expiatory. Seventh, the fact that a bird would fly away if let go nullifies the argument that transfer is not possible, since the laying on of hand/s was not performed in relation to the bird offering. In addition, the laying on of hand/s was never prescribed for cereal offering, even though it has expiatory function. Regardless of this, it is expiatory, but at the same time, it is the last possible choice for atonement. Eighth, there are multiple activities within the ritual process that undeniably reveal the identity of the offerer, making the understanding that that was the role of this gesture redundant. Ninth, confessions are a well-established ritual activity imbedded in the sacrificial offering ritual, and it is reasonable to assume that confession was performed on the sacrifices that would deal with sin.

The ten arguments identified in the scholarly debate regarding the meaning/function of this ritual gesture reflect a selective, subjective, and noncomprehensive reading of the Pentateuch texts and the present study demonstrates their 
weaknesses. Not being solid, these arguments cannot discredit the transfer/substitution theory, but were the chance to refine and strengthen this theory. After identifying weaknesses of these arguments, the present study pointed to certain additional arguments coming from the research done here.

\section{Further Arguments Supporting the Transfer/Substitution Theory}

First, the three Hebrew terms for sin, determining whether the sin is intentional or unintentional and expiable or inexpiable because they often semantically overlap and are used as synonyms. Second, פֶּשׁ cannot be restricted to intentional inexpiable/unforgivable sin as most scholars understand this term. It is mainly intentional and potentially, also unintentional, but still, always expiable sin. Third, $\sin$ was consequently transferred into the sanctuary in the same way as other sins that were there, via the sacrificial offering process. Fourth, the presence or absence of intent is not a reliable element to determine whether the sin is expiable or inexpiable. Some intentional sins are expiable/forgivable, as unintentional and expiable sins can invoke punishment if divine regulations to deal with that sin are not followed. Fifth, הָטָּזוֹת , the closing term of both lists of sins in Lev 16:16, 21 actually refers to sin offerings rather than sins. Such an understanding of understanding that the commonly believed atonement theory that assumes ADH of the sanctuary. The sinner of $\sin$ is not allowed to offer sacrifice and obtain forgiveness, but rather, experience capital punishment. The modification to this is that the Pentateuch does not provide the 
evidence that the ADH assumes that פָּ sin possesses some kind of intelligence that enables it to land exactly where it is supposed to land, the most holy place. Closer analysis of crucial texts used to support the ADH shows multiple grammatical and semantic lapses of the verb טָמָא and inconsistencies in the literary structure of related texts. Also, the foundational meaning of

Fourth, the meaning of רכִ as "to ransom" and the choice of the English "to atone for" or "atonement" to translate כִֶֶּּ removes misleading connotations or senses from the two most common scholarly suggestions, "to cover" or "to cleanse" for רכִִּּ that comes from the concrete meaning of this verb which is not supported by biblical texts.

Finally, because such as acceptance, forgiveness, sanctification, and cleansing, it always ransoms either GHS or a particular sin that is transferred to the animal. The laying on of hand/s is a distinct ritual activity that facilitates this transfer to the sacrificial animal that eventually dies in the offerer's place.

\section{Final Synthesis}

Because it is part of the sacrificial process, the laying on of hands is organically related to human sin or sinfulness and atonement as a prerequisite for broader concepts such as acceptance, forgiveness, sanctification, and cleansing. Identifying the meaning/function of laying on of hands depends directly on the understanding of sin and atonement.

First, sin is represented as a concept in the Pentateuch. It is ontologically 
perceived as an abstract reality in the cultic context. In the initial phases of some ritual impurity, it is portrayed as a physical entity to some extent, while moral impurity never possesses physical qualities. It is purely an abstract entity. Determining the presence/absence of intent related to an act of sinning cannot be established on the basis

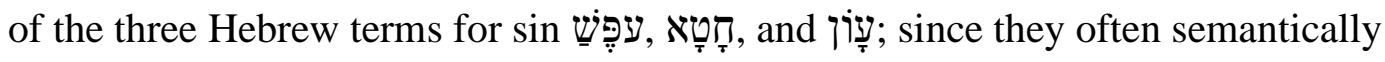
overlap, they are often used as synonyms. Thus, these terms refer to sin, in general, without conveying the presence or absence of intent on the part of the sinner, nor do they convey whether the sin they refer to is expiable or inexpiable. Thus, whether an act of committing sin was performed intentionally (brazen or non-brazen sin) or unintentionally (non-brazen sin) solely depends on the sinful activity itself or the immediate context of a given situation that includes that act of sinning. Some contexts provide insights concerning these elements; others do not. The corollary of such an understanding of sin is that in many cases, if one is not involved directly in the situation that includes the sin, he/she is not able to determine whether the sin was intentional/unintentional and expiable/inexpiable. This is also confirmed by the reading of Lev 4-6 suggested in the present study. It is the sinner, without anyone's involvement, who decides and chooses to offer a sacrifice and select an appropriate type of sacrifice. The priest is informed to assist in offering the sacrifice, but it is the sinner who decides to bring the sacrifice and which type of sacrifice in his/her interaction with God. The priest was never said to investigate or interrogate the offerer concerning the reason that made him/her offer the sacrifice. That remained within the limits of the interaction with the offerer and God himself.

The Pentateuch uses a variety of metaphors to express sin and presents it in terms of physical appearance. This, however, does not ontologically or intrinsically change the 
abstract nature of sin into a physical/quasi-physical or material in a cultic context, but rather, just aids in human comprehension. Sin remains an ontologically and intrinsically abstract entity in the cultic context. The sin itself and its context are decisive factors concerning the presence/absence of intent related to a given act of sinning or its expiability/inexpiability. These two points aid in identifying the meaning/function of the laying on of hands. Leviticus 16:16, 21 state that all three terms for moral impurity, ,

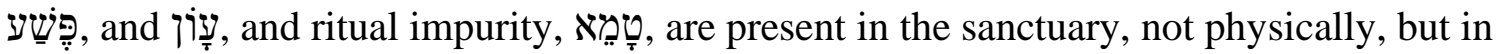
a real and yet abstract way. The offerer affected by these impurities brings them symbolically to the sanctuary (in the case of ritual impurity that requires sacrifice, the offerer needs to wait for a certain time elapse) and offer his/her sacrifice to deal with them as God prescribed in the cultic law texts. The conceptual understanding of sin and

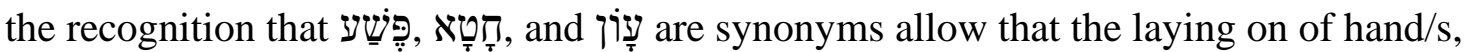
as the only activity in the ritual of animal sacrifice that is not necessary for the execution (performance) of the sacrificial offering, actually facilitates the transfer of both impurities into the sanctuary or on the priesthood. Identification can be implied as a secondary meanings of this ritual, but transfer is the only meaning/function that explains the two facts explicitly stated in the cultic legislation: (1) the fact that the offerer comes to the sanctuary with his/her impurity and leaves without it (forgiven, accepted, sanctified) and (2) the fact that the impurity is in the sanctuary on the Day of Atonement, because the offerer had brought such impurities to the sanctuary on a daily basis and obtained atonement concerning them. In this understanding of the defilement of the sanctuary the critical term biblically unsupported understanding that sins expressed through it cannot be 
expiated/forgiven through cult. It also eliminates an unsound understanding of שֶָׁ that it

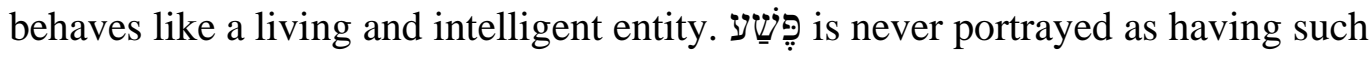
qualities in the metaphor and, even less so, conceptually or intrinsically. As such, the laying on of hands is a theologically crucial ritual gesture in the process of atonement because it serves to transfer impurity symbolically from the offerer to the sanctuary.

This interpretation of impurity negates the belief that an inevitable and unavoidable reaction of contact between the holy, such as God, sanctuary, or holy things, and the impurity, the human being, is death of the latter as a source and/or carrier of impurity. Embedded in this belief is the postulate that God is not able to cope with the effects of impurity, but rather, is subjected to them. He is forced to leave the sanctuary because of the high accumulation of impurity in the sanctuary. Instead, Pentateuchal texts prove that God chooses to tolerate impurity by storing it in the sanctuary or on the priesthood until the Day of Atonement when it is removed from both. This is conditioned by following procedures which Good revealed for dealing with impurity by human party. Both impurities are in the sanctuary and on the priests, but that does not disqualify these two entities from retaining their holiness or residing safely in the realm of the holy. God chooses to leave his sanctuary at the time when he realizes that the sacrificial procedures do not fulfill the purpose for which they had been established: to atone for sinners.

Second, the analysis of refers to abstract processes. A literal, concrete meaning of instance and that is at the same time as the only qal stem of the verb, Gen 6:14. All the other occurrences, whether in cultic or non-cultic contexts, are in piel and have an abstract meaning. In a few texts where the direct object of 
is, the sanctuary or its parts, the text uses the metaphor of "carrying away" or "removing" sin, which results in cleansing those objects. Nevertheless, the use of the metaphor does not make the sin or the process of an abstract process that includes real, yet abstract, elements, such as sin and removal that results in cleansing. This study affirms that the foundational meaning of sought in Lev 17:11 and that it is "to ransom," which consequently encompasses the idea of substitution, that is, the sacrificial animal functions as the offerer's substitute. Both of these two elements, ransom and substitute, are foundational for atonement. In this, the concept of atonement follows the conceptual and abstract understanding of sin that has been suggested in the present study.

The abstract understanding of is embedded in the biblical portrayal of human nature, but still neglected in the study of atonement. The present study demonstrates that GHS is a critical and ever-present human characteristic and, as such, made atonement in divine-human interactions necessary. It originated from the fall of humanity in the Garden of Eden when the first couple disobeyed God's commandment and since then, affects every human being. Influential scholars have recognized and accepted GHS as inseparably related to human beings. Disciplines outside of biblical studies, such as classical philosophy, moral philosophy, and philosophy of action, have also noted that human beings exercise weakness of will, that is, intentionally doing something that is known to be wrong. General human sinfulness affects all aspects of human life, including those related to human cognition, as well as those related to physical existence. Surprisingly, critical scholars of the cult of Ancient Israel cult have not included this concept in their study of atonement. They 
simply ignored it and it did not play a part in their studies of atonement. The present study demonstrates that GHS, like ritual and moral impurity, is a real, but at the same time, an abstract entity. General human sinfulness is foundational for both impurities, ritual and moral. Both of them come from GHS, and ritual impurity, in a small number of cases, is related to physical appearance. However, ritual impurity is atoned for only after the physical aspects of it have disappeared (healed and/or a certain amount of time has elapsed, etc.). Impurity, be it ritual or moral, or GHS were atoned for as abstract entities.

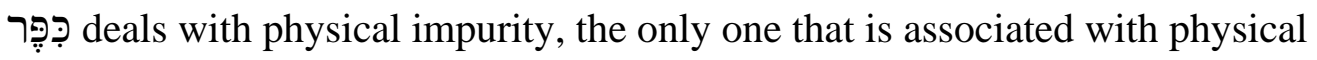
representation, but only after physical stage of it has disappeared.

This abstract understanding of רִּ based on ransom, that is constantly needed in divine-human interactions when a human being experiences any possible source of disruptions such as sinfulness, ritual, or moral impurity, is in stark contrast with the understanding "to cleanse, purify" the sanctuary suggested by Milgrom, or "to cleanse from" proposed by Gane. Milgrom's and Gane's understandings of atonement are informed by the biblically unsupported notion of כְִֶּ as cleansing. In Milgrom's case, it is not the offerer who is cleansed, but rather, the sanctuary, while in Gane's case, it is the offerer who is cleansed from these impurities. To the contrary, God chooses to accept human beings such as they are through atonement based on ransom. However, in order to control impurity, God prescribed the sacrificial system that would enable human beings to commune with him regardless of the disruptions inherent in them. The goal of such a system was to control and deal with the experiences of impurity in human life and to stress the significance of a holy life that is totally opposite to any experience of impurity. Within such an understanding of atonement, the laying on of hands symbolically serves 
to transfer those impurities from the offerer to the sanctuary at the time when human beings experience them. They are stored there until the Day of Atonement, when they are removed and taken away from the camp into the wilderness.

These arguments do not eliminate the fact that secondary meanings/functions of the laying on of hands could have been used to express identification or convey the ownership of the animal. However, in the light of the arguments mentioned above, the transfer/substitution remains the primary meaning/function for the laying on of hand/s. Transfer remains unspecified since the element transferred is determined by a given context. However, the interpretative framework and a given context should also be taken into consideration to control the elements that are transferred since in light of some contexts, some transfers are superfluous and redundant.

As it became obvious from the literature review presented in the introduction of the present study, the transfer/substitution has been the primary interpretation of laying on of hands with the longest history, but scholars began to challenge it since the end of the nineteenth century until now. The challenges posed by scholars during this time period are not textually defensible. They stream out of imposed assumptions about concepts from ANE contexts; adoption of methodologies foreign to biblical texts; and discriminatory, selective, rather than inclusive, comprehensive reading of biblical texts.

Thus, the meaning/function of the laying on of hand/s is best understood to convey a symbolic transfer of various qualities to the sacrificial animal which further serves as the offerer's substitute due to the human's constant unfavorable state that is described in the present study as GHS before God, even if no sin is committed. 
This meaning is never explicitly stated in biblical texts. The present research attempted to provide a biblically-informed interpretative context that helped identify the meaning/function of the laying on of hands. In the process of researching this ritual gesture, the present research noticed three tendencies imbedded in scholarly dialogue as it addresses the meaning/function of laying on of hands. First, scholarly proposals on the meaning/function of laying on of hands are laden with certain preconceived interpretations of selected texts. Second, they import these interpretations from a broad ANE context and relate them to biblical texts without the use of a consistent, comparative method. Third, these studies adopt ritual theories that do not arise from the biblical text, but rather, from social, philosophical, and literary disciplines, such as sociology, philosophy, anthropology, literary criticism, and the study of religion. Unfortunately, none of these disciplines is founded upon biblical postulates. Consequently, the results of these studies regarding this ritual gesture have been inordinately influenced by such disciplines. Therefore, the present research sought to base its conclusions on biblical texts alone and eliminate elements and interpretations informed by these disciplines that do not comport with biblical data. 


\section{BIBLIOGRAPHY}

Accordance Bible Software. Version 10.0. Altamonte Springs, FL: OakTree Software, 2012.

Adler, Rachel. "Tumah and Taharah: Ends and Beginnings." Pages 63-71 in The Jewish Woman: New Perspectives. Edited by Elizabeth Koltun. New York: Schocken, 1976.

Alden, Robert L. Job. NAC 11. Nashville: Broadman \& Holman, 1993.

Allen, Leslie C. Ezekiel 20-48. WBC 29. Waco, TX: Thomas Nelson, 1998.

Alon, Gedalyahu. Jews, Judaism and the Classical World: Studies in Jewish History in the Times of the Second Temple and Talmud. Jerusalem: The Magnes Press, 1977.

Alter, Robert. Genesis. New York: W.W. Norton, 1996.

American Academy of Sleep Medicine. "Sexual Activity Reported In Dreams Of Men And Women.” ScienceDaily, 15 June 2007. www.sciencedaily.com/releases/ 2007/06/070614085118.htm

An, Hannah S. "The Delayed Recognition of Sin in the Sacred Precinct: A

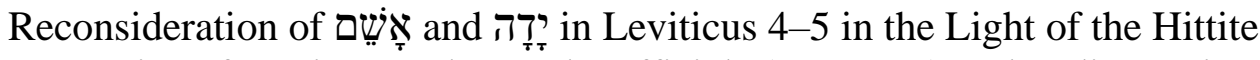
Instructions for Priests and Temple Officials (CTH 264)." PhD diss., Princeton University, 2014.

Andersen, Francis I. The Hebrew Verbless Clause in the Pentateuch. JBLMS 14. Nashville: Abingdon Press, 1970.

—. The Sentence in Biblical Hebrew. JLSP 231. The Hague: Mouton, 1974.

Anderson, Gary A. "The Interpretation of the Purification Offering (תאטח) in the Temple Scroll (11QTemple) and Rabbinic Literature." JBL 111 (1992): 17-35.

Andreasen, Niels-Erik A. "Death: Origin, Nature, and Final Eradication." Pages 314-346 in Handbook of Seventh-day Adventist Theology. Edited by Raoul Dederen. CRS 12. Hagerstown, MD: Review and Herald, 2000. 
Anglim, Christopher, ed. Encyclopedia of Religion and the Law in America. 2nd ed. Amenia, NY: Grey House Pub., 2009.

Archer, Gleason L. A Survey of Old Testament Introduction. Rev. and exp. ed. Chicago: Moody Press, 2007.

Arnold, Bill T., and H. G. M. Williamson, eds. Dictionary of the Old Testament: Historical Books. IVP's Bible Dictionary Series 2. Downers Grove, IL: Intervarsity Press, 2005.

Ashley, Timothy R. The Book of Numbers. NICOT 4. Grand Rapids, MI: Eerdmans, 1993.

Avalos, Hector Ignacio. "Illness and Health Care in Ancient Israel: A Comparative Study of the Role of the Temple." PhD diss., Harvard University, 1991.

Babcock, Bryan C. Sacred Ritual: A Study of the West Semitic Ritual Calendars in Leviticus 23 and the Akkadian Text Emar 446. BBRS 9. Winona Lake, IN: Eisenbrauns, 2014.

Bähr, Karl Christian Wilhelm Felix. Symbolik des Mosaischen Cultus. 2 vols. Heidelberg: J. C. B. Mohr, 1839.

Bailey, Lloyd R. Biblical Perspectives on Death. Philadelphia: Fortress Press, 1979.

—. Leviticus-Numbers. SHBC 3. Macon, GA: Smyth \& Helwys, 2005.

Baker, David W. "Leviticus 1-7 and the Punic Tariffs: A Form Critical Comparison." ZAW 99 (1987): 188-97.

_. "Leviticus" in Leviticus, Numbers, Deuteronomy. Edited by Philip W. Comfort. CBC 2. Carol Stream, IL: Tyndale House, 2008.

Balentine, Samuel E. Leviticus. IBCTP. Louisville, KY: John Knox Press, 2002.

- ed. The Oxford Encyclopedia of the Bible and Theology. 2 vols. New York: Oxford University Press, 2015.

Barr, James. Holy Scripture: Canon, Authority, Criticism. Philadelphia: Westminster Press, 1983.

—. The Semantics of Biblical Language. London: Oxford University Press, 1961.

Barr, James, and A. R. S. Kennedy. "Sacrifice and Offering." Pages 868-876 in Dictionary of Bible. Edited by James Hastings, Frederick C. Grant, and Harold Henry Rowley. New York: Scribner's Sons, 1963. 
Barton, John. Reading the Old Testament: Method in Biblical Study. Louisville, KY: John Knox Press, 1996.

Bauer, Johannes Baptist, ed. Bauer Encyclopedia of Biblical Theology. 3 vols. London: Sheed and Ward, 1970.

Beaucamp, E. "Péché." Pages 407-471 in vol. 7 of Supplément au Dictionnaire de la Bible. Edited by Louis Pirot, André Robert, and Henri Cazelles. 12 vols. Paris: Letouzey et Ané, 1966.

Becker, Lawrence C., and Charlotte B. Becker, eds. Encyclopedia of Ethics. 3 vols. New York: Routledge, 2001.

Beckman, John Charles. "Toward the Meaning of the Biblical Hebrew Piel Stem." PhD diss., Harvard University, 2015.

Behm, Johannes. Die Handauflegung im Urchristentum: Nach Verwendung, Herkunft und Bedeutung in Religionsgeschichtlichem Zusammenhang Untersucht. Leipzig: A. Deichert, 1911.

Bell, Catherine M. Ritual Theory, Ritual Practice. New York: Oxford University Press, 2009.

Bellinger, W. H. Leviticus and Numbers. NIBCOTS 3. Peabody, MA: Hendrickson, 2001.

—. Leviticus and Numbers. UBCS. Peabody, MA: Hendrickson, 2012.

Bergen, Wesley J. Reading Ritual: Leviticus in Postmodern Culture. JSOTSupp 417. London: T \& T Clark International, 2005.

Bergland, Kenneth. "Reading as a Disclosure of the Thoughts of the Heart: ProtoHalakhic Reuse and Appropriation between Torah and the Prophets." PhD diss., Andrews University, 2018.

Bergman, Paul, and Sara J. Berman-Barrett. The Criminal Law Handbook: Know Your Rights, Survive the System. Berkeley, CA: Nolo Press, 1997.

Bertholet, A. Das Dynamistische im Alten Testament. Tübingen: Mohr, 1926.

Bird, Phyllis A. “"Bone of My Bone and Flesh of My Flesh.” ThTo 50 (1994): 521-34.

Blackburn, W. Ross. The God Who Makes Himself Known: The Missionary Heart of the Book of Exodus. Downers Grove, IL: Apollos, 2012. 
Blumenthal, David R. "Repentance and Forgiveness." Crosscurrents. Released 18 Nov 2018. http://www.crosscurrents.org/blumenthal.htm.

Bobonich, Christopher, and Pierre Destrée. Akrasia in Greek Philosophy: From Socrates to Plotinus. PA 106. Leiden: Brill, 2007.

Boda, Mark J. A Severe Mercy: Sin and Its Remedy in the Old Testament. Winona Lake, IN: Eisenbrauns, 2009.

Born, Adrianus van den, and Louis Francis Hartman. Encyclopedic Dictionary of the Bible: A Translation and Adaptation of A. van den Born's Bijbels Woordenboek. 2nd rev. ed., 1954-1957. New York: McGraw-Hill, 1963.

Botica, Aurelian. The Concept of Intention in the Old Testament, Philo of Alexandria and the Early Rabbinic Literature: A Study in Human Intentionality in the Area of Criminal, Cultic and Religious and Ethical Law. PHSC 9. Piscataway, NJ: Gorgias Press, 2011.

Botterweck, G. Johannes, Helmer Ringgren, and Heinz-Josef Fabry, eds. Theological Dictionary of the Old Testament. 16 vols. Grand Rapids, MI: Eerdmans, 19742018.

- Theologisches Wörterbuch zum Alten Testament. 10 vols. Stuttgart: Kohlhammer, 1973-2015.

Brichto, Herbert Chanan. "The Case of the Śōtā and a Reconsideration of Biblical 'Law." HUCA 46 (1975): 55-70.

—_. "On Slaughter and Sacrifice, Blood and Atonement." HUCA 47 (1976): 19-55.

- The Problem of "Curse" in the Hebrew Bible. JBLMS 13. Philadelphia: Society of Biblical Literature, 1968.

Brockelmann, Carl. Grundriss der Vergleichenden Grammatik der Semitischen Sprachen. 2 vols. Hildesheim: G. Olms, 1961.

—. Hebräische Syntax. Neukirchen: Kreis Moers, 1956.

Bromiley, Geoffrey William, ed. The International Standard Bible Encyclopedia. 4 vols. Grand Rapids, MI: Eerdmans, 1982.

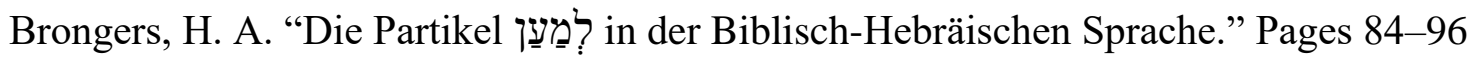
in Syntax and Meaning: Studies in Hebrew Syntax and Biblical Exegesis. Edited by C. J. Labuschagne, C. Van Leeuwen, M. J. Mulder, H. A. Brongers, B. Jongeling, L. Dequeker, and P. A. H. De Boer. OtSt 18. Leiden: Brill, 1973. 
Brown, Colin, and David Townsley, eds. The New International Dictionary of New Testament Theology. 4 vols. Grand Rapids, MI: Regency Reference Library, 1986.

Brown, Francis, S. R. Driver, and Charles A. Briggs. The New Brown, Driver, and Briggs Hebrew and English Lexicon of the Old Testament. Peabody, MA: Hendrickson, 2003.

Brown, Michael L. Israel's Divine Healer. SOTBT. Grand Rapids, MI: Zondervan, 1995.

Brownlee, William H. Ezekiel 1-19. WBC 28. Waco, TX: Thomas Nelson, 1998.

Büchler, Adolf. Studies in Sin and Atonement in the Rabbinic Literature of the First Century. London: Oxford University Press, 1928.

- Studies in Sin and Atonement in the Rabbinic Literature of the First Century. New York: Ktav, 1967.

Budd, Philip J. Leviticus: Based on the New Revised Standard Version. NCBC. London: M. Pickering, 1996.

—. Numbers. WBC 5. Nashville: Thomas Nelson, 1984.

Bullock, C. Hassell. An Introduction to the Old Testament Poetic Books. Chicago: Moody Publishers, 2007.

Burton, William C. Burton's Legal Thesaurus. 3rd ed. New York: Macmillan Library Reference, 1998.

Bush, George. Notes, Critical and Practical, on the Book of Leviticus: Designed as a General Help to Biblical Reading and Instruction. New York: Dayton \& Newman, 1843.

Butler, Trent C. Holman Concise Bible Dictionary. Nashville: Broadman \& Holman, 2001.

—. Isaiah. HOTC 15. Nashville: Broadman \& Holman, 2002.

Buttrick, George Arthur, Thomas Samuel Kepler, John Knox, Herbert Gordon May, Samuel Terrien, and Emory Stevens Bucke, eds. The Interpreter's Dictionary of the Bible. 4 + supplementary vols. Nashville: Abingdon, 1962-1976.

Cairus, Aecio E. "The Doctrine of Man." Pages 205-232 in Handbook of Seventh-day Adventist Theology. Edited by Raoul Dederen. CRS 12. Hagerstown, MD: Review \& Herald, 2000. 
Calabro, David. "A Reexamination of the Ancient Israelite Gesture of Hand Placement." Pages 99-124 in Sacrifice, Cult, and Atonement in Early Judaism and Christianity: Constituents and Critique. Edited by Henrietta L. Wiley and Christian A. Eberhart. RBS 85. Atlanta: SBL Press, 2017.

Carroll, R. P. "Rebellion and Dissent in Ancient Israelite Society." ZAW 89 (1977): 176204.

Cassuto, Umberto. A Commentary on the Book of Exodus. Translated by Israel Abrahams. Jerusalem: Magnes Press, 1997.

- The Documentary Hypothesis and the Composition of the Pentateuch: Eight Lectures. Jerusalem: Magnes Press, 1961.

Castang, Lazarus. "A Comparative Analysis of the Origin and Divine Causation of Death in Ancient Near Eastern Literature and in the Old Testament." PhD diss., Andrews University, 2011.

Cazelles, Henri. Le Lévitique. Paris: La Sainte Bible, 1958.

Charbel, Antonio. Zevah shelamim: Il sacrificio pacifico nei suoi riti e nel suo significato religioso e figurativo. Jerusalem: Commercial Press, 1967.

Childress, James F., and John Macquarrie, eds. The Westminster Dictionary of Christian Ethics. Philadelphia: Westminster Press, 1986.

Childs, Brevard S. Old Testament Theology in a Canonical Context. Philadelphia: Fortress Press, 1986.

Cholewinski, Alfred. Heiligkeitsgesetz und Deuteronomium: Eine Vergleichende Studie. ABib 66. Rome: Biblical Institute Press, 1976.

Christensten, Duane L. Deuteronomy 1:1-21:9, revised. WBC 6A. Nashville: Thomas Nelson, 2001.

Civil, Miguel, Ignance J. Gelb, A. Leo Oppenheim, and Erica Rainer, eds. The Assyrian Dictionary of the Oriental Institute of the University of Chicago. 21 vols. Chicago: The Oriental Institute Chicago, 1971.

Clauson, Marc A. "Human Nature and the Christian." GFP (2015): 7-21.

Clines, David J. A. ed. The Concise Dictionary of Classical Hebrew. Sheffield: Sheffield Pheonix Press, 2009.

The Dictionary of Classical Hebrew. 8 vols. Sheffield: Sheffield Academic Press, 1993. 
Cohen, Chaim. Biblical Hapax Legomena in the Light of Akkadian and Ugaritic. SBLDS 37. Missoula, MT: Scholars Press, 1978.

Cole, Dennis R. Numbers. NAC 3B. Nashville: Broadman \& Holman, 2000.

Cole, R. Alan. Exodus. TOTC 2. Downers Grove, IL: IVP Academic, 2008.

Coppens, Joseph. "Handauflegung." Page 632 in vol. 2 of Biblisch-Historisches Handwörterbuch: Landeskunde, Geschichte, Religion, Kultur, Literatur. Edited by Bo Reicke and Leonhard Rost. 4 vols. Göttingen: Vandenhoeck \& Ruprecht, 1962.

_. "L'imposition des mains et les rites connexes dans le Nouveau Testament et dans l'église ancienne. Étude de theologie positive." Diss. es ad gradum magistri, Universitas Catholica Lovaniensis, 1925.

Creason, Stuart Alan. "PQD Revisited." Pages 27-42 in Studies in Semitic and Afroasiatic Linguistics Presented to Gene B. Gragg. Edited by Cynthia L. Miller. SAOC 60. Chicago: Oriental Institute of the University of Chicago, 2007.

—. "Semantic Classes of Hebrew Verbs: A Study of Aktionsart in the Hebrew Verbal System.” PhD diss., University of Chicago, 1995.

“Crime.” Wikipedia. Released 17 July 2017. https://en.wikipedia.org/wiki/Crime.

Crüsemann, Frank. The Torah: Theology and Social History of Old Testament Law. Translated by Allan W. Mahnke. 1st English-language ed. Minneapolis: Fortress Press, 1996.

Damasio, Antonio R. Descartes' Error: Emotion, Reason, and the Human Brain. New York: Putnam, 1994.

Daube, David. Ancient Jewish Law: Three Inaugural Lectures. Leiden: Brill, 1981.

—. "Concessions to Sinfulness in Jewish Law.” JJS 10 (1959): 1-13.

—. "Error and Accident in the Bible." RIDA 2 (1949): 197-213.

—. The New Testament and Rabbinic Judaism. New York: Arno Press, 1973.

—. Studies in Biblical Law. Cambridge: The University Press, 1947.

Davidson, Richard M. Flame of Yahweh: Sexuality in the Old Testament. Peabody, MA: Hendrickson, 2007. 
—. "The Living Death: Typology of Leprosy and Its Cleansing." Pages 45-58 in Festschrift Honoring Merling Alomía. Edited by Benjamin Rojas, Lael Caesar, Teófilo Correa, and Joel Turpo. Lima, Peru: Peruvian Union University, 2015.

—. "The Nature of the Human Being from the Beginning: Genesis 1-11." Pages 1142 in 'What are Human Beings That You Remember Them?': Proceedings of the Third International Bible Conference NOF Ginosar and Jerusalem, June 11-21, 2012. Edited by Clinton Wahlen. Silver Spring, MD: Review and Herald, 2015.

Davies, Douglas. “An Interpretation of Sacrifice in Leviticus.” ZAW 87 (1977): 387-99.

Davis, John D. Davis Dictionary of the Bible. 4th ed. Grand Rapids, MI: Baker Book House, 1955.

Delaney, Janice, Mary Jane Lupton, and Emily Toth. The Curse: A Cultural History of Menstruation. Rev. ed. Champaign, IL: University of Illinois Press, 1988.

Dentan, Robert C. "Literary Affinities of Exodus XXXIV 6f." VT 13 (1963): 34-51.

Devlin, Patrick. The Enforcement of Morals. London: Oxford University Press, 1965.

DeWelt, Don. Leviticus. BSTS. Joplin, MO: College Press, 1975.

Diehl, Johannes F. Die Fortführung des Imperativs im Biblischen Hebräisch. AOAT 286. Münster: Ugarit-Verlag, 2004.

Dillmann, A., and V. Ryssel. Die Bücher Exodus and Leviticus. Leipzig: Hirzel, 1897.

Dobbs, Dan B. The Law of Torts. HSer. St. Paul, MN: West Group, 2000.

Douglas, James D., ed. The Illustrated Bible Dictionary. 3 vols. Downers Grove, IL: Inter-Varsity Press, 1980.

—. The New Bible Dictionary. Grand Rapids, MI: Eerdmans, 1962.

Douglas, Mary. "Holy Joy: Rereading Leviticus: The Anthropologist and the Believer." CJ 46 (1994): 3-14.

- Purity and Danger: An Analysis of Concepts of Pollution and Taboo. New York: Routledge, 2002.

Dozeman, Thomas B. Exodus. ECC. Grand Rapids, MI: Eerdmans, 2009.

Driver, Godfrey R. "Studies in the Vocabulary of the Old Testament II." JTS 32 (1931): 250-57. 
__. "Studies in the Vocabulary of the Old Testament V." JTS 34 (1933): 33-44.

Driver, Godfrey R., and John C. Miles. The Babylonian Laws. Oxford: Clarendon Press, 1968.

Durham, John I. Exodus. WBC 3. Nashville: Thomas Nelson, 1987.

Ebeling, Erich. Die Akkadische Gebetsserie “Handerhebung.” DAWBIO 20. Berlin: Akademie-Verlag, 1953.

Eberhart, Christian A. "Cult and Character: Purification Offerings, Day of Atonement, and Theodicy: A Review." JBL 125 (2006): 573-76.

Edersheim, Alfred. The Temple: Its Ministry and Services as They Were at the Time of Jesus Christ. London: Religious Tract Society, 1908.

Ehrlich, Arnold B. The Pentateuch. Vol. 1 of Mikrâ ki-Pheschutô: The Bible According to Its Literal Meaning. New York: KTAV, 1969.

—. Randglossen zur Hebräischen Bibel: Textkritisches, Sprachliches und Sachliches. Leipzig: J. Hinrichs, 1908-14.

Eichrodt, Walther. Theologie des Alten Testament. Translated by J. A. Baker. 3 vols. Göttingen: Vandenhoeck \& Ruprecht, 1961.

- Theology of the Old Testament. Translated by J. A. Baker. 2 vols. Philadelphia: Westminster Press, 1967.

Eilberg-Schwartz, Howard. The Savage in Judaism: An Anthropology of Israelite Religion and Ancient Judaism. Bloomington, IN: Indiana University Press, 1990.

Elitzur, Yoel. "Diachrony in Standard Biblical Hebrew: The Pentateuch vis-á-vis the Prophets/Writings." JNSL 44 (2018): 81-101.

Ellinger, Karl. Leviticus. HAT 4. Tübingen: Mohr, 1966.

Elliott, Charles. "The Unity of the Pentateuch." HSt 2 (1883): 304-08.

Elwell, Walter A., ed. Baker Encyclopedia of the Bible. 2 vols. Grand Rapids, MI: Baker Book House, 1988.

- Baker Theological Dictionary of the Bible. Grand Rapids, MI: Baker Books, 2000.

Elwell, Walter A., and Philip W. Comfort, eds. Tyndale Bible Dictionary. Carol Stream, IL: Tyndale House, 2001. 
Enns, Peter. Exodus. NIVAC. Grand Rapids, MI: Zondervan, 2000.

Erickson, Millard J. Christian Theology. 2nd ed. Grand Rapids, MI: Baker Academic, 2013.

Etymonline. Online Etymology Dictionary. https://www.etymonline.com/.

Evgeniy, Golovko V. "On Non-Causative Effects of Causativity in Aleut.” Pages 385-90 in Causatives and Transitivity. Edited by Bernard Comrie and Maria Polinsky. Philadelphia: John Benjamins, 1993.

Feder, Yitzhaq. Blood Expiation in Hittite and Biblical Ritual: Origins, Context, and Meaning. WAWS 2. Atlanta: Society of Biblical Literature, 2011.

—. "On kuppuru, kippēr and Etymological Sins that Cannot be Wiped Away." VT 60 (2010): 535-45.

Fee, Gordon D., and Douglas K. Stuart. How to Read the Bible for All Its Worth. Grand Rapids, MI: Zondervan, 2003.

Feldman, Emanuel. Biblical and Post-Biblical Defilement and Mourning: Law as Theology. New York: Yeshiva University Press, 1977.

Feldman, Liane Merquis. "Ritual Sequence and Narrative Constraints in Leviticus 9:110:3." JHS 17 (2017): 1-35.

Ferguson, W. Everett. "Ordination in the Ancient Church: An Examination of the Theological and Constitutional Motifs in the Light of Biblical and Gentile Sources." PhD diss., Harvard University, 1959.

Fletcher, George P. Basic Concepts of Criminal Law. Oxford: Oxford University Press, 1998.

Fohrer, Georg. History of Israelite Religion. Nashville: Abingdon Press, 1972.

Fokkelman, J. P. "Genesis." Pages 36-55 in The Literary Guide to the Bible. Edited by Robert Alter and Frank Kermode. Cambridge: Belknap Press of Harvard University Press, 1987.

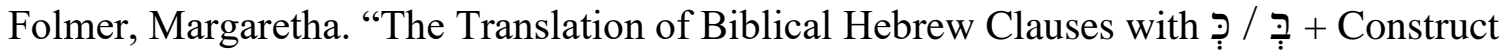
Infinitive in Targum Onqelos." AS 11 (2013): 113-44.

Fonrobert, Charlotte Elisheva. Menstrual Purity: Rabbinic and Christian Reconstructions of Biblical Gender. Contraversions. Stanford: Stanford University Press, 2000. 
Fowler, John M. "Sin.” Pages 233-270 in Handbook of Seventh-day Adventist Theology. Edited by Raoul Dederen. CRS 12. Hagestrown, MD: Review and Herald, 2000.

Fox, Everett. The Five Books of Moses: Genesis, Exodus, Leviticus, Numbers, Deuteronomy. SB 1. New York: Schocken Books, 1995.

Freedman, David Noel, ed. The Anchor Bible Dictionary. 6 vols. New York: Doubleday, 1992.

Freedman, David Noel, Allen C. Myers, and Astrid B. Beck, eds. Eerdmans Dictionary of the Bible. Grand Rapids, MI: Eerdmans, 2000.

Fretheim, Terence E. God and World in the Old Testament: A Relational Theology of Creation. Nashville: Abingdon Press, 2005.

Frimpong, Akua Darkoa. "Purity and Impurity: Menstruation and Its Impact on the Role of Akan Women in the Church.” PhD diss., Vrije Universiteit, 2011.

Frymer-Kensky, Tikva. "Pollution, Purification, and Purgation in Biblical Israel." Pages 399-414 in The Word of the Lord Shall Go Forth: Essays in Honor of David Noel Freedman in Celebration of His Sixtieth Birthday. Edited by Carol L. Meyers and Michael Patrick O'Connor. Winona Lake, IN: Eisenbrauns, 1983.

_ . "The Strange Case of the Suspected Sotah (Numbers V 11-31)." VT 34 (1984): $11-26$.

Füglister, Notker. "Sühne durch Blut: Zur Bedeutung von Leviticus 17, 11.” Pages 14364 in Studien zum Pentateuch: Walter Kornfeld zum 60. Geburtstag. Edited by Georg Braulik. Wien: Herder, 1977.

Galenieks, Eriks. "The Nature, Function, and Purpose of the Term Sheol in the Torah, Prophets and Writings." PhD diss., Andrews University, 2005.

Gane, Roy E. Cult and Character: Purification Offerings, Day of Atonement, and Theodicy. Winona Lake, IN: Eisenbrauns, 2005.

__ "Leviticus." Pages 284-338 in Genesis, Exodus, Leviticus, Numbers, Deuteronomy. Vol. 1 of Zondervan Illustrated Bible Backgrounds Commentary: Old Testament. Edited by John H. Walton. 5 vols. Grand Rapids, MI: Zondervan, 2009.

—. Leviticus, Numbers. NIVAC 3. Grand Rapids, MI: Zondervan, 2004.

_- "Loyalty and Scope of Expiation in Numbers 15." ZABR/JANEBL 16 (2010): $249-62$. 
_. "The Nature of the Human Being in Leviticus." Pages 43-57 in "What are Human Beings That You Remember Them?" Proceedings of the Third International Bible Conference NOF Ginosar and Jerusalem, June 11-21, 2012. Edited by Clinton Wahlen. Silver Spring, MD: Review and Herald, 2015.

_. "Numbers 15:22-31 and the Spectrum of Moral Faults." Pages 149-156 in Inicios, Paradigmas y Fundamentos: Estudios Teológicos y Exegéticos en el Pentateuco. Edited by Gerald A. Klingbeil. Serie Monográfica de Estudios Bíblicos y Teológicos de la Universidad Adventista del Plata 1. Libertador San Martín: Editorial Universidad Adventista del Plata, 2004.

- Old Testament Law for Christians: Original Context and Enduring Application. Grand Rapids, MI: Baker, 2017.

—_. "Privative Preposition $ן$ in Purification Offering Pericopes and the Changing Face of 'Dorian Gray."' JBL 127 (2008): 209-22.

—. Ritual Dynamic Structure. GD 14. Piscataway, NJ: Gorgias Press, 2004.

Gangel, Kenneth O., and Stephen J. Bramer. Genesis. HOTC 1. Nashville: Broadman \& Holman, 2002.

Gardiner, Alan Henderson. Egyptian Grammar: Being an Introduction to the Study of Hieroglyphs. 3rd ed. Oxford: Griffith Institute, 2005.

Garland, Norman M. Criminal Law for the Criminal Justice Professional. 2nd ed. New York: McGraw-Hill, 2009.

- Criminal Law for the Criminal Justice Professional. 4th ed. Dubuque, IA: McGraw-Hill Education, 2017.

Garner, Bryan A. Black's Law Dictionary. 8th ed. St. Paul, MN: Thomson Reuters, 2004.

—. Black's Law Dictionary. 10th ed. St. Paul, MN: Thomson Reuters, 2014.

—. A Dictionary of Modern Legal Usage. 2nd ed. New York: Oxford University Press, 1995.

Garnet, Paul. "Atonement Constructions in the Old Testament and the Qumran Scrolls." EvQ 46 (1974): 131-63.

- Salvation and Atonement in the Qumran Scrolls. WUNT 3. Tübingen: Mohr, 1977.

Gehman, Henry Snyder, ed. The New Westminster Dictionary of the Bible. Philadelphia: Westminster Press, 1970. 
Geller, M. J. “The Šurpu Incantations and Lev. V. 1-5.” JSS 25 (1980): 181-92.

Gensler, Harry J., and Earl W. Spurgin, eds. The Historical Dictionary of Ethics. Lanham, MD: Scarecrow Press, 2008.

Gerstenberger, Erhard S. Leviticus: A Commentary. OTL 3. Louisville: Westminister John Knox Press, 1996.

Gese, Hartmut. “The Atonement.” In Essays on Biblical Theology. Minneapolis: Augsburg, 1981.

Gesenius, Wilhelm. Gesenius' Hebrew Grammar. Edited by E. Kautzsch. Translated by A. E. Cowley. Oxford: Oxford University Press, 1910.

Gilders, William K. Blood Ritual in the Hebrew Bible: Meaning and Power. Baltimore: Johns Hopkins University Press, 2004.

— . "Cult and Character: Purification Offering, Day of Atonement, and Theodicy: A Review." CBQ 69 (2007): 116-18.

Givón, Talmy. Syntax: A Functional-Typological Introduction. 2 vols. Philadelphia: John Benjamins, 1984-90.

Goetze, Albrecht. "The So-called Intensive of the Semitic Languages.” JAOS 62 (1942): $1-8$.

Goldin, Hyman E. Hebrew Criminal Law and Procedure: Mishnah: Sanhedrin, Makkot. New York: Twayne, 1952.

Goldingay, John. Old Testament Theology: Israel's Gospel. Old Testament Theology. 3 vols. Downers Grove, IL: IVP Academic, 2003.

González, Rudolph. "Laying-on of Hands in Luke and Acts: Theology, Ritual, and Interpretation." PhD diss., Baylor University, 1999.

Gorman, Frank H. Divine Presence and Community: A Commentary on the Book of Leviticus. ITC. Grand Rapids, MI: Eerdmans, 1997.

Gorman, Frank H. The Ideology of Ritual: Space, Time and Status in the Priestly Theology. JSOTSup 91. Sheffield: JSOT Press, 1990.

_. Leviticus. HCBC. San Francisco: Harper, 2000.

"Ritual Studies and Biblical Studies: Assessment of the Past, Prospects for the Future." Semeia 67 (1994): 13-36. 
Gosling, J. C. B. The Weakness of the Will (Problems of Philosophy). London: Routledge, 1990.

Grabbe, Lester L. Leviticus. OTG. Sheffield: JSOT Press, 1993.

Gray, George Buchanan. A Critical and Exegetical Commentary on Numbers. ICCHSONT 4. New York: Scribner's Sons, 1903.

- Sacrifice in the Old Testament: Its Theory and Practice. Oxford: Clarendon Press, 1925.

Greenberg, Moshe. Ezekiel 1-20. AB 22. Garden City: Doubleday, 1983.

—. Ezekiel 21-37. AB 22A. New York: Doubleday, 1997.

Greengus, Samuel. Laws in the Bible and in Early Rabbinic Collections: The Legal Legacy of the Ancient Near East. Eugene, OR: Cascade Books, 2011.

Greenlee, J. Harold. Introduction to New Testament Textual Criticism. Grand Rapids, MI: Eerdmans, 1964.

Grimes, Ronald L. Ritual Criticism: Case Studies in Its Practice, Essays on Its Theory. SCR 52. Columbia, SC: University of South Carolina Press, 1990.

Gruenwald, Ithamar. Rituals and Ritual Theory in Ancient Israel. Leiden: Brill, 2003.

Gurney, O. R. Some Aspects of Hittite Religion. Oxford: Oxford University Press for the British Academy, 1977.

Haber, Susan. "They Shall Purify Themselves:" Essays on Purity in Early Judaism. Edited by Adele Reinhartz. EJL 24. Atlanta: Society of Biblical Literature, 2008.

Hallo, William W. "Biblical History in Its Near Eastern Setting: The Contextual Approach." Pages 1-26 in Scripture in Context: Essays on the Comparative Method. Edited by C. D. Evans, W. W. Hallo, and J. B. White. PTMS 34. Eugene, OR: Pickwick, 1980.

—. The Book of the People. BJS 225. Atlanta: Scholars Press, 1991.

_ . "Compare and Contrast: The Contextual Approach to Biblical Literature." Pages 1-19 in The Bible in the Light of Cuneiform Literature: Scripture in Context III. Edited by William W. Hallo, Bruce William Jones, and Gerald L. Mattingly. Ancient Near Eastern Texts and Studies 8. Lewiston, NY: Mellen Press, 1990. . "Offerings to the Temple Gates at Ur." HUCA 38 (1967): 17-58. 
Hamilton, Victor P. Genesis 1-17. NICOT 1. Grand Rapids, MI: Eerdmans, 1980.

—. Genesis 18-50. NICOT 1B. Grand Rapids, MI: Eerdmans, 1980.

Hare, R. M. "Weakness of Will." EncEth 3:1789-92.

Harrington, Hannah K. The Impurity Systems of Qumran and the Rabbis: Biblical Foundations. SBLDS 143. Atlanta: Scholars Press, 1993.

—. The Purity Texts. CQS 5. New York: T \& T Clark International, 2004.

Harris, R. Laird, Gleason L. Archer, and Bruce K. Waltke. Theological Wordbook of the Old Testament. 2 vols. Chicago: Moody Press, 1980.

Harrison, R. K. "Hands, Impositions of (Laying on of).” ZPEB 3:29-31.

- Leviticus: An Introduction and Commentary. TOTC. Downers Grove, IL: InterVarsity Press, 1980.

—. Numbers. WEC. Grand Rapids, MI: Baker, 1992.

Hartley, John E. Leviticus. WBC 4. Nashville: Thomas Nelson, 1992.

Hasel, Gerhard. "Studies in Biblical Atonement-I: Continual Sacrifice, Defilement//Cleansing, and Sanctuary." Pages 81-105 in The Sanctuary and the Atonement: Theological and Historical Studies. Edited by Frank B. Holbrook. Silver Spring, MD: Biblical Research Institute, 1989.

_ . "Studies in Biblical Atonement-II: The Day of Atonement." Pages 107-121 in The Sanctuary and the Atonement: Theological and Historical Studies. Edited by Frank B. Holbrook. Silver Spring, MD: Biblical Research Institute, 1989.

Hastings, James, ed., with John A. Selbie. A Dictionary of the Bible Dealing with Its Language, Literature, and Contents Including the Biblical Theology. Extra vol. New York: Scribner's Sons, 1911.

Hastings, James, Frederick C. Grant, and Harold Henry Rowley, eds. Dictionary of the Bible. Rev. ed. New York: Scribner's Sons, 1963.

Hastings, James, John A. Selbie, A. B. Davidson, S. R. Driver, and Henry Barclay Swete, eds. A Dictionary of the Bible Dealing with Its Language, Literature, and Contents Including the Biblical Theology. 4 vols. New York: Scribner's Sons, 1908-11.

Hayes, Christine. "Ritual and Morality: The Ritual Purity System and Its Place in Judaism: A Review Article.” JQR 93 (2002): 286-92 
Hayes, Christine Elizabeth. What's Divine about Divine Law?: Early Perspectives. Princeton, NJ: Princeton University Press, 2015.

Hayes, John H., and Carl R. Holladay. Biblical Exegesis: A Beginner's Handbook. Louisville: Westminster John Knox Press, 2007.

Heinisch, Paul. Das Buch Leviticus. Bonn: P. Hanstein, 1935.

Herrmann, Johannes. Die Idee der Sühne im Alten Testament: Eine Untersuchung über Gebrauch und Bedeutung des Wortes kipper. Leipzig: J. C. Hinrichs, 1905.

Hess, Richard S. "Leviticus.” Pages 563-826 in The Expositor's Bible Commentary: Genesis-Leviticus. Vol. 1 of The Expositor's Bible Commentary. Rev. ed. Edited by Tremper Longman III and David E. Garland. 13 vols. Grand Rapids, MI: Zondervan, 2006-12.

Hiers, Richard H. Justice and Compassion in Biblical Law. New York: Continuum, 2009.

Hildenbrand, Michael Dean. Structure and Theology in the Holiness Code. BIBAL Dissertation Series 10. North Richland Hills, TX: BIBAL, 2004.

Hills, Sidney O. "A Semantic and Conceptual Study of the Root KPR in the Hebrew Old Testament with Special Reference to the Accadian Kuppuru.” PhD diss., Johns Hopkins University, 1954.

Hobson, G. Thomas. "Cut off (One's) People: Punitive Expulsion in the Torah and in the Ancient Near East." Paper presented at the Annual Meeting of the Biblical Law of the SBL. San Francisco, CA, 24 November 2011.

Hoffmann, D. Das Buch Leviticus. 2 vols. Berlin: Poppelauer, 1905-06.

Hofmann, Johann C. K. von. Der Schriftbeweis: Ein Theologischer Versuch. 2 vols. Nördlingen: C. H. Beck, 1857.

—. Der Schriftbeweis. 2nd ed. Nördlingen: C. H. Beck, 1859.

Holbert, John H. "The Rehabilitation of the Sinner: The Function of Job 29-31." ZAW (1983): 229-37.

Holladay, William Lee. A Concise Hebrew and Aramaic Lexicon of the Old Testament. Grand Rapids, MI: Eerdmans, 1971.

Holtz, Shalom E. "Reading Biblical Law." Pages 2201-2207 in The Jewish Study Bible Edited by Adele Berlin and Marc Zvi Brettler. 2nd ed. Oxford: Oxford University, 2014. 
Hooke, S. H. "The Theory and Practice of Substitution.” VT 2 (1952): 2-17.

Horn, Siegfried H. Seventh-day Adventist Bible Dictionary. CRS 8. Washington, DC: Review and Herald, 1960.

Hu, Huiping. "Codes as Constitution: The Development of the Biblical Law-Codes from Monarchy to Theocracy." PhD diss., Durham University, 2009.

Hubert, Henri, and Marcel Mauss. Sacrifice: Its Nature and Functions. Translated by W. D. Halls. Chicago: University of Chicago, 1964.

Hurvitz, Avi. "Dating the Priestly Source in Light of the Historical Study of Biblical Hebrew a Century after Wellhausen.” ZAW 100.Suppl. (1988): 88-99.

_ . "The Language of the Priestly Source and Its Historical Setting: The Case for an Early Date." Pages 83-94 in vol. 5 of Proceedings of the Eighth World Congress of Jewish Studies, Jerusalem, August 16-21, 1981. Jerusalem: World Union of Jewish Studies, 1983.

—. A Linguistic Study of the Relationship between the Priestly Source and the Book of Ezekiel: A New Approach to an Old Problem. CahRB 20. Paris: J. Gabalda, 1982.

Husak, Douglas. "Negligence, Belief, Blame and Criminal Liability: The Special Case of Forgetting." CLP 5 (2011): 199-218.

Ibn Ezra. "Ibn Ezra on Leviticus." Sefaria: Ibn Ezra on the Pentateuch. Translated by Jay F. Shachter. https://www.sefaria.org/Ibn_Ezra_on_Leviticus.20.3.1-2?lang=bi.

Iser, Wolfgang. “The Reading Process: A Phenomenological Approach.” Pages 50-69 in Reader-Response Criticism: From Formalism to Post-Structuralism. Edited by Jane P. Tompkins. Baltimore: Johns Hopkins University Press, 1980.

Jackson, Bernard S. Essays in Jewish and Comparative Legal History. SJLA 10. Leiden: Brill, 1975.

—. "From Dharma to Law." AMJCL 23 (1975): 490-512.

-Wisdom-Laws: A Study of the Mishpatim of Exodus 21:1-22:16. Oxford: Oxford University Press, 2006.

Jackson, Frank. “Weakness of Will.” Mind 93 (1984): 1-18.

Jacobsen, Thorkild. “The Eridu Genesis.” JBL 100 (1981): 513-29. 
Jacobus, Melancthon W., Elbert C. Lane, and Andrew C. Zenos, eds. Funk and Wagnalls New Standard Bible Dictionary. 3rd rev. ed. Garden City, MI: Garden City Books, 1936.

Jankiewicz, Darius W. "Sin and Human Nature: Historical Background.” Pages 91-117 in Salvation: Contours of Adventist Soteriology. Edited by Martin F. Hanna, Darius W. Jankiewicz, and John W. Reeve. Berrien Springs, MI: Andrews University Press, 2018.

Janković, Slaviša. "The Rationale behind the Homocide Law in Numbers 35:30-34." Pages 81-104 in Searching the Scripture: Andrews University Seminary Emerging Scholars Pay Tribute to Their Professors. Edited by Slaviša Janković. Berrien Springs, MI: Andrews University, Theological Seminary, Old Testament Department, 2017.

—. "The Textual Evidence of the Omission Found in the LXX Translation of Lev 16:14-15." Paper presented at the 2016 Midwest Region Meeting of the SBL. Bourbonnais, IL, 5-7 February 2016.

Janowski, Bernd. Sühne als Heilsgeschehen: Studien zur Sühnetheologie der Priesterschrift und zur Wurzel KPR im Alten Orient und im Alten Testament. WMANT 55. Neukirchen-Vluyn: Neukirchener, 2000.

Jansen, Nils. "Duties and Rights in Negligence: A Comparative and Historical Perspective on the European Law of Extracontractual Liability." OJLS 24 (2004): 443-69.

Jenni, Ernst. Das Hebraische Pi 'el: Syntaktisch-Semasiologische Untersuchung einer Verbalform in Alten Testament. Zürich: EVZ-Verlag, 1968.

—. Die Präposition Beth. Vol. 1 of Die Hebräischen Präpositionen. Stuttgart: W. Kohlhammer, 1992.

Jenni, Ernst, and Claus Westermann, eds. Theological Lexicon of the Old Testament. 3 vols. Peabody, MA: Hendrickson, 1997.

—. Theologisches Handwörterbuch zum Alten Testament. 2 vols. München: Chr. Kaiser Verlag, 1984.

Jenson, Philip P. Graded Holiness: A Key to the Priestly Conception of the World. JSOTSup 106. Sheffield: JSOT Press, 1992.

Johnson, Mark. Moral Imagination: Implications of Cognitive Science for Ethics. Chicago: University of Chicago Press, 1993.

Joüon, Paul. "Notes on Lexicographie Hébraique.” Bib 19 (1938): 454-59. 
Joüon, Paul, and T. Muraoka. A Grammar of Biblical Hebrew. 2nd ed. Roma: Editrice Pontificio Istituto Biblico, 2006.

Kaiser, Otto, and Werner Georg Kümmel. Exegetical Method: A Student's Handbook. New York: Seabury Press, 1981.

Kaiser, Walter C. "Exodus." Pages 333-562 in The Expositor's Bible Commentary: Genesis-Numbers. Vol. 2 of The Expositor's Bible Commentary: With the New International Version of the Holy Bible. Edited by Frank E. Gaebelein. 12 vols. Grand Rapids, MI: Zondervan, 1976-91.

—. Toward an Exegetical Theology: Biblical Exegesis for Preaching and Teaching. Grand Rapids, MI: Baker Book House, 1981.

Kaiser, Walter C., and Moisés Silva. Introduction to Biblical Hermeneutics: The Search for Meaning. Rev. and exp. ed. Grand Rapids, MI: Zondervan, 2007.

Kaufmann, Yehezkel. The Religion of Israel: From Its Beginnings to the Babylonian Exile. Translated by Moshe Greenberg. Chicago: University of Chicago Press, 1960.

. תולדות האמונה הישראלית [Toldot HaEmunah HaYisraelit The Religion (Belief) of Israel]. 4 vols. Jerusalem: Bialik, 1937-56.

Kazen, Thomas. "Dirt and Disgust: Body and Morality in Biblical Purity Laws." Pages 43-64 in Perspectives on Purity and Purification in the Bible. Edited by Baruch J. Schwartz, David P. Wright, Jeffrey Stackert, and Naphtali S. Meshel. LHBOTS 474. New York: T \& T Clark, 2008.

- Issues of Impurity in Early Judaism. ConBNT 45. Winona Lake, IN: Eisenbrauns, 2010.

_. Jesus and Purity Halakhah: Was Jesus Indifferent to Impurity? ConBNT 38. Winona Lake, IN: Eisenbrauns, 2010.

Keel, Othmar. The Symbolism of the Biblical World: Ancient Near Eastern Iconography and the Book of Psalms. Translated by Timothy J. Hallett. Winona Lake, IN: Eisenbrauns, 1997.

Keil, Carl Friedrich and Franz Delitzsch. Biblical Commentary on the Prophecies of Ezekiel. 2 vols. BCOT 23-24. Grand Rapids, MI: Eerdmans, 1952.

The Pentateuch. Translated by James Martin. 5 vols. BCOT. Grand Rapids, MI: Eerdmans, 1952. 
Kim, Eun-Jung. "Reconsidering Eternal Life in the Old Testament: The Idea of Resurrection Rooted in the Torah.” PhD diss., The Southern Baptist Theological Seminary, 2015.

Kim, Gyung-Yul. "The Hattat Ritual and the Day of Atonement in the Book of Leviticus." PhD diss., University of Pretoria, 2013.

Kittel, Gerhard, ed. Theological Dictionary of the New Testament. 10 vols. Grand Rapids, MI: Eerdmans, 1964-76.

Kiuchi, Nobuyoshi. Leviticus. AOTC 3. Nottingham: Apollos, 2007.

- The Purification Offering in the Priestly Literature: Its Meaning and Function. JSOTSup 56. Sheffield: Academic Press, 1987.

Klawans, Jonathan. “The Impurity of Immorality in Ancient Israel.” JJS 48 (1997): 1-16.

—. Impurity and Sin in Ancient Judaism. New York: Oxford University Press, 2000.

—_. "Notions of Gentile Impurity in Ancient Judaism." AJSR 20 (1995): 285-312.

- Purity, Sacrifice, and the Temple: Symbolism and Supersessionism in the Study of Ancient Judaism. Oxford: Oxford University Press, 2006.

_ . "Ritual Purity, Moral Purity, and Sacrifice in Jacob Milgrom's Leviticus." RSR 29 (2003): 19-28.

Klingbeil, Gerald A. Bridging the Gap: Ritual and Ritual Texts in the Bible. Winona Lake, IN: Eisenbrauns, 2007.

- A Comparative Study of the Ritual of Ordination as Found in Leviticus 8 and Emar 369. Lewiston, NY: Mellen Press, 1998.

Knierim, Rolf P. Die Hauptbegriffe für Sünde im Alten Testament. Gütersloh: Gütersloher Verlagshaus, 1965.

— . "The Problem of an Old Testament Hamartiology: Considerations to the Book of Štefan Porúbcan, Sin in the Old Testament: Soteriological Study, Roma, 1963." VT 16.3 (1966): 366-385. doi:10.2307/1516567.

- Text and Concept in Leviticus 1:1-9: A Case in Exegetical Method. FAT 2. Tübingen: J.C.B. Mohr (Paul Siebeck), 1992.

Knobel, A. W. Die Bücher Exodus and Leviticus. Leipzig: S. Hirzel, 1880.

Knudsen, E. E. “An Incantation Tablet from Nimrud.” Iraq 21 (1959): 54-61. 
Koch, Klaus. “Gibt es ein Vergeltungsdogma im Alten Testament?” ZThK 52 (1955): 145.

Köhler, Ludwig, Walter Baumgartner, M. E. J. Richardson, and Johann Jakob Stamm, eds. The Hebrew and Aramaic Lexicon of the Old Testament. 2 vols. Leiden: Brill, 2001.

Koller, Aaron. "Diachronic Change and Synchronic Readings: Midrashim on Stative Verbs and Participles.” JSS 57.2 (2012): 265-294. https://doi.org/10.1093/jss/fgs003.

Kornfeld, Walter. "Die Unreinen Tiere im Alten Testament." Pages 11-27 in Wissenschaft im Dienste des Glaubens: Festschrift für Abt Dr. Hermann Peichl, O.S.B., Präsident der Wiener Katholischen Akademie, dargeboten zum 35. Abtjubiläum. Edited by Josef Kisser, Hermann Peichl, Ferdinand Krones, Ulrich A. Schöndorfer, and Walter Kornfeld. Studien der Wiener Katholischen Akademie 4. Wien: Wiener Katholische Akademie, 1965.

Kouwenberg, N. J. C. The Akkadian Verb and Its Semitic Background. LANE 2. Winona Lake, IN: Eisenbrauns, 2010.

- Gemination in the Akkadian Verb. SSN 32. Assen: Van Gorcum, 1997.

Krašovec, Jože. Reward, Punishment, and Forgiveness: The Thinking and Beliefs of Ancient Israel in the Light of Greek and Modern Views. VTSupp 78. Leiden: Brill, 1999.

Kulikov, Leonid I. “Causatives.” Pages 886-98 in vol 2 of Language Typology and Language Universals: An International Handbook. Edited by Martin Haspelmath, Ekkehard König, Wulf Oesterreicher \& Wolfgang Raible. 2 vols. Handbooks of Linguistics and Communication Science 20. New York: Walter de Gruyter, 2001.

Kurtz, J. H. Offerings, Sacrifices, and Worship in the Old Testament. Translated by James Martin. Peabody, MA: Hendrickson, 1998. . Sacrificial Worship of the Old Testament. Translated by James Martin. 1863. Repr., Minneapolis, MA: Klock \& Klock, 1980.

Labuschagne, Caspar J. "The Meaning of $b^{e} y \bar{a} d$ rāmā in the Old Testament." Pages 143148 in Von Kanaan bis Kerala: Festschrift für J. P. M. van der Ploeg O.P. zur Vollendung des siebzigsten Lebensjahres am 4. Juli 1979. Edited by J. P. M. van der Ploeg and W. C. Delsman. Alter Orient und Altes Testament 211. Kevelaer, Germany: Butzon \& Bercker, 1982.

LaFollette, Hugh, ed. The International Encyclopedia of Ethics. 9 vols. Malden, MA: Wiley-Blackwell, 2013. 
Lakoff, G., and M. Johnson. Metaphors We Live By. Chicago: University of Chicago Press, 1980.

_. Philosophy in the Flesh: The Embodied Mind and Its Challenge to Western Thought. (New York: Basic Books, 1999).

Lam, Joseph. "The Concept of Sin in the Hebrew Bible." RC 12.3-4 (19 February 2018). https://doi.org/10.1111/rec3.12260.

Lam, Joseph Ching Po. "The Metaphorical Patterning of the Sin-Concept in Biblical Hebrew.” PhD diss., University of Chicago, 2012.

Lambdin, Thomas Oden. Introduction to Biblical Hebrew. New York: Scribner's Sons, 1971.

Lambert, J.C., and M. H. Shepherd. "Laying on of Hands." Page 572 of A Dictionary of the Bible. Edited by James Hastings. Edinburgh: T \& T Clark, 1909.

Lambert, W. G. “DINGIR.ŠÀ.DIB.BA Incantations.” JNES 33.3 (1974): 267-322.

__. "Three Literary Prayers of the Babylonians.” AfO 19 (1959-1960): 47-66.

Landsberger, Benno. The Date Palm and Its By-Products According to the Cuneiform Sources. AfO 17. Graz, Austria: Weidner, 1967.

Lane, Edward William. An Arabic-English Lexicon: Derived from the Best and the Most Copious Eastern Sources. 8 vols. New York: Ungar, 1955.

Langdon, Stephen. Babylonian Penitential Psalms to Which are Added Fragments of the Epic of Creation from Kish in the Weld Collection of the Ashmolean Museum. OECT 6. Paris: Geuthner, 1927.

Lareau, François. "The Distinction between Conscious Negligence and Recklessness." Revised 2 December 2001. http://www.lareau-law.ca/article-consciousnegligence .html.

LaSor, William Sanford, David Allan Hubbard, and Frederic William Bush. Old Testament Survey: The Message, Form, and Background of the Old Testament. Grand Rapids, MI: Eerdmans, 1982.

Leaney, A. R. C. The Rule of Qumran and Its Meaning: Introduction, Translation, and Commentary. Philadelphia: Westminster Press, 1966.

LeFebvre, Michael. Collections, Codes, and Torah: The Re-Characterization of Israel's Written Law. LHB/OTS 451. New York: T \& T Clark, 2006. 
Levine, Baruch A. “The Descriptive Tabernacle Texts of the Pentateuch.” JAOS 85 (1965): 307-18.

-In the Presence of the Lord: A Study of Cult and Some Cultic Terms in Ancient Israel. SJLA 5. Leiden: Brill, 1974.

- "The Language of Holiness: Perceptions of the Sacred in the Hebrew Bible." Pages 241-255 in Backgrounds for the Bible. Edited by Michael Patrick O'Connor and David Noel Freedman. Winona Lake, IN: Eisenbrauns, 1987.

—. Leviticus $=[$ Y Translation. JPSTC 3. Philadelphia: Jewish Publication Society, 1989.

—. Numbers 1-20. AB 4. New York: Doubleday, 1993.

—.Numbers 21-36. AB 4A. New York: Doubleday, 2000.

—_. "Ugaritic Descriptive Rituals." JCS 17 (1963): 105-11.

Li, Fengxiang. "An Examination of Causative Morphology from a Cross-Linguistic and Diachronic Perspective." Pages 344-59 in Papers from the 27th Regional Meeting of the Chicago Linguistic Society, 1991, Part 1: The General Session. Edited by Lise M. Dobrin, Lynn Nichols, and Rosa M. Rodriguez. Chicago: Chicago Linguistic Society, 1993.

Lindström, Fredrik. Suffering and Sin: Interpretations of Illness in the Individual Complaint Psalms. ConBOT 37. Stockholm: Almqvist \& Wiksell International, 1994.

Lohse, Eduard. Die Ordination im Spätjudentum und im Neuen Testament. Berlin: Evangelische Verlagsanstalt, 1951.

Longacre, Robert E. An Anatomy of Speech Notions. PPPT 3. Lisse, Netherlands: Peter de Ridder Press, 1976.

Longman, Tremper, and Raymond B. Dillard. An Introduction to the Old Testament. 2nd ed. Grand Rapids, MI: Zondervan, 2006.

Lyonnet, Stanislas, and Leopold Sabourin. Sin, Redemption, and Sacrifice: A Biblical and Patristic Study. AB 48. Rome: Biblical Institute, 1970.

Lys, Daniel. Nèphèsh: Histoire de l'âme dans la révélation d'Israël au sein des religions proche-orientales. ÉHPR 50. Paris: Presses Universitaires de France, 1959.

Maccoby, Hyam. Ritual and Morality: The Ritual Purity System and Its Place in Judaism. New York: Cambridge University Press, 1999. 
MacCulloch, J. A. "Laying on of Hands.” ERE 6:493-99.

Macquarrie, John, and James F. Childress, eds. A New Dictionary of Christian Ethics. London: SCM Press, 1986.

Malul, Meir. The Comparative Method in Ancient Near Eastern and Biblical Legal Studies. AOAT 227. Neukirchen-Vluyn: Neukirchener, 1990.

Mankowski, Paul V. Akkadian Loanwords in Biblical Hebrew. Winona Lake, IN: Eisenbrauns, 2000.

Margolis, Eric, and Stephen Laurence. "The Ontology of Concepts-Abstract Objects or Mental Representations?” NOÛS 41 (2007): 561-93.

Martens, Elmer A. "Sin, Guilt." Pages 764-778 in Dictionary of the Old Testament: Pentateuch. Edited by T. Desmond Alexander and David W. Baker. IVPBD 1. Downers Grove, IL: InterVarsity Press, 2003.

Martin, Glen S. Exodus, Leviticus, Numbers. HOTC 2. Nashville: Broadman \& Holman, 2002.

Mathews, Kenneth A. Genesis 1-11:26. NAC 1A. Nashville: Broadman \& Holman, 1996.

—. Genesis 11:27-50:26. NAC 1B. Nashville: Broadman \& Holman, 2005.

- Leviticus: Holy God, Holy People. Preaching the Word series. Wheaton, IL: Crossway Books, 2009.

Matthes, J. C. “Der Sühnegedanke bei den Sündopfern.” ZAW 23 (1903): 97-119.

Mattingly, Keith Edward Krieghoff. "The Laying on of Hands on Joshua: An Exegetical Study of Numbers 27:12-23 and Deuteronomy 34:9." PhD diss., Andrews University, 1997.

Maxwell, Paul and John Perrine. "The Problem of God in the Presence of Grief: Exchanging 'Stages' of Healing for 'Trajectories' of Recovery." JSFSC 9.2 (2016): 176-93.

McClintock, John, and James Strong, eds. Cyclopaedia of Biblical, Theological and Ecclesiastical Literature. 10 vols. New York: Harper \& Brothers, 1867-1887.

McLean, Bradley H. "The Interpretation of the Levitical Sin Offering and the Scapegoat." SR 20 (1991): 345-56. 
Médebielle, Alexis. "Expiation." Pages 1-262 in vol. 3 of Dictionnaire de la Bible Supplément. Edited by Louis Pirot, André Robert, and Henri Cazelles. 12 vols. Paris: Letouzey et Ané, 1928.

- L'expiation dans l'Ancien et le Nouveau Testament. Rome: Institut Biblique Pontifical, 1923.

_. "Le symbolisme du sacrifice expiatoire en Israel." Bib 2 (1921): 141-69, 273302.

Merrill, Eugene H. Deuteronomy: An Exegetical and Theological Exposition of Holy Scripture. NAC 4. Nashville: Broadman \& Holman, 1994.

Merwe, B. J. van der. "The Laying on of Hands in the Old Testament." OTWSA 5 (1962): $34-43$.

Merwe, C. H. J. van der, Jackie A. Naudé, and Jan H. Kroeze. A Biblical Hebrew Reference Grammar. BLH 3. Sheffield: Sheffield Academic Press, 1999.

Metzinger, Adalbert. "Die Substitutionstheorie und das Alttestamentaliche Opfer mit besonderer Berücksichtigung von Lv 17:11.” Bib 21 (1940): 159-87, 247-72, $353-77$.

Milgrom, Jacob. “Atonement in the OT.” IDBSup 78-82.

— . "The Case of the Suspected Adulteress, Numbers 5:11-31: Redaction and Meaning." Pages 69-75 in The Creation of Sacred Literature: Composition and Redaction of the Biblical Text. Edited by Richard Elliott Friedman. UCPNES 22. Berkeley, CA: University of California Press, 1981.

_ חטאת . "Critical Notes: The Preposition in in thes." JBL 126 (2007): $161-91$.

- Cult and Conscience: The Asham and the Priestly Doctrine of Repentance. SJLA 18. Leiden: Brill, 1976.

_. שגגה and Its Influence in Psalms and Job." JQR 58 (1967): 115-25.

_. "Impurity is Miasma: A Response to Hyam Maccoby." JBL 119 (2000): 729-33.

_ _ "Israel's Sanctuary: The Priestly 'Picture of Dorian Gray."” RB 83 (1976): 39099.

—. Leviticus 1-16. AB 3. New York: Doubleday, 1991.

- Leviticus 17-22. AB 3A. New York: Doubleday, 2000. 
—.Leviticus 23-27. AB 3B. New York: Doubleday, 2001.

- Numbers $=[$ Ba-midbar $]:$ The Traditional Hebrew Text with the New JPS

Translation. JPSTC 4. Philadelphia: Jewish Publication Society, 1990.

_ . "The Paradox of the Red Cow (Num. XIX)." VT 31 (1981): 62-72.

—. "A Prolegomenon to Leviticus 17:11." JBL 90 (1971): 149-56.

—. "Sacrifices and Offerings, OT." IDBSup 763-71.

—. Studies in Cultic Theology and Terminology. SJLA 36. Leiden: Brill, 1983.

- Studies in Levitical Terminology: The Encroacher and the Levite. Berkeley, CA: University of California, 1970.

__. "Two Kinds of Hațtâ̄' t.” VT 26 (1976): 333-37.

Miller, Patrick D. "Israelite Religion." Pages 1-30 in The Hebrew Bible and Its Modern Interpreters. Edited by Douglas A. Knight and Gene M. Tucker. BMI 1. Philadelphia: Fortress Press, 1985.

—. The Ten Commandments. Louisville: Westminster John Knox Press, 2009.

Moberly, R. W. L. At the Mountain of God: Story and Theology in Exodus 32-34. JSOTSupp 22. Sheffield: JSOT Press, 1983.

Mobus, George E., and Michael C. Kalton. Principles of Systems Science. New York: Springer, 2015.

“Model Penal Code." Wikipedia. Released 2709 2018. https://en.wikipedia.org/ wiki/Model_Penal_Code.

Moore, George. F. "Sacrifice.” EncyBib 4:4183-233.

Moore, Michael S. and Heidi M. Hurd. "Punishing the Awkward, the Stupid, the Weak, and the Selfish: The Culpability of Negligence." CLP 5 (2011): 147-98. https://doi.org/10.1007/s11572-011-9114-0

Moskala, Jiri. "The Laws of Clean and Unclean Animals of Leviticus 11: Their Nature, Theology, and Rationale (An Intertextual Study)." PhD diss., Andrews University, 1998. 
__ "Origin of Sin and Salvation according to Genesis 3: A Theology of Sin." Pages 119-157 in Salvation: Contours of Adventist Soteriology. Edited byMartin F.

Hanna, Darius W. Jankiewicz, and John W. Reeve. Berrien Springs, MI: Andrews University Press, 2018.

Moyer, James Carroll. "The Concept of Ritual Purity among the Hittites." PhD diss., Brandeis University, 1969.

Neumann, Johannes. "Salbung und Handauflegung als Heilszeichen und Rechtsakt." Pages 1419-1434 in vol 2 of Wahrheit und Verkündigung: Michael Schmaus zum 70. Geburtstag. Edited by Leo Scheffczyk, Werner Dettloff, and Richard Heinzmann. 2 vols. München: Ferdinand Schöningh, 1967.

Neusner, Jacob. The Idea of Purity in Ancient Judaism. Leiden: Brill, 1973.

— - trans. The Mishnah: A New Translation. New Haven: Yale University Press, 1988.

Newell, Lynne B. “Job: Repentant or Rebellious?” VT 46 (1984): 289-316.

Newton, Michael. The Concept of Purity at Qumran and in the Letters of Paul. SNTSMS 53. Cambridge: Cambridge University Press, 1985.

Nichol, Francis D., ed. The Seventh-day Adventist Bible Commentary. CRS 12 vols. Washington, DC: Review and Herald, 1976.

Nicole, Emile. "Atonement in the Pentateuch." Pages 35-50 in The Glory of the Atonement: Biblical, Historical \& Practical Perspectives: Essays in Honor of Roger R. Nicole. Edited by Charles E. Hill and Frank A. James III. Downers Grove, IL: InterVarsity Press, 2004.

“Nocturnal Emission.” Wikipedia. Released 24 July 2018. https://en.wikipedia.org/ wiki/Nocturnal_emission\#In_males.

Noordtzij, A. Leviticus. Translated by Raymond Togtman. BSC. Grand Rapids, MI: Zondervan, 1982.

_. Numbers. BSC. Grand Rapids, MI: Zondervan, 1983.

Norlin, Julia M., and Wayne A. Chess. Human Behavior and the Social Environment: Social Systems Theory. 3rd ed. Boston: Allyn and Bacon, 1997.

Noth, Martin. Leviticus: A Commentary. OTL. Philadelphia: Westminster Press, 1965.

Olaffson, Gudmundur. "The Use of $n s$ ' in the Pentateuch and Its Contribution to the Concept of Forgiveness." PhD diss., Andrews University, 1993. 
Orlinsky, Harry M., ed. Notes on the New Translation of the Torah. Philadelphia: Jewish Publication Society of America, 1969.

Osborne, Grant R. The Hermeneutical Spiral: A Comprehensive Introduction to Biblical Interpretation. Downers Grove, IL: InterVarsity Press, 2006.

Oswalt, John N. The Book of Isaiah: Chapters 1-39. NICOT. Grand Rapids, MI: Eerdmans, 1986.

Oxford Advanced Learner's Dictionary. 8th ed. Oxford, UK: Oxford University Press, 2012. http://www.oxfordlearnersdictionaries.com/us/definition/american_english

Oxford English Dictionary. Oxford, UK: Oxford University Press, 2018. https://en.oxforddictionaries.com/definition.

Pădure, Ruxandra. "Comparison between the Biblical and the Near Eastern Laws." SJHS 3.4 (2011): 230-237.

Parker, R. Miasma: Pollution and Purification in Early Greek Religion. Oxford: Clarendon, 1983.

Paschen, Wilfried. Rein und Unrein: Untersuchung zur Biblischen Wortgeschichte. SANT 24. München: Kèosel-Verlag, 1970.

Paul, Shalom M. Studies in the Book of the Covenant in the Light of Cuneiform and Biblical Law. VTSupp 18. Leiden: Brill, 1970.

Pedersen, Johannes. Israel: Its Life and Culture. 2 vols. Atlanta: Scholars Press, 1991.

Péter, René. “L'imposition des mains dans l'Ancien Testament.” VT 27 (1977): 48-55.

Péter-Contesse, René. Lévitique 1-16. CAT 3A. Genève: Labor et Fides, 1993.

Péter-Contesse, René, and John Ellington. A Translator's Handbook on Leviticus. UBS Helps for Translators. New York: United Bible Societies, 1990.

Phillips, Anthony. Ancient Israel's Criminal Law: A New Approach to the Decalogue. Oxford: Blackwell, 1970.

—. Essays on Biblical Law. JSOTSup 344. London: Sheffield Academic Press, 2002.

Phillips, Anthony C. "The Undetectable Offender and the Priestly Legislator." JTS 36 (1985): 146-150. 
Platvoet, Jan. "Ritual in Plural and Pluralistic Societies." Pages 25-51 in Pluralism and Identity: Studies in Ritual Behaviour. Edited by Jan Platvoet and Karel van der Toorn. SHR 67. Leiden: Brill, 1995.

Podet, Allen. "Morenu Harabh: Elements in the Development of Rabbinical Ordination in the Codes." PhD diss., Hebrew Union College-Jewish Institute of Religion, 1964.

Porter, J. R. Leviticus. CBC. Cambridge: Cambridge University Press, 1976.

Porùbčan, Štefan. Sin in the Old Testament. Rome: Herder Roma, 1963.

Preuss, Horst Dietrich. Old Testament Theology. Louisville: Westminster John Knox, 1995.

Propp, W. H. C. Exodus 19-40. AB 2A. New York: Doubleday, 2006.

Qimron, Elisha. The Hebrew of the Dead Sea Scrolls. HSS 29. Atlanta: Scholars Press, 1986.

Queen, Christopher Scott. "Systems Theory in Religious Studies: A Methodological Critique.” PhD diss., Boston University, 1986.

Rad, Gerhard von. Genesis. Rev ed. OTL. Philadelphia: Westminster Press, 1972.

- Old Testament Theology. Translated by D. M. G. Stalker. 2 vols. Louisville: Westminster John Knox Press, 2001.

Rahner, Karl. On the Theology of Death. New York: Seabury Press, 1973.

Rainey, A. "The Order of Sacrifices in Old Testament Ritual Texts." Biblica 51 (1970): $485-98$.

Ramm, Bernard L. The Christian View of Science and Scripture. 1st ed. Grand Rapids, MI: Eerdmans, 1954.

Ratner, R., and B. Zuckerman. “'A Kid in Milk'?: New Photographs of KTU 1.23, Line 14." HUCA 57 (1986): 15-60.

Raz, Joseph. "Responsibility and the Negligence Standard." OJLS 30 (2010): 1-18.

Reilly, Richard. "Plato and Augustine on Human Weakness." Cithara 18.2 (1979): 4369.

Rendtorff, R. Leviticus. BKAT 3/1. Neukirchen-Vluyn: Neukirchener, 1985.

—. Leviticus. BKAT 3/3. Neukirchen-Vluyn: Neukirchener, 1992. 
Richards, Lawrence O., ed. The Revell Bible Dictionary. Old Tappan, NJ: Fleming H. Revell Co., 1990.

Ringgren, Helmer. Israelite Religion. Translated by David E. Green. Philadelphia: Fortress Press, 1966.

Robinson, Clayton David. "The Laying on of Hands, with Special Reference to the Reception of the Holy Spirit in the New Testament." PhD diss., Fuller Theological Seminary, 2008.

Robinson, Gnana. "A Terminological Study of the Idea of Sin in the Old Testament." IJT 18 (1969): 112-23.

Rodríguez, Ángel Manuel. "Sacrificial Substitution and the Old Testament Sacrifices." Pages 123-143 in The Sanctuary and the Atonement: Theological and Historical Studies. Edited by Frank B. Holbrook. Silver Springs, MD: Biblical Research Institute, 1989.

—. "Substitution in the Hebrew Cultus and in Cultic-Related Texts." PhD diss., Andrews University, 1979.

—_. "Transfer of Sin in Leviticus." Pages 169-197 in The Seventy Weeks, Leviticus, and the Nature of Prophecy. Edited by Frank B. Holbrook. Daniel and Revelation Series Committee 3. Hagerstown, MD: Review and Herald, 1986.

Röhser, Günter. Metaphorik und Personifikation der Sünde: Antike Sündenvorstellungen und Paulinische Hamartia. WUNT II/25. Tübingen: J. C. B. Mohr, 1987.

Rooker, Mark F. Leviticus. NAC 3A. Nashville: Broadman \& Holman, 2000.

Rowley, Harold Henry. Worship in Ancient Israel: Its Forms and Meaning. London: S.P.C.K., 1967.

Sailhamer, John. The Pentateuch as Narrative: A Biblical-Theological Commentary. Grand Rapids, MI: Zondervan, 1992.

Sakenfeld, Katharine Doob. The Meaning of Hesed in the Hebrew Bible: A New Inquiry. Missoula, MT: Scholars Press, 1978.

— ed. The New Interpreter's Dictionary of the Bible. 5 vols. Nashville: Abingdon Press, 2006-9.

Sanders, E. P. Jewish Law from Jesus to the Mishnah: Five Studies. Minneapolis: Fortress Press, 2016. 
- Paul and Palestinian Judaism: A Comparison of Patterns of Religion. 40th anniversary ed. Minneapolis: Fortress Press, 2017.

Sandmel, Samuel. “Parallelomania.” JBL 81 (1962): 1-13.

Sansom, M. C. "Laying on of Hands in the Old Testament." ET 94 (1983): 323-26.

Sarna, Nahum M. Exodus = [Shemot]: The Traditional Hebrew Text with the New JPS Translation. JPSTC 2. Philadelphia: Jewish Publication Society, 1991.

- Genesis $=[$ Be-reshit]: The Traditional Hebrew Text with New JPS Translation . JPSTC 1. Philadelphia: Jewish Publication Society, 1989.

Saydon, P. P. "Sin-offering and Trespass-offering." CBQ 8 (1946): 393-98.

Scharbert, Josef. "Fleisch, Geist, und Seele in der Pentateuch-Septuaginta." Pages 121143 in Wort, Lied und Gottesspruch: Beiträge zur Septuaginta: Festschrift für Joseph Ziegler. Edited by Josef Schreiner. FB 1. Würzburg: Echter Verlag, 1972.

Schenker, Adrian. "kōper et expiation." Bib 63.1 (1982): 32-46.

. "Das Zeichen des Blutes und die Gewißheit der Vergebung im Alten Testament: Die sühnende Funktion des Blutes auf dem Altar nach Lev 17.10-12." MTZ 34.3 (1983): 195-213.

Schertz, Mary H., and Perry B. Yoder. Seeing the Text: Exegesis for Students of Greek and Hebrew. Nashville: Abingdon Press, 2001.

Schipper, Bernd U. "Egyptian Influences on the Biblical Text." Bible Odyssey. Released 8 Nov 2017. http://www.bibleodyssey.org/places/related-articles/egyptianinfluences-on-the-biblical-text.

Schneider, Wolfgang, and Oskar Grether. Grammatik des Biblischen Hebräisch: Ein Lehrbuch. München: Claudius-Verlag, 1974.

Schötz, P. Dionys. Schuld- und Sündopfer im Alten Testament. Braslau: Muller \& Sieffert, 1930.

Schwartz, Baruch J. "The Bearing of Sin in the Priestly Literature." Pages 3-21 in Pomegranates and Golden Bells: Studies in Biblical, Jewish, and Near Eastern Ritual, Law, and Literature in Honor of Jacob Milgrom. Edited by David P. Wright, David Noel Freedman, and Avi Hurvitz. Winona Lake, IN: Eisenbrauns, 1995.

. "Cult and Character: Purification Offerings, Day of Atonement, and Theodicy: A Review.” AUSS 45.2 (2007): 267-272. 
_. "Leviticus." Pages 193-266 in The Jewish Study Bible. Edited by Adele Berlin and Marc Zvi Brettler. 2nd ed. Oxford: Oxford University Press, 2014.

_. "Leviticus." Pages 57-82 in The New Interpreter's Bible: One-Volume Commentary. Edited by Beverly Roberts Gaventa and David L. Petersen. Nashville: Abingdon Press, 2010. . "A Literary Study of the Slave-girl Pericope: Leviticus 19:20-22," Pages 24155 in Studies in Bible II: 1986. Edited by Sara Japhet. ScrHier 31. Jerusalem: Magnes Press, Hebrew University, 1986).

—. "The Prohibitions Concerning the 'Eating' of the Blood in Leviticus 17." Pages 34-66 in Priesthood and Cult in Ancient Israel. Edited by Gary A. Anderson and Saul M. Olyan. JSOTSup 125. Sheffield: JSOT Press, 1991.

- "Selected Chapters of the Holiness Code: A Literary Study of Leviticus 17-19." PhD diss., Hebrew University, 1987.

Scurlock, JoAnn. "The Techniques of the Sacrifice of Animals in Ancient Israel and Ancient Mesopotamia: New Insights through Comparison, Part 1." AUSS 44 (2006): 13-49.

Selman, Martin J. "Law." Pages 497-515 in Dictionary of the Old Testament: Pentateuch. Edited by T. Desmond Alexander and David W. Baker. IVPBD 1. Downers Grove, IL: InterVarsity Press, 2003.

Seux, Marie Joseph. Hymnes et Prières aux Dieux de Babylonie et d'Assyrie. LAPO 8. Paris: Le Cerf, 1976.

Seybold, K., and U. B. Mueller. Sickness and Healing. Translated by D. W. Stott. Nashville: Abingdon, 1981.

Shea, William H. "Literary Form and Theological Function in Leviticus." Pages 131-168 in The Seventy Weeks, Leviticus, and the Nature of Prophecy. Edited by Frank B. Holbrook. Daniel \& Revelation Committee Series 3. Hagerstown, MD: Review and Herald, 1986.

Sigvartsen, Jan Åge. "The Afterlife Views and the Use of the Tanakh in Support of the Resurrection Concept in the Literature of Second Temple Period Judaism: The Apocrypha and the Pseudepigrapha." PhD diss., Andrews University, 2016.

Silva, Moisés. Biblical Words and Their Meaning: An Introduction to Lexical Semantics. Grand Rapids, MI: Zondervan, 1983.

Simons, Kenneth W. "The Crime/Tort Distinction: Legal Doctrine and Normative Perspectives." WLJ 17 (2008): 719-32. 
—. "Deontology, Negligence, Tort, and Crime." BULR 273 (1996): 273-99.

. "When is Negligent Inadvertence Culpable?: Introduction to Symposium, Negligence in Criminal Law and Morality." CLP 5.2 (2011): 97-114.

Sklar, Jay. Leviticus: An Introduction and Commentary. TOTC 3. Downers Grove, IL: Inter-Varsity Press, 2014.

— . "Sin." OEBT 2:297-308.

—_. "Sin and Atonement: Lessons from the Pentateuch." BBR 22 (2012): 467-92.

_ . "Sin and Impurity: Atoned or Purified? Yes!" Pages 18-31 in Perspectives on Purity and Purification in the Bible. Edited by Baruch J. Schwartz, David P. Wright, Jeffrey Stackert, and Naphtali S. Meshel. LHB/OTS 474. New York: T\&T Clark, 2008.

- Sin, Impurity, Sacrifice, Atonement: The Priestly Conceptions. HBM 2. Sheffield: Sheffield Phoenix Press, 2005.

Smith, Charles Ryder. The Bible Doctrine of Sin and of the Ways of God with Sinners. London: Epworth Press, 1953.

Smith, Henry Preserved. "The Laying-on of Hands.” AJT 17 (1913): 47-62.

Smith, Holly M. "Non-Tracing Cases of Culpable Ignorance." CLP 5 (2011): 115-46.

Smith, Jonathan Z. To Take Place: Toward Theory in Ritual. Chicago: University of Chicago Press, 1987.

Smith, W. Robertson. Lectures on the Religion of the Semites. New ed. Burnett Lectures [Aberdeen University] 1888-89. London: A. \& C. Black, 1894.

Snaith, Norman H. Leviticus and Numbers. CB 3. London: Nelson, 1967.

Sørensen, J. P. "Ritualistics: A New Discipline in the History of Religion." Pages 9-25 in The Problem of Ritual: Based on Papers Read at the Symposium on Religious Rites held at Ábo, Finland, on the 13th-16th of August 1991. Edited by Tore Ahlbäck. Åbo, Finland: The Donner Institute for Research in Religious and Cultural History, 1993.

Sprinkle, Joe M. Biblical Law and Its Relevance: A Christian Understanding and Ethical Application for Today of the Mosaic Regulations. Lanham, MD: University Press of America, 2006. 
Staal, Frits. Rules Without Meaning: Ritual, Mantras, and the Human Sciences. TSR 4. New York: P. Lang, 1989.

Stamm, Johann Jakob. Erlösen und Vergeben im Alten Testament. Bern: A. Francke, 1940.

Steiner, Richard C. Disembodied Souls: The Nefesh in Israel and Kindred Spirits in the Ancient Near East, with an Appendix on the Katumuwa Inscription. ANEM 11. Atlanta: SBL Press, 2015.

Strawn, Brant A., ed. The Oxford Encyclopedia of the Bible and Law. 2 vols. New York: Oxford Univeristy Press, 2015.

Stroud, Sarah. "Weakness of Will.” The Stanford Encyclopedia of Philosophy. Spring 2014. http://plato.stanford.edu/entries/weakness-will/.

_ . "Weakness of Will and Practical Judgement." Pages 121-146 in Weakness of Will and Practical Irrationality. Edited by Sarah Stroud and Christine Tappolet. Oxford: Oxford University Press, 2003. doi:10.1093/0199257361.003.0006

Stuart, Douglas K. Exodus. NAC 2. Nashville: Broadman \& Holman, 2006.

Sun, Henry T. C. "An Investigation into the Compositional Integrity of the So-Called Holiness Code (Leviticus 17-26).” PhD diss., The Claremont Graduate University, 1990.

Swinburne, Richard G. “Original Sinfulness.” NZSTR 27 (1985): 235-50.

Taggar-Cohen, Ada. Hittite Priesthood. THeth 26. Heidelberg: Winter, 2006.

Tappolet, Christine. "Weakness of Will.” IEE 9:5412-21.

Tate, W. Randolph. Biblical Interpretation: An Integrated Approach. Peabody, MA: Hendrickson, 2008.

Tenney, Merrill C., ed. The Zondervan Pictorial Encyclopedia of the Bible. 5 vols. Grand Rapids, MI: Zondervan, 1975.

Tenney, Merrill C., and J. D. Douglas, eds. The New International Dictionary of the Bible. Grand Rapids, MI: Zondervan, 1987.

Thomas, D. Winton, ed. Documents from Old Testament Times. TB 85. New York: Harper \& Brothers, 1961.

Thompson, Sandra A., and Paul J. Hopper. "Transitivity in Grammar and Discourse." Language 56 (1980): 251-99. 
Tidball, Derek. The Message of Leviticus. BST. Downers Grove,IL: InterVarsity Press, 2005.

Tigay, Jeffrey H. Deuteronomy = [Devarim]: The Traditional Hebrew Text with the New JPS Translation. JPSTC 5. Philadelphia: Jewish Publication Society, 1996.

Tipei, John Fleter. The Laying on of Hands in the New Testament: Its Significance, Techniques, and Effects. Lanham, MD: University Press of America, 2009.

Toorn, K. van der. Sin and Sanction in Israel and Mesopotamia: A Comparative Study. SSN 22. Assen: Van Gorcum, 1985.

“Tort.” Wikipedia. Released 17 July 2017. https://en.wikipedia.org/wiki/Tort.

Tov, Emanuel. The Text-Critical Use of the Septuagint in Biblical Research. 3rd ed. Winona Lake, IN: Eisenbrauns, 2015.

Trevaskis, Leigh M. Holiness, Ethics and Ritual in Leviticus. HBM 29. Sheffield: Sheffield Phoenix Press, 2011.

Turner, Laurence A. Genesis. RNBC. Sheffield: Sheffield Academic Press, 2000.

Turner, Victor W. The Forest of Symbols: Aspects of Ndembu Ritual. Ithaca, NY: Cornell University Press, 1970.

- The Ritual Process: Structure and Anti-Structure. LHML. New York: Aldine de Gruyter, 1995.

_. "Sacrifice as Quintessential Process: Prophylaxis or Abandonment?" HR (1977): 189-215.

Van de Walle, René. “The Sin in the Garden and Sinfulness of the World." IJT 18 (1969): 124-64.

VanGemeren, Willem, ed. New International Dictionary of Old Testament Theology \& Exegesis. 5 vols. Grand Rapids, MI: Zondervan, 1998.

Van Gigch, John P. Applied General Systems Theory. 2nd ed. New York: Harper \& Row, 1978.

Vaux, Roland de. Ancient Israel: Its Life and Institutions. Grand Rapids, MI: Eerdmans, 1997.

—. Studies in the Old Testament Sacrifice. Cardiff: University of Wales Press, 1964. 
Vis, Joshua M. "The Purgation of Person through the Purification Offering." Pages 33-58 in Sacrifice, Cult, and Atonement in Early Judaism and Christianity: Constituents and Critique. Edited by Henrietta L. Wiley and Christian A. Eberhart. RBS 85. Atlanta: SBL Press, 2017.

Volz, Paul. “Die Handauflegung bein Opfer.” ZAW 21 (1901): 93-100.

Vriezen, Theodore C. An Outline of Old Testament Theology. 2nd ed., rev. and enl. Oxford: Blackwell, 1970.

Waltke, Bruce K., and M. O'Connor. An Introduction to Biblical Hebrew Syntax. Winona Lake, IN: Eisenbrauns, 1990.

Walton, John H. Ancient Near Eastern Thought and the Old Testament: Introducing the Conceptual World of the Hebrew Bible. Grand Rapids, MI: Baker Academic, 2006.

- "Genesis." Pages 3-159 in Genesis, Exodus, Leviticus, Numbers, Deuteronomy. Vol. 1 of Zondervan Illustrated Bible Backgrounds Commentary: Old Testament. Edited by John H. Walton. 5 vols. Grand Rapids, MI: Zondervan, 2009.

Walton, John H., Victor H. Matthews, and Mark W. Chavalas. The IVP Bible Background Commentary: Old Testament. Downers Grove: InterVarsity Press 2000.

Waring, Dawn Elizabeth. "The Nature of Yahweh's Relationship with His People: A Literary Analysis of Exodus 32-34.” PhD diss., Fuller Theological Seminary, 1985.

Wead, D. W. "Hands, Laying on of.” ISBE 2:611-612.

Weeks, Noel. "Problems with Comparative Method in OT Studies." JETS 62 (2019): 287-306.

Weinfeld, Moshe. The Place of the Law in the Religion of Ancient Israel. Leiden: Brill, 2004.

Wellhausen, Julius. Die Composition des Hexateuchs und der Historischen Bücher des Alten Testaments. 3rd ed. Berlin: G. Reimer, 1899.

Wells, Bruce. "Exodus." Pages 160-283 in Genesis, Exodus, Leviticus, Numbers, Deuteronomy. Vol. 1 of Zondervan Illustrated Bible Backgrounds Commentary: Old Testament. Edited by John H. Walton. 5 vols. Grand Rapids, MI: Zondervan, 2009. 
- The Law of Testimony in the Pentateuchal Codes. Wiesbaden: Harrassowitz, 2004.

—. "Liability in the Priestly Texts of the Hebrew Bible." SL 5 (2012): 1-38.

Wenham, Gordon J. The Book of Leviticus. NICOT 3. Grand Rapids, MI: Eerdmans, 1979.

—. "Genesis." Pages 53-91 in New Bible Commentary: 21st Century Edition. Edited by G. J. Wenham, J. A. Motyer, D. A. Carson, and R. T. France. Downers Grove, IL: Inter-Varsity, 1994.

—. Genesis 1-15. WBC 1. Nashville: Thomas Nelson, 1987.

—. Genesis 16-50. WBC 2. Nashville: Thomas Nelson, 1994.

- Numbers: An Introduction and Commentary. TOTC 4. Downers Grove, IL: Inter-Varsity, 1981.

—. "Why Does Sexual Intercourse Defile (Lev 15:18)?” ZAW 95 (1983): 432-34.

Westbrook, Raymond. "The Character of Ancient Near Eastern Law." Pages 1-90 in vol 1 of A History of Ancient Near Eastern Law. Edited by Raymond Westbrook and Gary M. Beckman. 2 vols. Handbook of Oriental Studies. Section 1: The Near and Middle East 72/1. Leiden: Brill, 2003.

—. Studies in Biblical and Cuneiform Law. CahRB 26. Paris: Gabalda, 1988.

Westbrook, Raymond, and Bruce Wells. Everyday Law in Biblical Israel: An Introduction. 1st ed. Louisville: Westminster John Knox Press, 2009.

Westermann, Claus. Genesis 1-11: A Commentary. Translated by John J. Scullion. Minneapolis: Augsburg, 1984.

- Genesis 37-50: A Commentary. Translated by John J. Scullion. Minneapolis: Augsburg, 1986.

- The Structure of the Book of Job: A Form-Critical Analysis. Translated by Charles A. Muenchow. Philadelphia: Fortress Press, 1981.

Williams, Glanville Llewelyn. Criminal Law: The General Part. 2nd ed. London: Stevens, 1961.

Williams, R. J. Hebrew Syntax: An Outline. 2nd ed. Toronto: University of Toronto Press, 1976. 
Williston, Byron. Review of Weakness of Will from Plato to the Present, ed. Tobias Hoffmann. NDPR (2008, 3 September). https://ndpr.nd.edu/news/weakness-ofwill-from-plato-to-the-present/.

Wilson, B. Systems: Concepts, Methodologies, and Applications. Chichester, West Sussex: Wiley, 1984.

Wilson, Monica. "Nyakyusa Ritual and Symbolism.” AA 56 (1954): 228-41.

Wold, Donald J. “The Kareth Penalty in P: Rationale and Cases.” SBLSP 1 (1979): 1-45.

—_. "The Meaning of Biblical Penalty Kareth." PhD diss., University of California, 1978.

Wood, D. G. W., I. Howard Marshall, Alan R. Millard, James I. Packer, and D. J. Wiseman, eds. New Bible Dictionary. 3rd ed. Downers Grove, IL: InterVarsity Press, 1996.

Woods, Clyde M., and Justin Rogers. Leviticus-Numbers. CPNCOTS. Joplin, MO: College Press, 2006.

Wright, David P. "Deuteronomy 21:1-9 as a Rite of Elimination." $C B Q 49$ (1987): 387403.

- The Disposal of Impurity: Elimination Rites in the Bible and in Hittite and Mesopotamian Literature. SBLDS 101. Atlanta: Scholars Press, 1987.

—. "The Gesture of Hand Placement in the Hebrew Bible and Hittite Literature." JAOS 106 (1986): 433-46.

—. "The Hermeneutics of Ritual Innovation: Hand Placement in Leviticus 24." Paper presented at the Annual Meeting of the Biblical Law of the SBL. Atlanta, GA, 23 November 2015.

—. "Historical Criticism: A Necessary Element in the Search for Religious Truth." Sunstone 16 (1992): 28-38.

—. "Holiness, Sex, and Death in the Garden of Eden." Bib 77 (1996): 305-29.

—. "Purification from Corpse-Contamination in Numbers XXXI 19-24." VT 35 (1985): 213-23.

- Ritual in Narrative: The Dynamics of Feasting, Mourning, and Retaliation Rites in the Ugaritic Tale of Aqhat. Winona Lake, IN: Eisenbrauns, 2001. 
- "Ritual Theory, Ritual Texts, and the Priestly-Holiness Writings of the Pentateuch." Pages 195-216 in Social Theory and the Study of Israelite Religion: Essays in Retrospect and Prospect. Edited by Saul M. Olyan. RBS 71. Atlanta: Society of Biblical Literature, 2012.

—. "Sex and Death in the Garden of Eden." Sunstone (1998): 33-9.

. "The Spectrum of Priestly Impurity." Pages 34-66 in Priesthood and Cult in Ancient Israel. Edited by Gary A. Anderson and Saul M. Olyan. JSOTSup 125. Edited by Gary A. Anderson and Saul M. Olyan. Sheffield: JSOT Press, 1991.

—. "The Study of Ritual in the Hebrew Bible." Pages 120-39 in The Hebrew Bible: New Insights and Scholarship. Edited by Frederick E. Greenspahn. Jewish Studies in the Twenty-First Century 4. New York: New York University Press, 2008.

Wright, G. Ernest. “The Divine Name and the Divine Nature.” Perspective 12 (1971): $177-85$.

Würthwein, Ernst. The Text of the Old Testament: An Introduction to the Biblia Hebraica. 2nd ed., rev. and enl. Grand Rapids, MI: Eerdmans, 1995.

Yahuda, A. S. The Language of the Pentateuch in Its Relation to Egyptian. London: Oxford University Press, 1933.

Young, Edward J. The Study of Old Testament Theology Today. Westwood, NJ: F. H. Revell, 1959.

Young, Ian. "Biblical Texts Cannot Be Dated Linguistically." HS 46 (2005): 341-51.

—_. "Is the Prose Tale of Job in Late Biblical Hebrew?" VT 59 (2009): 606-29.

Young, Ian, Robert Rezetko, and Martin Ehrensvärd. Linguistic Dating of Biblical Texts: An Introduction to Approaches and Problems. Vol. 1 of Linguistic Dating of Biblical Texts. 2 vols. London: Equinox, 2008.

Youngblood, Ronald. "A New Look at Three Old Testament Roots for 'Sin." Pages 201-05 in Biblical and Near Eastern Studies: Essays in Honor of William Sanford LaSor. Edited by Gary E. Tuttle. Grand Rapids, MI: Eerdmans, 1978.

Youngblood, Ronald F., F. F. Bruce, and R. K. Harrison, eds. Nelson's New Illustrated Bible Dictionary. Nashville: Nelson, 1995.

Younger, K. Lawson. "The 'Contextual Method': Some West Semitic Reflections." Pages xxxv-xlii in Archival Documents from the Biblical World. Edited by William W. Hallo. COS 3. Leiden: Brill, 1997. 
Younker, Randall W. "A Look at Biblical and Ancient Extra-Biblical Perspectives on Death.” JATS 16 (2005): 30-42.

Zeitlin, Solomon. "The Semikah Controversy Between the School of Shammai and Hillel.” JQR 56 (1966): 242-43.

Zeusse, E. M. "Ritual.” ER 12:7833-48.

Zheng, Yujian. "Interpretational Paradox, Implicit Normativity, and Human Nature: Revisiting Weakness of Will from a Perspective of Comparative Philosophy." DJCP 16 (2017): 145-63.

Zimmerli, Walther. Ezekiel 1: A Commentary on the Book of the Prophet Ezekiel, Chapters 1-24. Hermeneia 8. Philadelphia: Fortress Press, 1979.

. Gottes Offenbarung: Gesammelte Aufsätze zum Alten Testament. TBü 19. München: C. Kaiser, 1963.

. "Zur Vorgeschichte von Jesaja LIII." Pages 236-44 in Congress Volume: Rome, 1968. Edited by G. W. Anderson, P. A. H. de Boer, G. R. Castellino, Henry Cazelles, E. Hammershaimb, H. G. May and W. Zimmerli. VTSupp 17. Leiden: Brill, 1969.

Zohar, Noam. "Repentance and Purification: The Significance and Semantics of חטאת in the Pentateuch." JBL 107 (1988): 609-18. 